fòrum de recerca issn 1139-5486 n020/2015

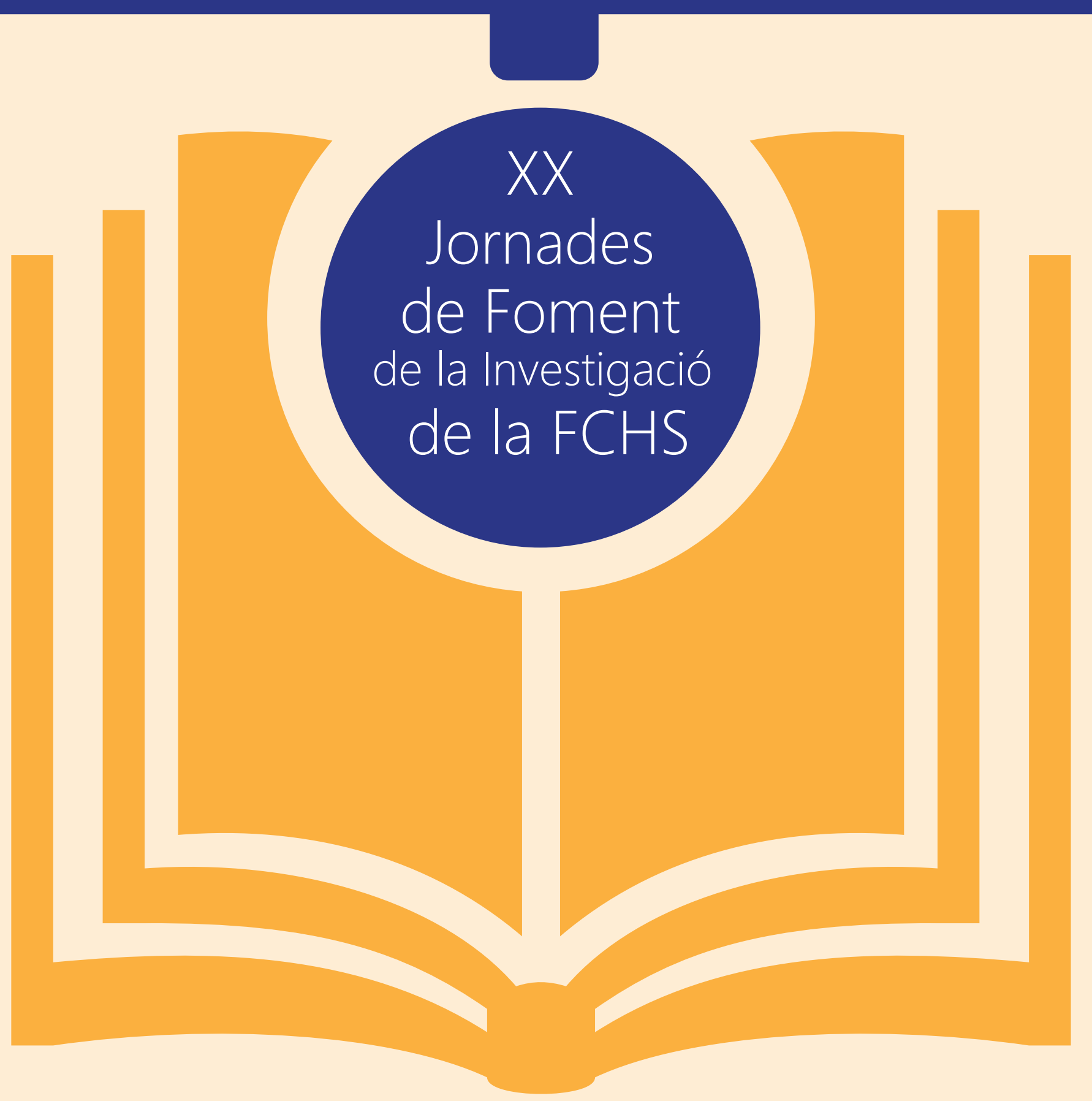




\section{FÒRUM DE RECERCA}

\section{núm.20}

XX Jornades de Foment de la Investigació de la Facultat de Ciències Humanes i Socials
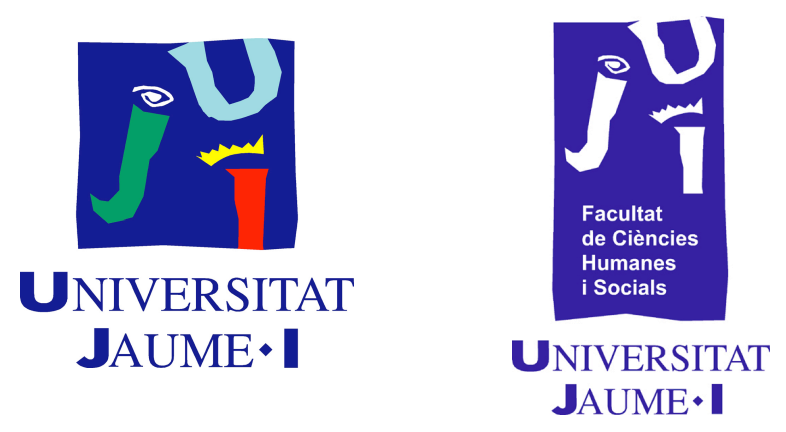

Any 2015 
Fòrum de Recerca és una publicació destinada a divulgar els continguts presentats per I'alumnat durant les diferents edicions de les Jornades de Foment de la Investigació de la Facultat de Ciències Humanes i Socials. El seu objectiu és la publicació d'investigacions novells sobre filosofia, historia, historia de l'art, ciències de la comunicació, educació, filologia i traducció.

Direcció: Vicent A. Querol Vicente, Departament de Filosofia i Sociologia, Universitat Jaume I.

Edició a càrrec de: Vicent A. Querol Vicente, Dep. de Filosofia i Sociologia, Universitat Jaume I.

Maria Medina-Vicent, Dep. de Filosofia i Sociologia, Universitat Jaume I.

Aquest monogràfic ha rebut el suport de la Facultat de Ciències Humanes i Socials de la Universitat Jaume I.

(C) Del text: els autors i les autores, 2015.

(C) De la present edició: Publicacions de la Universitat Jaume I, 2015.

ISSN: $1139-5486$

DOI Número Revista: http://dx.doi.org/10.6035/ForumRecerca.2015.20

DOI Revista: http://dx.doi.org/10.6035/ForumRecerca 



\section{ÍNDEX}

FILOSOFIA

Acercamiento al concepto de publicidad política desde Kant. Juan Carlos Sales. .3

Rigoberta Menchú: aportaciones a la construcción de una cultura para la paz. Anna López i Palomar

¿Puede la persona-masa aspirar a la lucha vital? Marc Salvador Queral

El viejo oficio de pintar en un entorno 3.0. Maria Hernández Reinoso 49

Arte e iconografía maya: la representación de los adornos corporales en las mujeres de la élite. Esther Parpal Cabanes. 61

Arte funerario maya. Maria Simó García ........................................75

Todo el poder para el ghetto. Ariadna Royo Herrera 91

Sueños animados Propuesta para un análisis comparativo entre Alicia en el País de las Maravillas, de Lewis Carroll, y Alice, de Jan Švankmajer". Rosa-Anna Ferrando Mateu ......................................103

Historias de vida como cambio metodológico. Andrés Ortí Buig .......117 Les gelades en la taronja al País Valencià. Roger Ferrando Pérez ......129

La renovación de la escultura figurativa en el cambio de siglo XIX-XX. Adrià Arnau Solsona 151

El concepto de democracia en el carlismo. Josep Miralles Climent i Manuel Martorell Pérez. 163

Un mayorazgo castellano en manos femeninas. Antonio López Amores

¡En este taller no bordamos cojines! David Luis Lopez.. 199

La representación del Allium cepa. Eva Calvo 213

La representación artística de la campaña de Carlos V en Túnez (1535): estado de la cuestión. Antonio Gozalbo Nadal. 
Determinantes que influyen en el rendimiento académico musical en la educación primaria y secundaria. Gustau Olcina Sempere.

El aprendizaje de la música con métodos del aprendizaje cooperativo en la enseñanza universitaria. Gustau Olcina Sempere.

Optimización de la rehabilitación de personas con DCA mediante una intervención psicopedagógica musical. Santiago Díaz Santamaría ....273

La situación del pianista acompañante en España. Luis Vallés Grau ..287

Los docentes de Educación Física en un centro educativo motórico de primaria. Pablo Vilar Renau i Luis Gimeno Moliner. 305

Análisis en la condición física y el rendimiento académico en niñas adolescentes. Mireia Adelantado Renau

Mejora de la calidad del prácticum en la titulación del Grado de Maestro en Educación Primaria. Mikel Peñalver Suller.

Metodología y reflexión del alumnado del Grado de Educación Infantil en sus prácticas externas. Alicia Benet Gil i Lucia Sánchez Tarazana.339

Una historia de vida, una historia de educación. Raquel Corbatón Martínez.... 351

Escola i mas: records i vivències. Andreu Serret Segura 369

Capacitat predictiva de les variables atribucionals sobre el rendiment acadèmic en Matemàtiques. Vicente Molinero Claramunt 381

La escuela en el circo. Un modelo de aula unitaria itinerante. Iris Hervás Jordán i M. Ángeles Llopis Nebot . 395

¿Qué piensan las abejas? Intervención en teoría de la mente en un niño con trastorno del espectro autista en su aula ordinaria. Raquel Casas Rustarazo 413

Avaluació de la competència emocional a través d'una app en un nen amb trastorn de l'espectre autista (nivell 1). Irene Benedito Sánchez, Eloy Soria-Izquierdo i Clara Andrés-Roqueta 431

La comprensió de les intencions comunicatives en adults amb síndrome de Down i altres tipus de discapacitat intel-lectual. Eloy Soria-Izquierdo i Clara Andrés-Roqueta

Estudio de casos: alumnado de altes capacidades con y sin trastorno del espectro autista. Raquel Nieto Garoz, Irene García Molina y Aida Sanahuja Ribés

El pas del temps a Betxí: una experiència de treball per projectes en educació primària. Ángela Moliner Torres i Aida Sanahuja Ribés .....479 
Análisis de una práctica educativa: hacia una escuela intercultural e inclusiva. Aida Sanahuja Ribés

Cambios en las rutinas periodísticas de producción y elaboración de la información en los gabinetes de comunicación de las instituciones locales. Alberto E. López Carrión

Redes sociales y política: El uso comunicativo de Twitter por parte de los principales partidos políticos. Aitor González Bengoechea...

Redes sociales y democracia. Una aproximación al debate sobre una relación compleja. Laura Alonso Muñoz 555

Twitter y comunicación política. Análisis del caso Podemos y la construcción de agenda. Silvia Marcos García.

El periodismo móvil y la creación de contenidos informativos en Internet. El caso de la revista digital Living Palermo. Laura Albiol Soler

Las diferencias del diálogo entre gobierno-sociedad y entre empresasociedad. Augusto Leiva Espinoza

FILOLOGIA

Teaching secondary students ICC through music.

Cristina Mas Marín 615

JClic as a Pedagogical Tool to Increase Students' Mastery of 'Present

Perfect Simple' in English. Sorina Stelea. 635

Más allá del lenguaje. J. Rafael Mesado 651

TRADUCCIÓ I INTERPRETACIÓ 663

Traducció, identitat, subversió. Reflexions cap a una praxi queer de la traducció. Robert Martínez Carrasco i Lourdes Frasequet Porta 663

El color rojo en español. Un estudio de su connotación basado en corpus. Alejandro Teruel Vidal 


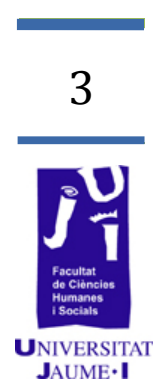

\section{Acercamiento al concepto de publicidad política desde Kant}

Juan Carlos Sales

al189148@uji.es 
El concepto de publicidad política, entendido fundamentalmente como instrumento de crítica política, pretende establecer las garantías de justicia en las acciones e instituciones de cualquier democracia y al mismo tiempo servir de principio regulativo en el campo de lo público. En este sentido, se hará aquí patente cuál es la base filosófica del término, sus diversos modos de aplicación, su alcance y delimitaciones. Para ello se contará con lo expuesto en la obra de I. Kant en su conjunto, en la cual las raíces del concepto se aprecian de forma clara, pero con especial atención a sus escritos políticos, donde desarrolla explícitamente la idea de Publizität.

Palabras clave: publicidad política, razón práctica, medios de comunicación, Sociedad Civil.

\section{Introducción y objetivos}

El concepto de publicidad política puede ser entendido como un mecanismo de legitimación en la forma, actuación y límites de las acciones políticas y de las instituciones públicas que se quieran denominar justas. Es, por tanto, una metodología, un instrumento de tránsito entre los principios éticos (individuales), los cuales se encargarían de mostrar lo moralmente justo y su realización efectiva en las instituciones que conforman una sociedad democrática. $Y$ es, además, la exigencia de una actividad transparente y abierta por parte de las instituciones de todos los niveles (centros sociales, asociaciones cívicas, partidos políticos, parlamento, etcétera) en su empeño por mantener el horizonte moral -en este caso respecto a la legalidad- de tales instancias públicas. Estos dos aspectos básicos se encuentran intrínsecamente relacionados con la asunción de una participación activa de la sociedad civil que irrumpe como nuevo contrapoder; es decir que, a los criterios normativos de legalidad y de transparencia, se une la necesaria y potencial apertura a la participación libre y pública y, también por ello, el establecimiento de un nuevo espacio que sirva de lugar de discusión para tratar los asuntos de interés públicos o comunes.

Considerando a Immanuel Kant como el creador del concepto moderno de publicidad política y teniendo en cuenta la forma en que han influido sus escritos políticos y sociales, se partirá de su obra para analizar de forma detallada todo lo relevante respecto a tal concepto. Este, sin embargo, se deja rastrear a lo largo de todo su legado de forma implícita: desde sus escritos sobre la razón práctica y el derecho, pero también desde los que versan sobre la razón especulativa. La referencia en los escritos kantianos a la libertad (en este caso legal: de reunión, de pensamiento, etcétera), a la necesidad de una discusión pública donde 
confluyan diferentes razonamientos, a mantenerse ávidos en el pensar crítico y autónomo, es constante. La importancia que le da Kant a estos asuntos es máxima, aun cuando se ha considerado a sus escritos políticos -los que sintetizan los recursos anteriormente citados- como escritos menores; más bien al contrario, puede que este sea el objetivo más preciado de la filosofía, la pregunta última que recoja las cuestiones teórica/especulativa, práctica y teológica en el ámbito del estudio del hombre y su medio idealmente político (Gil, 2007). Autores contemporáneos hablan incluso de su filosofía como antropología o como política. ${ }^{1}$

Entrando en materia, se explicitará brevemente la importancia que el filósofo prusiano le ofrece a la legalidad y al derecho (instancias que articulan su teoría política) en tanto que piezas clave en la construcción del camino a una comunidad jurídica justa -aunque la razón nos dirija a una comunidad puramente ética inalcanzable. Este camino será marcado desde los principios morales que, a través de imperativos éticos, funcionarán como base para la posterior plasmación de las leyes en su facticidad. En este punto es donde se posiciona de modo enérgico el concepto de publicidad política en su función de ser guía del tránsito necesario entre las esferas moral y política. Pero como este término no se agota en esa sola acepción, en este trabajo se hará un repaso de las diferentes perspectivas de tan relevante y ninguneado concepto: como principio normativo, como supresión de toda opacidad hacia la sociedad, como espacio teórico y conjunto de crítica social...

\section{El uso político de la razón}

Nuestra época es, de modo especial, la de la crítica. Todo ha de someterse a ella. Pero la religión y la legislación pretenden de ordinario escapar a la misma. La primera a causa de su santidad y la segunda a causa de su majestad. Sin embargo, al hacerlo, despiertan contra sí mismas sospechas justificadas y no pueden exigir un respeto sincero, respeto que la razón sólo concede a lo que es capaz de resistir un examen público y libre.

I. Kant, Crítica de la razón pura, A XII (1781)

Immanuel Kant (1724-1804) inicia un periodo de crítica en el contexto del movimiento ilustrado del siglo XVIII que obligó a aceptar la premisa de que todo lo relevante para la razón humana debía ser expuesto a revisión por parte de un análisis crítico: desde los principios epistemológicos hasta la religión, pasando por la moral y el derecho. El

1. Posiciones de G. Vlachos y H. Saner expuestas por Adela Cortina (Muguerza, 1989: 180). 
conjunto de las tres Críticas se propuso revisar los fundamentos de los conceptos de razón pura especulativos, prácticos y teleológicos. Los temas políticos, referidos en su caso a una condición histórica o empírica, sin embargo, parecían destinados a relegarse a escritos menores 0 irrelevantes filosóficamente, temas que hablan de quaestio facti cuestiones de hecho, meramente empíricas- sin ser remitidos a ningún principio o idea de la razón a priori, esto es, sin aspirar a contar con una cierta validez en su enunciado (Marzoa, 2003: 164). Esto quiere decir que, mientras en un uso teórico-especulativo la razón pura recurre a juicios sintéticos a priori que dan cuenta de la forma universal del conocimiento $y$, de igual modo, la razón pura en su uso práctico se encarga de establecer un principio objetivo y universalmente válido a través de un factum de la razón, etcétera, la teoría política como tal no cuenta para Kant con tales fundamentos apodícticos. ${ }^{2}$

Pero ello no significa que la política no deba ser expuesta a una crítica por parte del tribunal de la razón, sino muy al contrario: quizás deba ser esta la que más sometida esté al juicio estricto, en tanto que 1) no hay un camino objetivo que le otorgue universalidad -ni puede aspirar a ello- sino que sus avances están condicionados por las contingencias históricas con que la experiencia y el tiempo le dotan, y 2) con todo, sigue siendo una pieza clave al erigirse como sustento material en donde desarrollar las demás ciencias y al conseguir llevar a la facticidad las pretensiones de la razón de un bien supremo en el mundo y la consecución de la dignidad humana general -no sólo teórica- establecida por los principios de los derechos humanos (estos sí alcanzados a priori). El peso de pensar lo político es, así, incuestionable; las personas no se conforman sólo mediante las disposiciones puras de la razón sino que son historia, y las actuaciones científicas, religiosas o éticas de cada época no pueden discurrir al margen de la acción y gestión política. La antropología, entendida como el estudio del hombre en torno a sus condiciones empíricamente dadas en un determinado contexto histórico y a las relaciones que este emprende en su socialización, se presenta en Kant como la disciplina que debe responder a una pregunta que engloba las demás actividades de la razón. Tanto el progreso científico como el moral quedan sin sentido si obviamos estudiar al sujeto empírico que las porta. Y la política, como modo de organización humana, es la que procura la situación real y de facto para que se dé tal avance. ${ }^{3}$ Habrá que profundizar, pues, en el sentido exacto que Kant le otorga a lo político y analizar tanto su sustento teórico como las partes que lo componen.

2. Es precisamente la no necesidad de tener que recurrir a la experiencia la que hace avanzar la ciencia de forma a priori con principios universalmente válidos; en cambio, para Kant, la política representa una disciplina que progresa por la propia experiencia, mediante una continua serie de intentos históricos fallidos basados en lo meramente empírico.

3. El propio Kant loa al ilustrado Federico II El Grande como rey impulsor del progreso, la libertad y la tolerancia que permite la emancipación y autonomía del hombre (y, en consecuencia, el desarrollo de todo lo demás: la ciencia, el derecho, las artes...). 


\subsection{Estructuración y objetivos de la política}

Para entender el significado que Kant le da a la política y a lo que concierne a su ámbito de actuación de manera adecuada se han de aclarar varias cuestiones previamente. Antes que nada es necesario tener presente que nos estamos moviendo en todo momento en el terreno de lo práctico, no de lo teórico-especulativo; esto es, que la razón (Vernunft) está procediendo en el campo de la actuación, no en el de la cognoscibilidad-desde la perspectiva del qué debo hacer, no desde la del qué puedo conocer. Esto significa que, en un primer momento, se establecerán las pautas del obrar moralmente correcto por principios 0 , lo que es lo mismo, entender cómo la determinación del objeto de la voluntad debe estar inmediatamente sometida a la misma ley práctica. Es este un primer paso ético que da lugar a la aparición del derecho, el cual se fundamenta en los principios morales o, por decirlo con Adela Cortina, es la prolongación doctrinal de lo ya establecido en la Crítica de la razón práctica. $^{4}$

En el derecho se desarrollarán los principios prácticos que se han obtenido a partir de esa crítica, pero esto no significa que un campo sea irreductible al otro: en el terreno ético, la actuación responde a un móvil puramente moral, subjetivo, que coacciona internamente; en cambio, en el campo del derecho, tal coacción es externa y el móvil de la acción puede determinarse sin responder a la moralidad. La acción puede ser, en última instancia, la misma, pero el móvil que se sigue para actuar definirá si esta acción ha sido configurada conforme a la moralidad (ética) o a la mera legalidad (derecho). Es sobre esta legalidad, basada en el derecho y la coacción externa, en la que surge la política para Kant. Es decir, que hemos pasado de unos principios éticos que estructuran y dan sentido moral a la legalidad para posteriormente transitar de una metafísica del derecho (que también se abstrae de todas las condiciones de la experiencia) a los conceptos de la teoría política, aplicando esos conceptos a los casos empíricos de organización social e institucional (Kant, 2010: 193).

Hasta aquí el proceso que constituye la base de la teoría política en su fundamentación moral/legal; cabrá preguntarse ahora cuál es el sentido mismo de la política en Kant. Su principal cometido es, como hemos visto, la aplicación del derecho: trasladar los principios extraídos de la teoría al terreno de lo fáctico y articular esos principios en una determinada sociedad de modo efectivo, proceso mediante el cual posibilita la constitución de una comunidad jurídica. ${ }^{5}$ En palabras de Dulce María Granja, Kant comprende la política tanto como una filosofía del derecho como del Estado que se funda «sobre los principios morales de la coexistencia humana» (2010: 228). Es esta una muy breve aclaración de la estructuración y fundamento de lo moral y lo político en Kant, pero

4. Estudio preliminar a La metafísica de las costumbres (1994).

5. Soy consciente de que hay otras muchos otros temas a tratar en este terreno: el tema de la insociable sociabilidad, su polémica del contrato social, la cuestión teleológica y el llamado "fin final», etcétera. Son estas, sin embargo, cuestiones poco relevantes para el objetivo de este trabajo. 
suficiente como para entender correctamente el concepto de publicidad política (y que, aun perteneciendo este a la política, procede tanto desde la moralidad como desde la legalidad, como veremos más adelante).

\section{De la moralidad a la política}

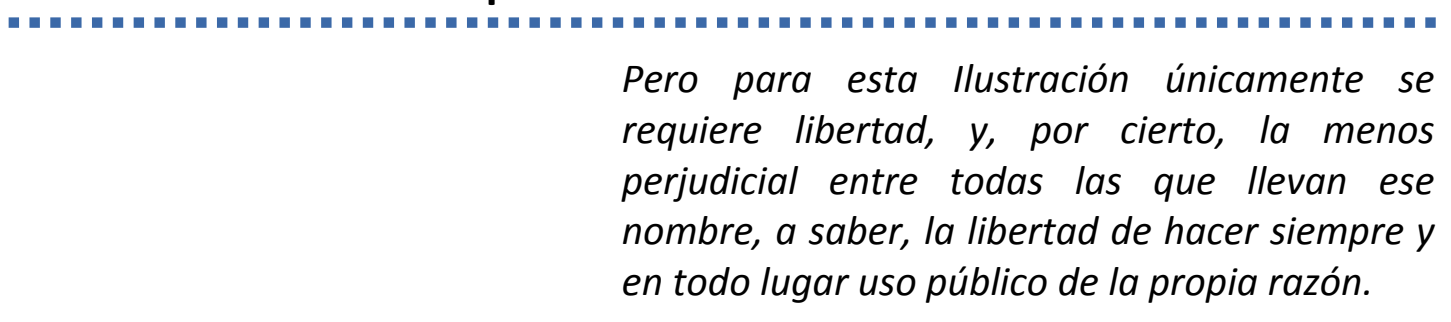

De lo dicho en el apartado anterior se siguen dos temas que se desenvolverán aquí: la importancia de la crítica y su ampliación en la política. Estos dos temas, por tanto, se van a desarrollar de manera conjunta, y se estudiará su combinación necesaria al servicio de aquello que Kant había denominado una sociedad justa (o sea, una comunidad jurídica establecida). ${ }^{6} \mathrm{Si}$ entendemos que esta sociedad y sus características sólo pueden darse en un estado de democracia, se hace comprensible a la vez la permanente necesidad de un profundo examen de los diferentes ámbitos y actores que la componen. La democracia es concebida de este modo como un sistema político y social basado en un poder limitado por el propio pueblo; democracia como modo de gobierno que se basa en la necesaria representación de los ciudadanos, en el sentido republicano moderno. Kant es tajante en este sentido al invocar una constitución republicana como la instancia que institucionaliza los principios democráticos de libertad, igualdad y sometimiento a la legislación, así como la separación de poderes (legislativo, ejecutivo y judicial); es esta constitución la que emana, además, del propio pueblo y la que dota por tanto de significación las normas jurídicas (Kant, 2010: 148-9).

Para el filósofo prusiano es importante entender la carga moral que supone el estar sometido a tal constitución, pues es la que nace del concepto de derecho, como hemos ido viendo hasta ahora. Esta dimensión moral es la que obliga subjetivamente al ciudadano a comportarse como tal y a implicarse en los asuntos de su propia sociedad. Aquí ya no se es un mero súbdito al servicio de unos intereses incuestionables, sino que los ciudadanos, organizados en sociedad civil, ${ }^{7}$

6. Obvio de nuevo una parte primordial en la consecución de un fin imperativo para el hombre como es la necesaria adaptación de la felicidad a la vida moral. Aquí no presenta relevancia para la parte de justicia política estrictamente, pero en Kant -contrariamente a lo que se suele pensar- la persecución de una vida feliz, para nosotros y para los demás, ocupa un lugar central en sus escritos (Kant, 2011: 221, 232, 244).

7. Entiendo el sentido de sociedad civil, siguiendo a Feenstra y García-Marzá, como «concepto complejo que pretende dar razón de ámbitos de interacción donde las capacidades de los sujetos para actuar y organizarse no depende directamente del Estado» (2008: 7). 
estarán dispuestos a debatir sobre todo lo relacionado con la comunidad y analizarán con inteligencia e integridad las diferentes facciones de esta. Este principio es intrínseco a la filosofía política kantiana vertida desde la óptica jurídica, y asimismo el ciudadano moral (dotado de libertad práctica) no es sólo aquel al que se le aplica una determinada legalidad sino el que es al mismo tiempo colegislador del derecho al que está sometido. Esta esencial interacción moral entre la sociedad y su Estado se muestra como categoría clave en la constitución del ciudadano del mundo kantiano y rompe a la vez con el estatismo $-\mathrm{y}$ muchas veces también paternalismo- del que hacían gala precedentes teorías políticas contractuales.

Como se aprecia, el espíritu crítico que Kant había concedido tanto al campo especulativo como al moral no se ha agotado ahí, sino que sigue siendo válido para los asuntos que afectan al modo de organizarse, esta vez constituyéndose como participación social -o lo que es lo mismo, participación ciudadana. El trabajo de crítica propio de la llustración sigue vertebrando el proyecto kantiano $y$, en relación a la política, esto comporta poner a exposición pública todo aquello que está en contacto con los asuntos de la comunidad (lo público o lo común). El criticismo continúa encarnando el espíritu del método que otorga a la razón la herramienta para validar la pretensión de justicia de una determinada actuación o institución pública, por ejemplo. Con esto llegaríamos a la conclusión de que todos los aspectos políticos, institucionales, sociales, etcétera, deberán hacerse públicos ante los ciudadanos para su libre examen mediante la razón ordinaria.

\subsection{Sentido común y discurso}

Para terminar de adentrarnos en los aspectos fundamentales de la teoría kantiana que sirven a este trabajo, cabe explicar un último apartado. Para ello es importante advertir que la razón humana es entendida en Kant como un "sentido común». Todos y cada uno de los ciudadanos, que estén en disposición de emplear todas las facultades del juicio, tienen igual capacidad de entendimiento o de uso de razón. El escrutinio de lo político puede hacerlo cada hombre sin distinción, aun aceptando las diferentes aptitudes que se sobreentienden con respecto a la naturaleza y la genética individual, porque en cada hombre se encuentra ya un sensus communis; este "sentido» es el mismo entendimiento común humano. ${ }^{8}$ Lo que se quiere evidenciar con esto es que no es útil realizar una crítica desde parámetros parciales o dirigida sólo por una élite intelectual, sino que hasta el más vulgar (vulgare) entendimiento dispone de la suficiente capacidad como para someter a crítica aquello que afecta a la sociedad, puesto que este tiene la capacidad de poder pensar por sí mismo y a la vez de estar en

8. «Pero por sensus communis ha de entenderse la idea de un sentido que es común a todos, es decir, de un Juicio que, en su reflexión, tiene en cuenta por el pensamiento (a priori) el modo de representación de los demás para atener su juicio, por decirlo así, a la razón total humana (...)» (Kant, 2007: 331). 
condiciones de ponerse en el lugar de cualquier otro ${ }^{9}$ (Kant, 2007: 332). En su artículo "Pensar por sí mismo y publicidad», Margin Ruffing concede incluso a este sentido común connatural a la humanidad un puesto decisivo: ser la condición necesaria mediante la cual puede darse la publicidad misma (2013: 75).

Además, esa "razón compartida» aparece como la posibilitación de la puesta en común de argumentos y la esperanza de encontrar soluciones conjuntas a conflictos necesariamente sociales. Sobre este supuesto se apoya el principio procedimental de la ética discursiva en su intento de hacer dialógicos los principios formales deontológicos y a este respecto comenta Karl-Otto Apel (Cortina y García-Marzá, 2003: 28):

Todos los seres capaces de comunicación lingüística deben ser reconocidos como personas, puesto que en todas sus acciones y expresiones son interlocutores virtuales, y la justificación ilimitada del pensamiento no puede renunciar a ningún interlocutor y a ninguna de sus aportaciones virtuales a la discusión.

Sin entrar ahora a explicar detalladamente los aspectos de la ética discursiva, conviene resaltar que esta filosofía pretende desentrañar la validez moral del discurso través de las estructuras comunicativas. Aquí interesa remarcar la idea central del interlocutor válido, o persona reconocida como participante en el proceso comunicativo precisamente por compartir el sentido racional común, por el cual sería reconocido como válido. ${ }^{10}$ Es decir, que sólo pueden ser válidas aquellas normas sobre las cuales podrían estar de acuerdo los participantes del discurso de forma a priori. Durante todo el proceso se pone de relieve la igualdad de los participantes y su reconocimiento recíproco (reconocer al "otro», ponernos en su lugar), lo que posibilita la relación intersubjetiva necesaria para pretender la validez moral del discurso (García-Marzá, 1992: 43).

\subsection{El concepto de publicidad política}

El concepto de Publizität ${ }^{11}$ aparece esparcido por varias obras del corpus kantiano, aunque es explicado de modo preciso en su escrito Hacia la paz perpetua (Zum ewigen Frieden), concretamente en sus apéndices finales. Pero teniendo en cuenta todo lo que ha sido expuesto aquí hasta ahora, se puede decir que la procedencia del término, lo que constituye la idea que después se desarrollará, está presente de modo explícito en casi todos sus escritos anteriores. No hay que olvidar que

9. Un «otro» no en sentido empírico, haciendo referencia a una persona o una comunidad concreta, sino en el sentido trascendental de un interlocutor ideal.

10. Aunque se debe advertir que en tales procesos de la ética del discurso sólo participan aquellos interlocutores que -además de contar con la razón común- son a la vez afectados por una situación normativa concreta, y esto último es también condición precisa de su validez como tales (Cortina, 2003: 29).

11. La terminología alemana distingue entre Publizität/Werbung lo que en español se traduce por la palabra 'publicida'. La primera de ellas, sobre la que versa este trabajo, es el concepto filosófico-político que se desarrolla en el apartado actual; la segunda posee un significado relativo simplemente a la actividad comercial. 
Hacia la paz perpetua es uno de los últimos trabajos de Kant, publicado en 1795; pues bien, podría decirse que al menos desde el comienzo del periodo crítico, iniciado en 1781 con la publicación de la Crítica de la razón pura, hay ya toda una serie de conceptos que subyacen a la idea de una razón pública y libre que camina de la mano del criticismo. Para evidenciar esto hay que recurrir a las obras escritas en este periodo; se observa en los prólogos o notas que, fuera de la temática concreta del opúsculo -epistemológica, moral, etcétera-, el conjunto general responde al interés de crear una sociedad o comunidad mejor y más justa como el fin de nuestra misma naturaleza (Kant, 2010: 25, 39). Y la consecución de una comunidad justa mediante la política comporta, a su vez, el medio por el cual el hombre puede alcanzar su realización en tanto que sujeto moral.

Con el objetivo de esclarecer un poco más el camino que da sentido a la aparición de la publicidad política, creo necesario puntualizar que, según Kant:

1. No hay ningún conflicto entre la moral -base de la teoría del derecho- y la política -aplicación de dicha teoría. No hay un conflicto como tal, pues, entre teoría y práctica. De hecho sería una contradicción (Widerspruch) asumir que las leyes morales, que son regulación de la praxis en su esencialidad, no pueden realizarse en el mundo real; pues en este caso perderían todo el sentido.

2. Cuando se produce algún conflicto en la aplicación de la teoría en la práctica, se ha incurrido en una desviación de la idea teorética en la experiencia real; de este modo ha fallado la aplicación de ésta (puesto que una ley moral teórica resulta clara e inequívoca para la razón común) por parte de quienes detentan el poder y se encargan de dar ese determinado paso. Dos ejemplos clarificadores de esto que el propio Kant da son: 1) el jurista como tal se encarga de aplicar las leyes que se dan sin investigar si necesitan mejora (pudiendo haber algún principio no moral en ellas); y 2) el gobernante que por su parte las toma y puede hacer de ellas un uso egoísta con vistas a su propio beneficio.

3. La solución a este problema común radica en la capacidad crítica e imparcial de los filósofos (entendidos como teóricos de la moralidad y el derecho). Los filósofos no deben, con todo, convertirse ellos mismos en políticos, ${ }^{12}$ pues es el mismo poder el que «daña inevitablemente el juicio de la razón» (Kant, 2010: 169). Así, la premisa fundamental para mantener saludable el estado de una democracia justa es, en

12. Es, de nuevo, el método trascendental kantiano el que aquí se refleja en tanto que no se toma parte en, ni desde, un bando o perspectiva de la «disputa», sino que llama a mantenerse en un tribunal independiente de la contienda a la que se juzga -desde fuera-, única vía por la cual se consigue la imparcialidad necesaria como para progresar del modo más objetivo (Kant, 2012: 9-10). 
primer lugar, permitir a los teóricos expresar sus denuncias y críticas públicamente.

Resumiendo esta última parte, no hay conflicto como tal entre moral y política de modo objetivo, pero sí subjetivamente (debido al egoísmo por parte de quien ostenta cualquier tipo de poder). En palabras de Kant (2010: 180):

la verdadera política no puede dar un paso sin haber antes rendido pleitesía a la moral, y, aunque la política es por sí misma un arte difícil, no lo es, en absoluto, la unión de la política con la moral, pues esta corta el nudo que la política no puede solucionar cuando surgen discrepancias entre ambas.

Alguna de las "soluciones» a tal problema moral, hasta que los gobernantes utilicen su poder de forma estrictamente acorde a la justicia, será la continua vigilancia de los asuntos públicos y ahí entra finalmente en acción la publicidad política.

Una última precisión al respecto: en Kant no se encuentra, como se deduce de lo dicho hasta ahora, una distinción entre la ética y la política en un sentido maquiavélico por el cual la política no debe responder necesariamente a la moral, argumentando que son ámbitos de acción diferentes, de manera que es aconsejable incluso que el gobernante sepa controlar al pueblo con técnicas como la mentira, el secretismo, etcétera, pues son estos instrumentos los que proveen de éxito a todo gobierno (Luban, 1988: 155). En Kant la política es el continuo intento de realización de las mismas ideas morales y que sea el gobernante el que se desvíe de los cauces normativos por intentar aproximarse cada vez más al ideal moral -engañando, mintiendo, al fin y al cabo no respondiendo a la objetividad ética- es un puro sinsentido teórico. Por tanto la política no se deja de suyo reducir al campo instrumentalizante de la razón (el cómo actuar según la mera prudencia, prevaleciendo la consecución de un fin cualquiera sobre los medios) sino que debe responder siempre a la razón práctica y al campo normativo basado en los principios morales.

\subsection{Las formulaciones del término}

Para esta parte del trabajo se van a analizar los aspectos precisos de la publicidad política desde el trabajo de García-Marzá (2012). En su artículo "Kant's Principle of Publicity» se presentan hasta tres formulaciones distintas de este concepto atendiendo a su determinada aplicación; representa por ello un concepto amplio y polifacético que precisa de una delimitación de sus partes. Antes de continuar, debe indicarse que estamos manejando un concepto que constituye ni más ni menos que la forma del derecho público, ${ }^{13}$ y que responde por ello a la pretensión de legitimidad de lo que se quiere denominar justo al ser él

13. La noción de forma es entendida aquí como la constitución o esencia misma de la justicia, la que le otorga validez a priori -sin materia; es el «aquello en lo cual consiste» y, por tanto, la propia condición de posibilidad del derecho (Marzoa, 1989: 24-25). 
mismo el garante de la pretensión jurídica (Kant, 2010: 181). Pues bien, en el segundo apéndice de Hacia la paz perpetua se encuentran un par de citas que Kant desvela como las fórmulas explícitas de la publicidad política, a saber: "son injustas todas las acciones que se refieren al derecho de otros hombres cuyos principios no soportan ser publicados" y «todas las máximas que necesitan la publicidad (para no fracasar en sus propósitos) concuerdan con el derecho y la política a la vez» (Kant, 2010: 181-186).

La primera formulación del término es acaso la más conocida o la que se suele estudiar de forma más recurrente. Se trata de un principio que enfrenta las acciones políticas al examen de la publicidad para verificar su posible condición de injusticia. Cabe advertir que cuando hablamos de examinar la justicia de las acciones políticas no se está evaluando a la acción empírica misma, sino -de nuevo- a su forma, que en este caso representa la máxima subjetiva que subyace a toda acción posible. ${ }^{14}$ Además, se requiere aquí que la máxima de tal acción sea justa, pero, como se explicó en un apartado anterior, no por mor de la ley práctica (lo que atañe a la moral) sino simplemente conforme a ella. Teniendo en cuenta esto, se puede decir que esta formulación del principio de publicidad es una idea de la razón, hipotética y enteramente formal, que abstrae todo lo empírico de la acción con el fin de comprobar su validez jurídica. Es, en definitiva, un imperativo categórico, pues procede con universal validez y necesidad, pero no pertenece al campo de lo ético sino que cae dentro del ámbito de la política y por ello no se refiere tanto a la libertad personal o individual como a la libertad y actuación de la comunidad (García-Marzá, 2012: 109). Como se aprecia, es esta una formulación a modo de herramienta en la que se juzga la posibilidad de que una máxima sea injusta, pero no de que esa misma máxima pueda ser, de hecho, justa; es un principio puramente negativo en este sentido, que no nos sirve para determinar lo que es justo sino para descartar lo injusto.

En la segunda fórmula de la publicidad - «todas las máximas que necesitan la publicidad (para no fracasar en sus propósitos) concuerdan con el derecho y la política a la vez»- podemos rastrear en cambio un sentido positivo del concepto, recordando lo que se dijo de que todo ciudadano es, por el hecho de serlo, al mismo tiempo colegislador del Estado de derecho. Esto significa que se requiere del consentimiento por parte del ciudadano del sistema de leyes y políticas que se establece sobre la sociedad. Se trata ahora de un escrutinio continuo de las acciones e instituciones del ámbito público que nos afectan, las cuales deben ajustarse a la idea -compartida- de derecho aras de conseguir nuestra aceptación como miembros colegisladores. Por ello esta formulación, además de transparencia, busca principalmente el acuerdo

14. Se trata de la misma distinción establecida para la moral en la Fundamentación para una metafísica de las costumbres, donde se sostiene que "una acción por deber tiene su valor moral, no en el propósito que debe ser alcanzado gracias a ella, sino en la máxima que decidió tal acción» (Kant, 2008: 74). 
mediante la participación abierta de los ciudadanos en torno a la justicia y su institucionalización.

A este respecto se debe leer con Luban (1988: 156) que el concepto de publicidad «no es sólo una proposición de la moralidad, sino que además es también un principio de diseño institucional». Una acepción positiva, como vemos, y que apela al consenso de los ciudadanos pero que no ha sido explotada en sus consecuencias como sí lo ha sido la formulación negativa. Cabe resaltar que lo que aquí se pone en juego no es un dispositivo que sirva para describir de modo histórico lo que han sido y son las instituciones existentes -asunto que también deberá ser objeto de análisis- sino que por este medio se trata de cuestionar su validez, verificar los términos de justicia que son condición de aparición de tales instituciones. No es por tanto una teoría de las instituciones empíricas sino más bien una teoría de la institucionalización (GarcíaMarzá, 2012: 97).

Hasta aquí dos formulaciones de este concepto, dos formas de ver un mismo principio moral. Algunas características intrínsecas a la publicidad política, como la crítica, la transparencia o la necesidad de consensos, nos conducen a dos apartados que surgen como correlatos destinados a finalizar o encauzar tales presupuestos teóricos: uno es la comunicación de la que me encargaré en la siguiente sección-y otro es la confianza. En la praxis cotidiana actuamos de facto asumiendo unos comportamientos o actuaciones que se dan en la vida real. De hecho, actuamos como si las premisas más básicas de la convivencia se fueran a dar inequívocamente; en este "como si» se erige el concepto de confianza (García-Marzá, 2011: 105). Por otro lado, cuando se habla de permitirnos entrar en un intercambio franco de opiniones con la intención de configurarnos una posición ante un determinado conflicto y nos vemos autorizados a creer en el éxito del futuro proyecto debido a su solvencia moral, estamos depositando una confianza en el "otro» con el fin de resolver un acuerdo; y si los ciudadanos respaldan la existencia de una institución justa, si se le da el "visto bueno» moral, se está automáticamente dando credibilidad a ese proyecto y por tanto se puede confiar en él.

La publicidad juega también, así, el papel de eliminar la desconfianza (Mißtrauen) de aquellas situaciones en las que se busca un compromiso sincero y transparente, tanto dentro de la misma sociedad civil como con respecto a los organismos institucionales. Esta es una perspectiva que aúna la primera formulación de la publicidad política, en calidad de aseguradora de unos mínimos éticos, y la segunda, como necesidad de entendimiento mutuo y razonamiento compartido. Esta tercera formulación del término surge, pues, de las dos anteriores, y es la que avala el compromiso social y por el cual se puede llegar confiar realmente en lo público. En palabras de García-Marzá (2012: 113): «[w]ith this formulation Kant stresses that publicity is a condition of posibility for 
producing the necessary trust to support the credibility or legitimacy of all social order». ${ }^{15}$

\subsection{Publicidad y razón comunicativa}

Un aspecto que ha aparecido a colación de lo que se ha explicado hasta ahora y que me parece de una importancia capital es el papel de la comunicación. Es así porque cuando hablamos de los ítems de la publicidad política, como la transparencia, una fuerte opinión pública y, especialmente, el intercambio libre de argumentos acerca de un tema social cualquiera -como el hipotético ideal de justicia que deben cumplir las instituciones- estamos al mismo tiempo ocupándonos de proveer vías de comunicación entre sujetos (sociedad civil), y entre estos y los organismos públicos que componen el Estado. La comunicación es, en todos sus aspectos, una pieza clave de la publicidad política, en unos casos porque los ciudadanos son conocedores de la acciones de la esfera pública, debidamente sometidos a crítica, a través de diferentes medios de difusión; en otros casos, la publicidad promueve la instauración de un espacio público dedicado al debate y por ello mismo la comunicación se convierte en su base indispensable. Hay, pues, una conexión intrínseca entre publicidad y comunicación, que atiende a la relación natural de la política definida como un ámbito más de la esfera pública cuyos asuntos deben ser de hecho anunciados a quienes la constituyen $y$ posteriormente debatidos. Se observa a este respecto la importancia de la comunicabilidad, sin la cual no podrían entenderse términos como «publicidad» o «lo público» (Ruffing, 2013: 79).

En la filosofía kantiana queda claro que existe la idea de la razón como comunicación -o razón pública- porque, si se sigue el hilo que nos ha traído hasta este punto, el proceso dialéctico en la comunidad jurídica aparece como guía para un incesante mejor futuro del hombre y la sociedad. Toda operación política que se pretenda justa sólo puede verse refrendada cuando es dotada de validez por la razón comunicativa, esto es, por el conjunto del pueblo abastecido con su sensus communis, habiendo debido ser antes forzosamente publicitada. La aceptación o el rechazo de determinadas políticas e instituciones atendiendo a su justicia se llevará a cabo tras la puesta en común de opiniones abiertamente expuestas, a través de la acción comunicativa intersubjetiva. Habiendo explicado esto, quedaría por señalar qué condiciones hacen válido el espacio de discusión, o dicho de otro modo, qué presupuestos posibilitarían la estancia dialéctica del debate riguroso y válido.

15. "Con esta formulación, Kant recalca que la publicidad es una condición de posibilidad para producir la confianza necesaria a fin de sostener la credibilidad o legitimidad de todo orden social». 
El objetivo de este trabajo ha sido analizar el concepto de publicidad política, rastrear sus orígenes y entender su aplicación. De forma general, se han tenido presente a lo largo de toda esta exposición las definiciones intrínsecas al término, aquello que constituye su esencia. En primer lugar, se ha planteado la publicidad política como una herramienta que, a modo de transición entre los principios éticos y los estatutos del derecho, puede legitimar las acciones y decisiones de las instituciones públicas o sociales. De este modo contribuye como elemento básico de cualquier teoría de la institucionalización y ayuda a reconocer la validez moral de las organizaciones.

Por otro lado, la publicidad se ha presentado como una «manera de actuar», un principio regulativo por cuanto exige una actitud de transparencia no sólo desde instancias políticas, sino también desde las diferentes organizaciones -públicas o privadas- y hasta en los procesos de diálogo en los que se persiguen unos resultados racional y moralmente consensuados. Finalmente, la publicidad encuentra sentido también como apertura hacia el debate y la promoción, acompañada del derecho a la información veraz, de la actividad crítica especialmente en la sociedad civil e instituciones públicas.

Así pues, la publicidad política viene a significar, de modo general, tanto metodología política y moral como exigencia de transparencia e información y posibilitación de participación pública. Para el acercamiento histórico y etimológico del concepto de publicidad política me he servido de su creador moderno, Immanuel Kant. Además, gracias a la atemporal relevancia que poseen sus escritos políticos, los he utilizado convenientemente como base teórica misma sobre la que emerge el resto del trabajo. Desde aquí he mostrado cómo Kant da cuenta del principio de publicidad, desde qué espacios lo extrae (razón práctica) y cómo es un elemento indispensable de la filosofía del derecho para el correcto funcionamiento de la política. Y se ha hecho patente cómo, a partir de este punto, se han venido desarrollando todas las demás partes de este trabajo: sentido común o general, ideal ilustrado, razón comunicativa o exigencia moral son conceptos que han copado lo escrito aquí y que se han explicado detalladamente.

Creo que el concepto de publicidad política y su aplicación en la vida social contemporánea responden a una actitud de tender a mejorar la sociedad como comunidad jurídica, a recobrar la fe en el sistema político y social, a restablecer la superioridad de la democracia frente a los poderes fácticos. Este trabajo es asimismo un llamamiento hacia ese progreso. De este modo, se tendrá al menos la esperanza de poder revertir la actual situación de desafección hacia lo político. Lo que la sociedad se juega con todo ello es demasiado importante como para dejarlo en manos de la indiferencia; demasiado valioso "como para que no tenga que ser recordado de nuevo al pueblo en ocasión propicia o en los momentos de crisis» (Kant, 2010: 31). 


\section{Bibliografía}

Arreola, E. (2012): «La política y los mass media en la globalización», Investigación Universitaria Multidisciplinar, no 11, Universidad Nacional Autónoma de México.

BeRnAL, D. (2010): La publicidad política y el espacio público: una revisión del problema a partir de Rawls y Habermas (Tesis Doctoral), FLACSO, México DF.

Cortina, A. y D. GarcíA-MarzÁ (Ed.) (2003): Razón pública y éticas aplicadas, Tecnos, Madrid.

DAvIS, K. (1991): "Kantian "Publicity" and Political Justice», History of Philosophy Quarterly, no 8, University of Illinois Press.

Feenstra, R. (2010): Sociedad Civil: Democracia monitorizada y medios de comunicación en John Keane (Tesis Doctoral), Universitat Jaume I, Castelló de la Plana.

Feenstra, R. y D. García-Marzá (2008): "Sociedad civil: Una perspectiva crítica», Recerca, no 8, Universitat Jaume I, Castelló de la Plana.

García-MARzÁ, D. (1992): Ética de la justicia, Tecnos, Madrid.

- (2011): Ética empresarial. Del diálogo a la confianza, Trotta, Madrid.

- (2012): «Kant's Principle of Publicity», Kant Studien, no 103, De Gruyter, Berlin/Boston.

GIL, J. (2007): Aproximación antropológica a la filosofía de la historia en Kant, Forum de Recerca, Castelló de la Plana.

GonZÁLEZ, E. (1996): «Imagen social de la empresa: Responsabilidad social y toma de decisiones empresariales», Papeles de ética, economía y dirección, no 4, EBEN, España.

GranjA, D. (2009): Cosmopolitismo, Anthropos, Barcelona.

- (2010): Lecciones de Kant para hoy, Anthropos, Barcelona.

GutiÉRREZ-RuBí, A. (2011): La política vigilada, UOC, Barcelona.

Habermas, J. (2000): Aclaraciones a la ética del discurso, Trotta, Madrid.

KANT, I. (1977): Zum ewigen Frieden, Suhrkamp, Frankfurt am Main.

- (2005): Metafísica de las costumbres, Tecnos, Madrid.

- (2007): Crítica del juicio, Porrúa, México.

- (2008): Fundamentación para una metafísica de las costumbres, Alianza, Madrid.

- (2010): Ensayos sobre la paz, el progreso y el ideal cosmopolita, Cátedra, Madrid. 
- (2011): Crítica de la razón práctica, Alianza, Madrid.

- (2012): Crítica de la razón pura, Taurus, Madrid.

KLEIST, E. (2005): "The Principle of Publicity as Kant's Response to the Intrinsic Indeterminacy of the Highest Good», Cuadernos de Anuario Filosófico, no 173, Universidad de Navarra.

LUBAN, D. (1988): "The Publicity Principle», The Theory of Institutional Design, Cambridge University Press, Cambridge.

MARZOA, F. (1989): Releer a Kant, Istmo, Madrid.

- (2003): Historia de la Filosofía II, Istmo, Madrid.

Muguerza, R. (1989): Kant después de Kant, Tecnos, Madrid.

RAWLS, J. (2006): Teoría de la justicia, FCE, México.

RuffiNG, M. (2013): «Pensar por sí mismo y Publicidad», Ideas y Valores, no 62, Universidad Nacional de Colombia, Colombia.

SPLICHAL, S. (2002): «The Principle of Publicity, Public Use of Reason and Social Control», Media, Culture \& Society, no 24, Londres.

THOMAß, B. (2011): WikiLeaks and the Question of Responsibility Within a Global Democracy, Centre for European Studies, Bruselas. 


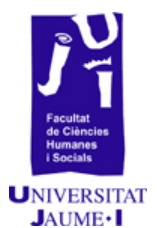

\section{Rigoberta Menchú: aportaciones a la construcción de una cultura para la paz Tikb'al Utziil, que significa 'sembrando la paz'}

Anna López i Palomar ann.lopa92@ggmail.com 
Entre 1962 y 1996 una cruenta guerra civil sumía a Guatemala en consecutivas olas de extrema violencia. Una guerra que había estallado tras muchos años de silencio y opresión al pueblo indígena. Rigoberta Menchú había nacido en 1959, el genocidio de la guerra es el contexto en el que le tocó vivir hasta los 21 años cuando tuvo que exiliarse a México. Todos estos acontecimientos, ligados a la triple desigualdad que marca su persona -de clase, etnia y género- moldearán su pensamiento y le harán sentir su lucha de clase, unida a la lucha por la supervivencia cultural y étnica, una lucha que ya no abandonará a lo largo de su vida y que aglutinará en su propuesta de ética para la paz, cuya finalidad sea construir una cultura de paz que dé valor a la interculturalidad.

El objetivo de este análisis no sólo es conocer la perspectiva de Rigoberta Menchú, sino también recalcar esa triple desigualdad que sufre y mostrarla como teórica de la filosofía para la paz. Para alcanzar mis propósitos, la metodología que emplearé será la investigación y el análisis del pensamiento de la autora a través de sus propios textos y la contextualización de su pensamiento con el de otros y otras autoras.

Las conclusiones del estudio se centran en la necesidad de una reorganización social en la que se respeten todas las culturas sin mermar los cuerpos por creencias, costumbres, clase, etnia o género, de modo que se cree una cultura para la paz.

Palabras clave: interculturalidad, indígena, cultura de paz, reconocimiento, genocidio.

\section{Introducción}

La razón que da inicio a este estudio es el interés por la construcción de una cultura para la paz desde un marco intercultural y ecológico. Partiendo de la visión de Rigoberta, la paz es el reconocimiento a todas las culturas, pero también el reto medioambiental al que nos impulsa un mundo globalizado: Una humanidad sin conflictos construidos ha de convivir en un espacio natural conciliado con los actos humanos. No obstante, la figura de Rigoberta Menchú Tum nos pone frente a tres aspectos fundamentales para las Humanidades y los estudios interculturales: la clase, la etnia y el género; estos tres aspectos -más el histórico- marcarán su conciencia y, por ende, su pensamiento.

\section{Objetivos}

El objetivo que se persigue es el de recalcar la figura de Rigoberta Menchú Tum como teórica de la filosofía para la paz a través del estudio de aspectos como su ética para la paz en acción, favorable para la 
preservación del medio ambiente y la construcción y el mantenimiento de culturas para la paz desde la realidad maya-quiché, por la cual también se conocerán algunos de los principales acontecimientos de su vida que han influido y marcado en su pensamiento.

\section{Material y método}

El objeto de estudio, como bien ya se ha dicho, son las aportaciones del pensamiento de Rigoberta Menchú Tum para la construcción de una cultura de paz. Hemos llegado hasta aquí a través de las publicaciones de la propia autora, como bien son: Me llamo Rigoberta Menchú y así me nació la conciencia (1997) y Rigoberta: la nieta de los mayas (1998), libros que nutren el estudio. Así mismo, cabe añadir que se ha recurrido a otras y otros autores como Ulrich Beck, Rosalía Torrent, Vicent Martínez Guzmán o Charles Taylor, con el fin de establecer paralelismos y apoyar en estas concepciones ideas de la autora que se estudia. En definitiva, la metodología empleada en la realización de este trabajo ha sido la investigación y el análisis del pensamiento de la propia autora a través de sus textos, conjugándolo con las ideas de otros y otras autoras.

\section{Resultados}

\subsection{Vida de Rigoberta Menchú}

Rigoberta Menchú nació el 9 de enero de 1959, en Chimel, una pequeña aldea que pertenece a San Miguel de Uspatán, dentro del departamento de El Quiché. La maya-quiché crece entre la pobreza, la explotación, la discriminación y otras muchas injusticias sociales; el contexto en el que le tocó vivir le fue alimentando un espíritu crítico y luchador que pronto le haría tomar conciencia de cuál es su lugar en la sociedad guatemalteca: es mujer, campesina e indígena. Los quichés son un pueblo indígena de Guatemala sumergido en la violencia estructural, pues aunque la mayoría de la población guatemalteca es de origen indígena son estos los más pobres, un factor que les impide desarrollarse y cubrir necesidades tan básicas como una vivienda digna o el acceso a la educación. Sobre El Quiché, Eduardo Galeano dice así (Menchú, 1998 b: 7):

una tierra desgarrada por el ejército, violada por los mercaderes, mentida por los políticos, despreciada por los doctores; esa tierra sagrada donde Rigoberta Menchú se alza sobre las ruinas y dice "A mí, la vida me maravilla".

Cuando Rigoberta tenía tres años estalla una cruenta guerra civil en Guatemala -de 1962 a 1996- que perjudicará gravemente a su etnia, la indígena. A los 21 años se verá obligada a exiliarse si no quiere morir, su nuevo destino será México, donde se refugiará durante trece años protegida por el obispo Samuel Ruíz García. 
Rigoberta Menchú debe su popularidad al poder que la hizo huir de su pueblo, al poder que acabó con su familia, el que asesinó a su padre, el que vejó y torturó hasta la muerte a su madre. El 18 de abril de 1988 regresó a Guatemala, donde sin motivos fue detenida junto a sus compañeros de la Representación Unitaria de la Oposición Guatemalteca, la noticia se globalizó y finalmente fue liberada por coacción internacional (Menchú, 1998 b). La querían anular y fue lanzada internacionalmente.

Rigoberta es una mujer comprometida con su causa de etnia, con la igualdad, la tolerancia, la justicia, la diversidad y la interculturalidad, una muestra de ello es su colaboración en 1991 con las Naciones Unidas en la elaboración de la Declaración sobre los Derechos de los Pueblos Indígenas. Así mismo, como reconocimiento por su labor en representación de los pueblos indígenas y la puesta en valor de la diversidad cultural se le otorgó en 1992 el Premio Nobel de la Paz, que coincidió con la conmemoración de "la llegada de los españoles al "nuevo mundo" y por tanto el inicio de la persecución de los indios» (Torrent, 1992: 132). Es una fecha que los indígenas no pueden celebrar, porque fue cuando se les arrebató desde el modo de ser al de vivir; para el pueblo indígena (Caudillo, 1998: 125):

la colonización implicó la destrucción y el sometimiento de sus antepasados y por eso no puede ser un encuentro -porque un verdadero encuentro lleva al equilibrio y a la interacción armónica entre las partes y el todo.

En honor a su trabajo en torno a la figura de la mujer, se le concedió en 1998 el Premio Príncipe de Asturias de Cooperación Internacional. En 2004 pasó a ayudar en la fundación catalana Comparte y a principios de 2010 colaboró con la Marcha Mundial por la Paz y la No Violencia. (Fundación Rigoberta Menchú Tum, 1992).

En definitiva, Rigoberta Menchú ha dado voz al silencio que sumía a los indígenas guatemaltecos, recordemos que "resume en sí misma cada una de las variantes de esta tragedia» (Menchú, 1998 b: 11), aunque es evidente que este es tan solo un testimonio entre otros muchos que pueden ser relatados, pero es a través de su narración personal cuando el pueblo quiché alzó la voz, y recuperó su dignidad y su derecho a existir, pues «como dijo Paul Valéry, las civilizaciones son mortales. Pero el hecho de que lo sean no significa que haya que matarlas» (Boutros, 1995: 15), y Rigoberta lucha para que su cultura maya-quiché no muera y lo hace buscando la construcción de una cultura de paz.

\subsection{Influencias}

La guatemalteca debe su pensamiento a diversas fuentes: a las huellas del proceso colonizador, a su familia -y en especial a su padre-, a las experiencias personales resultado del escarnio de los militares de Guatemala durante la guerra civil. 
Un factor esencial fue el proceso de colonización y todo lo que este conllevó. Con el proceso colonizador del siglo xv empezaron los abusos al pueblo guatemalteco. Las últimas olas más radicales de violencia se dieron durante la guerra civil, en las que se secuestraba, torturaba y asesinaba a la población indígena, con el incentivo de la violación si se trataba de una mujer. Así mismo, Guatemala es un país que conoce de cerca la violencia, acto que «desprecia de manera sistemática el valor de la vida» (Magallón, 2006: 263).

A mediados del siglo $\mathrm{xx}$, antes de levantarse la guerra civil, el Estado guatemalteco necesitaba, para aumentar sus ingresos, mano de obra en las haciendas de café. La solución que halló no fue otra que quitar a los campesinos sus tierras para que se viesen obligados a migrar hacia las fincas cafetaleras en busca de trabajo, un trabajo cuyas condiciones eran pobrísimas. De nuevo el pueblo indígena se veía acosado, perseguido, robado y ninguneado, pero a diferencia de lo acaecido quinientos años antes, los indígenas se resistían a perder las tierras que cultivaban desde hacía siglos, lo que desató enfrentamientos armados. Asesinaron a un elevado número de líderes indígenas acusados de comunistas, con el fin de descabezar y cercenar el movimiento campesino que se había levantado ante el arrebato de sus tierras fértiles, en las que antes cultivaban sus propios alimentos y donde ahora trabajaban a cambio de un ridículo jornal. Amézquita, basándose en el informe de la Comisión para el Esclarecimiento Histórico, ${ }^{1}$ expone que más de la mitad de los asesinados no fue por su «militancia armada dentro de las guerrillas sino por la pertenencia a determinadas organizaciones» (2000: 20), lo que implica que fueron asesinados por tener una ideología dispar a la del régimen que dirigía Guatemala. Y es que toda forma de opresión conlleva una revolución, que había llegado, pero poco imaginaban ante la represión de las autoridades que su vida no tendría ningún valor y la muerte se convirtió en una resignación diaria ante las atrocidades que se cometieron contra esta etnia.

Toda esta ardua situación que se escribía desde la llegada de los españoles a Guatemala en el siglo xV alimentó una voz crítica con los nuevos abusos e injusticias, una voz que se levantaría firmemente con la guerra civil y una voz a la que, por supuesto, se intentó silenciar con el terror. Tras medio milenio, se seguían anulando los vestigios que sobrevivían de la cultura milenaria del pueblo maya al que Rigoberta pertenece; un hecho que expone claramente que la colonización más que un proceso estratégico, territorial, económico o político fue antes que nada un proceso de imposición cultural. Este se ha estado alimentando de la minusvaloración de las otras culturas preexistentes a la llegada a América de Cristóbal Colón en 1492.

Retomando las afluentes de influencia para la conciencia de Rigoberta, nos encontramos quizás ante la principal: la de sus progenitores y abuelos; para la civilización maya el sentido de familia va ligado a la felicidad del colectivo. Dentro de su familia destaca como su

1. De aquí en adelante, utilizaremos el acrónimo CEH. 
gran ideólogo su padre, Vicente Menchú; podríamos considerar que Rigoberta Menchú es la extensión en vida de su progenitor. La figura paterna le hizo sentir la lucha de clase, de etnia y de cultura desde bien jovencita. Vicente Menchú Pérez fue perseguido por el Estado de Guatemala por ser uno de los líderes indígenas más reconocidos y un activista comprometido con los Derechos Humanos y con el pueblo indígena. Finalmente, fue asesinado en el incendio provocado por los militares en la embajada de España el 31 de enero de 1980. Un incendio que calcinó la vida de 37 personas sin miramiento alguno $y$, como se detalla en el informe de la $\mathrm{CEH}$, el fuego duró cerca de tres minutos y no se dejó operar a los bomberos hasta unos diez minutos más tarde. Vicente Menchú y otras 27 personas entraron en la embajada como denuncia pacífica ante la violencia a la que estaban siendo sometidos en sus tierras, puesto que los indios cultivaban una tierra que no poseían (Torrent, 1992). Los líderes campesinos de la comunidad maya extendieron una manta por una de las ventanas condenando la masacre de Chajul y cuando el embajador comunicó que se disponían a abandonar el edificio de la embajada, los policías entraron armados en el edificio -no iban a perder la oportunidad de dar muerte al movimiento campesino e indígena. Los ocupantes corrieron a encerrarse en el despacho del embajador situado en la segunda planta, cerraron la puerta y la atrancaron con un sofá y una consola, los policías, (Amézquita, 200: 32).

derribaron la puerta, [...] «todos retrocedimos unos pasos y súbitamente se produjo una enorme llamarada en la puerta, después de una leve explosión como una detonación amortiguada». El embajador no pudo escapar con las manos quemadas. Se desató un voraz incendio pero las fuerzas de seguridad no permitieron que los bomberos intervinieran de inmediato. Al menos pasaron diez minutos antes que los bomberos pudieran actuar.

El CEH declara que el incendio se debió a un lanzallamas o expulsor de gas inerte. El Gobierno había conseguido dar fin a quien consideraba un enemigo político del Gobierno de Guatemala, que no era otro que Vicente Menchú, quien fue asesinado por defender sus derechos, por alzar la voz. Ahora es su hija la que lucha pacíficamente por los derechos de su pueblo, la que alza la voz tomando el relevo de su padre. Su padre y los compañeros murieron sin poder defenderse, un hecho tan oprimente como violento que marcó la conciencia y personalidad de Rigoberta Menchú Tum.

Aparte de su padre, nos encontramos también con la presencia de su madre, quien le trasladó los valores del cariño, de la vida, del respeto, de la importancia del papel de las mujeres en la sociedad -el cual va más allá de lo que se cree- y también de las costumbres de su pueblo, quien, junto con la ayuda de sus abuelos, forjó su carácter alegre y luchador. Sus padres querían mostrarle la realidad, pero no hacían sino alimentar su espíritu de lucha cada vez que le decían «que los indígenas y sobre todo las mujeres nunca consiguen lo que ambicionan» (Salgado, 2009 a: 208), un consejo que nacía del miedo a perder a su hija, ya que a su misma vez, 
Rigoberta expresa en palabras de su madre "que una evolución, un cambio, sin la participación de las mujeres no sería un cambio y no habría victoria» (Martín, 2002: 86), lo que muestra que su madre sí que tenía una conciencia de género. Así es como su hálito se forjaba inquebrantable ante tanta desgracia, pero no le movía el rencor, lo que le zarandeaba era la justicia y el bienestar. Igualmente, no podemos dejar de recalcar que el hecho de ser mujer dificultó el proceso de divulgación de la autora; sin embargo, un acelerante fue el mérito de ser hija de Vicente Menchú.

Y por último, pero no por ello menos importantes, las experiencias personales fueron otro de los riachuelos que han regado su conciencia. Rigoberta ha sufrido el asesinato de dos hermanos y una cuñada, fusilamientos que dejaron a dos niñas huérfanas. El asesinato de su padre en el incendio provocado en la embajada de España en Guatemala, por la defensa pacífica del pueblo indígena. El secuestro de su madre, a quien los paramilitares torturaron, violaron, ataron a un árbol, le cortaron un pecho y dejaron que los animales devoraran su cuerpo, porque este es el incentivo de la tortura y muerte por ser mujer: las violaciones y las mutilaciones de los pechos. Actos de dominación de extrema violencia y degradación de los cuerpos femeninos, con la violación sexual las mujeres somos penetradas a la fuerza y sin ofrecer nuestro consentimiento, donde nuestros cuerpos quedan bajo la voluntad del violador que toma el cuerpo sin importarle los sentimientos de la mujer a la que veja y de la que abusa por su propio interés, por su egoísmo, por la creencia de su superioridad y dominio. Los senos son rasgos de identidad del cuerpo femenino $y$, al ser mutilados, la mujer se queda sin esa seña de identidad que pertenece a su cuerpo, a su naturaleza y que ayuda al alimento que da vida a sus descendientes. No cabe mayor atrocidad para una mujer que recibir estas barbaridades en sus carnes, son la más pura humillación.

Los militares habían sobrepasado los límites de la aberración, de la violencia, habían instaurado el terror a través del genocidio en toda la población indígena, pero también el feminicidio para tan sólo los cuerpos femeninos. Recordemos con esto que Rigoberta condensa en sí misma las cuestiones de etnia, clase y género, es indígena, campesina y mujer.

\subsection{Propuesta ética como vehículo para la paz integral}

La meta de su propuesta ética es alcanzar la paz integral, la cual garantizará una cultura de paz donde prime el diálogo. La paz integral supone una amplia idea, puesto que no sólo se trata de regular las relaciones humanas, sino también de regular la relación del ser humano con la Madre Tierra y todos los seres vivos.

De este modo, su propuesta nace a partir de dos conceptos de su lengua materna, el quiché. Por una parte, el término utzil, que supone la idea de bien más amplia, pues abraza todos los espacios de la vida. Este se basa en el respeto y el equilibrio como garantes de «la coexistencia armoniosa entre todas las formas de vida del planeta. Donde la diversidad cultural debe ser el espejo de la diversidad natural» (Menchú, 2002 a: 7). Utzil es sinónimo de paz exhaustiva, pero que Rigoberta traduce como 
«paz integral» (Menchú, 2002 a: 7). Por otra parte tenemos el concepto pixab, que hace referencia a una enseñanza completa y rica, un espacio donde se fusionan la espiritualidad, la cultura, la salud, los recursos naturales, la educación, los conocimientos y la política, un espacio en el que sólo se comprenden todos juntos porque son asuntos recíprocos que se complementan y son de gran importancia para la humanidad.

Ambos conceptos no pueden entenderse por separado, pues sin la pixab no se podrá alcanzar el utzil, ya que si la pixab pierde u olvida uno de sus asuntos se hace imposible el utzil, pues de este modo se rompe con el equilibrio de la diversidad, lo que supondría un desenriquecimiento de los valores positivos y esto es percibido por Rigoberta como un atentado a la propia paz.

Así mismo, queda expuesto que para Rigoberta todo está relacionado entre sí y se necesita una cohesión para lograr un equilibrio estable que lleve a una cultura para la paz. La cohesión de la que nos habla necesita de la igualdad, de la justicia, del reconocimiento, de la moralidad y del respeto a la naturaleza y todos los seres vivos. Toda esta idea de cohesión y relación recíproca queda expuesta en su código ético (Menchú, 2002 a: 16):

No hay paz sin justicia, No hay justicia sin equidad, No hay equidad sin desarrollo, No hay desarrollo sin democracia, No hay democracia sin respeto a la identidad y dignidad de las culturas y los pueblos.

Este código es el eje básico de la propuesta ética para una cultura para la paz. Por tanto, la cultura de paz rigobertiana no es más que la costumbre y el modo de vida empático.

Rigoberta piensa en una idea de paz que sea capaz de ascender en el ámbito mundial, pero que no sea tan general y escueta que olvide las regiones más pequeñas, pues no por ello han de ser consideradas insignificantes, más bien todo lo contrario, ya que el «reconocimiento y el respeto a la pluralidad de la humanidad son elementos claves para construir las nuevas relaciones de igualdad y convivencia pacífica entre nuestros pueblos y las diferentes naciones» (Menchú, 2002 a: 36), con esto hace referencia y da importancia a su comunidad indígena valorada como insignificante pese a que se rige por una cultura milenaria. Los indígenas son los afectados, como los stakeholders en el ámbito de la ética para las organizaciones y por eso son ellos mismos los que tienen que exponer cuáles son sus necesidades, pues lo saben en primera persona.

A partir de la idea anterior de Rigoberta sobre la necesidad del reconocimiento y el respeto, podemos recuperar la teoría del reconocimiento del libro de Charles Taylor El multiculturalismo y "la política del reconocimiento" (1993), desde la cual se defiende que la categoría básica de la vida social es el reconocimiento recíproco de los individuos. El reconocimiento forma parte de la identidad del ser humano, hasta el punto en que la falta o mal reconocimiento genera daño en el individuo y en el grupo, de forma que puede llegar a darse la 
autodepreciación del individuo. Este sería un método de opresión por el cual el individuo se convence de que vale menos.

Taylor defiende el igual valor de todas las culturas, teniendo en cuenta sus diferencias, ya que todos somos iguales de acuerdo con la interculturalidad, así mismo, llegamos a la idea de fusión de horizontes de Hans-Georg Gadamer y que Charles Taylor toma, en la que todas las culturas se han de fusionar, no sólo dejando sobrevivir las diferencias culturales, sino que también resulta esencial reconocerlas, y para ello es fundamental el papel de la educación. En el pensamiento de Rigoberta, la fusión de horizontes no existe, pero sin embargo sí que defiende la necesidad de reconocimiento de las diferencias culturales. Por tanto, es un concepto que no sólo ha trabajado Rigoberta Menchú, sino que también ha sido trabajado por otros filósofos. A partir del reconocimiento a las culturas, Rigoberta Menchú mantiene su idea de paz integral.

El camino para llegar hasta la paz integral es el del diálogo, pues es «responsabilidad de todos los pueblos, las culturas, las naciones y los estados construir un futuro promisorio sustentado de una cultura de diálogo» (Menchú, 2002 a: 45) a través del cual se entenderá la relación existente entre el reconocimiento y la identidad. La cultura del diálogo será motor de la cultura de paz.

Su concepto de paz no se queda aquí, va mucho más allá y salta a un escenario actual, el de la globalización y la ecología. Quizás sea este el parámetro más interesante e innovador de su propuesta ética para la paz.

La guatemalteca tiene presente que "la paz no debe ser entendida solamente como el silencio de las armas» (Menchú, 2002 a: 44), la idea de paz integral también supone una relación armoniosa entre la humanidad y la Madre Tierra. Una relación actualmente corrompida, ya que con la globalización «son muchas las causas que reclaman una atención urgente, pues amenazan la paz global. La globalización implica abrir los ojos a los errores globales que se han cometido» (Menchú, 2002 a: 31), como por ejemplo la degradación progresiva del medio ambiente.

La globalización es, sin duda, el reto a superar y la marca constante del siglo XXI. Resulta que las cuestiones nacionales se convierten en cuestiones internacionales cuando hablamos de degradación medioambiental. Los humerales de la Europa industrializada no dañan sólo a los europeos que han decidido ser productores masivos, esa contaminación también perjudica, y gravemente, a aquellos países que aún no han sido industrializados y por consiguiente también a su pueblo y a su ecosistema. Países que no construyen altos humerales que ensucien la atmósfera no abocan químicos que impotabilizan el agua, no arrasan vegetación para construir ociosamente, pero sin embargo han de convivir con algo que no han elegido: convivir con la polución a cuestas de que los países industrializados se enriquezcan y ellos lo que ganan son pérdidas: maltrato a su ecosistema y a la salud. Además, los países industrializados ahogan a estos países, la mayoría en vías de desarrollo. La contaminación no entiende de fronteras que han sido construidas, pues es un hecho que 
carece de la capacidad de razonamiento con la que cuentan sus causantes, quienes, al parecer, no la usan.

Los gobernantes tienen clarísimos los límites de los países que dirigen, pero se olvidan de que el consumo que se inyecta a la producción masiva lacera fuera de las fronteras establecidas, es decir, sí que existe una conciencia de globalización en el ámbito del consumismo pero no de la degradación progresiva del medio ambiente, cuando esta es un problema de ciertas naciones que salta al panorama global y ante el cual muchos países callan. De este modo es como comemos porquería y respiramos mugre, ya que nadie alza la voz porque el dinero compra silencios.

No hay que olvidar que los países capitalistas han enterrado los valores vitales y humanos para plantar los valores económicos; una planta que se riega con el consumo y que pone en jaque mate a la humanidad. No se dan cuenta de que viven por encima de sus posibilidades naturales y con ello están, como expone Rigoberta, generando antivalores, los cuales han de ser reconducidos por la ética para reconciliarnos con la Madre Tierra (Menchú, 2002 a).

Para la autora, nos encontramos en una sociedad que está perdida y "confundida sobre cuál es su destino común, cada vez menos solidaria y consciente de su responsabilidad en la preservación del equilibrio natural» (Menchú, 2002 a: 23). Con la intención de ayudar en todo esto, Rigoberta habla en nombre de su cultura milenaria, y la ofrece como portadora de soluciones. Sobre la naturaleza, el pueblo indígena cree primordial «aprovechar los recursos que esta nos provee para satisfacer nuestras necesidades, pero no como una fuente de enriquecimiento individual» (Menchú, 1998: 12), sino siempre de un modo positivo para la colectividad y en respeto con la naturaleza. Así, el ser humano no sólo ha de ser consciente de la existencia de la naturaleza, sino que ha de ir más allá y "assumes a coexistence and the development and the life of nature to be a guarantee of the development and full life of a human being» (Menchú, 2008: 73).

Desde la filosofía maya el agua está considerada «an inalienable human right» (Menchú, 2008: 91) por eso son «ethical responsibilities [...] the correct usage of water» (Menchú, 2008: 96). Para la comunidad maya-quiché el agua es la protagonista de sus vidas ya que alimenta sus cosechas, de forma que garantiza la vida y la paz. En el equilibrio del agua, Rigoberta encuentra el equilibrio entre la naturaleza y el ser humano, la falta de agua es un factor que lleva al conflicto porque es necesaria. El agua es "a vital element worthy of being valued, an element and subject also of rights» (Menchú, 2008: 78) por el mero hecho de que «is as the primary element for universal life» (Menchú, 2008: 74). La humanidad somos partícipes y responsables de mantener el equilibrio natural porque formamos parte de la misma naturaleza y el agua «is our life, it is our energy» (Menchú, 2008: 77), con el agua somos, sin el agua dejamos de ser. 
A partir de lo expuesto y con la finalidad de incluir a Rigoberta en los estudios para la paz, recupero las palabras de Vicent Martínez Guzmán: "Los seres humanos somos naturaleza, humus significa tierra, reivindicamos la terrenalidad de los seres humanos, el compromiso con el medio ambiente del que formamos parte» (2001: 115), por ello, los seres humanos hemos de reconocernos como unidad natural junto a los otros seres vivos con los que compartimos recursos. Así mismo, no es exclusivamente Rigoberta Menchú desde su punto de vista maya-quiché la única que reconoce al ser humano con la naturaleza. Convivir en un espacio de paz integral es tarea de todos y todas.

\section{Conclusiones}

Ninguna cultura puede explicar toda la realidad; las culturas no son estáticas, rígidas y monolíticas, unas deben abrirse a otras y al revés. Así mismo, el futuro de nuestra civilización global depende de nuestra capacidad para vivir juntos, es decir, de las regulaciones de paz. Las regulaciones de paz sólo podrán ser posibles a través del diálogo. Un espacio dialógico permite acercar la diversidad de standpunkte, para poder llegar a acuerdos y soluciones a través de medios pacíficos, de forma que se realiza la paz positiva. La humanidad ha de pensar y obrar en colectivo, porque el ser humano es un ser naturalmente social, sólo que el consumismo y el capitalismo nos han moldeado como seres individualistas y egoístas, donde prima el beneficio y la rivalidad.

Así mismo, por el hecho de ser seres colectivos que coexistimos, también hemos de cuidar el espacio sobre el que nos levantamos, puesto que para coexistir la humanidad necesita también un medio ambiente con el que estar conciliado y en paz. No podemos estar atacando con la deforestación de árboles, la contaminación del agua y el exceso de gases tóxicos que provocan el desequilibrio ecológico en el que vivimos, la pérdida de la biodiversidad o la destrucción de la capa de ozono. El dióxido de carbono aumenta a la misma vez que aumentan las arcas de los productores masivos. Directamente estamos bombardeando la vegetación, el suelo y el relieve que nos complementa naturalmente.

La globalización nos ha expuesto ante los problemas que no hemos sido capaces de tener bajo nuestro control, porque la naturaleza es naturalmente salvaje, $\mathrm{y}$ ante estos problemas se nos expone el gran reto del siglo xxI: un cambio global que resulta necesario. Unos países compiten con otros y generan conflictos; además se está perdiendo la identidad cultural de regiones o países porque los sume la cultura dominante, abocándonos a la homogeneidad cuando deberíamos aprovecharnos de la globalización para acercarnos a otras culturas ante las cuales abrirnos difuminando horizontes, aunque siempre salvando las diferencias que construyen las identidades y suponen la riqueza cultural.

La globalización también ha apartado a esas disciplinas que la frenan y no la dejan expandirse a su gusto, las disciplinas que comprenden las Humanidades, tan olvidadas como necesarias. La globalización ha 
proyectado una educación que no tiene espacio para la reflexión, para la imaginación, para los valores éticos o para los grandes pensadores de la historia. El sistema en el que vivimos gusta de controlar las mentes y hacerlas consumistas y productoras, para no dar opción a reflexionar ante las grandes cuestiones del ser humano, y nos cosifica y nos controla.

Una parte de la humanidad está sacrificando a la parte que no tiene voz mediante un cambio económico, social y ecológico que cada vez es más veloz, bajo un ritmo de vida que es insostenible y que nos aboca a nuestro propio fin. Los jefes globales son los representantes políticos de las grandes potencias, los que deciden por toda la humanidad, los que tienen el control sobre nuestra salud y sobre nuestro medio ambiente, el que es de todos y todas. Su mayor preocupación debería ser la de ser seres transgresores y no solamente ceñirse a la preocupación medioambiental en su discurso político, sino más bien ser capaces de llevar la teoría a la práctica, afrontando este gran reto globalizador de un cambio global absolutamente necesario al que nos lanza el comportamiento retrógrado, un cambio que el planeta Tierra viene pidiendo a gritos desde hace décadas porque se está asfixiando. En nuestras manos está la voluntad de salvar su vida, nuestras vidas.

En definitiva, no debemos de cometer el error de percibir la paz integral como una utopía; las utopías son inalcanzables y eso hace que no merezca la pena luchar por algo. Así pues, debemos tomarla como un ideal normativo, por el cual nuestros actos actúen como pequeños engranajes que nos vayan acercando a esa gran idea de paz integral.

\section{Bibliografía}

Amézquita, Carlos (2000): Guatemala: de Vicente Menchú a Juan Gerardi, Universidad de Deusto, Bilbao.

BARLOW, Maude (2008): "Blue Covenant: The Alternative Water», Montlhy, vol. 60, núm. 3, julio-agosto, p. 125-141.

Barlow, Maude i Tony Clarke (2004): Oro azul. Las multinacionales y el robo organizado del agua en el mundo, Barcelona, Paidós.

BECK, Ulrich (1997): "La irresponsabilidad organizada», Crisis ecológica y Sociedad, colección «Arcadia» 1, Alzira (Valencia), Germania.

Boutros, Boutros-Ghali (1995): "Prólogo», La voz de los Pueblos Indígenas, Palma de Mallorca, Plenum.

CAUDILlo, Gloria Alicia (1998): «Aproximación al discurso de Rigoberta Menchú», Espiral, vol. 5, núm. 13 septiembre-diciembre, p. 111-141.

Comisión PARA el EsClaReCIMIENTO HISTÓRICO (1999): "Caso ilustrativo núm. 79 La masacre en la Embajada de España» en el informe "Guatemala, memoria del silencio», Publicación de la Oficina de Servicios para Proyectos de las Naciones Unidas, TOMO VI, junio, Guatemala, p. 163181. 
Fundación Rigoberta Menchú Tum (1992): «¿Quién es Rigoberta Menchú Tum?», http://www.frmt.org/en/ [25/3/2014].

GuAL, Alfons (2003): «Niveles del diálogo y posibilidades de llegar a acuerdos interculturales institucionales», I Congreso de la Sociedad Académica de Filosofía, Universidad de Valencia.

HALPERIN, Tulio (1993): Historia contemporánea de América Latina, Madrid, Alianza Editorial.

JAHANBEGLOO, Ramin (2007): Elogio a la diversidad, Barcelona, Arcadia.

KANT, Immanuel (1991): «Tercer artículo definitivo para la paz perpetua», Sobre la paz perpetua, Madrid, Tecnos.

KüNHL, Reinhard (1997): «Sociedad en transformación», Cambios sociales y políticos, Colección Arcadia 3, Alzira, Germania.

KYMLICKA, Will (1997): Ciudadanía multicultural: una teoría liberal de los derechos de las minorías, Barcelona, Paidós Ibérica.

MARTín, Raquel (2002): «Rigoberta Menchú, 10 años de compromiso con la paz», Géneros, México, Universidad de Colima, p. 86-90.

MARTínez GuzMÁN, Vicent (2001): Filosofía para hacer las paces, Barcelona, Icaria.

Menchú, Rigoberta (1995): "Prefacio», La voz de los pueblos indígenas, Palma de Mallorca, Plenum; 2, Madre Tierra.

- (1997): Me llamo Rigoberta Menchú y así me nació la conciencia, Barcelona, Seix Barral.

- (1998 a): «La interculturalidad como utopía», Pentukun, 8, 13, p. 11-14.

- (1998 b): Rigoberta: La nieta de los mayas, Madrid, El País S.A. Santillana S.A.

- (2000): El clamor de la tierra: luchas campesinas en la historia reciente de Guatemala, Donostia, Gakoa Liburuak.

- (2002 a): Hacia una cultura de paz, Argentina, Lumen.

- (2008): Water and Humanity, Reciprocal Existence, Zaragoza, Expoagua Zaragoza.

- (2012): «Humanismo y conciencia social: herramientas para transformar el mundo», Conferencia impartida en el Centro de Investigación en Alimentación y Desarrollo, México.

SALGAdo, Rosa (2009): «Rigoberta Menchú», 1325 mujeres tejiendo la paz, Madrid, CEIPAZ-Fundación Cultura de Paz.

TAYLOR, Charles (1993): El multiculturalismo y "la política del reconocimiento", México, Fondo de Cultura Económica.

TORRent, Rosalía (1992): «Rigoberta Menchú, india quiché», Asparkía: investigación feminista, núm. 1, p. 129-133. 
FÒRUM DE RECERCA - ISSN 1139-5486 - http://dx.doi.org/10.6035/ForumRecerca.2015.20.2 Núm. 20/2015. p. 19-32

Valbuena, Juan Camilo (2008): Una defensa kantiana de los derechos humanos, Universidad del Rosario, Bogotá. 


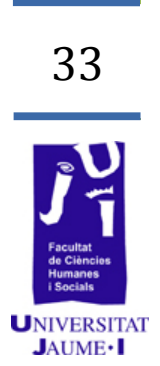

\section{¿Puede la persona-masa aspirar a la lucha vital? Reflexiones orteguianas en la máxima actualidad}


La pregunta del título nos permitirá adentrarnos en la filosofía orteguiana y en conceptos claves de máxima actualidad, que sin saberlo nos afectan día a día. Vida, trabajo, minoría o masa tienen una perspectiva vigente y muy especial para Ortega y Gasset. Podremos replantearnos conceptos que aparentemente tenemos muy definidos. Conoceremos lo que Ortega llamó el síndrome por excelencia del europeo junto a los tipos de personas y problemas derivados que conlleva. ¿En qué momento "trabajar para vivir» pasó a ser «vivir para trabajar»? Ortega propone una respuesta muy interesante. Analizó un sistema lleno de trampas y deficiencias estructurales por mucho tiempo desapercibidas y con funestas consecuencias.

Reflexionaremos y uniremos los conceptos hasta acercarnos mejor a nuestra actualidad y cotidianeidad. Gracias a su obra, buscaremos dar salida a los problemas estructurales de la occidentalidad y la Ilustración en el ámbito personal, social, continental e incluso mundial. Lo relacionaremos con la crisis del pensamiento del siglo $\mathrm{xx}$, tanto en la antesala como sus consecuencias y nos articularemos con la obra y biografía de un autor nuestro y muy cercano, que nos permitirá actuar como bisagra en este viaje filosófico.

Esta lectura también servirá como una introducción e invitación a leer dos obras imprescindibles como son El tema de nuestro tiempo o La rebelión de las masas. Veremos la propuesta de un sabio profético y su modelo para triunfar y aprovechar la vida (la lucha vital), al fin y al cabo, es nuestra identidad y circunstancia; que se vuelve un concepto muy valioso y presente en la sociedad de las masas. Al mismo tiempo, veremos cómo se puede conectar con otros autores clásicos o modernos demostrando la plasticidad de su pensamiento.

Palabras clave: Ortega y Gasset, minoría selecta, persona-masa, lucha vital, trabajo, cultura, razón y raciovitalismo.

\section{Introducción}

Como dirá Gasset: ¿la máxima actualidad y la tradición europea occidental son compatibles? ¿Nuestra vida y sociedad gozan verdaderamente de valores y sentido? ¿O camuflado entre muchos lujos y falsas necesidades; viajamos rumbo a un nihilismo hueco, sin sentido e inevitable? ¿Existe esperanza para una sociedad plagada de personasmasa? ¿Se puede evitar verdaderamente serlo en nuestros días? ¿Hemos perdido o simplemente renunciado a la lucha vital? A lo largo de estas páginas, buscaremos responder a estas y otras preguntas. Este humilde artículo es la ampliación y maduración de un trabajo de la asignatura Filosofía Moderna y Contemporánea que realicé en tercero de carrera, 
donde trabajábamos a un autor libre. Su evolución me permitió llevarlo positivamente a las jornadas presentes en esta revista.

Dos de sus obras principales: El tema de nuestro tiempo (1923) y La rebelión de las masas (1929) serán las principales acompañantes en nuestro viaje filosófico. La elección de ambos libros responde a su elevado grado de conexión y el segundo, en cierto modo, es la respuesta al debate abierto del primero. Al mismo tiempo, permiten presentar al lector los conceptos básicos orteguianos: la primera obra explica el raciovitalismo -revisando el espíritu racional e ilustrado-como propuesta integradora y regeneradora de la filosofía con el resto de facetas de la vida. Al mismo tiempo, la segunda recoge una sociología filosófica muy vigente; en la que distingue entre persona-masa y la minoría excelente.

En su conjunto se muestra una perspectiva distinta sobre la vida, cultura o Europa tal y como explicaremos a lo largo del trabajo. No responde a la mera crítica ácida o pesimista que no propone alternativas. Más bien todo lo contrario, ya que se puede vislumbrar una fuerte esperanza en el futuro de la humanidad en sus palabras. Sin embargo, simultáneamente se muestra muy receloso y se mantiene alerta con una civilización que si nos descuidamos acabará desapareciendo. Ortega era consciente de la delicada situación del mundo del pensamiento, la vida y el mundo en su conjunto tras la crisis del pensamiento de la modernidad. Pues había dejado un mundo ambiguo y en crisis, necesitado de respuestas urgentes y acertadas para reorientarse en su práctica totalidad (Gambra, 1987, y Russel, 2011), como iremos viendo más adelante. Por cuestiones cronológicas, no pudo ver todos los cambios, pero en cierto modo sí que supo hacer una acertada lectura del mundo del momento y de sus posibles variaciones.

Como aportación personal, su lectura con tintes proféticas que suponía una fuerte carga contra la tradición occidental ha transmitido en cierto modo la labor de los maestros de la sospecha (Marx, Freud y Nietzsche), en el sentido de criticar el mensaje oficial vendido como el definitivo y reinterpretarlo. En el conjunto de su obra, Ortega hablará del trabajo, de los instintos... como los autores anteriores comentados.

\section{Objetivos}

"¿Puede aspirar la persona-masa a la lucha vital?». Con esta pregunta -como título del trabajo- buscamos perseguir múltiples fines: el primero es acercar e incentivar al lector a leer la obra de un filósofo cercano a nuestra cultura, de prosa fácil y cercano como es Ortega y Gasset. En segundo lugar, recuperar una visión de filosofía más viva y cercana como intérprete de su sociedad y su rumbo (pasado, presente y futuro). En tercer lugar, la prioridad es comentar, cohesionar y relacionar ambas obras con otros autores clásicos mientras se suman aportaciones personales con cierto interés y habilidad. Finalmente, plantear al lector una serie de cuestiones -tanto directas como indirectas- que inviten a aprender algo nuevo y reflexionar. 
En cuestión de método, reside en un modelo más hermenéutico crítico, tras una lectura y maduración de los conceptos, nos adentramos en una interpretación y comprensión personal como propuesta de investigación.

La base de este proceso es la lectura de dos libros clave en la obra de Ortega y Gasset, como hemos explicado en la introducción. Para contextualizar su pensamiento se han empleado varios libros de la historia del pensamiento y su vinculación con los hechos históricos, aunque nos centraremos más en occidente propiamente. Nos referimos a Russell (2011) y Gambra (1987). Al mismo tiempo lo vinculamos con autores como Aristóteles (Aristóteles, 2015) o Kant (Kant, 2001) entre cuyos conceptos se pueden percibir muchas similitudes.

\section{Resultados}

Repasaremos aquí la estructura del trabajo, con el fin de delimitarlo un poco y permitir al lector alcanzar una visión más conjunta e interconectada de la investigación. En primer lugar, situaremos el contexto filosófico con datos breves sobre José Ortega y Gasset. Consideramos clave la necesidad de presentar al autor relacionándolo con su biografía vital. Por dos motivos: por un lado, por norma general, tras una contextualización biográfica se suelen entender mejor los conceptos y las reflexiones. Por otro lado, como motivo más concreto, Ortega le da gran importancia a la vida y como es vívida para marcar la identidad, dando a entender que somos el cúmulo de circunstancias y esfuerzo. Todos arrastramos las decisiones constantes e interminables "obligados» por nuestra libertad, junto al mayor o menor respeto y aceptación de nuestra genuinidad (Ortega y Gasset, 1981 y 1990). Por coherencia con el trabajo, debemos incluir necesariamente un bloque de este tipo.

En segundo lugar, analizaremos conceptos, corpus y propuesta de Gasset intentando aunarlos en un único cuerpo reflexivo.

En tercer lugar, un breve apartado donde se vinculará el autor a la máxima actualidad, de forma que se analizamos así lo profético. Finalmente, las conclusiones alcanzadas, de forma breve, a modo de síntesis final.

\subsection{Ortega, biografía y su contexto filosófico}

La humanidad se encuentra en uno de sus peores y más influyentes períodos: la primera mitad del siglo xx. Son problemas que afectan a todo el mundo: la explosión del imperialismo, la subida de los fascismos o el impacto de la Primera y de la Segunda Guerra Mundial, etc., entre otros muchos hechos decisivos. Todos supusieron una crisis severa reflejada en reflexión, revisión y crítica sobre la cultura occidental. Así los valores y fe 
ciega en la modernidad y las ciencias naturales quedan en duda. Además, la filosofía queda especialmente desprestigiada por la pérdida de la fuerza crítica e identidad, y tiende más a la pura imitación de las ciencias naturales o a la radicalización ideológica Russell (2011) y Gamba (1987).

En todo este proceso se plantearon diversas preguntas en un mundo perdido y en caos, y se abarcaron múltiples aspectos de la vida y la cultura: ¿Podemos mantener el mismo tipo de sistema y modelo de ciencia? ¿Debemos volver a nuestros orígenes, probar algo verdaderamente nuevo o formular un hibridismo de todas las posturas? ¿Existe un futuro para el campo social de las humanidades? ¿Qué ocurrirá con cada individuo si nada tiene ya sentido? ¿Y con Europa? ¿Y el mundo?

A raíz de todos estos cambios, un nuevo período filosófico crítico y urgente se encargará de revisar la filosofía occidental. Como respuestas distintas a un mismo problema aparecen a la vez muchos autores y corrientes: la posmodernidad, la Escuela de Frankfurt, recuperación de la hermenéutica y nuevos modelos de hacer ciencia, etc. Poco a poco se fue abandonando en parte la supremacía de la conciencia y la razón del período moderno y se alcanzó el paradigma del lenguaje caracterizado por la comunicación y el diálogo (Russel, 2011 y Gamba, 1987). Por cuestiones de extensión, no ampliaremos más el contexto histórico y filosófico general.

¿Qué relación exacta mantiene Ortega con este plano filosófico? Por biografía (1883-1955) se volverá testigo de la modernidad en sus últimos años: con el peso occidental en su máximo exponente -el período imperialista- junto a su decadencia -las dos guerras mundiales. Al mismo tiempo, en su vejez verá cómo nace el inicio del cambio: una generación que busca la necesaria crítica y regeneración y se muestra más activa y dialogante, y convivía al mismo tiempo con un mundo que se iba dividiendo con dos modelos sucesores en la Guerra Fría. Ahí es donde entra nuestro autor como fina bisagra entre esta transición difusa y cambiante entre el período que va tras la crisis de la modernidad y un mundo completamente abierto; con la responsabilidad de aprovechar y aprender lo previo, para alcanzar entre todos un mundo mejor o de repetir formulas y sistemas destinadas al fracaso y el conflicto.

En cuanto a lo más biográfico y personal, José Ortega y Gasset (18831955) es un filósofo y ensayista español con una obra prolífica decisiva, situada en la primera mitad del siglo xx. Como hijo de la aristocracia burguesa madrileña, estudió en la Universidad Central de Madrid donde se doctoró en Filosofía y Letras. Complementó su formación en Alemania de donde recibió importantes influencias, especialmente de Kant (Ortega y Gasset, 1981).

En mi opinión, su filosofía se caracteriza por combinar lo profético, lo periodístico y lo cotidiano. Ortega anticipó -o al menos intuyó- el tipo de sociedad e individuos de las décadas posteriores. Un logro especialmente destacable en un mundo tan convulso y protagonizado por el imparable cambio. Al mismo tiempo, expone duramente los problemas de la sociedad europea y española tras perder la fuerza vital y el lugar que les 
pertenece. Todas estas críticas le llevan a proponer un modelo personal de filosofía: el raciovitalismo.

Como intelectual, siempre quedará vinculado al mundo periodístico y político, muy constantes en su vida. A continuación, exponemos datos significativos para acercarnos a su ideología y postura política: la oposición tajante a Primo de Rivera, un fuerte compromiso público y universitario a la República. Se exilió en muchos países de Europa y ambas Américas antes y durante la Guerra Civil, lo que le permitió extender su obra a lo largo del mundo y se dio a conocer con inmediato éxito. Volvió en 1955, el mismo año de su muerte, en Madrid (Ortega y Gasset, 1990).

\subsection{Reflexión sobre el corpus filosófico orteguiano}

Este bloque interno lo dividiremos en tres apartados: el primero con el nombre de "Problemas derivados de la confusión entre vida y trabajo», donde nos centraremos en el raciovitalismo. En el segundo, «Personamasa, minoría selecta y la lucha vital», hablaremos de la antropología orteguiana. Concluiremos con el apartado « ¿La lucha vital posible tras la crisis mundial de la primera mitad del siglo xx?», donde aunaremos los dos libros y los relacionaremos con la realidad mundial de las últimas décadas hasta la actualidad.

\subsubsection{Problemas derivados por la confusión entre vida y trabajo}

Antes de empezar a filosofar, cabe advertir al lector de la siguiente observación: El tema de nuestro tiempo (1923) se escribió seis años antes. Lo destacamos por dos motivos: por un lado, buscamos asentarlo como base principal de la estructura conceptual. Por otro, queremos contrastarlo y complementarlo con La rebelión de las masas. Nuestro reto es averiguar las variaciones y evoluciones del pensamiento orteguiano en ese intervalo de tiempo. Una vez matizado nuestro modo de proceder iniciamos con las principales reflexiones.

Como curiosidad previa, ambas obras cuentan con un prólogo tanto para ingleses como alemanes. En nuestra opinión no es una casualidad, el hecho de que en ambos casos se repitiera este criterio expone claramente dos observaciones: por una parte, el éxito en vida de Ortega era notable; por otro debía explicar muchos matices que, como él expresa contantemente, solo entenderá el público español o latinoamericano. Pese a que su obra tiene un marcado carácter nacional, su éxito y la aplicación de ideas se extiende a todo el continente y al mundo como la pólvora de la época.

En El tema de nuestro tiempo, Ortega altera las ideas tradicionales de existencia de cuerpo y alma; pasan a transformarse en cultura y vida dentro de su universo filosófico. O lo que es lo mismo: razón y biología. Antes de decir nada, a priori es evidente saber que está mejor valorado. Desde la modernidad marcada por la llustración, lo intelectual siempre ha gozado de una mejor valoración respecto a lo corporal, aunque tiene sus 
matices, pues la apariencia física siempre ha estado presente, por ejemplo.

Así, poco a poco e inconscientemente, naturalizamos lo artificial (en este caso nuestros pensamientos e ideas). En esa transformación, lo que antes era propiamente natural (lo biológico) se queda sin sitio (Ortega y Gasset, 1981).

Mientras la jerarquía tradicional se altera, la vida y el cuerpo se vuelven innecesarios, menores o inapropiados. Así, esta conducta reniega del principio vital. Para Ortega, ¿no es lo más ilógico, ridículo y antinatural a lo que podría aspirar una persona? Se percata de que este paradójico proceso es único y genuino de lo europeo, ya que el resto de continentes han sabido compaginar mejor ambos universos -0 al menos no renunciar al otro.

Esta peculiaridad europea se ha radicalizado y ha llevado a la quiebra de la propia modernidad, como consecuencia principal, el concepto de ciencia, y especialmente la filosofía -tal y como acentuábamos en el contexto. Para Ortega, esta incapacidad de combinar ambos universos es sin duda la verdadera causa de todo, de la crisis interna y falta de identidad de Europa (Ortega y Gasset, 1981).

Curiosamente, como pequeño paréntesis personal, nos da la sensación de que aún hoy cuesta compaginar ambas facetas de la vida: desterrando la vida por un mundo cultural con una gran presencia del trabajo -uno de sus principales factores- pues es una de las vías de más aprendizaje y tiempo dedicado.

Un ejemplo evidente es que, en la sociedad actual, el concepto de vacaciones es renegado -cuando están comprobados sus beneficios para la salud y la vida-, y ya suele costar que la gente se las coja voluntariamente. Aun así, no se desconecta completamente; pues se sigue vinculado a través del teléfono móvil o el ordenador. Incluso peor, no se disfruta ni se aprovecha del tiempo libre pensando en las tareas pendientes o viendo peligrar el puesto de trabajo; y todo favorecido por el neocapitalismo, por su excesiva competitividad o incluso el despido. El segundo, en ocasiones, sale rentable $o$ es una herramienta de intimidación infalible. Se deshumaniza completamente el factor humano y el antiguo sentimiento de protección y relajación de tener un trabajo; es decir, lo que permitía construir tu proyecto de vida. Sin embargo, ahora todo es frívolo y maquiavélico, la ausencia estructural de trabajo ha vuelto al mercado laboral chantajista, masificado y frívolo: encontrar un sustituto dispuesto a trabajar por menos salario es fácil y seguro. Desde nuestra perspectiva, todo esto sucede por la alteración de jerarquías naturales -comentadas anteriormente- $y$ priorizar trabajo sobre vida hasta las últimas consecuencias.

¿Existe mayor suicidio vital que sacrificar nuestro ocio constantemente? Al fin y al cabo es necesario para vivir, evadirse, descansar y construir nuestra personalidad. Observando las ideas expuestas por Ortega, si nuestro autor pudiera ver el clima laboral actual diría que no hemos acabado de compensar, ni mucho menos, la balanza 
expuesta en el raciovitalismo. Más bien hemos ampliado aún más ese mundo obsesionado con el trabajo, con la infelicidad que trae cualquier radicalización y huida del término medio. Todos estos excesos nos alejan de perseguir el verdadero fin individual de cada uno, que uno mismo debe encontrar y que no coincide con el mensaje del sistema de «vivir para trabajar» (Aristóteles, 2015). Hace mucho que, como sociedad, superamos "el trabajar para vivir» y las consecuencias son visibles cada día.

Para Ortega, conocimiento real -es decir, de la realidad, aparentemente evidente, pero a veces parece que aún es necesario matizar- solo se puede aspirar mediante la propia vida, como único camino sensato y eficiente. Cuidado lector, ya sé que parece que Ortega renuncia a la razón, pero nada más lejos. Solo destaca que la cultura debe trabajar para la vida y no lo que sucede actualmente: una vida sacrificada por la razón y la cultura. Si no, entramos en una radicalización donde vida, sexualidad y cuerpo quedan secuestradas. A día de hoy parece que hemos malinterpretado el concepto y umbral de ciencia, seguramente por la influencia de movimientos o corrientes como el positivista (Ortega y Gasset, 1981: 24):

En cada instante necesitamos vitalmente y con cierta urgencia estar en claro sobre determinadas cuestiones. La ciencia tiene la obligación de no ocuparse solo de problemas gremiales, "técnicos», de taller. Está ahí, en definitiva, para resolver en todo instante el repertorio de respuestas a las preguntas vivas.

Ortega observa que el gran peligro de la razón, las ideas y las abstracciones se acaban convirtiendo en unos peligrosos fetiches. Se les otorga de un poder infalible, controlable e ilimitado, capaz de cuadricular la verdad. Así, la razón se integra inocentemente y abiertamente a nuestro servicio. Por tanto, como mínimo debemos recelar de cualquier principio cuadriculado, pues la vida no es ni mucho menos perfecta o lógica; es mucho más compleja que cualquier esquema (Ortega y Gasset, 1981).

Desde nuestro punto de vista y apoyándonos en Russel (2011), podemos volver a caer en la paradoja de la Diosa Razón donde una razón se radicaliza, y atribuye los atributos de fe y superstición (infalible, único, compartido, empoderante). Por lo tanto, las incompletas maneras de guiar las vidas y sociedad que venía a superar y sustituir acaban repitiendo los mismos errores con distinta fórmula. Destaco este proceso, porque fue uno de los déficits más importantes del sistema planteado por la modernidad y ya se dio en los propios revolucionarios franceses con funestas consecuencias.

Como pequeña apreciación, transmitir de lo teórico a lo práctico resulta la verdadera capacidad de comprensión y un momento complejo de gestionar: pasar de la mente a la práctica real y compartida. Entendemos que los pensamientos de Ortega siguen esta vía. Todo este proceso lo explica perfectamente Ortega (1981: 109 y 117): 
Se creía que se creía en la cultura; pero, en rigor, se trataba de una gigantesca ficción colectiva de que el individuo no se daba cuenta porque era fraguada en las bases mismas de su conciencia.

$[\ldots]$

La razón es solo una forma y función de la vida. La cultura es un instrumento biológico y nada más. [...] Urge reducirla a su puesto y oficio.

Desde nuestro punto de vista, ¿cuál es el verdadero error que recrimina Ortega a Europa occidental? Lleva enfrentado ambos modelos toda la vida desde sus orígenes (por ejemplo, el choque entre el mito y el logos): Ortega propone simplemente -que no es tan fácil y menos para el "europeo medio»- integrarlos. Esta situación es parte natural, pues se manifiesta ya en época clásica y sigue, por así decirlo, varias modas. Pondremos un ejemplo: Grecia clásica - razón y helenismo - vida. Ya en los orígenes de la cultura grecolatina se muestra una severa dualidad.

Desde un principio, Ortega mantiene que la vida permite gozar de una mente abierta que permita sobrevivir y adaptarse. Así pues, perspectiva vital equivale a ganancia y aportación como vemos en las siguientes citas: "La perspectiva es uno de los componentes de la realidad. Lejos de ser su deformación, es su organización» (Ortega y Gasset, 1981: 147). Vemos cómo se anticipa la importancia de salir del modelo puramente occidental, buscar otros modelos y fórmulas e intentar ir más allá. Para construir esa opinión, se nutre en gran parte de la experiencia vital, gracias a la que adquirimos nuestra unicidad y capacidad de aportar una opinión irrepetible y distinta: "Cada vida es un punto de vista sobre el universo. En rigor, lo que ella no puede ver no lo puede ver otra. Cada individuo - persona, pueblo, época- es un órgano insustituible para la conquista de la verdad». (Ortega y Gasset, 1981: 148).

Finalmente, Ortega se mostró opuesto a los dogmatismos y al modelo monológico que no permitían el diálogo, seguramente influenciado por el horror de los fascismo y las dictaduras de su país. La necesidad de múltiples perspectivas, combinada con huir de la pura y frívola homogenización de opinión (cuyo peligro principal era el estancamiento masivo como sociedad y el falseamiento de la vida e identidad como individual), se volvió un concepto clave y continuo en su obra. Como viene recogida en la siguiente cita, "La sola perspectiva falsa es esa que pretender ser la única» (Ortega y Gasset, 1981: 149).

Afortunadamente, con el cambio de paradigma de la conciencia en crisis después de todos los hechos históricos comentados, cobró fuerza la comunicación y el diálogo dentro del paradigma del lenguaje. Así, se dio lugar a un mundo de multiperspectivismo orteguiano.

Sin embargo, esa oportunidad no quita que la sociedad le cueste recuperar la lucha vital en la actualidad ante una peligrosa ola estandarizante de la sociedad de masas. Como se intuye por etimología, muy vinculada con la persona-masa orteguiana y sus aglomeraciones (Ortega y Gasset, 1990). 
No en vano, una de sus principales aportaciones es analizar el espíritu, la ideología y salud de Europa y el europeo, como una especie de tratamiento médico al individuo y su sociedad. Siguiendo la metáfora, la única cura para sus problemas es el raciovitalismo. La ignorancia completa de su enfermedad aún lo agrava más. Tal y como ya acontecieron los Maestros de la Sospecha, Europa no era consciente de su propia e inevitable caída ante los errores estructurales de planteamiento.

Para Ortega, Europa ha enfermado y ha parado el rumbo de toda la civilización. Comprender que la razón no puede ser absoluta ni integrar todo después de una larga tradición culturalista es el gran reto de un europeo que ha olvidado vivir entre tanta técnica e idea teórica y suprema (Ortega y Gasset, 1981).

Como pequeño análisis personal, sin duda un factor que justifique la situación explicada por Ortega es la herencia de las principales creencias religiosas, pues siempre han abogado que la importante es la otra vida: de manera más consciente o no hemos bebido de «aquí en el mundo terrenal estamos para sufrir y trabajar» y la cultura de la culpa. De ahí seguramente se deba la culpabilidad de vivir y de divinizar la razón como camino que conecta con el verdadero y aspirable mundo; pero con la ventaja de alcanzarlo en esta propia vida.

En la actualidad se ven las fallas de un sistema con claro déficit para formar a las personas en lo personal y vital: escaso sentimiento de ciudadanía, la generación nini, el abandono masivo de estudios básicos... Como apoyaría Ortega, antes de formar a un trabajador, dale un capital vital y humano con el que poder articularse y adaptarse a la realidad.

\subsubsection{Persona-masa, minoría selecta y la lucha vital}

Ya hemos analizado el problema del europeo medio -sin distinguir clase, género, sexo o edad- y de occidente, pues responde a un perfil generalizado. ¿Qué relación existe entre la debilidad vital, una falsa razón suprema y una posible rebelión de las masas? Como mejor transición, emplearemos una cita que relaciona directamente ambos libros: «Más importante que los antagonismos del pro y el anti, dentro del ámbito de una generación, es la distancia permanente entre los individuos selectos y vulgares» (Ortega y Gasset, 1981: 79).

Sin embargo, la sociedad necesita de una curiosa y compleja convivencia: la masa necesita una propuesta iniciadora, pero las alternativas minoritarias necesitan del resto y su aprobación para nacer. Esta es la esencia con la que se constituyen las generaciones, en cada una reside su misión. ¿Qué ocurre cuando esta queda desatendida? Inevitablemente surge un tipo de individuo que falsifica la vida (Ortega y Gasset, 1981).

Todo este proceso, su significado y alcance se explican en el segundo libro. Así, algunas de las cuestiones y preocupaciones sobre las que reflexiona Ortega y Gasset en La rebelión de las masas son: ¿qué es 
exactamente la persona-masa? ¿Por qué es tan peligroso que domine la sociedad, la cultura y la política? ¿Qué ocurrirá con el Estado y especialmente con una Europa decadente?

Esta cita nos puede ayudar a ver la potencialidad de un grupo y fenómeno social que causa gran interés en el autor. Como él mismo afirma «importa, pues, conocer mucho a fondo a este hombre-masa, que es pura potencia del mayor bien y del mayor mal» (Ortega y Gasset, 1990: 81).

Hasta que no decidamos uno de los dos rumbos estaremos cegados, vagamos perdidos en posibilidades y sumidos en el nihilismo negativo, tal y como sospechaba ya Nietzsche presente (Russell, 2011). Es la lucha vital del siglo XXI a gran escala, debemos recordar tal y como hemos explicado antes, que el europeo actual se caracteriza por un serio déficit para decidir y conocer la vida. Por tanto, la situación se agrava aún más, mientras no respondemos, cada minuto la Humanidad se aleja del avance social conseguido y se destaca que volver a escalar nuestros logros perdidos se vuelve un camino complejo y nada ni nadie asegure una completa recuperación (Ortega y Gasset, 1990).

Como propuesta propia, esta conexión dramática planteada por Ortega se podría considerar perfectamente una de las mayores vinculaciones entre ambas obras. Según tu postura vital y como se afronte, eres un tipo de individuo u otro. Estamos entrando aquí en la antropología filosófica orteguiana expresada propiamente en el segundo libro.

Ortega y Gasset empieza el libro planteando un hecho que se ha repetido a lo largo de la historia y ha traído consigo períodos decadentes: la presencia de aglomeraciones. O dicho de otro modo, todo se está llenando de muchedumbre. Para el autor son como parásitos de la sociedad que han venido a aprovecharse de sus recursos e incluso quieren decidir en ella. Por ese motivo, la masa quiere convertirse en la protagonista de la cultura y la política, es decir, básicamente de todo lo que influya socialmente.

La masa no se entiende ni responde a una clase social determinada, sino que depende del carácter y la actitud vital de cada persona. Es decir, la masa la integra un tipo de persona concreta y muy estereotipada; un ser humano vacío vitalmente, ignorante y estandarizado; bien malcriado, acomodado tanto como vago o sin ímpetu de formarse y vivir; todos falsifican su verdadero proyecto por el esfuerzo que le supone o aquel que no acepta la misión de su generación (Ortega y Gasset, 1990); en definitiva, en la sociedad actual quien no corrija los errores de la modernidad integrando la vida.

Como breve comparación personal, me recuerda mucho a la minoría de edad (Kant, 2005), donde aparecen individuos incultos, sin formación, que solo se mueven por ellos mismos y sus intereses y solo en casos concretos (imperativo hipotético), nunca de forma universalizable (imperativo categórico) pensando siempre y si es preciso anteponiendo el bien mayor. En este sentido, la élite nos recuerda a la mayoría de edad 
kantiana (Kant, 2005), la promesa de independencia, autolegislación y empoderamiento de la llustración. Para Ortega, una razón necesaria pero más sana y compensada.

El escaso y segundo colectivo: la minoría, formada por individuos especialmente exigentes, capaces de esforzarse y cualificados; genuinos y que afrontan la libertad vital del mejor modo que pueden; sin renunciar tal y como hemos visto a ninguna de las mitades; lo que tradicionalmente se ha ligado a la palabra ciudadano: pensando en el colectivo antes que en sí mismo. Dos modelos tan contrastados solo crean muchos problemas sociales: unos luchan por el avance de forma pacífica, otros abogan por sus intereses egoístas y de forma violenta (Ortega y Gasset, 1990).

La persona-masa huiría, por tanto, de la lucha vital, pero la vía para alcanzarla bastaría en cualquier momento con empezar a vivir de forma exigente y valiente, sin falsear la vida. Así pues, cualquiera puede vivir de este modo, al fin y al cabo es una cuestión de carácter y no tanto de clase o género. Afortunadamente para el destino de la humanidad.

\subsection{3 ¿La lucha vital posible tras la crisis mundial de la primera mitad del siglo $x x$ ?}

Después de resumir brevemente y aunar ambos libros, nos gustaría relacionar ese vacío existencial que en cierto modo dota Ortega a la persona-masa con algunas ideas muy llamativas. Hablaremos de la evolución de la segunda mitad del siglo xx, una etapa que Ortega no vivió, pero si vaticinó en aspectos importantes. Sin duda, este período se caracterizó por la gran lucha de ideologías de los grandes bloques en la Guerra Fría -comunismo contra capitalismo- que tanto arraigó y cambió al mundo. Abandonaríamos para siempre la escala local y continental y nos adentraríamos en hechos internacionales y un mundo interconectado por la globalización Rusell (2011) y Gamba (1987). Un concepto en la fina frontera de herramienta de occidentalización o la apertura de la verdadera sociedad intercultural como oportunidad de convivir y entendernos.

Durante la reconstrucción de la Europa destruida por los conflictos y unas colonias muy castigadas que se estaban descolonizando, apareció una población debilitada y sin respuestas, pues todo lo anterior -ya fueran fórmulas, sistemas, teorías, experimentos- había fracasado estrepitosamente. En esta época que bastó con sobrevivir, pero con completa ausencia de valores, ¿se puede hablar de lucha vital? Es una pregunta muy compleja, pero desde nuestra perspectiva: sí, al fin y al cabo sobrevivieron a un mundo destruido y poco a poco fueron deconstruyendo los valores previos y buscando alcanzar nuevos y mejores modelos. No hubiese sido posible sin la lealtad a uno mismo y el esfuerzo de sobrevivir a una época tan trágica y sin sentido.

¿Se les puede exigir responsabilidad histórica a los ciudadanos de dichas generaciones abatidas? Y más importante, ¿la situación ha vuelto a la normalidad o sigue distorsionada? ¿Existe un único modelo, el 
capitalista, o han aparecido alternativas competitivas? La sociedad, según Ortega, permanecerá en crisis y no podrá cumplir su labor generacional mientras solo exista la perspectiva consensuada de alcanzar la excelencia o lucha vital, y menos aún si está gestionada por las personas-masa.

\subsection{Lo profético en Ortega: sus reflexiones en la máxima actualidad}

De las múltiples ideas que hemos encontrado avanzadas a su época, por límites de extensión, solo podremos destacar las siguientes. En este apartado recogeremos la gran actualidad y utilidad de un autor que murió hace casi siete décadas, pero que supo anticiparse al cambiante mundo actual globalizado, lo que en nuestra opinión no es un mérito menor.

Primera idea, el nini actual equivale a la definición vital y visual de la persona-masa. Es un problema social y estructural de nuestro sistema actual. Como observamos, Ortega no falló en su pronóstico si combinamos ambos libros. El nini respondería a esa gente sin propósitos ni expectativas vitales, cuya falta de compromiso provoca que las deficiencias del sistema se agraven y perduren más.

Segunda idea a destacar, dentro del marco europeo, supo entender los límites autoimpuestos por el rígido concepto de la nación, y cada vez se volvió más necesaria una Unión Europea, para intentar salvar su decadencia (Ortega y Gasset, 1990). Aunque existen disonancias claras con la propuesta orteguiana, ya que esta no se constituyó como una supranación de unidad y diversidad, sino más bien como una empresa económica sujetada a los intereses capitalistas, ¿qué supone este cambio de postura? Un ejemplo muy claro de máxima actualidad: bajo la perspectiva de Ortega y Gasset, una Grecia débil debería ser ayudada sin exigencias ni pactos envenenados, aunque solo fuese por su legado clásico y por ser una nación hermana.

En el marco del conocimiento y el avance, el autor ya advertía de la confusión del progreso desde la modernidad. Nuestro autor sostiene que existe una necesidad obsesiva, entendido como el mal y excesivo uso de las herramientas - pese a su innegable potencialidad-, y una fe absoluta en la tecnología que ha derivado en el descuido del peso social y humano para mantener el complejo mecanismo de la civilización. O lo que es lo mismo: la deshumanización y la pérdida de las capacidades humanas en la sociedad (Ortega y Gasset, 1990). Proponemos un ejemplo muy claro: la incomunicación que produce el teléfono móvil supone una paradoja, pero... ¿ ¿cuántas veces hemos hablado con alguien tomando un café y este nos ha ignorado porque debía atender sus redes sociales? Es un ejemplo cada vez más común.

Finalmente, y en relación con el rumbo de la teoría democrática, Ortega y Gasset advierte del peligro de una democracia secuestrada y desatendida. Mientras que la élite raciovitalista queda bloqueada porque son menos y distintos, la ciudadanía en forma de masa y sin fuerza vital se vuelve pasiva y acomodada. Este descuido, que impide la bidireccionalidad entre exigencia real y actuación política, se traduce en la pérdida de unos derechos -considerados legítimos y básicos- obtenidos 
con mucha lucha social. Al mismo tiempo, en una época nihilista y sin valores, los nidos de corrupción aumentan como se puede apreciar en las noticias políticas de máxima actualidad. Esta idea subyace directamente si aunamos ambos libros.

\section{Conclusiones}

Tras la investigación y redacción del trabajo, hemos llegado a algunas conclusiones que exponemos en las siguientes líneas. En primer lugar, resumiremos la esencia del artículo: combinación de raciovitalismo y la sociología filosófica orteguiana para explicar problema -pero también la cura- en el ámbito individual, social y continental de Europa y su modelo occidental.

Como hemos visto a lo largo del libro, se entiende a la élite como la persona que busca responder al sentido de su vida y generación mediante lucha y esfuerzo vital. En ese sentido, la masa sería una persona perdida, acomodada o dormida entre las posibilidades de la vida, que reniega o dificulta su labor generacional. Cabe hacer especial hincapié en que Ortega en ningún momento habla de un estadio definitivo o natural; es decir, todo el mundo puede alcanzar la élite con esfuerzo. Al mismo tiempo, si esa minoría habitual se duerme en los laureles o cede su ilusión inicial también se volverá masa. $Y$ no basta con que lo piensa, pues al mismo tiempo se debe actuar -lo óptimo-o al menos criticar para ayudar a concienciar al resto de las deficiencias del sistema imperante. De este modo, y prácticamente solo así, se puede transformar y avanzar socialmente. Respondiendo al título: sí, todos podemos alcanzar la lucha vital y por tanto la excelencia, armonía y virtud del sabio (Aristóteles, 2015) y la mayoría de edad (Kant, 2001), integradas en concepto del autor.

En segundo lugar, hemos llegado a la conclusión de que la filosofía propuesta por José Ortega y Gasset goza de una gran vigencia. Nos ha llamado la atención el carácter profético que mantiene a lo largo de la obra, que incluye unas sorprendentes y agudas apreciaciones. Precisamente por ese motivo muchos lo consideran un sabio, ya que se adelantó varias décadas a su época y en fechas donde el rápido transcurso de los hechos y su área de influencia lo vuelven muy difícil de rastrear. Sin duda, uno de los principales intereses del trabajo era intentar evidenciarlo con sorprendentes resultados, ya que en ocasiones parecía un autor de la máxima actualidad.

En tercer lugar, nos gustaría advertir que parte de las complicaciones naturales de este trabajo ha sido comprender, conjugar y sintetizar tanto material de conocimientos en un espacio limitado; criticar y reflexionar a un gran intelectual como un estudiante aún en formación, y finalmente intentar buscar una escritura atrayente y clara sin perder calidad académica en el proceso. 
En cuarto lugar, un posible y potencial trabajo de investigación como apoyo al contenido de este, sería una comparación de Ortega con otros autores, pues se pueden encontrar un sinfín de conexiones que acercan nuestra filosofía a autores clásicos como Aristóteles (invirtuoso frente al sabio), Kant (persona-masa como minoría de edad egoísta frente al adulto cívico y empoderado capaz de actuar y pensar por todos, la élite). Por su antropología dual, lo podemos conectar con autores posteriores como Habermas y su ética discursiva (la masa usa la violencia, mientras la élite usa el diálogo) o la relación con superpersona o niño de Nietzsche con la minoría orteguiana. Al ver todas estas posibles conexiones, se demuestra la gran plasticidad del pensamiento orteguiano y se muestra el interés de retomar y ampliar las líneas del trabajo en un futuro.

Como conclusión final, viendo el peligroso auge de la persona-masa según las características e identificación propuesto por Ortega; nos preguntamos: ¿el egoísta persona-masa ganará una partida ya muy avanzada? ¿O aún estamos a tiempo de integrar razón, cultura, vida y biología de forma horizontal, armónica y necesaria? ¿Y de este modo aspirar al equilibrio sano y prudente aristotélico hacia un final feliz $y$ compartido? Al fin y al cabo, todo responde a actitud vital. ¿Usted, lector, qué opina? ¿Sabemos en el fondo cuál es la misión de nuestra generación? ¿Vive como élite o como masa? ¿Aprovecha su vida? En definitiva: ¿puede la persona-masa aspirar a la lucha vital?

\section{Bibliografía}

ARIStóteles (2015): Ética a Nicómaco, Alianza Editorial, Madrid.

GAMBRA, R. (1987): Historia sencilla de la filosofía, Rialp, Madrid.

KANT, I. (2001): Fundamentación de la metafísica de las costumbres, Alianza, Madrid.

Ortega y Gasset, J. (1981): El tema de nuestro tiempo, Revista de Occidente, Alianza Editorial, Madrid.

- (1990): La rebelión de las masas, Revista de Occidente, Alianza Editorial, Madrid.

RusselL, B. (2011): Historia de la filosofía occidental, Espasa, Madrid. 
El viejo oficio de pintar en un entorno 3.0 Análisis de la presencia en la red de la obra de Alex Alemany

María Hernández-Reinoso

maherei@alumni.uv.es 
Como bien indica el profesor Anaclet Pons en su libro El desorden digital, haciéndose eco de las palabras de Anthony Graffon, la mayoría de las investigaciones académicas comienzan por una búsqueda en Google.

La actividad cultural no puede mantenerse al margen de este nuevo entorno y tiene que estar dispuesta a ceder parte de su autoridad y control sobre los contenidos que se publican en Internet. Será gracias al uso de plataformas y herramientas de la Web 2.0 lo que les permitirá seguir jugando un papel relevante en la sociedad de la información.

La utilización de nuevos canales de información ofrece a los creadores grandes posibilidades de interactuar con los espectadores de las obras de arte que ahora pasan ya a ser considerados prosumidores, neologismo que surge en el entorno digital para definir una conversión de los consumidores en productores de ese servicio; en definitiva, miembros de una sociedad interconectada tanto en el mundo real como en el llamado entorno virtual. Sería, por tanto, incomprensible para los artistas no contar con presencia activa en el mundo digital.

En un primer momento las redes sociales fueron un ámbito empresarial que se sirvió de ellas para incrementar sus potenciales clientes. Mejorar la imagen corporativa, ampliar el espectro comercial o generar un diálogo, una interacción más allá de la mera publicidad, son los principales objetivos por los que se hace necesaria la presencia en las redes sociales.

Por lo tanto, en este artículo analizaremos cómo estos nuevos diálogos tendrán un papel clave como dinamizadores de la obra de los artistas utilizando como ejemplo la obra de Alex Alemany y su presencia en un este nuevo entorno puesto que, como se verá, en tanto que presente en el universo digital no puede obviar su participación en las nuevas tecnologías de la información y la comunicación.

Palabras clave: Alex Alemany, digital, comunicación, redes, virtual, pintura, arte, tecnología, web.

\section{Introducción}

Como bien indica el profesor Anaclet Pons (2013: 18) en su libro El desorden digital, haciéndose eco de las palabras de Anthony Graffon, la mayoría de las investigaciones académicas comienzan por una búsqueda en Google, pero a modo de introducción me gustaría remitirme a la comunicación que en 2004 pronunciara el profesor José Enrique Fillol en el $X$ Congreso de la Asociación Española de Semiótica que se celebró en la Universidad de La Rioja. En él, al abordar la relación entre arte, diseño y nuevas tecnologías a partir de lo que se ha dado en llamar "la muerte del arte», debemos generar estrategias para comprender el papel que, en 
relación con este, cumplen el diseño y lo que hoy se denominan nuevas tecnologías. La cultura digital produce una «nueva generación de vocabulario plástico que expande cualquier noción tradicional de estética». La actividad cultural no puede mantenerse al margen de este nuevo entorno y tiene que estar dispuesta a ceder parte de su autoridad y control sobre los contenidos que se publican en Internet. Será gracias al uso de plataformas y herramientas de la Web 2.0 lo que les permitirá seguir jugando un papel relevante en la sociedad de la información (Schwibenz, W. 2011: 3).

La utilización de nuevos canales de información ofrece a los autores grandes posibilidades de interactuar con los espectadores de las obras de arte que ahora pasan ya a ser considerados prosumidores, neologismo que surge en el entorno digital para definir una conversión de los consumidores en productores de ese servicio; en definitiva, miembros de una sociedad interconectada tanto en el mundo real como en el llamado entorno virtual. Sería, por tanto, incomprensible no contar con su presencia activa en el mundo digital.

Es para este público para quien será necesario diseñar una web dinámica y abierta a toda clase de información en la que se incluya no sólo contenido multimedia sino también que les permita la suscripción a canales de contenido sindicado (RSS).

Bruno Sokolowicz, director de Scanner FM, Barcelona, en su ponencia «Guerrilla Marketing. Museos 2.0» al analizar cómo llegar a nuevos públicos sostiene que los museos $-y$ por extensión los artistas visuales que deseen convertir su comunicación online en participativa e interactiva- deben adaptar sus sitios web a la Web 2.0, a través de las siguientes estrategias para obtener un mayor alcance entre usuarios y una mayor difusión de sus contenidos (Sokolowicz, B. 2011).

Según se desprende del estudio realizado por Jordi Busquets Albalate (2013) los museos de arte contemporáneo de España no aprovechan las posibilidades que ofrece Internet para desarrollar su función social. Además, y siempre de acuerdo con el citado informe:

En un entorno de recesión económica donde la cultura es una de las primeras afectadas en los recortes sociales, los recursos disponibles para que los museos puedan ejercer su función social son limitados. Pero quizá se debe ceder mayor protagonismo a la ciudadanía, a la creación individual y a la producción colaborativa, a ceder espacio en la autoría oficial y a confiar en los usuarios fomentando su participación.

En un primer momento las redes sociales fueron un ámbito empresarial que se sirvió de ellas para incrementar sus potenciales clientes. Las nuevas generaciones tienen hábitos de compras distintos y el eco de un producto es muy importante para estos nuevos mercados; mejorar la imagen corporativa, ampliar el espectro comercial o generar un diálogo, una interacción más allá de la mera publicidad son los objetivos principales por los que se hace necesaria la presencia en las redes sociales. 
La profesora María Luisa Bellido considera que las tecnologías de la información permiten al artista, si así lo desea, mantenerse al margen del mercado, lo que le proporciona una independencia hasta ahora inimaginable, y pone fin al carácter casi forzosamente venal de la obra de arte.

Hemos de pensar, también, en la indefinición del espacio físico que evidentemente altera profundamente las normas jurídicas de propiedad. También le permiten mantenerse oculto o, por el contrario, disponer de un extenso canal publicitario, complementar su obra con otras, incluir tantos accesorios como considere oportuno o mantenerse en comunicación con el espectador y recibir sus respuestas, algo completamente nuevo. Antes, el artista exponía su obra al criterio público y nunca recibía directamente la opinión del receptor, ni mucho menos su aportación. Ahora, el arte puede ser interactivo y el autor se nutre también de las experiencias de los espectadores, convertidos ellos mismos en autores. El artista puede verse también desligado de la servidumbre obligada a museos y galerías. Hace tiempo que se cuestiona la función de estas instituciones con relación a los creadores y a la sociedad. Generalmente, tales discusiones llevan a conclusiones contradictorias o, lo que es lo mismo, a una conclusión teórica y una realidad práctica.

Un reciente estudio del New Media Consortium «Horizon» sobre la implantación de la tecnología en los museos concluye con una afirmación cargada de lógica, pero no por ello menos necesaria para compartir: que los museos deben desarrollar estrategias digitales para sobrevivir a medida que cada vez más personas recurren a Internet para disfrutar de los contenidos culturales. Estas conclusiones son evidentemente extrapolables a las estrategias que debe desarrollar un artista.

Pero no sólo eso, la Unesco, en su reunión de especialistas para la protección y promoción de los museos y colecciones en Río de Janeiro en 2012, ya alertaba de que los miembros de la comunidad internacional del patrimonio reconocen la falta de recursos humanos, técnicos y financieros adecuados para proteger a los museos y las colecciones de una variedad de amenazas. Por ello, hacía hincapié en la necesidad de garantizar recursos humanos y técnicos, que son esenciales a la conservación y seguridad de los museos y sus colecciones; de adaptarse a las nuevas tecnologías y modernizar los sistemas de museos para reducir impactos ambientales negativos y promover un lugar de trabajo profesional, efectivo y sostenible en estrecha colaboración con comunidades diversas, y dotar a los museos de recursos financieros adecuados para que puedan llevar a cabo su trabajo en la preservación y difusión del patrimonio natural y cultural, tanto tangible como intangible.

Por lo tanto, como ya hemos citado, este producto cultural en tanto que presente en el universo digital no puede obviar su participación en las redes sociales al tiempo que ha de estar muy atento a la interacción con los receptores de su obra. 
No será de extrañar que, en próximas exposiciones en galerías comerciales, se incluya junto a las cartelas un pequeño código QR que identifique la obra en el mundo digital como ya hemos visto en algunos carteles promocionales de exposiciones. Según el informe de OBS Business School, España cuenta con una población conectada de 23 millones de personas. El $73 \%$ de esta población (17 millones de usuarios) utilizó activamente las redes sociales mensualmente en 2014. Según OBS, Facebook es la red más usada tanto por hombres como mujeres ( $47 \%$ del total de usuarios).

Siguiendo la estela empresarial, museos, galerías y más recientemente los artistas abrieron sus páginas de Facebook y las subsiguientes redes sociales para tener un nuevo canal de información. Con el tiempo se verá que además de un nuevo medio de comunicación unidireccional, necesitan que esta sea bidireccional, creativa y sobre todo arriesgada. Arriesgada porque no sólo recibimos el feedback de un espectador cuando visita una exposición a la que ha ido -en la mayoría de los casos invitado-, sino que gracias a las redes sociales puede, además, realizar una crítica, constructiva o no, en el muro de Facebook que deberá ser gestionada adecuadamente.

Por otra parte, la labor de comunicador en las redes sociales debe añadir un plus a los amantes del arte ya que esta es, en algunos casos, la primera ventana a la que se asoman los interesados en determinado tipo de pintura que no encuentran en los canales establecidos.

Un punto muy importante a tener en cuenta será diferenciar los públicos objetivos a los que se enfrenta un artista cuando decide tener un espacio público en el que mostrar su obra y que puede requerir estrategias diferenciadas para cada una de ellos.

Evidentemente, las tecnologías de la comunicación y la información en un entorno digital como el que nos encontramos son una herramienta de comunicación pero al mismo tiempo cumplen un cometido de marketing y promoción artística que hace necesaria la participación del artista pero también de su comisario o curator, así como las galerías con las que trabaje.

Para mejorar el posicionamiento de la web de un artista se requiere un entorno atractivo así como de sus perfiles en redes sociales que puedan retroalimentarse y establecer una política de interactuación con los usuarios y una comunicación eficiente. "Para la mayoría de los artistas, el éxito en última instancia se reduce a su eficacia en la comercialización", dice Darius Himes, director asistente de fotografía artística de la galería The Art Wolf, en Alemania. "Los artistas deben aceptar el hecho de que tanto su trabajo y ellos mismos como artistas, son marcas que deben ser comercializadas».

Es ahora cuando algunos autores, centros de arte y museos están pensando en la Web 3.0, en el momento para abordar cambios importantes en el rumbo ya sea en la web como en la actividad en las redes sociales en la estela de las pioneras iniciativas empresariales que han utilizado los medios que el entorno digital ha puesto a su disposición. 
La irrupción de las nuevas tecnologías no sólo en las webs de artistas sino también en los museos es una realidad evidente. Las aplicaciones para móviles de los principales centros expositivos españoles e internacionales baten récords de descargas. Además, como bien apunta Alberto Corazón «la creación artística del siglo XXI nace ya para ser reproducida aunque, como concluye en el artículo, «nada puede sustituir a su contemplación directa».

En función de todo lo anteriormente expuesto, analizaremos la presencia en Internet del artista Alex Alemany. Como ya hemos citado, las nuevas tecnologías nos ofrecen un amplio abanico de herramientas ad hoc que permite programar contenidos y publicarlos posteriormente para mantener una continuidad en las publicaciones. Por ello, en un futuro, y una vez superada la etapa 2.0 de introducción de contenidos y presencia en el mundo digital, quizás sea necesario incorporar otro tipo de herramientas digitales.

Demostraremos cómo la presencia en las redes ha sido especialmente útil para el artista en un contexto de crisis económica que está promoviendo la fuga de talentos, también artísticos, para contrarrestar la escasa proyección de las ferias internacionales que se realizan en España. Gracias a su difusión digital, el artista ha conseguido contactos con espacios expositivos, galerías y eventos artísticos que tienen lugar fuera de nuestra comunidad. No descartamos la posibilidad de que este acceso se hubiese producido de una u otra forma, pero sí que hay que hacer especial hincapié en que bajo parámetros tradicionales habría sido mucho más lento y, qué duda cabe, más costoso.

\section{Resultados}

En el caso que nos ocupa, la presencia de Alex Alemany en las redes sociales, al menos en cuanto a Facebook se refiere, cumple con una estrategia 2.0; es decir, no se limita a la mera exhibición. El artista ha conseguido integrar a sus seguidores en un dialogo virtual abriendo una metafórica puerta a la tertulia con ellos, a los que anima a participar.

Quizá por ello y a pesar de no haber utilizado en ningún caso herramientas de posicionamiento web, SEO o SEM, realizada la consulta en el buscador más utilizado en la red, los primeros resultados que nos devuelve remiten a la página principal de la web del artista, a la galería fotográfica de su página web, en tercer lugar a su perfil público en Facebook y en cuarto lugar a la voz "Alex Alemany» en el portal Wikipedia.

En cuanto a la búsqueda de imágenes, los resultados son igualmente satisfactorios, puesto que todas las imágenes que nos devuelve la consulta en el mayor buscador de la red corresponden a obras de arte recientes del autor. 
En lo que respecta a PageRank (PR) de Google, la web de Alex Alemany esta calificada con un $2 / 10$ que nos sitúa al nivel de otros artistas de coetáneos del artista o con una producción artística similar. El PageRank es la forma en que Google determina la importancia de una página. Y es importante porque es uno de los factores que determinan el ranking en los resultados de una búsqueda en Google. Hay que tener en cuenta que la web <www.alexalemany.com> no ha realizado en ningún momento aportaciones económicas para incrementar el PR de la misma.

Además, para promocionar la página en los buscadores, se tienen muy en cuenta las recomendaciones que una web recibe en forma de enlaces o menciones por parte de otras, por lo que sería interesante generar debates en blogs especializados.

Con el objetivo de potenciar y hacer más atractivo su entorno digital, en su perfil de Facebook, el autor o su comisario publican entradas atractivas que interesan a sus seguidores con el fin de generar más actividad. Para ello se nutre la página de promoción de exposiciones de museos y de otros artistas con propuestas interesantes. Además, la fanpage de Alex Alemany en Facebook publica un apartado llamado «Tal día como hoy...» en el que sin una periodicidad establecida el artista divulga una pequeña reseña de alguna efeméride del día importante, el nacimiento de un artista, su fallecimiento, alguna obra importante.

Evidentemente, el uso de las nuevas tecnologías de la información nos permite mayor información de contenidos visuales, no sólo la exposición virtual de obras de arte, que también, sino que mediante otros soportes innovadores -como pueden ser la aplicación de la realidad aumentada, las Google Glasses, la geolocalización, etcétera-, se puede propiciar el acercamiento a un nuevo público, el llamado nativo digital (sin duda más afín a nuevas tecnologías), que estaría en un principio alejado de nuestros planteamiento artísticos, expositivos o museográficos.

Además, la función del artista se verá también modificada en función de las nuevas tecnologías y de la inclusión de su obra en un entorno 2.0. Independientemente de que pueda contar con la colaboración de un community manager que pueda gestionar sus publicaciones o la inserción o no de determinados textos curatoriales o de promociones, será el artista en última instancia quien deberá responder a las cuestiones que sus seguidores le planteen. Desde cuál ha sido el motivo de una obra hasta la interpretación o el significado iconológico de la misma, estas inquietudes que tienen los seguidores de un artista requerirán de su implicación en mayor o menor medida para interactuar con ellos correctamente.

Estas publicaciones en redes sociales no sólo pueden contribuir a ampliar nuestro público objetivo sino que dotan a nuestra obra de acceso universal a personas con limitaciones o discapacitadas que visualizan exposiciones virtuales desde su domicilio.

Como apuntábamos al principio, la expansión internacional de la obra de Alex Alemany no habría sido tan evidente sin la presencia en las redes 
sociales. En la fecha de redacción de este artículo su cifra de seguidores en la mayor de las redes sociales -Facebook- es de 5.368 seguidores, de los cuales sólo 1.657 viven en nuestro país. Así, vemos que las redes posibilitan su presencia internacional.

La lectura rápida de estos datos no hace pensar que la fortuna crítica de este autor se haya incrementado, puesto que según criterios de Artprice -el portal especializado en obras de arte-, la obra de Alex Alemany sólo está presente en una subasta, ya que no es este su canal de ventas habitual. Al mismo tiempo, no pretendemos minusvalorar la importancia de otros artistas que no eligen estos canales como vías de promoción. En cambio, podemos inferir, basándonos en una lectura de sus antecedentes, que sí que ha mejorado la fortuna crítica de este autor gracias a la presencia en las redes sociales.

Sin lugar a dudas, la clientela del artista ha estado circunscrita básicamente hasta finales de los años noventa del siglo xx a la Comunidad Valenciana. Ha sido precisamente gracias a su presencia en la web cuando ha podido acceder a galerías de arte en el territorio nacional, por ejemplo en Gijón (Asturias), en A Coruña o en las galerías de arte del Grupo Escolá de Barcelona, que han contribuido a aumentar su red clientelar.

Y no sólo en el ámbito nacional, galeristas de los Estados Unidos también han contactado a través de su página web solicitando representar su obra en determinados Estados y, por poner un ejemplo de gran relevancia para su expansión internacional, que ha tenido continuidad en el tiempo, deberemos citar que Alex Alemany fue uno de los artistas internacionales invitados a la edición de 2014 de Art Revolution Taipei, una feria de arte organizada en la capital de Taiwan.

La inversión necesaria para la prospección de mercados, así como todos los costes de oportunidad requeridos para un mercado tan lejano, con toda seguridad habrían sido demasiado altos como para plantear semejante aventura. En este caso, una vez más, la presencia en Internet fue la clave para iniciar una expansión necesaria. No sólo en cuanto a participación en galerías o ferias de arte, la repercusión de la obra del artista en el público en general se ha incrementado considerablemente. El acceso a un nuevo mundo virtual como pueden ser las plataformas Flickr o Pinterest, por citar algunos, ha ampliado las fronteras de lo físico y ha permitido la generación de unos contactos que difícilmente habrían tenido lugar por medio de los canales tradicionales. En este sentido, podemos destacar los establecidos por el artista y su comisaria; en puntos tan alejados de su zona de influencia como Australia o Noruega se han recibido consultas que en varios casos han desembocado en ventas definitivas de obras.

En el canal de vídeo YouTube -que ya es el cuarto canal más visto en España- la obra de Alex Alemany inició su promoción en 2012, donde se incluyeron vídeos de sus exposiciones y de sus obras. El siguiente paso deberá ser incluir contenidos amenos e interesantes con el fin de interactuar con los usuarios, como ya se hace en la fanpage de Facebook. De hecho, uno de los aspectos en los cuales está trabajando el artista es 
la elaboración de un canal profesional de vídeos sobre el proceso de creación de las obras e incluso la utilización de un vídeo-blog.

\section{Conclusiones}

Debemos admitir que la división entre el mundo físico y el virtual es cada vez más escasa y que los internautas, al igual que los consumidores de productos generalistas (9 de cada 10 españoles), consultan antes de comprar y que el $70 \%$ de los internautas confían en las opiniones que se vierten en la red (datos extraídos del Congreso Nacional de Pymes celebrado en Valencia en 2012), por lo que se ha convertido en el nuevo mercado a potenciar.

En menos de nueve meses, Facebook consiguió crear una comunidad de usuarios de diez millones de personas mientras que el conjunto de las redes sociales ha generado 30.000 de contenidos.

Aunque se pensó que Facebook primaría sobre el resto, tanto Flickr como Pinterest, y sobre todo Instagram, están generando más actividad debido a que la red se está convirtiendo en un entorno eminentemente visual, por lo que una de las acciones a seguir será retomar la actividad en Flickr y publicar imágenes de obras de la colección (teniendo especial cuidado con los derechos de autor) y abrir, asimismo, un perfil en Instagram.

No debemos dejar de reflejar la incertidumbre que se creó en un inicio al promover la obra en la red. No fueron pocas las voces que se alzaron en contra, puesto que el miedo a la copia, a la réplica de la obra de arte con la facilidad de los medios técnicos de que se dispone, hacía pensar que eran acciones que irían en detrimento del las obras $y$, además, los prejuicios iniciales hacía la red hacían creer que las obras de arte no serían susceptibles de ser adquiridas de este modo. Hay que indicar que el artista consideró establecer la página web y el perfil de Facebook como una herramienta de promoción, pero no era su intención que se convirtiera en una galería en línea.

En este sentido, nos hacemos eco de las reflexiones que plantea Nuria Rodríguez en su ponencia "Mediación digital en los procesos de recepción, construcción e interpretación de la herencia cultural» en cuanto a las transformaciones en objeto digital que experimenta el objeto cultural y hemos entendido, como cita en el texto de referencia, que la función de la obra en un entorno digital amplía su conocimiento y facilita el acceso a un público especializado -o no-, y convierte este entorno no en una amenaza, como podría se podría haber visto, sino en «un instrumento para la democratización y acceso universal a la cultura» (Rodríguez, 2013: 446).

Es cierto, como también plantea Rodríguez (2013: 458), que: 
publicada: la apropiación social de los bienes culturales forma parte del proceso de patrimonialización, pues es esta apropiación la que nos permite reconocerlos como representativos de nuestra identidad e historia cultural [...]. Nos movemos aquí en un terreno resbaladizo y arriesgado, que bascula entre la riqueza inherente a la capacidad creativa e innovadora del conjunto social para dotar de nuevas significaciones a los objetos que forman parte de nuestra herencia cultural; y la pura oclocracia, la ignorancia global, la vacuidad, la banalidad.

Varias de las obras del artista que nos ocupa han sido reinterpretadas por otros pintores y a su vez publicitadas en sus correspondientes páginas web como propias. La frecuencia con que este proceso de apropiación o copia de obras de arte tenía lugar antes de la aparición de la red era infinitamente menor. No hay que olvidar que las obras de Alex Alemany pertenecen en un gran porcentaje a coleccionistas particulares y que sus exposiciones se circunscribían a galerías privadas. La difusión de las obras en la red ha permitido estas prácticas y es especialmente difícil controlarlas.

Es un paso más hacia la democratización del arte a la que hace referencia la profesora María Luisa Bellido (2001: 97), puesto que ya no nos dirigimos sólo a una élite cultural y no lo hacemos sólo a través de la obra gráfica sino que abrimos una ventana a toda la sociedad y todos los estratos culturales, lo que permitirá que sea este mercado el que guíe la demanda y el éxito de futuros creadores.

Por otra parte, ¿qué impedirá que este mercado virtual y globalizado sustituya a los canales habituales de gestión y promoción del arte, es decir, galerías de arte y museos? La red ofrece ya herramientas al alcance de todos los artistas y de todos los públicos que les permite interactuar con las obras y crear una exposición a la carta. Es, pues, el momento en el que se deberá redefinir el papel de los comisarios, curadores, galeristas y del propio artista que tendrá más medios a su alcance para llegar al consumidor final.

Como ya hemos apuntado anteriormente, el riesgo de vulnerar la propiedad intelectual, que en España está regulada por Real Decreto de 12 de abril de 1996 (Bellido, 2001: 97), es evidente puesto que existe un vacío legal ante el que las leyes no están teniendo la agilidad de respuesta requerida. El modelo económico de la llamada Web 2.0 está basado en la promoción del deseo de compartir e intercambiar y, siguiendo con lo que establece Martin Prada en "La Web "2.0" como nuevo contexto para las prácticas artísticas»:

Es por todo ello esperable que hoy ya no sean pocas las propuestas artísticas centradas en las formas de funcionamiento de las nuevas redes sociales digitales. Su intención es tematizar las formas en las que se opera la normalización de los juegos de lenguaje y de las interacciones comunicativas en general. Es decir, cómo se lleva a cabo la apropiación económica de la libre comunicación y de los deseos de cooperación, poetizando sobre el truncamiento del ideal de la interactividad (que sólo podríamos figurarnos adecuadamente como un darse lingüístico al otro, como un intercambiar lo que no se tiene, es decir, lo que uno es). El gran reto de la creación artística sería, 
por tanto, la construcción, en las dinámicas transfronterizas de presencias humanas en los entornos de redes, de flujos de valor y sentido independientes de las lógicas de los mercados y de los intereses corporativos.

$Y$ con todo este nuevo mundo digital a nuestro alcance, tendremos que hacer nuestra la frase de Umberto Eco cuando dijo que «el nuevo medio digital está más preocupado por difundir la información que por preservarla» (citado en Pons, A. 2011: 47).

Aún así, debemos considerar, como ya hemos citado anteriormente, Internet como la mayor herramienta educativa, de divulgación del conocimiento y de la cultura que se ha conocido en nuestra era. Sería de una flagrante ingenuidad resistirse a usarla incluso con los peligros e inconvenientes que pueda suponer.

Nicholas Negroponte en «El mundo digital» habla de que no vamos hacia un mundo frío y tecnológico, sino hacia «uno más abierto, que no separa de manera tan tajante el arte de la ciencia, o el hemisferio derecho del izquierdo». La cultura visual será digital o no será. Nuestro reto y nuestras prioridades serán adecuar el arte a estos cambios.

\section{Bibliografía}

Bellido Gant, M. L. (2001): Arte, museos y nuevas tecnologías. Trea, Gijón.

Busquets alBALATE, J. (2013): Trabajos de investigación de los programas de posgrado del Departament de Comunicació, Universitat Pompeu Fabra, Barcelona.

Corazón, A.: «Ver o no ver, esa es la cuestión». El País, 12 de marzo de 2014, p. 41.

Fernández peñuelas, I. (2014): "La cultura en la nube», Anuario ACE de cultura digital, 2014, p. 40-52.

Pons Pons, A. (2001): «Guardar como. La historia y las fuentes digitales». Historia Crítica, 43, p. 38-61.

- (2013): El desorden digital. Guía para historiadores y humanistas. Siglo XXI de España Editores, Madrid.

Prada, J. M. (2007): "La "Web 2.0" como nuevo contexto para las prácticas artísticas». Documentación del 10 encuentro Inclusiva-net. En: <http://medialab-prado.es/mmedia/578>.

- (2008): «La creatividad de la multitud conectada y el sentido del arte en el contexto de la Web 2.0». Revista de Estudios Visuales, núm. 5, p. 6580.

- (2012). Prácticas artísticas e Internet en la época de las redes sociales. Akal. Madrid.

Rodríguez Ortega, N. (2013): «Mediación digital en los procesos de recepción, construcción e interpretación de la herencia cultural», 
ARCINIEGA, L (ed.): Memoria y significado. Uso y recepción de los vestigios del pasado, Universitat de València, València.

Rodríguez NAVARRo, E. (2010): Espacios virtuales de museos e instituciones culturales: metodología para la evaluación de la calidad de los contenidos y definición de estrategias de comunicación y difusión. Universitat de Barcelona, Barcelona. PedrazA Jiménez R. (dir.). Trabajo final de estudios. Facultad de Biblioteconomía y Documentación, máster de Gestión de Contenidos Digitales. Universitat de Barcelona - Universitat Pompeu Fabra.

SCHWIBENZ, W. (2011): "Museums and Web 2.0: Some Thoughts About Authority, Communication, Participation and Trust», STYLIARAS G. y otros (ed.) (2011): Handbook of Research on Technologies and Cultural Heritage: Applications and Environments. Information Science Reference, Nueva York, EE. UU.

Sebastián lozano, J. 2004: "Ut poesis pictura. Lo que Horacio le diría a Google». Ponencia presentada en El posicionamiento en Internet de Instituciones culturales, científicas y educativas (del 5 al 7 de mayo de 2004), Universidad de Alicante, Fundación Biblioteca Virtual Miguel de Cervantes y Casa de las Américas. Alicante.

Sokolowicz, B. (2009). "Guerrilla Marketing: Museos 2.0», The 9th International Conference dedicated to Museum Professionals: Communicating the Museum.

Vozmedianio, E. (2010). "Las artes plásticas, Internet y la proyección internacional de la cultura», Revista Ari, Real Instituto Elcano, núm. 42, p. 1-8. 
Esther Parpal Cabanes. Arte e iconografía maya: la representación de los adornos corporales en las mujeres de la élite

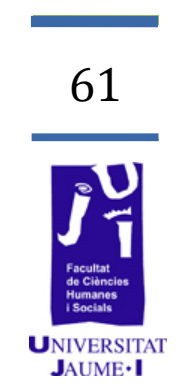

\section{Arte e iconografía maya: la representación de los adornos corporales en las mujeres de la élite}

Esther Parpal Cabanes

estparca@alumni.uv.es 
La antigua nobleza maya dejó patente la huella de su paso por las tierras mesoamericanas en forma de valiosas obras de arte. El carácter simbólico de dichas expresiones artísticas resulta ahora transcendental para conocer mejor a una cultura de la que, por diversas circunstancias, apenas se conservan documentos escritos.

Por este motivo, planteamos un estudio iconográfico con la intención de aproximarnos al conocimiento de un aspecto muy concreto de esta civilización, el colectivo femenino, que, hasta estas últimas décadas, siempre ocupó un segundo plano en la historiografía mayista, y se vale de las posibilidades y perspectivas que nos ofrece la historia del arte.

De este modo, el enfoque que planteamos utiliza los adornos corporales -elementos sumamente significativos y prolíficos en las representaciones- como hilo conductor, medio a través del cual acercarnos a la realidad de sus portadoras y la presencia de estas en el arte $y$, en consecuencia, en la cultura maya.

Aquellas antiguas damas no han dejado de representarse igual o más engalanadas que sus compañeros varones, sus nombres y hazañas también ocupan un lugar en las representaciones y todavía existen numerosos aspectos sobre ellas que, si se investigan correctamente, tienen mucho que enseñarnos sobre estas poderosas mujeres.

Palabras clave: iconografía, maya, mujeres, adornos corporales, género, alto rango, historia, arte.

\section{Introducción}

El clima extremo, la densa vegetación selvática, la fauna salvaje, las acciones del ser humano y, en conjunto, los estragos causados por el paso del tiempo fueron sepultando los vestigios de la que fuera una de las civilizaciones más desarrolladas y duraderas de la América prehispánica: la cultura maya. No obstante, son muchos los investigadores que, desde diferentes disciplinas, han ido contribuyendo a la reconstrucción de la historia de esta cultura. La labor de antropólogos, arqueólogos, epigrafistas, historiadores, arquitectos y restauradores, por citar algunos, ha sido fundamental para dar a conocer el pasado de los pueblos mayas y recuperar una enorme cantidad de vestigios arqueológicos y arquitectónicos diseminados en un área de más de $324.000 \mathrm{~km}^{2}$. A este respecto cabe destacar que muchos de estos hallazgos son de carácter artístico; es más, se han conservado y recuperado muchas más imágenes mayas en diferentes soportes plásticos (vasijas cerámicas, muros, códices, relieves, etc.) que documentos escritos. Por lo tanto, el papel que juega la historia del arte en el estudio de esta antigua cultura precolombina es sumamente importante. 
En este sentido, el método iconográfico-iconológico nos permite profundizar en el significado de las obras de arte maya y entender en qué medida reflejan el contexto en el que se crearon, al mismo tiempo que nos desvelan qué función tuvieron y cuál fue su intencionalidad.

Asimismo, este trabajo se inserta en la línea de los estudios de género puesto que, a pesar de que esta rama ha ido adquiriendo más protagonismo en el ámbito académico en estos últimos años, continúan existiendo muchos vacíos de conocimiento debido al segundo plano al que se ha relegado a este tipo de estudios en el pasado.

En síntesis, mediante este análisis pretendemos sumarnos a esa corriente de investigadores que abogan por hacer aportaciones en un campo de estudio todavía incipiente, como es el de los estudios de género mayas. Para ello se emplean las ventajas que nos ofrecen las herramientas y los enfoques propios de nuestra disciplina, la historia del arte. Además, partimos del estudio de los adornos corporales, puesto que somos conscientes de la importancia que, desde el punto de vista cultural, tienen los detalles más pequeños en las imágenes, la riqueza epistemológica de su iconografía. Así pues, consideramos que elementos tan apreciados en aquellas culturas, como eran las joyas, los tocados o los cosméticos, son idóneos para indagar acerca de los individuos que los portaban, concretamente las mujeres, para aproximarnos de una manera original al significado de su presencia en las representaciones artísticas y, en consecuencia, a la trascendencia de cada obra y de sus protagonistas femeninas en el seno de esta antigua sociedad precolombina.

\section{Objetivos}

El objetivo principal que persigue este trabajo es desarrollar un estudio en torno a la figura de la mujer de alto rango en el contexto de la civilización maya a través de los atributos que porta en sus representaciones.

Dicho objetivo se materializará finalmente como consecuencia del cumplimiento de una serie de objetivos específicos expuestos a continuación.

- Definición de las distintas categorías establecidas para el análisis de los personajes femeninos de la élite desde una perspectiva de género.

- Análisis y clasificación de los diferentes adornos corporales utilizados por las mujeres en la antigüedad maya.

Análisis e interpretación iconográfica de las obras de arte seleccionadas. 


\section{Material y método}

Al tratarse de un estudio que tiene por objeto las representaciones artísticas de los antiguos mayas, trabajamos principalmente con fuentes visuales, primarias, directas y necesariamente de segunda mano. Concretamente, reproducciones y fotografías de las obras de arte accesibles en libros sobre la materia o catálogos de museos que conservan obras de arte precolombinas. Asimismo, nos valemos del material gráfico disponible en bases de datos especializadas, fundamentalmente, la base de datos fotográfica de Justin Kerr, ${ }^{1}$ donde podemos visualizar una enorme cantidad de representaciones mayas al completo, que fueron plasmadas sobre vasijas, platos y vasos cerámicos. Muchas de estas piezas no serían accesibles de otro modo, ya que pertenecen a coleccionistas privados.

Del mismo modo, consultamos fuentes de carácter literario. Desde las versiones actuales, traducidas y comentadas de relatos mitológicos como el Popol $\mathrm{Vuh}^{2}{ }^{2}$ pasando por fuentes etnohistóricas como las transcripciones y ediciones actuales del manuscrito de Diego de Landa ${ }^{3}$ hasta las reproducciones de dos de los tres códices mayas, ${ }^{4}$ expuestos uno de ellos en el Museo de América de Madrid y el otro en la biblioteca estatal de Dresde. Este tipo de fuentes, junto con el estudio de la bibliografía complementaria (estudios críticos sobre las cuestiones que nos atañen: la cultura maya, la antigua mujer maya o trabajos precisos sobre iconografía y adornos corporales), que compone el corpus principal de materiales empleados, nos permiten conocer, contrastar y sentar las bases teóricas sobre las cuales construir nuestro discurso posterior, fruto del análisis de las imágenes.

Así pues, el manejo de este tipo de materiales nos lleva a plantear dos métodos de estudio.

Comenzamos con la investigación siguiendo el método historiográfico. Con el fin de alcanzar satisfactoriamente las metas propuestas, se efectúa un acercamiento inicial en el que a través de búsquedas, ayudados por las ventajas que ofrecen las nuevas tecnologías, recuperamos y guardamos de manera selectiva información sobre el tema que vamos a trabajar. A la busca y selección de las fuentes visuales mayas se suma la de fuentes textuales y de bibliografía específica, citadas anteriormente. Con la intención de hallar todo el material, sin obviar la consulta y lectura de estudios imprescindibles y tratando de visualizar y recopilar el mayor número de imágenes posible, dedicamos cerca de dos meses y medio a esta fase, crucial en todo tipo de investigaciones.

Finalmente, recurrimos al método iconográfico-iconológico, mencionado en el apartado introductorio, estructurado en el siglo xx por

1. @JustinKerr <www.mayavase.com>

2. Rivera (ed.), 2008.

3. Landa, 2002.

4. Manuscritos mayas que, por sus características y su originalidad, componen una de las fuentes más fiables sobre la antigua civilización precolombina. Actualmente, solo se conservan tres: uno de ellos en Dresde, otro en Madrid y otro en París. 
el historiador del arte Erwin Panofsky, desarrollado en su obra Studies in Iconology: Humanistic Themes in the Art of the Renaissance, ${ }^{5} \mathrm{y}$ enriquecido con las recientes investigaciones llevadas a cabo por el profesor Rafael García Mahíques, ${ }^{6}$ con el fin de profundizar en el estudio de las representaciones femeninas de élite en el arte maya, escogidas en la fase heurística anterior. Dicha selección se efectúa atendiendo a las necesidades de nuestro estudio, es decir, qué imágenes contienen las muestras más representativas de todo aquello que estudiamos y pretendemos demostrar. Retomando la cuestión metodológica, este procedimiento parte de un acercamiento progresivo a la obra estructurado en tres fases: localización, análisis formal y aproximación al significado (análisis iconográfico-iconológico), procurando abarcarla en todas sus vertientes. En este sentido cada aportación es fundamental, pues de la correcta ejecución de la primera parte dependerá la veracidad de la siguiente, y así sucesivamente. De este modo podemos llegar a entender la función de la obra como un factor de creación cultural que influye, en la misma medida en la que se impregna, en el entorno que la rodea. El sentido de esta metodología queda así resumido en palabras de Panofsky (1987: 187):

En una obra de arte, la forma no puede separarse del contenido; la distribución del color y las líneas, la luz y la sombra, los volúmenes y los planos, por delicados que sean como espectáculo visual, deben entenderse también como algo que comporta un significado que sobrepasa lo visual.

Esta última parte de la investigación requiere, además del manejo de las imágenes, trabajar con la información obtenida mediante el método anterior, con la finalidad de extraer conclusiones propias y aportar nuevas perspectivas a este campo de estudio. Completar esta labor nos lleva un mes y medio de trabajo.

\section{Resultados}

De acuerdo con los objetivos planteados inicialmente, la primera parte de este trabajo se centra en el estudio de la mujer maya de alto rango en el seno de su sociedad, qué funciones cumplía y qué características la definían. De este modo, las clasificamos en tres grupos:

\section{REINAS}

- Por lo general, fueron esposas de gobernantes o madres regentes.

- Aparecen lujosamente ornamentadas en las representaciones.

- Se les reconoció la función de legitimar el linaje real generación tras generación.

5. Panofsky, 1939.

6. García, 2009. 
- Protagonizaron actos importantes tanto en el plano ritual como en el político, realizando autosacrificios de sangre $u$ otorgando las insignias del poder a su descendiente, por ejemplo.

\section{MUJERES DE LA CORTE}

- Fueron personajes femeninos de la nobleza, normalmente mujeres de hombres importantes o familiares cercanas de los gobernantes.

- Se las representa en escenas palaciegas.

- Asumían tareas trascendentales tales como la hechicería, el arte de tejer, el cuidado de las parturientas o la danza ritual. También hubo quienes tuvieron el honor de ser escribas y pintoras.

- Lucían ricos ropajes y se engalanaban con joyas, pero en menor medida que las reinas.

\section{MUJERES EN EL ÁMBITO SOBRENATURAL}

- Se trata de las deidades femeninas del panteón maya.

- Desempeñaron funciones tan importantes como las de los dioses. De hecho, en la mayoría de los casos, ambos sexos necesitaban complementar sus funciones para llevar a cabo alguna acción.

- En ocasiones se las representa ejerciendo labores terrenales, ya que se constituían como modelos celestiales de las mujeres de la tierra.

- Son fáciles de reconocer puesto que la tradición las vincula con unas determinadas cualidades y funciones representadas por atributos concretos con los que siempre aparecen.

En segundo lugar, agrupamos y analizamos los adornos corporales empleados frecuentemente por el género femenino en el área maya. Obtenemos así una clasificación general, nuevamente en tres grupos, que nos permite ordenar y conocer este tipo de prácticas y piezas:

\section{MODIFICACIÓN CORPORAL}

Aquellas prácticas que suponen una transformación de carácter permanente y que inciden directamente en la fisionomía del ser humano: 
Tabla 1. Modificaciones corporales más características: fragmento del roll out de la vasija de cerámica policromada K6888 que muestra la deformación craneal de una noble / Fragmento de la figurillla K3803 que muestra una dentadura limada en forma de T según el diseño IK

\begin{tabular}{|c|c|}
\hline Deformación craneana & Decoración dental \\
\hline $\begin{array}{c}\text { Consiste en moldear el cráneo hasta } \\
\text { conseguir la forma deseada. Esta } \\
\text { práctica se llevaba a cabo desde el } \\
\text { nacimiento y tenía como finalidad } \\
\text { asemejarse al Dios del Maíz. }\end{array}$ & $\begin{array}{c}\text { Se trata de incisiones, limados, } \\
\text { perforaciones, pintadas e } \\
\text { incrustaciones de piedras preciosas, o } \\
\text { varias de estas técnicas combinadas } \\
\text { sobre la dentadura. }\end{array}$ \\
\hline
\end{tabular}

\section{ORNAMENTOS}

Complementos materiales adheridos al cuerpo que, aunque a veces también suponían una modificación, por ejemplo al perforar, ésta no conformaba una decoración por sí misma como ocurría con las anteriores, si no que se efectuaba por la necesidad de colocar la pieza. En este aspecto distinguimos entre tocados y adornos en el cabello, y joyas:

Tabla 2. Tocados y adornos en el cabello clasificados según nivel de complejidad: fragmento del roll out de la vasija de cerámica policromada K2794 (coleta) / Fragmento del roll out de la vasija de cerámica policromada K0764 (pañuelo) / Fragmento del roll out de la vasija de cerámica policromada K1202 (tocado sencillo) / Fragmento del roll out de la vasija de cerámica policromada K1377 (tocado complejo)

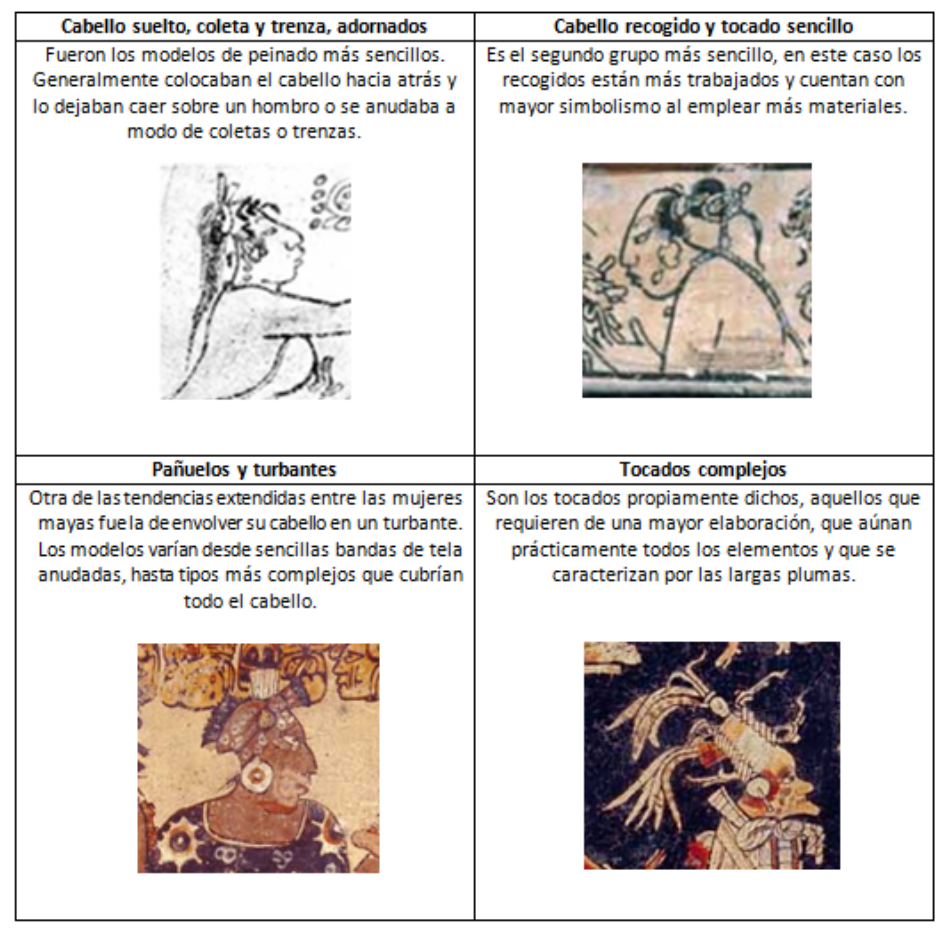


Tabla 3. Joyas principales

\begin{tabular}{|c|c|c|c|}
\hline Orejeras & Narigueras & Collares & Pectorales \\
\hline $\begin{array}{l}\text { Tipo de ornamento que } \\
\text { decora de forma muy } \\
\text { vistosa los lóbulos de } \\
\text { las orejas. Se trata de } \\
\text { uno de los distintivos } \\
\text { principales de las clases } \\
\text { altas y su forma más } \\
\text { común fue la que } \\
\text { imitaba una flor. }\end{array}$ & $\begin{array}{l}\text { Fue una pieza exclusiva } \\
\text { de las divinidades y las } \\
\text { clases altas. Existieron } \\
\text { diversos tipos que se } \\
\text { colocaban en la nariz, o } \\
\text { bien a modo de } \\
\text { decoración, o con la } \\
\text { intención de asemejarse } \\
\text { a sus dioses. }\end{array}$ & $\begin{array}{l}\text { Fue un atributo de poder } \\
\text { fabricado generalmente } \\
\text { en jade, jadeíta y } \\
\text { concha. Las formas de } \\
\text { sus piezas variaban pero } \\
\text { el diseño más común fue } \\
\text { el fabricado mediante } \\
\text { cuentas tubulares o } \\
\text { esféricas. }\end{array}$ & $\begin{array}{l}\text { Similares a los collares, } \\
\text { merecieron una } \\
\text { atención especial por la } \\
\text { cantidad de atributos } \\
\text { simbólicos de los que } \\
\text { se componían. Su gran } \\
\text { tamaño permitía, a su } \\
\text { vez, diseños más } \\
\text { variados. }\end{array}$ \\
\hline Pulseras & Brazaletes & Muñ & Tobilleras \\
\hline $\begin{array}{c}\text { Elementos finos que se } \\
\text { colocaba en las } \\
\text { muñecas y que se } \\
\text { fabricaba también con } \\
\text { materiales preciados, } \\
\text { contribuyendo a } \\
\text { construir la imagen de } \\
\text { poder de las mujeres } \\
\text { de élite. }\end{array}$ & $\begin{array}{l}\text { Fueron ornamentos } \\
\text { muy similares a las } \\
\text { pulseras que } \\
\text { únicamente se } \\
\text { diferenciaban de éstas } \\
\text { por su colocación. En } \\
\text { este caso, se ceñían en } \\
\text { el extremo superior del } \\
\text { brazo }\end{array}$ & $\begin{array}{l}\text { El uso de estas piezas } \\
\text { estuvo muy extendido } \\
\text { entre la corte. Los } \\
\text { personajes que } \\
\text { aparecen ricamente } \\
\text { ataviados siempre } \\
\text { cuentan con estas } \\
\text { piezas cubriéndoles un } \\
\text { tercio del antebrazo. }\end{array}$ & $\begin{array}{c}\text { Al igual que en los } \\
\text { brazos lucían pulseras o } \\
\text { muñequeras, los } \\
\text { tobillos se decoraron } \\
\text { con estos ornamentos } \\
\text { de uso cotidiano. Los } \\
\text { materiales principales } \\
\text { para su fabricación } \\
\text { fueron el jade y la tela. }\end{array}$ \\
\hline
\end{tabular}

PINTURA CORPORAL

Este fue uno de los primeros recursos empleados por el ser humano para cambiar su apariencia natural. Cubrían su piel parcial o totalmente con pigmentos de color, creando diseños y patrones con una finalidad estética y simbólica.

Con el tiempo, el deseo de mantener algunos de estos diseños de manera permanente sobre la piel les llevó a practicar también los tatuajes y las escarificaciones. Para realizar los primeros, se seguía la técnica de punción prácticamente igual que la que conocemos hoy en día. Y en las escarificaciones, heridas intencionadas con las formas deseadas, con la intención de que el dibujo quedara marcado, se insertaban tierra de colores en la piel para que las cicatrices quedaran abultadas y coloridas.

Finalmente, escogemos seis obras de arte representativas sobre las cuales aplicamos el método de análisis iconográfico-iconológico. Esta cuidada selección nos permite acercarnos a cada tipo de mujer: diosa, reina y cortesana. Asimismo, optamos también por estudiarlas representadas en diferentes soportes plásticos: un códice iluminado en el que aparece una diosa, una escultura donde nos aproximamos al ritual sagrado de una conocida reina, una pintura mural donde se aprecia el contraste social de una mujer de la corte frente a una plebeya y tres ejemplos diferentes de mujeres de alto rango presentes sobre uno de los soportes más prolíficos en imágenes mayas, las vasijas de cerámica policromada: 


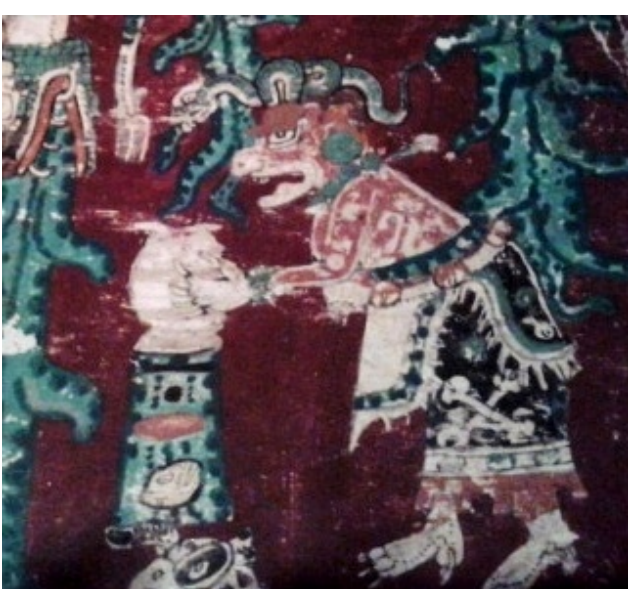

Figura 3. Fragmento de la pàgina 39 del códice de Dresde. Representación de la diosa Ixchel en su versión anciana

Figura 4. Fragmento del dintel 24 de Yaxchilán. Representación de la señora Xoc realizando un autosacrificio de sangre

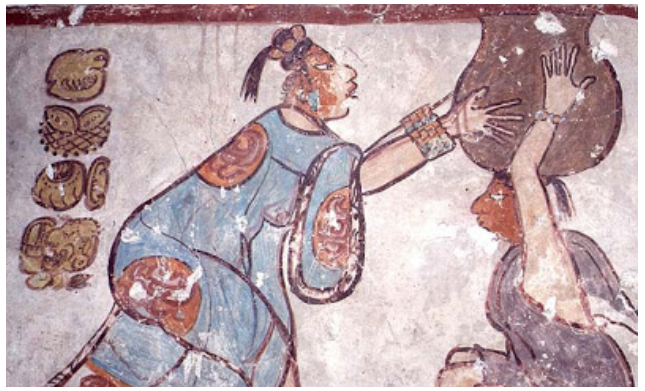

Figura 5. Fragmento de la escena de la cara sudeste de la base de la estructura de los murales de Calakmul. Representación de la noble del huipil azul

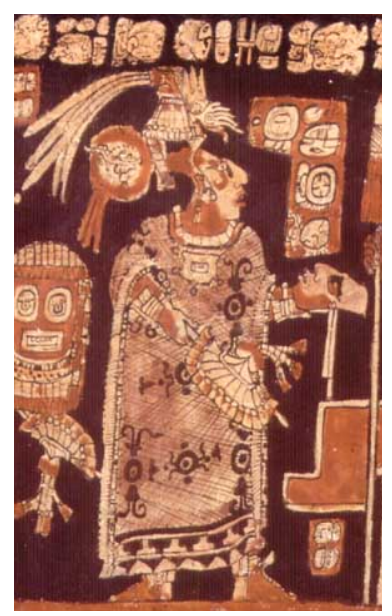

Figura 7. Fragmento del roll out de la vasija de cerámica policromada K2695. Representación de la esposa del gobernante ricamente ataviada
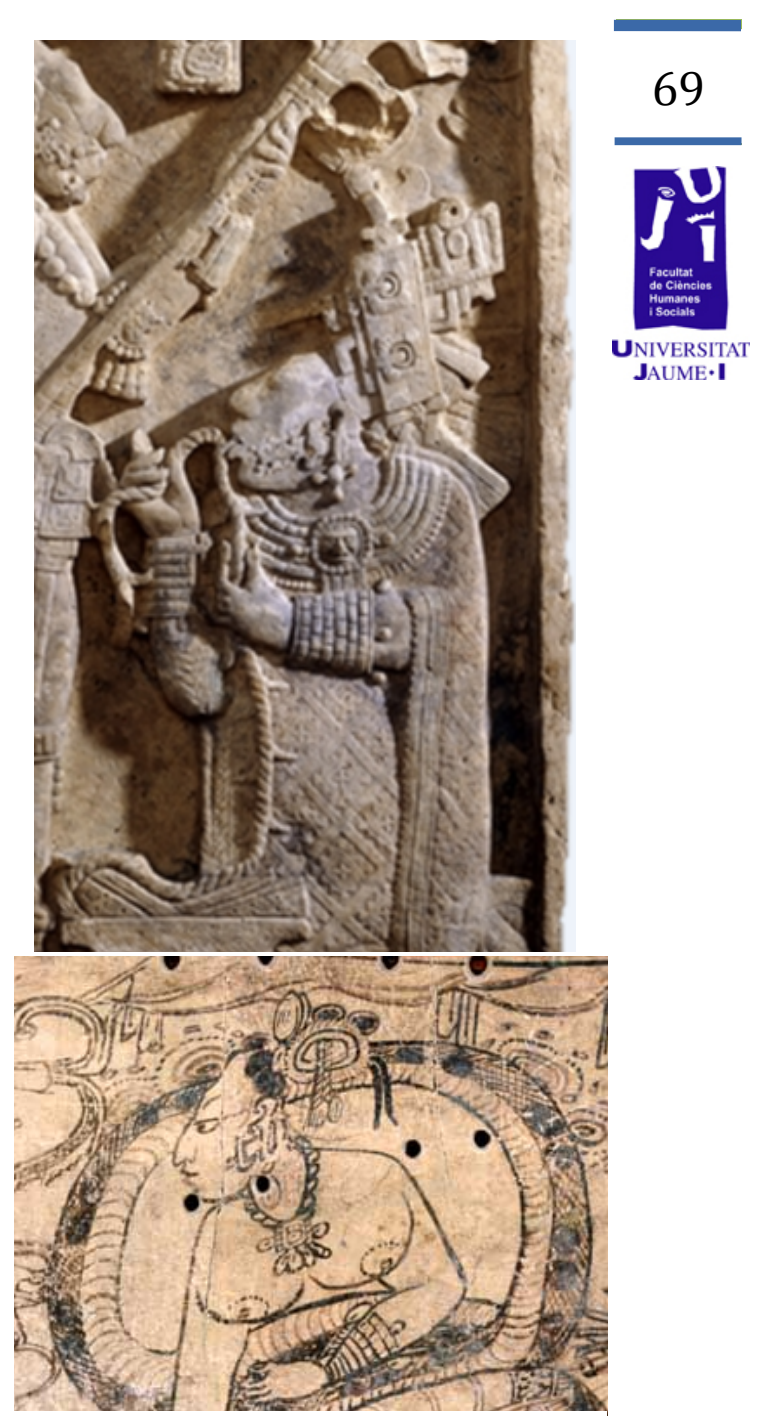

Figura 6. Fragmento del roll out de la vasija de cerámica K1198.

Representación de la señora Dragón

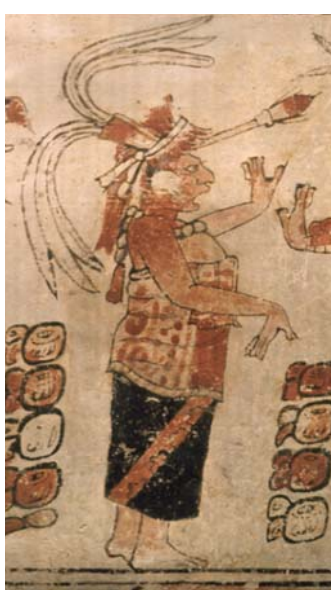

Figura 8. Fragmento del roll out de la vasija de cerámica policromada K0554. Retrato de una noble danzando 
Así pues, el resultado más destacado de este análisis es que verdaderamente los adornos corporales cumplen una función básica: identificar a su portador, en este caso portadora, en las representaciones. No solo nos permiten situarlas en una escala social (distinción entre nobles y plebeyas) y diferenciarlas entre ellas (reinas, diosas y nobles) dentro de un mismo rango, sino que además ofrecen información de carácter personal como el oficio que tenían en la corte o la función que cumplían como diosas, de carácter cultural -puesto que algunas presentan elementos propios de la cultura teotihuacana, testimonio de los contactos que hubo entre ambas civilizaciones- $y$, especialmente, de carácter religioso -pues desde los materiales con los que se fabricaban, pasando por la parte del cuerpo y quién las lucía, hasta el acto mismo de ponerse estos adornos, tuvieron connotaciones sagradas y rituales.

\section{Discusión y conclusiones}

La aproximación a los adornos corporales en las representaciones de las mujeres de alto rango en el arte maya nos ha ofrecido la posibilidad de profundizar de manera enriquecedora en uno de los aspectos culturales más interesantes de una civilización.

Las conclusiones que se han ido desprendiendo a medida que avanzaba el trabajo han sido las que han permitido posteriormente realizar un análisis iconográfico adecuado ya que nos han proporcionado las bases teóricas sobre las cuales fundamentar nuestras interpretaciones.

En primer lugar, del estudio de la mujer maya en el seno de su civilización se deduce una participación social y cultural destacada. Son numerosos, aunque recientes en el tiempo, los estudios que, independientemente de su inclinación acerca de cómo fue tratada la mujer con respecto al hombre en el pasado, documentan la cantidad de labores que desempeñaban para sus pueblos en todos los ámbitos: social, político y religioso. Y esto es especialmente palpable entre las mujeres de alto estatus, quienes desempeñaban trabajos indispensables.

Gracias a la lectura y el análisis exhaustivo de la bibliografía que se ocupa del estudio de la mujer maya hemos sido capaces de discernir cuáles eran los papeles que desempeñaban y qué prácticas se relacionaban con un tipo de mujer u otra, consiguiendo así establecer las características propias de cada categoría, distinguiendo y definiendo a reinas, cortesanas y diosas. El hecho de haber acotado este estudio únicamente a la figura de la mujer nos ha proporcionado, además, la posibilidad de extraer la máxima información sobre este sector de la población maya, lo cual nos permite, a su vez, llegar a conclusiones más específicas en el análisis iconográfico posterior, pues al centrar nuestro objeto de estudio atendemos a detalles -a veces descuidados- que nos aportan buena información y nos permiten ofrecer otro punto de vista. 
En segundo lugar, la investigación de los adornos corporales nos ha proporcionado las herramientas necesarias para poder reconocerlos e interpretarlos en las obras de arte. Asimismo, hemos podido efectuar una selección de los adornos concretos que tuvieron más cabida en el ámbito femenino de la corte (tanto terrenal como sobrenatural) y hemos proporcionado un análisis y una clasificación propios, orientados al ámbito artístico. Por un lado, destaca la importancia de la selección de los materiales, entre los cuales el jade fue el más preciado, pues lo reservaban para las élites $y$, cuando lo empleaban, lo hacían en abundancia y lo colocaban en lugares visibles para que el mensaje llegara correctamente. Sin embargo, no solo valoraron el jade, sino también las plumas y la variedad de colores de estas, el nácar que obtenían de la concha de caracoles marinos con dificultad, etc. Algunos considerados bienes de lujo por la dificultad de su obtención y otros por el simbolismo de sus colores. En síntesis, el material le daba calidad y valor añadido a los adornos que por sí mismos ya se fabricaban con una misión: comunicar.

En última instancia, es en el análisis iconográfico efectuado tras el estudio previo de la cultura, las mujeres y sus adornos corporales, donde se ponen en práctica las reflexiones extraídas. En este sentido, las imágenes analizadas nos han permitido, entre otras cosas, aportar algunas conclusiones que consideramos de interés a escala general. Una muestra de ello, además de la posibilidad que nos ofrecen los adornos corporales de obtener información sobre sus portadoras tal y como mencionábamos al final del apartado anterior, es que hemos podido observar que, de las seis figuras femeninas estudiadas, tres adquieren más protagonismo en las escenas que los varones que las acompañan (Ixchel, la señora Xoc y la noble del huipil azul), dos de ellas se muestran al mismo nivel que ellos, tanto en acciones como en ornamentos (la reina en la vasija K2695 y la artista-escriba en la vasija K0554) y solo una de ellas se encuentra en una posición más débil con respecto al género masculino (la señora Dragón), pero el papel que desempeña es igualmente importante en el capítulo que se representa en esta escena de la mitología maya. Por lo tanto, queda demostrada la participación activa y reconocida de muchas mujeres mayas del pasado en su sociedad, cuyos nombres y acciones quedan también grabados en la historia de sus muros, estelas y pinturas, engalanadas igual que los hombres.

Asimismo, este análisis nos permite incidir, además de en la cuestión de género, en la cuestión religiosa. Y es que para los mayas sus creencias actuaron como pilares de su existencia. Por ello, si prestamos atención más allá del valor y la función de estos objetos y de estas prácticas por motivos políticos y sociales, observamos la presencia continua de símbolos, de materiales simbólicos, de representaciones directas de divinidades y la intención de portar muchos de estos adornos y ejecutar muchas de estas modificaciones con tal de asemejarse a sus dioses.

En síntesis, estas reflexiones prueban que un estudio riguroso sobre las representaciones no solo puede aportar y completar información, sino que puede ayudar a resolver algunos interrogantes acerca de esta antigua 
civilización que la arqueología o la antropología no alcanzan a responder. En este caso en concreto, nos hemos centrado en los adornos corporales para aproximarnos a las representaciones de la mujer de la élite, pero en un futuro se podría enriquecer incluyendo también el estudio de la indumentaria.

A grandes rasgos, este trabajo ofrece una panorámica sobre los adornos corporales, y concretamente femeninos, que la historiografía, aunque sintética, no ha tratado específicamente. De este modo, no solo se ha pretendido plantear un estudio con vistas a una futura investigación de mayor envergadura, sino que además se ha intentado reivindicar, por una parte, la imprescindible labor de la historia del arte en el análisis de las abundantes imágenes que los mayas nos han legado y, por otra, la función que las antiguas obras de arte maya desempeñaron en su tiempo y que todavía tienen mucho que aportar si se estudian detenidamente en la actualidad.

\section{Bibliografía}

Ardren, T. (2002): Ancient Maya Women, Altamira Press, Walnut Creek.

Bautista MARTínez, J. (2002): "Alteraciones culturales en el cuerpo del hombre prehispánico», Estudios Mesoamericanos, Universidad Nacional Autónoma de México.

Fuente, B y A. Arellano (2001): El hombre maya en la plástica antigua, Universidad Nacional Autónoma de México, México.

García Mahíques, R. (2009): Iconografía e iconología. Volumen 2. Cuestiones de método, Ediciones Encuentro, Madrid.

JoyCE, R. (2001): Gender and Power in Prehispanic Mesoamerica, University of Texas, Austin.

LANDA, D. (2002): Relación de las cosas de Yucatán, Dastin, Madrid.

Martin, S. y N. Grube (2002): Crónica de los reyes y reinas mayas. La primera historia de las dinastías mayas, Editorial Crítica, Barcelona.

PANOFSKY, E. (1939): Studies in Iconology: Humanistic Themes in the Art of the Renaissance, Oxford University Press, Nueva York.

- (1987): El significado de las artes visuales, Alianza Forma, Madrid.

Rivera Dorado, M. (ed.) (2008): Popol Vuh, Trotta, Madrid.

ROdRIGUEZ-SHAdOW, M. J. y S. KELLOG (ed.) (2013): Género y arqueología en Mesoamérica. Homenaje a Rosemary A. Joyce, Centro de Estudios de Antropología de la Mujer, México.

Rodríguez-Shadow, M. J. y M. López HeRnÁndez (ed.) (2011): Las mujeres mayas en la antigüedad, Centro de Estudios de Antropología de la Mujer, México. 
Stone, A. y M. Zender (2011): Reading Maya Art. A Hieroglyphic Guide to Ancient Maya Painting and Sculpture, Thames \& Hudson, Londres.

Vela Ramírez, E. (ed.) (2010): «Decoración corporal prehispánica», Arqueología Mexicana.

- (ed.) (2015): «La joyería en el México antiguo», Arqueología Mexicana.

VIDAL LORENZO, C. (2005): "La mujer maya y su papel político y religioso», Alfaro Giner, C. (ed.): Protai Gynaikes: Mujeres próximas al poder en la antigüedad, Sema V-VI, Valencia.

* Las imágenes han sido extraídas de la base de datos @JustinKerr www.mayavase.com. 


\section{Arte funerario maya} Una aproximación desde la iconografía 
El arte funerario constituye una importante fuente de información para acercarse a la antigua ideología maya. Este tipo de estudios ha suscitado siempre un gran interés entre historiadores del arte y muchos otros especialistas. Así pues, con este trabajo se pretende contribuir a un mayor conocimiento sobre el tema.

Nuestro objetivo principal es el análisis y la interpretación de algunas escenas muy ilustrativas de las principales creencias de los mayas con respecto a la muerte y el viaje al más allá. Para ello, hemos hecho una selección de cuatro escenas del mundo funerario, tres de ellas plasmadas en vasijas cerámicas polícromas y una cuarta, en un altar pétreo. La selección de las obras analizadas se debe a que en ellas se recrean diferentes momentos vinculados al ritual de la muerte según las creencias mayas: la preparación del difunto, la procesión fúnebre, el entierro primario y renacimiento del difunto y el enterramiento secundario o culto posterior a la tumba del difunto.

Con el fin de ver cumplido el propósito de la investigación, la metodología empleada es, por una parte, el método historiográfico y, por otra, la aplicación del método iconográfico-iconológico.

A lo largo del análisis y la interpretación de las obras vamos a poder comprobar que el arte funerario recoge una amplia producción cultural donde se reflejan los rasgos propios y las características de la concepción ideológica de la muerte de la sociedad que lo conformó. Asimismo, la potente carga simbólica, así como la técnica con la que fueron realizadas todas las piezas analizadas contribuyen a reafirmar el alto grado de desarrollo que alcanzó esta civilización.

Palabras clave: maya, arte, funerario, más allá, ritual, vasija, cerámica polícroma, altar pétreo, iconografía.

\section{Introducción}

El presente trabajo ofrece una visión ordenada con respecto al tema abordado. La investigación se ha formado con ideas, conceptos, datos y el desarrollo de estos partiendo de una base de conocimientos adquiridos por los trabajos publicados hasta el momento. Los estudios críticos realizados hasta la actualidad se han centrado en la mayoría de los aspectos relacionados con la temática del arte funerario maya, sin embargo, no se ha tratado el tema como se ha hecho en este caso, es decir, a través de un análisis específico y amplio de una selección de obras altamente reveladoras de la concepción que los mayas tenían de la muerte. 
III. Objetivos

Este trabajo tiene como propósito principal el estudio y análisis de las manifestaciones artísticas propias del ámbito funerario maya, a partir de una selección de obras representativas. Todo ello se va a realizar con la finalidad de establecer las principales características de cada una de las prácticas y costumbres que envuelven a los ritos y creencias, haciendo especial mención a la concepción que los antiguos mayas tenían de la muerte, así como de determinadas características que envuelven al cuerpo de los difuntos y que están en relación con la propia ideología de la cultura, tal es el caso del recubrimiento del difunto con pigmento rojo.

Por todo ello, se plantean los siguientes objetivos específicos:

- Establecer cuáles eran las creencias que tenían los mayas respecto a la muerte y el viaje al más allá, con el fin de poder identificar los principales elementos simbólicos vinculados a ellas y plasmados en las representaciones artísticas escogidas.

- Realizar el estudio y análisis de una selección de escenas altamente representativas del mundo funerario en el arte maya.

\section{Material y método}

Como ya hemos dicho, esta investigación aborda el estudio del arte funerario de la antigua civilización maya. Con el fin de ver cumplido dicho propósito, la metodología empleada es la siguiente: por una parte, la recopilación y el análisis de datos a partir de los estudios críticos que hemos consultado y que tratan acerca de nuestra materia, es decir, el método historiográfico, $y$, por otra, la aplicación del método iconográficoiconológico para el análisis de las obras escogidas.

El primer paso a seguir en la aplicación de este método es la localización histórica del objeto de estudio, donde se trata de localizar la obra en el espacio y en el tiempo. Esta es una fase importante, ya que se convierte en la plataforma sobre la que se ha de desarrollar la construcción conceptual y discursiva que se abordará en las fases siguientes del método.

Todo proceso interpretativo conlleva una fase analítica previa, por ello hay que centrarse en el segundo paso del método, el análisis formal o estilístico del objeto artístico. En el segundo paso hay que tener en cuenta los aspectos materiales tales como el soporte, el procedimiento técnico y los aspectos estilísticos. El estilo se ha entendido como (Schapiro, 1999: 71):

la forma constante $-\mathrm{y}$ a veces los elementos, las cualidades y las expresiones constantes- que se da en el arte de un individuo o grupo. El término se aplica también a toda la actividad de un individuo o sociedad, como cuando se habla de un «estilo de vida» o del «estilo de toda una civilización» 
En un sentido general, las diferentes disposiciones formales configuran códigos, lo que nos permite hablar de diferentes estilos, como el propio estilo de la civilización maya.

El siguiente paso del método es la aproximación al significado, donde se realiza un análisis y una interpretación del contenido de la obra artística. Como historiadores de la cultura, el contenido de la obra de arte nos permite establecer conexiones entre la obra y el entramado cultural. En términos panofskianos, aproximar al significado es tratar de comprender esta relación con la actitud básica de un grupo, un periodo o una creencia religiosa, que han estado -consciente o inconscientementedispuestos por el creador de la obra condensados en el objeto artístico. El objeto principal de interpretación siempre es el contenido. Por tanto, en el último paso a seguir en el método se trata de interpretar o hacer comprensible la obra en el plano histórico, es decir, establecer conexiones entre la obra y su contexto histórico. Pero no se trata de descubrir sus motivaciones exteriores, sino de cómo algunos factores establecen una relación recíproca con la obra. Para ello, se ha de tener en cuenta la función de la obra o de la imagen, lo que nos introduce en la propia cultura.

La presente investigación se ha realizado utilizando principalmente bibliografía secundaria, es decir, los estudios críticos o históricos elaborados por historiadores e investigadores que han tratado sobre algún aspecto relacionado con este trabajo. Además, se han empleado las fuentes visuales; en otras palabras, las obras de arte, que para este trabajo constituyen las fuentes principales.

Para llevar a cabo la localización y la recopilación de los materiales ha sido necesaria una búsqueda sistemática, para así acercarnos a lo que se ha investigado hasta la fecha. Para ello nos hemos valido de las nuevas tecnologías, por ejemplo hemos manejado la base de datos TESEO, donde hemos hallado una tesis doctoral con un capítulo dedicado al tema funerario maya. ${ }^{1}$ Asimismo, ha sido de una gran utilidad el sumario ISOC, donde se han localizado algunos trabajos, tales como "El ritual en el mundo maya: de lo privado a lo público» (Ciudad et al., 2010). Dialnet también ha sido útil para realizar una búsqueda de publicaciones de la que proceden algunos artículos relacionados con el tema de nuestro trabajo, como "Una tumba en el corazón del templo» (Iglesias, 2006). La red social de investigadores Academia.edu ha sido otra herramienta usada para la recopilación de materiales.

A continuación, se buscaron y reunieron las representaciones visuales, que han sido el material principal del trabajo. Para llevar a cabo su recopilación, ha sido de gran ayuda la base de datos de las vasijas mayas, que consiste en un archivo fotográfico creado por Justin Kerr. ${ }^{2}$

1. La tesis doctoral hallada en Teseo es: VIDAL, C. (1999): Arte, arquitectura y arqueología en el grupo Ah Canul de la ciudad maya yucateca de Oxkintok, Universidad Complutense de Madrid, Madrid.

2. Podemos encontrar la base de datos en la siguiente dirección: http://www.mayavase.com 
Una vez finalizado el proceso de carácter heurístico, hemos abordado la fase hermenéutica, es decir, hemos procedido a la lectura pormenorizada y al análisis de los diversos estudios críticos y fuentes recopiladas o, lo que es lo mismo, a la lectura crítica de las fuentes que adquieren el valor al ser utilizadas para desarrollar el argumento. Durante este proceso se ha procedido a tomar notas, apuntes, ideas o datos relacionados con nuestro tema, que posteriormente se utilizaran para construir un discurso coherente. Todos los conceptos y las afirmaciones utilizadas serán bien definidas, ya que todo debe estar sustentado en datos relevantes.

Finalmente, hemos procedido a la redacción de las conclusiones de la investigación. Como último paso, se ha elaborado un apartado bibliográfico detallado de cada uno de los materiales empleados para la realización del presente estudio.

\section{Resultados}

Los resultados de este trabajo se han mostrado a través del análisis y de la interpretación de algunas escenas muy ilustrativas de los aspectos relacionados con la concepción ideológica de la muerte maya. La selección de las obras se centra en cuatro escenas del mundo funerario, tres de ellas plasmadas en vasijas cerámicas polícromas (vasijas K764, K7613 y K6547) y una cuarta, en un altar pétreo (Altar 5 de Tikal).

En primer lugar, hay que hacer mención al análisis de la escena de la vasija policromada, catalogada en el archivo fotográfico de Justin Kerr ${ }^{3}$ con el número K764. La pieza fue realizada durante el Clásico tardío, hacia el 600 y 800 d. C.

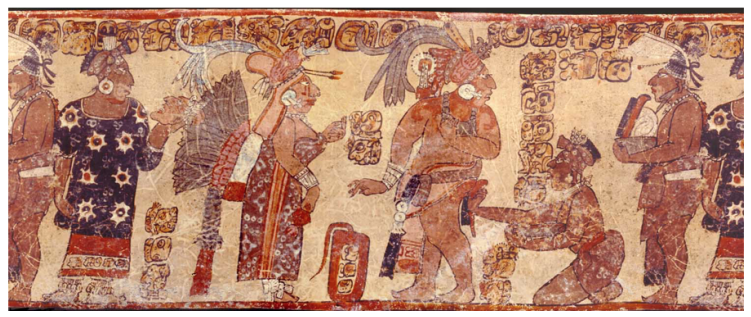

Figura 1. Roll out de la vasija K764

La pieza procede de Petén (Guatemala), pero actualmente se encuentra conservada en el Museum of Fine Arts de Boston. Sus medidas son 17,2 centímetros de altura y 11,7 centímetros de diámetro.

No se sabe muy bien para qué fin se concibió, aunque todo hace pensar que se realizó para ubicarla en un enterramiento, como parte del ajuar funerario de un personaje importante.

3. Justin Kerr estudió las vasijas mayas mediante el sistema de los roll outs fotográficos. Para realizar este sistema, la vasija se coloca en un plato giratorio y la cámara va fotografiando todo hasta llegar a la primera cara. La base de datos accesible en Internet donde se pueden consultar todas las escenas policromadas de las vasijas es http://www.mayavase.com 
Los colores más usados en la pieza fueron el naranja, el rojo, el marrón, el gris y el negro; además, hay restos del pigmento conocido como maya blue, que fue un color muy utilizado en esta cultura. Toda la pieza fue creada con una gran perfección técnica y elegancia estética.

En la escena hallamos dos figuras femeninas y tres masculinas que se recortan sobre un fondo ocre. Todas tienen la tez oscura, portan ropajes y el cabello recogido con tocados, desde más sencillos a más complejos.

Más concretamente, de izquierda a derecha encontramos en primer lugar a una mujer de frente con el rostro de perfil que sostiene sobre su mano izquierda una máscara y sobre la otra un objeto de color negro. La mujer está ataviada con un huipil (vestido) que cubre por completo sus piernas y parte de sus brazos. La prenda destaca por su decoración con estrellas sobre un fondo azul oscuro y por una banda inferior de color rojizo con signos jeroglíficos. Tiene el cabello recogido en un tocado sencillo compuesto por un pañuelo marrón, atado con un nudo. En su rostro se distinguen signos de pintura facial de color rojo y además tiene una sencilla orejera en forma de disco.

La siguiente figura también es femenina y aparece representada de pie completamente de perfil. En una de las manos sujeta un objeto de color rojo. Viste con una prenda larga que cubre todo su cuerpo menos los brazos y el escote. Su espalda sujeta una ligera estructura (backrack) con forma de penacho de plumas. El tocado que porta está compuesto por un pañuelo que cae por la nuca hasta la espalda y además tiene otros elementos entre los que destacan dos pinceles y un penacho de plumas largas y delgadas. Sobre su mejilla derecha se pueden observar restos de pintura facial, una orejera con un disco y una perla cilíndrica de adorno, además de un collar de finas perlas y un brazalete de color blanco.

A continuación, sobresale una figura masculina en el centro de la composición. Esta no sujeta ningún objeto pero gira el torso y el rostro hacia la derecha de la escena. El hombre está ataviado con un faldellín que se deja caer por delante de sus piernas, y que está sujeto por otra prenda. Del mismo modo que la mujer descrita anteriormente, su cabeza sujeta un tocado elaborado con un pañuelo con largas y delgadas plumas, pero esta vez se distingue el rostro de un animal. Otros elementos característicos que lleva este personaje son una orejera con un disco y una perla cilíndrica, un brazalete, un collar de grandes cuentas y la pintura roja en su cuello y parte del torso.

Otro individuo masculino aparece arrodillado en el suelo sosteniendo en su brazo izquierdo un recipiente y con su mano derecha un objeto que posa sobre las nalgas del personaje del centro de la composición. Del mismo modo que el personaje anterior, viste un faldellín corto aunque mucho menos elaborado, ya que solo lo sostiene un cinturón simple de color rojo. El cabello de este individuo está recogido en la parte superior de la cabeza por un tocado elaborado con un pañuelo atado con un nudo, muy semejante al de la mujer del extremo izquierdo.

Finalmente, destaca un personaje de pie sosteniendo con sus dos manos un espejo. La figura tiene un faldellín atado con un cinturón 
blanco, sobre su cuello sostiene un collar de pequeñas perlas y sus orejas están adornadas con un elemento punzante que las atraviesa. Por último, sobresale un tocado atado con un lazo.

Tanto las cualidades expresivas como las significantes de los personajes analizados nos permiten deducir la identidad de estos. Así, el corpulento personaje masculino del centro es, sin lugar a dudas, el gobernante o el señor principal ( $K^{\prime} u l$ ahau). Por ello, porta un tocado de plumas de quetzal, un material muy preciado por los antiguos mayas reservado a los miembros de la élite. En el tocado también se distingue la cabeza de un animal mítico, probablemente símbolo de alguna deidad relacionada con la figura del soberano. Las joyas que lleva, tales como las orejeras o el brazalete, junto con el atuendo, lo identifican claramente con esta figura. La mujer que tiene frente a él también se puede identificar como una mujer de alto rango en la sociedad, debido a la estructura o backrack que porta en la espalda; además, lleva un elaborado tocado con plumas y sus joyas son muy parecidas a las del gobernante, de ahí que deduzcamos que se trata de la esposa del monarca.

La mujer del extremo izquierdo lleva un tocado más simple, a modo de turbante, y porta adornos más sencillos. Tanto esta mujer como los otros dos personajes masculinos pueden considerarse personajes vinculados a la élite, pero de inferior rango que la pareja protagonista.

El soberano está contemplando su perfil en un espejo de obsidiana que le presenta un funcionario de la corte, fácilmente identificable por su tocado característico de tipo gorro. El espejo consistía en un marco de madera y luego en una pieza de obsidiana. Tal como expone Miguel Rivera (2006: 2014), "los espejos establecen un vínculo con el Otro Mundo y en sí mismos simbolizan el país de los muertos al que se dirigen los personajes depositados en las tumbas». De este modo, el gobernante se está comunicando a través del espejo con el mundo inferior, o inframundo, lugar donde residían los ancestros y donde el monarca irá en el momento de su fallecimiento.

El funcionario de la corte, que está arrodillado detrás del rey, está aplicando pintura sobre las nalgas del personaje. El pigmento aplicado es de color rojo, posiblemente se trate de cinabrio, ya que los antiguos mayas tenían la costumbre de rociar los cuerpos de sus fallecidos con cinabrio con el fin de dotar al cadáver de un aspecto natural de la carne o de la sangre, entre otras cosas.

Para la correcta interpretación de esta escena es muy importante fijarse en la máscara que sostiene la mujer del extremo izquierdo, dado que se trata de una máscara funeraria. La máscara era una pieza habitual que formaba parte de las piezas del ajuar funerario. Miguel Rivera (2006: 214) expone aspectos relacionados con este tipo de piezas:

la congelación del tiempo y de la vida que la máscara delata y, sobre todo, la suplantación ocasional de otra identidad, son indicadores de que la muerte enmascarada podía ser una ceremonia de regeneración tanto como un rito iniciático que da paso a un nuevo estado o condición. 
La representación de todos los elementos y las acciones que están aconteciendo en la escena aluden a que el gobernante está siendo preparado para su entierro. Por una parte, el monarca está viendo su reflejo en el espejo, símbolo de que él va a pasar por ese umbral para llegar al inframundo. Por otra, su cuerpo se está preparando con pigmentación roja y se representa la máscara funeraria que se le va a disponer sobre su rostro. Por consiguiente, se trata de una escena funeraria en la que se advierten algunas prácticas de los antiguos mayas, tales como la pigmentación del cuerpo del fallecido con cinabrio o la disposición de la máscara funeraria sobre el rostro del difunto. Se trata de un conjunto de rituales póstumos al fallecimiento del individuo, en los que se prepara el cuerpo del difunto para que esté listo para su enterramiento y el subsiguiente viaje hacia el más allá.

A continuación, se ha realizado el análisis de la escena plasmada en la vasija K7613, adscrita cronológicamente a comienzos del período Clásico tardío.

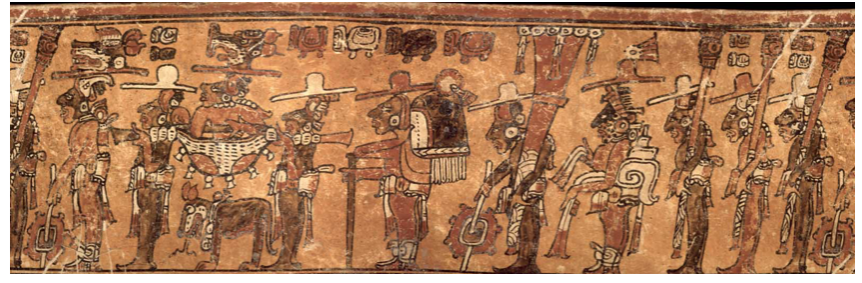

Figura 2. Roll out de la vasija K7613

La vasija procede del sitio arqueológico de Nebaj, departamento de El Quiché, en la región suroeste de Guatemala. En la actualidad se conserva en el National Museum of the American Indian (MAI) en Washington DC.

Se trata de una pieza cerámica, engobada y policromada, en la que destaca el color negro y los colores tierra, tales como el marrón, el ocre y el blanco. Sus dimensiones son 16,5 centímetros de altura por 15,3 centímetros de diámetro.

La escena representada en el cuerpo de esta pieza está integrada por un total de diez personajes masculinos y por un animal, enmarcados en un fondo ocre con signos jeroglíficos. Todos los individuos se representan de pie, descalzos, de perfil y con la tez oscura, aunque cada uno tiene una tonalidad diferente. Todos están ataviados con un faldellín corto, orejeras y un tocado, cada uno de diferente tamaño y forma.

En primer lugar, de izquierda a derecha, hay un individuo sujetando con su mano un instrumento de tipo estandarte, pero que apoya en el suelo. En su cabeza soporta un tocado característico en cuya parte superior se distingue lo que parece ser una cabeza de animal.

A continuación, dos figuras masculinas cargan a sus hombros un personaje que está siendo trasladado en un palanquín. Este individuo porta un tocado que termina con la cabeza de un animal, así como una elaborada joyería. Los dos individuos que cargan con el palanquín portan sendos sombreros de ala ancha. 
Otros seis personajes siguen al individuo que va sobre el palanquín, el primero porta un bastón y carga sobre su espalda un trono confeccionado con piel de jaguar y flecos. La siguiente figura sujeta un gran instrumento y otro objeto tipo estandarte que apoya sobre el suelo. Destaca otro individuo que lleva en su espalda una caracola, y los tres próximos soportan lo que parecen ser tres instrumentos alargados.

Por último, en la escena hay una representación de un perro que se extiende por debajo del palanquín y que está estrechamente relacionado con el individuo que va suspendido sobre él.

Al igual que en el caso de la vasija analizada anteriormente, las cualidades expresivas y significantes de los personajes descritos nos permiten deducir que nos hallamos ante la representación de una procesión funeraria, en la que el personaje que está en el palanquín es el difunto, el cual está siendo conducido a su propio entierro. La presencia del perro debajo del palanquín es determinante para esta interpretación, ya que se trata del way del fallecido, es decir, el acompañante o el espíritu protector del mismo. ${ }^{4}$

Lo que se observa en la imagen es, por tanto, la última procesión terrenal realizada por el individuo del palanquín, el cual es acompañado por sus criados y músicos. La procesión dirige al personaje a su camino hacia el otro mundo o Xibalbá.

Respecto a los músicos, Roberto Velázquez ha mencionado que esta vasija muestra imágenes de trompetas de diversas formas, estructuras y dimensiones. Una de ellas es una trompeta ancha y larga, decorada en la parte superior con telas, y otras, más estrechas y decoradas en su parte superior con glifos, son las que portan los últimos tres personajes del extremo derecho de la composición. Posiblemente, el material con el que se pudieron haber realizado estos instrumentos fue ligero, como madera o cañas. Esto debió de ser así porque las trompetas pintadas en la vasija se sostienen con facilidad con una mano sin ningún tipo de soporte. Otro instrumento que se ha identificado en la escena es una trompeta de caracol (Velázquez, 2015).

Por otro lado, es interesante resaltar que esta no es la única vasija maya en la que se representa este tipo de procesión funeraria, las vasijas catalogadas en el archivo fotográfico de Justin Kerr con los números K594 y $\mathrm{K} 5534$ son otras en las que se representa al difunto transportado a su propio entierro, junto con su way. Es decir, este tipo de representación estereotipada de la procesión fúnebre debió de ser una de las favoritas de los personajes de la élite para que formaran parte del escogido número de piezas que componían la ofrenda funeraria de estos individuos.

En tercer lugar, debemos proyectar el estudio de la vasija K6547, también conocida como la vasija trípode de Berlín ya que se encuentra en

4. Según la creencia maya, el way de un individuo es algo así como su «espíritu acompañante», de modo que en el momento en que fallecía su parte humana también moría junto a éste, por esta razón se ha representado en la composición el perro junto con el individuo que es transportado a su enterramiento. 
el Museum für Völkerkunde de esa ciudad, es una pieza del Clásico Temprano que proviene de la región del Petén central.

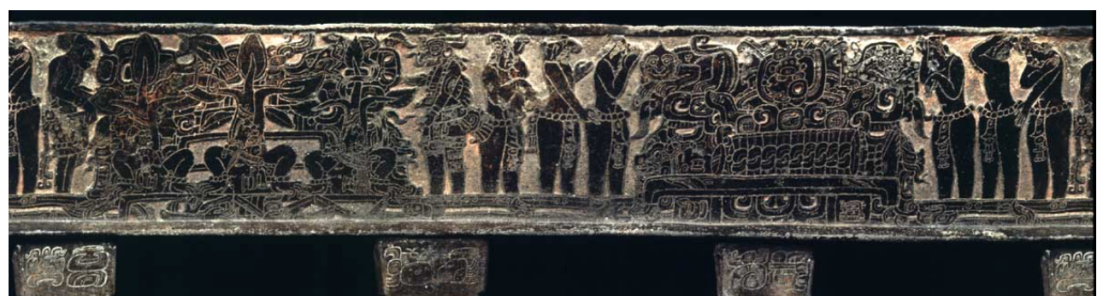

Figura 3. Roll out de la vasija K6547

Se trata de una pieza cerámica realizada en arcilla gris, en la que se plasmó una interesante escena hecha con la técnica del grabado. Tiene una altura de 12,9 centímetros y 17,3 centímetros de diámetro.

Michael D. Coe consideró que la función principal de las vasijas cerámicas con representación de escenas del Clásico fue funeraria. Teniendo en cuenta esto, puede ser que algunas vasijas llegaran a ser utilizadas en ceremonias religiosas, pero finalmente se utilizaban como parte del ajuar funerario de su propietario (Coe, 1978: 62). Los ejemplos de cerámica más elaborada se suelen encontrar en las viviendas y enterramientos pertenecientes a un individuo de alto rango social. Algunas de ellas se utilizaban como vasos para beber bebidas de cacao y, además, también se ha evidenciado que tales recipientes se ponían en el interior de los enterramientos formando parte de la ofrenda del difunto, repletas de estas bebidas (Chinchilla, 2011: 31-32).

La escena representada en la vasija se divide en dos partes principales; la primera, a la izquierda, la compone en el centro una construcción escalonada donde se posan tres árboles que destacan por tener tres personajes. Debajo de ellos hay un esqueleto que queda enmarcado dentro del primer escalón de la construcción. A los lados del edificio escalonado hay dos individuos masculinos, el de la izquierda viste con un faldellín corto decorado con flecos y perlas, el torso lo muestra desnudo aunque porta un collar y además tiene representado sobre su brazo un dibujo formado por dos aspas que se cruzan. El individuo de la derecha, también viste un faldellín mucho más elaborado con cintas. Del mismo modo que el personaje de la izquierda, también tiene el torso al descubierto con un collar, además de un dibujo en uno de los brazos y dos más en las piernas. Lo más característico de este personaje es su rostro en forma de animal.

La parte derecha de la composición la conforma en el centro un personaje fallecido, al cual rodean un total de seis hombres semidesnudos junto con dos animales y otros elementos simbólicos que se aprecian en el fondo de la escena.

En esta parte derecha de la composición, el cuerpo del fallecido concretamente se muestra amortajado. El personaje está ataviado con perlas de jade, orejeras y una diadema, indicadores de su alto rango; por tanto, se trata de un personaje importante en la sociedad. Lo más probable es que fuera un gobernante. La mortaja que porta el individuo 
consiste en nueve nudos, los cuales pueden aludir a la propia muerte y además están ligados con la idea de los nueve niveles del inframundo que el fallecido debe de recorrer en su viaje por el más allá. Por último, las seis figuras que rodean el cuerpo del difunto son un grupo de dolientes semidesnudos. El gesto que realizan los dolientes son los siguientes: hay un personaje que tiene las manos juntas cubriéndose el rostro (segundo personaje de derecha a izquierda), por cuyas mejillas se deslizan lágrimas. El personaje dispuesto en la derecha inclina la cabeza y apoya la mano derecha sobre el hombro izquierdo, lo que significa una muestra de consideración. Este último gesto también se encuentra en escenas de saludo y de arresto de prisioneros, como un gesto de obediencia (Eberl, 2005: 84-86). Otro doliente tiene el dorso de su mano apoyado en su frente, un símbolo que podemos encontrar también en los animales que Iloran la muerte de un difunto, como los que aparecen en los huesos incisos de la tumba de Jasaw Chan K'awiil I. Todas las muestras que realizan estos dolientes son gestos expresivos de tristeza y de respeto hacia el fallecido.

Sobre el cuerpo del difunto aparece una media luna y un disco solar con el dios del sol. Este disco solar sube la Montaña Sagrada, o Witz, la cual está representada al fondo de la escena. La Montaña es el lugar por donde el alma del difunto debe pasar para atravesar la entrada al más allá.

Sobre el cuerpo del fallecido hay dos animales: un mono a la izquierda y un jaguar a la derecha. Se trata de los animales que acompañan sus esencias anímicas, conocidos como los way. La parte inferior de la escena está decorada con la representación de las aguas del mundo inferior o del inframundo, haciendo una alusión del lugar por donde el muerto debe de realizar su viaje hacia su otra vida. El agua se representa a través de una banda acuática, en la que destacan volutas muy sinuosas que tienen círculos y puntos de pequeño tamaño, que insinúan el movimiento del agua.

En la escena de la izquierda el personaje difunto se representa como una figura esqueletada, que se encuentra en la parte inferior de un templo piramidal. Sobre el esqueleto resurge su imagen transformada en árbol y junto a él aparecen sus padres como antepasados (Romero, 2012: 11-12). Esto se asemeja al sarcófago de K'inich Janaab' Pakal I, donde aparecen los antepasados del monarca surgiendo del interior de la tierra en forma de árboles.

En definitiva, nos encontramos ante una composición donde se representan dos escenas relacionadas con la ceremonia fúnebre y la concepción ideológica sobre la muerte maya. Lo que se simboliza en ellas es una idea de muerte y renacimiento, donde el difunto gobernante renace del mundo de los muertos como una personificación del dios del maíz. Por lo tanto, para los antiguos mayas el enterramiento significa sembrar el cuerpo del difunto como si fuera una semilla y esperar a que resurja en una nueva vida. 


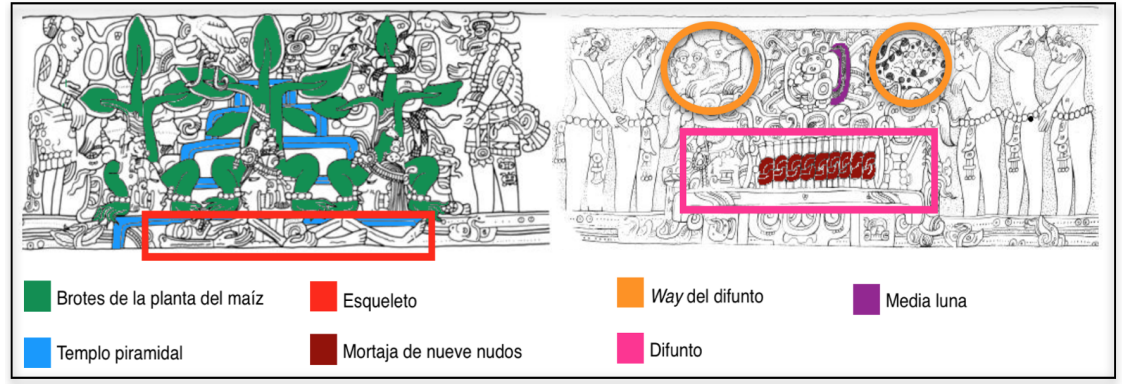

Figura 4. Dibujo del roll out de la vasija K6547

Por último, presentamos el resultado del análisis del Altar 5 de Tikal, que, originalmente, formó parte de las obras situadas en la Gran Plaza central de la ciudad de Tikal, concretamente en el complejo 5C-1 y, además, se alzó junto con la Estela 16. Sin embargo, actualmente la pieza se conserva en el Museo de Escultura de Tikal y fue realizada hacia el 711 d. C.

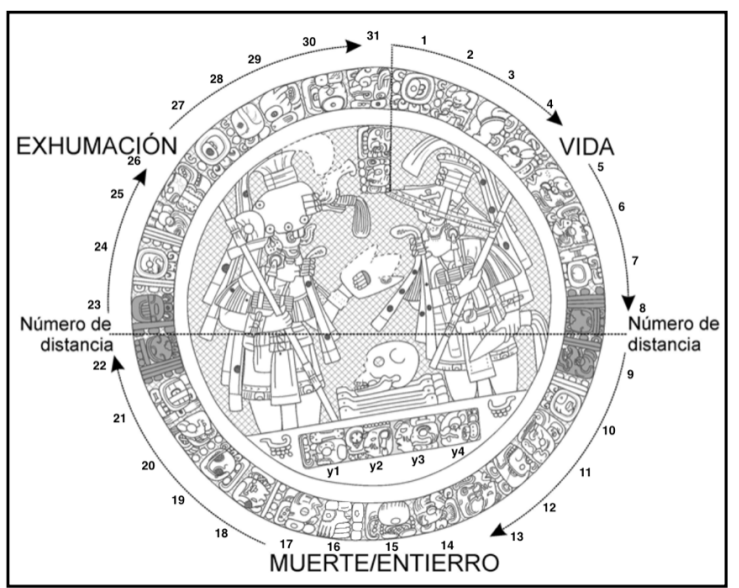

Figura 5. Dibujo del Altar 5 de Tikal

Se trata de una gran pieza circular tallada en piedra, de unas dimensiones considerables, ya que posee 167 centímetros de diámetro.

En la superficie superior se talló una escena compuesta por dos figuras masculinas de semejante tamaño. El individuo de la derecha está de pie portando un instrumento punzante en la mano izquierda a la altura de las rodillas y un objeto alargado en la mano derecha. El personaje de la izquierda se encuentra de pie sosteniendo un elemento de tres puntas con la mano izquierda y con la derecha sujeta un objeto alargado igual al de su compañero. Los dos individuos visten con un faldellín que cubre hasta las rodillas y portan sendos tocados muy ostentosos, que incluyen plumas y la representación de huesos. Ambas figuras rodean un grupo de huesos alargados y un cráneo, que se encuentra sobre un elemento que tiene grabadas inscripciones jeroglíficas.

Toda la composición está enmarcada por una banda circundante de signos jeroglíficos. Estas inscripciones hacen alusión a la muerte y posterior exhumación de una mujer de Topoxté (isla cercana a la ciudad de Yaxhá). Por eso se ha creído que los huesos que aparecen en el centro 
de la escena hacen referencia a esta mujer, a la que se menciona con el nombre de la Señora Tuun Kay Wak.

El texto se inicia con un acontecimiento once años antes de la muerte de este personaje, lo que se describe de los glifos 1 al 7. A continuación, en los dos glifos siguientes se hace referencia a la muerte de la señora en el año 703 d.C (9. 13. 11. 6. 713 Manik' 0 Xul) con la expresión $\mathrm{kim} / \mathrm{cham}$, «ella muere». Después de su muerte, en los glifos 10 al 21, se alude a dos sucesos de su enterramiento, pero no se insinúa en ningún momento el transcurso temporal entre ellos. Hay un glifo en el que se expresa que la señora "es colocada en el suelo" ( $k^{\prime} u h b^{\prime} a j$. Glifo 15). Esto se aclara en el glifo 16, el que muestra una mano sujetando un objeto de tres puntas, el cual se ha relacionado con el que porta el personaje de la izquierda de la composición. Esto último nos indica que al colocar en el suelo el objeto de pedernal se concluye el enterramiento del cuerpo de la señora.

Las últimas inscripciones terminan de este modo: «muhkaj b'olon 'ajaw naah "fue enterrada en la casa de los nueve señores" ( (Eberl, 2005: 98). Por último, el texto concluye con la indicación de la reapertura de la tumba de la Señora Tuun Kay Wak, alrededor de ocho años tras su enterramiento.

Estos últimos glifos son los que se encuentran debajo de los huesos (y1-y4). La inscripción jeroglífica y1 posiblemente representa «una copla en el sentido de tumba». En estos últimos glifos ya no se indica el nombre de la Señora Tuun Kay Wak, sino de la Señora Yax 'Okel Wayas (glifos y2y4), si bien todas las evidencias apuntan que se trata de otro título de la misma mujer, el cual adopta en el momento de su muerte (Eberl, 2005: 97-100).

El altar está dividido en dos partes por la fecha de la muerte y por la de la exhumación, las cuales están señaladas por números de distancia. En la parte inferior del altar se menciona la muerte y el enterramiento de la mujer en la casa de los nueve señores, lo que lo vincula con un simbolismo vinculado con el inframundo (Ciudad, 2010: 93). Y la parte superior de la pieza, donde se indica la vida y exhumación podría simbolizar el renacimiento de la señora. Por consiguiente, la iconografía plasmada en el Altar 5 parece insinuar una ceremonia de resurrección simbólica en la que la Señora Tuun Kay Wak vive, muere, es enterrada, exhumada y vuelve a resurgir a la vida.

Los dos personajes masculinos que aparecen en la escena son dos nobles, probablemente Chan Sak Wayas y Jasaw Chan K'awiil I, que portan un atuendo adecuado en su participación en el rito de la muerte y la renovación, concretamente el atavío del «dios de la muerte Mok Chih boca anudada» (Eberl, 2005: 97) y además sujetan en las manos herramientas relacionadas con el ritual. El personaje de la derecha tiene en la mano izquierda un cuchillo de pedernal y el otro personaje deja ver un pedernal de tres puntas en el centro de la escena. Por lo tanto, los dos individuos masculinos participaron en el ritual del enterramiento 
secundario, es decir de la reapertura de la tumba y de la exhumación que se le realiza a la mujer de la cual nos habla el texto.

El arqueólogo del proyecto del Museo de la Universidad de Pennsylvania, Christopher Jones, durante las investigaciones del Tikal Project, en Tikal, recuperó por debajo de la Estela 16 un grupo de huesos, entre los que se incluía un cráneo y unos huesos largos. Esto evidencia que la actividad que se representa en el Altar 5 ocurrió cerca (Fitzsimmons, 2009: 65).

Consideramos que es muy importante tener en cuenta que en otros contextos se han encontrado evidencias acerca de la práctica del enterramiento secundario realizado por los antiguos mayas. Por ejemplo, James L. Fitzsimmons nos indica que se han encontrado certezas acerca de que hubo restos óseos exhumados de su lugar original y utilizados por los personajes de la élite en el Dintel 25 de Yaxchilán, en el que aparece representado un cráneo sobre el brazo de K'ab'al Xook. Muy probablemente, los huesos utilizados se usaron a modo de reliquia (Fitzsimmons, 2003: 674-676).

\section{Discusión y conclusiones}

Como hemos visto a lo largo del texto y tras el análisis y la interpretación de las escenas funerarias, resulta incuestionable la consideración que los antiguos mayas ofrecieron al tratamiento póstumo de sus dirigentes, ya que estos, en la otra vida iban a demostrar el mismo poder e importancia que habían emanado durante su reinado.

También, como se ha desprendido del desarrollo del texto, el arte funerario recrea la visión de la creencia en la inmortalidad del alma después del fallecimiento del cuerpo. De ahí que parezca quedar claro que este arte solamente se puede explicar bajo la afirmación de que la muerte se convertía en una continuidad, de manera que constituye un punto de renovación que generaba un nuevo nacimiento.

A partir de las representaciones, queda sustentada la idea de que el inframundo -Xibalbá o también conocido como el más allá- estaba constituido por nueve niveles, que las almas de los difuntos debían de atravesar en su viaje para el renacer de sus almas.

También se ha desprendido de las imágenes analizadas que los antiguos mayas comparaban el inframundo con la superficie acuática, la cual se debe atravesar para llegar al más allá.

En cuanto a la consideración relacionada con la creencia de que del interior de la tierra resurge la vida, esta está fortalecida con la idea de que según la cultura maya cuando un hombre moría entraba en el interior de la tierra pero que tras emprender su viaje por el más allá resucitaba como un ancestro, y en el caso concreto de los gobernantes, como un ancestro divinizado. Esta apreciación se compara con la evolución de las plantas, las cuales se plantaban en el interior de la tierra para que luego resurgieran de su interior y renacieran de nuevo. 
Asimismo, el análisis de las escenas funerarias nos ofrece otros aspectos relacionados con las prácticas y costumbres de los antiguos mayas. Primeramente, la costumbre de amortajar los cuerpos de los individuos de alto rango $y$, además, en algún caso excepcional, el recubrimiento del cuerpo del difunto con pigmento rojo.

Por otra parte, resulta incuestionable, tras el análisis de algunas representaciones artísticas, la práctica del enterramiento secundario, la cual fue una práctica en la que se realizaba una reapertura del enterramiento primario para llevar a cabo un ritual de los restos óseos exhumados.

En nuestro análisis también hemos destacado la gran importancia de ciertos objetos, tales como el espejo de obsidiana. Para esta civilización, el espejo fue un medio de comunicación con el otro mundo, por lo tanto relacionado con el mundo funerario, y que simbolizaba el lugar de los muertos hacia donde se dirigen los hombres fallecidos. En cuanto al uso de máscaras funerarias debemos indicar que esta pieza formaba parte del ritual póstumo que se le daba al cuerpo del difunto antes de introducirlo en el enterramiento donde descansaría para el resto de la eternidad.

Cabe señalar que a través del arte funerario podemos indagar también en lo que significa en el pensamiento de los antiguos mayas la figura del way. Este era el acompañante animal de un individuo humano, el cual seguía acompañando a su mitad humana en la otra vida, por eso lo hemos podido encontrar en algunas de las representaciones funerarias.

Por último, a lo largo del estudio y análisis del arte funerario, podemos deducir que este recoge una amplia producción cultural donde se reflejan los rasgos propios y las características de la concepción ideológica de la muerte de la sociedad que lo conformó.

Asimismo, la potente carga simbólica y la técnica con la que fueron realizadas todas las piezas analizadas contribuyen a reafirmar el alto grado de desarrollo que alcanzó esta civilización, cuyas excepcionales manifestaciones artísticas rivalizan con las pertenecientes a otras grandes culturas de la Antigüedad, como la egipcia, en las que el culto a la muerte y las creencias en el más allá tuvieron un papel predominante en sus vidas.

\section{Bibliografía}

CHINCHILlA, O. (2011): Imágenes de la mitología maya, Museo Popol Vuh, Guatemala.

CIUDAD, A. et al. (ed.) (2010): El ritual en el mundo maya: de lo privado a lo público, SEEM, Madrid.

COE, M. (1978): Lords of the Underworld. Masterpieces of Classic Maya Ceramics, Princeton University Press, Princeton.

EberL, M. (2005): Muerte, entierro y ascensión. Ritos funerarios entre los antiguos mayas, Universidad Autónoma de Yucatán, Mérida. 
FITZSIMMONS, J. (2003): «Reyes difuntos y costumbres funerarias: epigrafía y arqueología de la muerte en la sociedad maya clásica», LAPORTE, J. (ed.): XVI Simposio de Investigaciones Arqueológicas en Guatemala, Museo Nacional de Arqueología y Etnología, Guatemala.

- (2009): Death and the Classic Maya Kings, University of Texas Press, Austin.

IGLESIAS, M. (2006): «Una tumba en el corazón del templo», Descubrir el Arte, 86, Arlanza Ediciones, Madrid.

RIVERA, M. (2006): El pensamiento religioso de los antiguos mayas, Trotta, Madrid.

Romero, R. (2012): «El devenir del mundo subterráneo», Revista Digital Universitaria, 11.

SCHAPIRO, M (1999): Estilo, artista y sociedad: teoría y filosofía del arte, Tecnos, Madrid.

VIDAL, C. (1999): Arte, arquitectura y arqueología en el grupo Ah Canul de la ciudad maya yucateca de Oxkintok, Universidad Complutense de Madrid, Madrid.

VelázQUeZ, R. (2011) "Análisis virtual de trompetas mayas», http://www.tlapitzalli.com/rvelaz.geo/bonampak/lek.html, [última consulta: 10 de agosto de 2015].

\section{Créditos de figuras}

Figura 1. Roll out de la vasija K764. En:

http://research.mayavase.com/kerrmaya_hires.php?vase=764, [última consulta: 11 de junio de 2015].

Figura 2. Roll out de la vasija K7613. En:

http://research.mayavase.com/kerrmaya_hires.php?vase=7613, [última consulta: 28 de junio de 2015].

Figura 3. Roll out de la vasija K6547. En:

http://research.mayavase.com/kerrmaya_hires.php?vase=6547, [última consulta: 2 de julio de 2015].

Figura 4. Dibujo del roll out de la vasija K6547. En: FITzsIMmons, J. (2009): Death and the Classic Maya Kings, University of Texas Press, Austin.

Figura 5. Dibujo del Altar 5 de Tikal. En: CIUDAD, A. et al. (ed.) (2010): El ritual en el mundo maya: de lo privado a lo público, SEEM, Madrid. 


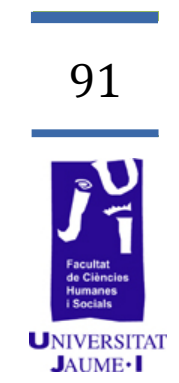

\section{Todo el poder para el ghetto Black Panther Party:} entre la violencia y el servicio a la comunidad 
El movimiento por los derechos civiles, liderado por Martin L. King y representado a través de boicots, marchas y sentadas, tuvo su punto álgido con la aprobación de la Ley de Derechos Civiles en 1964. Pero este fue solo el primer paso: aún tuvieron que enfrentar la oposición de los sectores blancos -sobre todo del sur-, que hacían caso omiso de la ley y ponían trabas para su aplicación. La segregación continuaba en la práctica; por ello, una nueva generación de jóvenes, cansados de enfrentarse con métodos pacíficos a la brutalidad policial, la discriminación y la exclusión comienzan a plantearse otras vías: responder a la violencia con violencia.

En este sentido, uno de los movimientos paradigmáticos fue el Black Panther Party, que canalizó la frustración de la población de los ghettos sumidos en la pobreza y la exclusión, olvidados por los gobiernos que destinaban más recursos a la guerra de Vietnam que a programas sociales. La imagen que ha trascendido de los Panteras Negras pone su énfasis en los mensajes agresivos y la autodefensa armada, mientras que los programas sociales -comedores, asistencia médica, etc.- han recibido un tratamiento menor.

En este trabajo, analizamos la dinámica interna de los Panteras Negras: ideología, actos, etc., así como su relación con el Gobierno. Se trata de comprender hasta dónde se corresponde con la realidad la imagen que ha llegado a nuestros días, desde un estudio cruzado donde examinamos, de un lado, la política que desarrollaron-violencia y enfrentamientos con la policía, junto a la práctica social-, y del otro, la imagen que transmite el Gobierno para justificar la represión COINTELPRO-, frente a la precepción dentro de la comunidad negra destinataria de estas ayudas. Incluimos, así mismo, el papel de las mujeres y la herencia en la lucha de otras minorías en Estados Unidos.

Palabras clave: Black Panther Party, ghetto, segregación, violencia, ayudas sociales, represión.

\section{Introducción}

El 9 de junio de 2015, mientras me encontraba realizando este trabajo, se publicó una noticia en los medios de comunicación: Albert Woodfox, miembro del Black Panther Party, o Partido de las Panteras Negras, era liberado tras pasar 43 años en aislamiento en la prisión estatal de Luisiana, más conocida como Angola, por la cercanía del correccional con una antigua plantación de esclavos con ese nombre. Woodfox estaba preso por robo a mano armada y, desde abril de 1972, cuando fue condenado por primera vez junto a Robert King y Herman Wallace por el asesinato de un guardia de prisiones durante una revuelta 
en el penal, ha estado en régimen de aislamiento 23 horas al día. El juez ordenó su liberación por su estado de salud y por «la falta de confianza en que el Estado celebre un tercer juicio justo». ${ }^{1}$

Más allá del debate sobre el sistema penal en los Estados Unidos y el estado de las cárceles -que excede los objetivos de este trabajo- sí que nos interesa destacar un hecho: Albert Woodfox ha insistido todos estos años en que era inocente y que fue acusado falsamente como venganza por crear dentro de la prisión una célula de los Panteras Negras.

El partido apenas funcionó poco más de una década. Sin embargo, tuvo que enfrentarse a la persecución del Gobierno estadounidense y de organismos como el FBI. Aún quedan panteras encarcelados, exiliados y perseguidos. Esto nos llevó a preguntarnos sobre el verdadero alcance y significado del intento de construir un sueño negro en los ghettos durante la décadas de 1960 y 1970.

La imagen habitual del Black Panther Party con sus miembros uniformados con chaquetas de cuero y portando armas provocó el recelo de la población blanca del momento, pero sobre todo la persecución de la policía y el FBI empeñados en su erradicación. ¿Un mal ejemplo? El propio Gobierno fomentó el temor, ya que en las mismas décadas se encontraban activas otras organizaciones como el Ku Klux Klan, con una intención menor, por ejemplo en los archivos del FBI.

La historiografía, siguiendo la estela oficial, ha mostrado al Black Panther Party como la fase final del movimiento por los derechos civiles; una etapa caracterizada por el radicalismo y la violencia. Pero, ¿̇hasta qué punto esta imagen se corresponde con la realidad? ¿Verdaderamente eran un grupo armado que se enfrentaba a todo blanco que veía? Este trabajo final de grado pretende examinar el contexto político, económico y social que llevó a la formación del Black Panther Party para comprender el verdadero significado, la labor y el alcance.

La construcción de los derechos civiles para los negros arranca en el período de Reconstrucción tras la guerra civil. Los gobiernos del norte procuraron dotar de ciertos derechos a los esclavos recién liberados, derechos que fueron escamoteados por los gobiernos estatales del sur con leyes particulares amparadas por el Tribunal Supremo en 1896 con la doctrina: "separados pero iguales». Los negros se convirtieron en ciudadanos de segunda en su propio país. Separados sí, pero iguales no, la población afroamericana tenía una esperanza de vida inferior, así como un nivel escolar y trabajos peor remunerados.

Pero a mediados del siglo xx los nuevos tiempos de cambio también trajeron un cambio en la mentalidad de los afroamericanos. Nuevos movimientos surgieron para reclamar los derechos negados durante casi un siglo. De la lucha legal protagonizada por la NAACP (National Association for the Advancement of Colored People) se pasó la rebelión pacífica liderada por Martin Luther King, cuyo punto culminante fue la aprobación de la Ley de Derechos Civiles en 1964, pero las reformas iban

1. Público, 9 de junio de 2015. Ver también El País, 10 de junio de 2015. King fue liberado en 2001 y Wallace, en 2013, falleció dos días después de obtener la libertad debido a un cáncer terminal. 
muy lentas, y la igualdad legal no significó la igualdad social. La nueva generación de jóvenes que vivía sobre todo en los ghettos y que no estaba dispuesta a seguir poniendo la otra mejilla sería la protagonista de estos cambios. En Oakland (California) dos jóvenes cansados de las falsas promesas del Gobierno y la brutalidad policial decidieron crear su propia organización, nació así el Black Panther Party que combinó las nuevas aspiraciones combinando el orgullo de ser negro con la defensa de los derechos que pretendían obtener y el trabajo social en la comunidad. Pretendían echar por tierra todas las teorías que planteaban que los negros eran incapaces de organizarse y gobernarse.

El Black Panther Party significó el inició de un sueño para la comunidad negra de los ghettos urbanos y de otras minorías que se inspiraron en ellos, pero también una amenaza para las autoridades que apelaron a todos los medios para su destrucción: desde la violencia directa hasta introducción de drogas en la comunidad. Finalmente, el sueño terminó hecho añicos con la mayoría de sus líderes encarcelados, exiliados, convertidos en adictos o muertos. La construcción, el desarrollo y la caída de este sueño a través del análisis del Black Panther Party serán el objeto de nuestro trabajo.

\section{Objetivos}

El objetivo principal fue la comprobación de si la imagen radical que se ha presentado del Black Panther Party correspondía con la realidad de esta organización. Para ello, se han realizado dos vías de estudio. Por un lado, el análisis de la política que desarrollaron, que volcaron especialmente en su programa de los diez puntos, así como sus enfrentamientos violentos y las prácticas sociales que realizaron dentro de los ghettos; por el otro, los argumentos del Gobierno para justificar la represión mediante el programa COINTELPRO, que se destacó por remarcar la imagen violenta.

Otros objetivos secundarios - pero no de menor importancia-fueron el papel de las mujeres y la influencia en otras minorías. En el caso de las mujeres, se centró en si su participación fue igual a los hombres y se contó con alguna líder destacada dentro de los Panteras Negras. Las minorías eran la búsqueda de organizaciones que tuvieran una estructura similar a los Panteras Negras o estuvieran colaborando con la organización.

\section{Material y método}

La principal fuente de este estudio ha sido de base bibliográfica, para la contextualización de las décadas de 1950, 1960 y 1970, así como el movimiento de los derechos civiles e ideologías como el panafricanismo que lo influenciaron. Gran parte de los autores empleados no tiene una versión traducida al español, por lo que se ha tenido que recurrir a la 
original en inglés. Además, se ha recurrido al periódico del Black Panther Party, denominado The Black Panther, y a los documentales de Lee LeeLew y Göran Olson, en los cuales encontramos el testimonio de los miembros de los Panteras Negras y grabaciones de las actividades de la organización durante su etapa activa.

Antes de concluir se debe señalar que en nuestro trabajo utilizamos una serie de términos que es necesario aclarar para que este se entienda mejor. En primer lugar, la denominación negros o afroamericanos para este segmento de población se emplea en dependencia del contexto. El primero se procura mantener como una diferenciación de la población blanca y de otras minorías raciales como los indios, que también eran y son clasificados en la cultura norteamericana como población de color, aunque en inglés existen diferentes matices en las denominaciones. ${ }^{2} \mathrm{Se}$ ha procurado utilizar afroamericanos en los apartados referidos al pensamiento y la ideología del movimiento en las décadas de 1960 y 1970 asociadas al panafricanismo que para distinguirlos de los naturales de África y demostrar su sentimiento de pertenencia a Estados Unidos manteniendo las raíces que aplicaban este vocablo.

\section{Resultados}

Podemos ver reflejados los objetivos marcados para este estudio en los materiales presentados a continuación. En ellos, podemos ver desde el programa de diez puntos publicado en The Black Panther el 30 de agosto de 1969, página 23; una fotografía de los desayunos para menores, también publicado en The Black Panther, el día 6 de septiembre de 1969, página 19, así como uno de los menús de estos desayunos. También encontramos una fotografía de Howard Bingham de una manifestación en la que aparecen mujeres participando al igual que los hombres, que se encuentran detrás de ellas. Además del programa de los Young Lords, grupo puertorriqueño basado en el Black Panther Party.

2. En inglés aparecen black, colored people, people of color y afroamerican. El contexto histórico ha hecho variar aspectos culturales y sociopolíticos que aplican connotaciones más o menos ofensivas de estos términos. Actualmente, el empleo de colored se encuentra anticuado. Negro es un término aceptable siempre y cuando se hable sobre un contexto histórico, pero nigger o nigga (una palabra derivada de negro) son totalmente ofensivos (Gates, 2013: 21) 

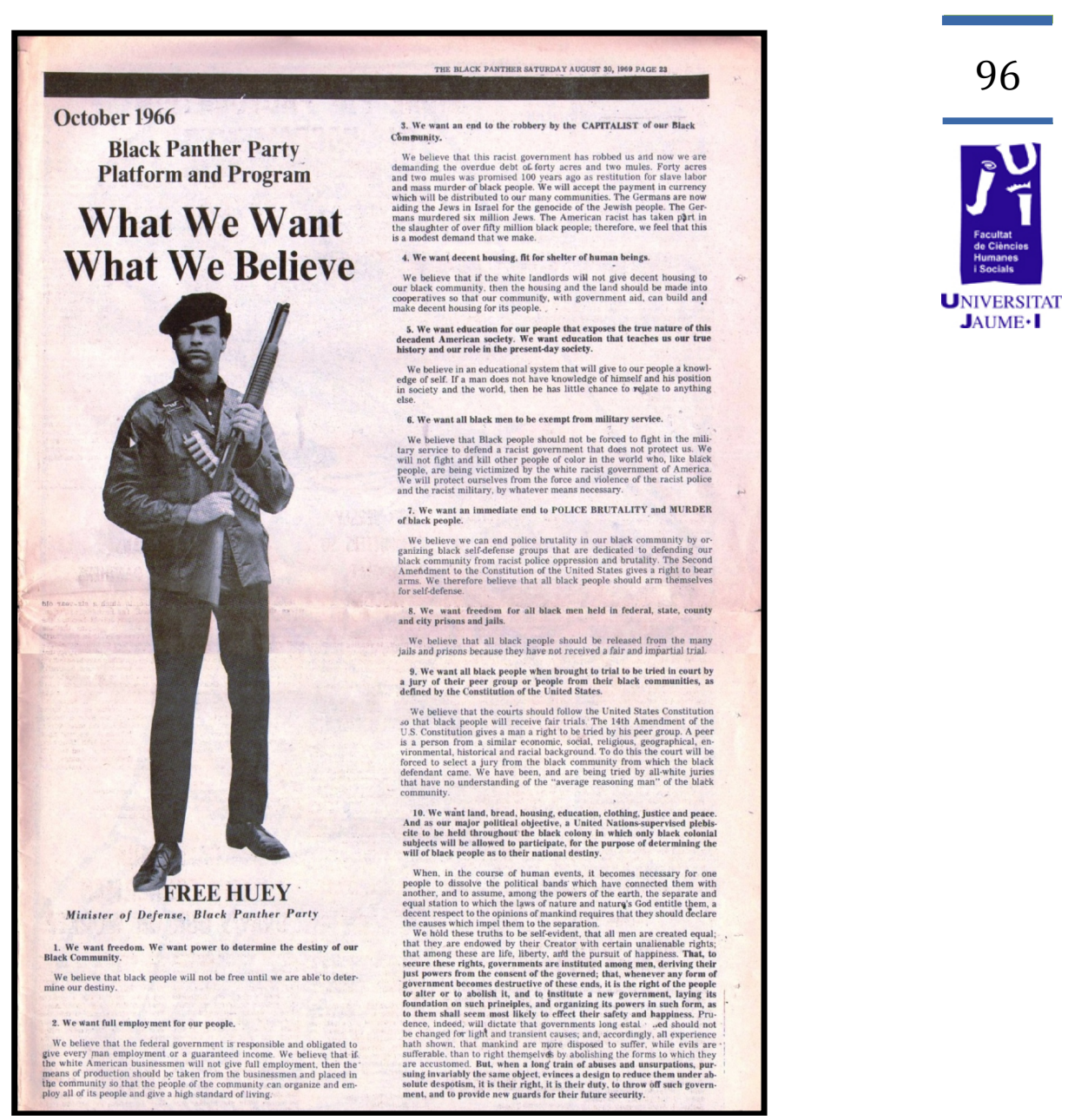

Figura 1. Programa de diez puntos del Black Panther Party

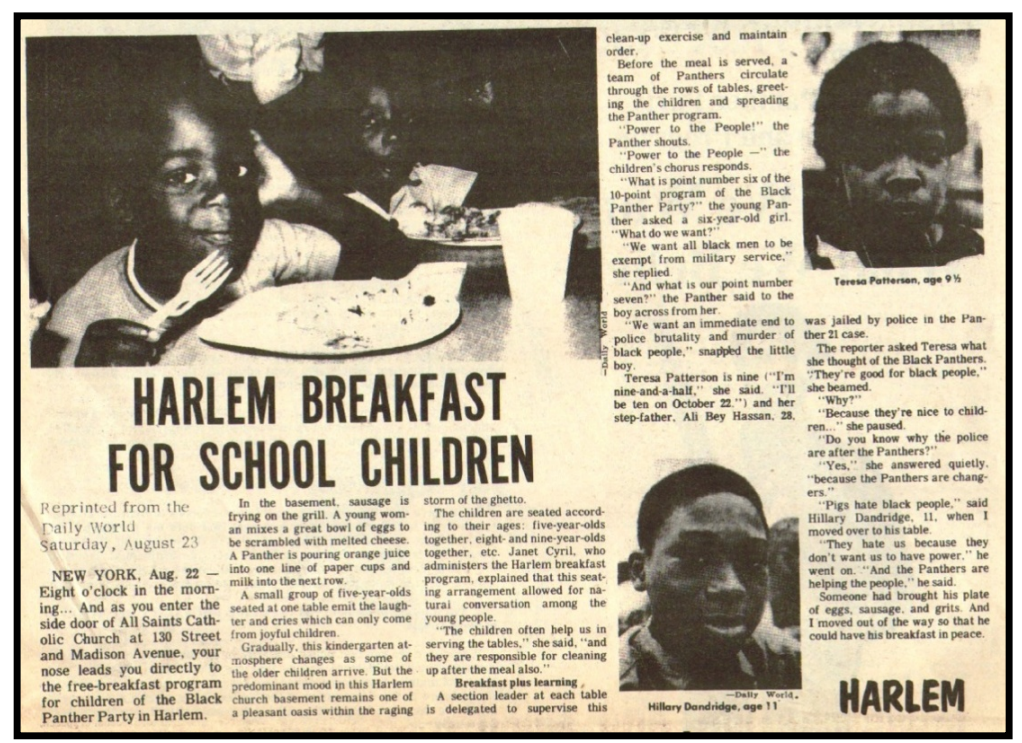

Figura 2. Recorte del The Black Panther sobre el comedor de Harlem (Nueva York) 
Tabla 1. Recreación del menú de desayunos gratuitos para los menores de edad

\begin{tabular}{|c|c|c|c|c|}
\hline Lunes & Martes & Miércoles & Jueves & Viernes \\
\hline Huevos revueltos & Panqueques & Huevos & $\begin{array}{l}\text { Tostadas } \\
\text { francesas }\end{array}$ & Huevos \\
\hline Sémola & Salchichas & Patatas fritas & Bacon & Sémola \\
\hline Bacon & Fruta fresca & Jamón & Fruta fresca & Bacon \\
\hline Tostadas y jalea & Chocolate caliente & Tostadas y jalea & $\begin{array}{c}\text { Chocolate } \\
\text { caliente }\end{array}$ & Tostadas y jalea \\
\hline Zumo o leche & $\varnothing$ & Zumo o leche & $\varnothing$ & Zumo o leche \\
\hline
\end{tabular}

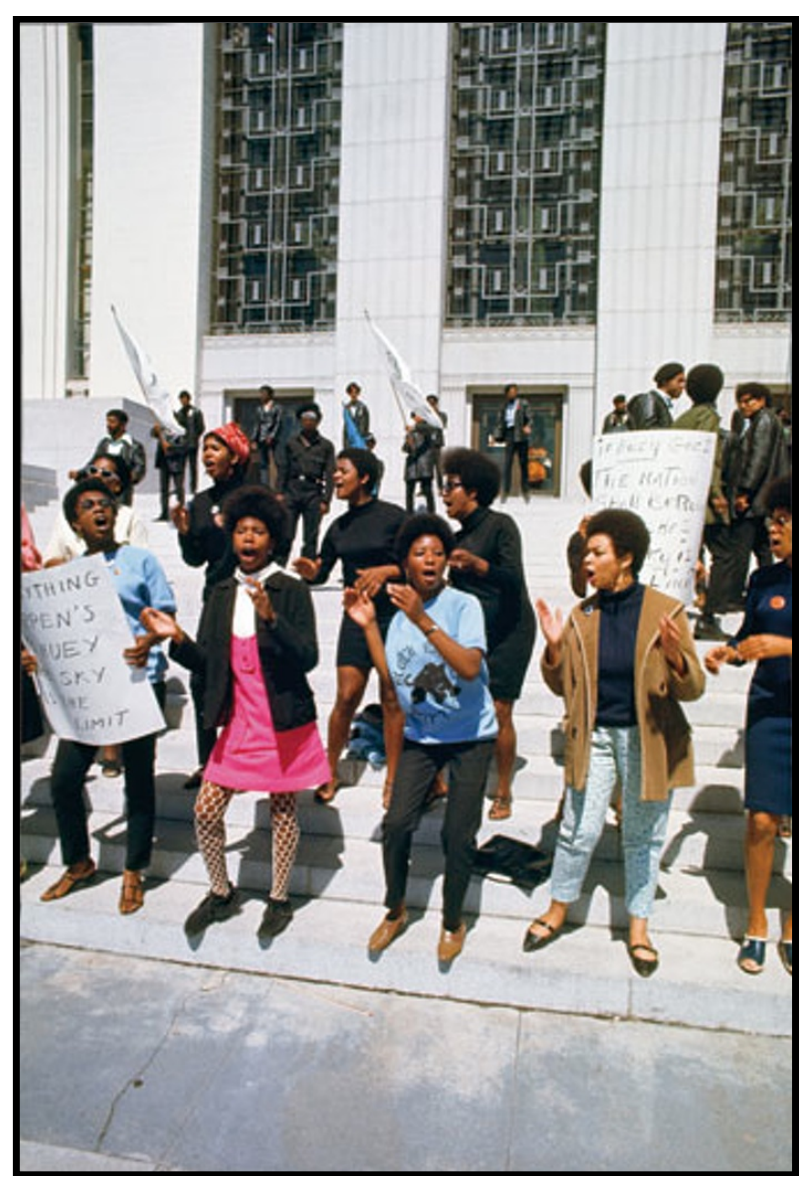

Figura 3. Manifestación del Black Panther Party 
Texto 1. Programa de Trece Puntos de los Young Lords

Young Lords Party 13-Points Program and Platform (revised November 1970)

1. We want self-determination for Puerto Ricans. Liberation on the island and inside the United States.

2. We want self-determination for all Latinos.

3. We want liberation of all Third World people.

4. We are revolutionary nationalists and oppose racism.

5. We want equality for women. Down with machismo and male chauvinism.

6. We want community control of our institutions and land.

7. We want a true education of our afro-indio cultura and Spanish language.

8. We oppose capitalists and alliance with traitors.

9. We oppose the Amerikkkan military.

10. We want freedom for all political prisioners and prisoners of war.

11. We are internationalists.

12. We believe armed self-defense and armed struggled are the only means to liberation.

13. We want socialist society.

\section{Conclusiones}

Las décadas de 1940 y 1950 fueron años de crecimiento económico, el avance industrial en las ciudades del norte y oeste funcionó como efecto llamada para la población afroamericana del sur. Estos inmigrantes se encontraban hacinados en barrios degradados -denominados como ghettos-, caracterizados por las construcciones antiguas, falta de infraestructuras urbanas públicas -como el alumbrado-, escasas escuelas, centros médicos, etc. La población blanca que contaba con mayores recursos se trasladó a barrios residenciales y se crearon nuevos núcleos urbanos exclusivos ellos. Esto generó dos focos habitacionales claramente diferenciados: los ghettos compuestos por afroamericanos que rozaban el umbral de la pobreza y los barrios residenciales en los cuales vivía la población blanca de clase media-alta.

La separación entre ambos colectivos estaba apoyada sobre las leyes segregacionistas de cada estado, agrupadas bajo el nombre de Jim Crow y amparadas en la doctrina del TS «separados pero iguales» que más bien era un eufemismo: vivían separados y en condiciones desiguales. Por ello, podemos considerar que en la década de los cincuenta comienza una rebelión por sus derechos que irá creciendo, en las dos décadas siguientes de la lucha legal de la NACCP al movimiento por los derechos civiles de Martin Luther King. Como trasfondo, el movimiento contracultural que dominó la sociedad estadounidense de los sesenta.

En 1964 se aprobó la Ley de los Derechos Civiles. Un primer paso sí, pero insuficiente para los afroamericanos ubicados en los ghettos que veían cómo se prestaba mayor atención a los afroamericanos sureños que 
a ellos, que continuaban abandonados por los gobiernos que gastaban más recursos en la guerra de Vietnam que en luchar contra la pobreza en el interior del país. Los discursos de Martin Luther King comenzaron a perder sentido ante la impaciencia de estos jóvenes cuyas demandas eran reprimidas duramente por la policía. Mientras tanto, los mensajes de Malcolm X, más agresivos, resultaban más atractivos y comenzaban a ser más populares entre los jóvenes de los ghettos.

Las esperanzas e impaciencias del ghetto comenzaron a tomar forma en una aspiración: "iQueremos el poder negro aquí y ahora!», lanzado por Stokely Carmichael en 1966 y que sintetizaba, por un lado, el orgullo de ser negro $y$, por el otro, la aspiración del poder, como forma de resolver los problemas de la comunidad ante unos gobiernos incapaces.

Quien mejor representaría estas aspiraciones y recogería el testigo de la lucha por los derechos civiles fue el Black Panther Party, fundado en 1966 por dos jóvenes de Oakland (California), Huey Newton y Boby Seale.

Frente a la imagen construida de violencia y radicalismo, alimentada por la práctica de la autodefensa -que comprendía el uso de armas- y la estética de sus militantes integrantes -uniforme, boinas y armas-, el partido también desarrolló una importante labor social en la comunidad en la que pocas veces se pone el foco.

El fundamento ideológico de los panteras se movía entre el comunismo -en su vertiente maoísta- y el panafricanismo, mientras que sus principales aspiraciones fueron recogidas en el programa. El programa de diez puntos: libertad para regir sus destinos, empleos, viviendas, educación -donde se incluyera las enseñanza de las raíces africanas-, el cese de la brutalidad policial, la suspensión del servicio militar o tribunales justos.

Los escasos miembros realizaban programas sociales que ayudaron a la comunidad de los ghettos incluso más que los gobiernos de Lyndon Johnson y Richard Nixon. Se crearon programas de ayuda que incluían lo siguiente: entrega de ropa para las familias necesitadas, clases de apoyo e historia del pueblo negro, la rehabilitación de los drogadictos, ayuda para encontrar empleo y vivienda, visitas carcelarias y clases de autodefensa. Los programas de desayunos gratuitos y el sanitario -clínicas médicas gratuitas, vacunación, etc.- fueron paradigmáticos. También fue importante su apuesta por la igualdad de género y la labor de las mujeres en el partido.

Esto les hizo ganar simpatías y apoyos entre la población, pero también, al demostrar cómo la comunidad negra de los ghettos podía conseguir grandes objetivos frente a la negligencia del gobierno, atrajeron su enemistad. Fueron considerados el enemigo público número uno y el FBI explotó su imagen agresiva en los medios de comunicación, de forma que se alimentaba el omnipresente temor de una parte de la población blanca. Como ya había advertido Malcolm X (The Black Power Mixtape, 21: 56 y 22: 27):

Si lo hace un blanco, está bien. Se supone que un negro no tiene sentimientos. Pero cuando un negro se defiende es un extremista. Se supone 
que debe estar quieto y que no tiene sentimientos. No debe ser violento y debe amar a su enemigo. No importa si es un ataque verbal o no. Si se levanta e intenta defenderse, entonces es un extremista.

El FBI también empleó otros mecanismos como el programa COINTELPRO, la verdadera arma contra el Black Panther Party. Se utilizaron desde escuchas telefónicas, cartas falsificadas, infiltrados, encarcelamientos hasta asesinatos. Los Panteras Negras eran un ejemplo no solo para una parte de la comunidad negra sino también para otras minorías -como la White Panther Party, los Young Lords y el American Indian Movement- que imitaron su modelo y también constituyeron organizaciones de autodefensa y ayuda.

Con la vuelta al conservadurismo en Estados Unidos comenzó a agonizar la contracultura y las aspiraciones que habían animado a toda una generación. La estrategia de acoso y derribo funcionó no solo para destruir el partido -sus dirigentes acabaron desperdigados 0 encarcelados- sino que se extendió a la comunidad, mientras los ghettos continuaron sumidos en la pobreza e invadidos por las drogas. El sueño de «iTodo el poder para el pueblo!» que alentara a la comunidad negra quedó como un recuerdo empañado por la imagen de violencia que ha trascendido y la labor social enmarcada en la memoria de unos pocos nostálgicos.

\section{Bibliografía}

AdAms, W. P. (1996): Los Estados Unidos de América, Siglo XXI, Madrid.

Agencias (2015): «EE. UU. libera a un preso que llevaba 43 años en régimen de aislamiento», Público [en línea], 9 de junio [Fecha de consulta: 19 de junio de 2015] Disponible en: http://m.publico.es/internacional/1922386/eeuu-libera-a-un-preso-quellevaba-43-anos-en-regimen-de-aislamiento.

Agencias (2008): "La sentencia de Mumia Abu-Jamal será revisada», El País [en línea], 28 de marzo [Fecha de consulta: 19 de junio de 2015]. Disponible en:

http://sociedad.elpais.com/sociedad/2008/03/28/actualidad/120665880 3_850215.html.

AnN ARBoR sun (1969): White Panther Party 10-Point Program, 28 de julio, [Fecha de consulta: 24 de junio de 2015]. Disponible en: http://freeingjohnsinclair.aadl.org/node/192878.

BINGHAM, H. (2009): "Life with the Black Panthers», The Observer, 25 de octubre de 2009. Disponible en: http://www.theguardian.com/world/gallery/2009/oct/25/blackpanthers-howard-I-bingham. 
BusH, R. D. (1999): We Are Not What We Seem: Black Nationalism and Class Struggle in the American Century, New York University Press, Nueva York y Londres.

Carmichael, S. (1967): «El poder negro», Pensamiento Crítico, núm. 4, La Habana, p. 165-176.

CleAVER, K. y G. KATSIAFICAS (2001): Liberation, Imagination, and the Black Panther Party: A New Look at the Panthers and Their Legacy, Routledge, Nueva York.

Cole, J. B. y B. GuY-Sheftall (2003): Gender Talk. The Struggle for Women's Equality in African American Communities, Ballantine Books, Nueva York.

DAVIS, A. Y. (1972): Si llegan a por ti en la mañana... vendrán por nosotros en la noche, Siglo XXI, Madrid.

ENRIGHT, M. (2014): «Robert Redford Renews Fight to Release Jailed AIM Activist Leonard Peltier». CBC News [en línea], 6 de abril [Fecha de consulta: 19 de junio de 2015]. Disponible en: http://www.cbc.ca/news/world/robert-redford-renews-fight-to-releasejailed-aim-activist-leonard-peltier-1.2598981.

FoHLEN, C. (1973): Los negros en Estados Unidos, Oikos-Tau, Barcelona.

GATES, H. L. (2013): Gente de color, Editorial Arte y Literatura, La Habana, p. 63-73.

HAAS, J. (2011): The Assassination of Fred Hampton: How the FBI and the Chicago Police Murdered a Black Panther, Lawrence Hill Books, Chicago (Illinois).

Hernández Alonso, J. J. (1996): Los Estados Unidos de América: Historia y Cultura, Colegio de España, Salamanca.

JeNKINS, P. (2002): Breve historia de Estados Unidos, Alianza, Madrid.

Jones, C. A. (1998): The Black Panther Party [Reconsidered], Black Classic Press, Baltimore.

JONES, M. A. (1996): Historia de Estados Unidos 1607-1992, Cátedra, Madrid.

LEW-LEE, L. (1996): Todo el poder para el pueblo [documental]

Morales, I. y D. Oliver-Velez (2010): The Young Lords: a Reader, New York University Press, Nueva York.

Novas, H. (2008): Everything You Need to Know about Latino History, Plume, Nueva York, p. 49-50.

Ogbar, J. O. G. (2005): Black Power: Radical Politics and American Identity, The Johns Hopkins University Press, Baltimore (Maryland).

O'ReILly, R. (1984): El pueblo negro de Estados Unidos: raíces históricas de su lucha actual, Ediciones Políticas, La Habana.

OLsoN, G.(2011): The Black Power Mixtape 1967-1975 [documental] 
OLSON, J. S. y R. WILSON (1984): Native Americans in the Twentieth Century, Brigham Young University Press, Utah.

PULIDO, L. (2006): Black Brown, Yellow \& Left: Radical Activism in Los Angeles, University of California Press, Londres.

ROMANUTTI, R. I. (2010): «Identidades africanas. Ideas sobre la política exterior del panafricanismo», 30 de abril de 2010. Grupo de Estudios Internacionales Contemporáneos (GEIC), Argentina, p. 4 [pdf]. Disponible en: https://geic.files.wordpress.com/2010/12/identidades-africanasideas-sobre-la-polc3adtica-exterior-del-panafricanismo.pdf.

SMITH, J. B. (1999): An International History of the Black Panther Party, Publishing, Inc., Nueva York y Londres.

The Dr. Huey P. Newton Foundation (2008): The Black Panther Party: Service to the People Programs, University of New Mexico Press, Albuquerque (Nuevo México).

The King Center, Black Power. [Fecha de consulta: 1 de junio de 2015] Disponible http://kingencyclopedia.stanford.edu/encyclopedia/encyclopedia/enc_bl ack_power/.

Torres, A. y J. E. Velázquez (1998): The Puerto Rican Movement: Voices from the Diaspora, Temple University Press, Philadelphia.

Van Deburg, W. L. (1992): New Day in Babylon: The Black Power Movement and American Culture 1965-1975, The University of Chicago Press, Londres.

Williams, T. (2011): «Execution Case Dropped Against Abu-Jamal», New York Times, 7 de diciembre [Fecha de consulta: 19 de junio de 2015]. Disponible en: http://www.nytimes.com/2011/12/08/us/execution-casedropped-against-convicted-cop-killer.html?_r=0.

ZINN, H. (2004): La otra historia de los Estados Unidos, Ciencias Sociales, La Habana, p. 150-151. 


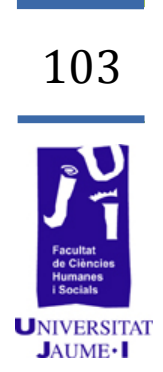

\section{Sueños animados}

Propuesta para un análisis comparativo entre Alicia en el País de las Maravillas, de Lewis Carroll, y Alice, de Jan Švankmajer

Rosa-Anna Ferrando-Mateu al097391@uji.es 
El presente trabajo gira en torno a la obra del cineasta de animación checo Jan Švankmajer (Praga, 1934) y más concretamente en su largometraje Alice (Něco z Alenky, 1988), una adaptación de la obra Alicia en el País de las Maravillas, de Lewis Carroll, publicada en 1865. Se propone un estudio comparativo entre el texto literario y el texto fílmico $y$, de forma secundaria y como consecuencia de lo anterior, se pretende profundizar en el análisis de este cineasta y en algunas de sus constantes temáticas; en particular, la infancia y los sueños, etc., como motivos que condensan cierto espíritu surrealista.

Palabras clave: surrealismo, sueños, Švankmajer, Carroll, Alicia, animación, stop-motion.

\section{Introducción}

Švankmajer es uno de los cineastas más reconocidos en el campo de la animación, si bien su obra transita por diferentes disciplinas artísticas: dibujo, pintura, escultura, poesía e ilustración. Pese a ello, es fundamentalmente conocido por su trabajo cinematográfico, vinculado al truco y la animación, y a la mezcla de técnicas como la imagen real y el stop-motion. Desde un punto de vista temático, su trabajo gira en torno a dos cuestiones principales, la libertad y la manipulación, que se repiten una y otra vez a lo largo de su producción, lo que le ha llevado a afirmar que en cierto modo toda su obra es una misma y única película, con múltiples versiones (Álvarez, 2012). Y es precisamente en relación con el primer tema citado, la libertad, donde los sueños y la infancia se presentan en su obra como momentos o espacios de suspensión de las normas establecidas.

Alicia se duerme en las primeras hojas del libro y también en los primeros minutos de la película, de forma que toda la historia que ocurre a continuación es (tal vez) un sueño. Espacio intermedio que los surrealistas y, más concretamente André Breton, nos decían que mediante esos vasos comunicantes entre el mundo de la vigilia y el mundo del sueño encontramos el surrealismo y con él conseguiremos la libertad. Švankmajer, mediante esos vasos comunicantes, consigue que lo animado tome vida y que los objetos cotidianos se metamorfoseen tomando propiedades que no le corresponden por naturaleza. Debido a la vinculación de Švankmajer con el surrealismo -en 1970 se afilió al grupo surrealista checo- no nos ha de extrañar que adaptara la obra literaria de Carroll, que constituye un claro referente del movimiento surrealista.

Junto a los sueños, Švankmajer también decía que es en la infancia cuando los seres humanos somos más libres (2014:108) ya que las normas y la razón aún no han repercutido en nuestro ser. Esta idea 
también la vemos reflejada en las cartas que escribió Lewis Carroll, donde le dice a la Alicia mujer que aún consigue ver en el fondo de ella a esa niña que fue (Carroll, 2013: 139). Por su parte, André Breton ya nos deja ver la importancia de la infancia para conseguir esa liberación (1991: 118):

la resistencia básica que el niño opondrá siempre a quienes tiendan a modelarlo, y luego a reducirlo, limitando más o menos arbitrariamente su magnífico campo de experiencias.

No sólo en la película Alice, sino en gran parte de su obra, Švankmajer nos muestra como la sociedad y la familia desde la infancia se dedican mediante castigos y normas a cambiarnos y moldearnos según sus necesidades.

Podemos encontrar múltiples adaptaciones de la obra de Lewis Carroll. En 1933, la dirigida por Norma Z. McLeod; la versión animada llevada a cabo por Disney en 1951, que no satisfizo a la críticos (incluso Švankmajer afirma en una entrevista que «Disney es el mayor corruptor de la imaginación infantil de la humanidad»); la adaptación para televisión en formato de larga duración realizada en 2009 por Nick Willing, y, ya para finalizar, aunque quedan muchas más, la última versión que encontramos, dirigida por Tim Burton en 2010. Pese a ello, nos centraremos en la de Švankmajer porque en esta, tanto sus personajes como las acciones ocurren enteramente dentro de la novela Alicia en el País de las Maravillas.

Hemos podido comprobar que apenas existe literatura académica especializada en castellano, con lo cual pensamos que este estudio puede suplir estas carencias y aprovecharemos, siendo Švankmajer un artista contemporáneo surrealista, y justificaremos en este trabajo que sigue vigente este movimiento de vanguardia.

\section{Objetivos}

En esta investigación se propone un análisis comparativo entre Alice de Švankmajer y el libro de Lewis Carroll, para examinar los mecanismos de traslación que emplea el cineasta, qué es lo que se pierde y qué es lo que consigue mantener fiel al texto. En este sentido, cabe señalar, que mientras las diferentes adaptaciones cinematográficas combinan referencias tanto de la novela, Alicia en el País de las Maravillas, como de su secuela, A través del espejo y lo que Alicia encontró allí, la película de Švankmajer se centra exclusivamente en la primera, de forma que cabe ser considerada a priori la adaptación más fiel a la novela de Carroll.

Para ello, analizaremos las estrategias adoptadas en esta traslación e intentaremos discernir de qué forma, si es que lo hace, se mantiene el espíritu original de la novela al tiempo que algunos de sus motivos se incorporan al universo surrealista propuesto por Švankmajer. En este sentido, y como veremos con más detalle a continuación, conviene 
señalar que las referencias a Lewis Carroll ya estaban presentes en su obra con anterioridad, como sucede en el cortometraje Jabberwocky (1971), basado en un poema del mismo escritor en inglés.

En suma, este análisis comparativo -centrado en las transformaciones que han experimentado la trama, el tratamiento de los personajes y los espacios- nos permitirá, por último, examinar cómo el autor checo inserta los motivos presentes en la obra de Carroll -la infancia y el sueño- a través de un prisma surrealista.

Para la elaboración de este trabajo, hemos ido en primer lugar a las fuentes, esto es, a las obras de los dos autores, Lewis Carroll y Jan Švankmajer, los cuales están detrás de la creación de la Alicia literaria y la cinematográfica. Para poder conseguir todos los objetivos planteados se ha realizado una fase destinada a la búsqueda de documentación que aporte información a nuestro tema de investigación. Tras ello se ha procedido a la fase hermenéutica con la lectura del material conseguido que nos servirá para contextualizar la obra a analizar.

Una vez finalizada dicha tarea se ha procedido al análisis comparativo entre ambas obras de acuerdo con el modelo analítico propuesto por José Luis Sánchez Noriega en su libro De la literatura al cine. Teoría y análisis de la adaptación (2000). Sánchez Noriega hace una división a la hora de clasificar el tipo de una adaptación de un texto literario: según la dialéctica fidelidad/creatividad, según el tipo de relato, según la extensión y según la propuesta estético-cultural. Nuestro estudio lo centraremos de manera específica según la dialéctica fidelidad/creatividad, y la consideraremos una adaptación como transposición (se reconoce los valores de su obra y a su vez encontramos entidad por sí mismo). En este punto estudiaremos la narración de la acción, la temporalidad y el espacio. Luego también nos fijaremos en la adaptación según la extensión (reducción o ampliación de acciones, personajes, diálogos). También prestaremos atención a todo lo que le acompaña, a las imágenes y a la utilización del sonido y de la música. $Y$ una vez realizado este análisis comparativo, interpretaremos los resultados de los cuales sacaremos unas conclusiones.

\section{Marco teórico}

\subsection{Del libro a la pantalla. Intertextualidad y traslación}

Umberto Eco ya nos decía en su obra La definición de arte (1972) que para hablar de las relaciones o analogías entre cine y literatura es conveniente distinguir entre las características específicas de estas dos formas de arte. La diferencia principal es que uno utiliza palabrasconceptos y otro, imágenes. En el caso de la literatura, el estímulo es 
provocado por un signo lingüístico (a través de una operación compleja), Eco (1972: 194):

una exploración del «campo semántico» ligado a dicho signo, hasta que, sobre la base de los datos del contexto, el signo evoque, con la aceptación apropiada, una suma de imágenes capaces de estimular emotivamente al receptor.

Por el contrario, el caso de estímulo a través de una imagen el proceso es inverso, "la primera reacción frente a la imagen no es, no ya intelectiva, sino ni siquiera "intuitiva" [...] es precisamente fisiológica» (Eco, 1972: 195).

Robert Stam, en su capítulo "Del texto al intertexto» que podemos encontrar en su libro Teorías del cine (2001: 235-246), nos explica el concepto de intertextualidad y como este no se puede reducir a cuestiones de influencias o de las fuentes de un texto, sino también es cuando entendemos que un texto está relacionado con otros textos, o las relaciones de un texto con sus circunstancias históricas y su contexto. Y como, según Stam (2001: 244)

las adaptaciones se encuentran atrapadas, por definición, en una continua vorágine de transformaciones intertextuales, de textos que generan otros textos en un proceso incesante de reciclaje, transformación y transmutación, sin un punto de origen claro.

Según José Luis Sánchez Noriega, en su libro De la literatura al cine. Teoría y análisis de la adaptación (2000) hablamos de trasvases para referirnos a todas esas creaciones artísticas cuyo origen se encuentra en textos previos. Aún así (2000: 24)

no todo trasvase tiene la misma entidad, al menos en tanto que la diferencia radical entre los medios expresivos exige hacer un obra original [...] y tanto que el genio artístico desborda el mero comentario para proponer una creación genuina.

Él distingue entre los trasvases que dan lugar a una obra nueva, de las adaptaciones que necesariamente son subsidiarias de la obra original.

¿Cómo podemos definir el término adaptación? Para Sánchez Noriega podemos entender una adaptación como (2000: 47):

el proceso por el que un relato, la narración de una historia expresado en forma de texto literario, deviene, mediante sucesivas transformaciones en la estructura (enunciación, organización y vertebración temporal), en el contenido narrativo y en la puesta en imágenes (supresiones, compresiones, añadidos, desarrollos, descripciones visuales, dialoguizaciones, sumarios, unificaciones o sustituciones), en otro relato muy similar expresado en forma de texto fílmico.

Por otra parte, y teniendo en cuenta la adscripción de Švankmajer al surrealismo, conviene detenerse en estudios centrados específicamente en las adaptaciones realizadas por otros directores de raigambre 
surrealista, como Luis Buñuel. Es el caso del libro Luis Buñuel de la literatura al cine. Una poética del objeto, de Antonio Monegal (1993). En concreto nos interesan los capítulos «Ejes de traslación» y "Composición del signo», donde nos explica cómo el director surrealista traslada del papel a la pantalla, poniendo de ejemplo la novela Cumbres borrascosas, de Emily Brontë, y la película Abismos de pasión (1953). De momento, Monegal rechaza el término adaptación, y prefiere traslación, (Monegal, 1993: 105):

por lo que tiene de movimiento de traslado del texto, incluso entre soportes materiales, y por las implicaciones que aporta al concepto de la palabra inglesa translation, que significa precisamente traducción.

De este modo, de acuerdo con el autor, en la adaptación de un libro si la película quiere mantenerse fiel- no hay mucho margen para la libertad del autor o director. Por lo tanto, siguiendo su argumentación, en los surrealistas, como Jan Švankmajer o Luis Buñuel, los procedimientos que utilizan para adaptar un texto no atienden a criterios de fidelidad; más que fidelidad hay que ver los diversos grados de desviación, fijándonos tanto en lo que se cambia como lo que se queda intacto (Monegal, 1993: 113).

Aún así, Sánchez Noriega (2000: 47) nos habla indistintamente de "adaptar, trasladar o transponer para referirnos al hecho de experimentar de nuevo una obra en un lenguaje distinto a aquel en que fue creada originariamente». Pese a estas disquisiciones, en este estudio adoptamos la perspectiva de Monegal centrada en el concepto de traslación -que enfatiza la desviación-, si bien desde un punto de vista metodológico, como expondremos más adelante, nos serviremos del modelo de análisis comparativo propuesto por Sánchez Noriega.

\subsection{Surrealismo: orígenes, motivos y vigencia}

En 1919, previa a la formación del grupo surrealista, Philippe Soupault, André Breton y Louis Aragon publican, por primera vez, la revista Littérature, con orientación dadá. Ese mismo año Breton propone a Soupault escribir un libro sin premeditación, sin un tema propuesto y sin una posterior corrección, de esto modo surgió Los campos magnéticos. En un principio, Breton quiso denominar esta forma de escribir "escritura mecánica» o "escritura de pensamiento», pero al final decidió llamarla «surrealista» en homenaje a Guillaume Apollinaire, quien creo el adjetivo surrealista, para expresar una vuelta a la naturaleza pero sin imitarla.

En agosto de 1924 aparece Una ola de sueños de Louis Aragon y en octubre de ese mismo año, Manifiestos del surrealismo, de André Breton. Ambos textos son crónicas de un momento, de unas vivencias en cuyo centro están los sueños.

Una ola de sueños es interesante porque aquí asistimos a una narración acerca del nacimiento del surrealismo que complementa la 
expresada por Breton en Manifiestos del surrealismo. En ambos casos se señala el año 1924 como el inicio de una nueva era surrealista, según Aragon (2004: 63):

1924: bajo este número que sostiene una daga y arrastra tras de sí una siembra de peces-luna, bajo este número ornado de desastres, extrañadas estrellas en sus cabellos, el contagio del sueño se expande por los barrios y las campiñas.

Tras la creación oficial ese mismo año del movimiento en el mes de octubre, se aceleran los acontecimientos $y$, en diciembre de ese mismo año, la revista Littérature pasa a llamarse La Révolution Surréaliste, dando comienzo una nueva acción colectiva. Según Walter Benjamin el surrealismo en sus inicios (2013: 33):

irrumpió sobre sus fundadores como una ola cargada de sueños, se anunció como el más cabal, concluyente y absoluto de los movimientos. Hacía suyo cuanto tocaba. Parecía que la vida sólo merecía la pena si el umbral entre vigilia y sueño quedaba anulado por un ingente flujo de imágenes; el lenguaje parecía serlo sólo si sonido e imagen, imagen y sonido se interpretaban con la automática y feliz exactitud que no dejaban resquicio alguno por donde insertar la ficha del «sentido». Imagen y lenguaje se imponían.

Otra obra necesaria para entender la conexión que existe entre el mundo de la vigilia y el mundo de los sueños es el libro que redacta André Breton entre 1931 y 1932, Los vasos comunicantes, centrado también en el sueño, y, como el título indica, la conexión entre el mundo de los sueños y el de la vigilia y como estos actúan como dos vasos comunicantes entre los cuales no existe barrera alguna (Sebbag, 2013: 32).

Aún teniendo sus orígenes en Francia, el movimiento surrealista pronto se extendió por todo Occidente, y años más tarde llegó a formarse el grupo surrealista checo al cual perteneció Švankmajer. Por otra parte, cabe considerar, de acuerdo con Cristina Díaz (2004: 80), que:

el surrealismo supera la categoría de escuela artística para convertirse en una filosofía de vida, en una nueva forma radical de ver el mundo, pues propone fórmulas para alcanzar una existencia plena mediante la liberación de todo aquello que constriñe el espíritu humano.

El propio Švankmajer tampoco se limita a encerrarlo como un movimiento artístico más, sino que para él es una actitud ante la vida, cuyo objetivo principal sigue siendo transformar el mundo y cambiar la vida (2012: 65 y 69):

Por encima de todo, el surrealismo no es arte. Es un cierto estado de espíritu que ni comienza con el primer manifiesto de 1924 ni termina con la Segunda Guerra Mundial (ni con la muerte de Breton). El surrealismo es un viaje a las profundidades del alma, como la alquimia y el psicoanálisis. Sin embargo, a diferencia de estos, no es un viaje individual sino una aventura colectiva. [...] A los ojos de un público poco informado, el carácter simbólico del surrealismo se 
asocia con una "estética surrealista». El surrealismo es mucho más: una visión del mundo, una filosofía, una ideología, una psicología, una magia.

De nuevo, como con anterioridad lo habrán dicho los surrealistas, Švankmajer considera que es en la infancia (incluso la compara con los sueños) donde más libertad tiene la imaginación. El imaginario de Švankmajer surge en el punto donde coincide la imaginación infantil y la magia. Este es uno de los motivos por el cual se siente atraído por el cuento de Carroll y las aventuras de Alicia, donde la realidad y el sueño se encuentran comunicados (Švankmajer, 2012: 71):

Si tuviera que comparar el sueño con algo, lo haría con la infancia. Los sueños son una extensión de la infancia. Para mí son, en verdad, un mensaje, quizá un augurio, algunas veces un puzle, e incluso un objeto de análisis. Depende del tipo de sueño, y sobre todo, de qué modo me estimula su contenido "misterioso» durante la vigilia, puesto que no todos los sueños tiene la misma carga emotiva. Něco z Alenky (Alicia), tal y como la rodé y, por supuesto, tal y como la concibió Lewis Carroll en su escrito, es un sueño infantil. [...] El sueño se fusiona con la realidad según el principio de los «vasos comunicantes».

Como ya hemos dicho en la introducción, desde los inicios del surrealismo aparece la figura de Lewis Carroll como un claro referente, ya que de algún modo se anticipa a la «escritura automática» del este. Estando siempre presente por su manera de escribir y de contarnos historias en las que parece que se ha perdido el sentido, y el absurdo reina entre las palabras, mezclando el sueño y la realidad, y tomando elementos domésticos de la vida cotidiana otorgándoles el don de la magia. Ya André Breton, en su Antología del humor negro, lo nombra (1991: 117):

La importancia del «non-sens» en Carroll reside en el hecho de que constituye para él la solución vital de una contradicción profunda entre la aceptación de la fe y el ejercicio de la razón por una parte; y por otra, entre la aguda conciencia poética y los rigurosos deberes profesionales.

Esa lucha que mantienen la lógica y la razón con el mundo de la imaginación y los sueños es la que ganarán con el surrealismo: la imaginación de la infancia que hemos perdido, de forma que, de acuerdo con Breton (1991: 117), "la complacencia hacia el absurdo vuelve a abrir al hombre el reino misterioso que habitan los niños». Es tal la importancia de la infancia que en el inicio de su Manifiestos del surrealismo ya deja plasmado que es gracias a ella que conseguiremos volver a darle a la imaginación el lugar que le corresponde, ya que los seres humanos vivimos bajo el imperio de la lógica y del racionalismo (2009: 15-16):

Si le queda un poco de lucidez, no tiene más remedio que dirigir la vista hacia atrás, hacia su infancia que siempre le parecerá maravillosa, por mucho que los cuidados de sus educadores la hayan destrozado. En la infancia, la ausencia de toda norma conocida ofrece al hombre la perspectiva de múltiples 
vidas vividas al mismo tiempo; el hombre hace suya esta ilusión; sólo le interesa la facilidad momentánea, extremada, que todas las cosas ofrecen. Todas las mañanas, los niños inician su camino sin inquietudes. Todo está al alcance de la mano, las peores circunstancias materiales parecen excelentes. Luzca el sol o esté negro el cielo, siempre seguiremos adelante, jamás dormiremos. Pero no se llega muy lejos a lo largo de este camino, y no se trata solamente de una cuestión de distancia. Las amenazas se acumulan, se cede, se renuncia a una parte del terreno que se debía conquistar. Aquella imaginación que no reconocía límite alguno, ya no puede ejercerse sino dentro de los límites fijados por las leyes de un utilitarismo convencional; la imaginación no puede cumplir mucho tiempo esta función subordinada, y cuando alcanza aproximadamente la edad de veinte años prefiere, por lo general, abandonar al hombre a su destino de tinieblas.

El arte surrealista rechaza plasmar los objetos de una manera realista. Los sueños, los trances hipnóticos, la histeria, incluso la locura serán la base para encontrar el material para realizar sus obras. De acuerdo con Díaz (2004: 82):

el arte surrealista plasma una realidad psicológica al interesarse los creadores por lo que se halla dentro de la mente más que por retratar el mundo circundante. Este interés por todo tipo de fenómenos mentales hará posible un arte compuesto por complejos procesos simbólicos, cuya consecuencia inmediata será ignorar el principio de realidad.

El cine desempeña un papel importante en el surrealismo. Al tratarse de imagen en movimiento, los surrealistas consideraron el cine como que este tenía más capacidad que las otras artes para reproducir el fenómeno onírico. Como expone Emilio Sanz (1983: 94):

los surrealistas convirtieron el cine en preocupación más que en realizaciones de sus sueños renovadores. El único que convirtiera sus sueños en realidades, en cine, fue Luis Buñuel. Sin Buñuel no existiría un cine realmente surrealista.

Junto a Buñuel, nombres como Salvador Dalí, Robert Desnos, Phillippe Soupault, Georges Huguet, etc., se encuentran relacionados al cine $y$ al surrealismo.

Podemos situar el inicio del cine surrealista con las películas Un perro andaluz (1929) y La edad de oro (1930), de Luis Buñuel y Salvador Dalí; estas son el mejor díptico surrealista que ha dado el cine: la primera con un mayor grado de onirismo y poesía, la segunda con mayor coherencia narrativa y provocación. Ya nos decía Buñuel en su conferencia «El cine, instrumento de poesía», impartida en 1958, que (Buñuel, 2001: 39):

el mecanismo productor de imágenes cinematográficas, por su manera de funcionar, es, entre todos los medios de expresión humana, el que más se parece al de la mente del hombre, o mejor aún, el que mejor imita el funcionamiento de la mente en estado de sueño.

Pero antes de pasar a la figura de Luis Buñuel nos detendremos a comentar brevemente la obra de Hans Richter. Aunque en un principio 
fue dadaista pronto se convirtió al surrealismo. Entre 1944 y 1947 realiza su película Sueños que el dinero puede comprar, ya totalmente surrealista y, como comenta Sanz (1983: 97):

compuesta de siete secuencias poéticas ligadas entre sí por la historia de un joven que, después de descubrir que sus ojos impresionaban los sueños decide comercializar su curiosa particularidad. Estos sueños fueron ideados por Alexander Calder, Man Ray, Marcel Duchamp, Max Ernst..., realizados todos por Hans Richter.

Es una de esas películas extrañas e intempestivas, donde lo real y lo escénico, el sueño y la vigilia, se mezclan sin una dimensión verdadera. La obra de Hans Richter se pudo llevar a cabo, ya que en tiempo de posguerra los artistas pertenecientes a las vanguardias europeas coincidieron en Estados Unidos. Entre 1955 y 1958 vuelve a repetir el experimento con $8 \times 8$, en el que también intervienen Calder, Duchamp, Max Ernst... y, además, Arp, Tanguy, Dorthea Tanning, José Luis Sert y Jean Cocteau.

Volviendo a Luis Buñuel, este sentía pasión por los sueños y fue esta pasión la que le hizo acercarse al surrealismo, como dirá en sus memorias Mi último suspiro, escritas en 1982 (Buñuel, 2008: 78):

Si me dijeran: te quedan veinte años de vida, ¿qué te gustaría hacer durante las veinticuatro horas de cada uno de los días que vas a vivir?, yo respondería: dadme dos horas de vida activa y veinte horas de sueños, con la condición de que luego pueda recordarlos; porque el sueño sólo existe por el recuerdo que lo acaricia.

Esta frase es enormemente significativa, pues nos da una idea de la fascinación que los surrealistas tenían por ese mundo al margen de la razón que nos pueden prestar tan excepcionales momentos para recordar.

Un perro andaluz fue escrito por Salvador Dalí y Luis Buñuel en apenas una semana del mes de febrero del mismo año de su estreno, 1929, siguiendo la regla de «no aceptar idea ni imagen alguna que pudiera dar lugar a una explicación racional, psicológica o cultural. Abrir todas las puertas a lo irracional» (Buñuel, 2004: 87). Muy significativamente, su nacimiento se produce a partir de dos sueños, uno de Dalí y el del propio Buñuel.

Esta película nació de la confluencia de dos sueños. Dalí me invitó a pasar unos días en su casa y al llegar a Figueras yo le conté un sueño que había tenido poco antes en el que una nube desflecada cortaba la luna y una cuchilla de afeitar hendía un ojo. Él, a su vez, me contó que la noche anterior había visto en sueños una mano llena de hormigas.

Después del éxito de Un perro andaluz, Buñuel fue a reunirse con Dalí en Figueres para trabajar en una nueva película. A los dos o tres días se da cuenta de que algo no funciona, no consiguen ponerse de acuerdo en ninguna de las ideas que se proponen. Al parecer el encanto de Un perro 
andaluz se había perdido: "De la noche a la mañana, Dalí ya no era el mismo. Toda concordancia de ideas desapareció entre nosotros, hasta el extremo de que yo renuncié a trabajar con él en el guion de La edad de oro» (Buñuel, 2004:81). Al final, el guion lo escribe Buñuel a solas, aun así, Dalí le envía varias ideas por carta y alguna de ellas aparece en la película: un hombre andando con una piedra en la cabeza pasea por un parque y pasa junto a una estatua con una piedra en la cabeza también. Una imagen típicamente daliniana.

Švankmajer inicia su decálogo indicando qué hacer para garantizar una buena película (2014: 111) «graba en tu espíritu que la poesía es solo una». La importancia de la poesía en el cine surrealista la podemos encontrar en palabras de Buñuel durante una conferencia impartida en México, en diciembre de 1958, bajo el título «El cine, instrumento de poesía» en la que nos decía (2001: 39): «el cine parece haberse inventado para expresar la vida subconsciente, que tan profundamente penetra por sus raíces, la poesía». No solo coinciden en la importancia de la poesía en la realización de su arte, ambos están de acuerdo en el rechazo de las grandes producciones, y más de aquellas que están realizadas para agradar a un gran número de espectadores. El cine surrealista de Buñuel es un claro referente para Švankmajer. De acuerdo con Pascal Vimenet (2010: 47), «sus películas, sean de ficción o de animación, se construyen, como en el cine de Buñuel, sobre tramas que oponen las convenciones sociales al deseo individual».

Las técnicas de animación que utiliza Švankmajer le permite cruzar y mezclar los mundos de los sueños y la vigilia como lo hicieron antes los primeros surrealistas. La animación cuadro a cuadro (también conocida como stop-motion) «supone una subversión de lo fotografiado, una irrupción o intervención de los objetos que vemos moverse en la pantalla, que ocurre en el intervalo entre toma y toma» (Eseverri, 2009:3). De este modo da vida a objetos que carecen de ella, en el cine de Švankmajer cualquier cosa puede animarse repentinamente.

\section{Conclusiones}

En este estudio proponemos examinar los mecanismos y las estrategias de adaptación -a partir de un modelo teórico y metodológico sustentado en la narratología- que Jan Švankmajer utiliza para trasladar el texto literario de Lewis Carroll a una obra audiovisual, en la que, de acuerdo con su estilo característico, el cineasta checo combina la imagen real y la animación de objetos mediante la técnica de stop-motion. Además, a través de un trabajo de revisión bibliográfica, señalaremos tanto la vinculación del director con el movimiento surrealista, como la influencia que en este movimiento de vanguardias ("una forma de vida» para Švankmajer, como hemos expuesto) tuvieron el personaje y el universo onírico articulados por Carroll. André Breton en su Antología del humor negro nos dirá que «no se puede negar que la mirada de Alicia 
gravita vertiginosamente en el centro de la verdad, sobre un mundo de inadvertencia, de inconsecuencia y, por decirlo todo, de inconveniencia» (1991: 118). En suma, no podemos olvidar que Alicia y Lewis Carroll tienen un lugar importante en los referentes del surrealismo.

Švankmajer dirá respecto a su adaptación de esta obra clásica de la literatura que no es exactamente una adaptación, sino que es más una interpretación de autor (2014: 90).

No sigo los objetivos del autor sino los míos propios. No me interesa saber lo que el autor quería decir con tal o cual cosa, sino en qué medida un motivo concreto se relaciona con mis propias experiencias (sentimientos).

En nuestro estudio, queremos mostrar cómo la película mantiene un alto grado de fidelidad al texto original, ya que este se centra exclusivamente en las aventuras que vive Alicia en ese texto y no en su secuela. Y cómo Švankmajer consigue trasladar las palabras del texto de Lewis Carroll a imágenes, de forma que Alice es una de las películas que mejor muestra ese país de las maravillas, donde el espectador consigue ver el absurdo, lo siniestro y el humor durante el filme, elementos presentes en el surrealismo.

Por otra parte, la infancia y los sueños son dos estados importantes en el surrealismo: en los sueños, los objetos y las personas, al no regirse por las normas de la lógica y la razón, pueden sufrir una serie de metamorfosis y adquirir características plurales que en buena lógica no le corresponden; tanto en el texto de Carroll como en el film de Švankmajer las metamorfosis son numerosas. Para los surrealistas y, junto con ellos, Švankmajer, soñar adquiere tal importancia que supera a lo que pueda ocurrir en estado de vigilia. Ellos encuentran en los sueños una forma de liberación de los seres humanos y un modo de huir de las normas establecidas, de la lógica y la razón. Para Švankmajer, como surrealista, es en el inconsciente donde encontrar el lugar del deseo y la libertad.

\section{Bibliografía}

Aragon, L. (2004): Una ola de sueños, Editorial Biblos, Buenos Aires.

BendAzZI, G. (2003): Cartoons. 110 años de cine de animación, Ocho y medio, Madrid.

Benjamin, W. (2013): El surrealismo, Casimiro libros, Madrid.

Bonet CorreA, A. (coord.) (1983): El surrealismo, Ediciones Cátedra, Madrid.

BRETON, A. (1991): Antología del humor negro, Editorial Anagrama, Barcelona.

- (2009): Manifiestos del surrealismo, Visor Libros, Madrid.

BUÑUEL, L. (2001): "Texto de Buñuel: El cine, instrumento de poesía», CAstro, A. Obsesiones Buñuel, Ocho y medio, Madrid, p. 35-42. 
- (2008): Mi último suspiro, Editorial Debols!llo, Barcelona.

CARroll, L. (1986): A través del espejo y lo que Alicia encontró al otro lado, Alianza Editorial, Madrid.

- (2013): El hombre que amaba a las niñas. Correspondencia y retratos, La Falguera Editores, Madrid.

CAstro, A. (2001): Obsesiones Buñuel, Ocho y medio, Madrid.

Díaz VALERA, C. (2004). "El surrealismo visto y oído: el cine de Luis Buñuel», SANTAOlalla, I. et al. (coord.) (2004): Buñuel, siglo XXI, Prensas Universitarias de Zaragoza. Institución "Fernando el Católico", Zaragoza.

Eco, U. (1972): «Cine y literatura: la estructura de la trama», La definición del arte (p. 194-200), Ediciones Martínez, Barcelona.

ESEVERRI, M. (2009): "Surrealismo y animación: notas a propósito de Jan Švankmajer», Diálogos de la comunicación, núm. 78, Revista académica de FELAFACS, Colombia: Cali-Jamundi, <http://dialnet.unirioja.es/servlet/articulo?codigo=3718847> [última consulta: 25 de marzo de 2014].

Foster, H. (2008) Belleza compulsiva, Adriana Hidalgo Editora, Buenos Aires.

GARDNeR, M. (ed.) (1984): Alicia anotada, Akal Editor, Madrid.

Jodoin Keaton, C. (2010): «El mundo de la infancia», Martín GutiéRREZ, G. (ed.) (2010): Jan Švankmajer. La magia de la subversión, T\&B Editores, Madrid, p. 93-111.

LóPEZ, C. y A. HISPANo (dir.) (2014): Visiones fantásticas de Starewitch, Svankmajer y los hermanos Quay, CCCB, Diputació de Barcelona, Barcelona.

MARTín GutiérRez, G. (ed.) (2010): Jan Švankmajer. La magia de la subversión, T\&B Editores, Madrid.

- (2010 b): "Jan Švankmajer: las raíces de una imaginación sin límites», Martín GutiérRez, G. (ed.) (2010): Jan Švankmajer. La magia de la subversión, T\&B Editores, Madrid, p. 15-33.

Monegal, A. (1993): Luis Buñuel de la literatura al cine. Una poética del objeto, Editorial Anthropos, Barcelona.

PALACIOS, J. (2013): «La linterna mágica de Jan Švankmajer. Švankmajer y el cine de animación checo» en Con A de Animación, núm. 3, Universitat Politècnica de València, Valencia, p. 92-107, <http://ojs.upv.es/index.php/CAA/article/view/1427> [última consulta: 25 de marzo de 2014).

SÁnChez NoriegA, J. L. (2000): De la literatura al cine. Teoría y análisis de la adaptación, Ediciones Paidós Ibérica, Barcelona. 
SANTAOlalla, I. et al. (coord.) (2004): Buñuel, siglo xxl, Prensas Universitarias de Zaragoza. Institución "Fernando el Católico", Zaragoza.

SANZ DE SOTO, E. (1983): "Los surrealistas y el cine», Bonet CoRreA, A. (coord.) El surrealismo, Ediciones Cátedra, Madrid, p. 91-104.

SebBaG, G. (2013): "Filosofía surrealista del sueño», VV. AA. (ed.): El surrealismo y el sueño, [Congreso internacional celebrado en Madrid, 8 y 9 de octubre de 2013], Departamento de Publicaciones del Museo Thyssen-Bornemisza, Madrid. Versión online. p. 25-34. [26/05/2014].

StAM, R. (2001): "Del texto al intertexto», Teorías del cine, Ediciones Paidós Ibérica, S.A, Barcelona, p. 235-246.

Ŝvankmajer, J. (2014): Para ver, cierra los ojos, Pepitas de calabaza ed., Logroño.

- (2014 b): "Los gabinetes de curiosidades», LóPEZ, C. y A. HISPANO (dir.). Visiones fantásticas de Starewitch, Švankmajer y los hermanos Quay, CCCB y Diputació de Barcelona, Barcelona, p. 146-148.

Villanueva, D. (1999): "Novela y cine, signos de narración» en PeÑA, C. (coord.) Encuentros sobre Literatura y Cine, Instituto de Estudios Turolenses, Zaragoza, p. 185-209.

VIMENET, P. (2010): «Una utopía del contínuum: materia fósil, materia fisible...» en MARTín GutiéRREZ, G. (ed.) (2010). Jan Švankmajer. La magia de la subversión, T\&B Editores, Madrid, p. 15-33.

VIMENET, P. (2014): «Starewitch, Švankmajer, Quay: un diálogo entre obras irreducibles» en LóPEZ, C. Y A. HISPANO (dir.) Visiones fantásticas de Starewitch, Švankmajer y los hermanos Quay, CCCB y Diputació de Barcelona, Barcelona, p. 40-49. 


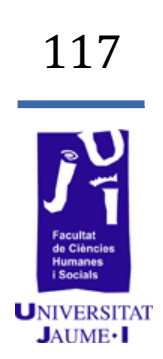

Historias de vida como cambio metodológico

Andrés Ortí Buig aorti@uji.es 
Este artículo parte de realizar un recorrido por la metodología más utilizada en las aulas en el proceso de enseñanza-aprendizaje en la asignatura de Historia, con especial atención a las unidades didácticas referentes a la Guerra Civil y el franquismo, para posteriormente analizar las características propias de las unidades didácticas a las que nos referimos y detectar las deficiencias en el proceso de enseñanzaaprendizaje. Finalmente, se proponen alternativas basadas en diversas metodologías, a saber: la historia social, la perspectiva de género, la educación emocional y las historias de vida.

Palabras clave: metodología, historias de vida, historia social, perspectiva de género, educación emocional, Guerra Civil y franquismo.

\section{Introducción}

El presente artículo nace después de cuatro años de estudio en el grado en Humanidades: Estudios Interculturales y como finalización del Máster en profesor de Educación Secundaria Obligatoria, Bachillerato, Formación Profesional y Enseñanza de Idiomas en la Facultad de Ciencias Humanas y Sociales de la Universitat Jaume I.

Los estudios cursados, así como la realidad percibida en el aula durante la realización del prácticum, han sido claves para la realización de este artículo, en el que se destacan los principales resultados del trabajo final de máster.

La forma en que se explica la asignatura de Historia en los institutos y más concretamente el periodo comprendido entre (1936-1975), es decir, la guerra civil española y el franquismo constituyen la columna vertebral de nuestro análisis. Así, hemos partido de la hipótesis en que el estudio de la historia a través de la metodología de memorización y repetición no ofrece resultados satisfactorios. Analizar las características que dotan de originalidad a las unidades didácticas a las que nos referimos y ver como, mediante la metodología tradicional, se dificulta un correcto aprendizaje de este periodo histórico, es el principal objetivo de este artículo. Finalmente, proponemos alternativas que constituyen una propuesta de mejora educativa.

\section{Objetivos}

El objetivo general que persigue este artículo es analizar la metodología tradicional en el proceso de enseñanza-aprendizaje de las unidades didácticas relativas a la Guerra Civil y al franquismo. Y, a partir de este estudio, analizar los resultados que se obtienen en el aprendizaje a través de esta metodología de corte tradicional. 
Además, se pretende analizar las características y los resultados que se obtienen en la docencia mediante la metodología tradicional de memorización y repetición. Para ello se analizan las características propias del periodo histórico que se estudia en las unidades didácticas referidas a la Guerra Civil y al franquismo, para, a partir de nuevos mecanismos metodológicos, proponer alternativas en el proceso se enseñanza-aprendizaje.

\section{Material y método}

La metodología seguida para la realización de este trabajo ha sido la investigación y el análisis de las teoría propuestas por diversos autores, entre los que destacan D. Ausubel (2002), J. Pagès (2003), E. Carr (1961), F. Levín (2007), M. Martí y T. Costa (2012). Igualmente, he apoyado mi investigación en propuestas metodológicas que giran en torno a la historia social, las historias de vida y la perspectiva de género.

La duración de la investigación fue, en una primera fase, de seis meses y se centró en la observación y el estudio a través del prácticum del máster, que se realizó en el IES Els Ports (Morella). Posteriormente, en una segunda fase, la investigación se centró en el análisis de las diferentes teorías y propuestas que elaboran los autores anteriormente citados. Finalmente, en una tercera fase, se realizó la redacción del trabajo y la discusión de los diferentes capítulos.

\section{Resultados}

\section{Historias de vida como cambio metodológico}

La asignatura de Historia tiene un peso importante dentro del currículo de la Educación Secundaria Obligatoria y del Bachillerato. Tras cursar el máster y las prácticas, me planteo una serie de interrogantes que podrían ayudar al desarrollo de mi labor como nuevo docente. ¿Cómo se explica la Historia en clase? ¿Qué metodologías se utilizan? ¿Qué educación, en definitiva, estamos dando a los alumnos?

Estas son algunas de las preguntas que me planteo, ya que lo percibido en las aulas no se ajusta en muchas ocasiones a las ideas en cuanto a metodologías, didácticas y contenidos que hemos tratado durante el desarrollo del máster.

Las ciencias sociales tienen un peso importante dentro del desarrollo del discente como persona y como ciudadano. Su presencia en las aulas es alta, pese a las continuas reducciones de horas, asignaturas, etc.

Así, en la primera fase de la investigación -centrada en la observación de la docencia-, constaté cómo la tónica general en cuanto a metodología en las aulas rompe con las propuestas y los contenidos metodológicos que se proponen en el máster. Las historias de vida, el aprendizaje cooperativo, los juegos de rol, las webquests, etc. parecen 
desterradas del seno de los centros. Las clases de historia basadas en las sesiones magistrales apoyadas en el libro de texto continúan siendo preponderantes. Es preciso señalar que no se trata de una característica propia de este centro sino que es una práctica habitual y generalizada en los institutos. Rafael Valls ha corroborado empíricamente cuál es la realidad en las aulas mediante cuestionarios a discentes y a los propios profesores $y$, además, ha analizado los manuales que se emplean para la enseñanza de la historia. Valls critica que la metodología que los docentes utilizan de forma general es -como también he podido constatar en el instituto- la sesión magistral, así como el estudio y la memorización del temario a partir del libro de texto. Los resultados que aporta esta metodología son deficientes: poco tiempo después del estudio y memorización de la materia, esta se olvida, ya que el discente no la ha asimilado ni integrado (Valls 2007: 61-73).

Otros autores también han cuestionado la tendencia generalizada al binomio clase magistral-memoria y consecuencias que tiene sobre el aprendizaje. Para Joan Pagès, este tipo de aprendizaje está divorciado de los intereses del alumnado y no contribuye a su formación (Pagès, 2003: 12):

Los resultados de estas investigaciones indican que la enseñanza y el aprendizaje de la historia no responde a aquello que los jóvenes esperan encontrar ni a aquello que algunos creemos que deberían encontrar para orientarse en su mundo, para desarrollar su temporalidad, para formar su consciencia histórica. Los saberes históricos escolares no tienen para el alumnado ningún sentido más allá de las paredes de la escuela. La historia escolar no es capaz de situar al alumnado ante el mundo, no le ayuda a entenderlo, no lo forma como ciudadano ni le da elementos para construir su identidad personal y colectiva.

El método rígido de enseñanza-aprendizaje -agrega Pagès- no es propio de la Historia sino que alcanza a otras disciplinas cuyos resultados no tampoco son mejores que los cosechados en las ciencias sociales. Pero esto no puede ni debe ser consuelo, es importante romper con esta tónica, ir más allá y proponer otras metodologías que nos permitan avanzar en la docencia de las ciencias humanas y sociales.

Esta forma de proceder en las aulas es contraproducente, las consecuencias a la larga cercenan el conocimiento. Por un lado, el temario se aprende para pasar la prueba evaluatoria de conceptos y no se trata, por tanto, de un aprendizaje significativo. Del otro, la explicación de determinados periodos históricos a partir de efemérides, fechas, batallas y personajes sin promover una educación en valores, fomenta que los alumnos no tengan realmente un conocimiento correcto del periodo estudiado ni de lo que es la Historia de forma general, al tiempo que alientan una concepción errónea de esta asignatura asociada a la capacidad de recordar; al decir de Joaquim Prats (2000), los discentes ven la Historia como una asignatura que solo exige de una gran memoria, no como una fuente del saber que necesita de compresión y análisis. 
Dentro de esta asignatura, la enseñanza del tiempo histórico ha sido una de las grandes preocupaciones de la didáctica. Si prestamos atención al qué se está enseñando también debemos fijarnos en el cómo se está enseñando y cuáles son los resultados (Pagès y Santisteban, 2010).

La forma mediante la cual se estudia el tiempo histórico en los institutos es generalmente lineal, una sucesión cronológica de hechos que el alumno asimila durante el periodo escolar y que es incapaz de retener. Esta forma de estudio hace que el alumno, al finalizar el instituto, tenga ciertas nociones de historia, pero sin sentido aparente. Un conocimiento del tiempo histórico por etapas que no logra conectar entre sí, de manera que al final se forma un conjunto de etapas inconexas basadas en la memorización; el caballo de Troya de las metodologías tradicionales de la enseñanza de la historia, que debe adaptarse a nuestros tiempos, a nuestra forma de hacer y estudiarla. Es un modelo que ya cuestionó en el siglo XIX Johann Heinrich Pestalozzi (1745-1827), quien combatió el aprendizaje memorístico y propuso la observación y la experiencia como los procedimientos más deseables (Moya Santoyo, et al., 1992: 44-45).

El aprendizaje es un proceso complejo cuya esencia es la adquisición de un nuevo conocimiento, habilidad o capacidad. Para que dicho proceso pueda considerarse realmente como aprendizaje, en lugar de una simple huella o retención pasajera, debe proyectarse en el futuro y contribuir a la solución de problemas concretos, incluso diferentes a los que motivaron inicialmente el desarrollo del conocimiento o habilidad.

\section{Un giro metodológico necesario}

El objetivo fundamental de la enseñanza es transmitir información mediante la comunicación directa o sustentada en medios auxiliares, con un mayor o menor grado de complejidad. Como resultado, debe quedar una huella en el alumno, un reflejo de la realidad objetiva, del mundo circundante que, en forma de conocimiento, habilidades y capacidades, le permitan enfrentarse a situaciones nuevas con una actitud creadora. El proceso de enseñanza produce un conjunto de transformaciones sistemáticas en los discentes, cambios graduales cuyas etapas trascurren en orden ascendente. Es, por tanto, un proceso creciente, dinámico y transformador (Alfonso, 2003).

Según las teorías constructivistas, aprender no es más que concretar un proceso activo de construcción que realiza en su interior el sujeto que aprende (Piaget, 1975:35-41). ${ }^{1}$ Así las actitudes, los conocimientos, las capacidades, las creencias que el alumno tiene antes de aprender nuevos contenidos son clave. Esta concepción del proceso de enseñanzaaprendizaje rompe por completo con el enfoque tradicional de la memorización y repetición que mencionábamos anteriormente.

\footnotetext{
1. Jean Piaget es considerado el padre del constructivismo y referente por excelencia de la psicología evolutiva del siglo xx. También debemos mencionar al prestigioso psicólogo y pedagogo David Ausubel, quien ha realizado grandes aportes a la corriente mencionada.
} 
Piaget, entre su ingente obra dentro del campo de la psicología, desarrolló la teoría epistemológica que sentó las bases del constructivismo. Propone al alumno como eje central del proceso educativo y al docente como acompañante en este proceso de descubrir nuevos conocimientos. También es conocido por su teoría de los niveles de desarrollo cognitivo que se desarrollan en la adolescencia en diferentes etapas.

Por otra parte, y dentro de la corriente constructivista, cabe mencionar a David Ausubel y su teoría del aprendizaje significativo, que consiguió modificar las técnicas memorísticas imperantes y sustituirlas por un enfoque pedagógico basado en el aprendizaje significativo por recepción. Así, para Ausubel, el material debe transferirse al alumnado de forma significativa, asociándolo a contextos relevantes que permitan conectarlos con los conocimientos preexistentes. De este autor es también la idea de la «transferencia vertical» - para facilitar el posterior aprendizaje dentro del mismo campo- y «transversal»-aprendizaje en otros campos diferentes- ${ }^{2}$ (Ausubel, 2002).

Debemos partir de la posición de que el alumno ya tiene un conocimiento previo y, como segundo paso, integrar los nuevos. En este proceso, el profesor actuará como guía para que el alumno descubra de forma autónoma los nuevos conocimientos. De esta forma, el estudiante no es solo el eje central de la educación, sino que también se convierte en un sujeto participativo.

Dentro de este giro metodológico que creemos necesario en las aulas, consideramos importante reivindicar que la formación en ciencias sociales, y más concretamente en Historia, debe ser necesariamente una formación en valores. Valores universales que ayuden al discente en su formación tanto profesional como personal, como ha destacado María José Sobejano (2002: 122):

Podemos decir que los valores son a las ciencias sociales lo que las leyes a las ciencias naturales: su esencia y razón de ser. Las ciencias sociales vehiculan valores porque el conocimiento social es un producto del pensamiento individual sobre la vida social y en el punto de partida está el sujeto con sus concepciones del mundo, su ideología y los presupuestos científicos o teoría sobre la realidad y las prácticas sociales.

Llegados a este punto cabría preguntarse: ¿Qué queremos enseñar? ¿Cómo enseñar? ¿Cuáles son las características básicas que debemos trasladar al alumnado? La formación en Historia no debe centrarse en el estudio del pasado en cuanto a hechos ocurridos, debe ir mucho más allá: se trata de analizar el pasado para comprender el presente, pues, como indica Joaquín Prats, "la Historia, entendida como saber científico es la única manera rigurosa y objetiva de explicar los tiempos pretéritos pese a la provisionalidad de sus conclusiones» (Prats, et al., 2001: 18).

2. Sobre la teoría del aprendizaje significativo ver David Ausubel, 2002. 
Apostamos entonces por una enseñanza abarcadora, que comprenda cuatro principios que consideramos básicos: a) conocer y analizar los hechos ocurridos en el pasado, para así comprenderlos; b) formar en valores universales; c) aprender de la diversidad y comprender que hay varias versiones de los hechos del pasado, y d) capacidad de saber organizar el conocimiento del pasado para así tener una visión global y conjunta.

La asignatura de historia debe facilitar en el alumno un proceso de comprensión que avance e integre pasado y presente. No se trata solo de conocer el pasado, como muchas veces se ha dicho, sino de analizarlo y comprenderlo para entender mejor el presente. Un análisis que fomente también el sentido de la identidad, que conecte con la necesidad de conocer nuestra cultura, ideales, costumbres, etc., para formar ciudadanos íntegros. Y aquí consideramos que se debe incluir el estudio de otras culturas. El conocimiento y la comprensión de otras realidades, países y formas de pensar, entre otras cuestiones, significa inculcar $\mathrm{y}$ fomentar valores. Aprender a respetar lo diverso es tan importante como poner en valor lo propio en un mundo globalizado como el actual. Por último debemos, capacitar a los alumnos para que puedan vislumbrar que puede haber varias versiones de los hechos pasados y que, progresivamente, puedan analizar y comprender el porqué de las diferentes versiones de un mismo hecho histórico según cuál sea la fuente (Pagès, 2004: 169):

enseñar Historia consiste en algo más que en saber Historia, existen puntos de vista y enfoques diferentes sobre el contenido y la metodología de la enseñanza de la Historia, para aprender a enseñar Historia hay que establecer relaciones estrechas entre la teoría y la práctica, etc.

Enseñar y aprender Historia es, por tanto, mucho más que memorizar y repetir datos, nombres y batallas. Como vemos, la complejidad de las ciencias sociales aparece en todo su esplendor en Historia. Así pues, el estudio debe ser reflexivo; esta disciplina debe ir mucho más allá de esta falsa percepción que de ella se hace.

\section{Propuesta metodológica}

Para el desarrollo de las unidades didácticas consideramos imprescindibles tres propuestas metodológicas, que se complementan entre sí. A saber: las historias de vida, la educación emocional y la historia social, analizadas además desde una perspectiva de género.

Las historias de vida son, a mi juicio, una metodología que se adapta a la complejidad del temario para el que proponemos los planes de mejora, es decir, la Guerra Civil y el franquismo. La proximidad en el tiempo de algunos hechos reflejados en el temario nos permite contar con testimonios directos. A partir de entrevistas, coloquios, talleres, etc., debemos ser capaces de aunar el relato en primera persona con la 
reconstrucción de los acontecimientos, transmitiendo al mismo tiempo las experiencias vividas, que en lo particular ayuden al conocimiento específico de la localidad, de forma que trascienda el carácter individual de lo que se transmite y se inserte en las colectividades a las que el narrador pertenece (Eliane Veras, 2010: 44). Convertimos así la teoría en práctica, apartándonos de las metodologías clásicas analizadas anteriormente, planteando el proceso de enseñanza-aprendizaje de una forma vivencial (Martí y Costa, en Rivas, J. et al. 2012: 142).

Este modo de proceder en el aula nos aportaría además emociones y sentimientos. Las entrevistas incluyen la subjetividad del entrevistado, por lo que será clave en el uso de esta metodología saber discernir las circunstancias de cada persona: la singularidad de su testimonio, sus contradicciones, su posicionamiento, el grado afectivo de su relato, etc., en definitiva, analizar su historia de vida para extraer lo histórico de la misma.

En este sentido, es preciso tener en cuenta la edad de los discentes, ya que los alumnos son adolescentes en pleno desarrollo tanto físico como psíquico y cognitivo. En este proceso de crecimiento, si bien es importante formar a los alumnos en conocimientos relativos a las materias académicas, tiene una relevancia crucial su formación en lo que a lo humano se refiere (Buxarrais y Martínez, 2009: 267):

las respuestas a la realidad de nuestra sociedad, compleja y plural, exigen un nivel de comprensión, respeto y tolerancia difícil de alcanzar si ignoramos la importancia del mundo de la afectividad y de la sensibilidad en la vida de la relación y la comunicación.

Mediante este formato, los alumnos tendrán la oportunidad de empatizar con los diferentes testimonios, "la capacidad para comprender al otro antes de aceptarlo o no» mediante «la educación de los sentimientos» y, posteriormente, analizar el contexto histórico y social (Buxarrais y Martínez, 2009: 267). Es importante destacar la oportunidad que tenemos en la actualidad de contar con estos testimonios, como comentaremos más adelante; para nuestro trabajo pudimos acceder a la experiencia de cuatro mujeres, un testimonio de primera mano que cobra mayor importancia dada la edad de las entrevistadas.

La historia social es otra de las metodologías fundamentales en el estudio de las unidades didácticas. Analizar la historia respecto a diversas variables y no solo como hechos del pasado es básico para que los discentes aprendan de forma clara y logren conectar periodos y acontecimientos. Explicar los cambios de las sociedades a lo largo del tiempo nos posibilita un proceso de enseñanza-aprendizaje que se aparta de la memorización y repetición de datos, nombres y fechas, para comprender la historia como unión de los factores que repercuten en las sociedades y que explican la configuración y el porqué de los acontecimientos. 
José Antonio Piqueras ha analizado los problemas con los que se encuentra un historiador social. De forma magistral compara la conocida obra de Daniel Defoe, Robinson Crusoe, con -según sus propias palabraslas tribulaciones de los historiadores sociales. Piqueras explica cómo la historia está bajo la influencia de muchas variables $y$, tomando como punto de partida la apasionante vida de Robinson Crusoe y cómo este se adapta a los avatares del destino según cambia su situación, explica la esencia de la historia social: entender a partir de unos hechos y el contexto en el que se inscriben los condicionantes que influyen en el ámbito socioeconómico y político (Piqueras, 2008: 86):

Nos limitamos a exponer unos hechos. Pero de estos se deriva que alguna relación debe existir entre trabajo, ingresos regulares, hábitat, modo de vida, territorio, modo de pensar, entre actividad laboral, mercado y mentalidad, por no hablar de orientación política.

Por último, debemos incluir la perspectiva de género en la educación. Actualmente, el papel de la mujer en la historia no es materia de estudio o, si lo es, esta aparece de forma testimonial. El libro de texto que se utiliza actualmente en el instituto de Morella, al igual que la gran mayoría de los libros enfocados a la Historia para Educación Secundaria Obligatoria y Bachillerato, no incluye más que algunas alusiones puntuales. El papel que jugaron las mujeres y la importancia de estas en el desarrollo de la historia es indiscutible e indispensable para comprender el desarrollo histórico en su totalidad.

Como nuevos docentes, debemos abogar por una mayor inclusión de la perspectiva de género en el sistema educativo español, para desterrar el sistema patriarcal aún vigente desde la enseñanza primaria hasta las universidades. Victoria Vázquez Verdera ha advertido que hacer autocrítica desde dentro del propio sistema educativo es necesario para empezar a cambiar la forma en la que, muchas veces de manera inconsciente, perpetuamos los roles de género y damos alas al sistema patriarcal (Vázquez, 2013: 163):

el sistema educativo ha de ser crítico consigo mismo y asumir que ha de transformar profundamente sus prácticas y teorías. La educación debe rediseñarse para afrontar el reto que supone desarrollar en el alumnado una postura crítica frente al pensamiento dicotómico y estereotipado por razones de género.

En definitiva, nuestra propuesta de análisis del periodo histórico desde las historias de vida pretende aportar nuestro grano de arena en la metodología como en la forma de llegar al contenido, poniendo en valor el papel de la mujer a lo largo del siglo xx español. Desarrollar este tipo de habilidades es, además de necesario, una cuestión clave para la vida en sociedad, de manera que se favorece, el desarrollo de las potencialidades de los discentes en cuanto a principios básicos como las relaciones 
interpersonales, la resolución de problemas, el arte de escuchar al otro, entre otros.

VI. Discusión y conclusiones

La metodología utilizada de manera extendida en las aulas actualmente, donde se privilegian la memorización de datos, ha incidido en la forma de entender la clase de Historia y en la preparación con que egresan los alumnos. Tales resultados han motivado la búsqueda por ofrecer una propuesta de mejora educativa como principal objetivo de nuestro trabajo.

Nuestra propuesta se basa en dos puntos fundamentales. En primer lugar, el cambio de metodología: incorporar nuevos enfoques como las historias de vida, la historia social y local, etc., que nos permitan enseñar de manera práctica, de forma que los alumnos se impliquen en el aprendizaje de este periodo.

A lo largo de estas páginas hemos analizado de manera general el modelo de enseñanza-aprendizaje, los contenidos y la metodología de estas unidades didácticas para trata de dotar a LA CLASE -y permítasenos el uso de las mayúsculas- de un atractivo único acorde con los nuevos tiempos. Durante la realización de las prácticas he podido comprobar que cada clase es una experiencia singular, distinta de las demás, en la que el resultado viene determinado no solo por el contenido, sino también por la forma elegida para trasmitirlo y la relación entre los profesores y los alumnos.

Lograr que la enseñanza de la historia sea atractiva, propiciar un aprendizaje significativo, apartándonos del estudio de datos mediante la memorización, invitando a la reflexión, al debate y a la comprensión del periodo partiendo del análisis de diferentes variables y con todo ello hacer la enseñanza perdurable -o, lo que es lo mismo, que los contenidos no se olviden al terminar el curso- es a nuestro entender un objetivo primordial, pues como diría Fernand Braudel (1974) «Para mí la historia es la suma de todas las historias posibles: una colección de oficios y de puntos de vista, de ayer, de hoy y de mañana».

\section{Bibliografía}

Agullar, P. (2008): Políticas de la memoria y memorias de la política, Alianza Editorial, España.

Alfonso, I. (2003): «Elementos conceptuales básicos del proceso de enseñanza-aprendizaje», Acimed, núm. 6, vol. 11. (versión electrónica: www.bvs.sld.cu/revistas/aci/vol11_6_03)

AusubeL, D. (2002): Adquisición y retención del conocimiento, Paidós, Barcelona. 
Braudel, F. (1974): La Historia y las ciencias sociales, Alianza, Madrid.

BuxarRais, M. y M. Martínez (2009): «Educación en valores y educación emocional: propuestas para la acción pedagógica», Revista Electrónica Teoría de la Educación. Educación y Cultura en la Sociedad de la Información, vol. 10, núm. 2, p. 363-275, España.

CARR, E. (1961): ¿Qué es la historia?, Ariel, Barcelona.

Franco, M. y F. LeVín. (2007). "El pasado cercano en clave historiográfica» en Franco, M. y F. Levín: Historia reciente. Perspectivas y desafíos para un campo en construcción, Paidós, Buenos Aires.

MARTí, M. y T. COSTA (2012): "Historias de vida: el valor de la experiencia» en RIVAS, J. I., et al. (ed.): Historias de vida en educación: Sujeto, diálogo, experiencia, Dipòsit Digital UB, p. 141-147, Barcelona.

Moya SANTOYo, J. et al. (1992): Historia de la psicología. Introducción, vol. 1, Siglo XXI, Madrid.

PAGÈs, J. (2003): "Ciudadanía y enseñanza de la Historia», Revista de la APEHUN, núm. 1, p. 11-44, Argentina.

- (2004): «Enseñar a enseñar la historia: La formación didáctica de los futuros profesores de Historia», Universidad de Murcia (ed): Miradas a la historia. Reflexiones historiográficas en recuerdo de Miguel Rodríguez Llopis, Servicio de Publicaciones Universidad de Murcia, p. 155-178, España.

PAgÈs, J. y SANTISTEBAN, A. (2010): "La enseñanza y el aprendizaje del tiempo histórico en la educación primaria», Cad. Cedes, núm. 30, p. 281309, Brasil.

PAn-Montojo, J. (1999): "Opiniones desde la barrera: enseñar el franquismo», Aula Historia Social, núm. 3, p. 80-83, primavera, España.

PiAgET, J. (1975): Seis estudios de psicología, Barral, Buenos Aires.

Piqueras, J. (2008): «El dilema de Robinson y las tribulaciones de los historiadores sociales», Historia Social, núm. 60, p. 59-90, España.

Prats, J. (2000): «Dificultades para la enseñanza de la Historia en la Educación Secundaria: Reflexiones ante la situación española», Revista de teoría y didáctica de las Ciencias Sociales, núm. 5, p. 71-98, Universidad de los Andes, Venezuela.

PRATS, J. et al. (ed.) (2001): Los jóvenes ante el reto europeo. Conocimientos y expectativas del alumnado de educación secundaria, Fundació La Caixa, Col. Estudis Socials, núm. 7, Barcelona.

SANTIDrián, V. (2007): "Las cosas de la memoria (histórica)», Hispania Nova, núm. 7, España (versión electrónica: http://hispanianova.rediris.es/7/)

SANZ, V. (1999): "Reflexiones sobre la enseñanza de la dictadura franquista», Historia Social, núm. 3, p. 84-89, España. 
Sobejano, M. (2002) "Los valores en la enseñanza de las ciencias sociales: una aproximación desde la didáctica de las ciencias sociales», Revista Educación y Pedagogía, vol. 14, núm. 34, p. 119-134, Colombia.

VALLS, R. (2007): "La Guerra Civil española y la dictadura franquista: Las dificultades del tratamiento escolar de un tema potencialmente conflictivo», Enseñanza de las ciencias sociales, núm. 6, España.

VÁzquez, V. (2013): «Nuevos retos para combatir la violencia de género desde el sistema educativo», Asparkía, núm. 24, p. 162-174 , España.

VERAS, E. (2010): «Historia de Vida: ¿Un método para las ciencias sociales?» Cinta de Moebio, núm. 39, Brasil.

Ley Orgánica 8/2013, de 9 de diciembre, para la mejora de la calidad educativa, BOE, 10 de diciembre de 2013, núm. 295, 99. p. 97858-97921.

Decreto 102/2008, de 11 de julio, del Consell, por el que se establece el currículo del bachillerato en la Comunitat Valenciana, DOCV, 15 de julio de 2008, núm. 5806, p. 71303-71547. 


\section{Les gelades en la taronja al País Valencià} Estudi de cas mitjançant la premsa: 1926 i 1956 
Aquest treball tracta d'explicar la repercussió econòmica que han tingut les gelades en el cultiu de cítrics al País Valencià, i en particular a la Plana. Se centra, sobretot, en dues de les gelades més importants del segle xx: la de 1925-26 i la de 1956. Se'n ressalten les repercussions en els aspectes econòmics, productius i socials d'un comerç tan important com el de l'exportació espanyola de cítrics.

Paraules clau: gelades taronja, economia citrícola, història ambiental, història taronja, onades fred, subsidis agrícoles, franquisme i taronja, gelades 1926 i 1956, premsa valenciana, exportació cítrics espanyols.

\section{Introducció}

Les gelades que ha sofert el cultiu del taronger a la Plana i a tot el País Valencià han comportat grans maldecaps als agricultors que en depenien. Per fer-nos una idea aproximada caldria dir que només els conflictes bèl-lics de la Primera Guerra Mundial, la Guerra Civil espanyola i la Segona Guerra Mundial han tingut repercussions semblants en la producció i l'exportació de taronja al País Valencià. És per això que les gelades mereixen ser estudiades amb més detall al nostre país, com siga que fins avui només han merescut l'atenció de dos estudiosos: per una banda, Lluís Font de Mora, en el seu llibre Taronja i caos econòmic, els hi dedica un capítol, I, per altra, Vicent Abad en la seua Historia de la naranja també en parla en alguns apartats.

El mateix Font de Mora (1971: 134) ens comenta:

els efectes del fred sobre els cítrics són de molt difícil valoració. Fins i tot pel que fa a la disminució dels volums de producció, manquem de mitjans per a una aproximació rigorosa [...] Tot el que envolta les gelades del taronger està molt mal estudiat, i sembla existir una barreja de complicitat entre aquells que desitgen mantenir obscur el panorama i aquells que haurien de dedicar-se a clarificar-lo.

És per açò que el meu interés s'ha centrat en aquestes adversitats climatològiques de repercussió cabdal en l'economia citrícola valenciana.

\section{Objectius}

Les grans gelades han afectat greument la principal activitat agrícola de la Plana des dels inicis. L'objectiu d'aquesta investigació és mostrar les conseqüències econòmiques, productives i socials d'aquestes adversitats climatològiques en el cultiu de la taronja. El meu interés, per tant, es focalitza sobretot en les reaccions dels grups implicats en l'economia citrícola: com els agricultors, els exportadors i l'Estat van respondre a les 
gelades de 1926 i de 1956, dues de les més importants del segle Xx, i sens dubte les que implicaren alguna iniciativa de rescabalament $i$ algunes mesures de previsió per evitar futurs daltabaixos econòmics en un comerç tan important com el dels agres.

\section{Material i mètode}

Per començar, el propòsit d'aquesta investigació és estudiar com un fenomen climàtic, una onada d'aire fred, pot tenir conseqüències en les activitats humanes. Més concretament, quines van ser les principals onades d'aire fred que van afectar comercialment el cultiu del taronger a la Plana. Així, la meua investigació estarà centrada en un fenomen molt concret de la història ambiental de la taronja a la Plana.

Pel que fa a l'objecte principal d'estudi, es tracta de veure les pèrdues en producció de cítrics i sobretot com van reaccionar els implicats en el negoci de la taronja.

La duració de la investigació ha estat d'un any, ja que el treball que a continuació es presenta és una part del meu treball final de màster.

El mètode d'investigació no ha estat altre que l'anàlisi de la informació recollida. Aquest mètode implica una lectura crítica del material obtingut durant la fase de recerca, així com la contrastació de les fonts investigades.

Pel que fa a aquestes fonts, $n$ 'he fet ús de gran quantitat.

- A la Biblioteca Valenciana he consultat llibres del Fons Nicolau Primitiu referents al comerç de la taronja i al cultiu d'aquesta, i altres documents del fons de l'Institut Valencià d'Economia en la sala Gregori Maians. En aquest últim es troben alguns dels materials que va produir aquesta institució durant els seus anys d'existència, la qual pretenia servir d'assessorament a les autoritats valencianes.

- Una altra font han sigut els periòdics de l'època, consultats a I'Hemeroteca Municipal de València: principalment Las Provincias $^{1}$ periòdic de caràcter agrarista a les primeries i la revista oficial de la Cambra Agrícola de València El Agrario Levantino.

- A l'Arxiu Municipal de Castelló he consultat els periòdics Mediterráneo, ${ }^{2}$ La Província Nueva i El Heraldo de Castellón, tots de caràcter local.

- També he fet ús de l'Arxiu de la Cambra Oficial de Comerç, Indústria, Serveis i Navegació de Castelló per consultar-ne les memòries anuals i l'Arxiu de l'Autoritat Portuària de Castelló on hi ha els llibres de càrrega i descàrrega d'aquest port.

- Altres biblioteques consultades han estat la biblioteca Rafalafena de Castelló i la biblioteca de la Universitat Jaume I de Castelló.

1. D'ara endavant LP en els citacions.

2. D'ara endavant $M$ en les citacions. 


\section{Resultats}

\section{GELADES HISTÒRIQUES AL PAÍS VALENCIÀ}

El cultiu del taronger a la Plana ha sofert diverses gelades al llarg dels segles XIX i Xx.

Pel que fa al segle $X I X$, aquest va ser especialment fred respecte a les variables climàtiques actuals $i$, en conseqüència, van haver-hi diverses onades d'aire fred de consideració. Aquest fenomen es troba relacionat amb la fi de l'anomenada Petita Edat del Gel, període comprés entre el segle XVI i meitat del segle XIX, que va ser anòmal pel que fa a les temperatures i les variables climàtiques, amb hiverns marcadament més freds que els actuals: un clima impredictible, sense unes constants climatològiques fixes, lleugerament més fred, però amb hiverns molt intensos. Cap a 1850 la tendència es va girar cap a un progressiu escalfament global, cosa que va fer possible, en part, que el cultiu del taronger a la Plana fóra viable. Amb temperatures per davall de $0{ }^{\circ} \mathrm{C}$ als hiverns els tarongers no haurien sobreviscut $i$ el cultiu comercial del taronger no s'hauria desenvolupat. Imaginem un camp de tarongers que es gela cada 3 o 5 anys: els arbres es moren i cal replantar-los de nou, amb la qual cosa l'hort mai arriba a ser rendible.

A continuació mostrem dues taules i una gràfica on es poden veure les principals gelades del taronger al País Valencià, l'evolució de la producció de taronja i les temperatures mínimes a la ciutat de Castelló de la Plana des que hi ha registres:

Taula 1. Gelades històriques al PV des que hi ha cultiu comercial de cítrics.

\begin{tabular}{|c|c|c|c|c|c|}
\hline Any & Mes & Any & Mes & Any & Mes \\
\hline $1788-1789$ & des.-gener & 1906 & març & 1962 & desembre \\
\hline 1810 & gener & 1914 & gener & 1963 & desembre \\
\hline 1829 & desembre & 1915 & març & 1964 & febrer \\
\hline 1833 & març & $1917-1918$ & des.-gener & 1965 & febrer i nov. \\
\hline 1838 & febrer & $1920-1921$ & març, des.-gener & 1967 & desembre \\
\hline 1842 & gener & 1924 & desembre & 1968-1969 & des.-gener-feb. \\
\hline 1871 & gener & 1925 & desembre & 1970-1971 & des.-gener i març \\
\hline 1880 & gener & 1926 & desembre & 1973 & desembre \\
\hline 1883 & març i des. & 1931 & gener & 1977 & març \\
\hline 1884 & desembre & 1933-1934 & gener, des.-gen. & 1978 & febrer \\
\hline 1885 & gener & 1935 & gener-febrer & 1981 & gener \\
\hline 1887 & febrer & $1937-1938$ & des.-gener & 1983 & febrer \\
\hline 1888 & gener-feb. & $1940-1941$ & gen.,des.-gen.-feb. & 1984-1985 & des.-gener \\
\hline 1889 & novembre & 1942 & gener & 1986 & abril \\
\hline 1890 & març i nov. & 1944-1945 & febrer,des.-gener & 1992 & gener \\
\hline
\end{tabular}




\begin{tabular}{|l|l|l|l|l|l|}
1891 & gener & 1946 & gener i des. & 1997 & gener \\
\hline 1895 & gener & 1954 & febrer & 2005 & gener \\
\hline 1896 & gener & 1956 & febrer & 2011 & gener \\
\hline 1901 & març & 1960 & gener & & \\
\hline 1905 & gener & 1961 & març & & \\
\hline
\end{tabular}

Font: elaboració pròpia a partir de Balbás (1892), CESV (1963), Font de Mora (1971: 133), Abad (1988: 68), Ginés (2014), entre altres.

Taula 2. Temperatures mínimes registrades a Castelló

\begin{tabular}{|c|r|c|r|c|r|}
\hline Any & Mínima & Any & Mínima & Any & Mínima \\
\hline 1880 & $-0,8$ & 1891 & $-10,4$ & 1960 & $-3,1$ \\
\hline 1883 & $-1,8$ & $1917-18$ & -2 & 1963 & $-1,3$ \\
\hline 1884 & $-2,8$ & $1920-21$ & -5 & $1970-71$ & $-1,4$ \\
\hline 1885 & $-5,8$ & $1944-45$ & $-1,6$ & 1983 & $-2,2$ \\
\hline 1887 & -5 & 1946 & $-5,4$ & $1984-85$ & $-4,4$ \\
\hline 1888 & $-4,2$ & 1947 & $-1,4$ & 2005 & -2 \\
\hline 1889 & $-3,6$ & 1954 & $-3,2$ & 2011 & $-1,8$ \\
\hline 1890 & -6 & 1956 & $-7,3$ & & \\
\hline
\end{tabular}

Font: elaboració pròpia a partir de Balbás (1892) i Ginés Llorens (2014).

\section{EXPORTACIÓ ESPANYOLA DE TARONJA 1850-1987}

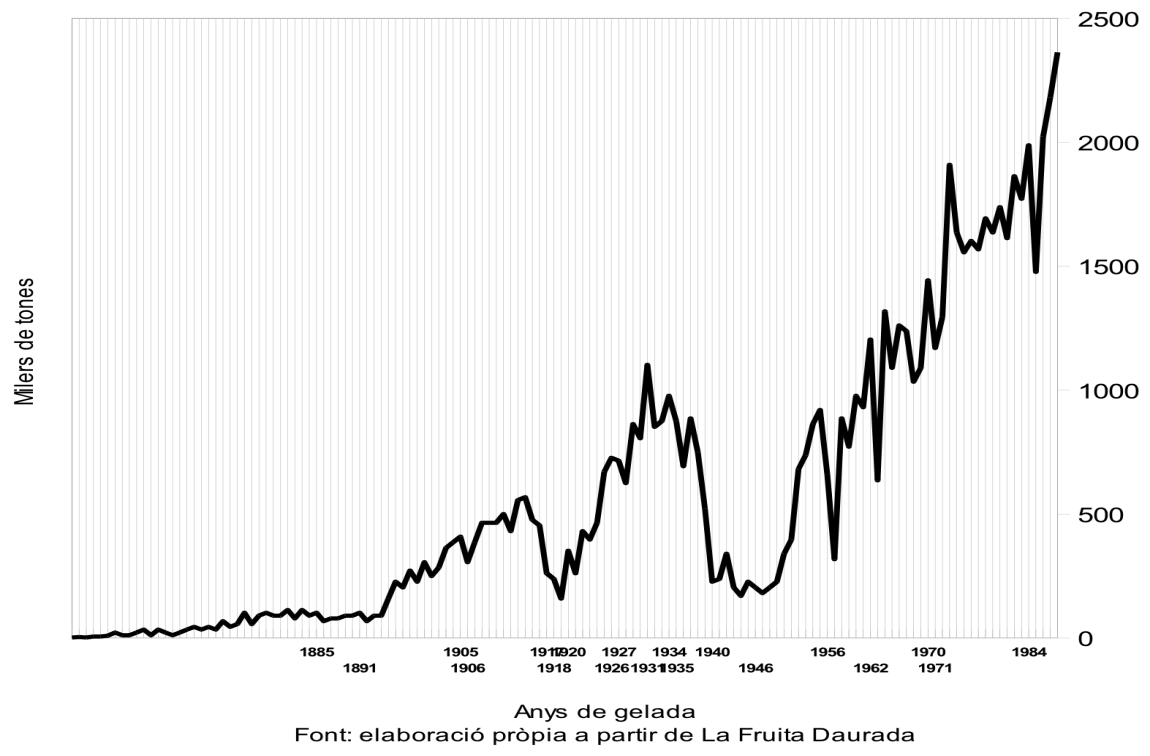

Figura 1. Gràfica aproximada de la producció valenciana de taronja

Precisament, la primera estació meteorològica instal-lada a la capital de la Plana cap a final segle XIX va ser pensada perquè servira d'ajuda als agricultors (Bou Gascó, 1879: 20-21): 
Carecíamos en esta provincia de observaciones meteorológicas [...] El infatigable profesor de Física, que desde aquella época ha venido llamando siempre la atención de todos acerca de la necesidad de establecer en Castellón un observatorio meteorológico que pudiera servir de guía a la agricultura, ha logrado por fin ver realizados sus deseos, fundándolo él mismo en el local del Instituto [actual Ribalta], el cual se ha inaugurado en 1 으 de marzo del presente año. Es una gran mejora para la Plana, hoy que el cultivo del naranjo y el de la caña de azúcar va tomando cada vez más importancia.

Així és que, de les gelades del segle XIX malauradament no tenim gaires registres termomètrics. A més, les dades que es prenien eren de manera puntual i no van començar a ser preses de manera constant fins els anys vint del segle xx. Per la qual cosa tant sols disposem de les breus notes que ens han deixat Balbás i Bou Gascó. Tampoc en la premsa de l'època se'n troben gaires referències. Però veient les mínimes absolutes de final segle XIX podem suposar que les gelades van afectar greument el cultiu de la taronja i van causar enormes danys a un cultiu que començava el seu desplegament comercial exportador. En la taula següent es pot apreciar com aquestes gelades de final de segle XIX i les de principi de segle xx van afectar l'exportació de taronja espanyola.

Taula 3. Exportació espanyola de taronja

\begin{tabular}{|c|c|c|c|c|c|}
\hline Any & $\mathrm{Kg}$ & Any & $\mathrm{Kg}$ & Any & $\mathrm{Kg}$ \\
\hline $1886-87$ & 1.386 .000 & $1894-95$ & 3.049 .000 & $1902-03$ & 4.423 .000 \\
\hline $1887-88$ & 1.874 .000 & $1895-96$ & 3.028 .000 & $1903-04$ & 4.152 .000 \\
\hline $\mathbf{1 8 8 8 - 8 9}$ & $\mathbf{1 . 7 5 8 . 0 0 0}$ & $1896-97$ & 3.715 .000 & $\mathbf{1 9 0 4 - 0 5}$ & $\mathbf{3} .333 .000$ \\
\hline $1889-90$ & 2.266 .000 & $1897-98$ & 2.534 .000 & $1905-06$ & 3.903 .000 \\
\hline $\mathbf{1 8 9 0 - 9 1}$ & $\mathbf{1 . 4 8 6 . 0 0 0}$ & $1898-99$ & $3.965 .000^{3}$ & $1906-07$ & 4.465 .000 \\
\hline $1891-92$ & 2.493 .000 & $1899-1900$ & 3.164 .000 & $1907-08$ & 4.523 .000 \\
\hline $1892-93$ & 1.968 .000 & $1900-01$ & $\mathbf{3 . 1 0 0 . 0 0 0}$ & & \\
\cline { 1 - 3 } $1893-94$ & 2.961 .000 & $1901-02$ & 4.512 .000 & & \\
\cline { 1 - 3 } & & &
\end{tabular}

Font: Sarthou (1920-1927).

En negreta, temporades en què hi va haver gelades

3. Prenent a Ribes Pla (1946) per a la campanya 1898-99 dóna una xifra de 3.565.000. Potser aquesta és més aproximada. 
Taula 4. Exportació de taronja des del port de Castelló

\begin{tabular}{|c|c|c|c|c|c|}
\hline Any & Kg taronges & Any & $\mathrm{Kg}$ taronges & Any & $\mathrm{Kg}$ taronges \\
\hline 1903 & 12.002 .142 & 1922 & 41.104 .800 & 1940 & 48.924 .000 \\
\hline 1904 & 57.745 .694 & 1923 & 27.962 .200 & 1941 & 31.805 .000 \\
\hline
\end{tabular}

\begin{tabular}{|l|l|l|l|l|l|}
\hline 1905 & $\mathbf{3 7 . 2 6 8 . 9 0 4}$ & 1924 & 98.343 .900 & $\mathbf{1 9 4 2}$ & $\mathbf{2 2 . 7 6 6 . 0 0 0}$ \\
\hline
\end{tabular}

\begin{tabular}{|l|l|l|l|l|l|}
\hline 1906 & 60.185 .750 & 1925 & 110.358 .000 & 1943 & 27.010 .000 \\
\hline
\end{tabular}

\begin{tabular}{|l|c|c|c|c|c|}
\hline 1907 & 70.529 .081 & 1926 & 92.267 .000 & 1944 & 7.536 .000 \\
\hline 1908 & 60.878 .387 & 1927 & 80.829 .000 & 1945 & 1.742 .000 \\
\hline
\end{tabular}

\begin{tabular}{|l|c|c|c|c|c|}
\hline 1908 & 60.878 .387 & $\mathbf{1 9 2 7}$ & $\mathbf{8 0 . 8 2 9 . 0 0 0}$ & $\mathbf{1 9 4 5}$ & $\mathbf{1 . 7 4 2 . 0 0 0}$ \\
\hline 1909 & 70.070 .280 & 1928 & 108.028 .000 & $\mathbf{1 9 4 6}$ & $\mathbf{6 9 3 . 0 0 0}$ \\
\hline 1910 & 66.643 .830 & 1929 & 90.199 .000 & 1947 & 2.003 .000 \\
\hline
\end{tabular}

\begin{tabular}{|l|c|c|c|c|c|}
\hline 1910 & 66.643 .830 & 1929 & 90.199 .000 & 1947 & 2.003 .000 \\
\hline 1911 & 60.425 .340 & 1930 & 123.062 .000 & 1948 & 17.619 .000 \\
\hline 1912 & 82.248 .870 & $\mathbf{1 9 3 1}$ & $\mathbf{9 6 . 2 2 7 . 0 0 0}$ & 1949 & 23.287 .000 \\
\hline
\end{tabular}

\begin{tabular}{|l|c|c|c|c|c|}
\hline 1912 & 82.248 .870 & $\mathbf{1 9 3 1}$ & $\mathbf{9 6 . 2 2 7 . 0 0 0}$ & 1949 & 23.287 .000 \\
\hline 1913 & 102.825 .282 & 1932 & 91.419 .000 & 1950 & 10.888 .000 \\
\hline $\mathbf{1 9 1 4}$ & $\mathbf{9 0 . 6 4 9 . 5 2 0}$ & 1933 & 104.984 .000 & 1951 & 23.199 .000 \\
\hline
\end{tabular}

\begin{tabular}{|l|l|l|l|l|l|}
\hline $\mathbf{1 9 1 5}$ & $\mathbf{6 0 . 9 8 8 . 7 2 0}$ & $\mathbf{1 9 3 4}$ & $\mathbf{7 6 . 8 1 7 . 0 0 0}$ & 1952 & 29.348 .000 \\
\hline 1916 & 69.970 .950 & $\mathbf{1 9 3 5}$ & $\mathbf{7 4 . 6 3 6 . 0 0 0}$ & 1953 & 50.886 .000 \\
\hline
\end{tabular}

\begin{tabular}{|l|c|c|c|c|c|}
\hline 1917 & 26.805 .820 & 1936 & 85.972 .000 & $\mathbf{1 9 5 4}$ & $\mathbf{2 6 . 5 4 2 . 0 0 0}$ \\
\hline $\mathbf{1 9 1 8}$ & $\mathbf{1 7 . 1 5 5 . 5 6 0}$ & $\mathbf{1 9 3 7}$ & $\mathbf{3 6 . 9 8 4 . 0 0 0}$ & 1955 & 33.933 .000 \\
\hline 1919 & 13.259 .700 & $\mathbf{1 9 3 8}$ & $\mathbf{1 8 . 7 2 4 . 0 0 0}$ & $\mathbf{1 9 5 6}$ & $\mathbf{8 . 0 4 7 . 0 0 0}$ \\
\hline $\mathbf{1 9 2 0}$ & $\mathbf{1 6 . 7 6 3 . 8 0 0}$ & 1939 & 71.116 .000 & 1957 & 5.273 .000 \\
\hline 1921 & $\mathbf{2 0 . 2 5 8 . 9 0 0}$ & & & & \\
\hline
\end{tabular}

Font: Las Provincias, 1926-1927. En negreta, anys de gelada

La primera gran gelada del segle Xx va ser la de l'any 1905. Després, en vindrien les de l'hivern de 1917-1918 i l'hivern de 1920-1921, que van sumar-se a la mala situació de l'economia citrícola en temps de la Primera Guerra Mundial.

Més tard, en vingueren les dues seguides dels anys 1926 i 1927. La primera d'aquestes va desaccelerar la lenta recuperació després del conflicte bèl-lic i va ser la gota que va fer vessar el got del desordre citrícola. Per això es va convocar una assemblea en l'àmbit estatal per a discutir els problemes que tenia l'economia citrícola. La segona va alarmar el món citrícola i ràpidament es van adoptar mesures de control per tal de no exportar taronja gelada a l'exterior. Tanmateix, s'ha d'afegir que 
aquestes en gran part van ser boicotejades. Més avant, en el primer estudi de cas n'ampliaré la informació de les campanyes 1925-26 i 1926-27.

Amb la gelada de 1933 es van adoptar per segona vegada mesures per al control comercial de la taronja gelada, encara que duraren poc.

Les gelades dels anys quaranta i cinquanta van suposar un factor negatiu que va dificultar l'expansió de la citricultura després de la tràgica Guerra Civil espanyola. A l'abandó dels camps pel conflicte bèl-lic i a la prohibició d'augmentar el cultiu del taronger en benefici de cultius de subsistència, van venir a sumar-se les gelades de 1940, durant les quals es va perdre vora el $40 \%$ de la collita; en la de 1942, vora el $70 \%$, i dues l'any 1944. Pel que fa a la gelada de 1946, aquesta va acabar d'enfonsar l'economia citrícola que es trobava en procés de lentíssima recuperació després del conflicte bèl-lic espanyol i mundial. Es va arribar a dir que no se n'havia coneguda cap de semblant en intensitat com aquella de 1946: molts arbres s'arrancaren per plantar cultius de subsistència i es va reobrir el vell debat envers la conveniència de canviar de cultiu, almenys temporalment, a l'espera que la conjuntura adversa que travessava la citricultura canviara. Davant del desastre i la poca ajuda rebuda «els agricultors, sorpresos $\mathrm{i}$ indefensos, es quedaren a soles amb la seua fe cega en el taronger, i increïblement, i a costa d'una austeritat poc divulgada, reconstituïren pacientment la riquesa destruïda» (Font de Mora, 1971: 130). Per a calibrar la gravetat del moment caldrà afegir que aquestes gelades postbèl-liques va suposar quasi el toc final d'una economia seriosament danyada.

Quan a penes la situació començava a millorar, les gelades de 1954 i 1956 van trencar el ritme de recuperació de la producció i el comerç de la citricultura valenciana. Cal dir que des de feia vuit anys no se n'havia produït cap i les perspectives de creixement començaven a ser bones. Tanmateix, al febrer de 1954 una onada d'aire fred va malmetre la situació. Tot i això, el desastre encara no havia arribat: amb la gelada de 1956 les conseqüències van ser més que desastroses. D’aquesta última també veurem com es va desenvolupar la campanya tarongera en el segon estudi de cas.

Quant a la de 1962, tot i que les temperatures no van ser extremadament baixes, hi va afectar notablement, ja que es va produir al desembre, és a dir, quasi a l'inici de campanya, amb la qual cosa bona part de la taronja encara era a l'arbre.

\section{PRIMER ESTUDI DE CAS: CAMPANYES CITRÍCOLES DE 1925-26 I 1926-27}

\section{Campanya 1925-26}

Les gelades del desembre de 1925 i del desembre de 1926, com hem comentat, van desaccelerar la incipient recuperació després de la Primera Guerra Mundial. Durant la de 1925 es va exportar taronja gelada, la qual cosa va desacreditar el producte a l'estranger. Arran d'aquest fet i de la penosa situació que arrossegava l'economia citrícola, el govern es decidí a 
actuar en l'ordenació del comerç citrícola a petició dels afectats. D'aquesta manera es va celebrar la Conferencia Nacional Naranjera.

En la temporada 1925-26 el fred va arribar prompte, així del 14 al 25 de desembre, una onada d'aire fred envaïa la Península. Arran d'aquest fet, els debats en la premsa i al si de les organitzacions tarongeres entorn de si es devia exportar taronja o no van ser constants. Les crítiques a la mala organització per part del sector citrícola i, en major mesura, dels productors -que es veien sotmesos a les demandes de les companyies navilieres que imposaven preus i càrregues- eren obertes. A mesura que la campanya avançava, la situació empitjorava $\mathrm{i}$, com a conseqüència d'aquesta, les principals associacions de productors demanaren al govern la celebració d'una gran assemblea tarongera on es posaren sobre la taula els principals problemes que hi tenia l'economia citrícola. Es va acordar que les parts interessades estudiarien per separat les bases que cregueren necessàries per a l'acord comú i després es reunirien en assemblea per tal de discutir-les i aprovar-les. D'aquesta assemblea, o conferència, hauria d'eixir un programa aprovat per tots, i així el govern dictaria les disposicions que regularien el futur de la riquesa tarongera.

Una de les principals discussions en l'economia citrícola era la regulació dels embarcaments per no saturar els mercats i la fiscalització de la taronja per tal de no exportar taronja verda o gelada. En aquest sentit, Borriana va ser la primera ciutat que, reunits en assemblea productors i exportadors, va concloure que no volia cap tipus de prohibició ni limitació a l'exportació, argumentant que l'aprofitarien països competidors; així, contràriament la mesura més convenient era l'adopció de facilitats per a l'exportació per part dels poders públics. Partidaris per tant de la no-regulació, també demanaven als poders públics la creació d'una flota de vaixells fruiters per a exportar la taronja amb garanties. Gandia no va tardar a sumar-se a la no-regulació dels embarcaments.

Al final de la campanya els preus eren baixos i la situació dolenta. Se'n feia balanç, i així es recordava qui sortia guanyant i qui perdent. Les crítiques als "vaporistes» eren obertes, perquè els embarcaments de taronja estaven monopolitzats per unes poques companyies que exercien gran control sobre les exportacions.

Els dies 12, 13 i 14 d'octubre de 1926 el Consejo de Economía Nacional va convocar l'esperada Conferencia Nacional Naranjera. El principal punt i el més conflictiu va ser el referent a l'ordenació de l'exportació, ja que, com hem vist, no la volien ni productors ni exportadors. Pel que fa a la fase tècnica agrícola, ràpidament es va arribar a un acord, principalment pel que fa a la necessitat de recollir estadístiques referents al cultiu i a la producció de taronja. Per a aquesta finalitat es volia dotar dels mitjans adequats a les cambres agrícoles. Els representants de les entitats presents es van comprometre a confeccionar les estadístiques de cada poble i entregar-les als centres agronòmics en un termini que acabaria en el mes d'abril. D'una altra banda, els tècnics agrícoles oficials devien recomanar les varietats més 
aptes a les diferents zones de cultiu i fomentar-ne el cultiu de varietats primerenques i tardanes per tal d'allargar el període d'exportació i simplificar les varietats de cítrics existents. Del reg es mencionava que era preferible que es fera comunitari a que es fera individual, per la qual cosa calia fomentar les comunitats de regants. Pel que fa als adobs, els tècnics havien de recomanar les fórmules més aptes segons la varietat. Quant a les plagues s'intensificaria la lluita contra malalties i plagues amb l'establiment d'estacions fitopatològiques. També es demanava que des del govern es fomentara la cultura citrícola i el consum de taronja.

Respecte a la fabricació de caixes de fusta per a exportar la taronja els agricultors es queixaven del lobby que hi havia en aquest àmbit, que posava uns preus elevats per a la fabricació de caixes. Volien, doncs, uns preus més barats i per això demanaven la importació de fusta francesa. Pel que fa al paper de seda, que era el que s'utilitzava per a embolicar les taronges de més qualitat, també es queixaven que hi havia un lobby que imposava preus abusius. Per tant, demanaren al govern l'admissió temporal de paper de seda o la rebaixa de l'aranzel per l'entrada de paper de seda.

Una altra demanda que es va recollir en la conferència va ser la creació d'una flota pròpia de vaixells fruiters, en resposta al control exportador que exercien les grans companyies navilieres estrangeres. També s'exigia als transportistes que els vaixells reuniren les característiques tècniques necessàries per al transport de la fruita: «La asamblea considera de capital importancia que los barcos que efectúen transporte de frutas reúnan las condiciones adecuadas, tanto de velocidad como por el medio de acomodar la fruta» (LP, 13-10-1926).

En concret, demanaven que la fruita s'embarcara de manera que poguera arribar al lloc de consum en perfectes condicions, ja que en l'afany de carregar els vaixells fins a dalt, sovint els "vaporistes» no prestaven atenció a les condicions mínimes de transport de la mercaderia.

Una altra demanda era la creació d'una cooperativa única que abastara tots els interessats en el negoci taronger a semblança del sistema seguit pels colliters de Califòrnia. En aquest punt va ser especialment insidiosa la Federación Sindical de Cultivadores del Naranjo de Castellón i la Federación de Sindicatos Agrícolas Católicos de Castellón.

Pel que fa a la fiscalització de la taronja, hi va haver més discussió. La conferència es reafirmava que a l'estranger calia remetre la millor taronja i que la roïna no sols s'enviava quan hi ha gelada, sinó sempre, i que, per consegüent, un comité fiscalitzador hauria de funcionar en qualsevol època. Per una banda, molts assembleistes es mostraven contraris als controls de qualitat i a les quotes d'embarcament, mentre que els experts presents, sobretot tècnics i alguns portaveus d'organitzacions tarongeres, es mostraven favorables a la fiscalització i a les limitacions. Tal era el desacord que les conclusions provisionals no van ser acceptades perquè hi figurava la paraula "ordenació» quant a l'exportació, i perquè hi faltava una al-lusió a la llibertat d'exportació marítima i terrestre. Després 
d'hores de discussió finalment es van aprovar unes conclusions. Tanmateix, en aquestes, el tema referent al control en l'exportació no es va recollir, ni pel que fa a les quotes per tal de no saturar els mercats, ni pel que fa a la fiscalització de la taronja. En aquest punt tot quedava supeditat a que el negoci de la taronja estiguera organitzat en una gran cooperativa que aglutinara productors i exportadors. En conclusió, tot i que en la conferència els experts creien en la necessitat d'una fiscalització en temps de gelada, aquesta no es va recollir en les disposicions finals que s'enviarien al Govern.

Campanya 1926-27

Una vegada més, la temporada començava amb enviaments de taronja verda. Així ho feien notar els periòdics (LP, 18-11-1926):

De continuo se nos dirigen ruegos y estímulos por agricultores y entidades regionales para que esta Federación [de productores de Naranja de Levante] se interese en poner fin a la justa alarma producida por las deficiencias que se observan en la calidad de los envíos de nuestra naranja al extranjero.

Novament el fred feia acte de presència i una onada d'aire àrtic va travessar tota la península el desembre de 1926. Aquesta vegada, però, es va actuar amb rapidesa i es van reunir a València els representants de les associacions de productors amb els alcaldes. En aquesta reunió es va demanar l'actuació immediata del Govern. En reunions posteriors entre productors i exportadors també es va demanar al govern espanyol la prohibició de l'exportació durant uns dies per tal d'avaluar els danys causats per la gelada (LP, 29-12-1926):

Por aclamación se acordó declarar que la petición de la prohibición, tal como la habían formulado los señores Lamo de Espinosa y Lassala era necesaria, pues ante todo se necesitaba dar al extranjero la sensación de que no se le remitiría género dañado.

Al si de les organitzacions hi va haver discussions sobre si era convenient o no prohibir l'exportació $i$, en general, es pensava que aquesta s'havia de fiscalitzar però no prohibir. Tanmateix, les discussions sobre quins havien de ser els mètodes fiscalitzadors també eren importants, ja que no es tenien clars. Mentrestant, el govern prohibia l'exportació per 15 dies, durant els quals els interessats s'havien de posar d'acord per trobar un mètode fiscalitzador.

Reunides en assemblea les organitzacions tarongeres, es va acordar no exportar taronja gelada i es donava la benvinguda a la mesura que havia pres el Govern (LP, 4-1-1927).

Evitando, ahora y siempre, por cuantos medios están al alcance de las organizaciones de cosecheros y exportadores, que salga de los puertos y fronteras españolas, cantidad alguna de naranja que no esté en condiciones de ser exportada [...] la asamblea aplaude y agradece la orden preventiva de 
suspensión de la recolección dada por el Gobierno [...] declara de necesidad urgentísima que sean llevadas a la práctica en lo que resta de campaña comercial todas las medidas para que sus buenos propósitos se traduzcan en actos de fiscalización directa sobre la naranja que haya de ser exportada.

Finalment, es va acordar crear juntes inspectores als pobles, a les estacions de ferrocarril i al ports; però la normativa que creaven tenia greus deficiències: les juntes estaven formades per representants de productors i exportadors, amb la qual cosa el bon propòsit d'aquestes no estava garantit. Tan sols les dels ports tenien a la seua disposició un tècnic agrícola en les inspeccions.

Mentrestant, a mesura que la campanya avançava, sorgien nous problemes. Una vegada passada la gelada, tant productors com exportadors exigien una renegociació dels contractes ja que el preu de la taronja no era el mateix que abans de la gelada. Val a dir que els contractes sovint es feien a principi de temporada, quan la taronja encara estava a l'arbre: els comerciants anaven a l'hort, l'ataüllaven, acordaven un preu amb l'agricultor i després el comerciant s'encarregava de collir la taronja quan a aquest li convenia exportar-la. Els contractes es feien de paraula i no per escrit. Després de la gelada, els agricultors exigien que se'ls pagara la taronja a preu del moment, que era més elevat, ja que hi havia poca taronja sana, mentre que els exportadors demanaven que no devien pagar la taronja gelada.

Per una altra banda, el Govern va posar a disposició dels productors crèdits. Tanmateix, l'accés a aquests era molt dificultós per als llauradors: no sabien on demanar-lo i, a més, se'ls exigien unes garanties que sovint no entenien i es reclamava que perquè els crèdits arribaren als pobles menuts s'havien de fer mitjançant organismes estatals que tingueren oficines obertes als pobles.

Les cases exportadores, per la seua banda, denunciaven l'arribada de taronja gelada als mercats estrangers i s'acusava a les juntes inspectores d'actuar amb partidisme i de ser flexibles a l'hora d'aplicar la fiscalització. En aquest sentit van haver-hi pressions al Consejo de Economia Nacional perquè suavitzés els controls sobretot per part d'exportadors.

Al final de la temporada novament sorgien dures crítiques a la desorganització del sector citrícola ( $L P, 14-5-1927)$ :

Pero la distribución de este dinero es lo que parece un poco desigual. Han ganado los propietarios de mercancía sana, muchos comerciantes, y seguramente nadie más. Han perdido los propietarios de mercancía dañada, los confeccionadores, los jornaleros del campo y los obreros del puerto, con caballetes y adyacentes. En una organización perfecta, ese mayor ingreso habría tenido una mejor distribución, pero aquí resulta difícil, porque impera el egoísmo, y nadie se preocupa más que de su interés momentáneo, sin pensar en el provenir y sin que las lecciones del pasado sirvan de gran cosa.

A pesar que aquesta temporada s'hi havia vist més organització que en cap altra, encara faltava molt per fer si es volien aconseguir les disposicions a què havia arribat la conferència. Feia la impressió que 
mentre no hi haguera cap desastre climàtic cadascú anava a la seua i quan aquest ocorreguera, llavors tot s'havia de fer de pressa i corrents. I aquest cas, el més perjudicat sempre eren els agricultors, ja que n'eren més i estaven més desorganitzats. Si no tenien una organització forta que defensara els seus interessos, sempre es veurien en mans alienes.

Al final de temporada la Junta Naranjera del Consejo de Economía Nacional feia la reunió anual per fer-ne el balanç. A aquesta se li criticava que no havia posat en pràctica els objectius de la Conferencia Naranjera $(L P, 24-6-1927)$ :

En vista de que la reunión iba a terminar como un trámite burocrático más, intervinimos nuevamente para lamentar que se llevaran al orden del día asuntos de tan poca importancia, y no se comenzaran a estudiar otros de verdadera trascendencia para el negocio naranjero, como la proposición que tenemos presentada al Consejo en pro de la organización del negocio nacional de la naranja, el examen del real decreto sobre inspección fitopatológica de la exportación agrícola y numerosas conclusiones de la Conferencia Nacional Naranjera.

Finalment, es va acordar que les juntes inspectores funcionarien d'aleshores endavant com a inspecció fitopatològica; per tant, no estarien vinculades a les gelades, funcionarien de manera permanent i s'aprovarien quaranta places d'enginyers agrònoms perquè en feren les inspeccions.

Així doncs, les juntes inspectores foren creades a corre-cuita, amb un control excessiu per part dels implicats en el negoci, sobretot dels exportadors, qui més les van pressionar, amb la qual cosa van actuar insuficientment. Però al mateix temps aquestes també van ser benvingudes per les principals organitzacions de productors i van rebre elogis dels seus dirigents per la rapidesa amb què s'havien implantat i per les pressions a les quals estaven sotmeses per part dels sectors més reticents.

Taula 5. Exportació de taronja en mitges caixes per via marítima des dels ports de Castelló, Borriana, València i Gandia en tres temporades diferents

\begin{tabular}{|c|c|c|}
\hline $1924-25$ & $1925-26$ & $1926-27$ \\
\hline 11.157 .321 & 9.970 .074 & 8.061 .774 \\
\hline
\end{tabular}

Font: Elaboració pròpia a partir de Las Provincias 1926-27

Taula 6. Exportació de taronja des del port de Castelló, en kg

\begin{tabular}{|c|c|c|c|}
\hline & 1925 & 1926 & 1927 \\
\hline Totals & 108.390 .435 & 92.267 .000 & 60.801 .280 \\
\hline
\end{tabular}

Font: Arxiu Autoritat Portuària Castelló 
Per a la temporada 1955-56 s'esperava que la producció de taronja fóra la més gran de la història. Es calculava la collita en 1.580 .000 tones, que comportaria un ingrés de més de 3.000 milions de pessetes per a l'Estat espanyol, quasi la meitat dels vora 7.000 milions que suposava l'exportació agrícola espanyola.

Cap a febrer, però, una forta onada d'aire fred va arribar a tota la península lbèrica i va deixar a molts llocs temperatures mínimes mai registrades.

Ràpidament, el Govern va enviar les autoritats al País Valencià per veure com afectaria la gelada l'economia citrícola i, per tant, els ingressos de l'Estat. De seguida es van suspendre les tasques de recol·lecció de la taronja per a la confecció i embarcament.

Des dels organismes oficials, com la Junta Interprovincial de Agrios, es proposaven mesures al Govern perquè alleugerara la situació dels agricultors afectats. Les reunions de les autoritats amb les organitzacions agrícoles oficials i les autoritats locals no cessaven. En aquestes, el govern pretenia captar quina era l'opinió general i intentava calmar la situació amb bones paraules. També es va acordar constituir una comissió reguladora de l'exportació per tal de fiscalitzar la taronja.

La premsa, per la seua part, lloava la retòrica oficialista de les visites que les autoritats franquistes feien a les zones afectades i confiaven en les promeses rebudes (LP, 9-12-1956):

La estancia en Valencia de los señores [...] en su calidad de alto representante [...] pone de manifiesto a la vez que lo decisivo que supone a la economía nacional todo contratiempo sufrido en la economía valenciana, un loable afán de los Poderes Públicos en tratar de mitigar cuanto antes la situación.

Per part de les autoritats locals es va fer un informe que es va presentar al Consell de Ministres, en què es posava de manifest que a l'economia citrícola sols se li feia cas quan hi havia un desastre ( $M, 8-2-$ 1956).

También queremos poner de relieve lo importante que sería extender tal inquietud, y preocupación, ésta atención que a la naranja se otorga en momentos anormales y desfavorables como los que vivimos, a épocas normales y de bonanza, porque quizás si en esos instantes propicios la naranja contara con el mismo ambiente de unánime atención y la misma conciencia general de lo que significa para una región y representa mucho para España, seria posible obtener de nuestra riqueza y su comercio mayores beneficios para quienes la crean y la movilizan y también para la nación en cuyo seno surge, por el trabajo y la audacia de nuestros hombres, esta cosecha de verdadero oro que es la naranja española.

Per agreujar la situació, el 10 de febrer va arribar una altra onada d'aire fred més intensa que l'anterior, catalogada com la invasió d'aire fred més intensa de tot el segle xx. 
Les reunions d'organitzacions que representaven el sector productor de la taronja no es van fer esperar. Posteriorment, també es reuniren representants dels organismes de la producció i de l'exportació amb les autoritats locals per avaluar la situació. En una d'aquestes reunions el governador civil de València va exposar la conveniència que s'estudiara amb deteniment la possibilitat d'establir un sistema d'assegurances obligatòries contra gelades.

Els Procuradores a Cortes de València en reunió demanaven que s'adoptaren mesures urgents encaminades a atenuar els greus efectes de les gelades, entre les quals destacaven auxilis de crèdit agrícola, facilitats bancàries, flexibilitat fiscal en l'aplicació dels tributs a les zones afectades, creació d'una indústria de derivats, crèdits extraordinaris per a mitigar l'atur al camp i que s'aprovaren de manera immediata les obres públiques pendents d'execució també per mitigar l'atur.

Una delegació d'autoritats de Castelló formada pel president de la Diputació Provincial i Governador Civil, el delegat provincial del SFPH (Sindicato de Frutos y Productos Hortícolas) i el cap provincial del Movimiento anà a Madrid per entregar personalment un informe a diversos departaments ministerials i a l'Administració Central, en el qual es posaven de manifest els danys causats per les gelades i es demanaven ajudes econòmiques de tot ordre per al seu remei. A Borriana també es reunien les autoritats locals per a proposar mesures al Govern. En general de molts ajuntaments valencians es demanava al govern central ajudes en forma de crèdits i l'activació d'obres públiques per tal de donar treball als desocupats.

Els dies 19 i 20 de febrer, una nova onada de fred, aquesta vegada, però, de menys intensitat, arribava a la península Ibèrica. Les tres onades consecutives queien sobre els agricultors com desastres que els conduïen a la ruïna: davant de la primera onada, aquests es preocupaven per la collita present; amb la segona, per la collita futura, i amb la tercera, pels arbres. Per a l'agricultor, això suposava haver de refer la seua riquesa citrícola mitjançant esforços econòmics que en aquell moment no podia assumir. Per tant, havia de demanar préstecs per tal d'atendre les necessitats agrícoles i personals.

En una segona visita de les autoritats provincials de Castelló a Madrid es tornaven a demanar ajudes per als llauradors i es posava de manifest davant les autoritats centrals que molts dels projectes que les entitats locals tenien previst dur a terme no es podrien realitzar per falta de recursos econòmics als ens locals. Una de les conseqüències de les gelades va ser la reducció de les inversions a les províncies valencianes perquè la recaptació per les exportacions de taronja havia minvat.

A mesura que les desastroses conseqüències de les gelades es feien més evidents i l'actuació del govern resultava insuficient, apareixien crítiques als periòdics ( $M, 25-3-1956)$ :

Tampoco podemos decir que el Estado a través de toda la vida agrícola de esta zona haya hecho mucho en defensa de esta riqueza vinculada directamente a nuestro cuidado. Cuando más se ha limitado a la concesión de 
unos créditos agrícolas económicos no siempre considerados suficientes por el agricultor [...] ¿hasta cuando hemos de conformarnos con buenos deseos? ¿hasta cuando hemos de permanecer, agricultores y Estado, cruzados de brazos mientras una fuente de riqueza del caudal de la nuestra se pierde baldiamente en el mar de la irresponsabilidad y la desidia?

Les crítiques als exportadors que tenien encara remeses a la despensa i que ara veien com el preu de la taronja a l'estranger estava pels núvols eren obertes (LP, 3-5-1956):

Somos nosotros, los pequeños agricultores, los que lo perdimos todo, porque los exportadores tenían mucha comprada, es cierto, pero ellos ahora la están exportando; es más, han hecho un verdadero negocio, pues al saber en el extranjero que en España se había helado la naranja, pero que la italiana y la de Israel estaba perdida del todo, al quedar desabastecido el mercado, subió la naranja, pagándose la que había almacenada en Alemania y Francia un setenta y cinco por ciento más cara, haciendo los exportadores un negocio redondo. Nosotros hemos perdido la total cosecha de este año y el cincuenta por ciento de la próxima, a más de mucho arbolado.

Finalment, el Govern aprovava les mesures següents: concessió de 200 milions de pessetes en crèdits agrícoles, crèdits extraordinaris per a l'atur, flexibilitat fiscal per als afectats en la contribució a la Hisenda Pública, facilitats de la banca al comerç exportador i un estudi per implantar una indústria de derivats.

Per tercera vegada, el governador civil de Castelló feia una visita a la capital per tal que s'acceleraren les obres públiques pendents d'execució. La Cámara Sindical Agraria de Valencia demanava audiència amb el cap de l'Estat per fer-li arribar la urgència de declarar la situació com "catàstrofe agrícola», que s'ampliara el termini per pagar els crèdits i que s'eximira els llauradors del pagament de l'arbitri sobre la riquesa agrícola del període 1955-56.

Podem afirmar que la posada en marxa d'obres públiques pendents d'execució era una resposta de keynesianisme econòmic que l'Estat franquista de caire paternalista feia per intentar solucionar el greu problema d'atur que havia generat les gelades. El governador civil de València deia al respecte (LP, 3-1956):

Bien puede afirmarse que si los daños inferidos a nuestros campos a causa de las adversas circunstancias climatológicas recientes, no tienen precedentes por su intensidad, tampoco ha existido en ningún sistema político anterior, una red tan completa de asistencia y ayudas, que permitirá, sin duda, no sólo combatir eficazmente el paro que puede avecinarse en la provincia, sino también estimular nuestra economía.

A causa de les constants demandes de les entitats locals, el Govern central ampliava les minses ajudes: es van ampliar en seixanta milions els préstecs als damnificats per les gelades i en sis milions els de l'atur, que, sumats als quatre anteriors, en feien un total de deu. Aquests préstecs vencien en quatre anys, mentre que els qui tenien préstecs pendents de 
la gelada de dos anys abans podien demanar una moratòria d'un any en el pagament de la segona anualitat. També es concedia una moratòria fiscal en el pagament de la contribució rústica de l'any 1956 a les províncies afectades per les gelades.

Tot plegat, ben poca cosa segons l'opinió general del moment. Per exemple, l'Ajuntament de Castelló, en sessió plenària, deia que no esperava ingressos de cap tipus per a aquell any i el següent, que el crèdit concedit pel govern era del tot insuficient i que d'acord amb que l'exportació de taronges omplia de divises les arques públiques, l'Estat havia de fer un esforç més gran a contribuir al desenvolupament citrícola.

Per l'abril la UTECO (Unión Territorial de Cooperativas del Campo) en reunió de la junta central feia balanç de la temporada esmentant que la moratòria fiscal i el crèdit concedits eren clarament insuficients. En el ministeri de comerç les preocupacions per la falta de divises provinents de la taronja eren evidents ( $L P, 8-5-1956)$ :

Nos hemos visto obligados a restringir las importaciones, ya que nos faltaban medios de pago [...] vamos a tratar de suplir las exportaciones de naranja con otros productos de primera estimación. Se ha hecho un gran esfuerzo por parte del ministerio de Comercio para suplir la falta de unos 80 millones de marcos de cítricos por diversos productos.

Les ajudes que va concedir l'Estat franquista van ser del tot escasses a tenor de les constants reclamacions de més ajudes per part de les autoritats locals i els organismes agrícoles oficials.

Taula 7. Exportació temporada 1954-55 des de Castelló, en kg

\begin{tabular}{|c|c|c|c|c|c|}
\hline \multicolumn{3}{|c|}{ Castelló 1954-55 } \\
\hline \multirow{2}{*}{} & \multicolumn{3}{|c|}{ Via marítima } & \multirow{2}{*}{ Via terrestre } & Total general kg \\
\cline { 2 - 5 } & Borriana & Castelló & Total & & \\
\hline Total & 102.663 .236 & 26.022 .526 & 128.685 .762 & 99.046 .657 & 227.732 .419 \\
\hline
\end{tabular}

Font: Elaboració pròpia a partir de l'IVE

Taula 8. Exportació temporada 1955-56 des de Castelló, en kg

\begin{tabular}{|c|c|c|c|c|c|c|c|}
\hline \multicolumn{7}{|c|}{ Castelló 1955-56 } & \multirow{2}{*}{ Total general kg } \\
\hline & \multicolumn{3}{|c|}{ Via marítima } & \multicolumn{2}{c|}{ Via terrestre } & \\
\cline { 2 - 7 } & Borriana & Castelló & Total & Ferrocarril & Camió & Total & \\
\hline Total & 61.560 .081 & 12.490 .779 & 74.050 .860 & 54.811 .694 & 7.424 .859 & 62.236 .553 & 136.287 .413 \\
\hline
\end{tabular}

Font: Elaboració pròpia a partir de l'IVE 
Taula 9. Exportació temporada 1956-57 des de Castelló, en kg

\begin{tabular}{|c|c|c|c|c|c|c|c|}
\hline \multicolumn{2}{|c|}{ Castelló 1956-57 } & \multirow{2}{*}{ Total general kg } \\
\hline & \multicolumn{3}{|c|}{ Via marítima } & \multicolumn{2}{c|}{ Via terrestre } & \\
\cline { 2 - 6 } & Borriana & Castelló & Total & Ferrocarril & Camió & Total & \\
\hline Total & 18.344 .972 & 3.241 .047 & 21.586 .019 & 28.153 .956 & 4.882 .609 & 33.036 .565 & 54.622 .584 \\
\hline
\end{tabular}

Font: Elaboració pròpia a partir de l'IVE

Taula 10. Exportació temporades 1955-56 i 1956-57 des de València i Alacant, en kg

\begin{tabular}{|l|c|c|c|c|c|c|}
\hline \multirow{2}{*}{} & \multirow{2}{*}{ Temp. } & \multirow{2}{*}{ Via marítima } & \multicolumn{3}{|c|}{ Via terrestre } & \multirow{2}{*}{ Total general kg } \\
\cline { 4 - 7 } & & & Ferrocarril & Camió & Total & \\
\hline \multirow{2}{*}{ València } & $1955-56$ & 238.591 .154 & 154.441 .445 & 14.356 .730 & 168.798 .175 & 407.389 .329 \\
\cline { 2 - 6 } & $1956-57$ & 33.615 .799 & 67.697 .312 & 10.171 .260 & 77.868 .572 & 166.375 .302 \\
\hline \multirow{2}{*}{ Alacant } & $1955-56$ & 1.811 .940 & 71.672 & 52.400 & 124.072 & 1.936 .012 \\
\cline { 2 - 6 } & $1956-57$ & & & 38.060 & 38.060 & 38.060 \\
\hline
\end{tabular}

Font: Elaboració pròpia a partir de l'IVE

Taula 11. Pèrdues econòmiques de la gelada de 1956

\begin{tabular}{|c|c|c|c|c|}
\hline & $1955-56$ & $1956-57$ & Total & \% Cítrics \\
\hline Castelló & $440(340)$ & $625(340)$ & $1.065(680)^{4}$ & $64 \%$ \\
\hline València & $1.387(1.000)$ & $1.665(1.600)$ & $3.052(2.600)$ & $85 \%$ \\
\hline Alacant & $340(80)$ & $120(80)$ & $460(160)$ & $35 \%$ \\
\hline Total & $2.167(1.420)$ & $2.410(2.020)$ & $4.577(3.440)$ & $75 \%$ \\
\hline
\end{tabular}

Font: Elaboració pròpia a partir de López Gómez (1956: 696). En milions de pessetes.

Entre parèntesi les pèrdues en la citricultura

4. En la Plana, els danys totals eren 810 milions; a la zona de mitja muntanya, 245, i en l'alta muntanya, 10 segons el mateix Gómez (693). Si tenim en compte que els cítrics estan plantats a la zona de la Plana, vol dir que dels 810 milions a la Plana, 680 eren de la taronja, és a dir, el $84 \%$. 
Les gelades consecutives de 1925 i 1926 van desaccelerar la recuperació citrícola de després de la Primera Guerra Mundial, van evidenciar la desorganització del sector citrícola, però van motivar la convocatòria de la Conferencia Nacional Naranjera, i van fer que el govern intervinguera per primera vegada en l'ordenació del comerç de la taronja. Aquest intent d'ordenació va ser hàbilment entorpit pels qui hi veien un obstacle per als seus interessos, però va ser la primera vegada que els interessats -agricultors, exportadors i Estat- van posar les bases per a una regulació del comerç de la taronja i, per tant, va servir per a establir un incipient diàleg que més tard es reprendria en anys de la Segona República.

En resum, podem dir que l'intent d'establir un diàleg entre productors $\mathrm{i}$ exportadors va ser una bona iniciativa que va tenir com a resultat l'esmentada conferència tarongera, la qual va posar en el debat citrícola temes importants que calia resoldre. Tanmateix, un dels principals problemes pel qual es convocava aquesta -com era l'exportació de taronja gelada- no va ser suficientment atés per tal d'actuar decididament: els interessos en joc eren molt grans i per part dels exportadors, sobretot, es va entorpir la fiscalització de la taronja en les juntes inspectores. Tampoc s'arribà a constituir la unió necessària dels agricultors en una cooperativa única, ni es va crear una assegurança o mutualitat entre productors, exportadors i Estat, ni tampoc una indústria que poguera donar eixida a la taronja malmesa per les gelades, com $s^{\prime}$ havia suggerit en la conferència.

El Govern de Primo de Rivera actuà d'intermediador entre les parts enfrontades del negoci taronjaire i va convocar la conferència a Madrid, però va actuar insuficientment pel que fa a la concessió dels crèdits, la rebaixa d'aranzels i la fabricació d'adobs que sol-licitava el sector.

Davant de la gelada de 1956, la més important del segle xx, el govern va actuar d'una manera més que insuficient pel que fa als ajuts donats als agricultors, com queda demostrat en les peticions constants i reiterades d'ajuntaments, cambres, cooperatives, sindicats, etc. Tenint en compte la gran aportació de divises a la balança comercial espanyola que implicava el comerç de la taronja, el govern hauria d'haver actuat més activament, per exemple amb la creació d'una mutualitat entre els productors, els exportadors i l'Estat que haguera salvat la situació en gran mesura, així com la creació d'una indústria de derivats de la taronja, dues antigues reivindicacions que mai van ser ateses seriosament. El règim enviava autoritats per a inspeccionar els danys que repercutirien en l'economia citrícola i, en conseqüència, en la recaptació de divises, i oferia bones paraules per a demostrar que es preocupava dels llauradors damnificats.

Pel que fa a altres organismes com ara diputacions, ajuntaments, cambres agrícoles i sindicats, constatem l'afany d'elaborar informes per a valorar els danys i la insistència a reclamar més ajudes i crèdits dels ja concedits, també perquè preveien que minvarien els recursos pel que fa $\mathrm{a}$ 
la recaptació d'impostos. D'altra banda, aquestes corporacions locals activen plans d'obres públiques per a mitigar l'atur obrer, però elles mateixes els reconeixen com a insuficients.

Quant a la premsa, hem constatat que d'una banda es lloava el règim en les visites oficials, mentre que en altres ocasions no podia fer menys que crítiques solapades o, més o menys directes -encara que escasses-, al règim, en defensa de l'interés agrícola local. De l'altra, i d'una manera global, es poden apreciar certes diferències entre els dos règims dictatorials: el directori militar del general Primo de Rivera sembla que tolerava una certa llibertat d'associació i de crítica -tot i que es decantava pels interessos dels exportadors-, com es pot veure al llarg d'aquest treball en la gran quantitat d'assemblees i en la mateixa Conferencia; mentre que la dictadura del general Franco s'exercia amb un autoritarisme i control absoluts, de manera que tot havia d'anar dirigit pels organismes oficials del règim. Això es fa palpable, sobretot, mitjançant la retòrica laudatòria de la premsa valenciana controlada pel règim franquista, tot i les queixes a favor del llaurador damnificat que alguns periodistes -i lectors que dirigien les seues protestes per mitjà de cartes-s'atrevien a exposar.

\section{Bibliografia}

ABAD, V. (1984): Historia de la naranja I (1781-1939), Comité de Gestión de la Exportación de Frutos Cítricos, València.

- (1988): Historia de la naranja II (1940-1962), Comité de Gestión de la Exportación de Frutos Cítricos, València.

- (1988): La Taronja (1781-1939), Edicions Alfons el Magnànim, Institució Valenciana d'Estudis i Investigació, València.

ABAD, V. et al. (1989): La fruita daurada: 750 anys amb taronges, Generalitat Valenciana. Conselleria de Cultura, Educació i Ciència, València.

Agustí, M. (2003²): Citricultura, Ediciones Mundi Prensa, Madrid.

Albero SANChIS, V. (1968): Las heladas en la zona naranjera de Levante, Servicio Meteorológico Nacional. Ministerio del Aire. Madrid.

AMORós, M. $\left(1999^{2}\right)$ : Producción de agrios, Ediciones Mundi Prensa, Bilbao.

ARRIBAS, L. (2000): La naranja entre milenios 30 años de citricultura, Phytoma, València.

Aupí, V. (2005): Guía del clima de España, Omega, Barcelona.

BALBÁs CRUZ, J. (1987): El libro de la provincia de Castellón, Caja de Ahorros y Monte de Piedad de Castellón, Castelló de la Plana. (reimpressió original de 1892). 
Bellver, J. (1927): La naranja española en el mundo, Servicio de Publicaciones Agrícolas, Madrid.

Bou GAscó, F., (1999): Estudio sobre el naranjo, limonero, cidro y otros árboles de la familia de las auranciáceas, que se cultivan en la provincia de Castellón, Librerías Paris-Valencia. Servicio de Reproducción de Libros, València.

CESV, Gabinete Técnico del Consejo Económico Sindical de Valencia (1963): Trascendencia de las heladas de la naranja, Consejo económico sindical de València, Madrid.

DD. AA. (1965): "Las heladas en los cítricos», Revista de Agroquímica y Tecnología de Alimentos, enero-marzo 1965, Caja de Ahorros y Monte de Piedad de València, València.

DD. AA. (1981): El llibre del bicentenari de la taronja, Ajuntament de Carcaixent, Carcaixent.

Diago Arcusa, M. i Guilabert RequenA, J. (Coords.) (2009): Castelló en blanc i negre, Ediciones Tivoli, Alcoi.

Domingo, C. (1983): La Plana de Castellón, formación de un paisaje agrario mediterráneo, Caja de Ahorros y Monte de Piedad de Castellón, Castelló de la Plana.

FAGAN, B. (2009): La pequeña edad de hielo, como el clima afectó a la historia de Europa 1300-1850, Editorial Gedisa, Barcelona.

FONT DE MORA, LI. (1971): Taronja i caos econòmic, Edicions 62, Barcelona.

FONT DE MORA, R. (1938) El comercio de los agrios españoles, Tipografia Moderna, València.

Font Tullot, I. $\left(2000^{2}\right)$ : Climatología de España y Portugal, Ediciones Universidad de Salamanca, Salamanca.

García Guijarro, L. (1927): Efectos de las bajas temperaturas en las plantas y frutas de agrios, Unión Nacional de la Exportación Agrícola, Madrid.

- (1930): Algunas normas para la exportación de los productos agrícolas: estudio comparado de las publicadas en España con las similares del extranjero, Unión Nacional de la Exportación Agrícola, Madrid.

GIL OlCINA, A. i J. OlCINA CANTOS (1997): Climatología general, Editorial Ariel, Barcelona.

GinÉs LloRens, F. (2014): "Olas de aire frío y temporales de nieve en Castellón». En http://repositori.uji.es/xmlui/handle/10234/63270

LASSALA EMO, M. (1909): Nuestra exportación naranjera: memoria presentada a los Consejos provinciales de Agricultura y Ganadería de las provincias de Valencia y Castellón, Editor J. Vila Serra, València.

LASSALA PALOMARES, V. (1873): Memoria sobre la produccion y el comercio de la naranja en España, imprenta de J. Domenech, València. 
LóPEz GómEZ, A. (1956): "Las heladas de febrero de 1956 en Valencia», en separata de la revista Estudios geográficos, any XVII, núm. 65.

NúÑEZ, J. Á., C. MUEDRA i V. Aupí (?): La gran ola de frío de febrero de 1956 en la España mediterránea.

QUeRedA SALA, J. (1976): El clima en la provincia de Castellón, Diputación Provincial de Castellón de la Plana, Castelló de la Plana.

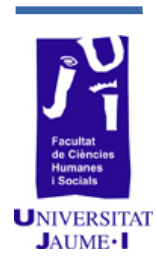

- (1985): El tiempo en la provincia de Castellón, Diputación Provincial de Castellón, Castelló de la Plana.

RIBÉs PLA, R. (1947): La naranja española. Su historia y situación actual, Est. Tip. Hijos de F. Armengot, Castelló de la Plana.

- (1989): La taronja i Castelló, Publicacions de l'Excel-lentíssim Ajuntament de Castelló de la Plana, Castelló de la Plana.

Rosselló Botey, V. (2011): «100 años del Servicio Meteorológico de la Federación Agraria de Levante: El inicio de las redes de observación y las primeras predicciones regionales en la Península Ibérica». En XVII Jornadas de Meteorología Edua. Escola Valenciana.

SALES V. (2000): "L'agricultura valenciana. La remor inaudible de la crisi», FOLCH, R. i Josep M. PALAU: Llibre verd del territori valencià 2007, València. Escola Valenciana.

SARTHOU FRANCESC, C. (1920-1927): "La naranja y su cultivo», CARRERAS y CANDI F. (1920-1927): Geografía del Reyno de Valencia, Barcelona. Alberto Martín.

Zaragoza Adriaenses, S. i R. Coscolla (1989): Riesgo de daños por frío de las áreas citrícolas de la Comunidad Valenciana, València. Generalitat Valenciana. Conselleria d'Agricultura i Pesca. 


\section{La renovación de la escultura figurativa en el cambio de siglo XIX-XX}

Adrià Arnau Solsona

8@adriaarnau.es 
A finales del siglo XIX París se convierte en la capital del mundo artístico y atrae a los nuevos artistas que buscaban crear un arte más acorde con las nuevas formas de vida de forma que supera los preceptos académicos a través de nuevos modelos plásticos.

En el ámbito de la escultura figurativa, destaca Auguste Rodin como gran renovador de una disciplina que había quedado atrapada en los cánones neoclásicos. A partir de su obra, la escultura emprende un nuevo camino y, más tarde, el escultor rosellonés Aristides Maillol retomará la revolución emprendida por Rodin dándole el último impulso para que el arte de las tres dimensiones abandone definitivamente el siglo XIX y emprenda el nuevo siglo donde la dialéctica figuración-abstracción condicionará los lenguajes de representación.

En esta comunicación se dibujará un recorrido desde las premisas de la obra de Rodin que provocaron la ruptura con la escultura académica, hasta la interpretación que los nuevos escultores dieron a la obra de Maillol, con especial hincapié en los artistas catalanes que trajeron esta nueva figuración a nuestras fronteras.

Palabras clave: escultura, Rodin, Maillol, figuración, noucentisme, mediterraneismo.

\section{Introducción}

La siguiente comunicación presenta el resumen del punto de partida de la propuesta de la tesis doctoral de Adrián Arnau y este es el de establecer un linaje de escultores que a lo largo del siglo xx cambiarán el paradigma de la escultura en Cataluña. Examinando el estado de la escultura a finales del siglo XVIII y de su evolución a lo largo del XIX, a través de los grandes nombres de referencia en la escultura, llegaremos a entender el punto culminante que supuso la llegada del siglo xx en la concepción de las teorías y la práctica escultórica.

Siempre dentro de los parámetros de la escultura figurativa, analizaremos cómo las propuestas de Auguste Rodin y Aristides Maillol supondrán una revolución, no únicamente en la estética, sino en toda la concepción de la escultura, de forma que abran el camino a la abstracción pero también a una nueva figuración.

\section{Objetivos}

Nuestro interés se centrará especialmente en cómo esta nueva figuración arraigará en Cataluña e impulsará a los escultores hacía una revisión del legado de la escultura clásica que transcienda las anteriores visiones del clasicismo para adentrar en la simplicidad y el equilibrio como 
vehículos que nos conducen a la esencia del culto a la belleza que profesaban los escultores de la Grecia clásica.

Así, el objetivo principal de la comunicación es evidenciar una tendencia en la evolución de la escultura de los dos últimos siglos que revolucionará el lenguaje escultórico e introducirá a esta disciplina, anclada en la tradición, en la modernidad que la pintura ya había iniciado con el Impresionismo.

El segundo objetivo es identificar las claves de cómo el desarrollo conceptual que supondrá la aparición de la obra de Rodin y Maillol cambiará la escultura en el territorio catalán.

\begin{abstract}
IV. Material y método
Para poder realizar un análisis como el que se pretende, ha sido necesario establecer una fuerte base bibliográfica que nos permita argumentar de manera sólida las características de la obra de cada uno de los escultores mencionados, así como de su influencia en la historia del arte.

Entre la bibliografía consultada se encuentran estudios sobre arte y escultura de los siglos XVII, XIX, y XX que nos han permitido establecer qué autores han sido los más influyentes en la renovación de la escultura. Partiendo de los resultados de la primera fase de la investigación se ha ampliado la búsqueda documental a monografías de los escultores más representativos.
\end{abstract}

\title{
V. Resultados
}

Después de analizar la bibliografía para establecer el marco de la investigación y el estado de la cuestión, se dibuja una tendencia en el desarrollo del lenguaje escultórico y en su pensamiento conceptual que, con matices, puede equipararse al desarrollo de la pintura.

El siglo XIX ve cómo el artista reclama su posición como intelectual, de forma que trasciende el carácter artesanal de algunas disciplinas. Este posicionamiento supondrá, en primer lugar, la devaluación de los aspectos técnicos de la escultura frente al tema, la composición, y otros componentes del oficio escultórico más relacionados con el intelecto que con el virtuosismo en la manufactura. Contemporáneamente, y gracias a los nuevos estudios sobre el mundo clásico resultantes de las excavaciones en el territorio de la antigua Magna Grecia, hace que la escultura se incline a una visión historicista de las formas clásicas.

La aparición de autores como Auguste Rodin y Aristides Maillol recuperará para la escultura una interpretación más viva del mundo clásico, que trascenderá la imitación y promulgará una vuelta a la escultura clásica que no se detenga en la estética, sino que escrutara los resortes íntimos de la concepción del arte griego. 


\section{Discusión y conclusiones}

Maillol es, junto con Rodin, el gran renovador de la escultura figurativa. Los dos franceses fueron clave para que la escultura decimonónica, de un academicismo decadente, reviviera para dar fruto a una nuevo ideal escultórico que podría dialogar con las propuestas artísticas más vanguardistas que traería el siglo $\mathrm{xx}$.

En los siglos precedentes, XVII y XVIII, los artistas, especialmente los escultores, habían reivindicado un papel que transcendiera la artesanía, rechazando que se les considerara meramente trabajadores manuales, y lucharon porque el público captara la verdadera dimensión de su obra. Esto hizo que se preponderara la inteligencia desplegada en el desarrollo de las obras más que la habilidad en la manufactura.

Las teorías de los filósofos alemanes tendrán en Francia, en el siglo XIX, una profunda influencia sobre la evolución de la noción de arte y sobre el comportamiento de los artistas, a través del movimiento literario del arte por el arte. El romanticismo alemán de fines del siglo XVIII y el romanticismo francés de comienzos del XIX van a hacer resurgir al artista del Renacimiento, ser de excepción o semidiós. (Gimpel, 1979: 105)

En la Academia, donde predominaba la estética y el lenguaje neoclásico, se insiste en una formación de talante humanístico, lo que conduce a la escultura a una recuperación de temas mitológicos como muestra de cultismo. Al entender la inteligencia como un aspecto fundamental en la creación, era necesario que el artista conociera y comprendiera el desarrollo histórico del arte, para poder crear a partir de la interpretación de los modelos heredados del pasado, especialmente del mundo clásico. Así, durante el siglo XIX, la escultura transita de la herencia ideológica y formal del siglo XVIII a los intereses historicistas del último tercio del siglo.

En este periodo, comienza a extenderse la idea de que el trabajo manual es indigno y que la verdadera obra de arte nace exclusivamente del intelecto. Los escultores, mayoritariamente, preferirán el trabajo del modelado en barro, y dejarán la tarea del paso a piedra o bronce en manos de los artesanos, de tal modo que el escultor, libre de las intensas jornadas y de la ardua tarea que supone el desbastado de la piedra o los procedimientos de fundición, puede dedicarse a la lectura de los clásicos, la contemplación o el disfrute de la música y la poesía. Los ejemplos del taller de Antonio Canova, donde se leen obras clásicas a la vez que se modela el barro, o Thorvaldsen, que se acompaña del piano del mismísimo Mendelssohn mientras trabaja.

Para este nuevo paradigma de la escultura la influencia de los escritos de Winckelmann sería decisiva, ya que popularizó que la escultura adquiriera en la sociedad un estatus que anteriormente no tenía. A través de su nueva concepción de la historia del arte, se desarrolló la estética neoclásica con una exaltación de los valores clasicistas y la mitología, lo que con el tiempo condujo a una escultura 
estereotipada y con un fuerte contenido moralista, que pretendía reaccionar contra la frivolidad del decorativismo del rococó.

Este cambio estuvo apoyado por los ideales de la ilustración, que surgían del racionalismo, y, en un creciente interés científico por la antigüedad clásica, provocó excavaciones arqueológicas y la formación de importantes colecciones públicas y privadas así como la publicación de estudios sobre el arte y la cultura grecorromana.

Bajo estas premisas, la escultura pondera por delante de todo la plasmación de un ideario que estilísticamente se basará en la repetición de los modelos clásicos, y donde los artistas infravalorarán los aspectos técnicos y dejarán de prestar atención a los materiales, de forma que crearán una homogeneidad de estilo que transcenderá fronteras, lo que como contrapartida supondrá la eliminación de la impronta local en beneficio de una estética más universal.

Hugh Honour parlà del neoclàssic com del primer estil internacional modern i indicà, encertadament, que el que perseguien els seus artífexs era la confecció d'un art de significat universal i validesa eterna.

Aquest estil, que coetàniament es descrivia com a estil «veritable» 0 "correcte» o, fins i tot, es qualificava com un segon risorgimento de les arts, va portar una sèrie de valors morals propis de la II-lustració als valors formals ja establerts a les Accadèmies. (Rodríguez Samaniego, 2013: 69)

A medida que se redundará en los estereotipos y la repetición devendrá copia de la estatuaria grecorromana sin aportar nuevos incentivos plásticos, esta corriente empezará a deteriorarse y perder fuerza, y llegará a finales del siglo xIx caduca y convaleciente a esperas de que la modernidad que comenzaba a vislumbrarse en la pintura llegara a las tres dimensiones (Alix, 2002: 22):

Las grandes transformaciones que había venido experimentando la pintura en el siglo XIX, desde los "plenairistas» hasta el Impresionismo, hacían aún más evidente el lamentable estado de la escultura y la urgente necesidad de renovación.

De entre los escultores de este primer tercio del siglo XIX podemos distinguir dos paradigmas que responden a dos generaciones sucesivas. Por un lado, se hayan escultores como los anteriormente citados Canova y Thorvaldsen, o Campeny en el territorio catalán, que recibieron sus enseñanzas en talleres tradicionales del siglo xVIII y que, por tanto, contaron con una base del conocimiento de los oficios escultóricos muy férrea, que, a pesar de que compartieran la concepción de la bajeza del trabajo material, conocen y dominan perfectamente los diferentes estados por los que una escultura debe pasar y son capaces de terminar sus esculturas una vez los obreros han realizado el vaciado y el sacado de puntos. En cambio, la generación que les seguirá estará formada por escultores que se iniciarán en una disciplina tan compleja, huérfanos de los conceptos formales y la sensibilidad hacia el oficio, con una formación 
notablemente más corta y precipitada y con los problemas que esta base insuficiente conllevará.

Las Academias son las encargadas de la formación de los jóvenes artistas y las que establecen concursos y becas de estudio en Madrid, Roma o París, además de imponer una rigidez basada en la imitación de la Antigüedad. Al concluir su pensionado, los más destacados se encaminan hacia puestos oficiales, como escultores de la corte o como cargos directivos en la Academia, cargos en todo caso que no permitían una experimentación formal, sino que más bien conducían a una perpetuación del modelo. La competitividad que se establece entre los artistas que optan a las condecoraciones y los méritos académicos $-\mathrm{y}$, por tanto, a los cargos oficiales- a menudo va en detrimento del mismo quehacer creativo y se tienen más en cuenta las cualidades políticas y los contactos que la calidad de la obra.

Así el siglo XIX se iniciará con el movimiento neoclásico procedente del siglo anterior y con una generación de escultores que o bien no podía o bien no le interesaba -o ambas cosas- reformar una escultura autocomplaciente encaminada a moralizar y ensalzar la imagen del poder establecido, lo que en esa época supone una decadencia de la escultura religiosa que deja paso a una producción donde cobra importancia la escultura como elemento decorativo de la arquitectura. La realeza será su gran mecenas, que con la construcción de sus nuevos palacios o la reforma de los existentes hace necesario que se establezca la plaza de escultor de cámara (Alix, 2002: 20):

Pero aún es destacable otro aspecto que llegó a tener singular importancia en la degradación de la escultura: su tradicional utilización como monumento conmemorativo y como expresión de poder. A lo largo del siglo XIX, con la exaltación de las virtudes burguesas, su misión fundamental llegó a ser la de educar y ejemplificar, proporcionando modelos éticos y morales a las masas. De ahí la pertinaz continuidad de unos principios y normas estéticas inamovibles que convirtieron a la escultura en sinónimo absoluto de clasicismo. En todos los salones oficiales se exhibían cientos de esculturas en las que, invariablemente, se repetían los mismo modelos y formas...

La decadencia de la escultura a lo largo del siglo XIX deviene una situación insostenible. Por un lado, los escultores quieren proclamarse con todo derecho artistas del más alto nivel, por encima de cualquier connotación artesanal, pero, en cambio, la «intelectualización» de los escultores no trajo consigo un desarrollo artístico comparable al que se estaba produciendo en la pintura.

La escultura siempre ha avanzado de manera más lenta que la pintura, pero en este siglo, al menos en lo plástico, lo que se produjo fue una involución, ya que los modelos recuperados del pasado no aportaban nueva vida a la escultura, únicamente transmitían el gusto de la época por la recuperación del pasado, pero sin adentrarse realmente en la esencia más intima del arte clásico, de forma que resulta un clasicismo 
estéril que no podía revivir la arcadia, sino solamente contemplar cadáveres del pasado.

Evidentemente, en esta visión desoladora de la escultura se pueden divisar algunos brotes de escultura de una calidad sobresaliente. Nos referimos a escultores como los franceses François Rude (1784-1855) o Jean-Baptiste Carpeaux (1827-1875), o Damià Campeny (1771-1855), entre otros, en el territorio catalán (Wittkower, 2006: 626).

Hay en la primera mitad del siglo XIX, e incluso en la segunda, largos trechos bastante estériles en lo que toca al arte de la escultura, aunque no pretendo decir con ello que todo fuera malo. Cuando pensamos en la escultura del XIX en seguida se nos viene a la memoria una interminable serie de monumentos públicos más bien vulgares, procedentes principalmente de la segunda mitad del siglo. Son los Garibaldis, Vittorio Emanueles y compañía, como una plaga que hubiera caído sobre todas las ciudades europeas. No obstante, no faltaron los escultores de talento y las obras de gran calidad.

En las postrimerías del siglo, aparecen dos figuras clave que reconducirán esta tendencia decadente de la escultura y la renovarán desde los cimientos para que el siglo xx pueda contemplar un nuevo paradigma escultórico que enriquecerá este arte y lo situará en la vanguardia de las artes. Estamos hablando de Auguste Rodin y Aristides Maillol. Hasta la llegada de estos dos genios, la escultura continuó un revisionismo del pasado que contrastaba con la situación de la pintura, lanzada ya hacia la búsqueda de nuevos registros expresivos.

Se podría decir que la pintura, orientada a un mercado del arte más fluido y cosmopolita, miraba hacía el futuro, mientras que la escultura, supeditada a los grandes encargos de las altas esferas de la sociedad, quedaba encorsetada en una visión al pasado endogámica, que no se sumergía en las intimidades de la esencia clásica sino que se contentaba con la repetición de los modelos oficialmente considerados correctos (Selz, 1964: 37):

Si los pintores avanzaban lenta, pero irresistiblemente, hacia lo que unos veinte años más tarde sería el Impresionismo, los escultores continuaban con los ojos fijos en el "gran arte» del pasado. La noción de "gran arte» estaba ligada teóricamente al eterno prestigio de la estatuaria antigua. Pero lo que más directamente influenciaba a los escultores de 1850 era la obra de los que, medio siglo antes, habían sido también influenciados por la estatuaria grecorromana. El inmenso renombre de Antonio Canova y de Bertel Thorvaldsen no había sido aún superado.

La escultura que habría de venir en las postrimerías del siglo, no obstante, no se erigió sobre la negación de la herencia clásica como se podría pensar, sino que se reveló contra la lectura anodina que se había hecho durante las últimas décadas, pregonando una «verdadera» vuelta al clásico, no a su estética sino a su esencia, una revisión de los valores plásticos de la antigüedad, de su sensibilidad hacia la forma y de su culto a la belleza. 
Para el historiador Rudolf Wittkower, el cambio en el nuevo paradigma escultórico se establece a partir de dos corrientes divergentes. Ambas concebían que la necesaria regeneración de la escultura no pasaba por abandonar la tradición, pero evidenciaban claramente que la relación con el pasado no podía ser una limitación como hasta ese momento lo era la rigidez estilística neoclásica, sino que debía ser un escalera que aupara a los nuevos escalones a ver más allá.

Estas dos corriente las personifica Wittkower en los escultores Auguste Rodin y Adolf von Hildebrand. Resulta curiosa la elección del escultor alemán como referente del cambio escultórico, al ser un autor poco considerado y con una obra que no se encuentra entre las más valoradas por la crítica y la historia del arte. Sin embargo, en la propuesta de Wittkower la figura de Hildebrand es totalmente esencial, ya que tanto su obra escultórica como su legado teórico -especialmente su libro El problema de la forma en la obra de arte- ilustran a la perfección una de las dos vertientes hacia las que derivará la escultura finisecular.

La de Hildebrand es una escultura basada en la talla directa, como metodología y como filosofía. No se trata únicamente de la preferencia por el mármol como material, la elección de la técnica es en Hildebrand toda una declaración de intenciones, una visión profundamente teorizada de los procesos escultóricos. En su obra, no hay sitio para la improvisación, para la casualidad, ni para el azar, todo movimiento de su cincel responde a un razonado proceso de construcción de la forma. Su ideario fue reconocido ampliamente y su libro repetidamente reeditado y traducido a diferentes idiomas; su concepción de la forma como un problema casi abstracto nos conduce a una percepción de la anatomía que nos aleja del anecdotismo académico y acercaba la escultura figurativa a la geometría.

El hándicap de la propuesta de Hildebrand es que su labor intelectual profundizó en la esencia de la construcción formal basada en la geometría y el dibujo de los perfiles, pero le alejó de otra de las grandes características del arte griego, su devoción mística por la belleza.

Lo que no consigue Hildebrand con su teoría lo consigue Rodin con su sensibilidad. En la argumentación de Wittkower, Rodin es el polo opuesto a Hildebrand. El escultor francés basa su trabajo en el modelado y deja el proceso de talla a sus ayudantes; además, en general, prefiere la fundición en bronce.

La diferencia entre la talla directa y el modelado no responde únicamente a una predilección de uno y otro por un proceso de trabajo, el motivo es algo más profundo, es la respuesta a dos concepciones de la escultura bien diferenciadas. Si de Hildebrand destacábamos su profunda intelectualización de la forma y su capacidad de abstracción del proceso de creación, y poníamos en entredicho su falta de sensibilidad y su frialdad, en Rodin veremos claramente lo contrario.

El modelado de Rodin expresa el gesto y la intensidad de carácter, detalles del tratamiento formal que se pierden cuando la escultura se pasa a piedra, pero que se mantienen en su obra vaciada en bronce. 
Resulta evidente que la escultura de Rodin adquiere su mayor énfasis en el bronce, donde además de los rastros del gesto del escultor a menudo se sumaban los «defectos» producidos por el proceso de vaciado y que el escultor dejaba visibles para incrementar los recursos formales de su lenguaje. Esta concepción de la escultura, fresca, sin tabúes, surgida directamente de las entrañas, fascinó a los pintores de la época, especialmente a los impresionistas, y con ellos llego la admiración posterior del resto del mundo del arte. Las superficies vibrantes de la obra rodiniana entonaban con el puntillismo de la pintura impresionista, y con su intención de captar el momento. Rodin busca el movimiento, el gesto, la intención.

La escultura llega a finales del siglo XIX con la certeza de que el clasicismo de la Academia está caduco y necesita una renovación acorde a las nuevas tendencias exploradas por los pintores y con dos caminos para enfocar ese cambio. El mundo clásico seguirá siendo el punto de partida y el desnudo la piedra de toque, pero la concepción de la forma se liberará por fin de los cánones y explorará nuevos lenguajes, ya sea desde el intelecto o desde la pasión la escultura flirteará con la abstracción y dejará de pretender ser una copia para ser un lenguaje expresivo. Entre la disyuntiva de estos dos caminos aflorará la figura de Aristides Maillol, que será clave para integrar las visiones de Rodin y Hildebrand en una nueva figuración. Punto de equilibrio entre concepto y sentimiento, Maillol será el iniciador del camino por el que la escultura del siglo Xx avanzará hacia la abstracción en unos casos y hacia una figuración totalmente moderna en otros (Infiesta, 1975: 133).

Com tothom sap, o hauria de saber, és amb Maillol que comença l'escultura moderna: més ben dit, és amb la Mediterrània (1905) que l'escultura recupera la seva plena tridimensionalitat, s'allibera de tot llast superflu i s'encamina cap a una creixent abstracció.

La escultura de Maillol tuvo un efecto liberador para la escultura europea. A partir de su obra se podían replantear las ideas de clasicismo y arcaicismo sin miedo a caer en el academicismo; no obstante, la frontera entre el clasicismo académico y la modernidad de Maillol, es a menudo, una línea muy sutil que fácilmente se puede confundir, ya que el peso que en cierto sentido supone el legado del arte griego es, en ocasiones, una carga que cuesta de llevar para escultores e historiadores, que, al quedarse con una interpretación epidérmica de las formas clásicas, no llegan a empaparse del gran mensaje de la Grecia clásica: la exaltación de la belleza hasta el límite de la religiosidad (Salvadó Jassans, 1995: 66):

Comprenc que és difícil per a molts no veure mediterraneïtat en tota l'escultura neoclàssica centreeuropea, quan a primera vista s'assembla tant a la grega, però la realitat és una altra. Els neoclàssics només copiaven dels grecs les formes externes. Com si haguessin ressuscitat alguns cadàvers de l'antigor, però se'ls escapa l'essencial de l'esperit de Grècia que consisteix en l'alegria de viure i que els menà a fer de l'estimació a la bellesa una religió. 
Más allá de recuperar el sentido íntimo de la acción escultórica, el regreso a esa comunión entre vida y forma escultórica, la otra gran aportación de Maillol reside en la simplicidad formal y la eliminación de todo aquello que pueda entorpecer la contemplación de la forma, de todo detalle superfluo y toda anécdota ya sea narrativa o formal.

Frente a la fascinación que supuso para los impresionistas la obra de Rodin, había una obra palpitante, con superficies que reverberaban al presentar una superficie llena de irregularidades donde la luz se expandía en infinidad de matices, donde el gesto del escultor y las marcas de la técnica (en sus bronces era un recurso usual el dejar al descubierto las imperfecciones generadas por los moldes) constituían un paisaje rocoso, fascinante, siempre cambiante. Por el contrario, Maillol entiende que estos recursos son anecdóticos, que no aportan, sino que por el contrario distraen, en la contemplación de la forma. El maestro rosellonés propone una escultura limpia, donde nada nos detenga al recorrer la forma, donde la luz repose suavemente y los volúmenes se sucedan de manera orgánica sin accidentes.

Maillol, con su simplicidad, rescata la estética de la escultura griega arcaica. Una escultura con una representación simplificada de la anatomía humana, cercana a las formas geométricas, donde todas las formas tienden a la convexidad, como si estuvieran hinchadas, como si se expandieran de dentro hacia afuera, en las que se mantiene la dosis justa de rigor anatómico para conservar el contacto con las formas vivas, sin exceso de virtuosismo, pero intentando evitar la frialdad o la desconexión con la vida. Maillol pretende un justo equilibrio entre concepto e intuición, entre forma ideal y forma natural (Infiesta, 1974: 143).

\footnotetext{
Maillol era un hombre no dotado, como Cézanne. Llegaba al arte por conceptos, no por otra cosa. Maillol tenía un sentido eterno de la escultura, era como un griego. Tuvo la suerte de saber jugar a favor del tiempo en que vivía, y, entre sus aportaciones, cabe subrayar el que suprimiera ese sabor a grasa que era la cualidad que más se apreciaba en el siglo pasado.
}

Con Maillol llega una corriente de aire limpio, purificador, que hará que la escultura recupere su sentido primigenio, que la devolverá al origen mismo de la vida.

\section{Bibliografía}

AA. Vv. (2007): Jassans: una vida dedicada a l'art de modelar, Universitat de Barcelona. Facultat de Belles Arts, Barcelona.

ABRIL, M. (1920): Enrique Casanovas. Tipografía Artística, Colección Estrella Volumen 1, Madrid.

AlIX, J. (2002): Un nuevo ideal figurativo. Escultura en España, 1900-1936. Fundación Cultural Mapfre Vida, Madrid.

BERGUA, J. (1934): Historia de la escultura. Librería Bergua, Madrid. 
CAMPS Miró, T. (2002): «La configuración y consolidación del modelo figurativo en la escultura catalana del momento noucentista», Fundación Cultural Mapfre Vida, Madrid.

CAMPS MiRó, T. y S. PORTell (2015): Les cartes de l'escultor Enric Casanovas. Publicacions i Edicions de la Universitat de Barcelona, Barcelona.

CIRLOT, J. E. (1956): La escultura del siglo XX. Omega, Barcelona.

ELÍAS, F. (1926): L'escultura catalana moderna. Barcino, Barcelona.

ELSEN, A. (1967): Auguste Rodin. Lecturas sobre su vida y su obra. Editorial Diana, México D. F.

FLYNN, T. (2002): El cuerpo en la escultura. Akal, Madrid.

FontBonA, F. y A. E. Solà (1989): L'escultor Jassans. Àmbit, Barcelona.

García, J.M. (2004): Apel·les Fenosa. els quatre elements, rere les petjades

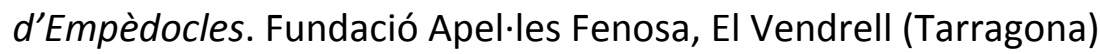

García Gutiérrez, P.F. Y J. Landa Bravo (1990): La escultura. Antiquaria, Madrid.

GIMPEL, J. (1979): Contra el arte y los artistas. Gedisa, Barcelona.

Gómez-Moreno, M. E. (1993): Pintura y escultura españolas del siglo XIX. Espasa-Calpe, Madrid.

GSELL, P. (1991): Auguste Rodin, conversaciones sobre el arte. Monte Ávila, Caracas.

Hamilton, G. H. (1980): Pintura y escultura en Europa: 1880-1940. Cátedra, Madrid.

Haskell, F., N. Penny y J. A. SuÁrez Hernández (1990): El gusto y el arte de la antigüedad: el atractivo de la escultura clásica, 1500-1900. Alianza, Madrid.

Hildebrand, A. Von (1989): El problema de la forma en la obra de arte. Visor, Madrid.

Hofmann, W. (1960): La Escultura del siglo xx. Seix Barral, Barcelona.

Hourtica, L. y M. L. Morales (1948): Historia de la escultura. Salvat, Barcelona.

INFIESTA Monterde, J. M. (1975): Un siglo de escultura catalana. Ediciones Aura, Barcelona.

Maderuelo, J. (2012): Caminos de la escultura contemporánea. Ediciones Universidad de Salamanca, Salamanca.

Marín-Medina, J. (1978): La Escultura española contemporánea, 18001978: historia y evaluación crítica. Edarcón, Madrid.

Martín González, J. J. (1964): Historia de la escultura. Editorial Gredos, Madrid. 
Martínez-Novillo, Á. y J. CAStro Arines (1987): Escultura figurativa, 19001950. Fundación Marcelino Botín, Santander.

MiRalles, F. (2009): Fascinació per Grècia. L'art a Catalunya als segles XIX i xx. Museu d'Art de Girona, Girona.

Miralles, F. y J. Salvadó Jassans (2003): Jassans: la pervivència de l'esperit clàssic. Diputació de Tarragona, Museu d’Art Modern, Tarragona.

Pons, A. y P. Parcerisas (1981): Hombres, tierras, Paisajes. Cataluña vista por sus artistas y escritores. Editorial H. M. B., Barcelona.

PRAT, J. L. (1981). Medio siglo de escultura: 1900-1945. Fundación Juan March, Madrid.

Racionero, L. (1985): El Mediterráneo y los bárbaros del Norte. Plaza, Esplugues de Llobregat.

Reyero, C. y M. Freixa (1995): Pintura y escultura en España: 1800-1910. Cátedra, Madrid.

Rodin, A., A. Le Normand-Romain, T. Dufrêne, y J. Alix, (2004): Rodin i la revolució de l'escultura: de Camille Claudel a Giacometti. Fundació «la Caixa», Barcelona.

Rodríguez SAMANIEgo, C. y J. Egea (2013): La imatge de l'heroi a l'escultura catalana (1800-1850). Grup de Recerca GRACMON, Universitat de Barcelona, Barcelona.

Salvadó Jassans, J. (1995): «Parlem d'escultura amb motiu de Julio Antonio", Revista de Catalunya, vol. 99, Septiembre, Barcelona.

SELZ, J. (1964): La escultura moderna, su origen y evolución. Editorial Eco, Barcelona.

SUBIRACHS, J. (1994): L'escultura del segle xIX a Catalunya: del romanticisme al realisme. Publicacions de l'Abadia de Montserrat, Barcelona.

Susanna, À., A. PApachristou y S. Walter (2015): Maillol i Grècia. Institut de Cultura de Barcelona, Barcelona.

TORMo y Monzó, E. (1903): La escultura antigua y moderna. Juan Gili, Barcelona.

Winckelmann, J. J. y L. Uhlig (1987): Reflexiones sobre la imitación del arte griego en la pintura y la escultura. Península, Barcelona.

WITTKOWER, R. (1980): La escultura: procesos y principios. Alianza forma, Barcelona. 


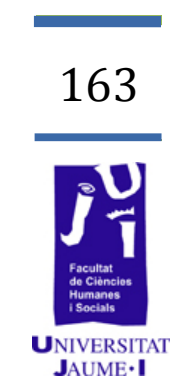

\title{
El concepto de democracia en el carlismo
}

\author{
Josep Miralles Climent \\ maneljsp@yahoo.es \\ Manuel Martorell Pérez \\ manumartel@hotmail.com
}


El carlismo suele ser considerado como un movimiento monárquico absolutista y contrarrevolucionario que se enfrentó al liberalismo en el siglo XIX, y a la democracia burguesa y partitocrática el XX. Sin embargo conviene matizar estos extremos: desde principios del siglo $x x$ se manifestó a favor de un tipo de democracia participativa según se desprende de los estudios de Juan Vázquez de Mella, que se basó en el sentido profundamente popular del movimiento carlista anterior. Tras su participación en el bando nacional en la Guerra Civil española, el sector mayoritario del carlismo se enfrentó a la dictadura franquista y acabó desarrollando un concepto de democracia basada en el socialismo autogestionario y participando con el resto de la oposición a la implantación de una democracia formal.

Palabras clave: Juan Vázquez de Mella, Estado, monarquía tradicional, democracia directa, democracia formal, sociedad civil, sociedalismo, soberanía social, concejo abierto, fueros, municipalismo, socialismo autogestionario, dictadura franquista, partido único.

\section{Introducción}

Muchas de las gentes que estuvieron comprometidos en la lucha contra el franquismo en su última década y en los años de la transición recordarán que el sector carlista mayoritario y mejor organizado de aquella época era la Comunión Tradicionalista o Partido Carlista que estaba bajo la dirección de D. Javier de Borbón Parma y su hijo Carlos Hugo. En esta época ese sector del carlismo mantuvo posiciones democráticas y revolucionarias con su propuesta de socialismo autogestionario y en contra de la dictadura franquista. En aquellos años era una organización de cierta importancia tal como se desprende de una reciente tesis doctoral (Miralles, 2015). Sin embargo, con posterioridad sufrió un desplome paulatino que llevó a esta organización a quedarse en un partido marginal y testimonial aunque hoy todavía continúa su andadura. Fueron muchas las razones de este descalabro. Por un lado, el criminal ataque terrorista contra este partido en su tradicional acto de Montejurra de 1976 por parte de los aparatos del Estado de la nueva monarquía franquista, que utilizó a la extrema derecha internacional, con el resultado de dos muertos y centenares de heridos, todos del lado del Partido Carlista. Por otra parte, la marginación que sufrió al ser denegada la legalización como partido político en las primeras elecciones de 1977. Finalmente, ya tocado por todos estos hechos, más una crisis debida a los desacuerdos internos en torno a la nueva constitución de 1978 y el desengaño sufrido por los malos resultados electorales en las elecciones 
de 1979, llevó a la dimisión de la dirección política del carlismo encabezada por Carlos Hugo.

A pesar de lo dicho, las actuales generaciones $-y$ los influenciados por la vieja propaganda franquista, que situaba al carlismo como uno de sus soportes-, ignoran estos hechos, así como que el Partido Carlista, junto al Partido Comunista -los dos PC-, fueron las dos fuerzas numéricamente más importantes de la época que se oponían a la dictadura (Jáuregui y Vega, 2007: 523). Además, con anterioridad, el carlismo fue también víctima de la represión franquista por haberse negado a aceptar, en primer lugar, el decreto de unificación de 1937 y después por no haber aceptado el régimen totalitario impuesto por el dictador. Tal como ya habían hecho los liberales en el siglo xIx, el régimen nacido de la Guerra Civil no solo reprimió al carlismo que no se plegó a sus deseos sino que, además, trató de ocultarlo: «En efecto, hubo una cierta conspiración para silenciar la historia de este antiguo y amplio movimiento sociopolítico mantuvieron los liberales y también, muy significativamente, la cultura política oficial del franquismo". Y es que, a pesar de que existió una «relación tortuosa entre el viejo Carlismo y el Régimen de Franco a partir de 1937» (Aróstegui, 1991, I: 30-31), es bastante habitual considerar al carlismo asociado al régimen franquista y unificado en el partido FET y de las JONS, incluso entre historiadores consagrados.

Por ejemplo, y pese a las nuevas aportaciones históricas realizadas en sentido contrario (Martorell, 2010 y 2014), Paul Preston defiende que el movimiento carlista aceptó «dócilmente incorporarse al partido único de Franco» (Preston, 2011: 634), y Stanley G. Payne (2010: 11), en el prólogo al libro Requetés. De las trincheras al olvido, dice que «cuando el generalísimo Franco insistió en la absoluta necesidad de alcanzar una unidad política estrecha para ganar la guerra, los carlistas aceptaron su subordinación política en el partido único». Pese a ello, la mayor parte de los testimonios recogidos en ese mismo libro, cuando hablan de la unificación y de Franco, lo hacen, a veces con desprecio, rechazando precisamente ese proyecto político autoritario. Otros historiadores que han profundizado en el estudio del carlismo de esa época reconocen esa oposición y la consecuente represión de la que fue víctima durante el franquismo, desde que, en plena Guerra Civil, Franco asumió el poder absoluto de las fuerzas rebeldes. ${ }^{1}$

También conviene recordar que la defensa de la democracia o las posiciones federalistas y socializantes no eran elementos ajenos al carlismo. En el pasado, el carlismo no defendía la democracia parlamentaria burguesa pero sí un tipo de democracia participativa como trataremos de explicar en este artículo.

1. Entre los estudiosos del carlismo que, desde distintos ángulos, coinciden en la oposición del carlismo a la dictadura franquista, cabe mencionar a Blinkhorn (1979), Santa Cruz (1985-1993), Aróstegui (1991), Clemente (1992), Caspistegui (1997), Canal (2000), Martorell (2010 y 2014) y Miralles (2015). 
De entrada convendría decir que el carlismo nunca ha sido un movimiento monolítico. No se puede hablar de carlismo sino de carlismos. Tal vez por eso existen tantas contradicciones entre los muchos autores que se han interesado por este movimiento de larga duración. Por cuestiones de espacio, no es este el lugar para exponer las diversas interpretaciones del carlismo, por lo que remitimos al estado de la cuestión en la tesis antes mencionada (Miralles, 2015: 24-42). Sin embargo, como queremos enfatizar sobre las interpretaciones democráticas del carlismo, recordaremos, a título significativo, en primer lugar la que ya hizo en su época socialista Unamuno, en su «deseo de profundizar en su conocimiento de aquel movimiento, que no encontraba suficientemente explicado en las historias al uso» (Pérez de la Dehesa, 1973: 131). Así pues, sobre el carlismo decimonónico decía Unamuno, en un artículo publicado en La España moderna en 1895, que:

Lo encasillaron y formularon y cristalizaron, y hoy no se ve aquel empuje profundamente laico, democrático y popular; aquella protesta contra todo mandarinato, todo intelectualismo y todo charlamentarismo, contra todo aristocratismo y centralización unificadora. Fue un movimiento más europeo que español, un irrumpir de lo subconsciente en la conciencia, de lo intrahistórico en la historia.

$Y$ es que, a diferencia de las democracias homologadas de los siglos $x x$ y $x x I$, en el siglo $x I x$ el sentido de la democracia era distinto, puesto que las elecciones se basaban en el sufragio censitario, por lo que no podía votar más que una minoría de la población, además existía el poder indiscutible de los caciques locales. Por lo cual, «aquel empuje profundamente laico, democrático y popular» que representaba el carlismo difícilmente se podía manifestar en las urnas y por ello adquirió forma de rebelión armada: las guerras carlistas.

Las llamadas guerras carlistas se producen en el siglo XIX en contra de los cambios que imponía el liberalismo. Fue un levantamiento con grandes dosis de espontaneidad pero con un hilo conductor, que era la defensa de la legitimidad, de los fueros y de los valores tradicionales frente al «robustecimiento sin límites del aparato estatal a costa de las libertades reales del pueblo» (Rodrigo, 2008: 73). Otros historiadores de diversas tendencias y épocas, obviando el legitimismo, han visto en los orígenes del carlismo una protesta social contra los efectos nocivos del capitalismo naciente y las desamortizaciones. ${ }^{2}$ 
IV. Carlismo y democracia en Vázquez de Mella y sus discípulos

Cuando Unamuno decía que al carlismo «lo encasillaron y formularon y cristalizaron, y hoy no se ve aquel empuje profundamente laico, democrático y popular», se estaba refiriendo, entre otros, a lo que hizo Juan Vázquez de Mella (Pérez de la Dehesa, 1973: 133). Y es que este pensador tradicionalista intentó organizar un corpus ideológico basado tanto en los planteamientos teóricos anteriores de algunos pensadores y prohombres del carlismo, tal como lo expone Alexandra Wilhelmsen (1995), como también en la praxis espontánea del campesinado adherido al carlismo, que es a los que sin duda se refería Unamuno.

Y si Unamuno fue crítico con lo que hizo Vázquez de Mella tal vez sea porque los planteamientos de este partían de una vertiente católica conservadora y de una concepción ordenancista y corporativa del Estado que en teoría política se encuentra en las antípodas de la democracia liberal. Sin embargo, obviando la teoría política, y al margen también de las llamadas «democracias populares» de los estados socialistas, o las «democracias orgánicas» como la franquista, pensamos que el concepto de democracia puede entenderse de una forma mucho más relativa de lo que se entiende en el mundo contemporáneo neoliberal donde, dicho sea de paso, el sistema democrático y constitucional homologado se encuentra cada vez más prisionero de los poderes económicos, y algunas libertades se hallan cada día más restringidas a expensas de la seguridad.

En cualquier caso, los planteamientos teóricos y modernizadores de Vázquez de Mella -como los de algunos de sus discípulos-, aun habiendo sido teóricamente asimilados en parte por los regímenes de Primo de Rivera y por el franquista, tenían, paradójicamente, unas connotaciones que le aproximaban a modelos participativos, de tipo socializante y hasta colectivista. No en balde, acuñó la palabra "sociedalismo» para manifestar el sentido profundo de lo que para él debía ser el socialismo, es decir, la participación de la sociedad en las tareas políticas que, $a$ priori, parece una mejor concepción de la democracia que la liberal, pues participar en la política es más democrático que el simple voto individual cada cierto tiempo para dejar después que sean los políticos profesionales quienes tomen las decisiones, muchas veces al margen e incluso en contra de la opinión pública.

Pues bien, a pesar de que Vázquez de Mella acabó sus días apartado del carlismo, ${ }^{3}$ fue el primer sistematizador de su cuerpo doctrinal después de la derrota militar de 1876 (tercera guerra carlista) y también un declarado defensor de su evolución y modernización ideológica, esforzándose, tanto desde su escaño de diputado como en sus numerosos mítines, en deshacer la leyenda negra que presentaba al carlismo a comienzos del siglo xx como un movimiento reaccionario,

3. Vázquez de Mella se apartó de la militancia carlista -llamada "Jaimista» en aquella época- en 1919 y formó un partido tradicionalista no legitimista. Los postulados teóricos que él había sistematizado entraban en contradicción consigo mismo puesto que la práctica política de Mella era de un mayor realismo y posibilismo. A pesar de todo, sus planteamientos doctrinales calaron en el carlismo posterior. Uno de sus discípulos, Hernando de Larramendi, llamó al tradicionalismo mellista el tradicionalismo personalista. Véase: Andrés (2000: 15-23 y 191). 
anclado en un absolutismo desfasado. $Y$ no lo hizo con nuevos planteamientos ideológicos sino en base a los valores políticos y culturales históricos del carlismo tradicional.

El modelo político de Vázquez de Mella -inspirador de otros pensadores carlistas de la época de la Guerra Civil, como Luis Hernando de Larramendi, Marcial Solana o Araúz de Robles-, concibe la sociedad como una compleja red de organismos, entidades y agrupaciones intermedias con un funcionamiento autónomo (autárquico, en expresión de los teóricos carlistas, que interpretan este término en su etimología originaria) que prevalecen y son anteriores a la organización jerárquica del Estado. En este sistema interclasista, profundamente impregnado por la religión y la doctrina social de la Iglesia, las principales entidades son los municipios y las regiones (los antiguos reinos), regidos por las leyes históricas y preconstitucionales de los fueros, y su máxima expresión política es la monarquía tradicional de corte federativo, un sistema monárquico más inspirado en la España descentralizada de los Austrias que en la orientación centralista de los Borbones. Más tarde, en los años sesenta del siglo pasado, este modelo inspirará la evolución del carlismo que desembocó, con cierto desconcierto entre parte de las bases carlistas, en el socialismo autogestionario (Martorell, 2008 y 2014).

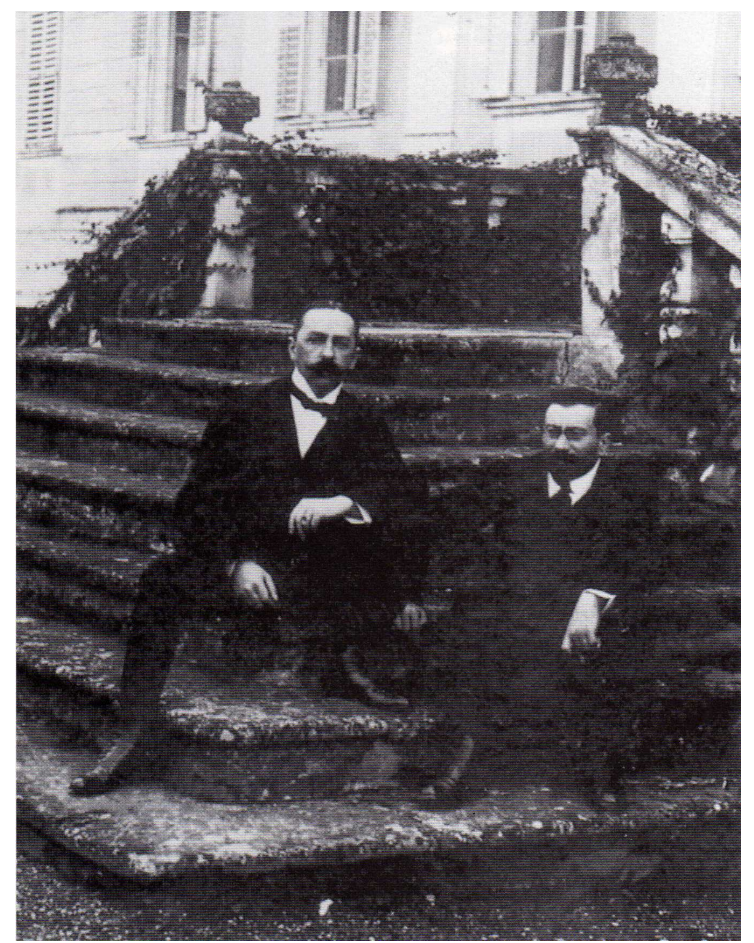

Figura 1. El rey carlista D. Jaime y Vázquez de Mella en la escalinata del Palacio de Frobsdorf, 1909 
Esta utópica filosofía política del carlismo, aunque con un profundo sentido religioso, tenía ciertas similitudes con el comunismo libertario. ${ }^{4}$ Era, por tanto, radicalmente opuesta a la ideología fascista que inspiró a la Falange y al primer franquismo. Tan es así que el propio cardenal Tarancón, en sus memorias, dice que la Iglesia «no se acababa de fiar de la Comunión Tradicionalista -a la que admiraba por su catolicismo profundo- porque su idealismo era peligroso para orientar el futuro de la sociedad» (Tarancón, 1984: 297).

Efectivamente, para Vázquez de Mella, el repetido término de autarquía es uno de los ejes conceptuales de su pensamiento político, junto a los de «soberanía social» y "sociedad civil». Esta autarquía nada tiene que ver con la acepción más difundida años después, sinónimo de aislamiento o autosuficiencia económica. En Mella la autarquía tiene su valor etimológico originario, es decir significa "valerse por sí mismo»o "gobernarse por sí mismo», y lo aplica de forma general a todas las sociedades intermedias, aunque de forma más específica al autogobierno, a la autonomía política y económica con las que deben regirse todos los municipios y regiones. Son innumerables sus referencias a la autarquía en este sentido, y siempre insistiendo en que el Estado no debe interferir en el funcionamiento de las instancias inferiores y en que todo el conjunto institucional debe quedar coronado por una "monarquía federativa». Para él, la autarquía supone el triunfo de la "soberanía social» de las sociedades intermedias sobre la «soberanía política» del Estado. Mella habla del antedicho concepto que denomina "sociedalismo», que para él significa «la desmembración de las atribuciones del Estado para que vuelvan a incorporarse a la sociedad de donde las arrancó» (Vázquez, 1931, X: 260). De esta forma, la soberanía social puede ejercerse, de forma autárquica, es decir con "vida propia, no sometida al Estado», en todos los grados y órganos -la escuela, los gremios, las corporaciones económicas, las universidades, el municipio, la comarca, la región"desde la familia hasta el Estado», siguiendo la «ley universal de la cooperación y el mutuo auxilio» (Vázquez, 1931, IV y X: 163 y 260). Estas diferentes entidades o "personas colectivas», como él prefiere llamarlas, "forman la base de la sociedad civil -él dice que la familia y el municipio son las raíces de la sociedad civil-, "un gran sistema" en el que, para satisfacer las "necesidades múltiples y comunes", se dotan de una representación común» que plasma orgánicamente esa «soberanía social» y se amplía a través de una «jerarquía ascendente» opuesta a la «jerarquía descendente» del Estado a través de su sistema funcionarial de cuya «voluntad depende». ${ }^{5}$

4. A este respecto es interesante comparar los planteamientos del estudioso del movimiento libertario y de la sociedad rural tradicional, Félix Rodrigo Mora, con los que aportan los carlistas Mella, Larramendi o Solana. Aunque los planteamientos de Rodrigo Mora son de una radicalidad total, tienen muchos puntos en común con estos, como son las críticas al Estado y a la democracia formal, la defensa del autogobierno por medio de la institución del concejo abierto, la recuperación de los comunales, la necesidad de armonía y concordia en la sociedad, la espiritualidad, etc. Véase: Rodrigo, (2011).

5. Vázquez de Mella se refiere explícitamente a esta concepción de la soberanía social como funcionamiento autárquico de las entidades y organismos que componen la sociedad civil sin la intervención del Estado, además de en el discurso del Teatro de Santiago de 1902 (Vázquez, 1931, IV y V: 163 y 301), en el que da en Barcelona el 20 de 
Como ejemplo de la intromisión «ilegítima» del Estado, incluido del Parlamento y la "oligarquía política» que representa, cita lo inaudito que para él resulta que en la Cámara de Diputados se debata sobre el uso de "la lengua de un pueblo», refiriéndose a las otras lenguas habladas en España. (Vázquez, 1931, XXVII: 100):

Parecerá cosa inaudita -dice sorprendido-, será asunto de befa para las generaciones venideras que en el Parlamento haya podido discutirse alguna vez si el Estado tiene derecho a intervenir para cercenar la lengua de un pueblo...

Si por Vázquez de Mella fuera, la democracia directa que propugnaban los padres del anarquismo Rousseau y Proudhon sería la única y consecuente -la única lógica, dice Vázquez de Mella-, ya que considera una burla la delegación del ejercicio del poder que hace la colectividad a través de la representación parlamentaria. Es uno de los temas socorridos con los que Vázquez de Mella afronta las críticas que le llueven por no aceptar el sistema electoral y la representación de los partidos en el Parlamento durante la Restauración monárquica. Lo dice al forjarse como político, en 1893, lo repite en 1895:

La verdadera democracia popular [es] aquella que hace que participen todos, lo mismo en el seno de la familia que de las clases, lo mismo en los municipios que en las regiones, de todas las libertades y garantías que corresponden, contra las invasiones de la soberanía política, a la soberanía social de los pueblos.

Lo reitera en 1916 -cuando goza de su máxima popularidad- y lo continúa afirmando en 1920, prácticamente al final de su carrera política: "Si la democracia fuera verdad, tendría que ser democracia "directa" y no representativa». Especial importancia da a este tipo de funcionamiento político en los pequeños municipios que «deben ser, como en lo antiguo, una asamblea individual y corporativa a la vez», al estilo de los "concejos abiertos». ${ }^{6}$

enero de 1907 (Vázquez, 1931, XX: 180), ante el Congreso el 1 de julio de 1912 (Vázquez, 1931, X: 260), también en la Cámara el 30 de julio de 1916 (Vázquez, 1931, III: 387), de nuevo en Santiago de Compostela el 31 de julio de 1918 (Vázquez, 1931, XXVII: 204 y 274), en el Teatro del Centro el 20 de abril de 1920 (Vázquez, 1931, XX: 11) y también en el citado mitin del Teatro Princesa del 14 de abril de 1921 (Vázquez, 1931, IV: 339).

6. Sobre las referencias a Rousseau y Proudhon se puede ver la intervención de Vázquez de Mella en el Congreso el 30 de mayo de 1893 y otras referencias a la «democracia directa» en sus discursos del Congreso el 29 de marzo de 1895, La Coruña (2 de septiembre de 1916), Covadonga (26 de octubre de 1916) y Teatro Real de Madrid (25 de mayo de 1920). 


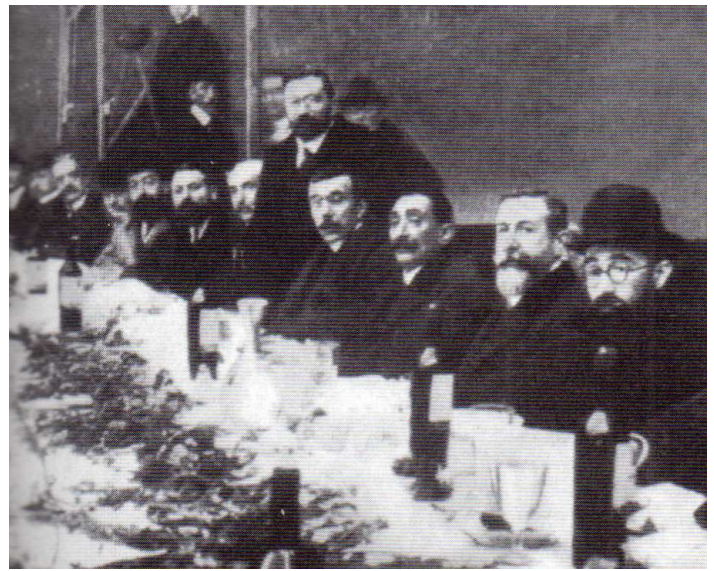

Figura 2: Reunión de carlistas con los diputados de su formación. En el centro, de pie, Vázquez de Mella; en primer plano, con sombrero, el escritor Valle Inclán.

12 de enero de 1911.

El problema que el mismo Vázquez de Mella observa es que ve difícilmente realizable esta forma de democracia a niveles superiores al municipio y, además, la delegación del ejercicio del poder que supone la representación política a través de los partidos o el sufragio universal en esta época supone la manipulación de un cuerpo electoral mayoritariamente falto de conocimientos para "responder por cuenta propia a cuestiones que no conoce». Y en Archanda, en agosto de 1919, añade:

cuando se desciende a la hora del sufragio, o lo dan como siervos, o miden el voto por su necesidad y la expresan en moneda, y se quedan con la moneda y venden el voto; el dinero será la voluntad de los ricos, que son los menos, no de los pobres, que son los más.

El otro tipo de democracia es la que "afirma la comunidad de derechos innatos, civiles y corporativos» vinculada a «la familia, las clases y la sociedad nacional». Es en este tipo de democracia donde propone la "universalización del sufragio a todas las clases», y añade que no tienen ningún inconveniente en que se conceda «dentro de las clases el sufragio a las mujeres», algo que, en su opinión, no defienden algunos partidos "porque en España las mujeres tienen mucho espíritu católico y tradicional» (Vázquez, 1931, VIII: 97). Y de esta democracia "proporcional» y "corporativa», la más genuina para los carlistas es la municipal, sobre la que se debe construir toda la estructura del Estado: "Queremos -dice en el Parque de la Salud de Barcelona el 17 de mayo de 1903- que España entera sea una federación de Repúblicas en los municipios». Los municipios no deben tener «más representación que la popular», su propia capacidad fiscal y ser "absolutamente independientes». En las sesiones del Congreso del 18 de junio de 1907 y del 30 de junio de 1916, insiste en que si no hay independencia y autarquía municipal tampoco habrá «regiones autónomas e independientes dentro de su propia esfera» y «la descentralización y mucho más la autarquía se convertirán en palabras huecas». 
El tribuno carlista insiste en otros dos aspectos políticos peculiarmente carlistas: la responsabilidad exigible a todas las instancias políticas del Estado, incluido el jefe del Estado, y el derecho de los electores a exigir cuentas de su actuación a sus representantes, es decir, lo que generalmente se denomina "mandato imperativo». En este sentido, Vázquez de Mella se queja repetidas veces de que el Gobierno y sus ministros estén amparados por la inmunidad que les otorga su cargo, lo que resulta de ello una situación que califica de régimen oligárquico y absolutista. (Vázquez, 1931, VII y VIII: 163 y 6). Sobre el monarca, en 1895, defiende el axioma de que «no son los pueblos para los reyes, sino los reyes para los pueblos» -Congreso, 29 de marzo- y, al final de su carrera política, el 23 de noviembre de 1919, en las páginas de El Pensamiento Navarro se queja de que el jefe del Estado «no responda de nada», lo que para él significa que "no hace nada» puesto que "la responsabilidad y la imputabilidad de las acciones son inseparables».

También tiene clara su posición ante la responsabilidad que deben mostrar los elegidos ante sus electores, comenzando con el mantenimiento de su independencia respecto al poder político. Son muchas las referencias suyas a los conceptos de incompatibilidad, mandato imperativo y de revocabilidad de los representantes elegidos en una votación. ${ }^{7}$ Así, entre los cuatro fundamentos en los que se debe basar la representación en las Cortes incluye «la incompatibilidad entre el cargo de diputado y toda merced, honor y empleo, exceptuando los que son obtenidos por rigurosa oposición» y «el mandato imperativo como vínculo entre el elector y el elegido", tal y como reitera cada vez que explica su sistema de representación corporativa. Los diputados deben ser responsables ante sus electores y no ante los partidos, y los electores deben tener la posibilidad de destituir a los diputados, cuyos cargos han de ser "mudables» y de mantener con ellos una «dependencia perpetua». Solamente así las Cámaras dejarán de ser «irresponsables» o, lo que considera peor, responsables solamente ante los partidos y ante los Gabinetes.

Entre los muchos discípulos de Vázquez de Mella -que falleció en 1928- figuran Luis Hernando de Larramendi, Marcial Solana o José María Araúz de Robles, que militaban en el carlismo cuando escribieron obras, durante los años de la Guerra Civil y el primer franquismo, siguiendo la estela de su maestro.

En 1937 Larramendi escribió El sistema tradicional, pero la censura prohibió su impresión hasta que se pudo publicar en 1952 aunque con el enrevesado título de Cristiandad, tradición, realeza, para poder sortear a los censores. En 1951, aprovechando igualmente la desfalangización del régimen, Marcial Solana consigue publicar El tradicionalismo político

7. En este caso las referencias son continuas y seguidas; comienzan en 1893 (31 de mayo en el Congreso) y acaban en 1920 ( 25 de mayo en el Teatro Real). Asimismo, igualmente se encuentran en discursos, intervenciones públicas y parlamentarias realizadas en 1894 (23 de abril, Congreso), 1895 (3 de octubre, en El Correo Español), 1902 (29 de julio, en el Teatro de Santiago), 1908 (27 de febrero, en el Congreso), 1909 (19 de julio, El Correo), 1914 (24 de diciembre, en una entrevista a La Nación) y 1919 (23 de noviembre, en El Pensamiento Navarro). 
español y la ciencia hispana, que había sido escrito también durante la Guerra Civil, en 1938. Para este autor, el sistema tradicional se basa en el conjunto de sociedades intermedias, como el municipio, la familia y demás colectividades infrasoberanas que son anteriores al Estado y en las que este nunca debe inmiscuirse. Al contrario de lo que ocurre en los sistemas totalitarios, para el carlismo las sociedades intermedias tienen «derecho a levantarse contra el Estado y a demandarle por algún robo de alguna de sus facultades o atributos» (Solana, 1951: 260-261). Recordando las palabras de Vázquez de Mella, insiste en que el Estado debe respetar "el sentido democrático de los antiguos concejos abiertos», celebrando "las asambleas municipales» $y$, cuando «las condiciones de la población lo impidan, sustituirlos con el referéndum», se debe "restaurar la libertad municipal [que] es la base de las libertades políticas» (Solana, 1951: 355-358).

Para Hernando de Larramendi, aparte de mantener la validez de propuestas políticas concretas de Vázquez de Mella, como son el mandato imperativo de los representantes populares o la defensa de un ejército profesional y voluntario, en El sistema tradicional coincide con Mella en concebir la tradición como base de partida para una evolución política siempre en progreso para perfeccionar y avanzar ideológicamente. Parafraseando a su maestro, Larramendi dice que «la tradición es el mecanismo del progreso» porque "no hay más progreso posible que el que puede producirse por la tradición». Con vehemencia se queja de que los tradicionalistas llevan «un siglo razonando, aclarando y demostrando que nada más lejano del absolutismo como la tradición» porque «en el sistema tradicional no hay de totalitario más que el orden orgánico de todas las libertades legítimas». Y añade que «el tradicionalismo legitimista es la oposición al absolutismo». Igualmente insiste en desmontar la imagen negativa que producía la defensa que hacía el carlismo de la aristocracia; para Larramendi -nueva coincidencia con Mella-, la aristocracia debía entenderse en el sentido más estrictamente etimológico del término, es decir, el gobierno de los mejores, de los más preparados, y no de los que forman la clase nobiliaria antigua, la clase de "los que tienen dinero, vaya usted a saber de qué procedencia», dice, con sorna, Larramendi (1952: 173). El sistema tradicional supone la conexión directa y orgánica con el carlismo más genuino, más ortodoxo, porque se identifica con el modelo de sociedad civil descrito por Vázquez de Mella, una sociedad civil a la que debe estar supeditada la estructura política del Estado porque la soberanía social reside en los organismos intermedios; la configuración del Estado, en consecuencia, debe tener una proyección federal. Larramendi admite, incluso, y en esto va más allá que Mella, «la posibilidad de salirse de la unidad política para naturalizarse súbdito de otra [...] Las naciones no implican forzosa y naturalmente lo que ahora se llaman Estados» (Hernando, 1952: 70). «El Estado -dice más adelante- no es más que la máscara detrás de la que, manejando la fuerza numérica de las muchedumbres en disolución y servidumbre, se sustituye por arribistas a 
las autoridades naturales y legítimas» (Hernando, 1952: 81). Por el contrario, lo que realmente tiene valor es la federación transversal y simultánea de la red de sociedades que se gobiernan a sí mismas en base al ejercicio de esas libertades naturales que son los fueros; entre esas sociedades cita las repúblicas, behetrías, gremios, señoríos, concejos abiertos de funcionamiento asambleario, que equipara con el "comunismo puro», comunidades laicas y religiosas... (Hernando, 1952: 211).

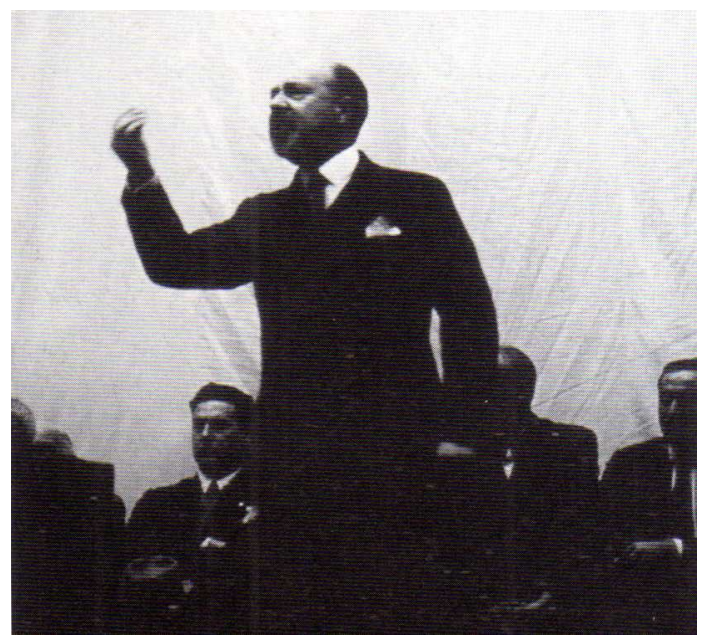

Figura 3: Luis Hernando de Larramendi durante un discurso en San Sebastián.

Por su parte, la obra Corporativismo gremial, de J. V. C., prologada por Araúz de Robles y editada por iniciativa del mismo dirigente tradicionalista, aunque se refiere casi exclusivamente al sistema social, laboral y productivo, también coincide con Mella en que el carlismo debe poner todo su empeño en reedificar la sociedad civil, en la que está depositada la soberanía social, la verdadera soberanía de una nación, por encima de la del Estado. En este proceso debe jugar un papel importante "el restablecimiento de las propiedades comunales y colectivas de los pueblos» aunque también habla del derecho de la Iglesia a tener bienes. Defiende, de forma paralela, el "fomento del asociacionismo libre» y pone, como ejemplo, el funcionamiento de los sindicatos, que «serán gobernados y dirigidos por un dirigente o jefe sindical designado por la Junta y responsable ante ésta y la Asamblea», y por una "Junta, que estará compuesta por representantes de los distintos oficios y categorías, elegidos por los que las integren» $y$, finalmente, por una "Asamblea general, que tendrá competencia específica para intervenir en todas las cuestiones de carácter económico y que podrá ser oída sobre los contratos colectivos de trabajo». Cuando todo ese sistema "horizontal» quede representado en las Cortes, los representantes lo serán por "sufragio orgánico» -no universal-, de los miembros de cada corporación y actuarán «bajo régimen de mandato imperativo y con plena responsabilidad siempre». En la línea «anticapitalista» mantenida por 
Mella, la obra rechaza radicalmente el capitalismo liberal porque está «basado en un materialismo y un egoísmo feroces» (J. V. C., 1937: 220223), porque es el responsable de que «hombres opulentos y riquísimos han puesto sobre la multitud innumerable de proletarios un yugo que difiere poco del de los esclavos» y porque, "en su afán de lucro desmedido", se ha olvidado de los "postulados de justicia y humanidad" que defiende el cristianismo. También señala explícitamente que sus posiciones están «inspiradas en las justas y admirables enseñanzas de la Iglesia», citando, concretamente, a las encíclicas Quadragesimo Anno de Pío XI y a Rerum Novarum, de León XIII. Lo que trata de impedir es la lucha de clases, o sea, el enfrentamiento social a que está llevando la explotación de los trabajadores y la respuesta del sindicalismo revolucionario. Igualmente Corporativismo gremial denuncia la injusticia social a que se había llegado en las tres primeras décadas del siglo xx y propone la potenciación del cooperativismo, como lo hizo Vázquez de Mella (Vázquez, 1931, XIV: 16 y 36-37).

En esta obra se insiste sobremanera en que es necesario mejorar las condiciones higiénicas tanto de los lugares de trabajo como de las viviendas, donde las infrahumanas condiciones de vida ponen en peligro la salud de las mujeres y los niños, lo que, a su vez, aparta a estas familias de la virtud cristiana (J.V.C., 1937: 56-61).

Ya en el Acta de Loredán, de finales de 1896, se adoptó como "programa social del carlismo» la encíclica Rerum Novarum publicada por León XIII en 1891. El Acta de Loredán supuso la primera inmersión oficial del carlismo en la problemática social y obrera. ${ }^{8}$ Pese a llevar la firma de Cerralbo, en realidad dicha acta habría sido inspirada por Vázquez de Mella.

Aunque Araúz de Robles hace en 1937 un planteamiento teórico del "sindicalismo carlista» no quiere decir que se partiera de la nada. De hecho el carlismo ya había sido el impulsor -al menos hasta 1923- de los potentes Sindicatos Libres, fundados en la Barcelona de 1919 por trabajadores carlistas de su cinturón industrial, que rivalizaron con los anarcosindicalistas. Colin M. Winston, en su investigación sobre los Libres, ha roto la leyenda negra de estos sindicatos, a los que se les ha catalogado de "amarillos», de que estaban dirigidos por curas o que han quedado reducidos a mera banda de pistoleros al servicio de la patronal. Winston, en su concienzudo estudio ha subrayando el papel movilizador de la clase trabajadora que tuvieron los Sindicatos Libres y la lucha por los derechos de sus afiliados, muchos de los cuales procedían de la CNT (Winston, 1989: 110-167), especialmente a partir de la hecatombe sufrida por este sindicato entre 1920 y 1922 y su ilegalización en 1924 (Del Río, 2002: 101 y 190-191). En cualquier caso la praxis de los Sindicatos Libres, con su experiencia de lucha reivindicativa y de clase, dista mucho de los

8. Parece que ya existían antecedentes nada menos que 40 años antes; Winston considera que un lejano precursor de los intentos del carlismo por llegar a las masas obreras urbanas fue la «Escola de Virtut» de Barcelona, donde también se debatían problemas sociales, y que fue cerrada por las autoridades liberales por su supuesta implicación en la huelga general de 1854 (Winston, 1989: 26). 
planteamientos más teóricos, utópicos y corporativos de Araúz de Robles y Vázquez de Mella.

\section{Carlismo: República y Guerra Civil}

A pesar de estas consideraciones, y en buena parte debido a su conspiración contra la Segunda República y después por su participación en la sublevación militar contra el Gobierno del Frente Popular, se ha englobado al carlismo bajo el término genérico de franquismo sin tener en cuenta las posiciones opuestas al totalitarismo que, incluso en plena Guerra Civil, adoptaron los seguidores de Javier de Borbón-Parma y Manuel Fal Conde que representaban el sector mayoritario dentro de este movimiento político.

$\mathrm{Ni}$ siquiera responde a la realidad que el carlismo acogiera con hostilidad el advenimiento de la Segunda República el 14 de abril de 1931, como demuestran varios documentos, de forma muy especial el "Manifiesto a los Españoles» de Jaime de Borbón, fechado en París el 23 de abril y publicado en El Correo Catalán el día 25. En esta importante declaración del pretendiente se proponen dos grandes medidas políticas: una «federación de las distintas nacionalidades ibéricas» y la adopción de un sistema de "representación proporcional» puro. Como es sabido, la Constitución de diciembre de 1931 no incluyó esa propuesta federal, de forma que se agudizó el problema autonómico tanto en Cataluña como en el País Vasco -rechazo del Estatuto Vasco-navarro de Estella-, e implantó un complejo sistema electoral mayoritario que, a la postre, contribuyó a polarizar políticamente la sociedad española.

Entre los destacados dirigentes "jaimistas» (nombre que recibía entonces el carlismo) que acogieron con esperanza la Segunda República destaca el caso de Tomàs Caylà, jefe carlista en el Principado, quien en esos momentos dice a sus seguidores que «tenim el deure moral de deixar que es faci la provatura, que es vegi si pot reeixir una república d'ordre i de veritable democràcia que pose remei a alguns dels mals del país». ${ }^{9}$ También el propio D. Jaime, en una entrevista a la revista Estampa, el 2 de mayo de 1931, decía:

-El gobierno provisional va, quizá, a verse atacado desde la derecha y desde la izquierda, y sin embargo, hace falta que se sostenga. Por el momento, es garantía de orden y de paz. Yo no comparto, naturalmente, muchas de las ideas de los hombres que lo forman, pero no cometeré la injusticia de negarles honradez, talento y patriotismo... Figuras como las de Lerroux, Alcalá Zamora, Azaña, Prieto, Marcelino Domingo y Maura me parecen de un indudable valor.

-Y los jaimistas, ¿̇los apoyarán?.

-Los jaimistas los apoyarán resueltamente hasta que se celebren las elecciones y el Parlamento exprese, en definitiva, la voluntad nacional...

9. "L'adveniment de la República», atículo publicado en Joventut, núm. 656 del 16 de abril de 1931 (Guinovart, 1997: 209-210). 
- ¿Y si, como parece probable, la voluntad nacional se decide por la República...?

-La respetaré... Yo no podía acatar la soberanía de la familia que acaba de salir de España, porque el Trono no le pertenecía; porque lo usurpaba, iporque yo era y soy el único representante legítimo del principio monárquico en nuestra patria!. Ante la Republica, que no comete ese fraude, ante la Republica, creada por la voluntad nacional, no tendría más remedio que inclinarme. ${ }^{10}$

Y tras reafirmar sus derechos dinásticos, pese a la proclamación de la República, D. Jaime continúa diciendo: "Pero que no renuncie a mis derechos no significa que hostilice a la República. Si España quiere la República, el deber de un buen español es respetarla, aunque contraríe sus ideas y sus sentimientos...»

Sin embargo, los carlistas acabaron conspirando contra la República apelando a un motivo fundamental que también les llevaría a participar en la Guerra Civil: la defensa de su religión y su fe católica que consideraban en peligro. Porque en otros aspectos, como el social, las bases carlistas se hallaban objetivamente más cerca de la izquierda que de sus enemigos, como se puede comprobar en la actividad de los Sindicatos Profesionales en Euskal Herría, la huelga general de la construcción en Pamplona, la defensa del cooperativismo o de los bienes comunales de los ayuntamientos. Es, en este sentido, muy significativo el comentario que en sus memorias hace el destacado dirigente comunista Santiago Carrillo tras interrogar a unos voluntarios carlistas que habían hecho prisioneros en la Guerra Civil (Carrillo, 1993: 596):

socialmente no se diferenciaban de la mayor parte de nuestros soldados, eran trabajadores de la tierra, quizá sus padres poseyeran o llevaran en arriendo una pequeña heredad. Pero eran muchachos acostumbrados a ganar el pan con el sudor de su frente, como los que combatían en el Ejército republicano.

Por lo que se refiere a la posición del carlismo respecto a los planteamientos democráticos en plena Guerra Civil, no hace falta insistir en que durante esta guerra, como suele ocurrir por lo general en los conflictos bélicos, se produce una situación de absoluta excepcionalidad debido al predominio de la organización, estructuras jerárquicas y objetivos militares. Tampoco hace falta demostrar que en el llamado «bando nacional» no todos eran fascistas ni en el bando republicano no todos defendían la democracia formal. Teniendo en cuenta los estudios existentes en estos momentos, resulta innegable que el carlismo, al menos el sector mayoritario -el denominado «javierista» o "falcondista»-, comenzó a ser perseguido desde sus inicios por el naciente régimen franquista debido, precisamente, a las posiciones antitotalitarias, especialmente con motivo del Decreto de Unificación de 1937 (Martorell, 2008 y 2010).

10. Estampa, 2 de mayo de 1931. 
Ese mismo año de 1937, la expulsión del territorio nacional, siguiendo órdenes directas de Franco, de Javier de Borbón-Parma, el destierro a Portugal y amenaza de ejecución contra Manuel Fal Conde y el encarcelamiento de Antonio Arrúe, uno de los dirigentes más destacados del carlismo vasco, además de secretario personal de D. Javier, son claras muestras de esta situación. Lo mismo se podría decir de los ya citados y censurados libros de Marcial Solana y Luis Hernando de Larramendi y, sobre todo, de la Jura de los Fueros Vascos ante el Árbol de Gernika el 19 de mayo de 1937, exactamente un mes después del Decreto de Unificación, un solemne acto que escenificaba la incompatibilidad de los dos modelos políticos.

Con todo, la posición política del carlismo queda plasmada formalmente en la llamada "Manifestación de Ideales», un documento trascendental contra el partido único elevado a Franco en marzo de 1939, aunque su elaboración se había realizado a lo largo de 1938. Este documento es fundamental para comprender la posición política del carlismo «javierista» durante toda la década de los cuarenta y la evolución ideológica posterior ya que, en el fondo, recuperaba el proyecto modernizador de Vázquez de Mella, y se convertía, por ello, en fuente ideológica para todos los manifiestos difundidos por la entonces Comunión Tradicionalista durante el periodo de la posguerra (Martorell, 2008 y 2010).

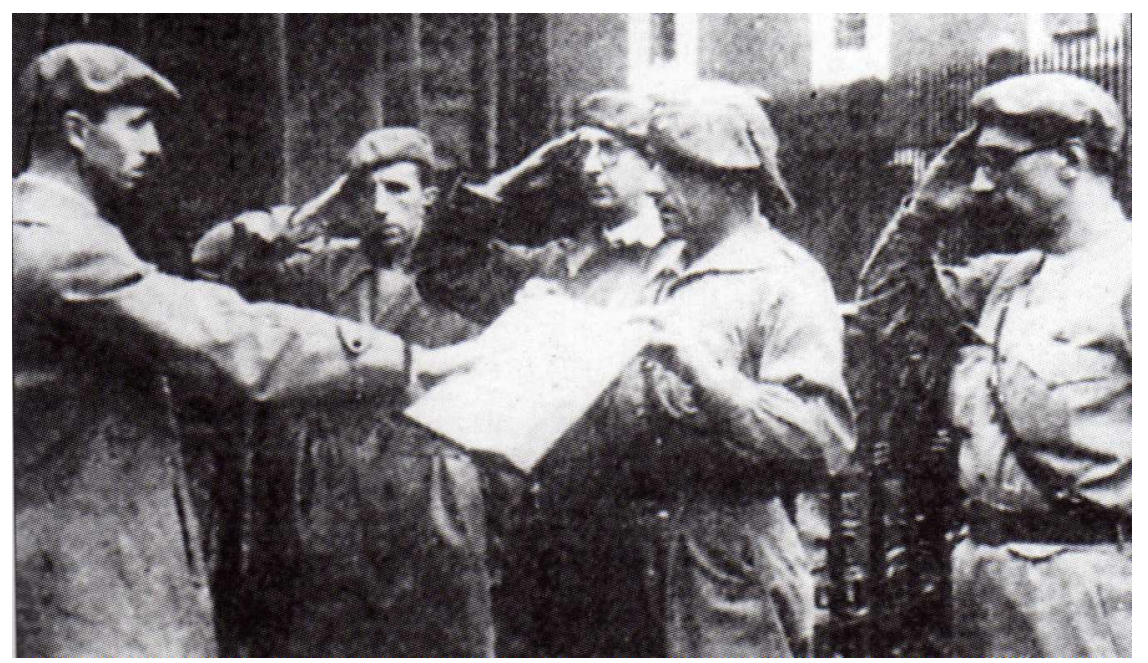

Figura 4: Solemne Jura de los Fueros Vascos por D. Javier de Borbón Parma ante el Árbol de Gernika el 19 de mayo de 1937, un mes después de que se decretara la Unificación. Toma el juramento el capellán Javier Erice rodeado por un grupo de oficiales requetés -Antonio Arrúe es el de la derecha-en posición de saludo militar y no con el brazo en alto como era preceptivo debido a la Unificación.

El choque entre los dos modelos políticos, el de corte fascista de FET y de las JONS, y el tradicional y fuerista del carlismo tuvo su máxima expresión en el atentado de Begoña el año 1942 y en los graves incidentes registrados en Pamplona y Valencia el 3 de diciembre de 1945, al celebrar los carlistas públicamente que D. Javier había sido liberado del 
campo de exterminio de Dachau, en el que había sido internado por la Gestapo bajo la acusación de colaborar con la Resistencia francesa.

\section{Documentos contra la dictadura}

A lo largo de los años cuarenta fueron varios los documentos, manifiestos y proclamas que, siguiendo la estela de la «Manifestación de Ideales», intentaban recuperar los planteamientos políticos difundidos por Vázquez de Mella. Entre ellos se puede destacar el titulado «La única solución", ${ }^{11}$ difundido el 2 de febrero de 1947, donde se insiste de nuevo en (Santa Cruz, 1985-1993: IX, 10):

La primera sociedad civil, anterior al Estado, con fines y esfera de acción propios son los Municipios, evolución de la primera sociedad natural, o sea, la familia. El Estado respetará y reconocerá la autónoma actuación de los Municipios, dentro de su competencia [...] Su elección debe ser libre, y hecha por todos los vecinos [...] Los alcaldes serán elegidos por los Ayuntamientos.

Garantizada su independencia administrativa por medio de los oportunos recursos, las hacienda locales serán nutridas libremente por los Ayuntamientos.

El documento continúa hablando de «esa restauración de la vida orgánica, connatural a la sociedad» con la que (Santa Cruz, 1985-1993: IX, 12-13):

el Estado se habrá desprendido de muchas de las funciones que hoy detenta, devolviendo a sus diversos sectores el gobierno efectivo y directo de sus intereses y actividades, participando así el pueblo en la tarea de Gobierno, dentro de su círculo de vida. La misión del Estado en este orden se concretará en garantizar que cada sector no se salga de su propia órbita; que dentro del mismo ni existen exclusiones de nadie, ni monopolios de dirección y administración de los fuertes con opresión de los débiles.

Sobre la organización de estas sociedades intermedias, dice que se regirán por su propio estatuto y que el Estado no podrá intervenir ni en la elección ni en la designación de los cargos. Asimismo, como garantía de los derechos de todos los individuos y sociedades infrasoberanas, "se dará vida y realidad a una Justicia dignamente dotada e independiente, a cuyo frente estará con plena y total separación del Gobierno, el Justicia Mayor del Reino».

Los últimos documentos importantes de este periodo de posguerra reiteran esta visión del Estado supeditado a la sociedad civil. Así se puede ver en la declaración de la Comunión Tradicionalista sobre las elecciones municipales convocadas en octubre de $1948^{12}$ y en las resoluciones

11. Puede verse el texto íntegro de este documento en Santa Cruz (1985-1993: IX, 6-25).

12. "Normas básicas de una ordenación económica y presupuestaria», artículo publicado por el número 12 del boletín Monarquía Popular. Tiempos Críticos en diciembre de 1948. 
adoptadas por el Consejo de la Comunión celebrado los días 9, 10 y 11 de marzo de 1951, pero sobre todo en un importante documento fechado en 1952 que, bajo el título "Palabras del Carlismo», describe, desde una perspectiva puramente teórica y académica, «lo que es y afirma la Tradición de las Españas en 1952», como reza el subtítulo. Se trata de un documento de 50 páginas mecanografiadas que realiza un sistemático repaso a los fundamentos ideológicos del carlismo, comparándolo con las tendencias filosóficas y políticas más relevantes de la época. Ya la referencia a «las Españas» y no a España, en singular, indica el grado de ortodoxia de este ensayo, que insiste, a lo largo de sus seis capítulos, en distanciarse y condenar al mismo tiempo los sistemas de democracia formal, los totalitarios -fascistas o estalinistas- y los liberales, aunque subraya de forma especial su rechazo a «movimientos políticos totalitarios del tipo Falange Española y de las JONS». ${ }^{13}$

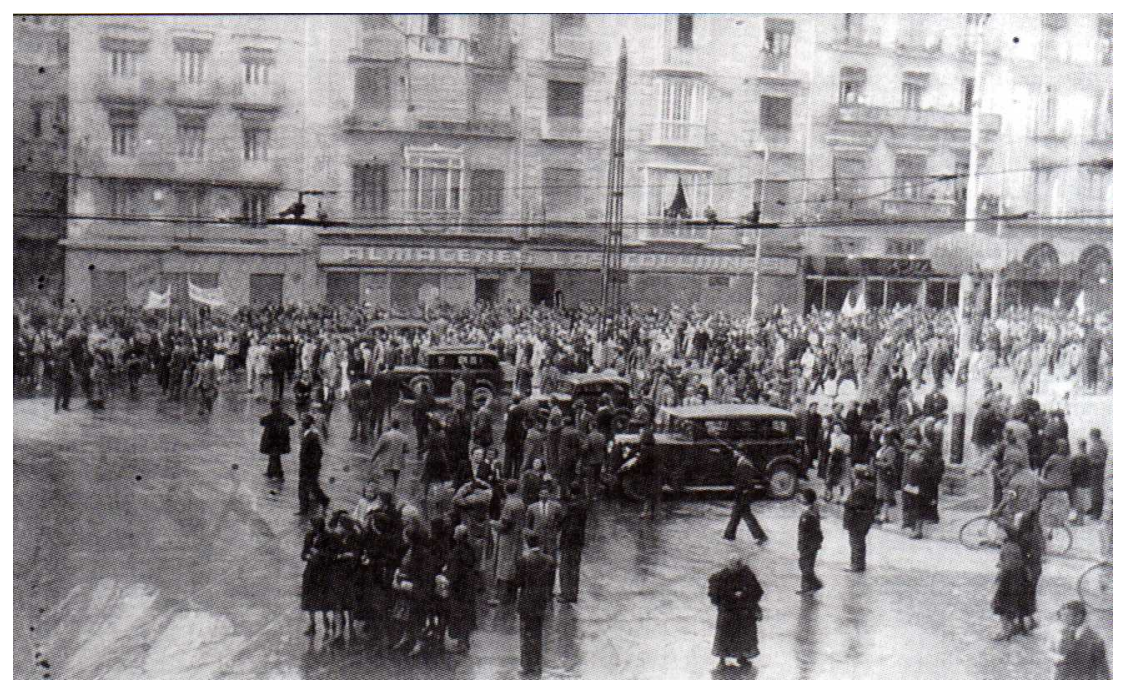

Figura 5: Aspecto de la multitudinaria manifestación celebrada en Valencia el 3 de diciembre de 1945 para celebrar la liberación de D. Javier de Borbón Parma del campo nazi de Dachau y que se desarrolló en un clima de gran tensión. En la de Pamplona se produjo un enfrentamiento armado entre carlistas y policías.

Del ideario de Falange Española y de las JONS dice que ha sido «impuesto dictatorialmente por Francisco Franco» a través de una unificación que «con ser forzada y ficticia implica la destrucción de los Fueros", de forma que queda anulada la personalidad de los "pueblos hispanos» y las "libertades concretas (...) porque el régimen nacionalsindicalista no reconoce más ley que la voluntad irresponsable e ilimitada del dictador omnipresente». El carlismo es algo bien distinto, comenzando por la reivindicación expresa que se hace del periodo de los Austrias, desde la "conversión» de Carlos I, frente al posterior de los Borbones, quienes implantaron un absolutismo inspirado en el centralismo versallesco que "aplastó los postreros restos de las individualidades regionales» y redujo "las Españas a la uniformidad, aniquilando aquella variedad unida». Sin hacer mención alguna a la

13. AHN. Fondo Familia Borbón-Parma.«Palabras del Carlismo», p. 3. 
«unidad» de los Reyes Católicos defendida por Víctor Pradera, ese documento aparece claramente inspirado en las doctrinas de Vázquez de Mella, presentando la "Monarquía Federativa y Misionera» como un sistema de instituciones y entidades intermedias que sirven de marco para que el «hombre concreto (tradicional)» -en oposición al «hombre abstracto» del liberalismo- pueda ejercer su libertad de forma independiente respecto al Estado. $\mathrm{Si}$ «el totalitarismo lo reduce todo al Estado» y el liberalismo "al individuo, desconociendo la sociedad y preparando la supresión del aparato estatal, el carlismo busca en la sociedad la armonía del individuo en el Estado».

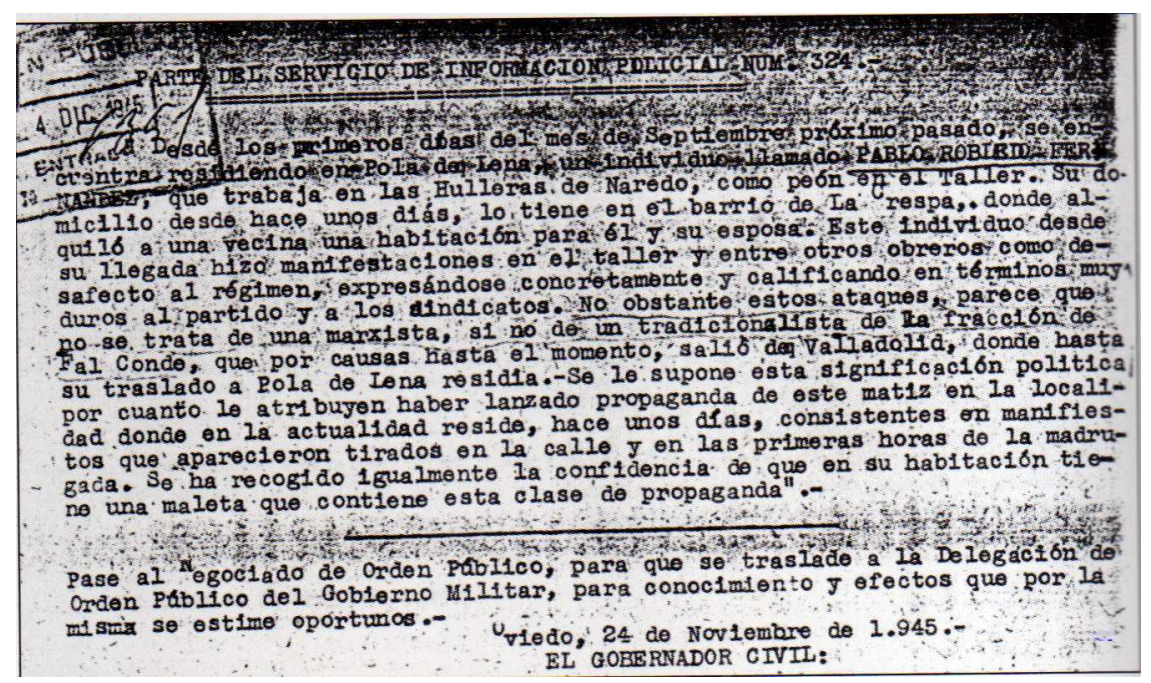

Figura 6: Atestado del Servicio de Información policial de Oviedo sobre propaganda contra el régimen, atribuida inicialmente a comunistas asturianos pero que finalmente resultó haberla distribuido un minero carlista.

Esto se concreta en que "las entidades locales de derecho natural (como el municipio o la región) poseen una realidad anterior a la de los poderes estatales»; es decir, debe haber un reconocimiento expreso de la "condición institucional autárquica de esas entidades menores, cuya actividad puede ser regulada con causa justa por el poder público, pero jamás sustituida, suplantada o ni siquiera menoscabada». Y continúa diciendo que «las sociedades inferiores aceptan del Estado una potestad directiva, jamás absorbente u opresiva». En este sistema, los Fueros son el «conjunto de normas peculiares por que se rige cada uno de los pueblos españoles», en una sociedad organizada horizontalmente. «El carlismo -sintetiza- concibe a las Españas como un conjunto de repúblicas autárquicas federadas en la monarquía» y los Fueros «son el instrumento legal para forjar concretamente la realidad libre de las entidades autárquicas menores ${ }^{14}{ }^{14}$

También mantiene posiciones muy duras respecto a las Cortes creadas por Franco porque "suprimen la representación popular» y no son otra cosa que la "voluntad omnipresente de un dictador». Sobre los sistemas totalitarios dice que «a veces admiten la existencia de Cortes o 
Parlamentos pero solo de modo nominal y ficticio, pues reduce el supuesto cuerpo representativo a dócil instrumento de los caprichos del dictador». Así califica a las Cortes del régimen franquista creadas por la ley de 17 de julio de 1942, "cuyos componentes no ostentan más representación que la de la voluntad de Franco, trocándose sus actuaciones en eco humilde de la omnipresencia del Caudillo y en la más cara de las farsas que jamás se escenificaron en España». Y añade que «no representan absolutamente a nadie [...] Ni uno solo entre los procuradores representa otra cosa que el beneplácito del dictador monologando». ${ }^{15}$ Dos años después, en 1954, volvería a exteriorizarse este enfrentamiento con motivo del "contrafuero» cometido por el gobernador civil de Navarra, el falangista Luis Valero Bermejo, contra el que los carlistas lanzaron una campaña propagandística y de manifestaciones callejeras que obligó a la intervención de unidades especiales de la Policía.

Con el esbozo que se ha apuntado sobre la filosofía que informaba al carlismo en los tiempos del primer franquismo $-y$ antes-, se podría concluir que se trata de una concepción política de tipo corporativo y ordenancista pero intrínsecamente democrática que, en cualquier caso, se hallaba en las antípodas del régimen autoritario o dictatorial del general Franco.

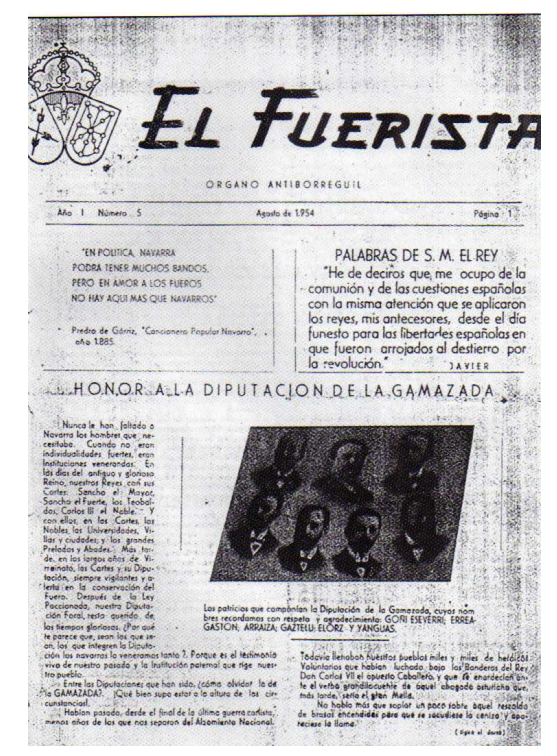

Figura 7: Portada del número de El Fuerista de agosto de 1954, en plena campaña carlista de defensa de los fueros navarros frente a los intentos del gobernador falangista Valero para reducirlos a la mínima expresión.

Todos estos planteamientos apuntados hasta aquí, fueron algunos de los fundamentos que en los años sesenta y setenta del siglo xx inspirarían al sector mayoritario del carlismo a adoptar como ideología -ahora tras

15. Ídem, p. 40. La palabra «humilde» y la frase "y en la más cara de las farsas que jamás se escenificaron en España» se pueden leer en el original mecanografiado pero después fueron tachadas. 
amplios debates entre los militantes en el seno del Partido Carlista- el Ilamado socialismo autogestionario que, en definitiva, era una concepción que pretendía alejarse tanto de la dictadura del proletariado o del socialismo de Estado, como de la democracia burguesa o democracia formal, ${ }^{16}$ una etapa que, por su complejidad y relevancia histórica, merece ser tratada en otro estudio monográfico. ${ }^{17}$

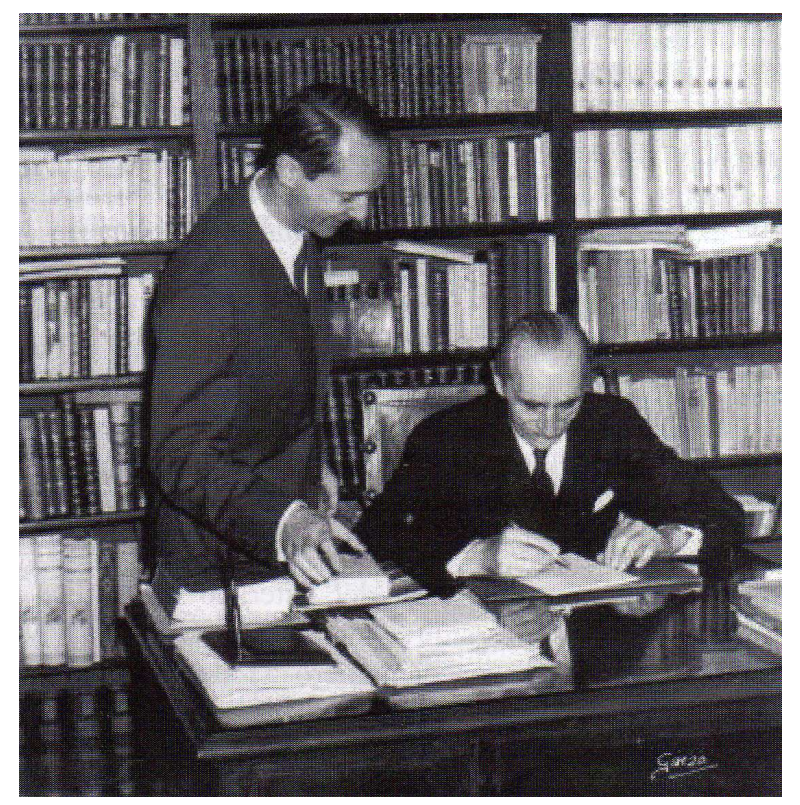

Figura 8: Carlos Hugo con su padre, D. Javier de Borbón Parma, iniciadores de la renovación ideológica del carlismo a mediados del siglo xx que desembocó en el socialismo autogestionario.

\section{Bibliografía}

ANDRÉs, J. R. de (2000): El cisma mellista. Historia de una ambición política, Actas, Madrid.

Aróstegul, J. (1991): Los combatientes carlistas en la Guerra Civil española, 2 tomos, Aportes, Madrid.

- «El carlisme en la dinámica dels moviments liberals espanyols. Formulació d'un model» en CANAL J. (coord.) (1993): El carlisme. Sis estudis fonamentals, L'Avenç y SCEH, Barcelona.

BADENES, M. À. (1982): «La venta de bienes eclesiásticos en las comarcas castellonenses. Desamortización de Mendizábal (1836-1845)», Estudios castellonenses, núm. 1, Diputació de Castelló.

BLINKHORN, M. (1979): Carlismo y contrarrevolución en España 1931-1939, Crítica, Barcelona.

16. Esta concepción, de la que existen abundantes documentos escritos en archivos diversos -nosotros hemos consultado en el Arxiu del Partit Carlista del País Valencià de Vila-real-, fue plasmada en el libro que publicó Carlos Hugo, el líder del Partido Carlista (C. H. Borbón-Parma, 1977).

17. Para esta última etapa del carlismo se pueden consultar: C. H. Borbón Parma, (1977); M.T. Borbón Parma (1979); Clemente, 1992; Caspistegui, (1997); Vallverdú, (2014); Miralles, (2015). 
BORBón-PARMA, C. H. de (1977): La vía carlista al socialismo autogestionario. Proyecto carlista de socialismo democrático, Ediciones Grijalbo, Barcelona.

Borbón PARMA, M. T. (1979): La clarificación ideológica del Partido Carlista, Editorial EASA, Madrid.

CANAL, J. (coord.) (1993): El carlisme. Sis estudis fonamentals, L'Avenç y SCEH, Barcelona.

- (2000) El Carlismo, Alianza Editorial, Madrid.

CARRILlo, S. (1993) Memorias, 3a edición, Planeta, Barcelona.

CASPISTEGUI, F. J. (1997): El naufragio de las ortodoxias. El carlismo, 19621977, Eunsa, Pamplona.

Clemente, J. C. (1992): Historia general del carlismo, Servigrafint, Madrid.

FERRER, M. (1941-1979): Historia del tradicionalismo español, 30 tomos, ECESA, Sevilla.

FonTANA, J. (1993): «Crisi camperola i revolta carlina» en CANAL, J. (coord.) (1993): El carlisme. Sis estudis fonamentals, L'Avenç y SCEH, Barcelona.

GuinOVART, J. (1997): Tomàs Caylà, un home de la terra, Cossetània, Valls.

Hernando de LaRRAmendI, L. (1952): Cristiandad, tradición, realeza, Cálamo, Madrid.

J. V. C. (1937): Corporativismo gremial. La organización social en la España nueva, Editorial Requeté, Burgos. Prólogo de José María Araúz de Robles.

JÁUreguI, F. Y P. Vega (2007): Crónica del antifranquismo, Planeta, Barcelona.

MARTORELl, M. (2008): La continuidad ideológica del carlismo tras la Guerra Civil, Tesis doctoral, UNED, Madrid.

- (2010): Retorno a la lealtad. El desafío carlista al franquismo. Actas, Madrid.

- (2014): Carlos Hugo frente a Juan Carlos. La solución federal para España que Franco rechazó, Eunate, Pamplona.

MiRAlles, J. (2015) El carlismo militante (1965-1980). Del tradicionalismo al socialismo autogestionario, Tesis doctoral, UJI, Castellón de la Plana.

Payne, Stanley G., prólogo en Larraz P. y V. Sierra-Sesúmaga (2010): Requetés. De las trincheras al olvido, La esfera de los libros, Madrid.

Pérez de LA DeheSA, R. (1973): Política y sociedad en el primer Unamuno, 2a edición, Ariel, Barcelona.

PIQUERAS, J. A. (1994): «El carlismo latente. Desposesión agraria y protesta campesina en Castellón (1843-1868)», Saitabi, XLIV, Universitat de València. València. 
PReSton, P. (2011): El Holocausto español. Odio y exterminio en la Guerra Civil y después, Debate, Barcelona.

Río, S. DEL (2002): Corporativismo y relaciones laborales en Cataluña. Una aproximación desde la prensa obrera, UAB, Barcelona.

RodRIGO, F. (2008): Naturaleza, Ruralidad y Civilización, Brulot, Madrid.

- (2011): La democracia y el triunfo del Estado. Esbozo de una revolución democrática, axiológica y civilizadora, 3a edición, Editorial Manuscritos, Morata de Tajuña.

SANTA Cruz, M. de (1985-1993): Apuntes y documentos para la Historia del tradicionalismo español, 28 tomos, ECESA, Sevilla.

SANZ, V. (2000): "Los condicionantes sociales del carlismo. El caso valenciano», Millars. Espai i Història, UJI, núm. XXII.

SOLANA, M. (1951): El tradicionalismo político español y la ciencia hispana, Editorial Tradicionalista, Madrid.

TARANCÓN, V. E. (1984): Recuerdos de juventud, Grijalbo, Barcelona.

TORRAS, J. (1993): «Contrarevolució pagesa?» en CANAL, J. (coord.) (1993): El carlisme. Sis estudis fonamentals, L'Avenç y SCEH, Barcelona.

VALLVERDú, R. (2014): La metamorfosi del carlisme català: del «Déu, Pàtria i Rei» a l'Assemblea de Catalunya (1936-1975), Publicacions de l'Abadia de Montserrat, Barcelona.

VÁzquez de Mella, J. (1931): Obras Completas. Junta de Homenaje a Vázquez de Mella, Madrid.

WilHeLmSEN, A. (1995): La formación del pensamiento político del carlismo (1810-1875), Actas, Madrid.

WINSTON, C. M. (1989): La clase trabajadora y la derecha en España: 19001936, Madrid, Cátedra. 


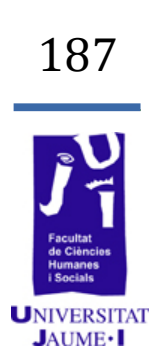

\section{Un mayorazgo castellano en manos femeninas.} El caso de doña Ana María de Catalá en la herencia de los condados de Cirat y Villafranqueza (s. XVIII)

Antonio López Amores Antonio.lopezamores@gmail.com 
Hacia finales del siglo XVIII, los condados de Cirat y Villafranqueza habían recaído, por razones sucesorias, en una misma rama familiar de los Zapata de Calatayud, fruto de las estrategias de ascenso desarrolladas junto con otras casas valencianas desde el siglo xVII. Sin embargo, los dos títulos de conde podían separarse si restaba como única descendencia una mujer, debido a las diferentes características de cada uno.

Gracias a la investigación realizada con fuentes documentales de diferentes archivos estatales, abordamos aquí la situación de la hija primogénita del conde de Cirat, doña Ana María de Catalá, en estos últimos años de la centuria. Así, buscamos mostrar la particular condición de las integrantes femeninas de las familias de la nobleza y cómo, debido al restrictivo marco normativo que pendía sobre la mujer en el Antiguo Régimen, los intereses de la casa se imponían a los de la propia descendencia más inmediata.

Con arreglo a tal fin, exploramos la particular herencia que recibió doña Ana, gracias a la victoria de un pleito sobre la posesión de un mayorazgo fundado en las postrimerías del siglo XVI. Este, pese a poder ser heredado por varones, pasaría, durante tres generaciones, de unas manos femeninas a otras y, al mismo tiempo, condicionaría el reparto de los bienes que establecería el propio conde, primando a sus hijos varones pero también garantizando una herencia para la primogénita acorde a su posición.

Palabras clave: nobleza, mujer, género, Reino de Valencia, Cirat, Villafranqueza, Meneses, mayorazgo, herencia.

\section{Introducción y objetivos}

A la hora de abordar el estudio histórico de una figura femenina, son varios los sesgos que deben ser superados, con tal de ofrecer una reconstrucción tan válida como veraz. Entre ellos, destaca la propia situación de desigualdad, parte del orden social del Antiguo Régimen, tanto legal como cultural, que se abría entre hombres y mujeres. Al mismo tiempo, también resulta problemática, todavía hoy, la poca atención prestada a la mujer como sujeto histórico. Situación que ha ido cambiando paulatinamente desde que los estudios de género comenzaron a adentrarse en la historiografía, a finales del siglo pasado.

Tratando de superar todo ello y gracias a las contribuciones de investigadores e investigadoras que han ayudado a identificar y sobrepasar estas limitaciones históricas e historiográficas, pretendemos aquí mostrar parte de los resultados de nuestra investigación. Esta ve sus objetivos centrados en torno a la familia Zapata de Calatayud y, más concretamente, los roles desempeñados por las mujeres que la 
conformaban durante los siglos del Antiguo Régimen. Podemos afirmar que el texto que se expone a lo largo de las siguientes páginas es el fruto de una labor investigadora que, debido a los lógicos márgenes de este trabajo, todavía está avanzando y en proceso de desarrollo. Asimismo, las conclusiones aquí presentadas se centran en una de las mujeres de la familia, doña Ana María de Catalá y, al mismo tiempo, suponen una primera aportación al estudio de la historia nobiliaria y de la historia de género.

Teniendo como objetivo el conocer y comprender las circunstancias que envuelven a un personaje histórico resulta imprescindible adentrarse en su entorno y contexto más cercano, es decir, su círculo familiar. Por ello, antes de centrar nuestro foco de atención en el caso de doña Ana María, profundizaremos primero en la conformación del patrimonio de los Zapata de Calatayud hasta las fechas próximas al ejemplo aquí presentado. Sólo entonces abordaremos la parte del estudio correspondiente a la hija del conde de Cirat y Villafranqueza, y su situación respecto a la herencia y estrategia familiar. Así, en definitiva, tras realizar un somero análisis del recorrido de ascenso de la familia, es nuestra intención individualizar los rasgos que representa en su seno este personaje femenino y que creemos identificativos de un marco mayor $y$ general.

\section{Material y método}

Para iniciar un estudio histórico nobiliario del Antiguo Régimen, resulta imperativo realizar, en primer lugar, una labor bibliográfica; una serie de lecturas que permitan al investigador conocer qué se ha escrito al respecto, qué casos similares pueden aportar puntos de apoyo al trabajo y qué conexiones pueden trazarse respecto a pasadas investigaciones. Dentro de la bibliografía utilizada, que ha permitido obtener las nociones y los conocimientos esenciales para ubicar los sucesos y personajes en su contexto, hemos accedido a obras procedentes de la historiografía de las últimas décadas del siglo pasado así como de los primeros años del presente. En el elenco de obras consultadas destacan aquellas pertenecientes a los estudios nobiliarios, particularmente las que se adentran en las familias nobles del Reino de Valencia. Del mismo modo, publicaciones referentes a la familia y al lugar de la mujer en la sociedad suponen una consulta obligada si se pretende prestar mayor atención a personajes femeninos.

Seguidamente, es el análisis de la información obtenida gracias a la consulta de las fuentes históricas lo que permite la formulación de nuevas hipótesis y la elaboración de un estudio coherente e innovador. Así, la documentación consultada, su selección y estudio ha variado considerablemente en función de la etapa de la investigación: más abierta y voluble en un principio, mientras que mucho más concreta y determinada en las fases más tardías del proceso. 
Tanto la figura de doña Ana María de Catalá como las situaciones relacionadas aquí descritas suponen solamente una porción del conjunto de la investigación. Previamente, como bien indicamos más arriba, fue necesario conocer el trasfondo de la familia, así como su desarrollo a lo largo de los siglos de la Edad Moderna. Otros personajes femeninos fueron individualizados, al mismo tiempo que se reconstruía la historia de la casa. En el actual proceso investigador, todavía en curso, continuaremos explorando roles, relaciones, vinculaciones y actuaciones de las mujeres de la familia Zapata de Calatayud.

\section{Trasfondo familiar: los dos condados de los Zapata de Calatayud}

Los condados de Cirat y Villafranqueza habían recorrido diferentes familias y linajes y habían investido a varios hombres y mujeres con sus títulos hasta las postrimerías del siglo xvII. Fue en estas fechas cuando, gracias a la ejecución de un doble matrimonio en la década de los noventa entre las familias valencianas Civerio Folch de Cardona y Zapata de Calatayud, se sentaron las bases que sirvieron de desencadenante de la unión de ambos títulos. Los resultados de esta estrategia, sin embargo, distaban de ser inmediatos: no sería hasta el ecuador del siglo xvIII que un miembro de los Zapata de Calatayud podría titularse con ambos condados. $^{1}$

Durante la Guerra de Sucesión, ambas familias desempeñaron una intensa participación en el bando austracista (Chiquillo Pérez, 1991: 122), lo que les supuso diferentes nombramientos y mercedes. Esto resultó particularmente notable para el entonces conde de Villafranqueza, don Joseph Civerio Folch de Cardona, que recibió la Grandeza de España en 1721 por parte del archiduque Carlos, asociada a dicho condado (Felipo Orts, 1997: 520-521). El fallecimiento sin sucesión de don Joseph permitió a los descendientes del matrimonio de su hermana, doña Teresa Civerio Folch de Cardona y el conde de Cirat, don Gaspar de Calatayud, recibir como herencia ambos condados.

1. Archivo de la Diputación de Castellón [ADC], Donación del Conde de Cirat, caja 13, leg. 1, documento 1. Parte de esta información puede también ser consultada en la obra de Felipo Orts (1997: 519). 


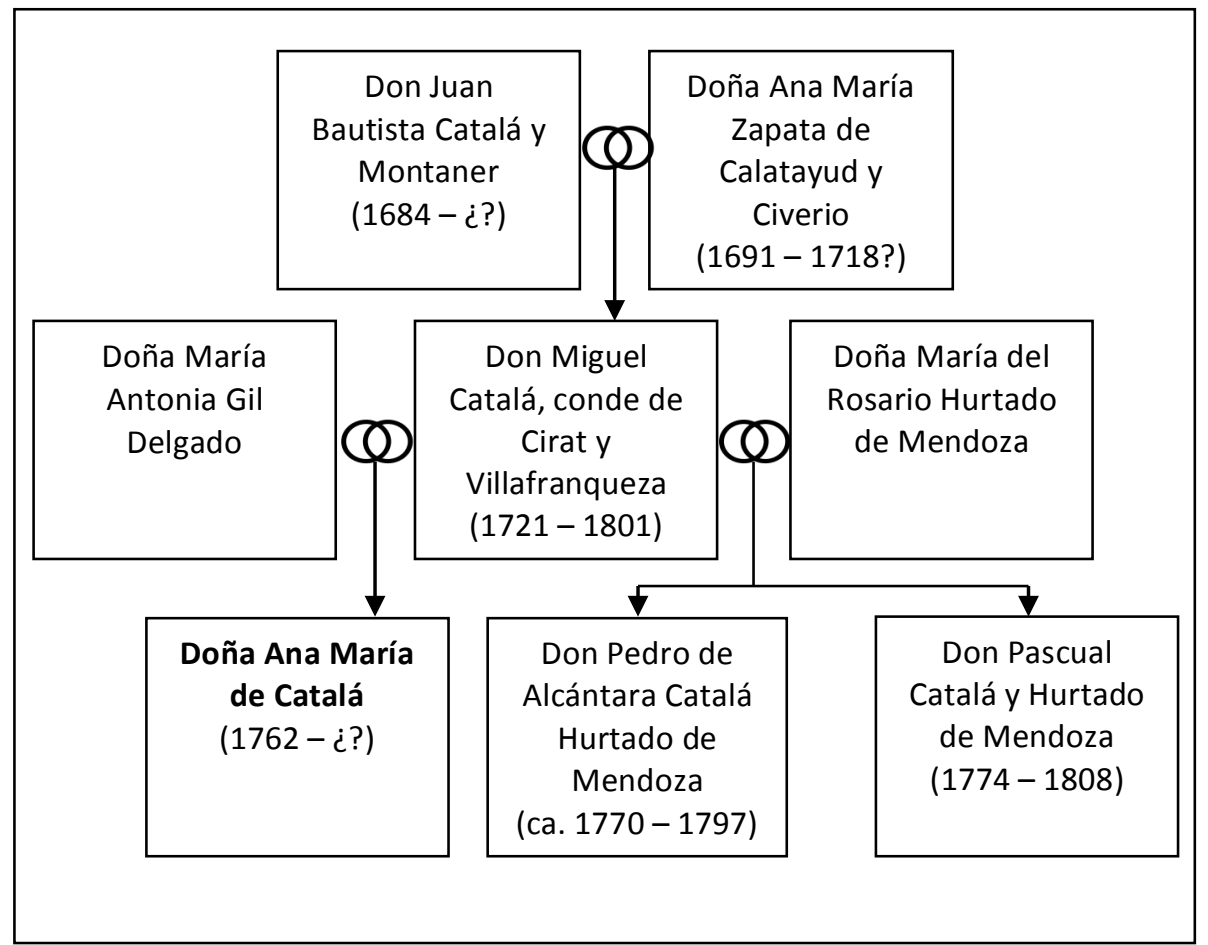

Figura 1. Familia próxima a don Miguel Catalá Zapata de Calatayud y doña Ana María de Catalá (1680 - 1810)

Fuente: elaboración propia según $A D C$, donación del Conde de Cirat, caja 23, leg. 5, documento 1.

Era esta, no obstante, una situación singular. El condado de Cirat, concedido en la primera mitad del XVII a favor de la familia Carroz, era de carácter agnado. Por ello, su obtención estaba limitada a los hombres de la familia y totalmente restringido a las mujeres. Por otro lado, el condado de Villafranqueza, instituido en 1603, presentaba una disposición regular, de modo que, agotados los herederos varones, podían recibirlo las mujeres (López Amores, 2015: 48-51). Esta configuración de ambos legados podía suponer un peligro a la hora de transmitir a un solo heredero ambos condados, ya que resultaba imposible que una mujer recibiese el de Cirat.

De este modo -con tal de ubicarnos en las inmediaciones históricas del caso que pretendemos analizar-, hacia finales del siglo XVIII, los condados de Cirat y Villafranqueza habían recaído sobre la persona de don Miguel Catalá Zapata de Calatayud, ${ }^{2}$ conocido también como don Bernardo de Vilarig. Este era hijo de don Juan Bautista Catalá y Montaner y de doña Ana María Zapata de Calatayud y Civerio, nacido el 1 de marzo de 1721, nieto directo del noble don Gaspar de Calatayud. ${ }^{3}$

Es esta la figura de un conde fuertemente involucrado en el engrandecimiento de su linaje, por lo que las trazas dejadas en la documentación de los diferentes procesos iniciados con este fin son notables. Destacan, sobre todo, los movimientos destinados a alcanzar el

2. Remitimos a la Figura 1 para la consulta de los lazos familiares de don Miguel Catalá Zapata de Calatayud y su hija, doña Ana María de Catalá.

3. $A D C$, Donación del Conde de Cirat, caja 23, leg. 5, documento 1. 
reconocimiento por parte del monarca Borbón, Carlos III, de las mercedes concedidas por el archiduque a sus antepasados. Principalmente, se trataba de conseguir el rango de Grandeza de España para el título de conde de Villafranqueza. Ello resultaba posible gracias a los acuerdos logrados con la firma de la paz de Viena en 1725, donde se estipulaba que todas las mercedes y gracias realizadas por ambos contendientes durante la Guerra de Sucesión debían ser ratificadas por el correspondiente adversario (Felipo Orts, 1997: 520-521, 537). Así, alcanzar la más alta dignidad nobiliaria se postulaba como una opción probable para los Zapata de Calatayud, dada la concesión ya mencionada realizada por el antiguo pretendiente austriaco.

Sin embargo, pese al acuerdo, la ratificación de la merced no se había producido y, en febrero de 1785, don Miguel Catalá, conde de Cirat y de Villafranqueza, realizó la petición al rey, con el fin de que se cumpliera el artículo IX de la mencionada paz y se le concediese el rango de Grande de España (López Amores, 2015: 51-52). No sería hasta tres años más tarde, el 17 de junio de 1788, cuando recibió finalmente la concesión de Grandeza de España de segunda clase (Guardiola y Spuche, 2004: I, 275). Este suceso otorgaba al título del condado de Villafranqueza una importancia y prevalencia significativa sobre el de Cirat, lo cual repercutiría, posiblemente, en que las estrategias familiares tratasen de salvaguardar la conservación del mismo.

A lo largo de su vida, don Miguel Catalá contrajo matrimonio en dos ocasiones. La primera de ellas fue con doña María Antonia Gil Delgado, hija de don Rafael Antonio Gil Delgado y doña Francisca Antonio Rodríguez de Salamanca. De esta unión nació doña Ana María de Catalá, mujer sobre la que centramos nuestro estudio en el siguiente apartado. Tras el fallecimiento de su primera esposa, celebró segundas nupcias con doña María del Rosario Hurtado de Mendoza, en el año 1770. Ya en el año 1774 habían concebido dos hijos: don Pedro de Alcántara Catalá -heredero directo de los condados-y don Pascual Catalá. ${ }^{4}$

\section{Un mayorazgo castellano en manos femeninas}

El 27 de octubre de 1782 falleció, en Burgos, doña Francisca Antonia Rodríguez de Meneses, última poseedora hasta ese momento del mayorazgo fundado por Gerónimo Meneses -también vecino de la ciudad de Burgos- casi dos siglos antes, en $1598 .{ }^{5}$ Inmediatamente, su hijo primogénito, don Manuel Francisco Gil Delgado, movió posiciones para reclamar la herencia, que constaba de diversas propiedades en la villa de Talavera de la Reina y alrededores. Poca conexión podrían tener estos acontecimientos con la familia de los Zapata de Calatayud, afincada en el Reino de Valencia. Sin embargo, don Miguel Catalá, conde de Cirat y

4. Ibídem y Archivo Histórico Nacional [AHN], Consejos, leg. 31317, exp. 10.

5. Remitimos a la Figura 2 para la consulta de los lazos de parentesco entre los diversos agentes a lo largo del pleito abordado. 
Villafranqueza, como esposo de la ya difunta doña María Antonia Gil Delgado, hija de la fallecida y hermana del primogénito don Manuel Francisco, reclamó también el mayorazgo. No lo hizo para sí mismo, sino para su hija doña Ana María de Catalá, como padre y legal administrador de sus derechos y, a efectos prácticos, responsable de defender y litigar por su hija. ${ }^{6}$

El inicio de este pleito, entonces, se fundamentaba en una de las cláusulas dispuestas por Gerónimo Meneses, fundador del mayorazgo, según la cual la hija del conde de Cirat y Villafranqueza -y su esposa, en caso de no haber fallecido- podía heredar los territorios. Las disposiciones de sucesión se basaban en un esquema de herencia regular, como otros tantos, a lo que el fundador añadió una serie de condiciones concretas -tal y como le permitía la reglamentación inclusa en la ley 27 de Toro (Peset, 1994: 19)-, que condicionarían notablemente el modo en el que se transmitiría el mayorazgo a lo largo de las sucesivas generaciones:

E subceda en ellos por vía de maiorazgo buestro hijo maior de vos el dicho mi hijo, y después de sus días su hijo maior, y a falta de barón subceda la embra, conforme a derecho da leies de estos reynos, prefiriendo siempre el maior al menor, el varón a la embra y así vaia de uno en otro para siempre por el tiempo que durasen los descendientes lejítimos, o naturales, o bastardos, descendientes de mi padre y madre.

\section{$[\ldots]$}

$\mathrm{Y}$ es mi voluntad que subcediendo este dicho maiorazgo en hembra, se case con hombre noble hijodalgo, limpio de todos quatro costados, e si tubiese el que así se casare con la dicha embra, otro maiorazgo de más rentas que éste, el hijo maior de tal se llamará su apellido, y el segundo se llamará de Meneses, que es mi apellido, y succederá en este mi maiorazgo, e sus hijos. ${ }^{7}$

De este modo, instituyó un mayorazgo regular, pero que gozaba de unas características especiales en el momento en el que la herencia recayese en manos femeninas. Bajo dicha circunstancia, se trataba de un vínculo de rasgo incompatible y de segundogenitura; es decir, con tal de evitar que el nombre de la casa Meneses desapareciese, obstruido por otro de mayores rentas, el fundador disponía que en caso de que una mujer, descendiente suya, casase con un noble que tuviese en su poder un mayorazgo de mayores rentas, debía heredar el mayorazgo la línea del segundo nacido y sus descendientes, siempre y cuando adoptasen el nombre y armas de Meneses. ${ }^{8}$

6. $A H N$, Consejos, leg. 31317, exp. 10.

7. Ibídem. Para las transcripciones nos hemos decantado por una opción que, con pocas modificaciones, facilite la lectura y comprensión de las mismas. Así, hemos optado por desarrollar las abreviaturas, separar o unir las palabras que no se adecuan a una composición actual, normalización de las mayúsculas y minúsculas, acentuación actualizada, introducción de los signos de puntuación básicos para la comprensión, regularización de grafías similares como «u» y «v» y, por último, conservación de la ortografía original, incluso -si aplica- en las abreviaturas desarrolladas.

8. Ibídem. 


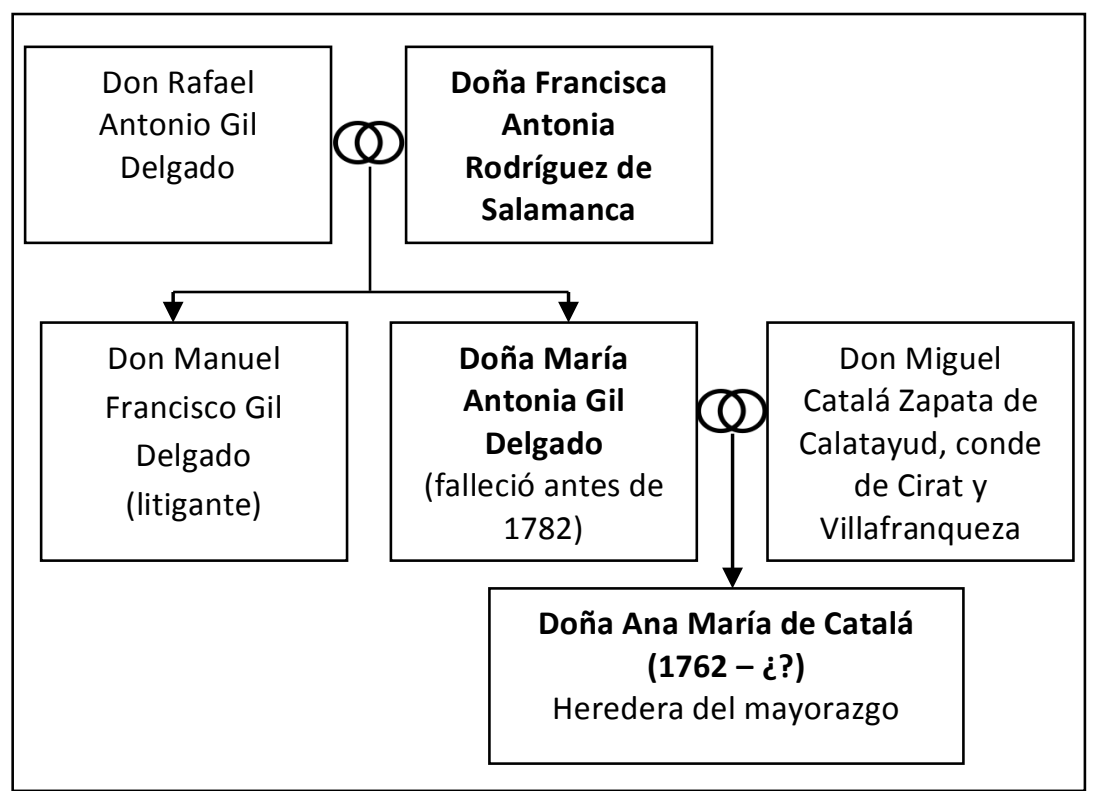

Figura 2. Familia próxima a doña María Antonia Gil Delgado y doña Ana María de Catalá.

Fuente: elaboración propia según $A H N$, Consejos, leg. 31317, exp. 10 y $A D C$, Donación del Conde de Cirat, caja 23, leg. 5, documento 1.

El pleito se prolongó durante varios años, durante los cuales el Consejo, tras apelaciones diversas, debía comparar las rentas del mayorazgo (o mayorazgos) pertenecientes a don Rafael Antonio Gil Delgado, esposo de la difunta doña Francisca Antonia, frente al valor del fundado por Gerónimo Meneses y que se encontraba en disputa. ${ }^{9} \mathrm{Si}$ el primero se probaba superior al segundo, la línea del litigante don Manuel Francisco Gil Delgado quedaba excluida a favor de doña María Antonia Gil Delgado, difunta esposa del conde de Cirat, siempre y cuando los herederos adaptasen sus nombres al del mayorazgo en cuestión.

La solución al conflicto llegó tras las pesquisas realizadas, donde quedaba claro que "los maiorazgos que posee el expresado don Rafael, que son varios, componen más renta que el littigioso de Meneses», por lo que la victoria definitiva sobre el pleito recayó, en el año 1785 , en don Miguel Catalá Zapata de Calatayud, siempre «como padre y legítimo administrador de doña Ana María Cattalá, su hija». ${ }^{10}$

No obstante, pese a la obtención por parte de la familia del conde de Cirat del mayorazgo de Meneses, la ausencia de un hijo varón en la descendencia de su primer matrimonio y la presencia de dos en la de su segundo, condicionó notablemente el futuro devenir de su hija doña Ana María. Debido a la diferenciación existente entre ambas herencias -el condado de Cirat, agnado, y el de Villafranqueza, regular-, había cierto riesgo de que se separasen, en el caso de que los dos hijos varones del segundo enlace falleciesen sin descendencia antes que su hermanastra 
mayor. Ello habría supuesto que doña Ana María hubiese sido la única heredera, pero sólo capaz de recibir el condado de Villafranqueza y, con él, la Grandeza de España. El otro condado, Cirat, al no poder recaer sobre una mujer, pasaría a otra rama familiar, como aquellas encabezadas por los hermanos del propio conde. ${ }^{11}$ Bajo este caso hipotético se habría dividido el poder de la casa, con dos herencias separadas que resultaría complicado volver a reunir: la Grandeza de España y el condado de Villafranqueza por un lado, el condado de Cirat por otro.

Esta posible separación de herencias no fue el escenario final. De los dos hijos varones de don Miguel Catalá, don Pedro y don Pascual, el primero falleció unos años antes que su padre, el 13 de febrero de 1797. El segundo, murió soltero en Francia, en el año 1808. Sin embargo, fruto del matrimonio que don Pedro había contraído con doña Joaquina Perellós y Palafox, le sobrevivió un heredero varón que a partir del 22 de octubre de 1801 pasaría a poseer los títulos de conde de Cirat y conde de Villafranqueza. ${ }^{12}$

Para doña Ana María, la obtención del mayorazgo de Meneses supuso una serie de consecuencias sobre el reparto de las herencias de su padre. Este, don Miguel Catalá, le otorgará una dote de 20.000 pesos pero la apartará del reparto de la herencia que, como hija suya, le correspondía. Se trata de la legítima, en la cual acostumbraba a incluirse, también, el valor de la dote (Catalá Sanz, 1995: 180-181). Pese a ello, resulta necesario comprender el esfuerzo económico que suponían las dotes para la nobleza, incluso en un siglo en el que el caudal aportado a las mismas se había reducido considerablemente, sobre todo en comparación con la centuria precedente (Catalá Sanz, 1993: 172-174).

Con la obtención de un mayorazgo menor para doña Ana María, su hija primogénita, y la compensación para su futura dote, se aseguraba don Miguel Catalá el futuro bienestar de su hija en caso de que a él le alcanzase la muerte. Respecto a la exclusión de la herencia, poco pudo hacer su hija al respecto, pues la reglamentación valenciana, que no se había visto modificada por la Nueva Planta, permitía al testador imponer cualquier configuración para sus bienes, de manera que se podía excluir a cualquiera de los posibles herederos o herederas de su porción legítima de la herencia, simplemente con mencionarles en sus últimas voluntades (Pla Alberola, 1987: 116).

El suceso presentado en las líneas precedentes tan sólo supone uno de los ejemplos que muestran la autoridad paterna en la familia (Friedman, 1986: 53). Si bien hace ya varias décadas que la historiografía ha demostrado que algunas mujeres nobles alcanzaron altos grados de protagonismo en la restrictiva sociedad del Antiguo Régimen (Blutrach Jelín, 2011: 30) y adoptaron roles proactivos en la defensa de sus

11. Los hermanos varones de don Miguel Catalá eran don José Pascual, don Joaquín José y don Gaspar Juan. La documentación consultada hasta la fecha asegura que el último de ellos se encontraba con vida, mientras que no aporta datos válidos sobre los otros dos: don Gaspar Juan falleció en 1799, mientras que el óbito del conde llegó tan sólo dos años más tarde, en 1801. ADC, Donación del Conde de Cirat, caja 23, leg. 5, documento 1. 12. $A D C$, Donación del Conde de Cirat, caja 23, leg. 5, documento 1. 
intereses familiares y personales, el caso aquí presentado muestra, más bien, el papel supeditado al varón -particularmente al paterfamilias. Este tipo de escenario presentado se producía, en gran medida, gracias al marco legal y social omnipresente en las estrategias nobiliarias de las distintas casas en las que se encontraban las mujeres a lo largo de su vida, desempeñando los diferentes papeles de hijas, esposas y viudas.

\section{Conclusiones}

A la luz de los hechos presentados, tal y como muestra el ejemplo propuesto de la familia Zapata de Calatayud y la hija del conde don Miguel Catalá, doña Ana María, resulta deducible que, aunque sujetas fuertemente a la autoridad paterna, las hijas de un linaje nobiliario representaban una de las piedras angulares no sólo en la estrategia matrimonial, sino también en la obtención de nuevas propiedades y, en definitiva, el engrandecimiento de la casa. Esta consideración no debe restringirse solamente a los grandes proyectos matrimoniales -que resultaban en la unión de familias, o en la obtención de títulos y oficiossino también en los que podríamos denominar secundarios, por carecer de repercusiones de gran calado y por formar parte de la estrategia global familiar de un modo colateral. Así resulta en el caso de doña Ana María: su victoria sobre el mayorazgo de Meneses no implicaba solamente a esta, sino que se imbricaba en las acciones llevadas a cabo por la familia, y se garantizaba la dignidad y el prestigio de la futura esposa, al tiempo que se la apartaba de la legítima sin mayor perjuicio para su persona.

Asimismo, resulta imperativo destacar, frente a la importancia que la mujer podía llegar a desempeñar en la relevante configuración de la estrategia familiar, el cariz supeditado, por partida doble, al que se veía sometida. En un primer lugar, tal y como hemos explicitado, se encontraba la propia autoridad del padre, esposo o figura masculina más próxima. En segundo lugar encontramos, en un estrato superior, a la propia familia, que imponía sus prioridades sobre las de los individuos que formaban la misma. En el ejemplo aquí presentado podemos apreciar cómo, tras vencer el pleito y conseguir un mayorazgo, la opción de retirar a doña Ana María de la herencia legítima ganó mayor valor, pues al hacerlo le correspondía mayor porcentaje de esta a sus hermanastros, de forma que se quedaba ella con la dote para su matrimonio y con los beneficios del mayorazgo de Meneses.

Por último, este análisis no resultaría completo sin destacar los efectos, previstos o no, que una serie de directrices impuestas en el momento de la fundación de un mayorazgo podían suponer para las generaciones venideras. Debido a las disposiciones de Gerónimo Meneses en el caso de que el mayorazgo que fundaba a finales del siglo XVI recayese sobre una mujer, los derechos sobre el mismo permanecieron, dos siglos más tarde, y durante tres generaciones consecutivas, bajo los nombres de mujeres. Desde el matrimonio de doña Francisca Antonia 
Rodríguez de Salamanca con don Rafael Antonio Gil Delgado, su segunda hija, doña María Antonia Gil Delgado, habría sido heredera en caso de haber estado viva en el momento del óbito de su madre. Sin embargo, dado que su única descendencia fue doña Ana María de Catalá, una vez más el mayorazgo pasaba a una mujer, por tercera vez sin interrupción alguna.

\section{Bibliografía}

Blutrach Jelín, Carolina (2011): «Mujer e identidad aristocrática: La memoria del vínculo materno en la Casa de Fernán Núñez», Arenal: Revista de historia de mujeres, Universidad de Granada: Instituto de Estudios de la Mujer, Granada, p. 23-51.

CAtalá SAnZ, Jorge Antonio (1993): «El coste económico de la política matrimonial de la nobleza valenciana en la época moderna», Estudis: Revista de historia moderna, 19, Universitat de València, Valencia, p. 165190.

- (1995): Rentas y patrimonios de la nobleza valenciana en el siglo XVIII, Siglo Veintiuno, Madrid.

Chiquillo PÉREZ, JuAn Antonio (1991): «La nobleza austracista en la Guerra de Sucesión. Algunas hipótesis sobre su participación», Estudis: Revista de historia moderna, 17, Universitat de València, Valencia, p. 115-148.

FELIPO ORTS, AMPARO (1997): «Aproximación al estudio de un austracista valenciano: el conde de Villafranqueza», Mestre SANChis, ANTONio y EnRIQUe GIMÉNEZ LóPEZ (ed.): Disidencias y exilios en la España moderna: Actas de la IV Reunión Científica de la Asociación Española de Historia Moderna; Alicante, 27-30 de mayo de 1996, vol. 2, Universidad de Alicante, Alicante, p. 515-542.

Friedman, Ellen G. (1986): «El estatus jurídico de la mujer castellana durante el Antiguo Régimen», García-Nieto París, MARÍA CARMEN (coord.): Ordenamiento jurídico y realidad social de las mujeres: siglos XVI a XX: actas de las IV Jornadas de Investigación Interdisciplinaria, Universidad Autónoma de Madrid y Seminario de Estudios de la Mujer, Madrid, p. 4154.

Guardiola y Spuche, Pascual (2004): Antiguos linajes del Reino de Valencia, Real Academia de Cultura Valenciana, Valencia.

LóPEZ AMOREs, ANTONIO (2015): "Desde el mito a la Grandeza: auge de una rama valenciana de la Casa "Zapata de Calatayud" (s. XVI-XVIII)", Millars. Espai i història, 38, Universitat Jaume I, Castellón de la Plana, p. 37-56.

Peset, MARIAno (1994): «Propiedad y legislación: los derechos de propiedad desde el Antiguo Régimen a la Revolución Liberal», PESET, MARIANO: Dos ensayos sobre la historia de la propiedad de la tierra, Editorial Revista de Derecho Privado, Valencia, p. 11-148. 
FÒRUM DE RECERCA - ISSN 1139-5486 - http://dx.doi.org/10.6035/ForumRecerca.2015.20.13 Núm. 20/2015. p. 187-198

Pla Alberola, Primitivo J. (1987): «Familia y matrimonio en la Valencia moderna. Apuntes para su estudio», La familia en la España mediterránea 198 (siglos XV-XIX), Editorial Crítica, Barcelona, p. 94-128. 
iEn este taller no bordamos cojines! Una aproximación a Charlotte Perriand desde el género 
Algunas mujeres del siglo xx llegaron a convertirse en auténticos referentes de la arquitectura del movimiento moderno. Uno de estos casos es el de la francesa Charlotte Perriand que, a pesar de vivir y desarrollar su actividad en uno de los periodos más convulsos de la historia europea y occidental, supo dar forma a sus ideas y colaborar con algunos de los más prestigiosos arquitectos y diseñadores de la historia, e influir de forma decisiva sobre sus trabajos y propuestas creativas más trascendentales. Así pues, desde la comprensión que la arquitectura y el diseño debían estar al servicio de las personas y no al contrario, Charlotte Perriand logró convertirse en un referente de la emancipación de la mujer dentro de la arquitectura contemporánea.

Palabras clave: género, arquitectura, historia, historia de la arquitectura y el diseño, estética, crítica feminista.

\section{Introducción}

El siglo $x x$ fue el periodo histórico en el que por primera vez las mujeres comenzaron a desarrollar sus primeros trabajos en determinados campos profesionales, como la arquitectura o el diseño. Surgen en este momento, las primeras escuelas técnicas en las que se acepta la entrada -siempre de forma regulada y minoritaria- de mujeres en las aulas. Muchas de estas mujeres tuvieron que superar restricciones $y$ enfrentarse a una sociedad patriarcal en la que para las mujeres sólo quedaba la esfera de lo privado: la casa. Y lo mismo ocurría en el ámbito laboral, dónde sólo determinadas y muy escasas actividades -todas ellas vinculadas con el cuidado y con la educación infantil- eran las que socialmente estaban aceptadas para las mujeres. Con todo, y a pesar de las dificultades para acceder a la formación reglada en la arquitectura y el diseño, su lucha seguía una vez acabados los estudios al tener que enfrentarse de nuevo ante unas estructuras que impedían, en la mayoría de los casos, su desarrollo profesional posterior.

Charlotte Perriand encarna el espíritu de esa nueva mujer que comenzaba atisbarse durante las primeras décadas del siglo xx. Su trabajo siempre apuesta por la innovación y la adaptación al uso de nuevos materiales para ofrecer productos de diseño que resuelvan problemas. La funcionalidad era la base elemental de sus planteamientos de diseño y arquitectónicos, y son precisamente estas premisas las que la llevan a desarrollar, entre otros muchos objetos, el que posiblemente haya tenido mayor trascendencia en la historia del diseño: una silla alternativa a los diseños de la Bauhaus. 
III. Objetivos

Los objetivos de este artículo de investigación consisten en acercarnos a la biografía de esta arquitecta y diseñadora del siglo $\mathrm{xx}$, Charlotte Perriand, desde una perspectiva de género. El análisis biográfico, y especialmente las diferentes etapas de su trayectoria profesional, se configuran como un marco idóneo para poder acercarnos, desde una mirada de género, a sus creaciones y su praxis arquitectónica en un campo eminentemente masculino. Del mismo modo, a través de la puesta en valor de su trabajo y la difusión de sus creaciones, se pretende la dignificación de una mujer en su esfera profesional, que se consolida como referente de emancipación femenina y que ha permanecido en silencio durante décadas, por una historiografía e historia del arte sesgada en la que los trabajos de las mujeres tendían a ser considerados como menores.

\section{Material y método}

La metodología utilizada para llevar a cabo esta investigación es, casi de modo necesario, la hermenéutica, esa interpretación de los textos en su propio contexto. La principal labor para la realización de esta investigación ha sido fundamentalmente la búsqueda bibliográfica, que ha empezado en las bibliotecas más cercanas, como la de la propia Universitat Jaume I, o también la del Colegio Territorial de Arquitectos de Castellón (CTAC) y, por supuesto, gracias a las nuevas tecnologías e Internet.

Es imprescindible hacer mención en este apartado de algunas de las referencias más importantes con las que hemos trabajado: la obra de Kevin Lynch The Image of the City; El espacio doméstico: la mujer y la casa, de Atxu Amann, y Arquitectura y Género, de Mónica Cevedio, o la obra de Carlos Hernández Pezzi, El género de la arquitectura: la Ciudad compartida. Todas narran de alguna forma la trayectoria de Charlotte Perriand, y muchas de ellas se centran específicamente en su faceta más conocida, la de colaboradora del arquitecto Le Corbusier, y evidencian la necesaria traslación a las investigaciones de género el proceso emancipatorio de esta mujer en su propio contexto vital.

\section{Resultados}

El ámbito de la arquitectura desarrolló, conforme estamos observando, profundos cambios que afectarían para siempre en las formas de elaborar y concebir los proyectos arquitectónicos, y por supuesto, el diseño del mobiliario que configuraba estos espacios. Del mismo modo, la presencia de mujeres fue muy reducida, pero, además de Eileen Gray -cuya trayectoria, como hemos visto, configura una parte necesaria de la historia de las mujeres en la arquitectura- queremos 
hacer referencia en estas páginas a otra arquitecta cuyos trabajos también han contribuido a la construcción de los cimientos de la historia de las mujeres en este campo.

Charlotte Perriand nació en París el 24 de octubre de 1903 y creció en el barrio Marché Saint-Honore. Allí vivían y trabajaban sus padres, un sastre y una modista, de manera que Perriand creció "observando el mundo de la alta costura desde el punto de vista del pequeño artesano» (McLeod, 2003: 11), aunque pasaría largas temporadas en la Borgoña y la región de Saboya, en casa de su abuelo paterno.

Desarrolló sus estudios en decoración y diseño durante los primeros años de la década de los veinte y lo hizo en la École Centrale de l'Union des Arts Décoratifs de París, donde recibió formación en art déco por parte de profesores como Maurice Dufrène. Esta educación formal, siempre en ambientes de refinado gusto francés, fue la base para sus posteriores trabajos, que paradójicamente, escaparon de los estilos de los que aprendió. Sin embargo, en esta escuela fue donde llegó a comprender que el diseño interior de los espacios era también una forma de crear arquitectura. En ese sentido, el propio director de la École Centrale de I'Union des Arts Décoratifs afirmaba que "las obras de la artesanía supuestamente inferiores son de igual estatura que el "gran arte" de la arquitectura. Un ebanista es un arquitecto" (Dufrène cit. en Rodríguez, 2013: 93).

En 1926, Perriand contrajo matrimonio con su pareja, Percy. Fijaron su lugar de residencia en un antiguo taller de fotografía en la rive gauche. En este periodo, Perriand asume su verdadera independencia familiar y descubre verdaderamente la modernidad literaria, gracias a la literatura inglesa o la musical, de la mano del jazz de Louis Armstrong. Era un periodo de revolución cultural y de apertura intelectual, en el que «Perriand también utilizó su vestuario como reflejo de su posicionamiento ideológico [...] su imagen andrógina evidenciaba su posicionamiento como nueva mujer francesa» (Rodríguez, 2013: 95).

Sin embargo, su condición de mujer casada no duró demasiado tiempo. La propia Perriand señalaba que «el matrimonio en esa época era la única vía posible para que una crisálida se transformara en mariposa. Y una mariposa vuela» (Perriand, 1998: 22), sin duda un gesto que nos muestra su moral progresista y liberal que rechazaba los cánones y las reglas establecidas en su sociedad contemporánea. En ese sentido, podemos pensar que Perriand también sería precursora en las nuevas relaciones interpersonales, y sentimentales, en las que los roles de género estaban cambiando.

En lo que respecta a su trayectoria profesional, no cabe duda que su forma de entender el mundo influiría considerablemente. Frente a unos estilos tan decorativos y anclados en un pensamiento decimonónico en los que fue instruida. Pronto descubre que su verdadera pasión es la arquitectura, aunque continúa realizando proyectos y diseños sobre piezas de mobiliario e interiores, en los que procura desmarcarse de toda tradición. Al respecto, Rodríguez (2013: 96) afirma que: 
Mientras que sus primeros interiores estaban motivados por el lujo asociado con las artes decorativas francesas, su producción posterior deriva de un compromiso crítico con los enfoques contemporáneos de la vivienda moderna, aunque el confort sensorial continuaría siendo una característica distintiva de sus proyectos.

Muy posiblemente, el giro en su forma de diseñar se produjo gracias a la lectura de varios libros que Le Corbusier había escrito al respecto. Al conocer su trabajo, trató de colaborar con él y recibió por respuesta una de las frases con mayores connotaciones machistas que Le Corbusier pudiera pronunciar «desgraciadamente en este taller no bordamos cojines» (Le Corbusier cit. en Rubino, 1982). Sin embargo, poco tiempo después, descubrió una pieza expuesta en el Salon d'Automne de 1927, Bar sous le toit que pertenecía a esta diseñadora. Se trataba de una pieza «únicamente construida con acero cromado y aluminio anodizado, [que] hizo cambiar de opinión al maestro [y] la invitó a colaborar en su estudio» (Espegel, 2012: 22).

Perriand participó en el Salon d'Automne de 1927 con un stand que reproducía su propia casa, un piso en el que planteaba una nueva forma de vivir y de habitar, que transformaba la forma de relacionarse. Es más, a partir de ese momento, Charlotte comenzó a considerar el cuerpo como unidad de medida propia de la arquitectura moderna, un retorno, en el sentido dimensional, al orden clásico, en el que la persona se configuraba como el centro de atención, y resultó que «Perriand planteaba aquello que Le Corbusier estaba buscando, la respuesta a las necesidades básicas del hombre» (Cruz, 2008: 138).

Tal vez uno de los hechos que -aunque no podemos afirmarlo con suficiente contundencia- animaron a Le Corbusier a pedir la colaboración de Perriand en su estudio de arquitectura fue precisamente que, siendo él quien había estado defendiendo que eran los arquitectos quienes debían realizar proyectos integrales -es decir, desde las construcciones arquitectónicas hasta el diseño de los objetos más pequeños-, el diseño de los espacios interiores y principalmente el del mobiliario con el que debía equipar esos espacios siempre fueron un problema por resolver. $Y$ es que, como apunta Espegel (2007: 198):

... los interiores desarrollados hasta 1927 por Le Corbusier y Pierre Jeanneret se organizaban con mobiliario de factura artesanal [...] muy poco acorde con la revolución espacial que proponían. La modernidad no había llegado todavía al mobiliario ni al interiorismo en su estudio de la Rue de Sevres.

Este hecho, su incapacidad de desarrollar una solución adaptada a sus formas arquitectónicas a través del mobiliario, le costó duras críticas. Tanto fue así que durante la exposición de Stuttgart de 1927, la responsable de interiorismo -la feminista Enra Meyer- afirmaba que (Erna Meyer, cit. en Rodríguez, 2013: 88) «Me ha decepcionado Le 
Corbusier, iel que más de todos! ¿Qué ocurrió con todos los principios de su libro? ¿Es esto lo que quería decir con estética maquinista?».

Sin duda, un problema que Le Corbusier afrontó con el fichaje de Perriand, quien llegaría a convertirse en un engranaje imprescindible para el desarrollo de los proyectos integrales del estudio, evitando a partir de entonces unas críticas que pudieran llegar a restar el prestigio adquirido durante años. Sin embargo, antes de la llegada de la diseñadora, el estudio ya había estado trabajando en la búsqueda de una solución. Como explica Cruz, «previa llegada de Charlotte Perriand, la búsqueda por comprender el problema del mobiliario era parte fundamental de esta exploración» (2008: 135). Y en el mismo sentido -aceptando el problema al que se enfrentaba él particularmente-, reconocerá durante "La aventura del mobiliario» (una conferencia que tuvo lugar en Buenos Aires) que (Melgarejo, 2011 a: 217):

... estaba obsesionado por la anomalía del mobiliario [...] Mencionó a Perriand, a la que se refirió como «nuestra asociada para el acondicionamiento de los interiores de las casas». Para acometer la renovación de la casa, Le Corbusier eligió a una mujer.

En definitiva, es gracias a la llegada de aquella joven mujer a la que cerró sus puertas en una primera instancia, con lo que se establece una coherencia entre mobiliario y diseño arquitectónico surgido en el estudio de Le Corbusier. Ahora, las premisas que Le Corbusier había defendido habían tomado su forma definitiva y estaban completamente adaptadas a los principios del diseño moderno. Así pues, el problema que resuelve Perriand es precisamente encontrar el equilibrio entre (Cruz, 2008: 136):

... el vacío corbuseriano, como contraposición al hórror vacui burgués, tan decimonónico, que está adecuadamente conformado desde el punto de vista de los límites que lo contienen. El contenedor se ha logrado, pero ante él aparece un gran inconveniente: a este vacío tan ligero se superponen aparatosos muebles, a cuya masa parece faltar ligereza y descomposición.

Sin embargo, resulta cuanto menos curioso que fuera precisamente Charlotte Perriand (que había desarrollado sus estudios dentro de los paradigmas clásicos del diseño de interiores y que creció en un ambiente de gusto refinadamente tradicional) la mujer capaz de encontrar la solución al problema del arquitecto. Como curiosidad, se considera que ese cambio producido en la forma de entender los espacios por parte de Perriand fue casi inconsciente, desde pequeña, a partir de su estancia en un hospital. En ese sentido, la misma arquitecta explica en su autobiografía que (Perriand, 1988: 14):

Con diez años, entré en el hospital infantil para que me extrajeran el apéndice, como a todos los niños de esa época [...] El lugar me gustó, era blanco, la habitación desnuda [...] De vuelta a casa, la leonera de muebles y objetos saltaba a la vista y lloré. La sobriedad del hospital me convenía. Por 
primera vez, inconscientemente, descubrí el vacío omnipotente porque lo puede contener todo.

Otro de los factores que contribuyeron al éxito de los diseños que elaboraron a partir de ese momento Le Corbusier, Jeanneret y Perriand, fue precisamente la visión femenina que aportaba. Su educación había sido muy diferente a la de ellos, en una sociedad en la que "la mujer tenía la responsabilidad moral y material del hogar y las tareas domésticas eran su forma de expresión» (Melgarejo, 2011 a: 217). En ese sentido, por su condición de mujer, Perriand conocía mejor que sus compañeros masculinos cuáles eran las necesidades del hogar y el espacio que requerían.

Con la llegada de Perriand al estudio, colabora en diversos proyectos de arquitectura, entre los que cabe destacar el mobiliario -o equipamiento- para las villas La Roche y Church. En ambos proyectos Perriand desarrolla un papel fundamental, pues se utiliza por primera vez en Francia mobiliario de acero tubular. Sin embargo, esto no sería algo pionero en la historia del diseño, ya que durante la década de los veinte otros diseñadores ya estaban trabajando con mobiliario metálico, como Mies van der Rohe o Marcel Breuer, o durante los mismos años la propia Eileen Gray. Uno de los principales retos a los que se enfrentaba el estudio de arquitectura con esta reforma era el diseño de una silla moderna, pero «no sólo era crear una nueva silla que respondiese a su máquina de descansar, sino además proponer una alternativa a los diseños de la Bauhaus» (Rodríguez, 2013: 110).

Charlotte Perriand lo acabó logrando. Y lo hizo de tal manera que acababa de diseñar para la Roche una pieza que se convirtió en un hito del diseño y, sin duda, en la pieza más reconocida y significativa de toda su carrera. "La chaise longue fue concebida para la Mujer Moderna Francesa. Sus cualidades formales y materiales evidenciaban el origen francés de un objeto ante todo lujoso» (Rodríguez, 2013: 110). La elaboración de esta Chaise Longue se convirtió en un éxito para el estudio que dirigía Le Corbusier, de manera que, tras mucho tiempo inmerso en esa búsqueda, se había diseñado una silla moderna que podía convertirse en una alternativa real a los modelos que hasta entonces se diseñaban en la Bauhaus, y había sido diseñada por una mujer.

Sin embargo, el diseño de esta genial pieza del diseño moderno sufrió algunas pequeñas modificaciones para optimizar todavía más su forma, de hecho (Schwartz-Clauss, 1997: s/p):

en el primer modelo, construido en 1928 por artesanos bajo la supervisión de Charlotte Perriand, para la biblioteca de la villa de Church, los extremos de las secciones de los pies y la cabeza de la silla estaban todavía soldados y por lo tanto interrumpían la línea continua de la estructura de acero tubular.

Un hecho significativo es consecuentemente que en este proceso de diseño de la chaise longue, y a diferencia de lo que ocurrió con otros muebles, quien se encargó de la total supervisión no fue Le Corbusier, sino Charlotte Perriand, y posiblemente fue una de las primeras ocasiones 
a lo largo de la historia en que una mujer estaba al frente de un grupo de artesanos que se encargaban de su elaboración.

Al hablar de la chaise longue de la arquitecta, necesitamos hablar de la famosa imagen de Pierre Jeanneret, quién «tomó muchas fotos de su admirada Perriand, que, a diferencia de Eileen Gray, posaba con sus creaciones» (Rodríguez, 2013: 97). Nos referimos, concretamente, a la imagen en la que aparece junto a esta pieza la propia Charlotte Perriand, con una falda corta - para aquel momento-, las piernas cruzadas y con una postura, tanto ella como la pieza, poco habitual. Sin embargo, un hecho que no pasa inadvertido en la imagen es que el rostro de Charlotte mira hacia el lado opuesto de la fotografía. Se oculta su rostro para la sorpresa de quien observa la imagen, aunque se trata de un gesto relativamente habitual en la fotografía de mobiliario y que también llevaría a cabo la escuela de la Bauhaus. Posiblemente, podamos encontrar la respuesta en el director de la sección de teatro de esta escuela, dado que la ocultación del rostro «era la pérdida de la individualidad. Las figuras aparecían sin rostro porque aspiraban a lo universal; se intentaba tipificar a los individuos» (Schlemmer cit. en Melgarejo, 2011 b: 103).

Resulta llamativa la contundencia con la que se afirma que Perriand fue capaz de diseñar el modelo de silla alternativo al de la Bauhaus -con carácter general- y que, sin embargo, en demasiadas fuentes sólo aparezca su autoría sobre la pieza en la que hemos querido profundizar, su chaise longue. A pesar de esto, fue autora de otros diseños que se han adjudicado únicamente a Le Corbusier. Así (McDermott, 2003: 116):

El mueble no fue un trabajo sólo de Le Corbusier. Trabajó en colaboración con una joven diseñadora de muebles, Charlotte Perriand, quien había estado experimentando con el acero tubular como material, así como con su sobrino y compañero Pierre Jeanneret. Es a estos tres a quienes debe ser atribuido el mueble, y algún otro sólo a Perriand, un hecho reconocido recientemente.

En ese mismo sentido, "She worked out with Jeanneret the designs and full-scale details, which Le Corbusier would then sometimes refine; but she took charge of their execution herself» (McLeod, 2003: 44). Así, nacerían también las otras dos piezas: por un lado siege à dossier basculant, una silla sobre la que Le Corbusier afirmaba que "as a chair in which to sit for living-room conversation» (McLeod, 2003: 45), y también el sillón fateuil grand confort, con el que se había diseñado «a machinefor-relaxing» (McLeod, 2003: 46). Además, los dos primeros diseños a los que hemos hecho mención, la chaise longue y el siege à dossier basculant, tienen una serie de características que los hace únicos y que, sin duda, nos acercan, por una parte a lo que se estaba desarrollando en otras escuelas de diseño europeas, como la Bauhaus alemana. Pero estos muebles también nos introducen de lleno a ese estilo personal que desarrolla Perriand, por su delicadeza, sensualidad y minuciosidad. Incluso llegan a ser objetos a través de los cuales la diseñadora nos recuerda su pasado vinculado a la formación en art déco. 
Durante ese mismo año en el que vieron la luz estos geniales diseños, 1928, Charlotte Perriand junto a una serie de arquitectos, escultores, y pintores deciden fundar la Union des Artistes Modernes (UAM), cuyo ideario se basaba en la integración de todas las disciplinas en un sólo arte, amparados en el concepto de obra de arte total que ya proponía la Bauhaus, siempre inspirada en la propuesta conceptual wagneriana del Gesamtkunstwerk. Ese mismo año, justamente en una recepción en honor a la Bauhaus que realizó la embajada alemana, conoció a Fernand Léger, un excelente pintor que pronto se convirtió en un buen amigo hasta su muerte, en el año 1955.

Asimismo, en este periodo, el estudio de arquitectura en el que colaboraba Perriand se encontraba en su máximo esplendor, y se producían grandes interacciones entre diferentes líneas de investigación arquitectónica, aunque todo debía pasar por el riguroso y racional filtro de las teorías de Le Corbusier para ser aceptado. De hecho, de este periodo de máximos en el estudio surge el germen de la futura Carta de Atenas, que Le Corbusier publicaría posteriormente.

En el año 1929, Charlotte Perriand escribe un artículo titulado "Wood or Metal?» en el que defiende el uso de ese novedoso material que había incorporado en los diseños. El metal, que desde su llegada al estudio de arquitectura había supuesto un giro en el diseño del mobiliario, se convirtió en una innovación indiscutible que había logrado configurarse como elemento distintivo del mueble moderno. «Era la revolución estética del metal. Pero la revolución había comenzado unos años antes, paradójicamente en el taller de ebanistería de la escuela Bauhaus» (Melgarejo, 2011 b: 108). Con todo esto, Charlotte Perriand afirmaba en ese artículo que (Perriand, cit. en Melgarejo, 2011 b: 118):

El metal desempeña el mismo papel en el mobiliario que el hormigón en la arquitectura.

El metal es la revolución.

El futuro será de los materiales capaces de resolver los problemas planteados por el hombre nuevo.

Entre las soluciones que introdujeron en el ámbito doméstico, destacan los casiers, un nuevo concepto de organización del espacio, cuyo diseño y producción seriada supondría el trabajo de Perriand sobre esta idea durante años. Para ello, trabajó en «precisar la medida mínima para cada función de la vida doméstica. Hasta el menor detalle, todo estaba registrado en sus tablas de dimensionado. Estableció unas superficies mínimas para cada función» (Melgarejo, 2011 b: 133). A pesar de lo dificultoso y duradero que pudiera llegar a ser realizar esta serie de minuciosos estudios, Charlotte estaba convencida de que al lograr solucionar el problema del almacenaje, "conseguirían la transformación de la vivienda» (Melgarejo, 2011 a: 219). Y es que, gracias a esta serie de estudios, se lograba resolver el problema de la vivienda moderna, esa Machine d'Habiter corbuseriana. 
Otro de los aspectos que trabajaron desde la llegada de Charlotte Perriand al estudio de arquitectura fue el proyecto de la célula mínima. Desde siempre, Le Corbusier había estado interesado en descubrir y desarrollar un espacio de dimensiones reducidas que fuera la medida exacta para satisfacer las necesidades básicas del hombre. Posiblemente, uno de los primeros proyectos que vieron la luz y que pretendía cumplir con estas condiciones fue, en la Exposición Internacional de París de 1937, un prototipo de unidad sanitaria que podía producirse en serie.

También es en esta época cuando Charlotte Perriand -quién siempre había sentido un especial interés por la fotografía- realizó una de las fotografías más transgresoras para el momento. Transcurrida una década desde que Jeanneret tomara la provocadora fotografía sobre la chaise longue, debió considerar que había llegado el momento de volver a repetir algo parecido para mostrar ante una sociedad conservadora que algo estaba cambiando y que el espíritu moderno y la libertad que proponía no se ceñían únicamente al ámbito del arte y el diseño. Ahora la libertad debía llegar también a las relaciones personales, todavía desiguales, y especialmente a las mujeres que seguían inmersas en una gran dependencia respecto a los hombres.

Durante el año 1937, Perriand se dio cuenta de que Le Corbusier "estaba más interesado en las asociaciones simbólicas de los materiales y técnicas que en la "exploración de nuevas posibilidades técnicas o experimentación con las propiedades físicas de los materiales"»" (Rodríguez, 2013: 97). Esto repercutió en la arquitecta, pues comenzaba a darse cuenta de que Le Corbusier había usado el mundo de la máquina como referencia visual, pero no técnica. Frente a esta concepción, ella pensaba que "los muebles debían servir estrictamente a las necesidades humanas y al uso. La tecnología no debía ser puesta sólo al servicio del estilo o la teoría abstracta» (Ockman cit. en Rodríguez, 2013: 112). De esta manera, comprendemos que Perriand fue una arquitecta con profundas convicciones, cuyos planteamientos de diseño siempre lo fueron para ser utilizados y útiles. Eran diseños para las personas, pues no creía en los diseños únicamente como expresión estética para lograr un reconocimiento pseudoartístico; sus propuestas tenían como fin mejorar la vida cotidiana de los usuarios, facilitando las acciones más elementales. Precisamente por eso, sus diseños siempre trataron de establecer «una nueva relación con el cuerpo que pretendía ofrecer a los extremos de los dedos las prolongaciones de nuestros gestos cotidianos" (Perriand cit. en Melgarejo, 2011 b: 103).

Ante estas circunstancias, Charlotte Perriand decidió abandonar el estudio de Le Corbusier, aunque en un futuro volvió a colaborar con él. Atrás quedaba aquella década en la trabajó en aquel estudio y que jamás volvería a repetirse. De esta forma, Perriand afirma «dejé el taller por un deseo de libertad, aunque no sin angustia, ya que diez años pasados con seres excepcionales dejan su marca» (cit. en Espegel, 2007: 212). Ante este hecho, Le Corbusier también se pronunció convencido de que «la revolución architecturale estaba ya realizada» (cit. en Melgarejo, 2011 b: 
1989). Así pues, finalizaba en 1937 el período más importante de lucha por la vida moderna, pero el germen de las ideas que se habían propuesto supondrían un punto de inflexión en el desarrollo arquitectónico posterior.

Con todo, tras haber pasado una década trabajando con los materiales más característicos del movimiento moderno -acero, aluminio, hormigón, vidrio o plásticos- fue a partir de su salida del estudio de Le Corbusier cuándo comenzó a investigar las posibilidades que le ofrecían otros materiales más tradicionales como la madera. Acepta, por tanto, la posibilidad de utilizar cualquier material, con independencia de su tradición. De hecho, en este momento, entre los años 1938 y 1939, diseña la mesa curvada junto a Jean Prouvé y Pierre Jeanneret, con quienes colabora para un proyecto de edificios prefabricados de carácter efímero.

Un año más tarde, en 1940, y en parte motivada por el estallido de la Segunda Guerra Mundial, viaja a Japón para trabajar como consejera en el Departamento de Artes Industriales del Ministerio de Industria del país. Fue una propuesta de trabajo que le había ofrecido Junzo Sakakura, con quien había coincidido durante los años de colaboración en el estudio de arquitectura de Le Corbusier. Sin duda, un ejemplo más en la biografía de Perriand que muestra su carácter abierto y las buenas relaciones personales que fue capaz de cultivar durante toda su vida.

Durante su estancia en Japón, «absorbió muchos valores de la cultura japonesa: el concepto de vacío, la esencia taoísta de la totalidad, el orden no cartesiano, la poética de la nada, el ritual del gesto, el refinamiento del detalle, la conexión espacial interior-exterior» (Espegel, 2007: 216) que junto a las últimas aproximaciones con materiales tradicionales, como la madera, desencadenaron el diseño reinterpretativo de su chaise longue, mediante el uso de materiales como el bambú. Pero no sólo se quedó aquí, ya que los valores y las soluciones que adquirió de la cultura japonesa como, por ejemplo, los paneles deslizantes, los asimilaría para siempre, aunque no sin someterlos a su mirada crítica bajo los principios de la modernidad.

En 1943, Perriand huye de Japón por la Segunda Guerra Mundial y se refugia en Indochina -cabe recordar que, en ese periodo histórico, este territorio formaba parte del imperio colonial francés- donde trató de seguir su trayectoria de diseñadora hasta que, tres años más tarde, consiguió ser repatriada a Francia. A su llegada, trabajó en diferentes proyectos también de forma independiente, como el prototipo de cocina para la Unité d'Habitation de Marsella, en el que pone en práctica los conocimientos que había adquirido. De esta forma, en este proyecto, (Melgarejo, 2011b: 135):

la cocina, ya abierta, se integraría completamente en el espacio de la sala de estar, poniendo en comunicación al alma de casa con su familia o sus amigos. En esta ocasión, el mobiliario utilizado fue diseñado por Charlotte Perriand y Jean Prouvé. 
Posiblemente, una de las razones por las que, tras su regreso, acabó distanciándose definitivamente de Le Corbusier -como también le ocurriría a Pierre Jeanneret- fue fundamentalmente porque este había cambiado por completo el funcionamiento del estudio. Lo que fue uno de los epicentros de debate, investigación y diseño de excelentes proyectos arquitectónicos era ahora el despacho de Le Corbusier. En aquel lugar sólo se trazaban las líneas maestras, las ideas básicas, mientras que el desarrollo de estas lo llevaba a cabo un estudio de ingeniería independiente, algo a lo que ninguno de estos dos colaboradores se acostumbró.

Afortunadamente, Charlotte Perriand, comienza en este momento su colaboración con Jean Prouvé, el autor e ideólogo de la fábrica experimental de Maxéville. Posiblemente, estar en contacto de forma directa con los procesos industriales que tanto le habían apasionado fue lo que les resultó más atractivo de esta colaboración. Ella misma definía a Prouvé como (Perriand cit. en Espegel, 2007: 218):

... un hombre que conocía perfectamente el proceso de producción, lo aprendió como artesano siendo joven y fue instrumento de su oficio; lo utilizó con gran precisión [...] existe una enorme diferencia entre "diseñadores» que trabajan en un tablero de dibujo y gente como Jean Prouvé. Tan pronto como tenía una idea la hacía realidad.

De su colaboración Prouvé destaca la introducción de Perriand en el mobiliario de oficina, remodelando por primera vez para la compañía Air France sus oficinas de Brazzaville. Desde entonces siempre trabajó con los arquitectos de mayor prestigio internacional. Su éxito en el diseño de oficinas hizo que la compañía Air France la eligiera para remodelar también sus sedes de Londres y Tokio.

Como apunta Espegel «Perriand reflexionó sobre la diversificación que debe asumir la creación, teniendo en cuenta el lugar, el programa y las posibilidades» (2007: 222). Bajo estas premisas comenzó a realizar diferentes estudios, muchos de ellos, investigaciones sobre la arquitectura en zonas extremas, como la alta montaña o el proyecto de Maison du Sahara -una residencia temporal para los trabajadores del petróleo. También bajo estas condiciones, proyecta en 1960 una residencia para sí misma en Méribel Les Allues, sobre la que tuvo que trabajar a partir de técnicas tradicionales y aplicar algunos parámetros que siempre se habían desarrollado en la arquitectura tradicional campesina. En esta nueva construcción ya no había muros y los espacios diáfanos dejaban de serlo mediante el uso de los paneles de estilo japonés que incorporó para dividir las diferentes estancias de la casa.

Entre 1967 y 1982, Charlotte Perriand «began working on the largest built project of her career, the ski resort of Les Arcs, located in the Alps in southeastern France» (McLeod, 2003: 190). En este proyecto, con capacidad para alojar a 18.000 personas, confluyen todas sus ideas de estandarización y prefabricación industrializada. En ese sentido, su idea era crear una serie de espacios basados en esa célula mínima, que había 
trabajado durante toda su carrera desde aquella primera llegada al estudio de Le Corbusier, con la que pretendía encontrar ese espacio mínimo necesario para habitar. Esto casaba muy bien con la idea del proyecto, en el que las habitaciones eran el lugar al que menos tiempo se destina en un periodo vacacional. Así, una de las aplicaciones más interesantes fue la creación de unas cabinas prefabricadas con poliéster y fibra de vidrio que aglutinaban en un único cuerpo, el lavabo, la bañera, el inodoro $y$, por la parte exterior, la cocina. Con su producción seriada logró reducir considerablemente el tiempo de ejecución de la obra. Durante este periodo, es también cuando la arquitecta reforma su apartamento de París, un reflejo de su personalidad diseñado con sencillez, serenidad en el que aplicó su propio estilo moderno.

En 1985, se celebró en París una retrospectiva sobre toda su carrera, que llevó por título el que bien podría haber sido el eslogan de su desarrollo vital, «Un art de vivre». Ya en ese momento, Perriand estaba convencida de que la civilización había sido superada por la máquina y que, muy especialmente en el campo de la arquitectura, todo se estaba planteando en términos de forma y no de necesidades. En definitiva, fue de las primeras arquitectas en ejercer una mirada crítica, una vez más, sobre esa realidad que no hacía otra cosa que deshumanizar la propia arquitectura y el diseño.

Su contribución principal al movimiento moderno fue la aplicación de la tecnología al servicio de las personas, siempre sin descuidar ese potencial sensual en el diseño del mueble y la arquitectura que caracterizaron sus creaciones. Posiblemente derivando de sus primeros contactos con las artes decorativas, su infancia caracterizada por su proximidad con el mundo de la moda y, por supuesto, por su estancia en Japón, que condicionó todos sus planteamientos y la hizo conjugar mobiliario, tecnología, confort y arquitectura en un todo. Perriand, falleció a los 96 años de edad, en 1999, tras una fructífera vida dedicada a aquello que le apasionaba.

\section{Bibliografía}

CRUz, M. (2008): «Charlotte Perriand y el equipamiento de la habitación moderna», DEARQ - Revista de Arquitectura, Universidad de los Andes, Bogotá, p. 132-141.

Espegel, C. (2007): Heroínas del espacio: mujeres arquitectos en el Movimiento Moderno, Nobuko, Buenos Aires.

- (2012): «Charlotte Perriand, sinergia entre industrialización y artesanía» en VV. AA.: Jornadas de Mujer y Arquitectura, Mujeres Arquitectas de Galicia 26-27, Universidad da Coruña, A Coruña, p. 22-25.

McDermott, C. (2003): Design Museum. Siglo XX, Lisma Ediciones, Londres. 
McLeod, M. (2003): Charlotte Perriand. An Art of Living, Harry N. Abrams, Nueva York.

Melgarejo Belenguer, M. (2011 a): "De Armarios y otras cosas de casas...», Feminismo/s, núm. 17, Universitat d'Alacant, Alacant, p. 213-228.

- (2011 b): La arquitectura desde el interior, 1925-1937, Lilly Reich y Charlotte Perriand, Fundación Caja de Arquitectos, Barcelona.

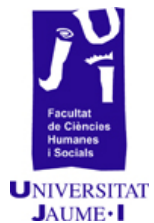

PerRIAND, C. (1998): Une vie de création, Éditions Odile Jacob, París.

Schwartz-Clauss, M. (1997), en VV. AA.: 100 sillas clásicas, Vitra Museum, Múnich.

Rodríguez, M. (2013): Arquitectura Petite: Charlotte Perriand \& Kazuyo Sejima, una historia transnacional, Tesis doctoral por la Escuela Técnica Superior de Arquitectura de Madrid de la Universidad Politécnica de Madrid, dirección de Juan Antonio Cortés Vázquez de Parga y Luis Antonio Gutiérrez Cabrero.

Rubino, L. (1982): "Charlotte, una cucina per Corbu», Chareau, P. y B. BIJVOET, Dalla Francia dell'art déco verso un'architettura vera, Kappa, Roma. 


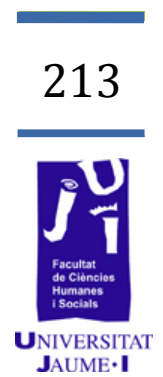

\section{La representación del Allium cepa.} Desde lo decorativo a lo documental 
El presente estudio gira en torno a la representación del Allium cepa, en el que se demuestra cómo su representación puede llegar a tener diferentes significados según el autor que la representa. Para ello se han seleccionado cinco obras de diferentes épocas en las que la hortaliza, conocida como la cebolla, es representada en una obra de arte.

El estudio se ha dividido en dos bloques. En el primero se realiza un recorrido breve por la historia de la hortaliza y de su propagación por todo el mundo y en el segundo se procede al análisis de las obras y de los artistas seleccionados.

Palabras clave: Allium cepa, cebolla, arte, bodegón, cerámica, mundo vegetal, hortaliza, sentidos, pintura de castas.

\section{Introducción}

El término Allium hace referencia a una serie de productos agrícolas del género al que pertenecen ajos, cebollas, puerros y cebolletas, hortalizas muy utilizadas en la cuenca del Mediterráneo y muy valoradas desde la antigüedad por sus múltiples propiedades. Este grupo, caracterizado por un fuerte olor y sabor, ha sido empleado tanto para la elaboración de medicamentos, como condimento alimenticio e incluso como ofrenda a los dioses.

Su importancia en la vida cotidiana de las diferentes culturas hizo que pronto fuese representada tanto en esculturas como en la arquitectura, pintura, orfebrería, etcétera. El trabajo que a continuación se presenta gira en torno a la representación del Allium cepa en un conjunto de cinco obras creadas por diferentes artistas, en diferentes lugares y periodos de la historia. Lo que se pretende mostrar en el estudio es cómo un mismo elemento puede tener diferentes significados dependiendo del momento de su creación, su contexto, su lugar en la composición y la relevancia que le otorgue el propio autor.

\section{Objetivos y metodología}

El punto de partida de este trabajo es la explicitación de la estructura de este. El objetivo principal del estudio es mostrar al lector cómo todos los elementos de una obra precisan de la atención del lector para un mayor entendimiento, a la vez que se pretende reflexionar sobre ciertos elementos que siempre son sometidos, inconscientemente, a un segundo plano de análisis.

Para poder conseguirlo se ha realizado una fase heurística destinada a la búsqueda de documentación que aporte información a nuestro tema de trabajo tanto en artículos como en monografías, que nos puedan 
ofrecer información acerca de la hortaliza. No obstante, la búsqueda no solo se limitará a las publicaciones sobre el vegetal concreto sino que se ampliará a las verduras en general puesto que tanto las notas de página como la bibliografía aportada en otros estudios puede resultarnos útil e interesante.

De igual modo, se han localizado museos con colecciones de pintura de naturaleza muerta puesto que podemos encontrarnos entre ellas representaciones de la cebolla. Así, por ejemplo, hemos hallado las pinturas de castas de Miguel Cabrera en el Museo de América que están acompañadas por frutos y hortalizas entre los que hemos encontrado los de nuestro estudio. Para ello se han utilizado diferentes buscadores de Internet y se han realizado las consultas en español, inglés, italiano y francés. Una vez recapitulada toda la documentación y conseguidas las obras que se desean comentar se ha procedido a redactar el trabajo.

Tras la localización se ha procedido a la fase hermenéutica con la lectura del material conseguido. Una vez finalizado dicho trabajo se ha procedido al análisis de la documentación, siguiendo el método de la Historia de la Cultura sugerido por el profesor Víctor Mínguez y la profesora Inmaculada Rodríguez, de la Universitat Jaume I. Este procedimiento tiene en cuenta diferentes corrientes historiográficas de la Historia del Arte, aspectos históricos, sociales, culturales, económicos y los puramente artísticos para realizar un análisis completo. Es decir, se partirá de la lectura realizada de una serie de publicaciones y documentos históricos, se examinará su contenido y se buscará vincular a las obras sobre las que gira nuestra investigación. Finalmente, se tendrá en cuenta el contexto histórico y social, para dotar de significado a los diferentes documentos, a los referentes literarios y documentales, y para comprender toda la significación de los mismos, su trascendencia y su importancia en el marco histórico y político.

\section{Historia}

El Allium cepa posee un origen incierto ya que diferentes estudios han señalado Asia Occidental y el norte de África como posibles lugares de nacimiento de esta hortaliza y otros, en cambio, lo sitúan en Oriente Próximo, el Mediterráneo e incluso China (Cubero, 2003). En cambio, parece ser que el cultivo de la cebolla, partiendo de plantas silvestres, tiene una opinión más compartida y se sitúa en el norte de la India, Cachemira, Afganistán y regiones limítrofes (Castell, 1996: 13) Perteneciente a la familia de las Aliceas, la cebolla se menciona en la Biblia y el Corán y fue muy utilizada por los sumerios, egipcios, griegos y romanos, quienes la incluyeron tanto en tratados médicos como en sus dietas alimenticias e incluso en los rituales fúnebres, como mostraremos a continuación (Torija, Matallana y Chalup, 2013: 30).

En el continente asiático también fueron muy valoradas e incluso se incluyeron como plantas decorativas en los jardines chinos. En Egipto las cebollas se consumían crudas y se utilizaban como condimento 
alimenticio. Además, se consideraba que proporcionaban fuerza por lo que eran el principal alimento de los encargados en construir las pirámides (Torija, Matallana y Chalup, 2013: 30). La cebolla egipcia, verde y alargada, estaba presente en los rituales funerarios tanto en las mesas de ofrendas como formando parte de los aderezos en las ceremonias fúnebres. Esto ha quedado demostrado en el hallazgo de tumbas con representaciones de dicha hortaliza que los arqueólogos han datado entre el 3200 y 2789 a. C. (Jones y Mann, 1963). No obstante, la cebolla también tuvo fuertes connotaciones religiosas y fue utilizada para el culto y cuidado de los vivos y de los muertos. Los egipcios creían que si enterraban cebollas junto a los muertos su fuerte olor les devolvería a la vida.

Graindorge afirma que la cebolla estaba vincula al dios solar (Eaton, 2013: 130) por lo que en su fiesta se ofrendaban collares hechos con esta hortaliza para el culto al difunto, colocándolas, en ocasiones sobre o dentro del cuerpo momificado. Así mismo, también se les dio uso para la momificación puesto que, por ejemplo, en la Dinastía XX se usaron para imitar los ojos de las momias (Torija, Matallana y Chalup, 2013: 30).

Su importancia en la medicina egipcia gira en torno a sus cualidades sanadoras y desinfectantes. En 1870 se descubrió un papiro en Egipto que recibió el nombre de Papiro de Ebers. ${ }^{1}$ Este contiene recetas y remedios medicinales en jeroglíficos. Como consecuencia del descubrimiento, Georg Ebers publicó la monografía con todas sus recetas. Por lo que respecta a nuestra hortaliza, la cebolla proporcionaba salud, actuaba como antídoto ante la picadura de animales y favorecía el flujo sanguíneo. Además, se introducía en muchas recetas como, por ejemplo, el remedio para la diarrea (higos 1 / octava copa y uvas, masa de pan, maíz hoyo, fresca tierra, la cebolla y el saúco). Por otro lado, la cebolla también se utilizaba para el parto, era afrodisiaca, abría el apetito y era eficaz contra el mal de ojo. Así pues, con todo ello, podemos afirmar que su utilización, en el Antiguo Egipto, abarcó muchos ámbitos.

Del siglo II de nuestra era nos llega otro tratado médico desde la India llamado Charaka-Samhita ${ }^{2}$ en el que dicho vegetal se utiliza como un excelente diurético y remedio contra enfermedades cardíacas, oculares o de las articulaciones.

Los griegos y romanos incluyeron la cebolla entre los alimentos principales de su dieta y fue muy utilizada por el ejército, puesto que consideraban que les proporcionaba fuerza. Su importancia la encontramos al ver cómo se perpetuó para la historia al introducirla en algunas de las esculturas clásicas. El griego Dioscórides ( 1 d. C.), primer botánico médico científico, incluyó la cebolla en su tratado Materia Médica y entre sus virtudes resaltó que la hortaliza provocaba apetito,

1. El Papiro Ebers es uno de los tratados médicos más antiguos que se conservan (circa 1500 a. C.). Fue descubierto en 1862 entre los restos de una momia en la tumba de Assasif, en Luxor, por Edwin Smith. Tras ello el egiptólogo alemán Georg Eber lo compró y realizó la traducción.

2. Charaka-Samhita ha sido dividido en dos volúmenes y ambos los ha traducido al inglés Gabriel Van Loon. Se pueden consultar en línea. 
diluía los humores y que era buena para el vientre, entre otras cosas. (Torija, Matallana y Chalup, 2013: 31). Asimismo, su importancia culinaria quedó reflejada en la obra De re conquista del experto en gastronomía romano Marco Gavio Apicio quien incluyó un total de 50 recetas que contenían cebolla. Por ejemplo, la receta número siete sería: calabazas fritas en puré, pimienta, aligustre, ${ }^{3}$ comino, orégano, cebolla (CEPAM), vino, garum y aceite, espesar con fécula en la cazuela y servir (Pastor Artigues, 1987: 23). El imperio romano, además, será quien introducirá el consumo de la hortaliza en las tierras conquistadas, de forma que propaga el consumo y desarrolla el cultivo durante la época de dominación imperial, igual que fueron los españoles quienes la transportarán al continente americano, como explicaremos a continuación.

\section{La representación de la cebolla en diferentes soportes}

La importancia del alimento hizo que la cebolla pronto apareciera en las representaciones artísticas, sobre todo en aquellas obras que reflejaban la vida cotidiana. Aun así, no fue esta su única forma de representación puesto que su función varía desde ser parte de un conjunto de elementos decorativos a convertirse en el elemento que da sentido a la obra. La mejor manera de entenderlo será analizando cinco autores y cinco obras diferentes.

La primera obra seleccionada es Interior de la cocina con la parábola del hombre rico y del pobre Lázaro de Pieter Cornelisz van Rijck (15881635) conservado en el Rijcksmuseum de Ámsterdam (Figura 1). Pieter Cornelisz van Rijck fue un artista holandés, nacido en Delft, especialista en naturalezas muertas, que vivió en Venecia durante un largo periodo. Por ello su pintura tuvo una fuerte influencia italiana que se vio reflejada en sus pinturas de cocinas que realizó a la vuelta a Haarlem en 1602. La que mostramos a continuación es un ejemplo de ello. La fábula de Hombre Epulón y pobre Lázaro hace referencia a la historia de un acomodado hombre que comía y desechaba cantidades de comida todos los días y que nunca se preocupó por ofrecer, ni siquiera sus sobras, a un pobre, llamado Lázaro, que se sentaba todos los días a su puerta esperando la caridad del noble. El "mendigo», que hasta los perros le lamían las llagas, hubiera deseado saciarse con lo que caía de la mesa del rico. Cuando ambos murieron, el pobre fue llevado al cielo junto a Abraham, y el rico al infierno, lugar de donde pidió clemencia a Abraham, así como que enviara a Lázaro a que le sofocara sus llagas. Abraham le recordó el trato que había recibido Lázaro por su parte cuando estaban en el mundo de los vivos.

3 Este término está mal escrito. En realidad, se trata de ligústico puesto que aligustre es venenoso. 


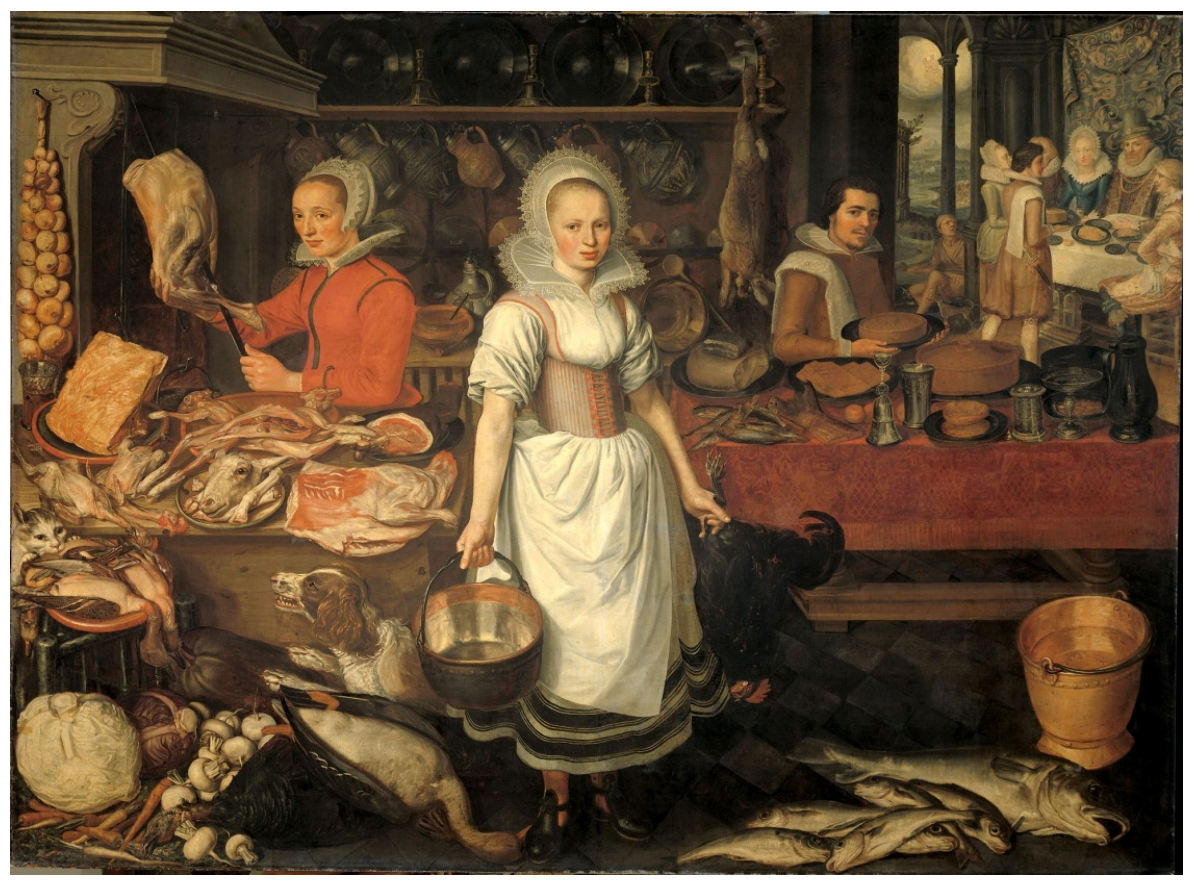

Figura 1. La fábula de Hombre Epulón y pobre Lázaro, Pieter Cornelisz van Rijck. Rijcksmuseum de Ámsterdam

El rico pidió que Lázaro volviera al mundo terrenal para avisar a su familia del daño que estaban ocasionando con el objetivo de que estos pudieran reparar en sus errores. "Tienen a Moisés y a los profetas: que los escuchen", contestó Abraham. El rico insistió en que la aparición de un muerto sería más eficaz. A dicha súplica este le replicó que si no escuchan a Moisés y a los profetas, aunque resucite uno de entre los muertos, no se convencerán (Chenoll Alfaro, 2000).

En la imagen que mostramos encontramos al fondo a la derecha la escena bíblica que narra la fábula. Observamos a Lázaro sentado en la puerta mirando a los ricos cómo disfrutan de un banquete. La escena tiene una visión desde la cocina, muy típica en la pintura de su autor, en la que se encuentran un exceso de productos de alimentación que interpretamos como una alusión a la gula, apelativo que recibe el vicio por comer y beber más allá de las posibilidades, en las que se desperdicia la comida. Entre toda la comida hallamos el conjunto de las hortalizas formado por zanahorias, col, coliflor y una gran cantidad de cebollas dividida en dos grupos: por un lado las secas, que se encuentran trenzadas junto a la cocina de leña, y por otro un grupo de cebollas derramadas en el suelo. Aquí la cebolla no ocupa ni un lugar principal ni uno secundario, como tampoco pretende mostrar, a mi entender, ningún significado sino que forma parte de un conjunto de elementos vegetales.

En la misma época encontramos al pintor José de Ribera y Cucó, nacido en 1591 en Xàtiva (España) quien desarrolló toda su carrera en Italia: primero en Parma, después en Roma y finalmente en Nápoles, donde se instaló en 1616 y donde vivió hasta su muerte en 1652 (del Amo Horga, s.f.: 689). Su establecimiento en dicha ciudad -región que vivía una etapa de opulencia comercial y de fomento del mecenazgo artístico- 
hizo que su pintura circulara por toda Europa de forma que se convirtió así en un referente para muchos.

Su estilo naturista fue evolucionando desde un principio más tenebrista hacia una estética más colorista y luminosa influenciada por el renacimiento veneciano y la escultura clásica. Junto a su pintura también encontramos cómo sus grabados alcanzaron un gran prestigio durante el siglo XVII. Reyes y virreyes, la propia Iglesia católica y los coleccionistas privados españoles se convirtieron en su mejor clientela y ello explica por qué el Museo del Prado tiene más de cuarenta obras del pintor (Fleta, 2015: 367).

Del gran número de obras realizadas por el artista hemos seleccionado su trabajo titulado Los cinco sentidos, que está formado por un total de cinco pinturas que aluden al olfato, la vista, ${ }^{4}$ el tacto, el gusto y el oído. De todos estos, el del olfato, contiene dos cebollas y un ajo que acompañan a una figura central. A diferencia de la obra tratada anteriormente, en la de Ribera, la hortaliza no forma parte del grupo sino que ocupa un lugar principal en la representación. Así pues, en esta ocasión, sí que podemos considerar que el vegetal está cargado de significado puesto que es el olor que desprende la que da sentido a la imagen. Sin él, la pintura, no podría representar uno de los cinco sentidos sino que podría mostrar, por ejemplo, el retrato de un anciano. Por otro lado, es interesante observar cómo la cebolla no se incluye como un elemento culinario, es decir, como parte de la imagen que muestra el sentido del gusto, sino que se ha utilizado para representar el olfato, que podría ser representado por muchos otros elementos. ${ }^{5}$

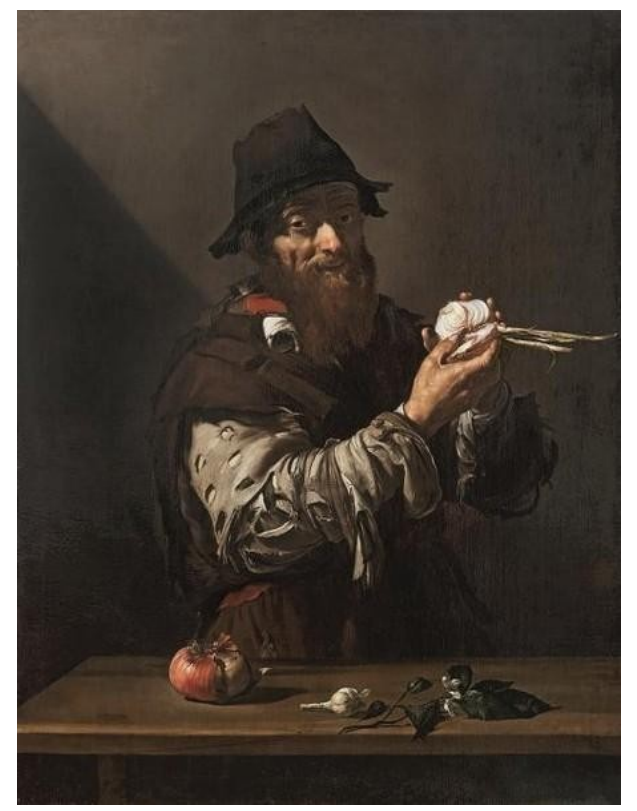

Figura 2. El olfato, José Ribera y Cucó

4. Interesante estudio sobre esta obra el que realiza Peter Mason y que se incluye en el apartado de bibliografía. 5. Para un mayor conocimiento de las obras del pintor -y en concreto del conjunto que forma la serie de Los cinco sentidos- cabe consultar el catálogo de la exposición «El joven Ribera» que se incluye en el apartado de bibliografía. 
Pero no todas las representaciones de la hortaliza se realizarán sobre lienzo, sino que en el siglo XVIII formará parte de la obra artística realizada sobre el material de moda: la loza fina y porcelana. Durante los últimos años del siglo XVII tuvo lugar una serie de acontecimientos históricos que provocaron un cambio en la sociedad europea. Todo ello fue acompañado de una nueva corriente estética que fue motivada, o reforzada, por un aumento del consumo en las clases altas de la sociedad. El gusto por el lujo y la ostentación quedó reflejado en el aumento de la demanda de tapices, orfebrería y cerámica en general que demostraba el prestigio de quienes los poseían (Díaz Manteca, 1996: 13).

Asimismo, el disfrute de la comida en la mesa cambió durante estas décadas. Los platos únicos con abundante comida evolucionaron hacia un gran número de platos con mucha variedad de alimentos. Además se ensalzó el gusto por la comida líquida como eran caldos, sopas, salsas, etcétera, que precisaban de un material adecuado para mantener los líquidos (hasta el momento las comidas eran más solidas) a la vez que pudiera aguantar los altos grados a los que se servía. Todo ello condujo a que la loza común evolucionara y esto, junto a un fuerte atractivo por el arte oriental, hizo que la porcelana se convirtiera en la obsesión para muchos. $^{6}$

Para conseguir su fórmula, nobles y reyes fundaron Manufacturas y Reales Fábricas que abastecieran al mercado del preciado producto. Algunos la consiguieron y otros se tuvieron que conformar con fabricar la loza fina. Desde platos hasta figuras, mobiliario y piezas de devoción se crearon con este nuevo material, siendo la imaginación del artista la que marcó, en muchas ocasiones, la diferencia. Una de las piezas que mostraremos a continuación fue creada en la Real Fábrica de Loza Fina y Porcelana que el IX conde de Aranda creó en su condado de Alcalatén en 1727. Como parte del conjunto de "platos de engaño» encontramos la cebolla de nuevo como protagonista (Calvo Cabezas, 2014: 139).

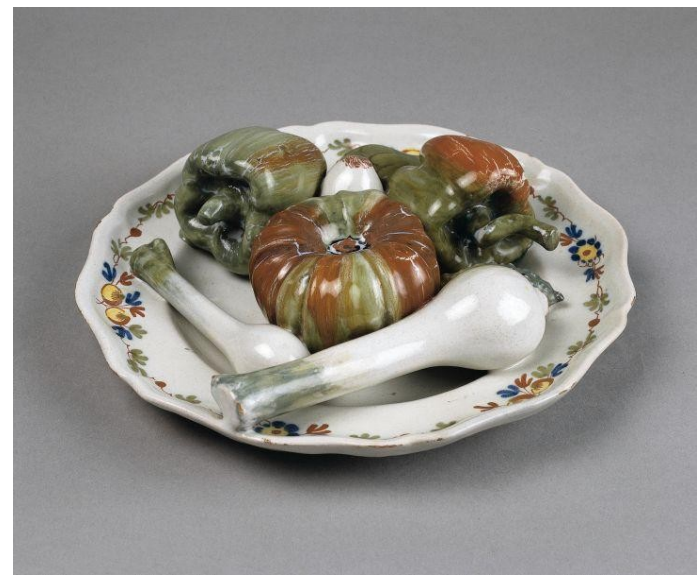

Figura 3. Plato de engaño. Real Fábrica de Loza Fina y Porcelana de Alcora

6. En oriente la porcelana alcanzaba el mismo estatus que en occidente recibían la pintura y la escultura, por lo que llegó el día que la escasa atención ofrecida por Europa hacia la porcelana dejó de ser eclipsada por la atracción tradicional hacia la seda. 
Este tipo de obras eran creadas por la imaginación del artista que mostraba un juego entre lo real y la fantasía que revelaba la calidad del producto. Uno de los motivos que más se repitió en la producción de dicha fábrica fueron los frutos (Figura 3), pero en ocasiones también se introducían hortalizas e incluso alguna forma de animal. En el ejemplo podemos ver tres cebollas, un tomate y dos pimientos. Lo que se buscaba en este tipo de trabajos era confundir lo artificial con lo real para llevar a la confusión. Si era así, quedaba reflejado el fantástico trabajo de una pieza adquirida, o creada, por quien amenizaba la fiesta.

Con este ejemplo encontramos una nueva función de la hortaliza puesto que esta, aunque formara parte del conjunto de elementos principales, también era una de las encargadas de iniciar el juego entre lo real y la fantasía.

Al igual que con otras hortalizas y verduras, la cebolla llegó al continente americano a través de los españoles en los primeros tiempos de conquista. Formaba parte de los alimentos que viajaban en los barcos que cruzaban el océano puesto que su buena conservación hacía posible que se almacenara en las despensas. No obstante, parece que la incorporación de los cultivos europeos en el Nuevo Continente no fue aceptado en todos los lugares por igual. Al parecer, las tribus tropicales fueron más reacias a incorporar los nuevos cultivos a su dieta a causa del rechazo a las plantas foráneas. En cambio, la aprobación voluntaria a los cambios culturales fue mucho más acelerada. No obstante, la facilidad de cultivo de la cebolla en los climas templados americanos hizo que se incorporara finalmente a la cocina americana, y fue en la isla de Santo Domingo, junto al río Janique, el lugar donde se cultivaron por primera vez (Torija, Matallana y Chalup, 2013: 32).

Con la llegada de los habitantes procedentes de Europa al Nuevo Continente se empezaron a crear diferentes capas sociales a consecuencia de la mezcla entre los autóctonos y los llegados al lugar. Ante la necesidad de controlar los privilegios y disfrutes que debían recibir cada uno nació un fenómeno artístico conocido como «Pinturas de Castas», cuya producción encontramos en los virreinatos de Nueva España y Perú. ${ }^{7}$ Su función era recoger las mezclas raciales del «español» (blanco europeo) y los nativos o los africanos que fueron importados como esclavos (Arbeteta Mira, 2007: 155). Aunque parece ser que esta ha sido la razón aceptada por la historiografía, tenemos que hacer mención a un trabajo muy interesante, "La pintura de castas: apología del mestizaje», en el que se reflexiona sobre el nacimiento de este género.

Lo verdaderamente interesante es la cantidad de datos visuales que se recogían en las series que se pintaron con esta temática, ya que las figuras se representaban con sus vestidos tradicionales y se acompañaban por elementos alusivos a sus oficios. Por esta razón, este género fue estudiado en un primer momento por los antropólogos y los etnólogos, y posteriormente, fue objeto de interés de los historiadores del arte.

7. Interesante estudio de Laura Catelli sobre las pinturas de castas que se realizan en Nueva España que se muestra en el apartado de bibliografía. 
Las pinturas de castas reflejaban a las personas de modo realista y con su particular indumentaria y ofrecían un ambiente de armonía familiar. Estos individuos se representaban rodeados por frutos $y$ hortalizas en la gran mayoría de los casos, que han sido muy interesantes para la historiografía, en general, y para nuestro estudio, en particular. Con ello, podemos documentar qué tipo de agricultura se cultivaba en el siglo XVIII y la podemos comparar en la de los diferentes virreinatos. No obstante, hemos de tener ciertas reservas al considerar que este tipo de pinturas copiaban la realidad social, puesto que pocos campesinos dispondrían de ropas con tanta riqueza, ni el ambiente familiar sería tan idílico como el plasmado en las pinturas. Nicolás Sánchez-Albornoz lo califica como un género artístico de entretenimiento más próximo a las formas del estilo rococó que a la propia vida de las Indias.

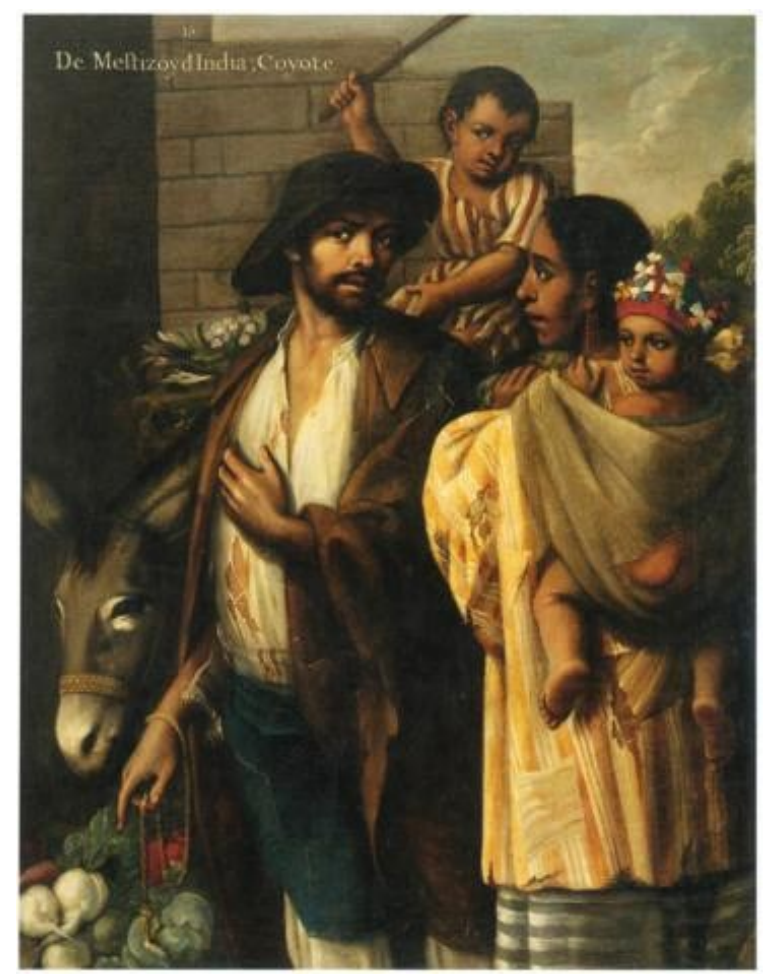

Figura 4. De Mestizo y de India, Coyote, Miguel Cabrera, ca. 1763. Colección de Elisabeth Waldo-Dentzel, Multicultural Music and Art Foundation of Northridge, California

De los artistas que trabajaron en la capital del virreinato de la Nueva España en el siglo XVIII, el más completo y que más temática abarcó fue Miguel Cabrera, pues su actividad recoge tanto la producción pictórica como el diseño de retablos o túmulos desde 1740 hasta su fallecimiento, en 1768. De su taller surgieron numerosas series de cuadros de temática religiosa y civil. Fue el gran representante de la sociedad criolla de su momento con sus pinturas de castas, que hoy en día se conservan en el Museo de América de Madrid (Gila Medina, 2006).

Por lo que refiere a la hortaliza que centra nuestro estudio, encontramos como Cabrera reflejó su existencia en el continente americano en sus famosas pinturas de castas. Lo que nos resulta curioso 
tras realizar un análisis de las series es que la cebolla siempre acompaña al indio, a la mestiza y al hijo de ambos, que recibe el nombre de coyote (Figura 4). Si tomamos al pie de la letra que la función de estas pinturas era mostrar las diferentes etnias y sus oficios, podríamos pensar que el cultivo de la hortaliza era muy común en estas etnias o que ellos eran más numerosos en los lugares idóneos para el cultivo de la cebolla. No obstante, Cabrera no fue el único pintor de castas y contamos con otros autores de prestigio e incluso muchos anónimos. Un ejemplo es el que mostramos a continuación, fechado en las últimas décadas del siglo XVIII y que se encuentra en el Museo de América de Madrid.

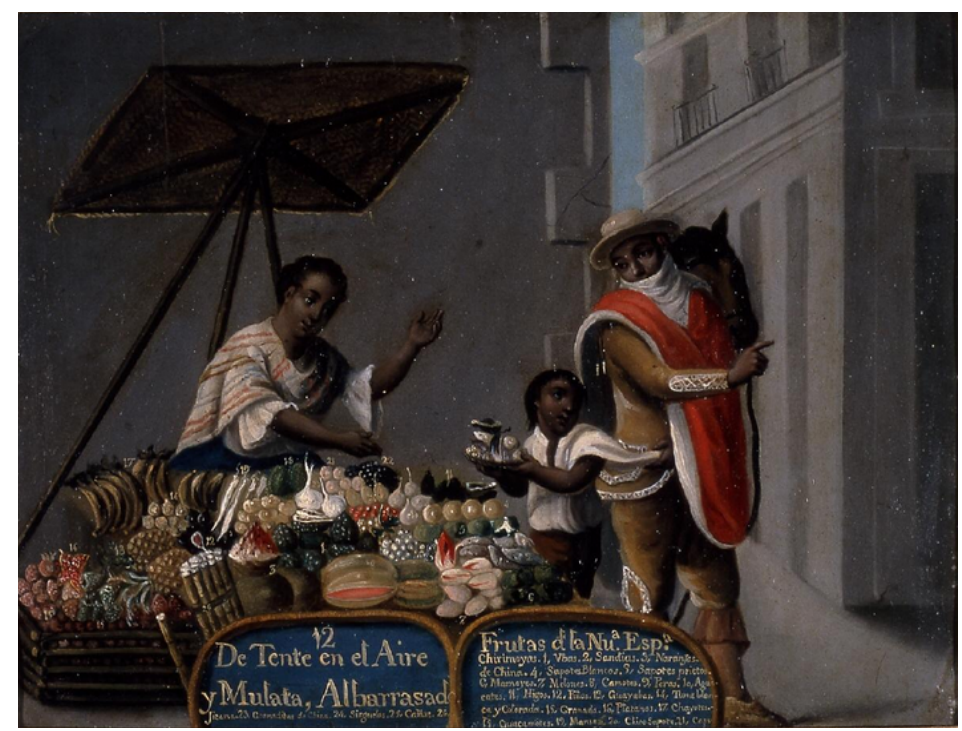

Figura 5. De tente en el aire y mulata, Albarrasado, Anónimo. Museo de América, Madrid

En la imagen encontramos un puesto de venta de frutos y hortalizas propias de la Nueva España, en la cartelera inferior aparecen todas las frutas nombradas pero en cambio ninguna hortaliza. Personalmente, considero que no hay duda en pensar que justamente en el centro, bajo el brazo de la mulata, encontramos tres cebollas blancas. En la actualidad, México es el principal exportador de cebolla mundial y el $90 \%$ de su cosecha es de la variedad de cebolla blanca. Ello nos lleva a pensar que existen posibilidades de que estamos en lo cierto, si tenemos en cuenta, además, que es un ingrediente fundamental en la gran mayoría de los platillos tradicionales mexicanos.

Recapitulando lo expuesto hasta ahora, observamos como una misma hortaliza, además de formar parte del conjunto pictórico y de dar sentido a la obra, puede tener la función de documentar e informar a quien iba dirigida la obra. Siguiendo esta línea, encontramos el quinto de nuestros ejemplos. Los bodegones o naturalezas muertas son obras de arte en las que sus elementos principales son frutos, hortalizas, animales, utensilios de cocina $\mathrm{y}$ otros objetos naturales representados en un espacio interior o exterior. El género lo encontramos ya en la antigüedad, 
en los mosaicos que adornaban las culinas romanas, ${ }^{8}$ y fue evolucionando en el transcurso de los años y llegó incluso a tener un simbolismo religioso y alegórico.

En el siglo XVIII el género evoluciona hacia representaciones con una alta riqueza en color y formas, que pretenden mostrar la comida cotidiana con todo detalle. Un buen ejemplo lo encontramos en el pintor napolitano Luis Egidio Meléndez, nacido en Nápoles pero que hizo la gran parte de su obra en Madrid. Gran número de sus bodegones fue creado en la década de 1770 para el servicio de la corona, concretamente para las colecciones personales del entonces príncipe de Asturias y posterior monarca Carlos IV. El conjunto está compuesto por cuarenta y cuatro piezas de un realismo impresionante que fueron expuestos en el Palacio de Aranjuez y que hoy en día se conservan, la gran mayoría, en el Museo del Prado (Espinosa Martín, 1989: 67).

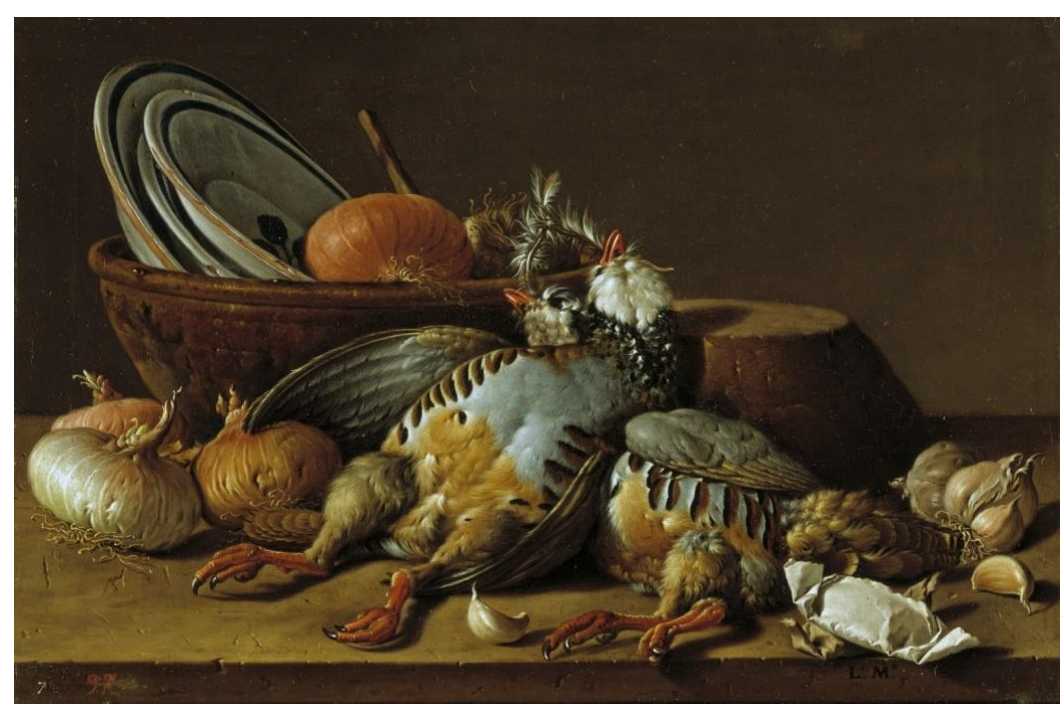

Figura 6. Dos perdices, cebollas, ajos y vasijas, Luis Egidio Meléndez. Museo Nacional del Prado, Madrid

El propio Meléndez pretendía que estos fueran un documento sobre las diferentes frutas y verduras autóctonas de España, por lo que nuevamente el producto vegetal se utiliza con un carácter informativo, como en el caso de las pinturas de castas. Entre sus trabajos de bodegón, resaltaré uno de los dos en el que el tema de la caza acompaña a la naturaleza muerta. Se trata de dos perdices de plumaje multicolor que se utilizan como elementos centrales en la composición. Junto a ellas, las cabezas y dientes de ajo. En segundo plano, dos lebrillos de Alcorcón conteniendo tres platos de loza decorada, de la serie de la adormidera, catalogada, según algunos especialistas, como procedente de la cerámica realizada en Talavera o del Puente del Arzobispo. ${ }^{9}$ Parece que la escena muestra el momento previo a empezar un guiso en el que se cocinarán las

8. Un ejemplo lo encontramos en el mosaico que se halló en Málaga (Balil Illana, 1983)

9. Para un mayor conocimiento de la loza que representa el pintor, sugerimos la lectura del estudio que realiza Luis Carlos Gutiérrez Alonso titulado «Precisiones a la cerámica de los bodegones de Luis Egidio Meléndez» 
perdices acompañadas de las cebollas y ajos en el lebrillo y que, después, se servirán en los platos para que se consuman.

El pintor no solo plasmó la cebolla común en sus trabajos sino que también hizo lo mismo con otras especies procedentes de la cebolla. Por ejemplo, podemos citar el trabajo «Bodegón: pescados, cebolletas, pan y objetos diversos» en el que se comparten muchos elementos en la anterior obra.

\section{Conclusiones}

Tras realizar el análisis de diferentes obras en las que aparece representada la cebolla, podemos concluir con las siguientes reflexiones. La primera de ellas es que un mismo elemento puede ofrecer un significado muy diferente dependiendo del protagonismo que un autor le otorgue, es decir, puede formar parte de un conjunto de elementos en el que si fuese sustituida la obra no cambiaría su sentido, o ser precisamente el elemento que da sentido a toda la obra. Inconscientemente, parece que nuestra mente solo otorgue dicho protagonismo a las personas, animales, grandes paisajes o conjuntos arquitectónicos y que desplace injustamente a un segundo plano a otros. Un claro ejemplo lo podemos observar en la pintura de José Ribera y Cucó, El olfato, en la que parece que no hay duda alguna de que el protagonista de la obra es el anciano y, en cambio, son los ajos y la cebolla los que dan el sentido. Esto nos muestra la importancia que juega en el arte la lectura del título que otorga el artista a su trabajo.

Por otro lado, también resulta muy interesante poder extraer información del género de las pinturas de castas. Aunque existan diferentes interpretaciones sobre la intención que se persiguió al ser creadas, lo que no deja lugar a dudas es que es una fuente de información fundamental sobre la cultura colonial americana. El análisis de estas obras, junto a estudios de otras disciplinas, nos puede proporcionar gran información. Por ejemplo, y centrándonos en el estudio de la hortaliza que nos ocupa, la duda de si eran o no cebollas lo representado en estas pinturas se despeja teniendo en cuenta estudios agrónomos actuales en los que se confirman que México es el mayor exportador mundial de esta hortaliza. Y no de cualquier cebolla, sino de la blanca, que es la variedad que más se asemejaba a las representadas. Tal vez esto no es suficiente para afirmarlo completamente puesto que 250 años son una gran distancia temporal, pero al menos nos indica que no estamos tan equivocados.

Sobre los bodegones de Luis Egidio Meléndez que hemos tratado, parece que existe un poco de controversia si fue Carlos III o Carlos IV quien los encargó al pintor. Sin pretender entrar en debates históricos, sea un rey u otro, considero que es fundamental para su entendimiento conocer el motivo por el que fueron realizados. Su obra no fue un simple encargo para embellecer un lugar concreto, sino que se buscaba documentar las hortalizas que en ese momento se cultivaban en España. 
Esto es muy diferente a, por ejemplo, la primera de las obras tratadas, en las que la cebolla, junto al resto de hortalizas, forma parte de un conjunto de alimentos que aluden a la gula. Por ello, los trabajos que buscaban documentar deben ser objeto de un estudio más profundo puesto que estamos seguros que entre sus elementos existe más información de las que pretendían mostrar. Por ejemplo, en el bodegón que tratamos, aparecen todos los ingredientes necesarios para la elaboración de un guiso. Aparece la carne (perdices), los condimentos alimenticios (cebolla y ajos), el recipiente para su elaboración (el lebrillo) y los platos para servir. Esto nos puede llevar a pensar que no solo se pretende mostrar los productos de la época sino también la cocina tradicional.

\section{Bibliografía}

Amo Horga, L. M. del (2001): "María Magdalena y San Antonio de Padua, de José de Ribera del Escorial a la Academia», El Monasterio del Escorial y la pintura: actas del Simposium, Real Centro Universitario Escorial - María Cristina, p. 687-708.

ARBETEA, L. (2007): «Precisiones iconográficas sobre algunas pinturas de la colección del Museo de América, basadas en el estudio de la joyería representada», en Anales del Museo de América, 15, p. 141-171.

BALIL, A. (1989): «Un bodegón en mosaico hallado en Marbella», Baética: Estudios de arte, geografía e historia, 6, p. 159-174.

Calvo, E. (2014): La Real Fábrica del conde de Aranda en Alcora: El programa ilustrado reflejado en sus piezas, Trabajo Final de Grado, Universitat Jaume I, Castellón de la Plana.

CASTELL, V. (1996): "Híbridos de cebolla», en Horticultura, 116, p. 13-23.

CATElLI, L. (2012): «Pintores criollos, pinturas de castas y colonialismo interno: los discursos raciales de las agencias criollas en la Nueva España del periodo virreinal tardío», CILHA, 17, p. 146-174.

CHENOLL, R. R. (2000): «Un capítulo neotestamentario sobre el más allá: el rico Epulón y el pobre Lázaro», Baética: Estudios de arte, geografía e historia, 22, p. 313-332.

Cubero, J. I. (2003): Introducción a la mejora genética vegetal, MundiPrensa, Madrid.

DíAz, E. et al. (1996): Alcora, un siglo de arte e industria, Bancaixa, Castellón de la Plana.

Eaton, K. (2013): Ancient Egyptian Temple Ritual: Performance, Patterns and Practice, Routledge, Nueva York.

ESPINOSA, M. C. (1989): «Aportes documentales a los bodegones de Luis Meléndez», Boletín del Prado, 28, p. 67-78. 
FLETA, J. (2015): "José de Ribera y el realismo barroco de sus niños», Pediatría integral, núm. 19, p. 365-367.

GILA, L. (2004): «Un cuadro inédito de Miguel Cabrera el del Cristo de Burgos de la Iglesia del Carmen del ex convento de San Ángel, en México, D.F.", Anales del Museo de América, 12, p. 205-216.

Gutiérrez Alonso, L. C. (1983): «Precisiones a la cerámica de los bodegones de Luis Egidio Meléndez», Boletín del Museo del Prado, vol. 4, 12, p. $162-166$.

Jones, H. A. y L. K. Mann (1963): Vegetables Production, Van Nostrand Reinhold, Nueva York.

MAson, P. (2012): «El catalejo de Ribera. Observaciones sobre La vista de la primera serie de Los cinco sentidos», Boletín del Museo del Prado, núm. 30, p. 50-61.

Milicua J. y J. Portus (ed.) (2011): El joven Ribera, Museo Nacional del Prado, Madrid.

PASTOR, B. (1997): Apicio. Cocina romana, Coloquio, Madrid.

ToriJa, M. E., M. C. Matallana y N. Chalup (2013): «El ajo y la cebolla: de las medicinas antiguas al interés actual», Boletín de la Real Sociedad Española de Historia Natural. Sección biológica, Tomo 107, núm. 1-4, p. 29-37.

VAN LoON, Gabril. "Charaka-Samhita», Vol.1, en https://ayurinfo.files.wordpress.com/2011/09/charak-samhita-handbook-vol-iedited-by-gabriel-van-loon.pdf [última consulta el 27 de noviembre de 2018].

VAN LooN, Gabril. "Charaka-Samhita», Vol.2, en https://ayurinfo.files.wordpress.com/2011/09/charak-samhita-handbook-vol-iiedited-by-gabriel-van-loon.pdf [última consulta el 27 de noviembre de 2018]. 
Antonio Gozalbo Nadal. La representación artística de la campaña de Carlos V en Túnez (1535): estado de la cuestión

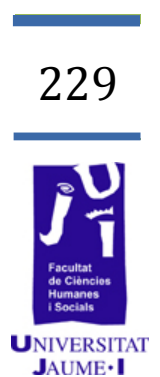

La representación artística de la campaña de Carlos V en Túnez (1535): estado de la cuestión

Antonio Gozalbo Nadal 
En el siglo XVI se asiste en el ámbito político a la gestación de poderosas monarquías autoritarias, deseosas en el campo de las artes de una imagen que atendiese a sus necesidades representativas, germen de un auténtico arte áulico y persuasivo. En este sentido, ocupa un papel fundamental la corte de Carlos V, cuya imagen oficial ha sido estudiada fundamentalmente por Fernando Checa. En sus trabajos plantea un proceso paulatino que, partiendo de unas bases medievalizantes y caballerescas, eclosionaría a partir de la década de 1530 en un arte maduro, heroico y de raíz clasicista. El momento de transición lo definieron dos hechos claves para la política y la retórica carolinas: la coronación imperial en Bolonia (1530) y la conquista de la Túnez de los Barbarroja en 1535. Esta campaña bélica tuvo escasos efectos prácticos, pero sí que derivó en un potente entramado artístico de carácter laudatorio. Su base formal se iba a asentar sobre el prestigio de la tradición clásica y el paragón con Escipión y la Roma imperial.

Con el presente trabajo queremos atender a una cuestión fundamental en cualquier investigación: conocer el estado de la cuestión, destacando la producción historiográfica más destacada. Para ello nos centraremos en los estudios generales sobre la Jornada de Túnez, la bibliografía acerca de la monumental serie de tapices, encargada posteriormente con fines celebrativos, así como los trabajos que estudian los efectos de la campaña en el resto de las artes y las entradas triunfales en Italia. También queremos evidenciar las carencias aún existentes y plantear posibles nuevas vías de investigación.

Palabras clave: Carlos V, Jornada de Túnez, bibliografía, tapices, artes, entradas triunfales.

\section{Carlos V y las artes}

"Carlos V sólo es comparable con Carlomagno y Julio César». Esta rotunda afirmación, realizada por el historiador M. Fernández Álvarez (2008), probablemente el que fuera su mayor conocedor, es una muestra evidente de la significación y alcance de la figura del emperador. La relevancia y complejidad de Carlos $V$ no se limitan únicamente al estudio de su actividad política o de su faceta humana, y se alcanzó también al análisis de su representación artística y la configuración y el desarrollo iconográfico de su imagen. ${ }^{1}$ Así, la aparición de los estudios culturales, el desarrollo de la historia social del arte, el interés por la relación entre arte

1. Este artículo se enmarca en la elaboración de una tesis doctoral: Las representaciones artísticas de las victorias de Carlos $V$ y su papel en la creación de la iconografía imperial, realizada por Antonio Gozalbo Nadal en la Escuela de Doctorado de la UJI y bajo la dirección de los profesores doctores Víctor Mínguez Cornelles y Fernando Checa Cremades. 
y poder o la creciente valoración de tipos de manifestaciones de arte efímero, han propiciado la mirada sobre Carlos $\mathrm{V}$ también desde la historiografía artística.

Los primeros estudios los encontramos aún en el siglo XIX o inicios del XX, entre los que se destacan los de Stirling-Maxwell (1853 y 1875), Madrazo (1889) o Bernhardt (1919). No obstante, la efeméride de la muerte del emperador, celebrada en 1958, fue la que posibilitó un gran impulso al campo de los estudios culturales y artísticos carolinos. El acontecimiento más significativo fue la exposición celebrada en el Hospital de la Santa Cruz de Toledo, organizada por Gallego Burín (1958), bajo el título "Carlos V y su ambiente. IV Centenario de la muerte del emperador». La celebración de los quinientos años de su nacimiento también iba a verse acompañada por numerosas exposiciones y congresos. Además, coincidió cronológicamente con la efeméride de la muerte de su hijo Felipe II, gran mecenas artístico. Para poder cohesionar todas estas celebraciones se creó la Sociedad Estatal para la Conmemoración de los Centenarios de Felipe II y Carlos V, dirigida por J. C. Elorza. Su labor fructificó en numerosos actos y publicaciones, entre los que se destacan exposiciones como "Carolus» (Checa, 2000), «El linaje del emperador» (Portús, 2000), "Carlos V. Las armas y las letras» (Marías, 2000) y «La fiesta en la Europa de Carlos V» (Morales, 2000).

En paralelo a estas propuestas se ha realizado un amplísimo número de estudios parciales relacionados con las artes tradicionales. ${ }^{2}$ Además, durante los últimos años ha eclosionado un interés renovado por los tapices, con aportaciones tan destacadas como las de M. A. Zalama (2011) y F. Checa (2010). Con ellos, se está recuperando la importancia de un arte que tuvo un papel clave en la articulación de los programas representativos reales, y que paulatinamente se ha minusvalorado hasta la actualidad. También han ido creciendo las investigaciones acerca de las artes efímeras, fundamentales dada su cercanía a la mayoría de súbditos. Destacan, así, las publicaciones sobre los túmulos funerarios de Carlos V (Bonet, 1960; Abella Rubio, 1978; Checa, 1979 a) y las entradas triunfales vinculadas a los grandes hechos imperiales, especialmente después de los aurorales estudios de Strong (1984) y Jacquot (1975), continuados por Popham (1939-40), Checa (1979 b) o muchos otros.

Todos estos trabajos, más allá del indiscutible valor de sus aportaciones, han evidenciado de forma clara la necesidad de estudios que traten de forma integral a la figura de Carlos $\mathrm{V}$ y el conjunto de producciones artísticas generadas a su alrededor. La aproximación más importante al tema es la de F. Checa, como muestra su tesis, publicada

2. Cabe destacar las investigaciones en el campo de la pintura, que ocupan un lugar preferente el estudio de la retratística imperial y la relación entre Carlos V y Tiziano (Cloulas, 1964; Mancini, 2000; Checa, 1994, 2001, 2013; Bustamante, 2004), el grabado (Stirling-Maxwell, 1853; Checa, 1980; Páez, 1993; Mielke, 2009), la arquitectura (Gómez Moreno, 1941; Chueca Goitia, 1953; Tafuri, 1969; Rosenthal, 1974, 1985; Marías, 1983-6; 1989; 2000). La escultura ha sido analizada por especialistas como Ciardi-Dupre (1968), y se ha destacado el protagonismo de la familia milanesa de los Leoni (Gilman, 1956; Urrea, 1994; Coppel, 2013). 
parcialmente bajo el título Carlos $V$ y la imagen del héroe en el Renacimiento (1987) o Carlos V. La imagen del poder en el Renacimiento (1999). En ambos trabajos incide en aportar un valor fundamental a la Jornada de Túnez como momento clave en la configuración definitiva de la imagen clasicista del emperador, aclamado tras su gesta como un César revivido o un nuevo Escipión. ${ }^{3}$

\section{Estudios generales sobre la Jornada de Túnez}

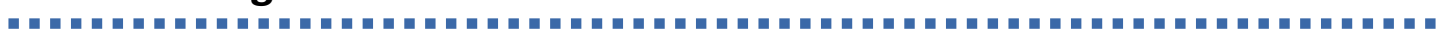

La importancia del conjunto de obras derivadas de la conquista norteafricana, a pesar de su abundancia, calidad y trascendencia en la imagen imperial, no ha sido, hasta el momento, estudiado con el rigor que se merece. Existen escasas obras de gran calado sobre la campaña tunecina, realizadas desde una perspectiva integral, como el libro de finales del XIX debido a la pluma de G. Voigt (1872). En él se recogen las principales crónicas escritas, y también se hace referencia a diversas obras como los tapices. Las aportaciones de la obra, más allá de su indiscutible valor, necesitan una revisión desde planteamientos historiográficos más actuales, pendiente aún de hacer. $Y$ es que, con posterioridad, se han realizado estudios de carácter general, pero de extensión y formato menos ambicioso, ya que se trata de artículos. Obra de referencia es el trabajo de S. Deswarte-Rosa (1998), publicado con el título «L'expédition de Tunis (1535): images, interprétations, répercussions culturelles». En el artículo se incide en la importancia de la campaña de Túnez en la generación de la imagen imperial, mucho más significativa en este sentido que en sus resultados políticos reales. La imagen del triunfo, establecida iconográficamente en las entradas italianas, iba a tener una repercusión permanente en todos los programas artísticos y decorativos en honor de Carlos V, e incluso de sus herederos, partiendo de un amplísimo programa articulado mediante todas las artes y posibilidades de lenguaje. Históricamente, alegórico, la victoria se mostró como una nueva cruzada o guerra púnica; se usó, además, el lenguaje narrativo, especialmente a través de las crónicas y los tapices, y la mitología y la emblemática también tuvieron su espacio. Más allá de estas representaciones «oficiales», las campañas contra el islam propiciaron la aparición de una moda «a la turquesca» en toda Europa, además de facilitar sinergias y vinculaciones culturales entre los dos mundos.

Junto con este artículo, el otro estudio reciente de mayor significación es el firmado por J. L. González (2007), bajo el título

\footnotetext{
3. Siguiendo los planteamientos de F. Checa, aunque Carlos V nunca tuvo un interés preferente por las artes, desde su entorno cortesano sí que se planteó la necesidad de articular una imagen de poder coherente, y como ideólogos se destacaron J. P. de Granvela y María de Hungría. De esta forma, la imagen del César pasó por un primer momento de raíz medieval, caballeresca, muy influida por la tradición borgoñona y el humanismo erasmista. Posteriormente, esta tendencia dio paso a un marco referencial de carácter renacentista y clásico, configurado a través de la obra de Tiziano, los Leoni, etc. El momento de inflexión se produjo en los años treinta, fundamentalmente a partir de dos hechos concretos: la coronación imperial de 1530 y la Jornada de Túnez de 1535.
} 
«"Pinturas Tejidas". La guerra como arte y el arte de la guerra en torno a la Empresa de Túnez (1535)». El texto coincide con el anterior en la idea que la acción bélica tuvo una mayor resonancia artística que política, ya que produjo la aparición de un amplio abanico de representaciones artísticas. El título del artículo puede ser engañoso ya que, aunque dedica una parte importante de su contenido a analizar la serie de tapices, también realiza un repaso por las crónicas escritas, grabados, monedas, armas, platería, pinturas, etc., así como a las entradas triunfales italianas. Se trata, pues, de una aportación importante ya que ofrece, de forma abreviada, una visión general de todo el programa artístico.

También podríamos hacer aquí referencia a un reciente trabajo conjunto, titulado "Túnez 1535» (2010), en el que se recoge una miscelánea de trabajos referidos a diferentes aspectos militares de la campaña carolina, interesante sobre todo por el importante material gráfico que aporta.

Como podemos ver, pues, a pesar de su calidad, estos trabajos presentan limitaciones evidentes, por su antigüedad o formato, y, por lo tanto, necesitamos nuevas lecturas y estudios.

\section{La serie de tapices}

Dentro de las manifestaciones artísticas generadas tras la campaña, destaca por su calidad y significado el conjunto de paños de la Jornada de Túnez, que suscita el interés de numerosos historiadores. Ya a finales del siglo XIX y principio del XX se realizaron estudios importantes, como los de Houdoy (1873) o las referencias en la publicación sobre las colecciones reales de F. J. Sánchez Cantón y E. Tormo (1919).

El interés se mantuvo con posterioridad, como reflejan los artículos publicados en la revista del Patrimonio Nacional Reales Sitios. En un número monográfico sobre representaciones navales, P. Junquera publicó su trabajo "Las batallas navales en los tapices» (1968). En él se recogen referencias interesantes al encargo, se transcribe parte de los textos que acompañan a los tapices $y$, además, se comparan con otros tapices de temática clásica y bélica de las colecciones reales. Años después, en la misma revista se publicó otro artículo importante, debido a la autoría de A. de Carlos (1981), donde se amplía el trabajo anterior.

El estudio de mayor profundidad realizado hasta ahora acerca de los tapices de Túnez es, indiscutiblemente, la monumental monografía de $\mathrm{H}$. Horn (1989). Titulada Jan Cornelisz Vermeyen, Painter of Charles $V$ and His Conquest of Tunis: Etchings, Drawings, Cartoons and Tapestries, se presenta en dos monumentales volúmenes, en los que el texto se apoya en un importante material gráfico. El autor incide en la importancia del pintor flamenco y en la propia serie de tapices y sus cartones, uno de los encargos más ambiciosos de la época. De esta forma, analiza el estilo del pintor, definido por un clasicismo monumental, que llega a su máximo desarrollo en esta serie de cartones. También se presentan sus vínculos con otros pintores, como Pieter Coecke. Por otro lado, se estudian otras 
obras del autor, sin llegar a configurar un catálogo razonado, pero sí a plantear una visión amplia de su producción pictórica.

En España, esta serie de tapices ha sido estudiada en años recientes por varios historiadores. En este sentido destacan los artículos de M. Á. de Bunes. El primero, realizado conjuntamente con M. Falomir, se titula "Carlos V, Vermeyen y la conquista de Túnez» (2001). De cronología posterior es su segundo artículo, «Vermeyen y los tapices de la conquista de Túnez. Historia y representación» (2006). En ellos se insiste en el papel de este conjunto textil como hito fundamental en la creación de la imagen de poder dinástico de la casa de Habsburgo. La vía para conseguirlo sería la representación de los hechos a través de un verismo monumental, mediante la narración cronológica, casi como una crónica de los hechos, el realismo geográfico, y el complemento de textos explicativos. Se otorga a los tapices, pues, una función fundamentalmente política, pragmática, resultado, al igual que toda la campaña en sí, más de los intereses geoestratégicos imperiales que de sueños caballerescos o de cruzada.

Otra obra importante, tanto por su contenido gráfico como por los textos que incorpora, es el catálogo de la exposición sobre los cartones de Vermeyen celebrada en el Kunsthistorisches Museum de Viena, lugar donde se conservan. El catálogo y los textos se deben a W. Seipel y G. J. Kugler (2000) y en ellos se estudia la campaña bélica, el trabajo artístico realizado por Vermeyen y también la copia de los tapices encargada por el archiduque Carlos durante la Guerra de Sucesión. En la exposición se mostraron los cartones más esta serie que, aunque no sea la prínceps, a diferencia de la conservada por Patrimonio Nacional, sí que está completa, lo que la dota de gran interés. Recientemente, el mismo museo ha realizado una nueva muestra, bajo el título Kaiser Karl V. erober Tunis. Dokumentation eines Kriegszuges in Kartons und Tapisserien, comisariada por S. Haag y K. Schmitz-Von Ledebur (2015). A este conjunto de trabajos debemos sumar el artículo de Werner en el catálogo de la exposición Kaiser Karl V (2000), justificada por la efeméride carolina del cambio de siglo.

Estas publicaciones aparecen, además, en el marco del referido nuevo interés por el mundo de los tapices. Fruto de estas investigaciones son publicaciones como Tesoros de la corona de España, de F. Checa (2010). En ella se analiza la importancia de los tapices como medio de representación del poder en el Renacimiento haciendo un recorrido por los grandes encargos de los Reyes Católicos y los Austrias del XVI. Como es evidente, se hace especial hincapié en la serie de Túnez, en la que se analiza su encargo, los contenidos de cada uno de los tapices, las características iconográficas y también formales, pues representan la consagración definitiva de las formas renacentistas en una técnica artística tan vinculada con la tradición medieval. A la figura de Checa tenemos que sumar la de otros investigadores como C. Herrero Carretero (1991), G. Delmarcel (1999), T. Campbell (2002) o E. Cleland (2014). 
Para concluir, también cabría hacer referencia aquí a otros planteamientos novedosos de investigación, tales como la visión de la campaña desde la óptica islámica. La producción en este sentido es aún escasa, pero interesante, como muestran los análisis de A. Gafsi Slama (2001) o C. Paredes (2005).

\section{La conquista de Túnez en el resto de las artes}

Aunque desde un punto de vista artístico la Jornada de Túnez se vincula directamente con la serie de tapices encargada por María de Hungría, con posterioridad a la campaña, se realizó un gran número de obras, en gran variedad de técnicas y formatos. En el campo de la pintura, la gran resonancia del triunfo imperial propició que se representase en varios ciclos de frescos, como los del "Peinador de la Reina», en la Alhambra granadina. Estudiados por R. López (2000), en estas pinturas se combinan las escenas mitológicas con representaciones veristas geográficamente, también del interés de M. Lillo (1998). Protagonista fundamental de la campaña fue don Álvaro de Bazán, marqués de Santa Cruz. En su palacio de Viso del Marqués, estudiado por R. López (1999) e I. Rodríguez (2009), también reprodujeron al fresco sus acciones navales, entre las que se destacó el triunfo tunecino. Junto con las pinturas, es necesario hablar de las estampas y los grabados, tan importantes desde un punto de vista propagandístico y como inspiración para otras obras. El valor de la conquista tunecina como hito clave en la política de Carlos $\mathrm{V}$ propició su representación en diversas series, y se destacan las de $A$. Tempesta, M. Heemskerk o F. Hogenberg, estudiadas y reproducidas en varios trabajos a los que ya hemos hecho referencia, ${ }^{4}$ o los de U. Mielke (2009).

Vinculados con este tipo de representación estarían los mapas y las vistas urbanas. Reflejo tanto del desarrollo de la geografía y la navegación en esta época como de la voluntad de mostrar gráficamente el dominio sobre un territorio, la campaña de Túnez generó varias representaciones cartográficas, como las de A. de Santa Cruz o P. Giovio. El mejor estudio realizado sobre la cartografía española del área tunecina se debe a J. B. Vilar (1991). Se trata de un trabajo amplio cronológicamente, donde la Jornada carolina ocupa un lugar preeminente. La obra se complementa, además, con importante material gráfico: mapas y vistas de la ciudad posteriores a la conquista, planos de las nuevas fortificaciones erigidas, además de imágenes e información sobre enclaves cercanos.

Otros medios tradicionales en la difusión de mensajes persuasivos a través del arte fueron la numismática, las medallas y la joyería. En el caso de la campaña de Túnez se acuñaron monedas en Barcelona, Flandes y el Franco Condado, como estudian Cayón y Castán en su catálogo de monedas históricas (1991). A esto deberíamos sumar medallas conmemorativas all'antica, estudiadas por Donati (1989) o Almagro- 
Gorbea, Pérez Alcorta y Moneo (2005). Este mismo tipo de representaciones clasicistas las encontramos en piezas de joyería y platería. N. Horcajo, en su artículo "La imagen de Carlos V y Felipe II en las joyas del siglo XVI» (2002), nos muestra diversas piezas de clara alegoría clasicista, vinculadas a la Jornada de Túnez. Igualmente, los trabajos de A. López-Yarto (1999; 2009) evidencian cómo la exaltación tunecina fue una constante también en la decoración de lujosas vajillas, y se reprodujo en fuentes, jarros, copas, etc.

El arte del metal más adecuado para este tipo de representaciones militares era, como es evidente, el de las armas y armaduras, piezas fundamentales en la configuración de la imagen del poder nobiliar y monárquico. Carlos $V$ fue, en este sentido, uno de los grandes comitentes de su época, ya que hizo importantes encargos a los principales talleres europeos, como los de Negroli o Helmschmid. Ya a principios del siglo Xx la imponente colección de la Real Armería fue catalogada por el conde de Valencia de Don Juan, en su obra Armas y tapices de la corona española (1902), aportación fundamental en la valoración de este tipo de piezas artísticas, junto con el estudio del "Inventario iluminado» de 1558 realizado por Grancsay (1966). Se trata de un documento fundamental, pues en él se describe la colección de armamento de Carlos $\mathrm{V}$, complementada con acuarelas de arneses, armas, banderas, etc. Algunas de estas piezas, además, se pueden vincular con la gesta africana. Durante los últimos años se han celebrado diversas exposiciones sobre arneses y armas, como la que se realizó en el Metropolitan Museum de Nueva York dedicada a la familia de armeros milaneses Negroli (1998). También a J. A. Godoy se debe la celebración de la monumental exposición «Parures Triomphales. Le maniérisme dans l'art de l'armure italienne» (2003). En España tuvo especial relevancia la exposición «El arte del poder. La Real Armería y el retrato de corte» (2010). El comisario y responsable del catálogo fue A. Soler del Campo, quien orientó la exposición a mostrar el papel de las armaduras en la articulación de la imagen regia. Se complementa, además, con fichas de las obras expuestas, algunas claramente vinculadas con la campaña imperial en el norte de África como el llamado «Arnés de Túnez» o la «Rodela del Plus Ultra».

\section{Las entradas triunfales de Carlos V en Italia}

Los ataques de las galeras tunecinas afectaron fundamentalmente a las costas italianas, por lo que el triunfo imperial fue celebrado con grandes conmemoraciones. Carlos V recorrió Mesina, Nápoles, Roma, Florencia o Siena, y fue recibido con grandes entradas triunfales. En estas ciudades, remodeladas all'antica, entró como un nuevo Escipión vencedor en las tierras de Cartago. Este baño de antigüedad fue fundamental en la evolución de la imagen imperial: a partir de este momento la producción artística carolina giró hacia postulados 
monumentales y clasicistas, desarrollados al máximo por Tiziano o los Leoni.

La trascendencia de estas entradas, pues, ha llevado a la realización de una importante bibliografía, debida en gran parte a la autoría de historiadores italianos. Se han producido análisis globales de todo el recorrido imperial, desde los debidos a G. Romano (1892) a los más recientes de M. A. Visceglia (2001). También la historiografía italiana ha generado estudios particulares para cada una de las entradas. Las celebradas en el sur de Italia, espacio especialmente afectado por los ataques norteafricanos y que, por tanto, recibió con importantes fastos a Carlos $V$, ha sido muy estudiado. Las entradas sicilianas han sido trabajadas por Torrisi (1958), y también lo han sido de forma específica las producidas en Palermo (Fagiolo, 1980), Mesina (Pugliatti, 1990) o Nápoles (Di Stefano, 1980; Toscano, 2001). Las entradas florentinas, por su parte, han propiciado las investigaciones de Gianneschi (1979) y Cazzato (1985). La significancia especial de la entrada en Roma, donde Carlos V fue recibido por Pablo III después de hacer un recorrido por la via triumphalis, ha propiciado una ingente cantidad de estudios. Destacan el clásico de Ossat (1943) o los de M. L. Madonna, como su artículo "L'ingresso de Carlo V a Roma», publicado en la obra dirigida por Fagiolo La festa a la Roma dal Rinascimento al 1870 (1997).

El aprecio por estas manifestaciones de arte efímero, tanto por su valor artístico como desde la óptica de su papel como máxima muestra de exaltación del soberano, ha ido creciendo durante los últimos años, especialmente tras la publicación de la obra de R. Strong Arte y poder (1984), donde se dedica un capítulo a estudiar las entradas triunfales de Carlos $V$ y sus efectos en la imagen de la ciudad y el mismo emperador. Temática similar tratan otras obras, como la dirigida por J. Jacquot Fêtes et cérémonies au temps de Charles Quint (1975). Publicada con anterioridad, pero cercana en sus planteamientos, el capítulo de referencia para nuestra investigación es el escrito por A. Chastel, titulado "Les entrées de Charles Quint en Italie». Otra obra cronológicamente cercana y de temática parecida es la de B. Mitchell The Majesty of the State (1986), centrada en analizar las grandes entradas triunfales de gobernantes extranjeros en la Italia renacentista.

El interés por la fiesta y el arte efímero también ha calado en España desde hace bastante tiempo, como muestran los estudios de F. Checa (1979 b; 1981). El principal impulso al tema ha venido, no obstante, y al igual que en otros campos novedosos de los estudios carolinos, en el marco de las efemérides del cambio de siglo. Así, la entrada romana ha sido tratada por M. Carrasco en su artículo «Carlos V en Roma: el triunfo de un nuevo Escipión» (2000). En él se describen todos los preparativos y la postura política de Pablo III, además de mostrar todo el recorrido. La autora, después de analizar en profundidad la ceremonia, plantea una lectura novedosa, al cuestionar el tan referido clasicismo identificando muchos elementos de claro regusto medieval. La ya mencionada M. L. Madonna también realizó una importante aportación en dicho momento 
con su artículo «El viaje de Carlos V por Italia después de Túnez: el triunfo clásico y el plan de reconstrucción de las ciudades» (2000). La autora describe las tipologías de construcciones fingidas erigidas, el recorrido concreto por cada ciudad y, además, algo tan importante como las huellas permanentes que estas entradas dejaron en el urbanismo. Además de estos artículos específicos, los dibujos, bocetos, etc. han sido analizados en diversas publicaciones, como las de F. Checa (1999) o en las fichas del catálogo "Carlos V. Las armas y las letras» (2000). Así pues, también las entradas triunfales en Italia de 1535-1536 han llamado la atención de los investigadores, tanto italianos como de otras nacionalidades, y se ha generado una bibliografía amplia y rigurosa.

VII. Conclusión

Como hemos podido ver a lo largo del trabajo, la importancia de la figura de Carlos $\mathrm{V}$ ha eclosionado en una amplísima producción de estudios, publicaciones, artículos, tesis, exposiciones o jornadas también en el ámbito artístico. Aunque la atracción real hacia la cultura por parte del emperador siempre ha sido motivo de debate, ciertamente su figura coincide con uno de los momentos más brillantes de la producción artística y cultural europea, en el que su círculo cercano es uno de los principales patrocinadores del Renacimiento. Además, políticamente, la época de Carlos $V$ coincide con la de la gestación de las modernas monarquías autoritarias. Como intuyeron Granvela o María de Hungría, el arte iba a ser un instrumento fundamental, dada su capacidad persuasiva en el asentamiento definitivo de este poder para propiciar la alianza entre las artes y los gobernantes.

Dentro de este marco cultural y político, siempre se ha definido la conquista de Túnez en 1535 como uno de los hitos claves en la política de Carlos V, y también en la gestación de la imagen imperial. Como hemos visto, desde el punto de vista de la historiografía artística los estudios realizados hasta el momento resultan, a pesar de la solvencia de muchos de ellos, bastante limitados. Apenas se han realizado aproximaciones de gran calado que analicen todas las producciones de forma conjunta. Los que existen, además, o son muy antiguos (Voigt, 1872) o, en el caso de los modernos, son artículos, rigurosos pero con las limitaciones propias de este formato (Deswarte-Rosa, 1998; González 2007). En ocasiones nos encontramos con la situación opuesta, como ocurre con los trabajos de $F$. Checa. A la campaña tunecina se le otorga la importancia que merece, pero al encontrarse dentro de investigaciones de alcance superior se la trata con menor profundidad.

En parte, esta carencia de publicaciones totalizadoras se cubre por la existencia de aproximaciones parciales. En este sentido, el conjunto más analizado es el de los tapices de la Jornada de Túnez. Junto a estas publicaciones también hay una amplia serie de estudios que se aproximan a temas muy concretos, como la joyería, las armas, los grabados o las 
entradas triunfales posteriores, pero, dada la amplitud y diversidad de esta bibliografía, es difícil trazar una imagen completa, global, de todo el conjunto artístico.

Además, a estas cuestiones hay que sumar la existencia de aspectos apenas tratados, como la pervivencia del tema en las representaciones habsbúrgicas mucho más allá incluso de la muerte del emperador. Asimismo, es interesante contrastar la gran cantidad de obras de arte referidas a la conquista tunecina en Italia, frente a la escasez en España. Otra vía de investigación interesante sería rastrear este tipo de representaciones en las obras patrocinadas por los nobles y militares presentes en los arenales tunecinos, sólo parcialmente estudiadas en el caso del marqués de Santa Cruz. Existen, pues, importantes lagunas, temas apenas tratados, que nos permiten plantear la necesidad de seguir investigando un tema de tanto calado político y artístico como la conquista de Túnez por parte del emperador Carlos $\mathrm{V}$.

\section{Bibliografía}

AbelLA, J. J. (1978): «El túmulo de Carlos V en Valladolid», BSAA, Valladolid.

Almagro-gorbeA, M. y otros (ed.) (2005): Medallas españolas, Real Academia de la Historia, Madrid.

Alvar, A. y J. I. Ruíz (2010): Túnez, 1535, CSIC-Real Gremio de Halconeros, Madrid.

BERNHARDT, M. (1919): Bildnismedaillen Karls V, Munich.

Bonet, A. (1960): "Túmulos del emperador Carlos V», Archivo Español de Arte, Madrid.

Bustamante, A. (2004): "Hechos y hazañas. Representaciones históricas del siglo XVI», REDONDO, M. J. (coord.): El modelo italiano en las artes plásticas de la península Ibérica durante el Renacimiento, Universidad de Valladolid, Valladolid.

CAMPBELL, T. (2002): Tapestry in the Renaissance: Art and Magnificence, New Haven-Yale University, Nueva York.

CARRASCO, M. (2000): "Carlos V en Roma: el triunfo de un nuevo Escipión», CHECA, F. (coord.): Carolus, Sociedad Española para la Conmemoración de los Centenarios de Felipe II y Carlos V, Toledo-Madrid.

CAYón, J. R. y C. CASTÁn (1991): Monedas españolas desde los visigodos hasta el quinto centenario del Descubrimiento y las medallas de proclamación, Fareso, Madrid.

Cazzato, V (1985): "Vasari e Carlo V: l'ingresso trionfale a Firenze del 1536», GarfagninI, G. C. (ed.): Giorgio Vasari, Leo S. Olschki, Florencia. 
CHECA, F. (1979 a): «Un programa imperialista: el túmulo erigido a Carlos V en Alcalá de Henares", RABM, LXXXII, Madrid.

- (1979 b): «La entrada de Carlos V en Milán el año de 1541», Goya, 151, Madrid.

- (1980): «Carlos V, héroe militar. (A propósito de la serie "Las batallas de Carlos V" de A. Tempesta)"», Goya, 158, Madrid.

- (1981): «Artificio y lenguaje clasicista en la Florencia medicea: Carlos V y el arte florentino del siglo XVI», Cuadernos de Trabajos de la Escuela Española de Historia y Arqueología en Roma, 15, Roma.

- (1987): Carlos V y la imagen del héroe en el Renacimiento, Taurus, Madrid.

- (1994): Tiziano y la monarquía hispánica, Nerea, Madrid.

- (1999): Carlos V. La imagen del poder en el Renacimiento, El Viso, Madrid.

- (coord.) (2000) Carolus, Sociedad Española para la Conmemoración de los Centenarios de Felipe II y Carlos V, Toledo-Madrid.

- (2001): Carlos V, a caballo, en Mühlberg, TF Editores, Madrid.

- (2010): Tesoros de la corona de España. Tapices flamencos en el Siglo de Oro, Fons Mercator-Sociedad Estatal para la Acción Cultural Exterior, Madrid.

- (2013): Tiziano y las cortes del Renacimiento, Marcial Pons, Madrid.

ChueCA, F. (1953): Arquitectura española del siglo XVI, Ars Hispaniae, Madrid.

CiARDI-DuprÉ, M. G. (1968): «Il modelo originale della Deposizione di Bandinelli per Carlo V», VV. AA.: Festschrift von U. Von Middelforf, Berlín.

Cleland, E. (2014) (coord.): Grand Design. Pieter Coecke van Aelst and Renaissance Tapestry, Metropolitan Museum of Art, Nueva York.

CloulAS, A. (1964): "Charles Quint et le Titien. Les premieres portraits d'aparat", L'information d'Histoire de l'Art, tomo IX, 5.

Coppel, R. (2013): Leone and Pompeo Leoni. Faith and Fame, Coll y Cortés, Madrid.

COPPEL, R. (2001): "La colección de tapices de la corona española. Notas sobre su formación y conservación", Arbor, tomo CLXIX, 665, Madrid.

De Bunes, M. A. y M. Falomir (2001): «Carlos V, Vermeyen y los tapices de Túnez", CAstellano, J. L. y F. SÁnchez (ed.): Carlos V, europeismo y universalidad, Sociedad Española para la Conmemoración de los Centenarios de Felipe II y Carlos V, Madrid.

De Bunes, M. A. (2006): «Vermeyen y los tapices de la Conquista de Túnez. Historia y representación», GARCíA, B. (ed.): La imagen de la guerra en el 
arte de los antiguos Países Bajos, Fundación Carlos de Amberes-UCM, Madrid.

De Carlos, A. (1981): «La conquista de Túnez de Carlos V. Según tapices y grabados del Patrimonio Nacional», Reales Sitios, 67, Madrid.

Delmarcel, G. (1999): Flemish Tapestry, Lanoo Publishers, Tielt.

Deswarte-Rosa, S. (1998): "L'expédition de Tunis (1535): images, interprétations, répercussions culturelles», BENASSAR, B. y R. SAUZET (coord.): Chrétiens et Musulmans à la Reniassance, Honoré Chamion Editeur, París.

Di Stefano, R. y S. Di Stefano, (1980): «Il potere del spazio nella Napoli cinquecentesca», vV. AA.: Napoli del '500 e la Toscana del Medici, Nápoles.

DonATI, V. (1989): Pietre dure e medaglie del Rinascimento, Belriguardo, Ferrara

ESILER, W. (1984): «Arte y estado bajo Carlos V», Fragmentos, 3.

Fagiolo, M. y M. L. Madonna (1980): II «Teatro del Sole». La rifondazione di Palermo nel'500 e l'idea della città barroca, Officina Edizione, Roma.

FernándeZ, M. (1999): Carlos V. El césar y el hombre, Espasa, Madrid.

GafsI SlamA, A. (2001): "A propos des traces et des images de Charles Quint en Tunisie», RubIeRA, M. J. (coord.): Carlos V. Los moriscos y el Islam, Sociedad para la Conmemoración de los Centenarios de Felipe II y Carlos V, Madrid.

Gallego, A. (1958): Carlos V y su ambiente, Ministerio de Educación, Toledo.

GIANNESCHI, M. y C. SOdINI (1979): "Urbanistica e politica durante il principato de di Alessando de Medici 1532-1537», VV. AA.: Storia della città, Florencia.

GILMAN, B. (1956): Pompeo Leoni, Hispanic Society of America, Nueva York.

Godoy, J. A. y S. LEYDI (2003): Parures Triomphales. Le maniérisme dans l'art de l'armure italienne, Musées d'Art et d'Histoire du Genève, Ginebra.

GómEZ, M. (1941): Las águilas del Renacimiento español, Gráficas Uguina, Madrid.

GonZÁlEZ, J. L. (2007): “"Pinturas tejidas”. La guerra como arte y el arte de la guerra en torno a la Empresa de Túnez (1535)», Reales Sitios, tomo XLIV, 17, Madrid.

Grancsay, S. V. (1996): "The Illustrated Inventory of the Arms and Armor of Emperor Charles V», VV. AA.: Homenaje a Rodríguez Moñino, Vol. 1, Madrid. 
HAAG, S. y K. Schmitz-VON Ledebur (ed.) (2015): Kaiser Karl V. erober Tunis. Dokumentation eines Kriegszuges in Kartons und Tapisserien, Kunsthistorisches Museum, Viena.

Herrero, C. (1991): "The Conquest of Tunis», Godoy, J. A.: Resplendence of Spanish Monarchy. Renaissance Tapestries and Armor from the Patrimonio Nacional. Metropolitan Museum, Nueva York.

Horcajo, N. (2002): «La imagen de Carlos V y Felipe II en las joyas del siglo XVI», Archivo Español de Arte, tomo LXXV, 297.

HoudoY, J. (1873): Tapisseries représentant la conquête de Tunis par l'empereur Charles Quint. Histoire et documents inédits, Lille.

Horn, H. (1989): Jan Cornelisz Vermeyen. Painter of Charles $V$ and His Conquest of Tunis: Paintings, Etchings, Drawings, Cartoons and Tapestries, 2 vol., Davaco, Doornspijk.

JACQUOT, J. (1975): Fêtes et cérémonies au temps de Charles Quint, CNRS, París.

JUNQUERA, P. (1968): "Las batallas navales en los tapices», Reales Sitios, 17, Madrid.

KOHLER, A. (2001): "Representación y propaganda de Carlos V», MARTíneZ, $\mathrm{J}$ : Carlos $V$ y la quiebra del humanismo político en Europa (1530-1558), Sociedad Estatal para la Conmemoración de los Centenarios de Felipe II y Carlos V, Madrid.

LILLO, M. (1998): "Consideraciones sobre el realismo geográfico de las pinturas sobre la conquista de Túnez existentes en la Casa Real Vieja de la Alhambra», Papeles de Geografía, 28, Granada.

LÓPEZ, R. (1999): "La relación del primer marqués de Santa Cruz con las artes», VV. AA.: El arte en las cortes de Carlos V y Felipe II, CSIC, Madrid.

- (2000): "Las pinturas de la Torre de la Estufa o del Peinador», VV. AA.: Carlos V y la Alhambra, Junta de Andalucía, Granada.

López-YARTo, A. y C. HeRedia (1999): "Los triunfos del emperador en las artes del metal», VV. AA.: El arte en las cortes de Carlos V y Felipe II, CSIC, Madrid.

LóPEZ-YARTO, A. (2009): "Escenas de guerra en la platería europea», VV. AA.: Arte en tiempo de guerra, CSIC, Madrid.

MAdRAZO, P. DE. (1889): «Über Krönungsinsignien und Staatwänder Maximilian I und Karls V under Schiksal in Spanien", JKS.

MadonnA, M. L.: "L'ingresso de Carlo V a Roma», FAGiolo, M. (coord.): La festa a Roma dal Rinascimento al 1870, vol. I, Umberto Allemandi, Turín.

- «El viaje de Carlos $V$ por Italia después de Túnez: el triunfo clásico y el plan de reconstrucción de las ciudades», MoRAles, A. (coord.): La fiesta en la Europa de Carlos V, Sociedad Estatal para la Conmemoración de los Centenarios de Felipe II y Carlos V, Sevilla. 
MANCINI, M. (2000): «La elaboración de nuevos modelos en la retratística carolina: la relación privilegiada entre el emperador y Tiziano», REDONDO M. J. y M. A. ZaLAma: Carlos $V$ y las artes: promoción artística y familia imperial, Junta de Castilla, Valladolid.

MARÍAS, F. (1983-6): La arquitectura del Renacimiento en Toledo, CSICIpitec, Toledo- Madrid.

- (1989): El largo siglo XVI. Los usos artísticos del Renacimiento en España, Taurus, Madrid.

- (coord.) (2000): Carlos V, las armas y las letras. Sociedad Española para la Conmemoración de los Centenarios de Felipe II y Carlos V, GranadaMadrid.

MieLKE, U. (2009): The New Holstein Duch \& Flemish Etchings, Engravings and Woodcuts 1450-1700, Sound \& Vision Publishers, Amsterdam.

Mitchell, B. (1986): The Majesty of the State. Triumphal Progresses of Foreing Sovereings in Renaissance Italy (1404-1600), L. S. Olschki, Florencia.

Morales, A. (coord.) (2000): La fiesta en la Europa de Carlos V, Sociedad Estatal para la Conmemoración de los Centenarios de Felipe II y Carlos V, Sevilla.

Ossat, A. D’. (1943): «Gli archi trionfali ideati del Peruzzi per la venuta a Roma di Carlo V», Capitolium, Roma.

PÁEZ, E. y otros (ed.) (1993): Los Austrias. Grabados de la Biblioteca Nacional, Biblioteca Nacional, Madrid.

Paredes, C. (2005): «Du texte à l'image. Les tapisseries de la Conquête de Tunis et les gravures de Moeurs et fachons des Turcs», Servantie, A. (coord.): L'empire ottoman dans l'Europe de la Renaissance, Universidad de Lovaina, Lovaina.

PhyRR, S. W. y J. A. Godoy (1998): Heroic Armor of the Italian Renaissance: Filippo Negroli and his Contemporaries, Metropolitan Museum, Nueva York.

Popham, A. E. (1940): "The Autorship of the Drawings of Binche», JCWI, tomo III.

PORTús, J. (coord.) (2000): El linaje del emperador, Sociedad Española para la Conmemoración de los Centenarios de Felipe II y Carlos V, Cáceres.

Pugliatti, V. (1990): "ll passagio di Carlo V», vV. AA.: Carlo V a Messina, Provincia Regional de Mesina, Mesina.

Rodríguez, I. (2009): "La ciudad en el palacio de Viso del Marqués», Mínguez, V. y otros (coord.): El sueño de Eneas. Imágenes utópicas de la ciudad, UJI, Castellón.

Romano, G. (1892): «Luigi Gonzaga de Borgoforte: Cronaca del soggiorno di Carlo V in Italia», Milán. 
RosenthaL, E. (1974): "Plus Ultra. The Idea Imperial of Charles V in its Columnar Device on the Alhambra», Hortus Imagines. Essays in Western Art, U. de Kansas, Kansas.

- (1985): The Palace of Charles Quint in Granada, U. Princeton, Princeton.

SÁnCHEZ, F. J. y E. TORMo (1919): Los tapices de la casa del rey nuestro señor, Artes Gráficas Mateu, Madrid.

SeIPeL, W. y G. J. KugleR (2000): Der Kriegszug Kaiser Karls V. Gegen Tunis. Kartons und Tapisserien, Skira-Kunsthistorisches Museum, Viena.

Soler, A. (dir.) (2010): El arte del poder. La Real Armería y el retrato de corte, Patrimonio Nacional-Sociedad Estatal para la Acción Cultural Exterior, Madrid.

StiRLING-MAXWELL, W. (1853): The Chief Victories of the Emperor Charles the Fifth, Londres.

- (1875): The Processions of Clement VII and Charles V, After the Coronation of Bologne 1530, Edimburgo.

Strong ,R. (1984): Arte y poder. Fiestas del Renacimiento (1450-1650), Alianza, Madrid.

TAFURI, M. (1969): L'archittetura dell'Umanesimo, Laterza, Bari.

TORRISI, N. (1958): "Nella Sicilia de Carlo V», Sicolorum Gymnasium, 2, Palermo.

Toscano, T. R. (2001): "Le Muse e i Colossi: apogeo e tramonto dell'umanesimo politico napoletano del "trionfo" de Carlo V», MARTínez, J: Carlos $V$ y la quiebra del humanismo político en Europa (1530-1558), Sociedad Estatal para la Conmemoración de los Centenarios de Felipe II y Carlos V, Madrid.

URREA, J. (1994): Los Leoni (1509-1608): escultores del Renacimiento italiano al servicio del corte de España, Museo del Prado, Madrid.

VAlencia, Conde de (1902): Armas y tapices de la corona de España, Real Academia de la Historia, Madrid.

VILAR, J. B. (1991): Mapas, planos y fortificaciones hispánicas de Túnez (s. XVI-XIX), Instituto de Cooperación con el Mundo Árabe, Madrid.

VISCEGLIA, M. A. «Il viaggio ceremoniale di Carlo V dopo Tunisi», MARTíneZ, $\mathrm{J}$ : Carlos $V$ y la quiebra del humanismo político en Europa (1530-1558), Sociedad Estatal para la Conmemoración de los Centenarios de Felipe II y Carlos V, Madrid.

VoIGT, G. (1872): Die Geschichtschreibung über den Zug Karl's V. gegen Tunis (1535), S. Hirzel, Leipzig.

Werner, E. A. (2000): «Der Tunisfeldug Karls V. Und die Tapisserien Willem de Pannemakers nach Kartons von Jan Cornelisz Vermeyen", 
VV. AA.: Kaiser Karl V (1500-1558). Macht und Ohnmacht Europas, BonnViena.

WoHLfeIL, R. (2001): "Retratos gráficos de Carlos V al servicio de la representación y la propaganda», MARTínEZ, J: Carlos $V$ y la quiebra del humanismo político en Europa (1530-1558), Sociedad Estatal para la Conmemoración de los Centenarios de Felipe II y Carlos V, Madrid.

Zalama, M. A. (2011): «Primacía de los tapices entre las artes figurativas en España en los siglos XV y XVI», CHECA, F. (coord.): Los Triunfos de Aracne. Tapices flamencos de los Austrias en el Renacimiento, Fundación Carlos de Amberes, Madrid. 


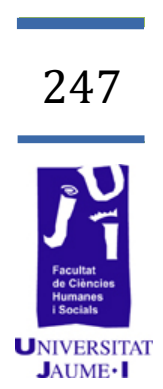

\section{Determinantes que influyen en el rendimiento académico musical en la educación primaria y secundaria}

Gustau Olcina Sempere

golcina@uji.es 
El presente estudio tiene como principal objetivo conocer cómo influye la creatividad, la lateralidad y la inteligencia musical en el rendimiento académico en Música en alumnos de educación primaria y secundaria. Los resultados de este trabajo revelan que los alumnos de primaria con lateralidad zurda e inteligencia musical obtienen un mayor rendimiento académico musical, así como aquellos que tienen una creatividad media y baja. Por otra parte, los resultados demuestran que la creatividad alta de los alumnos de primaria no tiene repercusión en el rendimiento académico musical. Los resultados para los alumnos de secundaria también ponen de manifiesto que la lateralidad zurda y la creatividad media y baja contribuyen a un mayor rendimiento académico musical, mientras que ni la inteligencia musical ni la creatividad alta influyen en el rendimiento académico musical de los alumnos de secundaria.

Teniendo en cuenta los resultados obtenidos, debemos considerar la aplicación de nuevas estrategias en las prácticas educativas donde se fomente la creatividad, la inteligencia musical y la lateralidad dominante.

Palabras clave: creatividad, dominancia lateral, inteligencia musical, rendimiento académico en música, educación.

\section{Introducción}

Desde que la enseñanza está sistematizada y reglada son muchos los países que han mostrado su interés por conocer el rendimiento académico de los alumnos en las etapas de primaria, secundaria y universitaria. Este interés lo ha potenciado la necesidad que tienen pedagogos, educadores e investigadores por conocer, principalmente, los niveles de fracaso escolar que se dan, sobre todo, en la etapa de educación primaria y secundaria, para establecer unos niveles educativos que contribuyan a la mejora de la educación, así como a su constante análisis y control.

Por ello es necesario conocer cuáles son todos los aspectos que están influyendo en el rendimiento escolar, analizando no sólo los conocimientos que el alumno posee, sino también todos los condicionantes y contextos que influyen en la adquisición de estos como la familia, la sociedad, el centro educativo, el sistema educativo, el aula, el maestro y el alumno, entre otras cuestiones (Navarro, 2003). Centrándonos en las cualidades del alumno, la evidencia previa (Holland, 1964; Aldalalah y Fong, 2010; Mayolas, Villarroya y Reverter, 2010) muestra que la creatividad, la lateralidad y la inteligencia musical, entre otras, influyen en el rendimiento académico de los alumnos. 
La enseñanza de la música a lo largo de la historia ha sido un tema de interés que ha motivado su estudio, así como la necesidad de incluir su aprendizaje en los centros educativos desde los niveles más elementales hasta los estudios superiores. Asimismo, las diferentes investigaciones como las realizadas por Hodges (2006) demuestran que la música influye en el desarrollo cerebral de los niños que se inician a una edad temprana en el aprendizaje de la música de manera que cuando llegan a la edad adulta sus repuestas ante los estímulos musicales son más rápidas. Desafortunadamente, la enseñanza de la música no se ha considerado ni se considera igual de importante como el resto de asignaturas que configuran el actual currículo de las enseñanzas, tanto básicas como superiores, produciendo su ausencia en estos ámbitos una desafección por su estudio e interés. Ello podría explicar la ausencia, que nosotros tengamos constancia, de estudios previos que hayan analizado la repercusión que la creatividad, lateralidad e inteligencia musical tienen en el rendimiento académico musical.

\section{Objetivos}

El presente estudio empírico plantea como principal objetivo analizar la relación existente entre la creatividad, la lateralidad, y la inteligencia musical de los alumnos de educación primaria y secundaria con el rendimiento académico que obtienen en música. Concretamente, se quiere estudiar si la creatividad, la lateralidad y la inteligencia musical predicen el rendimiento académico musical.

En orden a alcanzar este objetivo de este estudio, se formulan las siguientes hipótesis:

Hipótesis 1: La creatividad influye positivamente en el rendimiento académico musical.

Hipótesis 2: La lateralidad manual zurda influye positivamente en el rendimiento académico musical.

Hipótesis 3: La inteligencia musical influye positivamente en el rendimiento académico musical.

\section{Material y método}

En este estudio utilizamos una metodología no experimental, o conocida también con el nombre de ex-post facto, es decir, aquella en la que el investigador recoge los datos después de haber sucedido los hechos y trata de extraer las posibles relaciones entre ellos, e incluso la capacidad predictiva (que no casualidad) de unas variables sobre otras.

Para realizar este estudio de investigación, se utiliza la metodología cuantitativa siendo ésta de tipo descriptivo-relacional, ya que los datos recogidos nos describen los aspectos relacionados con la creatividad, la lateralidad, la inteligencia musical y el rendimiento académico y se trata de poner en relación dichos datos. 
Esta investigación se caracteriza por la ausencia de control del investigador sobre las variables independientes (creatividad, lateralidad e inteligencia musical), debido a que dichas variables no han sido manipuladas por el investigador antes de recoger los resultados, así como también por la rigurosidad y sistematicidad en el proceso de investigación.

La recogida de los datos se realiza en un único momento dentro del propio centro educativo a fin de evitar variables extrañas que pudieran afectar a las respuestas dadas por los sujetos (efecto de aprendizaje sobre el tema, eventos personales que pudieran afectar a la concentración o respuestas de los sujetos, entre otras).

La aplicación de las diferentes pruebas se realizará a primera hora de la mañana, con la intención de evitar la fatiga acumulada durante el día. También se ha realizado este control de las variables extrañas que puedan afectar al estudio o control de amenazas a la validez de resultados indicados, con la intención de controlar la varianza sistemática o secundaria.

En esta investigación hablamos de un diseño de "ciego único», el cual tiene la finalidad de no revelar a los alumnos el propósito de la investigación, para que los alumnos no tiendan a confirmar o rechazar las hipótesis planteadas en la investigación (control del efecto de deseabilidad social).

Así pues, por todo lo dicho anteriormente, nuestro diseño se define como un diseño ex-post facto, correlacional y de corte transversal.

\subsection{Población y muestra}

La muestra que vamos a utilizar en este estudio está formada 200 alumnos de primaria y 200 de secundaria. Concretamente, se han formado cuatro grupos de 100 alumnos cada uno, los cuales han sido clasificados en función del rendimiento en la asignatura de Música, de forma que se han obtenido dos grupos de alto rendimiento y dos de bajo rendimiento. Para ello, se han tenido en cuenta las calificaciones de música del tercer trimestre del presente curso escolar.

El colegio donde se ha llevado a cabo el estudio está situado en el extrarradio de una gran ciudad con un entorno socioeconómico y cultural medio. El principal motor económico de la zona en la que está ubicado el colegio son las pequeñas empresas de autónomos así como también el sector industrial.

En la tabla 1 que se presenta a continuación ofrecemos los estadísticos descriptivos de la muestra objeto de este estudio: 
Gustau Olcina Sempere. Determinantes que influyen en el rendimiento académico musical en la educación primaria y secundaria

Tabla 1

Estadísticos descriptivos

Panel A. Variables continúas

\begin{tabular}{lcccccc}
\hline \multicolumn{1}{c}{ Variables } & N & Media & Mediana & $\begin{array}{c}\text { Desviación } \\
\text { típica }\end{array}$ & Perc. 25 & Perc. 75 \\
\hline REND_ACD_MUS_Primaria & 200 & 6.400 & 6.000 & 1.770 & 5.000 & 7.750 \\
REND_ACD_MUS_Secundaria & 200 & 5.700 & 6.000 & 1.834 & 5.000 & 7.000 \\
INT_MUS_Primaria & 200 & 4.080 & 4.000 & 0.907 & 3.250 & 5.000 \\
INT_MUS_Secundaria & 200 & 4.430 & 5.000 & 0.867 & 4.000 & 5.000 \\
CREA_ALTA_Primaria & 200 & 2.520 & 3.000 & 1.105 & 3.000 & 3.000 \\
CREA_ALTA_Secundaria & 200 & 1.530 & 3.000 & 1.507 & 0.000 & 3.000 \\
CREA_MEDIA_Primaria & 200 & 0.180 & 0.000 & 0.575 & 0.000 & 0.000 \\
CREA_MEDIA_Secundaria & 200 & 0.580 & 0.000 & 0.912 & 0.000 & 2.000 \\
CREA_BAJA_Primaria & 200 & 0.040 & 0.000 & 0.197 & 0.000 & 0.000 \\
CREA_BAJA_Secundaria & 200 & 0.220 & 0.000 & 0.416 & 0.000 & 0.000 \\
\hline
\end{tabular}

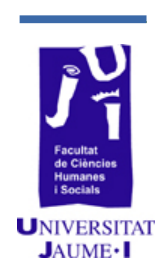

Panel B. Variables dicotómicas

\begin{tabular}{lcccc}
\hline & $\mathbf{0}$ & $\mathbf{\%}(\mathbf{0})$ & $\mathbf{1}$ & $\mathbf{\%}(\mathbf{1})$ \\
\hline SEXO_Primaria & 102 & $51 \%$ & 98 & $49 \%$ \\
SEXO_Secundaria & 120 & $60 \%$ & 80 & $40 \%$ \\
LATER_Primaria & 182 & $91 \%$ & 18 & $9 \%$ \\
LATER_Secundaria & 185 & $92.50 \%$ & 15 & $7.5 \%$ \\
\hline
\end{tabular}

REND_ACD_MUS es el rendimiento académico en música que han obtenido los alumnos en el tercer trimestre de este curso lectivo, medido mediante la nota obtenida en el tercer trimestre que puede oscilar entre 0 y 10 , tanto para los alumnos de primaria como para los de secundaria; la creatividad se mide mediante el test de inteligencia creativa (CREA) y el valor de esta variable resulta de la suma de un total de 20 preguntas que podía plantear el alumnado de primaria y secundaria en función de la visualización de una imagen: si los alumnos plantean entre 0 y 7 preguntas tienen una creatividad baja (CREA_BAJA) y toma el valor 1, si los alumnos plantean entre 8 y 14 preguntas tienen una creatividad media (CREA_MEDIA) y toma el valor 2 y si los alumnos plantean entre 15 y 20 preguntas tienen una creatividad alta (CREA_ALTA) y toma el valor 3. INT_MUS es la variable que refleja la inteligencia musical de los alumnos de primaria y secundaria, y se mide mediante el test de inteligencia musical de las inteligencias múltiples de Gardner (1983). Concretamente, se plantearon un total de 5 preguntas de índole musical y el total de síes acumulados daba lugar al resultado final de esta variable; SEXO es una variable dicotómica que toma el valor $1 \mathrm{si}$ el individuo de la muestra es un niño y 0 si es una niña; LATER es la variable que expresa la lateralidad de los alumnos de primaria y secundaria, medida mediante el test de dominancia lateral de Harris (1993). Concretamente, si la dominancia lateral es zurda, la variable toma el valor 1 , y si es diestra, toma el valor 0.

Tal y como se puede apreciar en la tabla 1 , el total de miembros que forman la muestra de este estudio es de 400, 200 de educación primaria y 200 de educación secundaria. El $49 \%$ de los alumnos de la muestra de primaria son niños y el $51 \%$, niñas; mientras que en secundaria el $40 \%$ son niños y el $60 \%$, niñas. Así pues, podemos concluir que la muestra está equilibrada en cuanto a la participación femenina y masculina, particularmente en educación primaria. Por otra parte, también puede observarse en la tabla 1 que el rendimiento medio académico musical en primaria (REND_ACD_MUS_Primaria) es 6,4, mientras que en secundaria (REND_ACD_MUS_Secundaria) esta cifra desciende hasta 5,7. Así pues, podemos concluir que el alumnado de primaria obtiene un bien alto en rendimiento académico musical y el de secundaria un suficiente alto, casi 
bien. Estos datos, por tanto, evidencian que los alumnos de primaria obtienen un mayor rendimiento académico musical que los de secundaria.

En lo referente a la variable inteligencia musical (INT_MUS), los datos arrojan un valor medio de 4,08 para los alumnos de primaria y de 4,43 para los de secundaria, revelando que el alumnado de la muestra, y particularmente el de secundaria, presenta una inteligencia musical elevada, ya que de 5 preguntas planteadas en el test, respondió afirmativamente, de media, a más de 4 preguntas. Si nos centramos en la creatividad, en la tabla 1 se puede apreciar que el alumnado de primaria obtiene una puntuación de 2,74 en creatividad total (suma de la creatividad alta, media y baja), lo que se desgrana en una puntuación de 2,52 en creatividad alta, 0,18 en creatividad media y 0,04 en creatividad baja, mientras que la creatividad total de los alumnos de secundaria asciende a 2,33, lo que se desgrana en una valoración de 1,53 en creatividad alta, 0,58 en creatividad media y 0,22 en creatividad baja. Por lo tanto, estos datos reflejan que los alumnos tanto de primaria como de secundaria arrojan una creatividad total similar: la de los alumnos de primaria es ligeramente superior $y$, por tanto, de media, los alumnos tanto de primaria como de secundaria han planteado más de la mitad de las preguntas que se les permitía, de un total de 20 . Por tanto, a tenor de los resultados obtenidos, podemos destacar que la creatividad de los alumnos de la muestra es media. Ahora bien, hay que destacar que en la muestra de los alumnos de primaria se aprecia una creatividad alta más elevada que en los alumnos de secundaria, mientras que la creatividad media y baja es más elevada entre los alumnos de secundaria que de primaria. Así pues, se puede concluir que la creatividad alta predomina más en los alumnos de primaria que en secundaria, mientras que la creatividad media y baja predomina más en los alumnos de secundaria que en los de primaria.

Finalmente, y con respecto a la lateralidad, también podemos apreciar que en la muestra de primaria el $9 \%$ de los alumnos tiene una lateralidad zurda y el $91 \%$ diestra, mientras que en secundaria el 7,5\% de los alumnos tienen lateralidad zurda y el $92 \%$ restante diestra. Ello implica que en la gran mayoría de los miembros de la muestra, tanto de primaria como de secundaria, predomina la dominancia lateral diestra y, por tanto, utilizan para sus actividades académicas y cotidianas el ojo, el oído, la mano y el pie derecho.

\subsection{Instrumentos de medida}

A continuación indicamos cómo hemos medido las variables utilizadas en este trabajo.

La variable dependiente, rendimiento académico en Música, se define como REND_ACD_MUS_Primaria y REND_ACD_MUS_Secundaria para el rendimiento académico musical en primaria y secundaria, respectivamente, y se calcula utilizando la nota media obtenida en la 
asignatura de música durante el tercer trimestre del curso académico en el que se realiza la prueba. La nota obtenida es el resultado de la evaluación continua en dicha asignatura, y se escoge esta por ser la calificación más cercana a la fecha en que se mide con el resto de instrumentos de medida, momento en el que se refleja el grado de consecución de los objetivos, contenidos y criterios de evaluación planteados en dicho curso académico.

Las variables independientes utilizadas en este trabajo son la creatividad, la lateralidad y la inteligencia musical tanto para los alumnos de primaria como de secundaria. Para medir la variable de creatividad se ha empleado el cuestionario de inteligencia creativa (CREA) de los autores Corbalán et al. (2003). El cuestionario de inteligencia creativa (CREA) consiste en realizar preguntas breves sobre la ilustración que se les presenta a los alumnos, hasta un máximo de 20 preguntas, de modo que si se formulan de 0 a 7 preguntas, tienen una creatividad baja; si plantean de 8 a 14, tienen una creatividad media, y si formulan de 15 a 20 preguntas, tienen una creatividad alta. Los alumnos se agrupan en cuatro grupos de 100 y se realiza la prueba de manera escrita y tienen quince minutos para realizarla. Para medir la creatividad hemos utilizado una variable categórica: hemos tomado el valor 1 si la creatividad es baja (CREA_BAJA), el valor 2 si la creatividad es media (CREA_MEDIA) y el valor 3 si la creatividad es alta (CREA_ALTA).

La variable de lateralidad se ha calculado utilizando el test de dominancia lateral de Harris (1993), que consiste en una serie de test de dominancia lateral, donde las puntuaciones obtenidas indican una mayor o menor preponderancia del dominio lateral. La prueba se realiza de manera individual a cada alumno, con una duración de 5 minutos para cada uno. Dicho test nos ofrece unas tareas que nos ayudan a conseguir los objetivos planteados en esta investigación. Además, el test se ha comparado con otros instrumentos de medida de las mismas características y se han obtenido unos resultados favorables en cuanto su validez, de forma que se permite, también, su puesta en práctica, al poder establecer diferencias entre grupos ya formados. La variable lateralidad se define como LATER y se calcula como una variable dicotómica; se toma el valor 0 si el alumno tiene lateralidad zurda y 1 , en caso contrario.

Para calcular la variable de inteligencia musical utilizamos el cuestionario de las inteligencias múltiples de Gardner (1983). El test para medir la inteligencia musical consta de cinco preguntas relacionadas con la música. Los niños se agrupan en cuatro grupos de 100 alumnos y se realiza la prueba de manera escrita durante un tiempo de cinco minutos. Las investigaciones realizadas sobre la fiabilidad y validez del test de las inteligencias múltiples de Gardner demuestran que el análisis factorial reproduce de manera clara la estructura de las inteligencias múltiples. La variable inteligencia musical se define como INST_MUS y se calcula con una escala Likert de 1 a 5 . El valor de esta variable se obtiene sumando los síes acumulados de un total de 5 preguntas planteadas. 


\subsection{Análisis univariante}

En las tablas 2 y 3 ofrecemos la media de las variables independientes para la muestra de primaria y secundaria, respectivamente. Para ello, se han creado dos grupos de acuerdo con la mediana del rendimiento académico musical, que tanto para la muestra de primaria como de secundaria, asciende a 6 . La finalidad del análisis univariante es analizar si existen diferencias de medias entre ambos grupos de estudiantes, tanto en la muestra de primaria como de secundaria.

Tabla 2

Dife rencia de medias para las variables de creatividad, inteligencia musical y lateralidad en base a la mediana del rendim iento académico musical en Primaria

\begin{tabular}{|c|c|c|c|c|}
\hline Variable & $\begin{array}{c}\text { REND_ACD_- } \\
\text { MUS_Primaria } \\
(>=6) \\
\text { Media }\end{array}$ & $\begin{array}{c}\text { REND_ACD_ } \\
\text { MUS_Primaria } \\
(<6) \\
\text { Media }\end{array}$ & $\begin{array}{c}\text { Diferencia } \\
\text { de } \\
\text { Medias }\end{array}$ & $\begin{array}{c}\text { Test } \\
\text { Univariante } \\
\text { (p.value) }\end{array}$ \\
\hline CREA_ALTA_Primaria & 2,670 & 2,140 & 0,530 & $\begin{array}{c}2,167^{* *} \\
(0,033)\end{array}$ \\
\hline CREA_MEDIA_Primaria & 0,430 & 0,080 & 0,350 & $\begin{array}{c}2,785^{* * *} \\
(0,006)\end{array}$ \\
\hline CREA_BAJA_Primaria & 0,070 & 0,030 & 0,040 & $\begin{array}{c}3,893^{* * *} * \\
(0,000)\end{array}$ \\
\hline LATER_Primaria & 7,000 & 14,000 & $-7,000$ & $\begin{array}{l}-1,148 \\
(0,254)\end{array}$ \\
\hline INT_MUS_Primaria & 4,240 & 3,680 & 0,560 & $\begin{array}{c}2,860 * * * \\
(0,005)\end{array}$ \\
\hline
\end{tabular}

REND_ACD_MUS_Primaria es el rendimiento académico en Música que han obtenido los alumnos de primaria en el tercer trimestre de este curso lectivo, medido mediante la nota obtenida en el tercer trimestre que puede oscilar entre 0 y 10 ; la creatividad se mide mediante el test de inteligencia creativa (CREA) y el valor de esta variable resulta de la suma de un total de 20 preguntas que podía plantear el alumnado en función de la visualización de una imagen: si los alumnos de primaria plantean entre 0 y 7 preguntas, tienen una creatividad baja (CREA_BAJA_Primaria) y toma el valor; si los alumnos de primaria plantean entre 8 y 14 preguntas, tienen una creatividad media (CREA_MEDIA_Primaria) y toma el valor 2, y si los alumnos de primaria plantean entre 15 y 20 preguntas, tienen una creatividad alta (CREA_ALTA_Primaria) y toma el valor 3. INT_MUS_Primaria es la variable que refleja la inteligencia musical de los alumnos de primaria y se mide mediante el test de inteligencia musical de las inteligencias múltiples de Gardner (1983). Concretamente, se plantearon un total de 5 preguntas de índole musical y el total de síes acumulados daba lugar al resultado final de esta variable; LATER_Primaria es la variable que expresa la lateralidad de los alumnos de primaria medida mediante el test de dominancia lateral de Harris (1993). Concretamente, si la dominancia lateral es zurda, la variable toma el valor 1 , y si es diestra, toma el valor 0. *Significatividad al $10 \%$, **significatividad al $5 \%$ y ***significatividad al $1 \%$. 
Tabla 3

Dife rencia de medias para las variables de creatividad, inteligencia musical y lateralidad en base a la mediana del rendimiento académico musical en Secundaria

\begin{tabular}{lcccc}
\hline Variable & $\begin{array}{c}\text { REND_ACD_ } \\
\text { MUS_Secundaria } \\
(>=6) \\
\text { Media }\end{array}$ & $\begin{array}{c}\text { REND_ACD_ } \\
\text { MUS_Secundaria } \\
(<6) \\
\text { Media }\end{array}$ & $\begin{array}{c}\text { Diferencia } \\
\text { de } \\
\text { Medias }\end{array}$ & $\begin{array}{c}\text { Test } \\
\text { Univariante } \\
\text { (p.value) }\end{array}$ \\
\hline CREA_ALTA_Secundaria & 2,117 & 0,918 & 1,199 & $\begin{array}{c}4,317^{* * *} \\
(0,000) \\
1,227\end{array}$ \\
CREA_MEDIA_Secundaria & 0,693 & 0,470 & 0,223 & $(0,223)$ \\
CREA_BAJA_Secundaria & 0,387 & 0,058 & 0,329 & $\begin{array}{c}4,281^{* * *} \\
(0,000)\end{array}$ \\
LATER_Secundaria & 13,720 & 0,000 & 13,720 & $2,764^{* * *}$ \\
INT_MUS_Secundaria & 4,450 & $4,007)$ & 0,246 \\
\end{tabular}

REND_ACD_MUS_Secundaria es el rendimiento académico en Música que han obtenido los alumnos de secundaria en el tercer trimestre de este curso lectivo, medido mediante la nota obtenida en el tercer trimestre que puede oscilar entre 0 y 10 ; la creatividad se mide mediante el test de inteligencia creativa (CREA) y el valor de esta variable resulta de la suma de un total de 20 preguntas que podía plantear el alumnado en función de la visualización de una imagen: si los alumnos de secundaria plantean entre 0 y 7 preguntas, tienen una creatividad baja (CREA_BAJA_Secundaria) y toma el valor 1; si los alumnos de secundaria plantean entre 8 y 14 preguntas tienen una creatividad media (CREA_MEDIA_Secundaria) y toma el valor 2, y si los alumnos de secundaria plantean entre 15 y 20 preguntas tienen una creatividad alta (CREA_ALTA_Secundaria) y toma el valor 3. INT_MUS_Secundaria es la variable que refleja la inteligencia musical de los alumnos de secundaria y se mide mediante el test de inteligencia musical de las inteligencias múltiples de Gardner (1983). Concretamente, se plantearon un total de 5 preguntas de índole musical y el total de síes acumulados daba lugar al resultado final de esta variable; LATER_Secundaria es la variable que expresa la lateralidad de los alumnos de secundaria medida mediante el test de dominancia lateral de Harris (1993). Concretamente, si la dominancia lateral es zurda, la variable toma el valor 1 , y si es diestra, toma el valor $0 .{ }^{*}$ Significatividad al $10 \%, * *$ significatividad al $5 \%$ $\mathrm{y} * * *$ significatividad al $1 \%$.

Tal y como se observa en la tabla 2, la diferencias de medias para la variable creatividad alta, media y baja de los estudiantes de primaria es positiva, como se ha predicho, y son estadísticamente significativas. Asimismo, la primera hipótesis no la podemos rechazar y se puede concluir, por tanto, que los alumnos de primaria con una valoración en la asignatura de Música por encima de la mediana del rendimiento académico musical (6) obtienen una mayor puntuación en creatividad (alta, media y baja) que aquellos que obtienen un rendimiento académico musical por debajo de la mediana. En la tabla 3 se ofrecen los resultados de las diferencias de medias para la creatividad de los alumnos de secundaria. Al igual que ocurre con los alumnos de primaria, en los tres tipos de creatividad la diferencia de medias es positiva, pero sólo son estadísticamente significativas para la creatividad alta y baja. Así pues, los resultados revelan que los alumnos de secundaria con un rendimiento académico por encima de su mediana obtienen una puntuación superior en creatividad alta y baja que aquellos alumnos que obtienen una calificación inferior a la mediana. 
Con respecto a la variable lateralidad manual zurda, los datos de la tabla 2 y 3 revelan que, para los alumnos de primaria, la lateralidad zurda arroja una diferencia negativa, pero no significativa, mientras que para los alumnos de secundaria, presenta una diferencia positiva, así predicho, y es estadísticamente significativa. Por tanto, la segunda hipótesis se tiene que rechazar para los alumnos de primaria, pero no se rechaza para los de secundaria. Así pues, estos resultados ponen de manifiesto que los alumnos de secundaria con lateralidad manual zurda obtienen un rendimiento académico musical por encima de la mediana.

Finalmente, la diferencia de medias para la variable inteligencia musical de los alumnos tanto de primaria como de secundaria arroja un signo positivo, tal y como se esperaba, pero sólo es estadísticamente significativa para los alumnos de primaria. A tenor de estos resultados, la tercera hipótesis no se puede rechazar para los alumnos de primaria, pero la rechazamos para los de secundaria. Por lo tanto, estos resultados nos permiten concluir que los alumnos con mayor inteligencia musical obtienen un rendimiento académico musical por encima de la mediana.

\subsection{Análisis multivariante}

En la tabla 4 y 5 presentamos los coeficientes de correlación de Pearson de todas las variables del estudio.

Tabla 4

Matriz coeficientes de correlación

\begin{tabular}{lccccc}
\hline & $\begin{array}{c}\text { REND_A } \\
\text { CD_MUS_- } \\
\text { Primaria }\end{array}$ & $\begin{array}{c}\text { LATER- } \\
\text { Primaria } \\
\text { Coeficiente }\end{array}$ & $\begin{array}{c}\text { INT_MUS_ } \\
\text { Primaria } \\
\text { Coeficiente }\end{array}$ & $\begin{array}{c}\text { CREA_ALTA- } \\
\text { Primaria } \\
\text { Coeficiente }\end{array}$ & $\begin{array}{c}\text { CREA_MEDIA } \\
\text { Primaria } \\
\text { Coeficiente }\end{array}$ \\
\hline REND_AC_MUS_Primaria & 1 & 1 & & \\
LATER_Primaria & $-0,191$ & $0,257^{* *}$ & 0,050 & 1 & 1 \\
INT_MUS_Primaria & $0,208^{* *}$ & $-0,053$ & 0,099 & $-0,721^{* * *}$ & 1 \\
CREA_ALTA_Primaria & $0,191^{*}$ & 0,023 & $-0,222^{*}$ & $-0,468^{* * *}$ & 0,064 \\
CREA_MEDIA_Primaria & 0,162 & 0,114 & 0,038 & & \\
CREA_BAJA_Primaria & & & & \\
\hline
\end{tabular}

REND_ACD_MUS_Primaria es el rendimiento académico en Música que han obtenido los alumnos de primaria en el tercer trimestre de este curso lectivo, medido mediante la nota obtenida en el tercer trimestre que puede oscilar entre 0 y 10 ; la creatividad se mide mediante el test de inteligencia creativa (CREA) y el valor de esta variable resulta de la suma de un total de 20 preguntas que podía plantear el alumnado en función de la visualización de una imagen: si los alumnos de primaria plantean entre 0 y 7 preguntas, tienen una creatividad baja (CREA_BAJA_Primaria) y toma el valor; si los alumnos de primaria plantean entre 8 y 14 preguntas, tienen una creatividad media (CREA_MEDIA_Primaria) y toma el valor 2, y si los alumnos de primaria plantean entre 15 y 20 preguntas, tienen una creatividad alta (CREA_ALTA_Primaria) y toma el valor 3. INT_MUS_Primaria es la variable que refleja la inteligencia musical de los alumnos de primaria y se mide mediante el test de inteligencia musical de las inteligencias múltiples de Gardner (1983). Concretamente, se plantearon un total de 5 preguntas de índole musical y el total de síes acumulados daba lugar al resultado final de esta variable; LATER_Primaria es la variable que expresa la lateralidad de los alumnos de primaria 
medida mediante el test de dominancia lateral de Harris (1993). Concretamente, si la dominancia lateral es zurda, la variable toma el valor 1 , y si es diestra, toma el valor 0. *Significatividad al $10 \%$, **significatividad al $5 \%$ y ***significatividad al $1 \%$.

Tabla 5

Matriz coeficientes de correlación

\begin{tabular}{lccccc}
\hline & $\begin{array}{c}\text { REND_ACD__ } \\
\text { MUS_ } \\
\text { Secundaria }\end{array}$ & $\begin{array}{c}\text { LATER- } \\
\text { Secundaria } \\
\text { Coeficiente }\end{array}$ & $\begin{array}{c}\text { INT_MUS_ } \\
\text { Secundaria } \\
\text { Coeficiente }\end{array}$ & $\begin{array}{c}\text { CREA_ALTA_ } \\
\text { Secundaria } \\
\text { Coeficiente }\end{array}$ & $\begin{array}{c}\text { CREA_MEDIA } \\
\text { Secundaria } \\
\text { Coeficiente }\end{array}$ \\
\hline REND_AC_MUS_Secundaria & 1 & & & & \\
LATER_Secundaria & $0,195^{*}$ & 1 & & & \\
INT_MUS_Secundaria & 0,139 & $-0,046$ & 1 & 1 & 1 \\
CREA_ALTA Secundaria & $0,497^{* * *}$ & $0,191^{*}$ & 0,071 & 1 & \\
CREA_MEDIA_Secundaria & $0,197^{*}$ & $-0,089$ & 0,065 & $-0,564^{* * *}$ & 1 \\
CREA_BAJA_Secundaria & $0,402^{* * *}$ & $-0,146$ & $-0,153$ & $-0542^{* * *}$ & $-0,339^{* * *}$ \\
\hline
\end{tabular}

REND_ACD_MUS_Secundaria es el rendimiento académico en Música que han obtenido los alumnos de secundaria en el tercer trimestre de este curso lectivo, medido mediante la nota obtenida en el tercer trimestre que puede oscilar entre 0 y 10 ; la creatividad se mide mediante el test de inteligencia creativa (CREA) y el valor de esta variable resulta de la suma de un total de 20 preguntas que podía plantear el alumnado en función de la visualización de una imagen: si los alumnos de secundaria plantean entre 0 y 7 preguntas tienen una creatividad baja (CREA_BAJA_Secundaria) y toma el valor 1 ; si los alumnos de secundaria plantean entre 8 y 14 preguntas, tienen una creatividad media (CREA_MEDIA_Secundaria) y toma el valor 2, y si los alumnos de secundaria plantean entre 15 y 20 preguntas tienen una creatividad alta (CREA_ALTA_Secundaria) y toma el valor 3. INT_MUS_Secundaria es la variable que refleja la inteligencia musical de los alumnos de secundaria y se mide mediante el test de inteligencia musical de las inteligencias múltiples de Gardner (1983). Concretamente, se plantearon un total de 5 preguntas de índole musical y el total de síes acumulados daba lugar al resultado final de esta variable; LATER_Secundaria es la variable que expresa la lateralidad de los alumnos de secundaria medida mediante el test de dominancia lateral de Harris (1993). Concretamente, si la dominancia lateral es zurda, la variable toma el valor 1 , y si es diestra, toma el valor 0 . *Significatividad al $10 \%, * *$ significatividad al $5 \%$ $\mathrm{y}^{* * *}$ significatividad al $1 \%$.

Tal y como se puede apreciar en la tabla 4, existe una relación positiva entre las variables lateralidad manual zurda, inteligencia musical y los tres tipos de creatividad y el rendimiento académico musical de los alumnos de primaria. Ahora bien, esta correlación es estadísticamente significativa para los pares entre inteligencia musical-rendimiento académico, creatividad alta-rendimiento académico musical y creatividad-media y rendimiento académico musical. Estos resultados sugieren que cuanta más inteligencia musical, alumnos con creatividad media y alta obtienen mayor rendimiento académico musical. Por otra parte, también se observa una relación positiva y estadísticamente significativa entre inteligencia musical y creatividad media, y una relación negativa y estadísticamente significativa entre creatividad alta $y$ creatividad media y baja. Así pues, estos resultados también sugieren que cuanta más inteligencia musical en los alumnos de primaria, más creatividad media, y cuanta más creatividad alta, menos creatividad media y baja. 
En la tabla 5 podemos observar una correlación positiva y estadísticamente significativa entre la lateralidad manual zurda y los tres tipos de creatividad y el rendimiento académico musical de secundaria. Por tanto, los alumnos de secundaria con lateralidad manual zurda y con creatividad alta, media y baja obtienen un mayor rendimiento académico musical. Por otra parte, también se puede apreciar en la tabla 5 una relación positiva y significativa entre lateralidad zurda y creatividad alta y una relación negativa y estadísticamente significativa entre creatividad alta y creatividad media y baja, así como entre creatividad media y creatividad baja.

Finalmente, en las tablas 4 y 5 también se puede observar que ningún coeficiente de correlación es superior a 0,8 de forma que puede causar verdaderos problemas de multicolinealidad.

La tabla 6 muestra los resultados obtenidos de la regresión lineal que nos permitirá contrastar las tres hipótesis planteadas.

Tabla 6

Resultados regresión lineal para la muestra de alumnos de primaria

\begin{tabular}{|c|c|c|c|}
\hline Variables & $\begin{array}{c}\text { Modelo } 1 \\
\text { REND_ACD_MUS_ } \\
\text { Primaria } \\
\text { Coeficiente estimado } \\
\text { (p-value) }\end{array}$ & $\begin{array}{c}\text { Modelo } 2 \\
\text { REND_ACD_MUS_ } \\
\text { Primaria } \\
\text { Coeficiente estimado } \\
\text { (p-value) }\end{array}$ & $\begin{array}{c}\text { Modelo } 3 \\
\text { REND_ACD_MUS_ } \\
\text { Primaria } \\
\text { Coeficiente estimad } \\
\text { (p-value) }\end{array}$ \\
\hline Constante & $\begin{array}{l}6,505^{* * *} \\
(0,000)\end{array}$ & $\begin{array}{l}4,354^{* * *} \\
(0,000)\end{array}$ & $\begin{array}{c}7,000^{* * *} \\
(0,000)\end{array}$ \\
\hline LATER_Primaria & $\begin{array}{l}1,172^{*} \\
(0,058)\end{array}$ & & \\
\hline INT_MUS_Primaria & & $\begin{array}{r}0,501^{* *} \\
(0,010)\end{array}$ & \\
\hline CREA_ALTA_Primaria & & & $\begin{array}{c}0,147 \\
(0,667)\end{array}$ \\
\hline CREA_MEDIA_Primaria & & & $\begin{array}{c}0,933^{* * *} \\
(0,000)\end{array}$ \\
\hline CREA_BAJA_Primaria & & & $\begin{array}{l}1,846^{*} \\
(0,073)\end{array}$ \\
\hline $\begin{array}{c}\mathbf{R}^{2} \\
\text { Estadístico } \mathrm{F}\end{array}$ & $\begin{array}{r}19,10 \% \\
3,691 *(0,060)\end{array}$ & $\begin{array}{c}25,70 \% \\
6,925 * *(0,010)\end{array}$ & $\begin{array}{c}26,20 \% \\
2,361^{*}(0,076)\end{array}$ \\
\hline
\end{tabular}

REND_ACD_MUS_Primaria es el rendimiento académico en Música que han obtenido los alumnos de primaria en el tercer trimestre de este curso lectivo, medido mediante la nota obtenida en el tercer trimestre que puede oscilar entre 0 y 10 ; la creatividad se mide mediante el test de inteligencia creativa (CREA) y el valor de esta variable resulta de la suma de un total de 20 preguntas que podía plantear el alumnado en función de la visualización de una imagen: si los alumnos de primaria plantean entre 0 y 7 preguntas, tienen una creatividad baja (CREA_BAJA_Primaria) y toma el valor 1; si los alumnos de primaria plantean entre 8 y 14 preguntas, tienen una creatividad media (CREA_MEDIA_Primaria) y toma el valor 2, y si los alumnos de primaria plantean entre 15 y 20 preguntas, tienen una creatividad alta (CREA_ALTA_Primaria) y toma el valor 3. INT_MUS_Primaria es la variable que refleja la inteligencia musical de los alumnos de primaria y se mide mediante el test de inteligencia musical de las inteligencias múltiples de Gardner (1983). Concretamente, se plantearon un total de 5 preguntas de índole musical y el total de síes acumulados daba lugar al resultado final de esta variable; LATER_Primaria es la variable que expresa la lateralidad de los alumnos de primaria medida mediante el test de dominancia lateral de Harris (1993). Concretamente, si la dominancia lateral es zurda, la variable toma el valor 1 y si es diestra, toma el valor 0. *Significatividad al $10 \%$, **significatividad al $5 \%$ y ***significatividad al $1 \%$. 
El modelo 1 analiza la capacidad predictiva de la lateralidad sobre el rendimiento académico. Así pues, vamos a estudiar si la lateralidad manual zurda de los alumnos de primaria influye en el rendimiento académico musical. Si observamos los resultados del modelo que arroja la tabla 6 , se puede apreciar que el $\mathrm{R}^{2}$ es un $19,10 \%$ y el modelo es estadísticamente significativo al $10 \%$. Por otra parte, se observa que la variable lateralidad (LATER_ZURDA_Primaria) arroja un signo positivo $(\beta=1,172)$ y es estadísticamente significativa al $10 \%$. Así pues, a tenor de este resultado, no podemos rechazar la primera hipótesis y podemos concluir que la lateralidad manual zurda de los alumnos de primaria predice rendimiento académico musical. Este resultado sugiere que la lateralidad manual zurda influye positivamente en el rendimiento académico musical.

En el modelo 2 estudiamos cómo la inteligencia musical de los alumnos de primaria repercute en el rendimiento académico musical. Tal y como se puede observar en la tabla 6, el modelo 2 es estadísticamente significativo y el $\mathrm{R}^{2}$ es del $25,70 \%$. La variable inteligencia musical presenta un signo positivo $(\beta=0,501)$ y es estadísticamente significativa al $5 \%$. Así pues, a tenor de estos resultados tampoco podemos rechazar la segunda hipótesis y se puede concluir que la inteligencia musical de los alumnos de primaria se asocia positivamente con el rendimiento académico musical.

En el modelo 3 analizamos la repercusión que los tres tipos de creatividad de los alumnos de primaria tienen en el rendimiento académico musical. El $\mathrm{R}^{2}$ del modelo es $26,20 \%$ y el modelo es estadísticamente significativo al $10 \%$. Los tres tipos de creatividad arrojan un signo positivo, tal y como se esperaba, pero sólo son estadísticamente significativas las variables creatividad media y creatividad baja. Por tanto, a tenor de estos resultados tampoco podemos rechazar la tercera hipótesis, de forma que sugerimos que los alumnos con creatividad media y baja obtienen un mayor rendimiento académico musical, mientras que la creatividad alta de los alumnos de primaria no influye en el rendimiento académico musical. 


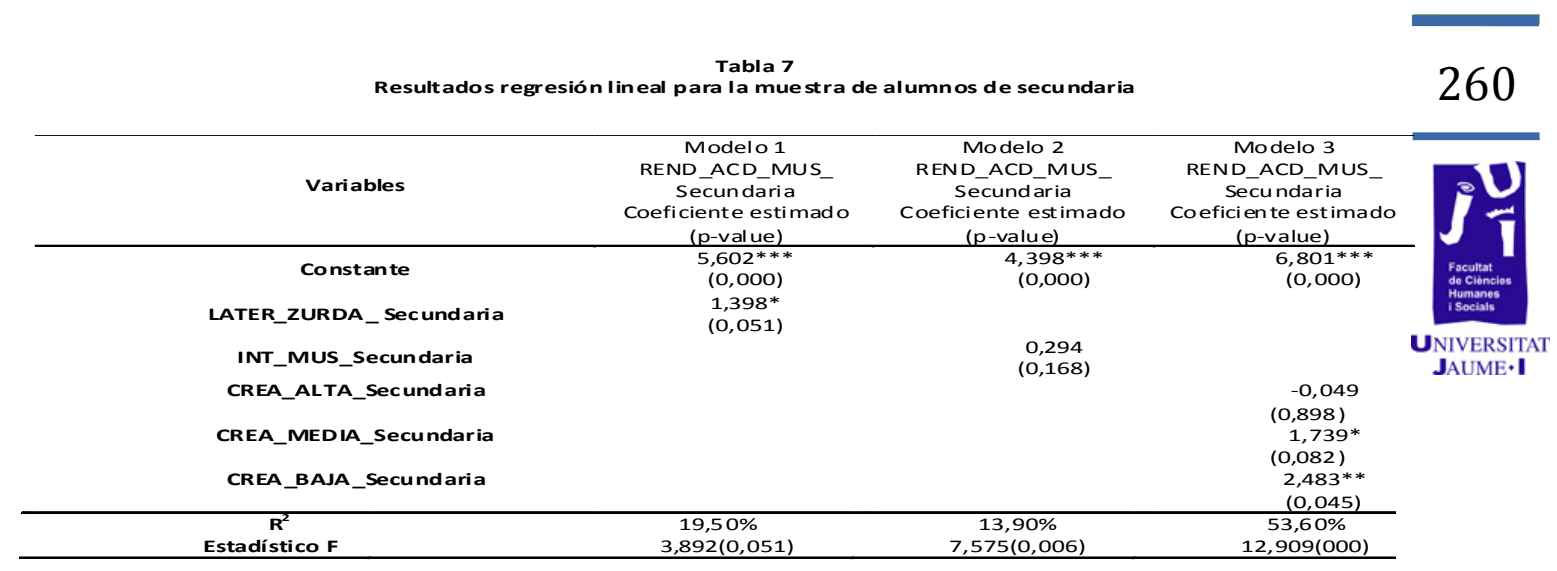

REND_ACD_MUS_Secundaria es el rendimiento académico en Música que han obtenido los alumnos de secundaria en el tercer trimestre de este curso lectivo, medido mediante la nota obtenida en el tercer trimestre que puede oscilar entre 0 y 10; la creatividad se mide mediante el test de inteligencia creativa (CREA) y el valor de esta variable resulta de la suma de un total de 20 preguntas que podía plantear el alumnado en función de la visualización de una imagen: si los alumnos de secundaria plantean entre 0 y 7 preguntas, tienen una creatividad baja (CREA_BAJA_Secundaria) y toma el valor 1; si los alumnos de secundaria plantean entre 8 y 14 preguntas, tienen una creatividad media (CREA_MEDIA_Secundaria) y toma el valor 2, y si los alumnos de secundaria plantean entre 15 y 20 preguntas tienen una creatividad alta (CREA_ALTA_Secundaria) y toma el valor 3. INT_MUS_Secundaria es la variable que refleja la inteligencia musical de los alumnos de secundaria y se mide mediante el test de inteligencia musical de las inteligencias múltiples de Gardner (1983). Concretamente, se plantearon un total de 5 preguntas de índole musical y el total de síes acumulados daba lugar al resultado final de esta variable; LATER_Secundaria es la variable que expresa la lateralidad de los alumnos de secundaria medida mediante el test de dominancia lateral de Harris (1993). Concretamente, si la dominancia lateral es zurda, la variable toma el valor 1 , y si es diestra, toma el valor $0 .{ }^{*}$ Significatividad al $10 \%, * *$ significatividad al $5 \%$ $\mathrm{y}^{* * *}$ significatividad al $1 \%$.

La tabla 7 presenta los resultados obtenidos en la regresión lineal para los alumnos de secundaria. Como se puede observar, los resultados son similares a los obtenidos en la tabla 6 , con la única diferencia que la variable inteligencia musical no es estadísticamente significativa, aunque arroja el signo esperado. Por tanto, a tenor de los resultados revelados en la tabla 7, no se puede rechazar ni la hipótesis primera ni tercera, pero sí la segunda. Así pues, estos resultados sugieren que los alumnos de secundaria con lateralidad manual zurda y con creatividad media y baja obtienen un mayor rendimiento académico musical, mientras que ni la inteligencia musical ni la creatividad alta de los alumnos de secundaria influyen en el rendimiento académico musical.

\section{Discusión y conclusiones}

La motivación intrínseca que se propone en esta investigación, principalmente por los profesionales e investigadores de la comunidad educativa, es conocer qué aspectos pueden intervenir en la mejora del rendimiento académico en Música. Por ello, el objetivo principal de este 
trabajo es analizar la relación existente entre la creatividad, la lateralidad, y la inteligencia musical de los alumnos de primaria y secundaria con el rendimiento académico que obtienen en Música. Concretamente, se quiere estudiar si la creatividad, la lateralidad y la inteligencia musical predicen el rendimiento académico musical.

Para alcanzar este objetivo se han planteado tres hipótesis. En la primera se predice que la creatividad influye positivamente en el rendimiento académico musical; en la segunda hipótesis se plantea que la lateralidad manual izquierda influye positivamente en el rendimiento académico musical, y en la tercera y última hipótesis, proponemos que la inteligencia musical influye positivamente en el rendimiento académico musical. Este estudio contribuye a proporcionar información sobre qué características neuropsicológicas, personales y formativas del alumnado pueden influir en el rendimiento académico musical.

Los resultados de este trabajo revelan que los alumnos de primaria con lateralidad zurda e inteligencia musical obtienen más rendimiento académico musical, así como aquellos que tienen una creatividad media y baja. Por otra parte, los resultados demuestran que la creatividad alta de los alumnos de primaria no tiene repercusión en el rendimiento académico musical. Los resultados para los alumnos de secundaria también ponen de manifiesto que la lateralidad zurda y la creatividad media y baja contribuyen a un mayor rendimiento académico musical, mientras que ni la inteligencia musical ni la creatividad alta influyen en el rendimiento académico musical de los alumnos de secundaria.

Este trabajo realiza varias contribuciones a la literatura previa. En primer lugar, evidencia cómo la creatividad, la inteligencia musical y la lateralidad influyen en el rendimiento académico musical de los alumnos de primaria y secundaria. Estudios previos sí que han analizado la repercusión de estas variables en el rendimiento académico, pero no tenemos conocimiento de que se hayan estudiado respecto al rendimiento académico musical de los alumnos de primaria y secundaria en la educación obligatoria en España. Por lo tanto, los resultados de este trabajo pueden contribuir a poner de manifiesto qué factores se tienen que mejorar y fomentar para contribuir a un mayor rendimiento académico musical. En segundo lugar, se ofrece una mayor amplitud y contextualización del rendimiento académico musical no solo en los procesos de adquisición de los conocimientos, sino también en las características de dominancia lateral y de conocimientos previos sobre música.

Los resultados de este estudio tienen implicaciones académicas y educativas, ya que nos permiten conocer qué aspectos influyen en el rendimiento académico musical, lo que podría potenciar y conocer qué aspectos intervienen tanto en el proceso como en la consecución de los objetivos académicos. Además, también nos puede ser útil la realización de una evaluación después de la aplicación de un programa de intervención, con la intención de conocer su funcionalidad y fiabilidad, así como para mejorar su contenido y desarrollo. Así pues, sería necesaria 
una adecuada legislación educativa que facilite los procesos a través de los cuales se pueden adquirir los conocimientos, donde se pueda fomentar y corregir una correcta dominancia lateral y se pueda promover e impulsar la inteligencia musical para la mejora en el rendimiento académico musical.

Asimismo, sería interesante llevar a cabo futuras líneas de investigación donde se estudie la creatividad, la lateralidad y la inteligencia musical en alumnos de diferentes niveles educativos como educación infantil, educación universitaria, y educación no obligatoria, con el propósito de poner de manifiesto que resultados arroja. Finalmente, se debería considerar también la utilización de diferentes test para la medición de las variables como el tipo de agrupamiento que realizamos, es decir, utilizar metodologías diferentes a las empleadas en este trabajo.

\section{Bibliografía}

AJURIAGUERRA, J. (1981): La escritura del niño. Barcelona: Laia (2 vol.)

Alberdi, A., M. Alsina, P. Alsina, C. Arriaga, S. Flores, A. Giráldez, G. IbarRetXe, loizaga, M., y A. Ramírez de loaysa (2010): Música: Complementos de formación disciplinar. Formación del profesorado. Barcelona: Grao.

Aldalalah, O. y S. F. Fong (2010): "Music Intelligence and Music Theory Learning. A Cognitive Load Theory Viewpoint». International of Psychological Studies. Vol. 2, núm. 2, en BANICH, M. (1993): The Neural Bases of Mental Function, Alexandria, Nueva York.

Barr, L., M. Dittmar, E. Roberts, y M. Sheraden (2002): «Enhancing Student Achievement Through the Improvement of Listening Skills». (ERIC Document Reproduction Service Núm. ED465999)

Bermejo, R., D. Hernández, M. Ferrando, G. Soto, M. Sainz, M. D. Prieto, (2010): "Creatividad, inteligencia sintética y alta habilidad», Revista Electrónica Interuniversitaria de Formación del Profesorado, 13 (1), 97109

BLoom, B. S. (1956): «Report on Creativity Research by the Examiner's Office of the University of Chicago», TAYLOR, C. W. (ed.), The 1955 University of Utah Research Conference on the Identification of Creative Scientific Talent, Salt Lake City, University of Utah Press, p. 182-194.

Corbalán, F. J., F. Martínez, D. Donolo, C. Alonso, M. Tejerina y R. M. LIMIÑANA (2003): CREA Inteligencia Creativa. Una medida cognitiva de la creatividad, TEA Ediciones, Madrid.

CostA, A., et al. (1991): Developing Minds, Vol. 1. ASCD, Washington. 
CAMpos, A, y M. A. González (1993): «Creatividad y rendimiento académico en estudiantes de Bellas Artes», Ciencias y Letras. Adaxe, 9, p. 19-28.

CHRISTOPHER, J. M., y J. E. MeMmott (2006): «Examination of Relationships Between Participation in School Music Programs of Differing Quality and Standardized Test Results». Journal of Research in Music Education, 54(4), 293-307.

DAVIDoV, V. V. (1988): La enseñanza escolar y el desarrollo psíquico. Editorial Progreso, Moscú.

De Ferrari, P., et al. (2003): Closing the Gap in Education and Technology. World Bank Latin American and Caribean Studies, Washington.

DE LA TORRE, S. (1985): “¿A qué llamamos creatividad?», Textos de Pedagogía, PPU, Barcelona, p. 166-173.

DORSCH, F.(1991): Diccionario de Psicología, Herder, Barcelona.

EdWARDS, M.P., y E. TYLER (1965): «Intelligence, Creativity and Achievement in a non-selective Public Junior High School», Journal 01 Educational Psychology, 56, 96-99.

Ferrándiz, G., Mạ. D. Prieto, P. Ballester y Mạ. R. Bermejo (2004): «Validez y fiabilidad de los instrumentos de evaluación de las inteligencias múltiples en los primeros niveles instruccionales», Psicothema, 16 (1):

Ferré, J., y Irabau, E. (2002): El desarrollo neurofuncional del niño y sus trastornos, Lebón, Madrid.

Ferré, J., V. CAsaprima, J. Catalán y J. V. Mombiela (2000): El desarrollo de la lateralidad infantil. Niño diestro- niño zurdo, Lebón, Barcelona.

Ferreiro, R. (1995): Educación para el talento, SEP Jalisco, Guadalajara.

- (1999): A Successful Program in Bilingual Education, ELI method, executive report.

GARDNER, H. (1993): «Inteligencias múltiples», La teoría en la práctica, Paidós, Barcelona.

Holland, J. L. (1964): «The Assessment and Prediction of the Creative Performance of High Aptitude Youth». En C. W. Taylor (ed.), Widening Horizons in Creativity. The Proceedings 01 the Fifth Utah Creativity Research Conference, John Wiley \& Sons, Nueva York, p. 298-315.

Hodges, D., D. O'CONNell (2006): «The Impact of Music Education on Academic», University of North Carolina, Greensboro.

Mayolas, M., A. Villarroya y J. ReVerter (2010): «Relación entre la lateralidad y los aprendizajes escolares», Apunts. Educación Física y Deportes 2010, núm. 101, 3ำ trimestre, p. 32-42.

NAVARRO, R. (2003): «El rendimiento académico: concepto, investigación y desarrollo", Revista Iberoamericana sobre la calidad, eficacia y cambio en Educación, 1 (2). 
Schellenberg, E. G. (2004): "Music and Cognitive Abilities», American Psychological Association, 14, (2).

SitNIKova, M. (2011): «Educational Peculiarities and Difficulties of Children with Left-sided Laterality: the Technical Solution of the Problem», Cypriot Journal of Educational Sciences. Vol 7, Issue 1, p. 14-24.

TAPSCOTT, D., y A. D. WiLliAms (2006): Wikinomics. La nueva economía de las multitudes inteligentes, Paidós, Barcelona. 
Gustau Olcina Sempere. El aprendizaje de la música con métodos del aprendizaje cooperativo en la enseñanza universitaria

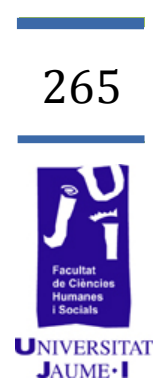

\section{El aprendizaje de la música con métodos del aprendizaje cooperativo en la enseñanza universitaria}

Gustau Olcina Sempere

golcina@uji.es 
En este estudio se quiere conocer las ventajas del aprendizaje cooperativo en la educación universitaria. Los procesos de enseñanzaaprendizaje que se generan en el aula determinan una educación basada en conseguir, mediante la cooperación y colaboración de todos los agentes que forman parte del proceso educativo en la enseñanza universitaria, una mejora en las acciones que se generan en el aula y, en consecuencia, de las nuevas formas de motivar y implicar a todos los alumnos en una educación integral y de calidad.

La necesidad de trabajar de manera cooperativa con los alumnos del grado de Maestro de Educación Primaria, y concretamente en la asignatura de Didáctica de la Expresión Musical, está motivada por el interés, tanto del alumnado como del profesorado, para que los procesos de enseñanza-aprendizaje favorezcan una mayor interacción del profesoralumno, tanto en los trabajos grupales como en los individuales que se generen en el aula.

Además, se tienen que potenciar los cambios necesarios para la mejora de la concienciación social, en donde la educación entre iguales potencie nuevas formas de organización y cambio social.

Palabras clave: aprendizaje cooperativo, enseñanza universitaria, cooperación, interacción social, educación primaria.

\section{Introducción}

En la actualidad la educación universitaria se ha adaptado y estructurado al nuevo contexto de enseñanza del Plan de Bolonia. Este plan ha adoptado un conjunto de medidas para la reforma de la estructura y reorganización de las enseñanzas universitarias con la finalidad de favorecer el Espacio Europeo de Educación Superior.

Los estudios realizados por Johnson y Johnson (1999) ponen de manifiesto que el aprendizaje cooperativo contribuye al desarrollo del pensamiento crítico, incremento del número de ideas, su calidad, la originalidad de la expresión en la resolución creativa de problemas y los sentimientos de estímulo y placer. Esta estrategia metodológica basada en el aprendizaje cooperativo, se ha propuesto tanto en la actual ley de educación LOMCE como en las anteriores como la LOGSE y la LOE.

No dicen Deutsch (1949) y Johnson y Johnson (1999) que cuando los estudiantes realizan sus trabajos de manera cooperativa sus intenciones se centran en alcanzar unas metas compartidas donde se esfuerzan en optimizar su propio aprendizaje como el de sus compañeros. Las investigaciones que han realizado Johnson y Smith (1991), con relación a la aplicación del aprendizaje cooperativo en la enseñanza universitaria, nos dicen que, a pesar de ser una de las técnicas de mayor eficacia, es de 
las menos utilizadas en la educación universitaria. En cambio, en la actualidad, la forma más común de enseñar está basada en la clase magistral y, en cambio, el aprendizaje cooperativo ofrece nuevas formas de plantear y organizar los conocimientos, propiciando nuevas formas de organización y dinámica de clase para ayudar a los alumnos a aprender a aprender.

El motivo de utilizar el aprendizaje cooperativo en el contexto universitario no es solo una necesidad del organigrama de la universidad, sino también de la posibilidad de ofrecer otra alternativa metodológica donde se eviten los modelos individualistas, la falta de participación, la inseguridad, así como la poca reflexión y espíritu crítico (León y Latas, 2007).

Además, es necesario que la universidad proporcione a sus profesores todas la herramientas necesarias para poder llevar a cabo un contexto educativo donde se generen situaciones en las cuales sea posible la adecuada aplicación de dicha técnica de aprendizaje cooperativo (Santos, 1990).

Así mismo, el aprendizaje cooperativo puede ser considerado como un instrumento válido tanto para el profesorado como para el alumnado, ya que se concibe como un instrumento de gran utilidad tanto para aprender, enseñar y vivir. Esta forma de entender la educación y, en consecuencia, los procesos que se articulan en las relaciones entre el profesor y el alumno, generan una forma de vida donde la solidaridad, la cooperación y el espíritu crítico constituyen una filosofía de vida (Traver, 2003).

El aprendizaje cooperativo se ha estudiado de manera manifiesta en las últimas décadas principalmente en EE. UU., y se ha estudiado desde diversas perspectivas teóricas (León y Latas, 2007). Estas investigaciones han sido de suma importancia ya que han dado valor y interés a las concepciones y aportaciones de Vygotsky, el cual sostiene que es necesario analizar no solo la interacción de los alumnos en el proceso de aprendizaje, sino que también se tiene que considerar la coordinación y el planteamiento de actividades entre el profesorado y el alumnado tanto para el contenido de aprendizaje como para las tareas que se vayan a desarrollar. (Coll, et al., 1995).

Un gran número de investigaciones (Ovejero, 1990; Johnson y Johnson, 1995; Slavin, 1999, y Traver, 2003) ponen de manifiesto las ventajas que ofrece a la educación el aprendizaje en grupos cooperativos. Además, esta mejora no se manifiesta solamente en los aprendizajes que establece el currículo para la asignatura de didáctica de la expresión musical del grado de educación primaria, sino que contribuye también a un mayor acercamiento entre el profesor y el alumno, de manera que se potencia la educación en valores y la relaciones entre iguales (Fernández, 2011).

La consideración de las características que sostienen algunos autores como (Coll y Colomina, 1990) en cuanto a las características o cualidades del aprendizaje cooperativo, defienden que para su desarrollo se realiza 
una división de la clase en grupos de aproximadamente seis personas, con la intención de llevar a cabo una actividad planificada y estructurada, donde los miembros que la forman suelen ser variados en sus aptitudes para el desarrollo de las actividades propuestas.

Johnson y Johnson (1999) entienden la concepción cooperativa desde el momento en que un grupo de personas deciden trabajar juntas con la finalidad de conseguir los objetivos propuestos por todos los miembros que constituyen el grupo cooperativo. La finalidad de trabajar de manera cooperativa, es que además de conseguir los logos desde un punto de vista individual también se consiguen unos beneficios grupales mediante las técnicas del aprendizaje cooperativo.

En el aprendizaje cooperativo se potencian unas situaciones en las cuales tanto los fracasos como los éxitos se comparten entre todos los miembros de cada grupo, con la finalidad que cada uno de los componentes aporte el máximo rendimiento al grupo (Gage y Berliner, 1988).

\section{Objetivos}

En nuestro estudio, que está centrado en el grado de Maestro de Educación Primaria, y concretamente en la asignatura de Didáctica de la Expresión Musical en la Universidad Jaume I de Castellón de la Plana, se tiene la intención de dar a conocer las prácticas de aprendizaje cooperativo que se llevan a cabo en dicha asignatura, donde se adquiere el conocimiento por las actividades que realizan en sus trabajos y en sus procesos de aprender haciendo.

\section{Material y método}

Esta experiencia se ha llevado a cabo como profesor del Área de Didáctica de la Expresión Musical en la Universidad Jaume I, con los alumnos de 3 o curso del grado de Maestro de Educación Primaria. El objetivo de esta experiencia es que a través del aprendizaje cooperativo los estudiantes adquieran un conjunto de herramientas útiles para sus futuras prácticas docentes como maestros de educación primaria. Además, también se quiere que, mediante dicha metodología, el alumnado adquiera la importancia que tiene para la formación integral del individuo la enseñanza musical y contribuya a generar una sociedad más solidaria, cooperante, tolerante y con espíritu crítico (Ovejero, 2013).

El eje central de este proyecto está centrado en la canción, como instrumento de integración y identificativo de un determinado contexto cultural y social, de manera que se adquiere mediante el canto grupal un carácter holístico de la música (Malagarriga, Gómez y Viladot, 2008).

La técnica de aprendizaje cooperativo que se lleva a cabo en el desarrollo de las clases se denomina Learning Together (Johnson y Johnson, 1999), la cual se caracteriza por los siguientes aspectos: 
- Los alumnos se organizan en grupos.

- El profesor distribuye una serie de tareas las cuales son guiadas y supervisadas por el profesor para fomentar que se preocupen tanto del rendimiento de sus compañeros como del suyo propio y que cada equipo trabaje conjuntamente.

- Se fomenta que los grupos se formen de manera diversa y que el liderazgo se comparta entre todos los miembros del grupo.

- El trabajo se realiza en el aula.

- El nivel de aprendizaje que se quiere obtener con las técnicas de trabajo cooperativo utilizadas en la asignatura de Didáctica de la Música es el máximo posible.

En cuanto a la evaluación, esta se realiza de manera grupal e individual. Cada miembro de cada grupo, expone en clase una actividad de las elaboradas en el dosier, para trabajar la canción en el aula de primaria, en cuyas prácticas participan sus propios compañeros, y reciben de ellos y ellas y del profesor las diferentes aportaciones y enfoques de la actividad presentada. Además, cada grupo realiza un dosier con las modificaciones y aportaciones que se han sugerido, tanto por el alumnado como por el profesor, de manera que se utiliza el dosier para la evaluación en grupo.

\section{Resultados}

Para analizar los resultados que se derivan del aprendizaje cooperativo, el cual se desarrolla con el alumnado de Educación Primaria de la Universidad Jaume I, y concretamente en los alumnos de 3 curso, destacamos las mejoras que hemos conseguido mediante esta metodología:

1. Mediante los procesos que se generan en el aprendizaje cooperativo se ha reducido en gran medida las clases magistrales.

2. Se ha potenciado la autoevaluación del alumnado mediante la realización de exposiciones orales.

3. Se ha conseguido transmitir en los procesos de aprendizaje, que la adquisición de los aprendizajes no se realiza solo en su periodo de educación universitaria, sino que se trata de entender que el aprendizaje se adquiere durante toda la vida.

4. Hemos trabajado en minimizar la competitividad así como el individualismo, con la intención de que estas prácticas se lleven a cabo en el contexto escolar.

5. Además de evaluar los resultados, también se han evaluado los procesos competenciales de nuestro alumnado. 
Por lo tanto, mediante estas acciones hemos conseguido desarrollar en nuestro alumnado un conjunto de valores y actitudes que faciliten la interacción entre el alumnado y entre este y el profesorado, potenciando unas actitudes más cooperativas y menos individuales.

También, nos hemos interesado en formar a ciudadanos con espíritu crítico, tolerantes y respetuosos con sus compañeros/as, para poder cambiar y promover nuevas ideas y conductas en la sociedad actual. Todo ello, debe proporcionar a los futuros docentes un conjunto de estrategias y acciones que les ayuden a desarrollar nuevos horizontes en la educación del siglo XXI.

\section{Discusión y conclusiones}

Teniendo en cuenta todas las apreciaciones que se han desarrollado en este estudio, podemos decir que el aprendizaje cooperativo debe considerarse como una herramienta útil para el desarrollo de los procesos de enseñanza-aprendizaje que se generen en la enseñanza universitaria. De manera que consideramos necesario que la universidad ofrezca a los docentes la formación, los medios, los recursos y los espacios necesarios para poder organizar y desarrollar prácticas educativas, donde el aprendizaje cooperativo se convierta en el eje vertebrador de la educación en la universidad.

Además, también es necesario que los docentes se preocupen y interesen por realizar un cambio en la forma de impartir los conocimientos, donde el interés de la enseñanza no sea la clase magistral y se busquen nuevas formas de establecer las relaciones entre los alumnos, así como de conducir la construcción del conocimiento acompañando a través de las enseñanzas que se realizan en el aula.

En el desarrollo de las clases en la universidad y mediante la utilización del aprendizaje cooperativo, se percibe que el alumnado se siente más motivado, muestra más interés por la asignatura, adquiere una mayor autonomía, se favorecen las relaciones entre sus iguales, la relación profesor-alumno es mucho más fluida y enriquecedora tanto para los alumnos como para los docentes.

Además, coincidiendo con la opinión de Ovejero (2013), la cual sostiene que mediante el aprendizaje cooperativo también se consigue un objetivo social, dirigido a fomentar determinados valores sociales como la solidaridad, la tolerancia, la cooperación y el espíritu crítico, es necesario conocer las ventajas que nos ofrece el aprendizaje cooperativo en la educación universitaria.

Teniendo en consideración las afirmaciones realizadas anteriormente, es oportuno tener en cuenta que el aprendizaje cooperativo es una metodología muy apropiada para la enseñanza musical en el ámbito universitario. Esta nueva filosofía de entender la educación nos hace pensar en un proceso de enseñanza-aprendizaje 
mucho más democrático en comparación con los modelos de enseñanza tradicional.

\section{Bibliografía}

ColL, C. y R. Colomina (1990): «Interacción entre alumnos y aprendizaje escolar», Coll C., J. PALACIOS y A. MARCHESI (comp.), Desarrollo psicológico y educación II. Psicología de la Educación, Alianza Psicología, Madrid, p. 335-355.

Coll, C., R. Colomina, J. Onrubia y M. J. Rochera (1995): Actividad conjunta y habla: una aproximación al estudio de los mecanismos de influencia educativa.

DEUTSCH, M. (1949): «A Theory of Competition», Human Relations, núm. 2, p. 129-151.

FERNÁNDEZ, N. F. (2011): "Música en el cine: Una propuesta de trabajo cooperativo en base a una red social educativa en un curso de 4ㅇ de la ESO", Profesorado. Revista de Currículum y Formación de Profesorado, núm. 15(2), p. 235-250.

Gage, N. L. y D. C. Berliner (1988): Educational Psychology, Houghton Mifflin, Boston.

Johnson, D. y JoHnson, R. (1995): Los nuevos círculos de aprendizaje: cooperación en el salón de clase y en la escuela, Aique Grupo Editor, Madrid

- (1997): "Una visió global de l'aprenentatge cooperatiu», Suports. Revista catalana d'educació especial i atenció a la diversitat, núm. 1, p. 54-64.

- (1999): Aprender juntos y solos. Aprendizaje cooperativo, competitivo e individualista, Aique, Buenos Aires.

Johnson, D. W., R. Johnson y K. SMITH (1991): Active Learning: Cooperation in the College Classroom. Edina, MN: Interaction Book Company.

LEÓN, B. y C. LATAS (2007): «La formación en técnicas de aprendizaje cooperativo del profesor universitario en el contexto de la convergencia europea», Revista de Psicodidáctica, núm. 12, p. 216-227.

Ley Orgánica 1/1990, de 3 de octubre, de Ordenación General del Sistema Educativo (LOGSE) (BOE de 4 de octubre de 1990).

Ley Orgánica de Educación 2/2006, de 3 de mayo, (LOE) (BOE de 4 de mayo de 2006). 
Ley Orgánica 8/2013, de 9 de diciembre, para la mejora de la calidad educativa (LOMCE) (BOE de 10 de diciembre de 2013).

MalagarRiga, T., I. Gómez y L. Viladot (2008): «Un proyecto compartido de innovación, formación de profesorado e investigación en el ámbito de las escuelas de música», Cultura y Educación, núm. 20 (1), p. 63-78.

OVEJERO, A. (1990) El aprendizaje cooperativo una alternancia eficaz a la enseñanza tradicional, PPU, Barcelona.

- (2013): Utilidad del aprendizaje cooperativo/colaborativo en el ámbito universitario. IV Congreso Internacional; Estrategias hacia el aprendizaje cooperativo. Girona.

SANTOS, M. A. (1990): «Estructuras de aprendizaje y métodos cooperativos en educación», Revista Española de Pedagogía, núm. 185, p. 53-78.

SLAVIN, R. (1999): Aprendizaje cooperativo: Teoría, investigación y práctica, Editorial Aique Grupo editor S.R.L., Buenos Aires.

Traver Martí, J. A. (2003): «Aprendizaje cooperativo y educación intercultural», A. SALES CIGES (coord.) Educació intercultural: la diversitat cultural a l'escola, UJI Colección Educación, Castelló de la Plana. 


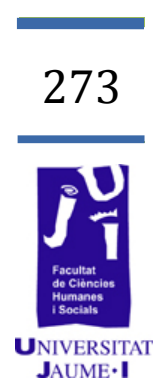

Optimización de la rehabilitación de personas con DCA mediante una intervención psicopedagógica musical

El proyecto NeuroHarmony

Santiago Díaz Santamaría sandisa83@gmail.com 
El daño cerebral adquirido (DCA) incide en las personas que lo padecen creando déficits persistentes en la motivación y alteraciones en el pensamiento formal por las cuales se producen carencias en el razonamiento logicodeductivo y abstracto. En un proceso de investigación-acción realizado en la Asociación Fundación Ateneu, centro de día para personas con DCA, se observó que estos déficits afectaban negativamente a su participación en los talleres ofertados por la Asociación Fundación y, por ende, al resultado terapéutico de los mismos. Se propuso y se implementó, en un reducido grupo de usuarios con problemas de apatía e interrelación, un proyecto de intervención psicopedagógica que, basándose en aspectos musicoterapéuticos y de educación musical especial, utiliza la música como herramienta en un triple proceso compuesto por aprendizaje, terapia e inclusión. Por medio de un análisis de datos se mostró que la citada intervención logró mejorar la participación de los sujetos en los talleres del proyecto, resultado que, a su vez, demuestra la eficacia de este tipo de intervenciones dirigidas a personas con afecciones cognitivas severas y el importante papel de la aplicación de la música en las intervenciones psicopedagógicas.

Palabras clave: intervención psicopedagógica, DCA, participación, educación musical especial, terapia, musicoterapia, rehabilitación.

\section{Introducción}

Los tratamientos rehabilitadores que se implementan en las personas afectadas por el DCA se estructuran en tres niveles compuestos por planteamientos terapéuticos diferenciados que corresponden a las tres fases de atención a esta lesión caracterizada por acaecer de forma súbita en las estructuras encefálicas. El nivel III de intervención, desarrollado en el ámbito asistencial de la $\mathrm{UCl}$, también denominado de alta especialización, es simultáneo a la fase de atención aguda del DCA. Por consiguiente, el nivel II, puesto en marcha en los ambulatorios, coincide con la fase subaguda de la lesión. El consecutivo nivel I, por último, tiene su contexto en los centros de día y realiza su tratamiento rehabilitador cuando el daño se encuentra en su última fase, la fase crónica. Es en este nivel, coincidente con esta fase en la que las secuelas del daño se han estabilizado, en el cual desarrollan su labor profesionales de la neuropsicología, logopedia, terapeutas ocupacionales y fisioterapeutas, también es en este momento terapéutico donde se realiza la intervención psicopedagógica que, por las características de la fase, pretende generalmente la preservación de habilidades y la compensación de deficiencias. Según la clasificación de Bisquerra (1996), este tipo de intervención se incluye en el modelo desarrollado en los medios sociocomunitarios. Por su parte, este tipo de intervención psicopedagógica 
se basa en el principio de intervención social (Rodríguez Espinar, 1993) y toma como referencia el modelo denominado de intervención por servicios.

Por otra parte, el empleo de la música como principal herramienta de la intervención psicopedagógica se refleja en trabajos como el de Mello (2011) en el cual se aplica una intervención con el arte sonoro a niños con dificultades de aprendizaje. En otra línea, Gainza (2002) relaciona la música y la psicopedagogía en su obra, con la que pretende paliar los procesos dolorosos vinculados con la música. Conocidos estos trabajos y teniendo en cuenta la inexistencia de un nexo disciplinar concreto que una directamente la psicopedagogía con la música, se opta finalmente por fundamentar la teoría de la presente intervención en aspectos de disciplinas relacionadas con la disciplinariedad dual ${ }^{1}$ de la psicopedagogía que, a su vez, posean relación con el arte musical. Es decir, según este planteamiento, se fundamenta la intervención en aspectos de la musicoterapia teniendo en cuenta las aportaciones de la psicología de la música por la relación de estas dos disciplinas con la psicología. Asimismo, se fundamenta la intervención psicopedagógica en aspectos de la educación musical especial por la vinculación de esta disciplina con la pedagogía. La psicología de la música, avalada también por estudios neurocientíficos, ${ }^{2}$ asevera la eficacia de la práctica musical para el desarrollo integral del individuo. Sabbatella (2005) concreta los ámbitos de incidencia de la música en el citado desarrollo; según su estudio se resumen en cinco: sensorial-psicomotor, psicoemocional, cognitivo, social y eticotrascendental.

Siendo conocidos los efectos terapéuticos que brinda la música cuando se administra como terapia y la necesidad social de poner en práctica una pedagogía inclusiva que contrarreste las necesidades derivadas de las conductas sociales existentes que integran, pero no incluyen, de forma que se obstaculiza la participación, la presencia y el aprendizaje en igualdad de condiciones de las personas que padecen deficiencias, se diseña el proyecto de intervención psicopedagógica NeuroHarmony. Este diseño y su posterior implementación está motivado por la necesidad detectada tras realizar un proceso de investigaciónacción en la Asociación Fundación Ateneu. El problema evidenciado se concreta en la falta de participación de un grupo de usuarios en los talleres que oferta la Asociación Fundación $y$, por ende, su nula optimización terapéutica. En un caso concreto, este problema se agrava con ciertas reacciones agresivas dirigidas a usuarios y a personal profesional.

Según los datos recabados en el periodo de observación prefase, el motivo de la inactividad y la insuficiente participación se debe principalmente, en unos individuos, a la apatía producida por las características concretas de la lesión padecida; en otros, es producto de

1. En la disciplina psicopedagógica convergen la psicología y la pedagogía.

2. Blood y Zatorre (2001), Costa-Giomi (2005), Hargreaves (1999), Julin y Sloboda (2001), Kratus (1993), KrumhansI (2002), Madsen (1979), Nawrot (2003), Schellenberg (2004) (2005). 
las alteraciones del pensamiento formal por las cuales se padecen déficits en el razonamiento logicodeductivo, en la resolución de problemas y en la abstracción. Las reacciones violentas referidas se deben a alteraciones perceptivas y de control de conducta. Además, este tipo de reacciones están enfatizadas por la hemiplejía que padece el individuo aludido, pues las personas que, junto a la afasia, ${ }^{3}$ sufren hemiplejía padecen un doble amordazamiento del cual proceden estados de indefensión, ansiedad, estrés, depresión y miedo (Albillo, 2007).

Habiendo detectado la falta de actividades musicales en la Asociación Fundación y valorando positivamente los beneficios que puede aportar la música como herramienta terapéutica y didáctica, se considera que una intervención psicopedagógica que utiliza la música como su principal recurso mejorará la participación de los usuarios en los talleres de la Asociación Fundación.

\section{Objetivos}

El objetivo general es lograr la participación de los usuarios no participativos e incrementar la participación de estos en los talleres y actividades terapéuticas ofertadas por la Asociación Fundación.

Los objetivos específicos son los siguientes:

- Crear o enfatizar la conciencia musical, es decir, hacer evidente la importancia del arte sonoro en la historia vital de la persona.

- Proporcionar a los usuarios, según sus capacidades, habilidades musicales básicas. ${ }^{4}$

- Mejorar las capacidades cognitivas implicadas y deficitarias (concretamente: el razonamiento abstracto y la memoria).

- Fomentar la motivación con actividades amenas que tengan en cuenta las preferencias individuales de los usuarios.

- Mejorar la autoestima.

\section{Material y método}

Para la consecución de los objetivos se diseña una intervención basada en el «triple proceso», estrategia de elaboración propia que, en el ámbito de un taller, pretende la creación delo siguiente:

- Un proceso terapéutico cuyo resultado sea, en la medida de lo posible, la contribución a la rehabilitación o mejora de ciertos aspectos neuropsicológicos relacionados con el problema.

3. La cual también padece por la persona referida.

4. Habilidades conocidas, en el proyecto, con el nombre de «rudimentos». 
- Un proceso de aprendizaje por el cual los usuarios adquieran destrezas básicas para lograr la expresión comunicativa por medio de una estrategia de compensación.

- Un proceso inclusivo cuyo resultado incida en la eliminación de las barreras que impiden la presencia, la participación y el aprendizaje en un contexto diverso.

El papel de la música, a pesar de ser desigual en los tres subprocesos, la convierte en el componente que lo cohesiona y dinamiza. Al igual que en la didáctica musical especial, la música actúa en el proceso pedagógico como resultado del aprendizaje para poder realizar posteriormente una estrategia de compensación. Los usuarios aprenden rudimentos musicales como la interpretación con instrumentos Orff de ritmos binarios o ternarios, matices, etc. que, a continuación, se utilizan como medio de expresión emocional. La música se utiliza en el proceso terapéutico para la mejora de ciertas capacidades alteradas y para el mantenimiento de las capacidades preservadas tras el daño (atención, razonamiento abstracto, etc.) así como para obtener los beneficios principales de la utilización de la música como terapia: mejora de la motricidad, alivio de la ansiedad, equilibrio psicofísico y emocional, mejora de las respuestas psicofisiológicas, etc. (Lacárcel, 1990). Por último, el arte sonoro se utiliza como herramienta del proceso inclusivo de manera que es la acción que une a todos los participantes de forma horizontal y provoca, así interacción entre iguales. La interpretación conjunta de motivos, acompañamientos y pequeñas piezas musicales convierte a los participantes en elementos clave de la actividad común. En el preciso momento de la ejecución musical, de forma especial, cada individuo es ponderado y pertenece activamente al grupo (Patterson, 1995).

El triple proceso se implementa en el contexto del taller. Este posee doble ubicación: por una parte, se establece en la Asociación Fundación Ateneu donde se realizan las sesiones ordinarias; por otra, se sitúa en el laboratorio de música de la Universitat Jaume I, en el que se llevan a cabo las sesiones inclusivas con alumnado de grados y de másteres.

Los miembros del taller son el psicopedagogo y sus auxiliares como administradores participantes de la intervención y el grupo de usuarios intervenido. Este grupo se crea por la aplicación de los tres criterios de selección. ${ }^{5}$ Del grupo de usuarios que presenta el problema se extrae una muestra por medio de dos de los tres criterios de selección ( $A$ y $B$ ).

Tanto el criterio $A^{6}$ como el $B$ son producto de las necesidades contempladas en el diagnóstico. El criterio $C$, por su parte, se incluye teniendo en cuenta que el hecho de que la intervención esté dirigida hacia un colectivo prioritario de personas, que presenta los déficits

5. Criterio A: usuarios con un déficit significativo en la comunicación e interacción social. Criterio B: usuarios con un déficit persistente en la motivación. Criterio C: usuarios con alta motivación para participar en las sesiones del proyecto.

6. El criterio A se formula atendiendo a los problemas de comunicación que se dan en el grupo. No obstante, en el presente artículo, no se contempla esta variable que fue intervenida y evaluada en el proyecto. 
descritos, no ha de producir un menoscabo en la participación de otras personas usuarias del centro porque el taller puede ser enriquecedor para todos (Mondragón et al., 2013). No obstante, los datos extraídos de la participación de estos usuarios incluidos por este criterio no se analizan por su irrelevancia en la investigación, ya que los usuarios incluidos por el criterio $\mathrm{C}$ no se consideran parte de la muestra.

Tras la aplicación de los criterios de selección, el colectivo participante prioritario ${ }^{7}$ se concreta en tres usuarios; $A 1, B 1$ y B2. Todos ellos padecen secuelas severas:

- A1 padece afasia global, hemiplejía y alteraciones perceptivas, sus capacidades cognitivas no se pueden medir por la gravedad de las secuelas; no obstante, se estiman muy bajas. Sus capacidades motrices finas y gruesas son muy bajas. Sus habilidades comunicativas se reducen a la gesticulación facial, a la gesticulación producida por el movimiento de la mano izquierda y el brazo izquierdo, y al movimiento craneal. Su conducta social se resume en dirigir, a ciertas personas, determinados gestos estereotipados de forma esporádica. En ocasiones, establece contacto ocular. Ocasionalmente su conducta social se daña con reacciones violentas. Su grado de discapacidad según la $\mathrm{GOS}^{8}$ es grave.

- B1 padece déficit persistente en la motivación, sus capacidades cognitivas están alteradas por la lesión, se estima que posee un $\mathrm{Cl}$ bajo con el cual solamente está capacitada para acciones manuales ordinarias y sencillas. Sus habilidades comunicativas se concretan en una capacidad verbal baja con la que se comunica a través de frases muy cortas, no posee expresividad gestual. Estas habilidades son, de forma recurrente, obstaculizadas por la tendencia de la usuaria a adoptar una posición corporal, con el cuello en hiperflexión, que entorpece físicamente el acto comunicativo. A esta posición recurrente se le denomina, en presente trabajo, «posición de inhibición». Su motricidad gruesa es baja, su motricidad fina; media-baja. Su conducta social se limita a dar brevísimas respuestas a algunas preguntas. El grado de discapacidad, según la GOS, es moderado.

- B2 padece déficit persistente en la motivación, alteraciones cognitivas ( $\mathrm{Cl}$ bajo). Sus habilidades comunicativas son fundamentalmente verbales, se comunica por medio de frases cortas, posee una baja gesticulación. Su conducta social se concreta en el establecimiento de contacto ocular y en la respuesta a estímulos verbales. Su motricidad gruesa es baja,

7. Es decir, el seleccionado por los criterios A y B.

8. Glasgow Outcome Scale 
su motricidad fina, media-baja. El grado de discapacidad que padece, según la GOS, es moderado.

\section{Los recursos secundarios característicos}

Para la consecución de los objetivos, el proyecto de intervención se vale de los recursos secundarios característicos ${ }^{9}$ que también pretenden la introducción de los usuarios en la dinámica de las actividades. Destacan entre otros recursos más comunes también utilizados en la intervención por su carácter particular y su recurrente uso, son tres: la canción representativa (CR), el MusicDraw (MD) y la PictoScore (PS).

El primer recurso, la $\mathrm{CR}$, es principalmente utilizado en el proceso terapéutico y en el proceso pedagógico, está basado en los métodos receptivos de la musicoterapia y en el principio musicoterapéutico del ISO. Concretamente en el ISO gestáltico, que es el que caracteriza al individuo (Benenzón, 1997). La canción representativa, por consiguiente, es una pieza musical elegida por el usuario siguiendo los criterios de gusto, significación emocional o vital, que, durante todas las sesiones de la intervención, actúa como su representación musical. Se utiliza como elemento motivador. También se maneja para producir interactuaciones entre los participantes, los cuales, en ocasiones, han de identificar a qué usuario simboliza la canción representativa que, en un momento dado, se reproduce. Pero, sobre todo, el recurso de la canción representativa se utiliza siguiendo el Principio del placer de Altshuler (1952).

El recurso del MD consiste en plasmar por medio de dibujos concretos o abstractos, incluso, por medio de letras u otros símbolos, una experiencia resultante de una audición musical. Se realiza, si es posible, con la interpretación musical en directo, con la cual se procura que los usuarios experimenten, de forma directa, la expresividad musical y las características sonoras que emanan de este tipo de interpretaciones. El recurso sirve como medio para establecer interrelaciones entre los usuarios a los cuales se les invita a mostrar y describir sus dibujos a los demás usuarios. Esta característica es una base para la realización de actividades expresivas que se describirán posteriormente.

La PS es un recurso que permite guiar a los usuarios en una interpretación musical sin necesidad de dar directrices orales en su curso, siendo capaz de ser comprendido de forma directa. Sin acaparar toda la atención, no interfiere en la fluidez de la ejecución instrumental. La técnica se basa en el uso de pictogramas que hacen el papel de una grafía musical. La PictoScore, por tanto, se puede considerar como una partitura de pictogramas. Esta grafía de carácter aleatorio, proyectada en una pantalla, guía una ejecución musical improvisada pero, no obstante, sujeta a unos estándares que la concretan. No representa ninguna pieza musical preconcebida como los musicogramas. Se puede afirmar que, la PictoScore, junto con la creatividad del que la sigue, crea la pieza musical.

9. Son recursos, de elaboración propia, denominados secundarios al tener en cuenta que el recurso primario del proyecto de intervención es la música. 
En algunas actividades, el significado de los caracteres de esta grafía -es decir los pictogramas- sí que está establecido por el enunciado; pero en otras, se otorga por el usuario extrayendo de él una característica que ha de ser común a la de un elemento musical. Tras este razonamiento, el pictograma representa ese elemento sonoro en la actividad interpretativa. Este proceso cognitivo, de atribución de significado al símbolo, brinda la oportunidad de implementar las actividades de razonamiento, las cuales se describirán posteriormente. En el marco de estas actividades, el uso de la PS supone, para el usuario, ejercitar el pensamiento abstracto y la memoria, también, el hecho de simultanear la visualización de los pictogramas y la interpretación musical, por medio de un instrumento, fomenta el trabajo de la atención dividida. La cualidad aleatoria controlada, de las interpretaciones que guía, y las diferentes atribuciones simbólicas que se pueden adjudicar a los pictogramas, así como la fácil comprensión de sus procedimientos, procuran convertir la PictoScore en una partitura con diseño universal.

\section{Las actividades}

Las actividades realizadas en las sesiones del proyecto de intervención se dividen en cuatro grupos dependiendo de las características más sobresalientes que las condicionan: auditivas, expresivas, de razonamiento y prácticas. Las actividades auditivas se basan en técnicas receptivas, consisten en la escucha atenta de piezas musicales. Las actividades expresivas se implementan por medio de técnicas activas por las cuales se ejercita la comunicación. Las actividades de razonamiento ejercitan el razonamiento abstracto y la memoria, son el preludio de interpretaciones musicales posteriores y se apoyan en la PictoScore. Asimismo, se utilizan para adjudicar motivos musicales a dibujos de la PictoScore que representan emociones. Con este procedimiento se pretende la identificación correcta de las emociones para mejorar la inteligencia emocional de los usuarios. Las actividades prácticas procuran la asimilación de los rudimentos técnico-musicales para la ejecución musical vocal y por medio de Instrumental Orff.

Con respecto a la temporalización, el proyecto NeuroHarmony se estructura en 20 sesiones de 60 minutos aproximadamente. Estas se reparten en tres fases. En cada fase se enfatiza una propiedad general vinculada al triple proceso y que es condición indispensable para la consecución del objetivo general.

\section{Instrumentos de seguimiento y evaluación}

Los instrumentos de seguimiento y evaluación empleados son los siguientes: entrevistas, grabaciones, fotografías y análisis de dibujos. Estos últimos se utilizan como técnica proyectiva para el refuerzo de los resultados, que se producen por la aplicación, tras la conclusión de cada fase, de las escalas de valoración individualizadas las cuales, configuradas por medio de indicadores, aportan un valor numérico al nivel de 
participación de los usuarios intervenidos. En este sentido, el valor 100 se adjudica a la máxima capacidad potencial del usuario y el valor 0 a la participación nula.

\section{Resultados}

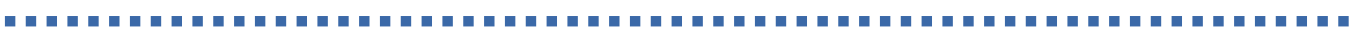

La aplicación de las escalas de valoración, en el área evaluada de la participación, aporta los siguientes resultados que se acopian en las tablas sucesivas:

Tabla 1. Promedios de participación en las sesiones NeuroHarmony y en los periodos de observación

\begin{tabular}{|c|c|c|c|c|c|}
\hline Usuarios & $\begin{array}{c}\text { Observación } \\
\text { prefase* }\end{array}$ & 1a fase & 2a fase & 3a fase & $\begin{array}{c}\text { Observación } \\
\text { posfase* }\end{array}$ \\
\hline A1 & 4,25 & 58,3 & 82,64 & 77,383 & 49,95 \\
\hline B1 & 41,6 & 44,4 & 78,63 & 96,93 & 95,8 \\
\hline B2 & 41,6 & 75 & 73,98 & 97,2 & 97,5 \\
\hline
\end{tabular}

* (Realizada en otros talleres ofertados por la Asociación Fundación)

Tabla 2. Promedios de participación en otros talleres de la Asociación Fundación durante las fases de intervención

\begin{tabular}{|c|c|c|c|}
\hline Usuarios & 1a fase & 2a fase & 3a fase \\
\hline A1 & 39,95 & 35,94 & 19,26 \\
\hline B1 & 43,3 & 46,43 & 54,883 \\
\hline B2 & 49,95 & 49,96 & 59,43 \\
\hline
\end{tabular}

Los presentes resultados muestran un aumento de la participación de los tres usuarios. Es significativo el incremento que se produce en A1, teniendo en cuenta la gravedad de su grado de deficiencia. También es destacable el mayor nivel de la participación de los usuarios en los talleres del proyecto con respecto al de los otros talleres ofertados por la Asociación Fundación y el aumento de la participación en estos talleres durante las fases de la intervención.

\section{Conclusiones}

El incremento considerable de la participación de los usuarios, mostrado en los resultados anteriores, deriva principalmente de la implicación eficaz de estas personas en las actividades del proyecto, de la correcta utilización de los recursos secundarios y de la motivación lograda con la que los sujetos abordaron los retos cognitivos y psicomotrices 
exigidos, a su vez, por la intervención. Como se ha mostrado, en menor medida, los usuarios incrementan también su participación en los otros talleres ofertados por la Asociación Fundación durante las tres fases del proyecto y en el periodo de observación posfase. Este hecho parece que se debe a la estimulación recibida en las sesiones NeuroHarmony, también a la motivación derivada de ellas pero, no obstante, tales afirmaciones no pueden aseverarse con rigor por el posible condicionamiento de variables extrañas. Es destacable que en estos talleres el usuario A1 da, por primera vez, repetidas muestras de participación eficaz utilizando sus mermadas capacidades con alta eficiencia.

Teniendo en cuenta el momento terapéutico del daño cerebral que padecen los usuarios, los resultados proceden de la ejercitación y el mantenimiento de las capacidades preservadas tras él o recuperadas en momentos terapéuticos previos. La potenciación de estas habilidades, que, por diversos motivos, los usuarios no ejercitaban se estima basándose en los resultados obtenidos- consecuencia directa de la intervención psicopedagógica.

Con respecto al proyecto de intervención NeuroHarmony, tras la valoración de los resultados, se considera óptimo para la resolución del problema que lo motiva. Su planteamiento teórico se muestra viable en su implementación, no obstante, según lo experimentado, requiere de la colaboración de más de un profesional para lograr todo el potencial didáctico y terapéutico que, hipotéticamente, puede ofrecer. La práctica muestra que, en el marco del taller, el proyecto puede acoger a diferentes profesionales de diversas disciplinas los cuales se pueden agregar, sin dificultad, a su dinámica, aportando sus conocimientos y habilidades.

En el proceso terapéutico, las actividades de método pasivo proporcionan a los usuarios una condición interna estable (Altshuler, 1952) que es perceptible, sobre todo, en $A 1$ al disminuir sus reacciones violentas. Las técnicas de compensación se realizan con éxito. A1, condicionado por sus capacidades, logra interpretar e improvisar ciertos ritmos, con ellos, se puede considerar, acentúa expresivamente sus emociones $y$, de este modo, mejora su autoestima, libera tensiones y mantiene el autocontrol (Sabbatella, 2005).

Respecto a los recursos secundarios característicos, su implementación en el proyecto de intervención demuestra su eficacia. El más valorado por los usuarios es el MusicDraw; en él se refleja su progreso de forma si no precisa, en cierto grado, evidente. En el usuario B1, verbigracia, la comparación del dibujo que realiza en la primera sesión de la primera fase (Figura 1) con el que traza tras la última sesión de la última fase (Figura 2) muestra un cambio substancial. El último dibujo incrementa su calidad estética. Contrariamente al primer dibujo, el último está centrado en el folio, representa una escena en la cual las figuras se ubican de forma coherente y están dibujadas con más detalle. Aquellas que representan seres humanos, expresan alegría con sus rasgos faciales 
y su aparente movimiento. En el primer dibujo, en cambio, el rostro lacónico trazado carece de los detalles esenciales que le posibilitan la expresión. El dibujo postrero difiere, también, en el trazo más preciso y firme de las líneas ${ }^{10}$ y en el conjunto, que es equilibrado en su disposición. Si bien, parte del progreso plástico se puede atribuir a la reiteración del ejercicio y, por ello, a la adquisición de cierto grado de experiencia; el trabajo de los detalles y la disposición racional de las figuras, así como el perfeccionamiento del trazo implican una disminución de la apatía, el uso de las capacidades cognitivas y las habilidades motrices finas, respectivamente. La canción representativa, como recurso motivacional, demuestra ser altamente eficaz. En A1 realiza un papel esencial que, tratado de forma estratégica en las diversas actividades, le incita sobremanera a participar e interrelacionarse incluso cuando las demandas de la actividad suponen un reto para sus habilidades. Es destacable, también, el papel que realiza en B1 y B2. A sendas usuarias les motiva a realizar las actividades de expresión vocal. La PictoScore sirve, en todo momento, como en su diseño se advirtió. No obstante, erróneamente, se diseñan con ella algunas actividades que rebasaron la capacidad cognitiva de los usuarios, estas dificultaron el proceso inclusivo. No obstante, en otras actividades se pudo comprobar su diseño universal con la participación de A1 que, a pesar de que los requerimientos eran demasiado exigentes para su nivel cognitivo, guiado por la inercia rítmica de la interpretación, se sumaba a ella y, en ella, realizaba una notable aportación.

La música, como recurso de la intervención psicopedagógica, ha demostrado ser, en esta práctica, una herramienta eficaz y flexible. Su repercusión en los ámbitos sensorial, psicoemocional, cognitivo, social y ético de los usuarios ha contribuido, de forma determinante, a la consecución de los objetivos. Basar el triple proceso pero, sobre todo, el proceso terapéutico, en la identidad sonora de las personas, por medio de la canción representativa, ha supuesto que la música actúe como un elemento integrador de los usuarios en la terapia, en la pedagogía y en la inclusión. Gracias a esto, el triple proceso no es para ellos una elucubración exenta a su realidad que, en cierto modo, administrándosela una persona ajena, les afecta; es una realidad en la que ellos, con su singularidad y preferencias, se sumergen siendo partícipes y protagonistas. Los usuarios, gracias a la utilización de la música, a la utilización de su música preferente, orientados por la disciplina psicopedagógica, impulsan el engranaje teórico para convertirlo en una práctica eficaz de la que resultan beneficiados. Es esta, entre otras, la gran aportación a la intervención presente de la utilización del arte musical como recurso. 

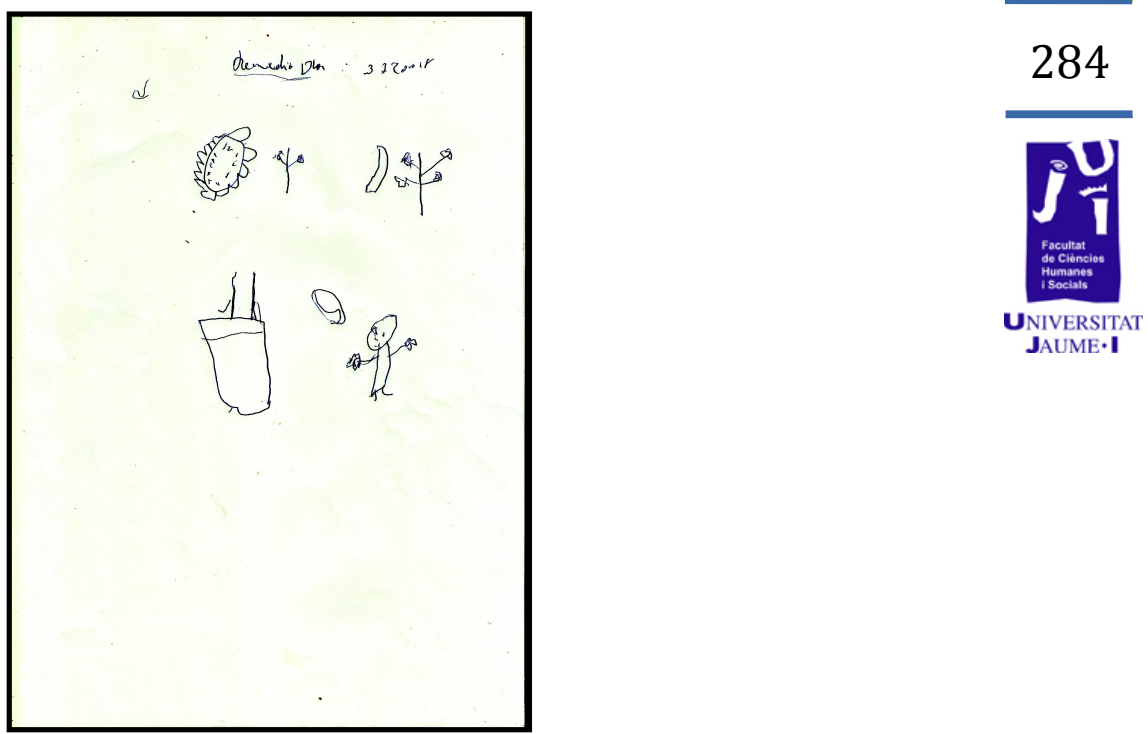

Figura 1. Dibujo realizado por B1 en la sesión 1.1.

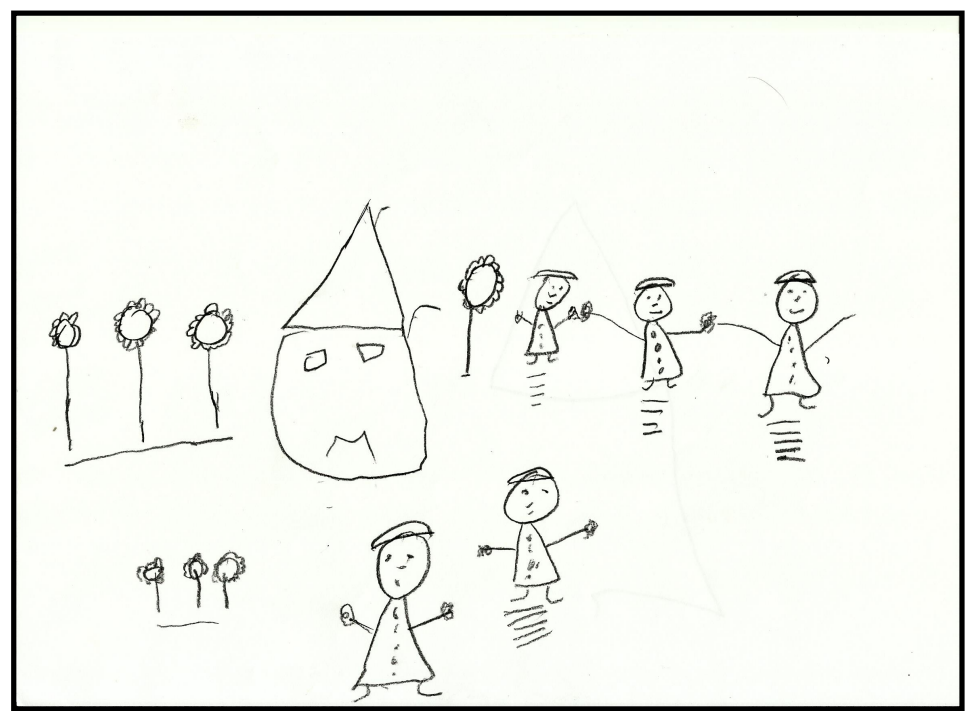

Figura 2. Dibujo realizado por B1 en el periodo de observación posfase.

\section{Bibliografía}

AlbILLo, M. (2007): "Hemiplejia, afasia, neuroplasticidad y arteterapia», en Arteterapia. Papeles de arteterapia y educación artística para la inclusión social, Publicaciones de la Universidad Complutense, Madrid.

AltShUleR, I. (1952): Music Therapy: Retrospect and Perspectives, Allen Press, Lawrence.

Bascones SerRano, L. M. y otros (2006): Daño cerebral sobrevenido en España: un acercamiento epidemiológico y sociosanitario, Defensor del Pueblo, Madrid. 
Benenzon, R. O. y otros (1997): Sonido, comunicación, terapia, Amarú, Salamanca.

BisquerRA, R y M. Álvarez (1996): Modelos de intervención en orientación, Praxis, Barcelona.

BLOOD, A. J. y R. J. ZATORRE (2001): «Intensely Pleasurable Responses to Music Correlate with Activity in Brain Regions Implicated in Reward and Emotion", Proceedings of the National Academy of Sciences, 98(20), National Academy of Sciences, Washington.

CostA-GıOMI, E. (2005): "Does Music Instruction Improve Fine Motor Abilities?», en Annals of the New York Academy of Sciences, 1060(1), New York Academy of Sciences, Nueva York.

GAINZA, V. H. (1988): Estudios de psicopedagogía musical, Summus, São Paulo.

HARgreaves, D. J. North, A. C. (1999): «Music and Adolescent Identity», en Music Education Research, 1(1), University of Leicester, Leicester.

Juslin, P. N. y J. A. SLOBoda (2001): Music and Emotion: Theory and Research, Oxford University Press, Oxford.

Kratus, J. (1993): "A Developmental Study of Children's Interpretation of Emotion in Music», Psychology of Music, 21(1), Case Western Reserve University, Ohio.

KRUMHANSL, C. L. (2002): "Music: A link between cognition and emotion», Current Directions in Psychological Science, 11(2), Cornell University, Ithaca.

LACÁRCEL, J. (1990): Musicoterapia en educación especial, Editum, Murcia.

Melto, M. (2011): «A música como Instrumento de Intervenção Psicopedagógica», Universidade Estadual do Norte Fluminense, Darcy Ribeiro.

Mondragón, J. A. y otros (2013): Diseño de talleres para el desarrollo personal y la inclusión social de las personas con DCA, FEDACE, Madrid.

NAWRot, E. S. (2003): «The Perception of Emotional Expression in Music: Evidence from Infants, Children and Adults», Psychology of Music, 31(1), Minnesota State University, Moorhead.

PAtTerson, C. E. (1995): Creating an Inclusive Schools Foreword, ASCD, Alexandria.

RODRÍGUEZ ESPINAR, S. y otros (1993): Teoría y práctica de la orientación educativa, PPU, Barcelona.

Sabbatella, P. (2005): «Intervención musical en el alumnado con necesidades educativas especiales: delimitaciones conceptuales desde la pedagogía musical y la musicoterapia», Universidad de Cádiz, 21 (123139), Cádiz. 
Schellenberg, E. G. (2004): "Music Lessons Enhance IQ», Psychological Science, 15(8), University of Toronto at Mississauga, Mississauga.

SchellenberG, E. G. (2005): "Music and Cognitive Abilities», Current Directions in Psychological Science, 14(6), University of Toronto at Mississauga, Mississauga.

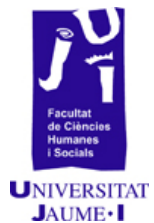




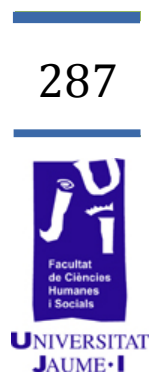

\section{La situación del pianista acompañante en España} Un acercamiento a la realidad pedagógica y profesional de su figura en el mundo musical español 
El artículo investiga en torno a la posición que ocupa actualmente la figura del pianista acompañante en España.

Se aborda tanto desde la perspectiva pedagógica como profesional. Con la realidad que nos encontraremos podremos concluir con la sugerencia de la necesaria ordenación y organización de todo cuanto concierne a la figura del pianista acompañante, es decir, crear el marco normativo para que se pueda estudiar como pianista acompañante y posteriormente poder desarrollar esta actividad satisfactoriamente.

Palabras clave: pianista acompañante, piano, educación, pedagogía, profesión, legislación, especialidad.

\section{Introducción}

La situación actual del mundo pianístico español es un tanto contradictoria. Acabados sus estudios superiores, un pianista se enfrenta a diversas salidas profesionales. Por una parte está la realidad concertística, por otra la pedagógica y por último la de pianista acompañante. La formación en el grado superior de piano se presupone que le capacita para todas estas opciones profesionales, ya sea eligiendo la vía interpretativa o la pedagógica. Sin embargo, para trabajar como pianista acompañante no recibe apenas formación y mucho menos especializada. He aquí la contradicción, pues en el terreno laboral se le exige una aplicación para la que no ha recibido formación adecuada.

Este es el motivo fundamental para la redacción de la presente comunicación. Hemos podido comprobar en primera persona, tanto como estudiante como profesional, la realidad que acabamos de relatar, con unas carencias e incoherencias de índole legislativa y pedagógica. Se necesita de un marco normativo adecuado para el desarrollo de los contenidos que precisa un pianista acompañante. Hemos advertido ciertos desequilibrios en la dotación de contenidos y falta de direccionalidad. En el terreno laboral quedan muchas lagunas que solventar, basadas fundamentalmente en el reconocimiento de la existencia de la figura del pianista acompañante y la consiguiente ordenación, organización y regulación.

A través de este artículo queremos manifestar la realidad que de un modo objetivo tenemos todos los profesionales pianista acompañantes, tanto en el ámbito formativo como en el profesional. Queremos plasmar ante la comunidad investigadora una serie de hechos que revelan estas carencias legislativas que condicionan toda la carrera musical de estos profesionales.

Cabe decir que para mayor ampliación sobre este tema se puede consultar la tesis doctoral titulada La especialidad de pianista 
acompañante en la titulación superior de música: una propuesta de currículum e integración en el sistema educativo español, de la cual somos autor. $^{1}$

\section{Objetivos}

Analizar la situación pedagógica de los estudios del acompañamiento pianístico.

Investigar la situación profesional del pianista acompañante.

Definir los campos de actuación del pianista acompañante y la formación necesaria para el éxito en cada uno de ellos.

\section{Material y método}

El procedimiento metodológico ha sido elaborado utilizando criterios cualitativos. Por tanto, hemos procedido al estudio legislativo y de los diferentes planes de estudio, así como al análisis de su marco profesional.

Para poder delimitar correctamente la figura del pianista acompañante conviene establecer unos antecedentes. Atendiendo a la definición de qué es un pianista acompañante debemos separar ambos vocablos para posteriormente unirlos y entender el significado conjunto. Como pianista es una persona, músico, que transmite la música a través del piano. Como acompañante es un adjetivo que le añade la calidad de ejercer dicha transmisión junto a otro componente. Este componente puede ser la danza, la voz u otro instrumento, y estos elementos pueden estar constituidos por una persona únicamente o bien por un grupo. Este es el caso de una compañía de danza, un coro o un grupo instrumental. Por tanto, un pianista acompañante es un músico especializado en interpretación pianística que ejerce como pianista al lado de otra persona o colectivo, ya sea músico instrumental, cantante o bailarín.

A partir de este punto debemos ampliar y aclarar el término acompañamiento. Diferenciamos acompañar de acompañamiento.

- Acompañar: Etimológicamente es proveer a un solista de un acompañamiento o fondo musical. Se definen como sonidos melódicos o polifónicos que acompañan a una melodía principal. $^{2}$

- Acompañamiento: Etimológicamente es el soporte o complemento armónico de la melodía principal, por medio de instrumentos $o$ de voces. Se consideran músicos acompañantes también cuando la formación no integra necesariamente al piano. ${ }^{3}$

1. Fue defendida en la UJI el 17 de septiembre de 2015 y se encuentra alojada en la base de datos TDX [http://hdl.handle.net/10803/319458].

2. Coromines, J. (2012): Breve diccionario etimológico. Gredos. Madrid.

3. Coromines, J. (2012): Breve diccionario etimológico. Gredos. Madrid. 
El dominio de la ejecución de ese fondo musical así como la dotación del soporte armónico, es lo que debe regir y fundamentar toda formación superior de un pianista acompañante. Por ello dependiendo de la direccionalidad del acompañamiento pianístico lo enfocaremos hacia el proveimiento que se le proporcione a una melodía interpretada por cualquier instrumento o voz, o hacia el soporte o complemento que sería la vertiente camerística de la orientación del piano como instrumento acompañante.

Por otra parte en el mundo laboral artístico actual el pianista se encuentra con varias vías de actuación. Dejando a un lado el lenguaje de la música jazz, en el mundo clásico, el pianista puede elegir entre tres opciones:

1. Acompañamiento: bien sea de forma libre donde se le requiera (pruebas, oposiciones, conciertos, etc.) o bien en un centro educativo de titularidad pública o privada, de grado elemental, medio o superior, de danza, instrumental o voz.

2. Solista: actuando en recitales, con orquesta o en grupo de cámara.

3. Pedagogía: impartiendo clases de piano, ya sea de manera particular o bien en un centro educativo de titularidad pública o privada, de grado elemental, medio o superior.

Cada aplicación pianística debe llevar implícita la elección por parte de la persona que vaya a realizar dicha labor, pero también unas aptitudes que se deben observar durante el grado medio y una posterior formación en el grado superior de acuerdo con cada una de las opciones laborales posteriores. Actualmente, la titulación superior española ofrece formación específica en dos de las opciones antes mencionadas: la de solista y la de pedagogía. La del acompañamiento se da por dotada a través de asignaturas comunes como pueda ser la del mismo "acompañamiento», opción que desde nuestra opinión no compartimos, pues pensamos que resulta escasa. Del mismo modo que hay conocimientos y destrezas que para un pedagogo son imprescindibles mientras que para un concertista no lo son, y viceversa, ocurre de manera análoga con el pianista acompañante. Claro está que tienen un nexo común que es el piano, comparten contenidos y conocimientos, pero hay diferencias entre estas tres opciones, carencias en algunas de ellas y elementos superfluos en otras.

Por ello, el pianista acompañante debe estudiar piano, obviamente, así como pedagogía, pero no de piano, pues no va a impartir clases de piano, sino que lo hará a otros instrumentos o agrupaciones. Asimismo, deberá conocer las características principales de lo que vaya a acompañar, a saber, la voz, la danza y los instrumentos. Por otra parte, para cada uno de estos elementos que acompañará se le exigirá una destreza. Por ello, es fundamental el estudio del bajo cifrado, la reducción de partituras, la repentización, la transposición, la improvisación y la 
realización de acompañamientos a melodías dadas. Del mismo modo, deberá profundizar en el estudio y conocimiento de la música de cámara, ya que fruto de la disociación a la que hacíamos referencia anteriormente entre acompañar y acompañamiento, la música de cámara representa el acompañamiento. Por tanto, deberá prestarle una importante atención para posteriormente saber transmitir sus contenidos y conocimientos. La perspectiva y finalidad posteriores deben ser distintas de la que trabaje el pianista concertista, ya que esta especialidad no va a impartir docencia como tal, sino que será de aplicación concertística con otros compañeros de nivel musical similar. Además el pianista acompañante deberá ampliar su concepto y trabajo, pues dicho trabajo camerístico no se va a ceñir únicamente al radio instrumental y/o vocal, sino también al de la danza y coros.

Estos conocimientos no son comunes a las vertientes de solista y de pedagogía. Esta última debe profundizar mucho en la pedagogía en general, pero particularmente en cómo transmitir los contenidos pianísticos a sus futuros alumnos. En cambio la opción de solista debe ahondar en recursos de escena y obviamente en un gran nivel instrumental, sin por ello menospreciar el nivel que debe adquirir tanto el pianista pedagogo como el acompañante.

Intentar formar en una única titulación para todas estas aplicaciones nos parece una mera quimera estando en una sociedad muy especializada. Por ello sugerimos la elección al inicio de los estudios de grado superior de las tres especialidades: concertística, pedagógica y pianista acompañante.

En el siguiente cuadro comparativo podemos observar de forma resumida y esquemática las características de las tres vertientes a las que puede optar un pianista y que hemos comentado en este capítulo. De este queremos plasmar la imposibilidad de pretender emprender una única titulación que englobe dos o tres áreas de conocimiento, ya que consideramos que por sí solas son ya lo bastante amplias como para erigirse de manera independiente. 
Tabla 1. Cuadro comparativo entre las asignaturas de los tres itinerarios posibles para un pianista.

\begin{tabular}{|c|c|c|c|}
\hline & Concertista & Pedagogo & Acompañante \\
\hline Asignaturas comunes & \multicolumn{3}{|c|}{ Piano y las generales de cualquier especialidad instrumental } \\
\hline \multirow[t]{4}{*}{ Asignaturas propias } & Interpretación & Pedagogía del piano & Música de cámara \\
\hline & Música de cámara & $\begin{array}{l}\text { Prácticas de } \\
\text { profesorado }\end{array}$ & Pedagogía \\
\hline & Repertorio pianístico & Psicología adaptada & $\begin{array}{l}\text { Características } \\
\text { instrumentales, vocales y } \\
\text { de la danza }\end{array}$ \\
\hline & & & $\begin{array}{l}\text { Práctica del } \\
\text { acompañamiento } \\
\text { Idiomas: alemán, francés } \\
\text { e italiano. } \\
\text { Bajo cifrado } \\
\text { Repentización } \\
\text { Reducción de partituras } \\
\text { Transposición } \\
\text { Improvisación } \\
\text { Acompañamiento } \\
\text { rítmico-melódico }\end{array}$ \\
\hline
\end{tabular}

En el ámbito histórico, el origen del acompañamiento musical va unido al del nacimiento de la música, la música instrumental y la notación musical. Se tienen noticias desde la cultura egipcia con arpas acompañando a la voz. La historia del piano como instrumento acompañante se inicia con el nacimiento del estilo monódico o melodía acompañada que caracteriza el primer periodo del Barroco, hasta entonces era el laúd. Durante su evolución, el acompañamiento pianístico cumplió dos funciones diferentes:

1. Concepción melódica que origina y adapta los acordes a la melodía. Los géneros más destacados de este origen son el lied y la sonata barroca y clásica.

2. Concepción armónica que improvisa melodías sobre esquemas armónicos preestablecidos.

Por último, los campos de actuación donde desarrolla la actividad el pianista acompañante son, como hemos dicho, el instrumental, el vocal y la danza. Para cada uno de ellos necesita de unas destrezas y formación concretas. Generalmente necesitará conocimientos de armonía, análisis, improvisación, música de cámara, flexibilidad y control del miedo escénico. Más concretamente, para acompañar instrumentos precisará de una rápida repentización, transposición y reducción orquestal. Para acompañar a la voz resultará imprescindible la transposición y la repentización. Y, para finalizar, en la danza será vital la facilidad rítmica tanto en su regularidad como en la variedad de ritmos, y la improvisación. 
Una vez expuestos estos antecedentes que creíamos necesarios nos disponemos a adentrarnos en la investigación en el ámbito pedagógico del pianista acompañante. En este artículo veremos de manera resumida todo el contenido que tiene un pianista acompañante a día de hoy en relación con su materia, tanto en las Enseñanzas Profesionales como en el Grado Superior. Lamentablemente, por cuestiones de espacio no podemos describir todo el contenido de los diferentes textos legales. En su lugar mostramos un cuadro resumen de las asignaturas relacionadas con el acompañamiento en el Grado Superior. En la anterior etapa, las Enseñanzas Profesionales, la dotación de conocimiento en esta materia se limita a la asignatura Acompañamiento impartida en los cursos 5 y 6‥ De su contenido debemos explicar diversas cuestiones. La primera de ellas es que por supuesto está íntimamente relacionada su práctica y teoría con lo que deberá aplicar el pianista acompañante, pero no se dirige explícitamente a lo que deberá saber desempeñar este pianista acompañante, es decir, se transmiten las bases, el conocimiento, pero con una direccionalidad teórica, nada pragmática a la hora de su posterior aplicación.

Los distintos currículos autonómicos dotan de destrezas instrumentales pianísticas, para ello están dirigidas sus titulaciones. Por tanto todos ellos citan en sus itinerarios la formación pianística, ya sea en el itinerario de interpretación como de pedagogía, pero en ningún caso hacia el uso del acompañamiento pianístico. La sociedad musical demanda pianistas acompañantes, tanto en estamentos públicos como privados, pero sin embargo no se le otorga la distinción de titulación específica, ni direccionalidad, ni formación. Será el pianista titulado superior quien tenga que hacer su propio currículo extrayendo posteriormente lo aprendido para dirigirlo a su labor posterior y acabar formándose gracias a la experiencia. De asignaturas como Transposición, Improvisación, Lectura a vista y Reducción de partituras es de donde se nutre el pianista acompañante, pero en ningún caso tiene ningún conocimiento de a qué va a acompañar, es decir, no conoce nada en particular de la voz, otros instrumentos que no sean el piano, ni la danza, que, como comentábamos anteriormente, le serán muy provechosos a la hora de realizar un buen acompañamiento. 
Figura 2. Distribución actual de las asignaturas relacionadas con el acompañamiento pianístico en el título de grado superior de música en la especialidad de piano.

\begin{tabular}{|c|c|c|c|c|c|c|}
\hline & $\begin{array}{l}\text { Improvisación y } \\
\text { acompañamiento }\end{array}$ & $\begin{array}{c}\text { Repentización } \\
y \\
\text { transposición }\end{array}$ & $\begin{array}{c}\text { Acompañamiento } \\
\text { vocal, instrumental } \\
\text { y danza }\end{array}$ & \begin{tabular}{|c|} 
Reducción \\
de \\
partituras
\end{tabular} & \begin{tabular}{|c|} 
Repertorio \\
con pianista \\
acompañante
\end{tabular} & $\begin{array}{l}\text { Música } \\
\text { de } \\
\text { Cámara }\end{array}$ \\
\hline Andalucía & $\begin{array}{l}\text { Cursos } 3.9 \text { y } 4.9 \\
\text { Creatividad e } \\
\text { improvisación }\end{array}$ & $\begin{array}{c}\text { Cursos 1.ํ y } \\
2.0\end{array}$ & $\begin{array}{l}\text { Cursos } 3.9 \text { y } 4.9 \text { sin } \\
\text { contenido en danza. } \\
\text { Además en } 2 . .^{\circ} \text { curso } \\
\text { Lectura e } \\
\text { interpretación del } \\
\text { lied }\end{array}$ & Curso 3.음 & $\begin{array}{c}\text { Cursos 3.ำ y } \\
4.9\end{array}$ & $\begin{array}{l}\text { Cursos } \\
1.0 \text { a } \\
4 . .9\end{array}$ \\
\hline Aragón & $\begin{array}{c}\text { Cursos } 1.0 \text { y } 2.0 \\
\text { sin } \\
\text { acompañamiento }\end{array}$ & & $\begin{array}{l}\text { Acompañamiento } \\
\text { canto en } 2 . .\end{array}$ & & & $\begin{array}{c}\text { Cursos } \\
3.0 y \\
4.0\end{array}$ \\
\hline Asturias & $\begin{array}{l}\text { Cursos } 2.0 \text { y } 3.0 \\
\text { sin } \\
\text { acompañamiento }\end{array}$ & & & Curso 3.9 & $\begin{array}{c}\text { Cursos 3.ำ y } \\
4.9\end{array}$ & $\begin{array}{c}\text { Cursos } \\
1.0 y \\
2.0\end{array}$ \\
\hline Canarias & \multicolumn{4}{|c|}{ Acompañamiento, transposición, repentización y reducción en cursos 1.ำ } & $\begin{array}{c}\text { Cursos 1.․ a } \\
4.9\end{array}$ & $\begin{array}{c}\text { Cursos } \\
1.0 \mathrm{a} \\
4 . .9\end{array}$ \\
\hline $\begin{array}{l}\text { Castilla y } \\
\text { León }\end{array}$ & $\begin{array}{c}\text { Curso } 3 . .9 \sin \\
\text { acompañamiento }\end{array}$ & 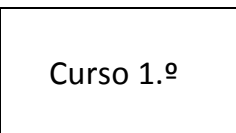 & & & $\begin{array}{l}\text { Cursos } 3.0 \text { y } \\
4.9\end{array}$ & $\begin{array}{c}\text { Cursos } \\
2.0 y \\
3.0\end{array}$ \\
\hline Cataluña & Cursos 1.9 a 4.9 & & Lied 2 cursos & & & $\begin{array}{c}\text { Cursos } \\
1.0 \mathrm{a} \\
4.0\end{array}$ \\
\hline $\begin{array}{l}\text { Comunidad } \\
\text { Valenciana }\end{array}$ & Cursos 2.9 y 3.9 & & $\begin{array}{c}\text { Cursos } 2.9 \text { y } 3.9 \\
\text { instrumental y vocal }\end{array}$ & & & $\begin{array}{c}\text { Cursos } \\
1.0 \text { a } \\
4 . .9\end{array}$ \\
\hline Extremadura & Cursos $1 . \circ$ y 2.9 & $\begin{array}{c}\text { Cursos } 1 .{ }^{\circ} y \\
3.9\end{array}$ & $\begin{array}{c}\text { Cursos 3. y 4.․ sólo } \\
\text { vocal }\end{array}$ & & Curso 3.9 & $\begin{array}{c}\text { Cursos } \\
1.0 \text { a } \\
4 . .9\end{array}$ \\
\hline Galicia & Cursos 1.9 y 2.9 & $\begin{array}{c}\text { Cursos } 1 .{ }^{\circ} \mathrm{y} \\
2.9\end{array}$ & & & $\begin{array}{c}\text { Cursos 2.․ a } \\
4 . .9\end{array}$ & $\begin{array}{c}\text { Cursos } \\
1.0 \mathrm{a} \\
4 . \stackrel{0}{ }\end{array}$ \\
\hline Illes Balears & $\begin{array}{c}\text { Curso } 3 . .9 \sin \\
\text { acompañamiento }\end{array}$ & $\begin{array}{l}\text { Sólo } \\
\text { repentización } \\
\text { en 2.o curso }\end{array}$ & & & Curso 4.9 & $\begin{array}{c}\text { Cursos } \\
1.0 \mathrm{a} \\
4 . \stackrel{0}{ }\end{array}$ \\
\hline Madrid & Cursos $1 . \circ$ y 2.9 & $\begin{array}{l}\text { Lectura a vista } \\
\text { en } 1.0 \text { y } 2 . .^{\circ}\end{array}$ & $\begin{array}{c}\text { Acompañamiento a } \\
\text { la danza y } \\
\text { acompañamiento } \\
\text { vocal e instrumental } \\
\text { en dos asignaturas } \\
\text { del } 3 . \text { o curso } \\
\end{array}$ & & & $\begin{array}{c}\text { Cursos } \\
1.0 \mathrm{a} \\
4 .{ }^{\circ}\end{array}$ \\
\hline Murcia & Cursos $1 . \circ$ y 2.9 & & & $\begin{array}{c}\text { Cursos 3.․ } \\
\text { y } 4.9\end{array}$ & & $\begin{array}{c}\text { Cursos } \\
1.0 \mathrm{a} \\
4.0\end{array}$ \\
\hline Navarra & Cursos 1.9 y 2.9 & Curso 3. & Curso 4. ․ sólo vocal & & & $\begin{array}{c}\text { Cursos } \\
1.0 \text { a } \\
4.0\end{array}$ \\
\hline País Vasco & Cursos 1.9 y 2.9 & $\begin{array}{l}\text { Cursos } 1 . .^{\circ} y \\
2.0 \text { sin } \\
\text { transposición }\end{array}$ & $\begin{array}{c}\text { Vocal en 3.․, } \\
\text { instrumental en 3.o } \\
\text { y } 4 . .9\end{array}$ & & & $\begin{array}{l}\text { Cursos } \\
2.0 \text { a } \\
4.0\end{array}$ \\
\hline
\end{tabular}


En cuanto a la realidad española que afecta al pianista acompañante en su entorno profesional, vemos que tiene varios focos de influencia. Por un lado se encuentran las administraciones de titularidad pública general tales como Gobierno estatal o Gobierno autonómico. Estos se encargan de convocar y organizar las plazas docentes a través de las cuales los pianistas acompañantes acceden a sus puestos. Dichos puestos estarán ubicados en conservatorios ya sean de música o danza, e institutos culturales en los cuales se desempeñe la docencia musical o de danza. Por otro lado, debemos hablar de la misma tipología de centros, es decir, conservatorios o institutos culturales, pero que sean de titularidad privada o de diferente administración, como diputaciones, ayuntamientos o fundaciones. El puesto será el mismo pero el mecanismo de acceso será diferente tanto en cuanto lo determine la autoridad competente. $Y$ por último podemos hablar de eventos puntuales y de índole liberal en los cuales se requiere al pianista acompañante pero no de un modo regular ni estable. Por ejemplo, nos referimos a audiciones para un puesto concreto de naturaleza musical o de danza en las cuales el órgano emisor facilita a los opositores un pianista acompañante en el lugar y momento de la realización de la prueba.

Estas tres modalidades son a las que se enfrenta el pianista acompañante en España y que denotan carencias de índole legislativa y pedagógica, de forma que la integración del pianista acompañante en la comunidad educativa no sea del todo "normal" como ocurre en otras especialidades como por ejemplo un profesor de piano. La razón es porque no está creado ni definido el puesto de pianista acompañante como sí lo está el de profesor de piano. Esto crea un estado de cierta ambigüedad, ya que si bien sí que existen pianistas acompañantes en conservatorios, su plaza no se denomina como tal, sino como profesor de piano. A este hecho se debe puntualizar que lógicamente en un conservatorio de danza un pianista únicamente puede ir en calidad de pianista acompañante, pero en el resto de conservatorios, ya sean profesionales o superiores, las plazas que ostentan los pianistas acompañantes son como profesores de piano, no como pianistas acompañantes. Posteriormente, será el centro quien organice las labores que desempeña cada profesor.

En el ámbito privado o público dos reales decretos ${ }^{4}$ son los que establecen el marco legal laboralmente. El único matiz de estos nuevos reales decretos radica en la creación de la creación y diferenciación de la especialidad de piano y de repertorio con piano para danza, voz o instrumentos, pero sin embargo ni estos textos legislativos ni los anteriores prevén la creación de esas especialidades en los diferentes centros públicos, como sí que ocurre por ejemplo con la especialidad de piano. Ello merma la capacidad de acción de este colectivo que si bien en lo pedagógico la Ley sí reconoce, no lo hace en lo profesional. Además lo

4. Real Decreto 427/2013, de 14 de junio, por el que se establecen las especialidades docentes del Cuerpo de Catedráticos de Música y Artes Escénicas vinculadas a las enseñanzas superiores de Música y de Danza y Real Decreto 428/2013, de 14 de junio, por el que se establecen las especialidades docentes del Cuerpo de Profesores de Música y Artes Escénicas vinculadas a las enseñanzas de Música y de Danza. 
redacta de un modo muy ambiguo, pues remite a las administraciones educativas especificar qué asignaturas impartirá.

Resulta obvio que los contenidos de la titulación exigida para entrar a formar parte del Cuerpo de Profesores o Catedráticos de Música y Artes Escénicas en la especialidad de piano no reúnen los contenidos formativos que luego se pide a los profesionales para el desempeño del acompañamiento. Por tanto, nos encontramos con cierto desamparo legal, puesto que si bien existe la secuencia formación-exigencia laboral para todas las especialidades, incluida el piano, si pasa a desempeñar el puesto de profesor de piano -entendiéndose la docencia del piano propiamente dicha- no existe tal binomio para desempeñar la labor de pianista acompañante.

La masificación del alumnado con ratios abusivas y el excesivo repertorio que ello conlleva son sólo dos ejemplos de lo que provoca esta inadecuada organización de la figura del pianista acompañante, lo que repercute en la calidad de la enseñanza y no solo se ven perjudicados los profesionales pianistas acompañantes sino también el resto de profesorado y el alumnado. La ausencia de una denominación propia como especialidad, su no asignación como plaza específica, la no existencia de asignatura propia en las enseñanzas elementales y profesionales, o la no convocatoria de oposiciones de pianista acompañante, son otros ejemplos de esta falta de organización que mencionamos.

Por supuesto, existen excepciones puntuales de petición de plazas que vienen demandadas desde la iniciativa privada, ya sea en conservatorios, teatros de ópera o cualquiera que sea la fundación u organización que gestionen, en las que sí que piden explícitamente un puesto de pianista acompañante. Posteriormente, bien sea de titularidad pública o privada, no tienen el ámbito definido para operar con autonomía.

En la opción liberal, el pianista acompañante no está sujeto a ley alguna y puede desarrollar su actividad con plena libertad. Puede ser tanto en el ámbito personal como desde cualquier estamento hacia el pianista acompañante. Para esta modalidad que en principio no tiene carácter pedagógico ni docente, también hace falta formación, aunque sobre todo como músico concertista y camerístico. No por ello queremos decir que para las anteriores no hará falta, que por supuesto sí, sino que en esta última tipología será más necesario ese tipo de formación y dedicación.

\section{Resultados}

Hemos podido constatar el vacío legislativo y pedagógico existente en España en esta materia. Sin duda, uno de los apartados más importantes es la realidad profesional del pianista acompañante, donde apreciamos incongruencias y falta de ordenación en torno a esta figura. 
En lo relativo a la formación, también hemos podido comprobar la heterogeneidad entre autonomías y la diversificación de conocimientos en torno al acompañamiento pianístico.

Esta situación es la que nos dirige a la sugerencia de la implantación de una especialidad propia de pianista acompañante, tanto como titulación (a nivel formativo) como ocupación profesional. El aprendizaje específico debe diferenciarle de las otras aplicaciones pianísticas y formarle adecuadamente, pues en el terreno laboral existe una gran y variada demanda de puestos de trabajo en este campo, diferentes de los de profesor de piano o concertista. Paralelamente también reclamamos una mejor y adecuada organización profesional, pues hemos podido comprobar la ausencia de ordenación en este terreno en España.

En términos comparativos no está creado ni definido el puesto de pianista acompañante como sí lo está el de profesor de piano y corresponde a la organización interna de cada centro. Encontramos incoherencias como la existencia de la asignatura Repertorio con piano, pero sin una especialidad específica que la imparta.

\section{Conclusiones}

Podemos concluir el estudio con la sugerencia de la creación de una especialidad de pianista acompañante tanto desde el punto de vista pedagógico como profesional. En el ámbito pedagógico como opción de estudio dentro de la titulación superior de música añadiendo una tercera vía ${ }^{5}$ y en el laboral con su plena integración en el mundo musical español, de forma que se dota de una especialidad con denominación propia y plena autonomía para poder convocar oposiciones, temarios propios y poder impartir una asignatura independiente.

Esta necesidad se ha hecho patente tanto a través de las carencias de formación que precisa cualquier pianista acompañante como de la realidad profesional, donde hemos visto la falta de ordenación de su actividad.

Proponemos, por tanto, la organización de la formación y la ordenación de su trabajo posterior, de manera que se establece el binomio de formación cualificada-trabajo especializado. Ello redundará, sin duda, positivamente en la calidad de la enseñanza del sistema educativo musical español.

\section{Bibliografía}

AgUILAR, E.: «La figura del profesor pianista acompañante en los conservatorios profesionales de la Comunidad Valenciana», Revista Electrónica Complutense de Investigación en Educación Musical [documento en línea]

5. Actualmente se puede optar por las vías concertística o pedagógica. 
<http://revistas.ucm.es/index.php/RECl/article/view/44049> [consultado el 16 de marzo de 2014].

COROMINES, J. (2012): Breve diccionario etimológico. Gredos. Madrid.

FERNÁNDEZ, B. y otros (ed.) (2013): «Perfil del pianista acompañante: soluciones a una problemática», Música y Educación, núm. 95. Madrid, p. 40-47.

GALÁN, C. (1999): "La improvisación, mero acompañamiento I», Música y Educación, núm. 38. Madrid, p. 125-135.

- (2011): "La improvisación, mero acompañamiento Il», Música y Educación, núm. 87. Madrid, p. 213-219.

LÓPEZ, E. (1999): «Educación musical profesional», Música y Educación, núm. 37. Madrid, p. 15.

MolinA, E. (1988): "Improvisación y educación musical en España», Música y Educación, núm. 1. Madrid, p. 33-56.

Perelló, V. (2003): La enseñanza musical en la Comunidad Valenciana. Conselleria de Cultura i Educació, Valencia.

PéreZ, M. (1993): "Los conservatorios españoles. Historia, reglamentaciones, planes de estudio, centros, profesorado y alumnado», en Música y Educación, núm. 15. Madrid, p. 17-48.

Randel, M. (1997): Diccionario Harvard de la Música. Alianza, Madrid.

SADIE, S. (1992): The New Grove Dictionary of Music and Musicians. Grove. Londres.

SANZ, R. (2011): «El profesor de instrumento y el profesor pianista acompañante», Música y Educación, núm. 46. Madrid, p. 45-62.

VAlLÉS, L. (2011): «El acompañamiento al piano (II)», en Artseduca, núm. 3. Valencia, p. 18.

- (2014): «El acompañamiento al piano (V)», Artseduca, núm. 8. Valencia, p. 24.

VARENNE, D. (1995): "L'accompagnateur: de la lecture á la schizophrénie», Marsyas, núm. 34. París, p. 27.

\section{Textos legales}

Real Decreto 1560/1995, de 21 de septiembre, por el que se regula el régimen de contratación de profesores especialistas.

Decreto 63/2001, de 20 de febrero, del Departamento de Educación de Cataluña (DOGC de 5 de marzo de 2001) por el cual se establece la ordenación curricular del grado superior de las enseñanzas de Música y se regula la prueba de acceso a dichos estudios.

Ley Orgánica 2/2006, de 3 de mayo, de Educación. 
Resolución, de 9 de mayo de 2006, del Ayuntamiento de Ribarroja del Turia (Valencia), referente a la convocatoria para proveer una plaza. BOE, viernes, 2 de junio de 2006.

Resolución, de 4 de septiembre de 2006, de la Fundación Municipal de Música de Irún (Guipúzcoa), referente a la convocatoria para proveer una plaza. BOE, lunes, 18 de septiembre de 2006.

Real Decreto 1577/2006, de 22 de diciembre, por el que se fijan los aspectos básicos del currículo de las enseñanzas profesionales de Música reguladas por la Ley Orgánica 2/2006, de 3 de mayo, de Educación.

Bases específicas que regirán la convocatoria para cubrir 31 plazas de profesor de Música del Ayuntamiento de Móstoles. BOCM, martes, 23 de enero de 2007.

Decreto Foral 21/2007, de 19 de marzo, por el que se establece el currículo de las enseñanzas profesionales de Música reguladas por la Ley Orgánica 2/2006, de 3 de mayo, de Educación, en el ámbito de la Comunidad Foral de Navarra.

Orden, de 3 de mayo de 2007, del Departamento de Educación, Cultura y Deporte, por la que se establece el currículo de las enseñanzas profesionales de Música reguladas por la Ley Orgánica 2/ 2006, de 3 de mayo, de Educación, que se imparten en la Comunidad Autónoma de Aragón.

Resolución, de 14 de mayo de 2007, del Ayuntamiento de Ribarroja del Turia (Valencia), referente a la convocatoria para proveer varias plazas. BOE, viernes, 6 de junio de 2007.

Decreto 28/2007, de 18 de mayo, por el que se establecen las características y la organización de las enseñanzas elementales de Música y se determina su currículo.

Decreto 29/2007, de 18 de mayo, por el que se establece el currículo de las enseñanzas profesionales de Música impartidas en los centros de la Comunidad Autónoma de La Rioja.

Decreto 110/2007, de 22 de mayo, por el que se regula el currículo de las enseñanzas elementales de Música de régimen especial reguladas por la Ley Orgánica 2/2006, de 3 de mayo, de Educación.

Decreto 111/2007, de 22 de mayo, por el que se establece el currículo de las enseñanzas profesionales de Música de régimen especial reguladas por la Ley Orgánica 2/2006, de 3 de mayo, de Educación.

Decreto 57/2007, de 24 de mayo, por el que se establece la ordenación y el currículo de las enseñanzas elementales de Música en el Principado de Asturias.

Decreto 58/2007, de 24 de mayo, por el que se establece la ordenación y el currículo de las enseñanzas profesionales de Música en el Principado de Asturias. 
Decreto 60/2007, de 7 de junio, por el que se establece el currículo de las enseñanzas elementales y profesionales de Música en la Comunidad de Castilla y León.

Decreto 30/2007, de 14 de junio, del Consejo de Gobierno, por el que se establece para la Comunidad de Madrid el currículo de las enseñanzas profesionales de Música.

Decreto 75/2007, de 19 de junio de 2007, por el que se regula el currículo de las enseñanzas elementales de Música y danza y se determinan las condiciones en las que se han de impartir dichas enseñanzas en la Comunidad Autónoma de Castilla-La Mancha.

Decreto 76/2007, de 19 de junio de 2007, por el que se regula el currículo de las enseñanzas profesionales de Música en la Comunidad Autónoma de Castilla-La Mancha.

Orden, de 25 de junio de 2007, de la Consejería de Educación y Ciencia, por la que se establece el horario y la distribución de algunas especialidades de las enseñanzas profesionales de Música en la Comunidad Autónoma de Castilla-La Mancha.

Orden Foral 78/2007, de 29 de junio, del Consejero de Educación, por la que se regula el acceso a las enseñanzas profesionales de Música establecidas por la Ley Orgánica 2/2006, de 3 de mayo, de Educación, en el ámbito territorial de la Comunidad Foral de Navarra.

Orden Foral 79/2007, de 29 de junio, del Consejero de Educación, por la que se establece la estructura y horario de las enseñanzas profesionales de Música establecidas por la Ley Orgánica 2/2006, de 3 de mayo, de Educación, en el ámbito territorial de la Comunidad Foral de Navarra.

Convocatoria para selección de Profesor Superior Pianista acompañante. Servicio de Gestión de Recursos Humanos. BOP, 24 de julio de 2007.

Decreto 241/2007, de 4 de septiembre, por el que se establece la ordenación y el currículo de las enseñanzas profesionales de Música en Andalucía.

Decreto 126/2007, de 20 de septiembre, por el que se establece el currículo de las enseñanzas profesionales de Música y se regula su acceso en la Comunidad Autónoma de Cantabria.

Decreto 158/2007, de 21 de septiembre, del Consell, por el que se establece el currículo de las enseñanzas profesionales de Música y se regula el acceso a estas enseñanzas.

Decreto 159/2007, de 21 de septiembre, del Consell, por el que se establece el currículo de las enseñanzas elementales de Música y se regula el acceso a estas enseñanzas.

Decreto 198/2007, de 27 de septiembre, por el que se establece la ordenación del grado elemental de las enseñanzas de régimen especial de Música. 
Decreto 203/2007, de 23 de septiembre, por el que se establece el currículo de las enseñanzas profesionales de régimen especial de Música.

Decreto 364/2007, de 2 de octubre, por el que se establece la ordenación y el currículo de las enseñanzas profesionales de Música en la Comunidad Autónoma de Canarias.

Orden, de 25 de octubre de 2007, por la que se desarrolla el currículo de las enseñanzas profesionales de Música en Andalucía.

Decreto 229/2007, de 11 de diciembre, por el que se establece el currículo de las enseñanzas profesionales de Música y el acceso a dichas enseñanzas.

Decreto 9/2008, de 17 de enero por el que se establece currículo de las Enseñanzas Elementales de Música y se regula su acceso en la Comunidad Autónoma de Cantabria.

Decreto 25/2008, de 29 de enero, por el que se establece la ordenación curricular de las enseñanzas de Música de grado profesional y se regula su prueba de acceso.

Decreto 58/2008, de 11 de abril, por el que se establece la ordenación y el currículo de las enseñanzas elementales de Música para la Región de Murcia.

Decreto 75/2008, de 2 de mayo, por el que se establece la ordenación y el currículo de las enseñanzas profesionales de Música para la Región de Murcia.

Orden 2777/2008, de 3 de junio, por la que se modifica la Orden 1754/2001, de 11 de mayo, del Consejero de Educación, por la que se establece el currículo del Grado Superior de las enseñanzas de Música.

Orden Foral 106/2008, de 1 de julio, del Consejero de Educación, por la que se regulan las asignaturas optativas en las enseñanzas profesionales de Música en la Comunidad Foral de Navarra.

Decreto 17/2009, de 20 de enero, por el que se establece la Ordenación y el Currículo de las Enseñanzas Elementales de Música en Andalucía.

Orden, de 25 de mayo de 2009, por la que se establece la organización académica de las enseñanzas profesionales de Música de la Comunidad Autónoma de Canarias.

Orden, de la consellera de Educación y Cultura, de 26 de mayo de 2009 por la que se establece la organización y el funcionamiento de las enseñanzas profesionales de Música reguladas por la Ley Orgánica 2/2006, de 3 de mayo, de educación, en las Islas Baleares.

Real Decreto 1614/2009, de 26 de octubre, por el que se establece la ordenación de las enseñanzas artísticas superiores reguladas por la Ley Orgánica 2/2006, de 3 de mayo, de Educación. 
Real Decreto 631/2010, de 14 de mayo, por el que se regula el contenido básico de las enseñanzas artísticas superiores de Grado en Música establecidas en la Ley Orgánica 2/2006, de 3 de mayo, de Educación.

Real Decreto 632/2010, de 14 de mayo, por el que se regula el contenido básico de las enseñanzas artísticas superiores de Grado en Danza establecidas en la Ley Orgánica 2/2006, de 3 de mayo, de Educación.

Edicto del Ayuntamiento de Cambrils, sobre provisión de una plaza de profesor titular de piano acompañante laboral fijo. DOGC, 19 de mayo de 2010.

Decreto 36/2010, de 2 de junio, del Consejo de Gobierno, por el que se establece el Plan de Estudios para la Comunidad de Madrid, de las enseñanzas artísticas superiores de Grado en Música.

Orden Foral 110/2010, de 1 de julio, del Consejero de Educación, por la que se establece el plan de estudios de las enseñanzas superiores de Música en el marco del Espacio Europeo de Educación Superior en la Comunidad Foral de Navarra.

Orden, de 28 de julio de 2010, de la Consejería de Educación, Formación y Empleo, por la que se implantan las enseñanzas artísticas superiores de Grado en Arte Dramático, en Diseño y en Música en la Región de Murcia.

Resolución, de 22 de septiembre de 2010, de la Delegación Provincial de Educación de Málaga, por la que se hace pública convocatoria urgente para la cobertura provisional de un puesto de pianista acompañante de danza para el Conservatorio Superior de Danza de Málaga para el curso 2010/11.

Orden, de 30 de septiembre de 2010 por la que se establece el plan de estudios de las enseñanzas artísticas superiores de Grado en Música en la Comunidad Autónoma de Galicia y se regula el acceso a dicho grado.

Bases específicas reguladoras del proceso de selección, mediante oposición, para suplementar la bolsa de trabajo de la especialidad de piano para cubrir las posibles contrataciones de profesor de piano o pianista acompañante de los conservatorios de Música y Danza. Ribarroja del Turia. 11 de enero de 2011.

Decreto 23/2011, de 1 de abril, por el que se establece la ordenación y el currículum de las enseñanzas elementales de Música reguladas por la Ley Orgánica 2/2006, de 3 de mayo, de educación.

Orden, de 29 de abril de 2011, por la que se aprueba, con carácter experimental, la implantación de los estudios oficiales de Grado en Música, Arte Dramático y Diseño en el ámbito de la Comunidad Autónoma de Canarias.

Fundación Pública Soinu Atadia (Leioa). Anuncio contratación laboral de un profesor/a pianista acompañante. BOB núm. 90 . Jueves, 12 de mayo de 2011. 
Decreto 53/2011, de 20 de mayo, del currículum de las enseñanzas profesionales de Música.

Resolución, de 14 de julio de 2011, de la viceconsejera de educación por la que se regulan para el curso 2011-12 las enseñanzas artísticas superiores de Grado en Música, en las especialidades de Composición, Dirección, Interpretación y Pedagogía, en la Comunidad Autónoma del País Vasco.

Decreto 260/2011, de 26 de julio, por el que se establecen las enseñanzas artísticas superiores de Grado en Música en Andalucía.

Convocatoria para la selección de profesores de danza. Septiembre 2011. Pianista acompañante de danza. ArCyL (Fundación para la enseñanza de las artes en Castilla y León).

Orden, de 14 de septiembre de 2011, de la Consejera de Educación, Universidad, Cultura y Deporte, por la que se aprueba el plan de estudios de las enseñanzas artísticas superiores de Grado en Música, Grado en Diseño y Grado en Conservación y Restauración de Bienes Culturales establecidas por la Ley Orgánica 2/2006, de 3 de mayo, de Educación y se implantan dichas enseñanzas en la Comunidad Autónoma de Aragón.

Decreto 57/2011, de 15 de septiembre, por el que se establece el Plan de Estudios de las Especialidades de Composición, Interpretación y Musicología, de las Enseñanzas Artísticas Superiores de Grado en Música en la Comunidad de Castilla y León.

Orden 24/2011, de 2 de noviembre, de la Conselleria de Educación, Formación y Empleo, por la que se establecen y autorizan los planes de estudio de los centros de enseñanzas artísticas superiores de Música dependientes del ISEACV, conducentes a la obtención del título de Graduado o Graduada en Música.

Orden, de 2 de febrero de 2012, de la Dirección General de Recursos Humanos y Calidad Educativa, por la que se publica la relación de aspirantes procedentes del servicio regional de Empleo y Formación de la Comunidad Autónoma de Murcia, para cubrir, en régimen de interinidad, posibles plazas de sustitución en la especialidad de piano del cuerpo de Profesores de Música y Artes Escénicas, como pianista acompañante, en el Conservatorio Superior de Música.

Resolución, de 7 de febrero de 2012, de la Dirección General de Profesorado y Gestión de Recursos Humanos, por la que se hace pública convocatoria para la realización de una prueba específica para ocupar determinados puestos específicos de pianistas acompañantes en los conservatorios profesionales y superiores de Música y de Danza y en las escuelas superiores de arte de dramático de Andalucía.

Resolución, de 7 de mayo de 2012, de la Dirección General de Recursos Humanos y Calidad Educativa, por la que se establece el procedimiento para la evaluación de los aspirantes de la lista de interinos de la especialidad de piano del cuerpo de Profesores de Música y Artes 
Escénicas que deseen ocupar plazas de pianistas acompañantes durante el curso 2012-2013.

Real Decreto 427/2013, de 14 de junio, por el que se establecen las especialidades docentes del Cuerpo de Catedráticos de Música y Artes Escénicas vinculadas a las enseñanzas superiores de Música y de Danza.

Real Decreto 428/2013, de 14 de junio, por el que se establecen las especialidades docentes del Cuerpo de Profesores de Música y Artes Escénicas vinculadas a las enseñanzas de Música y de Danza.

Resolución, de 25 de julio de 2014, de las direcciones generales de Formación Profesional y Enseñanzas de Régimen Especial, y de Centros y Personal Docente, por la cual se dictan instrucciones en materia de ordenación académica y de organización de la actividad docente de los conservatorios y centros autorizados de enseñanzas artísticas profesionales de Música y Danza de la Comunidad Valenciana para el curso 2014-2015.

Resolución, de 26 de enero de 2015 del director general de Centros y Personal Docente, por la que se convoca la constitución de bolsa extraordinaria para atender sustituciones en centros docentes públicos dependientes de la Conselleria de Educación, Cultura y Deporte. 
Los docentes de Educación Física en un centro educativo motórico de primaria El caso de Ateneo

Pablo Vilar Renau pablovilarrenau@gmail.com Luis Gimeno Moliner luisgimeno58@gmail.com 
Estudio de un caso de docencia en un centro especializado en alumnado con dificultades motrices y con alumnado de etnia gitana. Se trabaja la entrevista cualitativa sobre la vida y el trabajo de un docente de educación física analizando su día a día, sus metodologías, sus recursos, alumnos y relaciones con otros maestros, instituciones, padres y madres.

Se trata de un caso de docencia en la especialidad de Educación Física donde existen situaciones de problemas motores en los niños y niñas en las aulas de todos los cursos educativos de educación primaria. Se analiza, así, cómo es su trabajo y como interactúa con los demás miembros del cuerpo de docentes para llevar a cabo sus sesiones. Se estudia también su formación previa para llegar hasta su lugar de trabajo actual y de qué infraestructuras dispone para llevar a cabo sus sesiones.

Al mismo tiempo, se tienen en cuenta los resultados de nuestro trabajo, es decir, de dos entrevistas cualitativas realizadas a Ateneo, el maestro con quien se ha trabajado.

Palabras clave: inclusión, diversidad, estudio de casos, necesidades educativas especiales, etnia gitana.

\section{Introducción}

La investigación se ha realizado de acuerdo con los principios de privacidad del docente. En todo momento se ha mantenido su identificación anónima y se ha realizado un estudio de casos sobre su día a día en las aulas de Educación Física en primaria. En un primer momento, se ha analizado, como modelo de introducción al trabajo posterior, su vida y su formación como maestro. Más adelante, se ha estudiado la metodología de trabajo que sigue y el funcionamiento de sus clases. Finalmente, se ha realizado una pequeña conclusión sobre quién es Ateneo y cómo es su docencia con niños con problemas motores y de etnia gitana.

\section{Objetivos}

Los objetivos que se han llevado a cabo en esta investigación han sido los que se presentan a continuación. Se ha trabajado sobre el estudio de un caso de docencia en un centro educativo con alumnado con problemas motóricos. Se ha analizado la relación que hay entre este alumnado y el de etnia gitana en una misma aula y en un mismo ambiente de trabajo. Finalmente, también se ha observado cuál es la perspectiva del maestro que trabaja con este alumnado diariamente, cómo hace para que sus clases funcionen y cuál es su opinión sobre las posibles mejoras que podría haber en el ámbito educativo actual de los docentes de educación física. 
Este Trabajo de Fin de Grado lo presentaremos en forma de investigación cualitativa de caso único, es decir, hemos utilizado la propia narración para describir lo que ocurre en las clases con el fin de que nos podamos imaginar cómo es el día a día de este docente en el centro. Las fuentes de datos utilizadas han sido dos entrevistas semiestructuradas realizas únicamente al docente, utilizando nuestros teléfonos móviles para grabar. En estas, se llevó a cabo una categorización con el objetivo de dividir los temas de los que se iban a hablar. Estas categorías son las siguientes: su formación educativa en la infancia, el proceso hasta el que se convirtió en docente, su trabajo diario en la escuela y su vivencia en un centro con niños con NEE y de etnia gitana.

Además, hemos ocultado en todo momento la identidad del docente. Para ello, hemos utilizado el nombre de Ateneo como pseudónimo.

\section{Resultados}

El resultado de todo este proceso ha sido la consecución de la opinión que tiene el docente entrevistado acerca del proceso educativo actual, los niños con NEE, la etnia gitana y la relación entre estos y los alumnos que padecen NEE, y ha mostrado una actitud mucho más positiva a la hora de impartir las clases que la de otros muchos autores con quienes se le compara. De este modo se puede ver claramente un contraste de actitudes acerca de la educación hacia la diversidad.

\section{Discusión y conclusiones}

La conclusión a la que hemos llegado en este trabajo es que Ateneo considera que no todos los docentes están capacitados para dar clase en un centro donde hay un gran predominio de la diversidad. Esto lo justifica afirmando que, como principales problemas, se dan la falta de formación y de experiencia de algunos docentes. También afirma que el trabajo del profesor de Educación Física en un centro como este no se limita únicamente a todo aquello relacionado con su asignatura, sino que debe de trabajar otros aspectos como valores o conductas debido a la gran cantidad de conflictos existentes.

\section{Bibliografía}

AвAJO, J. E. (2004): «Infancia gitana y paya: convivencia y conflictos en la escuela», Tabanque, (18), p. 97-116.

Alemany, I., y M. D. Villuendas (2004): "Las actitudes del profesorado hacia el alumnado con necesidades educativas especiales», Revista Convergencia, (34), p. 183-215. 
Arnalz, P. (1996): "Las escuelas son para todos», Siglo Cero, 27 (2), p. 2534.

BLASCO, D. (2006): «Educación, género y deporte: jóvenes de etnia gitana y práctica físico-deportiva», Revista de Dialectología y Tradiciones Populares, julio-diciembre (2), p. 115-128.

Carranza, M., E. García, A. Fraile, J. Hernández, J. Mora y J. Cecchini (2001): "Diversidad y educación física», Tándem (5), p. 5-6.

DE HARO, R. (2009): «El alumnado gitano en los centros educativos: Claves para desarrollar una educación inclusiva e intercultural», Anales de Historia contemporánea, (25), p. 189-199.

ECHEITA, G. (2006): Educación para la inclusión o educación sin exclusiones, Narcea, Madrid.

Gamella, J. F. (1996): La población gitana en Andalucía: un estudio explorativo de sus condiciones de vida, Ministerio de Trabajo y Asuntos Sociales, Sevilla.

Gamella, J. F. y P. S. SÁnchez (1998): La imagen infantil de los gitanos, Fundació Bancaixa, Valencia.

GarcíA, A. (2005): "La educación con niños gitanos. Una propuesta para su inclusión en la escuela», Revista Electrónica Iberoamericana sobre Calidad, Eficacia y Cambio en Educación, 3 (1), p. 437-448.

García, J. A. (1982): «El profesor de educación especial en el equipo», Papeles del Psicólogo, (4 y 5).

Ley Orgánica 1/1990, de 3 de octubre, de Ordenación General del Sistema Educativo (LOGSE). (BOE núm. 238, 4 de octubre de 1990).

LoRenzo, J. A. (1995): "Perspectiva histórica de la formación de los maestros en España (1370-1990)», Revista Complutense de Educación, 6 (2), p. 203-229.

MerRIAM, S. B. (1988): «Doing Case Study Research in Education», GoETZ, J. P. y J. Allen (ed.): Qualitative Research in Education: Substance, Methods, Experience, The University of Georgia, Athens, p. 84-90.

PALACIOS, A. y J. ROMAÑACH (2008): «El modelo de la diversidad: una nueva visión de la bioética desde la perspectiva de las personas con diversidad funcional (discapacidad)», Revista Sociológica de Pensamiento Crítico, 2 (2), p. 37-47.

Pearpoint, J. y M. Forest (1992): "Foreword», Stainbach, S., StaINBACH, W.: Curriculum Considerations in Inclusive Classrooms (Faciliting Learning for All Students). Paul Brookes, XV-XVIII, Baltimore.

Puigdellívol, I. (2001): "El reto de la diversidad en la escuela de hoy», Tándem, (5), p. 7-19. 
Pablo Vilar Renau y Luis Gimeno Moliner. Los docentes de Educación Física en un centro educativo motórico de primaria

WALKER, R. K. (1983): La realización de estudios de casos en educación. Ética, teoría y procedimientos, Narcea, Madrid.

YIN, R. K. (1984): Case Study Research: Design and Methods, Sage Publications, Londres.

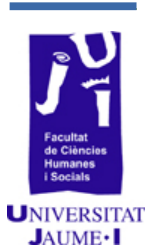




\section{Análisis en la condición física y el rendimiento académico en niñas adolescentes}

Mireia Adelantado Renau al117362@uji.es

Diego Moliner Urdiales dmoliner@uji.es 
Objetivos: analizar la relación entre el nivel diario de actividad física y el rendimiento académico y la relación entre el nivel de condición física y el rendimiento académico en un grupo de alumnas de 2. curso de Educación Secundaria Obligatoria.

Metodología: participaron un total de 15 niñas con una edad media de 13,4 $\pm 0,5$ años. 7 de ellas fueron clasificadas como deportistas y las 8 restantes, como sedentarias $(4,6$ vs. 0 sesiones de actividad física a la semana respectivamente). La condición física se evaluó empleando la Batería ALPHA-Fitness; el nivel de desarrollo puberal, mediante la escala autoreportada de Tanner y Whitehouse; la actividad física, a través del cuestionario PAQ-A, y el rendimiento académico mediante las calificaciones finales.

Resultados: las niñas deportistas empleaban un menor número de horas al estudio y la realización de tareas escolares respecto al grupo de no deportistas $(5,3 \pm 2,6$ vs. $8,5 \pm 2,0 ; P=0,017)$. Las niñas deportistas presentaron niveles de condición física (fuerza de piernas, velocidadagilidad y resistencia) estadísticamente superiores a los presentados por las niñas no deportistas; el rendimiento académico fue similar en ambos grupos ( 6,5 puntos en una escala de 0 a 10).

Conclusiones: la práctica regular de actividad física está asociada a una mejor condición física relacionada con la salud y no parece afectar de forma negativa al rendimiento académico durante la adolescencia.

Palabras clave: actividad física, condición física, rendimiento académico, adolescencia, fuerza, resistencia, sueño, composición corporal.

\section{Introducción}

La adolescencia constituye un periodo de rápido crecimiento en el que se producen múltiples cambios tanto físicos como psicológicos (Shin y Nam, 2015). Durante este periodo crítico del desarrollo humano se adquieren toda una serie de hábitos que pueden influir de forma positiva o negativa durante la etapa adulta (ej. alimentación, práctica de actividad física, consumo de alcohol y tabaco, etc.). Diversos estudios sugieren que los adolescentes gastan un elevado porcentaje de su tiempo libre en actividades sedentarias (p. ej. videojuegos, televisión, ordenador, etc.), duermen menos horas de las recomendadas, mantienen dietas poco equilibradas y se inician en el consumo de alcohol y tabaco a edades tempranas (Moreno y col., 2014). La promoción de hábitos saludables en estas edades ( $p$. ej. fomento de la actividad física, mejora de la condición física, cumplimiento de las horas mínimas de sueño, etc.) constituye una estrategia de salud pública eficaz que reporta múltiples beneficios, no 
sólo a nivel físico sino también psicológico y cognitivo (Paradells y col., 2015).

La actividad física se define como cualquier movimiento corporal producido por la acción de la musculatura que incrementa el gasto de energía por encima de los valores basales (Ortega y col., 2008 b). Entre los principales factores que definen la actividad física se incluyen la intensidad, la frecuencia, la duración y el tipo. La práctica regular de actividad física conlleva múltiples efectos positivos sobre la salud en niños y adolescentes (Penedo y Dahn, 2005), y ayudan al óptimo desarrollo del sistema músculo-esquelético y cardiovascular, mejoran la salud mental y minimizan el riesgo de padecer patologías durante la etapa adulta. Sin embargo, la adolescencia es un periodo en el que se reduce significativamente la actividad física, especialmente en chicas (DjordjevicNikic y col., 2013), lo que incrementa el riesgo de padecer obesidad (Galson, 2008) y alteraciones metabólicas graves como diabetes, hipertensión e hiperlipidemia (Vaynman y Gomez-Pinilla, 2006), a la vez que afecta negativamente a la salud cognitiva y a las funciones cerebrales (Chaddock y col., 2011).

Las actuales recomendaciones de actividad física para la salud establecen que un adolescente activo es aquel que realiza al menos 60 minutos diarios de actividad física de intensidad moderada o intensa (Ortega y col., 2008 a). Además de los múltiples beneficios para la salud derivados de esta práctica regular de actividad física durante la adolescencia, nuevos estudios parecen sugerir que este hábito podría estar asociado a una mejora de la capacidad cognitiva y del rendimiento académico (Hillman y col., 2008), aunque todavía son necesarias nuevas investigaciones que corroboren estos resultados.

La condición física relacionada con la salud se define como la capacidad para realizar las actividades de la vida diaria con vigor, y se diferencian 4 componentes: la resistencia cardiorrespiratoria, la fuerza muscular, la capacidad motora y la composición corporal (Ruiz y col., 2009). Numerosos estudios ponen de manifiesto que una buena condición física se asocia con un menor riesgo de enfermedades crónicas y muerte prematura en la etapa adulta y se considera desde las primeras edades como un potente marcador de salud (Ortega y col., 2008 b). Incluso recientes investigaciones indican que una buena condición física en la adolescencia podría estar asociada a una mejor capacidad cognitiva y un mayor rendimiento académico (Khan y Hillman, 2014), aunque son necesarios nuevos estudios que permitan validar estos resultados.

El rendimiento académico hace referencia al nivel de conocimientos y habilidades que un alumno demuestra a través de un sistema de evaluación. Habitualmente, las investigaciones recurren a las calificaciones obtenidas en las asignaturas instrumentales (Lengua y Matemáticas) como principales indicadores del rendimiento académico. El informe Programme for International Student Assessment (PISA) pone de manifiesto el bajo nivel del rendimiento académico de los adolescentes españoles en comparación con el resto de países de la 
Organización para la Cooperación y el Desarrollo Económico (OCDE). Según los datos obtenidos en 2012, los adolescentes españoles ocupan una posición por debajo de la media de la OCDE.

Diversos estudios asocian el rendimiento académico y la capacidad cognitiva con el nivel de actividad física y condición física en adolescentes. Taras (2005) pone de manifiesto la existencia de una relación positiva entre la práctica regular de actividad física y el rendimiento académico en adolescentes. Estudios recientes sugieren que determinados componentes de la condición física (fuerza, velocidad, flexibilidad, agilidad, etc.) podrían mejorar funciones del cerebro y el rendimiento académico (Esteban-Cornejo y col., 2014).

A pesar del creciente número de estudios científicos centrados en el análisis de las relaciones que se establecen entre la actividad física, la condición física y el rendimiento académico, los resultados obtenidos no son concluyentes, de manera que son necesarios nuevos estudios que permitan ampliar el nivel actual de conocimiento científico.

\section{Objetivos}

Los objetivos del presente estudio son analizar la relación entre el nivel diario de actividad física y el rendimiento académico y analizar la relación entre el nivel de condición física y el rendimiento académico en un grupo de alumnas de 20 curso de Educación Secundaria Obligatoria con diferentes niveles de actividad física.

\section{Material y método}

\section{Participantes y procedimiento}

Durante el curso académico 2014-2015 un total de 20 niñas adolescentes de institutos públicos de Castellón fueron invitadas a participar en el estudio. Finalmente, 15 niñas aceptaron participar y fueron incluidas tras comprobar que cumplían todos los criterios de inclusión establecidos: nacidas en el año 2001, cursando 2. de Educación Secundaria Obligatoria en un centro educativo de carácter público, sin limitaciones o patologías crónicas de tipo físico ni cognitivo y practicantes de actividades deportivas competitivas con al menos 3 sesiones de entrenamiento semanal o no practicantes de ningún tipo de actividad deportiva.

Las 15 niñas seleccionadas presentaban una edad media de 13,4 \pm 0,5 años, y se dividieron en dos grupos según su nivel de actividad física. Un total de 7 niñas fueron clasificadas como deportistas, mientras que las 8 restantes fueron clasificadas como no deportistas.

Todas las adolescentes participaron de forma voluntaria en el presente estudio $y$ sus padres $o$ tutores legales firmaron un 
consentimiento informado. El estudio fue aprobado por la Comisión Deontológica de la Universidad Jaume I.

\section{Composición corporal y condición física}

Las medidas para la determinación de la composición corporal se realizaron en una habitación habilitada para ello y convenientemente climatizada para obtener una óptima sensación de confort. Todas las mediciones se realizaron de forma individual bajo la presencia de un investigador cualificado y un ayudante.

El peso fue medido en ropa interior y sin zapatos, mediante una balanza (SECA 861) con una precisión de 0,1 kg. Se realizaron dos medidas y se empleó la media de ambas para los análisis. La altura se determinó mediante un tallímetro (SECA 225) con una precisión de $0,1 \mathrm{~cm}$. Cada niña era colocada con los talones juntos y con los brazos a lo largo del cuerpo. Los talones, glúteos y parte superior de la espalda estaban en contacto con el tallímetro. La cabeza se orientaba de tal manera que quedaban en un mismo plano horizontal la protuberancia superior del tragus del oído y el borde inferior de la órbita del ojo (plano de Frankfort). La medición se realizaba en el momento en el que cada niña inspiraba profundamente y mantenía la respiración. Se tomó como referencia el punto más alto. Se realizaron dos medidas y se empleó la media de ambas para los análisis.

EI IMC (índice de masa corporal) fue calculado como el cociente del peso de cada niña en kilogramos entre el cuadrado de su altura en metros.

La condición física se evaluó mediante la aplicación de la Batería ALPHA-Fitness (Ruiz y col., 2011). La Batería ALPHA-Fitness consta de una serie de tests de campo que permiten la evaluación de la condición física relacionada con la salud en niños y adolescentes.

La capacidad aeróbica fue medida mediante la realización del test de ida y vuelta de $20 \mathrm{~m}$ : cada niña se desplazaba entre dos líneas situadas a 20 metros de distancia, debiendo hacer un cambio de sentido al llegar a cada una de ellas y coincidiendo con el ritmo indicado por una señal sonora que iba acelerándose progresivamente. La velocidad inicial de la señal era de $8,5 \mathrm{~km} / \mathrm{h}$, y se incrementaba en $0,5 \mathrm{~km} / \mathrm{h}$. La prueba terminaba cuando la niña no era capaz de llegar por segunda vez consecutiva a una de las líneas con la señal de audio o cuando se detenía debido a la fatiga. Se registraba el número total de rectas completadas.

La fuerza de prensión manual fue evaluada mediante un dinamómetro manual (TKK 5401; Takei, Tokyo, Japan) con una precisión de $0,5 \mathrm{~kg}$. Cada niña apretaba el dinamómetro manual gradualmente y de forma continua durante al menos 2 segundos. El dinamómetro se ajustaba al tamaño de la mano. El codo quedaba extendido evitando que el dinamómetro contactara con cualquier parte del cuerpo. El test se realizaba en dos ocasiones con cada una de las manos. Se escogía el valor más alto de las dos medidas realizadas con cada mano y se realizaba la media de estos dos valores, obteniéndose así la fuerza media de prensión manual. 
La fuerza explosiva del tren inferior se midió utilizando el test de salto en longitud. Cada niña colocaba sus pies juntos tras la línea de salto y con una separación igual a la anchura de sus hombros, doblaba las rodillas a la vez que colocaba los brazos delante del cuerpo y paralelos al suelo. Se balanceaba y realizaba el salto lo más lejos posible tomando contacto con el suelo con los dos pies simultáneamente. El test se realizaba en dos ocasiones y se registraba el resultado más alto de los dos intentos en centímetros.

La capacidad de velocidad/agilidad se determinó mediante la prueba de velocidad agilidad $4 \times 10$ metros. En el suelo se dibujaban dos líneas paralelas a 10 metros de distancia. Cuando se indicaba la salida, la niña corría lo más rápido posible de una línea a la otra hasta completar la distancia de 10 metros en 4 ocasiones. El test se realizaba en dos ocasiones y el mejor resultado era anotado. El resultado se registraba en segundos con un decimal.

\section{Desarrollo puberal}

El desarrollo puberal se determinaba empleando la escala autoreportada de estadios madurativos de Tanner y Whitehouse (Tanner y Whitehouse, 1976). A cada participante se le mostraba la escala de Tanner con los diversos estadios, de forma que únicamente tenía que indicar su nivel de desarrollo respecto a los senos y el vello púbico.

\section{Actividad física}

La actividad física se evaluó empleando el cuestionario PAQ-A (Physical Activity Questionnaire for Adolescents) completado en un tiempo máximo de 15 minutos. Este cuestionario consiste en 9 preguntas y fue diseñado para valorar la actividad física en los últimos 7 días empleando una escala de Likert de 5 puntos. El resultado final obtenido es una puntuación que permite establecer el nivel de actividad física de cada niña (Martínez-Gómez y col., 2009).

\section{Rendimiento académico}

El rendimiento académico se estableció a partir de las calificaciones finales obtenidas por cada una de las niñas en el curso anterior (1. de ESO). Cada niña aportó el certificado original de notas proporcionado por su centro educativo. Para este análisis exclusivamente se utilizaron las calificaciones finales correspondientes a las asignaturas instrumentales: Castellano: Lengua y Literatura, Valencià: Llengua i Literatura, Lengua Extranjera: Inglés y Matemáticas. Se calculó la media aritmética de todas las asignaturas instrumentales para tener una valoración global del rendimiento académico. 


\section{Cuestionarios}

Las adolescentes completaron un breve cuestionario en el que se les preguntó información sobre diversas variables que podrían tener influencia sobre su rendimiento académico.

- Para conocer las horas de sueño se les preguntó cuántas horas de sueño real tenían cada noche desde que se iban a la cama hasta que se levantaban por la mañana.

- Para determinar el tiempo dedicado al estudio y a la realización de tareas escolares se les preguntó cuántas horas dedicaban un día entre semana y cuántas horas dedicaban en un día de fin de semana a estudiar y realizar tareas escolares. Para calcular los valores semanales de horas de estudio y tareas escolares se multiplicaron las horas que dedicaban a ello en un día entre semana por cinco y las horas que dedicaban al estudio en un día de fin de semana por dos. Los resultados obtenidos se sumaron y se obtuvieron las horas semanales de estudio.

- El máximo nivel de estudio alcanzado por sus padres fue reportado a través de la siguiente escala: sin estudios, educación primaria, educación secundaria, estudios de bachillerato, estudios universitarios.

\section{Análisis estadísticos}

Las características de la muestra analizada en el estudio se presentan como medias y desviaciones estándar. Las diferencias entre el grupo de niñas deportistas y no deportistas se calcularon utilizando el test de la $\mathrm{t}$ de Student.

Todos los análisis fueron llevados a cabo utilizando la versión 23.0 del paquete estadístico SPSS, considerando $\mathrm{P}<0,05$ como estadísticamente significativa.

\section{Resultados}

La muestra de participantes estaba formada por 7 niñas adolescentes deportistas que realizaban al menos 4 sesiones semanales de actividad deportiva y 8 niñas no deportistas que no realizaban ningún tipo de actividad física regular $(P<0,000)$.

Tabla 1. Características generales de las participantes del estudio

\begin{tabular}{lccc}
\hline & $\begin{array}{c}\text { DEPORTISTAS } \\
\mathbf{n = 7}\end{array}$ & $\begin{array}{c}\text { NO DEPORTISTAS } \\
\mathbf{n = 8}\end{array}$ & Valores $\mathbf{P}$ \\
\hline Edad (años) & $13,4 \pm 0,5$ & $13,1 \pm 0,4$ & 0,230 \\
\hline Tanner (estadio) & $3,4 \pm 0,5$ & $3,4 \pm 0,5$ & 0,847 \\
\hline Peso $(\mathrm{kg})$ & $54,5 \pm 5,4$ & $51,0 \pm 5,0$ & 0,215 \\
\hline Talla (cm) & $165,5 \pm 6,7$ & $159,6 \pm 7,1$ & 0,125 \\
\hline
\end{tabular}




\begin{tabular}{|c|c|c|c|}
\hline $\mathrm{IMC}\left(\mathrm{kg} / \mathrm{m}^{2}\right)$ & $19,9 \pm 1,7$ & $20,1 \pm 2,0$ & 0,892 \\
\hline Horas estudio (semana) & $5,3 \pm 2,6$ & $8,5 \pm 2,0$ & 0,017 \\
\hline Sueño (h/día) & $7,7 \pm 1,0$ & $7,1 \pm 0,8$ & 0,223 \\
\hline AF (días/semana) & $4,6 \pm 0,5$ & $0,0 \pm 0,0$ & $<0,000$ \\
\hline \multicolumn{4}{|c|}{ IMC indica índice de masa corporal } \\
\hline \multicolumn{4}{|c|}{ Valores P calculados mediante el test de la t de Student } \\
\hline
\end{tabular}

No se observaron diferencias estadísticamente significativas entre los grupos respecto a los valores referidos a los parámetros físicos. El índice de masa corporal para ambos grupos era de $20 \mathrm{~kg} / \mathrm{m}^{2}$ y todas las niñas manifestaron dormir una media de 7 horas diarias. Se observaron diferencias estadísticamente significativas respecto a la variable horas de estudio, donde las niñas no deportistas manifestaron dedicar más de 8 horas semanales frente a las 5 que indicaron la niñas deportistas $(P=0,017)$.

Tabla 2. Nivel de condición física de las participantes del estudio

\begin{tabular}{lccc}
\hline & $\begin{array}{c}\text { DEPORTISTAS } \\
\mathbf{n = 7}\end{array}$ & $\begin{array}{c}\text { NO DEPORTISTAS } \\
\mathbf{n = 8}\end{array}$ & Valores P \\
\hline Fuerza mano derecha $(\mathrm{kg})$ & $29,0 \pm 2,1$ & $26,2 \pm 4,0$ & 0,116 \\
\hline Fuerza mano izquierda $(\mathrm{kg})$ & $29,8 \pm 4,5$ & $24,6 \pm 5,0$ & 0,053 \\
\hline Fuerza media manos $(\mathrm{kg})$ & $29,4 \pm 2,9$ & $25,4 \pm 4,4$ & 0,059 \\
\hline Salto $(\mathrm{cm})$ & $192,9 \pm 17,3$ & $141,9 \pm 12,5$ & $<0,000$ \\
\hline Velocidad (seg.) & $12,4 \pm 0,5$ & $13,8 \pm 0,7$ & 0,001 \\
\hline Resistencia (rectas) & $82,9 \pm 16,9$ & $38,9 \pm 11,6$ & $<0,000$ \\
\hline
\end{tabular}

Los niveles de condición física presentaron diferencias estadísticamente significativas entre los dos grupos. Excepto para las variables de fuerza de prensión manual, las niñas deportistas presentaron unos niveles de fuerza de piernas, velocidad-agilidad y resistencia estadísticamente superiores a los presentados por el grupo de niñas no deportistas.

Tabla 3. Rendimiento académico de las participantes del estudio

\begin{tabular}{lccc}
\hline & $\begin{array}{c}\text { DEPORTISTAS } \\
\mathbf{n = 7}\end{array}$ & $\begin{array}{c}\text { NO DEPORTISTAS } \\
\mathbf{n = 8}\end{array}$ & \multirow{2}{*}{ Valores $\mathbf{P}$} \\
\hline Castellano: Lengua y Literatura & $6,9 \pm 1,6$ & $6,1 \pm 1,1$ & 0,314 \\
\hline Valencià: Llengua i Literatura & $6,6 \pm 1,1$ & $7,0 \pm 1,5$ & 0,550 \\
\hline Lengua Extranjera: Inglés & $6,3 \pm 1,4$ & $6,8 \pm 2,0$ & 0,613 \\
\hline Matemáticas & $6,9 \pm 1,9$ & $6,1 \pm 0,8$ & 0,366 \\
\hline Media & $6,6 \pm 1,4$ & $6,5 \pm 1,2$ & 0,836 \\
\hline $\begin{array}{l}\text { Media indica la media aritmética de las calificaciones obtenidas en castellano, valenciano, } \\
\text { inglés y matemáticas } \\
\text { Valores P calculados mediante el test de la t de Student. }\end{array}$ & \\
\hline
\end{tabular}

En relación con el rendimiento académico ambos grupos presentaron valores muy similares en todas las variables analizadas, sin identificarse diferencias estadísticamente significativas. La nota media de las materias 
instrumentales (Castellano: Lengua y Literatura, Valencià: Llengua i Literatura, Lengua Extranjera: Inglés y Matemáticas) fue de un $\approx 6,5$ para ambos grupos.

\section{Discusión y conclusiones}

En el presente estudio los datos obtenidos parecen indicar que la práctica regular de actividad física no influye negativamente sobre el rendimiento académico y que además conlleva una mejora notable de la condición física relacionada con la salud.

Nuestros resultados coinciden con los obtenidos por Daley y Ryan (2000), donde en un estudio con 232 adolescentes no encontraron correlación alguna entre la práctica regular de actividad física y el rendimiento académico. Estudios similares como los llevados a cabo por Bass y col., y Haapala (2013) sugieren la existencia de una relación positiva entre el rendimiento académico y la práctica de actividad física.

Las niñas deportistas evaluadas en nuestro estudio presentaban parámetros físicos (IMC, horas de sueño, peso, talla y Tanner) muy similares a las no deportistas, lo que pone de manifiesto que se trataba de dos grupos muy homogéneos. Ambos grupos presentaban diferencias significativas respecto al nivel de actividad física y las horas de estudio semanales. De hecho, las niñas no deportistas dedicaban al estudio y tareas escolares una media de $8,5 \pm 2,0$ horas a la semana, mientras que las deportistas empleaban de media 5,3 $\pm 2,6$ horas semanales. Todas ellas tenían la misma jornada escolar y afirmaban dormir $\approx 7 \mathrm{~h}$ al día. Por tanto, el hecho de que las deportistas dediquen menos horas al estudio podría deberse a que empleaban parte de su tiempo en entrenar y preparar sus competiciones, mientras que las niñas no deportistas como no realizaban ningún tipo de actividad deportiva tenían más tiempo libre disponible para dedicar al estudio y a la realización de tareas escolares.

Los niveles de condición física presentaron diferencias estadísticas entre el grupo de deportistas y no deportistas para todas las variables analizadas excepto para la fuerza de prensión manual. Los resultados obtenidos por el grupo de deportistas fueron muy superiores en las pruebas de velocidad, salto y resistencia. Probablemente esto sea debido a que el grupo de niñas deportistas practicaba atletismo, deporte en el que el uso de las extremidades superiores es muy limitado, mientras que las extremidades inferiores están en continua solicitación y, por tanto, presentan un nivel de desarrollo mayor.

Investigaciones recientes ponen de manifiesto una relación positiva entre la condición física y el estado de salud física y psicológica (Lankhorst y col., 2015). Además, nuevas líneas de investigación parecen apuntar que tanto la mejora de la resistencia cardiorrespiratoria, como de la fuerza muscular están asociadas a un mayor rendimiento académico en adolescentes (Kalantari y Esmaeilzadeh, 2015; Sardinha y col., 2015).

Los resultados de nuestro estudio muestran que la práctica de actividad física no influye de forma negativa sobre el rendimiento 
académico. De hecho, ninguna de las variables de actividad física presentó una relación significativa con las variables del rendimiento académico. A pesar del elevado volumen de horas que invierten las niñas deportistas en su práctica deportiva y al menor tiempo empleado en el estudio y la realización de tareas escolares, su rendimiento académico ( 6.5$)$ fue similar al de las niñas no deportistas. Consideramos que estos resultados podrían deberse en parte a la mejora de la plasticidad cerebral, al incremento de la capacidad de concentración y de la memoria y a la adquisición de habilidades académicas (Kamijo y col., 2012) que se asocian a la práctica regular de actividad física. De hecho, la práctica regular de actividad física presenta múltiples efectos positivos durante la adolescencia, ya que ayuda a controlar el estrés, a gestionar mejor el tiempo y además transmite valores asociados a la cultura del esfuerzo (Hansmann y col., 2007; Norris y col., 1992).

Entre los puntos fuertes de nuestro estudio cabe destacar que se trata de una muestra muy homogénea que presenta niveles muy diferentes de actividad física. Además, para analizar la relación entre la actividad física y el rendimiento académico se han tenido en cuenta la influencia de diversas variables de confusión como las horas de estudio semanales, el nivel de condición física y las horas de sueño diarias. Sin embargo, estos resultados han de ser interpretados con cautela debido al reducido tamaño de la muestra compuesta exclusivamente por niñas, el uso de cuestionarios para evaluar la actividad física y a la falta de control sobre otras variables que pueden influir en el rendimiento académico como la dieta, el nivel socioeconómico familiar o variables sociodemográficas (Torrijos-Niño y col., 2014). Además, el diseño transversal de nuestro estudio no nos permite establecer relaciones causa-efecto.

De acuerdo con el conocimiento científico actual y con los resultados encontrados en nuestro estudio podemos afirmar que la práctica regular de actividad física mejora la salud de las niñas adolescentes sin afectar de forma negativa a su rendimiento académico. Tanto las familias como las instituciones educativas deberían tener en cuenta estas evidencias a la hora de tomar decisiones orientadas a la promoción de la salud y la mejora del rendimiento académico durante la infancia y la adolescencia.

\section{Agradecimientos}

Los autores quieren dar las gracias a todos los participantes en el estudio por su implicación, y a todos los miembros del grupo de investigación LIFE de la Universitat Jaume I por el trabajo realizado durante la toma de datos.

El presente trabajo constituye un estudio piloto enmarcado dentro del proyecto DADOS que ha sido financiado por el Ministerio de Economía y Competitividad a través del Programa Estatal I+D+I Orientada a los Retos de la Sociedad en la convocatoria del año 2013 (Ref. Dep201345515-R) y cuenta con el patrocinio del Grupo Schweppes. 


\section{Bibliografía}

BASS, R. W. y otros (2013): "Physical Fitness and Academic Performance in Middle School Students», Acta Paediatrica, 102(8), p. 832-837.

CHADDOCK, L. y otros (2011): "A Review of the Relation of Aerobic Fitness and Physical Activity to Brain Structure and Function in Children», Journal of the International Neuropsychological Society, 17(6), p. 975-985.

Daley, A. J. y J. Ryan (2000): «Academic Performance and Participation in Physical Activity by Secondary School Adolescents», Perceptual and Motor Skills, 91(2), p. 531-4.

DJORDJEVIC-NIKIC, M. y otros (2013): «Nutritional and Physical Activity Behaviours and Habits in Adolescent Population of Belgrade», Vojnosanitetski Pregled, 70(6), p. 548-554.

Esteban-CoRnejo, I. y otros (2014): «Independent and Combined Influence of the Components of Physical Fitness on Academic Performance in Youth", The Journal of Pediatrics, 165(2), p. 306-312.e2.

GaLSON, S. K. (2008): "Childhood Overweight and Obesity Prevention», Public Health Reports (Washington, D.C. : 1974), 123(3), p. 258-9.

HaApala, E. A. (2013): "Cardiorespiratory Fitness and Motor Skills in Relation to Cognition and Academic Performance in Children - a Review», Journal of Human Kinetics, 36, p. 55-68.

HANSMANN, R. y otros (2007): «Restoration and Stress Relief Through Physical Activities in Forests and Parks», Urban Forestry \& Urban Greening, 6(4), p. 213-225.

Hillman, C. H. y otros (2008): "Be Smart, Exercise Your Heart: Exercise Effects on Brain and Cognition», Nature Reviews. Neuroscience, 9(1), p. 58-65.

KalantARI, H.-A., y S. EsmaeILZAdeh (2015): «Association Between Academic Achievement and Physical Status Including Physical Activity, Aerobic and Muscular Fitness Tests in Adolescent Boys», Environmental Health and Preventive Medicine.

KAMIJO, K. y otros (2012): «The Relation of Adiposity to Cognitive Control and Scholastic Achievement in Preadolescent Children", Obesity (Silver Spring, Md.), 20(12), p. 2406-11.

Khan, N. y C. H. Hillman (2014): "The Relation of Childhood Physical Activity and Aerobic Fitness to Brain Function and Cognition: a Review», Pediatric Exercise Science, 26(2), p. 138-46.

LANKHORST, K. y otros (2015): "Health in Adapted Youth Sports Study (HAYS): Health Effects of Sports Participation in Children and Adolescents with a Chronic Disease or Physical Disability», SpringerPlus, 4, p. 796. 
MARTíneZ-GómeZ, D. y otros (2009): «Reliability and Validity of the PAQ-A Questionnaire to Assess Physical Activity in Spanish Adolescents», Rev Esp Salud Pública, 83, p. 427-439.

MoRenO, L. A. y otros (2014): «Nutrition and Lifestyle in European Adolescents: the HELENA (HealthyLiftestyle in Europe by Nutrition in Adolescence) Study", Advances in Nutrition, 5(Part 2), p. 615A-623AS.

NoRRIS, R. y otros (1992): "The Effects of Physical Activity and Exercise Training on Psychological Stress and Well-being in an Adolescent Population", Journal of Psychosomatic Research, 36(1), p. 55-65.

ORTEGA, F. B. y otros (2008 a): "Los adolescentes físicamente activos presentan una mayor probabilidad de tener una capacidad cardiovascular saludable independientemente del grado de adiposidad». The European Youth Heart Study. Revista Española de Cardiología, 61(2), p. 123-129.

- «Physical Fitness in Childhood and Adolescence: a Powerful Marker of Health», International Journal of Obesity, 32(1), p. 1-11.

PARAdells, V. N., y otros (2015): «Effects of an Intervention Program (HHP) on the Promotion of Healthy Habits in Early Adolescence», Nutr Hosp., $32(6)$, p. 2640-2649.

Penedo, F. J. y J. R. Dahn (2005): «Exercise and Well-being: a Review of Mental and Physical Health Benefits Associated with Physical Activity", Current Opinion in Psychiatry, 18(2), p. 189-93.

RuIz, J. R. y otros (2009): "Predictive Validity of Health-related Fitness in Youth: a Systematic Review», British Journal of Sports Medicine, 43(12), p. 909-923.

RuIz, J. R. y otros (2011): «Batería ALPHA-Fitness : test de campo para la evaluación de la condición física relacionada con la salud en niños y adolescentes", Nutrición Hospitalaria, 26(6), 1210-1215.

SARDINHA, L. B. y otros (2015): «Longitudinal Relationship Between Cardiorespiratory Fitness and Academic Achievement», Medicine and Science in Sports and Exercise.

SHIN, A., y C. M. NAM (2015): «Weight Perception and its Association with Socio-demographic and Health-related Factors among Korean Adolescents». BMC Public Health, 15(1), p. 1292.

TANNER, J. M., y R. H. Whitehouse (1976): «Clinical Longitudinal Standards for Height, Weight, Height Velocity, Weight Velocity, and Stages of Puberty», Archives of Disease in Childhood, 51(3), p. 170-179.

TARAS, H. (2005): «Physical Activity and Student Performance at School», The Journal of School Health, 75(6), p. 214-8.

TORRIJOS-NIÑo, C. y otros (2014): «Physical Fitness, Obesity, and Academic Achievement in Schoolchildren», Journal of Pediatrics, 165, p. 104-109.

Vaynman, S., \& Gomez-Pinilla, F. (2006): «Revenge of the "Sit": How 
Mireia Adelantado Renau y Diego Moliner Urdiales. Análisis en la condición física y el rendimiento académico en niñas adolescentes

Lifestyle Impacts Neuronal and Cognitive Health Through Molecular Systems That Interface Energy Metabolism with Neuronal Plasticity", Journal of Neuroscience Research, 84(4), p. 699-715. 


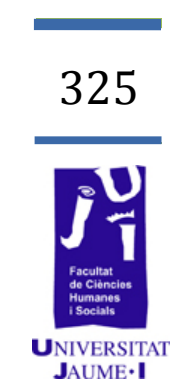

\section{Mejora de la calidad del prácticum en la titulación del Grado de Maestro/a en Educación Primaria}

Mikel Peñalver Suller al225245@uji.es 
A continuación se os presenta un análisis documental de memorias de las prácticas realizadas por alumnos del Grado de Maestro de Educación Primaria, tanto en tercer curso (Prácticum I) como en el último año, cuarto curso (Prácticum II), con el fin de reflexionar sobre la eficacia y la calidad de las prácticas docentes. Para ello los objetivos que buscamos alcanzar y sobre los cuales nos regimos son los siguientes: observar el método didáctico de los alumnos en prácticas y el método didáctico empleado por sus maestros supervisores y argumentar si existe una relación entre ambas, contemplar si existen diferencias entre las unidades didácticas presentadas por el alumnado y donde surgen, analizar si los estudiantes de Prácticum contemplan la interdependencia entre la teoría y la práctica en el proceso de prácticas y valorar el nivel de reflexión reflejado en las memorias de los estudiantes en prácticas en el que se dejan ver diferencias entre el Prácticum I y el Prácticum II. En definitiva, comprobar si el periodo de prácticas contribuye eficazmente para la formación de un docente innovador y crítico. El método que hemos utilizado en este trabajo en general es el análisis de contenido, hemos interpretado las memorias y observado las frecuencias en las que aparecen los conceptos. Como instrumentos hemos utilizado un formulario o registro de observación de las memorias. Los resultados demuestran que existe un nivel de semejanza alto entre la metodología del maestro supervisor y la del alumno. A su vez, los alumnos realizan un número de unidades didácticas diferente cuyos elementos varían de unos practicantes a otros. El nivel de reflexión alcanzado por los estudiantes es medio, sin relación con el prácticum que cursan $y$, por lo tanto, sin mostrar diferencias entre PI y PII.

Palabras clave: prácticum, formación docente, maestros/as de Grado de Primaria, competencia reflexiva.

\section{Introducción}

Como alumno que ya he cursado parte de estos periodos, la orientación de mi investigación con motivo de mi Trabajo de Final de Grado va a ir dirigido a la mejora del prácticum, a su memoria y a la aportación guiada que puede recibir el alumno, es decir, una mejora educativa.

Uno de los puntos más fuertes e importantes en la vida universitaria de un futuro maestro, ya sea de infantil o de primaria, es el periodo de prácticas. En este -para mí- corto periodo, los alumnos deben conocer la gran mayoría de los elementos que envuelven la realidad escolar. Anteriormente el Prácticum I y el Prácticum II se diferenciaban no solo por la temporalización -esta diferencia continua patente- sino por los 
objetivos planteados. En la actualidad, la normativa y la guía con la que se encuentran los estudiantes es similar, y se trata de asignaturas distintas.

El Prácticum requiere por parte del estudiante de una reflexión de toda su competencia, es decir, plasma todo aquello que ha observado, analizado, descubierto y elaborado en ese tiempo, creando una relación directa con las teorías educativas y sus conocimientos adquiridos hasta ese momento. Es la parte que da sentido a mi trabajo.

El trabajo va orientado a analizar aquellas cuestiones relacionadas en las competencias que permiten desarrollar la reflexión y el sentido crítico, además de la estructura y contenido de las memorias, para que sirvan para mejorar la formación de las mismas en un futuro.

\section{Objetivos}

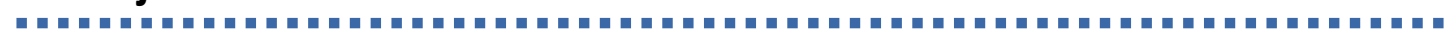

Realizar un estudio descriptivo y de análisis de las memorias de Prácticum del Grado de Maestro de Primaria. Los puntos específicos que se analizan son los siguientes:

1. Aspectos contextuales del aula de prácticas.

2. Semejanza entre la metodología didáctica del alumno y del supervisor.

3. Diferencias entre las unidades didácticas presentadas por el alumnado y observar donde surgen.

4. Interdependencia entre la teoría y la práctica.

5. Nivel de reflexión de las memorias.

6. Diferencias significativas entre las memorias del Prácticum I y el Prácticum II.

\section{Material y metodología}

El método que hemos utilizado en este trabajo es el análisis cuantitativo de contenido, técnica que hemos utilizado para seleccionar, categorizar e interpretar textos, en este caso, las memorias de prácticas de los estudiantes del Grado de Maestro/a de Educación Primaria.

Para ello, hemos seleccionado 20 memorias de prácticas del curso pasado (2013-2014) a través de un muestreo aleatorio, es decir elegidas al azar, de entre todos los estudiantes de la titulación Primaria, tanto del periodo de Prácticum I, realizado en el tercer curso, como el periodo de Prácticum II, que corresponde al último año de la titulación. Nos hemos puesto en contacto con tutores y alumnos para que nos facilitasen las memorias y seguidamente hemos empezado con la parte central del trabajo. Se trata de un análisis ex-post facto, es decir, una vez ocurridos los hechos, en este caso las prácticas, se recopila toda la información, en este caso las memorias de las prácticas de los estudiantes seleccionados.

Analizamos e interpretamos los datos del material reunido y puesto en relación con los objetivos agregando algunos rasgos característicos del centro y de las aulas. 
Para consolidar el criterio de valor de verdad propuesto por Guba y Lincoln (1981) y dar rigor científico a esta investigación hemos utilizado:

1. La triangulación, que significa conseguir varias aproximaciones de una misma realidad, para asegurar que las interpretaciones son correctas (Bartolomé, 1996). Este postulado se refleja del modo siguiente: triangulación de observadores, por el cual han participado en la recogida de datos dos personas diferentes. Triangulación de fuentes: para lo cual se han observado las memorias de Prácticum I y II (dos cursos diferentes).

2. Recogida de información de adecuación referencial: Para cumplir con esta premisa se ha buscado alcanzar una muestra representativa de la población, dando de este modo mayor rigurosidad a la muestra definitiva. El tipo de muestreo es aleatorio y representa aproximadamente al $9 \%$ de la población estudiada. El criterio del valor de verdad hace referencia a la credibilidad o validez interna de la investigación. Este criterio busca que los datos recogidos sean imagen de la realidad que se estudia evitando el sesgo o la subjetividad del observador.

\section{Características de las muestras}

La muestra la forman los 20 documentos escritos por los estudiantes una vez finalizado su periodo de sus prácticas, todas del curso 2013-2014 y realizadas en el segundo semestre, independientemente del curso 3.ㅇ o 4.․ Con respecto a las asignaturas, hemos observado las memorias de Prácticum I y II, que son dos asignaturas de dos cursos diferentes, de las cuales 13 corresponden a PI y 7, a PII.

\section{Instrumento y análisis de datos}

Los datos de las memorias se han vaciado en un instrumento de observación creado para tal fin bajo el soporte del formulario Google (ver Anexo I). Y para analizar los datos, hemos tenido en cuenta cuatro categorías que fundamentan nuestro trabajo. Las categorías han sido las siguientes:

1. Aspectos contextuales en las prácticas:

a. Contexto del centro escolar: en esta categoría se han recogido varias subcategorías como la ubicación, titularidad, el tamaño del centro y líneas.

b. Contexto del aula: se recogen las características del aula como son el número de alumnos, curso y ciclo, y si hay alumnos con dificultades de aprendizaje. 
c. Métodos de enseñanza del supervisor: bajo esta categoría se recogen las actividades y el modelo utilizado por el supervisor según las metodologías que propone Amparo Fernández March (2006), como hemos dicho anteriormente.

2. Con respecto al método del estudiante, se registran los datos similares a los del supervisor pero se amplían más las subcategorías, ya que se analizan también las características de la unidad o proyecto planificado por el estudiante en prácticas y el tipo de actividades y la valoración de la intervención.

3. Niveles de reflexión. En esta categoría se observan y analizan opiniones del estudiante respecto a su estancia en prácticas y se clasifican según los niveles de reflexión que hemos explicado anteriormente. Se recoge la interdependencia entre la teoría y la práctica, y se intenta buscar una diferencia entre el PI y el PII.

\section{Resultados}

Una vez recogidos todos los datos podemos analizar tres categorías de vital importancia en el Prácticum. Estamos hablando tanto de estructura, como de recursos personales. Aquí diferenciamos el papel del maestro supervisor del alumno en prácticas y el alumnado existente. $Y$ analizamos los niveles de reflexión aportados en la memoria.

\section{Aspectos contextuales de las prácticas del Grado de Maestro en Educación Primaria:}

a. Descripción de los centros de prácticas.

- Zona de prácticas: a pesar de que la Universitat Jaume I está situada en la capital de la provincia, solo el $35 \%$ del alumnado realiza las prácticas en la capital, Castellón de la Plana. El litoral cuenta con tan solo el $20 \%$ del alumnado de magisterio en estancia de prácticas, y casi la mitad, el $45 \%$, las realiza en el interior de la provincia.

- Titularidad de los centros: de las memorias de las que se han analizado los datos solo el $5 \%$ recogen información de prácticums realizados en colegios no públicos, es decir, centros privados o de carácter concertado, los cuales están situados en su totalidad en la capital.

- Ocupación de los centros: la ocupación de dichos centros, en más de la mitad de las ocasiones (60\%) no supera los 500 alumnos. En un $25 \%$ de los casos la cifra de alumnos matriculados está entre 500 y 1000 alumnos y solo en un $10 \%$ de los centros, situados en su totalidad en localidades del 
interior, los alumnos se agrupan en aulas heterogéneas en cuanto a edades, ya que los centros no superan los 100 alumnos.

- Proyectos especiales: también es un dato llamativo que tan solo en un $10 \%$ de los centros han introducido un proyecto especial en sus centros. Todos se han decantado por la lengua extranjera en auge: han aplicado un proyecto de inmersión lingüística del inglés.

- Líneas lingüísticas de los centros: a pesar de la importancia que han adoptado las lenguas, un $30 \%$ de los alumnos no habla de la cantidad de líneas que posee su centro. A pesar de esto, el $71,4 \%$ de los alumnos que habla de esta característica destaca la posesión de 2 líneas. En consecuencia, en el interior, encontramos centros con solo una línea, el 18,6\%, superior al $10 \%$ de centros con una línea que se encuentran en capital.

b. Descripción de las aulas de prácticas.

- Ciclos y aulas más concurridas: a pesar de que no existe ningún tipo de orientación o preferencia por ningún ciclo, es el segundo ciclo el que tiene más practicantes, con un $40 \%$, supera al primer y tercer ciclo que cuenta con un $30 \%$ cada uno.

- Cantidad de alumnos por aula: la baja población con la que cuentan algunas poblaciones del interior hace que el $30 \%$ de las aulas tenga menos de 20 alumnos. La cantidad más repetida en las aulas está entre los 20 y 25 alumnos, $40 \%$. En un $25 \%$, los maestros tienen entre 26 y 30 alumnos y solo en un $5 \%$ de los casos hay un número superior a 30 niños.

- La distribución espacial de los pupitres se realiza en parejas o pequeños grupos en el $75 \%$ de las ocasiones, aparecen diferentes motivos, entre los que destacan: el aprendizaje o resolución de dudas entre compañeros o simplemente el espacio. A pesar de esto, en un $15 \%$ de las aulas, los pupitres forman una $U$, y se deja espacio en el centro donde se coloca la mesa del maestro. Además de las sillas y las mesas, la pizarra convencional es la que aún aparece en todas las aulas. Esta se combina en el $75 \%$ de las aulas con un proyector y un ordenador de aula. Este avance hacia las nuevas tecnologías ha cogido velocidad, aunque en un $5 \%$ de los colegios existe un número reducido de proyectores, pero son comunes para todo el centro.

- NEAE: hay diferentes niveles de capacidad en las aulas, pero es en el $60 \%$ de las ocasiones cuando los practicantes se encuentran con alumnos con necesidades específicas de apoyo educativo, porque presentar necesidades educativas especiales, porque tienen dificultades específicas de 
aprendizaje, por sus altas capacidades intelectuales, por haberse incorporado tarde al sistema educativo o por condiciones personales o de historia escolar. En el 83,3\% de los casos se han diagnosticado trastornos por déficit de atención con hiperactividad (TDAH) y todos los alumnos cuentan con apoyo interno, aportado generalmente por los pedagogos.

- Acciones para la integración de la diversidad cultural: el alto grado de inmigración que ha ocupado gran parte de nuestro país ha provocado que en más de la mitad de los casos (60\%) nos encontremos con alumnos extranjeros en las clases y en el $58,3 \%$ de estas ocasiones el número de niños de otros países es superior a tres. A pesar de la gran cantidad, tan solo una de cada tres clases $(33,33 \%)$ realiza actividades o proyectos de carácter inclusivo para facilitar la socialización y adaptación de estos alumnos.

- Participación familiar: a pesar de la gran importancia del trato de la familia con el colegio, solo un $30 \%$ de los padres tienen una relación activa con el centro, alejada del trato formal habitual con el docente. El nivel de enriquecimiento gracias a los agentes de la comunidad es aún inferior, $10 \%$, el trato con los agentes de seguridad ciudadana está entre los más nombrados; después bomberos o policía, pero sin contemplar agentes culturales, según los registros de las memorias consultadas.

- Sea cual sea el número de alumnos, es muy reducido el nivel de decisión que se le da a los alumnos: en el $5 \%$ de las ocasiones los alumnos deciden sobre temas que los involucran, sobretodo en fiestas o proyectos.

c. Metodología del maestro supervisor.

Los alumnos en prácticas no hacen un uso adecuado del primer periodo de integración y reflexión, ya que simplemente realizan una visión sin la recogida clara de lo que ven. El $65 \%$ habla del papel del maestro supervisor y de la metodología que sigue.

De los datos comentados en estas memorias podemos diferenciar actividades o metodologías diferenciadas en tradicionales e innovadoras. En las tradicionales, el $61,5 \%$ de los docentes utilizan la explicación magistral para exponer los contenidos y un $38,5 \%$ se apoyan en la pizarra para complementar la explicación oral. Las actividades innovadoras más utilizadas en el aula de primaria son los proyectos (36\%) y las de estructura cooperativa ( $45 \%$ ), las cuales se desarrollan en el $75 \%$ de las veces en las asignaturas de ciencias. Con un $9 \%$, las sesiones de carácter competitivo y los grupos basados en resolución de problemas son mencionados en Matemáticas, y dejan a las lenguas sin ningún tipo de innovación. (La suma de los porcentajes supera el $100 \%$ ya que en el 
formulario se podían elegir formas tradicionales e innovadoras para el mismo supervisor sin la obligación de que fuera una sola.)

La importancia de los intereses del alumnado en su aprendizaje no necesita argumentarse, a pesar de ello, en las memorias analizadas, existe un sobreuso de la herramienta de apoyo analógico, el libro. El $80 \%$ de los alumnos lo ve como guía total en sus aulas y solo el $20 \%$ de los maestros desarrolla sus sesiones a partir de los intereses de los niños. En esta minoría también están incluidos aquellos que varían drásticamente el orden del libro para adaptarlo a las necesidades de la enseñanza y sobre todo los proyectos.

\section{Metodología y programación por parte del estudiante:}

Aunque los alumnos dispongan de una misma guía de prácticas, su rol como maestro dentro del aula tiene infinidad de diferencias, además de la estructura y el contenido reflejados en la memoria.

- Número de unidades didácticas: nos hemos encontrado que el número de unidades didácticas elaboradas y aplicadas durante el periodo de estancia en los centros varia de 3 hasta 10 unidades. Un $40 \%$ de los alumnos se aferra a la realización de una unidad para cada asignatura troncal: Matemáticas, Valenciano, Castellano y Ciencias Naturales. Un $20 \%$ completa una más, con un total de 5 unidades, y la asignatura adicional más repetida es plástica. Tan solo un $10 \%$ y $5 \%$ se sitúan en los extremos de 3 unidades y 10 unidades respectivamente. En el primer caso eliminan una asignatura troncal y en el segundo realizan 2 unidades didácticas por materia.

- Asignaturas usadas en las U.D.: como bien hemos dicho son Matemáticas (95\%), Ciencias Naturales (90\%), Valenciano (85\%) y Castellano (85\%) las asignaturas más impartidas por los alumnos de magisterio de primaria. A pesar de esto, más de la mitad ( $55 \%$ ) realiza una asignatura diferente a estas (plástica o música son las más mencionadas por los alumnos).

- Elementos de las unidades didácticas: ¿qué contienen las unidades didácticas programadas por los alumnos? Tan solo el $70 \%$ del alumnado ha introducido en sus unidades todos los elementos básicos, es decir, cuentan con objetivos, contenidos, competencias, actividades y el método de evaluación. Pueden aparecer descritas o desarrolladas en las memorias de diferente manera, pero en ellas aparecen estos puntos. Por otra parte, es muy llamativo que 1 de cada 4 alumno (25\%) no incluya las actividades llevadas a cabo y que un $5 \%$ no hable del sistema evaluador utilizado.

El PCC (proyecto curricular de centro) y las editoriales abastecen a los alumnos con cantidades de objetivos $y$ 
contenidos numerados en largas listas. Por eso, más de la mitad de las memorias cuentan entre sus hojas numerosos objetivos y contenidos copiados. Los objetivos se numeran en más ocasiones, ya que en un $30 \%$ los contenidos son descritos por parte del practicante. Solo un $15 \%$ elabora una descripción mínima de la meta de las sesiones y aporta una visión propia inexistente en los casos anteriores.

- Metodología: Siguiendo con los apartados de las unidades analizadas es muy llamativo el hecho de realizar o aplicar unas herramientas en el aula y a continuación no describirlas. Esto sucede a un $60 \%$ del alumnado, el cual no describe la metodología sobre la que trabajan o han seguido, o simplemente realizan descripciones.

Que la metodología del maestro supervisor se vea reflejada en el alumno de prácticas es una realidad. El alto nivel de dependencia y las facilidades que otorga el libro de texto provoca que el $90 \%$ del alumnado rija su papel como docente sobre esta herramienta. Tan solo un $10 \%$ desarrolla las sesiones alejadas del orden del libro o lo aprovecha con variaciones profundas.

Tres de cada cuatro alumnos en prácticas reconoce que emplea un método tradicional, cita en ocasiones la continuidad metodológica del tutor, se destaca la lección magistral con apoyo en la pizarra, mencionada en el $80 \%$ de estos casos. A pesar de esta gran cantidad de alumnado que se va decantando hacia una forma de enseñanza básica, la mitad del alumnado analizado reconoce que emplea actividades innovadoras, sobre todo en ciencias. Son las de carácter cooperativo (30\%) las que a través del trabajo grupal, y entre iguales, están por encima de los proyectos $(10 \%)$, el estudio de casos y las actividades competitivas (5\%).

- Evaluación: es sorprendente que, en un $40 \%$ de las memorias, las unidades didácticas no describían la evaluación, es decir, contaban con unos criterios numerados pero no incluían ninguna explicación del instrumento que los recoge. Finalmente, un $45 \%$ sí que aporta una prueba en papel, es decir, los exámenes.

- NEAE: a pesar de la realidad educativa que los practicantes se encuentran en los centros -los cuales en más de la mitad de las ocasiones cuentan con alumnos con necesidades específicas de apoyo educativo-, no aparece ni una sola adaptación en las memorias analizadas. 


\section{Niveles de reflexión:}

¿Verdaderamente los alumnos realizan una valoración, crítica y reflexiva, sobre la intervención? Es muy alto el porcentaje - $25 \%$ - de los estudiantes que confunden valoración con descripción y, por lo tanto, narra los acontecimientos vividos sin aportar subjetividad. Un $30 \%$ de las valoraciones sí que tiene este carácter reflexivo, pero solo un $35 \%$ suma un grado de autocrítica que produce en el estudiante preguntas y respuestas que mejoran y enriquecen su estancia en un aula. Un $10 \%$ refleja el porcentaje de memorias en el que no aparece ningún tipo de valoración reflexiva o crítica como docente. A pesar de no ser una herramienta obligatoria, el diario ayuda al pensamiento de los acontecimientos vividos, por lo que un $15 \%$ lo ha introducido en su memoria o, en su caso, en los anexos.

La interdependencia entre teoría y práctica es una relación que obliga al estudiante a reflexionar y argumentar sus acciones. En el $50 \%$ de los casos los alumnos citan autores que han dedicado su vida al desarrollo de teorías educativas, como Piaget (aprendizaje constructivista), David Paul Ausubel (aprendizaje significativo), William H. Kilpatrick (trabajo por proyectos), Valls (comunidades de aprendizaje), entre otros, o simplemente contenidos trabajados durante su estancia en la universidad, en este caso Didáctica y organización escolar sobresale entre las demás. La otra mitad no hace referencia bibliográfica durante su memoria, o generaliza con el concepto "aprendido durante la carrera».

El grado de reflexión de los alumnos se ha distribuido en 4 niveles de los 6:

1) Análisis: descripciones escuetas sin fundamento ni justificación.

2) Explicaciones del porqué o para qué, en las que se analiza el sentido de la acción.

3) Valoraciones y críticas.

5) Justificación con apoyo científico.

El $25 \%$ entrarían en el primer escalón, las reflexiones son más bien análisis en los que los alumnos no defienden sus acciones. Solo en un $5 \%$ de las ocasiones el alumnado aporta una necesidad real por la cual ejecuta una sesión, y se sitúan en el segundo. En el tercer nivel encontramos el mayor porcentaje de alumnado, un total de $45 \%$ de estudiantes realiza valoraciones o críticas. Por último, en el máximo grado se sitúa un $10 \%$ de la población analizada, la cual realiza una argumentación científica. Un $15 \%$ de los alumnos no proporciona datos suficientes, o muy escasos, como para asociarlos con ningún tipo de reflexión anterior.

Bajo los criterios subjetivos del personal encargado de la investigación, basados en las comparaciones de los elementos técnicos, como pueden ser las unidades didácticas, y los reflexivos, como las valoraciones y conclusiones, los resultados desvelan que un $45 \%$ de las memorias son reflexivas y un $55 \%$, técnicas. Por otra parte no existe una 
relación directa entre el Prácticum I y Prácticum II, con el grado de reflexión o tecnicismo aportados en las memorias. Así pues, se concluye que no existe una diferencia entre ambos prácticums (es decir, entre las asignaturas MP1025 y MP1038), ni rasgos característicos propios.

\section{Discusión y conclusiones}

Una vez completado el estudio y el análisis de las memorias de Prácticum para comprobar si el periodo de prácticas contribuye eficazmente en la formación de un docente innovador y crítico podemos presentar las conclusiones obtenidas.

Existen indicios que confirman la relación entre la metodología empleada por el maestro supervisor y la del practicante, sin tener en cuenta la innovación o tradicionalismo al que estén sujetos sus métodos. La facilidad y la baja complicación que conlleva una con baja creatividad produce que sea bajo el nivel innovador. Estos resultados se relacionan con lo dicho en el artículo de Bretones Román (2013) con respecto a que los métodos que más siguen utilizándose son los tradicionales basados en el dominio de contenidos mediante el uso del libro de texto.

La multitud de factores que determinan una memoria (alumno, tutor y maestro supervisor) ocasiona infinidad de contenidos y estructuras para esta. Esto también se ve reflejado en la programación de las unidades didácticas, a pesar de que las asignaturas troncales (Matemáticas, Valenciano, Castellano y Ciencias Naturales) son las más repetidas, encontramos diferentes números de unidades en memorias de alumnos que realizan el mismo prácticum e, incluso, el mismo tutor. La inexistencia de un patrón claro provoca que, aunque en su mayoría no, haya alumnos que se dejen elementos básicos en sus unidades como las actividades o la evaluación. Algunos alumnos no controlan la programación y no son capaces de solucionarlo sin una guía uniforme.

Se observa una actitud hostil y de aversión por parte de los alumnos hacia la teoría aprendida en los cursos de formación teórica, sienten que no les ha servido para sus prácticas o directamente no la tienen en cuenta en sus memorias. Este aspecto se relaciona con el hecho de que los alumnos no realizan unas prácticas enfocadas a la perspectiva reflexiva, estableciendo un vínculo entre la teoría y la práctica, sino a la perspectiva técnica, donde se resaltan más las competencias adquiridas en la práctica. Destacar el uso generalizado de la fuente de conocimientos "carrera» para justificar acciones basadas en conocimientos aprendidos en el Grado.

A pesar de realizar una recogida de memorias aleatoria, cuyos resultados son muy diversos, no existen alumnos que logren aportar propuestas de mejora, equivalentes al nivel 4 de reflexión según María Muradas López y Ma Isabel Porta Martin (2007). A su vez se confirma lo dicho por ambas autoras: que los alumnos alcanzan el nivel medio de reflexión, ya que la mitad de los alumnos oscilan en el nivel 3, valoraciones y críticas. 
Con este análisis documental hemos obtenido resultados muy llamativos sobre los que no habíamos planteado ningún objetivo. Estos aspectos colaterales son los siguientes: el altísimo grado de alumnado inmigrante que se encuentra en las aulas, al igual que el diagnóstico de varios alumnos con NEAE (para los cuales no se realiza ninguna adaptación por parte del practicante). De este modo, se demuestra que es una realidad educativa el trabajo con estos alumnos y se esfuma el pensamiento de que es raro el caso en que un alumno va a necesitar actividades de integración y atención a la diversidad.

Al mismo tiempo los alumnos reflejan la equipación y el uso aumentativo de las TIC en sus centros, y se habla de un mundo más tecnológico y menos analógico.

\section{Propuestas de mejora}

Diferenciar el Prácticum I y el Prácticum II para un aprendizaje integral, es decir, a pesar de ser dos asignaturas de prácticas realizadas en colegios los alumnos salen de los centros sin conocer su organización, sin tocar de primera mano los documentos que los rigen. Por lo tanto, los alumnos podrían dedicar un tiempo de su estancia en prácticas durante su cuarto año (Prácticum II) en conocer esta administración. El realizarlo en el PII tiene una razón sencilla: durante los últimos tiempos los documentos van cambiando año a año; de este modo, si los conocen en su último año es más fácil que continúen en vigor cuando terminen su formación como docentes. Para completar esta separación de competencias, los alumnos deberían tener un nivel de reflexión diferente entre ambos años, sería interesante que se les proporcionara una formación sobre la reflexión para así poder alcanzar la competencia reflexiva necesaria.

Unificar los criterios de evaluación, en los que el numero de unidades didácticas estuviera limitado y su estructura establecida. Por eso, la elaboración de una rúbrica sería muy positiva, los tutores conocerían lo que deben evaluar y los alumnos lo que deben realizar, y se alejarían de una guía tan global como la actual.

La metodología debe orientarse hacia la innovación para huir del tradicionalismo constante. En muchas ocasiones los alumnos argumentan su tradicionalismo con la poca libertad que les proporciona el maestro supervisor. Para que los alumnos reflexionen y aporten propuestas de mejora más innovadoras se podría añadir en las memorias un apartado de innovación o modificación, donde los alumnos comentaran cómo transformarían una actividad que el supervisor o ellos mismos han hecho tradicional, en innovadora. De esta forma, aunque no lo llevaran a cabo en el aula, se les obligaría a plantearse actividades diferentes y huir del famoso libro de texto.

Crear grupos de discusión que sean un espacio donde el alumnado pueda debatir, compartir dudas, experiencias y testimonios del periodo de las prácticas, tanto de una titulación como de otra. Una iniciativa que 
debería convertirse seminarios para el antes, el durante y el después de las prácticas de los alumnos.

La formación constante con seminarios ayudaría a los alumnos a mejorar su experiencia como docentes y enriquecer su Prácticum. Estos podrían estar orientados a potenciar la relación entre la teoría y la práctica, aportando casos prácticos para aportarle una argumentación científica, por ejemplo. Otro punto de vital importancia es la concienciación del alumnado de que se van a encontrar aulas con todo tipo de niños, es decir, plantear situaciones donde la integración y la diversidad sea esencial para formar a aquellos alumnos inmigrantes o con necesidades educativas diferentes.

Cuando hablamos de memoria de prácticas hablamos de un trabajo que recoge la información de meses. La presentación de esta se hace en una vez, es decir, no se fragmenta el trabajo. La fragmentación podría ser beneficiosa para realizar una corrección, no tan solo de lo aplicado por los alumnos en el aula, sino lo que están programando para futuras sesiones. De esta forma la presentación de fichas periódicas mejoraría y agilizaría la corrección, y se proporcionaría al alumnado un calendario continuo, un trabajo diario. Con esta medida evitaríamos el sobreesfuerzo por ambas partes en periodo final del curso.

\section{Bibliografía}

Aguado, A. W., C. R. Aguaded, N. C. Rodríguez y Listán, M. F. (2007): Las rúbricas de evaluación de los prácticum como instrumento de reflexión para estudiantes de maestro de educación primaria.

AlDEGUER, S. P. (2012): «Revisión, clasificación y propuestas de mejora del prácticum en educación musical», Revista de Currículum y Formación de Profesorado, p. 346-356.

Angulo, L. M. V. (1985): «Reflexiones sobre el entrenamiento en el rol de profesor supervisor instruccional», Cuestiones pedagógicas, 2 p. 127-129.

BeAs Collado, B. (2014): Las prácticas internacionales de los estudiantes y titulados de la Universitat Jaume I: organización y gestión desde un servicio de empleo universitario. Aprendizajes del proceso y retos de futuro.

BENAVIDES, R. (1995): "Una propuesta para evaluar práctica docente», Revista reflexiones.

Del Pozo, Mạ. J. C y L. RAYón (2009): «El prácticum como enseñanza reflexiva en las titulaciones de maestro: una propuesta de innovación didáctica», p. 271-281.

FERNÁNDEZ, N. G. (2006): «Evaluación y mejora del prácticum en las titulaciones de ciencias de la educación de la UPV/EHU», p. 145-158.

GonZÁlez, X. A., C. BUISÁN y S. SÁNCHEZ (2009): «Las prácticas docentes para enseñar a leer y a escribir», Infancia y Aprendizaje. Journal for the Study 
of Education and Development, p. 153-169.

MARCH, A. F. (2006): "Metodologías activas para la formación de competencias», Educatio siglo XXI, p. 35-56.

Muradás, M., y M. I. Porta (2007): «Las memorias del Prácticum I de maestros de Educación Infantil: sobre qué reflexionan los alumnos». Buenas prácticas en el Prácticum, p. 977-990.

OnCINS, M. F., y T. V. ARBonÉs (1997): «El Prácticum en el nuevo plan de estudios de magisterio: un camino hacia la investigación-acción». Revista electrónica interuniversitaria de formación del profesorado, 1(0).

Román, A. B. (2013): «El Prácticum de magisterio en educación primaria: una mirada retrospectiva». Revista Complutense de Educación, 24(2), p. 443-471.

Rivas, M. R., M. M. Figueira, P. C. M. Carril, A. P. Avellás y J. C. O López (coord.) (2011): «Evaluación y compromiso del prácticum: el compromiso con la calidad de las prácticas». XI Symposium Internacional sobre el Prácticum y las Prácticas en Empresas en la Formación Universitaria.

SÁNCHEZ, J. M. y R. C. GonzÁlez (2008): «La formación de maestros en España (1838-2008): necesidades sociales, competencias y planes de estudio», Eduación XX1, p. 73-101.

Orden $\mathrm{ECl} / 3857 / 2007$, de 27 de diciembre, por la que se establecen los requisitos para la verificación de los títulos universitarios oficiales que habiliten para el ejercicio de la profesión de Maestro en Educación Primaria. (BOE, de 29 de diciembre).

Real Decreto 1393/2007, de 29 de octubre, por el que se establece la ordenación de las enseñanzas universitarias oficiales. (BOE, de 30 de octubre)

Real Decreto 1707/2011, de 18 de noviembre, por el cual se regulan las prácticas académicas del alumnado universitario. 
Metodología y reflexión del alumnado del Grado de Educación Infantil en sus prácticas externas. Análisis de contenido de sus memorias

Alicia Benet Gil abenet@uji.es Lucía Sánchez-Tarazaga lucia.sanchez@uji.es 
El objetivo de esta investigación ha sido realizar un estudio descriptivo de las principales características de las memorias de las prácticas externas procedente de una muestra de 19 estudiantes del Grado de Maestro/a de Educación Infantil de la Universitat Jaume I, en el curso 2013-2014. A partir de un registro de observación, el método que hemos utilizado ha sido el análisis de contenido, hemos interpretado las memorias de las asignaturas de Prácticum I (tercer curso) y Prácticum II (cuarto curso) y observado las frecuencias en las que aparecen las categorías que fundamentan nuestro trabajo: la metodología utilizada (por el supervisor y el alumno) y el nivel de reflexión. Los resultados más significativos demuestran que predomina una metodología orientada a proyectos, en muchos casos centrada en los intereses del alumnado (si bien sigue teniendo un peso importante la planificación del libro de texto) y con poco uso de las Tecnologías de la Información y la Comunicación. En lo que respecta a la reflexión, el nivel alcanzado por el alumnado es medio y se observa poca conexión entre lo que aprenden en la academia o en la literatura especializada y lo que aprenden en el centro escolar. Estas evidencias han supuesto una revisión del planteamiento de las prácticas, a través de la participación de todos los agentes implicados en el proceso y que está siendo coordinado desde el Grupo de Innovación Educativa (GIE) de la Universitat.

Palabras clave: prácticum, innovación educativa, reflexión, metodología didáctica, formación del profesorado, Educación Infantil.

\section{Introducción}

Reflexionar no es simplemente contar la propia experiencia (lo que muchos de nuestros estudiantes hacen en sus memorias y diarios) sino, justamente, ser capaz de llegar más allá de la experiencia vivida, saber decodificarla, referenciarla, valorarla e integrarla en nuestros esquemas cognitivos

Zabalza (2011)

En la formación universitaria como maestro o maestra, ya sea de la etapa de infantil o de primaria, las prácticas externas (también conocidas como Prácticum) tienen un peso muy importante, pues no solo tienen una gran carga lectiva (18\% de los créditos del Grado), sino que, además, en los dos últimos cursos ocupan casi un $40 \%$ de las materias. Así pues, se trata de una formación imprescindible en la que el alumnado puede 
poner en práctica aquello aprendido durante la carrera y enriquecer su desarrollo profesional.

El Prácticum permite al alumnado conocer el funcionamiento de un centro educativo, así como almacenar la más directa experiencia de cómo trabaja un docente de acuerdo con la realidad que tenemos actualmente en un aula (alumnado, dificultades en el aprendizaje, metodologías empleadas por parte de los docentes que hoy trabajan en nuestros centros, contextos, materiales...).

Entre los objetivos más importantes de este periodo de prácticas externas, destaca aquel que busca crear profesionales aptos, cuya formación académica les permita adecuarse a las realidades que hoy viven nuestros centros educativos. En definitiva, aquel que fomenta la necesidad de crear maestros y maestras reflexivos que busquen en todo momento mejorar la calidad educativa de los centros, así como preparar de una forma más provechosa e idónea a los jóvenes del mañana.

Durante los últimos años, sobre todo a partir de la implementación de los títulos de grado en el marco del Espacio Europeo de Educación Superior, las prácticas externas se han visto reforzadas en el plan de estudios por el incremento que han tenido en el número de créditos. La importancia que tienen, la duración y sobre todo sus implicaciones en la formación inicial de los futuros maestros hace que nos replanteemos la necesidad de analizar si las prácticas reúnen las condiciones calidad.

El pedagogo Miguel Ángel Zabalza (Zabalza, 2004) considera que es imprescindible buscar herramientas y mecanismos para mejorar la calidad del Prácticum. Pero ¿a través de qué parámetro podemos medir dicha calidad?

A lo largo de la estancia de prácticas, el alumnado debe elaborar una memoria en la que debe reflejar su actuación y papel en el aula y en el centro. Se pretende que dicha memoria sea una autoevaluación y análisis personal sobre su desarrollo profesional, para poder comprender la realidad y reflexionar sobre su labor docente con el fin de buscar aspectos de mejora. La finalidad es crear docentes reflexivos, capaces de innovar, comprender la realidad educativa e intentar mejorar continuamente su práctica profesional.

Por ello, en este trabajo nos fijaremos en la calidad asociada a comprobar si las prácticas contribuyen en la formación de futuros docentes reflexivos e innovadores. Pues su riqueza no solo depende de la experiencia en sí misma, sino también de los procedimientos o instrumentos que articulemos para propiciar la reflexión.

Bretones Román (2013) recoge cuatro perspectivas teóricas de diferentes autores (Korthagen, 2010; Liston y Zeichner, 1993; Zeichner, 1999) que hacen referencia a la formación del profesorado (ver tabla 1): 
Tabla 1. Perspectivas teóricas de la formación del profesorado

\begin{tabular}{|c|l|}
\hline $\begin{array}{c}\text { ACADÉMICA, } \\
\text { CONSERVADORA } \\
\text { O TRADICIONAL }\end{array}$ & $\begin{array}{l}\text { Basada en los contenidos culturales que se transmiten, así como la } \\
\text { subordinación de la práctica docente a la teoría pedagógica. }\end{array}$ \\
\hline $\begin{array}{c}\text { TÉCNICA O } \\
\text { EFICACIA SOCIAL }\end{array}$ & $\begin{array}{l}\text { Da prioridad al dominio de una serie de habilidades, competencias } \\
\text { docentes específicas, es decir, prioridad de la práctica sobre la } \\
\text { teoría. }\end{array}$ \\
\hline REFLEXIVA & $\begin{array}{l}\text { Pone el acento en el desarrollo de habilidades intelectuales y en la } \\
\text { toma de decisiones en el trabajo del aula, de manera que se } \\
\text { establece un vínculo entre la teoría y la práctica. }\end{array}$ \\
\hline CRÍTICA & $\begin{array}{l}\text { Suma los objetivos de las tres perspectivas anteriores y proclama la } \\
\text { necesidad de una formación amplia del futuro profesor que incluya } \\
\text { la dimensión moral, social y política o de compromiso con una } \\
\text { sociedad más justa y la mejora de las condiciones laborales de los } \\
\text { docentes. }\end{array}$ \\
\hline
\end{tabular}

Fuente: Bretones Román (2013)

En este trabajo también hemos tenido en cuenta una clasificación de Muradás y Porta (2007) que establecen niveles de 0 a 5 según el grado de reflexión (tabla 2):

Tabla 2. Niveles de reflexión

\begin{tabular}{l}
\hline 0. Discurso factual: descripciones escuetas sin fundamento ni justificación. \\
$\begin{array}{l}\text { 1. Análisis: descripciones pormenorizadas, en las que se resalta la estructura de la acción } \\
\text { o el episodio narrado. }\end{array}$ \\
\hline 2. Explicaciones del porqué o para qué: analizando el sentido de la acción. \\
\hline 3. Valoraciones y/o críticas. \\
\hline $\begin{array}{l}\text { 4. Propuestas prácticas: otras posibilidades de acción que, supuestamente, mejorarían lo } \\
\text { se está describiendo. }\end{array}$ \\
\hline $\begin{array}{l}\text { 5. Justificación con apoyo científico: análisis o justificación de la acción con referencias a } \\
\text { autores o enfoques científicos. }\end{array}$ \\
\hline
\end{tabular}

Fuente: Muradás y Porta (2007)

A lo largo del Grado de Maestro se incide mucho en conocer las metodologías y recursos existentes para que el alumnado tenga las herramientas suficientes cuando se enfrente al mundo profesional. Por tanto, es imprescindible que el alumnado sea capaz no solo de conocerlas sino de debatir sobre ellas. Por todo ello, consideramos importante observar si el alumnado es capaz no solo de conectar la teoría y la práctica, sino también de observar aquella metodología que usa su supervisor y reflexionar sobre ella.

Para ello, nos hemos basado en las metodologías que propone Fernández March (2006) que van desde los modelos tradicionales -como pueden ser las clases magistrales- hasta metodologías donde se fomente la participación del alumnado y que versan sobre aspectos más innovadores. 


\section{Objetivos}

A partir de la exposición planteada, este trabajo tiene como propósito principal analizar en qué medida el periodo de prácticas en centros escolares contribuye eficazmente para la formación en la innovación y reflexión del alumnado de Grado de Maestro/a de Educación Infantil. Este objetivo general se complementa, a su vez, con tres objetivos específicos, que son los que guiarán los resultados del estudio:

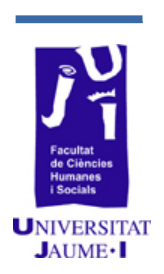

1. Observar si existe relación entre el método didáctico del alumnado en prácticas con el método didáctico empleado por sus maestros supervisores.

2. Analizar si el alumnado de prácticas contempla la interdependencia entre la teoría y la práctica en su estancia en el centro.

3. Identificar el nivel de reflexión alcanzado de los estudiantes en prácticas.

\section{Material y método}

\subsection{Muestra e instrumento}

La muestra está formada por las 19 memorias escritas por los estudiantes una vez finalizado su periodo de sus prácticas, todas ellas del curso 2013-2014 y realizadas en el segundo semestre, correspondientes a tercer (Prácticum I) y cuarto curso (Prácticum II). La selección de dichas memorias fue a través de muestreo aleatorio. Como hemos comentado anteriormente, se seleccionaron trabajos tanto de alumnado de magisterio de infantil como de primaria. En este trabajo nos detenemos en las memorias de los estudiantes del Grado de Maestro/a de Educación Infantil de las cuales 10 de ellas pertenecen al Prácticum I y 9 al Prácticum II, si bien en el análisis es agregado y no contempla resultados parciales por asignatura.

Los datos de las memorias se han vaciado en un instrumento de observación diseñado ad hoc bajo el formato de formulario y mediante el soporte electrónico de Google Drive.

Las categorías analizadas en este trabajo y que lo guían han sido la metodología didáctica utilizada por el supervisor y el maestro y los niveles de reflexión.

\subsection{Procedimiento metodológico}

La metodología utilizada corresponde al análisis cualitativo de contenido, técnica que hemos utilizado para seleccionar, categorizar e interpretar los textos (en nuestro caso, las memorias del alumnado). En concreto, utilizamos un análisis ex-post facto, puesto que se trata de un análisis posterior a la realización de las prácticas. 
Para dar rigor científico a esta investigación se ha seguido el criterio de valor de verdad (Guba y Lincoln, 1981). Este criterio hace referencia a la credibilidad o validez interna de la investigación y busca que los datos recogidos sean imagen de la realidad, evitando o minimizando el sesgo del observador. Su concreción es a través de la estrategia de triangulación; de esta manera, se intentan conseguir varias aproximaciones de una misma realidad para asegurar que las interpretaciones son correctas. Por un lado, por parte de los observadores, pues han participado en la recogida de datos dos personas; y por otro, las fuentes, ya que se han analizado tanto las memorias de dos cursos diferentes (Prácticum I y II) como las de dos carreras diferentes (Infantil y Primaria).

\section{Resultados}

A continuación mostramos los resultados más significativos, tras el análisis de frecuencias en cada una de las dimensiones de nuestro estudio y dando respuesta a los objetivos planteados.

\subsection{Observar si existe relación entre el método didáctico del alumnado en prácticas con el método didáctico empleado por sus maestros supervisores}

Para responder a este propósito hemos tomado como dimensión de análisis la metodología didáctica empleada, por un lado, del supervisor y, por otro, del alumnado. Respecto a la del supervisor (gráfico 1), predomina el estilo innovador (con el $67 \%$ ), que aglutina propuestas como el aprendizaje orientado a proyectos o rincones de trabajo. Son menos frecuentes los modelos mixtos (17\%) o tradicionales basados en pizarra o explicación oral (17\%), de manera que es un resultado que no sorprende demasiado ya que se trata de la etapa de infantil.

Además se ha observado que, en el $60 \%$ de los casos, la planificación se realiza según los intereses del alumnado, mientras que en el $40 \%$ restante, de acuerdo a lo planteado por los manuales (libros de texto).

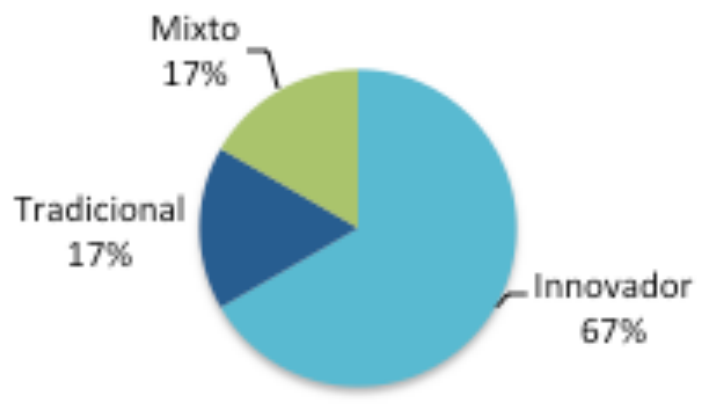

Gráfico 1. Método didáctico del supervisor 
En lo que respecta al método didáctico del alumnado, también predomina el modelo innovador (47\%), si bien con valores inferiores con respecto al supervisor (gráfico 2 ).

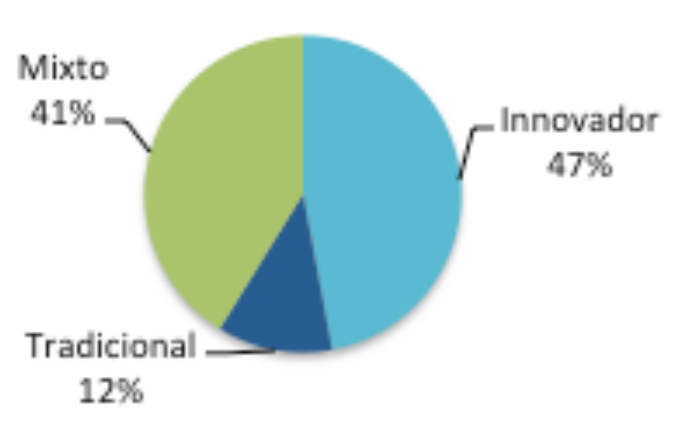

Gráfico 2. Método didáctico del alumnado

Además, un importante grupo de alumnos (59\%) desarrolla las actividades de manera mixta, es decir, combina las que sugiere el libro de texto con las que este colectivo por sí mismo diseña. De otra parte, observamos que un $35 \%$ las diseña sin tener en cuenta el libro y un pequeño grupo (6\%) sí que se apoya exclusivamente de un manual o libro de texto (gráfico 3).

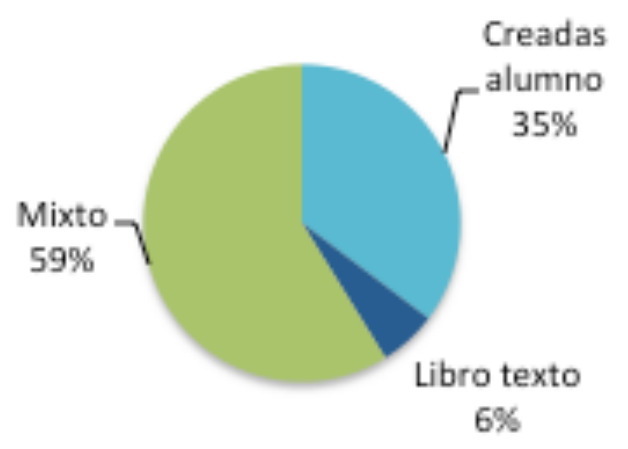

Gráfico 3. Diseño de las actividades por parte del alumnado

\subsection{Analizar si el alumnado de prácticas contempla la interdependencia entre la teoría y la práctica en su estancia en el centro}

En este caso, hemos tomado como eje de análisis la frecuencia en la que se incluye autores de la literatura o bien se realizan referencias concretas a asignaturas o profesorado del Grado y así observar si se producen conexiones entre teoría y práctica.

Los datos arrojan que un $56 \%$ del alumnado no hace referencia alguna a autores, asignaturas o profesores del Grado. El $44 \%$ hace 
referencias pero se observa que solo son relativas a asignaturas y no se incluyen citas teóricas de fuentes bibliográficas (gráfico 4).
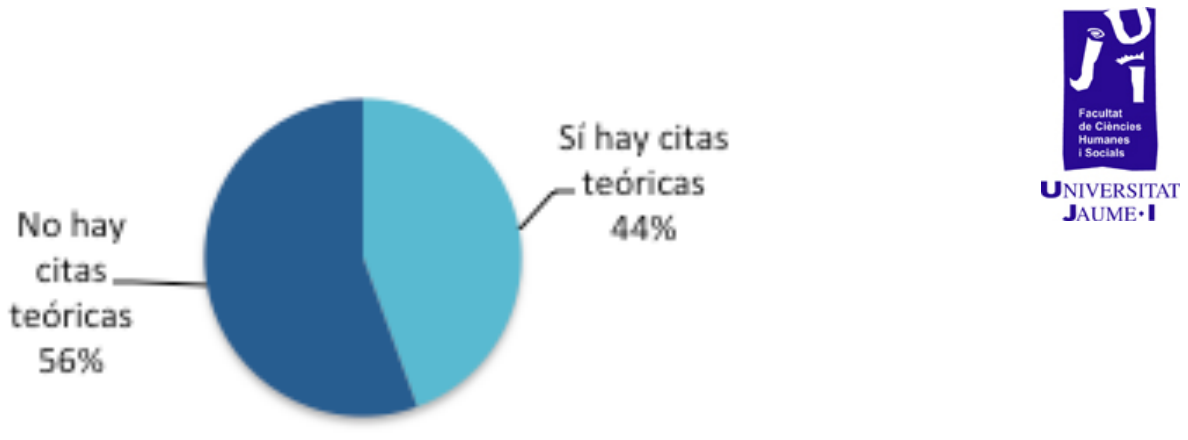

Gráfico 4. Interdependencia entre la teoría y la práctica

\subsection{Identificar el nivel de reflexión alcanzado de los estudiantes en prácticas}

En cuanto al nivel de reflexión del alumnado, se ha distribuido en los 6 niveles que proponen las autoras Muradás y Porta (2007), anteriormente descritos, si bien no se han encontrado reflejados todos estos niveles en la muestra del estudio.

Los resultados advierten (gráfico 5) un importante número de memorias (64\%) con un nivel de reflexión medio (nivel 3), que incluye un cierto nivel de análisis basado en valoraciones personales y críticas. Aunque con poco peso, se aprecia que hay un $21 \%$ de memorias que se quedan en un nivel bajo de reflexión (nivel 0 y 1 ), y se trata más de memorias de carácter técnico.

Si bien se identifican algunas memorias con el nivel 4 que incluyen algunas propuestas de mejora (concretamente el $14 \%$ ), no se tiene constancia de que el alumnado apoye sus justificaciones con expertos de la literatura (nivel 5), hecho que coincide con los resultados que encontrábamos en el apartado anterior.

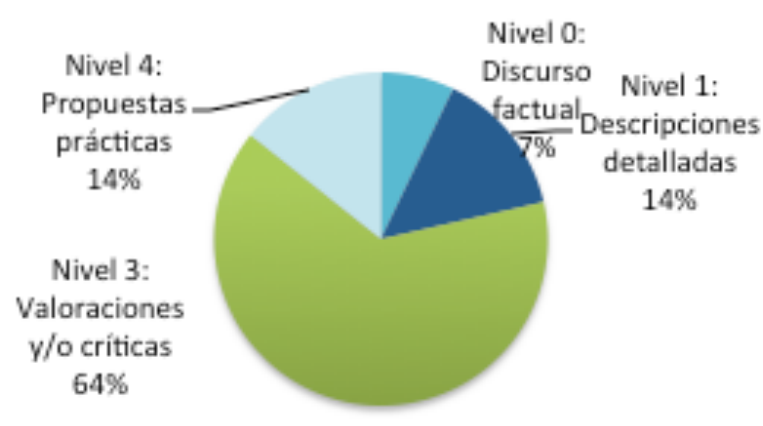

Gráfico 5. Nivel de reflexión alcanzado 


\section{Discusión y conclusiones}

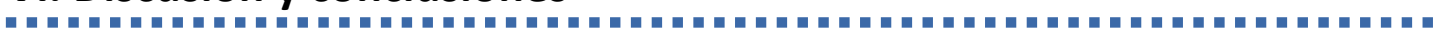

En este trabajo partíamos como objetivo fundamental analizar en qué medida el periodo de prácticas en centros escolares contribuye eficazmente para la formación en la innovación y reflexión del alumnado de Grado de Maestro/a de Educación Infantil.

Después de la recogida de datos y el análisis de las memorias del alumnado de prácticas podemos presentar algunas de las conclusiones. En primer lugar, se puede constatar que existe relación entre la metodología del maestro supervisor y el alumno de prácticas. El alumnado de prácticas suele reproducir el método empleado por su supervisor. Respecto a la metodología, podemos comprobar que se utilizan metodologías, en general, innovadoras.

Por otro lado, podemos observar que el alumnado apenas relaciona su periodo de prácticas con los conocimientos aprendidos a lo largo del grado. En la parte reflexiva de las memorias no se establecen apenas vínculos entre teoría y práctica, y el bajo porcentaje de referencias solo corresponde a asignaturas ( $y$ no se hallan conexiones con autores relevantes en la materia).

Por último, en lo referente a la actitud reflexiva del estudiantado sobre sus prácticas podemos decir que se encuentran en un nivel medio (nivel 3 de reflexión), en el cual se realizan críticas y valoraciones sobre su práctica profesional en el aula. Se confirma que existen algunas memorias (muy pocas) que alcanzan un nivel 4; dicho nivel recoge las propuestas de mejora por parte del alumnado. Para finalizar, no se ha encontrado ninguna de nivel 5, esto se debe a que, como decíamos anteriormente, ningún alumno hace alusión a enfoques científicos o a autores.

\section{Propuestas de mejora}

Se considera que una vez completado el estudio se deben poner en marcha una serie de acciones que conduzcan a la mejora de la calidad de las prácticas, sobre todo en lo referente a conseguir un mayor nivel de reflexión del alumnado durante este periodo. Entre algunas de ellas podemos destacar:

- Talleres de formación: "Cómo elaborar una memoria 10». Desde la Comisión de Coordinación de Prácticas de la titulación se ha propuesto un taller para el alumnado donde se orienta en la elaboración de la memoria de las prácticas contando como eje vertebrador un mayor nivel de reflexión así como pautas para la búsqueda de información bibliográfica.

- Cursos para tutores. Para trabajar de forma más coordinada se proponen unos cursos para los docentes universitarios que son tutores de prácticas. En dicho curso se comenta la estructura de las prácticas así como el calendario y, por otro lado, se presentan los resultados del estudio para reflexionar 
sobre el papel del tutor en la actitud reflexiva de su tutorando.

- Futuros proyectos de investigación. Para darle continuidad al estudio se plantea analizar más memorias y realizar estudios longitudinales para conocer si las acciones de mejora son concluyentes y si el nivel de reflexión del alumnado ha aumentado.

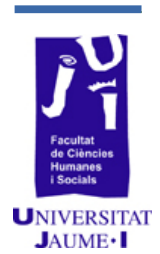

Estas propuestas se están articulando desde el Grupo de Innovación Educativa (GIE) creado en la Universitat Jaume I, actualmente convertido en un seminario permanente (SPIE), en el que, mediante un esquema de investigación-acción, se proponen y se analizan mejoras de manera continua. Tal y como explicábamos en un trabajo anterior (SánchezTarazaga, Mateu, Ruiz y Bertolín, 2015), este enfoque metodológico se representa en una espiral de ciclos formados por cuatro momentos clave y cada conjunto de iniciativas se apoya en el anterior:

1. Planificación: previsión de necesidades y apoyos para la ejecución del proyecto (septiembre-octubre).

2. Acción: puesta en práctica de las actividades previstas para la recogida de información (octubre-mayo).

3. Observación: seguimiento y evaluación de las actividades realizadas (diciembre-mayo).

4. Reflexión: sesiones para compartir las reflexiones y conclusiones sobre los resultados de este primer ciclo y hacer propuestas de mejoras futuras en los ciclos siguientes (mayojunio).

Por último, queremos señalar que la riqueza de este proceso de mejora reside en la pluralidad de las voces involucradas en las prácticas (alumnado, maestros de centros, personal de la Administración educativa) y en el seminario, de manera que su participación resultará clave para avanzar hacia una verdadera calidad del programa.

\section{Bibliografía}

BRETONES, A. B. (2013): «El Prácticum de magisterio en educación primaria: una mirada retrospectiva», Revista Complutense de Educación, 24(2), p. 443-471.

FERnÁNDEZ MARCH, A. (2006): «Metodologías activas para la formación de competencias», Educatio siglo XXI, 24, p. 35-56.

GubA, E. G. y Y. S. LINCOLN (1981): Effective Evaluation: Improving the Usefulness of Evaluation Results through Responsive and Naturalistic Approaches, Jossey-Bass, San Francisco. 
KORTHAgen, F. (2010): "La práctica, la teoría y la persona en la formación del profesorado», Revista Interuniversitaria del Formación del Profesorado, 68, p. 83-101.

LISTON, D. P. y K. ZEICHNER (1993): Formación del profesorado y condiciones sociales de la escolarización, Morata, Madrid.

Muradás, M., y M. I. Porta (2007): "Las memorias del Prácticum I de maestros de Educación Infantil: sobre qué reflexionan los alumnos», Buenas prácticas en el Prácticum, p. 977-990.

SÁNCHEZ, R y A. M. RAMOS. (2012): Compromiso docente y realidad educativa Retos para el maestro del siglo XXI, Síntesis, Madrid

Sánchez-Tarazaga, L., Mateu, R. , Ruiz, P. y García, R. (2015): «Avances y retos en la calidad del prácticum de maestros en la Universitat Jaume I: una mirada reflexiva», XIII Symposium Internacional sobre el Prácticum y las Prácticas Externas, Poio (Pontevedra), p. 1803-1806

ZABAlZA, M. A. (2004). "Condiciones para el desarrollo del prácticum», Revista de curriculum y formación del profesorado, 8 (2), p. 1-22

ZABALZA, M. A. (2011): «El Prácticum en la formación universitaria: estado de la cuestión», Revista de Educación, 354, p. 21-43.

ZEICHNER, K. M y D. P. LISTON, (1999): «Enseñar a reflexionar a los futuros docentes», Angulo, F., J. BARquín y A. I. PÉREZ (coord.) Desarrollo profesional del docente: política, investigación y práctica. AKAL, Madrid, p. 506-532. 


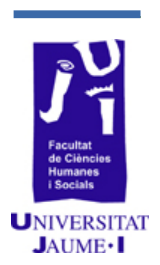

\section{Una historia de vida, una historia de educación}

Raquel Corbatón-Martínez corbaton@uji.es Manuel Martí Puig puig@uji.es 
En este trabajo se tratan las historias de vida desde la perspectiva de la investigación cualitativa. A través de este tipo de investigación se defiende el estudio de lo social a través de «lo social», es decir, estudiar la vida de un individuo a través de ella misma. Durante este trabajo se realiza una entrevista a una maestra transformándola en historia de vida a través de la cual la maestra desarrolla su «catarsis» valorando su propia vida y sacando sus conclusiones. Se pretende defender las historias de vida como una técnica principal en educación $y$, en este caso, como método para entender, descubrir y mejorar la práctica docente a través del recuerdo y la vida de una maestra. El trabajo empieza haciendo una conceptualización sobre las historias de vida y la investigación cualitativa. Posteriormente, se centra en las historias de vida en educación y la importancia de la investigación desde esta perspectiva. Después, se ejemplifica con un ejemplo de historia de vida de una maestra con la contextualización histórica y su interpretación. Para finalizar, se realiza una conclusión final sobre el trabajo.

Palabras clave: historias de vida, maestra, catarsis, investigación cualitativa.

\section{Introducción}

Durante mucho tiempo pensábamos (la gran mayoría) que, por una parte, la investigación era algo del campo únicamente de las ciencias experimentales y que no se podía transferir a otros ámbitos, y, por otra parte, que al hablar de historias de vida se hace referencia, únicamente, a la biografía de un individuo. Ambas afirmaciones son falsas y ambas se encuentran interrelacionadas ya que podemos considerar las historias de vida como un método de investigación cualitativo.

En educación se da gran importancia a la investigación ya que es un ámbito en el que tiene gran influencia la sociedad y en la cual se debe basar. Esta, a su vez, ha ido cambiando y evolucionando y por esto se necesita investigar y analizar la situación social, económica y psicológica del momento en el que nos encontramos para incidir y adaptar la educación de la manera más adecuada posible.

Por su parte, la historia de vida es una investigación mediante la que se tratan tanto los aspectos personales como sociales del individuo y diferente ya que se tiene en cuenta al sujeto, sus experiencias, opiniones y influencias. Las historias de vida, tal y como apunta Sewel (1990, citado por Nóvoa, 2003: 65) son "la forma que la gente construyó los acontecimientos al tiempo que los vivió». Estas propiedades biográficas no pertenecen solo a las personas sino a las colectividades: según Denzin 
(1989) «cada vida es una producción moral, política, médica, técnica y económica».

Es un método muy utilizado actualmente en la educación para adultos aunque también tiene su uso en las etapas inferiores, como puede ser para el aprendizaje y fomento de la lectura y la escritura. En este documento se analizan tanto las historias de vida como el método de investigación enmarcado en el tipo de investigación cualitativa, su importancia en la educación y, también, un análisis de una historia de vida de una maestra ya que, qué más adecuado en un trabajo de final de grado de magisterio que el análisis de la vida de una maestra, su vida, inquietudes, etc. Según Goodson (2004: 33) los relatos de los docentes pueden conectar de nuevo con «las historias de contexto». En este caso la maestra es la protagonista al igual que su historia, ambas imprescindibles y principales y mediante las historias de vida se da una "visión de la realidad más crítica y reflexiva» (Leite Méndez, 2011).

A lo largo de la narración conocemos profundamente a la maestra, la protagonista, así como la historia de su vida y el momento histórico que le tocó vivir. A partir del análisis y de la propia narración podemos entender sus actos, los hechos que tuvo que vivir y que formaron, así, su personalidad y su actitud, así como influyeron en su oficio de maestra. Debemos tener en cuenta, y como base, la frase de Weschenfelder (2009): "cuando narramos comprendemos cómo nos constituimos en la sociedad» para así comprender la importancia y la gran influencia que pueden llegar a tener las historias de vida.

Entendemos por una historia de vida el relato sobre la experiencia particular de un sujeto en sus situaciones de vida, en un escenario concreto. Las historias de vida se interesan por lo que cada persona piensa, siente y actúa, y cómo lo cuenta. Podríamos decir que es una biografía de la vida y con las opiniones y experiencias del individuo en la que se entrelazan unas y otras.

Si nos centramos detenidamente en las historias de vida, veremos que la principal herramienta que se utiliza para elaborarlas es la memoria que permite reconstruir de dónde venimos y en la cual pasamos por todas las etapas de su vida.

Seguidamente voy a comentar unos puntos que más tarde analizaré con detenimiento. Mediante las historias de vida realizamos un trabajo de investigación que también nos sirve para la docencia y que, según Thomas (1995), supone:

- Construir de un nuevo campo de estudio o área de especialización.

- Prestar interés en la investigación básica a la biografía como guía para la reflexión sobre la práctica y la experiencia.

- Introducir cambios en la formación docente a partir de la generación de diarios de la experiencia de formación, de manera especial en la escuela, la práctica de enseñanza y en la tutoría. De esta manera, se abría una nueva agenda para la 
formación inicial y continuada en la cual lo personal pasa a ocupar una parte fundamental del territorio de la formación.

- La consideración de que lo personal está profundamente vinculado a lo político, tanto en lo que se refiere las políticas de representación (visibilidad, invisibilidad) como en la importancia que adquiere la reivindicación del ejercicio de una democracia radical en la que los sujetos-ciudadanos recuperan su voz y la actuación que la democracia representativa les ha sustraído.

- La valorización del estudio de las narrativas como formas de representación de la realidad, frente a las representaciones basadas en modelos matemáticos o propositivos.

Así, también puede ser una herramienta correcta y muy provechosa para la formación de los docentes. Dicha herramienta pone énfasis en los aspectos emotivos y personales de los sujetos, no se centra solamente en los aspectos «científicos».

Por todo esto, las historias de vida son una «novedosa» herramienta, método o técnica que cada vez se utiliza más aunque se debe comentar que donde más éxito está teniendo es en la enseñanza de adultos. Esta es la causa por la que pretendo analizar las historias de vida, su importancia $y$, también, las repercusiones que pueden tener en la vida de los sujetos.

\subsection{Investigación cualitativa: historias de vida}

Las historias de vida están consideradas dentro de la investigación cualitativa. Dicha investigación, Según Goetz y LeCompte (1988), contiene unos diseños de investigación que extraen descripciones a partir de observaciones que adoptan la forma de entrevistas, narraciones, grabaciones, transcripciones de audio y vídeo, etc. Esta autora defiende que la calidad significa «lo real, más que lo abstracto; lo global y concreto, más que lo disgregado y cuantificado».

Según Denzin y Lincoln (2005), la investigación cualitativa es un campo interdisciplinar, transdisciplinar $y$, a veces, contradisciplinar. Es multiparadigmática en su enfoque. Taylor y Bogdan (1986: 20) defienden que dicha investigación es aquella que produce datos descriptivos: las propias palabras de las personas, habladas o escritas, y la conducta observable. Señalan, además, las siguientes características propias: es inductiva; el investigador el escenario y las personas desde una perspectiva holística y estos son considerados como un todo y es sensible a los efectos que ellos mismos causan sobre las personas que son objeto de su estudio; tratan de comprender a las personas dentro del marco de referencia de ellas mismas; suspende o aparta sus propias creencias, perspectivas y predisposiciones; para él todas las perspectivas son valiosas; los métodos cualitativos son humanistas; dan énfasis a la validez de su investigación, y para el investigador cualitativo, todos los escenarios y personas son dignos de estudio. 
Esta investigación implica que el diseño de investigación se caracterice por ser inductivo $y$, como ya se ha dicho, abierto, flexible, cíclico y emergente; es decir, surge de tal forma que es capaz de adaptarse y evolucionar a medida que se va generando conocimiento sobre la realidad estudiada (Bisquerra, 2004).

En la historia de vida, como investigación cualitativa, los datos provienen de la vida cotidiana, de las explicaciones, opiniones y reconstrucciones que el individuo lleva a cabo durante su vida (Ruiz, 2012). Es uno de los métodos de investigación descriptiva más puros y potentes para conocer el mundo social que rodea a las personas (Hernández, 2004).

Mediante este método, el investigador debe conocer cómo los individuos crean y reflejan el mundo social que les rodea. En las historias de vida la experiencia tiene vital importancia. Jones (1983) afirma que, de todos los métodos de investigación cualitativa, este es el que permite indagar mejor cómo los individuos crean y reflejan el mundo social que les rodea. Tradicionalmente era la manera de transmitir conocimientos y experiencias de vida de una generación a otra (Lucca y Berríos, 2009). Además, esta técnica ha sido aplicada a distintos campos del saber para demostrar cómo es la persona de manera personal y social, es decir, acumula información sobre toda la vida del sujeto y no solamente de su vida sino también de su relación con el contexto y las costumbres. En la narración, se sigue, normalmente, un orden cronológico y es totalmente individual. Para ayudarse en la investigación, el sujeto puede aportar grabaciones, vídeos, fotografías u otros elementos que le apoyen en su discurso.

\section{Objetivos}

El objetivo de este trabajo es defender las historias de vida como una técnica principal en educación. Las historias de vida se utilizan, en este caso, como método para entender, descubrir y mejorar la práctica docente a través del recuerdo y la vida de una maestra. Mediante la historia de vida, se analiza la situación en la que se encontraba la maestra, las diferencias y la evolución que se ha dado en la educación y las concepciones pedagógicas que se seguían en aquel momento.

\section{Las historias de vida en educación}

Las historias de vida, dentro de la investigación cualitativa, como ya sabemos, se desarrollan en educación en los diversos campos. Uno de los puntos fuertes que desarrolla esta técnica es la investigación de forma colaborativa, de manera que se realiza una reflexión compartida que nos da una experiencia que, posteriormente, nos puede llevar a cambios en la comunidad. En las historias de vida se observa la construcción de la identidad de los sujetos, se analiza y, a partir de este punto, se pueden 
sacar las conclusiones y reflexiones que llevan al cambio. A la vez, se observa la experiencia tanto personal como su papel y actuación en la sociedad y entorno en el que se encuentra ya que el ser humano es un ser social.

Otro aspecto en educación es el proceso de debate que se abre tras la realización y el análisis de una historia de vida a partir de las inquietudes e intereses de los participantes en el cual se revisan, modifican y analizan desde diferentes puntos de vista. Este hecho ayuda a crear unos alumnos críticos e íntegros.

El uso de esta metodología en educación, además, da pie al uso de diferentes técnicas como pueden ser las nuevas tecnologías. Mediante estas se puede pasar de tener las historias de vida de manera estática y limitadas en su trasmisión a poder aumentar sus posibilidades. Nos deja no solo centrarnos en el proceso de recogida de datos (que también se mejora), sino también en la comunicación de sus resultados. Otro punto a favor son los recursos, no solo narrativos, que podemos incluir en las historias de vida, como pueden ser los vídeos $u$ otros recursos interactivos.

Por otro lado, esta metodología, y es el ámbito donde se encuentra más extendida, se lleva a cabo en la educación para adultos y en la formación de docentes. En la formación de docentes, las historias de vida remarcan la importancia de la formación de la persona y la experiencia tanto individual como colectiva para la construcción del conocimiento profesional. En su uso en este ámbito existen dos dimensiones principales: la biográfica y la relacional. En la biográfica se pretende aumentar la fuerza del yo personal y social mientras que en la relacional se trasforman los estilos de vida y los aprendizajes colectivos. Las historias de vida en este ámbito ofrecen nuevas posibilidades ya que permiten que la experiencia de cada día sea una fuente de conocimiento profesional de los docentes (Rivas y Herrera, 2009; Hernández, 2004).

\subsection{La importancia de la investigación desde la perspectiva de las historias de vida}

Como ya se ha comentado, la investigación desde la perspectiva de las historias de vida abre un amplio abanico de posibilidades alternativas. Mediante este tipo de investigación se tiene en cuenta no solo lo que podamos averiguar sobre el sujeto o lo que nos cuente, sino también su punto de vista, sus razonamientos, reflexiones, sentimientos y puntos de vista sobre sus experiencias. Además no se centra solamente en la vida del sujeto sino también en su actividad como ser individual y social: se analiza su papel en la sociedad, cómo la sociedad le cambia y cómo él cambia a la sociedad ya que el ser humano es un ser social y ésta juega un papel importante en su vida.

Mediante este tipo de investigación cualitativa se obtiene y analiza información real con la cual se pretende mejorar la propia investigación y la realidad educativa. Es una investigación que pretende, así, acercarnos a 
la realidad en la que vivimos en cada momento. Según Álvarez (2012) «la investigación cualitativa consiste en descripciones detalladas de situaciones, eventos, personas, interacciones y comportamientos observables, incorporando lo que los participantes dicen, tal como lo expresan ellos mismos y no cómo lo expresaría el investigador».

En resumen, las historias de vida permiten describir, analizar y comprender la vida diaria del ser humano, la sociedad y el desarrollo de las comunidades o pueblos para así actuar en consecuencia y de la forma más adecuada posible en cada caso y en cada situación.

\subsection{Interpretación de la historia de vida de una maestra}

\section{a. Situación histórica en la que se encuentra}

La maestra en la cual se centra mi investigación, al igual que el de la mayoría de los maestros y maestras con los que he podido conversar, vivieron y trabajaron intentando cambiar la educación en un momento en el que estaban privados de libertad, tiempos en los que se vivía el miedo. Vivieron durante la dictadura de Franco en España y luego han podido ver los cambios que se han ido produciendo hasta nuestra época. No voy a centrarme tanto en la situación histórica general del momento, sino que mi atención va a centrarse, sobre todo, en la situación histórica de la educación, tema que nos ocupa.

Según se puede ver en la investigación realizada por Grana (2012), se considera que la vida en la escuela era «breve, existía una irregularidad en la asistencia, carencia de colaboraciones y ayudas, etc.". Además se pueden observar las grandes diferencias con la educación actual como la separación entre sexos, los castigos, la religión, etc. Otro aspecto muy observable en aquella época (y que poco a poco se está imponiendo también actualmente) era la existencia de la distinción de clases, la posibilidad de seguir estudiando según las «realidades económicas, sociales, ideológicas, familiares, culturales» en las que se movía el alumno. Es ahora, con una visión retrospectiva, donde aparecen las diferentes opiniones sobre la educación tanto de esta época como la actual. Así apunta que «algunos opinan que antes no había educación, sino que solo existía adoctrinamiento, mientras que otros han sacado la conclusión de que la educación era mucho mejor antes, etc.».

b. Interpretación de la historia de vida

A continuación se presenta una parte del análisis del relato de la maestra jubilada María Tena Marín, como ejemplo de historia de vida.

María Tena Marín nació en una época difícil, la Guerra Civil (19361939).

Me llamo María Tena Marín, nací el 13 de julio de 1937 en Castellón, en plena Guerra Civil. (Página 1, línea 1)

Esta época le marcó a lo largo de su vida, tanto en el ámbito personal como familiar. Era una familia que vivía en la pobreza que, por su poco poder adquisitivo, aprovechaba todo lo que estaba a su alcance. Desde 
pequeña sus padres le inculcaron dedicarse a la docencia, idea que apoyó el deseo por el aprendizaje. En sus primeros años de vida, vivía en una masía, un lugar humilde junto a sus padres y su hermana, a las afueras de la ciudad. Allí, la educación era de baja calidad en comparación con la ciudad de Castellón. Una de las cosas que tenían en común era el carácter religioso de las escuelas, debido a que el régimen franquista implantó el catolicismo como única religión, era un estado confesional.

Mis padres, Alfonso y Lola, formaron una familia pobre pero con mucha dignidad. Desde siempre, mis padres me implantaron el afán de aprender el deseo total, por parte de ellos y por parte mía, de convertirme en una persona de bien. Era el ideal plasmado en mi conciencia, desde el primer instante que tuve razón. Al mismo tiempo, a medida que crecía, comprendí que tenía que labrar un porvenir, ganar las algarrobas [...] porque me decían que cada algarroba era una hojita de un libro. Vivíamos en una masía y, a mis cuatro años, mi padre y mi madre ya me llevaban a una escuelita de una señora un poco más cultivada que nos hacía cantar y poco más. Allí aprendí el Dios te salve María pero, antes de cumplir los seis años, mi madre se dio cuenta de que tenía que buscar el porvenir de sus hijas en la Escuela Nacional. (Página 1, línea 2)

El instituto Francisco Ribalta fue el último instituto donde ingresó. En él logró su meta: conseguir ingresar en la escuela de magisterio.

Realicé en el instituto Francisco Ribalta los cuatro años de bachiller que se exigían para pasar a la escuela de magisterio, así, el 2 de octubre de 1952 aprobé el examen de ingreso en la normal, la de magisterio. (Página 2, línea 1)

A María Tena le marcaron las figuras de los conocidos pedagogos Pestalozzi y San José de Calasanz. Compartía con ellos su forma de pensar. Para ella la educación era la dirección racional de la evolución natural de las facultades específicas del hombre, su gran labor humana, eran unas personas de bien y sentían un gran amor hacia los niños, algo que ella consideraba muy importante. En aquella época la hambruna estaba al orden del día y gracias a gente como ellos, personas que no se podían pagar los estudios, tuvieron la oportunidad de recibir una mínima educación.

Nunca, nunca, nunca olvidé la definición de un pedagogo, Pestalozzi, que nació en el año 1746 y murió en el 1827. La definición decía: «La educación es la dirección racional de la evolución natural de las facultades específicas del hombre». La vi tan completa que me hizo pensar mucho, razonar y reflexionar. Fue también un punto de partida para mí. Luego, también la historia de otro pedagogo, San José Calasanz, llegó a mi alma, porque cuando me enteré leyendo de que este señor, viendo que los pobres no tenían escuelas, y los ricos sí, unos institutriz y otras escuelas pagando, pobres abandonados por esas calles de Roma, se concienció de que algo tenía que hacer y él, que era un monje, un fraile, junto con otros compañeros allí montaron su escuela en el patio de la escuela; y fue a más. Y son las escuelas Pías, por cierto, que es el patrón de los maestros nacionales, San José de Calasanz. Este señor me impresionó incluso la anécdota de que tenía tanto amor a los niños que cuando explicaba, mejor dicho, cuando se preparaba las lecciones en su casa, porque eso sí, un maestro no puede encararse con los niños sin preparárselo... Habrá 
una preparación remota, pero hay una próxima, que es en el momento de antes. Él, cuando se preparaba la lección para los niños, se arrodillaba y de rodillas se la preparaba, de una devoción tan enorme que tenía a los niños. (Página 2, línea 26)

Antiguamente, a la edad de los 19 años se obtenía el título que permitía ejercer de docente. El ciclo académico constaba de siete años, de los cuales los tres últimos correspondían a la carrera de magisterio. Su perseverancia y valentía le llevaron a oponerse a sus padres, quienes querían que opositara, ella anhelaba ejercer de maestra y no tuvo reparo para trabajar en una escuela rural.

El título de maestra lo obtuve el 31 de agosto de 1956, recién cumplidos los 19 años. Aquí lo tenéis. Con el título de maestra en la mano, mis padres pretendían que me quedase en casa... iestudiando, estudiando! Para opositar y ganar una plaza fija en el Ministerio de Educación y Ciencia. Yo no lo consideré oportuno. Por tres razones: primera, porque anhelaba ejercer de maestra en una escuelita pequeña, rural, que era a lo que podía aspirar, interinamente. Vertí allí mis ilusiones, mantener contacto y amor a los niños. Eso yo necesitaba sacarlo. Aprender como maestra, con la práctica del día a día. (Página 2, línea 3). En mi familia éramos muy pobres, yo también lo tenía en cuenta, hacía falta dinero. Y además no se sabía cuando vendrían las oposiciones, tardaban año y medio o dos años. Total, que sin consentimiento de mis padres, yo lo solicité, solicité una plaza de interina y el día 24 de septiembre de 1956 mi padre cogió de mi brazo y me llevó a Zucaina, a tomar posesión de la Escuela Nacional de niñas. (Página 3, línea 11)

En su labor como docente los primeros años fueron muy duros, por el hecho de que era una persona muy jovencita, con poca experiencia. Eso le produjo muchas desilusiones y decepciones que pagó con los niños, prometiendo que cumpliría como maestra, trabajaría, pero, no se enamoraría de ellos. A medida que pasó el tiempo maduró y comprendió que la clave de la docencia era el amor hacia los niños, porque sin él ni puedes ser buena maestra, ni puedes disfrutar. Al ser una persona tan luchadora, logró conseguir todo lo que se proponía, tal era su amor por la docencia que incluso fue a la Delegación para luchar por sus derechos y reclamar lo que creía que a ella le pertenecía: su puesto de maestra.

El 14 de diciembre, de forma aplastante, una maestra propietaria provisional, por consorte, porque su marido vino destinado como veterinario, me desplazó de forma agresiva. Subió a la escuela, yo digo: «¿quién viene a estas horas?». Era un piso, primer piso, y entonces entra y dice: «ihaga el favor de salir que esta escuela es mía!». Como comprenderéis, yo, con mis 19 años, me cogí un berrinche de muerte, me harté a llorar y las niñas también. Y tomé una reflexión personal: jamás me enamoraría de los niños. Cumpliría como maestra, trabajaría, pero, no me enamoraría de los niños, no entregaría mi almita porque me la habían destrozado. No estaba dispuesta a seguir sufriendo mientras durase mi voluntario peregrinaje de interinidad, hasta que llegase la plaza mía. Eso pasó antes de navidad, y yo que fui un poquito valiente me defendí. Fui a la Delegación y dije que no había derecho a lo que me pasó. Por lo menos haberme avisado, porque eso de subir... Bueno, total, que, inmediatamente, en diciembre, el día 24 , ya me dieron una plaza de interina en Villavieja. (Página 3, línea 21) 
Era tal el amor y la devoción por la escuela y sus alumnos, que nunca

la cambió por nada en el mundo, ni aun teniendo un trabajo mejor cualificado con el que podía ayudar a su familia y tener una estabilidad económica. Trabajó en la Telefónica solo durante tres meses, porque la escuela le llamaba.

Me examiné para entrar en teléfonos, porque lo solicité al terminar la carrera. (Página 5, línea 11) [...] Me aprobaron y me entró pánico, porque mi alma ya estaba dividida entre la escuela, que era como la canción «del corazón partido», yo ya tenía el corazón partido. "¿Dónde voy aquí o allá?». Y unos me dijeron: «iEstás loca si te dejas la Telefónica en Castellón!». Cada uno me decía una cosa; la mayoría, Castellón porque cobraba más y estaba delante de mi casa. Vivía en la ronda Mijares y la Telefónica estaba en la plaza del Rey, al empezar. Cobraba más, un empleo de lujo y por eso no me comprendían. (Página 5, línea 16) [...] Ya cuando aprendí lo que tenía que aprender, me vio un día doña Marina que era la jefa, y me dijo: «Maruja, ¿verdad que trabaja a gusto?». Y yo le contesté con todo el aparato: "Sí, señora, pero si las clavijas se convirtieran en niños, mejor!» (Página 5, línea 29) [...] «Pues la verdad, hija, que no me puedo dividir, si me pudiera dividir me quedaba, me duele muchísimo, pero me voy, ime llama la escuela, me llama!». (Página 5, línea 34).

A la hora de trabajar es importante la relación entre las personas. Es normal que haya compañeros con los que te puedas llevar mejor, pero con sintonía y buen ambiente es como mejor se lleva a cabo el trabajo. De esta manera, habrá una mayor compenetración y será más ameno. Ella utiliza esta sintonía con los compañeros para guiarse en qué centro debía trabajar en Almazora.

En Almazora, en cuanto a experiencias, he pasado muy buenas, muy tristes, he pasado de todo. Era un barrio muy pobre, porque cogí ese grupo, pero habría podido coger el del Embajador Beltrán, pero en el colegio Hernando Vilar, tenía más cantidad de amigos y me llamaban: «iMaría, ven aquí!». Estaban cuatro amigos. Tenía gran cantidad de amigos. En el otro no tenía tantos y por eso elegí ese, pero era el más exterior y el más de barrio, como si dijéramos. (Página 6, línea 26)

Durante su experiencia como maestra, ha vivido buenos y malos momentos, pero ella siempre se queda con los bueno y con el cariño que le ha cogido a sus alumnos durante esos años. Es una persona muy implicada en la escuela ya que se preocupa por la vida de los alumnos, por los problemas que tienen, por su bienestar... Siente que el maestro es una persona muy cercana a los alumnos y que, por tanto, los influye en su comportamiento mucho más de lo que la gente puede percibir. Piensa que un maestro puede llegar a observar, más que los padres, cuándo un niño tiene algún problema. «A lo mejor ves que un niño está malito y lo ves antes que su padre. Un maestro desde aquí lo ve todo, es una maravilla. Pero tampoco estás empotrada todo el día a una silla, pero un rato sí porque desde la silla se ve todo». 
Allí he tenido el disgusto más grande de mi vida porque una criaturita a la que yo quise mucho era un «pernales». Ya lo veía desde que era pequeñito. Una noche, incluso soñando, soñé lo que luego fue verdad. No es que fuera una premonición, es que los maestros ven mucho cariño, mucho. A lo mejor ves que un niño está malito y lo ves antes que su padre. Un maestro desde aquí lo ve todo, es una maravilla. Pero tampoco estás empotrado todo el día a una silla, pero un rato sí y desde la silla se ve y se hace mucho porque desde la silla se ve todo. Yo he estado en Almazora con esta mano dando lección y con esta otra corrigiendo. Con una dando lección a la fila de "castilleros» y con la otra mano corrigiendo. (Página 7, línea 2)

La enseñanza que solo persigue la reproducción de los contenidos por el alumno, que no le plantea situaciones que hagan necesaria su iniciativa y creatividad, no es lo suficientemente útil para conseguir un buen aprendizaje. También se necesitan métodos de razonamiento en los que el niño utiliza sus recursos ya aprendidos para obtener otros mediante la razón. Es decir, el profesor debe actuar como orientador, facilitador o mediador del aprendizaje del estudiante.

Una vez explicados y mandados los problemitas me dirigía a la pizarra para que alguien lo hiciera. Primero cogí a los más tontos para que me lo explicaran. Después a todo el mundo que los entendieran. Al final siempre lo llamaba a él porque sabía que él lo tenía bien. Entonces los demás niños lo podían escuchar aunque me lo dijera así tipo confesión. Al final lo explicaba él o yo, u otro que lo hubiese hecho bien en la pizarra. Era un tostón, pero lo hacía muy a gusto y lo encontraba muy didáctico. (Página 7, línea 31)

Nombra como metas u objetivos la formación de personas, le da mucha importancia a la buena educación moral. A partir de este momento ya se puede completar una persona con más conocimientos y crear una relación más afectiva. Se centra mucho en el cariño, en que haya un acercamiento más afectivo y así poderse acercar más para mejorar el aprendizaje, incluso jugar aprendiendo.

Mis metas, mis objetivos, siempre os diré lo mismo, son que haya buenas personas, eso lo he tenido muy claro. Ante todo, crear buenas personas y luego ofrecerles el máximo de conocimientos y entablar amor. (Página 10, línea 14)

La importancia que le da a la enseñanza se basa sobre todo en enseñar la capacidad de aprender por sí solos. Aunque dice que enseñó todos los valores morales posibles, comenta que culturalmente prefirió aumentar la capacidad de aprendizaje o absorción de estos elementos, ya que estos conocimientos se los busca uno siempre que quiere, manteniendo así la mente abierta. Por lo tanto si rechaza este aprendizaje y mantiene una mente cerrada se limitará a ser un estudiante que se basará puramente en la memoria y no en el entendimiento, que es lo que verdaderamente importa.

La enseñanza si, de moral y eso todas, pero enseñanzas de cultura he preferido ampliar, que la cultura se la busca uno siempre, quien la quiere la busca, si la mente la tiene abierta, claro. Si la tiene cerrada se limitará a ser un autómata y un estudiante de memoria y punto. (Página 10, línea 30) 
Las escuelas rurales estaban poco avanzadas y limitadas en cuanto a conocimientos. Como dice, lo básico y más importante era leer y escribir, y en muchos casos centrarse en matemáticas y así aprender a contar y dividir, pero muchas más cosas no se podían llegar a dar. La causa de estas limitaciones era la pobreza, viviendo en una sociedad mayoritariamente agrícola, la enseñanza en esa época, que era todo un lujo, se limitaba a lo básico y esencial, dejando aparte gastos o tiempo, tiempo que se usaba en lo verdaderamente importante, en lo que les daba de comer: el campo y el trabajo. Todo esto hacía que el desarrollo cultural y social fuera mínimo y la analfabetización predominó en gran parte de la sociedad durante décadas. Ahora mismo la situación es muy diferente, ya que para lograr un buen empleo y un salario en condiciones tienes que seguir una enseñanza de calidad y poseer los máximos estudios posibles.

En la escuela rural lo principal era eso, los niños que aprendían a leer y escribir. Y contar y dividir que solían llegar, pero muchas cosas más no, era imposible, además solo estuve dos años, no es una labor que puedas hacer demasiado. (Página 10, línea 34)

Cuando habla de los candiles y las chimeneas, demuestra la diferencia en cuanto ha remedios para el frío, o cualquier otro problema, ya que entonces todo era mucho más elaborado y manual, ahora, en cambio, aunque hay chimeneas, predominan los aparatos eléctricos como radiadores. Las infraestructuras de los colegios eran precarias. Lo primero que se le viene a la cabeza son las ratas, muestra de la suciedad y pobreza de esa época, llena de epidemias y enfermedades comunes entre la sociedad. Durante la guerra y postguerra el destrozo y la suciedad se hicieron con gran parte del país, hecho por el cual los hongos, ratas... estaban por todas partes. En su experiencia nos muestra como una simple chimenea podía ser básica para pasar una noche agradable. Ahora la mayoría de casas tienen su propia fuente de calor para los días fríos, y en su época, como le ocurre con su compañera, en ocasiones se tenía que trasladar a otras viviendas con el simple objetivo de no pasar frío durante la noche.

La infraestructura del colegio, pues lleno de ratas, ya os lo conté. Dos partes, aquí tenéis la fotografía, si la queréis poner ahora, o sino la ponéis luego. Un edificio con dos partes, una la casa del maestro y la otra la escuela. Yo me he pasado la vida dentro de la escuela, yo allí con mi mesa, iba a decir con mi estufita pero allí de estufita nada, qué va. (Página 11, línea 28)

Nombra dos organizaciones: la Cruzada Misional y la Educación Católica, lo que nos vuelve a señalar la directa influencia de la Iglesia más conservadora en la educación de su época, todo esto, lógicamente le ha repercutido en la carrera docente. Otro punto de vista interpretativo más social y general de esta educación dada en esa época, es el fuerte sentimiento religioso y conservador de esta generación. 
Era muy importante, porque ella se preocupo más de recoger toda la juventud, o sea la juventud de mujeres iban a la sección femenina, incluso tenían que hacer el servicio social. Las chicas iban a una fábrica pero fuera de horas tenían que ir a hacer el servicio social. Una servidora llevó el servicio social en Castellón, en la escuela Cervantes, y otro año, a lo mejor no eran cursos de medios años, a lo mejor serían medios meses, mientras no tenia escuela me apunté a uno de esos, con las chicas mayores de las fábricas en la escuela Herrero, a esos dos colegios fui yo a enseñar el servicio social a las chicas, y como maestra también tenías que enseñar el servicio social. Que te daban una placa que ponía S. S., y nosotras decíamos "Siempre Solteras", aquella época no era la de ahora tampoco, eso de ser soltera parecía como si alguien mirara a una. Ahora no es igual, ahora una es soltera si le da la gana, que ha cambiado mucho todo. La cuestión es que eso es la sección femenina. Luego también había otras cosas como la Cruzada Misional, yo me apuntaba a todo y nadie me enseñó nada malo. íbamos a un edificio, que hoy en día creo que es el Instituto de la Mujer, en la calle donde está la Casa de la Cultura, pues otra calle que baja por allí; pues allí íbamos y nos hacían sermones, venía un cura misionero, una monjita... nos contaba cosas, a mí no me gustaban y yo entendía que todo era para aprender, nadie me enseñó nada malo. También me apunte a educación católica, no me quisieron, porque yo soy un poco rebelde y me dijeron que en verano con medias y yo dije: «No, eso no». Y me dijeron: «ah, pues no puede ser», y yo me lo tomé a risa. Es el reglamento, pues no. (Página 14, línea 4)

Al mostrarnos su visión sobre la finalidad de la educación, se ve que tiene una mentalidad abierta en cuanto a las culturas y a la diversidad, con el objetivo de conseguir un cerebro con ganas de aprender de todas las culturas, de todas, y ser una persona lanzada en todas las direcciones. En definitiva, para ella era necesario formar a personas capaces de desenvolverse en la sociedad y superar su defecto. De lo que se interpreta que tiene una mente abierta y progresista pese a sus influencias.

Yo creo que hay que educar, estoy totalmente convencida, cariño, para ser buenas personas eso es lo primordial, y luego tener un cerebro abierto para todo, un cerebro con ganas de aprender de todas las culturas, de todas, y ser una persona lanzada en todas las direcciones. Y para machacar los defectos humanos como son la envidia, los celos, las ambiciones... eso lo tengo más claro que el agua, eso lo tengo claro. (Página 14, línea 12)

Los maestros de esa época tuvieron que enseñar a generaciones más mayores que no sabían ni leer ni escribir, gracias a su labor el analfabetismo está casi erradicado hoy en día:

Hicieron campañas, entonces había campañas de alfabetización, pero para eso venían unos maestros de noche, eso en Villafamés lo vi, educación de adultos le llamaban, eran otros maestros, cariño. En Villafamés, donde he dicho lo de la universidad y todo, pues también había un compañero (que hace poco se murió) subía con su amoto ya, a dar clase de alfabetización. (Página 16, línea 31)

Es importante conocer multitud de métodos pedagógicos que nos pueden ayudar en nuestra tarea educativa. Como es el caso del método 
onomatopéyico de Sanabria, que le ayudó mucho a enseñar las letras y leer en parvulitos, que aún lo recuerda y conserva sus guías. De esto podemos comprender que, en las edades más tempranas, una de las mejores formas de aprender es mediante juegos lúdicos.

El método utilizado era el método onomatopéyico de Sanabria [...] consistía en que cada letra tiene un sonido y un movimiento, pero tengo miedo de decirlo mal y no quiero decir ninguno. Lo utilicé con los parvulitos sobre todo y cuando menos me di cuenta allí sabía leer todo el mundo, o sea, fantástico. En Almazora, como era un barrio muy malo, cuando tuve primero, segundo y tercero, venían sin leer y apliqué el método. [...] Jugando, jugando, en párvulos, cuando me di cuenta allí acababan todos leyendo. Decían que no tenía que correr, pero es que aprendían a leer sin darme cuenta. Muy bonito, muy bonito. Método onomatopéyico de Sanabria. (Página 18, línea 10)

Se refleja su idea en cuanto a cómo ha cambiado todo con el tiempo, entre otras cosas la educación. En la época en la que trabajaba ella era un icono cultural del pueblo, al igual que el cura, por la gran importancia que se le daba a la religión. La importancia de los maestros se debe a que estos son los que enseñan a recoger los conocimientos, así que no enseñan cultura, sino que enseñan a aprenderla; "aquello de no coger peces, enseñarles a pescar». La importancia de los maestros se ha reducido; esto se debe a que hay más, a la vez que han aparecido personajes con más altos cargos.

El maestro no tiene la misma personalidad hoy que años atrás. Antiguamente, un maestro en un pueblo era muy importante porque era un foco de cultura, él y el cura, porque los médicos se dedicaban más a otras cosas. En realidad, en los pueblos, el maestro era muy importante y muy responsable. Actualmente, ha cambiado mucho, gracias a Dios. El maestro es parte de la cultura de los niños, por eso creo yo que hoy en día un maestro más que creer que ofrece la cultura debe preparar a los niños para que la tengan, para que la sepan buscar, aquello de no coger peces, enseñarles a pescar. Pues enseñarles a educarse, a que vean las ventanas abiertas y que cojan todo lo que pasa, esa es la labor de hoy en día. Por tanto, ha cambiado mucho. (Página 18, línea 29)

\section{Discusión y conclusiones}

Las conclusiones del trabajo se presentarán desde una doble perspectiva. Por un lado, me centraré en la entrevista realizada, he puesto la vista atrás en el tiempo. A través de esta he obtenido más información sobre la educación y las diferencias entre la enseñanza actual y la de épocas pasadas viendo detalles sobre los que no había tratado nunca.

El principal consejo que he sacado de esta entrevista, y que en un futuro, como docente, usaré, ha sido el gran cariño y amor que siempre se debe ofrecer a nuestros alumnos para obtener buenos resultados. Sé a ciencia cierta que esta profesión es totalmente vocacional, lo que implica que hay que dedicarse a ella en cuerpo y alma. Así, el respeto no se impone, sino que se gana a través de nuestros actos. 
Por otro lado, su visión de la educación me ha hecho reflexionar respecto a la misión que tenemos como docentes: no se basa solamente en impartir conocimiento, sino también en crear personas críticas, con ambición y ganas de perfeccionarse y de ayudar a los demás. También defiende como pilares básicos los agentes de socialización: la escuela y la familia. Ambos influyen en los procesos de aprendizaje por lo que se necesita una buena comunicación entre ellos y también tienen como meta formar a personas para que, en un futuro, puedan convivir en sociedad.

Después de haber hecho la transcripción y la posterior interpretación he podido comparar los dos tipos de escuela, la tradicional y la actual, y he visto las grandes diferencias entre las dos. Llegados a este punto, y en el momento actual en el que nos encontramos, deberíamos valorar más todas las ventajas de las que disponemos, como puede ser la tecnología que tantas puertas nos abre.

Esta maestra entrevistada, aún viviendo en esa época tan difícil, no fue una maestra propiamente dicha de la escuela tradicional. Su metodología se decantaba por la participación en las clases: eran los niños quienes explicaban la lección. Los niños eran los protagonistas. Todos participaban, ya que la colaboración y la ayuda mutua hacen que todos los alumnos y alumnas avancen más rápido.

Era una profesora cercana, no autoritaria, que considera que la escuela está abierta y la vida entra en ella. Esta entrevista me ha servido para darme cuenta de la precaria situación en la que esta maestra trabajó $y$, sin embargo, con todo en su contra, defendió los ideales de una escuela libre y participativa, que hoy tanto buscamos y defendemos.

Como conclusión de este trabajo, se debe considerar, en primer lugar, la influencia y el efecto que tiene la historia de vida en la propia historia de vida. Mediante la entrevista hecha a la maestra se ha podido comprobar toda la documentación previamente estudiada. En primer lugar, ella misma ha ido haciendo un pequeño resumen de su vida, ha ido pasando por todas las etapas que ha vivido centrándose más o menos en los hechos que pretendía destacar o que no. Al ir contando su propia historia, y después poder leerla, se ha producido la dicha «catarsis» en la cual se ha visto como espectadora de su propia vida y a partir de este hecho ha sacado sus propias conclusiones.

Desde siempre, lo lógico era recordar y actuar de acuerdo con tus recuerdos, con la memoria colectiva. Es aquí donde entra la historia de vida y su uso. Dejando a un lado toda la parte «teórica» de las historias de vida, de la historia de vida como investigación, me atrevo a decir que es un campo del que se pueden sacar muchas y distintas posibilidades, que aunque, sobre todo, se use en el campo de la educación para adultos, o bien en la universidad -porque evidentemente ha habido mucho más camino recorrido-, veo muchas alternativas en su uso. Sería de otro estudio ver sus usos en etapas inferiores, intentando que individuos menores, con «menos» recorrido de vida, realizaran esta catarsis. Tal vez 
en estas etapas se pudieran evitar muchas cuestiones que en un futuro se pudieran dar.

Aun así, centrándome en el trabajo realizado, la entrevistada y yo hemos hecho un recorrido juntas, es decir, hemos pasado del desconocimiento de una técnica, como son las historias de vida, hasta vivirlas en nuestra propia carne: vivir el recuerdo, los sentimientos, el cambio que se realiza tras echar la vista atrás. Para mí ha quedado bastante claro que "somos lo que hacemos» y con esta pequeña «investigación» lo he podido vivir en mi propia carne. Ver las reacciones de esta maestra tras recuperar sus recuerdos y analizarlos, cambiar su actitud, no tiene ningún precio.

Así, como ya he comentado, me ratifico con una cita que he encontrado durante la realización de este trabajo y que tanto me ha sorprendido por la identificación y la explicación que he visto en ella sobre todo lo que he estado estudiando (Esteve, 2010: 18):

Durante siglos, hemos educado a nuestros hijos sin los consejos de la Pedagogía o la Psicología, que son ciencias relativamente recientes; y para educar a sus hijos, las personas se han basado en el sentido común y en la memoria de la experiencia acumulada a lo largo de sus vidas. (...) Educar es, pues, un compromiso con la memoria; con nuestra memoria individual y con la memoria colectiva que se transmite a través de la tradición oral, de la cultura y de la Historia.

\section{Bibliografía}

Álvarez, M. y E. De la Cruz (2012): «La investigación biográfica, en el marco de la investigación cualitativa», Revista Universitaria de Investigación y Diálogo Académico, 8(3).

BISQUERRA, R. (2004): Metodología de la investigación educativa, Editorial La Muralla, Madrid.

DENZIN, N. (1989): Interpretative Biography, Sage, London.

Denzin, K. Y Y. S. LINCoLn (2005): The Sage Handbook of Qualitative Research, Sage Publications, Inc., Londres.

ESteVE, J. M. (2010): Educar: un compromiso con la memoria, Ediciones Octaedro, Barcelona.

Goetz, J. P. y M. D. LeCoMPTE (1988): Etnografía y diseño cualitativo en investigación educativa, Morata, Madrid.

Goodson, I. F. (2004): Historias de vida del profesorado, Octaedro-Eub, Barcelona.

GranA, I. (2012): "La educación en tiempos de Franco" a través de las historias de vida", III Foro Ibérico de Museísmo Pedagógico, V Jornadas Científicas de la SEPHE (483-493). 
HeRnÁndeZ, F. (2004): «Prólogo. Las historias de vida como estrategia de visibilización y generación de saber pedagógico», en Goodson, I. F. (ed.): Historias de vida del profesorado, Octaedro-Eub, Barcelona.

JONES, G. R. (1983): "Life History Methodology», en MorgAN, G. (ed.): Beyond Methods, Editorial Bilbao, Buenos Aires.

LeITE, A. E. (2011): Historias de vida de maestros y maestras. La interminable construcción de las identidades: vida personal, trabajo y desarrollo personal (tesis inédita de doctorado). Facultad de Ciencias de la Educación, Departamento de Didáctica y Organización Escolar, Universidad de Málaga.

LUCCA, N. y R. BerRíos (2009): Investigación cualitativa. Fundamentos, diseños y estrategias, Ediciones SM, Puerto Rico.

NóvoA, A. (2003): «Textos, imágenes y recuerdos. Escritura de nuevas historias de la educación", en POPKEWITZ, T. S. y otros (coord.): Historia cultural y educación. Ensayos críticos sobre conocimiento y escolarización, Pomares Corredor, Barcelona.

Rivas, J. I. y D. HerRera (2009): Voz y educación. La narrativa como enfoque de interpretación de la realidad, Octaedro, Barcelona.

RuIz, J. I. (2012): Metodología de la investigación cualitativa, Universidad de Deusto, Bilbao.

TAYLOR, S. J, y R. BOGDAN (1986): Introducción a los métodos cualitativos de investigación, Paidós, México.

THomAs, D. (1995): Teachers' Stories, Open University Press, Buckingham/Philadelphia.

WESCHENFELDER, N. V. (2009): "Historia de vida y memoria de los maestros del movimiento sin tierra de Brasil: recuerdos de la niñez, escuela y proceso de formación», Revista de Didácticas Específicas, 1, p. 167-190. 


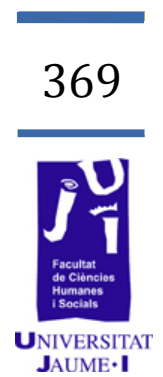

Escola i mas: records i vivències

Andreu Serret Segura inal193008@uji.es 
El treball que es presenta mira de donar veu a l'experiència viscuda pels xiquets i xiquetes dels masos de la comarca dels Ports, una zona d'alta muntanya situada al nord de la província Castelló, durant els anys trenta i quaranta del passat segle. Per tal de fer-ho, hem utilitzat les històries de vida, una tècnica d'investigació qualitativa que consisteix en l'anàlisi del relat d'una persona a partir d'aquells esdeveniments $i$ vivències més destacats de la seua vida. En el nostre cas, ens basem en l'experiència de Leonila, una dona de vuitanta-tres anys que va nàixer i va viure en un mas del terme de Morella, municipi on hi ha més de trescentes seixanta masos al llarg i ample del territori.

A partir del relat de Leonila podrem comprendre quins eren els principals factors i circumstàncies que condicionaven l'educació de l'època. Les diferents tasques del mas, les dures condicions meteorològiques de la zona o el convuls període polític que s'esdevenia en aquell moment són alguns dels principals eixos entorn dels quals girarà aquesta investigació.

Així doncs, gràcies a les històries de vida ens aproximarem a una realitat amb una gran riquesa en l'àmbit educatiu, però també en l'àmbit històric, social o cultural i que està a punt de perdre's en l'oblit.

Paraules clau: experiència, xiquets i xiquetes, masos, comarca dels Ports, històries de vida, educació.

\section{Introducció}

La investigació que ara ens ocupa naix amb la intenció de donar resposta a diferents qüestions entorn del nostre passat educatiu més proper, de conèixer quins eren els factors $i$ les circumstàncies que condicionaven l'educació de la primera meitat del segle passat. Concretament, s'aprofundeix en l'essència de l'educació a zones de muntanya com és el cas dels Ports i es tracta de donar veu a un tipus de realitat educativa que està a punt de perdre's en l'oblit.

Per tal de portar a terme aquest treball, utilitzarem l'eina de les històries de vida. Aquestes constitueixen una mena de biografia de la vida, on les experiències i les opinions de l'individu en qüestió s'enllacen $i$ es combinen les unes amb les altres. En aquest sentit, podem dir que la memòria adopta un paper protagonista, ja que gràcies a aquesta tenim accés a una gran quantitat d'informació. Pel que fa a la metodologia de treball de les històries de vida, cal assenyalar que aquestes s'emmarquen dins de la investigació qualitativa.

Per tant, la història de vida es converteix en un mecanisme que ens aproxima a la realitat educativa dels masos de Morella i ens ofereix la possibilitat d'analitzar-la, interpretar-la i extraure'n conclusions. 
Precisament, el fenomen de la interpretació, ens obri un ampli ventall de possibilitats en el camp de l'educació, ja que dóna peu a distints punts de vista $i$ en conseqüència es promou el sentit crític entre els alumnes que tant ens esforcem a promoure.

D'altra banda, per tal d'entendre millor aquest treball, oferirem una breu descripció de la situació educativa de l'època a l'Estat espanyol. L'any 1931 es proclamava a Espanya la Segona República i amb ella naixia la constitució de 1931, una constitució que contemplava reformes de caire educatiu. Les noves lleis educatives posaven fi a la llei més longeva de tots els temps en l'Estat espanyol, la Llei de Moyano, que es trobava en vigor des del 9 de setembre de 1857.

En la mateixa direcció, també trobem una descripció, o més ben dit, una contextualització geogràfica de la zona en la qual se centra la nostra investigació. Com hem dit, el nostre treball gira entorn de la situació educativa als masos de Morella per la qual cosa es fa referència a la manera com es trobava estructurat el terme i quines són les principals característiques que el descriuen. En aquest sentit és interessant destacar que la protagonista de la història de vida pertany a una zona concreta d'aquest terme. Es tracta d'una dona de vuitanta-tres anys, que va viure, va créixer i va anar a l'escola en una zona coneguda com els Llivis, caseriu del terme de Morella, que per uns motius o altres sempre ha estat lligat amb l'educació.

Finalment, en l'última part del treball es fa referència a la nostra experiència investigadora gràcies a les històries de vida. A partir d'aquesta, es fa un anàlisi i una interpretació d'allò extret al llarg de l'entrevista i se n'extrauen unes conclusions que ens ajuden a conèixer i a comprendre més bé com era la realitat educativa de les zones rurals ara fa setanta i vuitanta anys.

\section{Contextualització històrica}

La primera llei a partir de la qual a l'Estat espanyol es regulava tot allò referent a l'ensenyament i els diferents graus educatius va ser la Llei Moyano, publicada a l'any 1857 . Sobre el paper convertia l'ensenyament primari en universal al mateix temps que determinava la llengua castellana com a l'única llengua a estudiar.

Pel que fa l'índex d'analfabetisme a Espanya a principis del segle $x x$ era escandalosament elevat comparat amb el dels països de l'Europa occidental, ja que dues terceres de la població eren pràcticament analfabetes. L'escolarització dels xiquets i les xiquetes es feia en edificis vells, aules amb importants deficiències d'il/luminació i la preparació dels mestres era deficient. A més, un elevat nombre de xiquets no assistien a l'escola per manca d'edificis escolars, desinterés del pares, necessitat del treball infantil familiar o misèria econòmica. D'altra banda, l'escassetat dels pressupostos municipals i estatals dedicats a l'ensenyament feia que l'educació es trobara en una situació absolutament precària al començament del segle xx. 
D'aquesta manera, podem conèixer millor quin era el context en què es trobava la situació educativa espanyola abans del període que abasta el nostre treball d'investigació, centrat en els anys trenta i quaranta de la passada centúria i, per tant, entendre més bé la situació en la qual s'emmarca. D'aquesta manera, el 14 d'abril de 1931, s'esdevenia la proclamació de la Segona República i, amb ella, una sèrie de canvis que per a res deixaven de costat el món de l'educació. Els nous governants republicans creien fermament que una bona educació escolar asseguraria la permanència de l'ideal republicà. Per aquest motiu, volien que el mestre i el xiquet foren els primers ciutadans de la República.

A més a més, els principis pedagògics de l'Escola Nova havien estat assumits pels intel-lectuals i polítics republicans espanyols, els quals van ser introduïts en la constitució republicana de 1931. La nova República va establir, tal com apunten Raimon Portell i Salomó Marqués (2006), en l'article tercer de la seua Constitució, que «l'Estat espanyol no té religió oficial» i en l'article 48, deia que "l'ensenyament serà laic, farà del treball l'eix de la seua activitat metodològica i s'inspirarà en ideals de solidaritat humana». Per tant, des d'aquest moment, l'organització de l'aparell educatiu es basaria en els principis de l'escola unificada, gratuïta, obligatòria i laica, on es reconeixia la llibertat de càtedra i es proposava una nova pedagogia basada en el treball.

D'altra banda i seguint aquesta línia de modificacions educatives, entre 1931 i 1933 s'aprovaren decrets referents a l'ensenyament primari, a l'Escola Normal de mestres i a l'escola laica. Pel que fa a l'Escola Normal és important destacar el nou pla de magisteri, el pla professional, de quatre anys de formació per exercir-lo. Els tres primers cursos eren de formació i el quart era un curs de pràctiques al costat d'un bon mestre. L'objectiu era dignificar l'ensenyament públic per mitjà d'un professorat ben format.

\section{Contextualització geogràfica}

Al nord del País Valencià trobem la comarca dels Ports on hi ha el terme de Morella. Aquest abasta una gran quantitat de territori i és el més gran de la província de Castelló. A més, al llarg i ample del seu terme hi ha una gran quantitat de masos. Foren entorn de 365, és a dir, tants com dies té l'any. Actualment, però, està sofrint un progressiu deteriorament i abandonament: el dur clima de l'hivern, la falta de grans extensions per al conreu, la baixa rendibilitat de l'agricultura de muntanya, les allaus migratòries, etc. són factors que, sens dubte, han influït i segueixen fent-ho.

L'estructura organitzativa dels masos morellans ha anat canviant al llarg de la història. Així mateix, la primera notícia escrita que tenim sobre l'organització administrativa del terme de Morella la trobem en el Capbreu, un preuat manuscrit de l'any 1445, que figura en l'Arxiu històric eclesial de l'església Arxiprestal de Morella. Segons aquest document, el 
terme de Morella estava organitzat en partides i alguns dels noms d'aquestes eren els següents: Gibalcolla, Mas del Taravall, Vall dels Gavaldans, La Llèqua, Planelles...

Segles després, tot i que sense documentació que ho acredita amb exactitud perquè es va cremar l'Arxiu Municipal l'any 1840, van desaparèixer les partides esmentades i van donar lloc a altres demarcacions completament noves, les quals van rebre el nom de Denes. Aquest nom va sorgir perquè en principi eren deu les zones 0 demarcacions en les quals es dividia el terme municipal.

Avui en dia, encara es conserva aquesta nomenclatura, tot i que són dotze les denes que integren l'estructura actual del terme. Aquest fenomen ve propiciat gràcies a l'adició com a denes de les aldees d'Herbeset i La Pobla d'Alcolea. No obstant això, aquestes dues continuen sent independents del municipi morellà pel que fa a festes i parròquies. Una dena, seguint la definició de Gamundí Carceller i Sangüesa Ortí (1991), és una demarcació de terreny, que comprén un nombre determinat de masos, el nombre dels quals és variable, així com l'extensió, i que a efectes demogràfics constitueix un nucli de població definit i concret.

D’altra banda, com qualsevol entitat de població legalment constituïda, cada dena té una capitalitat pròpia. Aquesta capitalitat es coneix amb el nom genèric de cap de dena i era el lloc on antigament s'emmagatzemava el gra com a impost de l'estat i el delme per a I'Església. També servia i encara serveix actualment, com a lloc d'encontre dels veïns per a determinades situacions (benedicció del terme, festes, etc.).

Com hem dit, el terme de Morella alberga una gran extensió de terreny, per la qual cosa en la realització d'aquest treball ens centrarem en l'experiència educativa que va tenir lloc en la dena dels Llivis. Aquesta dena està situada al nord-oest del terme de Morella i la capital és el mas de la Torre Querol. Respecte a la ramaderia, cal destacar que la major part de la dena és terreny apte per al ramat i que hi trobem oví, boví i cabrum. Pel que fa a l'agricultura, cal assenyalar que es tracta d'una de les zones més completes pel que fa a l'explotació de cultius, si bé és cert que trobem algunes petites zones d'horta, l'agricultura de la dena és fonamentalment de secà. A més a més, aquesta dena comprén una superfície de 28,377 quilòmetres quadrats i està composta per més d'una vintena de masos.

Així mateix, cal precisar que la nomenclatura Llivis fa referència al conjunt total de la dena i també a un dels masos concrets que la integren. A més a més, aquest últim era el lloc on es trobava ubicada l'escola on anaven els xiquets i xiquetes de la dena. Es tracta d'un mas o, més ben dit, un caseriu, format per un conjunt de cases, graners i corrals per al ramat en el qual a més també hi ha un petita ermita. Era precisament en aquest indret on la protagonista de la història de vida i els seus companys anaven a l'escola. 
La dena dels Llivis sempre ha tingut un especial interés per apropar l'educació als seus xiquets i xiquetes. Tal és així, que en l'any 1936 es van obrir dues finestres d'1,30 × $1 \mathrm{~m}$ en la nau de l'ermita de Sant Pere, per tal de facilitar l'accés de llum i habilitar part de l'ermita per desenvolupar les tasques d'una escola. L'objectiu era crear una escola mixta i que pogueren assistir tots els xiquets i les xiquetes dels voltants. També per aquesta raó, es va instal-lar una estufa de més d'un metre d'altura i trenta centímetres de diàmetre. Cal indicar que durant els anys trenta del segle XX vivien 146 persones en aquesta dena, de les quals aproximadament unes trenta eren xiquets i xiquetes.

Així mateix, el 10 de març de 1956, el Ministeri d’Educació Nacional va crear una escola unitària per als alumnes de la dena. Aquesta es va ubicar a la planta baixa de la casa on vivia el mestre que donava classe a l'ermita i que des d'aleshores ho faria en aquest indret. Es tractava d'una sala bastant espaiosa, amb dues pissarres grans i tres finestres que proporcionaven una gran il-luminació. A més, també hi havia servei de bany. L'escola va estar en funcionament fins al 19 de juny de 1974, la milloria en els mitjans de transport va possibilitar als alumnes de la dena anar a l'escola de Morella.

\section{Objectius}

Com hem manifestat al llarg del treball, la nostra investigació naix amb la intenció de donar resposta a diferents qüestions entorn del nostre passat educatiu més proper. Així doncs, el nostre treball contempla els objectius següents:

- Conèixer quina era la realitat educativa als masos de Morella als anys trenta i quaranta del segle passat.

- Comprendre els principals factors i circumstàncies que condicionaven l'educació de l'època.

- Descobrir quin era el perfil del mestre que portava a terme la tasca educativa.

- Entendre fins a quin punt era rellevant la formació acadèmica en aquella època.

\section{Metodologia}

La metodologia utilitzada a l'hora de portar a terme aquesta investigació ha estat la de les històries de vida. Aquestes ens permeten reunir els esdeveniments més significatius de les nostres vides, des que naixem fins al moment en què ens asseiem per tal d'ordenar els passos caminats. Per fer una història de vida utilitzem la memòria com a eina principal, perquè ens permet reconstruir d'on venim, la formació gradual de la nostra família, el context social, cultural, polític i econòmic que ens ha tocat viure $i$ tots aquells fets que, per algun motiu, ens han deixat petjada. Podríem dir, tal com apunta González (1992), que és tracta d'una 
biografia de la vida, on les experiències i opinions de l'individu en qüestió s'enllacen, o més ben dit, es mesclen unes amb altres.

Les histories de vida s'emmarquen dins de la investigació qualitativa, concretament en la biogràfica i narrativa. En relació amb aquesta, Olabuénaga (1996) apunta que la investigació qualitativa consisteix en descripcions detallades de situacions, esdeveniments, persones, interaccions i comportaments observables, incorporant-hi el que els participants diuen, tal com ho expressen ells mateixos $\mathrm{i}$ no com ho expressaria l'investigador. Per tant, a través d'aquest tipus d'investigació es defensa l'estudi social mitjançant el fenomen social, és a dir, l'estudi de la vida d'un individu mitjançant el mateix individu.

Així doncs, l'individu és el protagonista central de les històries de vida. Folguera (1994) afirma que de tots els mètodes de recerca qualitativa, aquest és el que més bé permet indagar com els individus creen i reflecteixen el món social que els envolta i afegeix que si aquesta tècnica és capaç de captar els processos i les formes com els individus perceben el significat de la seua vida social, és possible corroborar el sentit que la vida té per a ells.

De la mateixa manera, Méndez (2011) defineix les històries de vida com una metodologia que no es recolza en procediments de caràcter estadístic sinó que, per contra, reivindica un aspecte important del coneixement social com és la pròpia experiència humana; la pròpia subjectivitat com a font de coneixement $\mathrm{i}$ el relat dels diferents actors, siga de processos socials, d'elements puntuals, de fenòmens socials que serveixen de correlat o punt de referència per construir el coneixement social. Per tot això, les històries de vida ens permeten descriure, analitzar i comprendre la vida diària de l'ésser humà, la societat i el desenvolupament de les comunitats o pobles, per poder, així, actuar en conseqüència i de la manera més adequada possible en cada cas i en cada situació.

Dit açò i continuant amb el disseny metodològic de la nostra investigació, cal dir que la mostra de la nostra història de vida va ser Leonila Garcia Prades, una dona de vuitanta-tres anys, veïna de Morella i que va anar a l'escola de la dena dels Llivis. Seguint amb el procediment d'estudi, cal assenyalar que l'instrument emprat va ser l'entrevista en profunditat. Vull afegir, també, que l'entrevista va ser enregistrada audiovisualment i que aquesta va tenir lloc en la pròpia escola dels Llivis.

\section{Resultats}

Seguidament, com a resultat del nostre treball, es presenta part del relat de la protagonista. La intenció és recollir aquelles paraules que descriuen de manera més significativa la realitat de l'època.

La historia de vida de Leonila Garcia Prades comença I'any 1931, amb el seu naixement al mas de Cardona situat a la dena els Llivis del terme de Morella. Aquest any també tenia lloc en Espanya la proclamació de la Segona República i, amb ella, l'aprovació de la Constitució de 1931, que 
contemplava diverses reformes en l'àmbit educatiu. Quan només tenia mig any de vida, els seus pares van haver d'abandonar aquest mas per motius de treball i tota la família se'n van anar a viure al mas dels Llivis, caseriu que comparteix nom amb la dena i en el qual vivien dues famílies més. Cal assenyalar que es tractava d'una família de masovers, és a dir, gent que realitzava les feines del mas, però que en moltes ocasions no eren propietaris d'aquestes terres, sinó que aquestes pertanyien a algun senyor al qual li les arrendaven amb l'objectiu de traure'n el màxim rendiment. Així doncs, fins als cinc anys va estar vivint en aquest mas i va ser en aquest lloc quan va anar a l'escola per primera vegada. El caseriu dels Llivis tenia una ermita i aquesta es va habilitar per tal que els xiquets i les xiquetes de la zona tingueren possibilitat de rebre ensenyament escolar.

Tot i que pràcticament no ho recordo, els meus primers anys de vida van ser molt moguts, en cinc anys vaig canviar fins a tres vegades de casa.

A l'escola únicament anaven a l'hivern (entenent com a hivern també les èpoques de fred de la tardor i la primavera) ja que a l'estiu havien de treballar a casa i els pares no els deixaven anar a l'escola. La faena del mas augmentava considerablement amb l'arribada del bon oratge i algunes d'aquestes tasques els impedien assistir a l'escola, ja que la subsistència familiar depenia totalment dels treballs del camp i el més important era ajudar a casa. Cal recordar que en una zona agrícola i ramadera com la dels Ports, el temps meteorològic jugava un paper fonamental, ja que era en funció d'aquest que es veien alterats els diferents cicles de les tasques dels masovers: llaurar, sembrar, segar, emmagatzemar el gra... Així doncs, aquest era un dels motius, o una de les circumstàncies, que dictaminaven el període acadèmic. D’aquesta manera, podem observar que el període acadèmic responia a motius estrictament laborals que tenien en ment el sosteniment familiar.

Solament anàvem a l'escola a l'hivern, a l'estiu hi havia molta feina i no ens hi deixàvem anar, uns havíem de guardar els corders, altres els porcs, altres segar... amb la bona hora hi havia molta feina i no podíem anar a l'escola.

Així mateix, quan vivia als Llivis tenia l'escola al costat de casa, però quan va marxar a viure a Donís, la climatologia adversa propiciava que molts dies tampoc pogueren assistir a l'escola. Recordem que els hiverns morellans solen ser durs i que per tal d'arribar a l'escola era necessari caminar pràcticament dues hores a la intempèrie. Pel que fa a l'escola, sembla recordar que havia una gran estufa de llenya per a combatre el fred. Així doncs, seguint amb el transcurs de la jornada, cal destacar que les deu en punt del matí era l'hora establerta per a començar les classes i aquestes s'allargaven fins a les cinc de la vesprada. Les classes començaven a les deu del matí perquè hi assistien xiquets de diferents masos i la gran majoria havien de fer un trajecte considerable per a arribar a l'escola. Per norma general, aquest trajecte es realitzava a peu, 
tot i que en algunes ocasions algun xiquet s'ajudava d'un ase perquè el viatge fóra més còmode.

Quan viva als Llivis no tenia problema, ho tenia al costat de casa, però quan havia de baixar de Donís, un dia nevava, l'altre plovia, l'altre havia d'ajudar a casa... tots aquests fets provocaven que alguns dies no poguera anar a l'escola.

Pel que fa al menjar, els alumnes esmorzaven abans d'eixir de casa i es portaven el dinar a l'escola, on dinaven tots junts al porxo de l'ermita. La dona entrevistada encara recorda els exquisits entrepans que li preparava sa mare. En aquest sentit, la cansalada virada és un exemple clar del que era l'alimentació típica als masos dels Ports, ja que aquesta s'obtenia després de la matança, esdeveniment que proporcionava l'aliment per a bona part de l'any.

La meua mare em preparava uns entrepans de truita amb cansalada virada que estaven molt bons; sens dubte, el dinar era dels millors moments de la jornada escolar.

Als Llivis anaven entorn d'uns vint alumnes i les classes les feien tots junts, no hi havia cap tipus de separació ni per edats ni per sexe. Tot i això, aquells que tenien més facilitat per aprendre rebien una atenció més personalitzada per part del mestre, igual que aquells que tenien més dificultats. En aquest sentit, la protagonista recorda la diversitat que hi havia dins l'aula. Per exemple, el seu germà tenia tres anys més que ella i recorda que tenia gran capacitat per aprendre ràpidament. En canvi ella, tenia dificultats per seguir-li el ritme.

A l'escola anàvem tots junts, xics i xiques, menuts i grans... Venien xiquets de tots els masos de la dena, recordo que a les classes érem de quinze a vint alumnes.

La totalitat de les classes i les explicacions dels continguts es feien en castellà. Tot i això, la llengua utilitzada fora de l'aula era el valencià. Fora de I'horari escolar el mestre es dirigia als alumnes amb la llengua que aquests utilitzaven per a comunicar-se a casa: el valencià. De la mateixa manera, respecte a la metodologia emprada, cal indicar que aquesta no destacava per l'originalitat: el mestre se centrava únicament en l'explicació de continguts purament acadèmics i no feia referència a aspectes relacionats amb les tradicions o els costums de la zona. Podem dir que no hi havia cap tipus d'interés per preservar la cultura i la identitat d'aquella terra o que almenys aquesta funció no requeia en el mestre. Com hem dit abans, i a tall d'exemple, a l'escola no es tractaven temes com el Nadal, el Sant Antoni... Pel que fa a l'ús de materials, ens explica que aquests es limitaven a la pissarra, el mestre hi anotava les lliçons, les de caràcter numèric i lingüístic i ells les copiaven en el quadern. Tampoc era habitual que el mestre utilitzara llibres a l'hora de portar a terme les explicacions; es dedicava a donar les classes de manera oral, fent 
anotacions a la pissarra i després ja dedicava una atenció més personalitzada en funció del grau de necessitat de cada alumne.

A classe el mestre sempre ens parlava en castellà, les explicacions eren en castellà i a nosaltres ens feia parlar en castellà. En canvi, al pati o en eixir de l'escola sempre parlava valencià, igual que amb els nostres pares.

Així mateix, també cal destacar que el mestre mai no es pronunciava ni donava la seua opinió respecte a temes com la llengua, la política, la religió... Fins i tot mai no feia referència a la situació de guerra que estaven vivint, tot $\mathrm{i}$ que en ocasions la classe es veia alterada per circumstàncies relacionades amb aquest succés. Així doncs, la guerra hi estava molt present, i en més d'una ocasió, la classe es va paralitzar per tal d'anar a amagar-se sota les pedres del calciner que es trobava a pocs metres de l'ermita. En aquest sentit, tampoc no era habitual sortir fora de l'ermita per tractar continguts de caràcter més dinàmic com podien ser els relacionats amb la natura o el medi que els rodejava, ni tampoc feien excursions per a visitar algun indret particular de la zona o relacionar-se amb alumnes d'altres escoles rurals veïnes. És a dir, no existia cap tipus d'interés a fomentar entre els alumnes aquells aspectes que distaven dels purament acadèmics, ni tan sols aquells més socials, relacionats amb el desenvolupament personal o la relació amb la resta de companys.

El mestre sols parlava de coses de classe, no parlava ni de l'oratge que feia. La classe era sempre a l'ermita, cada dia, mai eixíem fora.

Pel que fa a la manera de ser del mestre, Leonila ens explica que en ocasions els renyia, però sovint es tractava de motius justificats i per raons que els mateixos alumnes es buscaven. Així doncs, utilitzava alguns càstigs com a mesura disciplinària, però aquests eren sempre de caràcter acadèmic: copiar un dictat, fer operacions matemàtiques... mai no utilitzava la força o la violència com a mesura de càstig entre els seus alumnes. D’aquesta manera, la relació mestre-alumne era positiva i els alumnes sentien un gran respecte i admiració cap a la figura del mestre. En relació amb això, la protagonista del relat ens explicava que en determinades ocasions -tot i que no era l'habitual-, els alumnes portaven algun tipus d'obsequi al mestre. Per exemple, alguns alumnes li duien embotits després de la matança o altres li portaven cigrons i fesols quan aquests abundaven als horts.

Era molt bona persona i molt bon mestre, una d'eixes persones que es fan d'estimar.

\section{Discussió i conclusions}

La realització d'aquest treball ens permet indicar que la realitat educativa dels masos de la comarca dels Ports, i concretament la de la dena dels Llivis de Morella, distava molt de la d'altres zones i que no tenia 
en compte aquelles idees d'educació moderna que a principis del segle $x \mathrm{x}$ arribaven d'altres indrets del món. Podríem dir que hi havia una desconeixença total respecte d'aquestes i que ja era tot un èxit que els xiquets $\mathrm{i}$ les xiquetes d'aquella zona pogueren rebre alguns tipus d'educació. Així, les mesures de política educativa promogudes pel govern de la Segona República Espanyola no van tenir cap tipus de repercussió a les zones rurals, com és el cas de la dena dels Llivis. Es pot establir, per tant, que l'activitat educativa que es portava a terme en aquestes zones no estava promoguda per l'Estat sinó que naixia de la preocupació dels pares per tal d'oferir un servei educatiu als seus fills.

Pel que fa al perfil del mestre i la metodologia emprada a l'hora de portar endavant les classes, és interessant destacar que aquesta era de caràcter tradicional i que comprenia la realització de dictats i el càlcul d'operacions matemàtiques com a eixos principals. Així mateix, la llengua utilitzada per a fer les explicacions era el castellà. En aquest apartat també és interessant observar la resposta que oferia aquest tipus d'educació davant de l'atenció de la diversitat: l'escola dels Llivis $d$ 'aquella època albergava aproximadament vint alumnes, cadascun amb una edat i amb un ritme d'aprenentatge diferent. Així mateix, per tal de portar a terme aquesta tasca només hi havia un únic mestre, la qual cosa ens dóna peu a imaginar el repte que devia suposar posar-se davant d'una aula amb aquestes característiques.

D'altra banda, per tal de tractar la rellevància de la formació acadèmica de l'època cal fer referència a la situació d'absentisme escolar que es produïa. Així doncs, els principals motius que impedien als alumnes assistir a l'escola eren la climatologia adversa -sovint plovia, nevava o les temperatures eren molt baixes- i el fet d'haver d'ajudar en les tasques del mas on vivien. D'aquesta manera, podem dir que el sosteniment familiar era prioritari davant l'educació, ja que arribava una edat en què els alumnes es veien obligats a abandonar l'escola. Tot i això, aquesta afirmació dóna peu a una altra possible interpretació, els xiquets i les xiquetes havien d'ajudar en les tasques de casa per tal de poder pagar el servei educatiu que ells mateixos rebien. En aquest sentit, també podem afirmar que no hi havia cap tipus de distinció per raons de sexe a l'hora d'abandonar l'escola. Així doncs, les tasques del camp no entenien de masclisme, i tant xiquets com xiquetes abandonaven l'escola per tal d'ajudar les seues famílies.

Seguint amb la informació extreta d'aquesta investigació, cal fer menció de la forta petjada que va deixar la guerra en les generacions d'aquella època. El transcurs d'aquesta marca de manera brutal els records de l'etapa educativa d'aquestes persones. Es torna pràcticament impossible pensar en la infantesa i l'escola i no recordar tots aquells moments en què era necessari abandonar l'escola per tal d'amagar-se dels avions militars de la guerra.

Finalment, cal fer referència al grau d'autosuficiència i la diversitat de fonts d'aprenentatge que tenien les xiquetes i els xiquets d'aquella època i d'aquella zona. Estaven sotmesos a un procés d'ensenyament 
permanent i aquest provenia de diferents fonts. Per un costat, trobem un aprenentatge, podríem dir acadèmic, que era el que tenia lloc a l'escola, i per un altre, trobem l'aprenentatge rebut a partir de l'ensenyament familiar, bàsic per a la supervivència i tirar cap a endavant.

\section{Bibliografia}

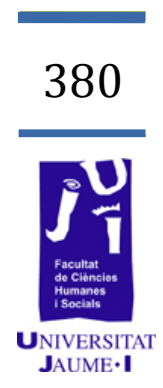

BISQUeRRA, R. (2004): Metodología de la investigación educativa, Editorial La Muralla, Madrid.

Ferraroti, F. (1991): La historia y lo cotidiano, Ediciones Península, Barcelona.

Folguera, P. (1994): Cómo se hace historia oral, Eudema, Madrid.

Gamundí Carceller, S. i C. SAngüesa Ortí (1991): Morella. Guía del antiguo término, Ajuntament de Morella.

GonzÁlez, A. (1992): The Archivist and Oral Sources, K. G. Saur, París.

Leite Méndez, A. E. (2011). Historias de vida de maestros y maestras. La interminable construcción de las identidades: vida personal, trabajo y desarrollo personal, Facultad de Ciencias de la Educación, Departamento de Didáctica y Organización Escolar, Universidad de Málaga.

Portell, R. i S. Marquès (2006): Els mestres de la República, Ara Llibres, Badalona. 


\section{Capacitat predictiva de les variables atribucionals sobre el rendiment acadèmic en Matemàtiques}

Vicente Molinero Claramunt vicente.molinero.claramunt@gmail.com 
S'analitza longitudinalment la capacitat predictiva d'un conjunt de variables d'estil atribucional cap a l'aprenentatge sobre el rendiment acadèmic en l'àrea de Matemàtiques. Les anàlisis correlacionals i de regressió múltiple es realitzen sobre les dades avaluades en dos moments en una mostra $(N=180)$ de subjectes que abasta des d'Educació Infantil 5 anys fins a $2 n$ curs d'Educació Primària en contextos educatius formals. S'obté que la dimensió atribucional amb més poder predictiu és la internalitat positiva. Els resultats es discuteixen en termes de les seues implicacions teòriques i pràctiques per a la millora del procés d'ensenyament-aprenentatge.

Paraules clau: estil atribucional, rendiment acadèmic, matemàtiques, Educació Infantil, Educació Primària, internalitat positiva.

\section{Introducció}

Actualment hi ha una gran preocupació en la comunitat educativa davant l'important nivell de fracàs escolar. A Espanya, tal com assenyalen les xifres proporcionades pel Ministeri d'Educació, Cultura i Esport, l'abandonament educatiu primerenc (alumnes que no han assolit la titulació d'Educació Secundària Obligatòria) en el curs 2014-2015 va ser del $21,9 \%$, dada que duplica la mitjana comunitària (11,1 \%).

Les dificultats són especialment destacables en l'àrea de les Matemàtiques on, estudis internacionals d'avaluació, com l'informe PISA (Programme for International Student Assessment), recullen que el 2012, un $24 \%$ de l'alumnat se situava en nivells entre $<1$ i 1 , dels 6 nivells existents, amb la mitjana espanyola 10 punts per sota de la mitjana de l'OCDE (Organització per a la Cooperació i el Desenvolupament Econòmics).

Arran la inquietud generada per l'actual taxa d'abandonament escolar, l'estudi de les variables relacionades amb el rendiment acadèmic constitueix avui dia un dels temes de més interés en la investigació educativa.

L'atribució escolar com a predictor del rendiment acadèmic és la temàtica que més qüestions i incògnites suggereix tant en l'exercici educatiu com en el rendiment acadèmic de l'alumnat. Assíduament s'observa entre els docents expressions com ara: "Què podria fer perquè el meu alumnat estiguera motivat a l'aula? Per què no vol estudiar? Per què el meu alumnat comença el curs amb il.lusió $\mathrm{i}$ al poc temps no mostra interés? Per què a alguns dels meus alumnes els resulta fàcil i plaent I'hàbit d'estudi i, en canvi, a altres els provoca avorriment i repulsió?». Oferir una resposta aclaridora a aquests i altres interrogants similars no suggereix una tasca senzilla. 
Dins el context de les teories sobre la motivació humana, cal destacar la teoria atribucional sobre la motivació i l'emoció (Weiner, 1980, 1986) fruit de la valuosa contribució a l'estudi de la interrelació entre les variables atribucionals $\mathrm{i}$ el rendiment acadèmic en les institucions escolars, la qual té, a més, una gran evidència empírica (per exemple, Manassero i Vázquez, 1995; Wambach, 1993; Weiner, 1980, 1986).

En tractar la temàtica de la motivació i considerant els nombrosos enfocaments i variables que es disposen per al seu estudi, hi ha, entre els autors, cert consens sobre els fonaments estructurals que guien el comportament dels individus: la consecució de l'èxit i l'evitació del fracàs.

Weiner (1986) sosté que el comportament motivat està influït per les expectatives d'assoliment d'una meta i el mateix valor d'aquesta, els quals, al seu torn, vénen determinats per les atribucions expressades mitjançant les creences personals sobre quines són les causes originàries tant dels seus èxits com dels seus fracassos. Per això, l'autor, apunta que són les atribucions causals les determinants primàries de la motivació causa de la seua influència sobre les expectatives, les reaccions afectives $i$, en conseqüència, sobre la conducta de rendiment i sobre els resultats que es cullen. Per a l'autor, les creences personals sobre quines són les causes originàries dels seus èxits $\mathrm{i}$ fracassos comporten importants conseqüències tant en l'àmbit emocional, cognitiu i motivacional. A aquestes conseqüències psicològiques Weiner les anomena dimensions atribucionals: (a) internalitat-externalitat (es refereix a la localització de les causes d'uns resultats donats), (b) estabilitat-inestabilitat (es refereix a la durabilitat en el temps d'aquesta localització causal) i (c) controlabilitat-incontrolabilitat (seria la modificabilitat a voluntat de tal factor causal).

Respecte a la primera dimensió, internalitat-externalitat, una atribució causal interna de l'èxit produirà emocions positives com una del fracàs produirà emocions negatives. Al contrari, si l'èxit o el fracàs són atribuïts a causes externes, les emocions patiran canvis limitats. En referència a la segona dimensió atribucional, estabilitat-inestabilitat, Weiner sosté que quan l'individu atribueix a causes estables l'èxit i el fracàs, les seues expectatives futures continuaran en la mateixa senda, prolongant en el temps el mateix èxit o fracàs en diferents contextos $i$ situacions. No obstant això, si l'èxit o el fracàs s'atribueixen a causes inestables, l'individu atresorarà incertesa sobre el que albergarà el futur ja que podrà esdevenir tant en forma d'èxit com de fracàs. Finalment, en la dimensió controlabilitat-incontrolabilitat, l'autor afirma que l'atribució de l'èxit o fracàs a factors controlables pel mateix individu (p. ex., esforç) hi reportarà un increment de la motivació i la persistència, la qual cosa contribuirà a augmentar, probablement i en el context escolar, el rendiment acadèmic. Per tant, si l'èxit o el fracàs es justifiquen mitjançant causes incontrolables (p. ex., atzar o sort), passarà exactament el contrari. Una altra de les dimensions atribucionals vinculades a la motivació, prevista en la teoria de la indefensió apresa (Abramson, Seligman i Teasdale, 1978), és l'especificitat-globalitat, segons la qual resulta 
adaptatiu atribuir tant els èxits a causes globals (generalització) com els fracassos a causes d'índole específica.

Arribats a aquest punt, sembla clar que les dimensions d'estil atribucional (internalitat, estabilitat $\mathrm{i}$ globalitat) exerceixen certa influència sobre el rendiment acadèmic en l'àrea de matemàtiques. Els treballs revisats reflecteixen una tendència investigadora cap a mostres d'alumnes escolaritzats en les etapes d'Educació Primària, Secundària i estudis superiors i/o universitaris. Són escassos els estudis que utilitzen mostres des d'edats primerenques per a valorar la influència de les atribucions sobre el rendiment matemàtic i, encara, són més escassos els treballs desenvolupats des d'un vessant longitudinal. Es considera necessari aprofundir, des de l'etapa d'Educació Infantil i amb caràcter exploratori, en la influència conjunta que exerceixen aquestes variables sobre el rendiment. Aquest serà l'objectiu últim d'aquesta investigació.

\section{Objectius}

Són els redactats seguidament:

1. Analitzar la magnitud de la relació de les conductes atribucionals avaluades en Educació Infantil 5 anys amb les habilitats matemàtiques en 2 n curs d'Educació Primària.

2. Explorar el poder predictiu de les variables atribucionals avaluades en l'últim curs d'Educació Infantil amb les habilitats matemàtiques de $2 \mathrm{n}$.

\section{Material i mètode}

\section{Participants}

La mostra d'estudi inicial (temps 1) estava constituïda per 209 subjectes d'Educació Infantil 5 anys, 47,8 \% xiquetes i 52,2 \% xiquets, on el $63,6 \%$ assistien a centres públics i el $36,4 \%$ a centres concertats. Dos cursos escolars després, es va produir el moment d'avaluació del seguiment en $2 \mathrm{n}$ d'Educació Primària (temps 2 ) que dóna una mostra final de 180 subjectes.

Quan es va iniciar la investigació, els subjectes de l'etapa d'Educació Infantil 5 anys tenien una edat compresa entre 5 i 6 anys (mitjana $=70,02$ mesos; DT $=3,61$ ). Dos cursos escolars després, presentaven edats compreses entre 7 i 8 anys (mitjana $=94,16$ mesos; DT =3,78). El Cl equivalent es va mesurar mitjançant les subproves vocabulari i quadrats de l'escala WPPSI-R (Weschler, 1996) seguint les directrius de Spreen i Strauss (1991).

Els subjectes presentaven una mitjana de $\mathrm{Cl}$ equivalent de 98,63 mesos (DT $=12,23$ ). No van formar part de l'estudi aquells subjectes el $\mathrm{Cl}$ equivalent dels quals era inferior o igual a 70, o superior o igual a 130. Així mateix, tampoc no van formar part de l'estudi aquells alumnes amb 
problemes les dificultats dels quals es puguen deure a un trastorn de l'espectre autista (TEA), deficiències sensorials o problema psicològic greu.

En el temps 2 de la investigació, $2 n$ curs d’Educació Primària, únicament el $0,5 \%$ dels subjectes posseïa una Adaptació Curricular Individualitzada ( $\mathrm{ACl}$ ) per a les àrees de Matemàtiques i Llengua Castellana i Literatura. El 19,1\% dels participants assistia a sessions amb un especialista del propi centre: suport $(7,7 \%)$, compensatòria $(1,9 \%)$, pedagogia terapèutica $(3,3 \%)$, audició i llenguatge $(3,8 \%)$ i combinat $(2,4 \%)$. Pel que fa a l'existència d'una necessitat específica de suport educatiu, el $4,4 \%$ dels subjectes presentava les següents: dificultats d'aprenentatge $(1 \%)$, problemes atencionals $(1 \%)$, epilèpsia $(0,5 \%)$, dificultats de la parla i del llenguatge $(0,5 \%)$ i altres $(1 \%)$.

Pel que fa a les famílies, el $88 \%$ de la mostra tenia nacionalitat espanyola mentre que l' $11,5 \%$ procedia d'altres països. Pel que fa al nivell d'estudis dels familiars, el 30,6\% de les mares i el $25,4 \%$ dels pares posseïen estudis universitaris; el $34,9 \%$ de les mares i el $34,4 \%$ dels pares tenien un nivell d'estudis de tipus mitjà (Batxillerat i Formació Professional); i el 33,5\% de les mares i el 39,7\% dels pares posseïen el Graduat Escolar.

\section{Instruments}

\section{Mesures d'estil atribucional emprades en Educació Infantil 5 anys}

Es va administrar el qüestionari Children's Attributional Style Interview (CASI; Conley, C., Haines, B., Hilt, L. i Mestalky, G., 2001) a manera d'entrevista, desenvolupat per a avaluar l'estil atribucional de xiquets a partir de 5 anys.

En aquesta tasca, es mostren a l'alumne una sèrie d'illustracions (16 històries) d'esdeveniments relacionats amb el rendiment (per exemple tasques cognitives, situacions escolars, esport, etc.), que permeten que genere les seues pròpies atribucions i les valore en termes d'internalitat ( $1=$ «depén de mi» vs. $0=$ «depén d'altres») globalitat $(1=$ «passa a tot arreu» vs. $0=$ «ocorre només en un escenari concret») i estabilitat ( $1=$ «passa moltes vegades» vs. $0=$ «passa només aquesta vegada»). La meitat d'esdeveniments posseeix un valor positiu i la resta, negatiu. Les alternatives de resposta es van aplicar de manera contrabalancejada, amb l'objectiu de minimitzar les interferències en les respostes dels subjectes.

La prova posseeix indicadors de fiabilitat i validesa (Conley et al., 2001). Es van prendre com a referència el sumatori de les respostes a cadascun dels índexs del qüestionari. 
Mesures de rendiment matemàtic emprades en 2n curs d'Educació Primària

Es va aplicar la prova estandarditzada Test de Competència Matemàtica Bàsica (TEMA-3; Ginsburg i Baroody, 2007). Es tracta d'un test vàlid $\mathrm{i}$ fiable per avaluar xiquets d'edats compreses entre els 3 anys i 8 anys i 11 mesos. Consta, en total, de 72 elements, presentats en ordre de dificultat creixent, en funció de l'edat, distribuïts en diversos aspectes que valoren tant habilitats com conceptes de caràcter informal (aquelles que el xiquet aprén en contacte amb el seu entorn proper a través d'interaccions no reforçades) i formal (aquelles apreses dins el context escolar). Per a cada alumne, a més de les puntuacions clàssiques (puntuació directa, edat i curs equivalent, índex de competència matemàtica i percentil), s'obté un perfil d'execució, en el qual es reflecteixen les seues fortaleses i debilitats, de manera que la seua anàlisi és un valuós punt de partida per a aclarir les dificultats específiques d'un alumne concret i articular la intervenció.

L'aspecte informal del pensament matemàtic es valora mitjançant 41 ítems distribuïts en quatre components: a) numeració, que valora el domini de la seqüència numèrica, a través de tasques que impliquen habilitats bàsiques i avançades, tant de comptatge com d'enumeració; b) comparació de quantitats, que implica l'habilitat d'establir distàncies relatives entre els nombres; c) càlcul informal, on es plantegen senzilles situacions de suma i resta amb objectes concrets i després es valoren les habilitats de càlcul mental (no necessàriament automàtic), i d) conceptes bàsics, on es considera l'ús de la regla de cardinalitat, la comprensió de la constància numèrica, l'aplicació d'estratègies de comptatge avançades i la comprensió bàsica del repartiment d'objectes.

L'aspecte formal s'avalua mitjançant 31 ítems, al seu torn, també repartits en quatre components: a) convencionalismes de lectoescriptura de quantitats, b) domini de fets numèrics, on es mesura la capacitat de recuperar de manera automàtica el resultat d'operacions de sumar, restar i multiplicar, amb quantitats d'un dígit -les taules-; c) càlcul formal, on es valora tant la seguretat com el procediment seguit, i d) conceptes bàsics relacionats amb el sistema numèric decimal, avaluats mitjançant ítems que impliquen la comprensió del valor posicional i les equivalències entre els diferents ordres de magnitud.

\section{Procediment}

Després d'obtenir els permisos de la Conselleria d'Educació per a dur a terme el projecte de recerca, es va contactar amb els centres educatius sol-licitant la seua participació. Posteriorment, es va obtenir consentiment per escrit per a la participació en la investigació per part dels pares i mares. Amb la finalitat d'abastar un ampli rang de centres, es van seleccionar sis alumnes per aula a l'atzar mitjançant la tècnica del mostreig aleatori simple en centres educatius de les províncies de València i Castelló. 
L'avaluació, la van dur a terme professionals familiaritzats amb l'aplicació i correcció dels tests. L'administració va ser individual, en el temps mitjà d'aplicació que s'estableix en el manual i respectant ritmes individuals. D'altra banda, els espais físics reunien les condicions adequades per a l'avaluació.

En el temps 1, es va administrar el qüestionari CASI a manera d'entrevista i individualment als alumnes d'Educació Infantil 5 anys en horari lectiu sense interferir en les activitats significatives del currículum i al llarg del tercer trimestre del curs escolar. Dos cursos escolars després, en el temps 2, es va tornar als centres escolars on es va administrar la prova estandarditzada TEMA-3 als mateixos subjectes, seguint el mateix procediment descrit anteriorment.

\section{Anàlisis estadístiques}

Per a l'anàlisi estadística, el programa utilitzat va ser el paquet estadístic Statistical Package for the Social Science (SPSS), versió 22.00 (SPSS Inc., Chicago, IL USA).

Per al primer objectiu, es va realitzar una anàlisi de correlacions bivariades utilitzant el mètode estadístic de Pearson entre les diferents variables atribucionals avaluades en Educació Infantil 5 anys i el rendiment matemàtic en $2 n$ curs d'Educació Primària.

En el segon objectiu, es va realitzar una anàlisi de regressió lineal múltiple pel mètode de passos successius per a comprovar quines conductes atribucionals d'Infantil 5 anys predeien les habilitats matemàtiques als 7 anys.

\section{Resultats}

En la taula 1 s'observen els resultats relatius a l'anàlisi de les correlacions bivariades entre les diferents dimensions de l'estil atribucional, tant positives com negatives, avaluades en l'últim curs d'Infantil i el rendiment matemàtic de $2 n$ curs de Primària.

Són positius tots els resultats obtinguts per a les correlacions de la dimensió atribucional categoritzada com a internalitat positiva. En aquest sentit, resulten més significatives les variables següents: puntuació total $(r=0,176 ; p=0,018)$, numeració informal $(r=0,187 ; p=0,012)$, comparació informal $(r=0,174 ; p=0,019)$, càlcul informal $(r=0,182$; $p=0,015)$ i conceptes informals $(r=0,186 ; p=0,013)$.

Continuant amb la dimensió internalitat positiva i en relació amb les habilitats matemàtiques formals, correlacionen significativament les variables catalogades com a fets numèrics $(r=0,184 ; p=0,014)$, càlcul $(r=0,176 ; p=0,018)$ i conceptes $(r=0,149 ; p=0,046)$. Finalment, cal esmentar que només la variable convencionalismes formal no correlaciona significativament dins de la dimensió atribucional internalitat positiva. 
Una última observació que es desprén dels resultats presentats és la no correlació amb caràcter significatiu entre les dimensions atribucionals internalitat negativa, estabilitat $i$ globalitat respecte a les habilitats matemàtiques avaluades.

Taula 1. Correlacions bivariades entre dimensions positives i negatives de l'estil atribucional (CASI) i el rendiment en matemàtiques (TEMA - 3)

\section{CASI}

\begin{tabular}{|c|c|c|c|c|c|c|}
\hline & \\
\hline & \multicolumn{2}{|c|}{ Internalitat } & \multicolumn{2}{|c|}{ Estabilitat } & \multicolumn{2}{|c|}{ Globalitat } \\
\hline & Positiva & Negativa & Positiva & Negativa & Positiva & Negativa \\
\hline \multicolumn{7}{|l|}{ TEMA-3 } \\
\hline Puntuació total & $.176^{*}$ & 0.22 & 0.95 & -.030 & .072 & -.001 \\
\hline \multicolumn{7}{|l|}{ Habilitats informals } \\
\hline Numeració & $.187^{*}$ & .098 & .128 & -.040 & .077 & .075 \\
\hline Comparació & $.174 *$ & .009 & .033 & -.060 & .051 & .027 \\
\hline Càlcul & $.0182 *$ & .061 & .039 & -.028 & .019 & -.014 \\
\hline Conceptes & $.186^{*}$ & .038 & .146 & .054 & .005 & .034 \\
\hline \multicolumn{7}{|l|}{ Habilitats formals } \\
\hline Convencionalismes & .132 & .054 & .074 & -.040 & .026 & .046 \\
\hline Fets numèrics & $.184^{*}$ & .051 & .092 & -.080 & .078 & -.015 \\
\hline Càlcul & $.176^{*}$ & .033 & .134 & -.080 & .027 & -.006 \\
\hline Conceptes & $.149 *$ & .067 & .055 & -.058 & .006 & .008 \\
\hline
\end{tabular}

$* \mathrm{p} \leq .05$

En la taula 2 es presenten els resultats de l'anàlisi de regressió lineal múltiple per passos successius per a les variables d'estil atribucional de l'últim curs d'Infantil pel que fa a les habilitats matemàtiques avaluades als 7 anys.

La variable internalitat positiva explica la variància total de les puntuacions obtingudes per a les diferents subproves de rendiment matemàtic analitzades amb variàncies que oscil.len, en conjunt, entre el $4,1 \%$ i el $2,2 \%$.

De manera desglossada, els resultats obtinguts en la regressió lineal per a les dimensions d'estil atribucional són els assenyalats: puntuació total $\left(\Delta R^{2}=0,041, p=0,006\right)$, numeració informal $\left(\Delta R^{2}=0,035, p=0,012\right)$, comparació informal $\left(\Delta R^{2}=0,030, p=0,019\right)$, càlcul informal $\left(\Delta R^{2}=0,033\right.$, $p=0,015)$, conceptes informals $\left(\Delta R^{2}=0,034, p=0,013\right)$, fets numèrics formals $\left(\Delta R^{2}=0,034, p=0,014\right)$, càlcul formal $\left(\Delta R^{2}=0,031, p=0,018\right) i$ conceptes formals $\left(\Delta R^{2}=0,022, p=0,046\right)$. 
Taula 2. Anàlisi de regressió entre dimensions positives i negatives de l'estil atribucional (CASI) i el rendiment en matemàtiques (TEMA - 3)

\begin{tabular}{llll}
\multicolumn{6}{c}{ CASI } \\
\hline $\mathrm{F}$ & $\mathrm{R}^{2}$ & $\Delta \mathrm{R}^{2}$ & $\beta$ \\
\hline
\end{tabular}

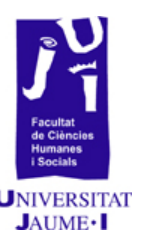

\section{TEMA-3}

Puntuació total

$\begin{array}{lllll}\text { Internalitat positiva } & 7.61^{*} & .041 & .041 & .203\end{array}$

Habilitats informals

Numeració

$\begin{array}{lllll}\text { Internalitat positiva } & 6.45^{*} & .035 & .035\end{array}$

Comparació

$\begin{array}{lllll}\text { Internalitat positiva } & 5.56^{*} & .030 & .030 & .174\end{array}$

Càlcul

$\begin{array}{lllll}\text { Internalitat positiva } & 6.07 * & .033 & .033\end{array}$

Conceptes

Internalitat positiva

$6.36^{*}$

.034

.034

Habilitats formals

Fets numèrics

$$
\text { Internalitat positiva }
$$

$6.22 *$

.034

.034

.184

Càlcul

Internalitat positiva

$5.72 *$

.031

.031

.176

Conceptes

Internalitat positiva

4.03*

.022

.022

.149

$* p \leq .05$

\section{Discussió i conclusions}

El primer objectiu d'aquest estudi longitudinal ha estat examinar la influència de les diferents conductes atribucionals cap a l'aprenentatge en l'etapa d'Educació Infantil 5 anys sobre el rendiment matemàtic en $2 \mathrm{n}$ curs d'Educació Primària.

Els resultats assenyalen una estreta relació entre la dimensió atribucional internalitat positiva i les diferents habilitats matemàtiques. A més, totes les correlacions resulten positives. Aquests resultats van en la línia d'autors com Alonso García et al. (1996), Shanahan i Walberg (1985) i Valle et al. (1998), els quals suggereixen l'existència d'una relació directa, positiva i significativa entre les atribucions causals internes i el rendiment acadèmic. De la mateixa manera, i d'acord amb els resultats, sembla albirar una tendència clara en edats primerenques de l'anomenat 
autoconcepte positiu o locus de control intern positiu on com més atribució dels èxits a un mateix (cosa que comporta sentiments d'autoeficàcia percebuda i autocompetència més grans), més bo serà el rendiment matemàtic. D'acord amb Seegers i Boekaerts (1993), podem afirmar que l'autoconcepte positiu de l'alumnat funciona (ja des d'Educació Infantil 5 anys) com una força motivacional mediadora que incideix sobre el seu propi rendiment.

D'altra banda, cal remarcar que no es van trobar correlacions significatives per a les altres variables d'estil atribucional analitzades (internalitat negativa, estabilitat i globalitat tant en el component positiu com negatiu). Aquest últim resultat està d'acord amb els trobats en diferents investigacions (Cole et al., 2008; Conley et al., 2001; Rholes i Ruble, 1984) on s'exposa que sembla que els alumnes amb edats compreses entre 5-6 anys no mantenen estables i globals seues creences i atribucions causals, tant de manera temporal com situacional, perquè aquestes s'assenten cognitivament i evolutivament al llarg de l'etapa d’Educació Primària.

El segon objectiu pretenia explotar el poder predictiu de les variables atribucionals avaluades en l'últim curs d'Educació Infantil amb les habilitats matemàtiques bàsiques de $2 \mathrm{n}$.

En avaluar la capacitat predictiva de les dimensions d'estil atribucional, com s'esperava, només ha posseït la dimensió internalitat positiva un pes significatiu sobre el rendiment acadèmic amb valors compresos entre el 2,2 \% i el 4,1\%. Així doncs, els resultats recollits en el segon objectiu relatius a les dimensions d'estil atribucional convergeixen en la mateixa direcció, amb les investigacions de Platt (1988) i Relich, Debus i Walker (1986). S'hi exposa que mentre les atribucions causals internes de l'alumnat sobre el seu propi rendiment eren febles (en el nostre cas, amb variàncies entre $2,2 \%$ i 4,1\%), els efectes d'aquestes atribucions sobre l'autoeficàcia percebuda eren consistents, cosa que, al seu torn, tindria un efecte directe sobre el rendiment acadèmic. D'acord amb els resultats del present treball i als estudis d'autors com González i Tourón (1992), Marsh (1984), Marsh i Yeung (1997) i Martínez-Otero (2009), es pot concloure que des d'edats primerenques coexisteixen vincles complexos i entrellaçats entre motivació, atribucions i rendiment acadèmic. De la mateixa manera, també s'observa en l'alumnat d'Educació Infantil una tendència a assignar els èxits acadèmics a factors interns i controlables, la qual cosa comporta l'increment de les seues percepcions d'autoeficàcia percebuda i d'autoconcepte acadèmic, fet que es reproduirà en més interés per aprendre i impulsarà l'ús d'estratègies cognitives amb més freqüència (per exemple, atenció) i persistència en les tasques, influint positivament en el rendiment acadèmic.

En síntesi, sembla que, des de l'etapa d'Educació Infantil, les variables atribucionals $d$ 'autocompetència acadèmica (interés, esforç i persistència per l'aprenentatge) influeixen tant positivament com negativa sobre el rendiment futur. Així mateix, sembla que el pes d'aquestes variables sobre el rendiment augmenta amb l'edat o la promoció a cursos superiors 
en detriment de les variables cognitives. A més, en la mateixa etapa educativa, s'albira també com a determinant del rendiment acadèmic l'assignació de l'èxit en les tasques escolars a causes internes i positives. Finalment, les atribucions causals no es mantenen estables i globals, tant temporal com situacionalment, al llarg de l'etapa d'educació infantil a causa que aquestes s'assenten en etapes educatives posteriors.

Entre les limitacions d'aquest estudi, cal assenyalar la dificultat existent a l'hora d'avaluar variables atribucionals en alumnes de 5 anys. En les diferents investigacions revisades (Chamorro-Premuzic i Furnham, 2006; Colom i Flores-Mendoza, 2007; Deary, Strand, Smith, i Fernandes, 2007; Laidra, Pullman, i Allik, 2007; Miñano i Castejón, 2008, 2011; Watkins, Lei, i Canivez, 2007) es constata la dificultat d'aquest treball ja que, per a estudiar les mateixes variables, s'utilitzen mostres d'alumnes des d’Educació Primària fins a estudis universitaris. Així doncs, el present estudi resulta pioner tant per la novetat com per la seua dificultat, perquè ha estat realitzat amb una finalitat exploratòria, ja que hi ha molt pocs treballs que utilitzen mostres d'Educació Infantil per a analitzar la capacitat predictiva de les variables atribucionals sobre el rendiment amb caràcter longitudinal.

Entre les aplicacions pràctiques que es deriven de l'estudi, s'apunta la necessitat d'incorporar, des de l'etapa d'Educació Infantil, components de caràcter motivacional i d'estil atribucional amb caràcter interdisciplinari per a la formació de l'alumnat i del mateix cos docent.

El docent ha d'acompanyar el seu alumne en el procés d'educar transmetent-li la seua passió i entusiasme per l'aprenentatge, fomentant la reflexió i l'aprofundiment sobre aquest, sent el màxim responsable de la creació d'un clima motivacional positiu a l'aula. Així mateix, ha de prestar especial atenció a aquells alumnes que no es veuen capacitats per a aprendre, de manera que reforce els seus esforços i els seus èxits i premie més pel procés que pel simple producte. El seu gran objectiu és desenvolupar en l'alumne el convenciment que l'estudi i el corresponent aprenentatge són funcionals per a la vida, ajudant, de manera individualitzada, al fet que cada alumne puga fixar-se les seues pròpies metes educatives, incorporant les bastides necessàries que l'ajuden a construir el seu propi camí i li faciliten l'enlairament cap a metes superiors. Per aquest motiu, perquè un alumne progresse en el context escolar, l'acompliment del docent haurà de focalitzar tant en la part instruccional de la matèria (mitjançant activitats funcionals i motivadores en si mateixes que no siguen llargues i amb una dificultat assequible) com en potenciar els sentiments d'autoeficàcia i autocompetència acadèmica com a base de l'èxit educatiu. En definitiva, el docent, com a locomotora de l'èxit, ha de desenvolupar la motivació idònia per a l'aprenentatge en cadascun dels seus alumnes, ha de fortificar dia a dia, d'acord amb l'ús $d^{\prime}$ 'interaccions comunicatives multidireccionals i l'ocupació d'estratègies d'aprenentatge cooperatiu-col·laboratiu a l'aula. 
Abramson, L., M. E. P. Seligman i J. D. Teasdale, (1978): «Learned Helplessness in Human: Critique and Reformulation", Journal of Abnormal Psychology, 87, p. 49-74.

Alonso García, E., J. Machargo, G. Méndez, M. Pérez i M. Socorro (1996): "Predicción del rendimiento académico al inicio del Bachillerato", Renovación Pedagógica, 3, 297, p. 1559-1561.

Chamorro-Premuzic, T., i A. Furnham (2006): "Self-assessed Intelligence and Academic Performance», Educational Psycholgy, 26(6), p. 769-779.

Cole, D. A., J. A. Ciesla, D. H. Dallaire, F. A. Jacquez et al. (2008): "Emergence of Attributional Style and its Relation to Depressive Symptoms», Journal of Abnormal Psychology, 117, p. 16-31.

Colom, R. i C. E. Flores-Mendoza (2007): «Intelligence Predicts Scholastic Achievement Irrespective of Ses Factors: Evidence From Brazil», Intelligence, 35(3), p. 243-251.

Conley, C. S., B. A. Haines, L. M. Hilt i G. L. Metalsky (2001): «The Children's Attributional Style Interview: Developmental Tests of Cognitive DiathesisStress Theories of Depression", Journal of Abnormal Child Psychology, 29, p. $445-463$

Deary, I. J., S. Strand, P. Smith i C. Fernandes (2007): «Intelligence and Educational Achievement», Intelligence, 35(1), p. 13-21.

Ginsburg, H., i A. BARoody (2007): Test de Competencia Matemática Básica (TEMA 3), TEA, Madrid.

GONZÁLEZ, M., i J. TOURÓN (1992): Autoconcepto y rendimiento académico. Sus implicaciones en la motivación y en la autorregulación del aprendizaje, EUNSA, Pamplona.

LaidRA, K., H. Pullman, i J. Allik (2007): «Personality and Intelligence as Predictors of Academic Achievement: A Cross-Sectional Study from Elementary to Secondary School», Personality and Individual Differences, 42(3), p. 441-451.

Manassero, M. A., i A. Vázquez (1995): "La atribución causal y la predicción de logro escolar: patrones causales, dimensionales y emocionales», Estudios de Psicología, 54, p. 3-22.

MARSH, H. W. (1984): «Relationship Among Dimensions of Self-attribution, Dimensions of Self-concept, and Academic Achievements", Journal of Educational Psychology, 76, p. 1291-1308.

MARSH, H. W., i A. S. Yeung (1997): "Causal Effects of Academic SelfConcept on Academic Achievement: Structural Equation Models of Longitudinal Data», Journal of Education al Psychology, 89, p. 41-54. 
Martínez-Otero, V. (2009): «Diversos condicionantes del fracaso escolar en la educación secundaria», Revista Iberoamericana de Educación, núm. 51.

MiÑANO, P., i J. L. CASTEJón (2008): «Capacidad predictiva de las variables cognitivo-motivacionales sobre el rendimiento académico», Revista Electrónica de Motivación y Emoción, 28, p. 11-32.

- (2011): «Variables cognitivas y motivacionales en el rendimiento académico en Lengua y Matemáticas: un modelo estructural», Revista de Psicodidáctica, 16(2), p. 203-230.

PLATT, C. W. (1988): «Effects of Causal Attributions for Success on FirstTerm College Performance: A Covariance Structure Model», Journal of Educational Psychology, 80, p. 569-578.

Relich, J. D., R. L. Debus i R. Walker (1986): "The Mediating Role of Attribution and Self-efficacy Variables for Treatment Effects on Achievement Outcomes», Contemporary Educational Psychology, 11, p. 195-216.

RHOLES, W., i D. Ruble (1984): «Children's Understanding of Dispositional Characteristics of Others», Child Development, 71, p. 1662-1671.

Seegers, G., i M. Boekaerts (1993): "Task Motivation an Mathematics Achievement in Actual Task Situations», Learning and Instruction, 3, p. 133-150.

Shanahan, T., i H. J. Walberg (1985): «Productive Influences on High School Student Achievement», Journal of Educational Psychology, 78, p. 357-363.

Valle, A., R. Cabanach, J. C. Núñez i J. A. González-Pienda (1998): "CognitiveMotivational Variables, Approaches to Learning and Academic Achievement», Psicothema, 10, p. 393-412.

WAMBACH, C. (1993): "Motivational Themes and Academic Success of AtRisk Freshmen", Journal of Developmental Education, 16(3), p. 8-10.

Watkins, M. W., P. W. LeI i G. L. Canivez (2007): «Psychometric Intelligence and Achievement: A Cross-Lagged Panel Analysis», Intelligence, 35(1), p. 59-68.

WEINER, B. (1980): Human motivation. Holt, Rinehart and Winston, Nova York.

- (1986): An Attributional Theory of Motivation and Emotion, SpringerVerlag, Nova York. 


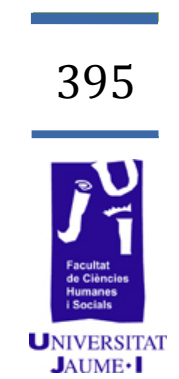

\section{La escuela en el circo. Un modelo de aula unitaria itinerante}

Iris Hervás Jordán al238647@uji.es Ma Ángeles Llopis mallopis@uji.es 
La escuela del circo es un tema desconocido para la mayoría de la sociedad y de los docentes. Este trabajo pretende profundizar en el modelo educativo que suponen las aulas unitarias itinerantes de los circos. Para ello se indagará tanto en el origen de su historia como en sus características organizativas y metodológicas. A través de tres entrevistas realizadas a maestros de escuelas itinerantes se espera entender mejor la realidad de estas escuelas. Para esto se contó con la colaboración de tres circos que disponen del Programa de Aulas Itinerantes que son el Gran Circo Mundial, el Circo Wonderland y el Gran Circo Americano y sus respectivos docentes. En los resultados obtenidos se observa que este tipo de aulas tiene algunos aspectos organizativos y didácticos en común con las aulas ordinarias como horarios y legislaciones pero también diversas diferencias en cuanto a metodología, número de alumnado en las aulas, programación y comunicación con las familias, entre otras. Mediante este estudio se pone de manifiesto que la escuela dentro del circo ha avanzado mucho a lo largo de estos años pero todavía necesita de una mejor regulación y reconocimiento profesional ya que no en todos los circos existe este servicio al que todos los niños tienen derecho.

Palabras clave: aulas itinerantes, aulas unitarias, educación, escuela de circo.

\section{Introducción}

Dentro del campo de la educación una de las áreas menos estudiada y más olvidada es la relativa a niños y niñas que se educan en contextos de itinerancia (temporeros del campo, trabajadores del circo, feriantes, etc.) (Sequeira, 2009). En este trabajo se aborda la problemática relacionada con la educación en el ámbito circense, haciendo un breve recorrido a través de la historia de la educación en el circo hasta llegar al estado actual de la cuestión.

A lo largo de los años, se ha luchado por el derecho a la educación de los hijos de las familias itinerantes y por la superación de las dificultades que este colectivo tenía a la hora de asistir a un centro ordinario por sus necesidades continuas de desplazamiento. Así pues, el Ministerio de Educación, en 1986, inicia el Programa de Aulas Itinerantes, bajo el cual proporciona profesorado a toda la población circense favoreciendo la asistencia continuada a un aula y facilitando la adquisición de conocimientos académicos adecuados a cada edad.

La organización y la didáctica en las aulas itinerantes sucede de manera similar a las escuelas unitarias. Un aula unitaria se caracteriza por tener un único espacio bajo el cual un docente atiende a varios alumnos de diferentes edades y niveles educativos. Estas aulas suelen encontrarse 
en los ambientes rurales, y en especial en aquellas poblaciones con un número reducido de habitantes y alejadas de las ciudades. En las aulas unitarias, el docente desempeña todas las funciones del centro, y lleva a cabo su enseñanza con un número reducido de alumnos, que puede variar entre dos o doce niños. Cuando el número de alumnado sobrepasa los doce, se plantea la posibilidad de incorporar otro docente al aula.

La metodología de las aulas unitarias se basa principalmente en una enseñanza personalizada en la cual el docente busca el desarrollo integral de cada alumno partiendo de su individualidad (edad, características evolutivas, maduración, conocimientos previos, necesidades especiales) y de manera flexible va adaptando su enseñanza para alcanzar a todo el grupo-clase. Guerrero (2011) expone que una metodología muy común en este tipo de aulas es la enseñanza multigrado que requiere de ciertos componentes metodológicos básicos, de los cuales destacan: la planificación de las clases, el trabajo en grupo y el interaprendizaje, el aprendizaje autónomo, profesores guías y facilitadores del aprendizaje con diversas metodologías, organización y programación del currículum, variedad de estrategias para atender al alumnado y tener en cuenta el rol activo del estudiante y sus conocimientos previos.

Así pues, se puede decir que el circo funciona como un aula unitaria debido a que cuenta con un maestro que desempeña todas las funciones del centro y con un número reducido de alumnos de diferentes edades y niveles educativos concentrados en un mismo espacio, pero, a su vez, se diferencia de esta en el hecho de no estar fija en un lugar sino que se desplaza continuamente.

\subsection{Breve historia del circo}

Según se describe en el documento publicado por el Parlamento Europeo en 2003, sobre la situación del circo en Europa, la historia del circo se remonta hasta hace aproximadamente 3000 años. En algunas civilizaciones de Oriente (China, Mongolia, etc.) y otras de Occidente (Grecia, Roma, etc.) se llevaban a cabo algunas actividades para el entrenamiento de sus ejércitos que hoy en día relacionaríamos con el circo tales como las acrobacias, el contorsionismo o el equilibrio. Pero fueron los romanos quienes dieron nombre al circo, en aquel entonces llamado circus refiriéndose a un espacio circular abierto en el que se desarrollaba un espectáculo de entretenimiento. Tras la caída del Imperio romano y durante toda la Edad Media, este tipo de espectáculos decayeron y tan solo algunos acróbatas continuaron realizando sus ejercicios de manera pública.

En 1770, el jinete británico Philip Astley creó el ahora conocido como circo tradicional, definido por la Asociación Internacional de Historiadores de Circo como el punto de encuentro entre un programa artístico organizado y una compañía musical, con actuaciones de acróbatas, clowns y domadores de animales salvajes y domésticos dentro de una explanada con forma oval (Parlamento Europeo, 2003). En 1820, en Estados Unidos, se integra la carpa de lona, hecho que perdura hasta la 
actualidad, ya que facilita tanto el desplazamiento en largas distancias durante las giras como el montar y desmontar las carpas con mayor rapidez (Seibel, 1993:14).

A mediados del siglo xx el circo entró en una etapa de decadencia debido a la aparición de nuevas tecnologías como la radio y la televisión, que captaban la atención de la sociedad de aquel entonces, quedando el circo en segundo plano. Otro factor que afectó al circo fueron las grandes dimensiones de las carpas y caravanas, ya que al crecer el centro urbano no había suficiente espacio para montarlas, consecuencia de lo cual el circo tuvo que desplazarse a las afueras de las ciudades.

En España, la historia reciente del circo remonta hasta el siglo XIX, momento cumbre en cuanto a rendimiento artístico circense y a partir del cual se asentó completamente como parte de la cultura popular de entretenimiento. Sin embargo, su expansión fue súbitamente frenada durante la Guerra Civil, momento en el que un gran número de circos tuvieron que cerrar y muchos artistas tuvieron que emigrar a otros países. No será hasta los años sesenta que tendrá un pequeño renacimiento que vuelve a ser frenado en la siguiente década debido a la introducción de nuevas formas de ocio entre la población como la televisión (Pernas, 1999).

En la actualidad, el circo forma parte de nuestra cultura, construida a lo largo de los siglos y que goza de cierta estabilidad a pesar de que ha tenido que adaptarse a los nuevos tiempos, incorporando las tecnologías o acomodándose a las legislaciones europeas y españolas en lo referido a la tenencia de animales con el fin de evitar el maltrato.

\subsection{Historia de la educación en el circo en Europa y España}

En Europa, el reto de abordar la problemática de la educación de los hijos e hijas de las familias circenses se han encontrado dos dificultades. Por un lado, la dificultad de establecer una regulación europea homogénea de directrices educativas, debido a las diferencias de cada país respecto a la temporada de actuaciones, ya que mientras en países como Alemania o Francia la temporada es estacional, en otros países como Italia o España, la temporada dura el año completo. En segundo lugar, se hace especialmente difícil realizar seguimiento educativo a los niños y niñas pertenecientes a familias que trabajan en circos pequeños y que suelen ir cambiando de compañía en función de sus contratos. La dispersión y lo imprevisible de su situación hace que la escolarización regular sea prácticamente imposible.

Para intentar optimizar la educación de los niños y niñas del circo y de cualquier otro tipo de trabajador itinerante en Europa, en 1988 se crea por iniciativa de la Comisión Europea, la Federación Europea para la Educación de los Niños de los Trabajadores Itinerantes (EFECOT) y que supuso la denuncia de muchos problemas existentes respecto a la calidad educativa que recibían los hijos de familias itinerantes y la necesidad de iniciar acciones que lo abordaran. Un año después se aprueba la 
Resolución del Consejo Europeo respecto a las medidas generales a tomar para los niños de trabajadores itinerantes. Progresivamente la situación comienza a mejorar, especialmente en educación primaria, sin embargo, queda a día de hoy todavía pendiente la mejora de la educación infantil y la secundaria.

En España, al igual que sucedió en Europa, durante muchos años, han sido muchas las familias circenses que se han visto forzadas a dejar a sus hijos en ciudades alejadas de ellos, junto a otros familiares, o en escuelas hogares, para que recibieran una educación escolar. La gran mayoría de las veces, era tan dura esta situación que los trabajadores del circo decidían estar junto a sus hijos aunque esto significara dejarlos sin escolarización.

En 1978, se aprueba la Constitución Española en cuyo artículo 27, se reconoce el derecho de todos los españoles a la educación, de manera que el Estado debe garantizar una formación que permita desarrollar la personalidad para poder convivir en sociedad y adquirir derechos $y$ libertades fundamentales.

Según describe Martín (2003), en 1986, Pierre Paret publicó un estudio llamado Educación y escolaridad en el circo, en el cual reflexionaba sobre cómo desde el circo se había priorizado la formación artística del joven por delante de la intelectual. Para Paret, la educación no podía verse dificultada por el hecho de vivir en circunstancias ambulantes o incluso de trabajar en los propios espectáculos. La necesidad de entrenar, es decir, de recibir una formación artística debía realizarse paralelamente a la educación formal, académica y reglada, buscando la máxima calidad. Paret también describe la voluntad existente por proporcionar una educación privada a los hijos de los trabajadores del circo y el fracaso de dicha voluntad, por lo que respalda la necesidad de un apoyo educativo de carácter estatal.

Esta necesidad se formalizó en España cuando en 1983 el Ministerio de Educación y Ciencia promulgó el Real Decreto 1174/1983, de 27 de abril, mediante el cual se trató de disminuir la situación de desigualdad de los colectivos itinerantes. El Real Decreto hacía especial hincapié en la función del sistema educativo para eliminar desigualdades así como a la función compensatoria e integradora de la educación en colectivos cuyas condiciones de inferioridad eran especialmente acusadas en comparación con las ofrecidas por el sistema escolar general.

Al amparo del Real Decreto 1174/1983, se acordó el Primer Convenio entre el Ministerio de Educación y Cultura y la Asociación Española de Empresarios de circo con el que se daba comienzo al Programa de Aulas Itinerantes teniendo como principal objetivo dar respuesta a las necesidades de niños y niñas, hijos de artistas, que por su especial modo de vida no podían asistir a un aula normal (Sánchez, 2006). El convenio, plantea un mínimo de seis alumnos para poder constituirse como aula y asignar profesorado, y en los casos en los que haya un número de alumnos igual o superior a doce se constituirá una segunda aula. Además también determina responsabilidades del circo como la provisión de una 
caravana para el docente y otra para la escuela. Durante el curso 19861987 comienza el programa de la mano de los maestros Carlos Pulido Blas y Damián que trabajaron en los circos Mundial y de Teresa Rabal, respectivamente (Martín, 2003). Diez años después se aprueba el Real Decreto 299/1996 que regula las medidas de compensación y de prevención de desigualdades educativas de los colectivos itinerantes y que todavía mejora y refuerza la dotación de profesorado y de subvenciones para la adquisición y renovación de materiales educativos.

En 1998, Hernández describió la situación educativa de los niños itinerantes según su calidad. Así, encontró un primer grupo conformado por hijos de personal circense con contratos fijos y que eran quienes gozaban de una educación de mayor calidad. Un segundo grupo que dependía de la duración de los contratos establecidos con el circo y para quienes la asistencia educativa era intermitente, y finalmente un tercer grupo de hijos de trabajadores temporales poco cualificados, cuya asistencia educativa era particularmente baja.

En 1999 se crea la Asociación de Maestros de Escuelas de Circo, cuyo objetivo principal es defender y promover la mejora de la educación de los niños y niñas que se desplazan con circos y ferias por España.

En la Orden de 1 de febrero de 2001 de la Delegación de competencias del Ministerio de Educación y Ciencia, se plasma la ordenación, coordinación y gestión del Programa de Educación Compensatoria e Intercultural. Y en 2002 la Ley Orgánica 10/2002 de 23 de diciembre, establece entre sus principales objetivos la adquisición de un sistema educativo de calidad y la integración de este a la mayoría de alumnos. Así pues, durante el curso 2001-2002, se consiguió aumentar el número de docentes de circo a 16 en 11 circos diferentes. Además durante este curso se inician planes formativos específicos para el profesorado del circo con el fin de mejorar los contenidos y la metodología pedagógica a las características, los recursos y el contexto particular de estos alumnos (Molinero, 2010).

En la Resolución de 25 de febrero de 2004 de la Secretaría de Estado de Educación y Universidades se establecieron las bases que regulaban y convocaban subvenciones a las empresas circenses para la atención educativa a la población itinerante en edad de escolarización obligatoria y desde entonces hasta la actualidad han seguido convocándose diferentes ayudas para la difusión del arte circense.

Dos son los proyectos más destacables que desde el Ministerio de Educación se han llevado a cabo para mejorar la educación de los niños y niñas itinerantes.

Por un lado, el proyecto CINFO, que cuenta con el apoyo europeo como parte de la Acción 1 del Programa Sócrates Comenius y que pretende informar y dar a conocer a la sociedad la situación educativa en el circo mediante la elaboración de un libro de fotografía sobre la población escolar del circo, y una guía didáctica de trabajo para el profesorado y potenciar la formación de estos para que puedan crear sus propios materiales adaptados a la realidad de sus aulas. 
Por otro lado, existe el Proyecto de Educación Telemática que intenta mejorar la enseñanza y aumentar la motivación del alumnado en el ámbito circense aprovechando las ventajas que ofrecen las TIC.

Así pues se puede observar que ha sido mucho el esfuerzo y la constancia de los trabajadores itinerantes para reivindicar una educación escolar en condiciones de igualdad para sus hijos e hijas, sin embargo, todavía queda mucho recorrido por hacer ya que el actual sistema pedagógico contempla la atención directa a los niños y niñas de educación primaria, mientras que a partir de secundaria es habitual la deserción de los estudios, al tener que regirse por un programa de educación a distancia (Sequeira, 2009).

\section{Objetivos}

El objetivo principal del trabajo es indagar en el funcionamiento de las escuelas de circo, desde un punto de vista tanto organizativo como didáctico.

Como objetivos secundarios se pretende explorar los orígenes de las aulas circenses así como establecer una comparación entre estas y las ordinarias. Finalmente, se plantea describir el contexto y la problemática que rodea a la creación de escuelas itinerantes en el mundo del circo.

\section{Metodología}

Esta investigación consiste en un estudio de casos en el cual se analiza de forma cualitativa el discurso de tres maestros que desarrollaron parte de su carrera profesional en un aula itinerante circense.

El instrumento utilizado para llevar a cabo este estudio fue la entrevista semiestructurada. Para elaborar esta entrevista se tuvieron en cuenta aquellos aspectos que según la bibliografía revisada se consideraron de mayor interés y relevancia y, finalmente, quedó dividida en tres partes: preguntas sobre organización escolar, preguntas didácticas y pedagógicas y preguntas sobre vivencia personal.

La primera parte incluía preguntas sobre la organización del colegio circense como: si el factor itinerante afecta a la organización en cuanto a horarios lectivos, descansos, espacios en el aula o en la docencia durante los desplazamientos, cómo ha afectado la LOMCE en la dinámica habitual, qué ayudas se ofrecen desde el gobierno o cómo es la comunicación con las familias del alumnado.

La segunda parte se centró en la metodología y la planificación del curso, por lo que respecta a la programación anual, salidas extraescolares, refuerzos, etc. También se preguntó por los materiales pedagógicos, la evaluación, el servicio de orientación académica y de detección o atención a las NEE y la resolución de conflictos dentro del aula. 
Y en la tercera y última parte, entraron cuestiones sobre la vivencia personal del entrevistado como docente de circo, en la que se le preguntó por su tiempo libre y los pros y contras de ser maestro de circo, entre otras.

La muestra del estudio fueron tres personas entrevistadas, dos hombres, de 23 y 27 años y una mujer de 39 años. El primer entrevistado fue un murciano recién graduado en el Grado de Educación Primaria de Murcia, que estaba llevando a cabo su primer empleo como docente en el Circo Mundial, situado en ese momento en la ciudad de Valencia. El segundo entrevistado fue un manchego titulado en Educación Primaria, que también estaba llevando a cabo su primer empleo como docente en el Circo Wonderland, situado en aquel momento en la ciudad de Castellón. Y la tercera entrevistada fue una docente valenciana titulada en Educación Infantil con un año de experiencia como maestra de circo en el Circo Americano y el Circo de la Alegría, durante el curso 2009-2010.

El procedimiento que se siguió para poder realizar este trabajo fue en primer lugar, la preparación y revisión de la entrevista semiestructurada; en segundo lugar, se concretaron las reuniones para dos de las cuales hubo que desplazarse a la localidad donde estaba situado el circo en ese momento y el tercer caso se grabó el registro telefónico utilizando un dispositivo móvil. Finalmente, se transcribieron los datos obtenidos a través del software de audio Audacity, para su posterior análisis.

\section{Resultados}

Para comentar los resultados, a continuación se establecen tres grandes bloques. El primero de ellos relativo a la organización (horarios, espacio del aula, docencia en los desplazamientos, legislación y comunicación con las familias), el segundo a la didáctica (número de alumnado, metodologías, materiales pedagógicos, las TIC, evaluación, planificación del curso, NEE y aspectos de convivencia y conflictos) y el tercero vivencia personal (obtención del empleo, experiencia, alumnado del circo, tiempo libre y pros y contras del trabajo como docente de circo).

En la organización en cuanto a horarios lectivos y recreos, se observa que en los tres circos se sigue la jornada continua, es decir, el horario escolar se lleva a cabo de 9 a $14 \mathrm{~h}$ para los alumnos y de 9 a $15 \mathrm{~h}$ para los docentes.

Los horarios los marca el Ministerio, como es un aula itinerante, bueno como es un aula de circo, el horario es continuo, de 9 a $14 \mathrm{~h}$ los alumnos y hasta las $15 \mathrm{~h}$ los maestros. Y bueno eso está muy bien porque es todo continuo [...].

Cuando el circo se traslada a otra ciudad y la escuela se ve afectada por la itinerancia, los docentes deben adaptar su horario y recuperar esas horas impartiendo clases por la tarde o incluso los fines de semana. 
[...] cuando el circo se mueve si tú tienes clase por la mañana tienes que adaptarlo o bien hacer la clase por la tarde o recuperándolo otro día, un sábado o un domingo, eso ya lo que tú decidas, es a la voluntad del profesor. Es él el que tiene la potestad de recuperar el tiempo de la clase cuando él quiera.

En cuanto al espacio del aula, los tres circos cuentan con un camión adaptado con el fin de tener un espacio en el que se pueda llevar a cabo la educación de los niños circenses. En el caso del Gran Circo Americano y el Circo Mundial, el camión cuenta con dos aulas, una de menor y otra de mayor dimensión. Normalmente solo se utiliza una debido al escaso número de alumnos, pero cuando hay dos profesores o un número mayor de niños, se divide la clase en dos grupos: Educación Primaria y ESO, y cada grupo ocupa un aula diferente

En el caso del Circo Wonderland, el camión adaptado solo cuenta con un aula en la que se encuentran todos los alumnos y, en caso de que el número de alumnos sea mayor a la capacidad del aula, tienen preferencia los niños de primaria ya que es una educación obligatoria.

el espacio es esto [extiende los brazos refiriéndose al aula], ahora tengo más o menos dos de infantil, primaria y la ESO. Es pequeño pero si entraran más alumnos, tantos alumnos como caben en el aula, tienen prioridad los alumnos de primaria, después los de infantil y por último los de la ESO.

Como dato curioso, en los resultados se observa que en las aulas existe la norma de no entrar al aula con los zapatos de calle, que tienen que cumplir tanto los alumnos como el docente.

Hay una norma y es que no podemos entrar con zapatos de calle aquí al colegio, porque lo puedes ensuciar. Nos cambiamos y nos ponemos unas de estar por casa, incluso yo. [...] subíamos las escaleras del camión y todos teníamos allí las zapatillas de estar por casa, entonces todo el mundo se quitaba las zapatillas de ir por la calle, la dejaban en un rinconcito y se ponía las de ir por casa $[\ldots]$

Los resultados también muestran que la nueva ley educativa (LOMCE) sí que afecta a la dinámica habitual de las aulas itinerantes, aunque en ninguno de los tres circos se haya puesto en vigor debido a que la mayoría de alumnos están cursando el segundo curso de los diferentes ciclos.

[...] nosotros este año al tener, por ejemplo, más número de alumnos de segundo, cuarto y sexto, que son en los cursos donde aún no ha entrado, con permiso de la directora hemos dejado aun la LOE [...].

Respecto a las ayudas del gobierno, los alumnos de la escuela itinerante tienen las mismas becas y ayudas que cualquier alumno de un centro ordinario.

Están las becas que hay para cualquier alumnado, de cualquier región de España [...] y no por estar en el colegio del circo tienes una ayuda, tienes las mismas ayudas, tú las pides y si te las dan bien y si no pues nada. 
Además de estas becas, los circos reciben una subvención para cubrir los gastos de la caravana del docente y para el material escolar necesario.

Los tres docentes coincidieron en que la comunicación con las familias es mejor que en una escuela ordinaria, ya que al vivir en un mismo espacio la comunicación es constante.

La comunicación con las familias es muy buena porque al vivir aquí todos juntos nos vemos todos los días y vamos hablando y si hay algún problema o tienes que decirle algo especial sobre su hijo puedes hablar con ellos sin ningún problema.

En los resultados obtenidos en el bloque de didáctica, se observa en cuanto al número de alumnos en el aula, que la clase cuenta con un número muy reducido de alumnos que tienen un mismo profesor que desempeña las diferentes funciones del centro.

[...] yo aquí tengo ocho alumnos y, bueno, en cuanto funcionamiento también, porque eres el único profesor [...] tú eres el profesor de todo y aparte de ser el profesor de todo, tú eres el director, tú eres el jefe de estudios, tú eres el secretario, entonces todas las funciones recaen sobre ti.

Respecto a la metodología los tres circos utilizan una enseñanza individualizada, en la que el maestro empieza la clase dando los buenos días y poniendo la fecha en la pizarra y después se dedica a ir alumno por alumno explicando los nuevos contenidos y resolviendo dudas mientras el resto de compañeros van realizando la tarea que el docente ha mandado.

[...] yo no vengo y explico como en una clase normal ordinaria que les explico para todos, yo tengo que hacer una clase más individualizada mesa por mesa atendiendo a cada uno [...] Entonces me voy pasando y resolviendo dudas, explicándoles, [...] Que a veces estás explicándole a uno y claro el otro al que ya le has explicado y ya comprende lo que le he explicado está haciendo su tarea, y mientras acabo de explicar ya ha acabado; entonces, a veces están un tiempo que no hacen nada, que es diferente a que si tú estás explicando en una clase donde todos tienen la misma edad y van al mismo ritmo. Sí que es verdad que uno termina antes que otro, pero es mínima la diferencia.

Los materiales pedagógicos que utilizan los tres circos son las plataformas de Internet (CIDEAD) para la realización de las tareas con los alumnos de la ESO y Bachillerato, y el uso de libros de texto en el alumnado de primaria.

[...] los mayores como los de bachiller trabajan por una plataforma de Internet, y los de primaria sí que trabajan con libros, como los libros normales de un colegio ordinario [...]

El uso de los materiales pedagógicos citado anteriormente indica que las nuevas tecnologías están presentes en las aulas itinerantes, ya que disponen de impresoras, tabletas y ordenadores con acceso a Internet, excepto el Circo Mundial a quien el Ministerio, por tener un docente privado, no le ofrece acceso a la red. 
[...] proyector no tenemos, sí que tenemos ordenador, impresora... pero nos falta Internet, porque claro, el Internet lo trae el profesor del Ministerio [...] Entonces yo estoy mirando para comprar un pincho o el Internet del Ministerio [...] si vienen más niños pues sí que tendrán que enviar un profesor del ministerio. Entonces yo me iría con los mayores y si ya traen Internet pues ya no tengo que mirar ningún pincho.

El Circo Americano y el Circo Wonderland trabajan más con las TIC ya que el acceso a Internet les proporciona un mayor repertorio de recursos para utilizar en clase. El primer circo se centra en el uso de diferentes programas interactivos (JClic y edu75) en los que los alumnos pueden practicar los contenidos con diferentes juegos.

El Ministerio te proporcionaba pinchos de estos de Internet pero con mucha potencia. El temario era muy corto entonces te daba tiempo a hacer juegos con ellos en Internet, Jclic y eso [...] Yo con el que más trabajaba era Jclic porque era el que yo conocía y pues con el que más me manejaba [...] Ahora también hay mucha diversidad como por ejemplo el edu75 y el epistec que tienen muchos juegos; yo también los gastaba.

El segundo circo hace uso de un ordenador portátil para estimular a los alumnos mostrando imágenes y audios que a su vez completan los contenidos estudiados. Para una mayor motivación y dinamización de la enseñanza también utiliza las tabletas con las que llevan a cabo una serie de actividades en los diferentes programas interactivos.

Yo siempre trabajo en el portátil, entonces siempre que puedo utilizo el tema de fotos, música y demás para estimularles; también estoy trabajando con ellos las tabletas. Hay una serie de programas que facilitó el Ministerio, nos formó, entonces son programas interactivos donde tú escoges un vídeo en concreto y tú estableces hasta quince preguntas que pueden ser abiertas o cerradas. [...] entonces haces que ellos aprendan que la tableta no solo sirve para jugar sino que tiene otras funciones.

Aunque todos disponen de dispositivos electrónicos, los tres entrevistados coinciden en que les gustaría adquirir otras tecnologías como puede ser una pizarra digital o un proyector ya que esto facilitaría y haría una enseñanza más dinámica y significativa para el alumnado.

Yo soy partidario de que si hay subvención para aulas del Ministerio voy a intentar pedir, a ver si puedo conseguir un proyector para una pizarra digital, aunque son muy caras y no es fácil conseguirlas. He trabajado con pizarra digital y es una ventaja muy grande, pero es algo que de momento no hay y hay que adaptarse a lo que hay.

En cuanto a la evaluación del alumnado itinerante, los resultados muestran que varía dependiendo del tipo de docente, es decir, si este es privado o mandado por el Ministerio. Así pues, si el docente es privado como es el caso del Circo Mundial, el alumnado es evaluado por el Ministerio. Este pasa el examen al docente y el docente se encarga de pasarlo a los niños y de devolverlo al Ministerio de Educación, para que 
este pueda corregirlos y valorar si han adquirido los conocimientos necesarios o no. En este caso, los alumnos son evaluados con dos pruebas anuales, una en diciembre y otra en junio.

[...] el Ministerio les hace exámenes cada... [piensa]; a ver ellos en vez de trimestres tienen cuatrimestres, son como en la universidad, tienen dos exámenes al año, uno en diciembre y otro en junio. Antes de llegar al examen tienen que ir enviando cada quince días o un mes actividades. $Y$ van enviando las tareas y el Ministerio se lo va corrigiendo, las tareas y los exámenes, y les van diciendo mira aquí has fallado o esto tienes que mejorarlo.

En el caso de que el docente sea enviado por el Ministerio de Educación, como es el caso de los circos Wonderland y Americano, es el maestro el que evalúa a los alumnos. Este prepara la prueba basándose en los mínimos que considera que tienen que alcanzar los niños y estos la completan. Una vez realizadas las pruebas, el profesor las corrige y trasmite las notas al Ministerio. Este proceso se llevaba a cabo con los alumnos de primaria debido a que es una educación obligatoria, pero los de la ESO realizan la educación a distancia.

[...] Yo les hacía el examen y luego le pasaba las notas al Ministerio y ya está, menos a los de tercero de la ESO que ya no pertenecían a nosotros. Ellos lo que hacían era educación a distancia, [...] y ellos cada quincena tenían que enviar el temario y las actividades y el Ministerio los evaluaba.

Respecto al tema de la programación anual, los tres circos coinciden en que es muy difícil programar anualmente debido a la gran cantidad de desplazamientos que se efectúan a lo largo del curso escolar. Así pues, hacen una posible programación anual con los contenidos que se quieren dar y a medida que va avanzando el curso van adaptando la programación.

Yo programo día a día, yo tengo hecha una programación anual donde tengo recogido todo lo que voy a dar, que básicamente son los contenidos que tengo en los libros pero que hay muchas cosas que quito, que pongo, que luego saco, pero mi planificación la tengo en un cuaderno. [...] Hay días por ejemplo que te vas a algún sitio y a lo mejor no tienen luz, entonces te tienes que adaptar a lo que tengas, por eso no puedes planificar cosas que no sabes si van a estar o no, te tienes que adaptar al día a día y conocer el entorno.

En la organización de salidas extraescolares sucede exactamente lo mismo, debido a que hasta que no saben el destino de la siguiente parada no pueden organizar ninguna excursión, y esta información la reciben un par de días antes del desplazamiento. Una vez conocen el destino, se informan de las diferentes exposiciones o las actividades que pueden realizar y que les pueden ser de provecho.

[...] las tienes que organizar cuando sabes ya más o menos el recorrido, porque yo no sé el recorrido hasta donde será, entonces más o menos intento saber un sitio, una o dos ciudades un poquito antes para poder orientarme, 
pero tú no puedes planificar lo que vas a hacer en junio, [hace una pausa] es imposible, de hecho no podría programar casi nada.

Respecto a los refuerzos o clases particulares, los entrevistados comentan que normalmente no es necesario llevar a cabo este tipo de actividades ya que al ser un número pequeño de alumnos da tiempo a resolver dudas y a trabajar profundamente todos los contenidos sin necesidad de hacer uso del horario no escolar, pero en algunos casos como el que se dio en el Gran Circo Americano, en el que una niña tenía dificultades de aprendizaje, sí que se ofrece ayuda extraescolar. De la misma manera que si algún alumno encuentra alguna dificultad a la hora de realizar los deberes, el docente ofrece su ayuda.

Tenía una alumna que tenía necesidades especiales y yo iba a su casa a ayudarle a hacer los deberes porque su madre se ponía muy nerviosa [...] o venían los mayores y decían que no me aclaro a hacer esto, pues ale, ellos venían a mi caravana y hacíamos los deberes.

Relacionado con las necesidades educativas especiales, los docentes entrevistados afirman que son ellos los que tienen que dar el aviso al Ministerio de Educación de que se están observando anomalías en el aprendizaje de algún alumno y que es posible que se deba a un trastorno o dificultad en el aprendizaje. Entonces el Ministerio manda a un psicopedagogo $u$ orientador que realiza un estudio y lo confirma o desmiente. Si existe necesidad educativa especial, el psicopedagogo hace un seguimiento del alumno afectado a través de la observación del docente, y acude a la escuela de nuevo al cabo de un tiempo para repetir las pruebas y comprobar si hay una mejora o si se debe cambiar el diagnóstico.

Tú puedes detectarlo y tú puedes ir apuntando, [...] pero no eres un experto, y en este caso es un guión como profesor-tutor. Yo le llevo eso a la orientadora y le comunico lo que esté apuntando, notas o lo que percibes y ella es la encargada de que luego les dé el diagnóstico que para eso está. La orientadora es la que se encarga del tema de cualquier cosa que pueda suceder en el aula (psicólogos). [...] Tú puedes detectarlo puedes decir esto y esto, o veo que esta niña tiene un déficit de atención y puede ser que sea ese déficit o no... No lo sabes, se tiene que asegurar, entonces: ¿Qué mejor que un especialista para que te lo confirme?

Respecto a la convivencia y a la resolución de problemas, se observa que dentro del aula hay unas normas básicas en todas las clases. Aunque al estar en contacto las 24 horas del día, en muchas ocasiones entran conflictos exteriores al aula y el docente debe de actuar de manera que esta disputa no se pronuncie dentro de la escuela.

Hay unas normas en clase que ellos saben y que tienen que cumplir, [...] a veces hay conflictos que vienen de fuera y que entran al aula, entonces esos también los tienes que parar, porque claro... ellos viven las 24 horas del día juntos, entonces eso es como un pueblo pequeño donde todos se conocen y todos saben de qué pie cojean. 
Dentro del bloque de experiencias y después de analizar los resultados se ha observado que hay dos maneras de acceder a una escuela de circo. Una de ellas es de carácter privado, como es el caso del docente del Gran Circo Mundial, que busca profesor por su cuenta debido a que no tienen el mínimo de alumnos que pide el Ministerio para poder ofrecer un maestro.

Conocía a un compañero [...] que trabajó aquí en el circo, estuvo tres años creo, $[\ldots .$.$] y le comentaron que no les iban a mandar maestros del Ministerio$ porque no hay el número mínimo de alumnos y que si conocía a alguien magisterio que fuese bueno, que acabara de salir de la carrera, bien formado y que tuviera un buen nivel de inglés. Y él le dijo pues si mira conozco a un chico, y pues entonces él me habló y me lo comentó y yo le dije que sí. Y a partir de ahí les envié mi currículum para que lo viesen y me dijeron que de acuerdo, que estaba contratado, y me contrataron así.

La otra manera es a través de una convocatoria que organiza el Ministerio en la que se presenta un proyecto a defender ante tribunal y se hace una entrevista personal.

[...] había una convocatoria por el Ministerio de Educación y presenté un proyecto y al cabo de unos meses me llamaron [...]. Fui a Madrid y me hicieron una entrevista personal, y me enviaron un correo electrónico diciéndome que estaba preseleccionado. $Y$ luego tienes que hacer un proyecto de veinticuatro hojas [...] luego tienes que defenderlo delante de un tribunal. Son como unas oposiciones pero sin temario [...]

En cuanto a la experiencia en una escuela de circo, los tres docentes afirman que es una experiencia increíble y que aconsejan para todos los docentes jóvenes, ya que si no se lleva a cabo en una temprana edad luego es difícil disfrutarla porque los intereses de la persona cambian. $Y$ profesionalmente opinan que te ayuda a formarte como maestro, desarrollando tus competencias y aprendiendo a organizarte con los recursos que hay y sin prácticamente ayuda:

Profesionalmente [...] te enseña a tener que organizarte con pocos recurso [...] a trabajar en un aula que se mueve físicamente y académicamente [...] y también te ayuda a organizarte. Y personalmente una experiencia increíble [...]

Referente a las actuaciones del alumnado, se observa que los niños de primaria no suelen actuar en los espectáculo, solo en algunas ocasiones como por ejemplo hacer una voltereta. Aunque no actúen empiezan a entrenar desde los seis años o menos, solo son los alumnos más mayores los que tienen su número junto a los otros adultos.

Aunque no tengan un número sí que salen a hacer cosas pequeñas como algún volantín o salen como un niño del público [...] algunos sí que tienen su número, pero claro los más pequeños no.

Durante el tiempo libre del docente, los tres entrevistados afirman que lo emplean para la preparación de las clases, el estudio de los 
contenidos, sobre todo el de las asignaturas con especialistas ya que tienen que adquirir un buen nivel para poder enseñar estas materias y seguir formándose como maestros, el turismo por las diferentes ciudades que visitan y para el entretenimiento personal al gusto de cada docente, ya sea leer un libro o ver la televisión, entre otras.

Yo aquí tengo mi portátil, mi iPad, tengo acceso a Internet, tengo la Play 4 que me la compré, tengo mi tele, ¿a quién no le gusta ver una película o una serie? También tienes un rato de lectura, tu rato para estudiar, para pensar actividades que puedes hacer en tu día a día, actividades que puedes hacer con los niños, o donde puedes ir. [...] Al principio lo gastaba para empaparme de lo que era la vida del circo y luego pues turismo.

Y para acabar este apartado, los resultados respecto a los pros y contras de ser docente de circo muestran que los tres entrevistados coinciden en que los pros son la experiencia personal y la independencia que adquieres de alguna manera. $Y$, en contra, estar lejos de la familia y los amigos y no poder disfrutar junto a ellos algunas celebraciones como aniversarios $\mathrm{u}$ otros eventos importantes para la familia y el sentirte solo en algunas ocasiones.

Pros: es una experiencia muy buena, que te ayuda mucho a saber organizarte y a formarte como docente, adquieres experiencia y también, al estar lejos de casa y tener que solucionarte tú tus problemas sin tener a tus padres ahí, es como una manera de independizarte y saber solucionar tú mismo los problemas que surjan. Y contras... pues que estás lejos de la familia y de los amigos, y no puedes celebrar con ellos los cumpleaños y las fiestas que se hagan.

\section{Discusión y conclusiones}

Como se ha visto a lo largo de la investigación, ha sido mucho el esfuerzo que se ha tenido que hacer para conseguir una escolarización adecuada de los hijos e hijas de las familias circenses, empezando por la Constitución del 1978 que impulsó a Pierre Paret a mediados de los años ochenta a realizar su estudio y consiguiendo ese mismo año el comienzo del Programa de Aulas Itinerantes, hasta la actualidad en la que se sigue trabajando para que estos niños y niñas obtengan una educación de calidad.

Después de analizar los resultados se puede decir que las aulas itinerantes tienen varios aspectos en común con las aulas ordinarias como por ejemplo lo relativo a las leyes educativas como la LOMCE y la obligatoriedad de ajustarse a esta y los horarios, ya que en la actualidad muchos centros cuentan con un horario continuo. Pero también hay muchos aspectos diferentes como es el número de alumnos en las aulas y los niveles que hay dentro de estas, la metodología docente empleada que se acerca más a la de un aula unitaria ya que el docente debe cumplir todas las funciones del centro y tiene que tener en cuenta en su docencia no solo las características individuales del alumnado sino también los 
diferentes niveles de éstos. Por otro lado, la relación con las familias es otro aspecto diferenciador, debido a que viven en una misma comunidad y el contacto es mucho más estrecho y directo. La manera de programar el curso es más precaria que en el aula ordinaria y se ve afectada por los continuos desplazamientos y por las características de los lugares donde establecen su campamento, obligando al docente a planificar día a día.

Aunque es mucho lo que se ha conseguido a lo largo de estos años todavía falta mejorar algunos detalles como puede ser el aumento de nuevas tecnologías como proyectores o pizarras digitales dentro de las aulas itinerantes, un mayor apoyo por parte del Ministerio de Educación en cuanto a profesionales especializados que realicen seguimiento en el caso de alumnado con necesidades educativas especiales $y$, finalmente, seguir luchando para que siga creciendo el número de aulas itinerantes en los circos, con el fin de garantizar que todos los circos puedan disfrutar de este servicio y todos los menores, del derecho a una educación gratuita y de calidad.

En cuanto a futuras líneas de investigación, se podrían llevar a cabo más entrevistas a diferentes docentes de diversos circos para tener más información sobre las aulas itinerantes, sobre el rol del docente y para comparar con otras realidades y experiencias. También se podría entrevistar al alumnado de este tipo de aulas para conocer sus opiniones y demandas e incluso entrevistar a artistas de circo que comenten cómo fue durante su propia infancia la experiencia educativa.

Para finalizar, me gustaría decir que hay 14 circos españoles que en la actualidad cuentan con el Programa de Aulas Itinerantes, sin embargo se tiene que seguir luchando para que este servicio mejore y llegue a circos más pequeños que no puedan tener el mínimo de usuarios para constituir un aula, dando la oportunidad también a estos niños de poder elegir su futuro.

Así pues, este trabajo pretende ser también un reconocimiento a la gran labor de los y las docentes que trabajan o han trabajado como maestros itinerantes, contribuyendo asimismo en la difusión de esta posibilidad laboral dentro de la educación, dando una visión positiva del Programa de Aulas Itinerantes y de la tarea del maestro en el circo

\section{Bibliografía}

Constitución española de 1978, de 27 de diciembre, Boletín Oficial del Estado, 311.

GueRrero, M. C. (2011): «Nos expresamos: una sesión de educación física en una escuela unitaria», EmásF: Revista Digital de Educación Física, 9.

HeRnÁndez, J. P. (1998): «Educational Attention for the Travelling Population in Spain», EFECOT (1998): Travelling on Together, 10 Years of EFECOT, EFECOT, Bruselas. 
Ley Orgánica 10/2002, de 23 de diciembre, de Calidad de la Educación, Boletín Oficial del Estado, 307.

Martín, A. (2005): Folclore en las grandes ciudades: arte popular, identidad y cultura, Libros del Zorzal, Buenos Aires.

MARTín, F. M. (2003): "Umbrales de esperanza: circo y escuela», VV. AA.: El circo español ante el tercer milenio. Colección "El Circo». La Avispa, Madrid.

Molinero, R. (2010): "La magia de las aulas del circo», Revista Digital Innovación y Experiencias Educativas, 30.

PARet, P. (1986): «Educación y escolaridad en el circo», AIC: Análisis e Investigaciones Culturales, 27.

Parlamento Europeo (2003): "The Situation of the Circus in the EU Member States», Education and Culture Series, 111.

Pernas, R. (1999): Circo, en Amorós, A y J. M. J. Borque, Historia de los espectáculos en España, Editorial Castalia, España.

Real Decreto 299/1996, de 28 de febrero, de Ordenación de las Acciones dirigidas a la Compensación de Desigualdades en Educación, Boletín Oficial del Estado, 62.

Real Decreto 1174/1983, de 27 de abril, sobre Educación Compensatoria, Boletín Oficial del Estado, 112.

Resolución de 25 de febrero de 2004, de la Secretaría de Estado de Educación y Universidades, por la que se establecen las bases reguladoras y se convocan subvenciones a empresas circenses para la atención educativa a la población itinerante en edad de escolarización obligatoria, Boletín Oficial del Estado, 67.

Resolución de 25 de julio de 2001, de la Subsecretaría, por la que se dictan instrucciones sobre jornada, vacaciones, licencias y permisos del personal del Departamento destinados en el extranjero, Boletín Oficial del Estado, 237.

SÁnCHEZ, R. M. (2006): «Aulas de circo iMás difícil todavía!», P@K-ENREDES Revista Digital, 1.

SelBel, B. (2005): Historia del circo, Editorial del Sol, Buenos Aires.

SequeIRA, H. D. S. P. M. (2009): «Potential Circumstances to Special Education Needs in Circus Artist's Children, When Travelling», Revista Educación Inclusiva, 1. 


\section{¿Qué piensan las abejas? Intervención en teoría de la mente en un niño con trastorno del espectro autista en su aula ordinaria}

Raquel Casas Rustarazo al080529@alumail.uji.es

Clara Andrés-Roqueta candres@psi.uji.es 
La teoría de la mente (TM) es una habilidad cognitiva que permite comprender y predecir el comportamiento de otras personas según la comprensión de sus intereses, sentimientos, estados de ánimo. Algunos niños con trastorno del espectro autista (TEA) presentan dificultades en el reconocimiento y la comprensión de estados mentales ajenos y propios. Clásicamente, la intervención sobre estas habilidades se ha realizado de manera individual, sin embargo, estudios recientes demuestran la posibilidad de trabajarlas de manera inclusiva en edades tempranas. Siguiendo el enfoque inclusivo, en este trabajo se presenta una intervención educativa aplicada de manera inclusiva en un aula ordinaria de Educación Infantil (EI) con el objetivo de mejorar las habilidades de TM en un niño de 5 años diagnosticado con TEA (grado 1). Para ello, se han trabajado algunas de las habilidades que engloban aspectos de TM adecuadas a su edad, tales como la identificación y el reconocimiento de expresiones faciales; la identificación de sentimientos y sus causas; las habilidades de prestar, ayudar y consolar; los globos de pensar, y las habilidades de comprensión de falsa creencia (mediante situaciones de contenido inesperado y cambio de ubicación). La intervención llevada a cabo ha incorporado en su metodología actividades, juegos, fichas, cuentos y representaciones de mímica y se ha aplicado de manera integrada junto a un proyecto educativo («las abejas») y de manera conjunta con el resto de los niños del aula ordinaria. Para comprobar la efectividad de la intervención, se realizó un pretest y dos postest empleando medidas de TM. Los resultados evidenciaron que las habilidades de la TM del niño con TEA mejoraron mediante un entrenamiento cotidiano e inclusivo. Se concluye sobre la efectividad del método en el caso concreto, siendo a su vez beneficioso para el resto de compañeros.

Palabras clave: trastorno del espectro autista (TEA), intervención, teoría de la mente (TM), inclusión, educación infantil.

\section{Introducción}

Las personas con TEA muestran dificultades para ponerse en el lugar del otro e intuir su mundo mental. Estas personas tienen limitaciones severas para mantener interacciones sociales fluidas, dinámicas y recíprocas (Freire, Llorente, González, Martos, Martínez, Ayuda y Artigas, 2004).

La investigación en el tema del TEA en la etapa infantil es confusa y amplia debido al desconocimiento de su etiología (Choto, 2007). Los primeros estudios se basaron en pocos casos y desde hace pocos años se 
le ha ido dedicando mayor atención y han aumentado el número de investigaciones.

Actualmente, se puede explicar el TEA como un «trastorno neurológico definido por criterios conductuales» (Giraldo, 2010: 97). Además, Morales, Domènech-Llaberia, Jané y Canals (2013) apoyan la idea de que los TEA se presentan como un continuum de cuadros sintomatológicos que tienen diferente severidad y que están caracterizados por déficits persistentes en las habilidades de comunicación e interacción social. Además, se caracterizan por la presencia de unos patrones de comportamiento y unos intereses que son restringidos y repetitivos que los distinguiría de otros trastornos ligados solamente al lenguaje y la comunicación. En la actualidad, no existe un consenso claro entre las causas y conductas que incluyen o excluyen el autismo, pero sí que hay un acuerdo al señalar la presencia de alteraciones en la comunicación, en lenguaje y las relaciones sociales (Choto, 2007).

Las dificultades más frecuentes que tienen las personas con TEA se hacen visibles a la hora de relacionarse y comunicarse con sus iguales, al entender y emplear lo intangible (por ejemplo, la imaginación o el pensamiento) y la falta de destreza para programar, organizar su conducta y entender al resto de personas (Chamorro, 2010). Además, los niños con TEA tienen un déficit muy importante en las funciones ejecutivas, ya que sus conductas y sus procesos de pensamiento suelen ser rígidos, inflexibles, repetitivos y perseverantes (Freire et al., 2004). A nivel neurológico, la presencia de una disfunción en el hemisferio derecho conlleva a una dificultad para captar el significado de la información emocional expresada a través de canales no verbales, dar respuestas emocionales exageradas y dificultades para adaptarse a situaciones nuevas (Freire et al., 2004).

Por otra parte, también hay que tener presente que todos los niños con TEA no tienen los mismos síntomas y en la misma intensidad, ya que las manifestaciones varían del momento evolutivo y de cada persona (Morales et al., 2013). A pesar de ello, existen unas diferencias observables entre los niños con y sin TEA. Por ejemplo, en el manual DSM-V se describe que estos niños se muestran intolerantes a los cambios que se producen en sus rutinas, hacen movimientos estereotipados, desarrollan hipersensibilidad ante determinados sonidos, $y$, además, muestran pocas habilidades para iniciar o aceptar contacto físico, evitan el contacto visual, etc. Lo cual impide la correcta interacción social, la comunicación verbal y no verbal y en la actividad imaginaria, y también la restricción en el repertorio de actividades e intereses (Choto, 2007).

Como ya se ha comentado anteriormente, los niños con TEA tienen unas deficiencias que conllevan una discapacidad y unas limitaciones en determinadas áreas y habilidades relacionadas con la comprensión de las emociones y estados mentales de otras personas. En este sentido, la teoría de la mente (TM) es la capacidad cognitiva que permite a las 
personas llevar a cabo la representación de los estados mentales, de pensar, creer y desear. Por tanto, permite predecir y comprender la conducta de los demás y la nuestra propia, así como distinguir lo que individualmente pensamos, queremos y creemos de lo que piensan, quieren y creen otras personas. Por tanto, resulta esencial para entender que no todas las personas piensan y sienten igual (Chamorro, 2011). Así, se considera una habilidad metacognitiva que en muchos casos se supone deficitaria en el autismo (Martín, Gómez y Garro, 2012). Se han realizado numerosos estudios de la TM en niños con TEA y estos han evidenciado que las dificultades se pronuncian a la hora de tomar perspectiva de otras personas (cognitiva y emotiva). La mayoría de estas investigaciones han demostrado que los niños con autismo fracasan en la resolución de pruebas de falsas creencias o comprensión de emociones, o bien las resuelven, pero tienen dificultades para transferir los aprendizajes a otras situaciones o pruebas (Martín et al., 2012).

Estas dificultades para intuir el mundo mental de los demás tienen consecuencias graves en su desarrollo social. Por ejemplo, puede conllevar problemas para predecir e interpretar la conducta y las intenciones de otras personas, así como entender las emociones propias y ajenas y desarrollar actitudes empáticas. Además, presentan dificultad para mentir y comprender engaños y también, o para anticipar lo que los demás pueden pensar sobre su comportamiento. Por todo ello, tienen dificultades sociales en la mayoría de las actividades cotidianas y fundamentales para conseguir un desarrollo óptimo personal y una buena calidad de vida (Freire et al., 2004). Preocupados por estas dificultades, distintos estudios se han marcado el objetivo de buscar un método de intervención efectivo para mejorar las habilidades de TM de los niños con TEA. Por ejemplo, la mayoría de trabajos se han centrado en entrenar habilidades de detección de falsas creencias (Martín et al., 2012). Estos estudios han demostrado mejoras en la habilidad de tomar distintas perspectivas y reafirman que "dicha habilidad es entrenable a través de un correcto análisis funcional de las claves contextuales a discriminar» (Martín et al., 2012: 547).

Concretamente, Martín et al. (2012) llevaron a cabo un estudio en el que realizaron varias pruebas con las que entrenaron la capacidad de los niños con TEA para tomar perspectivas distintas a las suyas. Su método produjo mejoras en las habilidades para distinguir conceptos espaciales y en la ordenación de secuencias, pero también mejoras en la comprensión lectora, en las habilidades sociales de saludar, en el desarrollo simbólico y en su habilidad de reconocimiento y expresión de las emociones. Asimismo, en cuanto a las tareas de falsa creencia, los niños generalizaron lo aprendido a distintas situaciones y con diferentes personas conocidas.

Finalmente, y ligando con el tema central de la presente investigación, otro aspecto a considerar, es que cada vez más, gracias a las perspectivas inclusivas, se están escolarizando alumnos con discapacidades en aulas regulares, con la intención de mejorar su desarrollo académico y social. Sin embargo, algunas personas tienen 
deficiencias en las habilidades sociales y, hoy en día, hay muy poca información sobre las relaciones amistosas que pueden llegar a establecer en estos entornos escolares. En este sentido, se detecta el riesgo (y no solamente el beneficio) de incluir niños autistas en aulas ordinarias sin intervenir sobre todos estos aspectos comentados. En edades más tempranas, ya se observa que los niños que tienen el TEA escolarizados en aulas ordinarias, presentan unas actitudes $y$ unos patrones de conducta diferentes a sus iguales. Por tanto, las incursiones en el mundo social, aunque pueden traer grandes retos y beneficios, si no se abordan adecuadamente, también pueden conducir al rechazo social y a la victimización (Chamberlain, Kasari, Rotheram-Fuller, 2006). Este trabajo se apoya en una perspectiva conductual y constructivista, basándose en datos empíricos previos que demuestran que las habilidades de TM como, por ejemplo, la toma de perspectiva, pueden ser entrenadas con el fin de que los niños tengan éxito en estas habilidades y puedan generalizarse a otros contextos. Además, el sistema educativo debe poder atender adecuadamente las necesidades de este tipo de alumnado, a través de la diversidad y la personalización (Duk, Loren, 2010).

\section{Objetivos}

El objetivo de esta investigación es mejorar las habilidades de TM de un niño que tiene TEA y que está escolarizado en un colegio público, concretamente en un aula de infantil de 5 años. Para ello se llevará a cabo una intervención en el ámbito escolar (dentro de su aula ordinaria), de una manera inclusiva y a partir de un proyecto educativo de "las abejas».

Los contenidos de TM se trabajarán de una manera transversal, adaptada a los contenidos que se dan en el aula (concretamente, enmarcadas en el tema de "las abejas») y centrada en aquellas áreas dónde el estudiante presenta más deficiencias.

A modo de resumen, los contenidos de TM que se pretenden trabajar son los siguientes:

- La comprensión de las emociones y la consecución de la empatía.

- El reconocimiento y la comprensión de las expresiones faciales.

- La comprensión de los sentimientos y su causa.

- La comprensión de los verbos mentales creer y saber.

- La comprensión del verbo mentalista pensar.

- El desarrollo y la comprensión de las capacidades de ayudar, prestar y consolar.

- Globos de pensar.

- Las habilidades en el reconocimiento de la falsa creencia y el cambio de ubicación

Para comprobar la efectividad de la intervención, se realizará una evaluación en una situación pretest $y$ dos en situación postest (se 
realizará una semana después de finalizar la intervención y un mes después, para controlar el efecto de la memoria inmediata).

A partir del objetivo, se señalaron las siguientes hipótesis:

- Se espera obtener una mejora en las habilidades de TM del niño después del entrenamiento (mejores resultados en las medidas de TM en el primer postest en relación con el pretest).

- Asimismo, se tiene la expectativa de que los resultados del pretest sean inferiores al primer postest y que, a consecuencia del efecto de memoria inmediata, los resultados del primer postest sean superiores a los del segundo.

\section{Material y método}

Esta intervención se puede considerar bajo la metodología de caso único, ya que se ha aplicado únicamente sobre un niño con TEA de 5 años. Esto implica que los datos no se pueden generalizar ni extrapolar a la población de niños con TEA. A pesar de ello, se considera que sí que se puede obtener información con un cierto grado de fiabilidad sobre la intervención realizada, siempre y cuando esta se aplique a casos y condiciones similares.

En relación con todo lo anterior, el presente estudio se ha hecho aplicando una metodología basada en la investigación-acción en un caso único y los pasos han sido los siguientes:

1. Medir en situación pretest para establecer una línea base del nivel de TM (fase de investigación).

2. Decidir sobre qué aspectos intervenir (llevar a cabo la acción).

3. Diseñar y planificar las actividades de intervención.

4. Intervenir en el aula mediante las actividades diseñadas.

5. Evaluar la efectividad del método al finalizar la intervención (pretest 1, una semana después).

6. Evaluar la efectividad del método al finalizar la intervención pasado un mes (pretest 2, un mes después).

\subsection{Muestra}

El presente trabajo forma parte de un estudio en el que ha participado un niño del segundo ciclo de El de 5 años escolarizado en un aula de P3 de un colegio público de la provincia de Castellón. Este alumno está diagnosticado con el TEA grado $1 \mathrm{y}$, por tanto, tiene buen potencial cognitivo y lingüístico. Asiste a un aula ordinaria y recibe diariamente ayuda de la psicopedagoga del centro. Pertenece a una familia con un nivel socioeconómico medio. 


\subsection{Procedimiento}

El participante fue evaluado en tres momentos distintos: primero en situación pretest $y$, posteriormente, en dos postest. Las pruebas en pretest se aplicaron antes de iniciar la intervención, el primer postest se llevó a cabo una semana después de la última sesión, y el segundo postest se aplicó un mes después de finalizar la intervención. Se decidió realizar dos postest para controlar el efecto de recuerdo de las actividades de intervención.

Entre el pretest y el primer postest pasó un mes y el participante realizó actividades encaminadas a mejorar habilidades de TM todos los días, con una duración de una hora cada día.

Finalmente, los datos se registraron y analizaron con el programa Excel para Windows 2000.

\subsection{Instrumentos de pretest y postest}

Para la evaluación inicial de las habilidades de TM del niño se utilizó el libro En la Mente 1 (Monfort, 2001) y, a partir de ella, se diseñaron situaciones paralelas para evaluar la TM en situación de pretest y postest.

Los primeros (instrumentos pretest) se emplearon con el objetivo de obtener una información inicial del niño de todas sus habilidades relacionadas con TM y poder hacer hincapié en las habilidades en las que hay un desempeño más deficiente. Los segundos (instrumentos postest) se han empleado con el objetivo de obtener una información con la que comprobar la efectividad de la intervención una vez ya aplicada.

Todas las pruebas del pretest, postest 1 y postest 2 se hicieron a lo largo de una misma mañana, en la que se administraron un total de 10 pruebas:

- 2 pruebas de reconocimiento y comprensión de expresiones faciales.

- 1 prueba de emoción-causa.

- 2 pruebas de verbos mentalistas creer y saber.

- 1 prueba del verbo mentalista pensar.

- 1 prueba de verbos mentalistas ayudar, prestar y consolar.

- 1 prueba de globos de pensar.

- 2 pruebas de falsa creencia.

A continuación, se detallan las pruebas de TM administradas, el procedimiento de administración y el rango de puntuación que se tuvo en cuenta a la hora de corregirla:

\section{Pruebas de reconocimiento y comprensión de expresiones faciales}

Reconocimiento de expresiones faciales: se le presentó al participante una tabla con seis imágenes. En cada imagen aparecía la cara de un niño y transmitía un sentimiento. Se le pidió que señalara utilizando 
su dedo la cara triste, la cara contenta, la cara cansada, la cara sorprendida, la cara enfadada y, finalmente, la cara asustada.

Expresión de palabras sobre las expresiones faciales: la evaluadora señaló las mismas caras y le preguntó al participante cómo se encontraba el niño de cada imagen que señalaba y el motivo de ese sentimiento.

Material y puntuación: se utilizaron las mismas pruebas en el pretest y en los dos postest. Las dos pruebas se evaluaron con un mínimo de 0 puntos y un máximo de 6 puntos.

\section{Pruebas de asociación de la emoción y su causa}

Se le mostraron al participante un total de seis dibujos en los que aparecían personas en diferentes situaciones, y se le pidió que identificara la emoción que transmitía el personaje de cada situación y que dijera el motivo.

Material y puntuación: en ambos postest se utilizaron las mismas imágenes, pero en el pretest se utilizaron imágenes distintas. A esta prueba se le asignó un rango mínimo de 0 puntos y máximo de 12 puntos. De forma desglosada, cada emoción identificada se puntuó con un máximo de 2 puntos.

\section{Pruebas de verbos mentalistas saber y creer}

Se mostró una secuencia de imágenes en la que se observaba cómo una niña tenía una caja de cartón y no sabía lo que había dentro y, finalmente, descubría que en el interior había un gato. La prueba consistió en hacerle preguntas al participante sobre lo que él creía que pensaba la niña del dibujo y lo que había dentro de la caja.

Material y puntuación: en el postest 1 y 2 se mostró una secuencia de imágenes en las que se observaba como un hombre tenía unas cajas de cartón y no sabía lo que había dentro y la expresión de su rostro variaba al abrir las cajas. La prueba consistió en hacerle al participante preguntas sobre lo que él creía que había guardado en cada una de ellas. A esta prueba se le asignó una puntuación mínima de 0 puntos y máxima de 3 puntos.

\section{Pruebas de verbos mentalistas pensar}

Se mostró una secuencia de 4 imágenes en la que se observaba un hombre escuchando sonidos detrás de una puerta. La prueba consistió en preguntarle al participante cuestiones sobre lo que pensaba el hombre del dibujo que había detrás de cada puerta.

Material y puntuación: esta prueba se administró de manera idéntica en el pretest y en el postest 1 y 2 . Se le asignó una puntuación entre 0 puntos y máximo de 4 puntos.

Pruebas de verbos mentalistas ayudar, prestar y consolar 
Se le mostraron al participante 4 imágenes. En cada imagen aparecían dos personas una de las cuales necesitaba la ayuda de la otra. La prueba consistió en preguntarle al participante lo que había pasado en cada imagen y cómo, según él, cada persona del dibujo debía de mostrar su ayuda al otro.

Material y puntuación: en los dos postest se utilizaron las mismas imágenes; en el pretest se utilizó el mismo tipo de imágenes, pero con situaciones diferentes. El rango mínimo de puntuación de la prueba fueron 0 puntos y el máximo 8 puntos. De forma desglosada, cada imagen se puntuaba entre 0 y 2 puntos.

\section{Prueba de los globos de pensar}

Se mostraron al participante cinco imágenes diferentes en las que aparecía un hombre mirando por la ventana y observando distintas situaciones. La prueba consistió en preguntarle al niño lo que, según él, debía de pensar el hombre de la ventana en cada una de las situaciones.

Material y puntuación: las imágenes utilizadas fueron las mismas en el pretest y en los dos postest. A esta prueba se le otorgó una puntuación mínima de 0 puntos y máxima de 10 puntos. De forma desglosada, cada imagen se puntuaba entre 0 y 2 puntos.

\section{Pruebas de falsa creencia}

Se le administraron al participante dos pruebas, una de falsa creencia y otra de cambio de ubicación:

Prueba de falsa creencia: se enseñó una secuencia de imágenes en la que aparecía un policía que había ido a cubrir un robo a una casa y observaba unas zapatillas detrás de una cortina. La prueba consistió en preguntarle al participante lo que, según él creía, debía de pensar el policía al ver las zapatillas.

Se mostró una secuencia de imágenes en las que se observaba un niño introduciendo un cangrejo en una bolsa de patatas fritas. A continuación, una niña metía la mano para sacar una patata frita y le picaba el cangrejo. La prueba consistió en preguntarle al participante sobre los pensamientos de la niña.

Prueba de cambio de ubicación: se le presentó al participante una secuencia de seis imágenes en la que se observaba cómo un hombre dejaba sus gafas encima de la mesa y salía de la habitación. A continuación, entraba una mujer en la habitación y las guardaba en un cajón y cuando el hombre volvía a la habitación, en consecuencia, ya no encontraba las gafas encima de la mesa. La prueba consistió en preguntarle al participante acerca de los pensamientos que él pensaba que debía de tener el hombre de la historia.

Material y puntuación: las imágenes utilizadas en la primera prueba de falsa creencia, fueron las mismas en el pretest y en los dos postest. Sin embargo, las imágenes de la playa y el cangrejo fueron sustituidas en los postest por otras en las que se observaba a un niño que estaba en el sofá 
viendo la tele y reflexionaba sobre quién había tocado al timbre de su casa. La prueba consistió en preguntarle al participante lo que, según él creía, debía de pensar el niño al escuchar el timbre y abrir la puerta

Respecto a la segunda prueba, esta fue diferente en los postest. Se presentó al participante una secuencia de imágenes en la que aparecía un hombre con una caja de bombones. Salía de la habitación y al volver estos habían desaparecido porque se los había llevado un niño. La prueba consistía en preguntarle al participante acerca de los pensamientos del individuo de la historia.

A esta prueba se le asignó un rango mínimo de 0 puntos y un máximo de 6 puntos. De forma desglosada, cada prueba se puntuaba entre 0 y 3 puntos.

\subsection{Método de intervención de TM}

A continuación, se exponen las actividades que se realizaron en el aula:

\section{Actividades para trabajar el reconocimiento y la identificación de expresiones faciales}

Se trabajó a través de un taller de mímica, cuatro fichas de identificación y reconocimiento de emociones y un juego de abejas.

Taller de mímica: consistió en que los niños del aula vieran a la maestra disfrazada de abeja representando distintos sentimientos, y adivinaran y escribieran en una ficha la emoción que esta estaba representando en cada momento.

\section{Fichas de identificación de emociones}

Ficha 1. Objetivo: unir la expresión facial de varias abejas con las palabras que definían el sentimiento que mostraba su cara.

Ficha 2. Objetivo: seleccionar entre todos los insectos los que estaban contentos (ver anexo 2.1.3).

Fichas 3 y 4 . Objetivo: seleccionar las abejas que estaban sorprendidas y las que estaban cansadas.

Juego de abejas: el objetivo era seleccionar entre un conjunto de imágenes todas aquellas en las que aparecían abejas y mostraban los mismos sentimientos.

Actividades para trabajar los sentimientos y la identificación de sus posibles causas

Se trabajaron con tres fichas y un cuento.

Fichas: en cada ficha aparecían dos imágenes y los niños tenían que explicar y describir el sentimiento de las abejas de los dibujos y sus posibles causas. 
Cuento: El objetivo del cuento era escuchar la lectura de una historia que hablaba sobre una abeja a la que le sucedían varias cosas. Debían identificar y representar con cartulinas los sentimientos de la protagonista del cuento. Además, los niños tenían tres caras de cartulina (una de alegría, otra de tristeza y otra de enfado) y las tenían que ir levantando según se iban relatando en el cuento los sentimientos de la abeja.

\section{Actividades para trabajar los verbos mentalistas creer y saber}

Se trabajaron con dos juegos, una ficha y una actividad.

El juego de la caja: en el primer juego el objetivo era que un niño se tapara los ojos con un pañuelo y el resto de niños introdujera un panal de abejas dentro de una caja. A continuación, el objetivo era reflexionar con los alumnos el motivo por el que ellos sí que sabían lo que había dentro de la caja, y el niño que tenía los ojos tapados no lo sabía.

El juego del baile de las abejas: se dividió la clase en dos grupos, un grupo se tapó los ojos mientras el otro grupo escondía los objetos. A continuación, la reflexión giró en torno al motivo por el que un grupo sí que sabía dónde estaban escondidos los objetivos y el otro grupo no lo sabía. Los niños tenían que bailar al encontrar los objetos escondidos.

Ficha. Objetivo: observar unas imágenes en las que aparecían unos personajes en situaciones diferentes y lograr interpretar lo que sabían o desconocían los personajes de las imágenes.

Actividad tarjeta de situaciones: la actividad de tarjetas de situaciones consistió en repartir dibujos para que los niños los observaran e interpretaran lo que sentían los personajes de las mismas.

Actividades para trabajar los verbos mentalistas de ayudar, prestar y consolar

Para trabajar estos verbos mentalistas se hizo una ficha en la que aparecían abejas que, por diferentes motivos, necesitaban ayuda. El objetivo de la ficha era que los niños reflexionaran y escribieran de qué manera podrían ayudar a los insectos.

\section{Actividades para trabajar los globos de pensamiento}

Para trabajar las habilidades mentales de los globos de pensamiento se hicieron tres fichas.

Fichas 1 y 2: el objetivo de estas dos fichas era que los niños observaran la imagen de una abeja y una oruga en dos situaciones diferentes, e interpretaran y escribieran el pensamiento de estos dos animales en los globos de pensamiento.

Ficha 3: el objetivo de la tercera ficha era que los niños observaran cuatro dibujos de abejas y unieran cada dibujo con su respectivo globo de pensamiento. 
Actividades para trabajar la falsa creencia

Se hizo un juego y dos fichas, una de contenido inesperado y otra de cambio de ubicación.

Juego: un niño guardó un peluche de abeja en el armario y salió de la clase. Mientras tanto, otro niño cambió el peluche de sitio, de manera que, cuando el niño que había salido del aula volvió, el peluche no estaba en el sitio donde él lo había dejado. El objetivo del juego fue reflexionar el motivo por el que había desaparecido el peluche.

Fichas:

- Ficha 1. Objetivo: trabajar el cambio de ubicación. En la ficha había una secuencia de imágenes en la que se observaba cómo una abeja guardaba miel en su colmena, un gusano le robaba la miel y, cuando volvía la abeja, la miel ya no estaba en la colmena.

- Ficha 2. Objetivo: trabajar el contenido inesperado. En la ficha aparecía una secuencia de imágenes, en la que aparecía una abeja introduciendo patatas fritas en un bote de miel, de tal manera que, más tarde, cuando llegaba otra abeja a comer miel, se encontraba las patatas. El objetivo era reflexionar sobre lo que había sucedido con la miel.

Temporalización:

La intervención ha tenido una duración de cuatro semanas y, durante este tiempo, se ha realizado una actividad o ficha diaria. Para cada actividad o ficha se ha empleado una sesión de 45- 60 minutos.

\section{Resultados}

A continuación se presentan los resultados del estudio. En la Figura 1 se muestra las habilidades de TM del participante de este estudio en evaluadas en tres momentos (pretest, postest 1 y postest 2). La comparación de los datos obtenidos entre el pretest y los dos postest evidencian una mejora gradual en todas las habilidades trabajadas de TM. Tal como se muestra en la Figura 1, las habilidades son superiores en el postest $y$, desde el postest 1 hasta el postest 2 , la evolución ha sido más acentuada. 


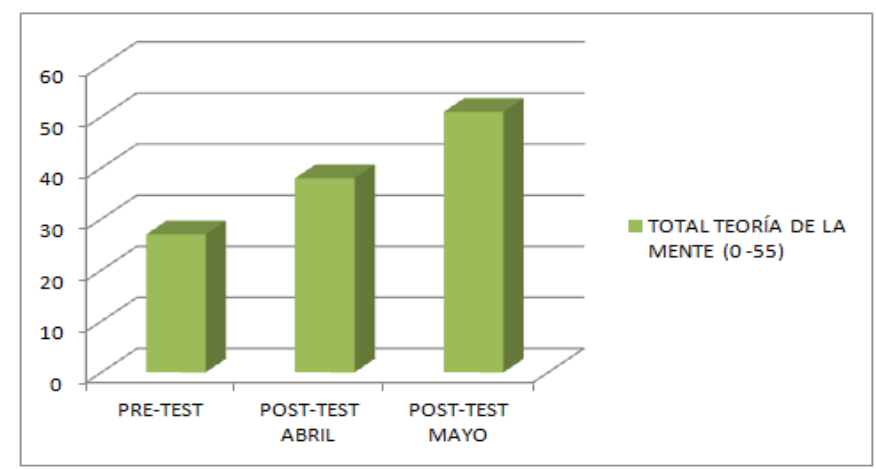

Figura 1. Evolución habilidades TM pretest, postest1 y postest 2.

A continuación, pasamos a comentar los datos de la efectividad del método de una manera desglosada, detallando la comparación de los datos obtenidos en el pretest y los postest en las distintas habilidades de TM por separado:

\section{Habilidades de expresión e identificación de expresiones faciales}

Las habilidades de expresión e identificación de las expresiones faciales se evaluaron con una puntuación de 0 a 6 . En el pretest el participante alcanzó una puntuación de 3 puntos sobre 6 en la identificación de expresiones faciales, y una puntuación de 4 puntos sobre 6 en la expresión de las mismas. El dominio de estas habilidades mejoró, puesto que tanto en el postest 1 como en el 2 el participante alcanzó la máxima puntuación en ambas habilidades.

\section{Habilidades de reconocer emociones y sus causas}

Las habilidades de emoción-causa se evaluaron con una puntuación de 0 a 12. En el pretest el participante obtuvo una puntuación de 4 puntos sobre 12. Esta puntuación mejoró notablemente en el postest 1 y 2 , donde el participante obtuvo, respectivamente, una puntuación de 7 y 9 puntos sobre 12 .

\section{Habilidades de los verbos mentalistas de saber, creer y pensar}

La evaluación de estas habilidades oscila entre 0 y 7 puntos. Los resultados evidencian una clara evolución ya que, antes de iniciar la intervención, el participante obtuvo una puntuación de 0 en todas estas habilidades. Sin embargo, en el postest 1 , el niño obtuvo una puntuación total de 5 puntos sobre 7 y en el postest 2 una puntuación total de 6 puntos sobre 7 .

\section{Habilidades prosociales (ayudar, prestar y consolar)}

El desarrollo de las habilidades de ayudar, consolar y prestar ha tenido una mejora muy significativa. La evaluación de estas habilidades oscila entre 0 y 8 puntos. En el pretest el participante obtuvo una 
puntuación total de 4 puntos. Sin embargo, en ambos postest el participante obtuvo una puntuación total de 8 puntos.

\section{Habilidades de los globos de pensamiento}

En el pretest el participante obtuvo una puntuación de 3 puntos sobre 10. Sin embargo, en el postest 1 se observó un retroceso en estas habilidades ya que el niño obtuvo una puntuación de 0 puntos.

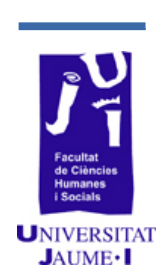

\section{Habilidades de falsa creencia}

La evaluación de estas habilidades oscila entre 0 y 6 puntos. En el pretest el participante obtuvo una puntuación de 5 puntos y en ambos postest la puntuación alcanzada fue de 6 puntos.

\section{Comparación desglosada de las puntuaciones obtenidas en las habilidades} de TM

La siguiente figura evidencia que se ha producido una mejora en las habilidades trabajadas con el participante. Destaca, especialmente, la mejora que se ha producido en el reconocimiento de emociones y sus posibles causas. También el avance que se ha producido en el desarrollo de las habilidades prosociales, las habilidades de saber, creer y pensar, y en los globos de pensamiento.

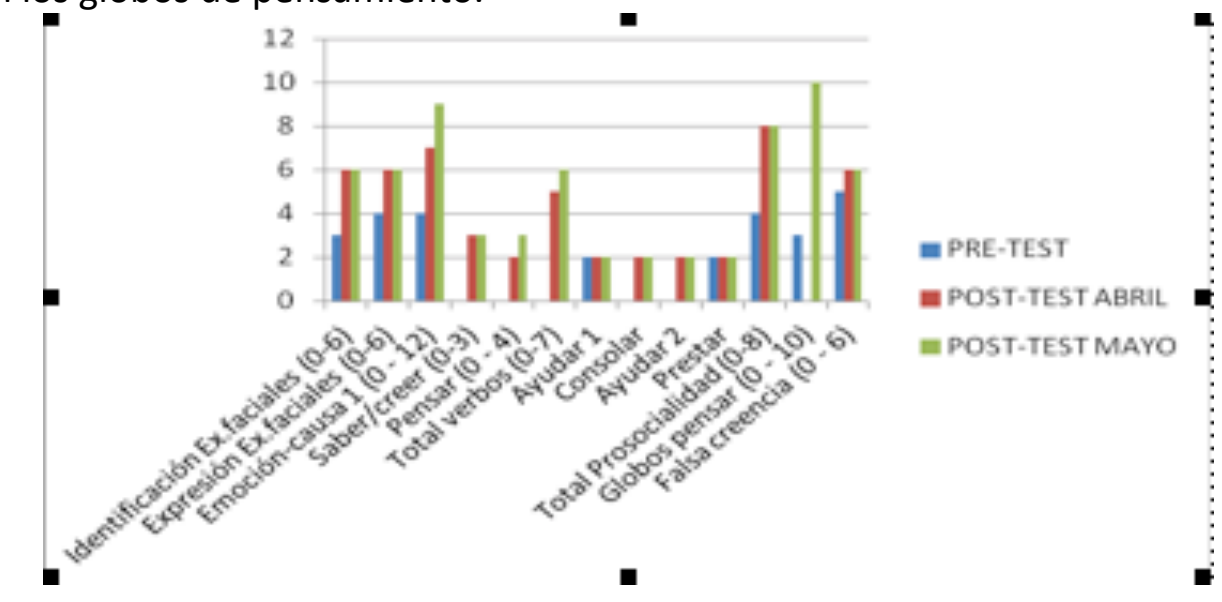

Figura 2. Evolución habilidades teoría de la mente pretest, postest 1 y postest 2.

\section{Discusión y conclusiones}

El objetivo de este trabajo radicaba en mejorar las habilidades de TM de un niño que tiene TEA y que está escolarizado en un colegio público, en un aula de Infantil 5 años. Para ello, se diseñó un método de trabajo basado en las dificultades en TM demostradas, hipotetizando que habría una mejora después de implementarlo.

Después de analizar los datos de comparación del nivel del niño en situación pre y postest, se puede afirmar que se ha cumplido la hipótesis 1 , ya que el participante ha mejorado en las habilidades de TM. Sin 
embargo, la hipótesis 2 no se ha cumplido porque, en contra de lo esperado, los resultados del segundo postest han sido superiores a los del primer postest. Esto es positivo, ya que puede significar que las respuestas que dio el participante en el primer postest no se debieron al efecto de recuerdo y que, por lo tanto, contestó en función de todo lo que realmente había aprendido y que, de hecho, fue afianzando con el tiempo.

Concretamente, después de la intervención, en las habilidades en las que se ha observado una mejora más pronunciada han sido, por orden: los globos de pensamiento, las habilidades de saber y creer, emoción causa y las habilidades prosociales de ayudar, prestar y consolar. Esto puede deberse a que el participante nunca había trabajado estas habilidades y, en consecuencia, la intervención ha tenido un impacto muy grande en el alumno y le ha servido para mejorar.

Aún así, cabe destacar que, en las pruebas de globos de pensar, el participante obtuvo una puntuación inicial de 3 puntos sobre 10 y en el primer postest la puntuación retrocedió a 0 puntos. Sin embargo, en el segundo postest logró un 10. Esto hace sospechar que las respuestas que ofreció el estudiante en el segundo postest estuvieron condicionadas por algún factor externo que distrajo al niño e influyó negativamente en sus respuestas.

Por otra parte, las habilidades en las que ha tenido una mejora menos pronunciada han sido las de expresión e identificación de expresiones faciales y falsa creencia. Esto se debe a que el participante obtuvo una puntuación muy elevada en el pretest y, por lo tanto, el desarrollo de estas habilidades ya era muy elevado desde antes de empezar la intervención. En consecuencia, la intervención habría sido más provechosa si las actividades se hubieran adaptado de manera más rigurosa a las necesidades reales del alumno empleando, por ejemplo, situaciones un poco más complejas.

Para finalizar, se establece la importancia de este trabajo ya que, a nivel de aula, ha servido para que todos los niños pudieran trabajar y mejorar sus habilidades de TM. Además, la intervención ha ofrecido la posibilidad de innovar en la clase y de aprender unas habilidades que no están especificadas en el currículum de El y que no se trabajan de manera habitual en los colegios, pero que, sin embargo, son muy importantes y suscitan mucho interés y motivación en los niños.

La intervención también ha permitido trabajar de una manera muy directa las emociones en el aula, y ha servido para que los estudiantes aprendieran a comprender sus sentimientos, explicar sus pensamientos y preocupaciones al resto de compañeros y resolver de manera efectiva los pequeños conflictos del día a día.

Por otra parte, las actividades y fichas que se han desarrollado han sido muy beneficiosas para aprender en grupo, compartir emociones y desarrollar relaciones afectivas entre los estudiantes. Esto le da un valor añadido al aprendizaje de los niños y al trabajo. 
Los resultados de esta intervención apoyan la literatura existente que hemos nombrado al inicio de este trabajo y que versa sobre el beneficio que implica trabajar la TM en niños autistas, de una manera integrada en un aula ordinaria. En este sentido, autores Chamberlain et al. (2006) afirmaron que la inclusión de los niños en el aula ordinaria es beneficiosa para los alumnos con TEA y que, además, puede aportar grandes retos para la educación. Así, este estudio contribuye a ofrecer una demostración empírica novedosa más de los beneficios que conlleva trabajar la TM con niños con TEA en el aula ordinaria. Además, trabajar la TM puede ser beneficioso para reducir el riesgo de problemas de relación social de estos niños en etapas posteriores.

En cuanto a las limitaciones, un contratiempo a la hora de hacer el trabajo ha sido la falta de tiempo al aplicar la intervención, ya que esta se ha limitado a un tiempo y espacio cerrado. Aunque los resultados obtenidos han sido muy positivos, quizás una intervención más larga habría implicado un desarrollo más amplio de las habilidades de TM.

Dada la mejora de resultados obtenidos entre el primer postest y el segundo postest, sería interesante que se realizara un estudio longitudinal en el futuro para comprobar si unos meses después de la intervención, se mantienen, descienden o aumentan las capacidades de las habilidades de TM de los niños autistas que recibieron la intervención.

\section{Agradecimientos}

Las autoras desean agradecer su colaboración a los niños y niñas que participaron de este trabajo, así como la ayuda financiada del proyecto GV/2015/092 subvencionado por la Conselleria de Educación, Cultura y Deporte de la Generalitat Valenciana (España).

\section{Bibliografía}

Cornago, A; M. Navarro y F. Collado (2012): Manual de teoría de la mente para niños con autismo: Ejercicios, materiales y estrategias: Las personas percibimos, sentimos, pensamos o creemos distinto, Psylicom, Valencia.

Chamberlain, B; C. Kasari, y Rotheram-Fuller, E. (2007): «Involvement or Isolation? The Social Networks of Children with Autism in Regular Classrooms", Journal of Autism and Developmental Disorders, 37(2), p. 230-242.

Сното, М. C. (2007): "Autismo infantil: el estado de la cuestión», Revista de Ciencias Sociales, (116), p. 169-180.

DUK, C; i LOREN, C. (2010): "Flexibilización del currículum para atender la diversidad», Revista latinoamericana de educación inclusiva, 4(1), p. 187210. 
Freire, S; M. Llorente, A. González, J. Martos, C. Martínez, R. Ayuda y J. ARTIGAS (2004): Un acercamiento al Síndrome de Asperger: una guía teórica y práctica, Asociación Asperger España, Valencia.

GarCíA, M. J. M; I. G. BeCERRA, y M. J. G. Espín (2012): «Teoría de la mente en un caso de autismo: ¿cómo entrenarla?», Psicothema, 24(4), p. 542-547.

García Maldonado, G; A. H. Saldívar González, A. Llanes Castillo y i. G. SÁNCHEZ JUÁREZ (2011): "El DSM-V. Luces y sombras de un manual no publicado. Retos y expectativas para el futuro», Salud mental, 34(4), p. 367-378.

GIRALDO, B. (1996): Autismo: un desorden biológico. Revista Suma Psicológica, 3(2), 97-106.

IgARTUA, J. J y M. L. HUMANES (2004): Teoría e investigación en comunicación social, Síntesis, Madrid.

MALEVAL, J. (2010): «Autismo, enunciación y alucinaciones», Interrogant, (10), p. 49-59.

MARTíneZ, M. C. (2010): «El trastorno del espectro autista: intervención educativa», Pedagogía Magna, (9), p. 53-66.

MOnfort, M. y I. MONFORT JuÁrez (2001): En la mente, Entha, Madrid Morales, P; E. DomèneCh-Llaberia, M. C. Jané y J. Canals (2013): «Trastornos leves del espectro autista en educación infantil: Prevalencia, sintomatología co-ocurrente y desarrollo psicosocial», Revista de Psicopatología y Psicología Clínica, 18(3), p. 217-231. 


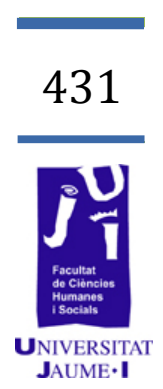

\section{Avaluació de la competència emocional a través d'una app en un nen amb trastorn de l'espectre autista (nivell 1)}

Irene Benedito Sánchez ibenedit@uji.es Eloy Soria-Izquierdo esoria@uji.es Clara Andrés-Roqueta candres@psi.uji.es 
Els nens i nenes amb trastorns de l'espectre autista (TEA) demostren dificultats en l'àrea de competència emocional en diversos components més enllà del reconeixement d'expressions facials. Existeixen distintes eines (analògiques i digitals) per a avaluar les habilitats emocionals dels nens amb TEA, però la major part avaluen aspectes parcials d'aquesta competència.

Per tant, en el present estudi es pretén administrar de manera pilot I'aplicació mòbil (app) EMOCIONATEST per a avaluar la competència emocional per a nens i nenes de 3 a 12 anys en un nen amb TEA nivell 1 de 12 anys, i comparar-la amb la d'un nen sense TEA de la mateixa edat, per detectar possibles diferències en l'execució i decidir les millores escaients per a la ferramenta. L'app té 5 nivells de dificultat basats en les fites evolutives del desenvolupament emocional típic en l'edat infantil: reconeixement d'expressions facials; construcció d'expressions facials; identificació d'emocions a partir de situacions comuns; reconeixement d'emocions basades en experiències cognitives; reconeixement d'emocions ocultes. Aquesta app es trobava en fase experimental i ha estat dissenyada per investigadors de la Universitat Jaume I de Castelló (UJI).

Després d'avaluar els dos nens amb l'app, s'han trobat diferències pel que fa a la resolució correcta de cada nivell, i s'ha vist que té més dificultat per a resoldre els ítems en general el nen diagnosticat amb TEA. Es conclou que la ferramenta presentada permet avaluar la competència emocional en nens i nenes d'edat escolar i també establir diferències entre nens i nenes amb dificultats. Així mateix, s'aprecien distintes millores que cal realitzar en l'aplicació en fase experimental, de cara a obtenir la versió final. Les millores en l'app i la validació d'aquesta en població amb i sense problemes permetran oferir a la comunitat psicoeducativa una ferramenta útil i motivadora que serà interessant per als professionals que treballen amb aquesta població.

Paraules clau: trastorn de l'espectre autista (TEA), competència emocional, aplicació mòbil (app) i avaluació.

\section{Introducció}

Segons l'actual manual diagnòstic i estadístic dels trastorns mentals (DSM-5, American Psychiatric Association - APA, 2013), els nens i nenes amb trastorn de l'espectre autista (TEA) es caracteritzen per la presència de dèficits persistents en la comunicació social i la interacció social donats en diversos contextos (dèficits en reciprocitat socioemocional, dèficits en conductes comunicatives no verbals emprades en la interacció social o dèficits per a desenvolupar, mantenir o comprendre relacions) i patrons 
repetitius i restringits de conductes, activitats o interessos, caracteritzats per moviments motors, ús d'objectes o parla estereotipada o repetitiva; insistència en la igualtat; interessos altament restringits i hipereactivitat 0 hiporeactivitat sensorial (APA, 2013).

A més, com a canvi notable en aquesta nova edició del manual diagnòstic, el DSM-5 classifica diversos nivells de TEA dins d'aquest trastorn segons la severitat d'aquest, i són els següents:

- Nivell 1: necessita suport. Mostren dificultats iniciant interaccions socials $\mathrm{i}$ inflexibilitat en el comportament de manera que causa interferència significativa en el funcionament en un context o més.

- Nivell 2: requereixen un suport substancial. Mostren dificultats marcades en habilitats de la comunicació social (verbal i no verbal). El comportament inflexible i les dificultats per a afrontar el canvi apareixen amb freqüència en varietat de contextos.

- Nivell 3: requereixen un suport molt substancial. Mostren dificultats greus en habilitats de comunicació social (verbal i no verbal que causen alteracions greus en el funcionament. La inflexibilitat del comportament i les dificultats extremes per a afrontar els canvis interfereixen en tots els contextos.

Des de fa alguns anys, tant en l'àmbit de la psicologia com en l'educació han aprofundit en l'estudi del món de les emocions, de manera que ha augmentat el nombre de publicacions i teories que reconeixen la rellevància de les emocions en la vida social, l'evolució d'aquestes i repercussions al llarg del desenvolupament i la importància d'arribar a ser «social i emocionalment competent» (Giménez-Dasí i Quintanilla, 2009). En aquest àmbit, s'han observat que els nens diagnosticats amb TEA mostren diverses dificultats, anomenades anteriorment en els diferents nivells de severitat.

Els nens amb TEA es caracteritzen per mostrar un deteriorament greu en la flexibilitat cognitiva i la interacció social i poden ser variables en les seues habilitats de comunicació. Dins de l'àrea de la interacció social, durant el desenvolupament d'aquesta, els nens i nenes amb TEA mostren importants alteracions en la seua competència emocional (Deruelle et al., 2004), que s'observen tant mitjançant les seues conductes no verbals (com ara, en la dificultat per a establir contacte visual, per a comprendre i expressar facialment les emocions o per a regular la postura corporal) com verbals (com ara, la dificultat per a empatitzar amb els altres o per compartir interessos o plaers) (American Psychiatric Association - APA, 2008).

Les investigacions entorn d'aquesta àrea han vinculat aquest dèficit en la competència emocional als problemes en la seua capacitat de teoria de la ment, és a dir, la capacitat de predir el comportament de la gent diferenciant entre la realitat $i$ els seus estats mentals (Baron-Cohen, 
Wheelwright, Hill, Raste i Plumb, 2001). Actualment, es coneix que aquests nens no tenen massa problemes en la gestió i en el reconeixement de les emocions bàsiques (Grossman, Klin, Carter i Volkmar, 2000), però sí que mostren problemes en la incapacitat de comprendre el context en què es produeixen (causes internes 0 externes), a causa de l'ús parcial de la informació continguda en la situació, així com de la tendència a prestar més atenció als detalls físics o explícits que als detalls socials relacionats amb l'emoció (Klin, 2000). Per tant, és evident que els nenes i nenes amb TEA necessiten ajuda tant en la comprensió i l'expressió d'emocions pròpies (i d'altres), com en el processament de la informació social relacionada amb ells en diverses situacions.

No obstant això, cal assenyalar que existeix certa discrepància respecte d'aquesta postura: mentre alguns autors demostren l'existència d'un dèficit o trastorn sever en aquesta competència emocional (Deruelle et al., 2004; Hobson, 1986; Yirmiya et al., 1992), altres autors han demostrat que no hi ha excessius problemes en el maneig $i$ reconeixement de les emocions bàsiques (Grossman, Klin, Carter i Volkmar 2000; Loveland et al., 1997), o que el problema està relacionat amb la incompetència per a generar una coherència contextual adient, causa de l'ús parcial de la informació que es dóna en la situació (Frith, 2003).

El que sí que està clar és que aquestes dificultats en la comprensió de les emocions pròpies i d'altres persones els impedeixen formar relacions de qualitat amb els seus iguals durant l'edat de l'escolaritat primària als centres ordinaris, situació que s'agreuja en l'etapa de secundària. Actualment, diversos estudis d'intervenció han demostrat la possibilitat de millorar la competència emocional d'aquests nens i nenes. Encara així, la majoria d'aquests estudis s'han centrat en aspectes parcials de la competència emocional i s'han caracteritzat per una falta de rigor científic i metodològic que ha fet impossible demostrar-ne l'efectivitat.

Conseqüentment, aquests nens estan en risc de caure en un bucle de reclusió social i cal crear mètodes educatius per a treballar el món social des de situacions estructurades (com l'aula ordinària o dins d'aules específiques integrades en escoles ordinàries) per posar en pràctica aquestes habilitats i generalitzar a situacions no reglades de la vida quotidiana (exemple: patis o sortides extraescolars). D'aquesta manera, per proveir a aquests nens d'aquestes habilitats, entre les quals destaquen les habilitats interpersonals relacionades amb la comprensió emocional, una bona intervenció hauria d'incloure l'entrenament en diferents episodis socioemocionals quotidians $i$ adequats a la seua edat $i$ sexe. A més, sense una bona intervenció en l'àrea socioemocional, aquesta situació s'agreuja durant l'etapa de secundària.

Durant els últims anys, s'han generat diverses ferramentes des de l'àmbit de les Tecnologies de la Informació i la Comunicació (TIC) per compensar les dificultats dels nens i nenes amb TEA, ja que s'adapten més bé a la seua manera de processar la informació (Gómez i García, 
2012). A més, l'equipament en TIC als centres escolars (pissarres digitals, tabletes, etc.) s'ha incrementat notablement com a indicador de qualitat $\mathrm{i}$ de millora dels processos d'ensenyament-aprenentatge.

A més a més, s'ha donat un creixent interés de les famílies d'aquests nens i nenes per obtenir un suport que puga utilitzar-se també a casa, $\mathrm{i}$ així complementar i donar seguiment als avanços que es fan a l'escola. En aquest sentit, recentment s'ha promogut l'ús dels videojocs i aplicacions mòbils, ja que inclouen un component lúdic i motivador en l'aprenentatge, encara que molts han sigut dissenyats amb finalitats comercials i manquen de les didàctiques. Per aquesta raó, es detecta la necessitat de dissenyar amb una base científica, una ferramenta que puga utilitzar-se en distints àmbits: classe ordinària, individualment, classe de xicotet grup, a classe d'audiovisuals o a casa.

Per tot allò comentat en els paràgrafs anteriors, es detecta la necessitat de dissenyar amb una base científica una ferramenta que es puga usar en diferents escenaris: classe ordinària, individualment, classe de petit grup, classe d'ordinadors o casa. Així, es desenvolupa una aplicació mòbil (tant aplicació web com aplicació nativa) per a l'avaluació de la competència emocional en nens amb TEA (EMOCIONATEST; dissenyada a I'UJI per un grup d'investigació), el disseny de la qual està basat en l'anàlisi d'estudis evolutius sobre desenvolupament d'emocions en població amb desenvolupament típic i amb TEA. Aquesta app va dirigida a nens $\mathrm{i}$ nenes amb TEA de 6 a 12 anys i combina un mètode d'intervenció lúdic en competència emocional (amb diferents nivells de dificultat) i un sistema d'avaluació d'aquesta competència.

\section{Objectius}

Una vegada explicada anteriorment la utilitat i la conveniència d'aquesta app com a ferramenta per a avaluar la comprensió emocional en les diverses edats escolars, es detallen els objectius d'aquest estudi.

El primer objectiu és comparar el funcionament de l'app com a instrument d'avaluació en un nen de 12 anys amb TEA nivell 1 (TEA N1) i un altre de la mateixa edat amb desenvolupament típic (DT).

Sota aquest primer objectiu, es planteja la hipòtesis principal de l'estudi segons estudis previs: s'apreciaran diferències en l'execució de l'app entre els dos casos (DT i TEA N1).

El segon objectiu del estudi és provar de manera pilot l'eficàcia de l'app EMOCIONATEST ( $i$ tots els seus nivells) com a ferramenta per a avaluar de manera comprensiva la competència emocional en nens $i$ nenes amb TEA entre 3 i 12 anys. 


\subsection{Mostra}

Per poder complir els objectius d'aquest estudi, és a dir, comparar el funcionament de l'app com a instrument d'avaluació, es va procedir a seleccionar un nen de 12 anys amb TEA N1 i un altre de la mateixa edat amb DT.

El model seguit en aquesta estudi és la comparació de dos casos:

Participant amb TEA: és un nen de gènere masculí, de 12 anys d'edat i amb diagnòstic de TEA nivell 1 , que va ser seleccionat d'un gabinet psicopedagògic privat (on li havien realitzat el diagnòstic de TEA i on rebia setmanalment suport fora de l'horari escolar).

Participant amb Desenvolupament Típic (DT): paral-lelament, es va seleccionar com a subjecte control (d'edat i gènere) un altre nen de la mateixa edat (12 anys) amb DT d'un centre escolar privat de la província de Castelló.

\subsection{Instruments}

L'instrument utilitzat en el present estudi ha sigut l'app EMOCIONATEST. Aquesta aplicació mòbil s'ha dissenyat per a l'avaluació de la competència emocional en nens i nenes amb TEA entre 3 i 12 anys.

El disseny es basa, d'una banda, en l'anàlisi d'estudis evolutius sobre desenvolupament d'emocions anteriorment esmentats, ja que es busca abordar la competència emocional d'una manera comprensiva, i de l'altra, en les particularitats per a processar, comprendre, expressar i reaccionar davant les emocions dels nens amb TEA .

Aquesta aplicació s'estructura en cinc nivells de dificultat creixent, amb 12 ítems cadascun. És a dir, oscil·la entre el nivell més fàcil (nivell 1) i el més difícil (nivell 5). Per a cada bloc d'ítems, els protagonistes de les històries són $50 \%$ dels ítems xics i en el $50 \%$, xiques.

La durada aproximada de l'administració individual de la prova és de 20 minuts (depenent de l'edat i dificultats de cada nen/a) i es disposa d'un manual d'aplicació per al professional on estan narrades les ajudes verbals per a cada història.

A continuació, es descriuen aquests cinc nivells.

Nivell 1: Reconeixement de l'expressió facial

L'objectiu d'aquest nivell és que el nen identifique una emoció entre diverses expressions facials presentades. Se'ls mostren sis expressions facials i se'ls demana que seleccionen d'aquestes la que és correcta per a una emoció específica, així ells hauran de seleccionar la cara que mostra l'emoció correcta dins de les diverses opcions.

Hi ha un total de 12 ítems (dos per a cada expressió facial: feliç, trist, fàstic, por, enuig, sorpresa). En la Figura 1 s'adjunta un exemple d'un dels ítems (masculí) per a avaluar la identificació de l'expressió facial felicitat. 

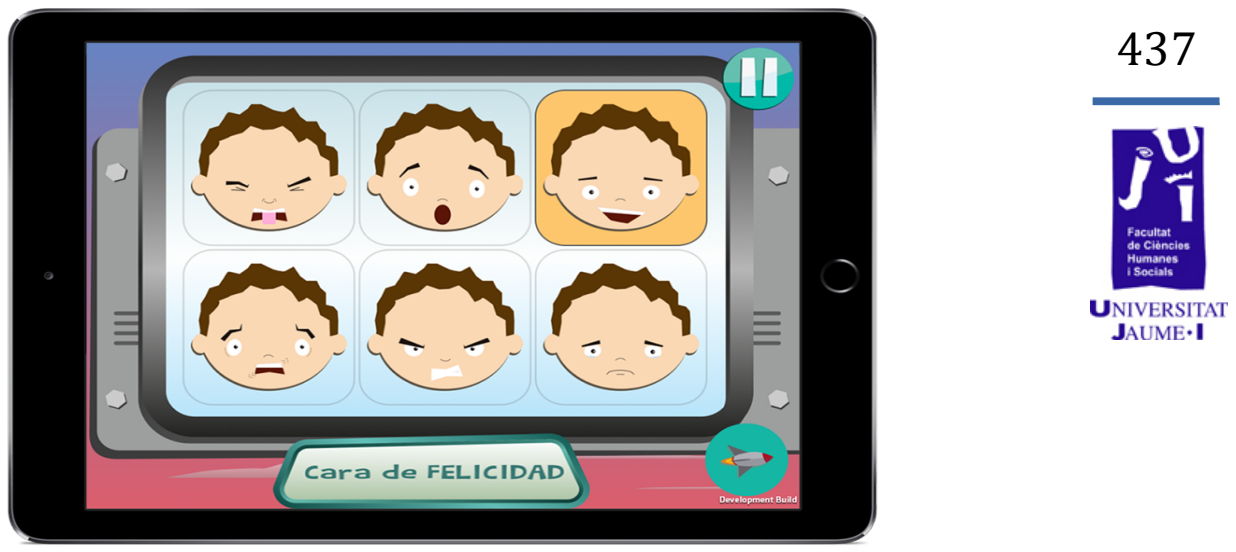

Figura 1. Exemple d'identificar l'emoció de felicitat en el nivell 1.

\section{Nivell 2: Construcció d'expressions facials}

En aquest segon nivell, es requerirà als nens construir diferents expressions facials amb parts de la cara (la boca d'una banda i els ulls i les celles d'una altra), implicats en gestos d'emoció.

De nou, hi ha un total de 12 ítems (dos per a cada expressió facial: feliç, trist, fàstic, por, enuig, sorpresa).

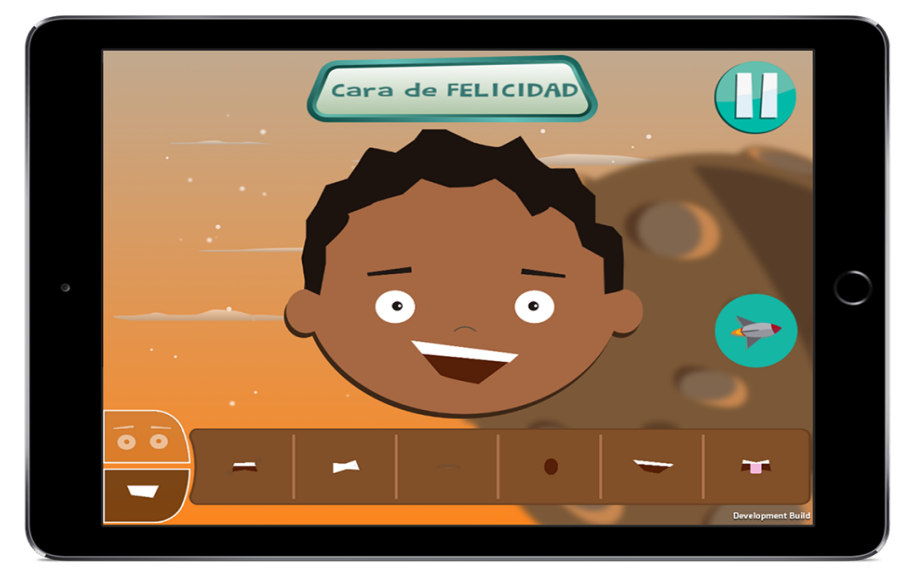

Figura 2. Exemple de construir l'emoció de felicitat en el nivell 2.

\section{Nivell 3: Identificació d'emocions a partir de situacions}

En aquest nivell, després de mostrar les diferents situacions d'una història, els nens hauran d'identificar l'emoció que pensen que el personatge principal sent (entre sis expressions donades). Per aconseguir aquest objectiu, els nens han d'entendre la causa de l'emoció, que consisteix en la comprensió de la situació o context donat.

De nou, hi ha un total de 12 ítems (dos per a cada expressió facial: feliç, trist, fàstic, por, enuig, sorpresa). En la Figura 3, s'explica l'exemple d'una de les històries per avaluar tristesa. 

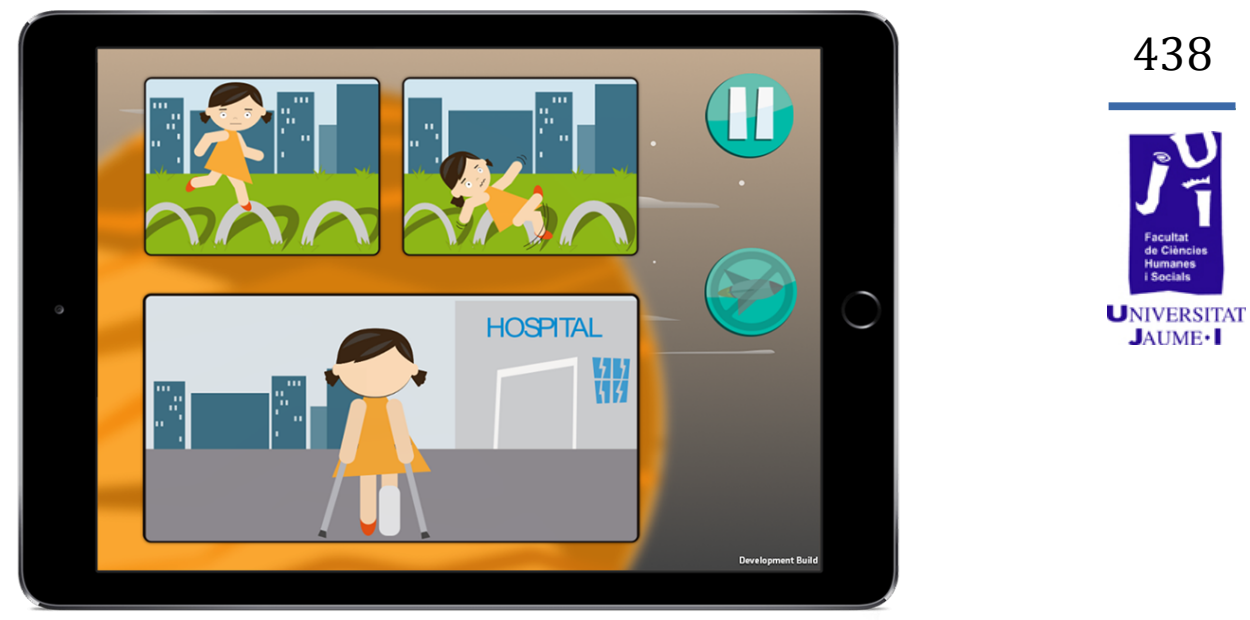

Figura 3. Exemple d'una situació en el nivell 3, on s'ha d'identificar l'emoció de la protagonista després del que li ha ocorregut.

Nivell 4: Reconeixement de les emocions basades en elements cognitius

Aquest nivell avalua les emocions basades en el record (per exemple, quan mirem una foto del passat) o en falses creences en una situació.

De nou, hi ha un total de 12 ítems, on sempre hi ha un canvi en l'experiència emocional del protagonista (abans i després), en relació amb una experiència cognitiva. En la Figura 4 s'adjunta un exemple d'un dels ítems per a avaluar una emoció basada en una falsa creença (és a dir, la nena de la història primer està contenta perquè pensa que en la caixa trobarà galetes).

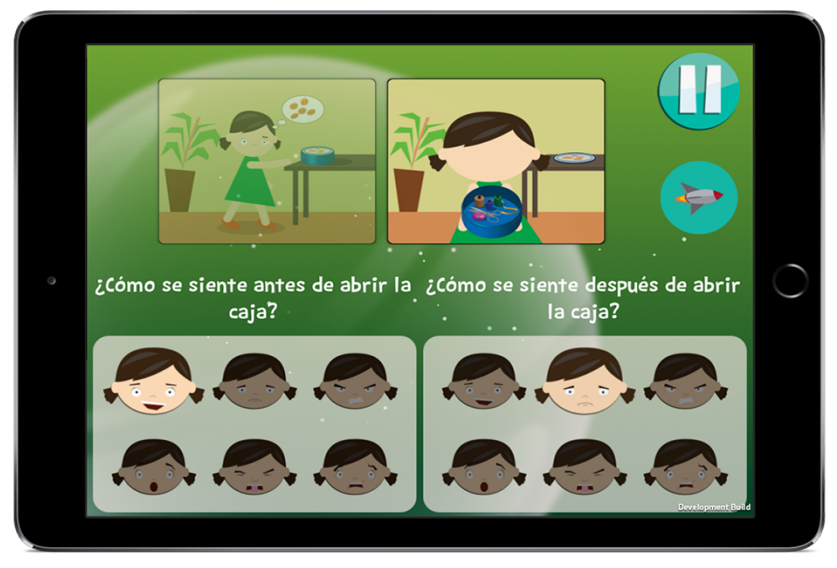

Figura 4. Exemple d'una situació en el nivell 4, on s'ha d'identificar l'emoció basada en elements cognitius. 
Nivell 5: Reconeixement d'emocions ocultes (aparença/realitat emocional)

En aquest nivell, els nens han d'entendre que les persones de vegades amaguen les seues emocions reals i en mostren unes altres, és a dir, pot haver-hi una discrepància entre les emocions que una persona mostra a l'exterior i el que realment sent internament.

Hi ha un total de 12 ítems, dels quals en el $50 \%$ de les situacions el protagonista amaga una emoció negativa (p. ex. tristor) i en el $50 \%$ $n$ 'amaga una de positiva (p. ex. felicitat). A més, en aquest nivell s'afegeix la cara neutra, ja que és essencial per dissimular una emoció.

En la Figura 5 s'adjunta un exemple d'un dels ítems per a avaluar una emoció basada en una falsa creença (és a dir, la nena de la història primer està contenta perquè pensa que en la caixa trobarà galetes).

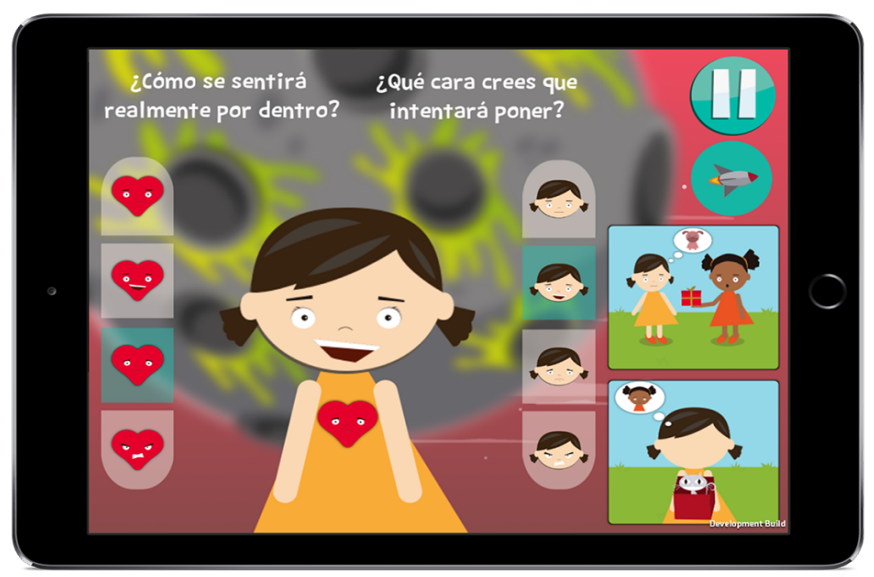

Figura 5. Exemple d'una situació en el nivell 5, on s'ha d'identificar l'emoció interna de la protagonista i l'externa.

\subsection{Procediment}

Per a dur a terme aquesta investigació, en primer lloc es va contactar amb un centre escolar privat de la província de Castelló i s'hi va seleccionar un nen amb DT. En paral-lel, es va contactar amb un centre privat de psicologia per seleccionar un nen amb TEA nivell 1.

Posteriorment, es van sol-licitar tots els permisos necessaris per a dur a terme l'estudi i l'autorització dels pares dels menors. Una vegada es va tenir tot el que era necessari, es va administrar la tasca als nens de manera individual, i es va recollir feedback sobre com els nens executaven cada nivell (dificultats que s'hi 'observaven, no enteniment dels ítems, etc.) per tal de realitzar les millores escaients. 


\section{Resultats}

Resultats relacionats amb el primer objectiu

Després de l'avaluació dels dos nens, es va observar que el nen diagnosticat amb TEA tenia dificultats en 3 dels 5 nivells, mentre que el nen amb DT els va realitzar correctament tots. En concret, el nen amb TEA presenta dificultats en el nivell 2 (quan se seleccionen els ulls i les celles), en el nivell 3 (confonent emocions amb valència negativa: tristesaenuig, tristesa-fàstic) i en el nivell 5 (incapaç d'identificar les emocions internes i externes).

\section{Resultats relacionats amb el segon objectiu}

Després de l'anàlisi de les dades i del feedback, es van realitzar els canvis en l'app següents:

- Respecte el nivell 1, es va modificar la transició d'ítem a ítem (rapidesa de l'aparició de les cares) i es va augmentar la mida de les expressions facials (per permetre que el nen puga seleccionar el que necessite més còmodament).

- En el nivell 2 es van afegir unes petites instruccions visuals, que faciliten al nen la selecció del document o resposta.

- En el nivell 3, es va modificar una de les històries per donar suport visualment millor la comprensió de l'emoció (la d'alegria basada en una invitació a jugar). La resta d'històries resultaven comprensibles.

- En el nivell 4 es va canviar una història i se la va dotar de detalls més deliberats (emoció basada en record trist), ja que es va veure que era confusa i no es comprenia com s'esperava.

- Finalment, en el nivell 5 es van modificar dues de les històries i la distribució de la imatge a la pantalla, de manera que aquesta era més accessible per comprendre-la.

\section{Discussió i conclusions}

Al principi d'aquest estudi, es plantejaven dos objectius principals. El primer era tractar de comparar el funcionament de l'app com a instrument d'avaluació en un nen de 12 anys amb TEA N1 i un altre de la mateixa edat amb DT. D'aquest primer objectiu s'hipotetitzava que s'apreciarien diferències en l'execució de l'app entre els dos casos (DT i TEA N1).

Després de la realització de la investigació, es pot afirmar que s'ha confirmat la hipòtesis plantejada ja que, comparant els dos casos, es veu que el nen amb TEA N1 té una pitjor execució en la major part de nivells en comparació amb el nen control amb DT.

El nen amb TEA N1, com que té 12 anys, els primers nivells -per tant més senzills- els superava sense cap inconvenient. En canvi les 
diferències més notables s'aprecien en els nivells 3 i 5 , ja que aquest nen confon les emocions neutres 0 amb valència negativa, com ara sorpresa 0 fàstic amb l'emoció tristesa.

El segon objectiu plantejat era provar de manera pilot l'eficàcia de l'app EMOCIONATEST per a l'avaluació de la competència emocional en nens i nenes amb TEA entre 3 i 12 anys. En aquest cas, no hi havia cap hipòtesi, ja que l'aplicació es va provar i es va prendre nota de les errades per resoldre-les de cara al futur

Una vegada realitzada la prova pilot d'aquesta aplicació mòbil, es pot afirmar que sí que permet avaluar la competència emocional en els nens d'edat escolar. També permet establir diferències entre nens i nenes amb TEA, tant quantitatives com qualitatives.

Com s'ha comentat abans, mentre s'administrava aquesta ferramenta, es va anar anotant tot el feedback que anava eixint, i s'anaven apreciant distintes millores a realitzar en l'app en fase experimental i que caldria modificar de cara a l'aplicació final per poder millorar-ne el rendiment i les prestacions.

En primer lloc, per la dificultat de la comprensió, es va eliminar un nivell (emocions basades en la comprensió dels desitjos del protagonista), de manera que finalment queda formada per 5 nivells, en lloc de $6 \mathrm{com}$ al principi. Aquest nivell feia massa llarga l'avaluació i requeria massa explicacions verbals. A més, es va considerar que alguns d'aquests aspectes ja s'avaluaven en el nivell següent (actual nivell 4). En segon Iloc, es van modificar alguns aspectes més superficials dels 5 nivells.

Actualment, s'ha contactat amb diferents escoles públiques de la província de Castelló (amb aules de comunicació i llenguatge integrades), en les quals es procedirà a validar la versió definitiva de l'app tant amb població normotípica, com amb TEA, juntament amb altres tests estandarditzats (qüestionaris per a pares i altres mesures de funcionament socioemocional).

En paral·lel, s'han creat dos manuals:

1. Un manual d'avaluació, amb l'objectiu de donar les directrius necessàries per a administrar l'app als futurs professionals que la utilitzen. En aquest manual, apareixeran les instruccions i pautes a seguir i les narracions que donaran suport al desenvolupament visual de l'app, etc.

2. Un manual d'intervenció, amb l'objectiu d'emprar l'app i el seu contingut en l'àmbit didàctic a les aules. En aquest material apareixen directrius d'intervenció per als professionals i es proposa una sèrie d'exercicis a realitzar tant amb l'app, com amb el contingut corresponent ( $p$. ex. imprés $i$ treballat de manera manipulativa).

La creació d'una app per a l'avaluació en la competència emocional de nens i nenes amb TEA suposa una novetat per diversos motius: en primer lloc, perquè no hi ha materials per a avaluar el component 
emocional de manera comprensiva; en segon lloc, perquè els mètodes existents obliden el component motivador, no solen estar adaptats a les característiques dels nens i nenes amb TEA i són de difícil accés, i en tercer $\mathrm{lloc}$, perquè és una oportunitat per a donar una garantia a professionals d'atenció psicoeducativa sobre un mètode d'intervenció en un àrea tan complexa com és la competència social.

Al contrari que moltes app existents amb finalitats comercials o purament lúdiques, es busca donar una garantia científica al mètode educatiu proposat, ja que comportarà un rigor metodològic tant en el disseny com en la implementació per avalar la millora de la competència emocional.

Els resultats de la validació d'EMOCIONATEST seran beneficiosos tant per a la comunitat científica, com social i tecnològica:

- Científicament, suposarà un avenç important en la recerca de mètodes d'intervenció basats en estudis empírics. Així mateix, permetrà demostrar l'efectivitat de les aplicacions mòbils com a mètode educatiu en el camp psicoeducatiu.

- Tecnològicament, s'obtindrà un producte motivador, atractiu i senzill d'utilitzar per part de les persones implicades en l'educació dels nens i les nenes amb TEA. A més, l'aplicació mòbil es pot traduir a diferents idiomes, tot i que en principi es dissenyarà en castellà i valencià. A més, la ferramenta comptarà amb un suport científic garantit per un equip d'investigació expert en temàtiques de competència socioemocional i trastorns del desenvolupament.

- Pel que fa a l'àmbit econòmic i social, l'aplicació es compartirà amb els diferents sectors interessats en l'àmbit autonòmic $i$ estatal (centres educatius, serveis psicopedagògics escolars, associacions d'Asperger i TEA, etc.), de manera que serà una ferramenta que també podran utilitzar altres nens i nenes que presenten dificultats en la competència emocional (p. ex. síndrome de Down o TDAH).

\section{Agraïments}

Els autors d'aquest article volen agrair la participació a les persones de San Cristóbal Centres Educatius i del Centre de Psicologia Camins que van participar d'aquest treball, així com l'ajuda finançada atorgada pel projecte Herramienta para la evaluación en la competencia emocional de niños y niñas con Trastorno del Espectro Autista (Código: VAL-2004-04), subvencionat per l'Acción 4.1. del Plan de Promoción de la Investigación 2014 - Convocatoria StartUJI de Valorización de Resultados de Investigación. 
AmericAn Psychiatric Association (2013): Diagnostic and Statistical Manual of Mental Disorders (5th ed.), Washington, D.C.

- (2008): Diagnostic and Statistical Manual of Mental Disorders: DSM-IV$T R$. (4th ed.), Washington, DC.

BARON-Cohen, S. i altres (eds.) (2001): "The "Reading the Mind in the Eyes" Test Revised Version: A Study with Normal Adults, and Adults with Asperger Syndrome or High-Functioning Autism», Journal of Child Psychology \& Psychiatry \& Allied Disciplines, 42, p. 241-251.

Deruelle, C. i altres (2004): "Spatial Frequency and Face Processing in Children with Autism and Asperger Syndrome», Journal of Autism and Developmental Disorders, 34 (2), p. 199-210

EICH, E. i J. W. SCHOOLER, (2000): «Cognition/Emotion Interaction», EICH, E., J. F. Kilhstrom, G. H. Bower, J. P. Forgas i P. M. Niedenthal (Eds.), Cognition and Emotion, Oxford University Press, Oxford, p. 3-29.

FRITH, U. (2003): «Autism: Explaining the Enigma» ( $2^{\text {nd }}$ ed.), Blackwell, Oxford.

Giménez-DAsí, M. i L. Quintanilla (2009): "“Competencia” social, "competencia" emocional: una propuesta para intervenir en Educación Infantil», Infancia y Aprendizaje, 32:3, p. 359-373

Gómez, J. L. C. i V. A. GARcía, (2012): «Tecnologías de la información y la comunicación: aplicaciones en el ámbito de los trastornos del espectro del autismo", Siglo Cero: Revista Española sobre Discapacidad Intelectual, 43(242), p. 6-25.

Grossman, J. B. i altres (ed.) (2000): «Verbal Bias in Recognition of Facial Emotions in Children with Asperger Syndrome», Journal of Child Psychology and Psychiatry and Allied Disciplines, 41, p. 369-379.

HoBson, R. P. (1986): «The Autistic Child's Appraisal of Expressions of Emotion: A Further Study», Journal of Child Psychology and Psychiatry, 27, p. 671-680.

KLIN, A. (2000): «Attributing Social Meaning to Ambiguous Visual Stimuli in Higher-Functioning Autism and Asperger Syndrome: the Social Attribution Task», J Child Psychol Psychiatry, 41, p. 831-46.

LoVELAND, K. A. i altres (1997): «Emotion Recognition in Autism: Verbal and Non-Verbal Information", Development and Psychopathology, 9, p. 579593.

YIRMIYA, N. i ALTRES (1992): «Empathy and Cognition in High-Functioning Children with Autism», Child Development, 63, p. 150-160. 


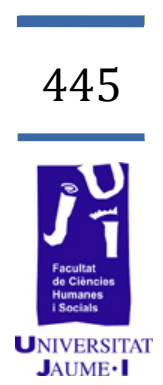

\section{La comprensió de les intencions comunicatives en adults amb síndrome de Down i altres tipus de discapacitat intel'lectual}

Eloy Soria-Izquierdo esoria@uji.es

Clara Andrés-Roqueta candres@psi.uji.es 
Antecedents: entre les habilitats de teoria de la ment (TM), la comprensió de les intencions comunicatives resulta essencial per a desenvolupar relacions socials i comprendre les accions d'altres persones. Entre altres poblacions, les persones amb síndrome de Down (SD) i altres discapacitats intel-lectuals (DI) presenten dificultats en aquest camp. Tanmateix, la competència sembla variable dins dels trastorns.

Objectius: aquest estudi pretén oferir una comparació de les intencions comunicatives en persones adultes amb SD i altres DI, ampliant la informació prèvia sobre aquest tema, així com observar la relació d'aquestes amb l'adquisició del llenguatge.

Mètodes i procediments: trenta-sis adults (divuit d'ells amb SD i divuit amb altres DI) es van avaluar amb una tasca de comprensió d'intencions comunicatives (les "Històries Estranyes», de Happé, 1994; tasca que és resolta entre els 4 i 10 anys d'edat en xiquets amb desenvolupament típic), juntament amb dues tasques receptives de llenguatge (gramàtica i vocabulari).

Resultats: tota la població amb DI (SD i DI amb altres dificultats) van demostrar un nivell baix en totes les tasques de les "Històries Estranyes». El grup amb DI obtingué, en general, més bons resultats que el grup amb SD. A més, el nivell de llenguatge va resultar clau en la resolució de la tasca.

Conclusions: les persones adultes amb SD presenten dificultats en la comprensió de les intencions comunicatives, encara que siguen més hàbils que altres adults en altres trastorns (ex. autisme) a l'hora de relacionar-se amb els iguals. Aquestes dificultats es relacionen, sobretot, amb el seu nivell de llenguatge.

Implicació: aquests resultats destaquen la importància de dur a terme una intervenció en la comprensió de les intencions comunicatives per a persones adultes amb SD en particular i DI en general, i així poder millorar la qualitat i percepció de les relacions socials amb els iguals.

Paraules clau: síndrome de Down (SD), intencions comunicatives, discapacitat intel·lectual (DI), llenguatge, teoria de la ment (TM), adults.

\section{Introducció}

\subsection{Concepte de teoria de la ment (TM)}

Tal com assenyala Adolphs (2001), la cognició social és un procés complex en el qual hi ha mecanismes per a percebre, processar i avaluar els estímuls de manera que es permet una representació de l'entorn social. Dins d'aquesta es troba l'habilitat coneguda com teoria de la ment (TM). Tal com afirmen Tirapu-Ustárroz, Pérez-Sayes, Erekatxo- 
Bilbao i Pelegrín-Valero (2007), existeix una terminologia molt variada Iligada a aquest concepte: "ToM» (Theory of Mind), "cognició social», «mentalització», «psicologia popular», «psicologia intuïtiva» o "conducta intencional». Comunament, s'accepta de que es tracta de l'habilitat per a comprendre i predir la conducta d'altres persones, els seus coneixements, intencions i creences (Tirapu-Ustárroz et al., 2007). Segons aquests autors, la TM es compon d'un conjunt d'habilitats metacognitives complexes entre les quals es poden identificar components com el reconeixement facial d'emocions, la comprensió de creences de primer i segon ordre, la d'expressions metafòriques, el reconeixement de posades de pota (faux pas, en francés), l'expressió emocional a través de la mirada, o l'empatia i el judici moral.

Actualment, des de l'àmbit de la psicologia evolutiva, es concreta la TM com la capacitat per a reconèixer $i$ atribuir estats mentals a un mateix i als altres (Benson, Abbeduto, Short, Bibler i Maas, 1993; Giaouri, Alevriadou i Tsakiridou, 2010), poder-los reconèixer com a iguals o diferents (Yirmiya, Solomonica-Levi i Shulman, 1996), a part d'utilitzar-la per a comprendre i predir el propi comportament i el dels altres en tots els seus contextos socials en els quals es desenvolupen (Wellman, 1990). No es tracta d'una habilitat que s'ensenya explícitament als infants, sinó que s'aprén amb l'experiència (Premack i Woodruf, 1978). Per tant, tenir TM es un prerequisit per a la interacció humana, fonamental per a la supervivència en la societat (Yirmiya, Erel, Shaked i Solomonica-Levi, 1998).

\subsection{Nivells de complexitat i avaluació de TM}

En l'àmbit evolutiu, i com a fita clau de TM, es considera que sobre els 4-5 anys els xiquets i les xiquetes comencen a distingir clarament entre representacions mentals i realitat (fita que s'avalua amb la tasca clàssica de falses creences), el que els permet predir l'actuació d'una persona segons les seues creences (Perner, 1991; Wellman, 1990). I durant l'etapa escolar, es desenvolupen distintes habilitats de TM fins arribar a l'adolescència. En aquest sentit, segons la classificació de Tirapu-Ustárroz, et al. (2007) hi ha distints nivells de complexitat, tenint avui en dia un repertori ampli de distintes tasques per avaluar-los, més enllà de l'avaluació de la falsa creença. Aquests nivells són els següents:

- Reconeixement facial d'emocions: competència en reconèixer emocions mitjançant l'observació d'expressions facials.

- Falses creences de primer i segon ordre: ser capaç de posarse en la situació d'altra persona, ometent la informació adquirida, i així poder predir l'acció que realitzarà en determinat context. Segons la seua complexitat n'hi ha de primer i de segon ordre.

- «Posades de pota» (o malentesos): Baron-Cohen, O’Riordan, Stone, Jones i Plaisted (1999) defineixen la comprensió de 
"posades de pota» com quan algú diu alguna cosa sense tenir en compte (o saber) si l'oient ho vol escoltar, de manera que pot comportar conseqüències negatives per a aquest sense ser intencionades per part del parlant.

- Expressió i comprensió emocional a través de la mirada: es tracta d'un dels nivells de cognició social amb més dificultats, atés que inclouria la capacitat de reconèixer emocions i estats mentals complexos a través de la mirada (Baron-Cohen, Wheelwright, Scahill, Lawson i Spong, 2001).

- Empatia i judici moral: aquest nivell ha suscitat un gran debat i polèmica entre els que estudien la conducta humana, però es considera part de la TM ja que existeix un solapament entre les regions cerebrals implicades en aquesta $\mathrm{i}$ les implicades en els judicis ètics $\mathrm{i}$ "dilemes morals».

- Comunicacions metafòriques i històries estranyes: competència a l'hora de detectar intencions sota enunciats literals o metafòrics.

\subsection{Teories d'adquisició i poblacions amb dificultats}

L'origen de la TM, es troba en els primers treballs de Premack $i$ Woodruf (1978) quan van intentar demostrar que els ximpanzés podien comprendre la ment dels éssers humans. Són diverses les postures adoptades entorn a l'adquisició de les dificultats en TM.

Les primeres teories, com la proposada per Leslie (1987), suggerien que aquest mecanisme pot ser innat, específic i independent (ToMM o Theory of Mind Module), i per tant, una persona amb una intel-ligència típica en altres aspectes, el puga tenir afectat d'una manera independent com ocorreria en el trastorn de l'espectre autista (TEA). Tanmateix, els últims anys, un gran nombre d'investigacions ha demostrat l'existència d'una relació entre el desenvolupament de la TM i el desenvolupament del llenguatge (Astington i Baird, 2005), ja que sembla clar que l'adquisició del llenguatge afavoreix el desenvolupament de la TM (i viceversa). A més, el desenvolupament més gran en TM és entre els 3 i 5 anys, coincidint amb el període de desenvolupament i consolidació del llenguatge (Astington i Jenkins, 1999). En aquest, es van veure correlacions entre proves de creença falsa i diferents mesures lingüístiques (vocabulari o memòria d'oracions) en xiquets i xiquetes d'aquest interval d'edat. Posteriorment, Milligan, Astington i Dack (2007) realitzaren una metaanàlisis on demostraren per mitjà de distints estudis que hi ha una intensa relació entre TM i les habilitats lingüístiques.

En aquest sentit, diversos autors han intentat identificar quins aspectes del llenguatge estan primordialment relacionats amb la TM, de manera que se li dóna èmfasis a la semàntica, la sintaxi, la pragmàtica o 
inclús el llenguatge en general (Serrano, 2012). Encara així, no està tan clar quin aspecte propi del llenguatge és el més relacionat amb el desenvolupament de la TM.

El que està clar i és comunament acceptat és que el llenguatge és un prerequisit per a iniciar o tenir relacions interpersonals amb iguals $i$, per tant, la mancança d'aquest pot contribuir a l'aparició de desajustos conductuals o un retard en el desenvolupament de la cognició social (Jerome, Fujiki, Brinton i James, 2002). Estudis com el de Bishop (1997) o el de Miller (2001) permeten afirmar que el fracàs en tasques de TM (p. ex., de creença falsa) està relacionat amb les capacitats lingüístiques. A més, dades empíriques provinents de poblacions amb dificultats comunicatives (autisme i síndrome de Down) sustenten que les dificultats pragmàtiques poden obeir a dèficits en la capacitat de formar-se teories de la ment dels interlocutors (Olivar, Flores i de la Iglesia, 2004). Tanmateix, autors com Farrant, Fletcher i Maybery (2006) afirmen que la mancança en la comprensió de les tasques de creença falsa no pot explicar-se exclusivament a partir de les demandes lingüístiques i memorístiques pròpies de la tasca, ni tampoc per l'ús adequat de conceptes sobre estat mental en les respostes. Així, altres autors com Varley, Siegal i Want (2001) observen que l'afectació en aspectes gramaticals en pacients amb dany cerebral (on el llenguatge ja estava desenvolupat) no influeix en la TM.

Aquesta relació de la TM amb el llenguatge es pot observar en persones amb un desenvolupament normotípic, però és més evident en persones amb trastorns que tenen afectada la comunicació (Happé, 1995; Pons, Lawson, Harris i de Rosnay, 2003). De fet, en un principi, es va afirmar que les dificultats en TM eren específiques de les persones amb autisme (etiologia de la seua simptomatologia) i es va proposar que la causa dels trastorns generals del desenvolupament era una absència d'aquesta habilitat (Baron-Cohen, Leslie i Friht, 1985). El dèficit bàsic de les persones en autisme radica en la incompetència per a formar-se representacions mentals sobre creences, pensaments i intencions dels altres i diferenciar-les d'un mateix, la qual cosa suposa una incapacitat per a entendre els estats mentals o perspectives diferents als propis (Baron-Cohen, et al., 1985).

Les persones amb trastorn específic del llenguatge (TEL) són un altra de les poblacions amb dificultats per al desenvolupament de la TM, no tan greus com en l'autisme, però el retard en el desenvolupament del llenguatge provoca un desfasament de 2 a 3 anys en algunes habilitats bàsiques, com ara la comprensió de creences falses (Andrés-Roqueta, Adrian, Clemente i Katsos, 2013). "Llenguatge i TM estan entrellaçats durant les fases inicials del desenvolupament $i$ interaccionen de manera dinàmica i constant» (Andrés, 2009: 23). Aquestes dificultats es tradueixen, per exemple, a l'hora d'interaccionar amb iguals demostrant habilitats de negociació pobres i resolució de conflictes improductius (Brinton, Fujiki i McKee, 1998) i tenint dificultat per a iniciar interaccions socials (Brinton, Fujiki, Spencer i Robinson, 1997). 
Un tercer col-lectiu amb retards en el desenvolupament de la TM és la població amb dèficit auditiu que naixen en famílies oients (coneguts com late-signers) ja que també presenten retards comunicatius a causa $d^{\prime}$ un període de no-exposició a converses amb els adults del voltant ( $p$. ex., Peterson i Siegal, 2000; Schick, de Villiers, de Villiers i Hoffmeister, 2007). A mesura que els xiquets amb sordesa aprenen el llenguatge de símbols van assolint la capacitat de comunicar-se i conseqüentment van desenvolupant les seues habilitats mentalistes (Peterson i Siegal, 1995).

Finalment, i en relació amb la població que s'estudia en aquest article, també s'han trobat dificultats de TM en persones amb discapacitat intel-lectual (DI), i més concretament, s'ha estudiat el cas de les persones amb síndrome de Down (SD). Tanmateix, la quantitat d'evidències empíriques és més baixa que en la resta de trastorns esmentats, sobretot en persones adultes, i una sèrie d'estereotips sobre aquestes persones ha comportat que avui en dia encara no es tinga clar quines habilitats de TM tenen aquestes persones, en comparació amb les persones de la seua edat.

\subsection{Síndrome de Down (SD) i teoria de la ment (TM)}

La SD és una alteració genètica pròpia de l'espècie humana des dels seus orígens (Amadó, 2014). Aquesta alteració ve donada per una trisomia en el cromosoma 21, és a dir, en compte de dos cromosomes en el parell 21, en tenen tres. Segons Lambert i Rondal (1982) formen el $25 \%$ de les persones amb discapacitat intel-lectual (DI). Pel que fa a les seues dificultats, s'ha demostrat que les habilitats lingüístiques i comunicatives en les persones amb SD no es desenvolupen seguint el mateix patró que la resta d'habilitats cognitives (Chapman, 1995; Miller, 1987), ja que, en general, el seu nivell lingüístic sol ser inferior al nivell de competència social i intel-lectual (Ruiz, 2001). A més a més, és important tenir present que entre les persones amb SD existeix una gran variabilitat entre uns individus i altres, encara que aquestes persones presenten un retard significatiu en l'emergència del llenguatge i les habilitats lingüístiques (Miller, Leddy i Leavitt, 2001).

La percepció estereotipada que les persones amb SD són «molt sociables», pot ser un dels factors que més contribueix a la falta d'estudis sobre aquest tema (Down, 1866; Fidler, Most, Booth-LaForce i Kelly, 2008; Gilmore, Campbell i Cuskelly, 2003; Hines i Bennett, 1996; Rogers, 1987; Wishart i Johnston, 1990; Wishart i Manning, 1996).

A més, la major part d'estudis s'han basat en xiquets i xiquetes, i no tant en adults, com a conseqüència de prendre als xiquets amb SD com a «participants control» de xiquets amb TEA (p. ex., Yirmiya, Solomonica-Levi i Shulman, 1996), la qual cosa ha fet que algunes de les dificultats no s'hagen estudiat en profunditat, entre altres la font principal d'aquesta investigació, la comprensió acurada de les intencions comunicatives de les persones. 
Aquest últim nivell serà la font principal d'aquest estudi. Happé (1994), la creadora de la tasca més emprada per a tal motiu (tasca d'Històries Estranyes), afirma que aquestes històries estan situades en un nivell de complexitat més alt dins de la TM, ja que aquestes se centren en la capacitat per a extraure un significat en funció d'un context social particular (i no general). Per tant, són necessàries també les anomenades habilitats de "coherència central o global» per tal de superar el significat literal en un context concret.

En la tasca de Happé (1994), s'avalua la capacitat de comprendre les intencions comunicatives següents: mentida, mentida piadosa, acudit, ficció, malentés, persuasió, aparença vs. realitat, metàfora, sarcasme, oblit, doble engany i emocions oposades.

\section{Objectius}

Els dos principals objectius d’aquest estudi són:

1. Oferir un perfil comprensiu de les intencions comunicatives en persones adultes amb SD i DI, de manera que es complete la informació prèvia sobre competència emocional i comprensió de creences falses, atenent a factors que puguen afectar aquest desenvolupament com el tipus de DI (SD vs. altres DI).

2. Esbrinar si el llenguatge i el raonament no verbal, són variables predictores d'un nivell més bo en intencions comunicatives dins de la població adulta amb DI.

A partir d'aquests objectius es formulen les hipòtesis següents:

- Hipòtesis 1: després de la revisió de la literatura que versa sobre les habilitats implicades en el desenvolupament de la TM, s'hipotetitza que les dificultats en les intencions comunicatives estaran tant les persones amb DI, com les persones amb SD, ja que els dos grups tenen problemes en el llenguatge. No s'estableix cap hipòtesi pel que fa a quina població tindrà més problemes.

- Hipòtesis 2: per altra banda, s'hipotetitza que el llenguatge serà una variable predictora en les intencions comunicatives en les persones amb DI, tal com ocorre també en altres poblacions

\section{Material i mètode}

\subsection{Participants}

En aquest estudi van participar 36 adults amb DI d'edats compreses entre 17 i 52 anys ( $M=28$ anys; DT $=107.36$ mesos). Tots els 
participants procedeixen de la Fundació Síndrome de Down de Castelló de la Plana, on divideixen la seua modalitat d'escolarització en tres tipus: formal (22,2 \%), no formal (63,9\%) i ocupacional (13,9\%).

La informació sobre els participants s'ofereix en la Taula 1. Aquest grup es va dividir en dos:

- Grup amb síndrome de Down (SD): es van seleccionar 18 adults diagnosticats amb SD.

- Grup amb altres tipus de DI (DI): una vegada seleccionat el grup amb SD, es van reclutar participants del centre amb altres tipus de DI amb una edat i gènere semblants, per tal de formar el grup de comparació.

Cal aclarir que, encara que ambdós grups tenen discapacitat intel-lectual, en aquest article es farà referència amb els acrònims «SD" per referir-se al grup amb síndrome de Down, i «DI» per a referir-se al grup d'adults amb altres tipus de discapacitat intel-lectual.

\subsection{Instruments}

Instruments sobre les capacitats individuals: raonament no verbal $i$ habilitats lingüistiques.

- Raonament no verbal: Matrius progressives - escala de color (Raven, Court i Raven, 1996).

Es tracta d'una prova per a avaluar el $\mathrm{Cl}$ no verbal mitjançant 36 ítems de dificultat creixent i consisteix a assenyalar, entre sis opcions possibles, la peça que li falta en un puzle per a completar-lo. Es pot aconseguir una puntuació màxima de 36 punts. Tal com recomana el manual, s'ha administrat l'escala a color, ja que aquesta és molt apropiada per a valorar tant a xiquets com a adults d'una dotació intel.lectual baixa com és el cas del present estudi. Com que es treballar amb adults, s'utilitza la puntuació directa sense transformar-la en percentils.

- Habilitats lingüístiques:

a) Mesura gramatical: test de comprensió d'estructures gramaticals (CEG) (Mendoza, Carballo, Muñoz i Fresneda, 2005).

El CEG mesura la comprensió d'estructures gramaticals en xiquets entre $4 \mathrm{i} 11$ anys. El test conté 80 ítems que consisteixen a assenyalar el dibuix, entre quatre de diferents, a què correspon l'enunciat llegit. Per tant, la puntuació directa per la suma d'ítems pot anar de 0 a 80 punts. Es poden traure percentils a partir de les puntuacions directes segons l'edat, tanmateix, en tractar-se d'adults amb l'edat mental més baixa que la cronològica, s'utilitzen les puntuacions directes.

b) Mesura de vocabulari: Peabody (Dunn, Dunn i Arribas, 2006)

El test de vocabulari en imatges Peabody (PPVT-III) mesura el coeficient verbal de xiquets d'entre 2 i 17 anys. Consisteix a assenyalar 
el dibuix correcte, entre quatre opcions, que correspon a la paraula llegida. Els ítems d'aquesta prova s'organitzen per blocs de 12 ítems cada un per edats, i comencen de 2 anys i mig fins al de més grans de 17 anys. En el present estudi, com que es tracta de persones en edat adulta, no s'ha començat des del principi de la prova sinó del bloc de 6-7 anys. Si cometien una errada o més, es va anar baixant blocs fins arribat al primer. Mentre van encertant ítems, es va pujant blocs fins aplegar al «bloc sostre», és a dir, 8 errades o més en un mateix bloc. D’aquest test també s'ha utilitzat la puntuació directa com la resta de proves ja que no estan dissenyades per a adults. La puntuació total pot anar des dels 0 fins als 192 punts.

\section{Instrument sobre Intencions comunicatives}

- Històries Estranyes (Happé, 1994; adaptació Andrés, 2009).

Les Històries Estranyes avaluen aspectes de la vida quotidiana on ocorren episodis mentalistes, com ara la comprensió de la mentida, la mentida piadosa, la metàfora, els malentesos, el doble engany, la ironia, la persuasió, les emocions oposades, els zels, les intencions i les posades de pota. Aquestes històries es van crear inicialment per avaluar I'habilitat dels xiquets autistes a l'hora d'atribuir intencions als altres (Happé, 1994).

Per a aquest treball, s'han utilitzat un total de sis històries de les dotze originals: simulació, l'acudit, la mentida, la mentida piadosa, la ironia i la frase feta.

La forma d'administrar aquest test és contar cada història amb unes vinyetes utilitzades de suport visual. Per exemple, la història de "simulació» tracta sobre dues amigues, Maria i Rosa, que estan jugant a casa. De sobte Rosa agafa un plàtan del fruiter i se'l posa a l'orella i li diu a María que estava parlant per telèfon. En finalitzar la breu narració es formulen dues preguntes:

- Pregunta 1: És cert el que diu Rosa?

- Pregunta 2: Aleshores... Per què ho diu?

La puntuació de cada història oscil.la de 0 a 3 punts, en funció de l'apropament a la detecció de la intenció del protagonista (3 punts = intenció correcta; 2 punts = resposta correcta amb al·lusió a aspectes físics; 1 punt = intenció distinta; 0 punts $=$ respostes incoherents). Finalment se suma la puntuació total de les sis històries utilitzades fent servir aquesta com puntuació directa que pot anar des de 0 fins a 18 punts.

\subsection{Procediment}

En primer lloc es va contactar amb la Fundació Síndrome de Down de Castelló de la Plana per tal de poder realitzar allí el present estudi amb els seus alumnes. Posteriorment, es van sol-licitar tots els permisos 
pertinents en el centre per a realitzar la investigació i les autoritzacions per part dels alumnes i les seues famílies. Finalment, es van administrar les proves a la mostra escolaritzada en el centre de formació i del centre ocupacional.

Totes les proves van ser administrades en aules o despatxos que estaven lliures tant en el centre de formació com en l'ocupacional en I'horari escolar dels alumnes per part de l'autor de l'article i sempre de manera individual.

Finalment, les proves es van corregir i es van introduir en el paquet estadístic IBM SPSS Statistics 22 per a analitzar-les.

\section{Resultats}

A continuació es mostren els resultats obtinguts en les distintes mesures, atenent als objectius de l'estudi. En primer lloc, donades les característiques de la mostra, es van emprar proves no paramètriques ( $U$ de Mann-Whitney) per tal de comparar els grups SD i DI en les distintes mesures. Posteriorment, es va realitzar un estudi correlacional (Pearson) dins de cada grup per separat, així com en la globalitat de la mostra. I finalment, per tal d'esbrinar quins són els predictors d'un millor nivell de TM dins de la mostra amb DI, es va dur a terme un estudi predictiu amb distintes regressions lineals prenent les tasques de TM com a variables dependents.

\subsection{Descriptius i comparacions grupals de les variables lingüístiques i no verbals}

En la Taula 1 es pot veure la comparativa realitzada entre els dos grups que s'extrau de la mostra amb la prova $U$ de Mann-Whitney. Es tracta de grups equilibrats en edat, gènere i raonament no verbal.

En relació amb el llenguatge, s'observa una diferència significativa favorable al grup amb $D I$ en ambdues proves: gramàtica $(U=73,5$, $p=.004$, Cohen's $d=-.911)$ i vocabulari $(U=98,5, p=.044$, Cohen's $d=-$ $.751)$.

Taula 1. Descriptius i comparacions grupals en les variables de control i selecció de la mostra

\begin{tabular}{|c|c|c|c|c|c|c|c|c|c|}
\hline & \multicolumn{3}{|c|}{$D I(n=18)$} & \multicolumn{3}{|c|}{$S D(n=18)$} & \multirow[b]{2}{*}{$d$} & \multirow[b]{2}{*}{$U$} & \multirow[b]{2}{*}{$p$} \\
\hline & $M$ & $D T$ & Rang & $M$ & $D T$ & Rang & & & \\
\hline Edat (mesos) & 357,17 & 132,83 & $215-627$ & 324,61 & 74,33 & $227-492$ & .302 & $\mathrm{DI}=\mathrm{SD}$ & $p=.791$ \\
\hline Gènere [M/F] & $11 / 7$ & - & - & $7 / 11$ & - & - & - & $\mathrm{DI}=\mathrm{SD}$ & $p=.265$ \\
\hline CI no verbal & 18,33 & 10,36 & $2-34$ & 16,94 & 6,13 & $4-27$ & .163 & $\mathrm{DI}=\mathrm{SD}$ & $p=.767$ \\
\hline Gramàtica & 56,33 & 13,43 & $26-76$ & 45,11 & 11,09 & $30-73$ & .911 & $\mathrm{DI}>\mathrm{SD}$ & $p=.004$ \\
\hline Vocabulari & 109,67 & 38,14 & $40-179$ & 83,94 & 29,89 & $44-142$ & .751 & $\mathrm{DI}>\mathrm{SD}$ & $p=.044$ \\
\hline
\end{tabular}


Per tant, el grup de SD i el grup de DI es diferenciaren en el raonament no verbal, però fonamentalment en el seu nivell lingüístic, el grup amb DI va obtenir més bona puntuació en els dos casos.

\subsection{Descriptius i comparacions grupals en la tasca de les intencions comunicatives}

En el cas de les intencions comunicatives, s'han trobat diferències entre els dos grups experimentals, com es pot observar en la comparació de les puntuacions mitjanes que apareixen a la Taula 2.

$\mathrm{Hi}$ ha una diferència significativa en el total de les intencions comunicatives (Històries Estranyes) $(U=75, p=.005, d=1,068)$. En el desglossament d'aquesta tasca, es poden veure diferències significatives en la simulació $(U=72, p=.004, d=1,101)$ i en la mentida piadosa $(U=65, p=.002, d=1,403)$. També s'aprecia una diferència amb tendència a la significació en la ironia $(U=101,5, p=.055, d=.749)$. En tots els casos, el grup amb DI demostra una competència superior.

Taula 2. Descriptius i comparacions grupals en la tasca de les Històries Estranyes

\begin{tabular}{|c|c|c|c|c|c|c|c|c|c|}
\hline & \multicolumn{3}{|c|}{$D I(n=18)$} & \multicolumn{3}{|c|}{$S D(n=18)$} & \multirow[b]{2}{*}{$d$} & \multirow[b]{2}{*}{$\boldsymbol{U}$} & \multirow[b]{2}{*}{$p$} \\
\hline & $M$ & $D T$ & Rang & $M$ & $D T$ & Rang & & & \\
\hline H1. Simulació & 1,61 & 1,24 & $0-3$ & .44 & .85 & $0-3$ & 1,101 & $\mathrm{DI}>\mathrm{SD}$ & $p=.004$ \\
\hline H2. Acudit & 1,22 & 1,00 & $0-2$ & .89 & 1,02 & $0-2$ & .327 & $\mathrm{DI}=\mathrm{SD}$ & $p=.406$ \\
\hline H3. Mentida & 2,61 & .99 & $0-3$ & 2,00 & 1,33 & $0-3$ & .520 & $\mathrm{DI}=\mathrm{SD}$ & $p=.252$ \\
\hline H4. M. piadosa & 2,11 & 1,23 & $0-3$ & .67 & .77 & $0-3$ & 1,403 & $\mathrm{DI}>\mathrm{SD}$ & $p=.002$ \\
\hline H5. Ironia & 1,89 & 1,45 & $0-3$ & .83 & 1,38 & $0-3$ & .749 & $\mathrm{DI}>\mathrm{SD}$ & $p=.055$ \\
\hline H6. Frase feta & 1,28 & .96 & $0-3$ & 1,05 & 1,05 & $0-3$ & .229 & $\mathrm{DI}=\mathrm{SD}$ & $p=.481$ \\
\hline H. Estranyes (total) & 10,72 & 5,52 & $0-17$ & 5,89 & 3,23 & $0-11$ & 1,068 & $\mathrm{DI}>\mathrm{SD}$ & $p=.005$ \\
\hline
\end{tabular}

\subsection{Correlacions entre la tasca de les intencions comunicatives i la resta} de mesures

En aquest estudi s'han fet dos estudis correlacionals diferents: dins de la mostra de DI $(n=18)$ i dins de la mostra de SD $(n=18)$. S'ha emprat la correlació de Pearson i sempre entre les variables i la tasca de les Històries Estranyes (HE). Aquestes dues correlacions estan representades en la Taula 3.

\subsubsection{Correlacions del grup amb DI}

$S^{\prime}$ observen correlacions significatives dels aspectes relacionats amb el llenguatge (vocabulari i gramàtica) amb totes les HE inclús en el valor total. També s'aprecia una correlació amb tendència a la significació del raonament no verbal amb el valor total de les HE i amb l'acudit. 


\subsubsection{Correlacions del grup amb SD}

Ací s'observen menys correlacions significatives. En relació amb el llenguatge, es descobreix una correlació de la gramàtica amb el total de les $\mathrm{HE}$, amb la mentida i amb la ironia, en canvi, en el vocabulari soles s'aprecia una tendència a la significació amb el total de les $\mathrm{HE}$.

Pel que fa al raonament no verbal, apareixen tan sols dues tendències a la significació, una a la mentida i altra a la ironia

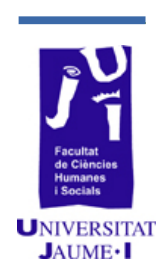

Taula 3. Correlacions de la mostra

\begin{tabular}{lcccccc}
\hline & \multicolumn{3}{c}{ DI $(n=18)$} & \multicolumn{3}{c}{ SD $(n=18)$} \\
\hline H1. Simulació & $.574^{*}$ & $.484^{*}$ & .289 & -.077 & -.241 & -.074 \\
\hline H2. Acudit & $.632^{* *}$ & $.762^{* *}$ & $.445(\mathrm{t})$ & .160 & .261 & .027 \\
\hline H3. Mentida & $.603^{* *}$ & $.677^{* *}$ & .176 & .292 & $.539^{*}$ & $.448(\mathrm{t})$ \\
\hline H4. M. piadosa & $.507^{*}$ & $.638^{* *}$ & .334 & .287 & .032 & -.092 \\
\hline H5. Ironia & $.673^{* *}$ & $.681^{* *}$ & .320 & .373 & $.500^{*}$ & $.443(\mathrm{t})$ \\
\hline H6. Frase feta & $.563^{*}$ & $.751^{* *}$ & .393 & .201 & .020 & .064 \\
\hline H. Estranyes (total) & $.739^{* *}$ & $.819^{* *}$ & $.404(\mathrm{t})$ & $.443(\mathrm{t})$ & $.468^{*}$ & .362 \\
\hline
\end{tabular}

Nota: ${ }^{*} p<.05 ;{ }^{*} p<.01 ;(t)$ tendència $.05<.10$

\section{Discussió i conclusions}

Al principi d'aquest estudi es plantejaven dos objectius principals. El primer objectiu era oferir un perfil comprensiu de les intencions comunicatives en persones adultes amb SD i DI, i ampliar la informació prèvia sobre competència emocional i comprensió de creences falses, atenent a factors que puguen afectar aquest desenvolupament com el tipus de DI: per una part SD i per l'altra altres tipus de DI. En aquest sentit, s'hipotetitzava que les dificultats en comprensió d'intencions comunicatives estarien presents tant en les persones amb DI, com en les persones amb SD, ja que els dos grups tenen problemes amb el llenguatge i amb funcions executives. Pel que fa a quina població tindrà més problemes, no s'establia cap hipòtesi.

Després de la realització d'aquest estudi, es pot afirmar que s'ha confirmat que les persones adultes amb SD i altres tipus de DI tenen dificultats per a resoldre tasques d'intencions comunicatives que haurien de ser superades entre els 6 i els 11 anys, com ara quan les persones volen realitzar una broma, dir una mentida o parlar de manera irònica per a demostrar allò contrari. A més, i com a dada important trobada en aquest estudi, cal remarcar que els adults amb SD tenen, fins i tot, més problemes pera resoldre les tasques que altres adults amb altres tipus de DI. 
Així, s'ha demostrat que encara que les persones adultes amb SD no tinguen problemes per a superar tasques simples de TM (com ara, reconeixement d'emocions simples o creences falses), les seues dificultats afloren en aquest nivell de TM que amb anterioritat no havia sigut explorat. Aquestes dificultats podrien explicar que les persones amb SD tinguen de vegades biaixos a l'hora d'interpretar la conducta de les persones que els envolten i, per exemple, no captar subtileses com la «no-intencionalitat» de ferir en una mentida piadosa.

El segon objectiu plantejat en aquest estudi era esbrinar si el llenguatge i el raonament no verbal són variables predictores d'un nivell més bo en intencions comunicatives dins de la població adulta amb DI (en aquest cas, sense diferenciar entre SD i altres tipus de DI). A partir de les evidències prèvies de la literatura, s'hipotetitzava que dins del col-lectiu d'adults amb DI, les variables lingüístiques predirien més bé aquest nivell de TM, d'una manera semblant al que passa en altres poblacions (Andrés-Roqueta et al., 2013).

Seguint aquest objectiu i analitzant aquest treball, es pot afirmar que, tal com ocorre en la major part de poblacions amb i sense dificultats (per exemple, Astington i Baird, 2005; Bishop, 1997; Miller, 2001; Milligan, et al., 2007), la comprensió de totes les intencions comunicatives correlacionen significativament amb el llenguatge (mesurat en aquest estudi mitjançant dues tasques: comprensió gramatical i comprensió de vocabulari). Per tant, es pot confirmar que aquells individus amb més dèficit en el llenguatge dins del col·lectiu amb DI són els que han demostrat pitjor competència en la comprensió d'intencions comunicatives (i no aquells amb un $\mathrm{Cl}$ no verbal més baix).

Generalment, doncs, es pot afirmar que aquest nivell de TM està significativament relacionat amb el llenguatge, sobretot en el grup amb DI més que en el grup amb SD i guarden menys relació amb altres aspectes on també aquestes persones poden mostrar dificultats, com ara el raonament no verbal. Per tant, sembla que la tasca d'Històries Estranyes (Happé, 1994) requereix un bon nivell en vocabulari per poder comprendre-la i demostrar-ne una execució competent.

Com a conclusió general, es pot afirmar que les persones amb SD i DI sí que presenten certs problemes amb la comprensió de les intencions comunicatives i, per tant, en les seues habilitats de TM. En aquests termes no s'havia trobat informació al respecte, però altres autors com Fernández-Alcaraz, et al. (2010), ja afirmaven que les persones amb SD sí que tenen problemes en TM, sobretot en el reconeixement d'emocions. També s'han trobat estudis que afirmen que en alguns nivells de TM els adults continuen millorant a mesura que transcorre el seu desenvolupament (Giaouri, et al., 2010; Yirmiya, et al., 1998), per tant, caldria comprovar si en la comprensió de les intencions comunicatives passaria el mateix. Si així fóra, seria important dissenyar mètodes d'intervenció adaptats a les dificultats particulars de TM d'aquestes persones, de manera que se supere l'estereotip que no tenen dificultats a l'hora de relacionar-se amb les persones. El disseny 
d'aquest tipus d'intervencions és indispensable en aquesta població independentment del $\mathrm{Cl}$, sobretot en l'edat adulta, i habitualment no se li sol donar prou importància i, en canvi, resulta essencial per a establir correctament relacions interpersonals i una bona socialització amb el món que els envolta. A més, es podria millorar fins i tot l'autoestima i la qualitat de vida d'aquests col-lectius.

Com a dada rellevant d'aquest estudi es demostra l'existència de dificultats en TM que són importants a l'hora de relacionar-se amb les persones, com ara la comprensió d'intencions comunicatives amagades sota enunciats indirectes o no literals (frases fetes, mentides, ironies, etc.), entre d'altres.

En futurs estudis seria interessant administrar aquestes mateixes tasques a un grup control d'edat mental i lingüística similar al grup d'adults per a realitzar-ne la comparativa, de manera que es puguen estudiar amb profunditat els problemes concrets de la població amb SD i DI respecte a la població amb desenvolupament normotípic. Així mateix, també seria convenient estudiar altres variables que podrien estar implicades, tant en l'àmbit intrapersonal (p. ex. funcions executives), com en l'interpersonal (p. ex. estils paterns o socialització entre iguals).

\section{Agraïments}

Aquest estudi ha estat possible gràcies a la Fundació Síndrome de Down de Castelló de la Plana, tant al Centre de Formació com al Centre Ocupacional. Els autors volen agrair els directors, professionals i alumnes, per donar l'oportunitat de realitzar l'estudi. A més, els autors volen agrair a l'ajuda finançada atorgada pel projecte GV/2015/092 subvencionat per la Conselleria d'Educació, Cultura i Esport de la Generalitat Valenciana (Espanya).

\section{Bibliografia}

Adolphs, R. (2001): "The Neurobiology of Social Cognition», Current Opinion in Neurobiology, 11, p. 231-9.

AmAdó, A. (2014): Habilitats sociocognitives i de funcionament executiu en nenes i nens amb síndrome de Down d'entre 4 i 12 anys, Tesis Doctoral no publicada, Universitat de Girona, Girona.

ANDRÉs, C. (2009): Pragmática y cognición social en niños y niñas con trastorno específico del lenguaje (TEL), Tesis Doctoral no publicada, Universitat Jaume I, Castelló de la Plana.

Andrés-Roqueta, C. i altres (ed.) (2013): «Which are the Best Predictors of Theory of Mind Delay in Children with Specific Language Impairment?», International Journal of Language and Communication Disorders, 48 (6), p. 726-37. 
Astington, J. W. i J. BAIRD (2005): «Introduction: Why Language Matters», Why Language Matters for Theory of Mind, Oxford, Nova York, p. 3-25.

Astington, J. W. i J. M. Jenkins (1999): «A Longitudinal Study of the Relation Between Language and Theory-of-Mind Development», Developmental Psychology, 35, p. 1311-1320.

BARon-Cohen, S. i altres (ed.) (1985): «Does the Autistic Children Have a "Theory of Mind"?» Cognition, 21, p. 113-125.

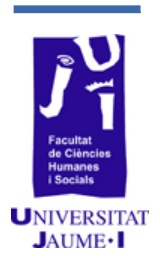

- (1999): «Recognition of Faux Pas by Normally Developing Children and Children with Asperger Syndrome or High- Functioning Autism», Journal of Autism and Developmental Disorders, 29, p. 407-418. doi: 10.1023/A:1023035012436.

- (2001): "The 'Reading the Mind in the Eyes' Test Revised Version: A Study with Normal Adults, and Adults with Asperger Syndrome or HighFunctioning Autism», Journal of Child Psychology and Psychiatry, 42, p. 241-51.

BENSON, G. i altres (ed.) (1993): «Development of Theory of Mind in Individuals with MR», American Journal on Mental Retardation, 98, p. 427-433.

BISHOP, D. V. M. (1997): Uncommon Understanding, Psychology Press, Hove, UK.

BRINTON, B. i altres (ed.) (1997): "The Ability of Children with Specific Language Impairment to Access and Participate in Ongoing Interaction", Journal of Speech, Language, and Hearing Research, 40 (5), p. 1011-1025.

BRINTON, B. i altres (ed.) (1998): «Negotiation Skills of Children with Specific Language Impairment», Journal of Speech, Language and Hearing Research, 41 (4), p. 927-940.

CHAPMAN, R. S. (1995): «Language Development in Children and Adolescents with Down Syndrome», FletCher, P. i B. MacWhinney (ed.), Handbook of Child Language, Blackwell, Oxford, p. 651-663.

Down, J. L. H. (1866): «Observations on an Ethnic Classification of Idiots», London Hospital Clinical Lectures and Reports, 3, p. 259-62.

DUNN, LL. M. i altres (ed.) (2006): Test de vocabulario en imágenes Peabody (PPVT-III), TEA Ediciones, Madrid.

FARRANT, B. i altres (ed.) (2006): "Specific Language Impairment, Theory of Mind, and Visual Perspective Taking: Evidence for Simulation Theory and the Developmental Role of Language», Child Development, 77, p. 18421853. doi:10.1111/j.1467- 8624.2006.00977.x

Fernández-Alcaraz, C. i altres (ed.) (2010): «Emotion Recognition in Down's Syndrome Adults: Neuropsychology Approach», Procedia Social and Behavioral Sciences, 5, p. 2072-2076, Universidad Autónoma de Madrid, Madrid. 
FIDLER, D. J. i altres (ed.) (2008): «Emerging Social Strengths in Young Children with Down Syndrome», Infants and Young Children, 21, p. 20720.

GIAOURI, S. i altres (ed.) (2010): «Theory of Mind Abilities in Children with Down Syndrome and Non-Specific Intellectual Disabilities: An Empirical Study with Some Educational Implications», Procedia Social and Behavioral Sciences, 2, p. 3883-3887.

GILMORE, L. i altres (ed.) (2003): «Developmental Expectations, Personality Stereotypes and Attitudes Towards Inclusive Education: Community and Teacher Views of Down Syndrome», International Journal of Disability Development and Education, 50, p. 63-78.

HAPPÉ, F. (1994): «An Advanced Test of Theory of Mind: Understanding of Story Characters' Thoughts and Feelings by Able Autistic, Mentally Handicapped, and Normal Children and Adults", Journal of Autism and Developmental Disorders, 24, p. 129-154. doi:10.1007/BF02172093.

- (1995): "The Role of Age and Verbal Ability in the Theory of Mind Task Performance of Subjects With Autism», Child Development, 66, p. 843855.

HINES S. i F. BENNETT (1996): "Effectiveness of Early Intervention for Children With Down Syndrome», Ment Retard Development Disabilities Research Reviews, 2, p. 96-101.

Jerome, A. C. i altres (ed.) (2002): "Self-Esteem in Children With Specific Language Impairment», Journal of Speech, Language, and Hearing Research, 45, p. 700-714.

LAMBERT, J. L. i J. A. RondAL (1982): El mongolismo, Herder, Barcelona.

LESLIE, A. M. (1987): «Presence and Representation: The Origins of 'Theory of Mind'», Psychology Review, 94, p. 412-36.

MendozA, E. i altres (ed.) (2005): Test de comprensión de estructuras gramaticales, TEA ediciones, Madrid.

Miller, C. A. (2001): «False Belief Understanding in Children With Specific Language Impairment», Journal of Communication Disorders, 34, p. 73-86. doi:10.1016/S0021-9924(00)00042-3.

MilleR, J. F. (1987): "Language and Communication Characteristics of Children with Down Syndrome», S. Pueschel, C. TIngey, J. Rynders, A. Crocker i D. Crutcher (ed.), New Perspectives on Down Syndrome (p. 233262), Paul Brookes, Baltimore, MD.

Miller, J. F. i altres (ed.) (2001): Síndrome de Down: comunicación, lenguaje y habla, Masson, Barcelona.

Miluigan, K. i altres (ed.) (2007): «Language and Theory of Mind: MetaAnalysis of the Relation Between Language Ability and False Belief Understanding", Child Development, 78 (2), p. 622-646. doi:10.1111/j.1467-8624.2007.01018.x. 
OLIVAR, J. S. i altres (ed.) (2004): «Relación entre teoría de la mente y comunicación referencial. Una explicación de los déficits pragmáticos en personas con autismo y síndrome de Down», Acción Psicológica, 3 (1), p. 31-42.

PERNER, J. (1991): Understanding the Representational Mind, MA: MIT Press, Cambridge.

Peterson, C. C. i M. Siegal (1995): «Deafness, Conversation and Theory of Mind», Journal of Child Psychology and Psychiatry, 36, p. 459-474. doi: 10.1111/j.14697610.1995.tb01303.x.

- (2000): "Insights into a Theory of Mind from Deafness and Autism», Mind and Language, 15, p. 77-99.

Pons, F. i altres (ed.) (2003): «Individual Differences in Children's Emotion Understanding: Effects of Age and Language», Scandinavian Journal of Psychology, 44, p. 347-353.

Premack D. i G. Woodruff (1978): «Does Chimpanzee Have a Theory of Mind?", Behavioral and Brain Sciences, 4, 9-30.

RAVEN, J. C. i altres (ed.) (1996): Raven. Matrices progresivas. Escalas Color (CPM), General (SPM), Superior (APM), TEA Ediciones, Madrid.

Rogers C. (1987): «Maternal Support for the Down's Syndrome Stereotype: The Effect of Direct Experience of the Condition", Journal of Mental Deficiency Research, 31, p. 271-8.

RUIZ, E. (2001): «Evaluación de la capacidad intelectual en personas con síndrome de Down», Revista de Síndrome de Down, 18, p. 80-88.

SCHICK, B. i altres (ed.) (2007): «Language and Theory of Mind: A Study of Deaf Children», Child Development, 78, p. 376-396.

SERRANO, J. (2012): Desarrollo de la teoría de la mente, lenguaje y funciones ejecutivas en niños de 4 a 12 años, Tesis Doctoral no publicada, Universitat de Girona, Girona.

TIRAPU-USTÁRROZ, J. i altres (ed.) (2007): «¿Qué es la teoría de la mente?», Revista de Neurología, 44 (8), p. 479-489.

Wellman, H. M. (1990): The Child's Theory of Mind, MA: MIT Press, Cambridge.

WISHART, J. G. i F. H. JOHNSTON (1990): «The Effects of Experience on Attribution of A Stereotyped Personality To Children With Down's Syndrome», Journal of Mental Deficiency Research, 34, p. 409-20.

Wishart, J. G. i G. MANNING (1996): «Trainee Teachers' Attitudes To Inclusive Education for Children With Down's Syndrome», Journal of Intellectual Disability Research, 40, p. 56-65.

YIRMIYA, N. i altres (ed.) (1996): "The Ability To Manipulate Behavior and To Understand Manipulation of Beliefs: A Comparison of Individuals With 
Autism, Mental Retardation, and Normal Development», Developmental Psychology, 32, p. 62-69.

- (1998): «Meta-Analyses Comparing Theory of Mind Abilities in Individuals with Autism, Individuals with Mental Retardation, and Normally Developing Individuals», Psychological Bulletin, 124, p. 283-305.

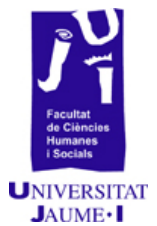




\section{Estudio de casos: alumnado de altas capacidades con y sin trastorno del espectro autista ¿Podemos hablar de inclusión en el aula?}

Raquel Nieto Garoz raquel.nieto@uji.es Irene Garcia Molina imolina@uji.es Aida Sanahuja Ribés asanahuj@uji.es 
Según la Unesco (2005), la educación inclusiva puede ser concebida como un proceso que permite abordar y responder a la diversidad de las necesidades de todos los educandos a través de una mayor participación en el aprendizaje, las actividades culturales y comunitarias y reducir la exclusión dentro y fuera del sistema educativo. Sin embargo, la realidad de muchos alumnos no responde a los principios de la educación inclusiva, puesto que estos no son atendidos en el aula ordinaria y tienden a ser segregados por su diagnóstico.

Nos situamos en el paradigma de la investigación cualitativa, concretamente en el estudio de casos. En este trabajo presentamos seis casos de niños cuyas edades están comprendidas entre 7 y 9 años, con un $\mathrm{Cl}$ igual o superior a 120, por lo tanto, diagnosticados de altas capacidades. Además, tres de ellos han sido diagnosticados de trastorno del espectro autista nivel 1 (según DSM-5). De los 3 alumnos con TEA, uno de ellos asistía a un aula CIL (mod. B), otro estaba incluido en el aula y asistía a una asociación específica y el tercer alumno estaba incluido en el aula ordinaria. Por lo que respecta a los tres alumnos diagnosticados de AACC, uno de ellos estaba escolarizado en el aula ordinaria, pero salía a clases de refuerzo impartidas por el especialista de pedagogía terapéutica, otro estaba incluido en el aula ordinaria y el último estaba acelerado un curso. Los tres asistían a una asociación específica.

Con los diferentes casos expuestos queremos resaltar, además de la importancia de implantar en el aula los principios que persigue la educación inclusiva, la necesidad de trabajar con este tipo de alumnado habilidades sociales y relaciones interpersonales, considerando el aula el contexto social idóneo donde poder trabajar estos aspectos. Finalizamos el trabajo aportando algunas propuestas pedagógicas que pueden ayudar a los docentes a atender los diferentes ritmos, intereses y necesidades del alumnado en el aula.

Palabras clave: educación inclusiva, estudio de casos, TEA, AACC.

\section{Introducción}

Ya hace 22 años de la Declaración de Salamanca (Unesco, 1994), en la cual 92 gobiernos y 25 organizaciones internacionales reafirmaron su compromiso con la educación para todos, y se reconoció la necesidad y urgencia de impartir enseñanza a todos los niños, jóvenes y adultos con necesidades específicas de apoyo educativo dentro del sistema común de educación. Sin embargo, el enfoque dominante en España sigue siendo el de integración. Tal y como introduce Arnáiz (2004), en la mayoría de los casos, la respuesta educativa que se da al alumnado con discapacidades o diagnosticados corresponde a una propuesta individualizada y 
descontextualizada de lo que realiza el grupo clase y generalmente estos asisten a aulas de apoyo o de pedagogía terapéutica. Esto se debe principalmente al hecho de importar prácticas emanadas de las experiencias originadas en la educación especial (Ainscow, 2001). En palabras de Florian (2013), cada vez existe un mayor reconocimiento de que los modelos tradicionales basados en las necesidades específicas de apoyo educativo, que proporcionan servicios distintos o adicionales a los proporcionados a otros niños de edad similar, son injustos porque conllevan a la segregación y perpetúan la discriminación. Así pues, ante esta situación se les plantea a los docentes el reto de atender a la diversidad de sus aulas desde un marco escolar común, esto es, tienen que encontrar formas de atender a todos los alumnos en su diversidad en una escuela en la que están todos (Pujolàs, 2001). Para ello, es necesario entender la diversidad del alumnado como una dimensión que mejora y enriquece la práctica educativa (Moriña, 2008). Según la Unesco (2005:14):

La educación inclusiva puede ser concebida como un proceso que permite abordar y responder a la diversidad de las necesidades de todos los educandos a través de una mayor participación en el aprendizaje, las actividades culturales y comunitarias y reducir la exclusión dentro y fuera del sistema educativo.

Consideramos de vital importancia «revitalizar el ideal de la escuela inclusiva, una vez que este ha comenzado a formar parte del lenguaje escolar políticamente correcto» (Susinos y Rodríguez, 2011: 15). Queremos remarcar también que la inclusión educativa implica (Echeita, 2008:11):

no solo un sentimiento de pertenencia y de bienestar emocional y relacional al que se puede llegar desde la periferia de la acción educativa. La inclusión educativa debe entenderse con igual fuerza como la preocupación por un aprendizaje y un rendimiento escolar de calidad y exigente con las capacidades de cada estudiante.

Así pues, coincidimos con este autor al remarcar la idea de que la inclusión en el aula presenta una doble vertiente: la educativa (responder a los diferentes intereses, motivaciones y estilos de aprendizaje de todo el alumnado) y la social.

En cuanto a la inclusión social del alumnado, queremos acentuar que los diferentes autores que se han ocupado del estudio de las necesidades básicas y motivos del ser humano (Murray, 1938; Maslow, 1954; Deci y Ryan, 2000) coinciden en remarcar la importancia de las necesidades afectivas, de pertenencia y de contacto social del individuo. Según las investigaciones consultadas, los iguales proporcionan apoyo emocional (Bisquerra, 2000) y la influencia de estos se extiende también al desarrollo cognitivo y al ajuste escolar (Gifford-Smith y Brownell, 2003). Así pues, la participación en los procesos interactivos y de aprendizaje que tienen lugar en la familia, la escuela y el grupo de iguales es fundamental y necesaria para el desarrollo infantil (Menéndez, Jiménez y 
Lorence, 2008). Reforzando esta idea, López (1995) señala que los distintos escenarios sociales en los que los niños participan son los encargados de atender y satisfacer las necesidades de desarrollo y educación durante la niñez.

En este trabajo queremos reflexionar sobre la realidad educativa que viven alumnos diagnosticados de altas capacidades intelectuales y de trastorno del espectro autista, por ellos pasamos a remarcar las características más destacables de los alumnos que presentan dichos tipos de diagnóstico.

\subsection{Altas capacidades intelectuales}

\subsubsection{Definición de altas capacidades}

El alumnado con altas capacidades intelectuales se sitúa dentro de la atención a la diversidad desde nuestra actual legislación educativa, altas capacidades intelectuales es el término utilizado para nombrar la capacidad intelectual excepcional. Actualmente no existe una definición asumida por parte de los especialistas en el tema del concepto de altas capacidades intelectuales o alta habilidad. El concepto que introduce la LOE, es un término más general que el de superdotación y reclama la atención también sobre los talentosos, los niños o niñas precoces, y de aquel alumnado que está demostrando diariamente que puede manifestar conductas propias del alumnado bien dotado. Los modelos y conceptos de inteligencia han evolucionado $y$, a lo largo de los siglos $x x y$ $\mathrm{XXI}$, se ha pasado de la inteligencia psicométrica a la inteligencia como un concepto dinámico, cambiante y desarrollable a lo largo de la vida.

Tal y como introducen Alonso et al., (2003), una de las definiciones de superdotado más generalmente aceptada ha sido la de Renzulli del Research Institute for Gifted Education de la Universidad de Connecticut (EE. UU.). Para este autor, lo que define a un individuo superdotado es la posesión de tres conjuntos básicos de características:

1. Una capacidad intelectual superior a la media.

2. Un alto grado de dedicación a las tareas.

3. Altos niveles de creatividad.

Dentro de las altas capacidades, para un mayor entendimiento de las mismas existen distintos conceptos relacionados que pasamos a presentar en la Tabla 1.

Tabla 1. Conceptos relacionados con altas capacidades

(adaptado de Martínez, 2009)

\begin{tabular}{|l|l|}
\hline Superdotado & $\begin{array}{l}\text { Persona que manifiesta un nivel de rendimiento intelectual } \\
\text { superior en una extensa gama de aptitudes y aprende con } \\
\text { facilidad en cualquier área o materia. Se caracteriza por su } \\
\text { competencia general. }\end{array}$ \\
\hline
\end{tabular}




\begin{tabular}{|c|l|}
\hline \multirow{2}{*}{ Talento } & $\begin{array}{l}\text { Persona que muestra habilidades excepcionales en áreas o } \\
\text { materias muy concretas. Se caracteriza por su competencia } \\
\text { específica. }\end{array}$ \\
\cline { 2 - 3 } & $\begin{array}{l}\text { Talentos simples y múltiples: matemático, lógico, social, } \\
\text { creativo, verbal. }\end{array}$ \\
\cline { 2 - 3 } & Talentos complejos: académico y artístico-figurativo. \\
\hline \multirow{2}{*}{ Precoz } & $\begin{array}{l}\text { Persona que manifiesta un mayor desarrollo evolutivo a una } \\
\text { edad más temprana que los niños y niñas de su misma edad } \\
\text { cronológica. Se caracteriza por la competencia general } \\
\text { prematura y admirable. }\end{array}$ \\
\hline Genio & $\begin{array}{l}\text { Persona que a edad temprana es capaz de realizar un producto } \\
\text { admirable e inusual en un campo específico, comparándolo con } \\
\text { los niveles de rendimiento en el adulto. }\end{array}$ \\
\hline Eminencia & $\begin{array}{l}\text { Persona que, debido a sus excepcionales capacidades de } \\
\text { inteligencia y creatividad, ha producido una obra importante } \\
\text { para la cultura, y la sociedad lo reconoce y exalta. }\end{array}$ \\
\hline $\begin{array}{l}\text { Persona caracterizada por su competencia que, debido a la } \\
\text { perseverancia, oportunidad, azar, etc., ha producido una obra } \\
\text { genial sin que el nivel intelectual sea el factor determinante. }\end{array}$ \\
\hline
\end{tabular}

\subsubsection{Características del alumnado de altas capacidades}

Seguidamente pasaremos a remarcar, en la Tabla 2, las características generales más destacables del alumnado con altas capacidades intelectuales.

Tabla 2. Características generales del alumnado con altas capacidades intelectuales (Albes et al., 2013).

\begin{tabular}{|l|}
\hline \multicolumn{1}{|c|}{ CARACTERÍSTICAS GENERALES } \\
\hline 1. Elevada curiosidad por aprender desde edades tempranas. \\
2. Alto nivel de actividad, energía y concentración. \\
3. Razonamiento complejo. \\
4. Maduración precoz y/o disincronía entre las diferentes áreas del desarrollo. \\
5. Buena memoria a largo plazo. \\
6. Dominio del lenguaje, vocabulario preciso. \\
7. Alta sensibilidad e intensidad emocional. \\
8. Creatividad. \\
9. Intereses y preocupaciones amplias. \\
10. Motivación intrínseca. \\
11. Preocupación temprana por problemas sociales. \\
12. Capacidad crítica con las normas.
\end{tabular}

\subsubsection{Disincronía o asincronía}

Esta característica hace referencia a un desarrollo no homogéneo o desequilibrado de las áreas: social, cognitiva, psicomotora y afectiva. A menudo está presente en el alumnado con altas capacidades. Por ejemplo, se puede observar un desarrollo cognitivo precoz, pero no 
necesariamente acorde con el emocional o el social. Este hecho puede hacerles sentirse diferentes a los demás, generar dificultades en su identificación con los otros y, además, puede generar confusión tanto al profesorado como a los familiares respecto a los roles, establecimiento de límites, trato debido a la coexistencia de preguntas de adulto junto a comportamientos más infantiles. Asimismo, Terrassier (1994) diferencia dos tipos de disincronía, la interna y la social, tal y como se recoge en la Tabla 3.

Tabla 3. Tipos de disincronía: interna y social

\begin{tabular}{|c|l|}
\hline \multicolumn{2}{|c|}{ TIPOS DE DISINCRONÍA } \\
\hline Interna & $\begin{array}{l}\text { Desarrollo no homogéneo entre la capacidad cognitiva y el lenguaje, } \\
\text { la capacidad psicomotora y la emocional. }\end{array}$ \\
\hline Externa & $\begin{array}{l}\text { Discrepancia entre el niño o la niña y la escuela, la familia y las } \\
\text { amistades. }\end{array}$ \\
\hline
\end{tabular}

\subsubsection{Aspectos sociales y emocionales}

Los estudios más recientes han observado que existe unanimidad entre los estudiosos y teóricos de las altas capacidades en considerar el aspecto emocional como parte intrínseca de las altas capacidades (Albes et al., 2013).

En la Tabla 4, presentamos los aspectos sociales y emocionales característicos en el alumnado con AACC.

Tabla 4. Características emocionales y sociales del alumnado con altas capacidades intelectuales (adaptado de Albes et al., 2013).

\begin{tabular}{|c|l|}
\hline $\begin{array}{c}\text { Intensidad } \\
\text { emocional }\end{array}$ & $\begin{array}{l}\text { Empatía, preocupación por los sentimientos de los demás, } \\
\text { por la muerte, sensibilidad y profundidad en las relaciones. } \\
\text { Apego a los animales, miedos, sentimientos de inferioridad o } \\
\text { de inadecuación, profundidad de sentimientos: alegría, } \\
\text { tristeza, ambos a la vez. }\end{array}$ \\
\hline $\begin{array}{c}\text { Intensidad sensorial } \\
\text { overexcitabilities }\end{array}$ & $\begin{array}{l}\text { Alta capacidad sensorial y de placer/displacer elevados ante } \\
\text { los sonidos, el ruido, la música, los olores, los sabores, las } \\
\text { texturas, los colores, la belleza, etc. }\end{array}$ \\
\hline $\begin{array}{c}\text { Desarrollo moral y } \\
\text { del sentido de la } \\
\text { justicia }\end{array}$ & $\begin{array}{l}\text { Cuestionan normas sociales y morales. Además pueden tener } \\
\text { creencias y opiniones independientes de las demás personas } \\
\text { o de la sociedad. }\end{array}$ \\
\hline Perfeccionismo & $\begin{array}{l}\text { Disconformidad ante la mediocridad, la ambigüedad, la } \\
\text { exigencia de calidad. Puede ir acompañado con el miedo al } \\
\text { fracaso y con una baja tolerancia a la frustración. }\end{array}$ \\
\hline Sentido del humor & Elaborado, irónico, inteligente incluso corrosivo. \\
\hline Autorregulación & $\begin{array}{l}\text { Control interno de la conducta de acuerdo a las diferentes } \\
\text { demandas sociales, cognitivas o emocionales que surgen en } \\
\text { situaciones específicas }\end{array}$ \\
\hline
\end{tabular}




\subsection{Trastorno del espectro autista}

\subsubsection{Definición}

El trastorno del espectro autista (TEA) es un trastorno neurológico que manifiesta una serie de síntomas que se pueden identificar en dos grandes bloques: deficiencias en la comunicación social y comportamientos restringidos y repetitivos (según DSM-5).

\subsubsection{Criterios diagnósticos}

Según el nuevo manual del DSM (DSM-5), los criterios diagnósticos del TEA son los siguientes:

1. Déficits persistentes en comunicación social e interacción social a lo largo de múltiples contextos, según se manifiestan en los siguientes síntomas, actuales o pasados:

- Déficits en reciprocidad socioemocional; ejemplos de comportamientos según severidad: acercamientos sociales inusuales, problemas para mantener conversaciones; disposición reducida por compartir intereses, emociones y afecto, o fallo para iniciar la interacción social o responder a ella.

- Déficits en conductas comunicativas no verbales usadas en la interacción social; ejemplos de comportamientos según severidad: anomalías en el contacto visual y el lenguaje corporal, déficits en la comprensión y uso de gestos, falta total de expresividad emocional o de comunicación no verbal.

- Déficits para desarrollar, mantener y comprender relaciones; ejemplos de comportamientos según severidad: dificultades para ajustar el comportamiento para encajar en diferentes contextos sociales, dificultades para compartir juegos de ficción o hacer amigos, ausencia aparente de interés en la gente.

2. Patrones repetitivos y restringidos de conductas, actividades e intereses, que se manifiestan en, al menos, dos de los siguientes síntomas, actuales o pasados:

- Movimientos motores, uso de objetos o habla estereotipada o repetitiva, como por ejemplo: alinear objetos, dar vueltas a objetos, ecolalias...

- Insistencia en la igualdad, adherencia inflexible a rutinas o patrones de comportamiento verbal y no verbal ritualizado, como por ejemplo: malestar extremo ante pequeños cambios, dificultades con las transiciones, patrones de pensamiento rígidos, rituales para saludar, necesidad de seguir siempre el mismo camino o comer siempre lo mismo... 
- Intereses altamente restringidos, obsesivos, que son anormales por su intensidad o su foco, como por ejemplo apego excesivo o preocupación excesiva con objetos inusuales, intereses excesivamente circunscritos o perseverantes...

- Hiperreactividad o hiporreactividad sensorial o interés inusual en aspectos sensoriales del entorno, como por ejemplo indiferencia aparente al dolor o la temperatura, respuesta adversa a sonidos o texturas específicas, oler o tocar objetos en exceso, fascinación por las luces u objetos que giran...

Además, estos síntomas se deben presentar en el período de desarrollo temprano y deben causar alteraciones clínicamente significativas a nivel social, de trabajo u otras áreas. También cabe destacar que estas alteraciones no se explican mejor por la presencia de otro trastorno, aunque frecuentemente se pueda realizar un diagnóstico de comorbilidad de TEA con cualquier otro trastorno, o en este caso, la alta capacidad.

\subsubsection{Diagnóstico para el trastorno del espectro autista nivel 1}

Para un adecuado diagnóstico diferencial, según el nuevo manual DSM-5, se debe especificar la severidad. La severidad de cada caso se basa en la necesidad de apoyos en la alteración social y comunicativa y en la presencia de patrones de comportamientos repetitivos y restringidos.

Centrándonos en los casos que presentamos en este trabajo, encontramos en la Tabla 5 las diferentes características en el nivel 1 de severidad para el TEA.

Tabla 5. Severidad del trastorno del espectro autista nivel 1 según DSM-5.

\begin{tabular}{|c|c|c|}
\hline Nivel 1: requiere apoyo & $\begin{array}{l}\text { Sin apoyos, las dificultades de } \\
\text { comunicación social causan } \\
\text { alteraciones evidentes. } \\
\text { Muestra dificultades iniciando } \\
\text { interacciones sociales y ofrece } \\
\text { ejemplos claros de respuestas } \\
\text { atípicas o fallidas a las aperturas } \\
\text { sociales de otros. Puede parecer } \\
\text { que su interés por interactuar } \\
\text { socialmente está disminuido. Por } \\
\text { ejemplo, una persona que es } \\
\text { capaz de hablar usando frases } \\
\text { completas e implicarse en la } \\
\text { comunicación pero que a veces } \\
\text { falla en el flujo de ida y vuelta de } \\
\text { las conversaciones y cuyos } \\
\text { intentos por hacer amigos son } \\
\text { atípicos y generalmente fracasan. }\end{array}$ & $\begin{array}{l}\text { La inflexibilidad } \\
\text { del } \\
\text { comportamiento } \\
\text { causa una } \\
\text { interferencia } \\
\text { significativa en el } \\
\text { funcionamiento } \\
\text { en uno o más } \\
\text { contextos. Los } \\
\text { problemas de } \\
\text { organización y } \\
\text { planificación } \\
\text { obstaculizan la } \\
\text { independencia. }\end{array}$ \\
\hline
\end{tabular}




\subsubsection{Problemas en el alumnado diagnosticado de TEA nivel 1 en la escuela}

El niño con TEA nivel 1 suele entrar a la educación primaria sin haber sido adecuadamente diagnosticado (aunque actualmente esto está cambiando). En algunos casos, ya desde los años preescolares se han presentado una serie de conductas no habituales para un niño normotípico: una cierta problemática conductual (hiperactividad, falta de atención, agresión, rabietas) o puede haber existido cierta preocupación sobre la "inmadurez» de sus habilidades sociales e interacciones con sus compañeros. Durante los primeros años de la escuela, sus progresos académicos serán relativamente importantes; por ejemplo, en lectura mecánica pueden ser muy buenos, así como en matemáticas. Debido a esto, el docente en ocasiones puede sentirse sorprendido por las áreas de interés obsesivas del niño, por sus logros y por sus limitaciones.

En referencia a sus iguales, la mayor parte de los niños TEA nivel 1 muestran algún interés social hacia los demás niños, aunque sea reducido; no obstante, su capacidad para hacer amigos y mantenerlos es débil y sus interacciones son casi siempre relativamente superficiales (Calderón Astorga, 2005).

A continuación, en la Tabla 6 , se recogen los posibles problemas de un niño o niña con TEA nivel 1 en el contexto escolar y como esto les puede generar problemas a la hora de relacionarse con sus compañeros o profesores (Thomas, Barratt, Clewley y Joy, 2004).

Tabla 6. Problemas en la escuela.

(Adaptado de Thomas et al., 2004).

\begin{tabular}{|c|l|}
\hline \multirow{2}{*}{$\begin{array}{c}\text { Interacción y } \\
\text { relaciones } \\
\text { sociales }\end{array}$} & $\begin{array}{l}\text { Intentan a duras penas ser sociables, pero cuando se acercan a } \\
\text { otros parecen ser socialmente torpes. } \\
\text { Es posible que no miren a la persona a la que se están } \\
\text { aproximando o puede que inadvertidamente den "señales } \\
\text { erróneas». } \\
\text { A veces son excesivamente formales. } \\
\text { Tienen grandes dificultades a la hora de interpretar las claves que } \\
\text { les indican qué se espera de ellos en una determinada situación: } \\
\text { es probable que se porten con un profesor de la misma manera } \\
\text { que lo harían con sus amigos o con sus padres. } \\
\text { También es probable que tengan problemas de enfrentamientos y } \\
\text { que de forma involuntaria muestren comportamientos } \\
\text { antisociales. }\end{array}$ \\
\hline Comunicación & $\begin{array}{l}\text { Es posible que ignoren cómo pedir ayuda o cuándo deben } \\
\text { imponerse. } \\
\text { Es posible que hablen en un tono de voz monótono, con un pobre } \\
\text { control del volumen o la entonación. }\end{array}$ \\
\hline
\end{tabular}




\begin{tabular}{|c|c|}
\hline & $\begin{array}{l}\text { Muchos de ellos centran sus conversaciones en temas preferidos } \\
\text { que repiten una y otra vez con una monotonía excesiva. } \\
\text { Es probable que tengan dificultades para comprender chistes, } \\
\text { dobles sentidos o metáforas. } \\
\text { Su lenguaje puede parecer más bien pedante. } \\
\text { La escasa comprensión de expresiones faciales, de gestos y del } \\
\text { lenguaje corporal de las otras personas, también contribuye a sus } \\
\text { dificultades de comprensión y relación. }\end{array}$ \\
\hline $\begin{array}{l}\text { Imaginación e } \\
\text { inflexibilidad } \\
\text { mental }\end{array}$ & $\begin{array}{l}\text { Prefieren actividades mecánicas tales como coleccionar, reunir o } \\
\text { desmontar. } \\
\text { Es posible que aprendan a hacer juegos de ficción, pero más tarde } \\
\text { que sus iguales. } \\
\text { Poseen bastante resistencia a los cambios, insistencia en la } \\
\text { invariancia del ambiente y el desarrollo de rutinas y rituales. } \\
\text { Es común que desarrollen de manera muy intensa intereses más } \\
\text { bien limitados e inusuales. } \\
\text { Tienen problemas «para ponerse en el lugar de los otros» o ver las } \\
\text { cosas desde diferentes puntos de vista. Se sienten mejor cuando } \\
\text { solo tienen que enfrentarse a lo concreto y predecible. }\end{array}$ \\
\hline $\begin{array}{l}\text { Habilidades } \\
\text { motoras y } \\
\text { alteraciones } \\
\text { sensoriales }\end{array}$ & $\begin{array}{l}\text { Las dificultades en las habilidades motoras pueden contribuir a sus } \\
\text { dificultades en habilidades de estudio o en ciertas asignaturas } \\
\text { como Educación Física. Además, la posible hipo- o } \\
\text { hipersensorialidad puede desencadenar situaciones en clase o el } \\
\text { recreo que afecten a su vulnerabilidad emocional o sus relaciones } \\
\text { sociales entre sus iguales. }\end{array}$ \\
\hline
\end{tabular}

\section{Objetivos}

Este trabajo se enmarca dentro de la metodología cualitativa. Por tanto, no se han establecido hipótesis concretas, debido a que el objetivo principal del estudio es reflexionar en torno a la realidad educativa que viven los alumnos identificados de altas capacidades intelectuales y TEA. Así mismo, pretendemos ofrecer posibles pautas de actuación dirigidas al profesorado y especialistas, que no solo serán beneficiosas para este alumnado sino para todo el grupo clase.

\section{Método}

Para el propósito anteriormente citado, se ha optado por el estudio de caso. Según Simons (2011), la principal finalidad de emprender un estudio de caso es investigar la particularidad, la unicidad, del caso singular. En palabras de Stake (1995: 9), "el estudio de caso es el estudio de la particularidad y la complejidad de un caso, por el que se llega a comprender su actividad en circunstancias que son importantes». Dentro de la clasificación de casos que propone Stake (1998), nos situamos ante 
un estudio instrumental de casos, puesto que el caso particular se analiza para obtener mayor comprensión sobre una temática.

Presentamos seis casos, es decir, seis niños (una niña y cinco niños) cuyas edades están comprendidas entre 7 y 9 años, con un $\mathrm{Cl}$ igual o superior a 120, diagnosticados de altas capacidades y tres de ellos de TEA. Con este estudio no pretendemos hacer generalizaciones a toda la población con dichos dictámenes, sino más bien pretendemos reflexionar y establecer algunas pautas de actuación para materializar en el aula los propósitos de la educación inclusiva.

Una vez centrado nuestro objeto de investigación, pasaremos a determinar cuál fue el procedimiento de actuación en este estudio. Primeramente, se seleccionaron seis casos de niños diagnosticados con AACC, tres de ellos diagnosticados de TEA. Para llevar esto a cabo, previamente se necesitó la conformidad de las autoridades autonómicas. Por una parte, se realizaron varias reuniones con escuelas de la Comunidad Valenciana en las que estaban escolarizados niños o niñas con trastorno del espectro autista. Asimismo, se comunicó a los padres y madres implicados acerca de la investigación y estos firmaron los correspondientes permisos para la valoración de sus hijos o hijas. Por otra parte, la Asociación Castellonense de Apoyo al Superdotado y Talentoso (ACAST) nos proporcionó toda la ayuda necesaria para poder trabajar con los niños identificados de altas capacidades sin diagnóstico de TEA.

Tras la cumplimentación del consentimiento informado de los padres se realizaron unas entrevistas con los niños y se valoró su cociente intelectual mediante la escala de inteligencia de Weschler para niños (WISC-IV).

\section{Descripción de los casos}

En este apartado se presentan los diferentes casos seleccionados. No tan solo en lo descriptivo: habilidades cognitivas, edad o escolaridad, sino que también haciendo partícipe sus cualidades, problemas sociales o relacionales.

Caso 1: niño de 7 años y 4 meses, con un cociente intelectual de 134 (según WISC-IV), identificado de altas capacidades intelectuales. Su escolaridad es en un centro ordinario, él está incluido en el aula y socialmente adaptado, aunque su profesor refiere que molesta mucho en clase y que tiene una actitud «chulesca». Acude a la Asociación Castellonense de Apoyo al Superdotado y Talentoso (ACAST), donde trabaja habilidades sociales y emocionales con un grupo de niños y niñas de su misma edad.

Caso 2: niño de 7 años y 4 meses, con un cociente intelectual de 128 (según WISC-IV), identificado de altas capacidades intelectuales. Acude a un centro ordinario y sale al aula de apoyo donde está atendido por un PT. A pesar de que está socialmente adaptado, tiene problemas de ansiedad que le generan malestar psicológico e interfieren en su vida 
cotidiana. Acude a ACAST, donde ha hecho amigos con los que queda los fines de semana.

Caso 3: niño de 7 años y 6 meses, con un cociente intelectual de 138 (según WISC-IV), identificado de altas capacidades intelectuales. Su escolaridad es en un centro ordinario y él ha sido acelerado un curso, actualmente refiere estar adaptado, aunque sus profesoras dicen que en lo emocional no es igual que sus compañeros un año más mayores. Esto se está trabajando en un grupo en ACAST. Como aficiones le gusta leer y escribir, especialmente.

Caso 4: niño de 8 años y 5 meses, con un cociente intelectual de 120 (según WISC-IV), con diagnóstico TEA nivel 1 y altas capacidades. Su escolaridad es en un centro ordinario con Aula CyL, modalidad B; es decir, asiste al Aula CyL el $40 \%$ del horario lectivo, de manera que así pasa más tiempo en su aula ordinaria. En menos de 2 años cambió dos veces de colegio por problemas de adaptación, tanto por parte de los compañeros como de los profesores. La madre resalta que por fin el niño está saliendo contento de la escuela. El niño comenta que juega con sus compañeros al Minecraft y que comparten libros, debaten estrategias...

Caso 5: niña de 8 años y 8 meses, con un cociente intelectual de 123, con diagnóstico TEA nivel 1 y altas capacidades. Su escolaridad es en un centro ordinario, en un aula ordinaria, aunque tiene 2 horas de refuerzo con la maestra de pedagogía terapéutica y por las tardes asiste a una clínica privada especializada en trastornos del neurodesarrollo. Allí le imparten clases de habilidades sociales y emocionales, ya que la niña presenta dificultades para expresar sus sentimientos y lo ocurrido durante el día y manifiesta malestar por no entender a su grupo de amigas. A la niña le gusta mucho aprender y hacer los deberes, estar en casa y buscar información en su ordenador o tableta; por eso parece que cada vez más se está alejando del prototipo que les gustaría a sus amigas para salir. Además, últimamente suele presentar pequeños episodios de ira por no saber expresar qué le ocurre o no saber comunicar cómo se siente.

Caso 6: niño de 8 años y 10 meses, con un cociente intelectual de 135 (según WISC-IV), con diagnóstico TEA nivel 1 y altas capacidades. Su escolaridad es normalizada en un centro ordinario. Aunque el niño es aceptado por su grupo-clase, la principal preocupación de familiares y maestros radica en el ámbito social, ya que el niño no muestra interés por asistir a cumpleaños, quedar con sus amigos o jugar con sus compañeros en los recreos. El niño prefiere pasar las tardes mejorando en sus partidas de ajedrez. Suele relacionarse mejor con los adultos.

\section{Discusión y conclusiones}

Como hemos visto en los casos expuestos observamos que existen diferentes perfiles de niños y de escolarización. Se detecta que no por estar adelantado un curso o incluido en clase sin ningún tipo de apoyo el 
niño va a estar mejor, más adaptado y no va a tener problemas sociales o emocionales. Tengan uno o ambos diagnósticos, la escuela debe proporcionar la ayuda necesaria en otros ámbitos de la vida escolar del niño. No tan solo en las materias de aprendizaje, sino en temas como la inteligencia emocional, las habilidades sociales o relacionales, la comunicación y el lenguaje o la resolución de conflictos.

La literatura consultada apunta que independientemente del tipo de discapacidad o diagnóstico se recomiendan las mismas estrategias de enseñanza (Davis y Florian, 2004; Lewis y Norwich 2005). Así pues, los investigadores y los docentes se preguntan «¿Cómo puedo trabajar con todo el grupo y al mismo tiempo llegar a todos y cada uno de los alumnos de mi clase?» La respuesta a esta pregunta pasa por "Transformar la cultura y las prácticas de las escuelas de manera que el programa educativo que se ofrezca interpele directamente y personalmente a todos los niños» (Ainscow, 2001:10).

Por tanto, el docente debe utilizar métodos eficaces que permiten una mayor participación del alumnado en el proceso de aprendizaje. Algunos de estos métodos pueden ser: el enfoque propuesto desde las inteligencias múltiples (Gardner, 1983), el aprendizaje cooperativo (Pujolàs, 2001, 2008), los proyectos de trabajo (Lacueva, 1998; Hernández, 2000; López y Lacueva, 2007), grupos interactivos (Elboj y Niemelä, 2010)... Cabe remarcar que no existen propuestas cerradas, sino que debe ser el propio docente, como principal conocedor de los intereses, motivaciones y necesidades de aprendizaje de su alumnado, quien escoja unas prácticas u otras. Señalamos también el aula ordinaria como un contexto rico socialmente para trabajar habilidades sociales (Monjas, 2012) y aspectos intra- e interpersonales. Aspectos, tal y como hemos visto, afectados en algunos alumnos que suelen recibir apoyo en el aula de pedagogía terapéutica o alumnos que han sido acelerados. Seguidamente pasamos a enumerar algunas pautas pedagógicas que pensamos que pueden ser de utilidad para atender la diversidad del aula:

- Explicar al resto de alumnado qué significa tener TEA y AACC. Partir de la idea de que todos somos diferentes y celebrar esas diferencias (Moriña, 2008).

- Incluir al maestro o maestra de pedagogía terapéutica en el aula como un recurso personal más (Traver, 2014), de esta manera, todos los alumnos se podrán beneficiar de su presencia.

- Crear formas de trabajo activas, creativas, participativas y que desarrollen la autonomía.

- Permitir diferentes formas de realización de las tareas.

- No frenar sus inquietudes, sino incentivarlas y potenciarlas.

- Posibilitar aprendizajes más extensos, interdisciplinares, utilizando fuentes diversas.

- Desarrollar la creatividad y aumentar su motivación. 
- Profundizar el autoconcepto positivo. Conocer fortalezas y debilidades de todo el alumnado.

- Realizar trabajos cooperativos con espacios de trabajo autónomo.

- Llevar a cabo actividades con temas novedosos mediante aprendizaje por descubrimiento.

- Etc.

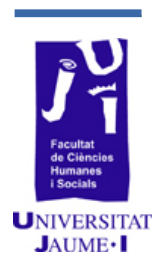

Cabe destacar que algunos docentes utilizan los recursos disponibles con el fin de estimular y apoyar la participación de todo el alumnado, lo que es significativamente común a estos docentes es que entienden que los recursos más importantes para el aprendizaje son ellos mismos y sus alumnos (Ainscow, 2001). Así pues, una de las claves recae en la manera en la que el docente entiende la educación y la diversidad de su aula.

En este estudio se han intentado dar unas pequeñas pinceladas a un tema muy amplio y actualmente conflictivo. Somos conscientes de que la realidad dista de ser la descrita en este estudio. Aunque los casos referidos nos han permitido reflexionar al respecto. Como limitación del estudio, cabe remarcar que se habría podido profundizar más en cada caso. Como futura línea de investigación sería interesante analizar la aplicación de algunas técnicas o estrategias que se han referenciado en este trabajo en cada uno de los casos presentados y de esta manera ver si son beneficiosos tanto para el aprendizaje como para la adaptación social de estos niños y niñas.

A modo de cierre, nos gustaría remarcar que la pedagogía de la inclusión se sustenta en la cooperación y en la consideración del carácter único de cada estudiante, en una pedagogía orientada a la participación y la autonomía y en una pedagogía que favorezca la construcción y la integración de los conocimientos (Vienneau, 2011).

\section{Referencias bibliográficas}

Ainscow, M. (2001): Desarrollo de escuelas inclusivas. Ideas, propuestas y experiencias para mejorar las instituciones escolares, Narcea, Madrid.

Albes, C., L. Aretxaga, I. Etxebarría, I. Galende, A. Santamaría, B. Uriarte, P. VIGO (2013): Orientaciones educativas. Alumnado con altas capacidades intelectuales. Eusko Jaurlaritza.

Alonso, J. A., Renzulul, J. S., y Y. B. Mate (2003): Manual internacional de superdotación, Editorial Eos, Madrid.

American Psychiatric Association (2003): Diagnostic and Statistical Manual of Mental Disorders: DSM-5. ManMag.

ARnalz, P. (2004): "La educación inclusiva: dilemas y desafíos», Educación, Desarrollo y Diversidad, 7 (2), p. 25-40

BISQUERRA, R. (2000): Educación emocional y bienestar, Praxis, Barcelona. 
CAlderón Astorga, N. (2005): El niño Asperger y su interacción escolar, Federación Asperger España. Madrid, España. Recuperado de http://asperger.es/publicaciones.php

DAVIS, P. y L. FLORIAN (2004): Teaching Strategies and Approaches for Children with Special Educational Needs: A Scoping Study. Research Report 516, DfES, Londres.

DeCl, E. L. y R. M. Ryan (2000): "The "What" and "Why" of Goal Pursuits: Human Needs and the Self-Determination of Behavior», Psychological Inquiry. Vol. 11, 4, p. 227-268

ECHEITA, G. (2008): "Inclusión y exclusión educativa. "Voz y quebranto"». REICE: Revista Iberoamericana sobre Calidad, Eficacia y Cambio en Educación, 2, (6), p. 9-18.

ElboJ, C. y R. Niemelä (2010): «Sub-Communities of Mutual Learners in the Classroom: The Case of Interactive Groups», Revista de Psicodidáctica. 15, 2, p. 177-189.

FLORIAN, L. (2013): «La educación especial en la era de la inclusión: ¿El fin de la educación especial o un nuevo comienzo?», Revista Latinoamericana de Inclusión Educativa, 7(2), p. 27-36.

GARDNER, H. (1983): Multiple Intelligences: The Theory and Practice, Basic Books, Nueva York.

Gifford-Smith, M. E. Y C. A. Brownell (2003): «Childhood Peer Relationships: Social Acceptance, Friendships, and Peer Networks», Journal of School Psychology, 41, p. 235-284.

HERNÁNDEZ, F. (2000): «Los proyectos de trabajo: la necesidad de nuevas competencias para nuevas formas de racionalidad», Educar, 26, p. 39-51.

LACUEVA, A. (1998): "La enseñanza por proyectos: ¿mito o reto?», Revista Iberoamericana de Educación, 16, p. 165-190.

LEWIS, A. y B. NORWICH (ed.) (2005): Special Teaching for Special Children? Pedagogies for Inclusion, Open University Press, Maidenhead, UK.

LóPEZ, A. M. y A. LACUEVA (2007): «Proyectos en el aula: cinco categorías en el análisis de un caso", REICE: Revista Electrónica Iberoamericana sobre Calidad, Eficacia y Cambio en Educación, 5, p. 78-120.

LóPEZ, F. (1995): Necesidades de la infancia y protección infantil. Fundamentación teóricas, clasificación y criterios educativos, Ministerio de asuntos sociales, Madrid.

Martínez Medina, F. (2009): «Altas capacidades intelectuales», Innovación y experiencias educativas, 15, p. 1-9.

MasLow, A. (1954): Motivación y personalidad, Ediciones Díaz de Santos, Madrid.

MENÉNDEZ, S., L. JIMÉNEZ y B. LORENCE (2008): «Familia y adaptación escolar durante la infancia», XXI. Revista de educación, 10, p. 97-110. 
Monjas, I. (2012): Programa de enseñanza de habilidades de interacción social, CEPE, Madrid.

MoriñA, A. (2008): La escuela de la diversidad, Síntesis, Madrid.

MurRaY, H. A. (1938): Explorations in Personality, Oxford University Press, Nueva York.

PUjolìs, P. (2001): Atención a la diversidad y aprendizaje cooperativo en la educación obligatoria, Aljibe, Málaga.

- (2008): 9 ideas clave: El aprendizaje cooperativo, Graó, Barcelona.

SIMONS, H. (2011): El estudio de caso: Teoría y práctica, Morata, Madrid.

Stake R. E. (1995): "Case studies». N. K. Denzin y Y. S. Lincoln (ed.), Handbook of Qualitative Research, Sage, Londres, p. 236-247.

- (1998): Investigación con estudio de casos, Morata, Madrid.

SUSINOS, T. y C. RODRÍGUEz (2011): "La educación inclusiva hoy. Reconocer al otro y crear comunidad a través del diálogo y la participación», Revista Interuniversitaria de Formación del Profesorado, 70, (25.1), p. 15-30.

TERRASSIER, J. C. (1994): El síndrome de la disincronía. Investigación psicoeducativa en alumnos superdotados, Amarú, Salamanca.

Thomas, G., Barratt, P., Clewley, H., y Joy, H. (2004): El síndrome de Asperger-estrategias prácticas para el aula: guía para el profesorado. AAPC Publishing.

Traver Albalat, S. (2014): "¿Que el maestro de pedagogía terapéutica atiende al alumnado dentro del aula? y eso... ¿cómo se hace?» XI Congreso Internacional y XXXI Jornadas de Universidades y Educación Inclusiva. Universidad Jaume I. QUADERNS DIGITALS.net

UNESCO (1994): Declaración de salamanca y marco de acción para las necesidades educativas especiales, Ministerio de Educación y Ciencia, España.

- Guidelines for inclusión: Ensuring Access to Education for All, Unesco, París.

VIENNEAU, R. (2011). "Integración escolar, inclusión escolar y pedagogía de la inclusión", Moliner, O. (d.), Prácticas inclusivas: experiencias, proyectos y redes. Publicacions de la Universitat Jaume I, Castelló de la Plana, p. 121-124. 
Ángela Moliner Torres i Aida Sanahuja Ribés. El pas del temps a Betxí: una experiència de treball per projectes en educació primària

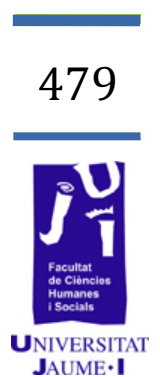

\section{El pas del temps a Betxí: una experiència de treball per projectes en educació primària}

Ángela Moliner Torres al225212@uji.es

Aida Sanahuja Ribés asanahuj@uji.es 
El temps és un concepte complex i difícil de definir. Així ho mostren les diferents aportacions i aproximacions que han realitzat els estudis en vers aquesta noció. Per tant, tampoc no resulta fàcil l'aprenentatge d'aquest concepte a l'alumnat dels primers cursos d'educació primària.

Aquest estudi mostra una experiència de treball per projectes portada a terme en l'aula de $2 \mathrm{n} B$ d'educació primària del CEIP Cervantes J. Dualde de Betxí. Ha sigut realitzada durant el tercer trimestre del curs acadèmic 2014-2015. Concretament el projecte que es desenvolupa s'anomena Com passa el temps? Betxí, el nostre poble. El punt central del projecte és el rol d'investigadors i d'historiadors que adquireix l'alumnat, amb el propòsit de contextualitzar i donar-li sentit a allò que aprenen. Descobreixen detalladament allò que conforma el pas del temps, coneixen l'abans del seu poble en referència amb el que ara saben per a construir un coneixement global de la temporalitat. Aquest permet una presa de contacte de l'alumnat amb la història familiar i amb la local.

En els resultats es comparen les qualificacions obtingudes per l'alumnat en una prova d'avaluació de coneixements realitzada a l'inici del projecte respecte de la mateixa prova d'avaluació realitzada al finalitzar-lo. La comparació mostra millores considerables entre les qualificacions obtingudes en l'avaluació inicial i l'avaluació final. A més, s'aporten les valoracions dels implicats, les quals s'han recollit mitjançant entrevistes.

Amb aquest estudi es pot concloure que és possible un procés d'ensenyament-aprenentatge efectiu del pas del temps, utilitzant una metodologia activa i participativa com són els projectes de treball. A més, aquesta metodologia ens ofereix a l'aula diferents camins d'adquisició, la qual cosa permet al docent respondre als diferents interessos, necessitats i estils d'aprenentatge de tot l'alumnat.

Paraules clau: educació primària, projectes de treball, aprenentatge significatiu, temporalitat, història local.

\section{Introducció}

Al llarg de la història, molts filòsofs, pensadors, científics, etc. com Aristòtil, Plató, sant Agustí, Newton, etc. han aportat els seus coneixements per tal d'elaborar diferents definicions, explicacions i aproximacions a la noció de temps. Però no es tracta d'una tasca fàcil, tots els pensadors no coincideixen en les seues definicions. Així doncs, tampoc no resulta fàcil l'aprenentatge d'aquest concepte a l'alumnat dels primers cursos d'educació primària.

Els xiquets $\mathrm{i}$ les xiquetes solen tenir en la consciència temporal nocions i elements que han observat, o se'ls han informat, guardats de 
manera dispar. Aquests escassegen de relació i organització temporal i I'únic significat que tenen és el que el mateix xiquet o xiqueta li atribueix, $d^{\prime}$ acord amb les seues experiències $i$ al que considera rellevant. Perquè adquirisquen el pensament temporal, és necessari establir nexes entre els fets formant una xarxa de relacions (Mattozzi, 2002). La relació que s'ha de compondre entre passat, present i futur des d'una visió personal i social és el fonament bàsic per a la formació de la temporalitat i una finalitat essencial de l'ensenyament de la història. Tanmateix, és important que els xiquets i les xiquetes obtinguen el concepte de temps quan estan adquirint consciència del món que els envolta. L'ensenyament de la història i, més concretament, de la temporalitat està vinculada a la creació d'identitats, establint el coneixement de la pròpia persona per situar-se en una societat. La didàctica del temps procura que l'alumnat adquirisca una concepció concreta de la seua representació del món en què viu i de la repercussió temporal que té (Pagès, 2009). A més a més, partir de la història personal de l'alumnat és adequat i té molts avantatges, ja que és la seua realitat més assolible. D'aquesta manera, tractant les seues pròpies experiències, es poden afrontar temes relatius del coneixement del seu propi temps, els períodes de vida, els canvis significatius que experimenten, etc. S'ha de procurar que s'impliquen ells i elles mateixos en el temps, que se senten protagonistes de la història $i$ s'hi endinsen en aquesta, considerant-se éssers històrics (Tutiaux-Guillón, 2003). Fer-los visibles en la història permetrà desenvolupar la consciència històrica i la seua temporalitat. Altrament, el temps històric ha d'estar present en totes les temàtiques i les àrees, ja que es tracta d'un element transversal. Es troba endinsat en molts problemes i situacions d'aprenentatge, tant d'una manera implícita com explícita. Té la peculiaritat d'establir relacions amb altres conceptes, referents a aspectes essencials per a la comprensió general d'un xiquet o una xiqueta (Stow i Haydn, 2000).

Hi ha diverses investigacions que afirmen que l'alumnat és capaç d'identificar o explicar canvis mitjançant l'aprenentatge de la cronologia. Per tant, el pas previ s'atribueix al temps cronològic, suport necessari per a una construcció temporal posterior. Si no es tenen en compte les perioditzacions $\mathrm{i}$ els estrats temporals en què es localitzen els esdeveniments, s'assegura un desordre mental de la temporalitat (Lautier, 1997; Trepat, 2002). Els períodes històrics es comprenen dins d'una dimensió temporal i és necessari contextualitzar-los en uns fenòmens humans, socials, polítics o econòmics $i$ en un temps $i$ espai determinats, establint-hi relacions, la qual cosa determina que el temps històric no és unidireccional. D'aquesta manera, és possible confeccionar una estructura mental per tal de donar significat a la historia i a la realitat (Díaz-Barriga, 1998). Així mateix, aquest ensenyament ha de realitzar-se Iligat a unes nocions temporals bàsiques relacionades, que han de ser interioritzades per a estructurar l'esquema mental, tant des d'una perspectiva històrica objectiva com personal. La duració, el canvi, les unitats de mesura, la triple dimensió passat-present-futur, l'ordre, els 
eixos cronològics, la relació, la successió, les qualitats del temps històric i els ritmes temporals s'han de comprendre per a elaborar estudis històrics posteriors més complexos.

A més, la comprensió del temps històric és més efectiva si s'utilitzen diversos materials i, també, fonts històriques. Aquestes són uns dels principals recursos per a l'ensenyament de continguts temporals i històrics (Feliu i Hernández, 2011). Permeten efectuar un treball d'investigació actiu i participatiu en què l'alumnat és el protagonista investigador. S'estableixen relacions entre el passat i el present i en altres realitats. D'aquesta manera, s'ix d'un mecanisme rígid i organitzatiu de l'ensenyament de la història (Tribó, 2005). Les fonts visuals tenen un gran valor: il·lustrar els canvis. Resulta bàsica la utilització, possibilitant una apreciació directa de la vida temps enrere fins avui, que fa possible una comprensió efectiva del pas del temps (Stow i Haydn, 2000). Les fonts orals també són molt importants i valuoses. Es crea una història oral des de la pròpia veu de l'experiència, de manera que s'aporten aspectes de la realitat estretament vinculats a la memòria dels subjectes.

Una metodologia útil per a introduir el temps en l'aula són els projectes de treball. Es tracta d'un mètode principalment actiu, dinàmic, participatiu i significatiu. Aquesta metodologia té com a finalitat principal desenvolupar un aprenentatge significatiu basat en el constructivisme. Ausubel (1963) fou qui implantà aquesta teoria de l'aprenentatge, afirmant que l'aprenent ha de ser capaç de relacionar d'una manera essencial i justa els coneixements nous amb la seua estructura cognoscitiva. Tal com defensa Díaz Navarro (1998), els projectes donen forma natural al desig d'aprendre, partint d'un enfocament globalitzador obert que parteix dels interessos, les necessitats, les experiències $i$ els coneixements previs de l'aprenent. Per això propicia una investigació per part de l'alumnat, a partir d'interrogants que considera valuosos. Per tant, el vertader protagonisme radica en el discent, amb la implicació del docent com a facilitador que posa problemes als estudiants amb el coneixement i que amplia els seus interessos (López i Lacueva, 2007; Hernández, 2000).

Després d'aquesta breu conceptualització teòrica, passarem a presentar de manera detallada com s'ha anat desenvolupant el projecte de treball. Seguidament, comentarem els resultats obtinguts a partir d'una prova realitzada abans i després del projecte (pre i post) i també presentarem les principals valoracions dels implicats, les quals s'han recollit mitjançant entrevistes. Acabarem amb les conclusions i discussions de l'estudi.

\section{Desenvolupament del projecte}

El projecte de treball que presentem s'anomena Com passa el temps? Betxí, el nostre poble. S'ha realitzat amb xiquets i xiquetes de 7 i 8 anys, pertanyents a la classe de $2 \mathrm{n} B$ d'educació primària del CEIP Cervantes J. 
Dualde de Betxí durant el tercer trimestre del curs acadèmic 2014-2015. L'aplicació del projecte es realitza al llarg de 6 setmanes, en 37 sessions de 45 minuts aproximadament. Tot seguit, passarem a desenvolupar de manera detallada els passos i les activitats principals que caracteritzen el projecte que presentem.

\section{Assemblea i acta: nou projecte de treball}

Per posar inici al projecte, en assemblea, es proposa a l'alumnat estudiar el pas del temps a Betxí. Es reflexiona entorn de quin tipus d'informació necessitaran per a poder veure com ha canviat el poble. Pensen qui els pot ajudar i qui deu saber coses de fa molt de temps. Conclouen que els iaios, iaies, oncles, ties, etc. podran contar-los coses molt interessants. L'alumnat es mostra motivat i se'ls desperta la curiositat per saber més del seu poble. A més, el fet de poder comptar amb la participació dels familiars els engresca molt. Després, entre tots $\mathrm{i}$ totes, aporten idees sobre com elaborar l'acta. Per torns diuen què s'ha d'escriure mentre es redacta a la pissarra i ho copien al dictat, cada xiquet i xiqueta en la seua llibreta. La copia al dictat facilita revisar i corregir les faltes abans d'escriure-les. Tot seguit es presenta l'acta de l'assemblea (vegeu Figura 1).

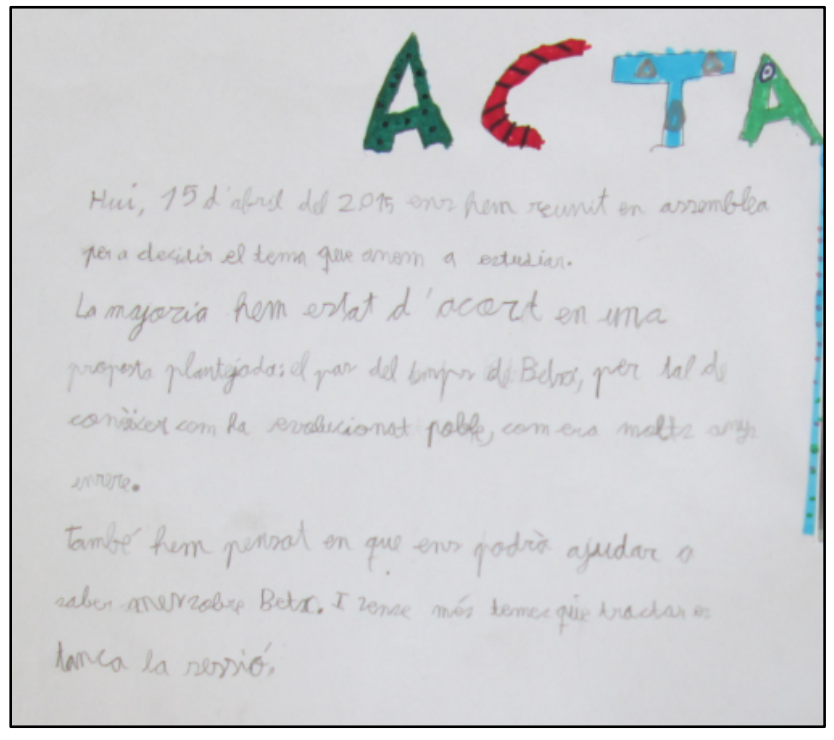

Figura 1. Acta de l'assemblea

\section{Avaluació inicial: Què en sabem?}

Per comprovar què coneixen sobre el tema, les seues capacitats i poder iniciar el projecte, es realitza una avaluació inicial; extraure el Què en sabem? Cada alumne individualment elabora la seua fitxa (vegeu Figura 2). S'avalua la percepció del poble, quant a la quantitat de població i l'extensió. També han de fer memòria dels llocs de Betxí i d'altres aspectes més generals que veuen diàriament, sabent quins s'han quedat darrere en el temps, quins hi han perdurat fins ara i quins han aparegut 
recentment. Així, s'observa si són conscients que el pas del temps ha sigut el responsable d'aquests canvis. Tanmateix, hi ha una part amb imatges, on han de saber què és d'ara i què era d'abans.
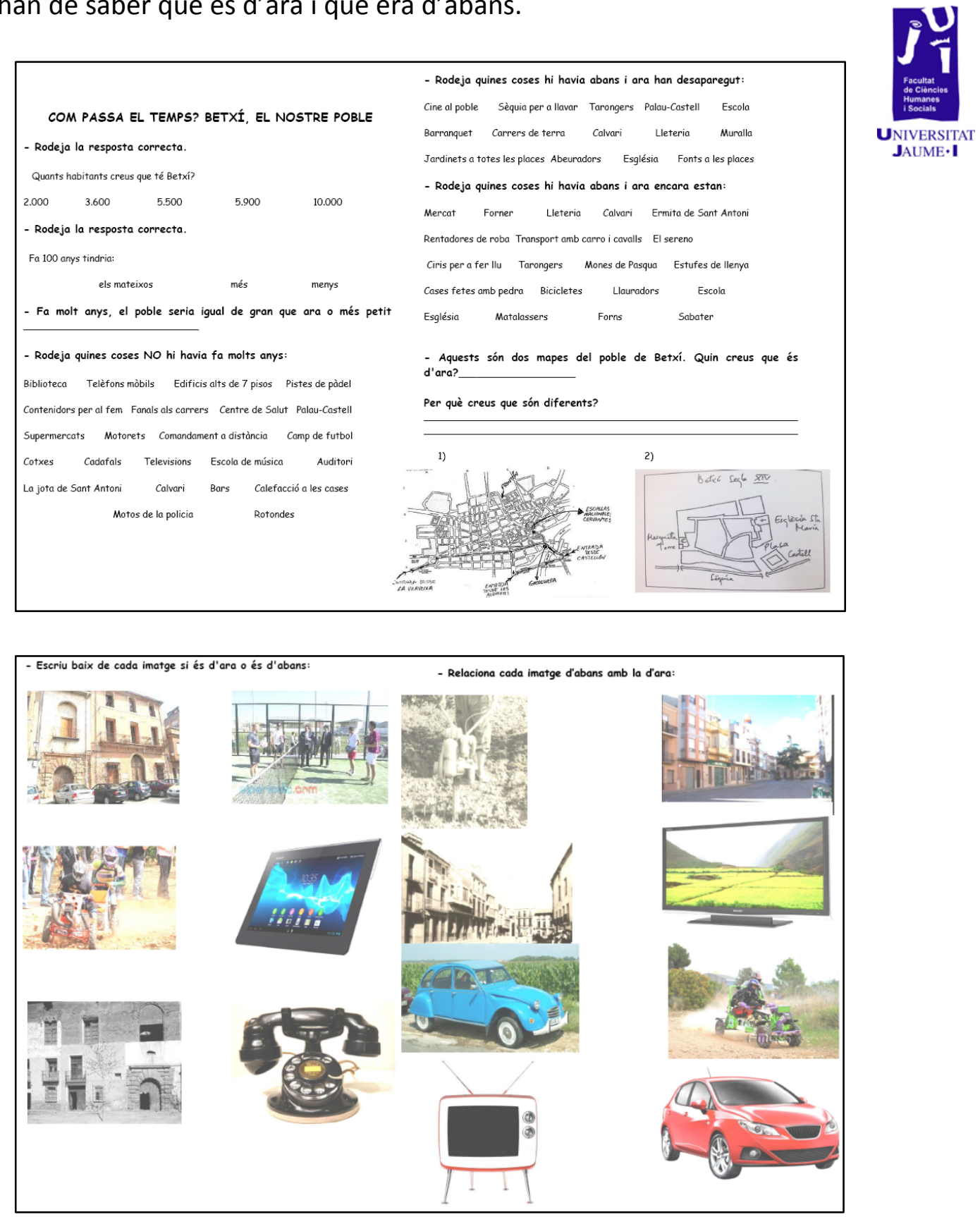

Figura 2. Prova d'avaluació

\section{Què en volem saber?}

A continuació, s'extrau allò que volen saber sobre la temàtica mitjançant l'activitat Què en volem saber? Per torns, aporten els seus interessos i allò que els agradaria aprendre, s'apunta en la pissarra i ho copien en el quadern. 
Veiem com la figura de l'alumnat, dinàmic i actiu, és la protagonista de l'aprenentatge. És realitza un ensenyament Bassat en el constructivisme, on l'alumnat confecciona el seu propi coneixement mitjançant la zona de desenvolupament pròxim (Vigotsky, 1979), apreciant fins on és capaç d'arribar amb l'ajuda d'iguals i d'adults, sense que tinga tanta importància el paper del docent. Des del primer moment, són ells i elles qui agafen el comandament de la situació. El projecte té un condicionament entorn d'un contingut de gran rellevància que han d'adquirir: el rol d'investigadors. Tot seguit, en la Figura 3 es mostra el que els alumnes volen saber.

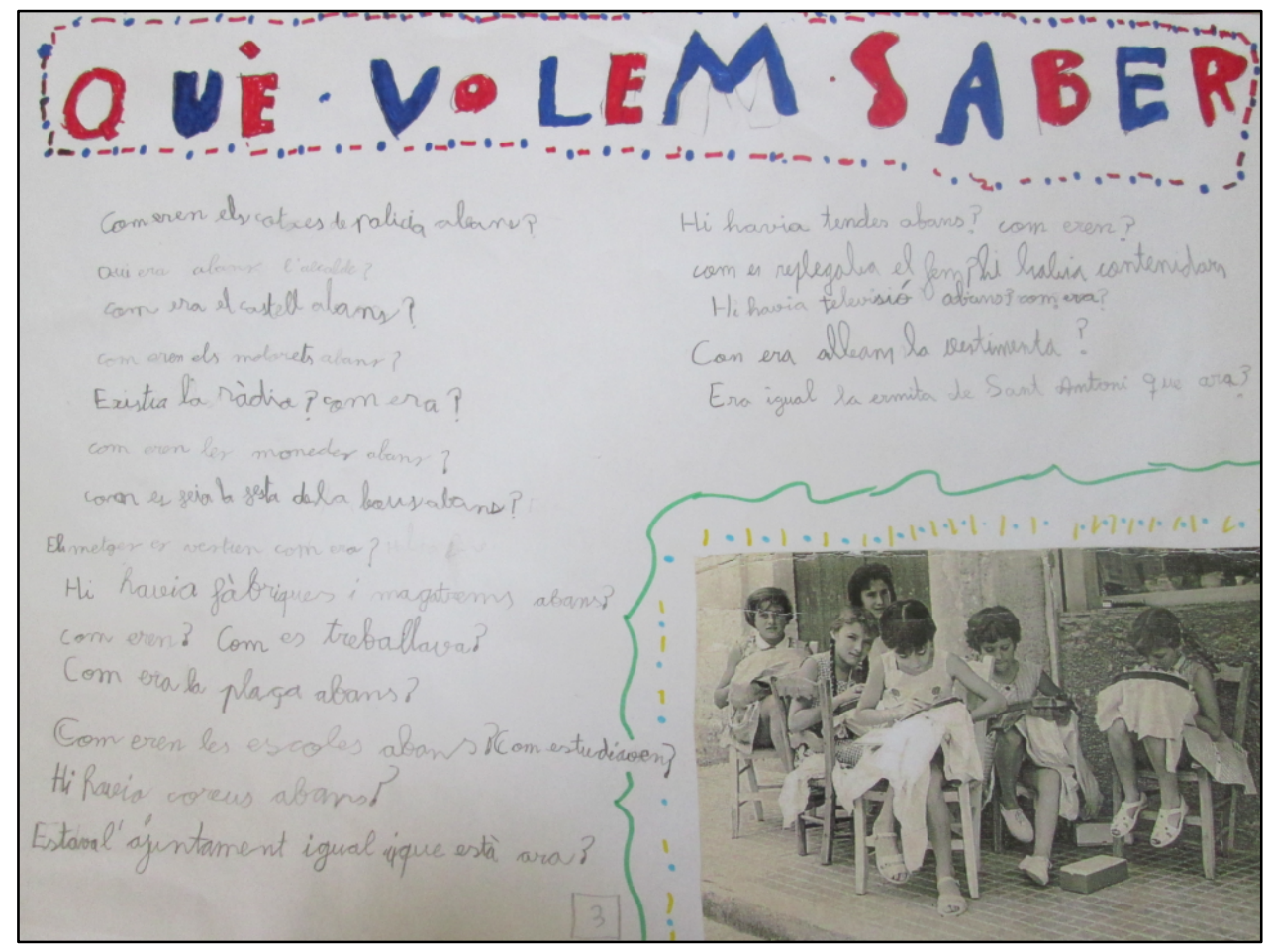

Figura 3. Què en volem saber?

\section{Procés d'investigació i organització de la informació}

El projecte depén en gran part d'aquest pas, és a dir, de la capacitat d'investigació que adquireix l'alumnat, ja que condiciona la realització de les activitats següents. L'alumnat investiga amb les famílies buscant informació de Betxí i es concreta que hi han d'aportar fotografies antigues. En poden buscar de tradicions, espais, oficis, instal-lacions, llocs, objectes, monuments, alguna persona coneguda del poble, etc. Posteriorment, es dedica alguna sessió per tractar la informació, en què la mostren i l'expliquen als companys. Perquè les fotografies no es facen malbé, la mestra les fotocopia o les escaneja, les imprimeix i les plastifica perquè les puguen manipular i, si cal, n'introdueix més. La col-laboració de les famílies juga un paper destacat, formen un vincle molt especial, ja que amb ells i elles realitzen la investigació de manera compartida. A més 
a més, una etapa important és el procés investigador a través de la història oral.

\section{Carta i preguntes per als iaios i les iaies}

Entre tots i totes escriuen una carta en què s'adrecen als majors. Els conviden i preparen unes preguntes per fer-los una xicoteta entrevista, considerant els interessos de l'alumnat. Tot seguit en la Figura 4 es mostra un exemple de carta als iaios.

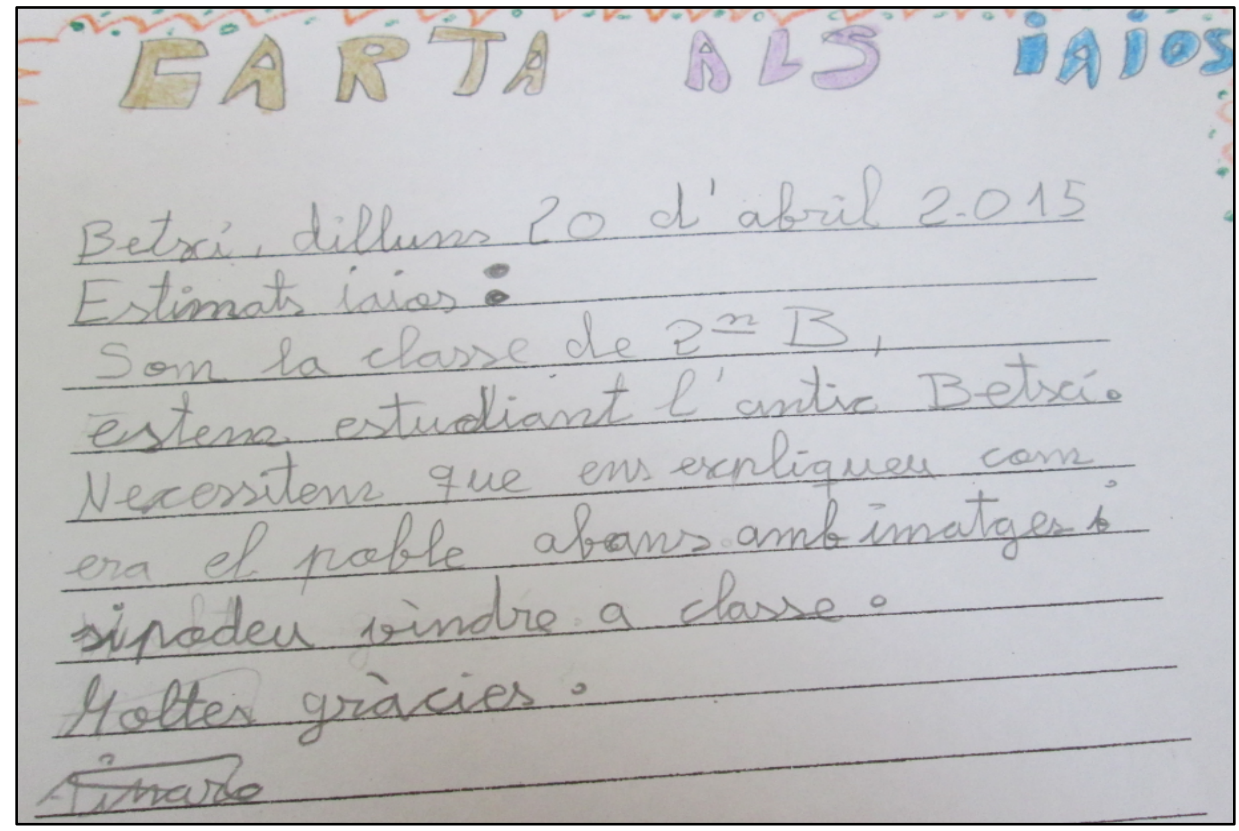

Figura 4. Exemple carta als iaios i iaies

\section{Els iaios i les iaies ens visiten}

Concretament es dediquen tres sessions on diferents iaios i iaies els conten i comenten diferents aspectes relacionats en el transcurs del temps al seu municipi. La dinàmica de les tres sessions és similar: es projecten les fotografies antigues escanejades i es dóna curs a la veu dels grans. S'insisteix que aquests desxifren un any aproximat per a cada fotografia.

En la primera sessió, hi ha la presència de dos iaios i quatre iaies. La gent gran s'asseu entre l'alumnat per crear un col-loqui entre tots i totes. Es dóna el torn de paraula a l'alumnat perquè faça les preguntes que havia preparat. S'han anat posant algunes imatges al projector, llançant preguntes com "Què és açò?», "Algú coneix aquest lloc?», "On està?», etc. D'aquesta manera s'inicia una conversa entre l'alumnat i la gent gran. S'aprofita qualsevol element per a comentar-lo, com ara cotxes, fonts, cases, carrers, etc. Es projecta també la imatge actual del lloc, de manera que els queda clar com era abans i com és ara. Els grans també diuen l'any aproximat de cadascuna i l'alumnat les col-loca a la galeria. 
La segona sessió segueix la mateixa dinàmica. Hi assisteixen tres iaies i tres iaios. També expliquen antics oficis que han desaparegut, com la Ileteria o vaqueria, l'agutzil i el sereno. Han dit a què i com jugaven quan eren menuts i què feien en el seu temps Iliure. Una dona canta algunes cançons i les balla amb els xiquets i les xiquetes. S'intenta conscienciar l'alumnat de la gran oportunitat de poder rebre la visita d'uns grans experts del poble, ja que no hi ha ningú que els ho puga explicar tan bé com la gent que ho ha viscut.

En la tercera sessió, hi assisteixen dotze iaios i iaies de l'Escola de Persones Adultes (EPA) de Betxí. Es comença amb una presentació entre menuts i grans i se segueix el mateix procediment amb les fotografies i la galeria. Les explicacions del camp de futbol, un tema que els ha cridat molt l'atenció, són molt interessants. Observen com era abans en referència al que coneixen i es parla del camp, els equipaments, la pilota, etc. També s'hi expliquen més oficis antics i es compara com es realitzen aquests treballs actualment. Es comenta un que encara hi perdura: el sabater. Els resulta interessant i curiós conèixer a què es dedicava la gent abans. A més, sorgeix la possibilitat de calcular anys els xiquets i les xiquetes han comptat cap enrere per saber-ho.

Al llarg d'aquestes sessions s'ha anat confeccionant La galeria de Betxí, ja que al mateix temps que es parla de cada fotografia, es va sabent què hi ha i l'any. Cada alumne n'agafa una, l'apega en el mural i escriu dalt el nom i davall l'any corresponent. Així s'aconsegueix un producte final molt atractiu i motivant: una gran galeria d'imatges antigues de Betxí. També es fa alguna recapitulació oral del que es va tractant, per veure què han aprés i si resulta eficaç aquest procés d'investigació. En la Figura 5 mostrem la galeria de Betxí.

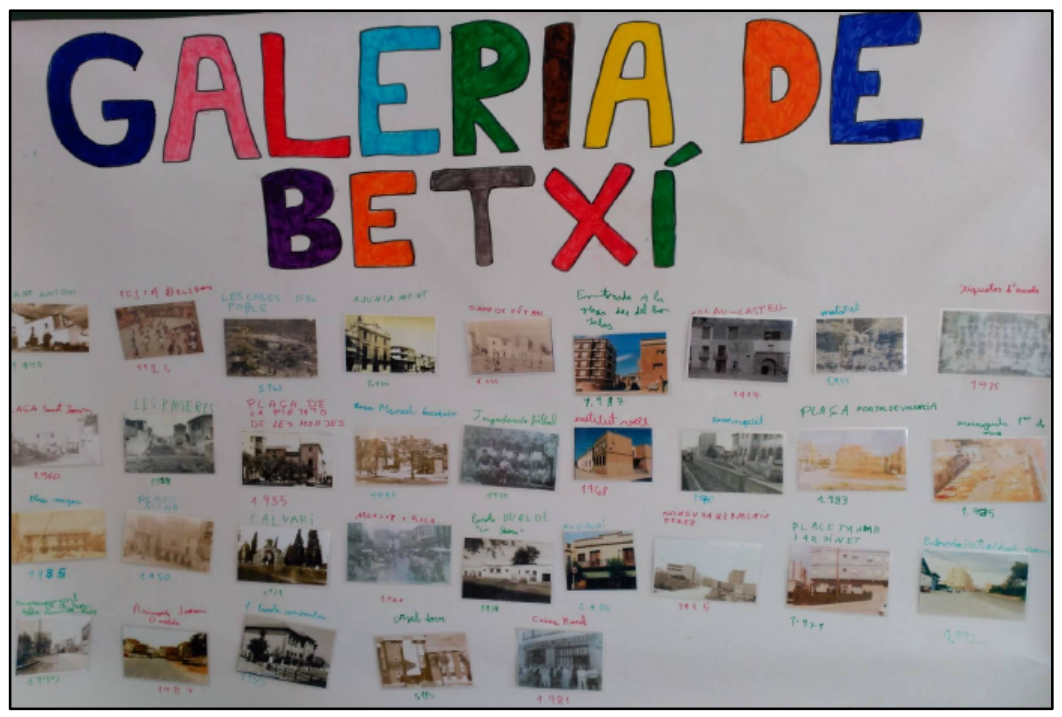

Figura 5. Galeria de Betxí. 
Carta i visita de l'historiador

Es comenta la idea als xiquets i les xiquetes de telefonar a un historiador. Per això, se'ls llancen preguntes: «Com podríem saber coses del nostre poble de molts anys abans que els iaios nasqueren?» o "Qui ens podria contar coses que els iaios no coneixen?». Es forma una discussió i de seguida s'arriba a la conclusió que un expert els hi podria ajudar. Aleshores, tracten de saber quin tipus d'expert i finalment conclouen que caldria avisar un historiador. Després, escriuen una carta per a convidar-lo (vegeu Figura 6).

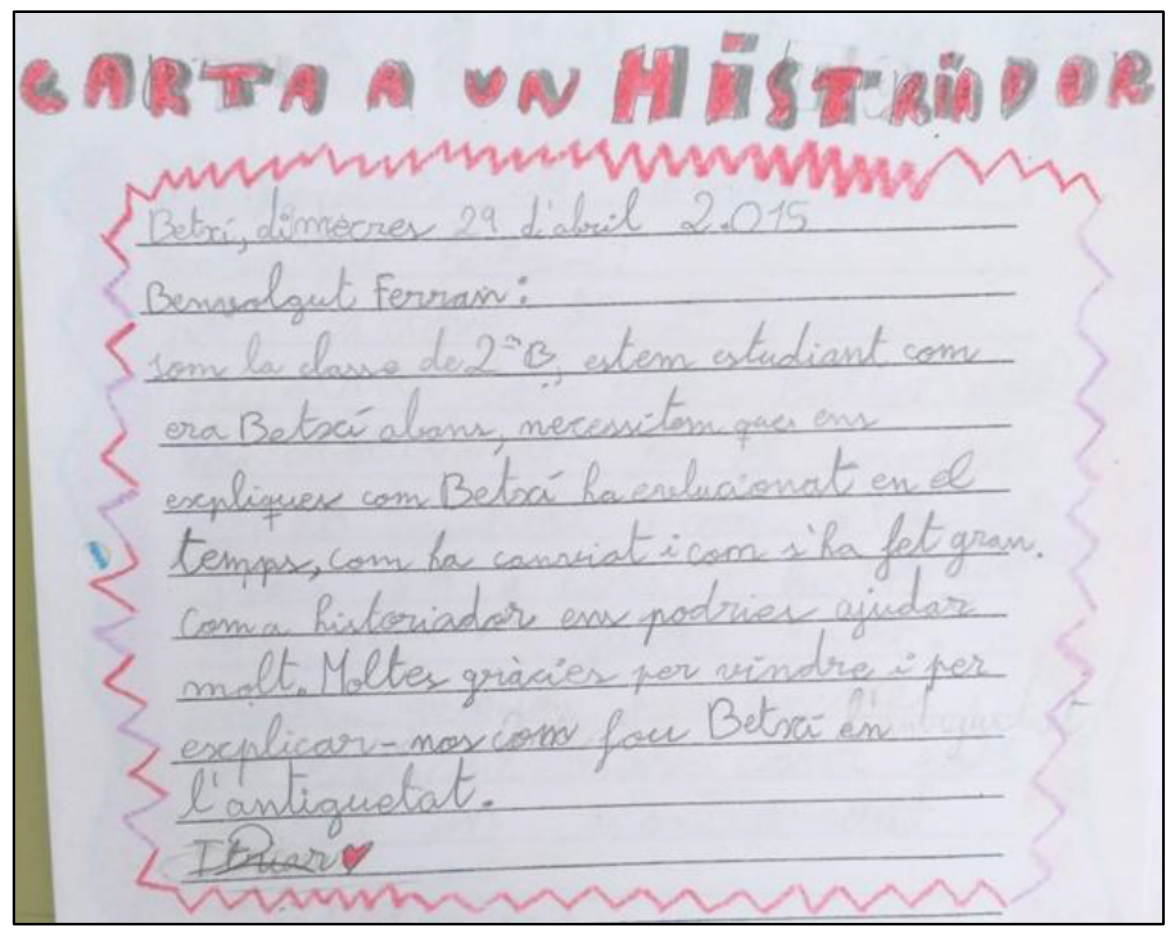

Figura 6. Exemple carta a l'historiador

Pel que fa a la visita, I'historiador mostra un mapa del poble en el projector on s'observava com s'ha ampliat el municipi des del segle XIV fins al segle XXI. L'historiador, conta com era el poble en aquells anys, què hi havia, què el formava i quins n'eren els límits. D’aquesta manera, l'alumnat ha pogut ser conscient de com de petit era abans i com de gran és actualment. Després, explica com ha crescut any rere any. Seguidament, pregunta en quina època creien que hi hauria menys habitants, referint-se a les zones del mapa. També els conta per què ara s'amplia més ràpidament. Els ha dit que abans es tardava més perquè hi havia molt poca gent i no tenien maquinària ni materials especials, però, amb el pas del temps, amb més població i amb els aparells que han sorgit, tot va més ràpid. Tot seguit, es realitza el mateix procediment amb les fotografies que s'ha fet amb els iaios i les iaies. L'historiador les ha explicades. Altrament, ha ensenyat unes tècniques per a desxifrar l'any aproximat de les fotografies, en què s'observa la qualitat de la fotografia, si hi ha cotxes i els models, els tipus de cases, edificis, carrers, etc. A 
l'alumnat ha quedat molt captivat per saber que podien desxifrar una data aproximada.

\section{Visitem el Barranquet i el barri antic de Betxí}

Una activitat important i significativa és la realització de xicotetes excursions per a visitar el poble. Com que el dia anterior ja s'havia comentat aquesta idea, els xiquets i les xiquetes estaven ansiosos per visitar el començament del Barranquet. Una vegada allà, l'alumnat s'ha apropat per veure el barranc des d'una barana. S'ha explicat el lloc, per on va l'aigua quan plou. Han fet preguntes com "Què passaria si I'hagueren cobert tot?», "I si no s'haguera cobert?», "On va l'aigua?», etc. Els ha agradat i captiva molt poder veure una mica el que queda del Barranquet descobert.

Quant a la segona visita, s'ha anat al camí que limitava el poble antigament. Des d'allà se'ls ha explicat que aquell era l'últim carrer i on estava situada una de les parets de la muralla. Després, s'ha avançat dins del nucli antic, a una placeta. Tots i totes sols I'han reconeguda, els han recordat que fou el primer lloc del poble i ho han comparat amb com és actualment. Després han anat per alguns carrers del voltant, veient que són estrets, fan corbes i que alguns no tenen eixida. Així, s'han adonat que són molt diferents als altres. Hi han vist una placa on posa «segle XVI», la qual cosa els ha resultat interessant. També s'han observat detingudament les cases antigues que encara es conserven, les característiques que tenen i les han comparades amb les actuals. Per últim, s'ha visitat la plaça Major i el palau-castell. Se'ls ha explicat la façana, han vist restes de les antigues columnes i del fossat. Dins, s'ha vist el pati i s'ha comentat un poc el que es veia. A més, hi ha un plànol antic on es pot veure el nucli antic, rodejat per la muralla, el qual ha paregut molt interessant. Amb aquestes activitats han pogut veure cada lloc tal com és avui, l'han comparat amb el que han vist en les fotografies antigues i els ha resultat molt captivador conèixer els llocs antics que s'hi conserven i els alumnes han mantingut l'interés tota l'estona. Han fet moltes preguntes i s'han resolt alguns dubtes. En tornar a l'aula, s'ha fet una recopilació per veure qui havia estat atent. $S^{\prime}$ ha preguntat algun nom dels carrers i algun any que s'havia estat repetint i la majoria ha sabut contestar correctament.

\section{Recorrem el Barranquet amb Google Maps i treballem amb mapes}

S'ha repartit un mapa a cada alumne i s'ha seguit el recorregut del Barranquet. Després s'ha projectat el mapa de la localitat amb Google Maps. En veure el poble a la pantalla, els carrers i les cases d'una manera tan real, s'han quedat molt sorpresos. Aleshores, s'han dirigit cap al principi del Barranquet i des d'allà han anat fent el trajecte fins arribar al lloc de la desembocadura. Mentre es feia el recorregut, s'han anat fent pauses en alguns llocs interessants per comentar-los, s'ha explicat com era abans i algunes coses que ja no estan. Hi apareixien destacats els llocs 
més importants i significatius del poble, la qual cosa ha sigut molt útil com a referència per situar-se. També s'han buscat les cases dels diferents xiquets i xiquetes per veure-les-hi projectades.

\section{Recapitulació per escrit: el dossier}

Es plasma per escrit allò que han aprés del procés d'investigació. En l'assemblea, es pretén que vaja eixint d'ells i elles tot el que han interioritzat i es vaja escrivint en la pissarra cada tema que hi sorgeix. L'alumnat va aportant idees i comentaris i, finalment, es recullen un total de vint-i-sis temes. També s'han explicat alguns detalls que no es van contar o que no van entendre bé. Finalment, s'ha realitzat un comentari sobre com de valuosa és la memòria dels iaios i les iaies, que ningú com qui ho viu pot explicar-los-ho millor, que per això els han aportat tant i han d'estar molt agraïts per la seua ajuda. Tot seguit, en la Figura 7, es presenten els temes que han sorgit en l'assemblea.

$r$ 1. Barranquet (Les passeres)

2. El mercat a la plaça

3. El sereno

4. La vaqueria

5.La sèquia (Com es llavava la roba?)

6. L'afilador

7. Sant Antoni

8. El pou i les fonts

9. El matalasser

10. Els cadafals i les barreres

11. El bar Salas

12. L'ajuntament i l'agutzil

13. El sabater

\author{
14. El treball al camp \\ 15. Abeuradors \\ 16. La panderola i els carros de cavall \\ 17. L'escola Dualde i la de monges \\ 18. Els corrals \\ 19. El camp de futbol \\ 20. L'institut \\ 21. El cotxero i el carter \\ 22. El taxista \\ 23. Els jocs \\ 24. El llanterner \\ 25. El drapaire \\ 26. El ferrer
}

Figura 7. Llista de subtemes.

En un altra assemblea es reparteixen els temes que conformen el projecte de Betxí per parelles. Una vegada ja s'han distribuït es dediquen unes sessions a la redacció i descripció de cada un. En un full en posen el títol $i$ tots $i$ totes sols escriuen explicacions breus del que saben sobre els assumptes en qüestió. Posteriorment, ho corregeixen ells i elles mateixos. Després, la mestra passa els escrits a ordinador i els imprimeix sense cap correcció, tal com ho havien redactat. Seguidament, se subratllen les paraules a corregir $\mathrm{i}$ entre cometes alguna cosa que potser no té sentit, $\mathrm{i}$ l'alumnat reescriu el text ja corregit. D'aquesta manera ells i elles tenen la possibilitat de detectar els seus propis errors i aprendre a corregir-los, controlar-los i escriure'ls bé.

Tota aquesta tasca té l'objectiu de confeccionar un dossier del projecte on es recull tot allò que s'ha treballat. Per aquest motiu, la mestra en realitza una segona correcció $\mathrm{i}$ es procedeix a la confecció del dossier. Cada parella passa a net els seus escrits a fulls DIN A3. Després, hi ha un munt de fotografies $i$ han d'elegir les corresponents als seus temes $i$ apegar-les en els fulls. Quan l'acaben, poden decorar-lo i, posteriorment, fan conjuntament la portada i alguns fulls introductoris. Cal destacar que 
durant aquest procés una alumna ha portat a classe una poesia (vegeu Figura 8).

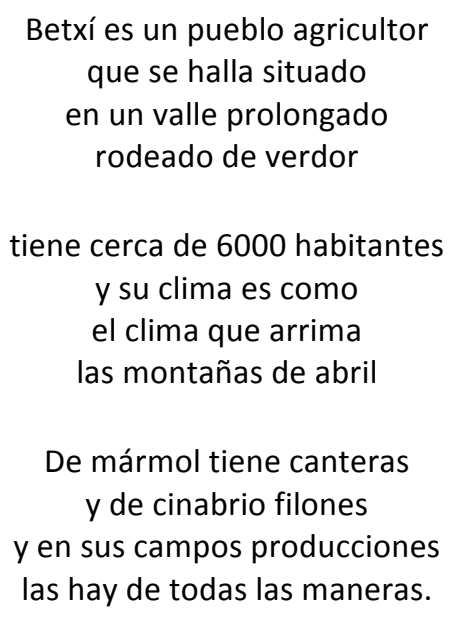

Figura 8. Poema del poble de Betxí

Després de llegir-la es posa èmfasi en l'estrofa «tiene cerca de 6000 habitantes». Aleshores, se'ls ha preguntat què vol dir. Després, entre tots i totes elaboren una llista de nombres que estan a prop de 6000. Amb això, han pogut comprendre què vol dir que una xifra és aproximada a una altra, han posat en pràctica el càlcul mental $i$, per descomptat, han conegut el nombre d'habitants de Betxí. Els nombres grans els solen captivar i s'han sorprès en relacionar una xifra tan alta amb la quantitat d'habitants.

A més, han rebut la visita d'una classe de $3 r$ amb una necessitat: que uns experts en el pas del temps, com és la classe de $2 n B$, els expliquen com ha evolucionat Betxí. L'alumnat s'ha sentit molt important i motivat en veure que algú necessitava de la seua experiència. Així doncs, han explicat com han evolucionat els llocs més puntuals del poble, amb imatges al projector. Amb ajuda, han contat el que sabien. La classe de $3 r$ hi estava molt atenta i s'ha quedat sorpresa amb moltes coses que no coneixia. L'alumnat s'ha sentit protagonista d'un procés molt beneficiós per a tots i totes.

\section{El joc del pas del temps a Betxí i la confecció de l'eix cronològic}

Es fa un joc en què es posa en pràctica tot el que han aprés d'una manera lúdica. Els materials que s'utilitzen són les fotografies col·locades en la galeria i les actuals corresponents, que ha proporcionat la docent, totes amb l'any corresponent escrit al revers, així com targetes amb els noms i els anys. El joc té tres activitats diferents, però estan encaminades cap a uns objectius comuns. La mestra organitza les fotografies per parelles, és a dir, l'antiga amb l'actual, i es reparteixen equitativament en tres grups referents a cada activitat. Cada alumne es reparteix en una activitat $i$, al senyal de la docent, canvien d'activitat. Així, tots els alumnes 
les fan totes i manipulen totes les fotografies. Les activitats són les següents:

1) Troba la parella: troben les fotografies barrejades cap avall, de manera que només veuen el revers (els anys). Per torns, han de trobar les parelles, és a dir, l'antiga i l'actual. Un alumne alça una fotografia i després una altra. Si n'és la parella, les deixa cap amunt i, si no ho és, les torna a posar cap avall i així successivament, fins que estiguen totes emparellades.

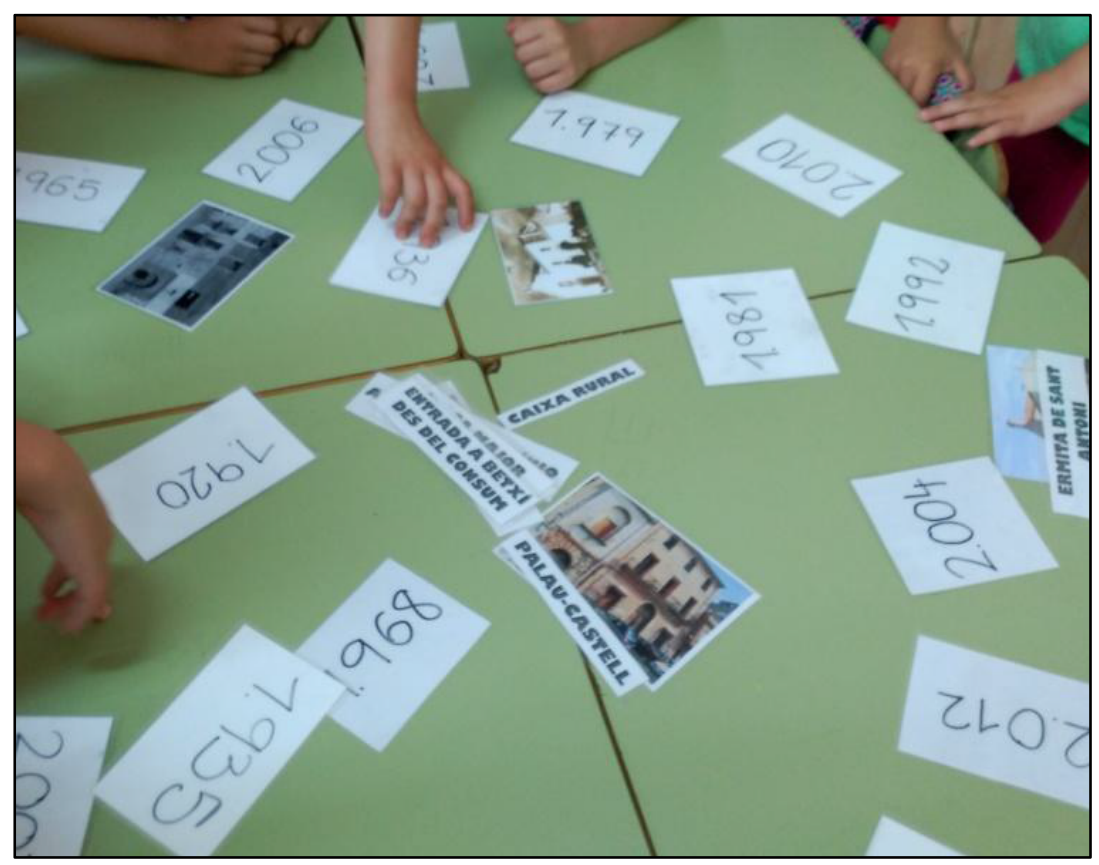

Figura 9. Joc Troba la parella.

2) Organitzem per parelles: cada xiquet té una fitxa (Figura 10) amb uns buits que han d'omplir amb fotografies i targetes d'anys i noms, que es troben barrejades damunt la taula. La targeta amb el nom està apegada, de manera que han de trobar les fotos corresponents d'abans i d'ara, les targetes dels anys corresponents i apegar-ho amb Blu-Tack.

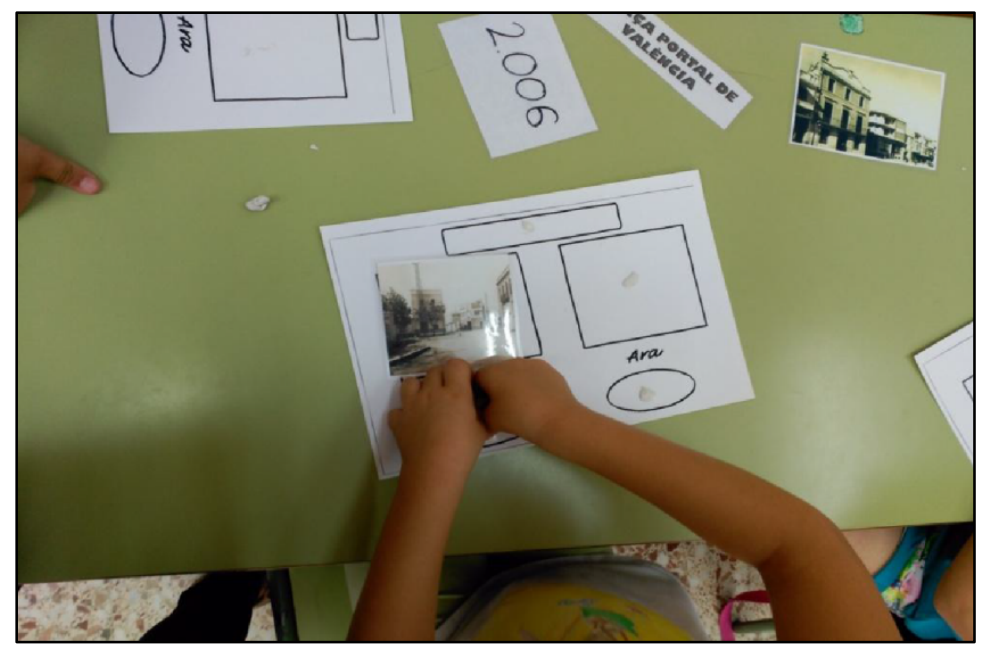

Figura 10. Joc Organitzem per parelles 
3) Busquem les diferències: cada xiquet disposa d'una fitxa (Figura 11) amb uns buits que han d'omplir amb fotografies i les dades que s'hi indica. Cadascun ha d'elegir una fotografia, buscar-ne la parella i apegarles amb Blu-Tack en el full. També ha de buscar la targeta del nom i escriure-la al seu lloc i el mateix amb els anys. Hi ha quatre línies on han d'escriure quatre diferències que troben entre la fotografia d'abans i la d'ara. Hi ha tantes targetes com alumnes a l'aula, així tots tenen l'oportunitat d'escriure les diferències que hi troben.

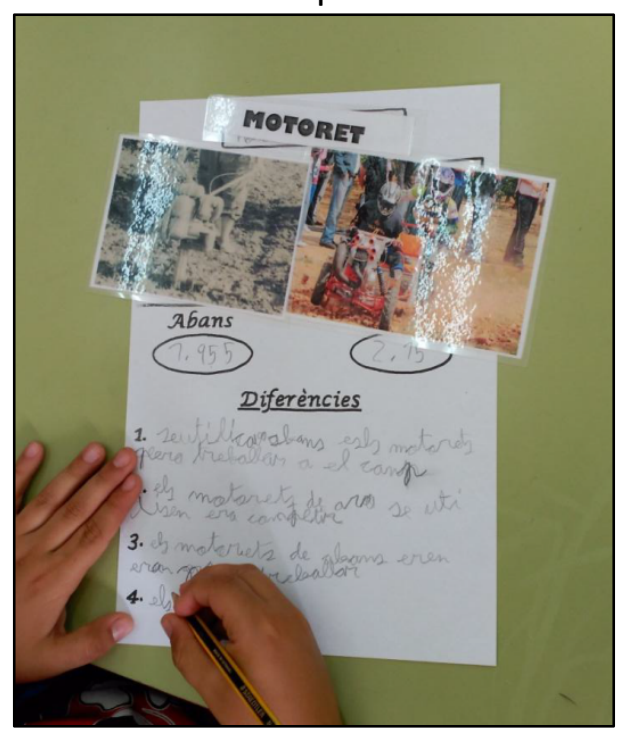

Figura 11. Joc Busquem les diferències

Posteriorment, el joc té activitat final que es realitza col-lectivament, en què es fa un eix cronològic. S'ajunten totes les fotografies i es barregen. Es penja a l'aula un cordell llarg que la travessa diagonalment, a l'altura de l'alumnat. L'activitat consisteix a eixir per parelles i agafar dues fotografies a l'atzar. Han de dir què hi ha en cada fotografia i de quin any es tracta. Seguidament, raonen i decideixen on les han de penjar, de la més antiga a la més actual. Després de colllocar-les, es pregunta als altres si les hi han col-locades bé i, si és necessari, es corregeix. Com es pot comprovar, s'introdueix a aquesta metodologia una característica lúdica. Aquest tret té l'avantatge de satisfer els principals requeriments individuals de l'alumnat $i$, al mateix temps, aconsegueix entrar en una socialització i diversió que afavoreix el procés d'aprenentatge (Zapata, 1989). 


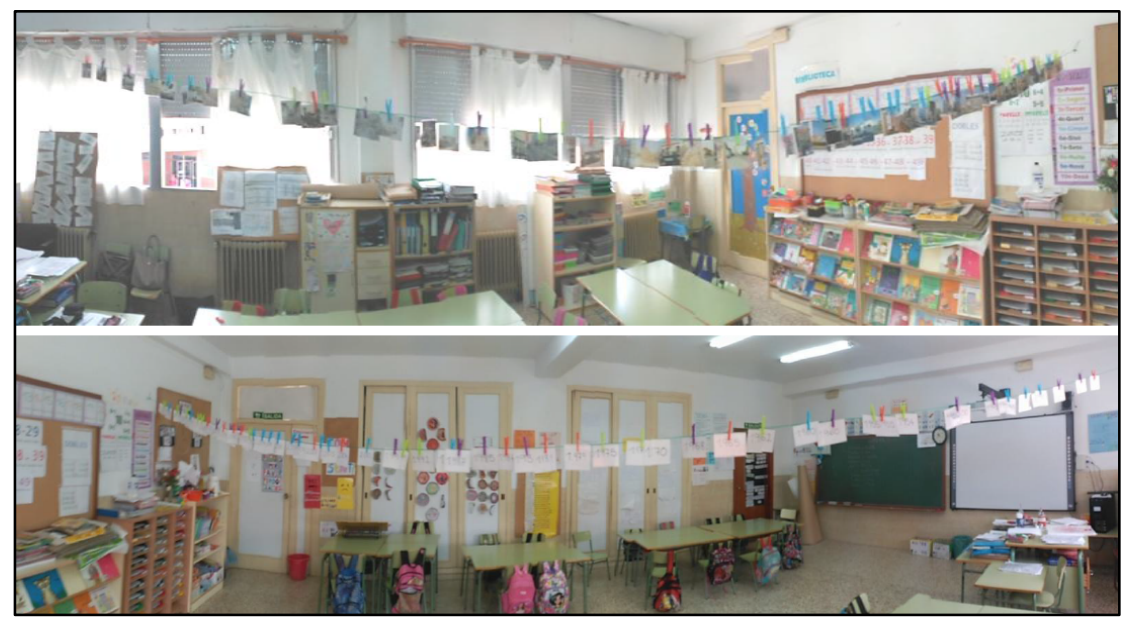

Figura 12. Joc l'eix cronològic de Betxí

\section{Exposició oral}

Anteriorment a aquesta sessió es realitzen diferents assajos. En la sessió de l'exposició oral, expliquen tot allò que han aprés. S'hi convida especialment els iaios i les iaies, les famílies, altres companys i companyes de l'escola... Es pretén que ara siguen els qui els explique tot el que han aprés. Es produeix un canvi dels rols i ara qui és l'expert és l'alumnat. Així doncs, cadascú exposa un dels temes que ha redactat en el dossier; per tant, s'ho ha d'estudiar molt bé. Prèviament, s'assagen les intervencions les observen, les avaluen i les corregeixen, si cal, entre tots i totes. Es projecta una presentació amb les imatges dels temes que estan exposant. Es disposa d'un micròfon.

\section{Avaluació final: Què n’hem aprés?}

Per finalitzar el projecte, es coneix i s'avalua tot allò que han aprés al llarg de tot el procés. Per comprovar-ho, es realitza la mateixa activitat que es porta a terme en l'avaluació inicial, però ara anomenada "Què n'hem aprés?» (presentada en la Figura 2).

Es llegeix conjuntament cada activitat per tal que saberen allò que calia fer, es concentraren, no es confongueren, i les feren a poc a poc. En l'activitat d'escriure s'ha considerat necessari anar fent una avaluació oral. Se'ls feia algunes preguntes referents a l'activitat de manera individual, en parelles o en trios, segons la situació, com ara les següents: «Per què ara el poble és més gran?», "Per què creus que ara han construït més cases?», "Per què creus que el que hi ha ara és diferent?», "Per què creus que ha vingut més gent?», etc. D'aquesta manera, en contestaven una i se'ls en feia la següent, segons la resposta, recordant el que sabien i, després, ho escrivien. Per tant, també s'ha considerat allò que anaven dient oralment. 
En aquest apartat presentarem els resultats de l'avaluació inicial i final realitzades mitjançant el material exposat en la figura 2. També aportarem les valoracions dels implicats obtingudes a partir de 3 entrevistes: una realitzada a dos alumnes, una realitzada a un grup de iaios i iaies i una realitzada a tres mares.

En la Gràfica 1, que es presenta a continuació, es mostren les notes numèriques de 1 al 10 que han obtingut els alumnes en els dos moments.

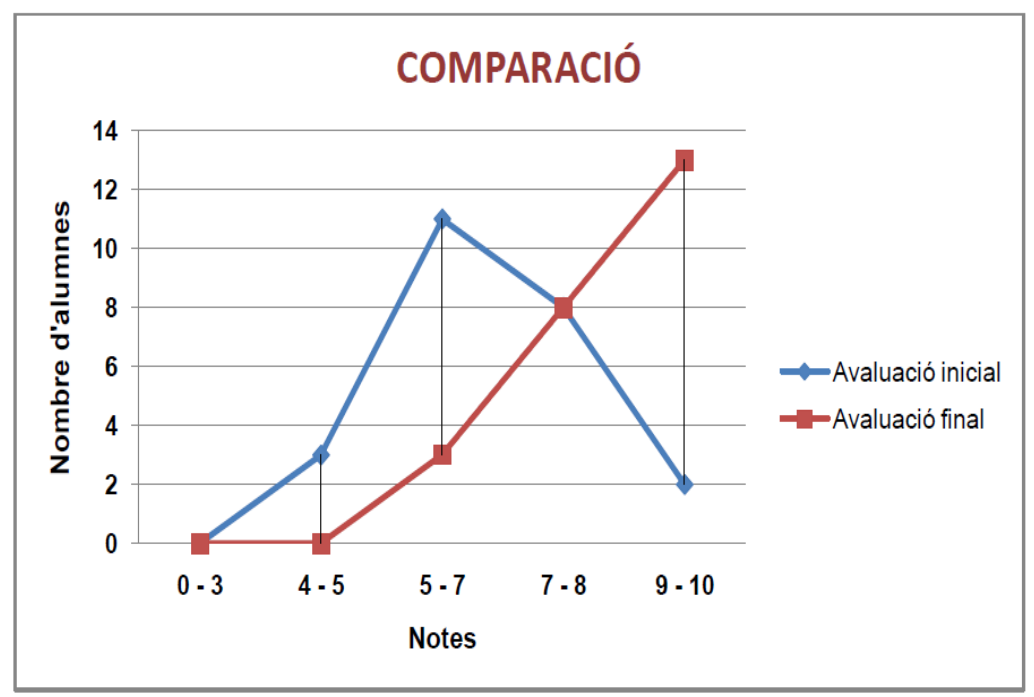

Gràfica 1. Comparació de les notes de l'avaluació inicial i final

A simple vista, podem observar la millora que hi ha hagut respecte de l'avaluació inicial. Tots els suspensos i notes suficients han desaparegut i també han disminuint en gran part les del 5-7, que han passat a ser notables i excel-lents. El nombre d'alumnes amb notes del 7 al 8 es mantenen, la qual cosa no afecta negativament. Aquestes xifres són els punts aproximats de la diferència entre les notes de les dues avaluacions. $S$ 'ha detectat que les evolucions més baixes fan referència a notes notables i excel-lents; per tant, no perjudica l'aprenentatge d'aquest alumnat, ja que prèviament ja se n'hi havia detectat un coneixement elevat. El més destacable ha sigut l'evolució més significativa, amb quasi quatre punts de diferència entre l'inici i el final de la realització del projecte.

Quant a la valoració dels implicats, val a dir que una de les dues alumnes entrevistades manifesta que prefereix treballar en grup o en parella, ja que d'aquesta manera es poden ajudar uns a altres. L'altra alumna afirma: "En una cosa que diu un xiquet aprenem tots els altres, com la informació. Per exemple, un oncle meu $\mathrm{m}^{\prime}$ ha donat una poesia que jo no sabia i ja me l'he apresa». També ressalten la idea de poder escollir mitjançant assemblea el projecte que volen estudiar. En el curs acadèmic 2014-2015 han realitzat tres projectes: el dels minerals, el de l'antic Egipte i el de Betxí, el nostre poble. Una alumna manifesta que el darrer projecte és el que més li ha agradat. La mateixa explica que quan treballen en equip «la primera lletra l'escriu la mestra, després la passa al 
primer xiquet i a continuació anem rodant fins que acabem i el pintem». Diuen que cada xiquet i xiqueta treballa alguns subtemes per a confeccionar entre tots i totes el dossier i després ho expliquen a la resta dels companys i les companyes. Per exemple, una alumna comenta que ella ha treballat el taxista perquè era un membre de la seua família. L'altra ha treballat el bar Salas, ja que era dels pares de la seua iaia. A més, comenten que hi ha alguns xiquets o xiquetes que no els agrada tant el projecte de Betxí perquè no són del poble. Concretament es refereixen a una xiqueta de Romania. Tot i això, la xiqueta va portar en alguna sessió fotos antigues dels seus avantpassat quan estaven a Romania i es van comentar alguns aspectes de la vestimenta. Finalment, remarquen que els ha agradat molt que vingueren els iaios i iaies a l'aula i que aquests s'han sentit molt contents d'haver-hi anat.

Mitjançant l'entrevista realitzada a dos iaios i tres iaies podem extraure que a ells també els ha resultat una experiència molt bonica $\mathrm{i}$ gratificant. Una iaia afirma

és molt bonic treballar amb els néts, és com quan treballes amb els teus fills però llavors tens menys temps, ja que vas a treballar perquè eres jove i no tens temps [...] i és molt bonic saber com ells enfoquen l'ensenyament

Un altra iaia afegeix que als xiquets i les xiquetes els fa molta il.lusió que els grans estiguen a la classe. Un iaio manifesta que:

jo en un principi fins i tot tenia por [...] per si em ficaven en un compromís. Per què és que a casa et fan unes preguntes que dius: Aquest xiquet d'on ha tret açò? I ja no el teu nét, sinó els altres xiquets i xiquetes. Però vaig parlar amb la mestra i em va comentar que venien més iaios.

Durant l'entrevista, una iaia mostra tots els materials que ha portat: documentació, cançons, jocs... fins i tot ha parlat prèviament amb una companya seua que té més memòria per recordar jocs i cançons de la infantesa. Un iaio explica: "a $\mathrm{mi} \mathrm{m}^{\prime}$ ha paregut molt interessant, perquè així els demostrem que tenim interès per el que ells estan fent venint a l'escola [...] i podem donar testimoni». La majoria dels iaios i les iaies comenten que ells ja han participat altres vegades al centre amb la seua presència en les exposicions orals, que ja han vingut a explicar alguna cosa del seu treball, per ajudar-los a confeccionar les disfresses, etc. Una iaia afegeix que "ells es senten més segurs [fa referencia als xiquets i xiquetes], els agrada participar i els agrada que hi participem, perquè agafen confiança amb nosaltres». Comenten que els néts els han donat una carta que els convidava a l'aula. Tot i que alguns manifesten no saber llegir en valencià i que no acaben d'entendre massa bé la lletra dels seus néts i nétes. A pesar d'això, la mestra també havia parlat amb la gent gran per a concretar el que volien fer. Per acabar, revelen que els pareix magnífic que els seus néts i nétes estudien el pas del temps al seu municipi. Un iaio afirma que «el primer que haurien de conèixer es això». 
Pel que fa a l'entrevista a les tres mares, cal remarcar que una d'elles comenta que «els xiquets i les xiquetes es fiquen supercontents de veure't a l'escola, que hi participes amb ells». Un altra mare comenta que als xiquets i les xiquetes els motiva molt la presència de les famílies a l'aula. A més, remarquen també que aquesta participació els permet conèixer altres xiquets i xiquetes i que aquests també els coneguen a ells o elles. Pensen que bàsicament el que facilita que les famílies puguen entrar a l'aula és l'ideari de la mestra. Les famílies participen en els tallers intercicle, als grups interactius $\mathrm{i}$ als projectes de treball. Una mare comenta que «estan tots molt espavilats [...] no pensa que els aportem saviesa, perquè a vegades ells saben més que tu». Una mare afegeix que els xiquets i les xiquetes se senten bé de veure'ls a l'aula. L'altra mare comenta que li encanta poder participar-hi. Expliquen que la mestra sol-licita la seua participació mitjançant l'agenda escolar o els ho diuen els seus propis fills i filles. Una mare especifica que «La mestra ens comenta abans si podem venir, tampoc t'obliga, ella pregunta qui hi pot venir». L'altra mare afegeix que ja es el segon any que treballen així i que la mestra els va explicar el funcionament de l'aula en la reunió inicial. Comenten que en infantil ja participaven a l'aula. Les mares valoren molt satisfactòriament el funcionament de la classe i estan molt complagudes dels aprenentatges realitzats pels seus fills i filles. Una mare afegeix «Jo pense que aprenen més treballant per projectes que, per exemple, obrint un llibre i memoritzant». L'altra mare afirma «[...] així participen més, hi col-laboren més i se'ls queda més». Per concloure, val a dir que una mare declara «Tant de bo que el pròxim any, no sé en $3 r$ com ho faran, però tant de bo l'any que ve facen projectes de treball».

\section{Discussió i conclusions}

Els resultats d'aquest estudi mostren que es pot ratificar la idea que és possible un procés d'ensenyament-aprenentatge efectiu del pas del temps. Açò ha sigut gràcies a una metodologia activa i participativa com són els projectes de treball. Aquest projecte s'havia dissenyat seguint un propòsit molt important en cada activitat: engrescar l'alumnat en l'aprenentatge. Des de la primera activitat s'ha pretés motivar-los, fentlos veure les parts més entusiasmadores del poble i d'un procés d'investigació. Açò ha fet possible que cada pas que s'anava donant en el projecte fera créixer la seua admiració pel tema i sentint-se cada vegada més motivats. Les seues idees i inquietuds concretes sobre el tema anaven in crescendo. Se'ls ocorrien coses que volien saber, que recordaven, que volien compartir, preguntes, etc., cada vegada s'entusiasmaven més. Açò reflecteix la importància de la discussió oral a l'aula. De la mateixa manera, s'aprofitava la situació més insignificant per aprendre. Sabien traure-li suc del que trobaven pel camí, la qual cosa els commovia més i més. És d'admirar com la diversió dóna un punt molt positiu a l'aprenentatge. Les activitats han resultat ser molt productives $\mathrm{i}$ han donat molt bons fruits. Jugant, s'han pogut adonar de tot el que 
saben i que s'han convertit en experts del poble, la qual cosa els ha commogut i els ha implicat en gran part. S'ha aconseguit que unes activitats tan atractives cobriren un contingut difícil d'assimilar. Un aspecte importat en la metodologia és l'activitat en grup. Té gran rellevància la discussió oral i l'argumentació, amb l'aportació d'idees i opinions, respectant sempre el torn de paraula. Sempre que siga possible, es pretén realitzar l'aprenentatge oralment, tant escoltant els experts com manifestant ells i elles el que saben. En el treball en grups reduïts $i$ parelles dóna curs a les seues possibilitats, de manera que s'han de posar d'acord i organitzar-se tots sols. Aquesta manera de treballar ajuda a potenciar la cooperació, la inclusió, la responsabilitat, la interacció, la colllaboració i el compromís, de manera que es fomenten els valors del respecte, la solidaritat i la companyonia.

En el projecte també s'han introduït les TIC (Tecnologies de la Informació i la Comunicació). Els docents del segle XXI han d'oferir a l'alumnat la possibilitat d'entrar en contacte amb referències i fonts d'informació propis d'aquesta època. Per tant, es dóna la possibilitat d'ampliar la informació, de manera que poden aprendre i treballar continguts bàsics d'informàtica i fer recerques en la xarxa. Per això, són investigadors que naveguen per diferents referents informatius.

Pel que fa a les avaluacions, cal dir que les proves escrites a vegades poden no ser eficients i no reflectir el que realment saben. Resultava difícil per a l'alumnat expressar-se per escrit, per la qual cosa s'han hagut d'intercalar en algun moment avaluacions orals. Així, han pogut comprovar que saben molt més del que estaven escrivint en un principi, per tant ha sigut convenient introduir aquest procediment. D'altra banda, ha sigut gratificant veure unes diferències tan grans entre l'avaluació inicial i la final, sobretot les evolucions tan significatives que hi ha hagut quant als coneixements. La satisfacció d'aquesta evolució ve sobretot de la prosperitat que ha tingut el projecte i de tot allò que al final sabien explicar i que al principi no eren capaços de fer-ho. Molts dels alumnes que al principi tenien un mínim de coneixements, al final eren uns complets experts.

En conclusió, s'ha pogut demostrar l'eficàcia de la metodologia, la temàtica i les activitats, que han permés a l'alumnat adquirir la noció de temporalitat. Gràcies a la introducció d'estratègies inèdites i actives i la colllaboració de gran part de la comunitat educativa, la immersió dels xiquets i les xiquetes en el procés educatiu s'ha vist potenciada. Aquesta participació aconseguida ha sigut la clau per a endinsar l'alumnat en un viatge al passat amb un mitjà de transport anomenat temps, de manera que han sigut conscients del que ha comportat el seu progrés fins avui 
AusubeL, D. P. (1963): The Psychology of Meaningful Verbal Learning. Grune and Stratton, Nova York.

Díaz Navarro, C. (1998): La oreja verde de la escuela. Trabajo por proyectos y vida cotidiana en la escuela infantil. Ediciones de la Torre, Madrid.

DíAz-BARRIGA, F. (1998): «Una aportación a la didáctica de la historia. La enseñanza-aprendizaje de habilidades cognitivas en el bachillerato». Perfiles educativos, 82.

Feliu Torruella, M i F. X. Hernández Cardona (2011): 12 Ideas Clave. Enseñar y aprender Historia. Graó, Barcelona.

HERnÁNDEZ, F. (2000): "Los proyectos de trabajo: la necesidad de nuevas competencias para nuevas formas de racionalidad», Educar, 26, p. 39-51.

LAUTIER, N. (1997): Enseigner l'histoire au lycée. Colín, París.

LóPEZ, A. M. i A. LACUeVA (2007): «Proyectos en el aula: cinco categorías en el análisis de un caso", REICE: Revista Electrónica Iberoamericana sobre Calidad, Eficacia y Cambio en Educación, 5, p. 78-120.

Mattozzı, I. (2002): «Presentazione per il docente. La formazione del pensiero temporale negli adolescente», E. PERILto, (ed.). La storia. Istruzione per I'uso. Materiali per la formazione de competenze temporali degli studenti, Tecnodid, Nàpols, p. 9-22.

PAGÈs, J. (2009): "Enseñar y aprender ciencias sociales en el siglo XXI: reflexiones casi al final de una década», Investigación en Educación, Pedagogía y Formación Docente, II Congreso Internacional. Vol. 2, p. 140154.

Stow, W., i HAYDN, T. (2000): "Issues in the Teaching of Chronology», J. Arthur i R. Phillips (ed.), Issues in History Teaching, Routledge, Londres, p. 83-97.

Trepat, C.A. (2002): Fundamentos teóricos para una didáctica del tiempo en las ciencias sociales. El tiempo y el espacio en la didáctica de las ciencias sociales, Graó, Barcelona.

TRIBÓ, G. (2005): Enseñar a pensar históricamente: los archivos y las fuentes documentales en la enseñanza de la historia, Horsori, Barcelona.

TUtiauX-Guillon, N. (2003): «Los fundamentos de una investigación sobre la concepción de las finalidades cívicas y culturales del profesorado de geografía e historia: objetivo de esta etapa», Enseñanza de las ciencias sociales: revista de investigación, 2, p. 27-35.

VIGOTSKY, L.S. (1979): El desarrollo de los procesos psicológicos superiores, Grijalbo, Barcelona.

ZAPATA, O. A. (1989): El aprendizaje por el juego en la escuela primaria, Pax, México. 


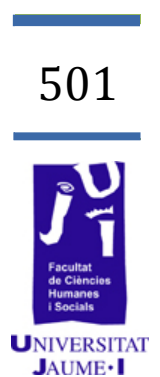

\section{Análisis de una práctica educativa: hacia una escuela intercultural e inclusiva}

Aida Sanahuja Ribés asanahuj@uji.es 
En este trabajo se reflexiona en torno a los elementos que caracterizan a la escuela intercultural e inclusiva, la cual consiste en hacer efectivo el derecho a la no discriminación y a la participación de todos los estudiantes, independientemente de su condición social o cultural, de su género o de sus características personales (Sales, Ferrández y Moliner, 2012). Se trata de un estudio de caso y se utiliza la observación participante como técnica de recogida de datos. Se describe de manera pormenorizada una práctica educativa, que fue llevada a cabo en un aula de educación infantil de 4 años del CEIP Isabel Ferrer de Castellón. En ella participaron 25 alumnos (10 chicas y 15 chicos), la maestra y cinco voluntarios. Se comentan aspectos relativos a la distribución del aula, a la estructura de las sesiones, a las técnicas de aprendizaje cooperativo utilizadas, a la especial atención prestada al lenguaje escrito y a la lectura y a la evaluación. Posteriormente se analiza la práctica educativa presentada siguiendo la dimensión C de la guía CEIN para la construcción de la escuela intercultural inclusiva (Sales, Moliner y Traver, 2010). Se finaliza con las conclusiones, donde se remarca la importancia de avanzar hacia una escuela intercultural e inclusiva y se comentan las limitaciones del estudio.

Palabras clave: escuela intercultural e inclusiva, práctica educativa, relación escuela-comunidad, voluntariado, aprendizaje cooperativo.

\section{Introducción}

Es ampliamente compartida y aceptada la idea de que existe una gran diversidad $y$ heterogeneidad en las aulas. Tal y como introduce López Melero (2004) todos somos diferentes, no existen ni han existido dos seres humanos idénticos. Según Gómez Montes (2005), esta diversidad se puede resumir en torno a dos factores esenciales: 1) Factores de ámbito sociológico, derivados del propio contexto sociocultural y económico y originados por aspectos de carácter geográfico, étnico y religioso, y 2) Factores de ámbito psicopedagógico, derivados de las diferencias en las capacidades intelectuales de cada alumno, de la motivación por el aprendizaje, los intereses académicos y profesionales, los diferentes estilos de enseñanza y aprendizaje, etc. No obstante, en la práctica educativa de algunos docentes esta idea de diversidad parece ser ignorada. Esta concepción la reflejan muy bien Gregory y Chapman (2007) al introducir la analogía de que «una misma talla no sirve para todos», esto es, no podemos enseñar a todos los alumnos de la misma manera. O lo que es lo mismo en palabras de Beaudoin (2013), "la mayoría de las escuelas hacen que sus alumnos marchen al compás del mismo tambor, y el enfoque es diferente hay que tocar al compás de cada alumno». Esto no significa realizar una educación 
individualizada y descontextualizada de lo que realiza el grupo clase o recibir apoyos fuera del aula ordinaria. Aunque esta suele ser la respuesta educativa más común que se da al alumnado con discapacidad o dificultades de aprendizaje (Arnáiz, 2004). Más bien, se trata de entender y atender a la diversidad desde un marco en el que partiendo de la realidad seamos capaces de aplicar estrategias reales y perfectamente viables en nuestras aulas (Gómez Montes, 2005). Esto es, se deben introducir metodologías que propicien en el aula diferentes caminos de aprendizaje, acorde con las necesidades, intereses y estilos de aprendizaje de todo el alumnado, para ellos hay que entender la diversidad del aula como una dimensión que mejora y enriquece la práctica educativa (Moriña, 2008). Este propósito es el que persigue el modelo intercultural e inclusivo, «el cual consiste en hacer efectivo el derecho a la no discriminación y a la participación de todos los estudiantes, independientemente de su condición social o cultural, de su género o de sus características personales». (Sales, Ferrández y Moliner, 2012: 154)

Con el objetivo de avanzar hacia una escuela intercultural inclusiva surge la guía CEIN (Sales, Moliner y Traver, 2010) como un instrumento de autoevaluación escolar, que consta de tres dimensiones y de diversos factores clave. Cada factor introduce una serie de preguntas de reflexión para hacer una primera exploración de la realidad, en una segunda fase se toman decisiones colectivas sobre las dimensiones y factores seleccionados. En la Tabla 1, que se presenta a continuación, se recogen las tres dimensiones de dicha guía con sus respectivos factores.

Tabla 1. Dimensiones para la construcción de la Escuela Intercultural Inclusiva

(Sales, Moliner y Traver, 2010)

\section{A. Cómo somos (cómo nos vemos y cómo nos ven)}

A.1. Valores compartidos

A.2. Valoración positiva de la diversidad

A.3. Altas expectativas

B. Cómo nos organizamos

B.1. Proyecto educativo intercultural inclusivo

B.2. Liderazgo inclusivo

B.3. Cultura colaborativa

B.4. Tiempos y espacios para la reflexión y la innovación

B.5. Comunicación y mediación intercultural

B.6. Participación de la comunidad

C. Cómo aprendemos y enseñamos

C.1. Agrupamientos heterogéneos

C.2. Objetivos y contenidos curriculares por competencias

C.3. Metodología participativa y cooperativa

C.4. Actividades globalizadoras

C.5. Evaluación diversificada

C.6. Gestión dialógica del aula

C.7. Competencias de comunicación intercultural del profesorado

C.8. Desarrollo profesional y comunitario 
Una vez realizada esta breve contextualización teórica se pasará a presentar la metodología recurrida en este estudio y se describirá de manera pormenorizada una práctica educativa, comentando aspectos relativos a la distribución del aula, a la estructura de las sesiones, a las técnicas de aprendizaje cooperativo utilizadas, a la especial atención prestada al lenguaje escrito y a la lectura y a la evaluación. Posteriormente se analizará la práctica educativa presentada siguiendo la dimensión C de la guía CEIN.

\section{Material y método}

Este estudio se enmarca dentro de la metodología cualitativa. Se trata de un estudio de caso y se utiliza la observación participante como técnica de recogida de datos. Según Walker (1983: 45):

el estudio de caso es el examen de un ejemplo en acción. El estudio de unos incidentes y hechos específicos y la recogida selectiva de información de carácter biográfico, de personalidad, intenciones y valores, permite al que lo realiza captar y reflejar los elementos de una situación que le dan significado.

El método más importante de la etnografía es el de la observación participante. Este método permite que el investigador adopte un rol dentro del grupo y posibilita la observación desde la menor distancia posible (Woods, 1987).

En el caso que nos ocupa la observación participante fue realizada por una de las voluntarias participantes en la experiencia que se describe en el siguiente apartado de este trabajo.

\section{Descripción de la práctica educativa}

Esta práctica educativa fue llevada a cabo durante el primer y el segundo trimestre del curso académico 2011-2012 en un aula de infantil (4 años) del CEIP Isabel Ferrer de Castellón. El objetivo principal era iniciar en la lectura y la escritura a los alumnos, así como la cooperación y la participación de la comunidad educativa en el aula. En ella participaron 25 alumnos (15 niños y 10 niñas), la maestra y cinco voluntarios (un padre, dos madres y dos estudiantes de la Universitat Jaume I).

Primeramente, la maestra se puso en contacto con los voluntarios. Hizo un primer llamamiento a las familias y también a estudiantes de magisterio y psicopedagogía de la Universitat Jaume I. Una vez se contó con los cinco voluntarios necesarios, se realizó una reunión inicial, en la cual la maestra explicó cómo se coordinarían. Por lo que respecta a la organización general de trabajo, es necesario destacar que cada semana, antes de las sesiones, la maestra enviaba por correo electrónico un cuadro-resumen de lo que haría cada voluntario en cada grupo. Y al 
finalizar cada proyecto se reunieron los cinco voluntarios y la maestra para intercambiar impresiones y aportar propuestas de mejora.

Los voluntarios asistían al aula los jueves a primera hora de la mañana, después de las llamadas "rutinas» de infantil: pasar lista, ver el tiempo, organizar el trabajo del día,... hasta aproximadamente la hora del patio. Durante el curso se trabajaron dos proyectos: el proyecto de las tortugas (1.o trimestre) y el proyecto del agua (2.o trimestre). Ambos fueron escogidos mediante asamblea por el alumnado.

A continuación se procederá a explicar de manera detallada cómo se llevó a cabo la práctica educativa, mostrando la distribución del aula, la estructura de las sesiones, las técnicas de aprendizaje cooperativo que se utilizaron, la especial atención que se prestó a la escritura y a la lectura y finalmente se presentan aspectos relacionados con la evaluación.

\subsection{Distribución del aula}

Los alumnos estaban agrupados en cinco grupos heterogéneos de cinco miembros cada uno. Los cinco voluntarios pasaban por cada grupo, de manera que al terminar la sesión los cinco habían interactuado con todos los grupos. La maestra iba observando y guiando a quien lo necesitaba. Cada grupo realizaba una actividad concreta y disponía de una persona adulta encargada de dinamizarla. Aunque las actividades de cada grupo eran diferentes, mantenían relación entre ellas. La temática general era la misma y había sido votada en una asamblea por los propios alumnos, quienes habían decidido qué es lo que querían aprender.

Es importante remarcar que el espacio físico del aula tiene que facilitar la interacción de los alumnos tanto en su grupo como con el resto de los grupos (Sánchez Palomino y Carrión, 2002). La clase estaba distribuida como espacio versátil, tal y como se puede observar en la Figura 1. Con esta distribución se favorecía y se potenciaba la comunicación tanto en el grupo de trabajo como entre los grupos diferentes. De esta manera, al terminar cada sesión el portavoz del grupo explicaba a toda la clase que es lo que había trabajado su grupo, sin necesidad de cambiar de espacio físico.

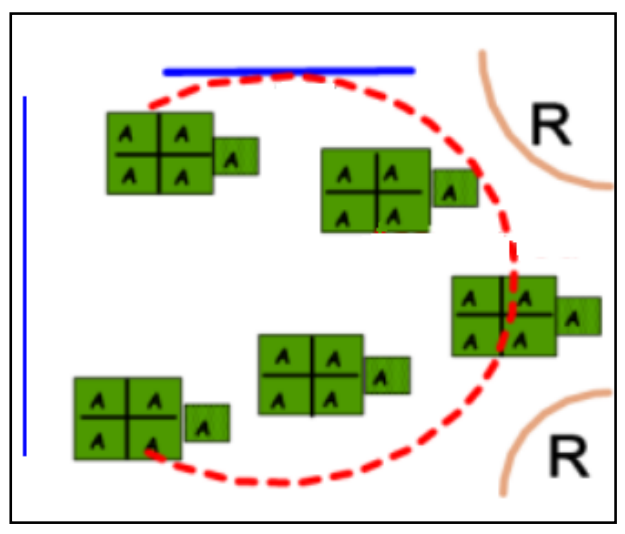

Figura 1. El aula como espacio versátil 


\subsection{Estructura de las sesiones}

En la Tabla 2, que se presenta a continuación, se recoge lo que hacía cada voluntario en cada subsesión. Cada sesión estaba dividida en cinco subsesiones y, como ya se ha dicho anteriormente, en cada subsesión los voluntarios estaban en un grupo diferente.

Tabla 2. Estructuración de las sesiones

\begin{tabular}{|c|c|c|}
\hline Subsesiones & Tarea a realizar & Tiempo estimado \\
\hline $\begin{array}{l}\text { Voluntario en la } \\
\text { subsesión } 1\end{array}$ & $\begin{array}{l}\text { Colaborar en el marcaje de los cargos. Y } \\
\text { supervisar el registro de estos por parte del } \\
\text { secretario del grupo. }\end{array}$ & Tiempo aproximado $5 \mathrm{~min}$. \\
\hline $\begin{array}{c}\text { Voluntario en la } \\
\text { subsesión } 2\end{array}$ & $\begin{array}{l}\text { Revisar con el secretario, en el plan del equipo, } \\
\text { los cargos. Remarcar que el plan del equipo } \\
\text { consiste en un cuaderno donde los equipos } \\
\text { hacen constar los cargos y funciones, las tareas } \\
\text { a realizar y las evaluaciones. } \\
\text { Ayudar en la definición del tema que van a } \\
\text { escribir. } \\
\text { Escribir, al dictado de las palabras, el texto } \\
\text { acordado entre todos. Animar a la escritura } \\
\text { individual en la hoja y supervisar que todos los } \\
\text { miembros del equipo colaboran e interactúan. } \\
\text { Reflexionar con el alumnado sobre los ítems } \\
\text { de evaluación. }\end{array}$ & $\begin{array}{l}\text { Tiempo aproximado } 20 \\
\text { min. } \\
\text { Asegurarse que todos } \\
\text { tienen claro su cargo. } \\
\text { El responsable del } \\
\text { material trae el material } \\
\text { necesario. } \\
\text { ¿Sobre qué tema vamos a } \\
\text { escribir? ¿Qué } \\
\text { conocemos? } \\
\text { El voluntario escribe y los } \\
\text { alumnos copian. Ayudar } \\
\text { en la coherencia del texto. } \\
\text { Empieza a escribir el } \\
\text { portavoz y se hacen turnos } \\
\text { siguiendo las agujas del } \\
\text { reloj. Si se puede, } \\
\text { conviene que cada alumno } \\
\text { escriba una palabra } \\
\text { completa. } \\
\text { Tiempo aproximado } 5 \text { min. } \\
\text { El secretario saca el plan } \\
\text { del equipo y se van } \\
\text { registrando las respuestas } \\
\text { a las preguntas de } \\
\text { evaluación. Hacemos las } \\
\text { preguntas y esperamos la } \\
\text { reflexión y el diálogo del } \\
\text { equipo. Es necesario } \\
\text { asegurar la objetividad. }\end{array}$ \\
\hline
\end{tabular}




\begin{tabular}{|c|c|c|}
\hline $\begin{array}{l}\text { Voluntario en la } \\
\text { subsesión } 3\end{array}$ & $\begin{array}{l}\text { Preparar la exposición oral del contenido } \\
\text { trabajado y de la actividad que se ha realizado. }\end{array}$ & \begin{tabular}{l|l} 
Tiempo aproximado 10 \\
min \\
¿Qué se ha \\
explicado/escrito en esta \\
hoja? ¿Se ha terminado el \\
trabajo o hay que \\
continuar?
\end{tabular} \\
\hline $\begin{array}{l}\text { Voluntario en la } \\
\text { subsesión } 4\end{array}$ & $\begin{array}{l}\text { Escuchar al portavoz en la exposición oral y } \\
\text { hacer preguntas. }\end{array}$ & $\begin{array}{l}\text { yiempo aproximado } 5 \text { min. } \\
\text { ¿Quién es el portavoz? } \\
\text { Explica que habéis hecho } \\
\text { en esta hoja. }\end{array}$ \\
\hline \multicolumn{3}{|c|}{$\begin{array}{l}\text { Exposición oral del portavoz de cada equipo a todo el grupo clase } \\
2 \text { minutos por portavoz ( } 10 \mathrm{~min})\end{array}$} \\
\hline $\begin{array}{l}\text { Voluntario en la } \\
\text { subsesión } 5\end{array}$ & $\begin{array}{l}\text { Ayudar en las reflexiones en referencia a la } \\
\text { expresión oral. }\end{array}$ & $\begin{array}{l}\text { Tiempo aproximado } 5 \text { min. } \\
\text { ¿El portavoz ha explicado } \\
\text { todo el trabajo? ¿Le ha } \\
\text { faltado explicar alguna cosa? } \\
\text { ¿Todos le hemos escuchado? } \\
\text { ¿Ha hablado en un tono de } \\
\text { voz adecuado y hemos podido } \\
\text { escucharle? ¿Le hemos } \\
\text { ayudado en la explicación? }\end{array}$ \\
\hline
\end{tabular}

Esta estructura de trabajo se llevó a cabo en cada una de las sesiones, tanto en el proyecto de las tortugas como en el proyecto del agua.

\subsection{Aprendizaje cooperativo}

Según Pujolàs (2008), en un aula organizada en equipos cooperativos de trabajo, los alumnos aumentan su protagonismo y participan de una forma mucho más activa en el proceso de enseñanza y aprendizaje y en la gestión de la clase, y comparten con el profesorado la responsabilidad de enseñar, también ellos a sus propios compañeros. Los alumnos se convierten en individuos autónomos y se propicia un clima de aula muy favorable para el aprendizaje, puesto que se van dando las condiciones emocionales y relacionales imprescindibles para que los estudiantes puedan aprender efectivamente.

Seguidamente se abordaran las dos técnicas que se utilizaron en esta experiencia: la técnica de la instrucción compleja y el folio giratorio.

\subsubsection{Técnica de la Instrucción compleja}

La técnica de la instrucción compleja consiste en asignar a cada miembro del grupo un rol o responsabilidad con funciones claramente marcadas (Cohen, 1999). De esta manera, cada miembro del grupo se ocupa de la organización y la gestión del trabajo, de forma que se potencia la participación de todo el grupo. A medida que van avanzando 
las sesiones los roles van rotando. De esta manera cada miembro del grupo va desempeñando diferentes tareas cada vez.

Los cargos así como las tareas y responsabilidades de cada miembro del grupo se resumen en la Tabla 3, que se presenta a continuación.

Tabla 3. Cargos de los miembros del grupo

\begin{tabular}{|c|c|}
\hline Cargos & Tareas y responsabilidades \\
\hline PORTAVOZ & $\begin{array}{l}\text {-Anima a los miembros del equipo para avanzar en el trabajo. } \\
\text {-Habla en nombre de todo el equipo cuando se solicita la opinión } \\
\text { del grupo. } \\
\text {-Expone oralmente el trabajo realizado. } \\
\text {-Asume las funciones del secretario y del avisador cuando estos no } \\
\text { han venido. }\end{array}$ \\
\hline $\begin{array}{l}\text { ENCARGADO DE LA } \\
\text { LIMPIEZA }\end{array}$ & $\begin{array}{l}\text {-Mantiene el espacio de trabajo limpio y ordenado. } \\
\text {-Limpia las mesas después de trabajar. }\end{array}$ \\
\hline $\begin{array}{l}\text { RESPONSABLE DEL } \\
\text { MATERIAL }\end{array}$ & $\begin{array}{l}\text {-Proporciona los materiales necesarios. } \\
\text {-Cuida los materiales. } \\
\text {-Ordena y recoge los materiales. } \\
\text {-Asume las funciones del encargado de la limpieza cuando este no } \\
\text { ha venido. }\end{array}$ \\
\hline SECRETARIO & $\begin{array}{l}\text {-Rellena los formularios de registros de los cargos y de la } \\
\text { evaluación. } \\
\text {-Reparte las hojas. } \\
\text {-Asume las funciones del responsable del material y del portavoz } \\
\text { cuando estos no han venido. }\end{array}$ \\
\hline AVISADOR & $\begin{array}{l}\text {-Controla el tono de la voz de los miembros del equipo. } \\
\text {-Anuncia al portavoz si algún miembro del equipo no cumple con } \\
\text { sus responsabilidades. }\end{array}$ \\
\hline
\end{tabular}

\subsubsection{Folio giratorio}

El voluntario asigna una tarea al equipo (una lista de palabras relacionadas con el tema, las cosas que saben sobre ese tema, una frase que resuma una idea fundamental del tema estudiado,...) y un miembro del equipo empieza a escribir su parte o su aportación en un «folio giratorio». Mientras los demás se fijan en cómo lo hace, le ayudan si hace falta, le corrigen, le animan, etc. A continuación, pasa el folio al compañero que tiene al lado, siguiendo la dirección de las agujas del reloj para que escriba su parte de la tarea en el folio, y así sucesivamente hasta que todos los miembros del equipo han participado en la resolución de la tarea. 
Cada alumno puede escribir su parte con un rotulador de un determinado color (el mismo que ha utilizado para escribir su nombre en la parte de detrás del folio). Así a simple vista puede verse la aportación de cada uno (Pujolàs, 2008).

\subsection{Especial atención al lenguaje escrito y a la lectura}

Recordemos que uno de los principales objetivos del trabajo era la iniciación a la lectura y la escritura del alumnado de dicha clase. Así pues los voluntarios dedicaron en cada sesión especial atención a estos procesos. Las pautas fueron las siguientes:

- Escribir una hoja al dictado del texto de los niños.

- Leer lentamente cada palabra que se escribe y se les ayuda a:

- Dar coherencia al texto.

- Distinguir entre un texto oral (la explicación de una idea) y un texto escrito (cómo queremos escribir esa idea).

- Si la longitud del texto lo permite, se les ayuda a organizar los turnos para que cada alumno escriba una palabra entera. Si no, cada alumno escribe una letra de la palabra en cuestión.

- Empieza a escribir el secretario y, a continuación, se siguen los turnos según las agujas del reloj.

- Mientras uno escribe, los compañeros miran y ayudan, le corrigen, le dictan...

- Se revisa (leyendo) lo que se va escribiendo, para asegurarse de que se está escribiendo todo aquello que se quiere.

- Al terminar, se lee todo el texto.

\subsection{Evaluación}

Los voluntarios conjuntamente con la reflexión de los distintos miembros del grupo eran los encargados de realizar la evaluación de los alumnos, la cual quedaba recogida en el plan del equipo. En la Tabla 4, se agrupan algunos puntos que se tenían en cuenta para valorar cada apartado.

Tabla 4. Posibles ítems a tener en cuenta en la evaluación

\begin{tabular}{|l|l|}
\hline Apartado & \multicolumn{1}{|c|}{ Ítem a valorar } \\
\hline & -Conoce cuál es su cargo. \\
& -Se responsabiliza de sus funciones. \\
& -Conoce los cargos de los otros miembros del grupo. \\
1. Registro de los & -Reconoce los nombres de los compañeros para registrar los \\
cargos & $\begin{array}{l}\text { cargos correspondientes. } \\
\text {-Exige a sus compañeros que hagan uso de sus } \\
\end{array}$ \\
& responsabilidades. \\
\hline
\end{tabular}




\begin{tabular}{|c|c|}
\hline $\begin{array}{l}\text { 2. Escritura de la } \\
\text { información }\end{array}$ & $\begin{array}{l}\text {-Aporta ideas para escribir la información. } \\
\text {-Tiene iniciativa. } \\
\text {-Se implica en la tarea, colabora. } \\
\text {-Su escritura es lineal. } \\
\text {-Necesita mucha ayuda, poca o ninguna. } \\
\text {-Conoce el nombre de las letras para dictarlas a los compañeros. } \\
\text {-Hace hipótesis silábicas. } \\
\text {-... } \\
\text {-Es objetivo en la autoevaluación y coevaluación. } \\
\text { - Acepta las valoraciones de los otros compañeros. } \\
\text {-... }\end{array}$ \\
\hline $\begin{array}{l}\text { 3. Preparación de la } \\
\text { exposición oral }\end{array}$ & $\begin{array}{l}\text {-Participa en la explicación del trabajo realizado. } \\
\text {-Se centra en la información que se quiere escribir o en la } \\
\text { utilización del material, las ayudas, el proceso de escritura, pintar, } \\
\text { recortar,... } \\
\text {-... }\end{array}$ \\
\hline $\begin{array}{l}\text { 4. Preguntas al } \\
\text { portavoz para la } \\
\text { exposición oral }\end{array}$ & $\begin{array}{l}\text {-Contesta a las preguntas realizadas. } \\
\text {-Explica coherentemente la información. } \\
\text {-La explicación es correcta con el trabajo realizado. } \\
\text {-Los compañeros escuchan con atención la explicación del } \\
\text { portavoz. } \\
\text {-... }\end{array}$ \\
\hline $\begin{array}{l}\text { 5. Reflexiones sobre } \\
\text { la exposición oral } \\
\text { realizada }\end{array}$ & $\begin{array}{l}\text {-Lo ha explicado todo. } \\
\text {-El tono de voz era adecuado. } \\
\text {-Ha escuchado el portavoz mientras explicaba. } \\
\text {-Ha ayudado al portavoz en la explicación. } \\
\text {-... }\end{array}$ \\
\hline
\end{tabular}

Así pues al finalizar cada sesión, cada grupo conjuntamente con el voluntario correspondiente reflexionaba sobre cómo había trabajado el equipo de manera grupal e individual. Primeramente se reflexionaba conjuntamente sobre qué aspectos era necesario mejorar para el buen funcionamiento del grupo, por eso el secretario en el plan del equipo marcaba una cruz sobre lo que se había hecho (muy bien, bien o era necesario mejorar). Seguidamente, se pasaba a la evaluación individual, en este caso era el voluntario quien decidía objetivamente y teniendo en cuenta los criterios anteriormente presentados en la Tabla 4, quien pegaba el adhesivo (el cual tenía representado un grupo trabajando) en su casilla del plan del equipo, es decir, donde se indicaba su nombre, en función de:

- Su participación aportando ideas para escribir.

- La escucha de lo que comentaban los compañeros.

- La ayuda prestada a los compañeros en referencia a escribir palabras, recortar, enganchar, pintar...

- Si evitaba molestar en la mesa. Entendiendo la conducta de molestar como: el coger los materiales que están en la mesa 
cuando no los necesita nadie, hablar sobre otros temas no relacionados con el proyecto mientras un compañero trabaja sin ser ayudado y agobiar a los compañeros.

Se valoraba también la escucha de la exposición oral de los diferentes portavoces, de esta manera se enganchaba en el plan del equipo otra pegatina con una oreja dibujada. En cada sesión, cada niño podía obtener un máximo de dos adhesivos, uno que valoraba el trabajo realizado en la sesión y otro la escucha. Durante todo el proyecto los alumnos podían ver en el plan del equipo cómo trabajaban en grupo, cuántos adhesivos tenían de participación y cuántos en escucha a los compañeros.

\section{Análisis de la práctica educativa: hacia una escuela intercultural e inclusiva}

Tal y como se ha mencionado anteriormente, para analizar la práctica presentada se utilizará la guía CEIN para la construcción de la escuela intercultural inclusiva (Sales, Moliner y Traver, 2010). Al tratarse de una práctica educativa desarrollada en una sola aula de la escuela centraremos nuestro análisis en la dimensión C. Cómo aprendemos y enseñamos. A continuación, se procederá a comentar y desarrollar cada uno de los factores de la tercera dimensión de la guía.

C.1. Agrupamientos heterogéneos: a lo largo de la sesión se promueven principalmente dos tipos de agrupamientos: pequeño grupo y gran grupo/clase. El alumnado trabaja en un pequeño grupo dinamizado en cinco momentos diferentes por cinco voluntarios y al finalizar la sesión se promueve la participación en el gran grupo o grupo clase para que cada grupo pequeño comparta con el resto de la clase lo que han trabajado en esa sesión. De esta manera se promueven competencias para que el alumnado sepa trabajar en distintas modalidades de agrupamiento. Cabe destacar también que el criterio básico para crear los grupos de trabajo es la heterogeneidad, teniendo en cuenta el género, la lengua, las capacidades, los intereses, los ritmos... Además, cada alumno a lo largo de las diferentes sesiones va adoptando roles y funciones diferentes que deben desempeñar para el buen funcionamiento de este.

C.2. Objetivos y contenidos curriculares por competencias: los objetivos de aprendizaje son claros y se priorizan aquellos objetivos y contendidos más significativos y funcionales para el grupo-clase según los intereses y las curiosidades que el alumnado manifiesta en la asamblea.

C.3. Metodología participativa y cooperativa: con esta práctica educativa se fomenta tanto el aprendizaje intergrupal e intragrupal. Con los roles o cargos se da la oportunidad al alumnado de asumir diferentes responsabilidades y funciones que guían su propio aprendizaje. La principal metodología utilizada es la de los proyectos de trabajo. Se 
potencia que el alumnado explore puntos de vista diferentes al suyo, puesto que entre todos acuerdan lo que van a escribir. Como se ha mencionado en la descripción de la práctica, se fomenta el aprendizaje cooperativo y la maestra actúa como facilitadora del aprendizaje, destacando el papel dinamizador de los voluntarios, aprovechando así los recursos personales de la comunidad. Se utilizan diferentes fórmulas de motivación: primeramente cabe destacar que el proyecto nace de los propios intereses del alumnado que lo escoge mediante asamblea general, además en la evaluación se dan adhesivos para incentivar el trabajo cooperativo y la escucha a los compañeros. La presencia de voluntarios en el aula son por sí mismos otro elemento motivador para el alumnado. Así pues, a lo largo de las sesiones cada grupo va construyendo continuamente el aprendizaje de la temática que habían planteado y que quería aprender. El plan de trabajo permite al alumnado organizar y recoger los diferentes materiales e informaciones necesarias para la sesión.

C.4. Actividades globalizadoras: con esta práctica se potencia la globalización del aprendizaje a través de la participación en la búsqueda de los interrogantes previamente planteados por el propio alumnado. A lo largo de la sesión, el alumnado desempeña diferentes actividades que incluyen diferentes estrategias: organización del trabajo, desempeño de diferentes roles, discusión oral, escritura, dibujo, reflexión, exposición oral al gran grupo, etc. Durante la evaluación se proporciona feedback al alumnado sobre cómo ha trabajado tanto individual como grupalmente, sobre lo que ha aprendido y sobre lo que debería de realizar para mejorar.

C.5. Evaluación diversificada: en el momento de la evaluación se reflexiona sobre cómo se ha trabajado individual y grupalmente y se evalúa tanto en el proceso de aprendizaje como el producto. Se favorece la autoevaluación y la coevaluación, además se permite al voluntario participar en el proceso de evaluación. Este proceso propicia la igualdad evitando las clasificaciones y discriminaciones. Además de los conceptos, se evalúan los procedimientos y las actitudes. En la evaluación se propicia la reflexión, tanto individual como grupal, de cómo se ha trabajado, de los aspectos que han de mejorar, del trabajo pendiente, etc.

C.6. Gestión dialógica del aula: el voluntario provoca el intercambio y la comunicación entre todos los miembros del grupo. El ambiente, la organización y los recursos del aula contribuyen a la autonomía y responsabilidad del alumnado. Los problemas de conducta u organizacionales son comentados y reflexionados en la evaluación para ir fomentando poco a poco la mejora en proceso de enseñanza-aprendizaje. Los alumnos mediante la asamblea toman decisiones sobre su proceso de aprendizaje. 
C.7. Competencias de comunicación intercultural del profesorado: en esta práctica la maestra se encarga de facilitar y guiar a los grupos que lo necesitan, delegando todo el protagonismo en el alumnado y el voluntariado encargado de dinamizar cada uno de los grupos.

C.8. Desarrollo profesional y comunitario: a través de las reuniones entre la maestra y los voluntarios se adoptan las propuestas de mejora que se consideran, haciendo flexible la práctica educativa y reflexionando de manera colectiva sobre ella.

\section{Discusión y conclusiones}

La experiencia fue muy gratificante para todos los participantes (alumnos, maestra y voluntarios). Se consiguió una buena dinámica de trabajo y se observaron mejoras a medida que iban avanzando las sesiones tanto en el trabajo en grupo, como en la escucha y en los procesos de lectura y escritura. Cabe destacar que la eficacia de los grupos cooperativos se debe principalmente a la diversidad y complementariedad de las funciones de todos los miembros (Pujolàs, 2003). Además, hay que subrayar de esta práctica educativa el hecho de permitir tanto a las familias como a la comunidad participar en ella. Tal y como introducen Stainback y Stainback (1999), para que se dé una verdadera inclusión es imprescindible la interrelación familia-escuelacomunidad. Así pues, mediante la práctica descrita se contribuyó a una mayor inclusión tanto social como educativa en el aula, ya que se logró la participación y la cooperación de todos. Los alumnos valoraban muy positivamente la presencia de personas adultas en el aula. $Y$ es que, tal como revelan otras investigaciones, la presencia de voluntarios en el aula acelera el aprendizaje del alumnado (Vieira Parra y Puigdellivol, 2013). Para los voluntarios esta experiencia también fue muy enriquecedora. Por una parte estaban los padres, quienes podían observar como aprendían sus hijos y como interactuaban con sus compañeros. Las estudiantes de la universidad pudieron contactar con la realidad del aula y conocer y valorar las implicaciones organizativas, metodológicas y de clima del aula desde el marco de la respuesta a la diversidad, de manera que esta experiencia tuvo una gran repercusión en su formación.

¡TODOS! Alumnos, maestra y voluntarios compartieron lo que sabían y aprendieron:

- Sobre el proyecto de las tortugas: qué beben y qué comen, cómo nacen, los reptiles, dónde viven, cómo duermen, las partes de su cuerpo y del caparazón, qué diferencia hay entre los machos y las hembras y cómo respiran.

- Sobre el proyecto del agua: qué deportes se pueden practicar en el agua, hay agua en nuestro cuerpo, para qué utilizamos el agua, el agua en el planeta tierra, por qué hay olas en el mar, el ciclo del agua, cómo llega el agua a nuestras casas, las 
tres formas del agua: líquida, sólida y vapor y que no tiene sabor, color, ni olor.

Como limitaciones del estudio presentado, cabe destacar que solamente se ha analizado la dimensión $C$ de la guía CEIN y sería interesante abarcar también la dimensión $\mathrm{A}$ y $\mathrm{B}$ para reflexionar en torno a cuestiones relacionadas con cómo somos y cómo nos organizamos, e involucrar así a todo el centro escolar. Es importante reflexionar sobre estos aspectos para avanzar hacia una escuela intercultural e inclusiva donde todos puedan aprender y participar. Como futuras líneas de investigación, se podría seguir indagando sobre las percepciones de los implicados en la práctica educativa -alumnado, familias, miembros de la comunidad y la docente- a partir de entrevistas en profundidad.

A modo de cierre, cabe decir que en este trabajo se muestra una buena experiencia en la que con la participación conjunta del alumnado, la familia y los voluntarios se genera una educación de calidad, gracias a una docente innovadora que abre su aula permitiendo a las familias y la comunidad en general a que sean partícipes en la educación integral de sus alumnos.

\section{Referencias bibliográficas}

ARNálz, P. (2004): «La educación inclusiva: dilemas y desafíos». Educación, Desarrollo y Diversidad, 7 (2), p. 25-40

BEAUdoIn, N. (2013): Una escuela para cada estudiante. La relación interpersonal, clave del proceso educativo, Narcea, Madrid.

COHEN, E. G. (1999): Organizzare i gruppi cooperativi. Ruoli, funzioni, attività, Erickson, Trento.

Gómez MonTES, J. M. (2005): "Pautas y estrategias para entender y atender la diversidad en el aula», Pulso, 28.

Gregory, G. H. y C. Chapman (2007): Differentiated Instructional Strategies: One Size Doesn't Fit All, Corwin Press, Thousand Oaks, CA.

López Melero, M. (2004): Construyendo una escuela sin exclusiones: una forma de trabajar en el aula con proyectos de investigación, Ediciones Aljibe, Málaga.

MoriñA, A. (2008): La escuela de la diversidad, Síntesis, Madrid.

Pujolìs, P. (2003): Aprendre junts alumnes diferents. Equips d'aprenentatge cooperatiu a l'aula, Eumo Eidtorial, Vic.

PujolÀs, P. (2008): 9 ideas clave: El aprendizaje cooperativo, Graó, Barcelona.

Sales Ciges, A.; R. Ferrández Berrueco, O. Moliner García (2012): «Escuela intercultural inclusiva: estudio de caso sobre procesos de autoevaluación», Revista de Educación, 358, p. 153-173. 
Sales, A., O. Moliner y J. Traver (2010): La construcción de la escuela intercultural inclusiva desde procesos de investigación-acción. Servicio de Publicaciones de la Universitat Jaume I, Castelló.

SÁnCHEZ PALOMINO, A. Y J. CARIÓN (2002): «Una aproximación a la investigación en Educación Especial», Revista de Educación, núm. 327, p. 225-247.

StAInBACK y StAInBACK (1999): Aulas inclusivas, Narcea, Madrid.

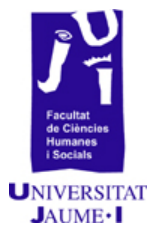

Vieira ParRa y Puigdellivol (2013): «¿Voluntarios dentro del aula?» REXE. Revista de Estudios y Experiencias en Educación, 12 (24), p. 37-55.

WALKER, R. (1983): "La realización de estudios de casos en educación. Ética, teoría y procedimientos", Dockrell W. B. y D. HAMILTON, Nuevas reflexiones sobre la investigación educativa, Narcea, Madrid, p. 42-82.

Woods, P. (1987): La escuela por dentro. La etnografía en la investigación educativa, Paidós, Barcelona. 


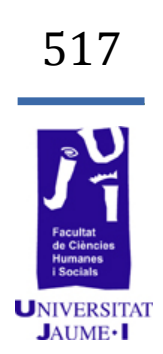

Cambios en las rutinas periodísticas de producción y elaboración de la información en los gabinetes de comunicación de las instituciones locales: el caso de la provincia de Castellón

Alberto E. López Carrión alberto.lopez@alumail.uji.es 
Con los avances en las nuevas tecnologías ha aparecido una serie de herramientas en la escena comunicativa: redes sociales, teléfonos de última generación con conexión a internet, aplicaciones de mensajería instantánea entre móviles, salas de prensa virtuales... Todas ellas facilitan la comunicación no sólo entre gabinetes y periodistas, sino también con los ciudadanos. Los gabinetes de comunicación de las instituciones públicas han visto las posibilidades de todas estas herramientas y las han incorporado a su actividad comunicativa. Este trabajo pretende analizar cómo los gabinetes de comunicación de las principales instituciones públicas de Castellón han incorporado estas nuevas herramientas y qué dinámicas siguen tanto a la producción de una información como a su difusión. Para conseguir este objetivo se ha difundido una encuesta entre los gabinetes de comunicación de los municipios con más de 10.000 habitantes, además de la Diputación de Castellón, en la que se les pregunta por sus rutinas productivas y la difusión de sus contenidos. Por otra parte, se ha querido conocer el punto de vista de los profesionales de la información, por lo que la opinión de los medios de comunicación referentes de Castellón sobre estas nuevas herramientas también aparece reflejada en este estudio. En los resultados veremos que muchos gabinetes actualizan su web y redes sociales de manera constante y que buscan facilitar lo máximo posible el trabajo al periodista, suministrándole mucha información de alta calidad en el menor tiempo posible.

Palabras clave: gabinetes de comunicación, comunicación institucional, nuevas herramientas comunicación, cambios rutinas periodísticas, Castellón.

\section{Introducción}

En los últimos años el sector de la comunicación se ha visto seriamente afectado por la crisis que ha afectado a las economías globales, un fenómeno que ha acelerado su renovación. La comunicación como la conocíamos hasta el momento ha cambiado. Cada vez hay menos periodistas en las redacciones de los medios de comunicación pero, al contrario, cada vez más empresas se esfuerzan en cuidar su imagen y los departamentos de comunicación van cobrando importancia. Las instituciones públicas se han sumado a esta tendencia y desde el ayuntamiento más pequeño hasta el de una capital de provincia, cualquier localidad ya cuenta con una página web en la que difunde públicamente su actividad diaria. Recientemente ha aparecido una serie de herramientas tecnológicas que han cambiado por completo el alcance de la comunicación de estos gabinetes de prensa: redes sociales, salas de 
prensa virtuales, aplicaciones para móviles... El alcance de la comunicación institucional ha ampliado su horizonte gracias a estas nuevas herramientas, conocidas como Tecnologías de la Información y la Comunicación (TIC) y, en este estudio, se pretende ver cómo han afectado a las corporaciones públicas locales: cambios en cuanto a acceso a las fuentes, búsqueda de la inmediatez o calidad en la información... Existen pocos trabajos que investiguen la comunicación de las instituciones locales de Castellón, y este documento pretende arrojar un poco de luz sobre este hecho y contribuir a que se vean reflejados todos los avances -y también aquellas cuestiones a mejorar- de las TIC en los ayuntamientos más poblados de la provincia de Castellón, así como en la Diputación provincial.

\section{Objetivos}

Este estudio propone los siguientes objetivos: en primer lugar, investigar los efectos derivados de los cambios en la producción de la información, debido al auge de las nuevas tecnologías. Sobre esta cuestión se plantea la hipótesis de que existe un alto porcentaje de gabinetes de prensa que actualizan su portal corporativo y redes sociales frecuentemente.

En segundo lugar, estudiar cómo los periodistas de los medios de comunicación acceden a la información proporcionada por las instituciones públicas locales. Sobre este aspecto se plantea la hipótesis de que los últimos avances tecnológicos han mejorado su acceso a la información.

En tercer lugar, demostrar la búsqueda de la instantaneidad a la hora de publicar noticias por parte de los gabinetes de prensa de las instituciones locales. Sobre esta cuestión se plantea la hipótesis de que la mayoría de gabinetes de prensa de las entidades locales castellonenses ofrecen contenidos propios en directo tanto a los medios de comunicación como a la ciudadanía.

En cuarto y último lugar, dejar patente el auge de las redes sociales en la comunicación local respecto a otros canales más clásicos como el correo electrónico, el fax o la llamada telefónica. En este sentido, se plantea la hipótesis de que el primer paso que se da desde el gabinete de comunicación a la hora de publicar un contenido es la difusión a través de las redes sociales.

\section{Material y método}

Para la elaboración de este estudio se ha optado por escoger técnicas cualitativas y cuantitativas, expuestas a continuación. En los siguientes epígrafes, se detalla también el objeto de estudio de esta investigación, analizando diversas perspectivas teóricas de otros autores y autoras. 


\subsection{Enfoque cualitativo}

En cuanto a las primeras técnicas, las cualitativas, parten de la base de una metodología interpretativa, que «pretenden recoger el significado de la acción de los sujetos. Se prima el sentimiento o las razones que tiene un individuo para realizar una acción concreta sobre la cantidad de veces que se realiza dicha acción» (Berganza Conde, Ruiz San Román, 2005: 32). Para la realización de este estudio se ha enviado a los medios de comunicación más destacados de la provincia de Castellón una breve entrevista por correo electrónico para que la respondan voluntariamente. Es la técnica más acertada porque, tal y como se recoge en la definición expuesta por Berganza Conde y Ruiz San Román, el encuestado responderá reflejando su propia interpretación de los hechos. Sobre la muestra utilizada, se envió a once periodistas de diferentes medios de comunicación (ver Tabla 1), concretamente al responsable de la sección dedicada a la información local, de los cuales tres medios decidieron abstenerse de participar (El Mundo Castellón al Día, Radio CastellónCadena SER y La Plana al Día):

\begin{tabular}{|c|c|c|c|}
\hline Persona & Medio de comunicación & Tipo de medio & ¿Participa? \\
\hline Daniel Nager & El Periódico Mediterráneo & Prensa escrita & sí \\
\hline Pepe Beltrán & Levante de Castelló & Prensa escrita & sí \\
\hline Quique Rodríguez & COPE Castellón & Radio & si \\
\hline Lorena Pardo & Onda Cero Castellón & Radio & sí \\
\hline Antonio Felip & RTVE Castellón & Radio/Televisión & si \\
\hline Javier Ruiz & Televisión de Castellón & Televisión & si \\
\hline Antonio García & Castellón Diario & Digital & sí \\
\hline Ximo Tirado & Castellón Información & Digital & sí \\
\hline
\end{tabular}

Como se puede observar, en la tabla aparecen los medios más consumidos en la provincia de Castellón según la Oficina de Justificación de la Difusión (OJD) de los distintos tipos de medios (prensa escrita, radio, televisión...), por lo que se puede considerar una muestra suficientemente representativa, algo útil cuando (Quivy, Van Campenhoudt, 1997: 158-159):

la población es muy numerosa y hay que recoger muchos datos sobre cada individuo o unidad o cuando, por algunos aspectos especialmente importantes para el investigador, conviene recoger una imagen que globalmente refleje la que obtendríamos si interrogáramos a todo el conjunto de la población 


\subsection{Enfoque cuantitativo}

En cuanto a las técnicas cuantitativas (Berganza Conde, Ruiz San Román, 2005: 32):

parten de considerar el hecho de que a las Ciencias Sociales pueden aplicárselas los principios de las Ciencias Naturales. Tratan de resumir la realidad en números. Enlazan con el paradigma positivista y, por tanto, con el enfoque explicativo, debiendo usarse en aquellos casos en que se necesite un análisis en extensión y generalizador, dándose énfasis a la búsqueda de la causalidad y la validación de la teoría.

Se ha optado, para la elaboración de este estudio, por enviar a diversos los departamentos de comunicación de distintos ayuntamientos y entidades locales de la provincia de Castellón una encuesta a través de correo electrónico. Sobre el contenido del cuestionario, está organizado en cuatro baterías de preguntas, con un total de 21 cuestiones. La primera batería es sobre la estructura del gabinete de comunicación (número de trabajadores, subdepartamentos...); la segunda batería, sobre herramientas de comunicación (sobre si cuentan o no con un perfil en las distintas redes sociales, uso de newsletter o de la sala de prensa virtual...); la tercera batería, sobre la actualización de contenidos (grado de actualización y frecuencia de envío de información a los medios...) y la cuarta batería de preguntas, sobre los cambios introducidos por las nuevas TIC. Sobre este tipo de cuestionarios a través de internet, Wimmer y Dominik afirman que «en general es poco costoso y muy fácil de manejar porque los investigadores nunca tienen que dejar la oficina» (Wimmer, Dominik, 2001: 184). No obstante, como desventajas, los dos autores citan varias (Wimmer, Dominik, 2001: 185), como que:

no existe una manera de asegurar que la persona reclutada sea realmente quien llena el cuestionario [...]. La investigación por internet, como cualquier otro procedimiento electrónico de recopilación de datos, no permite el control sobre los procedimientos.

También pretende ser representativa la muestra elegida para las baterías lanzadas a los gabinetes de comunicación de los distintos entes locales de la provincia de Castellón. Siguiendo el criterio de la población, se ha optado por escoger aquellos municipios con una población superior a los 10.000 habitantes, que son los siguientes: 
TABLA 2: Muestra para el trabajo de campo

\begin{tabular}{|l|l|l|}
\hline \multicolumn{2}{l}{ TABLA 2: Muestra para el trabajo de campo } & ¿Participa? \\
\hline Lunicipio & Población (INE 2013) & Sí \\
\hline Almassora & 10.797 habitantes & Sí \\
\hline Benicarló & 26.186 habitantes & Sí \\
\hline Benicàssim & 26.491 habitantes & Sí \\
\hline Burriana & 18.989 habitantes & Sí \\
\hline Castellón de la Plana & 34.744 habitantes & Sí \\
\hline Nules & 180.185 habitantes & Sí \\
\hline Onda & 13.573 habitantes & Sí \\
\hline La Vall d'Uixó & 25.572 habitantes & Sí \\
\hline Vila-real & 32.202 habitantes & Sí \\
\hline Vinaròs & 51.180 habitantes & Sí \\
\hline
\end{tabular}

Además de los once municipios encuestados (se registró un $100 \%$ de participación en el cuestionario), también se ha incluido en el estudio a la Diputació de Castelló que, pese a no ser el ayuntamiento de una localidad en concreto, es también un organismo de carácter municipal (frecuentemente conocido como "ayuntamiento de ayuntamientos) que aglutina a la población de toda la provincia.

En cuanto a la muestra escogida, y teniendo en cuenta que la población de Castellón es de 601.600 habitantes en 2013 (según el Instituto Nacional de Estadística), se puede ver que es suficientemente representativa, ya que si sumamos la población de los once municipios (448.748 habitantes), la cifra resultante supone más del $50 \%$ de la población total castellonense.

Un buen punto de partida para el marco teórico para este trabajo es el concepto de "periodismo de fuente» o «información de fuente», para el cual puede resultar complejo establecer una concepción teórica que lo defina con exactitud. En la Revista Latina de Comunicación Social podemos encontrar una reseña de Concha Mateos Martín sobre la obra EI periodismo de fuente (Losada Vázquez, Esteve Ramírez, 2003), en la que define este concepto como la práctica periodística que intenta superar "la polaridad tradicional en la teoría de la información» entre los medios informativos y las fuentes informativas. Con el periodismo de fuente se redefinen las fronteras conocidas del periodismo y, a modo de "vuelta de tuerca», su ámbito de aplicación va más allá de las funciones tradicionales de los medios de comunicación de masas. De este modo, no sólo el periodista ejerce su profesión cuando, después de una ardua tarea de búsqueda de información y contraste de fuentes, da forma a un mensaje periodístico en uno de los tantos soportes en los que puede llegar a su audiencia, sino que también se es periodista cuando trabaja para una fuente y, según Mateos Martín (2003):

para dar forma, contenido, estructura, expresión y continuidad a una fuente informativa institucional [...] siempre que siga anteponiendo los criterios de veracidad e interés de la audiencia, por encima de los imperativos de persuasión de la entidad. 
Si la tarea informativa fuera así, pasaría de ser periodística a ser corporativa.

\subsection{Objeto de estudio de la investigación}

\subsubsection{Los gabinetes de comunicación como fuentes informativas}

El gabinete de prensa de una empresa o institución es el órgano o sede por excelencia del periodismo institucional. Ana Almansa afirma que la evolución de estos gabinetes ha sido paulatina (Almansa, 2011: 36):

Primero fue el nacimiento de una profesión (las relaciones públicas) y después la creación y consolidación de estructuras organizadas y con funciones específicas (lo que entendemos por gabinetes de comunicación.

Marta González San Ruperto marca el inicio de los gabinetes de prensa en empresas e instituciones bien entrada la transición española, afirmando también que entre 1995 y 2005 se habría producido un auténtico boom que la habría convertido a los gabinetes de prensa en una nueva salida profesional para periodistas (González San Ruperto, 2006). En esta línea, Almansa recuerda que al final del franquismo las únicas fuentes válidas eran las propias instituciones públicas, y que en la transición las fuentes informativas se multiplican: «nacen nuevas fuentes y va a ser más compleja la distribución de información» (Almansa, 2011: 41). Sobre los valores que definen a estos departamentos después de afirmar que "cada gabinete es un mundo y varían sus prioridades y su eficacia» (González San Ruperto, 2006: 664), les atribuye la credibilidad como el verdadero valor que los define. A pesar de que en muchas ocasiones, los departamentos de prensa y comunicación son acusados de censuradores o de impedir el acceso a ciertos datos que pueden ser de interés público también dice que «lo que hace bueno a un gabinete y a un director de comunicación es su credibilidad, su respeto a la verdad» (González San Ruperto, 2006: 664) o, en otras palabras, siempre debe respetar la labor del periodista de redacción en su búsqueda de información. Nunca jamás le debe mentir, si bien se puede dar a los medios de comunicación la información que el gabinete de prensa esté autorizado a proporcionar, pese a que tenga unos límites marcados. Sobre los profesionales que lo integran, afirma que «se hace necesaria la presencia de periodistas que organicen su funcionamiento, aunque pueden y deben estar apoyados por otros profesionales (abogados, financieros, comerciales, expertos en marketing" (González San Ruperto, 2006: 665-666). En las corporaciones públicas locales, lo más común hasta hace poco tiempo es que el responsable o director de comunicación de una entidad local sea un funcionario o, en las localidades con menor población, el secretario del alcalde o alcaldesa, una tendencia muy instaurada.

¿Cuáles son los servicios que ofrece un gabinete de prensa? La Asociación de Empresas Consultoras en Relaciones Públicas y 
Comunicación (ADECEC) publicó en 2004 un estudio titulado «La Comunicación y las Relaciones Públicas. Radiografía del sector 2004» en el que, por este orden, se distinguen las siguientes actividades como las más desempeñadas en los gabinetes de comunicación: relación con los medios de comunicación, comunicación corporativa, relaciones institucionales, la comunicación de marketing o la relación con la comunidad geográfica, entre otros. Siguiendo con nuestro estudio de los departamentos de prensa, que con el paso de los años han ido ganando importancia para los que tienen el control de la empresa o institución, en ellos trabajan profesionales de la información que guardan algunas diferencias con los periodistas de los medios de comunicación. El porqué de todas sus funciones equivale al porqué del periodismo institucional. Del mismo modo que es importante que los medios de comunicación masivos mantengan informadas a sus audiencias con el mayor rigor y rapidez posibles, también es importante que las empresas e instituciones comuniquen, con un lenguaje y unos contenidos diferentes a los habituales, su actividad diaria. Esta función de información adquiere más importancia, si cabe, cuando las empresas e instituciones son de carácter público, que es el principal objeto de estudio de este trabajo.

María José Canel habla de que la comunicación de la institución pública es un proceso de carácter estratégico, ya que «tiene un horizonte: se aspira a producir el cambio en una determinada dirección» (Canel, 2007: 31). La autora pone como ejemplo que la comunicación muchas veces va dirigida a que los políticos se ganen una buena imagen comunicando sus acciones en el gobierno (Canel, 2007). Por otra parte, y citando a Martín Algarra, María José Canel también cita el carácter transaccional de la comunicación de las instituciones públicas: «el producto no hace posible interpretar cuál es la intención de quien se comunica» (Martín Algarra, 2003, citado en Canel, 2007: 71-72). Por último, cabe recordar que los gabinetes de comunicación se enmarcan en lo que conocemos como periodismo institucional, que según dice Cebrián Herreros (2012: 22):

tiene un objetivo no lucrativo. Busca la rentabilidad social y cultural, y en los casos en que las instituciones obtienen rendimiento económico reinvierten los beneficios en otras actividades sociales y culturales, no en otros negocios

En otras palabras, las organizaciones públicas o privadas, a pesar de no ser medios de comunicación, han de informar sobre su actividad al resto de la sociedad sin perseguir el beneficio económico, sino buscando el servicio público.

\subsubsection{Los gabinetes de prensa de las instituciones públicas. Una alternativa en la profesión periodística}

Es momento de centrarse, en esta parte del trabajo, en estos departamentos en el ámbito de las instituciones públicas. Goretti Palau habla sobre los gabinetes de medios en la administración pública. Bajo su 
punto de vista, en la Administración la diversidad de funciones y de medios que tiene a su disposición el periodista es mucho más amplia, y distingue, por una parte, "las grandes áreas de la administración central, como la presidencia del gobierno o los ministerios, que acostumbran a tener grandes estructuras con unas funciones delimitadas y que destinan una gran cantidad de recursos a la comunicación» (Palau Sicart, 2002: 29) $\mathrm{y}$, por otra parte, «los ayuntamientos o administraciones locales que apenas pueden tener un periodista, que hace lo que puede con los escasos recursos de los que dispone» (Palau Sicart, 2002: p. 29). Berta García Orosa distingue varias características de la comunicación de la Administración Pública, como que tiene que ser contextualizada, de carácter público, tiene que informar obligatoriamente de todo, ser transparente, orientada al ciudadano, que acerque la Administración al receptor de sus mensajes y que produzca mensajes específicos dirigidos a sus públicos (García Orosa, 2005: 159-160). Más adelante, la autora también menciona las dos tareas importantes que destacan dentro de la actividad diaria de la comunicación en estos gabinetes: las relaciones informativas y la comunicación con los ciudadanos (García Orosa, 2005). González San Ruperto hace una radiografía de los departamentos de prensa de las instituciones públicas locales, y afirma que «cada vez son más los Ayuntamientos que cuentan con un responsable de comunicación» (González San Ruperto, 2006: 667). Ahora bien, también habla de que "estos gabinetes aún están poco profesionalizados y, en muchas ocasiones, las personas encargadas de ellos no tienen los conocimientos mínimos imprescindibles para desarrollar su labor» (González San Ruperto, 2006: 667), algo que es debido, fundamentalmente, a una tendencia instaurada en los departamentos de prensa en los que la persona que se pone al frente es un funcionario y no un periodista debidamente cualificado.

¿Qué denominación exacta definen estos entes? Suelen ser muy variadas. Berta García Orosa (2005: 221) cita varias, como «Gabinete de Prensa, Departamento de Prensa, Gabinete de Comunicación, Técnico Municipal de Comunicación, Secretario de Prensa...». En la obra de esta autora también podemos observar tres gráficos que aportan luz sobre estos gabinetes: en cuanto al tipo de comunicación, el $78 \%$ es comunicación externa y el $22 \%$ comunicación interna: en cuanto al tipo de gabinete, el $40 \%$ se define como Gabinete de Comunicación, un $50 \%$ como Gabinete de Prensa y un $10 \%$ como Gabinete de Prensa y Relaciones Públicas. Y en cuanto a los trabajadores del gabinete, en el $78 \%$ de los casos sólo trabaja una persona (es unipersonal), en el $11 \%$ dos personas, y en otro $11 \%$ de los casos trabajan más de dos personas. Por otra parte, sobre la esfera de la comunicación corporativa en el ámbito local, González San Ruperto incide en su potencial ya que «es la más próxima al ciudadano, a sus problemas, inquietudes y necesidades». Más adelante podremos observar en los resultados de las encuestas realizadas en el ámbito de la provincia de Castellón, a propósito de este trabajo, cómo la comunicación en las instituciones locales tiene un gran 
margen de mejora. Ana Rosa Sanfeliu (2006) establece tres vertientes de los gabinetes de comunicación local: servicio público, carácter político y potenciadores de la democracial. Por último, también Sanfeliu (2006) habla de una tendencia actual en los gabinetes de comunicación: la incorporación de las nuevas tecnologías a la comunicación pública y la utilización de la imagen de la ciudad como producto para vender. En los siguientes apartados profundizaremos en estos conceptos.

\subsubsection{La generación de contenidos en las Administraciones Públicas}

Es el turno ahora de analizar cuáles son los contenidos generados en los departamentos de prensa y las rutinas que se siguen a la hora de producir dichos contenidos informativos. Fabrizio Muzzati (2006) propone los siguientes canales para hacer llegar la información a los medios de comunicación: contacto directo con los periodistas, notas de prensa y comunicados y ruedas de prensa. Sobre este último aspecto, Sonia González Molina (2012) habló sobre la digitalización de las oficinas de prensa a partir del caso concreto del Servei Català de Trànsit (SCT). Enumeró las vías con las que cuenta este departamento, a día de hoy, para producir y distribuir contenidos informativos: el teléfono fijo y móvil, internet (página web corporativa, correo electrónico, sala de prensa virtual y redes sociales), fibra óptica y dispositivos de almacenaje externo, como el DVD o los USB (González Molina, 2012). Gracias al auge de las nuevas tecnologías, la distancia es cada vez menos un obstáculo para la intermediación entre los gabinetes de prensa y los periodistas, algo que se agradece aún más en circunstancias difíciles como la actual crisis económica, y las consecuencias fatales que ha tenido en el sector de la comunicación.

Volviendo a las tesis de Fabrizio Muzzati, también habló de los principales problemas del día a día que vivió en su departamento, que se pueden hacer perfectamente extensibles al resto. En primer lugar, habla de la falta de medios o, como recalca Muzzati, la desproporción de los medios, en referencia a la gran cantidad de publicaciones que, cada mañana, hay que repasar todo lo que haga referencia a nuestra institución y decidir si se da, o no, una respuesta. Otro problema dentro de los gabinetes de prensa son las filtraciones, tanto internas como externas. Muzzati define las filtraciones como «mensajes que se están lanzando al margen de tu estrategia de comunicación» (Muzzati, 2006: 90), a lo que añade que sólo por ser una filtración suele tener éxito: «la información clandestina es la que mejor compra un periodista en el momento en el que sabe que no es la oficial» (Muzzati, 2006: 90). El último problema que describe Fabrizio Muzzati es las ofensivas que se reciben continuamente si no ocupas un puesto de poder, es decir, que las notas de prensa de los grupos de la oposición serán bombardeadas, en palabras textuales de Muzzati, desde distintos frentes. El ponente añadió (Muzzati, 2006: 92):

que nuestro trabajo consiste en estar todo el día intentando reconducir las situaciones, ver por dónde van las tendencias, quién ha dado el mensaje y cómo 
solucionar o cómo conseguir que tu propuesta llegue a su fin, es decir, que se haga

Como concluye el exresponsable de comunicación del PSPV-PSOE en su intervención en el $\mathrm{V}$ Congreso de Comunicación Local, que también nos sirve para concluir este apartado, el mensaje final o producto periodístico que recibe las audiencias locales se nos escapa un poco de las manos. Esto se debe a que en nuestro país existe el fenómeno del bipartidismo y, desde los gabinetes de prensa locales de ambos bandos, se emiten contenidos corporativos, notas de prensa, comunicados y más mensajes que, según qué partido controle a cierto medio de comunicación, el tratamiento que recibe nuestra información es distinto.

\subsubsection{El portal corporativo, epicentro de la comunicación de las instituciones locales}

Dentro de los muchos canales con los que las corporaciones locales se comunican con sus ciudadanos, es evidente que el canal central que aglutina todos los servicios que ofrece un ayuntamiento es la página web corporativa del mismo. Este contenido, generado habitualmente por el departamento de comunicación de la entidad, se diferencia de los canales mencionados en el punto anterior en que no va dirigido a los periodistas exclusivamente, sino que se ofrece como servicio público a los ciudadanos de la localidad.

Miguel Ángel Vázquez Burgos (2004) distingue los elementos habituales o comunes en los portales web corporativos, que aquí aplicaremos al de las instituciones públicas locales: mensajes corporativos de salutación, direcciones de contacto, información sectorial genérica, información estadística, directorios, archivo de notas de prensa, archivo de artículos y discursos de los representantes del ayuntamiento y vínculos relacionados. Siguiendo con el análisis de los portales corporativos de las instituciones locales, Vázquez Burgos habla también, en su obra, de que la web corporativa perfecta será «aquella que responde a la totalidad de las preguntas de la totalidad de los visitantes» (Vázquez Burgos, 2004: 79). Por otra parte, siempre han sido un elemento de imagen muy importante, pero si en un principio eran muy estáticas y existían más por obligación que por otro motivo, en los últimos tiempos se ha producido un crecimiento de forma exponencial en la cantidad de contenidos, servicios y aplicaciones municipales accesibles por el ciudadano a través de internet. Sobre este asunto, entra en escena el concepto de la eadministración, un término con el que Comisión Europea de la Unión Europea define a los que se conoce como Administración Electrónica:

La Administración electrónica es el uso de las TIC en las Administraciones Públicas, combinado con cambios organizativos y nuevas aptitudes, con el fin de mejorar los servicios públicos y los procesos democráticos y reforzar el apoyo a las políticas públicas. 
Leopoldo Seijas Candelas distingue dos fases en la evolución de estos portales web: en una primera fase los servicios que se ofrecían se limitaban a "proporcionar información de interés para el ciudadano» (Seijas Candelas, 2005: 464) mientras que, en una segunda fase, "se evolucionó para permitir la posibilidad de realizar trámites telemáticos» (Seijas Candelas, 2005: 464), incrementando el grado de interactividad con el ciudadano. Más adelante, Seijas Candelas profundiza en este aspecto, que ha sido posible bajo su punto de vista gracias a tecnologías como la fibra óptica o la tecnología inalámbrica y, cambiando de tercio, tiene un rendimiento político importante, ya que supone un ahorro de costes importante para el Ayuntamiento.

\subsubsection{Nuevas herramientas de comunicación en las Administraciones Públicas locales}

A continuación se exponen los principales cambios tecnológicos que han experimentado estos departamentos, es decir, cómo han afectado la entrada de nuevas Tecnologías de la información y la Comunicación (TIC) en el ámbito periodístico de las corporaciones públicas locales.

Berta García Orosa, en su libro Gabinetes de comunicación on-line. Claves para generar información corporativa en la red (2009) habla de los aspectos positivos y negativos de la digitalización de estos departamentos. Como puntos fuertes, «las innovaciones tecnológicas actuales que facilitan el trabajo del periodista, la rapidez en la comunicación con las fuentes y con el lector, y la accesibilidad a un mayor número de información» mientras que cita como puntos débiles «la pérdida del contacto humano y la proliferación del denominado "periodismo de despacho"» (García Orosa, 2011: 22).

Antes de sumergirnos en la gran cantidad de herramientas y aplicaciones que han revolucionado la comunicación de los Ayuntamientos, hay que introducir el concepto de Gobierno Abierto u Open Government. Noa María Carballa Rivas, directora de comunicación de la Universidad Pontificia de Salamanca, cita en su texto "La Comunicación 3.0 en el Gobierno Abierto: las redes sociales como estrategia de comunicación para la información para la información cotidiana» (2012) la definición de Gobierno Abierto que Calderón, César y Lorenzo, y Sebastián dan en su obra Open Government - Gobierno Abierto (2010), que dice así (Calderón, César y Lorenzo, Sebastián, 2010):

Un Gobierno Abierto es aquel que entabla una constante conversación con los ciudadanos con el fin de oír lo que ellos dicen y solicitan, que toma decisiones basadas en sus necesidades y preferencias, que facilita la colaboración con los ciudadanos y funcionarios en el desarrollo de los servicios que presta y que comunica todo lo que decide y hace de forma abierta y transparente.

De esta definición conviene destacar algunos términos, tales como conversación, ciudadanos, necesidades, preferencias, colaboración, abierta o transparente, que responden a por qué las nuevas tecnologías 
Alberto E. López Carrión. Cambios en las rutinas periodísticas de producción y elaboración de la información en los gabinetes de comunicación de las instituciones locales

han revolucionado la comunicación. Uno de los fenómenos que cabe destacar en este aspecto es el de las redes sociales que, precisamente, han fomentado la conversación entre instituciones y ciudadanos.

En el texto de Carballa Rivas (2013), la autora ya habla de que las instituciones públicas «quieran hacer llegar un mensaje con eficacia a la ciudadanía, cuenten con una política informativa clara y con estrategias de comunicación, contando con Internet como eje fundamental» (Carballa Rivas, 2013: 176) añadiendo, además, la importancia de las redes sociales que, bajo su punto de vista, "se han convertido en uno de los escenarios donde los debates en torno a la actividad del Gobierno se desarrolla con más frecuencia» (Carballa Rivas, 2013: 177).

García Pastor (2005) habla en su trabajo de investigación de doctorado de los nuevos lenguajes que se han introducido gracias a las Tecnologías de la Información y Comunicación (TIC). En cuanto a cómo han influido en los gabinetes de prensa municipales, la autora enumera los siguientes cambios y/o avances: instantaneidad, información multimedia, actualización dinámica, interactividad y personalización de la información, información on-line, hemerotecas on-line y documentación y almacenamiento. Gracias a las nuevas tecnologías, cada vez es más fácil almacenar y compartir una información.

Por último, cabe destacar una herramienta que en los últimos tiempos se ha ganado una gran popularidad entre usuarios e instituciones: la plataforma de microblogging Twitter que permite el envío de mensajes de hasta 140 caracteres. González Molina (2013) dedica a esta plataforma el estudio «El uso de Twitter en el entorno del Periodismo Institucional 2.0: estrategias cross-media y diálogo informativo" (2013), en el que concluye que en el ámbito del periodismo institucional su uso «descansa en una estrategia basada en reutilizar los contenidos disponibles en la web, sin apenas adaptaciones» y, por otra parte, que «si bien las estrategias comunicativas implementadas por el gabinete a través de Twitter eluden la conversación con el público con los usuarios, no renuncian a generar comunidad acumulando seguidores y generando retuiteos» González Molina, 2013: 155).

\section{Resultados}

"

Preguntados periodistas tanto de los diferentes gabinetes de comunicación municipales como los profesionales de las principales redacciones de la provincia de Castellón sobre este aspecto, se han obtenido los resultados expuestos a continuación.

\subsection{Sobre la estructura del gabinete de comunicación}

Preguntados sobre diversos aspectos de la estructura del gabinete de comunicación, casi la totalidad de los encuestados afirma que su ayuntamiento cuenta con un gabinete como tal, es decir, que cuenta con al menos un profesional que trabaja aspectos de comunicación desde 
dentro de la institución. Eso sí, al preguntar de cuántos trabajadores dispone el gabinete, en siete casos -que son, como salta a la vista, la mayoría- es tan sólo una persona la que trabaja en el gabinete de comunicación, por lo que se puede observar que esta estructura unipersonal en los gabinetes de comunicación de las instituciones públicas locales es la tendencia dominante. ¿Es esta estructura suficiente, teniendo en cuenta las necesidades informativas de ciudadanos y periodistas? Mientras que los representantes de los gabinetes castellonenses se muestran algo divididos sobre este asunto (siete creen que sí, y cinco encuestados piensan que no es el número adecuado), Daniel Nager, de El Periódico Mediterráneo, relaciona este hecho con la fuerte implantación de las nuevas tecnologías en la actividad del gabinete de prensa: todo es en función del tamaño de los consistorios y de los recursos de que disponen. Otra característica que es también "denominador común» de todos los gabinetes -y más después de lo que se ha expuesto en las últimas líneas - es que la actividad comunicativa se gestiona desde un único departamento. De hecho, en algunos cuestionarios la persona responsable del gabinete de comunicación matiza que la comunicación se trabaja desde la propia alcaldía (ya sea un teniente de alcalde, secretario de alcaldía, etc.) que, en la mayoría de casos, no cuenta con la titulación o formación apropiadas. Por último sobre aspectos de estructura y funcionamiento, para este estudio se pidió a los encuestados ordenar del 1 al 5 los pasos seguidos para hacer público un contenido informativo. Si obtenemos la media de cada paso, vemos que el proceso (ver Gráfico 1 ) comienza con el envío del pertinente correo corporativo a los medios de comunicación (1,25 de media), seguido de la publicación en el portal web oficial de la institución pública (2,42 de media). El proceso prosigue con la difusión a través de los distintos perfiles en redes sociales (2,67 de media), la publicación de contenidos en la sala de prensa virtual (4,17 de media) y el envío de newsletter (4,50 de media).

GRÁFICO 1: Orden de prioridades de los gabinetes de prensa de las instituciones locales

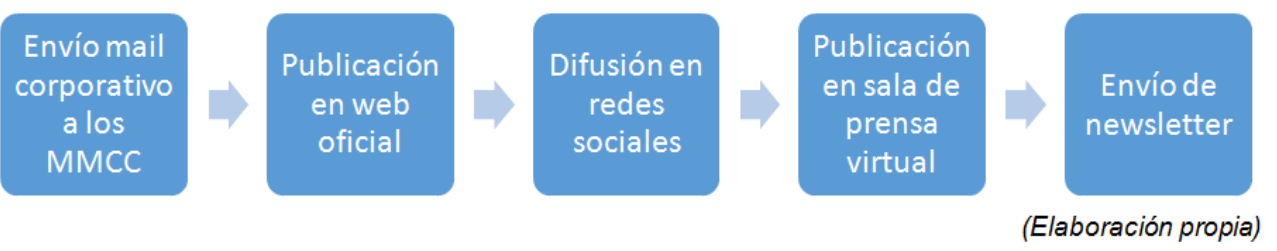

\subsection{Sobre herramientas de comunicación}

Sobre las herramientas de comunicación que se utilizan en los gabinetes de prensa, existe una clara unanimidad en cuanto a que la existencia de un portal municipal corporativo se antoja fundamental (las doce instituciones encuestadas disponen de uno), y prácticamente este porcentaje se repite al preguntar si disponen de un perfil oficial en una o varias redes sociales. 


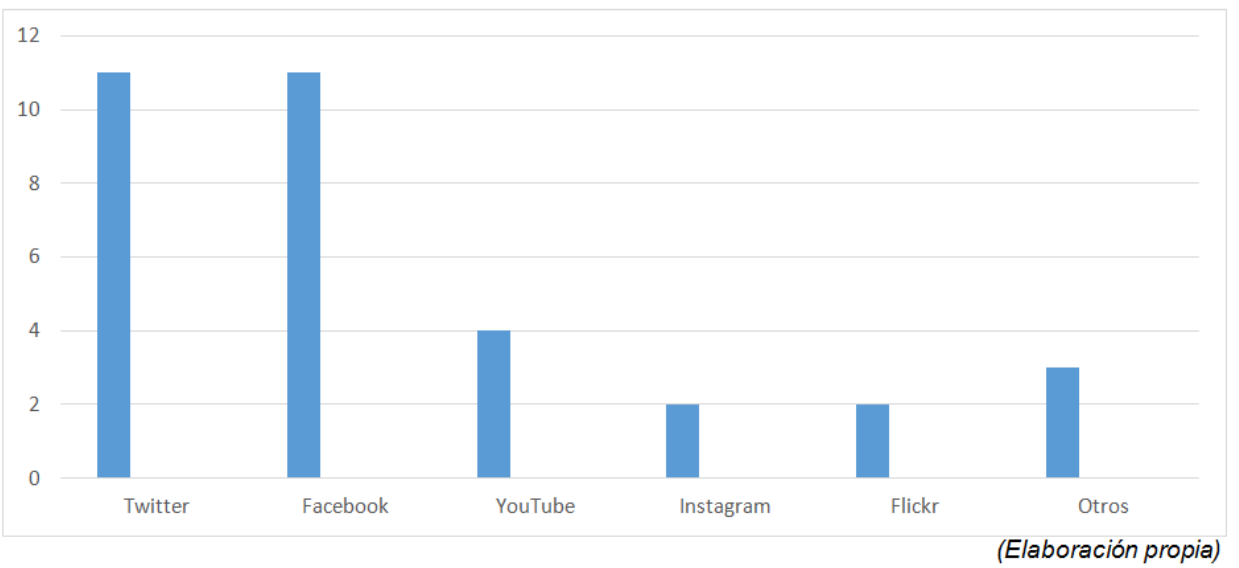

Como se puede ver en el anterior gráfico, preguntados por las redes sociales que emplean los gabinetes de las instituciones locales para difundir contenidos informativos, Twitter y Facebook lideran a partes iguales esta parcela informativa, seguidos de YouTube, con tan sólo cuatro de las doce principales instituciones públicas locales de la provincia de Castellón, y ya en un segundo plano otras redes sociales como Instagram, Linkedin, Flickr, Soundcloud o Google+. Quique Rodríguez, de COPE Castellón, alaba el avance que ha supuesto para los periodistas radiofónicos las redes sociales pues:

ayuda a que, en ocasiones, se pueda reflejar una noticia o cualquier situación que esté pasando sin necesidad de que, por ejemplo, los servicios de emergencia, tengan que redactar una nota de prensa para remitir si están trabajando en algún incendio o se ha producido un accidente.

Lo hace en referencia a que se ha reducido considerablemente el tiempo que transcurre desde que se produce una noticia hasta que ésta sale a la luz. Como demuestran los resultados de la encuesta realizada a los principales departamentos de prensa de la provincia de Castellón, dos herramientas que todavía no se ha extendido su uso son las salas de prensa virtuales (con acceso restringido para periodistas y medios de comunicación) y el newsletter, ya que son más los gabinetes que no las utilizan (un $80 \%$ de los casos) a los que sí lo hacen. La emisión de contenidos en directo tampoco es una práctica muy extendida, ya que ningún departamento de comunicación difunde las ruedas de prensa de los principales líderes políticos de la provincia en tiempo real, aunque algunos representantes matizan que los plenos de algunos ayuntamientos sí que se difunden en directo a través de alguna televisión local, pero no en un canal del propio gabinete. En cambio, la práctica totalidad de los organismos encuestados (diez de los doce encuestados) facilitan la grabación de actos institucionales y ruedas de prensa a los medios de comunicación para que puedan difundirlos a sus respectivas audiencias. Por otra parte, las cifras del estudio demuestran que la mitad de las instituciones encuestadas sí que pone a disposición de sus ciudadanos 
estos contenidos informativos. Javier Ruiz, presentador y responsable de informativos de Televisión de Castellón, preguntado por los contenidos que recibe desde las instituciones públicas comenta, a modo de queja, que «la mayoría de notas de prensa están centradas en los medios de comunicación escrita y los cortes de voz en las radios», por lo que los medios televisivos se sienten un poco olvidados en este sentido, ya que muy pocos gabinetes de prensa envían cortes de vídeo que puedan ser emitidos por las televisiones locales y comarcales. Por otra parte, Ximo Tirado, director de la publicación digital Castellón Información, preguntado por las publicaciones en los perfiles en las instituciones locales, opina que utilizan estas herramientas «para dar a conocer lo que hacen», y que lo hacen "más para la ciudadanía que para los medios de comunicación», por lo que el debate sobre este punto está servido.

\subsection{Sobre actualización de contenidos}

Los gabinetes de comunicación de las principales instituciones públicas de la provincia de Castellón difunden sus contenidos informativos a través de tres canales, principalmente: el portal web corporativo, los distintos perfiles en redes sociales o con el envío de notas de prensa y comunicados a los medios de comunicación, a través del correo electrónico. Una mayoría aplastante de los gabinetes encuestados opina que el grado de actualización de su página web y perfiles en redes sociales es muy alto (en el caso de la página web, nueve departamentos se autoevalúan con la máxima nota y, en el caso de las redes sociales, once). En cambio, al ser preguntados sobre con qué frecuencia mantienen contacto con los medios de comunicación a través del correo electrónico, las cifras se reducen: cinco gabinetes opinan que lo hacen con una frecuencia alta y siete con una frecuencia muy alta. El director de la publicación digital Castellón Diario, Antonio García, alaba la gran utilidad de las nuevas tecnologías en los gabinetes de prensa de las instituciones locales de Castellón "sobre todo en el caso de la Diputación Provincial» que, según el periodista, "el alto grado de profesionalidad de su gabinete de prensa y la puntualidad en la actualización de las noticias supone casi un seguimiento de 24 horas sobre la actualidad provincial». Aun con estas ventajas, el veterano profesional de la información comenta que la gran desventaja de estas nuevas herramientas tecnológicas es:

que se ha perdido el auténtico periodismo y el contacto, día a día, con los protagonistas de la noticia. "Se puede conseguir más información, por ejemplo, en una charla amigable de diez minutos con el alcalde, presidente de la Diputación o concejal de turno, que toda la información remitida por sus gabinetes de comunicación a lo largo del día. 


\subsection{Sobre los cambios introducidos por las nuevas tecnologías de información y comunicación (TIC)}

Tras una visión sobre la estructura de los gabinetes de comunicación de las principales instituciones públicas castellonenses, cuáles son las nuevas herramientas comunicativas que más utilizan en su actividad informativa y con qué frecuencia actualizan sus contenidos en los diferentes canales que disponen, en este punto se analizan los cambios introducidos por las TIC en estos departamentos. En primer lugar, una amplia mayoría de los responsables de gabinete (nueve de los doce encuestados, un $75 \%$ de los casos) opina que la aparición de los smartphones ha cambiado bastante o totalmente su relación con los medios de comunicación, mientras que una pequeña minoría de tres encuestados (un $25 \%$ ) piensa que los teléfonos móviles de última generación no ha cambiado mucho su relación con los periodistas. Algo más divididos se muestran los encuestados de los distintos departamentos de prensa de las instituciones locales cuando se les pregunta si las aplicaciones de mensajería instantánea para teléfonos móviles (WhatsApp, Google Hangouts, Telegram...) han cambiado su relación con los medios, ya que pese a que sí que es cierto que muchos opinan que ha cambiado bastante o totalmente (siete de los doce gabinetes encuestados), un tercio de los encuestados (cuatro gabinetes) se posicionan neutralmente, es decir, opinan que no ha cambiado ni mucho ni poco. Lorena Pardo, de Onda Cero Castellón, respondió las preguntas para este estudio alabando las ventajas de las nuevas herramientas tecnológicas. Bajo su punto de vista «hacen mucho más cómodo y rápido el trabajo en relación a años anteriores. Tenemos más agilidad en el contacto con los gabinetes: más contactos y fuentes a las que acudir en ciertos momentos». Además, destacó los avances en comunicación que ha supuesto la aplicación de mensajería instantánea para móviles WhatsApp sobre el resto.

GRÁFICO 3: ¿Han contribuido las redes sociales a mejorar la difusión de los contenidos propios entre los ciudadanos?

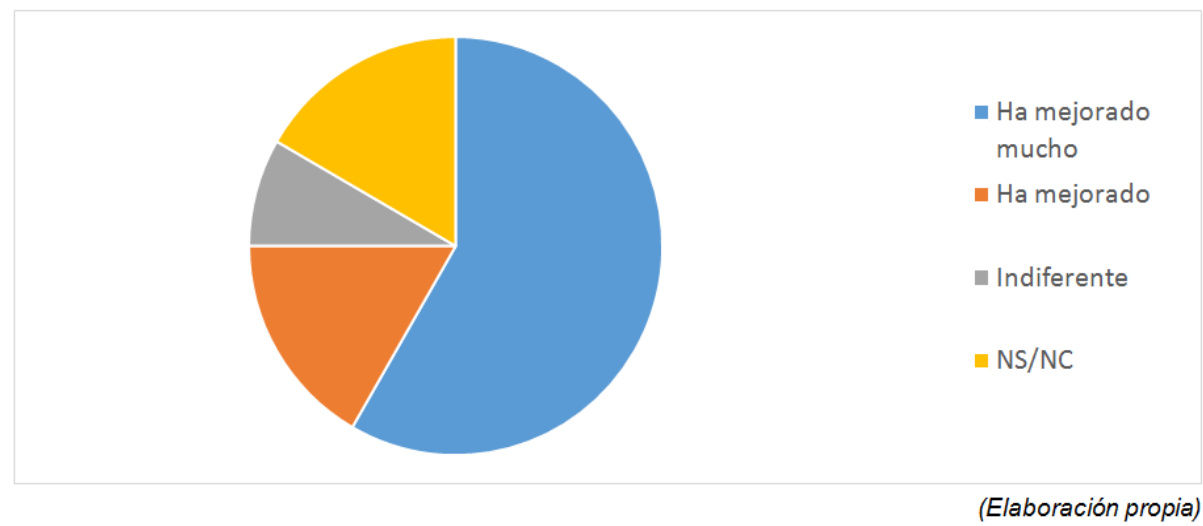

Como se puede apreciar en el gráfico circular superior, el $75 \%$ de los gabinetes de prensa encuestados piensa que las redes sociales han contribuido a mejorar la difusión de los contenidos propios entre los 
ciudadanos, al ser preguntados sobre la influencia de esta nueva herramienta. Como demuestran estas cifras, los gabinetes de prensa dependen cada vez menos de los medios de comunicación tradicionales y consiguen llegar a su público (en este caso, los ciudadanos de un municipio, provincia...) sin tenerse que someter a la interpretación de los medios. El delegado de Levante de Castelló, Pepe Beltrán, señala este aspecto como positivo pero, por otra parte también señala como una contra que «estas nuevas herramientas se ciñen por parte orgánica únicamente al mensaje oficial, no admiten réplica verdadera de los medios y uniformizan en demasía la realidad que llega a los receptores», en referencia a que el punto de vista de los medios de comunicación sigue siendo imprescindible para que el ciudadano se construya una buena interpretación sobre los hechos que acontecen en el día a día del municipio al que pertenece. Esta visión la comparte Antonio Felip, de la delegación de Radiotelevisión Española (RTVE) en Castellón, que declaró para este estudio que siempre existirá «el inconveniente del sesgo que introduce el organismo que generó la noticia». En definitiva, pese a los avances tecnológicos la ciudadanía seguirá necesitando a los medios de comunicación como "cuarto poder» de control político. Por último, dos herramientas tecnológicas a las que aún les queda un largo camino por recorrer son el newsletter y las salas de prensa virtuales. Como muestran los datos cuantitativos de este estudio, la mayoría de los gabinetes encuestados no creen en su utilidad o incluso opinan negativamente de estas herramientas, sobre todo en el caso de las salas de prensa on-line.

\section{Discusión y conclusiones}

Los resultados de este estudio muestran cómo los gabinetes de comunicación de las instituciones locales han dado un paso al frente al incorporar diversas herramientas tecnológicas a su quehacer diario con los medios de comunicación tradicionales. Si bien es cierto que cumplen los estándares previstos en cuanto a la actualización de su portal web corporativo y sus perfiles en las principales redes sociales, los datos en cuanto al uso de newsletter y salas de prensa virtuales no son tan positivos ya que, o bien no están incorporados al trabajo de estos gabinetes, o bien no se cree en su utilidad comunicativa. Por otra parte, se ha podido apreciar que el uso de las redes sociales en estos departamentos ha mejorado la difusión de los contenidos propios entre los ciudadanos de los distintos municipios. Este hecho hace pensar, a priori, que la actividad de los gabinetes de comunicación de las instituciones públicas locales se ha reorientado más hacia el ciudadano dejando al periodista en un segundo plano. No obstante, el hecho de que el primer paso para la mayoría de los responsables de estos gabinetes a la hora de comunicar o difundir una noticia sea el envío del clásico correo de comunicación corporativo a los medios de comunicación disipa estas posibles dudas y demuestra que los medios de comunicación siguen 
teniendo mucha fuerza pese a la crisis que ha sufrido el sector de la prensa. Por otra parte, cabe enfatizar que este estudio podría haber sido más ambicioso a la hora del número de gabinetes y periodistas encuestados, pero las limitaciones materiales y temporales que rodean esta labor impiden que las muestras analizadas no sean más numerosas. No obstante, las dos muestras presentadas son suficientemente representativas del sentir general, ya que los gabinetes de las poblaciones estudiadas representan a más de la mitad de la población provincial y, además, en este estudio ha participado la Diputación de Castellón, que representa a todos los municipios de la provincia. Por otra parte, también han participado la mayoría de periodistas responsables de la sección local de los medios de comunicación seleccionados. En este caso, no han podido participar la totalidad de los medios pretendidos por decisión propia o porque no pudieron responder en el plazo establecido. En cambio, para la investigación cuantitativa de las encuestas a los gabinetes de comunicación de las distintas instituciones públicas sí que se logró una participación total en la encuesta que, al fin y al cabo, muestra los datos y resultados más científicos y exactos de este estudio.

En cuanto a las conclusiones de este trabajo, se exponen las siguientes:

La mayor parte de los gabinetes de comunicación de las instituciones locales actualiza su portal corporativo y sus distintos perfiles en las principales redes sociales frecuentemente. Este dato valida la hipótesis formulada al principio de este estudio: existe un alto porcentaje de gabinetes de prensa que actualizan su portal corporativo y redes sociales frecuentemente.

- Los avances en las tecnologías de la información así como la aparición de nuevas herramientas ha mejorado el acceso a la información tanto del público en general como de los periodistas. En el caso, la totalidad de los periodistas encuestados para este estudio alaba las ventajas de estas nuevas herramientas, que permiten ahorrar en costes y en tiempo, por lo que se ha mejorado el acceso a la información y queda respondida afirmativamente la segunda hipótesis planteada: los últimos avances tecnológicos han mejorado el acceso a la información por parte de los periodistas.

- La mayor parte de los gabinetes de comunicación de las instituciones públicas castellonenses no ofrece contenidos en directo, por lo que si los periodistas o ciudadanos quieren seguir en tiempo real algún acto institucional o rueda de prensa, en la mayoría de los casos será obligado personarse. La tercera hipótesis formulada anteriormente (afirmaba que la mayoría de gabinetes de prensa de las entidades locales castellonenses ofrecen contenidos propios en directo tanto a los medios de comunicación como a la ciudadanía), por lo tanto, es inválida. 
- Pese al auge de las redes sociales, que es la herramienta que actualiza con más frecuencia la mayoría de gabinetes, estos departamentos saben de buena mano que a través de los medios de comunicación su mensaje llega a más gente. Por este motivo, la notificación corporativa a los medios de comunicación es el primer paso que se da desde el gabinete, en la mayoría de los casos. La cuarta hipótesis planteada para este trabajo, que afirmaba que el primer paso que se da desde el gabinete de comunicación a la hora de publicar un contenido es la difusión a través de las redes sociales, es también es incorrecta.

Aparte de lo anteriormente expuesto, este trabajo también ha permitido constatar que:

- La mayoría de gabinetes de comunicación de las instituciones públicas castellonenses tiene una estructura unipersonal.

- Twitter y Facebook son las redes sociales más utilizadas en los gabinetes de comunicación de las instituciones públicas de Castellón.

- La mayoría de gabinetes de comunicación de las instituciones castellonenses usa muy poco herramientas como las salas de prensa virtuales de acceso restringido para periodistas o el newsletter.

\section{Bibliografía}

Almansa Martínez, A. (2011): Del gabinete de prensa al gabinete de comunicación: la dirección de comunicación en la actualidad, Comunicación Social, Zamora.

Berganza Conde, M. R., y J. A. Ruiz SAn Román (ed.) (2005): Investigar en comunicación: guía práctica de métodos y técnicas de investigación social en Comunicación, McGraw-Hill, Madrid.

CAnel, M. J. (2007): Comunicación de las instituciones públicas, Tecnos, Madrid.

Cebrián Herreros, M. (2012): Periodismo empresarial e institucional. Comunicación Social, Zamora; Universidad de Salamanca, Salamanca

Congreso de Comunicación Local, Universitat Jaume I. (2006): La Comunicación corporativa en el ámbito local. (R. LóPEZ LITA, F. FERNÁNDEZ Beltrán, y A. Durán Mañes, ed.). Universitat Jaume I, Servei de Comunicació i Publicacions, Castelló de la Plana.

GARcíA OROSA, B. (2005): Los altavoces de la actualidad: radiografía de los gabinetes de comunicación, Netbiblo, A Coruña.

- (2009): Gabinetes de comunicación on line: claves para generar información corporativa en la red, Comunicación Social, Sevilla, Zamora. 
García RiAZA, B., y otros. (2013): Las media enterprises y las industrias culturales: investigar la comunicación y los nuevos medios: libro de actas del III Congreso Internacional Comunicación 3.0, celebrado el 10 y 11 de octubre de 2012, Salamanca.

GonzÁlez MolinA, S. (2013): «El uso de Twitter en el entorno del Periodismo Institucional 2.0: estrategias cross-media y diálogo informativo», Icono 14, volumen 11 (2), p. 141-162. Doi: 10.7195/ri14.v11i2.582

ORTEGA, F. y R. QUIVY, R. (1997): Manual de recerca en ciències socials, Herder, Barcelona.

RAMíreZ de LA PISCINA, T. (2007): Formación de portavoces: los movimientos sociales ante la esfera pública, Bosch, Barcelona.

Universidad Pontificia de Salamanca \& Universidad Complutense de Madrid. (2003): El periodismo de fuente. Servicio de Publicaciones, Universidad Pontificia de Salamanca, Salamanca.

VÁzqueZ Burgos, M. Á. (2004): El profesional de las relaciones externas: los gabinetes de comunicación desde la perspectiva periodística, Bosch, Barcelona.

WIMMER, R. D. (2001): Introducción a la investigación en medios masivos de comunicación, 6. ${ }^{\text {a }}$ ed., International Thomson, México [etc.]: 
Redes sociales y política:

El uso comunicativo de Twitter por parte de los principales partidos políticos

Aitor González Bengoechea aitorgonzabengo@gmail.com 
La política, como muchos otros campos, ha sufrido cambios con la irrupción de internet. Con la aparición de las redes sociales, los partidos políticos han descubierto un nuevo contexto comunicativo en el que relacionarse con sus públicos.

Por ello, el presente trabajo busca analizar el uso comunicativo que los partidos políticos realizan de la red social Twitter, así como la relación que se produce entre dichos políticos y los medios de comunicación.

La muestra escogida consta de seis partidos políticos, tres con representación en el Congreso de los Diputados y tres de los denominados partidos emergentes. Junto a ellos, cuatro medios de comunicación en línea, dos que también cuentan con edición impresa y otros dos con exclusividad digital.

La metodología escogida contempla un análisis cuantitativo y cualitativo de los mensajes publicados por los partidos en Twitter, así como un estudio de los titulares de tema político publicados en los medios presentados, todo ello durante una semana fuera del periodo de campaña electoral. Posteriormente, se analizará la influencia que tienen los tuits políticos en la confección de noticias, así como la influencia de los medios en los mensajes políticos.

Los resultados indican que los partidos emergentes realizan un mayor uso de Twitter, integrando más elementos a sus tuits, tales como imágenes, hiperenlaces o etiquetas. Sin embargo, la influencia hacia los medios es mínima. Los periodistas no utilizan la red social como una fuente informativa para generar noticias. Del mismo modo, los medios tampoco influyen en gran medida en los mensajes publicados en Twitter por los políticos.

Palabras clave: Twitter, partidos políticos, medios, comunicación, influencia, internet.

\section{Introducción}

En un contexto social como el actual, donde internet ha penetrado en todos los ámbitos de nuestra vida, en una sociedad bautizada por el sociólogo Manuel Castells como la "Sociedad Red" y definida como una sociedad donde las estructuras sociales y actividades clave son organizadas alrededor de redes digitales (Castells y Cardoso, 2005), no es de extrañar que la política haya realizado también esa conversión hacia el entorno digital. Así pues, se puede plantear necesario analizar el uso que la clase política hace de una de las herramientas más extendidas durante el último lustro: las redes sociales.

En el caso del presente trabajo, la red social elegida es Twitter, nacida en 2006 de la mano de Jack Dorsey. Tal es la importancia de esta 
página basada en la publicación de mensajes con un máximo de 140 caracteres, que hasta el $53 \%$ de los usuarios de internet disponen de una perfil (GlobalWeblndex, 2014), cifra que se traduce en 284 millones de cuentas activas al mes (Socialbakers).

Así, para demostrar ese cambio en la comunicación de los partidos políticos a través de Twitter, es necesario contar con una muestra apropiada para sacar unas conclusiones fundadas. Por eso, el análisis contará con la presencia de los perfiles en dicha red social de los tres principales partidos representados en el Congreso de los Diputados (@PPopular, @PSOE y @ciu), así como con tres de los partidos emergentes durante los últimos años (@ahorapodemos, @CiudadanosCs y @vox_es). Tras ello, se realizará un estudio de los titulares relacionados con la política de cuatro medios de comunicación en línea: El Mundo, El País, Público y El Confidencial.

Así, una vez analizadas ambas variables y con el fin de conocer la proximidad a la actualidad mediática que tiene la clase política, se estudiará la relación entre ambos sectores, el político y el periodístico, para ver qué influencia tiene el uno sobre el otro.

En cuanto a la metodología, la muestra será de los seis perfiles políticos de Twitter presentados anteriormente, más cuatro periódicos digitales, dos con versión impresa y otros dos íntegramente en formato digital. El periodo de análisis comprenderá una semana que no estará incluida dentro de un periodo de campaña electoral, con el fin de apartarse de los estudios sobre el tema que sí que tratan sobre una muestra en periodo electoral.

Una vez presentada la metodología y expuesto el análisis de los resultados, las conclusiones mostrarán si se han cumplido las hipótesis que a continuación se describirán y la discusión realizará una valoración crítica sobre los resultados del trabajo, así como del propio estudio.

\section{Objetivos e hipótesis}

Los principales objetivos del presente trabajo son los siguientes:

1. Estudiar las diferencias de uso (tanto cantidad como contenido) de los perfiles de Twitter de los partidos presentados.

2. Conocer la proximidad a la agenda mediática de los partidos en base a sus publicaciones en Twitter.

3. Analizar la influencia de la comunicación política en Twitter en los medios de comunicación.

4. Analizar la influencia de los medios de comunicación en la actividad comunicativa en Twitter de los partidos políticos.

De acuerdo con estos cuatro objetivos, son varias las hipótesis planteadas antes del análisis: 
1. Los partidos emergentes (Podemos, Ciudadanos y Vox) usan Twitter con mayor frecuencia y calidad que los partidos del Congreso.

2. Los partidos emergentes cubren más sus actos que los partidos del Congreso para obtener visibilidad al margen de los medios de comunicación.

3. Los medios de comunicación recurren a otras fuentes de información política antes que a Twitter.

4. Los partidos emergentes comentan más las noticias de actualidad que los partidos del Congreso.

\section{Metodología}

Para conocer el uso comunicativo que los políticos hacen de Twitter se recurrirá a la técnica de análisis de contenido, tanto de los perfiles de la red social, como de los medios digitales presentados. Empezando por el análisis de Twitter, a partir de un recuento manual de todas las publicaciones, se contemplarán dos variables de estudio:

- Análisis cuantitativo: se contabilizarán todos los mensajes publicados por las cuentas estudiadas, así como su efectividad (medida a través de los retuits y los favoritos que logren con cada publicación). También se medirán los mensajes que sean respuestas directas a otras cuentas. Gracias a esto, podremos ver qué partido político es el más activo en las redes sociales.

- Análisis cualitativo: se estudiarán aspectos de los mensajes, como enlaces, imágenes, vídeos o etiquetas. También se analizará si se respeta el criterio de los 140 caracteres o se publican en serie; si los hiperenlaces utilizados son del propio partido, de medios de comunicación o de otras páginas web; si las imágenes aportan información o son accesorias; si realizan una cobertura informativa de los actos de sus políticos (ya sean mítines o participaciones en medios de comunicación), y, por último, si se produce una coincidencia de agenda con los medios, es decir, si comentan noticias de actualidad. Gracias a este análisis podremos descubrir qué perfil es el que realiza un mayor y mejor uso comunicativo de Twitter.

Paralelamente a este estudio de los perfiles, se realizará una revisión de los titulares de los medios elegidos. Aquí, se establecerá como condición el hecho de que una fuente informativa de la noticia sea un tuit publicado por un perfil político de Twitter. Por último, se realizará una comprobación para conocer la influencia de ambos sectores entre sí, es decir, para ver si los medios de comunicación hablan de los perfiles 
políticos de Twitter y viceversa, si los partidos utilizan la red social para hablar de lo publicado por los medios.

La muestra elegida para el trabajo consta de seis perfiles de partidos políticos que intentan englobar todas las alternativas ideológicas $y$ representar a los nuevos partidos emergentes:

- Partidos con representación en el Congreso: se han escogido los tres partidos con mayor presencia y que además cubren las ideologías de derechas, izquierdas y nacionalismo catalán: Partido Popular (@PPopular), Partido Socialista Obrero Español (@PSOE) y Convergència i Unió (@ciu).

- Partidos emergentes: el primero, Podemos (@ahorapodemos), con ideología de izquierdas y nacido del movimiento ciudadano 15M. El segundo, Ciudadanos (@CiudadanosCs), ha cobrado mayor presencia durante el último año, aunque se fundó en 2006. Su ideología es de centro izquierda no nacionalista. Por último, Vox (@vox_es), nacido a finales de 2013, se sitúa en la derecha, más allá del Partido Popular.

- En cuanto a los medios de comunicación elegidos, se ha optado por utilizar cuatro medios englobados en dos grupos. Aquí se estudiarán los titulares que tengan que ver con política de la sección correspondiente a las noticias nacionales («España» o «Política» según el medio):

- Medios con versión en papel: se han escogido las webs de las dos cabeceras generalistas de mayor tirada según la Oficina de Justificación de los Medios: El Mundo (www.elmundo.es) y El País (www.elpais.com).

- Medios con exclusividad digital: se han elegido dos medios de diferente origen. El primero nacido exclusivamente para la web, El Confidencial (www.elconfidencial.com), y el segundo, Público (www.publico.es), que se convirtió en exclusivo digital tras cerrar su edición impresa.

En cuanto al periodo, se realizará el estudio durante siete días en los que todavía no haya comenzado la campaña electoral, con el fin de diferenciarse de los estudios realizados hasta ahora. Así, el periodo elegido abarca desde el 23 hasta el 29 de abril de 2015.

\section{Resultados}

\subsection{Análisis del uso de Twitter}

En primer lugar, cabe exponer el número de seguidores y de tuits publicados de cada uno de los perfiles, dato que puede ayudar a comprender algunas de las diferencias que se presentarán. Así, 
@Ppopular cuenta con 233.000 seguidores y 20.000 tuits publicados, @PSOE tiene 234.000 seguidores y 35.000 publicaciones y @CiU posee 67.000 seguidores y 33.000 tuits. Por su parte, @ahorapodemos supera los 579.000 seguidores (siendo el que más tiene) y los 23.000 tuits, @CiudadanosCs roza los 158.000 seguidores y los 25.000 tuits, mientras que @Vox_es cuenta con 36.000 seguidores y en torno a 6.000 tuits.

\subsubsection{Análisis cuantitativo}

Tras los siete días de estudio, se han contabilizado un total de 692 tuits publicados entre los seis partidos políticos de la muestra. Como se puede ver en la Figura 1, el perfil que más ha tuiteado ha sido @ahorapodemos, con un total de 258 mensajes, más del doble que el resto de partidos, mientras que el menos activo en la red social ha sido @vox_es, con apenas 34 publicaciones. Esta diferencia muestra un mayor compromiso de Podemos con la red social que el mostrado por el resto de partidos en el periodo no electoral.

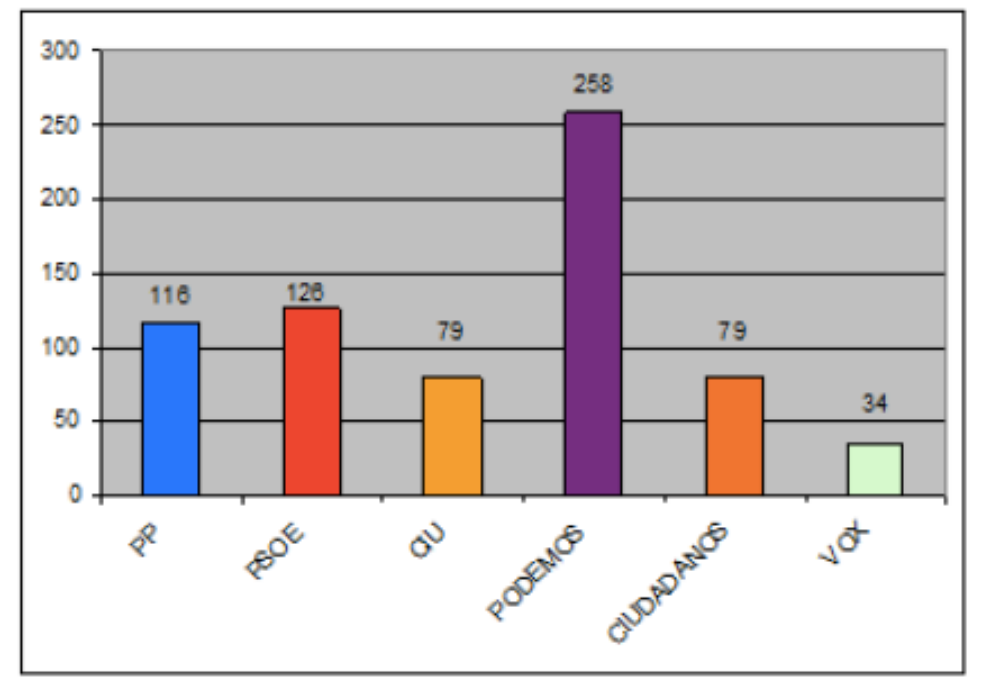

Figura 1. Tuits publicados durante el periodo estudiado. Fuente y elaboración propia.

Este mayor número de publicaciones se traduce también en una mayor efectividad en forma de retuits (RT) y favoritos (FAV). Así, la Figura 2 muestra que, a lo largo del periodo, de nuevo Podemos es quien más interacciones ha recibido, con 39.243 RT y 21.429 FAV, aventajando en gran cantidad al resto de partidos. En esta ocasión, es @ciu quien menos interacciones ha recibido por parte de sus usuarios: 863 RT y 462 FAV. Este dato refleja que los mensajes enviados por el partido de Pablo Iglesias gozan de un mayor éxito entre sus seguidores que el cosechado por el resto de partidos. 


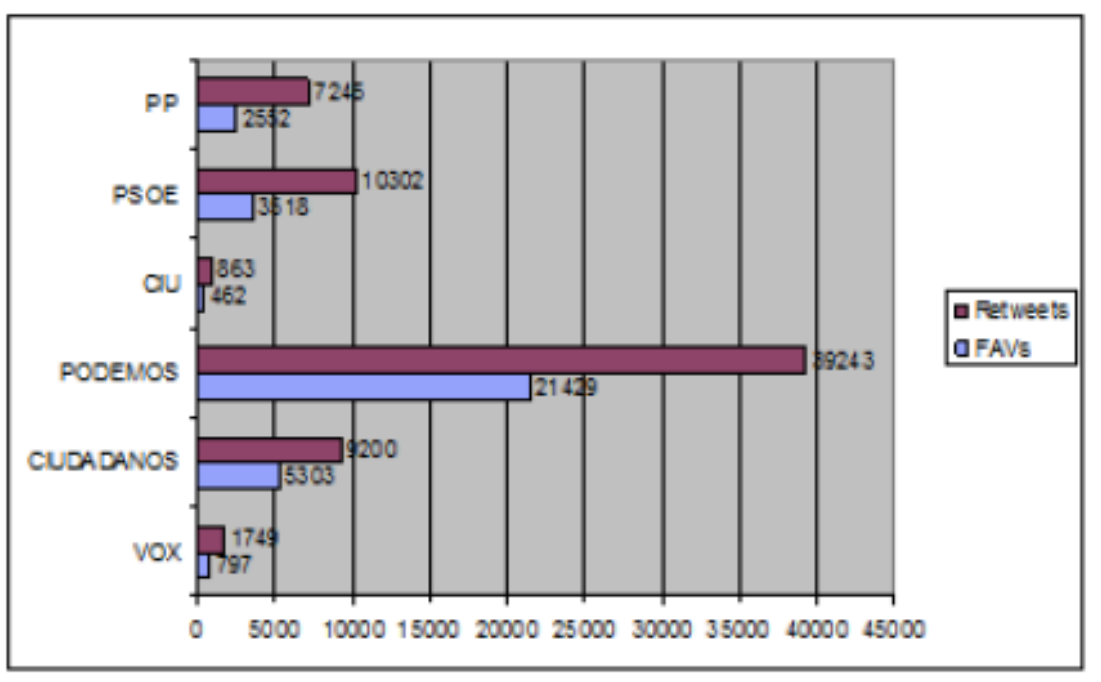

Figura 2. Número de retuits y favoritos recibidos. Fuente y elaboración propia.

Por último, en lo referente al número de respuestas directas aportadas a los usuarios, destaca la poca interacción realizada por parte de los partidos políticos. De los 692 tuits estudiados, solo cinco eran una respuesta directa a un usuario, cuatro realizadas por @PSOE y una por @ciu. Esta cifra representa un escueto 0,72 \% en el total de los mensajes, dato que no llega al aportado por las profesoras Mancera y Pano, quienes exponían en los resultados de su análisis que solo un $2,84 \%$ de los tuits eran respuesta directa. Sin embargo, el hecho de que no dialoguen sí que coincide con lo aportado por las profesoras Mancera y Pano (2013: 221226).

\subsubsection{Análisis cualitativo}

Una vez presentados los datos numéricos del estudio, a continuación se estudiarán una serie de aspectos gracias a los cuales se podrá descubrir qué partido es el que más se preocupa por la calidad de sus mensajes en Twitter. En primer lugar, cabe señalar que todos los perfiles estudiados han respetado la limitación de los 140 caracteres y no ha habido ningún partido que haya utilizado tuits en serie para hablar de un mismo tema, lo cual demuestra la adaptación de las organizaciones políticas a la red social y denota una comprensión de los beneficios de la brevedad del mensaje.

\section{Hiperenlaces}

La Figura 3 muestra el número de hiperenlaces utilizados por cada uno de los perfiles estudiados. Además, también se diferencian en función de si los enlaces dirigen a una web gestionada por el partido, a un medio de comunicación o a otra página diferente. 

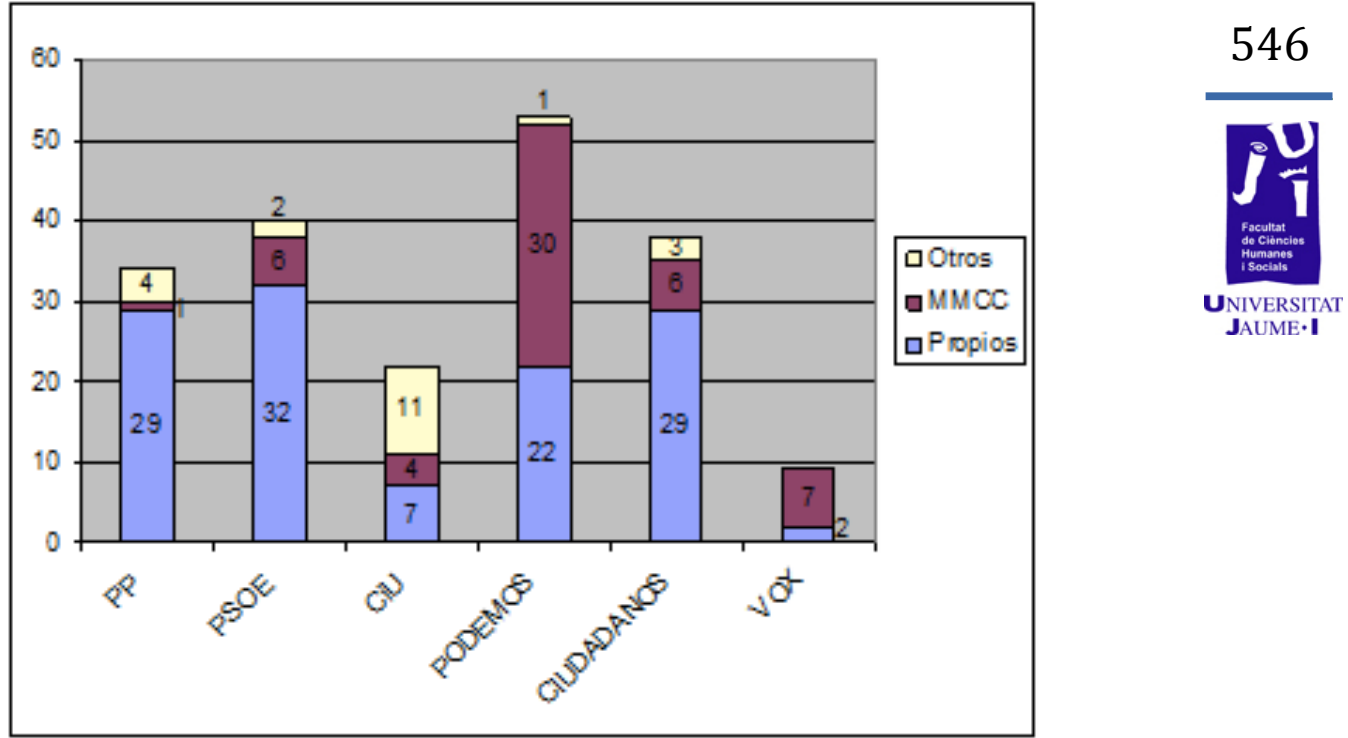

Figura 3. Cantidad y propiedad de hiperenlaces adjuntados. Fuente y elaboración propia.

Pese a que se observa que Podemos es el perfil que más enlaces insertados en sus tuits (con hasta 53 hiperenlaces), hay que tener en cuenta la cantidad de mensajes totales publicados durante el periodo analizado. De este modo, mientras PP, PSOE, CiU y VOX insertan enlaces en un $30 \%$ de los tuits aproximadamente (PP-29,31\%, PSOE-31,75\%, CiU-27,85\% y VOX-26,47\%), se observa que la cifra de Podemos cae hasta el 20,54\% fruto de la gran cantidad de mensajes que publican. Por su parte, Ciudadanos demuestra un mejor uso de la hipertextualidad y aporta hiperenlaces en el $48,1 \%$ de sus publicaciones, casi en la mitad.

En cuanto a la tipología de los enlaces, se observa una tendencia hacia un mayor uso de enlaces que conducen a sitios web gestionados por el propio partido (cabe matizar que los 11 hiperenlaces de $\mathrm{CiU}$ del grupo "Otros» conducen a la página del Govern de la Generalitat de Catalunya, autonomía donde gobierna $\mathrm{CiU}$, por lo que podrían considerarse también como propios). Esta tendencia coincide con lo aportado por los profesores Fox y Ramos (2012: 206-232), quienes señalan que los políticos utilizan los enlaces para aumentar la información de sus mensajes, ya que, ya sea a través de un medio de comunicación, o a través de la página del propio partido, los enlaces utilizados aumentan el contenido aportado en el tuit.

Con las cifras presentadas sobre el uso de hiperenlaces en las publicaciones estudiadas, se demuestra lo afirmado por Mancera y Pano (2013: 44, 210-216), quienes señalan que son muchos los mensajes en Twitter que incluyen enlaces a noticias o vídeos para ampliar el contenido del tuit.

\section{Contenido visual}

En lo referente al contenido visual, la Figura 4 refleja la cantidad de imágenes y de vídeos incluidos en los tuits analizados. Además, se hace una distinción entre las imágenes que son accesorias (que generalmente 
muestran a un político en un acto) y las imágenes que aportan información (ya sea a través de un gráfico o de una cita relevante).

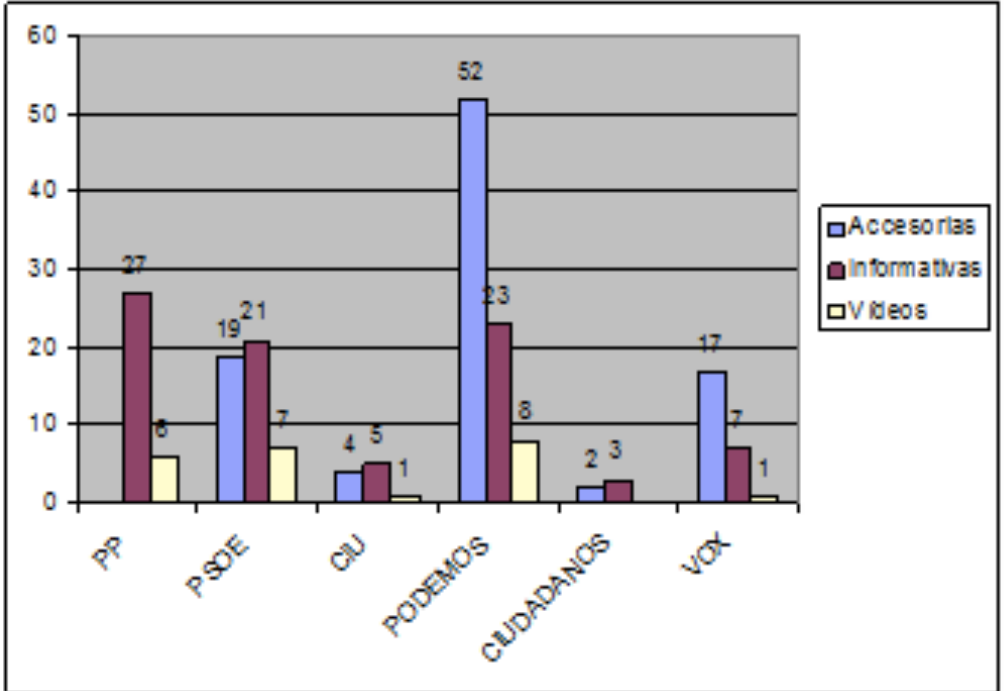

Figura 4. Cantidad de imágenes y vídeos adjuntados. Fuente y elaboración propia.

De este modo, la Figura 4 identifica diferentes comportamientos entre los partidos en el Congreso y los emergentes. Se observa que PP, PSOE y CiU hacen un mayor uso de las imágenes informativas (en especial los Populares, que no han utilizado ninguna imagen accesoria). También Ciudadanos entra dentro de esa tendencia, aunque la poca relevancia dada al contenido visual hace que no se pueda tomar como algo significativo.

En cuanto a los partidos emergentes, se observa una clara tendencia hacia el uso de las imágenes accesorias, sobre todo mostrando a sus candidatos realizando actos. Se puede afirmar que los partidos emergentes, con la intención de realizar una mejor cobertura de sus eventos, recurren a las imágenes para hacer más atractivo y fuerte el mensaje hacia sus seguidores.

En lo referente a los vídeos, no hay un uso diferenciado entre ambos grupos de partidos. Podemos, PSOE y PP han incluido ocho, siete y seis vídeos respectivamente, demostrando que también se tiene en cuenta el contenido audiovisual de sus tuits. Por su parte, CiU y Vox apenas han añadido un vídeo, mientras que Ciudadanos no ha publicado ninguno.

Sin embargo, atendiendo a los porcentajes, se descubre que Vox es el partido que más se preocupa por añadir contenido visual a sus tuits, ya que el 73,53 \% de los mensajes de este partido incluyen algún contenido visual. Mientras que Podemos, pese a contar con 83 publicaciones con imágenes o vídeos y ser el que más cantidad ha publicado a lo largo de la semana, se queda en un $32,17 \%$ de los mensajes. Por contra, Ciudadanos es el partido que menos importancia da al material audiovisual, ya que solo ha publicada cinco imágenes a lo largo de la semana, lo que representa un escaso $6,33 \%$. 


\section{Etiquetas}

En cuanto al uso de etiquetas o hashtags, la Figura 5 muestra por un lado, las diferentes utilizadas, y por otro, el número total de veces en las que se ha usado una etiqueta a lo largo del periodo estudiado.

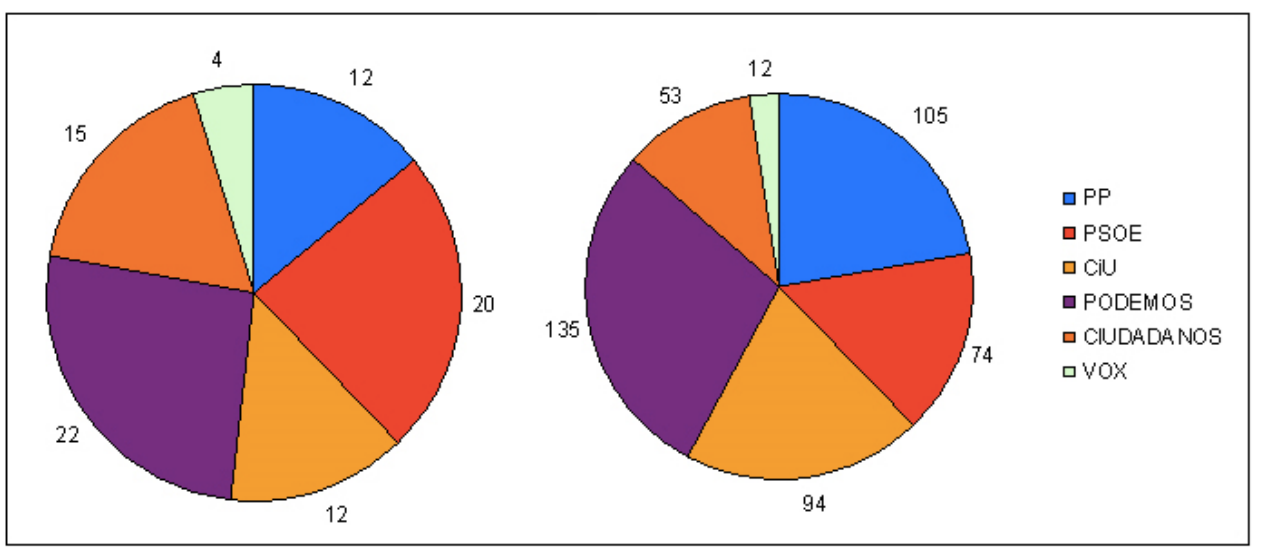

Figura 5. Diversidad y total de etiquetas utilizadas. Fuente y elaboración propia.

En primer lugar, se observa que tanto PSOE como Podemos son los partidos que han utilizado más etiquetas diferentes, con 20 y 22 respectivamente. Esto puede provocar que las etiquetas pierdan fuerza al variarse constantemente. Por otro lado, destaca también la poca importancia que se da desde Vox a este recurso, con apenas cuatro etiquetas diferentes utilizadas.

Sin embargo, es en el uso total de etiquetas utilizadas donde se pueden sacar mayores conclusiones. Se observa que Podemos es el partido que más veces ha utilizado este recurso, hasta las 135 ocasiones. De hecho, el partido liderado por Pablo Iglesias llega a utilizar hasta en 66 ocasiones el hashtag \#L6Ncalleiglesias para informar de lo que diga su candidato en el programa La Sexta Noche de La Sexta. Este uso de las etiquetas para publicar citas de los políticos es algo que todos los partidos, a excepción de Vox, han realizado a lo largo de la semana, en mayor o menor medida.

Mención especial requiere también el uso dado a las etiquetas por parte del Partido Popular y del PSOE, y es que, en consonancia con lo aportado por las profesoras Mancera y Pano (2013: 192-209), quienes afirman que los hashtags son un recurso para la adopción de eslóganes políticos. Así, vemos cómo los dos partidos con mayor presencia en el Congreso recurren a las etiquetas con el mismo fin. El Partido Popular, con 105 hashtags insertados a lo largo de la semana, ha utilizado hasta en 55 ocasiones la etiqueta \#TrabajarHacerCreer, lema adoptado por los populares para las próximas elecciones municipales. Por su parte, los socialistas, que han utilizado este recurso 74 veces, también recurrieron a la etiqueta \#GobernarParaLaMayoría en 14 ocasiones, siendo este también uno de los lemas del partido encabezado por Pedro Sánchez. 


\section{Cobertura informativa}

Por último, en lo referente a la cobertura que los partidos políticos han hecho de las intervenciones de sus integrantes, la Figura 6 presenta, en primer lugar, los eventos o intervenciones cubiertas, $y$, en segundo lugar, el número total de mensajes destinados a informar de lo dicho por sus políticos.

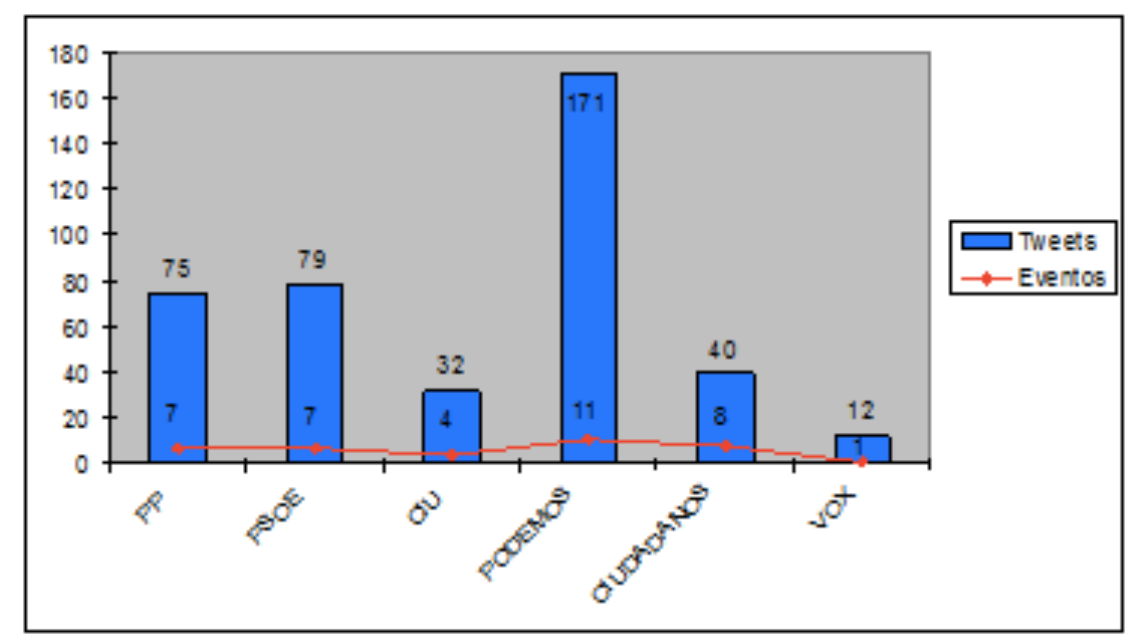

Figura 6. Cobertura informativa de los partidos. Fuente y elaboración propia.

En primer lugar, se destaca que los partidos emergentes han cubierto más intervenciones de sus políticos que los partidos del Congreso (20 contra 18). Aunque cabe matizar que es, sobre todo, gracias a Podemos, que ha informado sobre 11 eventos de sus integrantes. Esta mayor implicación del partido del círculo morado con sus eventos coincide con lo aportado sobre el 15-M (el movimiento social predecesor al partido) por parte de los profesores Casero y Feenstra (2012), quienes afirman que el movimiento aprovechó las potencialidades del nuevo entorno para hacer circular las noticias que ellos consideraban relevantes. Noticias que, en este caso, se han convertido en tuits.

Por contra, se observa que partidos como CiU o Vox no dan tanta importancia a esta capacidad de Twitter y apenas han informado sobre cuatro intervenciones, en el caso de los catalanes, y sobre un único acto, en el caso de Vox.

En segundo lugar, en lo referente a los tuits destinados a la cobertura de los eventos, Podemos es, sin lugar a dudas, el partido que más se ha implicado en esta tarea. En total, el partido de Pablo Iglesias ha destinado hasta 171 mensajes para cubrir las 11 intervenciones realizadas por sus integrantes a lo largo de la semana. De esos eventos, destaca la entrevista realizada a Pablo Iglesias en La Sexta Noche, intervención a la que el perfil de Podemos destinó un total de 68 mensajes, el evento con mayor número de mensajes de todo el estudio.

También destaca la cobertura informativa del PSOE y del PP, con una media de 11,3 y de 10,71 tuits por evento, respectivamente. $Y$ es que, pese a ser los dos partidos mayoritarios y los principales protagonistas de las noticias políticas de los medios, estos partidos tienen en cuenta el 
potencial que tiene la red social para transmitir sus mensajes, evitando así el filtro que pueden darle los periodistas y publicando los mensajes tal y como quieren. Este hecho encaja con lo aportado por los profesores Gainous y Wagner (2014: 11), quienes afirman que las redes sociales son una oportunidad para que los políticos gestionen su imagen e influencia al margen del filtro periodístico.

\subsection{Análisis de los medios de comunicación}

En lo referente al estudio de los titulares de tema político, se han contabilizado hasta un total de 366 noticias publicadas a lo largo de la semana. Sin embargo, mucho menor es el número de noticias en las que Twitter ha servido como fuente informativa para los periodistas, una cifra que desciende hasta las 17 piezas.

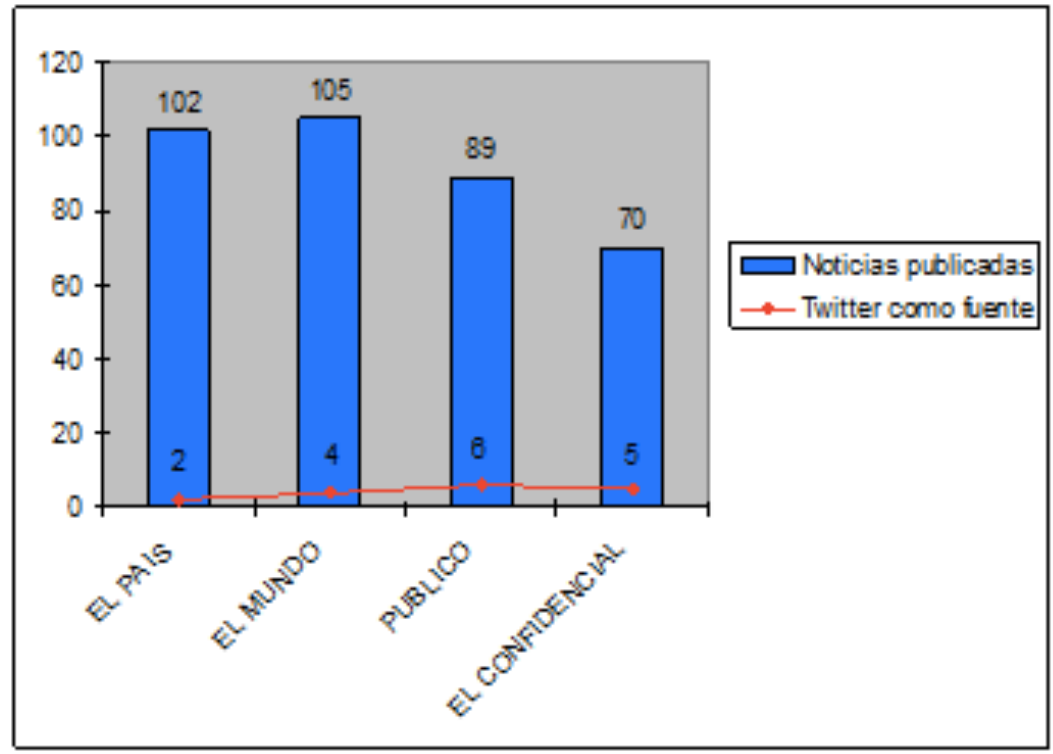

Figura 7. Presencia de Twitter en las noticias. Fuente y elaboración propia.

Como se puede ver en la Figura 7, las dos cabeceras que cuentan con una dualidad de soportes (El Mundo y El País) son los medios que más noticias de tema político han publicado a lo largo de la semana analizada, con 105 y 102 piezas, respectivamente. Por su parte, menor ha sido la contribución informativa de los medios exclusivamente digitales. Público ha publicado hasta 89 noticias, mientras El Confidencial disminuye hasta las 70 piezas.

Sin embargo, esta tendencia varía al tener en cuenta el número de noticias que cuentan con Twitter como una de sus fuentes informativas. Así, se observa que tanto Público como El Confidencial recurren más a la red social (en seis y cinco ocasiones respectivamente) que El Mundo y El País (con cuatro y dos piezas cada uno). En cualquier caso, en las cuatro páginas estudiadas se ve que la cifra de Twitter como fuente informativa es muy pequeña y que los periodistas siguen mostrándose reacios a incluir la red social como una fuente dentro de la noticia. 


\subsubsection{Presencia de los perfiles políticos en los medios}

En cuanto al uso de los perfiles en la red social de los partidos políticos como fuente de información, en la Figura 8 se muestra el número de noticias que han contado con dichos perfiles como fuente informativa durante el periodo estudiado.

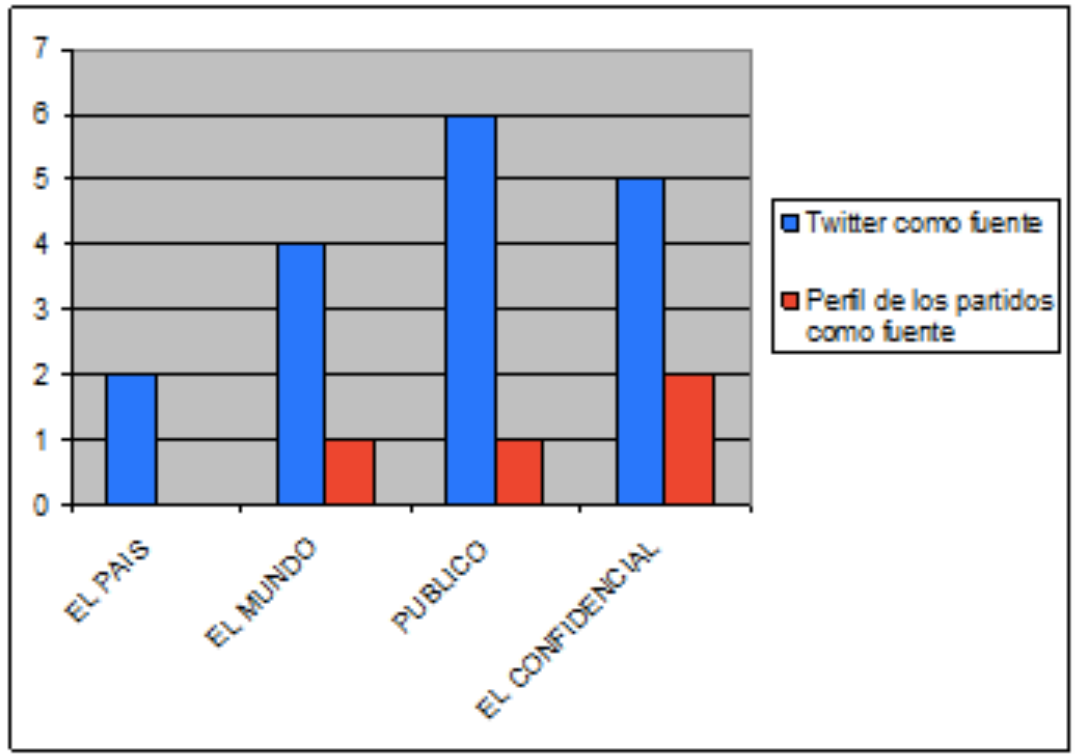

Figura 8. Perfil de los partidos políticos como fuente. Fuente y elaboración propia.

Así, se observa el poco uso que los periodistas realizan de los perfiles en Twitter de los partidos a la hora de confeccionar sus piezas informativas. De hecho, de las 102 noticias publicadas por El País, en ninguna se recurre al perfil en la red social de los partidos para completar la información. En El Mundo y Público, se recurre a la fuente mencionada en tan solo una pieza. Por su parte, El Confidencial se sitúa como el medio que más recurre a los perfiles de los partidos en Twitter, aunque solo se produzca en dos noticias.

De este modo, se observa que, pese al crecimiento de internet y de las redes sociales, los periodistas no recurren a este como fuente informativa (al menos, no la incluyen en sus noticias). Así, se puede rebatir lo afirmado por los profesores Rodríguez y Ureña (2011: 10), quienes apuntan que "cada vez es más frecuente, por ejemplo, ver noticias basadas en las "declaraciones" de un político a través de su cuenta de Twitter». Además, se demuestra lo expresado por Herrera (2013: 232-233), quien explica que los periodistas siguen dando poca credibilidad a las redes sociales como fuente y recurren más a las fuentes tradicionales para confeccionar sus informaciones.

\subsubsection{Presencia de los medios en los perfiles políticos}

Por último, en lo que se refiere a la influencia que los medios de comunicación tienen sobre los perfiles de los partidos políticos en 
Twitter, la Figura 9 presenta la cantidad de mensajes publicados por las cuentas estudiadas que incluyen un enlace a un medio de comunicación.

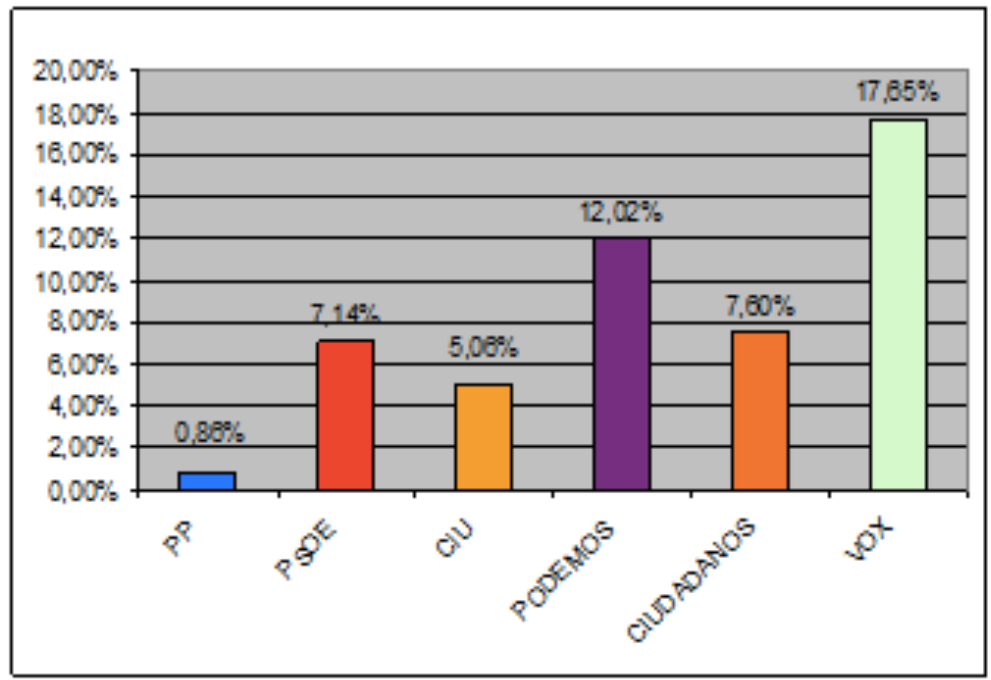

Figura 9. Porcentaje de tuits con enlaces a MMCC. Fuente y elaboración propia.

Así, se observa una mayor preocupación de los partidos emergentes por incluir contenidos de medios en sus tuits. La formación de Pablo Iglesias ha publicado un total de 31 mensajes durante la semana de estudio, lo que supone un $12,02 \%$ del total. Por su parte, Ciudadanos incluye este tipo de enlaces hasta en el 7,60\% de sus tuits, mientras que Vox lo hace en el $17,65 \%$ de sus publicaciones.

Menor es la preocupación de los partidos del Congreso por incluir enlaces a medios. De hecho, el Partido Popular solo ha incluido un enlace a un medio en los 116 mensajes contabilizados, lo que representa un $0,86 \%$ del total.

Cabe matizar que los partidos no incluyen los contenidos de los medios en sus mensajes con la misma finalidad. Teniendo en cuenta los datos de la Figura 10, se nota un uso diferenciado entre quienes incluyen el contenido periodístico para comentarlo y quienes se limitan a aportar enlaces a medios para poder seguir en directo las intervenciones de sus candidatos a través de internet.

Así, se observa que Podemos es quien más contenidos periodísticos valora en sus tuits. Entre las páginas más utilizadas por el partido destaca Público, del que se incluyen siete noticias. Por detrás, El País, El Mundo y eldiario.es le siguen con tres piezas cada uno.

También destaca este uso en el PSOE, que además de enlaces, utiliza otro recurso para hacer referencia a los contenidos de los medios. El partido de Pedro Sánchez es el único que incluye capturas de noticias en sus tuits para comentarlas. Este recurso lo utiliza hasta en tres ocasiones. 


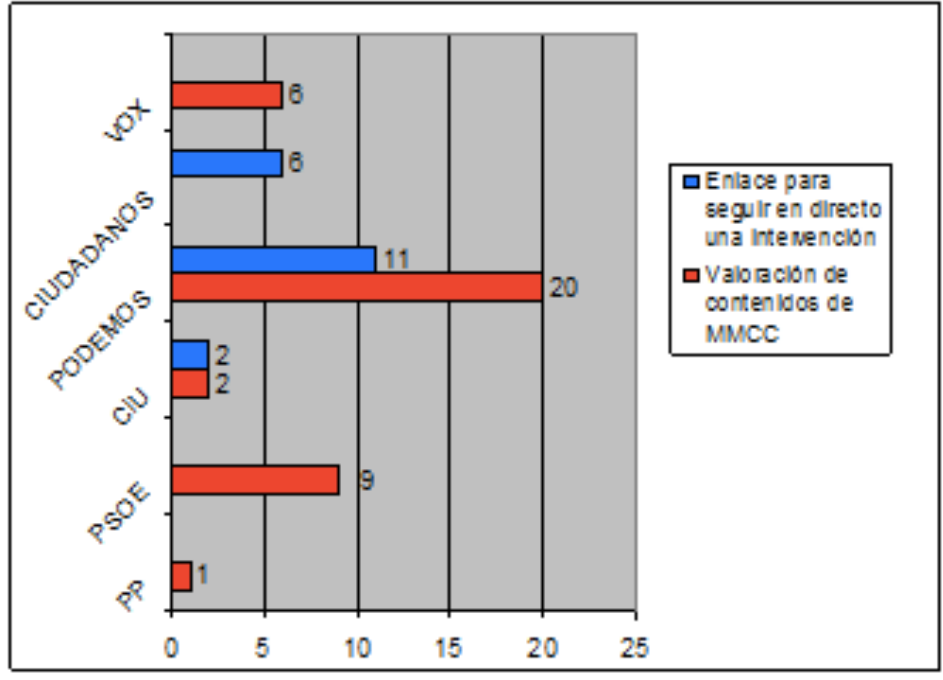

Figura 10. Uso del contenido de los MMCC en los perfiles políticos de Twitter. Fuente y elaboración propia.

En cuanto al uso de enlaces para seguir en directo a los políticos, destaca un predominio en el grupo de los partidos emergentes. De nuevo, Podemos es el partido que más enlaces aporta con este fin, con hasta 11 enlaces para seguir en directo a sus miembros. También sobresale este uso en Ciudadanos, que solo enlaza contenidos a medios de comunicación para seguir en directo a sus políticos, hecho que realiza en seis ocasiones. En cuanto a Vox, cabe matizar que de los seis enlaces, tres remitían a entrevistas realizadas por sus candidatos en diferentes programas. La voluntad de remitir a los seguidores la intervención de sus candidatos hace que se pueda equiparar dicho uso al realizado por el resto de partidos emergentes.

\section{Conclusiones y discusión}

Los resultados reflejan una concienciación, en mayor o menor medida, por parte de los partidos políticos de que Twitter es una herramienta clave para sus procesos comunicativos en la sociedad que ha surgido con la irrupción de internet y de las redes sociales. Sin embargo, sí que destaca que Podemos es el partido que ha tomado la delantera en el uso de la red social y es la candidatura que más se preocupa por los contenidos que publica en Twitter.

Así, se corrobora la hipótesis de que los partidos emergentes realizan un uso mayor, tanto en cantidad, como en calidad, de Twitter fuera de la campaña electoral. Sin embargo, sí que cabe apuntar que esa superioridad se debe a la gran actividad de Podemos en la red social. Atendiendo a las cifras registradas por Partido Popular y PSOE, se descubre que superan a las de Ciudadanos, igual que las de CiU son superiores a los datos de Vox.

Del mismo modo sucede con la cobertura informativa de los actos políticos. De nuevo, se puede confirmar la hipótesis que afirmaba que los 
partidos emergentes usan más su perfil para cubrir las intervenciones de sus candidatos. Sin embargo, cabe tener en cuenta, otra vez, que las cifras de Podemos son las que desequilibran la balanza, puesto que PP y PSOE superan en este aspecto los datos obtenidos por Ciudadanos y Vox.

En cuanto a la relación entre medios y políticos, se puede comprobar la hipótesis que afirma que los medios de comunicación recurren a otras fuentes de información política antes que a Twitter. Al menos, en lo que se refiere a fuentes presentes en la información, se utilizan en muy pocas ocasiones perfiles de la red social, y cuando se usan suelen ser de los líderes políticos y no tanto de los partidos. Esto no quiere decir que los periodistas no recurran a la red social como fuente de información, ya que no se puede demostrar que se utilice Twitter como un recurso para conocer la actualidad o para conocer datos que se contrastarán mediante fuentes más tradicionales.

Del mismo modo, también se descubre que no hay una continua coincidencia de agenda entre los partidos políticos y los medios. Las veces que las agrupaciones políticas comentan la actualidad publicada por los medios tampoco son muy numerosas. Sin embargo, sí que se confirma la hipótesis que afirmaba que los partidos emergentes comentan más las informaciones de actualidad publicadas por los medios que los partidos del Congreso, ya sea para criticar a los partidos mayoritarios o bien para promocionar sus medidas.

De cara a futuras investigaciones, se plantea la necesidad de estudiar también el número y la variación de seguidores de cada cuenta a lo largo del periodo de análisis, puesto que podría ayudar a comprender el porqué de la superioridad de ciertos partidos sobre el resto y a conocer mejor el éxito o no de las comunicaciones en Twitter que realizan los partidos políticos.

Por otro lado, enriquecería más la investigación si el análisis se realizara día a día, conociendo así también qué días de la semana son los más utilizados por los partidos y en cuáles tienen más éxito entre sus seguidores los mensajes que publiquen.

Por último, en relación con el estudio de titulares, el hecho de excluir todas aquellas noticias que no se publiquen en la sección especificada y el requisito de que Twitter sea la fuente de información primaria ha provocado que los datos en ese sentido sean escasos y reflejen poca relación entre la red social y los medios de comunicación. Para futuras investigaciones, sería más apropiado utilizar un método de entrevistas a periodistas para conocer de primera mano cuál es el uso que estos dan a la red social a la hora de confeccionar las informaciones políticas. 
CASero, A. y Feenstra (2012): «Nuevas formas de producción de noticias en el entorno digital y cambios en el periodismo: el caso del 15-M», Revista Comunicación y Hombre, 8, p. 129-140.

Fox, R. y J. Ramos (2012): iPolitics. Citizens, Elections, and Governing in the New Media Era, Cambridge University Press, Nueva York.

Gainous, J. y K. WAgner (2014): Tuiting to Power, Oxford University Press, Nueva York.

Global Web Index. GWI Social Report Q4 2014 [en línea]. Disponible en: http://www.slideshare.net/globalwebindex/gwi-social-report-q4-2014

[Fecha de consulta: 20 de abril de 2015].

Herrera, E. (2013): Periodistas y redes sociales en España. Del 11M al 15M (2004-2011), Tesis doctoral Universidad Carlos III, Madrid.

Mancera, A. y A. PANo (2013): El discurso político en Twitter, Anthropos Editoral, Barcelona.

RodrígueZ, R. y UREÑA, D. (2011): «Diez razones para el uso de Twitter como herramienta en la comunicación política y electoral». Revista Comunicación y Pluralismo, 10, p. 89-116.

SOCIALBAKERS [en línea]. Disponible en: http://www.socialbakers.com/statistics/twitter/ [Fecha de consulta: 20 de abril de 2015]. 
Redes sociales y democracia. Una aproximación al debate sobre una relación compleja

Laura Alonso Muñoz lalonso@uji.es 
Comunicación y democracia están estrechamente relacionadas y no podemos concebir la una sin la otra. Las redes sociales han irrumpido con fuerza en el ámbito de la comunicación, especialmente en el de la comunicación política, que se ha visto reflejado en las prácticas democráticas. Las potencialidades inherentes de las tecnologías digitales han transformado el ejercicio del activismo político, propiciando una clara redefinición de las relaciones de poder y generando una especie de contrapoder ciudadano. Sin embargo, pese a las múltiples oportunidades que presentan, las redes sociales también suscitan dudas. Mediante una revisión de la literatura, el objetivo de este artículo es realizar una aproximación teórica al profuso debate existente entre los académicos sobre si las redes sociales contribuyen a solucionar los problemas democráticos que padecen las sociedades actuales o si, por el contrario, los agravan. Se concluye al respecto que existen dos posturas. La de los ciberoptimistas, que establecen que las potencialidades de Internet favorecen la participación, el intercambio y la deliberación. Y la de los ciberescépticos, que se muestran reacios a creer que las tecnologías digitales y las redes sociales sean per se intrínsecamente democráticas ya que, pese a su potencial, su uso no es siempre lo positivo que debiera ser. Asimismo, se han detectado posibles líneas de investigación a tener en cuenta en futuras investigaciones.

Palabras clave: redes sociales, democracia, comunicación política, activismo político, ciberescépticos, ciberoptimistas.

\section{Introducción}

La web 2.0 y las redes sociales han revolucionado el panorama comunicativo actual al quebrar el monopolio informativo que ejercían tradicionalmente medios como la televisión o la prensa. Se crea un modelo comunicativo alternativo que permite la participación de actores que con el modelo tradicional quedaban silenciados, como ciudadanos y movimientos sociales (Castells, 2009). En este sentido, el público ya no es un ente pasivo que sólo consume, ahora también crea y distribuye la información, lo que no hace sino que empoderar a la ciudadanía y otorgarle un papel preferente en el cambio social impulsado a través de las tecnologías digitales (Jenkins, 2006).

El activismo político ha encontrado en las redes sociales una herramienta útil para comunicar y movilizar además de para captar la atención de los medios de comunicación tradicionales e introducir sus temas y enfoques en la agenda política y mediática. No sólo eso, movimientos sociales como la Primavera Árabe o el $15 \mathrm{M}$ se valieron de redes sociales como Twitter y Facebook para intentar cambiar aspectos 
que consideraban poco democráticos u opacos de los sistemas políticos de sus respectivos países. Pese a que las redes sociales cuentan con enormes potencialidades que mejoran los procesos participativos, existen voces críticas que cuestionan el inherente carácter democratizador de las redes sociales y plantean que los efectos que generan no son tan positivos como se quiere creer. Otros expertos ensalzan sus virtudes y las consideran elementos fundamentales para la mejora democrática.

El objetivo de esta investigación es realizar una aproximación teórica al profuso debate existente entre los académicos sobre si las redes sociales contribuyen a solucionar los problemas democráticos que padecen las sociedades actuales o si, por el contrario, los agravan. Para ello, se realizará una amplia revisión de la literatura en la que nos centraremos en autores referentes en la materia.

\section{Las redes sociales democratizan la información}

La aparición de las tecnologías digitales ha traído consigo la democratización de la información, lo que a su vez implica el surgimiento de nuevas formas de ejercer el periodismo. Las redes sociales han roto el monopolio que poseían las élites políticas y periodísticas en la construcción de la realidad social y política (McNair, 2006) de manera que han cedido a los ciudadanos un papel preferente dentro del proceso comunicativo. El público ya no es un ente pasivo que sólo consume, ahora también crea y distribuye la información, lo que otorga a la ciudadanía un papel preferente en el cambio democrático impulsado a través de estos nuevos medios (Castells, 2009; Jenkins, 2006). Con Internet, y especialmente con las redes sociales, la construcción de la realidad ya no depende de un pequeño grupo de personas, sino que cualquier ciudadano puede ser productor y transmisor de noticias, lo que plantea un panorama comunicativo mucho más competitivo que el existente en décadas anteriores (Chadwick, 2011). Esto evidencia un claro progreso hacia la descentralización de la producción informativa (Heinrich, 2010).

Las redes sociales como Twitter han cambiado la forma de consumir información. El ciudadano ya no es un mero espectador. Esta nueva capacidad de crear información que tiene el ciudadano provoca, asimismo, un notable incremento de la cantidad de noticias que circulan por la red y a las que puede acceder el público (Chadwick, 2012), y la aceleración de la difusión de noticias en tiempo real gracias a las características técnicas de la red de microblogging. En contraposición, también se han visto afectadas las rutinas periodísticas, especialmente las de los medios convencionales, que han tenido que adaptar sus rutinas a este nuevo panorama informacional (Lasorsa, Lewis y Holton, 2012). Ya no son la voz preferente y deben convivir con nuevos actores, como movimientos sociales $\mathrm{u}$ organizaciones alternativas, $\mathrm{y}$ ciudadanos anónimos que adquieren un rol cada vez más importante, escapando del control de las élites políticas y periodísticas (McNair, 2006). Además, diversos estudios dilucidan que estos «nuevos» actores servirán al 
periodista como fuente informativa, y que asumirán o colaborarán en funciones hasta ahora ejercidas por periodistas como la función de watchdog (perro guardián) o curador de contenidos, funciones altamente necesarias en un momento en el que hay que extremar las precauciones debido a la descomunal cantidad de información que circula por la red (Bakker, 2014; Bruno, 2011; Cappeletti y Domínguez, 2014; Hermida, 2012; López-Meri, 2015; McElroy, 2013).

Otra de las potencialidades que ofrecen las tecnologías digitales es la monitorización cívica para la fiscalización del poder. Keane (2009), uno de los primeros autores en acuñar este término, definió el concepto de democracia monitorizada como la fiscalización de los centros de poder político y económico por parte de la sociedad civil. Este escrutinio es posible debido al uso de herramientas tecnológicas y al gran torrente informativo derivado del entorno digital. En otras palabras, la monitorización «es una forma de contrapoder que desafía a los centros de poder político y económico» (Feenstra y Casero-Ripollés, 2014: 2462) y en la actualidad también mediáticos (Keane, 2009).

Los ciudadanos se tornan vigilantes de las acciones llevadas a cabo por estos de una forma similar a la clásica función de perro guardián ejercida por los medios (Casero-Ripollés, 2008). La práctica de la mediación se construye principalmente sobre la base de dos pilares: la rendición de cuentas y la exigencia de responsabilidades, y el ejercicio de la critica social y política (Feenstra, 2012). En este sentido, lo que se pretende con esta forma de escrutinio es dar respuesta a los abusos de poder cometidos por los sectores más poderosos de la sociedad (Keane, 2009), de forma que se pueden convertir en una forma de contrapoder (Castells, 2009) y llegar incluso a alterar las relaciones de poder establecidas, generar cambios en la decisiones políticas, provocar dimisiones o incorporar nuevos temas a la agenda pública (Feenstra, 2012).

En definitiva, ciudadanos y organizaciones, hasta el momento sin voz en los grandes medios, han encontrado en las redes sociales su principal espacio de comunicación, y han arrebatado parte del poder simbólico ostentado por periodistas y políticos como informantes preferentes (Casero-Ripollés, 2009; Van Dijk, 1993). Es lo que Castells (2009) denomina "autocomunicación de masas» y que hace referencia a la nueva forma de comunicación en la red. Para el autor, cuanta más autonomía proporciona la tecnología a los usuarios, más oportunidades tendrán de que nuevos valores e intereses entren a formar parte del imaginario colectivo.

Numerosos estudios (Anduiza et al., 2014; Casas, Davesa y Congosto, 2015; Casero-Ripollés y Feenstra, 2012; Ferreras-Rodríguez, 2011; Haro y Sampedro, 2011; Linares-Lanzman y Pérez-Altable, 2015; Micó y CaseroRipollés, 2014; Subirats, 2015; Toret, 2013) han demostrado que las redes sociales también han tenido un papel fundamental para movimientos sociales como el $15 \mathrm{M}$ o la PAH. Las tecnologías digitales les han permitido dar a conocer sus mensajes y reivindicaciones e intentar así cambiar los 
aspectos negativos del sistema democrático actual. Es más, existen autores que defienden la idea de que las redes sociales tienen ya la suficiente capacidad como para transformar las democracias actuales (Margetts, 2013).

\section{Redes sociales y democracia: ciberoptimistas vs. ciberescépticos}

Durante los últimos años hemos asistido a numerosas revueltas que cuestionaban los sistemas políticos actuales y demandaban una mayor transparencia y democracia a sus gobernantes. La denominada Primavera Árabe (Hermida, Lewis y Zamith, 2014; Papacharissi y De Fátima Oliveira, 2012) se inició en 2010 cuando los ciudadanos egipcios deciden ocupar las plazas para exigir el cese del gobierno de Hosni Mubarak, en el poder durante más de treinta años. A Egipto le siguieron países como Túnez, Turquía, Irak, Siria o Marruecos, que con regímenes políticos similares demandaban mejores condiciones de vida, más democracia y un mayor poder para el pueblo. Un año después, en 2011, las protestas se extienden a los países occidentales en los que la crisis económica y política había hecho mella en los ciudadanos, cansados de que el $1 \%$ de la población acaparase más de la mitad de la riqueza del planeta y se enriqueciera a costa del resto y de que mientras se pedían sacrificios a la ciudadanía vieran la luz cada vez más escándalos de corrupción. Así aparecieron movimientos como Occupy Wall Street (Fuchs, 2014) en Estados Unidos, inspirado por el 15M en España. Gran parte de estas revueltas o movimientos tienen en común el uso de las redes sociales como herramienta para comunicar, movilizar y organizar las protestas, escapando del control político y de la mediación ejercida por los medios de comunicación, que en el caso de España, inicialmente, no reflejaron el fenómeno 15M (Ferreras Rodríguez, 2011). Lo que en un momento determinado resultó ser una revuelta local se extendió a otros territorios a través de las redes sociales. Por eso, se dice que fue el año de las revoluciones de Twitter y Facebook (Fuchs, 2014). Internet ha favorecido la transnacionalización de las protestas encabezadas por los activistas, conectando demandas inicialmente locales a un ámbito global (Della Porta, 2011).

Tesis como estas son las que han generado un polarizado debate sobre si los medios sociales pueden o no transformar la democracia de un país (Fuchs, 2014). Existen elementos en la actualidad que pueden llevar a cuestionar los sistemas democráticos y en este marco se ha generado un intenso debate sobre si las redes sociales son capaces de regenerar la democracia y otorgarle un mayor protagonismo a los ciudadanos, debate que enfrenta los argumentos de ciberoptimistas y ciberescépticos (Resina de la Fuente, 2010).

A grandes rasgos, los ciberoptimistas o ciberutópicos establecen que las potencialidades con las que cuenta Internet favorecen la participación, el intercambio y la deliberación. Autores como Sampedro (2000) aluden al hecho de que esto supone una mejora en la opinión pública discursiva, 
entendida como un proceso en el que la ciudadanía delibera entre sí y crea argumentos conjuntos, frente a una opinión pública agregada, en la que lo único importante son las mayorías procedentes de los sondeos y las urnas (Haro y Sampedro, 2011). Los ciberescépticos o ciberrealistas, en cambio, se muestran reacios a creer que las tecnologías digitales y las redes sociales sean per se intrínsecamente democráticas (Loader y Mercea, 2012) y enfatizan el hecho de que, pese a su potencial, su uso no es siempre lo positivo que debiera ser.

\subsection{Ciberoptimistas}

Entre los ciberutópicos destacan autores como Manuel Castells, que considera que los medios sociales ayudan a reconfigurar las relaciones de poder existentes y permiten a los ciudadanos ejercer de contrapoder. Se produce, por lo tanto, un empoderamiento de la ciudadanía (Castells, 2009; Jenkins, 2006). La red permite a los ciudadanos crear y compartir mensajes alternativos a los difundidos por las élites políticas y mediáticas, en definitiva, crear sus propios significados. En una sociedad organizada alrededor de "una metarred de redes de comunicación electrónica, Internet proporciona nuevas oportunidades de cambio social» (Castells, 2009: 531). Es decir, las redes sociales no sólo han cambiado la forma de comunicar de sus usuarios, sino que configuran y reconfiguran las estructuras sociales y la vida pública y privada del conjunto de la sociedad.

Mientras los «poderosos» han estado «espiando a los súbditos desde el principio de los tiempos» (Castells, 2009: 532), con las tecnologías digitales el súbdito adquiere el poder de vigilar al gobernante. Si los ciudadanos sorprenden a los políticos mintiendo, dice Castells, ahora tienen la capacidad de organizarse y demandar explicaciones prácticamente de forma instantánea, por lo que los gobernantes deberán permanecer atentos y prestar una mayor atención a los principios democráticos que durante tantos años han vulnerado.

En la misma línea que Castells, Shirky asegura que las redes sociales favorecen la libertad y la cooperación porqué permite encontrarse sin tener que acudir a un espacio físico determinado. Por lo tanto, los medios sociales benefician la democracia. Las herramientas comunicativas fomentan la transferencia de poder ya que ofrecen un espacio de discusión que puede conducir a la acción de los ciudadanos ya comprometidos (Shirky, 2011). Además, considera que herramientas diseñadas específicamente para ser utilizadas por disidentes son políticamente fáciles de cerrar por parte del Estado, mientras que las herramientas creadas para que se haga un uso masivo de ellas, como Twitter y Facebook, son más difíciles de censurar sin correr el riesgo de politizar a una parte de la población sin opción política determinada. Respecto a los casos de censura en las redes sociales, Shirky considera que el efecto más importante de los medios sociales es su potencial. Asegura que la mejor razón para pensar que los medios sociales pueden 
traer el cambio político a la sociedad es que tanto activistas como políticos creen que pueden hacerlo (Shirky, 2011).

\subsection{Ciberescépticos}

Internet también puede ser utilizado para propósitos menos honestos. Los regímenes dictatoriales, como el Egipto de Mubarack, pueden utilizarlas como una herramienta para elogiar las virtudes de la dictadura, incrementar el control y la vigilancia sobre la ciudadanía e incluso censurar contenidos (Howard, Agarwall y Hussain, 2011; Morozov, 2011a). Las dictaduras utilizan la red para vigilar y perseguir a las personas contrarias al régimen que lo cuestionan a través de redes sociales y blogs (Micó y Casero-Ripollés, 2014).

Las tesis de Morozov, que se autodenomina ciberrealista aunque su visión es más bien pesimista, siguen esta línea. En su libro, The Net Dilusion: How to Liberate the World (2011 a), además de analizar el impacto de Internet en los Estados autoritarios, critica el creciente entusiasmo en torno al potencial liberador de Internet. El autor sugiere que el poder democratizador de los medios sociales no trae ni democracia ni libertad, pero si afianza a los regímenes autoritarios. Argumenta que la promoción temeraria de las tecnologías digitales y las redes sociales como agentes democratizadores impulsada por occidente ha derivado en una mayor represión en los regímenes autoritarios. La actividad online se somete en dos sentidos: cerrando y bloqueando páginas web y blogs que difundieran informaciones contrarias al régimen e infiltrándose en grupos de protestas para rastrear y fiscalizar a los manifestantes y para propagar su propia publicidad (Morozov, 2011 a).

Difiere con los ciberutópicos en dos cuestiones. No cree en que Internet y las redes sociales son inherentemente emancipadoras y rechaza el convencimiento de que todas las cuestiones trascendentes de la sociedad moderna y la política se puedan enmarcar en términos de Internet (Morozov, 2011a). Además, sostiene que «los ciberutópicos que crean que la Primavera Árabe fue conducida por las redes sociales ignoran en qué se basa el activismo en el mundo real» (Morozov, 2011b).

En la misma línea, Gladwell afirma tajantemente que los medios sociales no han reinventado el activismo y recalca que no existe ningún tipo de evidencia de que estas herramientas actúen como agentes directos del cambio. Para ilustrar su tesis cuenta la historia de cuatro universitarios de Estados Unidos que, a principios de los sesenta, se sentaron en el mostrador de una tienda en Greensboro (Carolina del Norte) e iniciaron una protesta que acabó convirtiéndose en una revolución por los derechos civiles. Una lucha larga y sin violencia que consiguió que todos los ciudadanos, especialmente los afroamericanos, adquirieran los mismos derechos y libertades que el resto. $Y$ fue sin Twitter, ni Facebook, ni correo electrónico (Gladwell, 2010).

Este autor argumenta que los medios sociales se construyen alrededor de lazos débiles: Twitter te acerca a gente que nunca has conocido y Facebook te acerca a familiares y amigos. Estos lazos sólo son 
eficaces cuando la acción que se persigue es fácil y no conlleva riesgos. El activismo generado en Facebook tiene éxito porque se motiva a la gente a que realice sacrificios que no se habían planteado realizar antes. Se anima a millones de personas a que sigan páginas de Facebook relativas a programas de caridad por los damnificados de tragedias o guerras, pero sólo unos pocos usuarios estarían dispuestos a donar dinero. Es lo que él denomina clicktivism, o activismo de clic (Gladwell, 2010). Este termino, acuñado por Morozov (2011a) como slacktivism o activismo débil, pretende explicar que es muy fácil protestar a través de las redes sociales o sumándose a plataformas digitales de recogida de firmas como Change.org, pero muy pocos serían capaces de salir a la calle a realizar la misma acción. En consecuencia, los vínculos participativos son frágiles y no todos los que se movilizan en la esfera online lo harían en la offline.

\section{V. ¿Pueden las redes sociales regenerar la democracia?}

El debate en torno al carácter regenerador y democrático de las redes sociales sigue abierto en la actualidad. Gran parte de los regímenes democráticos mundiales está siendo cuestionado por la ciudadanía y las redes sociales podrían ser un elemento clave para su regeneración.

La relación entre redes sociales y democracia es muy compleja y los académicos no han conseguido dar una respuesta clara a si las redes sociales tienen o no una capacidad regeneradora democrática. Ambas tesis confrontadas (ciberescépticos y ciberoptimistas) cuentan con argumentos sólidos y válidos. Redes sociales como Facebook y Twitter dan voz a la ciudadanía para que opine y se queje sobre lo que no le gusta (ciberoptimistas), pero también es cierto que estas plataformas han acomodado a la sociedad y dificultan que las protestas digitales puedan dar el salto a la calle y algunos gobiernos autoritarios pueden utilizarlas con fines poco legítimos (ciberescépticos).

Ambas partes, por tanto, tienen parte de razón en sus argumentos. Se trata de un fenómeno muy complejo $y$, por ello, quizás resulta demasiado simplista que la literatura se divida únicamente en argumentos a favor y en contra y no se decante por una postura intermedia. Antes de posicionarse sería necesario, por tanto, analizar los elementos de cambio y continuidad existentes y para poder formarnos una visión más amplia de los hechos (McChesney, 2013).

\section{Nuevas líneas de investigación abiertas}

Si bien las redes sociales permiten a los ciudadanos cambiar o influenciar algunas prácticas democráticas, nuevas líneas de investigación abiertas demuestran que las redes sociales también dotan a ciudadanos y activistas de la capacidad de participar en la construcción de la agenda pública. Es decir, de intentar introducir sus temas y enfoques en los 
medios de comunicación convencionales con el objetivo de acabar introduciendo el tema en la agenda de los ciudadanos.

Las potencialidades de Internet y las redes sociales han abierto un sinfín de oportunidades en términos comunicativos. Se ha creado la coyuntura perfecta para que ciudadanos, blogueros y activistas, entre otros, puedan participar de forma activa en la construcción de la agenda pública. Se trata de una gran oportunidad para los movimientos sociales, que a través de la red pueden expandir sus protestas y transmitirle al público su mensaje, sin necesidad de pasar por los medios de comunicación primero y evitando cualquier posible sesgo. El establecimiento inverso de la agenda (Sung-tae y Young-hwan, 2007) responde a esta nueva capacidad de los ciudadanos para condicionar la agenda de los medios y, por consiguiente, la agenda pública.

En la reversed agenda o agenda inversa, el público, tradicionalmente receptor pasivo, se convierte en un agente activo que propone temas que los medios aceptan, de manera que se produce una construcción inversa de la agenda. En las teorías clásicas de la formación de la agenda-setting, los medios eran los únicos agentes que influenciaban la agenda del público. En la actualidad, Internet revierte la agenda de los medios para que las agendas de la red ocupen una posición preferente en la formación de la opinión pública (Sung-tae y Young-hwan, 2007).

Según estos autores, la formación de la agenda inversa está compuesta por tres fases. En la primera, un internauta anónimo difunde información a través de su perfil en redes sociales, un blog, una web personal o un foro y esta adquiere una especial relevancia en el entorno digital. En la segunda, el tema se extiende a través de la red y llega a un numero mayor de usuarios a través de la cobertura realizada por portales digitales o medios de comunicación alternativos. En la última etapa, debido a que el tema ha tenido una gran repercusión en la red, es recogido por los medios de comunicación convencionales e incorporado a la agenda pública. Sin embargo, destacan que estas tres fases no tienen porqué darse en este orden. En algunos casos el proceso se inicia con la primera etapa, pero en otros, el tema está cubierto por los medios de comunicación convencionales $y$, posteriormente, emerge de nuevo como una agenda mayor tras el escrutinio del tema en Internet. A veces, incluso, puede darse a través de las tres fases a la vez en un periodo de tiempo muy reducido (Sung-tae y Young-hwan, 2007).

En su artículo, Sung-tae y Young-hwan (2007), analizan diez casos en los que se ha producido una mediación de la agenda inversa por parte de la ciudadanía a través Internet. Establecen que los comportamientos poco éticos o adecuados de políticos y parlamentarios son los que más suscitan esta práctica. Ying Jiang (2014) aplicó esta teoría al caso chino, examinando cómo Weibo, una de las redes sociales más populares en China, fue capaz de fijar la agenda-setting. Su investigación proporcionó evidencias de cómo tendencias (trending topics) de Weibo habían sido capaces de impactar en la agenda de los medios de comunicación 
controlados por el Estado. De este análisis se extrae que los casos de corrupción son los que más generan esta práctica.

En España, recientes investigaciones (Feenstra y Casero-Ripollés, 2012) han corroborado que el $15 \mathrm{M}$ logró incorporar una de sus demandas, la supresión del Senado, a la agenda de los medios de comunicación. En 2011 empezó a circular un correo electrónico en el que se detallaba cuál era el gasto del Senado en España y se exigía su supresión tal y como ocurre en países como Noruega o Suecia. El tema tuvo una gran repercusión en blogs, foros y redes sociales y el $15 \mathrm{M}$ lo incorporó como una de sus demandas y uno de sus principales temas de discusión. Lo que había nacido en la red, dio el salto a los medios convencionales de la mano de Salvados que dedicó un capítulo a intentar averiguar la función del Senado. La mayoría de senadores entrevistados respondió que no tenía ninguna utilidad en la actualidad. El programa fue visto por más de un millón de espectadores, muy activos en las redes sociales, especialmente Twitter, donde comentaban con sorpresa e incredulidad las declaraciones de los políticos entrevistados por el presentador del programa, Jordi Évole. Dos meses después, a una semana de las elecciones generales, el diario El País publicó un crítico reportaje sobre esta cuestión. Aunque el movimiento consiguió introducir esta noticia, ambos expertos coinciden en el hecho de que los medios convencionales aún ocupan una posición central en la esfera pública, por lo que todavía es necesaria su mediación para que el mensaje llegue a un número más amplio de personas y adquiera una mayor visibilidad social.

Peso a ello, todavía queda mucho por investigar, especialmente en el caso español.

\section{Bibliografía}

ANDUIZA, E. y otros (2013): «Mobilization Through Online Social Networks: The Political Protest of Indignados in Spain», Information, Communication y Society, 17(6).

BAKKER, P. (2014): «Mr. Gates Returns», Journalism Studies, 15(5).

BRUNO, N. (2011): Tweet First, Verify Later: How Real-Time Information Is Changing the Coverage of Worldwide Crisis Events, Reuters Institute for the Study of Journalism, Oxford.

CASAS, A. y otros (2015): «Protesta multitudinaria. ¿Mensaje caótico?. La interacción entre el 15M y los medios de comunicación», Repositorio Universidad de Washington.

CAPPeletti, M. y S. Domínguez (2014): «La curaduría de contenidos y la narrativa colaborativa en el Ciberperiodismo: Estudio de caso de Storify en el diario digital Elpais.com», Estudio sobre el Mensaje Periodístico, 20(1). 
Casero-Ripollés, A. y R. Feenstra (2012): "The 15M Movement and the New Media: A Case of Study of How New Themes Were Introduced into Spanish Political Discourses», Media International Australia, 144.

CASERo-RIPollés, A. (2009): «El control político de la información periodística», Revista Latina de Comunicación Social, 64.

CASERo-Ripollés, A. (2008): "Modelos de relación entre periodistas y políticos: La perspectiva de la negociación constante», Estudio Sobre el Mensaje Periodístico, 14.

CAstells, M. (2009): Comunicación y Poder, Alianza, Madrid.

CHADWICK, A. (2011): "The Political Information Cycle in a Hybrid News System: The British Prime Minister in the 'Bullygate' Affair», International Journal of Press Politics, 16(1).

- (2012): «Recent Shifts in the Relationship Between the Internet and Democratic Engagement in Britain and the United States: Granukarity, informational exuberance and political learning", ANDUIZA, E.; M. JENSEN Y L. JORBA (ed.): Digital Media and Political Engagement Worldwide, Cambridge University Press, Nueva York.

Della PoRTA, D. (2011): «Communication in Movement: Social Movements as Agents of Participatory Democracy", Information, Communication $y$ Society, 14(6).

Feenstra R. A. y A. Casero-Ripollés (2014): «Democracy in the Digital Communication Environment: A Typology Proposal of Political Monitoring Processes», International Journal of Communication, 8.

Feenstra R. A. y A. CASERo-Ripollés (2012): «Nuevas formas de producción de noticias en el entorno digital y cambios en el periodismo: el caso del 15-M», Comunicación y Hombre, 8.

Feenstra, R. A. (2012): Democracia monitorizada en la galaxia mediática, Icaria, Barcelona.

Ferreras-Rodríguez, E. M. (2011): «Redes sociales y cambio social. El movimiento $15 \mathrm{M}$ y su evolución en Twitter», Telos, 89, Madrid.

FuCHS, C. (2014): Social Media: a Critical Introduction, Sage, Londres.

GladWELL, M. (2010, 4 de octubre): «Small Change: Why the Revolution Will not be Tweeted", The New Yorker.

HARO, C. y V. SAMPEDRo (2011): «Activismo político en Red: del Movimiento por la Vivienda Digna al 15M», Teknocultura, 8(2).

HEINRICH, A. (2010): Network Journalism. Journalistic Practice in Interactive Spheres, Routledge, Londres.

Hermida, A. y otros (2014): "Sourcing the Arab Spring: A Case Study of Andy Carvin's Sources on Twitter during the Tunisian and Egyptian Revolutions", Journal of Computer-Mediated Communication, 19(3).

HermidA, A. (2012): «Tweets and Truth», Journalism Practice, 6(5-6). 
Howard, P. N. y otros (2011): "When do States Disconnect Their Digital Networks? Regime Responses to the Political Uses of Social Media», The Communication Review, 14(3).

Jenkins, H. (2006): Convergence Culture: Where Old and New Media Collide, NYU Press, Nueva York.

JING, Y. (2006): «'Reversed Agenda-Setting Effects' in China. Case Studies of Weibo Trending Topics and the Effect on State-Owned Media in China», Journal of International Comunnication, 20(2).

KEANE, J. (2009): The Life and Death of Democracy, Simon \& Shuster, Londres.

LASORSA, D. y otros (2012): "Normalizing Twitter: Journalism Practice in an Emerging Communication Space», Journalism Studies, 13(1).

Linares-Lanzman, J. y L. Pérez-Altable (2015): «Usos de Twitter durante el 15M. El caso de la prensa catalana», Sur le Journalism, 4(1).

LoAder, B. D. y D. Mercea (2012): Social Media and Democracy: Social Media Innovations in Participatory Politics, Routledge: Londres.

López-MerI, A. (2015): "Twitter como fuente informativa de sucesos imprevistos: el seguimiento de hashtags en el caso de \#ArdeValencia», Anuario Electrónico de Estudios en Comunicación Social "Disertaciones", 8(1).

Margetts, H. (2013): "The Internet and Democracy», en Dutton, W. H. (ed): The Oxford Handbook of Internet studies, Oxford University Press, Gran Bretaña.

MCCHESNeY, R. W. (2013): Digital Disconnect: How Capitalism Is Turning the Internet Against Democracy, The New Press, Nueva York.

McElroY, K. (2013): "Where Old (Gatekeepers) Meets New (Media)», Journalism Practice, 7(6).

McNaIR, B. (2006): Cultural Chaos. Journalism, News and Power in a Globalised World, Routledge, Londres.

Micó J. L. Y A. CASERo-Ripollés (2014): "Political Activism Online: Organization and Media Relation in the Case of 15M in Spain», Information, Communication y Society, 17(7).

Morozov, E. (2011 a): The Net Delusion. The Dark Side of Internet Freedom, Public Affairs, Nueva York.

- (2011 b, 7 de marzo): «Facebook and Twitter are Just Places Revolutionaries Go», The Guardian.

PApacharissi, Z. y M. De FÁtima Oliveira (2012): «Affective News and Networked Publics: The Rhythms of News Storytelling on \#Egypt», Journal of Communication, 62(2). 
ReSINA DE LA FUENTE, J. (2010): "Ciberpolítica, redes sociales y nuevas movilizaciones en España: el impacto digital en los procesos de deliberación y participación ciudadana», Mediaciones Sociales. Revista de Ciencias Sociales y de la Comunicación, 7.

SAMPEDRO, V. (2000): Opinión pública y democracia deliberativa, Istmo, Madrid.

SHIRKY, C. (2011): "The Political Power of Social Media», Foreign Affairs, 90(1).

SUBIRATS, J. (2015): «Todo se mueve. Acción colectiva, acción conectiva. Movimientos, partidos e instituciones», Res, 24.

SUNG-TAE, K. y L. YOUNG-HWAN (2007): «New Functions of Internet Mediated Agenda-Setting: Agenda-Rippling and Reversed Agenda-Setting», Korea Journalism Review, 1(2).

TORET, J. (2013): Tecnopolítica: la potencia de las multitudes conectadas. El sistema red 15M, un nuevo paradigma de la política distribuida, UOCIN3, Barcelona.

VAN DIJK, T. A. (1993): "El poder y los medios de comunicación», Periodística, 6. 


\section{Twitter y comunicación política. Análisis del caso Podemos y la construcción de agenda}

Silvia Marcos García smarcos@uji.es 
La irrupción de Internet y de las redes sociales durante las últimas décadas ha transformado numerosas áreas del ámbito de la comunicación, como la comunicación política. Políticos, medios de comunicación y ciudadanos han intercambiado los roles que tradicionalmente ejercían, y han adoptado nuevas funciones y estrategias comunicativas. En este contexto, Twitter se ha convertido en un escenario clave donde partidos y representantes políticos difunden su mensaje, dialogan y movilizan a la ciudadanía sin necesidad de someterse al filtro mediático.

El objetivo de esta investigación es conocer las estrategias de Podemos - uno de los partidos con mayor presencia en los medios de comunicación este último año 2015- en Twitter para construir y proponer su agenda temática. Para ello, se analizará la actividad que tienen sus perfiles y los contenidos que proponen.

Mediante un análisis métrico se conocerán aspectos como la frecuencia de actualización, el tipo de publicación, sus seguidores y la interacción de los mismos. Asimismo, el análisis cuantitativo se centrará en los temas propuestos. En concreto, se han estudiado los perfiles del partido y de sus principales líderes -Pablo Iglesias, Iñigo Errejón y Juan Carlos Monedero- durante dos semanas, comprendidas entre los meses de marzo y abril de 2015.

Los resultados obtenidos establecen que los perfiles de Twitter analizados tienen un alto grado de actividad con una publicación considerable de tuits y retuits, así como una gran interactividad por parte de sus seguidores. Además, se hace un gran empleo de la plataforma como altavoz para dar a conocer multitud de sus temas. No obstante, cada perfil destaca por dotar de una mayor relevancia a determinadas cuestiones, mostrando así discrepancias entre la estrategia comunicativa realizada por el partido y la de sus miembros.

Palabras clave: comunicación política, Twitter, Podemos, agenda temática.

\section{Introducción}

Las últimas décadas han supuesto un relevante cambio a la hora de concebir la comunicación política actual. Tradicionalmente, esta estaba limitada a un escenario basado en estructuras jerárquicas y en una comunicación unidireccional encabezada únicamente por partidos y políticos. Junto a ellos, los medios de comunicación tenían un gran poder, pues eran aquellos que actuaban como filtro e intermediario entre estos actores y la ciudadanía. Políticos y medios de comunicación eran los únicos capaces, no solo de construir la realidad política, sino también de 
influir en la opinión pública (Mazzoneli, 2010). Por el contrario, la ciudadanía quedaba relegada a interpretar el papel de mero receptor, incapaz de participar y cuya única fuente de información era la prensa, radio y televisión (Strömbäck, 2008). De esta manera, sin un poder ciudadano capaz de controlar a los medios de comunicación y a los actores políticos, se creaba lo que autores como Mazzoneli y Schulz (1999) definen como "mediatización de la política», es decir, un monopolio en el que se restringía el acceso directo al ámbito político tanto a la sociedad como a otras organizaciones sociales.

Sin embargo, a pesar de que hoy en día todavía se mantiene parte de esta estructura jerárquica -especialmente por la posición de los medios tradicionales como núcleo de la comunicación- la aparición de Internet y de las redes sociales ha introducido nuevos paradigmas en el actual escenario político (Chadwick, 2013). Uno de los cambios más importantes se encuentra en el concepto de interacción, pues con la Web 2.0 y, sobre todo, con plataformas sociales como Facebook, Twitter o YouTube se ha creado un espacio donde se comparte la información y se potencia el intercambio entre usuarios, donde se incluye tanto a los agentes políticos como a los ciudadanos (O’Reilly, 2005). Así, la ciudadanía pasa de ser un mero receptor a convertirse en un público activo capaz de difundir y producir de forma autónoma cualquier contenido (Sampedro, 2011; Chadwick, 2013).

Es más, la sociedad ha pasado a tener el suficiente poder como para convertirse en voces alternativas capaces de participar e introducir sus protestas en la esfera pública (Casero-Ripollés, 2010). Gracias a las nuevas tecnologías, el ciudadano puede acceder a muchos más datos, supervisar qué es aquello que están haciendo los agentes políticos e incluso denunciar los casos en los que estos se aprovechen de su poder. Es lo que John Keane (2009) plantea como «democracia monitorizada». El caso de Edward Joseph Snowden en 2013, quien hizo públicos documentos clasificados como alto secreto sobre varios programas de la NSA, o el caso conocido como la Lista Falciani en 2010 son algunos de estos claros ejemplos.

Tal es la revolución que han producido las redes sociales en el escenario político, que ya hay estudios que se plantean su capacidad y su poder para transformar las democracias actuales (Margetts, 2013). Sobre todo, la plataforma social Twitter es la que se ha posicionado como la red social con mayor peso en el ámbito de la comunicación política (Barberá y Rivero, 2012). Con más de 302 millones de usuarios en todo el mundo y un total de 500 millones de tuits por día, esta red social se ha convertido en uno de los instrumentos comunicativos más poderosos de la historia (Piscitelli, 2011) puesto que "ha cambiado la red y ha completado el giro social que iniciaron los blogs a finales de los años noventa» (Orihuela, 2011: 21).

El ejemplo por excelencia de esta realidad se sitúa en el año 2008, en la campaña electoral del hoy presidente de Estados Unidos, Barack Obama, un episodio que para muchos expertos fue el antes y después en 
la política virtual. A través de la utilización de los medios sociales cuya estrategia se basó en representar a un candidato cercano y en hacer partícipes del éxito a sus seguidores, no solo logró recaudar 500 millones de dólares en microdonaciones, sino que también consiguió un elevado número de votantes y se dio a conocer por gran parte del mundo. A partir de entonces, alentados por este precedente, cada vez fueron más los políticos que se animaron a buscar un hueco en las redes sociales (Túñez y Sixto, 2011).

En el caso de España, las elecciones generales de 2008 y las elecciones autonómicas y municipales de 2011 supusieron un punto de inflexión ya que los partidos en campaña emplearon, por primera vez y de manera masiva, las herramientas digitales intentando captar la atención y fomentar la implicación de la ciudadanía (Sampedro, 2011). Sin embargo, lejos de realizar una buena gestión, su uso denotó que solo contemplaban estas herramientas como altavoz ideológico para promocionar sus propuestas (Alonso y Adell, 2011). En la mayoría de los casos, una vez finalizó la campaña dejaron de emplear sus perfiles en Twitter (Toribio y Ibáñez, 2011). De hecho, el uso que hacían apenas implicaba interacción con otros usuarios y su función era principalmente difundir consignas y mensajes de contenido político y sus mensajes no lograban irradiar al público o lo hacían en términos negativos (López, 2015). De esta forma, pese a entender la importancia de Internet y contar con presencia en las redes sociales, los agentes políticos no supieron hacer un uso efectivo (Abejón, et al., 2012).

No obstante, la campaña electoral de 2008 sí que fue el inicio de un cambio. Según Sampedro (2013: 106):

permitió identificar tendencias que darían lugar a cibermovilizaciones posteriores que, sumadas, desembocarían en el movimiento de los indignados o $15 \mathrm{M}$ que irrumpió en el tramo final de la siguiente campaña electoral dos años más tarde.

De esta manera, en España los antecedentes que pueden equipararse al éxito de movilización de Obama son el conocido como 13M, cuando en marzo de 2004 los españoles salieron a las calles como respuesta a la manipulación electoralista de los atentados sucedidos dos días antes; el Movimiento por una Vivienda Digna (MVD); la Plataforma de Afectados por la Hipoteca (PAH), o el más reciente 15M, en 2011. Todos ellos se definen por el uso de las tecnologías de la información. Las TIC han generado un nuevo perfil de movimiento social que se caracteriza principalmente por su organización y coordinación en red y por su carácter descentralizado, flexible y colectivo. Es más, se han convertido en un mecanismo fundamental para controlar el poder político e impactar en los medios de comunicación convencionales (Sampedro, 2011).

No obstante, lo más importante de este movimiento en relación con la temática que aborda esta investigación es su ámbito comunicativo. Tal y como se ha dicho anteriormente, los medios de comunicación convencionales se han posicionado como la institución dominante a la 
hora de establecer la agenda (McCombs, 2004). Sin embargo, con la aparición de Internet y las redes sociales, los ciudadanos y los activistas pueden aspirar a captar la atención de los medios convencionales provocando que estos incorporen sus temas e, incluso, sus marcos discursivos a su agenda (Casero y Feenstra, 2012). Se ha producido un proceso en el que las esferas públicas periféricas, es decir, aquellos segmentos de la sociedad civil que no conseguían introducir sus temas en la esfera pública central, se han multiplicado en número (Sampedro, 2011). Por consiguiente, los actores de la sociedad civil, en suma, «han ganado en centralidad y en capacidad para elaborar sus propios mensajes y hacerlos públicos, interactuando continuamente entre ellos e incluso con el poder, que pierde opacidad» (López, 2006: 241).

$Y$ es que iniciativas como la del $15 \mathrm{M}$ responden a una lógica cuyo objetivo no se centra en la consecución única de poder, sino en informar y trabajar sobre los problemas que afectan al sistema democrático. Una filosofía que, tras todo el trasfondo que conllevó, produjo que se diera un paso más y aparecieran nuevos partidos políticos cuyas bases se sentaban sobre sus mismas intenciones. Según explican Keane y Feenstra (2014:54):

la transformación en partido de algunos grupos de activistas o de ciudadanos responde al propósito de emplear la forma de partido y la participación en las elecciones como una estrategia política válida para mostrar los déficits del sistema político.

En España, el caso por excelencia que ha protagonizado esta evolución ha sido Podemos. Fundado en enero de 2014, nació a partir de un manifiesto presentado por un grupo de intelectuales así como por otros profesionales en el que se expresaba la necesidad de crear una candidatura para las próximas elecciones europeas que tendrían lugar en mayo de ese mismo año y que tuviera como objetivo denunciar y oponerse a las políticas puestas en marcha por la Unión Europea de cara a la crisis económica. Entre los componentes de este grupo se encontraba Pablo Iglesias, profesor de Ciencias Políticas de la Universidad Complutense de Madrid y analista político conocido por su presencia en programas como La Tuerka y posteriormente elegido como secretario general del partido. Cuatro meses más tarde de su nacimiento lograron cinco escaños de 54 en el Parlamento Europeo, y se convirtieron así en la cuarta fuerza política más votada en España.

Unos resultados influenciados en gran parte por las redes sociales, pues la existencia y el trabajo de este partido viene dada gracias a las facilidades de comunicación proporcionadas por las nuevas tecnologías (Vallespín, 2015). Al contrario que lo que ocurría en otros casos, donde los políticos se abrían sus cuentas en redes sociales con motivo de campaña, en el caso de Pablo Iglesias su presencia en Twitter ha sido constante y activa desde su ingreso en la red social en el año 2010. Un comportamiento que, sumado a sus múltiples apariciones en tertulias y en programas televisivos, le sirvió para poder ampliar y contar con un alto 
número de seguidores ya el año previo a las elecciones europeas (López, 2015). De hecho, su estrategia mediática consiste en una combinación secuencial de producción audiovisual propia, viralización en redes digitales y presencia en medios y formatos convencionales mayoritarios (Sampedro, 2015). A pesar de que los medios de comunicación siguen siendo un escenario principal para el desarrollo de la vida política, estos ya no monopolizan el acceso a este escenario $y$, es más, deben compartirlo con la nueva comunidad virtual (Vallespín, 2015). De hecho, la estrategia de comunicación política de Podemos, sumada a un clima de descontento ciudadano por el contexto de crisis, el desprestigio de los partidos tradicionales y los casos de corrupción, entre otros factores, explica su éxito electoral y su estrategia política para llegar al poder.

Como conclusión, Podemos ha supuesto una verdadera revolución en el panorama político español. La formación de Iglesias ha irrumpido en las encuestas gracias a una completa renovación frente a los partidos tradicionales. La construcción de un discurso donde Podemos y la ciudadanía aparecen como un «nosotros» frente a un sistema político dominado por «la casta», su continua presencia en medios de comunicación, tanto propios como de los grandes grupos mediáticos, y un comportamiento en las redes centrado principalmente en la participación, han hecho de Podemos un referente en una estrategia de comunicación política en la que los medios no son entendidos únicamente como una herramienta para lanzar mensajes, sino también como instrumento de interacción y diálogo.

\section{Objetivos}

Los objetivos que se plantean en esta investigación son los siguientes:

En un primer lugar, se pretende analizar cuál es el uso que tanto el partido político Podemos como sus principales líderes -Pablo Iglesias, Iñigo Errejón y Juan Carlos Monedero- realizan de la plataforma Twitter. La finalidad es precisar si existe una homogeneidad en la actividad llevada a cabo por todos los perfiles o, si por el contrario, existen discrepancias entre ellos a la hora de gestionar esta herramienta.

En segundo lugar, se contempla identificar qué tipo de temas y contenidos son los que presentan estos cuatro perfiles en el momento de construir su agenda temática en esta red social. De la misma manera que en el objetivo anterior, se busca comprobar si existe una estrategia común o si contrariamente cada perfil plantea una serie de contenidos independientes y sin relación al resto.

\section{Material y método}

Para responder a los objetivos planteados la metodología empleada en esta investigación es un análisis de contenido cuantitativo 
complementado con un análisis métrico de los perfiles de Twitter seleccionados.

En primer lugar, el análisis métrico está enfocado a conocer los datos más importantes de cada perfil así como su influencia dentro de la red social. Son el número de seguidores y seguidos, su grado de actividad diaria o la interacción con otros usuarios, entre otros. Para la obtención de esta información se ha empleado la herramienta MetricSpot, especializada en este tipo de análisis.

En segundo lugar, el análisis de contenido se desarrolla con el objetivo de estudiar la estructura de los tuits, especialmente, la temática de cada uno de ellos con el fin de conocer cuál es la agenda que plantea cada perfil. El uso de esta técnica de investigación posibilita entender la estructura y los componentes de los mensajes para finalmente mostrar el significado oculto que hay tras ellos (Igartua y Humanes, 2004). En concreto, se ha seguido el modelo planteado por el Grupo de Análisis de la Agenda Política en España, ${ }^{1}$ grupo de investigación con una trayectoria consolidada en el campo de la investigación política y reconocida por la AGAUR (Agència de Gestió d'Ajuts Universitaris i de Recerca).

Tabla 1. Resumen del protocolo utilizado en el análisis cuantitativo

\begin{tabular}{|c|c|c|}
\hline \multicolumn{3}{|c|}{ Temáticas } \\
\hline Macroeconomía & Libertades civiles & Política Fiscal \\
\hline Discriminación de género & Inmigración & Política de empleo \\
\hline Medioambiente & Política social & Política de vivienda \\
\hline Política bancaria & Mercado de valores & Medios de comunicación \\
\hline Corrupción & Organización institucional & $\begin{array}{c}\text { Sistema electoral y de } \\
\text { partidos }\end{array}$ \\
\hline Gobierno y democracia & Memoria histórica & Monarquía \\
\hline & Otros \\
\hline
\end{tabular}

En cuanto al diseño metodológico, teniendo en cuenta la variable temporal, se han seleccionado dos periodos que corresponden a la semana del 2 al 9 de marzo de 2015 y a la semana del 13 al 20 de abril de 2015, una elección que se plantea de acuerdo a tres aspectos. El primero de ellos es la actualidad, puesto que en las semanas elegidas Podemos ya se ha asentado como una fuerza política sólida que ha definido sus bases de actuación y, por tanto, su comunicación. El segundo de ellos, es la intención de evitar actos o momentos clave que puedan sesgar la muestra. De esta forma, por ejemplo, no se ha podido analizar el mes de enero, dada la celebración de uno de los actos más importantes en la historia del partido, la "Marcha por el cambio», y tampoco el mes de mayo con motivo de la celebración de las elecciones autonómicas y

1. http://www.comparativeagendas.info/ 
municipales de 2015. Por último, el tercer motivo es el alto grado de actividad que se ha observado en el análisis previo de Twitter, donde cada perfil contaba con un número muy alto de tuits.

En cuanto a la selección de perfiles de Twitter se refiere, se ha decidido optar por el que posee el partido a nivel general y por el de tres de sus dirigentes: Pablo Iglesias, Iñigo Errejón y Juan Carlos Monedero, quien todavía no había dimitido de su cargo. Utilizando la herramienta online MetricSpot se ha observado que estos perfiles cuentan con un alto nivel de actualización y engagement, rasgos muy importantes a la hora de llevar a cabo una buena estrategia de comunicación. De hecho, tal es la actividad que diariamente se produce en el perfil de Podemos, que la selección de los tuits de esta cuenta se ha debido limitar a la franja horaria concentrada entre las $10 \mathrm{~h}$ y las $13 \mathrm{~h}$, aquella en la que muestran mayor número de publicaciones. Si no se hubiera hecho esta limitación, los resultados obtenidos estarían sesgados ya que el número de tuits diarios del partido sumaba una cifra mucho mayor que la suma de las publicaciones de los perfiles de los dirigentes. Así, de este modo, la muestra está mucho más equilibrada y se puede llegar a unos resultados mucho más fiables. En concreto, el número total de tuits analizados es de 168 - de los cuales, 48 pertenecen a Podemos; 35, a Pablo Iglesias; 50, a Iñigo Errejón, y 35, a Juan Carlo Monedero.

\section{Resultados}

\subsection{Análisis métrico}

El análisis métrico de los perfiles analizados muestra, en primer lugar, como al contrario de la dinámica llevada a cabo hasta ahora por los políticos españoles, quienes se abrían el perfil de cara a la campaña electoral, la antigüedad de las cuentas de Pablo Iglesias, Iñigo Errejón y Juan Carlos Monedero oscila entre los tres y los cinco años (Tabla 2). Esto demuestra cómo la importancia que le han dado al uso de esta herramienta no se limita únicamente a la autopromoción o lo usan como un simple altavoz de sus propuestas electorales. Al contrario, desde que Twitter fuera ganando peso en el ámbito político, estos tres líderes le han dado mucha relevancia, incluso antes de su participación en la vida política.

Asimismo, analizando el grado de actividad de todos los perfiles, se observa como en todos ellos el número de tuits publicados al día es realmente considerable, un factor que demuestra una gestión fuerte a la hora de usar esta herramienta para transmitir sus mensajes, opiniones y reflexiones. Destaca, sobre todo, el caso de Íñigo Errejón quien, pese a no ocupar el cargo de líder de la formación, llega a doblar la actividad diaria de Iglesias con una media de diez tuits al día frente a los cinco del secretario general. 
Complementario al grado de actividad, los datos demuestran como la tipología de publicaciones que realizan está muy equiparada. En este sentido se observa que, en todos los casos, el porcentaje de tuits propios y el de los retuits es muy similar, de forma que demuestran así que dan gran importancia a los mensajes aportados por otros usuarios.

Tabla 2. Análisis de los datos métricos de las cuentas de Podemos y sus principales líderes

\begin{tabular}{|c|c|c|c|c|}
\hline & Podemos & P.Iglesias & I.Errejón & JC. Monedero \\
\hline Inicio de la cuenta & 12.01 .2014 & 22.06 .2010 & 03.02 .2012 & 26.01 .2010 \\
\hline Número seguidores & 730.000 & 1.240 .000 & 249.000 & 204.000 \\
\hline Tuits & $58 \%$ & $51 \%$ & $44,5 \%$ & $31 \%$ \\
$(38$ tuits/día) & $(5$ tuits/día) & $(10$ tuits/día) & (5 tuits/día) \\
\hline $\begin{array}{c}\text { Respuestas (\%) } \\
\text { Retuits (\%) }\end{array}$ & $1 \%$ & $5 \%$ & $9,5 \%$ & $43 \%$ \\
\hline $\begin{array}{c}\text { Tuits con hashtag } \\
\text { (\%) }\end{array}$ & $55,5 \%$ & $44 \%$ & $46 \%$ & $26 \%$ \\
\hline $\begin{array}{c}\text { Tuits con } \\
\text { menciones (\%) }\end{array}$ & $75,5 \%$ & $75 \%$ & $67 \%$ & $90 \%$ \\
\hline $\begin{array}{c}\text { Tuits como } \\
\text { favoritos }\end{array}$ & $100 \%$ & $100 \%$ & $100 \%$ & $100 \%$ \\
\hline \begin{tabular}{c} 
Tuits retuiteados \\
\hline
\end{tabular} & $100 \%$ & $100 \%$ & $91 \%$ & $95 \%$ \\
\hline
\end{tabular}

Sin embargo, un dato que no sigue esta tendencia es el del uso de hashtags por un lado y el uso de menciones o respuestas por otro lado. En primer lugar, los perfiles del partido, de Iglesias y de Errejón hacen un uso muy similar del hashtags, un hecho que demuestra que emplean correctamente herramientas que permiten dar mayor alcance a sus mensajes. Sin embargo, el uso que hace Monedero es prácticamente mínimo. Por el contrario, es este último el que más atiende a la relación directa con otros usuarios al dar un peso mucho más relevante a las menciones o a las respuestas, con un $80 \%$ y $43 \%$ de peso en su perfil, respectivamente.

Finalmente, por lo que respecta a la influencia de estos perfiles se observa que todos ellos cuentan con una ratio de tuits marcados como favoritos y retuiteados muy elevados, llegan al $100 \%$ en el caso de los primeros y superan el $95 \%$ en los segundos.

Como conclusión, los datos revelan como todos los perfiles analizados tienen un gran peso dentro de la plataforma Twitter, pues no solo cuentan con un alto grado de actividad y ejercen un uso constante, sino que también cuentan con un alto alcance e influencia. 


\subsection{Análisis de contenido cuantitativo. La agenda temática}

Una vez analizado el uso y la actividad que presentan todos los perfiles y vistas sus similitudes, se plantea estudiar los contenidos planteados por Podemos y sus dirigentes en cuanto a la agenda temática para definir si se sigue con esta tendencia 0 , por el contrario, hay divergencias entre ellos.

En primer lugar, se observa que la totalidad de los perfiles muestra una variedad temática muy amplia, de manera que se cumple el modelo de clasificación propuesto en la metodología. Solo temas como macroeconomía, mercado de valores y política bancaria no han sido tratados por ninguno de los perfiles. De esta manera, el análisis demuestra como Podemos ha publicado tuits sobre diez temáticas distintas en los periodos temporales seleccionados; Pablo Iglesias lo ha hecho sobre catorce temas diferentes; Iñigo Errejón, sobre doce, y Juan Carlos Monedero, sobre trece. Asimismo, estas temáticas son muy similares pues, excepto casos como monarquía que solo se encuentra en el perfil de Iglesias, o el de política fiscal en el de Monedero, el resto coinciden en los cuatro perfiles.

No obstante, a pesar de que se asemejan a la hora de publicar sobre determinadas temáticas, no lo hacen en la misma medida, pues cada uno de ellos le otorga un determinado peso a cada contenido.

En primer lugar, el 31,25 \% de los tuits publicados por Podemos giran en torno al tema de sistema electoral y partidos (Figura 1). El motivo principal de este resultado es la cercanía de las elecciones autonómicas y municipales del mes de mayo de 2015, por lo que gran parte de las publicaciones englobadas en esta área se dedicaba a informar acerca de actos que se iban a celebrar, propuestas hechas por el partido o información acerca de su programa electoral. Asimismo, los temas que le siguen más de cerca son el de política social, con un $16,70 \%$, y el de organización institucional con un $14,60 \%$, un hecho que se justifica del mismo modo que el punto anterior. Por una parte, los tuits relacionados con la política social se corresponden a iniciativas de carácter social propuestas por Podemos y a críticas al posicionamiento que el Gobierno actual del Partido Popular está teniendo frente a esta área. Por otra parte, las publicaciones sobre organización institucional giran principalmente en torno a la propia estructura del partido, en cuanto a la incorporación de nuevos cargos o la reorganización del mismo. Por último, otro tema frecuente en las publicaciones del partido es aquel relacionado con los medios de comunicación y, más concretamente, a la información referente a las ruedas de prensa que realiza la formación. En concreto el porcentaje suma casi un $15 \%$. 


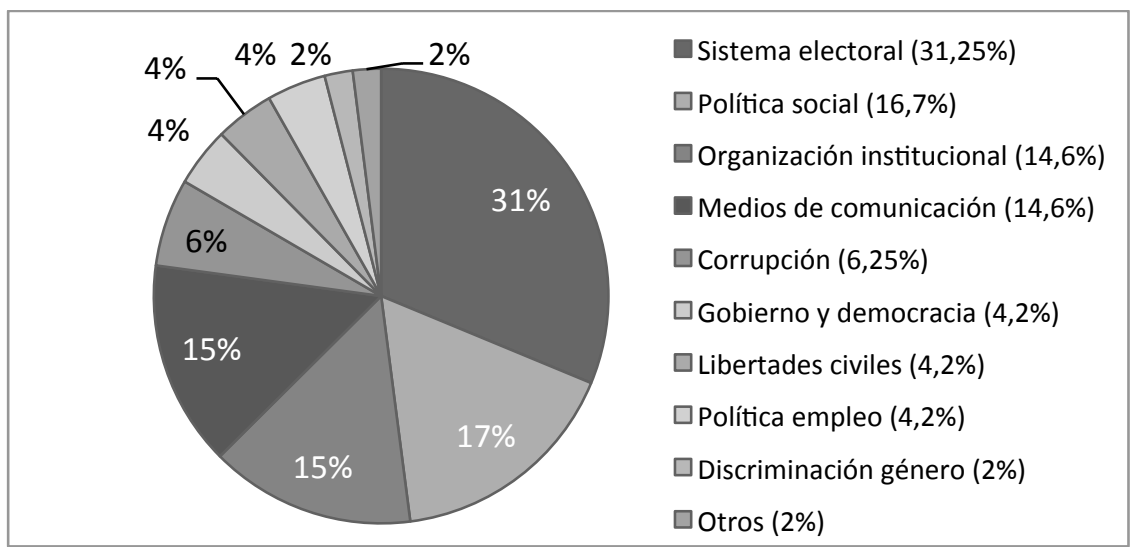

Figura 1. Temas presentados en el perfil de Podemos

De esta forma, por tanto, se observa que el uso prioritario de este perfil se relaciona con una intención principalmente política en la que la mayoría de publicaciones giran en torno a las acciones llevadas a cabo por el partido, sus propuestas para un futuro gobierno y sus críticas acerca de la actual actuación del partido que ocupa la presidencia de España, el Partido Popular.

Asimismo, otro de los perfiles cuyo tema principal es el del sistema electoral y de partidos es el de Iñigo Errejón quien, en concreto, cuenta con un $34 \%$ de publicaciones relacionadas con este área (Figura 2). La razón que justifica este resultado es que es el miembro que mayor participación ha tenido en actos de naturaleza electoral en las dos semanas escogidas para este estudio. En concreto, Errejón ha sido quien ha acompañado en la mayoría de los actos en Andalucía a la secretaria general de Podemos en esta comunidad autónoma, Teresa Rodríguez. Por este motivo gran parte de sus tuits tienen como intención informar acerca de los próximos actos en los que estará presente, así como de las reflexiones e impresiones a las que se han llegado después de la celebración de los mismos.

Sin embargo, lejos de seguir una tendencia de publicaciones únicamente de carácter institucional y político relacionadas con las propuestas y acciones de Podemos, Iñigo Errejón introduce tres nuevos temas principales como son la corrupción, presente en un $16 \%$ de sus publicaciones, Gobierno y democracia y política de empleo, ambos son el asunto central en el $12 \%$ de sus tuits. Se trata de tres áreas muy presentes en el discurso que han planteado tanto el partido como todos sus miembros desde el momento de su creación y que hoy en día, tal y como se observa, sigue planteándose como una materia importante. 


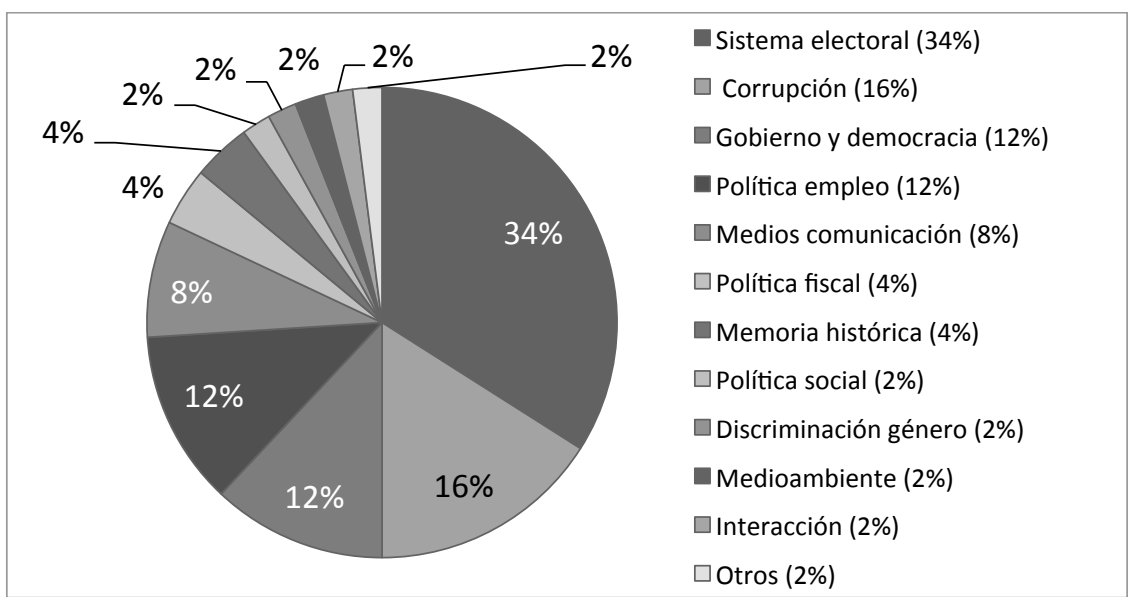

Figura 2. Temas presentados en el perfil de Iñigo Errejón

Un poco dispar es la temática que propone el secretario general de Podemos, Pablo Iglesias, quien a pesar de compartir con Errejón su interés por temas como la corrupción (14\%) o el sistema electoral (11\%), la materia a la que presta mayor atención a la hora de publicar en Twitter es la de medios de comunicación (Figura 3). En concreto, el $29 \%$ de los tuits publicados por Iglesias tienen como tema central, bien la información y enlaces para acceder a las webs o vídeos de los programas dónde ha participado -principalmente La Tuerka o Fort Apache- o bien a artículos escritos por él mismo o por otros periodistas en medios como $\mathrm{El}$ País, eldiario.es o Público y que propone leer dado el interés que le han suscitado. En este caso el resultado se justifica teniendo en cuenta la posición que ocupa Pablo Iglesias dentro del partido, lo que supone que sea el que mayor interés despierta para los medios de comunicación y aquel que, por tanto, cuenta con mayor presencia en los mismos. Asimismo, no solo participa en programas, sino que también es el encargado de presentar la tertulia política Fort Apache emitida en Hispan TV, otro factor que demuestra la estrecha relación que Iglesias mantiene con los medios.

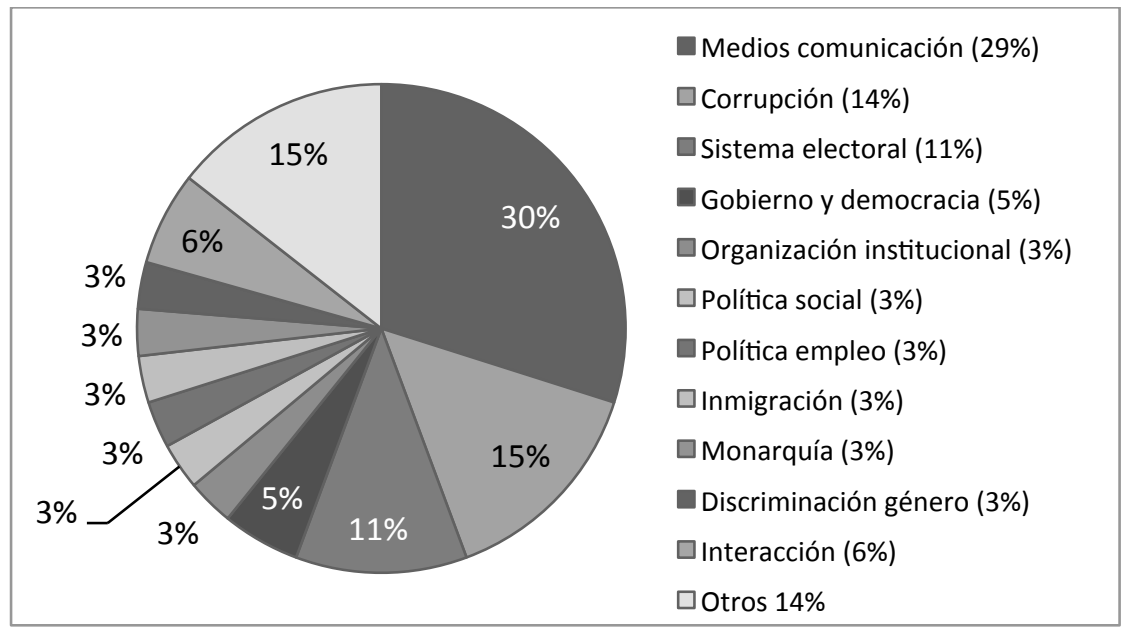

Figura 3. Temas presentados en el perfil de Pablo Iglesias 
Un hecho que cabe destacar dentro de la agenda temática propuesta por el líder de Podemos es que, además de ser aquel que mayor variedad de contenidos muestra con respecto al modelo de estudio utilizado en esta investigación, es el que mayor porcentaje representa dentro de la clasificación de "Otros», concretamente, un $14 \%$. Este porcentaje se debe a que él utiliza Twitter de una forma más personal publicando, por ejemplo, recomendaciones musicales o fotografías de sus viajes. Asimismo, y al igual que los otros miembros, también lo emplea para homenajear y despedirse de figuras tan importantes como los escritores Eduardo Galeano o Günter Grass, fallecidos ambos el 13 de abril de 2015.

Por último, el análisis de las publicaciones de Juan Carlos Monedero permite observar que, al contrario de lo que ocurre en los casos anteriores, no hay ningún tema que haya monopolizado el perfil de este político. Por el contrario, la comunicación llevada a cabo por Monedero destaca por tratar múltiples temas de una forma más o menos equilibrada. De esta forma y al igual que ocurría en los perfiles de Iglesias y Errejón, el tema corrupción (14\%) vuelve a ser uno de los más tratados en el perfil de Monedero, así como el de gobierno y democracia (11\%) y el de política de empleo (9\%). Por el contrario, temas como sistema electoral (6\%), organización institucional (6\%) o medios de comunicación $(6 \%)$ que encabezan la lista en los perfiles anteriores se encuentran, en este caso, en un nivel de importancia medio.

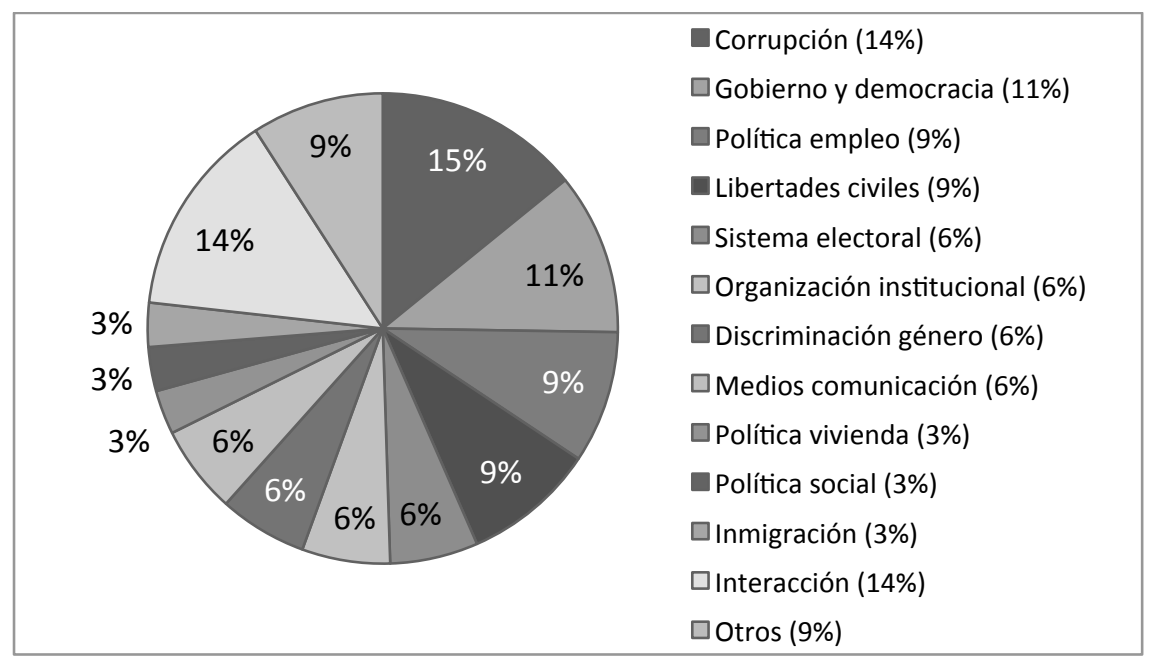

Figura 4. Temas presentados en el perfil de Juan Carlos Monedero

De hecho, si existe un dato a destacar en el caso de Juan Carlos Monedero es que es el perfil en el que hay más de tuits cuya intencionalidad se basa principalmente en la interacción con otros usuarios ajenos al partido. En concreto, se trata de publicaciones en las que el político agradece la propuesta de un determinado usuario y promete trasladarlas al partido o les corrige aclarando un mensaje anterior.

En primer lugar, esto demuestra como la agenda planteada por el perfil de los líderes se corresponde con el cargo que ocupa cada uno de 
ellos en el partido. Así, mientras que la agenda temática planteada por Iglesias gira en torno a su papel como líder y principal representante $y$, por tanto, a su aparición en los medios de comunicación, Juan Carlos Monedero como secretario de Programa del partido y miembro del Consejo de Coordinación y del Consejo Ciudadano destaca por presentar temas de carácter social y relacionados con los principales pilares que marcan la actuación del partido como son las libertades civiles, el empleo o la vivienda. De hecho, tal y como se ha destacado anteriormente, Monedero es el miembro que se mantiene en un nivel mucho más cercano a los usuarios de Twitter, pues se esfuerza por mantener una conversación horizontal y continua y potencia la interactividad. Por su parte, Errejón como secretario de Política y Área de Estrategia y Campaña del partido, presenta una agenda mucho más cercana a la temática electoral, muy importante en las dos semanas seleccionadas pues, como se ha dicho anteriormente, son los meses previos a las elecciones autonómicas y municipales de mayo de 2015.

En segundo lugar, se observa como generalmente la agenda planteada por Podemos y sus líderes es muy diferente. Por el contrario, solo existen pequeñas semejanzas al hablar, por ejemplo, de temas como corrupción, donde todos los perfiles se centran en comentar la detención de Rodrigo Rato, o en las temáticas con menor peso. En este sentido, el área de discriminación de género oscila en todos los perfiles entre el 2 y $6 \%$, la de política de empleo entre el 2 y $4 \%$ y la de inmigración alrededor del $3 \%$, entre otros.

De hecho, las discrepancias entre agendas aumentan cuando se analizan los subtemas incluidos dentro de cada área temática.

Uno de los casos más relevante es el de gobierno y democracia. Como se observa (Figura 5), la gran parte de los tuits tienen como asunto central la crítica a la actuación que está llevando a cabo el actual Gobierno del Partido Popular. No obstante, mientras que Errejón y Monedero utilizan Twitter para reprochar la mala utilización de las instituciones públicas que hacen el PP y políticos como Esperanza Aguirre - Cristóbal Montoro, Podemos lo enfoca hacia otros aspectos como la falta de políticas correspondientes a este ámbito. Por su parte, Iglesias omite cualquier crítica y se centra en las propuestas que hace su propio partido ante un futuro con posibilidades de gobernar. En cuanto a Monedero, amplía su temática para valorar la democracia cuya calidad, califica, «depende de la apertura y permisión para debatir». 


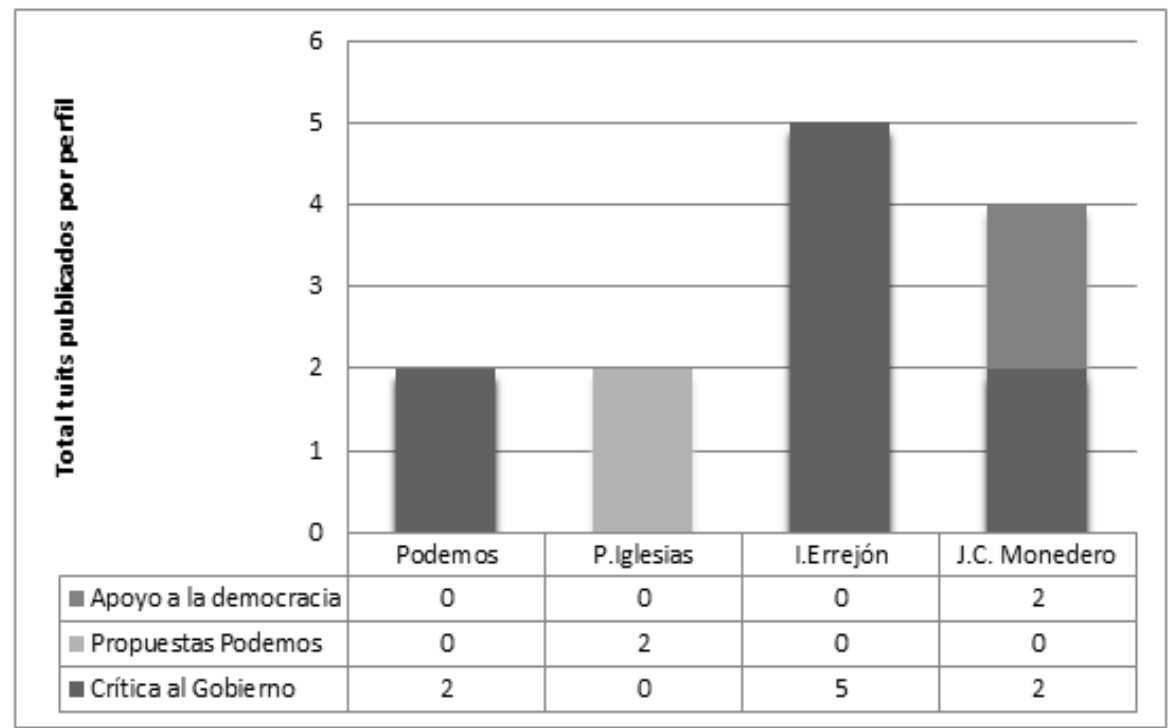

Figura 5. Clasificación de temas en el área de gobierno y democracia

De igual modo, otro ejemplo clave es el de política de empleo. A pesar de que, a excepción del partido, en todos los perfiles el tema central es la anulación del ERE a Coca-Cola, se observa cómo en el caso de Errejón o el del perfil de Podemos también se da cuenta a otro tipo de factores. En este sentido, ambos vuelven a utilizar este tema como crítica al actual gobierno del Partido Popular así como a los bajos salarios españoles. Asimismo, Errejón también utiliza Twitter para denunciar la precariedad laboral o la desigualdad entre trabajadores. Unos temas que, a pesar de ser Pablo Iglesias el líder del partido o Monedero el encargado de la parte social, no aparecen en sus perfiles.

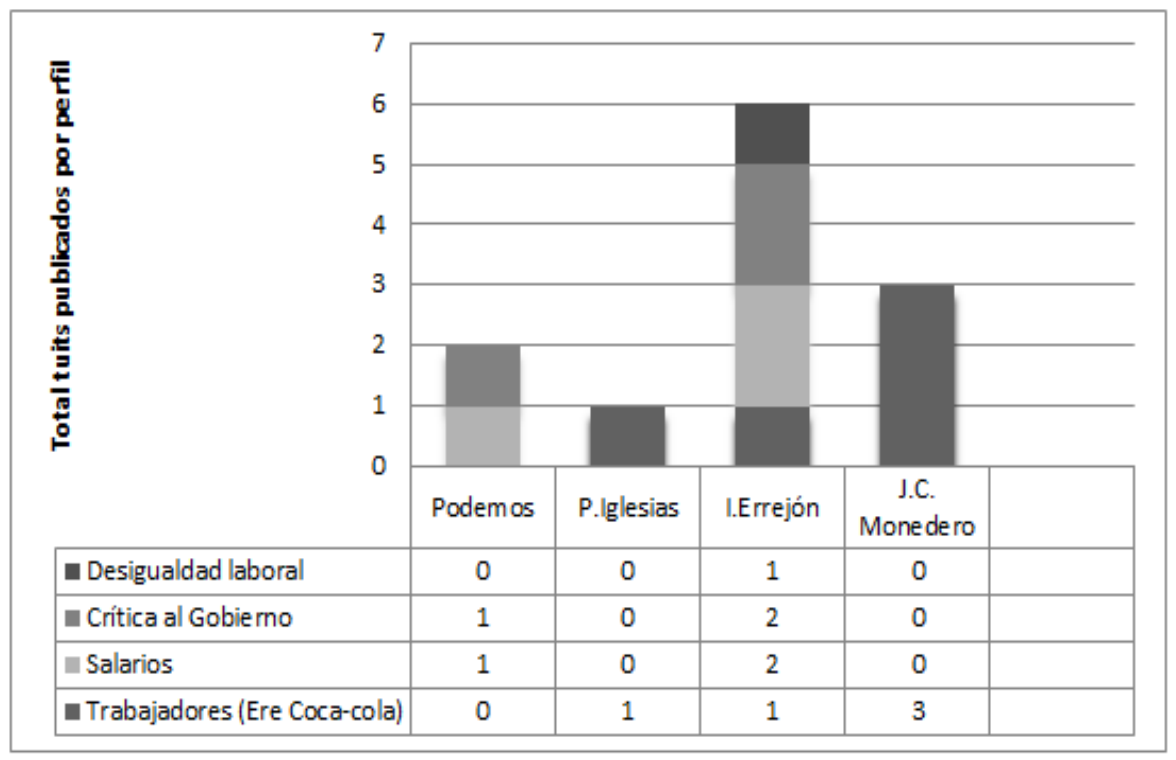

Figura 6. Clasificación de temas en el área de política de empleo 
Los resultados obtenidos tras la realización del análisis empírico demuestran que, respondiendo al primer objetivo, la estrategia de Podemos y sus líderes en la red social Twitter se ha articulado bajo los principios de actualización constante y un alto grado de influencia. Tanto el análisis métrico hecho a través de la herramienta MetricSpot, como la propia experiencia basada en el trabajo sobre los cuatro perfiles, han permitido observar a una formación cuya filosofía se basa en una comunicación tenaz cuyo objetivo principal es hacer del usuario un miembro más del partido con el fin de que participe y sienta que desde Podemos se están preocupando por sus intereses. Por ello, el lenguaje empleado apela en muchas ocasiones al «tú», pues lo que buscan es que el usuario se sienta identificado.

Sin embargo, cuando nos centramos en términos de interacción directa, la estrategia a nivel general todavía no es efectiva ya que la mayoría de los perfiles apenas hace uso de herramientas como las menciones o de la respuestas. Esta circunstancia solo se da en el caso de Juan Carlos Monedero, cuyo peso de tuits que apelan y hacen participes a otros usuarios es incluso mayor que el de tuits propios.

Asimismo, atendiendo al segundo de los objetivos, se ha demostrado como la agenda temática propuesta por Podemos y sus miembros, en un primer nivel, muestra una gran coincidencia. En este sentido, se observa como todos ellos atienden a una gran variedad de temas que, en menor o mayor grado, están presentes en todos los perfiles. En concreto, áreas como corrupción, sistema electoral y de partidos o gobierno y democracia son aquellos con mayor presencia en el ámbito general. Igualmente, temáticas como inmigración o discriminación de género son aquellos que aparecen en un menor grado en todos los casos.

No obstante, esta tendencia desaparece una vez se estudia el peso de los temas en cada perfil. Se percibe que no hay una estrategia comunicativa fuerte y común, pues cada uno le da una determinada relevancia a una tipología de temas $y$, dentro de los mismos, a unos determinados hechos y/o factores. El ejemplo clave de esto lo vemos en las principales temáticas de cada perfil ya que, mientras Podemos y Errejón atienden más a áreas como sistema electoral, Iglesias publica principalmente tuits sobre medios de comunicación, y Monedero sobre corrupción, gobierno y democracia o libertades civiles, entre otros.

Es más, como se ha advertido en el análisis de los subtemas, incluso en aquellas áreas en las que coinciden, cada uno de ellos atiende a unos hechos o datos muy diversos, tal y como se ha visto en el caso de gobierno y democrática o política de empleo, entre otros.

De esta manera y a modo de conclusión, podemos decir que ciertamente nos encontramos en un nuevo escenario donde los límites en las relaciones entre políticos, medios y ciudadanos están cada vez más difusos. No obstante, todavía es muy difícil saber hacia dónde llevará este cambio ni cuáles serán sus transformaciones definitivas. Lo que sí que es 
posible afirmar es que la política, y más concretamente la comunicación política, no podrá plantearse sin el uso de Internet $\mathrm{y}$, mucho menos, de las redes sociales.

\section{Bibliografía}

ABEJón, P. y otros (ed.) (2012): «Facebook y Twitter en campañas electorales en España», Anuario Electrónico de Estudios en Comunicación Social Disertaciones, 5(7), p. 129-159.

Alonso, M. A. y A. Adell (2011): Marketing Político 2.0. Gestión2000, Barcelona.

BARberá, P. y Rivero, G. (2012): «¿Un tweet, un voto? Desigualdad en la discusión política en Twitter», I Congreso Internacional en Comunicación Política y Estrategias de Campaña, Alice, Madrid.

Casero-Ripollés, A. y R. Feenstra (2014): "The 15-M Movement and the New Media: a Case Study of How New Themes Were Introduced into Spanish Political Discourse» MIA. Media International Australia, 144, p. 68-76.

CASERo-Ripollés, A. (2010): «¿El despertar del público? Comunicación política, ciudadanía y web 2.0», Martín Vicente, M y D. RotChberG, D. "Meios de comunicaçao e ciudadanía», Cultura académica, Sao Paulo.

Chadwick, A. (2013): The Hybrid Media System. Politics and Power. Oxford University Press, New York.

IgARTUA, J. J. Y M. L. HumAnes (2004): Teoría e investigación en comunicación social, Síntesis, Madrid.

KeAne, J. (2009): The Life and Death of Democracy, Simon and Shuster, London.

KeAne, J. y R. Feenstra (2014): «Democracia monitorizada en España. Nuevas formas de participación política en el marco de la era digital», Telos: Cuadernos de comunicación e innovación, p. 48-57.

López-GarcíA, G. (2015): «Estrategias de movilización política de los partidos para un público desmotivado: Internet y las Elecciones Europeas de 2014», III Congreso Internacional en Comunicación Política y Estrategias de Campaña: Marketing Político, estrategias globales en escenarios globales y regionales, ALICE, Asociación Latinoamericana de Investigadores en Campañas Electorales.

LóPEZ, G. (2006): "Comunicación en red y mutaciones de la esfera pública», Zer, 20, p. 231-249.

Mazzonel, G. (2010): La Comunicación Política, Alianza, Madrid.

MazzolenI, M. y W. Schulz (1999): «Mediatization of Politics: A Challenge for Democracy?», Political Communication, 16, p. 247-261. 
MargetTs, H. (2013): "The Internet and Democracy», Dutton, W.H. (ed.) "The Oxford Handbook of Internet Studies» Oxford University Press, p. 421-437, Oxford.

McCombs, M. (2004): Setting the Agenda: The Mass Media and Public Opinion, Polity Press, Cambridge.

O’Reilly, T. (2005): Web 2.0: "Compact definition» Message posted to http://radar. oreilly. com/archives/2005/10/web_20_compact_definition. html.

ORIHUELA, J. L. (2011): Mundo Twitter, Alienta, Barcelona.

PISCITELLI, A. (2011): "Twitter, la revolución y los enfoques ni-ni», ORIHUELA, J. L., Mundo Twitter, Alienta, Barcelona.

SAMPEDRO, V. (2015): «Podemos, de la invisibilidad a la sobre-exposición». Revista Teknokultura, 12, p. 137-145.

SAMPEDRO, V. y otros (ed.) (2013): «Ciudadanía y tecnopolítica electoral. Ideales y límites burocráticos a la participación digital». Co-herencia, 18, p. 105-136.

SAMPEDRo, V. (2011). Cibercampaña. Cauces y diques para la participación. Las elecciones generales en 2008 y su proyección tecnopolítica. Editorial Complutense, Madrid.

StRÖMBÄCK, J. (2008): «Four Phases of Mediatization: An Analysis of the Mediatization of Politics», The International Journal of Press/Politics, 13, p. 228-246.

TORIBIO, B. y C. IBÁÑEZ, (2011): «José María Barreda y Tomás Gómez, entre los tuiteros por conveniencia» La Información.

TúÑEZ, M. Y J. SIXTo (2011): «Redes sociales, política y Compromiso 2.0: La comunicación de los diputados españoles en Facebook». Revista Latina de Comunicación Social, 66, p. 1-25.

VAllespín, F. (2015): "La gestión de la democracia en el entorno digital. Política y nuevas redes», Telos: Cuadernos de comunicación e innovación, 100. 


\section{El periodismo móvil y la creación de contenidos informativos en Internet. El caso de la revista digital Living Palermo}


El periodismo móvil se está convirtiendo en un nuevo nicho de mercado. La creación de contenidos y la proliferación de las app específicas para smartphone otorga mucho más protagonismo a este tipo de dispositivos. Cuando hablamos de periodismo móvil el éxito está conectado a algunas de las características que comparte con los teléfonos móviles, como la portabilidad, la ubicuidad o la utilización personal. Pero también está relacionada con las capacidades propias de estos mismos modelos, como la multimedialidad, la hipertextualidad y la interactividad.

La siguiente propuesta tiene como objetivo demostrar la viabilidad del periodismo móvil a partir de la experiencia de Living Palermo, una revista digital elaborada únicamente con un dispositivo móvil. Mediante el análisis del desarrollo de una revista digital a partir de un smartphone o tableta se examinará la viabilidad del periodismo móvil como modus operandi para la creación de contenidos periodísticos en Internet y si esto cumple con los estándares de calidad mínimos para poder ser un publicación digital rentable. Con esto, también se busca detectar las habilidades y herramientas que un profesional de la comunicación necesita a la hora de gestionar los contenidos y distribuirlos. La figura del periodista polivalente supone un papel esencial para poder desarrollar este tipo de proyectos.

El estudio del caso demuestra, pese a algunas limitaciones, que se puede realizar una publicación digital que cumpla unos mínimos cualitativos periodísticos mediante la generación de contenido, única y exclusivamente, a través de una herramienta móvil.

Palabras clave: periodismo móvil, multimedia, smartphone, interactividad, publicación digital.

\section{Introducción}

El periodismo móvil se está convirtiendo en un nuevo nicho de mercado, ya que la creación de contenidos y la proliferación de las app específicas para smartphone otorgan mucho más protagonismo a este tipo de dispositivos.

Cuando hablamos de periodismo móvil, el éxito de los smartphones está conectado a algunas de las características que comparte con los teléfonos móviles, como la portabilidad, la ubicuidad o la utilización personal. Pero también está relacionada con las capacidades propias de estos mismos modelos, como la multimedialidad, la hipertextualidad y la interactividad facilitada por los altos niveles de usabilidad (Canavilhas, 2013).

Las posibilidades que se abren a los contenidos periodísticos vía móvil son inmensas. La consolidación del carácter multimedia de los 
contenidos en el móvil revolucionará la manera de contar historias; la velocidad y la movilidad de la conexión a Internet, consolidan, por otro lado, al teléfono como puerta de acceso a la Red (Cebrián Herreros y Flores Vivar, 2011: 69).

La posibilidad de testear la viabilidad de realizar periodismo mediante un teléfono móvil, de forma que se respeten los estándares de calidad y se cumplan las características de multimedialidad, hipertextualidad e interactividad. Crear contenidos de todo tipo, ya sea videos, podcasts o artículos mediante un Smartphone, acentúa, más si cabe, la tarea un periodista polivalente. Del periodista que solo se centra en elaborar una pieza informativa se está pasando cada vez más al profesional que también se ocupa de grabar los cortes de voz o efectuar las fotografías del suceso. Los dispositivos móviles tipo smartphones y tabletas añaden un elemento nuevo, el de la movilidad, con suficiente capacidad para transformar las competencias de los profesionales del periodismo (González Molina, 2013).

La capacidad para crear contenidos con un mínimo de calidad periodística requiere el cumplimiento de siete características del webperiodismo identificadas por diferentes autores (Bardoel y Deuze, 2000; Díaz Noci, 2001; Machado y Palacios, 2013; Salaverría, 2005; Zamith, 2008).

- Hipertextualidad: posibilidad de conectar documentos digitales o diferentes partes de un documento a través de enlaces.

- Multimedialidad: combinación integrada de texto, imagen y sonido.

- Interactividad: capacidad de permitir al usuario interactuar con los contenidos.

- Personalización: capacidad de ofrecer al usuario la información específica para su interés.

- Perennidad/memoria: capacidad de almacenar y organizar información de forma permanente para consulta.

- Instantaneidad/actualización continua: capacidad de añadir nuevas informaciones de inmediato.

- Ubicuidad: capacidad de acceder a la información en cualquier momento y desde diferentes puntos.

En la discusión de los resultados se pretende averiguar si estas característica son identificables en las aplicaciones para iPhone, y buscar alguna eventual conexión entre los contenidos para Web y para smartphones (Canavilhas, 2009: 11).

Se busca detectar qué habilidades y capacidades necesita el profesional del periodismo para conseguir información, distribuir contenidos y relacionarse con la audiencia. El auge que actualmente experimenta el mercado de dispositivos móviles aconseja el abordaje académico de esta cuestión, máxime cuando la comunicación vive un 
momento convulso con los medios, en el que se replantea su modelo de negocio (Casero-Ripollés, 2010).

Actualmente, los informadores desarrollan todo tipo de funciones dentro de la redacción de sus medios, desde grabar y elaborar sus propias piezas informativas en les televisiones, hasta redactar para la versión impresa y digital. Se han vuelto polivalentes. Una situación que la actual crisis económica acentúa, ya que las empresas apuestan por la reducción de costes y la optimización de los recursos, desembocando en denominaciones como la del periodista orquesta para aludir a esta realidad (González i Ortells, 2012). En Living Palermo se ha desarrollado este papel de periodista orquesta.

Con este nuevo panorama comunicativo, Living Palermo ha sido una apuesta en la que la multimedialidad y la inmediatez han supuesto dos requisitos indispensables para realizar la publicación. La explotación de estas posibilidades ha sido fundamental para crear un producto de calidad. Una forma de realizar periodismo en vivo y en directo para demostrar que el periodismo móvil es posible ante este nuevo marco mediático en el que los actores comunicativos cada vez son más.

\section{Objetivos}

El primer objetivo es desarrollar una publicación digital especializada en el calendario social y cultural del barrio de Palermo en Buenos Aires, la revista digital Living Palermo. La utilización de una herramienta móvil para desarrollar una plataforma óptima para este tipo de acción y la generación de contenido propio son clave para cumplir este primer objetivo. Sin el cumplimiento de este no se podría establecer el segundo: valorar la viabilidad del periodismo móvil como modus operandi en la publicación digital. Al tratarse del estudio de un caso concreto en el que se ha llevado a cabo un proyecto práctico, Living Palermo, se realizará un análisis a través de la metodología con la que se ha desarrollado el proyecto.

\section{Material y método}

Living Palermo es una publicación digital llevada a la práctica durante el desarrollo de un Trabajo de Final de Grado del Grado en Periodismo. De este modo, el estudio del caso propuesto y sus resultados se desarrollarán en el siguiente epígrafe, se detallarán los resultados y cada una de las fases. 
Al tratarse de un estudio de caso, cabe destacar las diferentes fases que se han tenido en cuenta y los procedimientos para desarrollar toda la publicación digital; los resultados. En primer lugar, la fase de producción, donde se realizó un estudio comparativo y un análisis de la competencia.

\section{Preproducción}

Para empezar a diseñar Living Palermo, era necesario estudiar los modelos ya existentes para delimitar con exactitud la temática y la forma de la publicación digital. Para ello se realizó un trabajo de análisis de la competencia de los distintos medios de comunicación, tanto privados como públicos, que ofrecieran información sobre Palermo, ya fuera de actualidad como social o cultural.

En primer lugar, el Gobierno de Buenos Aires tiene una página web en la que se puede encontrar información de carácter cultural, una especie de programa donde se ofrece toda la información acerca de los eventos organizados por el Gobierno de la Capital Federal. No está exclusivamente dedicada a esta labor, ya que en ella también se ofrece información de servicio para el ciudadano, así como para los turistas que desean visitar la ciudad, por lo tanto, podríamos decir que no se trata de una página web que puramente trata el contenido de carácter social y cultural en el que se centrará la publicación digital que se desarrolla.

En segundo lugar, Agenda Cultural de Buenos Aires es una página web que también depende del Gobierno de Buenos Aires, en este caso se puede seleccionar la oferta cultural por barrios. También posee un perfil en Twitter y Facebook. Sin embargo, como la página web anterior, no realizan ningún tipo de análisis, reportaje, crónica... Tampoco tiene ningún apartado multimedia dedicado a describir cómo ha sido el acontecimiento marcado en la agenda cultural. En este caso, el poder incluir reportajes, ya sean multimedia, escritos o radiofónicos, permite ampliar las posibilidades y realizar un tipo de servicio diferente.

Palermo Online es un portal de noticias de este barrio porteño. Su diseño está bastante obsoleto, no está actualizado a las últimas novedades de Internet. Publica de tres a cuatro noticias relacionadas con el barrio por día, pero en ningún momento hay signos de multimedialidad, interactividad o hipertextualidad. Es un volcado de las notas de prensa que emiten los diferentes colectivos públicos o privados.

En este caso, lo que diferencia a Living Palermo de la competencia podría describirse en de la siguiente forma: además de actuar como una agenda cultural, también incluye y habla de la actualidad del barrio, no se centra tan solo en los acontecimientos culturales sino también sociales.

En segundo lugar, dentro de la fase de preproducción se centra también la selección de contenidos. El objetivo de Living Palermo era realizar, al menos, tres publicaciones semanales, ya que la actividad cultural es extensa y existen muchos temas de creación propia. Ha sido una apuesta arriesgada, ya que es necesario tenerlo muy bien 
programado para poder llevar la publicación digital al día. Se delimitaron los días para poder compatibilizar este trabajo con los días de asistencia a clase. La distribución de los contenidos para cada día se ha ido realizando poco a poco para poder cuadrar todas las fechas.

Había un total de 21 publicaciones programadas, que finalmente han pasado a ser 39 (número total de post de la publicación) desde el miércoles 1 de abril hasta el lunes 25 de mayo, debido a la gran actividad social y cultural del barrio. La selección de contenidos ha sido precisa y concisa, se ha intentado en todo momento elaborar piezas que tuvieran cabida en la publicación y que fueran de interés periodístico.

La selección de contenidos ha sido muy variada, existen entradas que hablan sobre política pero también hay apartados dedicados a la naturaleza o el fútbol. También cabe destacar que cada una de las entradas, y dependiendo de su contenido, ha recibido un tratamiento distinto. Más tarde detallaré esto en el apartado de producción.

A continuación, se adjunta la tabla con el calendario de publicaciones completamente detallado, poco a poco y durante el proceso de elaboración esta selección de contenidos ha ido modificándose. La actualidad primaba por encima de todo, de modo que algunos temas que en un principio había programados finalmente no han tenido cabida en la publicación.

ABRIL

\begin{tabular}{|c|c|c|c|c|c|c|}
\hline LUNES & MARTES & MIÉRCOLES & JUEVES & VIERNES & SÁBADO & DOMINGO \\
\hline 30 & 31 & $\begin{array}{l}1 \text { Inicio } \\
\text { publicación }\end{array}$ & 2 & 3 & 4 & 5 \\
\hline $\begin{array}{l}6 \\
\text { Un paseo } \\
\text { por los } \\
\text { bosques de } \\
\text { Palermo }\end{array}$ & 7 & 8 & $\begin{array}{l}9 \\
\text { Un partido } \\
\text { en el } \\
\text { Monumental }\end{array}$ & 10 & 11 & $\begin{array}{l}12 \\
\text { Los } \\
\text { resultados } \\
\text { del paro } \\
\text { de } \\
\text { transporte }\end{array}$ \\
\hline 13 & $\begin{array}{l}14 \\
\text { Feria } \\
\text { Gastronómica } \\
\text { Le Marché }\end{array}$ & 15 & 16 & $\begin{array}{l}17 \\
\mathrm{BAFICl}\end{array}$ & 18 & $\begin{array}{l}19 \\
\text { Feria del } \\
\text { libro } \\
\text { permanent } \\
\text { e }\end{array}$ \\
\hline $\begin{array}{l}20 \\
\mathrm{ECOBICl}\end{array}$ & 21 & 22 & $\begin{array}{l}23 \\
\text { Elecciones, } \\
\text { ¿cómo se } \\
\text { organizan en } \\
\text { Buenos } \\
\text { Aires? }\end{array}$ & 24 & 25 & $\begin{array}{l}26 \\
\text { Cubrimient } \\
\text { o } \\
\text { elecciones } \\
\text { en directo }\end{array}$ \\
\hline $\begin{array}{l}27 \\
\text { Nota post- } \\
\text { elecciones }\end{array}$ & $\begin{array}{l}28 \\
\text { Nota feria } \\
\text { libro }\end{array}$ & $\begin{array}{l}29 \\
\text { Galería } \\
\text { Feria del } \\
\text { Libro } \\
\end{array}$ & $\begin{array}{l}30 \\
\text { Nota Turf 1을 } \\
\text { Mayo }\end{array}$ & $\begin{array}{l}1 \\
\text { Entrevista } \\
\text { feria libro }\end{array}$ & 2 & $\begin{array}{l}3 \\
\text { Visita } \\
\text { Jardín } \\
\text { Botánico } \\
\end{array}$ \\
\hline
\end{tabular}


MAYO

\begin{tabular}{|c|c|c|c|c|c|c|}
\hline LUNES & MARTES & MIÉRCOLES & JUEVES & VIERNES & SÁBADO & $\begin{array}{l}\text { DOMING } \\
0\end{array}$ \\
\hline $\begin{array}{l}4 \\
\text { Hipódromo } \\
\text { Palermo }\end{array}$ & 5 & 6 & 7 & $\begin{array}{l}8 \\
\text { Reportaje } \\
\text { radiofónico } \\
\text { "Little Italy" }\end{array}$ & $\begin{array}{l}9 \\
\text { Visita } \\
\text { MALBA }\end{array}$ & 10 \\
\hline 11 & $\begin{array}{l}12 \\
\text { Datos Feria } \\
\text { del Libro } \\
2015\end{array}$ & 13 & $\begin{array}{l}14 \\
\text { No } \\
\text { comment } \\
\text { Feria del } \\
\text { Libro }\end{array}$ & $\begin{array}{l}15 \\
\text { Reportaje } \\
\text { Creatavist } \\
\text { Feria del } \\
\text { Libro }\end{array}$ & 16 & 17 \\
\hline 18 & 19 & 20 & 21 & 22 & 23 & 24 \\
\hline $\begin{array}{l}25 \\
\text { Fin publicación }\end{array}$ & 26 & 27 & 28 & & 30 & 31 \\
\hline 1 & 2 & 3 & 4 & 5 & 6 & 7 \\
\hline
\end{tabular}

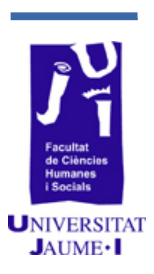

La previsión de los gastos en cuestión de material y de programas para edición ha sido escasa. En primer lugar, como instrumento imprescindible para poder desarrollar este proyecto. El smartphone ha sido la pieza fundamental, concretamente el iPhone 6 equipado con los programas de edición para imagen, video y audio. Todo eso no ha tenido un coste cero, ya que tenía el material antes de empezar esta publicación. El programa de edición de video iMovie, incorporado en el iPhone 6; el programa de edición de imagen PicLab, descargado gratuitamente desde el programa de app para iPhone; el programa de edición de audio Audacity, de descarga gratuita para cualquier soporte; la plataforma Wordpress, con la que he desarrollado toda la publicación, de utilización gratuita, y por último la agenda, para ello se utilizaron 2,99 $€$ en la aplicación iCalendar, para sincronizarla con Google Calendar y poder desarrollar la agenda en la publicación digital.

\section{Producción}

En cuanto a la fase de producción, para empezar con la publicación, después de haber establecido algunos esbozos en la fase de preproducción, la plataforma se definió con el nombre de Living Palermo. Un nombre que definía a la perfección este proyecto, en castellano "Viviendo Palermo». Acompañado de un subtítulo: "una ventana a la vida social del barrio», que acotaba lo que se podía esperar de esta publicación, la temática y a qué estaba dedicada.

Una vez elegido el nombre se creó una identidad corporativa que fuera sencilla y que invitara al lector a entrar en esta plataforma y consultar los contenidos. Mediante la aplicación PicLab se creó el logotipo que ha sido desde un primer momento la imagen de Living Palermo, escrito en letras blancas y acompañado de un color azul claro, que se 
instauró en todas las plataformas que he utilizado para publicar cualquier tipo de contenido. Esa ha sido la seña de identidad.

Para empezar con el diseño y darle forma, se utilizó la plataforma Wordpress, ya que, además de haberla utilizado en algunas asignaturas de la universidad, creo que es muy completa para un tipo de publicación digital como Living Palermo. Tiene numerosas posibilidades para enlazar contenido multimedia $\mathrm{y}$ hacer del proyecto un lugar interactivo $\mathrm{y}$ atractivo para el potencial lector.

Además de contar con Wordpress, también se utilizaron dos redes sociales a través de las que se han viralizado los contenidos, como son Twitter e Instagram, que también forman parte del diseño de Living Palermo. Con Twitter, no solo se ha viralizado contenido, sino que se ha creado contenido propio, que más tarde en el apartado de interactividad se explicará.

Esta publicación ha estado hecha y pensada para utilizarse a través de un dispositivo móvil, el proyecto ha sido desde un principio crear contenido con el teléfono móvil para que cualquier persona a través de su celular pudiera consultarlo, de manera que se eligió una plantilla en Wordpress que fuera lo más visual posible, que se adaptara a las condiciones de un smartphone y que a la vez diera la posibilidad de acceder desde la computadora.

Para poder dividir el contenido de manera adecuada y situar los contenidos de la mejor forma posible se estableció un menú con nueve secciones diferentes:

- Actualidad: En esta sección se incluyen las principales noticias y reportajes ligados con la actualidad más pura del barrio, las principales novedades o acontecimientos que se celebren en Palermo.

- Calendario de actividades: mediante la aplicación iCalendar y Google Calendar, se ha incluido un calendario en la publicación digital en la que los lectores pueden observar cuándo y dónde tendrán lugar los principales eventos en el barrio de Palermo.

- ¿Qué hacer en Palermo?: una sección creada para aquellos que deseen visitar el barrio de Palermo, es decir, en ella se incluirán los lugares que visitar. Es un apartado enfocado a los turistas.

- Los mejores lugares de Palermo: un recorrido por los principales lugares de Palermo, en él se incluyen fotografías y reportajes de los lugares más representativos de este barrio.

- Galería: en la galería tiene cabida todo tipo de fotografías sobre las diferentes temáticas de la publicación digital.

- Multimedia: además de las fotografías, también se incluyen videos y locuciones con temáticas diferentes, así como distintos contenidos realizados con soportes especializados para un tema determinador, en este caso, Creatavist o Prezi. 
- ¿Qué es Living Palermo?: qué es esta publicación digital y cuáles son sus objetivos, su enfoque y el público al cual va dirigido.

- ¿Quién soy?: una breve descripción de quién soy y de qué hago en Buenos Aires realizando esta publicación digital como Trabajo de Final de Grado.

- Contacto: un apartado dedicado a aquellos que deseen ponerse en contacto con Living Palermo.

El menú de inicio es muy visual, en la parte superior izquierda aparece el logotipo y a continuación se pueden encontrar las entradas, todas representadas mediante una fotografía y un título y organizadas por orden de publicación, de más reciente a menos. La barra de menú se encuentra arriba a la derecha, hay que desplegarla para poder ver cómo se dividen los contenidos, hay un total de nueve secciones que en el apartado siguiente explicaremos.

Además, para dar a conocer las redes sociales, en la parte inferior de la publicación se encuentran enlazados el Twitter e Instagram de la publicación. Asimismo la agenda se encuentra en dos lugares: en una de las barras del menú y en la parte inferior junto con las dos redes sociales utilizadas.

La interactividad de la página se ha conseguido a través de diferentes herramientas. En primer lugar, las redes sociales, que han sido Twitter e Instagram, a pesar de no tener numerosos seguidores, siempre que se ha publicado alguna entrada en Living Palermo el contenido se ha adaptado mediante enlaces y fotografías en cada una de estas plataformas. Además, con Twitter, se han realizado coberturas en directo de diversos eventos, como han sido las elecciones Primarias, Abiertas, Simultáneas y Obligatorias de la Ciudad de Buenos Aires (PASO) y de la 41. a Feria Internacional del Libro de Buenos Aires. Mediante esta propuesta, se conseguía relatar en directo mediante 140 caracteres, videos e imágenes, lo que estaba sucediendo, sacándole el máximo partido a la posibilidad de hacer periodismo móvil. Esta idea surgió a partir de la visualización del Twitter de Carmela Ríos, periodista en Unidad Editorial y que explora nuevas narrativas en dispositivos móviles y redes sociales. Su visión y su forma de narrar fue relevante a la hora relatar los hechos de esta forma.

Los enlaces e hipervínculos en cada uno de los artículos que se han publicado en Living Palermo también han propiciado esta interactividad y navegación por capas. En algunos artículos se ha redirigido al lector a diferentes enlaces dentro de la misma publicación digital, como ha sido en el caso de que una galería complementara directamente al reportaje realizado de manera escrita.

Los lectores también contaban con una zona donde podían dejar cualquier comentario y establecer así comunicación e interactividad con la publicación. Cada una de las entradas de Living Palermo, contaba con etiquetas para posicionar la página web en el buscador de Google. 
Otro de los puntos que cabe destacar en el apartado de interactividad es la cantidad de plataformas que se han utilizado para hacer la publicación más amena. Google Maps ha ayudado a localizar en todas la publicaciones, a designar de manera visual el lugar en el que se encuentra situado el lugar del que se habla durante una publicación, ha sido una herramienta fundamental. Otra de las que se han utilizado ha sido Creatavist, para desarrollar un reportaje multimedia y explotar así todas las cualidades de la publicación, volcando imagen, texto, audio y video en una misma entrada. Y por último Prezi, con la que se han plasmado datos de manera distinta para que el lector interactuara de manera diferente con los números.

Dejando de lado esto, hablando ahora de la interactividad que se ha producido entre los usuarios, se ha analizado la pequeña muestra de visitas durante los 55 días de publicación, con un total de 1165.

Para poder empezar este proyecto se tuvieron que destinar las dos primeras semanas de la estancia en Buenos Aires a conocer el barrio. Se desconocía por completo la ciudad y Palermo, por lo tanto se hizo un trabajo de investigación en el que se intentó conocer, en primer lugar, los sitios más atractivos y se fue profundizando, más tarde, en cuestiones de actualidad. No fue una tarea fácil, ya que el barrio de Palermo es uno de los más grandes de Buenos Aires en extensión y con más habitantes, alrededor de 250.000. Además, es el centro neurálgico de la mayoría de los acontecimientos que se celebran. También cuenta con muchos centros culturales y parques al aire libre, lo cual lo convierte en un gran atractivo para turistas y residentes en la ciudad porteña.

Una vez explorado Palermo se comenzaron las labores de diseño de la publicación y de imagen, esto llevó dos semanas más. Perfeccionar la página, crear un perfil en las redes sociales y conseguir una homogeneidad en la imagen de Living Palermo para poder empezar a publicar.

Durante este tiempo también se hizo una agenda de temas sobre los que se podía trabajar, la mayoría de ellos atemporales y sin periodicidad. Por este motivo, se tuvo que modificar en numerosas ocasiones el calendario de publicaciones, ya que la actualidad es lo que prima y a medida que pasaba el tiempo acontecían hechos relevantes que tenían cabida y eran atractivos para la publicación.

El día 1 de abril se inauguró Living Palermo, una vez con las ideas claras y definidas. El camino hasta llegar aquí no fue fácil, pero todo lo que ha seguido tampoco. El desconocimiento de las fuentes y de la geografía ha sido en ocasiones una problemática. Pero, finalmente, en cada una de las publicaciones que se han realizado han conseguido un estándar de calidad para el artículo, ya fuere a través de Internet o acercándome a la fuente directamente.

El elevado ritmo de publicaciones, no menos de tres a la semana, ha supuesto más de un mes y medio de dedicación plena a Living Palermo. Para cada uno de los temas, se trató de contactar con las fuentes que 
pudieran aportar la información adecuada para realizar cualquiera de los géneros que he desarrollado en la publicación.

\section{Postproducción}

Y por último la fase de postproducción, donde el smartphone tiene un papel fundamental.

Todas las fotografías de Living Palermo han sido tomadas con el iPhone 6 y las que han requerido edición han sido retocadas con la aplicación PicLab. El reportaje televisivo y los videos han sido íntegramente grabados y editados con el iPhone 6, con el programa iMovie. El sonido también he podido editarlo mediante este programa. Los audios subidos a la plataforma Ivoox también se han grabado y editado con el iPhone 6 y con el programa Audacity.

\section{Discusión y conclusiones}

El desarrollo de esta publicación digital ha puesto de manifiesto que es posible realizar contenido periodístico de calidad a través de un dispositivo móvil. La ventaja de poder elaborar el contenido al momento, editarlo, subirlo a la plataforma y divulgarlo por las diferentes redes sociales, hace que el periodismo digital cumpla con una de sus máximas actuales: la inmediatez. Además, la interactividad que se ofrece a partir de los enlaces y la viralización de contenidos, promulgan una lectura multimedia y por capas que favorece la explotación del medio.

Los smartphones son cada vez más plataformas de entretenimiento y dominadas por la presencia de información. Obviamente, existen diferencias entre el periodismo móvil y la web, pero las limitaciones, como la dimensión de la pantalla o el incorrecto funcionamiento de la red en algunas localizaciones, son insignificantes frente al nuevo mundo de posibilidades que se abre con el gran potencial que ofrecen hoy en día los smartphones en cuanto a creación de contenido para una plataforma online.

\section{Bibliografía}

Artículos en la web:

BUTLER, P. La velocidad y el contexto, factores claves para una estrategia de periodismo móvil. Disponible en: https://ijnet.org/es/blog/lavelocidad-y-el-contexto-factores-claves-para-una-estrategia-deperiodismo-m\%C3\%B3vil [Última consulta: 7 abril, 2015].

Gómez Escalonilla, G. Periodismo digital: nuevas exigencias para el profesional de la información. Disponible en: http://www.compoliticas.org/redes/pdf/redes1/7pdf [Consulta: 7 abril, 2015]. 
Artículos en publicaciones periódicas

CANAVILHAS, J. (2009): Contenidos informativos para móviles: estudio de aplicaciones para iPhone. Universidad da Beira, Portugal.

- (2013): «El periodismo en los tiempos de un nuevo ecosistema mediático: propuestas para la enseñanza superior», Universidad da Beira, Portugal.

Canavilhas, J. y otros (2013): Hacia el periodismo móvil. Portal de Comunicaciones Iberoamericanas, Santiago de Chile.

CASERo Ripollés, A. (2010): "Prensa en Internet: nuevos modelos de negocio en el escenario de la convergencia», El profesional de la información.

Cebrián Herreros, M. y J. M. Flores Vivar (2011): Periodismo en la telefonía móvil. Madrid.

González Molina, S. y S. ORtells Badenes (2008): «La polivalencia periodística de los profesionales en redes», Estudios sobre el mensaje periodístico. 
Augusto Leiva Espinoza. Las diferencias del diálogo entre gobierno-sociedad y entre empresasociedad

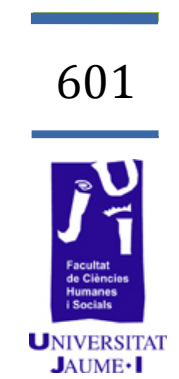

\section{Las diferencias del diálogo entre gobierno-sociedad y entre empresa-sociedad. Revisión bibliográfica}

Augusto Leiva Espinoza augustoleiva@hotmail.com 
Con el pasar del tiempo y la entrada de las nuevas generaciones, se han dado cambios de progreso social y de desarrollo dentro de las organizaciones. Existen líderes más jóvenes y se nota un leve incremento del género femenino en las posiciones de alta dirección de las organizaciones. Las estructuras organizacionales van realizando pequeñas modificaciones para tratar de adaptarse y responder con el contexto social y generacional del entorno. Sin embargo, la estructura central de las organizaciones aún conserva patrones relacionales y de comunicación establecidos desde sus inicios. Según las autoras Majken Schultz y Mary Jo Hatch, ${ }^{1}$ una correcta buena práctica dentro de las organizaciones es reforzar su cultura organizacional y valores corporativos a través de «la revisión de su identidad diferencial o corporativa para determinar la dirección estratégica» (Schultz y Hatch, 2008: 178). Por otro lado, autores como Oriol Iglesias y Nicholas Ind confirman la importancia de definir la identidad corporativa a través de la marca corporativa y enfatizan la importancia (de la identidad) en la empresa para marcar una perspectiva pasada, presente y futura que ayude a la toma de decisiones. ${ }^{2}$ Frente a este fenómeno organizativo surge la duda de saber si los valores iniciales de las empresas respondían con un contexto muy diferente del de ahora y esto se vea reflejado en la forma de comunicar que las organizaciones se encuentran efectuando en la actualidad. Es interesante saber si estos mensajes informativos de las organizaciones son recogidos o entendidos dependiendo de las diferentes generaciones como las de los Baby Boomers, Generación X y millennials, existentes en la sociedad. Partiendo de que el diálogo que mantiene la sociedad con las organizaciones públicas y privadas se sostiene con las relaciones dentro del contexto en el que se encuentran, es conveniente analizar si los mensajes que emiten las empresas y administraciones públicas encuentran una comprensión (o correcta interpretación) por parte de todas las generaciones que se encuentren con la capacidad suficiente para mantener un diálogo que contribuya con su desarrollo. La revisión bibliográfica de la información referente al tema de las diferencias generacionales en la comunicación institucional y pública para ver si existen brechas generacionales no actualizadas que se deben de analizar, arroja que las instituciones públicas y privadas responden generacionalmente con la relación que mantienen con sus grupos de interés. Esto significa que no solo se hablan de clientes o consumidores dentro de la sociedad, sino que implica una relación de interdependencia con otros públicos que son muy diversos y diferentes dependiendo del tipo de organización que se analice (pública o privada) y también del tipo de mercado en el que trabaje (sectores de banca, turismo, construcción, consumo, entre otros). Para el presente estudio, se ha logrado analizar la viabilidad de la comparación de los grupos de interés entre la empresa y la administración pública en los

1. Schultz y Hatch, Taking Brand Initiative: How Companies Can Align Strategy, Culture, and Identity.

2. Ind, y otras (ed.) (2013): Building Brands Together: Emergence And Outcomes of Co-Creation. 
empleados, la alta dirección y la relación con los organismos sin ánimo de lucro.

Palabras clave: stakeholders, generaciones, interpretación, comunicación, empresa-sociedad, gobierno-sociedad.

\section{Introducción}

Los estudios de la semiótica así como el desarrollo de la narrativa social son factores claves para la comunicación entre personas, grupos sociales, empresas y también instituciones. El común denominador son los sistemas de lenguaje (a través de diferentes formatos y estilos narrativos) que establecen una correcta comunicación en que la información que se emite es la que se recibe y viceversa. Sin embargo, existen componentes racionales y emocionales dentro del contexto comunicativo que afectan a la emisión y recepción de los mensajes. Esta particularidad se incrementa cuando se encuentran diferencias generacionales, que manejan el lenguaje desde contextos y condiciones totalmente diferentes entre sus interlocutores, que a su vez generan labores adicionales de interpretación.

Si llevamos esta premisa a la comunicación de instituciones públicas y privadas con la sociedad, encontraremos que cada actor social (empresa - administración pública) posee un estilo común o una subcultura organizacional (o corporativa) en la forma de comunicar sus mensajes. Estos rasgos distintivos de la organización vienen derivados de su identidad corporativa que la hace única en la forma de operar, contratar, abordar los problemas del mercado, comunicar productos y servicios, etc. Sin embargo, la organización es un conjunto de subgrupos de personas (divididos por áreas y jerarquías internas) que coexisten en un espacio común. Dentro de esta variedad humana que contiene la organización, los modelos jerárquicos establecen el orden interno y marcan la importancia y valor de los roles de cada persona dentro de este grupo organizativo. El principal líder de la empresa, o el que se sitúa en lo más alto de la jerarquía corporativa (CEO de la empresa o presidente del país), es el que marca la estrategia o la ruta a seguir para el beneficio de todos los que conforman la organización. El común denominador a lo largo de la historia es que este líder contenga la experiencia y conocimiento suficiente para lograr situarse en la punta más alta de la pirámide jerárquica y por ello la mayoría poseen edades promedio entre los cincuenta y los setenta años. También ha sido común a lo largo de la historia que estos líderes sean de género masculino.

Con el paso del tiempo y la entrada de las nuevas generaciones, se han sucedido cambios de progreso social y de desarrollo dentro de las organizaciones. Hay líderes más jóvenes y cada vez más se nota un incremento del género femenino en las posiciones de alta dirección de las 
organizaciones. Las estructuras organizacionales van realizando pequeñas modificaciones para tratar de adaptarse y responder con el contexto social y generacional del entorno. Existen cambios, traspasos de confianza, nuevas iniciativas, correcciones y propuestas que mejoran o alteran el orden anterior del equilibrio inicial. Una interesante reflexión del profesor Benavides que realiza sobre los nuevos espacios de diálogo entre las organizaciones y la sociedad ${ }^{3}$ donde sostiene que (Benavides, 2015: 12):

[...] en la actualidad conviven lógicas diferentes porque la percepción visual de la realidad es plural y debemos investigar y definir el suelo epistemológico que está detrás de los procesos de comunicación.

La estructura central de las organizaciones aún conserva patrones relacionales y de comunicación establecidos desde sus inicios. Una correcta buena práctica dentro de las organizaciones es reforzar su cultura organizacional y valores corporativos a través de la revisión de su identidad diferencial o corporativa (Schultz y Hatch) para determinar la dirección estratégica y marcar una perspectiva pasada, presente y futura que ayude a la toma de decisiones (Ind e Iglesias). Ind ha desarrollado en otra investigación titulada Living the Brand: How to Transform Every Member of Your Organization into Brand Champion en el año 2007 que la cultura corporativa se ve reflejada en la forma de comunicar y de actuar que las organizaciones se encuentran efectuando en la actualidad. ${ }^{4} \mathrm{El}$ estudio de Edelman en 2012 que mide la confianza en las empresas e instituciones en el ámbito mundial, llamado Trust Barometer, muestra que, de la lista de los temas importantes que valoraba la sociedad en el año 2012, las instituciones presentaban temas de poco interés para las personas que los ubicaban en los últimos puestos de la lista de temas relevantes. ${ }^{5}$ Aquello, además de reflejar este desnivel de atención en los mensajes con las necesidades sociales de las organizaciones hacia la sociedad, también enfatiza una lenta reacción de las organizaciones ante los cambios coyunturales (provocados por las nuevas generaciones) tanto para abordar temas sociales sensibles como para poder responder 0 dialogar en el mismo nivel y con la misma empatía y entendimiento de las nuevas necesidades generacionales.

3 Benavides, El nuevo diálogo social: organizaciones, públicos y ciudadanos, p.12, 2015.

4 Ind, N. (2007): Living the Brand: How to Transform Every Member of Your Organization into a Brand Champion.

5 Edelman (2012): Trust Barometer. 


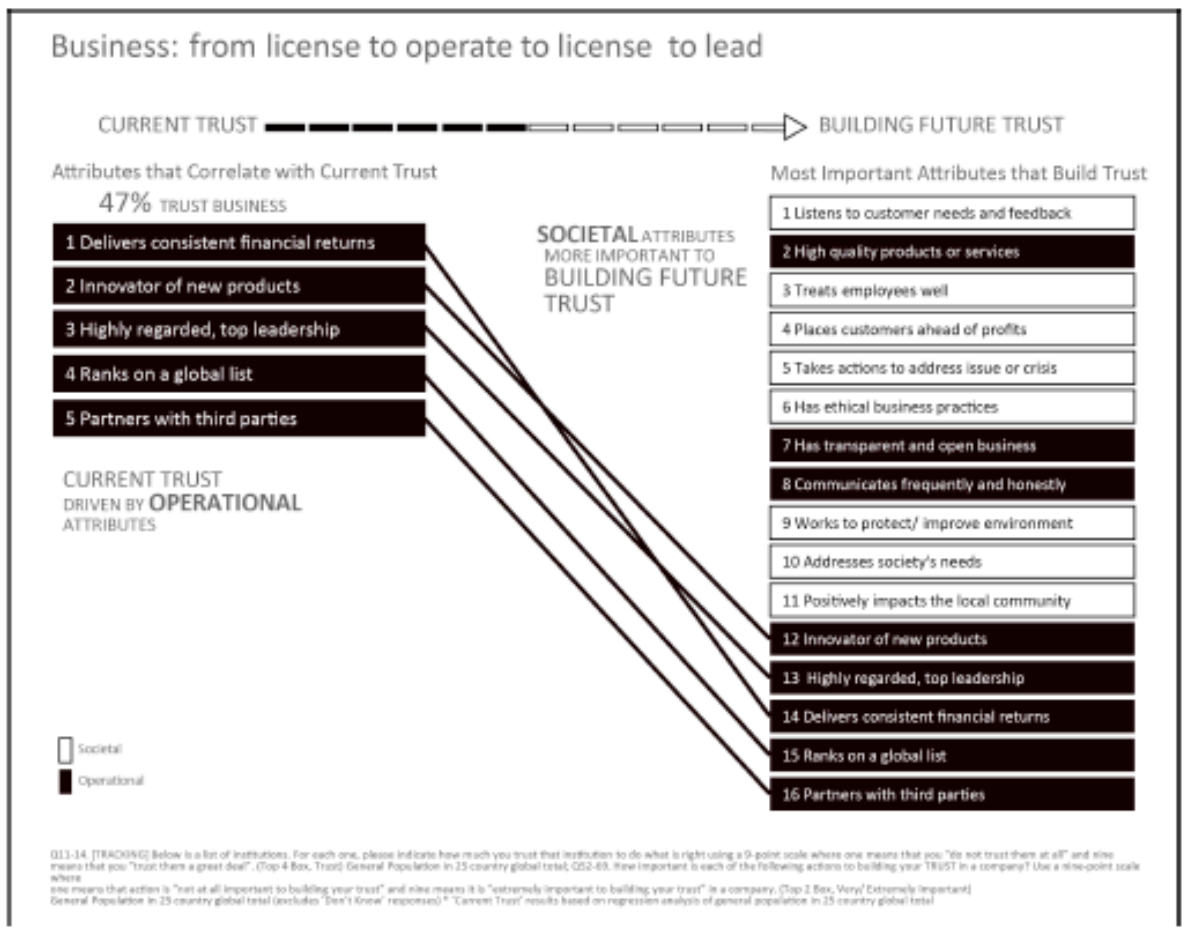

Figura 1. Business: from license to operate to license to lead. Edelman, Trust Barometer, 2012

Una lectura inicial o primera conclusión sería que los cambios generacionales van más rápido que las estructuras organizativas y ello se puede comprobar en la forma en la que, tanto empresas como instituciones públicas, emiten la información y cuánto tarda esta en ser procesada, interpretada y comprendida en la sociedad en sus diferentes generaciones.

Parece conveniente que se analicen las diferencias de comprensión e interpretación de los mensajes que existen entre las organizaciones y las diferentes generaciones dentro de la sociedad. Una primera hipótesis a comprobar en futuras investigaciones cualitativas y cuantitativas es la existencia de una mayor comprensión de los mensajes que las organizaciones públicas y privadas con las generaciones nacidas entre los años 1940 y 1950 debido a que el desarrollo de las estructuras organizativas tuvieron un desarrollo después de la Segunda Guerra Mundial y tanto las empresas como las administraciones públicas podían responder con los mismos niveles de lenguaje y comunicación que frente a la sociedad de esa época.

Si las empresas y administraciones públicas se encuentran emitiendo mensajes informativos solo comprensibles para un grupo determinado de la sociedad y el aspecto generacional tiene una influencia en esta diferencia o sesgo, son dos aspectos centrales de la investigación ya que genera nuevas incógnitas y líneas de investigación para demostrar cuál de los dos actores (empresa o administración pública) posee menos problemas de interpretación por parte de la sociedad y cuál se encuentra muy distante de comprensión por parte de las nuevas generaciones. Es 
conveniente resaltar que los problemas de interpretación o compresión de los mensajes contribuyen o refuerzan la percepción negativa o positiva que la sociedad tiene sobre la empresa y la administración pública y aquello establece las condiciones suficientes para determinar su legitimidad y diferenciación. ${ }^{6}$

Por lo tanto, partiendo de que el diálogo que mantiene la sociedad con las organizaciones públicas y privadas sostiene las relaciones dentro del contexto, la revisión bibliográfica sirve a la investigación para analizar si los mensajes que las empresas y administraciones públicas encuentran una buena comprensión o correcta interpretación por parte de las todas generaciones que se encuentren con la capacidad suficiente para mantener un diálogo que contribuya con su desarrollo, en especial para las nuevas generaciones denominadas millennials que buscan introducirse al mercado laboral y buscan ofertas laborales de las organizaciones públicas y privadas en todas sus variantes comunicativas.

\section{Objetivos}

Llegar a determinar si existe un compendio bibliográfico que nos permita conocer el estado de la cuestión sobre la forma en que las instituciones públicas y organizaciones privadas dialogan con las nuevas generaciones mejor entendidas como millennials.

Encontrar una relación entre los mensajes de las organizaciones públicas y privadas con las generaciones nacidas entre los años 1980 y 1995 que nos permita ver las dificultades de interpretación y entendimiento de las organizaciones con las generaciones.

Encontrar similitudes de grupos de personas con los que ambas organizaciones se relacionan para encontrar una viabilidad comparativa que se pueda analizar en investigaciones futuras.

\section{Material y método}

Para el cumplimiento de los objetivos trazados, se ha realizado un acopio de materiales de fuentes primarias y secundarias (vídeos, audios, libros, artículos, entrevistas no propias, estudios, lecturas monográficas, etc.) en relación con la comunicación de organizaciones públicas y privadas; con la gestión de la identidad, comunicación y marca corporativa; con los problemas de comunicación e interpretación por parte de los públicos de las organizaciones, y con los grupos de interés de las empresas e instituciones públicas. Dichos materiales serán nacionales e internacionales para llegar a tener una bibliografía vasta sobre los temas tratados. Posterior al acopio de materiales para la investigación, se procederá con la redacción del trabajo y la extracción de conclusiones.

6. Carreras, Alloza y Carreras (2013): Reputación Corporativa. 
De la revisión bibliográfica focalizada en la comunicación de las organizaciones públicas y privadas con la generación millennial, la diferencia de entendimiento y comprensión de los mensajes que emiten tanto la empresa como la administración pública hacia las personas que buscan iniciarse en el mundo laboral, se encuentra condicionada por el rango generacional y de antigüedad de las organizaciones. Esta primera conclusión se logra gracias al análisis de la relación de mensajes de las organizaciones con su comprensión generacional. Para realizar este análisis, se ha partido de tres tipos de organizaciones divididas por su antigüedad en la sociedad que se contrastarán con tres tipos de generaciones divididas por los rangos de edades comprendidas entre los 20 a 24 años, 25 a 29 años y 30 a 35 años, respectivamente. La aplicación de ambos ejes (organizaciones vs. generaciones) se puede apreciar en la Tabla 1:

\section{Relación de mensajes de las organizaciones con su comprensión generacional}

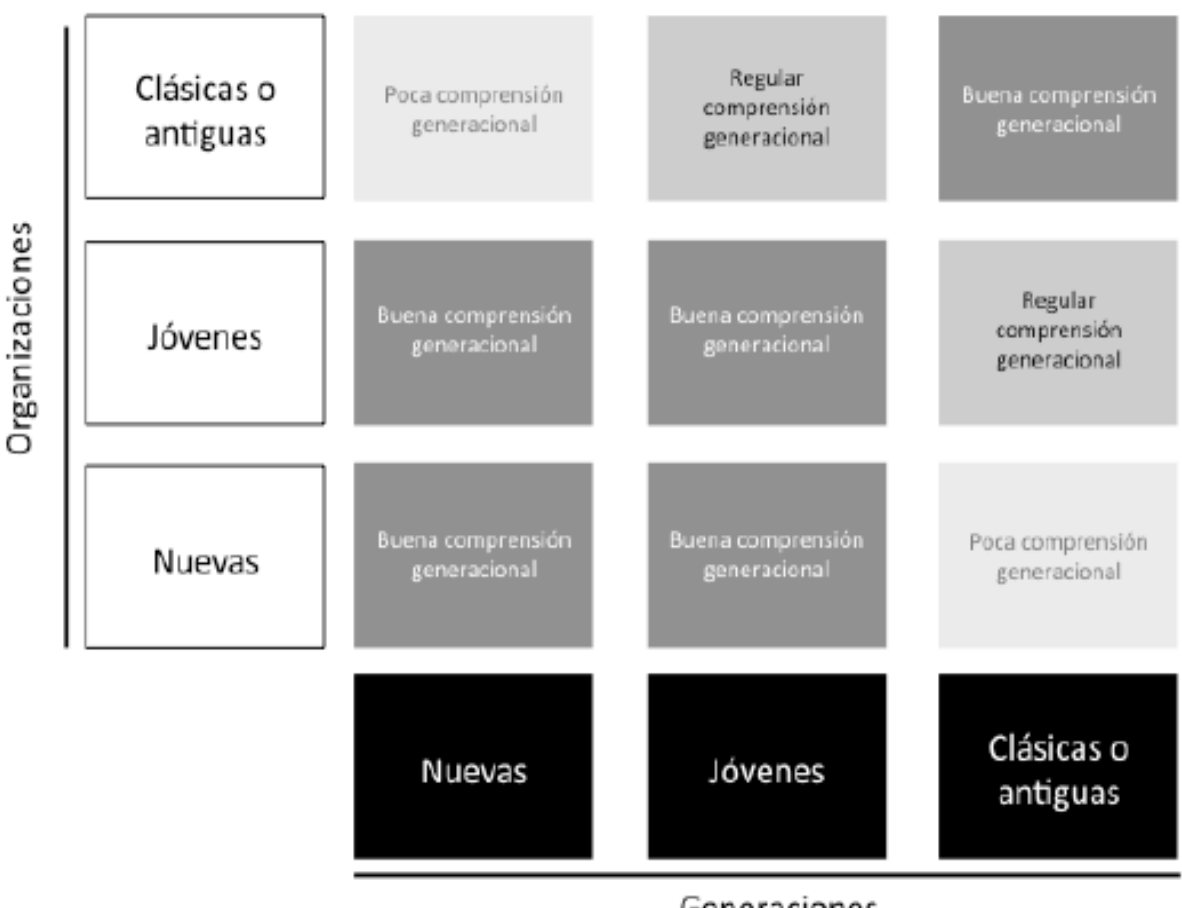

Generaciones

Tabla 1. Hipótesis de la relación de mensajes de las organizaciones con su comprensión generacional. Elaboración propia.

De la Tabla 1 se pueden extraer las siguiente conclusiones:

Existe una relación directa de la antigüedad de las organizaciones con su símil generacional. Es decir, una organización con más años dentro de la sociedad ha sabido comprender a las generaciones más antiguas, mientras que las organizaciones jóvenes y nuevas encuentran comprensión y entendimiento con las dos generaciones más jóvenes de las tres analizadas. 
Existe una generación puente entre las generaciones nuevas y las antiguas y es la que se encuentran en mitad de ambas debido a que pueden comprender los argumentos para la comprensión entre ambas generaciones.

Tanto las generaciones nuevas como antiguas poseen pocas líneas de entendimiento entre ambas cuando se trata de comunicación organizacional. Ello hace que una de las diferencias entre organizaciones nuevas y clásicas sea su rápida capacidad de respuesta y adaptación al cambio que tienen las primeras versus las segundas.

Las generaciones más antiguas logran entender las estructuras organizativas sociales y, por ende, su comunicación. Sin embargo, aquello no implica que las nuevas organizaciones logren cambiar las bases estructurales sociales con el paso de los años. Iriso y Rubio sostienen que son las organizaciones públicas las que deberían de llegar a realizar intentos de acercamiento social para su mejor comprensión en cuanto a necesidades e intercambio de propuestas; ${ }^{7}$ aunque también plantean problemas de entendimiento e interpretación de los mensajes debido al paradigma que maneja cada ciudadano por separado y en conjunto al no lograr diferenciar organizaciones públicas de la administración (Rubio e Iriso, 2010: 27):

Podríamos decir que vivimos en una jungla comunicativa en la que se entremezclan los intereses de todos los sectores público y privado [...] La audiencia recibe la información de una manera selectiva. Hay cosas que pueden no interesar a unos y sí a otros.

Durante la revisión bibliográfica se han encontrado muchos criterios aún más abiertos para la investigación, estos arrojaban criterios generacionales y también de grupos de interés que no se ajustaban con el objeto de la investigación pero que sin embargo ha servido para comprobar conceptos generacionales y culturales que servirán de contraste para una futura investigación cualitativa derivada de esta inicial. Se ha centrado el objeto de estudio en la revisión de la bibliográfica de las investigaciones y publicaciones que aborden las generaciones nacidas entre 1980 y 1995 . Con las investigaciones que aborden este espectro de personas se puede elaborar un análisis más enfocado partiendo de las necesidades de inclusión y preparación para el mundo laboral que posee este grupo de personas, así como el análisis de los mensajes de la Administración Pública emite en ello sobre empleabilidad y también los mensajes de las empresas en la búsqueda de puestos de trabajo.

Un primer hallazgo que se encuentra durante la revisión bibliográfica de la investigación, es la escasa existencia de material de investigación académica de los espacios comunicativos donde no se pueda realizar una comprobación simultánea tanto de la Administración Pública como de las organizaciones privadas o empresas, circunscrita en la generación

7. Rubio e Iriso, (2010): Comunicar para compartir: Un viaje hacia una mejor comunicación pública. 
analizada y que aporte una reciente novedad al objeto. Esto se debe a que el tema de los millennials es novedoso para el análisis y veremos nuevos hallazgos sobre esta generación y su relación con las organizaciones en los años siguientes. Frente a esta premisa, se recurrió a la teoría de los grupos de interés, concepto introducido en 1984 por Edward Freeman en su obra Strategic Management: A Stakeholder Approach en el que afirma que existen agrupaciones de personas vinculadas e interesadas en las organizaciones. ${ }^{8} \mathrm{El}$ concepto de los stakeholder o grupos de interés ha dado un cambio importante en la gestión empresarial ya que, a finales de la década de los ochenta, los directivos y gestores comienzan a interesarse en preguntar por las necesidades y opiniones de otros grupos de personas diferentes de los clientes o consumidores.

Si bien la teoría de los grupos de interés de Freeman enfatiza la relación de los grupos de personas con la organización, para la presente investigación se ha ajustado esta teoría en que los grupos de interés sean los mismos tanto para la empresa como para la Administración Pública. Producto de este trabajo de homologación de grupos de interés en que se puedan encontrar puntos de relación de las dos organizaciones, se ha desarrollado una comparabilidad entre ambas entidades de donde se podrá extraer las líneas de trabajo para la presente investigación. De esta manera se listarían los diferentes los grupos de interés de la empresas y de la Administración Pública y se describiría cuáles son los grupos de interés en ambas organizaciones $\mathrm{y}$ si es viable $u$ homologable la comparabilidad de la investigación. Para el análisis de los grupos de interés y su comparabilidad entre las organizaciones públicas y privadas, se tomarán en consideración los nueve grupos de interés considerados por Freeman, a saber: clientes, consumidores, empleados, administración pública, accionistas, proveedores, alta dirección, competidores y organizaciones sin ánimo de lucro u ONG. El desarrollo se puede observar en la Tabla 2:

8. Freeman, (1984): Strategic Management: A Stakeholder Approach. 


\begin{tabular}{|c|c|c|c|}
\hline Grupas de interés & Empresa & Administración Pública & $\begin{array}{l}\text { Mabilidad de } \\
\text { comparación }\end{array}$ \\
\hline Clientes & Personas que compran productos o servicios & $\begin{array}{l}\text { No tene-Ies ciudadanos pueder legara a } \\
\text { acercarse a esta definicion }\end{array}$ & $\begin{array}{l}\text { No se puede } \\
\text { comparar }\end{array}$ \\
\hline Consumidores & $\begin{array}{l}\text { Personas que consumen los productos y servidios } \\
\text { que se comercializa }\end{array}$ & $\begin{array}{l}\text { Personas que consumen los servicios } \\
\text { públicos - los ciudadanos }\end{array}$ & $\begin{array}{l}\text { No se puede } \\
\text { comparar }\end{array}$ \\
\hline Empleados & $\begin{array}{l}\text { Persoras que prestan servicios retribuidos y } \\
\text { s.bordinados }\end{array}$ & $\begin{array}{l}\text { Personas que prestan servicios retribuidos } \\
\text { y subordinados }\end{array}$ & $\begin{array}{l}\text { Se puede } \\
\text { comparar }\end{array}$ \\
\hline $\begin{array}{l}\text { Administración } \\
\text { Pública }\end{array}$ & $\begin{array}{l}\text { Grupo de personas y organismos que dirigen una } \\
\text { división político-administrativa en la sociedad } \\
\end{array}$ & Son ellos mismos. & $\begin{array}{l}\text { No se puede } \\
\text { comparar }\end{array}$ \\
\hline Accionistas & $\begin{array}{l}\text { Grupos de personas que invierten un capital } \\
\text { economico que pertenecen a una sociedad } \\
\text { financiera, comercial o industrial. }\end{array}$ & $\begin{array}{l}\text { No diene-Ios ciudadanos pueden llegara a } \\
\text { acercarse a esta definicion a traves del } \\
\text { pago de impuestos }\end{array}$ & $\begin{array}{l}\text { No se puede } \\
\text { comparar }\end{array}$ \\
\hline Proveedores & $\begin{array}{l}\text { Grupos de empresas que se dedican a abastecer } \\
\text { de productos o servicios necesarios a una } \\
\text { empresa. }\end{array}$ & $\begin{array}{l}\text { Grupos de empresas que se dedican a } \\
\text { abastecer de productos o servicios } \\
\text { necesarios a una empresa. }\end{array}$ & $\begin{array}{l}\text { Se puede } \\
\text { comparar }\end{array}$ \\
\hline Alta dirucción & $\begin{array}{l}\text { Personas de una empresa con altos cargos y de } \\
\text { elevada responsabilidad que participan en la } \\
\text { toma de decisiones estratégicas }\end{array}$ & $\begin{array}{l}\text { Personas de la administración con altos } \\
\text { cargos y de elevacia responsabilidad que } \\
\text { participan en la toma de decisiones } \\
\text { estratégicas }\end{array}$ & $\begin{array}{l}\text { Se puede } \\
\text { comparar }\end{array}$ \\
\hline Competidores & $\begin{array}{l}\text { Empresas que poseen los mismos objetuvos } \\
\text { comerciales con productos y servicios sim lares }\end{array}$ & No tene & $\begin{array}{l}\text { No se puede } \\
\text { comparar }\end{array}$ \\
\hline $\begin{array}{l}\text { Organizamos sin } \\
\text { ánimo de lucro - ONG }\end{array}$ & $\begin{array}{l}\text { Agrupaciones de iniciativa social y fines } \\
\text { humanitarios, que son independiantes de la } \\
\text { administración pública y que no tienen afán } \\
\text { lucrativo. }\end{array}$ & $\begin{array}{l}\text { Agrupaciones de inio ativa social y fines } \\
\text { humanitafios, que son independientes de } \\
\text { Ia administración pública y que no tienen } \\
\text { atán lucrativa. }\end{array}$ & $\begin{array}{l}\text { Se puede } \\
\text { comparar }\end{array}$ \\
\hline
\end{tabular}

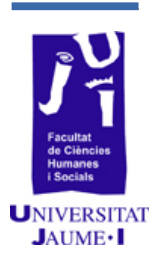

Tabla 2. Viabilidad de la comparación de grupos de interés entre empresa y Administración Pública. Elaboración Propia

De la tabla se pueden extraer las siguientes conclusiones: no todos los grupos de interés de la empresa son comparables con los grupos de interés de la Administración Pública debido a que no poseen la misma naturaleza de sus funciones o de su sostenibilidad, aquello hace que ambas organizaciones gestionen de forma muy diferente la relación que mantienen con sus grupos de interés.

Los grupos de interés que podrían ser comparables para la investigación -que en este caso serían los empleados, los proveedores, y las organizaciones sin ánimo lucrativo- poseen variantes en las que, de momento, no es necesario profundizar pero que servirán para determinar las nuevas líneas de investigación que pueden desprenderse de este trabajo.

Otra interesante conclusión es que, tal como se vio en la Tabla 1, existen cruces generacionales entre iguales y entre las generaciones intermedias con las otros dos restantes, e incluso dentro de la misma organización con sus grupos de interés. Por ejemplo, para el caso de proveedores, si bien ambas organizaciones tienen la necesidad de un abastecimiento de recursos materiales, los requerimientos que derivan en negocios de empresa a empresa (o Business to Business) en las que la relación se hace a través de comerciales o agentes que se encuentran en las generaciones Baby Boomers o Generación $X$ debido a la empatía generacional que existe entre las empresas proveedoras con sus clientes (es decir que la edad de los agentes comerciales se equilibra con la edad de sus clientes para reforzar una mayor empatía y facilitar la venta). Otro caso similar se puede ver en la relación con los organismos sin fines de 
lucro debido a su composición mixta. Si bien las ONG necesitan tanto de las empresas (a través de sus voluntariados corporativos, la filantropía y la cooperación para el desarrollo) como de las administraciones publicas (a través de las subvenciones para proyectos en campo o su grado de influencia facilitando información técnica y social), la gama generacional se sigue estructurando a través de la jerarquía clásica de los años de experiencia y edad, y también al mismo factor de empatía frente a las relaciones, es decir, rango de edad similar entre interlocutores para reforzar las negociaciones (Tabla 1). Se tendrían que analizar elementos en los que ambos grupos se encuentren sin condicionantes y que la comunicación sea claramente visible en los canales comunicativos de la información.

El grupo de interés que guarda cierta comparabilidad entre empresa y Administración Pública son los empleados ya que estos obedecen a unas directrices de la organización y presentan un rango de edades muy variado para poder elegir en la investigación. Sin embargo, los empleados poseen la misma jerarquía de experiencia laboral en su estructura organizativa. Otra diferencia resaltante entre los empleados de las empresas en comparación con los empleados de la Administración Pública es que los primeros obedecen a un sueldo y están supeditados a cumplir con los resultados a costa de su salario o su puesto de trabajo. Muy por el contrario, los empleados de la Administración Pública provienen de las oposiciones que concede el Estado para poder trabajar dentro de los organismos de la Administración Pública. Es decir que su sueldo no está condicionado con los objetivos que la Administración Pública presente. Por ello, a los empleados de esta se les llama funcionarios y a los de la empresa, empleados. Sin embargo la empleabilidad posee intereses comunes en las personas de la sociedad que desean empezar en el mundo laboral. Tanto empresa como Administración Pública ofrecen oportunidades de empleo y becas formativas para optimizar el trabajo, para personas que se encuentran en un rango de edad que interesa a la investigación. Es, por tanto, la empleabilidad y las becas, una oportunidad para iniciar la investigación debido a que tanto empresa como administración pública emiten mensajes de acuerdo con su cultura organizacional que pueden ser o no entendidos por las personas interesadas en las ofertas laborales o de becas para su formación profesional.

\section{Discusión y conclusiones}

La revisión bibliográfica de la información referente al tema de las diferencias generacionales en la comunicación institucional para ver si existen brechas generacionales no actualizadas que se deben analizar arroja que las instituciones públicas y privadas responden generacionalmente con la relación que mantienen con sus grupos de interés. Aquello se debe a que cada actor social (empresa o 
administración pública) posee un estilo común o una subcultura organizacional (o corporativa) en la forma de comunicar sus mensajes. Otro factor de la relación es la coincidencia temporal, es decir, que las organizaciones que poseen edades similares a las generaciones a las que se dirigen poseen mejor comprensión frente a generaciones más jóvenes; así como las organizaciones jóvenes saben dejarse entender e interpretar con generaciones jóvenes o nuevas.

Se ha logrado analizar la viabilidad de la comparación de los grupos de interés entre la empresa y la Administración Pública utilizando la teoría de Freeman en tres grupos de interés que son los empleados, la alta dirección y la relación con los organismos sin ánimo de lucro. Para la presente investigación se han eliminado las relaciones generacionales similares para tratar de encontrar un contraste virtuoso y no de necesidad estructural o económica; producto de ello se han eliminado los grupos de interés de las organizaciones sin ánimo lucrativo y la alta dirección. Del grupo de interés de empleados, se ha separado a las personas que tienen una empleabilidad de las que recién buscan entrar en el mundo laboral. Se realizó esta separación para poner en el mismo nivel a empresa y Administración Pública en la oferta laboral en la sociedad ya que se dirigen al mismo público (gente de 20 a 35 años).

El presente trabajo de revisión bibliográfica ha arrojado dos conclusiones teóricas que valdría seguir ampliando y enriqueciendo con líneas de investigación cualitativas y cuantitativas futuras que darían más solvencia a lo trabajado hasta el momento.

VII. Bibliografía

Aaker, D. A.; E. Joachimsthaler (2009): Brand Leadership, The Free Press.

ArgentI, P. (2014): Comunicación Estratégica y su contribución con la reputación corporativa, LID Editorial.

BovalRD, T., y E. Löffler (2003): Public Management and Governance, Rouledge.

CAPRIOTTI, P. (1992): La imagen de empresa: estrategia para una comunicación integrada. El Ateneo.

Carreras, E. y otros (ed.) (2013): Reputación Corporativa, LID Editorial.

CARroll, C. E. (2013): The Handbook of Communication and Corporate Reputation, Wiley-Blackwell.

Fombrun, C. y C. B. M. VAn Riel, (2004): Fame \& Fortune, Prentice Hall.

Freeman, E. (1984): Strategic Management: A Stakeholder Approach, Cambridge University Press.

HATCH, M. J., y M. SCHULTZ (2008): Taking Brand Initiative: How Companies Can Align Strategy, Culture, and Identity Through Corporate Branding, Jossey Bass. 
IND, N. (2007): Living the Brand: How to Transform Every Member of Your Organization into a Brand Champion, 3rd Edition, Kogan Page.

- (2012): Brand Together, Kogan Page.

MARín, F. (2009): Comunicación de crisis, Colección Acción Empresarial. LID Editorial.

MontaÑÉs DuATO, P. (2011): ¿Aquí quién manda? Levantando el mapa del poder en las organizaciones del siglo XXI, Biblioteca Altrán, Vol. 2 Pearson Educación.

RIES, A. y L. RIES (2005): El origen de las marcas. Empresa Activa.

RUBIO, L. y R. IRISO (2010): Comunicar para compartir: Un viaje hacia una mejor comunicación pública. Sinergia Papers.

Schmiтt, B. H. (2003): Customer Experience Management, John Wiley \& Sons Inc.

Sonnenfeld, A. (2011): Liderazgo ético: La sabiduría de decidir bien. Segunda Edición, Encuentro.

Stengel, J. (2011): Grow: How Ideals Power Growth and Profit at the World's Greatest Companies, Crown Business.

TrujlLlo, E. (2013): La sociedad que no quería ser anónima. Colección Acción Empresarial. LID Editorial.

Villafañe, J. (2004): La gestión profesional de la imagen corporativa. Pirámide.

- Artículos:

Aaker, J.; S. Foumier; S. Brasel; S. Adam (2008): «When Good Brands do Bad», Center for Responsible Business, UC Berkeley, Working Paper Series, Journal Of Consumer Research, Inc., Vol. 31.

Alloza, Á; S. Conley; F. Prado; J. Farfan y R. Espantaleon (2004): «Creating the BBVA Experience: Beyond Tradictional Brand Management", Corporate Reputation Review, Vol. 7, núm. 1, p. 66-81.

BALMER, John M.T. (2001): "Corporate Identity, Corporate Branding and Corporate Marketing: Seeing Through The Fog», Bradford School of Management, European Journal of Marketing, Vol. 35 No. 3/4, p. 248291.

BivaINIENE, L. (2010): "Brand Life Cycle: Theoretical Discourses», Siauliai University, Economics and Management, p. 15.

BOWKeR, D. (2009): "The Public Relations Perspective On Branding», Brands and Branding, 2nd Edition, Cap. 10, p. 146-156.

Dauvergne, P. y J. Lister (2011): «Big Brand Sustainability: Governance Prospects and Environmental Limits», Liu Institute for Global Issues, University of British Columbia, The Global Environmental Change.

De Chernatony, L. (2001): «Would a Brand Smell Any Sweeter by a 
Corporate Name?», Birmingham University Business School.

GAINES-Ross, L. (2010): «Reputation Warfare, Spotlight on Social Media and The New Rules of Branding», Hardvard Business Review, diciembre, p. 70-76.

HaRris, F. y L. De Chernatony (2001): «Corporate Branding and Corporate Brand Performance», Open University Business School and The Birmingham Business School, European Journal of Marketing, Vol. 35 No. 3/4, p. 441-456.

HATCH, M. J. y M. SCHULTZ (2003): «Bringing the corporation into corporate branding", McIntire School of Commerce, University of Virginia, Charlottesville, Virginia, USA, y Copenhagen Business School, Copenhagen, Denmark, European Journal of Marketing, Vol. 37 No. 7/8, p. 1041-1064.

- (2010): «Toward a Theory of Brand Co-Creation with Implications for Brand Governance», Brand Management, p. 1-15.

Iglesias, O.; A. SAuquet; y J. Montaña (2011): "The Role of Corporate Culture in Relationship Marketing», ESADE, Universitat Ramon Llull, European Journal of Marketing, Vol. 45 núm. 4, p. 631-650.

IND, N. (2007): «Branding Governance», Brandmanager, núm. 2, p. 30-37.

IND, N.; O. IGLESIAS; M. SCHULTZ (2013): «Building Brands Together: Emergence And Outcomes of Co-Creation», California Management Review, Vol. 55, núm. 3 Spring.

LANE KelleR, K. (2010): "The New Branding Imperatives: Insights for the New Marketing Realities», Marketing Science Institute.

SCHULTZ, M. (2011): «Relationships Between Culture and Institutions: New Interdependencies in a Global World?», Journal of Management Inquiry 2012 21: 102 originally published online 28 December 2011.

URDE, M.; S. A. GReyser y J. M. T. Balmer (2007): «Corporate Brands with a Heritage», Working Paper Series, núm. 07/18, July.

- Estudios, publicaciones y memorias académicas:

Arthur W. Page Society (2012): «Building Belief: A New Model For Activating Corporate Character And Authentic Advocacy». Arthur W. Page Society.

Bajo, A. y N. Villagra García (2012): "Los desafíos de la empresa ante la sostenibilidad: Diagnóstico, reflexiones y propuestas». Memoria Académica Curso 2011-2012. Reflexiones Comillas «Economía y Empresa». Universidad Pontificia de Madrid.

Corporate Excellence - Centre For Reputation leadership (2012): «Asuntos Públicos: Marco conceptual y modelo de gestión. Ranking Global Issues 2012». Corporate Excellence - Centre for Reputation Leadership y Aula de Liderazgo Público de la Universidad Pontificia ICADE Comillas, 2012. 
Augusto Leiva Espinoza. Las diferencias del diálogo entre gobierno-sociedad y entre empresasociedad

Edelman (2012, 2013, 2014 y 2015): Trust Barometer, Eshuis, J. \& E. H. KLIJN, (2012): «Branding in Governance and Public Management». Routledge.

ESIC (2011): AdResearch ESIC: Revista Internacional de Investigación en Comunicación, núm. 3, primer semestre, enero-junio.

Foro Académico de Investigación en Comunicación (2015): El nuevo diálogo social: organizaciones, públicos y ciudadanos. 


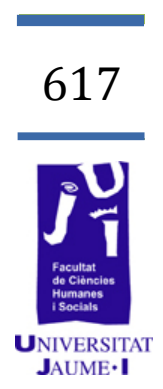

\section{Teaching secondary students ICC through music. A teaching proposal}


This paper aims at supplying some guidelines related to contents and methodology that might be implemented to teach ICC in secondary school. First, a theoretical introduction is provided. After that, the proposal is fully explained. Then, assessment is discussed and, finally, conclusions are drawn and expected learning outcomes described.

The teaching proposal that is going to be described takes as its leading theme the history of (pop) music in English speaking countries during the second half of the $20^{\text {th }}$ century, from the 1960 s to the end of the century. It has been devised to be carried out in a Spanish secondary education institution, either public or private (students aged between 12 and 16) in an intact classroom; therefore, the number of participants could range from twenty-five to thirty-six pupils (Generalitat Valenciana, Conselleria d'Educació, Cultura i Esports, 2014). All the classes will carry out the same type of tasks, although each one will be focused on a different decade, in terms of topic and information.

The project could be carried out as a part of English as a Foreign Language (EFL), by devoting one weekly class session (out of three) to it, and leaving the other two for strict language instruction. This option has the advantage of benefitting all the students in the class, since EFL is a compulsory subject in secondary education in Spain. On top of that, it could easily be included in the regular schedule of the subject.

Key words: intercultural, communication, English, secondary, education, music.

\section{Introduction}

\subsection{Intercultural Communication Competence: the relationship between language and culture}

Languages are not spoken in the void; they belong to a community of speakers, which has a culture of its own (history, arts, politics, educational system, etc.), social conventions, and so on (Celce-Murcia, 2007). All of these factors affect languages and the way they are used in interaction.

For most scholars "language and culture are seen as inseparable in the learning process» (Byram \& Feng, 2004, p. 161) for a number of reasons. First, "language is the vehicle of culture and (...) categorizes reality according to its corresponding culture» (Hofstede, 1986, p. 314). Moreover, according to Xue (2014), culture influences communication in a double sense. On the one hand, each cultural system encourages a particular communicative style. On the other hand, it has the power to shape perception. As a result, language teaching should also entail culture teaching, so that communication can be successful. Furthermore, culture 
has been demonstrated to even have an impact on the learning style, on «a person's preference for abstract conceptualization versus concrete experience» (Joy \& Kolb, 2009, p. 83). If culture is connected to such an intimate variable as this, it might also be linked to other aspects. However, the truth is that, very often, "the "teaching of and about culture" seems to be neglected» (Young \& Sachdev, 2011, p. 95).

Educational legal directions often include guidelines concerning culture and language which, despite highlighting their importance, end up being too vague. If we focus, for example, on the European framework, the European Commission $(2006,2007)$ refers to a number of key competences for lifelong learning in the European Reference Framework, which are closely related to intercultural understanding: communication in foreign languages, social and civic competences, and cultural awareness and expression. The general directions provided by the European Commission have been reflected in the different laws of education of the member countries and, to illustrate one such case, the Spanish example will be dealt with more thoroughly below.

Spanish education is going through a time of change, since a new Law of Education is being implemented at the moment. As a result, depending on the year of instruction, the law which is applied to it differs. During the present academic year (2015/2016) the new Law of Education (LOMCE) affects the first and third years of secondary education, whereas the second and fourth are regulated by the old one (LOE), so one might expect improvements in the way in which different issues are presented. However, one of the things they have in common is how the aforementioned topic is dealt with. The old Spanish Law of Education (Real Decreto 1631/2006, 29th December), for example, does not limit learning a foreign language to the language itself; it also encourages the development of intercultural awareness as a means for understanding global issues. According to this law, the goals connected to Intercultural Communication Competence (ICC) that should be present in the foreign language (FL) curriculum are:

- To know and critically interpret multilingual and multicultural diversity in order to develop a positive attitude towards linguistic diversity, regarded as a cultural wealth;

- To reflect about the different social customs to adopt effective strategies which allow them to communicate in different social and cultural contexts, regarding foreign languages as means of communication and understanding among people from different origins, languages and cultures, and avoiding linguistic stereotypes linked to any kind of prejudice. (Real Decreto 1631/2006, 29th December).

On the other hand, in the new Law of Education (Real Decreto $1105 / 2014$, 26th December) it is admitted that both socio-civic competences and cultural expression are an integral part of intercultural competence and, as such, they should be inherent to learning foreign languages. As a result, among the teaching goals that are contemplated in 
the subject of English as a Foreign Language, the following is included: «integrating the most relevant socio-cultural and sociolinguistic aspects of the target language in the student's own intercultural competence» in order to get beyond the differences and stereotypes, as well as to avoid mistakes which lead speakers to potentially conflictive situations.

Regardless of which law is in force, in spite of the legal formulation that is employed, a simple question could be posed here: what does that mean, in terms of specific content to be taught in a classroom? Or, in other words, how is a teacher supposed to translate those words into his/ her daily practice? All in all, teaching ICC does not seem to be an easy task due to several circumstances. First, although, generally speaking, ICC is mentioned in most curricula, those curricula provide excessively general intercultural learning goals and «fail to indicate how these general goals are to be taught» (Fageeh, 2011, p. 66). Consequently, teachers usually find themselves with a total lack of precise information on what to teach and how to do it.

Moreover, ICC is usually learnt as part of another subject. Most of the times, it is included in the FL class (Fageeh, 2011). The problem here is that attaining culture goals usually comes second to attaining linguistic objectives (grammar, vocabulary, pronunciation, etc.), which are usually the real target in most courses. If we take official examinations as an example (university entrance exams, Cambridge, Official School of Languages, etc.), there are no sections devoted to assessing the learners' IC competence. Therefore, not being real "content" for exams, it is often skipped or "left for tomorrow".

Another obstacle that may be encountered when trying to instruct students in ICC is the lack of appropriate materials. Those teachers who use textbooks, for example, often find serious weaknesses in their cultural content. Some of the most frequently mentioned are the absence of controversial social issues, a tourism-oriented view of the foreign society, abundant stereotyping, or excessive focus on language form (Skopinskaja, 2003), to name but a few of them. As a result, materials are often replaced or, simply, censored, because they fail to provide suitable resources. Consequently, the cultural view they offer might be biased or incomplete.

\subsection{Developing ICC in the secondary school}

As previously stated, in spite of agreeing on its importance to carry out successful communication, ICC is not always dealt with properly in foreign language teaching. In the following sections, some guidelines will be provided on what to include (contents) and how to instruct learners (methodological hints) in order to deepen their insight on the matter.

\subsubsection{What to teach: contents}

If a teacher took Ferraro's (1995, as quoted in Xue, 2014, p. 1493) allencompassing definition of culture as «everything that people have, 
think, and do as member of a society", he/ she would probably feel overwhelmed when facing the task of teaching culture to his/ her students. That apparently simple concept covers everything: objects, beliefs and behaviours (Xue, 2014), and it is just common sense that it is too much and, consequently, should be limited in some way. Therefore, the question here is: What should be taught and what should be left out?

First of all, it should be taken into account that teachers might find legal constraints due to educational legislation. In Spain, however, there is no such problem, since, as was previously mentioned, ICC goals are not explicit at all. Some of them are as follows: reading as a means of acquiring information about different cultures and ways of life; appreciating and valuing the foreign language as a means of communication; knowing the fundamental aspects of the socio-cultural milieu; valuing other ways of organizing experience and of structuring personal relationships; etc. (Real Decreto 1631/2006, 29th December). Therefore, at least in this country, teachers have quite a lot of freedom to introduce those contents they consider more relevant.

According to Byram and Feng (2004, p. 160), «the most conventional and the most criticised dimension of culture teaching is what critics call the facts-oriented approach in which culture is basically viewed as civilisation, the "big C" culture, as well as everyday lives, the "small c" culture». In this model, culture is divided in a series of topics for teaching. The main sources of criticism have been that it might lead to the teaching of stereotypes, and that it does not deal with the social dimension of this construct. However, in spite of that fact, this perspective is still one of the most widespread in language teaching. Some experts (Hu \& Gao, 1997 as quoted in Byram and Feng, 2004, p. 161) consider that «knowing facts is necessary as a starting point for culture learning» and propose an approach which starts by providing learners with more or less stereotypical knowledge, which is then analysed from a critical perspective and compared to a variety of representations of the concept under discussion. In other words, they suggest teaching culture by broadening the learners' views beyond simple stereotypes and by, basically, fostering their critical thought capacities.

Xue (2014), for his part, elaborates on a less ambitious set of contents. In his opinion, what should be taught as part of the ICC is: cultural connotation of words; idioms; cultural factors affecting verbal and non-verbal communication; general knowledge of English-speaking countries; and differences in cultural values and thinking patterns between the target culture and the students'. Xue's proposal seems to be more language-centred than others, which might seem logical to many when dealing with EFL contents. In addition, it might be too general, so, again, too much responsibility would be placed on the teachers' shoulders, since they would have to design a more specific syllabus of their own.

The truth is that most EFL teachers in Spain use textbooks which, to a bigger or lesser extent, contain cultural information. This fact has an 
obvious time-saving advantage and provides a given and, more or less, structured syllabus. Nevertheless, they often present an excessively limited view of the foreign culture and foster stereotypes (Paricio, 2005). In our "real-life" teaching context, a sensible choice seems to be using the existing materials (in the textbook), which are normally more languagefocused, and, at the same time, enrich them by designing cross-curricular projects which can be revised and implemented every year.

When devising a project to teach ICC to EFL students, there are several variables that should be considered, so that the information the learners receive is not biased or incomplete. Teachers can and should check the adequacy of the materials they are using in a number of ways in order to make sure they are appropriate to achieve the learning targets. For example, according to Sercu (1995, p. 140-142), there are four criteria teachers should apply to make sure the materials they are using are suitable to teach ICC. The first criterion is related to representativeness and realism: is the picture of the society complete, up-to-date and realistic? Or does it show an idealistic, "tourism-oriented" view, where conflict does not exist? The second criterion deals with the characters in the book: how is the population depicted in terms of age, ethnicity, social class, mood, behaviour, etc.? The third aspect is language. Educators must check if the language used carries either positive or negative connotations in relation to the different social or ethnic groups. Finally, teachers must take the pupils' role into account, too, and analyse if they are supposed to have a more active, opinion-giving attitude or a more passive behaviour.

\subsubsection{How to teach: methodology}

Most scholars agree that culture learning is more difficult to teach in the classroom context than language (Byram \& Feng, 2004). They assume that interacting "with people who embody a culture, who are native speakers of a language, is crucial» (p. 153). In this sense, they regard study-abroad programmes as opportunities to develop both the learners' linguistic competence and their cultural awareness and intercultural competence. Despite sharing their views, it must be admitted that «our students have never been to any English-speaking countries before they start to learn and use the target language» (Fageeh, 2011, p. 66). As a result, an alternative approach should be proposed, which is valid and reliable for all kinds of learners, from absolute beginners to more advanced students.

Although it has not been fully explored, the internet seems to be a powerful tool for students and teachers to explore diverse ethnographic aspects of the target culture (Byram \& Feng, 2004). In fact, most teenagers (if not all) in Spain are familiar with different English/ American cultural products they can have access to through the internet, such as sitcoms, music, magazines, etc. Consequently, it can be used as an 
effective tool to learn English culture (Fageeh, 2011), both in an independent way and with the teacher's guidance.

Several authors (Fageeh, 2011; Dogancay-Aktuna, 2005; Skopinskaja, 2003; Gray, 2000) agree that, in general terms, encouraging students to adopt a comparative perspective might be an effective way of attaining a two-fold objective. On the one hand, it could be a motivating technique for students to upgrade their knowledge from their own culture. On the other hand, it could help them learn about the similarities and differences between the target culture and their own.

In the context of English as a Foreign Language (EFL), "some authors believe that teaching EFL means more than teaching the language; it also involves learning how to slip into the English culture as smoothly and as naturally as can be possible» (Fageeh, 2011, p. 64). An ideal language learner, then, should end up being both bilingual and bicultural.

In the secondary school context, teachers face the following challenge: developing intercultural communication competence (ICC) together with linguistic competence, so that their students can be competent language users who can get on successfully in the foreign culture. The problem a lot of FL instructors encounter is that, due to different reasons, they find it difficult to teach ICC to their pupils effectively.

After having analysed what ICC is and how it can be taught, we turn to explain a teaching proposal through which teaching IC to secondary students in Spain is aimed at.

\section{Teaching proposal}

This paper aims at supplying some guidelines related to contents and methodology that might be implemented to introduce the teaching of ICC in secondary school. First, a teaching proposal is fully explained, followed by some hints on how to assess the students' performance.

\subsection{Teaching goals}

The teaching proposal that is going to be described has various objectives, which are different in nature. As it has been conceived as a project, that is to say, a series of interconnected tasks, the goals that are sought are diverse. The main ones are:

a) Improving the students' Intercultural Competence (ICC) by fostering their acquisition of knowledge related to the recent historical and socio-cultural background of some English-speaking countries (the big " $\mathrm{C}$ " culture), especially that connected to youth culture. As has already been mentioned, it is generally agreed (Byram and Feng, 2004) that merely teaching bare facts is not enough to improve the learners' ICC, nevertheless, as some authors state (Hu \& 
Gao, 1997 as quoted in Byram and Feng, 2004), it could be a useful starting point for learners to get acquainted with the L2 culture.

b) Motivating students through the use of music and the performance of tasks, so that they start using English as a means of communication. Swain (2013, p. 195) stated that «emotions are an integral part of cognition». This means that all the intellectual processes we engage in are influenced by them and, as well as that, they (emotions) are said to mediate our learning outcomes. Both emotions (affect) and cognition (beliefs), together with behaviour, conform our attitudes towards a specific learning target. In terms of language learning, this means that attitude defines the relationship between a subject (the learner) and an object (the language), and informs us about the subject's disposition towards the object (Espí \& Azurmendi, 1996).

In addition, it has been stated (Gardner and Lambert, 1959) that motivation, that is, the reason or reasons why an individual learns something, has an important role to play in language learning. That reason can have and integrative orientation or an instrumental one. An integrative attitude, initially associated with the learner's interest to identify with the target language community, seems to be an outdated concept in the globalized world of the twenty-first century (Kormos \& Csizér, 2008). In turn, it is said to reflect a desire to learn about the language group and to meet people belonging to it. Instrumental attitudes, in contrast, are represented by utilitarian motives (Gardner \& Lambert, 1959). Although both can be effective in terms of making learners succeed (Ehrman, Leaver \& Oxford, 2003), integratively oriented students are said to be more successful than instrumentally oriented students (Gardner \& Lambert, 1959).

c) Fostering the learners' acquisition of fundamental learning skills that they will need to master in order to ensure they pick up useful techniques which help them improve their lifelong learning skills. For example, students will work in small groups, which will aid them to realize «they can achieve learning goals that would be much more difficult if they had to do it on their own» (García \& Sylvan, 2011, p. 395). Consequently, that experience is believed to enrich their teamwork skills. Other learning skills that are thought to be upgraded are self-assessment, autonomous information search, critical thinking, etc. Furthermore, showing students how to work collaboratively and, then, making them put it into practice, enhances their learning experience, which means that they will learn more and better than being merely passive receivers of input (Kagan, 2009).

In spite of the fact that teaching ICC is the main aim of this teaching proposal, it should not be forgotten that it is part of a subject: EFL. As a 
result, some of the teaching goals that are sought are connected to linguistic criteria. These are namely:

d) Getting the students produce intelligible oral messages, according to their level of proficiency. In order to achieve that goal, the classes will be leaner-centred. This way, the pupils' linguistic opportunities will not be limited, as collaborative dialogue will be employed to develop new linguistic skills (García \& Sylvan, 2011). In this context, the teachers are seen as facilitators of the students' learning process. This means that materials, methods, activities and so on are nearly tailor-made and, as some authors claim, putting students at the centre of the process increases their possibilities to succeed (Cohen, 2003).

e) Amelioration of the pupils' pronunciation. Learners will be provided with plenty of opportunities to listen to authentic oral messages and that input is thought to help them make progress in their own oral skills. It is true that some authors (Cenoz and Gorter, 2011) state that the native speaker as the only ideal for perfection has traditionally been overestimated. However, whenever someone learns something, it is useful to have a 'model' which serves the learner as guidance. In that sense, the idea of the NS could be useful.

\subsection{Description of the proposal}

The proposal that is going to be described takes the history of pop music in several English-speaking countries during the second half of the twentieth century as its leading theme. It has been devised to be implemented in all four different levels in compulsory secondary education (in Spain, ages 12-16). All the classes will carry out the same type of tasks, although each one will be focused on a different decade (60s, 70s, and so on), in terms of central topic and related information. As a result, the first year class (ages 12-13) will focus on the 60s; the second year (ages 13-14), on the 70s; the third year (ages 14-15), on the 80s; and the fourth year (ages 15-16), on the 90s.

Five tasks have been designed to introduce students into the topic on a step-by-step basis, so that they start by grasping general information related to the historical and socio-cultural context they are to learn about. After that, they will focus on specific music icons, as well as on their lives and the messages they transmitted through their songs (if any). Next, they will explore the language and contents of a specific song in detail. Later, watching a film or a documentary will enable students to actually "see with their own eyes" a visual example of some of the things they have been learning about. The last task (the Quiz) is meant to be a revision task aimed at revisiting all the contents that have been covered throughout the project. 


\subsection{The tasks}

In this section, a detailed description of the different tasks the students are going to perform will be provided. Apart from a step-by-step explanation of the assignments, the materials that are necessary to carry them out and the class sessions that might be employed will also be referred to.

\subsubsection{Task 1. The Poster}

The first task has been designed as a broad introduction for students to the historical background they are going to focus on. Most pupils in the first year of secondary education do not have an overall knowledge of the history and culture of the twentieth century, since it has not been studied in primary education (Real Decreto 126/2014, 28th February). As a result, having them glance at what was going on at that time is a way to help them place themselves in context. Moreover, they will be getting high amounts of L2 input, as they will have to read texts, or watch videos, which will help them "warm up" for the following, more demanding activities.

\subsubsection{Task description}

First of all, the class will be arranged in groups of three or four students (depending on the class size). Then, they will be asked to make an internet search to look for information on the main historical and socio-cultural events which took place during the decade they have been assigned. When they have completed their search, they will have to select those episodes that, in their opinion, were the most crucial in the decade. After that, they will have to provide a title or caption for each one of them and a brief summary (three or four lines) which reports it. Also, an image which depicts the event will have to be looked for.

Once all the data have been gathered and organized appropriately, each group will make a poster. First of all, students will be provided with art paper roll, which they will cut out to the size they wish. First, they will draw a timeline sideways, across the middle of the piece of paper, where they will mark all the years in the decade they are working about. On the upper part of the paper, just above the corresponding year in the timeline, the learners will stick each caption, the short texts and the images they have previously prepared, showing the main historical events they have chosen in chronological order. In the lower part of the poster, just below the timeline, they will have to do the same thing, but this time they will have to focus on news related to the cinema, fashion, music and culture of the given decade.

After completing the task, all the posters will be displayed on the classroom walls and each group of students will briefly speak about the importance of the facts they have included in their placard, by explaining 
the rest of the class why they have chosen to depict those specific events, and not others.

\subsubsection{Comparison with students' own culture}

The following step consists of a comparison between what students have learnt about the foreign culture and their own. As has already been mentioned, this is a necessary activity so that learners can analyse data from a critical perspective, so that they go beyond simple stereotypes. In order to carry out this activity, the students, organized as they are (in the same groups), will choose one of the years in the decade they have been researching. After that, each group will do a quick internet search to look for what, in their opinion, was the most important event in their home country (Spain) in that year. As they had previously done, they will provide a title or caption for it and a brief summary (three or four lines) to report it. On top of that, an image which depicts the event will also have to be looked for. Furthermore, each group will have to focus on a specific piece of news related to the cinema, fashion, music and culture which took place at that time.

Once all the pupils have finished, all the students (as a class) will have to make a poster (similar to the one they have previously made), on which each group will stick their information. The result will be a timeline in which they will be able to observe the main events that took place in their country during the given decade, and what was going then in terms of fashion, culture, music, etc. A class discussion will take place after that, in which students will compare what had happened in their country and in the foreign countries at that time. It will be interesting to highlight the similarities and differences between both of them, so that learners can analyse them.

\subsubsection{Task 2. Oral Presentation}

After they have finished Task number 1, learners are expected to have had an initial approach to the most popular singers and/ or bands at the time. Taking that for granted, the second task will be started from that point. This time, they will be working in pairs so that they have more opportunities to interact with each other and with the rest of the class in the $L 2$.

\subsubsection{Task description}

To begin with, the whole class will brainstorm as many music icons (from the time studied) as they can think of and, right after that, the teacher will write a list of their names on the whiteboard. If necessary, the teacher might give them hints to help them place popular artists in the right decade or provide them with names of musicians who are not so familiar to them. 
Next, each pair will choose one of them, after which they will have to prepare an oral presentation (which will last from 6 to 8 minutes), necessarily including the subsequent items: name of the band or singer; brief biography of the singer or individual members of the band; when, how and why they started playing (together, in the case of bands); brief history of their musical career; most important hits. The first session will take place in the computer lab, because learners will probably need to search for information on the internet.

The second class will be employed to design and prepare the presentation. In order to make their presentations more interesting, students will be allowed to use any audio-visual resources that might enrich their performance (power point presentation, sample music, images, short videos and so on). Once they all have finished them, they will have to present their findings to the class and the teacher.

\subsubsection{Comparison with students' own culture}

In order to analyse how the music scene (fashions, interests reflected on the lyrics, etc.) were similar or different in the foreign countries and in Spain, the whole class will brainstorm as many Spanish music stars as they know and the teacher will write a list of their names on the whiteboard. If necessary, the teacher might help them or provide them with names of popular musicians who were successful in Spain at that time.

Next, each pair will choose one of them, after which they will search for information on the internet. They will have to focus on the type of music the chosen singer or band played and the message in their lyrics, as a reflection of popular worries, interests, etc. After that, each pair will briefly expose what they have found out to the rest of the class and a subsequent class discussion will take place, where similarities and differences will be analysed.

\subsubsection{Task 3. Learning with songs}

This task differs from the others that integrate this teaching proposal in that it has a twofold objective, one of which is not directly linked to ICC. On the one hand, it obviously pursues teaching ICC to secondary students, being that the central aim of the proposal. On the other hand, though, we must remember that it has been devised to be integrated as a part of EFL and, as such, attaining linguistic-related objectives is also expected. As a result, there are two parts to the task: the first, which is directly connected to the previously stated teaching goals d) and e) (see section 3.1), and more linguistic in nature; and the second, which focuses more on ICC, as stated in teaching objective a) (see section 3.1).

\subsubsection{Task description}

In order to carry out this task, students will work in pairs (with the same person as in Task 2). Each couple will have to prepare two activities, 
based on the lyrics of a song by the singer or the band they delivered the presentation about. They will be free to choose any song they like, as far as the lyrics have enough "content" to enable them to work with it. The first part will be a listening comprehension activity and the second will be a True/ False exercise.

In the first place, the teacher will show the pupils how to exploit the lyrics of a song for learning purposes. Different options will be dealt with, apart from the traditional "gap-filling exercises", and learners will be able to implement the format they prefer. Some of the model exercises they will learn about will be:

- Gap-filling: certain terms (verbs, prepositions, nouns, etc.) are erased in the lyrics of a song (leaving a "gap"). Then, the students have to listen to it and decide what word has been eliminated and try to complete the lyrics by writing that term.

- Code change: The pupils transcribe the lyrics of a song by using an alphabet which is different from the English one. They can either use an already existing code or devise their own. After providing their classmates with the key, they (their classmates) will have to recover the original lyrics. Then, they will have to listen to the song to check if they have done it correctly or not.

- Writing the opposite: In this model, the lyrics of the song must be re-written by substituting as many words as possible by their antonym (boy-girl, go up- go down, feel blue- feel happy ...). The pupils, then, have to provide the authentic words, after listening to the song.

- Pictograms: Pictograms are used to substitute some or all of the nouns which appear in the lyrics. First, the students will have to work out their meaning and, after that, they will listen to the song in order to check if their deduction was right or wrong.

- Blanks and riddles: Some terms are eliminated from the song. Then, the pupils are provided with a list of riddles (one per each word that has been erased) which they have to guess, in order for them to find out those terms. Finally, they will listen to the song for correction.

- Scrambled lines: Students will jumble the verses in a song. Then, their classmates will have to listen to the song and decide which the correct order for those verses is.

Once the pupils have decided which exercise format they are going to implement, they will have to search the internet and get a copy of the lyrics of the song they are going to work with. Afterwards, they will prepare a worksheet in which they will use those lyrics to prepare a listening comprehension exercise. Apart from that, they will have to make sure that they know the vocabulary and the grammatical structures which appear in the song. In addition, they will have to look for a version of their song that they can use and play in the class. 
Finally, the pupils will take over the teacher's role (in pairs) in the classroom. This way, they will use the handouts they have prepared in order to lead a listening comprehension session with the rest of the class. Pairs will be selected randomly by the teacher.

Once that part of the task has been completed, learners will have to carry out the second part of the task. Here, they will have to ask their classmates to write a short text (about 100 words) in which they will explain what aspect of the historical or socio-cultural context of the time is presented in the song and why, in their opinion, it is dealt with. For instance, if Zombie (The Cranberries, 1994) was dealt with, the students could ask their mates to connect the lyrics of the song to the conflicts in Northern Ireland during the 1990s. Another example could be Fortunate Son (Credence Clearwater Revival, 1969), which would help them consider the issue of the Vietnam War. When they have finished, they will use those texts to set up a ten-minute class discussion in which they will contrast their views.

\subsubsection{Comparison with students' own culture}

After all the songs have been presented to the class, it would be interesting to have each pair of students look for a Spanish song that, from their point of view, reflects a historical or a socio-cultural issue of the time. After that, they can compare what kinds of topics were dealt with in pop music both in and out of Spain and discuss what similarities and differences there were and the reasons why they might have existed.

\subsubsection{The Film}

The aim of this task is to help students put together or internally "summarize" everything they have learnt up to this point. It is intended to help them integrate all the information they have been exposed to and make it more meaningful and comprehensible for all of them.

\subsubsection{Task description}

In the first place, a film or a documentary in English (with English subtitles) will be watched in class. It will be either a musical made at the time studied or a more recent film, which depicts the historical time they have learnt about. Some suggestions for the different levels could be the following:

- 1st ESO (60s): West Side Story/ Documentaries The Beatles or The Rolling Stones;

- 2nd ESO (70s): Saturday Night Fever;

- 3rd ESO (80s): Footloose, The Blues Brothers, Flashdance, Fame;

- 4th ESO (90s): The Commitments. 
After watching the film, students will get together in groups of four people in order to fulfil a comprehension activity (Appendix) related to the film they have watched. When they have completed the activity, answers will be discussed in the classroom with the rest of their classmates.

\subsubsection{Comparison with students' own culture}

It might be interesting to have pupils watch a short clip (part of a film, for example) or documentary depicting the studied decade in their own country. After that, they could establish similarities and differences between both visual documents (the Spanish and the foreign one) and draw conclusions, which could be exposed in the form of a class discussion. At this point, it could be stimulating for students to pay attention to the characters' concerns, the socio-cultural backgrounds depicted in the films and, broadly speaking, what the reasons for those similarities and/ or differences could be.

\subsubsection{The Quiz}

This task is intended to assist students in revising everything they have learnt and done throughout the project. They are asked to stop and go back over all the contents that they have seen.

\subsubsection{Task description}

In the first place, student groups will get together and will write fifteen questions related to anything they have learnt during the project. After that, they will be given fifteen cards, where they will write one question on one side and the answer on the other side of the card. When they have finished, all the groups will give the teacher their cards so that he/ she revises them to avoid repetitions.

During the next class, all the pupils (in groups) will take part in a "Super Quiz". The teacher will shuffle all the cards (about 50-70 per group). Then, he/she will read one question and the student groups will take turns to answer them. The group who gets the right answer, earns a point. If they do not know it or give a wrong answer, the following will give it a try. They have to provide as many correct answers as they can. The group who answers more questions correctly, wins the contest and, as a result, obtains an extra mark.

\subsubsection{Comparison with students' own culture}

This task is based on what learners have been doing throughout the project as a whole. Consequently, it might be a good idea to have them include a few questions highlighting similarities and differences that they have observed in the different sections of the project. 


\section{Assessment}

The final grade the students will obtain, when they have completed the project, will be made up of three components:

- Teacher assessment (60\%): The teacher will assess attainment by providing students with a 0-10 mark for each task, which will be averaged in the end. The criteria that will be implemented for the poster and the oral presentations will be known by the pupils beforehand, since they will be given rubrics where requirements are explained in detail. The song and the film questionnaire will be evaluated in terms of task completion and delivery to the teacher. As for the quiz, only the winning students will get the extra mark.

- Peer assessment (20\%): Each pupil will provide a mark for the students they have been working with (group work and pair work), based on a marking sheet (rubric) provided by the teacher.

Self-assessment (20\%): Each student will assess their own work, using the same rubric they have employed to evaluate their classmates' performance.

\section{Conclusion: expected learning outcomes}

In the first place, the learners' Intercultural Competence is supposed to have improved substantially. They will have read about a variety of historical characters and events, and will have listened to what their classmates have researched about. Furthermore, they will have done some investigation about youth culture and lifestyle in the past, both in foreign countries (probably, most of it will be focused on the UK and the United States) and in their own. They will have had the chance to know about it and compare it with their immediate reality. As a result, they are expected to widen their viewpoints and become more tolerant towards difference.

The students' attitudes and motivation towards other languages and cultures (in this case, English) is expected to improve. Moving the focus away from linguistic correctness and using the topic of music as the driver is supposed to have fostered positive integrative attitudes on learners, since the topic chosen is generally thought to be interesting and motivating for teenagers (Hudson, n.d.). The leading theme of music is considered as the "hook" which will have caught the learners' attention. Besides, having made pupils compare what they have discovered with their own reality is hoped to get them intrigued on the differences, as well as the similarities that they may find.

By carefully designing the different tasks students have to carry out, they are expected to have acquired or, at least, improved their lifelong learning skills. First, they will have worked their teamwork abilities. As a 
result, they will have practiced negotiating, discussing, analysing, etc. Furthermore, they will have had to assess their classmates' performance, as well as their own; consequently, they will have had to critically analyse a series of parameters and decide on their level of correctness, according to them. As well as that, they are thought to have improved their critical thinking skills, by comparing, categorizing, selecting information (in terms of their importance), etc.

Apart from the above-mentioned outcomes, the proposal is supposed to have had a positive impact on the learners' oral skills (listening comprehension, fluency, pronunciation). First of all, students are, in a way, "pushed" to listen to and speak in English. Moreover, as linguistic correctness is not the focus, they are thought to take more risks, since the ultimate goal is successful communication. Moreover, they will have got plenty of authentic input, which is expected to help them improve their pronunciation, intonation, vocabulary range, and so on.

\section{References}

Byram, M. And A. Feng (2004). «Culture and language learning: teaching, research and scholarship». Language Teaching, 37, 149-168.

Celce-Murcia, M. (2007). "Rethinking the role of communicative competence in language teaching». In E. Alcón \& P. Safont-Jordá (eds.) Intercultural language use and language learning. (p. 41-55) Springer Netherlands.

Cenoz, J. ANd D. Gorter (2011). "A holistic approach to multilingual education: Introduction». The Modern language Journal, 95, 339-343.

COHEN, D. H. AND THE FACULTY AND STAFF OF INDEPENDENT DAY SCHOOL (2003). It's all about kids. Every child deserves a teacher of the year. Tampa: Bee Happy Publishing.

DogancaY-AkTUNA, S. (2005. "Intercultural communication in English language teacher education». ELT Journal, 9, 99-107.

Ehrman, M. E., B. L. Leaver AND R. L. Oxford (2003). "A brief overview of individual differences in second language learning». System 31, 313-330.

ESPÍ, M. J. \& M. J. AzURMENDI (1996). «Motivación actitudes y aprendizaje del español como lengua extranjera». RESLA, 11, 63-76.

EUROPEAN COMMISSION. (2006). "Recommendation 2006/962/EC of the European Parliament and of the Council of 18 December 2006 on key competences for lifelong learning». Official Journal L 394. Retrieved on February 1st, 2015 from http://europa.eu/legislation_summaries/education_training_youth/lifelo ng_learning/c11090_en.htm 
EUROPEAN COMmission. (2007). "Key competences for lifelong learning. European Reference Framework». Luxembourg: Office for Official Publications of the European Communities.

FAgeeH, A. (2011). "At crossroads of EFL learning and culture: How to enhance cross-cultural awareness in EFL college students». Cross-cultural Communication, 7 (1), 62-72.

GarcíA, O. AND C. SyLVAN (2011). "Pedagogies and practices in multilingual classrooms: singularities in pluralities». The Modern Languages Journal, 95: 385- 400.

Gardner, R., \& W. LAMbert (1959). "Motivational variables in secondlanguage acquisition». Canadian Journal of Psychology. Retrieved on 4th April from http://psycnet.apa.org/journals/cep/13/4/266/

Generalitat Valenciana, Conselleria d’Educació, Cultura i Esport. (2014). «El curso 2014-15 comienza con 96.047 alumnos en Castellón, 1.234 más que el pasado curso». Retrieved January 26, 2015 from http://cece.gva.es/es/agenda.asp?id=2729

GRAY, J. (2000). "The ELT coursebook as cultural artifact: how teachers censor and adapt». ELT Journal, 54 (3), 274-282.

Hofstede, G. (1986). "Cultural differences in teaching and learning». International Journal of Intercultural Relations, 10, 301- 320.

Hudson, C. (n.d.). "Go with the flow: 10 ways to easily engage teenagers». Retrieved June 18th 2015 from http://understandingteenagers.com.au/blog/2010/09/go-with-the-flow10-ways-to-easily-engage-teenagers

JoY, S. \& D. A. KOLB (2009). «Are there cultural differences in learning style?» International Journal of Intercultural Relations, 33(1), 69-85.

KAGAN, S. (2009). "Un cambio de paradigma para la educación del siglo XXI». Retrieved February 3rd 2014, from http://talleres.global-learning.es KORMOS, J. AND K. CSIZÉR (2008). «Age-related differences in the motivation of learning English as a foreign language: attitudes, selves, and motivated learning behavior». Language Learning 58, 327-355.

ReAL DeCRETo 1105/2014, 26th December. BOE number 3, 3rd of January, 2015: p. 169-546

ReAl DeCRETo 126/2014, 28th February. BOE number 52, 1st March, 2014: p. 349-420.

ReAl DeCReto 1631/2006, 29th December. BOE number 5, 5th January, 2007: p. 677-773

PARICIO, M. S. (2005). "La dimensión cultural en los libros de texto de lenguas extranjeras: pautas para su análisis». Glosas Didácticas (15), p. 133-144. 
SERCU, L. (1995) Intercultural Competence. Denmark: Centre for Languages and Intercultural Studies.

SKOPINSKAJA, L. (2003). "The role of culture in foreign language teaching materials: an evaluation from an intercultural perspective». In Lázár, J. (ed.) Incorporating intercultural communicative competence in language teacher education. Strasbourg: Council of Europe.

SWAIN, M. (2011). "The inseparability of cognition and emotion in second language learning». Language Teaching, 46(02), 195-207. doi:10.1017/S0261444811000486

XUE, J. (2014). "Cultivating intercultural communication competence through culture teaching». Theory and Practice in Language Studies, 4 (7), p. 1492-1498.

Young, T. J. AND I. SACHDEV (2011). «Intercultural communicative competence: exploring English language teachers' beliefs and practices». Language Awareness, 20 (2), p. 81-98. 
Appendix. Questionnaire for films

1. Provide a brief summary of the film. (Two or three sentences are fine; you don't need to include a lot of details.

2. State your opinion about the film. What are its strengths and weaknesses? Provide specific examples (scenes, situations) from the film.

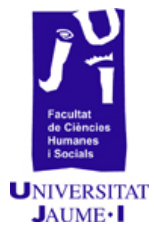

3. What character(s) do you most identify with? What are the main personality traits of this (these) character/s?

4. In your opinion, what was the director's intention or message?

5. How does the film relate to American/ British/ ... culture?Specifically, how does it relate to the era in which it was made?

6. From your point of view, was watching the film useful in order to know more about American/ British/ ... culture? Why? 
JClic as a Pedagogical Tool to Increase Students' Mastery of 'Present Perfect Simple' in English 
As several studies suggest (Celce-Murcia \& Larsen-Freeman 1999; Larsen-Freeman, Kuehn \& Haccius 2002; Riddell 2014) the present perfect simple continues to be a challenge for many English language learners. In particular, high school students often find it difficult to discriminate between the simple past and the present perfect simple in English. Then, in order to help students improve their mastery of the present perfect simple we have designed and developed fifteen computer-based activities with the JClic software as an innovative approach to address the research problem. Furthermore, we consider that the present investigation may be helpful for teachers to update their teaching techniques and materials to better support students' academic success and to gain more insight into the types and causes of students' errors in using these two troublesome tenses. Accordingly, this small-scale quasi-experimental study sought to answer two research questions. Concerning the first research question, the results have shown that students' initial knowledge level in the use of present perfect simple was very low. About the second research question, the data analysis showed evidence that the educational software JClic has proved to be an effective tool for teaching and training the correct use of the present perfect simple. In addition, the paired two samples Student's t-test was used when comparing pre-test ( $2^{\text {nd }}$ end-of-term exam) and post-test ( $3^{\text {rd }}$ end-of-term exam) scores to test the first hypothesis and the results indicated statistical significant difference in the population scores. Then, we can assert that the use of JClic in the English classroom was a good strategy to enhance the language learning process.

Key words: present perfect simple, simple past, JClic, computerbased activities, errors.

\section{Introduction}

By the end of high school English language learners (ELLs) are expected to achieve mastery of the verb tense-aspect system in order to control grammatical accuracy and communicate fluently in English. Nevertheless, sometimes that goal may be hard to reach because many students "struggle to learn verb-tense aspect in English" (LarsenFreeman, Kuehn \& Haccius 2002:3). Similarly, other researchers have noted that the English verb tense-aspect system is a problematic grammatical area for language learners (Curell \& Gotor 1990; CelceMurcia \& Larsen-Freeman 1999; Riddell 2014). One of the most controversial issues of the tense-aspect theory and of language teaching and learning is the use of present perfect simple. In particular, the concept of uindefinite time» to describe an action that happened at an unspecified time in the past can often be puzzling to English language learners. On top of that, the fact that there is a certain similarity between 
present perfect simple and simple past, as both tenses can be used to talk about past events, can make the choice of these two tenses even more difficult for the learners of English. Incorrect use of verb tenses can generate confusion, misunderstanding, disagreement and many times can hinder the interpretation of meaning. In addition, wrong tense errors reveal students' poor grammar knowledge of the target language. Therefore, in order to help students overcome this difficulty and make them understand that verb tenses interact and relate with one another, we followed Celce-Murcia \& Larsen-Freeman's (1999:109) suggestion to present and explain the present perfect simple in contrast to past simple. Some important benefits of mastering the use of these two tenses are that students can improve their grades in written assignments and endof-term tests and also be better prepared for University entrance exams. Another important aspect we have looked at in the first phase of our research project is the effect of the use of computer-assisted instruction (CAI) on students' achievement. Regarding this issue, Nutta (1998:50) as well as Beatty (2003:7) agree that the use of computers for instruction and learning can provide intellectual and academic benefits. Moreover, Ross, Morrison \& Lowther $(2010: 19,20)$ consider educational technology a «tutor» and a "teaching aid». Additionally, Girón-García (2013:157) acknowledges that «many teachers have discovered that media materials can be valuable in a variety of instructional tasks, helping to make complex subject matter accessible and engaging». Besides, Rabab'ah \& AbuSeileek (2009) show in their research that computer-assisted instruction brings better results regarding the learning of English tenses in comparison to direct instruction. Furthermore, Guerrero, Muñoz \& Sotelino (2007); Bangs (2012); Livingstone (2012) point out that the use of the JClic authoring software can effectively be used to support language teaching. What is more, Livingstone (2012:48) affirms that the immediate feedback provided by the JClic platform through the multimedia activities it makes available, promotes second language acquisition. Then, in order to provide an innovative solution to the complex problem of the use of present perfect simple we have created 15 computer-based activities with the JClic application. Even though the effects of computer-assisted instruction on students' achievement have been thoroughly investigated, no similar study was found in the literature to examine the effects of JClic on students' achievement in the use of present perfect simple through this new method. Therefore, in this paper we show that JClic as a pedagogical tool can have a positive impact on students' academic performance.

\section{Objectives}

The purpose of the present empirical investigation is to improve students' mastery of the present perfect simple in English since this is a problematic form for many English language learners (ELLs). 
To address this problem, the present study raises two basic questions for further study:

1. What is students' initial knowledge level of the English present perfect simple?

2. Does the use of JClic as a pedagogical tool increase students' performance in the correct use of present perfect simple in written production?

In addition, in order to identify whether or not the population means are different the research questions are translated into the following hypothesis:

- As a result of using JClic activities there will either be no significant difference in students' performance $\left(3^{\text {rd }}\right.$ end-ofterm exam scores) in the use of present perfect simple or there will be a significant change.

\section{JClic as a pedagogical tool}

Bangs (2012 web article) defines JClic as «a freeware application, formerly known simply as CLIC, developed by Francesc Busquets, for the development of multimedia activities for language learners." Additionally, Bangs states that «with JClic you can create different types of activities: puzzles, associations, crosswords, identification activities, exploration activities, open-ended answers, multiple choice, etc.»

According to Guerrero, Muñoz and Sotelino (2007:172) JClic is a program created in Spain, which is free for "educational purposes» and which can run under the three most common operating systems: Microsoft Windows, Apple Mac OS X and Linux. Moreover, the JClic program has the following advantages:

- It can be used both online and offline.

- It incorporates all the multimedia elements (images, animation, audio, video).

- All media files can be turned into «zip» files.

- The number of attempts per question and the time limit can be previously set.

- The info boxes provide information about the time spent, number of tries, etc.

- It provides performance reports for teachers to better monitor student progress.

- It can promote participation and maintain student engagement and motivation through 16 types of instructional activities. These types of activities are: simple association, complex association, double puzzle, explore activity, memory game, identify cells, information screen, exchange puzzle, hole puzzle, complete text, fill-in-the-blanks (text), identify elements (text), order elements (text), written answer, crosswords and word search. (Guerrero et al. 2007:173-174) 
What is more, JClic is free software released by the Ministry of Education of the Government of Catalonia under the terms of the GNU General Public License (Generalitat de Catalunya WebPage) and it is now implemented in many Spanish public schools. Then, the instructional activities can be created under the Creative Commons licence, which means that «the project can be modified or changed by another person providing that the authorship of the same one is respected» (Guerrero et al. 2007:176). Another point worth mentioning is that JClic includes three main sections: (1) JClic player which "allows the activities to be played from the local disk (or from the local network) without the necessity of being connected to the internet»; (2) JClic Author which "allows the creation, edition and publication of activities in a simpler, more visual and intuitive way", and (3) JClic Report "collects data and generates reports on the results of the activities done by the students." (Guerrero et al. 2007:173-174)

Therefore, JClic as a pedagogical tool can be successfully used to support the teaching and training of complex grammatical concepts. Furthermore, due to the range of features available, JClic can help teachers identify individual strengths and learning needs, on the one hand, and provide students a positive learning experience, on the other.

\section{Method and materials}

The present research project was developed in the year 2014, in a local high school classroom as part of the teacher training master's degree programme. In this study, classroom action research is undertaken as a methodology to find the answer to specific grammatical problems identified during the teacher-training program. According to Van Lier (2004:195) "action research is often problem oriented, and it introduces a change, the implementation of which is then monitored, studied and reported." Nonetheless, a better way to define action research is through the words of O'Leary (2004:140) who describes it as a:

Cyclical process that takes shape as knowledge emerges. Cycles converge towards better situation understanding and improved action implementation; and are based in evaluative practice that alters between action and critical reflection. Action research can therefore be seen as an experiential learning approach to change.

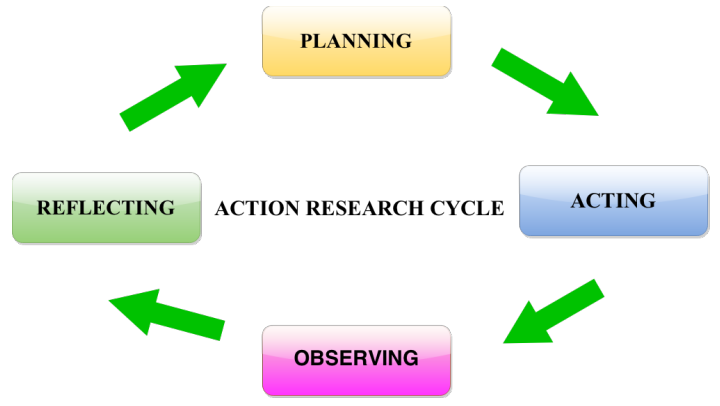

Figure 1. Action Research Cycle 
Then, in order to improve students' mastery of the present perfect simple we have developed a plan of action with the following steps:

1. Initial Reflection (field notes taken during classroom observation):

- Problem identification - The students seemed to have great difficulty with the use of present perfect simple in contrast to simple past tense.

- Brief Report on the existing situation - (1) The students received their graded $2^{\text {nd }}$ end-of-term English exam and they were very disappointed with their results. (The results helped us determine students' initial performance level on the use of present perfect and past simple). (2) English grammar was taught through the traditional method (textbook approach) and assessed through a paper and pencil method.

- Finding Relevant Literature - In this step we conducted a literature review to identify existing research and gather significant information on the chosen topic.

2. Planning: This step consisted of developing the research questions and the hypothesis, and establishing the project objectives that describe the outcomes to be accomplished, on the one hand. On the other hand, it involved collecting, organizing and interpreting data in order to imagine a way to help students improve their use of the present perfect simple and past simple tenses in written production. In addition, we developed an action plan in which we described the method and the steps needed to design and implement the JClic program.

3. Acting: In this stage, we designed the JClic activities and then we implemented them in the English classroom.

4. Observing (field notes): During the intervention we observed how the program worked and monitored students' progress. This was done by means of classroom observation and field notes.

5. Reflecting: In this step, we reflected on the effects of the use of the JClic activities as a basis for further planning. We also examined if the initial diagnosis was correct and if the action was taken in an appropriate manner.

Participation in the study was completely voluntary and confidential. In other words, the research participants had the opportunity to agree or refuse to participate. In addition, students who agreed to participate were assigned individual identification numbers to maintain their confidentiality. The participants of this study were 17 students in the $1^{\text {st }}$ Year of Bachillerato, with age range from 16 to 17 years old. The students were enrolled in the Science and Technology Studies and their English level, according to the Common European Framework of Reference for Languages, was between $\mathrm{A} 2$ and $\mathrm{B} 1$. The participants were chosen on the basis of their poor $2^{\text {nd }}$ end-of-term exam results. 
Then, in order to answer the research questions and verify the hypothesis, a classroom-based quasi-experimental pre-test/post-test design was used, in which only one group of participants was observed. In addition, for data collection and analysis a mixed-methods approach was used. That is to say, both qualitative and quantitative data were collected and further analysed in order to answer the research questions and test the hypothesis. The qualitative data were obtained from the classroom observation (field notes) and the quantitative data were obtained from the pre-test, the intervention and the post-test. Subsequently, both types of data were compared and analyzed to measure the accomplishment of the objectives after the implementation of the program. The research instruments used to gather the data were:

Classroom observation (field notes) - First, it was used to establish the research objectives, the research questions, the method and the design of this study. Second, it was used to record specific behaviour, events and interactions before, during and after the program implementation.

$2^{\text {nd }}$ end-of-term exam - This exam was analysed as pre-test. It was used to collect the preliminary data about students' ability in using past simple and present perfect simple. The scores were compared with the ones students obtained in the $3^{\text {rd }}$ end-of-term exam (post-test). Then, it also served as a baseline to measure students' progress.

JClic program - This program was the experimental treatment and the results were compared with the $2^{\text {nd }}$ and $3^{\text {rd }}$ end-of-term exam results to find out its impact on students' achievement.

$3^{\text {rd }}$ end-of-term exam - This exam was analysed as post-test. The scores were compared with the ones students obtained in the $2^{\text {nd }}$ end-ofterm exam. This exam was performed after the intervention (JClic program implementation).

In addition, when elaborating the teaching-learning procedure for the present study, we have used the materials that seemed most appropriate to help us reach our goals:

- Visual images (printed material)

- Classroom blackboard

- Notebooks and pencils

- Computers with internet access

- Computer software JClic

These materials were used to facilitate the knowledge transfer, to provide useful feedback and to assess the outcomes of instruction. Besides, another reason for choosing these materials was to help students transfer the information provided during this training program from short-term memory to long-term memory. That is to say, these materials were used in order to encourage the transfer from mere thoughts to consciousness. Therefore, the materials used in our study 
allowed students obtain a more comprehensible knowledge of the instructional content.

\section{Procedure}

The main objective of this investigation was to improve students' mastery in the use of present perfect simple. Then, to achieve our objective, during the Teacher Training Program, we embarked on a smallscale research project. With the help of the software JClic Author we developed 15 training activities and implemented them in an experimental classroom. The study consisted of three 55-minute sessions developed over a study period of one-week in a computer laboratory where each student was assigned a computer to work on the learning activities. The sessions were organised as follows:

\section{Session 1}

This session started with a warm-up to catch students' attention and to engage them in the steps that followed. First, students were handed out two printed images (visual aids to support the explicit explanation): "The Timeline Chart» and the "Present Perfect vs. Past Simple» and then example sentences using the two tenses were elicited from the students. In addition, for a better understanding of the differences in usage between present perfect simple and past simple, students were explained their formation and functions. Further, in order to determine whether the students understood what was taught, the information was drawn on a timeline on to the blackboard and some example sentences were elicited from the students. What is more, to reinforce and summarize the information being taught, some extra information and examples of the present perfect simple and past simple tenses were displayed on the computer screen. After that, students started to perform the computer activities designed in order to help them master the use of the two tenses. During this session students performed on the computer the following JClic activities:

- Activity 1. Choose the right answer (present perfect simple or past simple).

- Activity 2. Finish the sentences (match with the proper time adverb).

- Activity 3. Type the correct form of the verbs (present perfect simple or past simple).

- Activity 4. Choose the right tense for the following time references (present perfect simple or past simple).

\section{Session 2}

This practice session started with a warm-up to elicit students' answers and get them involved in the lesson. First, students were handed out a printed image ("For and Since» - visual aid) with explanations of the use of present perfect with "for» and «since». Then, some example 
sentences were elicited from the students. During this session students performed on the computer the following JClic activities:

- Activity 5. Add «For» or «Since» (present perfect simple).

- Activity 6. Choose a suitable time expression (present perfect simple and past simple).

- Activity 7. Find the mistakes and rewrite the sentences correctly (present perfect simple and past simple).

- Activity 8. Read the story and identify the past simple and present perfect simple.

- Activity 9. Word search puzzle (Find 8 verbs in past simple).

- Activity 10. Put the conversation in the correct order (past simple).

\section{Session 3}

In this session students performed and finished the following JClic activities:

- Activity 11. Match the questions to the pictures (questions in present perfect simple).

Activity 12. Put the words in the correct order to make a sentence (present perfect simple).

- Activity 13. Turn the sentences into negative and use the contracted form of the verbs (present perfect simple and past simple).

- Activity 14. Match the subjects to the verbs (present perfect simple "have/has»).

- Activity 15. Write the past simple form of the verb you listen (verbs listening).

In order to cater for the diversity of learning styles and enhance the learning experience for all the students we made a diversified use of the learning materials, such as: visuals (pictorial illustration), blackboard drawings, graphic representations, texts and audio. On the other hand, as research has shown, computer-based fun and enjoyable activities can stimulate students' interest, decrease their anxiety and improve their self-confidence.

In addition, extra information, time and assistance were provided to slow learners. What is more, by creating fun and engaging activities with game elements such as: word search puzzle, match questions with pictures, make a sentence from scrambled words and scrambled sentences (put the conversation in the correct order) we expected equal participation from both slow and fast learners. In other words, these types of activities were student-focused and required an active engagement of all students. 
The findings of the present study were divided into four main sections: (1) data from the $2^{\text {nd }}$ end-of-term exam; (2) data from the $3^{\text {rd }}$ end-of-term exam; (3) data from the JClic program implementation and (4) data from the field notes.

\section{1) DATA FROM THE $2^{\text {nd }}$ END-OF-TERM EXAM}

Research question 1: What is students' initial knowledge level of the English present perfect simple?

In order to answer the first research question and find out students' initial knowledge level of the English present perfect simple and establish future requirements, we examined their $2^{\text {nd }}$ end-of term exam (as pretest). The $2^{\text {nd }}$ end-of-term exam was a final examination which included reading, vocabulary, grammar review, listening and writing. The grammar review section consisted of mixed tenses exercises. However, we gave qualifications only to those exercises that were relevant to our study. That is to say, we assigned grades only to the exercises in which students had to use the present perfect simple.

The exercises provided in $2^{\text {nd }}$ end-of-term exam tested students' knowledge of the present perfect simple (affirmative and negative forms) and their comprehension of the present perfect time markers: since, for, and never. The results show that students experienced difficulties with the correct use of present perfect simple. What is more, students appeared to be confused with tense and aspect. In fact, most of the errors corresponded to wrong choice of tense. In other words, students used past simple instead of present perfect. This type of error could be described as faulty analogy because students seemed to extrapolate the use of past simple. On top of that, sometimes students used the two tenses the other way around: present perfect instead of past simple, which means that they overused the present perfect. However, there were situations where students used present simple or present continuous instead of present perfect tense. Moreover, another common error was the incorrect use of past participle form of irregular verbs, which means that students were applying the rules inaccurately.

Therefore, the errors that students committed were mainly of four types: misformation (wrong forms of verbs are selected as an alternative to the correct ones), addition (not required elements are added), omission (important elements are omitted) and ordering (correct elements are placed in the wrong order).

In addition, the following grading system was used for all the answers:

\begin{tabular}{|l|l|l|l|}
\hline $\begin{array}{l}\text { GRADING } \\
\text { SYSTEM }\end{array}$ & $\begin{array}{l}0=\text { WRONG } \\
\text { ANSWER }\end{array}$ & $5=$ HALF ANSWER IS CORRECT & $\begin{array}{l}10=\text { CORRECT } \\
\text { ANSWER }\end{array}$ \\
\hline
\end{tabular}

Table 1. Grading System 
The average of the $2^{\text {nd }}$ end-of-term exam scores was 1,76 which means low performance in the correct use of present perfect simple in written production. Therefore, students' exam results and classroom observation data motivated us to undertake action research.

\section{2) DATA FROM THE $3^{\text {rd }}$ END-OF-TERM EXAM}

The $3^{\text {rd }}$ end-of-term-exam was an exam given to students at the end of the $3^{\text {rd }}$ academic term and included reading, vocabulary, grammar review, listening and writing. The grammar review section consisted of mixed tenses, relative pronouns and modal verbs. However, we assigned scores only to the exercises in which students had to use present perfect simple. In other words, we obtained the exam scores by dividing the exam into several parts. In addition, a score was given to each sentence according to a previously established grading system. The grading system used was the one shown in Table 1.

The average of the $3^{\text {rd }}$ end-of-term exam scores was 4,71 which means high performance level in the correct use of present perfect simple. In addition, in order to illustrate the difference in average performance as part of a whole, we used the following bar chart:

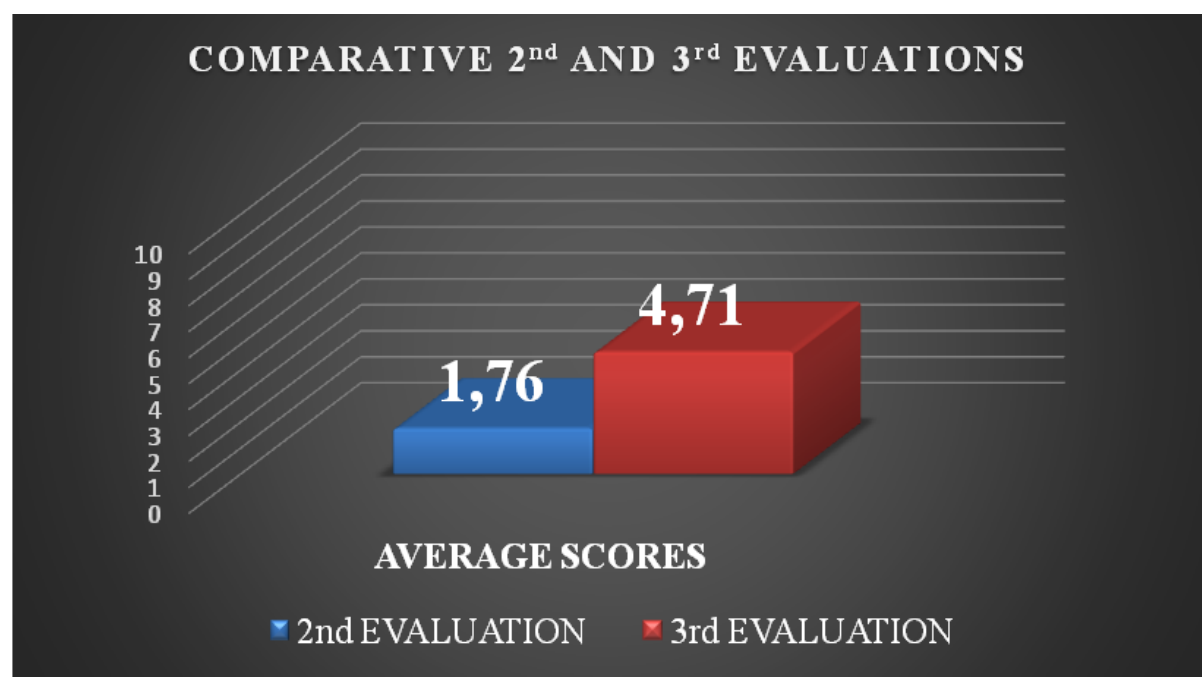

Graph 1. Average Performance $2^{\text {nd }}$ and $3^{\text {rd }}$ End-of-Term Exams

As shown in Graph 1, the achievement of the objectives has been satisfactory as the average of the pre-test $\left(2^{\text {nd }}\right.$ end-of term exam $\left.=1,76\right)$ is lower than the average of the post-test $\left(3^{\text {rd }}\right.$ end-of-term exam $=4,71$ ): $1,76<4,71$. However, in order to increase the reliability in the assessment of students' achievement and progress we correlated the $3^{\text {rd }}$ end-of-term exam results with the results obtained during the program implementation (JClic results). 


\section{3) DATA FROM THE JCLIC PROGRAM IMPLEMENTATION}

Research question 2: Does the use of JClic as a pedagogical tool increase students' performance in the correct use of present perfect simple in written production?

In addition, as the JClic project was the treatment, we only evaluated students' overall performance. Moreover, the results were correlated with the ones that students obtained in the $3^{\text {rd }}$ end-of-term exam. Then, the JClic activities were graded based on student responses. Within each question students were allowed a certain number of attempts. So, once the student exceeded the maximum number of attempts the mark decreased.

Then, to obtain the score, the rule of three (inverse proportion) was used. That is to say, the number of correct answers was multiplied by 10 (maximum score) and divided by the total number of attempts per question:

E.g.: $(19 * 10) / 19=10$

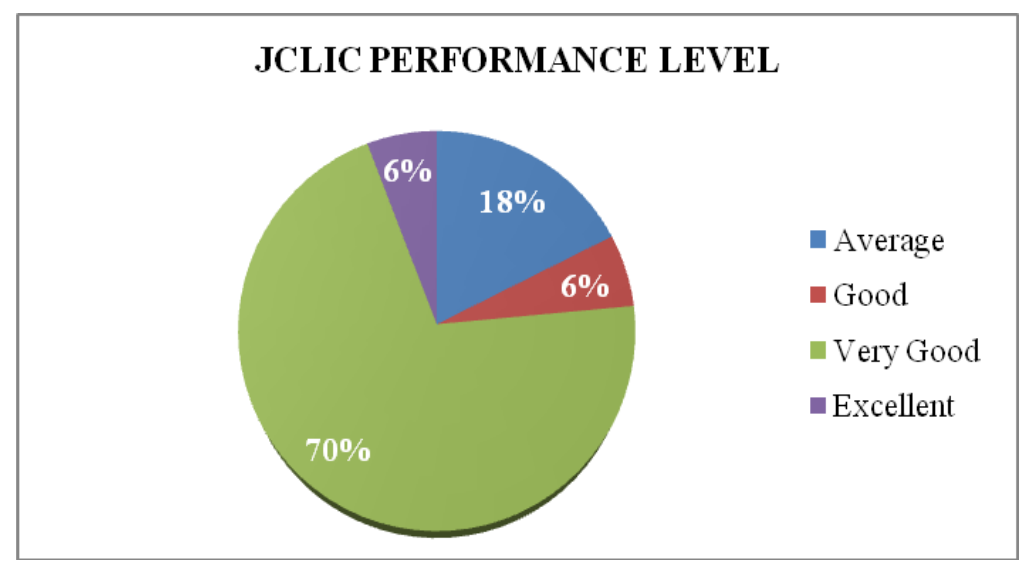

Graph 2. JClic Overall Performance Level

As can be seen in Graph 2 the overall performance level in the JClic activities was very good with $70 \%$ of the students obtaining a mark between 7,50 and 8,49. Furthermore, there were no students with poor level of performance in the JClic activities. Therefore, most of the students demonstrated very good performance level which means that the JClic project improved students' learning and mastery of present perfect simple and past simple and provided students a positive learning experience.

\section{Initial Hypothesis:}

1. As a result of using JClic activities there will either be no significant difference in students' performance ( ${ }^{\text {rd }}$ end-of-term exam scores) in the use of present perfect simple or there will be a significant change.

To test the first hypothesis we compared the $2^{\text {nd }}$ end-of-term exam results (pre-test scores) with the $3^{\text {rd }}$ end-of-term exam results (post-test scores). In addition, to determine the significance of the difference in the 
arithmetic means and know whether or not the JClic program was effective we used the paired two samples for means Student's t-test in Excel 2013. Namely, this tool helped us compare the before and after treatment scores from the same group at different times $\left(2^{\text {nd }}\right.$ and $3^{\text {rd }}$ academic terms) and test the first null hypothesis. Then, the null hypothesis ( $\mathrm{HO})$ is that there will be no difference in students' performance in the use of present perfect simple. The alternate hypothesis, claims that the average difference of exam scores will be greater than 0. Taking into account the results obtained with Student's ttest, we can state that our sample provides enough evidence to reject the null hypothesis and conclude with $95 \%$ confidence that there is statistical significant difference in the population means and that the results are not due to randomness.

\section{4) DATA FROM THE FIELD NOTES}

In the present study, throughout the participant observation period we took extensive field notes to record what was observed in the natural setting. Then, the data that was relevant for our objectives and research problem were categorized into patterns that later on supported us in performing a better analysis of the program implementation process. In other words, observational data was used to better contextualize, describe and increase the understanding of the phenomena under study.

According to our field notes students experienced difficulties with the correct use of the present perfect simple. Another pattern is associated to the use of technology. During the program implementation, we noticed the effect that the use of computer-based activities had in the learning process. Moreover, according to our observations students were anxious and motivated to complete every activity because it implied the use of the computer. Therefore, implementing technology in the teaching practice favoured and promoted students' learning, on the one hand, and increased their self-confidence and motivation, on the other.

\section{Conclusions}

The purpose of this research was to increase students' mastery of the present perfect simple with the help of the JClic computer-based activities. Then, the study's point of departure was based on students' poor performance of the tense usage, in particular of present perfect simple and past simple, demonstrated by the $2^{\text {nd }}$ end-of-term exam results and by classroom observation.

In addition, the findings strongly support the proposal that JClic as a pedagogical tool has the potential to develop students' grammatical competence and consequently improve their knowledge of verb tenses such as the present perfect simple and past simple. Accordingly, JClic can be a valuable device for integrating technology into any lesson and develop student knowledge. Therefore, JClic can become a very useful 
complement to traditional classroom-based teaching and learning. What is more, the findings clearly support our initial hypothesis. Then, we can draw some practical conclusions regarding the research questions and the hypothesis. Concerning the first research question, the results have shown that students' initial knowledge level in the use of present perfect simple was very low. In the light of this evidence, we decided to find an innovative solution to this practical problem. As regards the second research question, the data analysis showed evidence that the educational software JClic proved to be an effective tool for teaching and training the correct use of the present perfect simple.

The overall performance level in the JClic activities was very good which means that most of the students improved their knowledge of the present perfect simple. In addition, the paired two samples Student's ttest demonstrated statistical significant difference in the population scores, which means that the objectives of the study were accomplished and the results were not due to randomness. Then, the use of JClic in the classroom was a good strategy to enhance the language learning process and to reach the research objectives. However, regardless this proven effectiveness, the difficulty to use correctly the present perfect simple continues to be a challenge for many English learners. Then, more research needs to be done using a longitudinal case study and larger samples to better justify the causality between the variables and find out the long-term effect of the JClic program on the improvement of the knowledge of present perfect simple and past simple tenses. What is more, we may think that due to its novelty and ludic interface JClic could be a suitable computer-based tool to increase student motivation, engagement and confidence in the ability to learn and understand complex English grammatical concepts. Therefore, additional research could focus on examining the effect of JClic as a technological and pedagogical tool on student engagement, motivation and self-efficacy.

\section{References}

Bangs, P. (2012). Introduction to CALL authoring programs. Module 2.5 in Davies G. Information and Communications Technology for Language Teachers (ICT4LT), Slough, Thames Valley University. (Online) Retrieved 26 September 2014 from http://www.ict4lt.org/en/en_mod2-5.htm

BEATTY, K. (2003). Teaching and researching computer-assisted language learning. Pearson Education Limited. Hong Kong Printed.

Celce-Murcia, M. \& D. Larsen-Freeman (1999). The Grammar Book: An ESL/EFL teacher's course, $\left(2^{\text {nd }}\right.$ edition). New York: Heinle \& Heinle Publishers.

Curell \& Gotor, H. (1990). The Present Perfect in English and in Catalan: Uses and Meanings. PhD dissertation, Autonomous University of Barcelona. Retrieved 
http://www.tdx.cat/bitstream/handle/10803/4917/THCG2de2.pdf?sequenc $\mathrm{e}=2$

GIRÓN GarCíA, C. (2013). Learning Styles and Reading Modes in the Development of Language Learning Autonomy through "Cybertasks». (Thesis).

[http://hdl.handle.net/10803/125440 2013].

Guerrero, E., A. Muñoz \& C. Sotelino (2007). JClic: A New Software to Teach and Learn Easily. Implementation of Multimedia Activities in Our Classroom. ICT in Education: Reflections and Perspectives. Bucharest: FISTE, 172-176, $\begin{array}{lllll}\text { Retrieved } & 26 & \text { September } & 2014 & \text { from }\end{array}$ http://bscw.ssai.valahia.ro/pub/nj_bscw.cgi/d257171/Paper22_E_Guerrero_ 172_176.pdf

KeLler, J. M. (1983). Motivational design of instruction. In C. M. Reigeluth (Ed.). Instructional design theories and models: an overview of their current status (p. 383-434). Hillsdale, NJ: Lawrence Erlbaum Associates. Retrieved 25 September 2014 from https://depts.washington.edu/dlis/onlinecoursehandbook/Keller1983.pdf

- (1987). IMMS: Instructional materials motivation survey. Florida State University.

- (2010). Motivational design for learning and performance: The ARCS model approach. New York, NY: Springer.

Larsen-Freeman, D., T. Kuehn, \& M. Haccius (2002). Helping Students Make Appropriate English Verb Tense-Aspect Choices. TESOL Journal, vol. 11, núm. 4, p. 3-9. Retrieved 20 October 2014 from http://teach-grammar.com/wpcontent/uploads/2012/07/Helping-students-make-appropriate-verbtenseaspect-choices.pdf

LIVINGSTONE, K. A. (2012). The importance of feedback and reinforcement in Computer Assisted Language Learning. Baraton Interdisciplinary Research Journal (BIRJ), vol. 2, núm. 1, p.43-51. Retrieved 15 September 2014 from http://works.bepress.com/kerwin_livingstone/23/

NUTTA, J. (1998). Is computer-based grammar instruction as effective as teacher-directed grammar instruction for teaching L2 structures? CALICO Journal, vol. 16, núm. 1. Retrieved 15 September 2014 from https://calico.org/html/article_640.pdf

O'LeARY, Z. (2004). The Essential Guide to Doing Research. London: Sage.

Rabab'ah, G. A. \& A. F. Abuseileek, A. F. (2009). The Effect of Computer-Based Grammar Instruction on the Acquisition of Verb Tenses in an EFL Context. The International Arab Journal of Information Technology, vol. 6, núm. 4, October.

RIDDELL, D. (2014). Teach EFL; The Complete Guide (3rd edition), Teach Yourself Books, London. 
Ross, S. M., G. R. Morrison \& D. L. Lowther (2010). Educational Technology Research Past and Present: Balancing Rigor and Relevance to Impact School Learning. Contemporary Educational Technology, vol. 1, núm. 1, p. 17-35.

StelEA, S. (2015). JClic as a Pedagogical Tool to Increase Students' Mastery of 'Present Perfect Simple' in English, (Master's Thesis). Universitat Jaume I.

VAN LIER, L. (2004). The Ecology and Semiotics of Language Learning: A Socio-- UNIVERSTTAT Cultural Perspective. Kluwer Academic Press, Boston.

\section{Website:}

ZonaClic, Generalitat de Catalunya (Departament d'Ensenyament). Retrieved 26 September 2014 from http://clic.xtec.cat/en/jclic/info.htm 


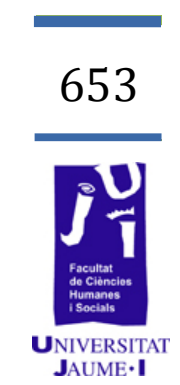

\section{Más allá del lenguaje: los aerolitos de Carlos Edmundo de Ory \\ J. Rafael Mesado Gimeno rafamesado@hotmail.com}


Los aerolitos son segmentos lingüísticos breves e intensos, a modo, de sentencias y aforismos, que presentan, desde un significante inconexo y desde un significado paradójico, un instante de lucidez. José Ramón Ripoll (2011: 205) señala la impronta radiante, luminosa y vívida de los aerolitos:

Ory llamaba aerolitos a esos fugaces instantes de conciencia representados por frases inconexas que, desde el espacio caótico del pensamiento, caen sobre el papel tras un viaje milenario. Son formas perdidas del sueño, experiencias acumuladas de lecturas, luces de la observancia que van configurando en su esparcimiento el extraordinario apriorístico de su poesía.

Los aerolitos oryanos se hallan contenidos en varias obras y, también de modo disperso, en otras publicaciones como revistas y antologías. Los primeros aerolitos se publicaron en francés en el año 1962 con el título de Aèrolithes y acompañados de un prólogo de Michel Béalu. También en francés y en versión del propio autor apareció en 1966 otra publicación de los aerolitos en la revista Réalités Secrètes, titulada también Aèrolithes. Las dos publicaciones francesas se editaron en castellano en la revista Cuadernos Hispanoamericanos, la primera en $1965^{1}$ y la segunda en $1969 .^{2}$ En 1985 , tal y como queda indicado en la bibliografía, los aerolitos se publicaron en castellano en forma de libro en la editorial El Observatorio con el título de Aerolitos. Algunos de estos ya habían aparecido en 1970 en la antología oryana realizada por Féliz Grande, Poesía 1949-1969 y en 1978, recogidos por Rafael de Cózar, en la antología Metanoia, ampliada en 1991. Posteriormente han aparecido dos ediciones más en la editorial Calambur, una en 2005 y otra en 2011, prologada por Félix Grande. En 1995 Ory publicó un nuevo grupo de aerolitos bajo el título de Nuevos Aerolitos y en 2009 otra entrega más: Novísimos Aerolitos. En la antología realizada por Jaume Pont y editada en 2003, Música de lobo. Antología poética (1941-2001) aparece una breve selección de los aerolitos y en la antología-homenaje a Ory realizada en 2006, El desenterrador de vivos, se publican varios aerolitos inéditos. Por otra parte, fragmentos de lo que son los aerolitos han aparecido en otras publicaciones. ${ }^{3}$

Pont (1998: 308-309) encuentra los antecedentes de los aerolitos en la literatura postista, lúdica y experimental: las pulgas, los emblemas y los ejercicios de enderezamiento aparecidos en las dos revistas que editó el Postismo en 1945, Postismo y La Cerbatana. Las pulgas y los emblemas, al tratarse de frases breves y lacónicas, son relevantes por su brevedad y su

1. Núm. 181, enero, Madrid, 1965.

2. Núm. 230, febrero, Madrid,1969.

3. Alcance, núm. 9, León, 1981; Barcarola, núm. 15, Albacete, 1984; Hora de poesía, núm. 50-51, Barcelona, 1987; Diario de Cádiz, abril, 1993; Cuadernos Hispanoamericanos, núm. 545, Madrid, 1995; El ciervo, núm. 544-545, Barcelona, 1996; La carátula, separata, Elche, 1998; Caleta, núm. 2, Cádiz, 1998; RevistAtlántica de Poesía, núm. 27, Separata dedicada a Ory, Cádiz, 2004. 
impetuosidad. El enderezamiento, técnica intertextual mediante la que aplicando mínimas variaciones se puede modificar el texto de manera infinita, importan por la tarea paródica de subvertir el texto. Pont (1988: 10-11) señala también como un antecedente del aerolito las proposiciones establecidas por Ory en el Atelier de Poésie Ouverte, ${ }^{4}$ aunque estas sesiones, fechadas entre 1967 y 1968, son posteriores a las primeras ediciones de los aerolitos.

\section{Hacia una definición de aerolito}

El propio Carlos Edmundo de Ory ofrece en las ediciones de sus aerolitos (1995: 13; 2005: 7) algunas pistas y referencias acerca del discurso minimal de los aerolitos.

Novalis los llama: polen; Rozanov: hojas caídas; Baudelaire, cohetes; Nietzsche: sentencias y dardos; Antonio Porchía: voces; Louis Scutenaire: inscripciones; Cioran: pensamientos estrangulados; André Siniavski: pensamientos repentinos; Malcom de Chazal: sentido-plástico; yo: aerolitos.

En su diario (2004) Ory teoriza sobre la especificidad del discurso de los aerolitos y plantea, desde su particular mirada poética, algunas definiciones:

Sigo haciendo aerolitos de cuando en cuando, cuando me viene la chispa. Son perlas del cráneo llenas de corazón. A veces no tengo tiempo de trasladar a mi Diario los trozos sueltos de texto que escribo con una finalidad temática, y luego no utilizo dejándolos desunidos. Mejor reunirlos en archipiélago, como islitas en el mar de la escritura (2004, Vol. III: 185).

Resulta muy interesante la definición que ofrece su autor: «son perlas del cráneo llenas de corazón». Discurso psicosomático, integrador de la totalidad del ser humano, sin escisiones entre cuerpo y mente, que conecta el discurso cerebral, cuyo signo es el concepto, con la visceralidad propia del discurso de la emoción. El aerolito oryano, cuyo referente más alejado se encuentra en la literatura gnómica medieval, se distingue de la máxima y del aforismo en el rechazo del concepto como único punto de interés. No es un puro artefacto conceptual, simple labor de orfebrería inteligible; el aerolito surge de la emoción, del sentimiento y de la experiencia interior. Es un breve paisaje de la interioridad lanzado como un rayo, que ilumina en la noche, hacia el exterior. El aerolito rehúye el discurso intelectual y se sitúa como discurso periférico. Discurso poético, visceral, emocional, onírico, absurdo, paradójico, lúdico, metafísico. En el Diario de Ory encontramos diversas calves que pueden acercarnos a una definición del aerolito: 
Quintaesenciar, ser elíptico, discontinuo. Saltos, digresiones. Decir lo indecible: balbucir.

Economía verbal extrema. No verbalización. Gnómica, haikú. Mejor que nada: el silencio. La sentencia wittgenstiana: «De lo que no se puede hablar hay que callar» (2004, Vol. III: 273).

El discurso salta, liberado de la tiranía de una semántica que lo atrapa, en el vacío, como los fuegos artificiales iluminan la noche. En este sentido, es un relámpago de luz, símbolo del satori en el budismo zen, que estalla en la mente lectora. Ory instala los aerolitos en la poética del silencio y los compara con la estética del haiku budista. Son fragmentos mínimos del lenguaje del silencio, para ello Ory cita las palabras de Wittgenstein que cierran el Tractatus logico-philosophicus (1921). Los aerolitos no son máximas, sino mínimas, pequeñas islas en el mar del discurso. Como las palabras, que son islotes que sobresalen en el océano del silencio, representado por la luz del blanco de la página.

Ory va ofreciendo las referencias precisas de sus aerolitos: Novalis, Nietzsche, Heidegger, Kafka, Breton, Friedrich Hebbel... Pero los aerolitos son herederos de la dislocación discursiva de la vanguardia, del dadaísmo, del surrealismo... Son herederos de las afiladas declaraciones de los manifiestos de Tistan Tzara o de André Breton. Por ello las greguerías de Ramón Gómez de la Serna resultan una referencia muy especial debido al juego lingüístico, al componente lúdico, al humorismo inteligente, a la ruptura semántica y a la incongruencia. La presencia de la greguería en la poesía oryana viene de lejos, se efectuó en los años del Postismo. ${ }^{5}$

De hecho algunos aerolitos oryanos presentan evidentes similitudes con las greguerías. La estética postista se plegaba perfectamente sobre la

\footnotetext{
5. Resulta paradójico, pero Gómez de la Serna cita a Ory como uno de los herederos de las greguerías. Así lo testimonia el siguiente fragmento del Diario de Ory: Ver el artículo «Releo el Diario de Friedrich Hebbel, en una edición italiana de 1912, que poseo desde abril de 1954 desde entonces uno de mis libros de cabecera, y un espejo de aforismos semejantes a mis Aerolitos.

Leí uno que dice: L'odore e la morte del fiore.

Es un «aerolito» o una "greguería». Y veo que lo cita Ramón Gómez de la Serna en su prólogo a la sexta edición de sus Greguerías / selección 1910-1960, publicado en colección Austral, en febrero de 1960. Traducida al español, así como otras perfectas "greguerías» del poeta y dramaturgo alemán, continúa citando autores de todos los tiempos (que greguerizan): «...y las de Hebbel: el perfume es la muerte de las flores, o Las pulgas son los únicos animales que no tienen pulgas, o El hombre únicamente está en éxtasis cuando reza y cuando de afeita.»

Y también cita -ino me lo esperaba!- «entre los buenos gregueristas de última hora», cosas de Jacinto Miquelarena y mías, que no sé de dónde las sacara por permanecer inéditas y hasta olvidadas por mí: "Son buenas las de Edmundo de Ory: "El silbido es el esqueleto de la palabra», "La luna es la cáscara del silencio del mundo», "El acordeón de la semana se rompe siempre los domingos».

Cita estos tres ejemplos de mi cosecha ramonesca, de los años del Postismo, cuando yo acudía a la tertulia del Café Pombo, en la calle Carretas, los sábados por la noche. Fui asiduo de la Sagrada Solana Cripta Pombo, pero sin Ramón» (y 2004, Vol. III: 315).

En la Historia del postismo, escrita por Ory y publicada en la antología que realizó Félix Grande en 1970, aparece también la misma referencia: «En cuanto a Ramón, él hubiera saludado el Postismo sin duda alguna. Lo hubiera saludado por encima o por debajo de su ramonismo. Ya en la selección que hizo de sus GREGUERÍAS (1010-1960), en la Colección Austral, pude ver que me saluda personalmente en la página 41 al pasar revista a sus coríferos: "Son buenas las de Edmundo de Ory: "El silbido es el esqueleto de la palabra", "La luna es la cáscara del silencio del mundo", "El acordeón de la semana se rompe siempre los domingos", y las del escritor argentino Gotardo Croce» (1970: 267-268).
} 
impronta ramoniana. La risa, el juego y la estridencia pueden observarse perfectamente en los siguientes aerolitos:

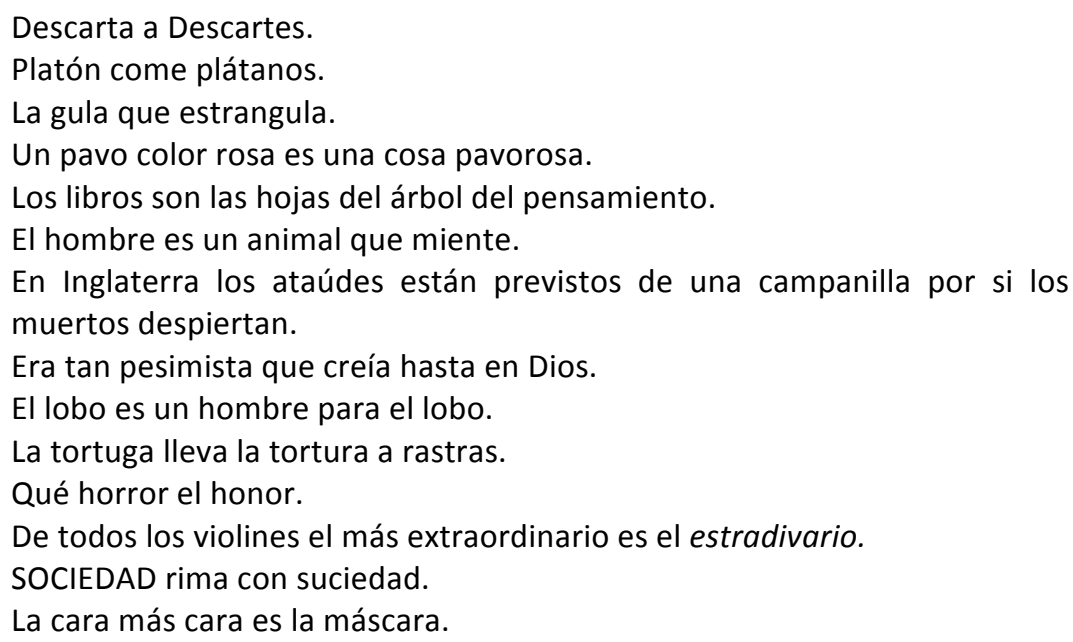

La experimentación lingüística es el signo de este lenguaje dislocado, en el que la proximidad fónica articula los signos, sacudiendo la coherencia y la referencialidad. De otro lado, el humor, que surge del enfrentamiento de los significados, es el eje central hacia el que gravita este lenguaje deshilvanado. Lenguaje que se basa en la significación periférica de las palabras y atiende a un significado profundamente emocional, basado en la plurisignificación, en las resonancias connotativas despegadas del significado central denotativo (calambur, retruécano, paranomasia, metáfora...). Juego y deformación del significado. Las siguientes greguerías de Gómez de Serna ${ }^{6}$ podrían perfectamente pertenecer a Ory:

\section{El minotauro de minutero.}

¿Cuál es la mujer más antigua? Antígona.

Descartes: es el que se descartó de muchas ideas para quedarse sólo con las buenas.

Mentor parece ser el que enseña a decir mentiras.

No sólo el juego, el humor y la experimentación son los ingredientes que definen el aerolito, este se configura como un instante de iluminación, como un rayo nocturno que alumbra los paisajes mentales más ocultos y despeja las sombras para que nuevos significados surjan de sus escondites. Los aerolitos oryanos tratan desde cuestiones puramente metapoéticas hasta las metafísicas, pasando por referencias sociales, culturales, religiosas... En ellos Ory desvela su pensamiento, muestra claramente sus referencias y ofrece su punto de vista particular hacia los autores citados, óptica que en algunos casos supone apropiaciones e identificaciones $\mathrm{y}$ en otros exclusiones $\mathrm{y}$ ataques. Los aforismos siguientes, que pertenecen al pensador escéptico y pesimista por

6. Ejemplos de greguerías tomados de la edición Total de greguerías, Aguilar, Madrid, 1955. 
excelencia, E. M. Cioran, poseen un regusto oryano. Ambos autores se acercan a la paradoja, al contraste y a la oposición:

Cada ser es un himno destruido.

Estamos todos en el fondo de un infierno, cada instante del cual es un milagro. ${ }^{7}$

La definición de los aerolitos, en todo caso, se encuentra en uno de ellos.

Ory nos la ofrece en esta frase, lapidaria como una pedrada:

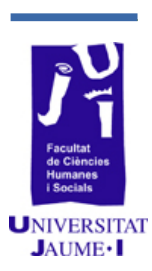

Poesía como operación visceral diamantina, como alquimia digestiva o etílica. Si la poesía es joya, lo es también el aerolito: una perla de sabiduría.

\section{Identificaciones y exclusiones}

En los aerolitos Ory va estructurando las coordenadas de su particular viaje cultural. Estos, junto a sus ensayos y su Diario, son el cuaderno de bitácora que ofrece la cartografía del extraño laberinto por el que Ory transita. Los aerolitos se configuran como tarea de meditación y de reflexión sobre un territorio temáticamente acotado que responde a las preocupaciones de su autor: metapoesía, metalenguaje, cultura, simbología, metafísica... En ellos Ory ofrece su mirada sobre el estado de las cosas y ofrece acercamientos al misterio inefable de la existencia.

Ory muestra sus cartas boca arriba y son ellas las que definen su ideario plegándose sobre las referencias ofrecidas. Los aerolitos funcionan como un mapa mental que estructura el territorio mediante una señalización emocional. Son, pues, una vía de acceso intuitiva a la realidad, un acercamiento poético a la existencia.

El aforismo, por sí mismo, posee siempre una carga poética que lo erige, por condensación, en una alquimia de la palabra. Comparado con el discurso narrativo e informativo, el aforismo, como el lenguaje poético, consiste en una palabra vehemente, de alto octanaje. En este sentido, José Antonio Marina (2003: 10) señala en el prólogo a la obra que recopila los aforismos dispersos de Max Aub, Aforismos en el laberinto, que los aforismos «suponen a veces un aerolito de poesía en el campo de la prosa». Ofrecemos aquí unos aforismos de Aub que tienen evidentes paralelismos con los aerolitos oryanos:

Dejar y no dejarse.

Ser molino y no molienda.

Primero fue el silencio.

Todo está por hacer: hagas lo que hagas, nunca se hizo. ${ }^{8}$

7. Aforismos pertenecientes a El aciago demiurgo (1969), tomados de la antología realizada y prologada por Fernando Savater: Adiós a la filosofía y otros textos, Alianza Editorial, Madrid, 1998, p. 161, p. 162.

8. Aub, Max (2003): Aforismos en el laberinto, ed. de Javier Quiñones, Barcelona, Edhasa. 
Escritura ideológica donde el lenguaje se abre ante el lector mostrando sus resquicios significativos ocultos. Los aerolitos de Ory van cargados de un potente significado oculto, en ocasiones corrosivo, que hace de esta escritura un texto ideológicamente pregnante, tal y como ocurre en los siguientes aerolitos:

El Hombre de Damasco (Pablo). El hombre vestido de damasco.

Existencia oficial del infierno (concilio de 547).

La lluvia, del cielo para abajo, no moja a Dios.

Los besos: pecados mortales (Padres de la Iglesia).

Los aerolitos de Ory suponen verdaderos ataques a los sistemas opresivos del ser humano, a sus creencias y a sus prácticas. Existen en ellos diatribas contra la explotación material y mental del hombre. Entre los símbolos culturales rechazados se encuentran: San Lucas, San Juan Evangelista, San Mateo, San Agustín, San Pablo, Aristóteles, Descartes, Pascal, Leibniz, Kant, Hegel, Tolstoi, Hitler, Franco, Lenin, Stalin... Así Ory acerca su discurso al pensamiento libertario y erige la heterodoxia como símbolo cultural:

De mis listas de gente interesante: idiotas, enanos, monstruos, payasos, apaches, vagabundos, gitanos, harapientos, amerindios, esquimales, beduinos, lapones, bobos, ufólogos, insumisos.

Mi patria es el aire que respiro.

Los dardos de Ory apuntan a la misma diana que las afiladas sentencias de Friedrich Nietzsche: al cristianismo cuyos valores fueron los supuestos en los que se edificó la decadence:

\footnotetext{
Se ha observado mal la vida, cuando no se observa la mano que, con todos los respetos, mata...

En tiempo de paz, el hombre belicoso se hace la guerra a sí mismo.

No amar más que a uno solo es una forma de barbarie, pues va en detrimento de todos los demás. Así el amor a Dios. ${ }^{9}$

Una decisión peligrosa. La decisión cristiana de encontrar un mundo feo y malo ha hecho un mundo feo y malo. ${ }^{10}$
}

Como Nietzsche, Ory no sólo ataca al cristianismo como método de subyugamiento, sino también a su sombra, el racionalismo y sus derivaciones políticas: los totalitarismos, tanto de signo capitalista como comunista:

CONCIENCIA comunista: Prohibido el inconsciente en la sociedad soviética. Maud Tabachik, escritora israelita, atormentada por el recuerdo del Holocausto: "Hitler fue seguramente un chiquillo encantador. Pol Pot, también».

9. Nietzsche, Friedrich (1886): Más allá del bien y del mal, traducción de Carlos Vergara, EDAF, Madrid, p. 93. 10. Nietzsche, Friedrich (1882): La gaya ciencia, traducción de José Mardomingo Sierra, EDAF, Madrid, p. 215. 
Otras referencias, contra las que se recorta de manera positiva la geografía cultural oryana son: Diógenes, Heráclito, Montaigne, Spinoza, Hölderlin, Goethe, Flaubert, Nietzsche, Heidegger, Kierkegaard, Thoreau, Baudelaire, Rimbaud, Poe, Kafka, Whitman, Valéry, Freud, Jung, Breton, Benjamin Péret, Eluard, Artaud, Wittgentein, Jorge Guillén, Juan Ramón Jiménez, Lorca, Maiakovsky, Céline, Cioran, Nabokob, Ernest Jünger, Bernanos, Bachelard, Koestler, Hebbel, Pavesse, César Vallejo, Konrad Lorenz, Thomas Merton, Krishnamurti, Ginsberg, Castaneda, Malcom Lowry, Lyotard, Lipovetsky... Ory sigue a través de la brecha abierta por Nietzsche y transita recorridos más allá de la dogmática establecida por el conocimiento científico y por el pensamiento sistemático. Se sitúa pues en las coordenadas de un pensamiento borroso que intenta aprehender un realidad líquida y flexible, continuamente dinámica, donde los límites que encierran los conceptos y entidades no quedan precisados con rigidez. El diario oryano nos lo aclara con más nitidez (2004, Vol. III: 286):

Más allá del dominio del conocimiento científico, existe el vasto campo de lo incognoscible y de la nesciencia, desde siempre explorado por la metafísica y por la religión de los misterios. Un más allá que los positivistas llaman «inmensidad» y Freud "sentimiento oceánico», que se apodera del espíritu y lo sumerge.

Los aerolitos muestran vislumbres y resplandores, a modo de instantáneas, de esa zona abierta que desemboca en la metafísica y en el misterio existencial. "Aforismos del espíritu libre» los denomina Ory en el diario (2004, Vol. III: 286) cuya función es desvelar territorios ocultos por la sombra de la razón (2004, Vol. III: 288):

Frases anormales, ondeantes y versátiles, cuanto más ilógicas más mágicas.

Contra el lenguaje tradicional y la palabra declamatoria, registro de ensueños y de reflejos infinitos, comunicando tonos privativos de la imaginación y del inconsciente.

Citamos aquí varios ejemplos:

La luna es una obra maestra.

El tiempo es la respiración del espacio.

Con mis manos llenas de curiosidad toco el insecto de lo desconocido.

Chocamos contra el muro del infinito.

Llueve luego existo.

Dios está en la sal y en el azúcar.

El cosmos no oye la campana de la iglesia llamando a oración. En cambio, oye el zumbido de un mosquito o el roer de un ratón.

Los huesos de la respiración.

Ama la lluvia como a ti mismo.

Se dice el más allá, pero nunca decimos el más aquí. 
IV. Más allá del lenguaje

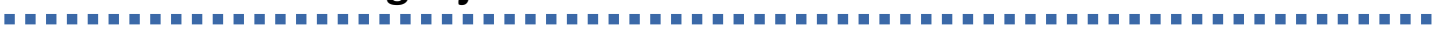

La poesía oryana supone un proceso de meditación, la búsqueda de un lenguaje que pueda trascender el pensamiento racional y la referencialidad pragmática (Mesado, 2014: 83-84). Ory busca en el pensamiento del budismo zen, en su lenguaje terriblemente disparatado y absurdo, pero cargado de evocación, la transgresión del pensamiento lógico. En este sentido, el koan ofrece una fractura lingüística que nos hace saltar más allá del pensamiento. El koan hace estallar el lenguaje porque supone una situación sin salida. Busca la experiencia directa, la fluidez inmediata, la ocurrencia repentina, la clarividencia del gesto. El koan se dirige a la realidad y no al pensamiento. Se dirige al silencio mediante la ruptura del lenguaje. Se trata de la supresión del pensamiento, tal y como ocurre en la meditación zazen.

En el budismo zen japonés se dan dos direcciones: la escuela rinzai y el soto zen. El zen rinzai utiliza el koan como método de ayuda para alcanzar el satori en el proceso de la meditación, samadhi. El zen soto, en cambio, rechaza el uso del koan por considerarlo un soporte artificial en el proceso de búsqueda de la iluminación. Para esta escuela, la práctica del zazen es la única vía posible para llegar al satori. De todas formas, el koan impregna todo el pensamiento budista, extraño, paradójico y absurdo. En la literatura zen existen diversas colecciones de koans, en otras ocasiones el koan se ofrece en una situación o en un diálogo ${ }^{11}$. El monje Nansen cuando su maestro iba a partir con su sable un gato por la mitad, objeto de una disputa de los monjes del monasterio, se puso los zapatos sobre la cabeza. Otro monje visitó a Basho para preguntarle cuál era el principio del budismo y Basho le pego como repuesta. Existen algunos famosos koan como los que siguen:

Dime cual es el sonido de una sola mano (Hakuin, 1685-1768).

¿Cuál es el rostro que tenías antes de nacer? (Hui.Neng / Eno, 683-713).

¿Un perro tiene la naturaleza de Buda? (Joshu Jushin / Chao-Chou, 778897).

El lenguaje de silencio de la poesía oryana está más próximo al koan que al haiku, toda ella está atravesada por la lógica paradójica del koan. La poesía postista supuso una semántica ilógica, lúdica, extraña y absurda que desembocó en el arte conceptual de los aerolitos. Si la poesía del haiku es como la reverberación de las ondas creadas al caer una piedra en un estanque, los aerolitos son como pedradas a la cabeza, relámpagos en la noche que súbitamente iluminan. Ellos intentan subvertir las coordenadas que estructuran nuestro pensamiento, su impronta es abrir brechas para que el pensamiento opere en nuevas direcciones. Los aerolitos son chispas que provocan un incendio cerebral, plantean un impasse en nuestras rígidas y acomodaticias estructuras mentales que propone un salto mental, un juego que apunta a la terrible paradoja que

11. Ver Cleary, Thomas (1993): Cien historias de iluminación, traducción de Sebastián Vázquez Jiménez, EDAF, Madrid, 1995. 
supone el propio lenguaje. Como apunta Alan Watts (1958: 23-24) en la frase "qué le ocurre a mi mano cuando cierro el puño», el lenguaje se desvela incapaz de representar la realidad. La paradoja, como señalaba Zeón de Elea, ${ }^{12}$ únicamente existe en la representación, no en la realidad. Y desvela que la representación no se ajusta a ella. Los aerolitos se acercan al silencio porque destruyen el lenguaje. Al igual que el koan, lo hacen estallar y su fractura crea una explosión que provoca un terremoto cerebral que expande el pensamiento, proyectándolo más allá de las palabras, hacia las cosas. El aerolito apunta hacia la percepción directa de la realidad:

\author{
Di algo que no sepas decir. \\ ¿De qué color es el silencio? \\ Ciegos son aquellos que no ven lo invisible. \\ Nunca cambia de sitio el infinito. \\ Un beso no se describe. \\ El silencio tatuado. \\ En el vacío del aire nada es nada. Nadie ha visto los pensamientos. \\ Ningún esqueleto es metafísico. \\ La muerte no se acaba nunca. \\ Acuérdate de ahora mismo. \\ Sin silencio previo las palabras no suenan.
}

\title{
V. A la estela de los aerolitos
}

Los aerolitos oryanos significan una propuesta poética, teórica y metafísica a la vez, que trasciende el puro juego literario y lúdico. En este sentido, las minimás de la escritora y poeta Carmen Camacho (Alcaudete, Jaén, 1976), ligada a la acción poética y a la interrelación entre la poesía y las artes escénicas, suponen la continuación directa de los aerolitos de Ory. La poesía de Carmen Camacho converge con la poesía oryana en el minimalismo poético que incorpora el lenguaje del silencio, en la libertad que presupone una poesía auténtica y vital, que intenta desvelar los enigmas interiores y aquellos que quedan ocultos en los pliegues de la realidad menos visible, en la ironía de un lenguaje apartado de normativas grupales y de tendencias. Este lenguaje mínimo y naï, expresado en poemarios como Campo de fuerza (2012) o Vuelo domestico (2014), rechaza los artificios para expandir los resortes de la sugerencia. Lenguaje que recupera la antigua oralidad popular, el minimalismo poético y la poética del silencio cercana al haiku.

Las minimás de Camacho, establecidas en la obra Minimás (2008, 2009), son la derivación de los aerolitos de Ory. Entre la greguería y el aforismo, las minimás se acercan al lenguaje de los sueños, a la ingenuidad poética de la infancia, a las anodinas y breves expresiones de la calle, a las pintadas de los muros urbanos, a los cantares de la tradición popular y, como no, a la lógica paradójica del koan. Los siguientes

12. Las paradojas de Zeón apuntan a la insostenibilidad de la teoría, no a la de la realidad. Pues, Aquiles alcanza a la tortuga. Se trata, evidentemente, de un impasse conceptual. 
fragmentos tienen un sabor totalmente oryano, sin perder la impronta de su autora, sugerente y sensible:

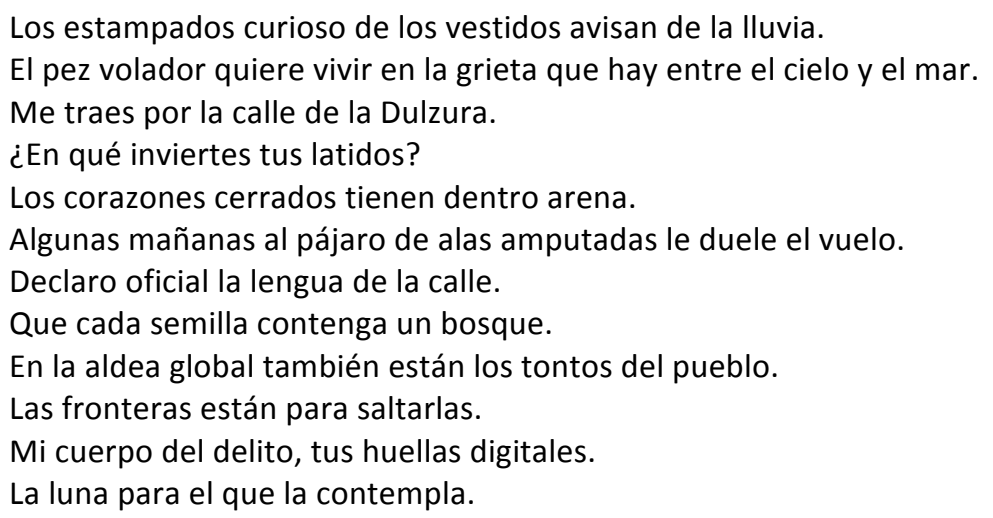

Las minimás sortean el lenguaje comunicativo, sustentado en el significado referencial, para despistar a la lógica e ir más allá, hacia la paradoja. Desde la más radical irracionalidad, ofrecen un chispazo, una llamarada que surge del choque de los conceptos desubicados entre sí en las capas freáticas del paisaje mental. Esta libertad lingüística que las minimás alcanzan supone el origen perdido, aquel que todavía puede hallarse en las asociaciones de los juegos de los niños o en el discurso extraño de los locos. Las minimás de Camacho, contenidas entre lo breve y lo sonoro, agitan en lenguaje desligando los significantes de la tiranía de la razón para acercarlos a una significación basada en la emoción. La intuición, la sorpresa y la sugerencia no son meros juegos de artificio, sino que son los goznes que abren las puertas a lo desconocido, al misterio que se halla en la cotidianeidad más cercana. Por ello, las minimás, como los aerolitos de Ory, se proyectan sobre el espacio de la metafísica. La poesía es el anzuelo que permite pescar en las aguas mágicas de la realidad, la linterna que explora e ilumina la extraña geografía de la existencia, velada a los ojos del supuesto sentido común.

\section{Bibliografía}

CAMACHO, C. (2008, 2009): Minimás, Baile del sol, Tenerife.

CleARY, T. (1993): Antología zen. Cien historias de iluminación, traducción de Sebastián Vázquez Jiménez, EDAF, Madrid, 1995.

Marina, J. A. (2003): "Lectura privada de Max Aub», en QuiÑones, J. (ed.): Aforismos en el laberinto, Edhasa, Barcelona.

Mesado, R. (2014): “Ory: poesía y silencio», en Vela, J. (ed.): Coordenadas, III Jornadas en torno a Carlos Edmundo de Ory, Fundación Carlos Edmundo de Ory, Cádiz.

ORY, C. E. (1962): Aèrolithes, Imprimerie Rougerie, París.

- (1965): Aerolitos, en Cuadernos Hispanoamericanos, núm. 181, enero, Madrid. 
- (1966): Aèrolihtes, en Les Rèalités Secrètes, núm. 28-29, diciembre, París.

- (1969): Aerolitos, en Cuadernos Hispanoamericanos, núm. 230, febrero, Madrid.

- (1970): Poesía 1949-1969, GRANDE, F. (ed.), Edhasa, Barcelona.

- (1970): Metanoia, CózAR, R. (ed.), Cátedra, Madrid.

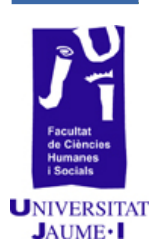

- (1985): Aerolitos (pensamientos y aforismos), El Observatorio, Madrid.

- (1991): Metanoia, CózAR, R. (ed.), Cátedra, Madrid.

- (1995): Nuevos aerolitos, Ediciones Libertarias, Madrid.

- (1991): Música de lobo. Antología poética (1941-2001), Pont, J. (ed.), Galaxia Gutenberg, Barcelona.

- (2004): Diario, 3 Vol., Servicio de Publicaciones de la Diputación, Cádiz.

- (2005): Aerolitos, Calambur, Madrid.

- (2006): El desenterrador de vivos, Galaxia Gutenberg, Barcelona.

- (2009): Novísimos aerolitos, Fundación César Manrique, Madrid.

- (2011): Los aerolitos, Calambur, Madrid.

Pont, J. (1998): La poesía de Carlos Edmundo de Ory, Pagés Editors, Universitat de Lleida.

RIPOLL, J. R. (2011): «El último aerolito (Aerolitos de Carlos Edmundo de Ory)», en Caleta, Literatura y Pensamiento, Segunda Época, núm. 16, octubre, Cádiz.

SuzUKI, D. T. (1959): El zen y la cultura japonesa, traducción de María Tabuyo y Agustín López, RBA, Barcelona, 2002.

WATTS, A. (1958): El camino del zen, traducción de Juan Adolfo Vázquez, Pocket-Edhasa, Barcelona, 1971. 


\section{Traducció, identitat, subversió.} Reflexions cap a una praxi queer de la traducció

Robert Martínez Carrasco rcarrasc@uji.es Lourdes Frasquet Porta al226026@uji.es 
Aquesta comunicació advoca per una praxi queer de la traducció, conscient de les asimetries de poder presents en el textos i enquadrada dins un marc dels estudis feministes de la traducció. Partint del concepte del llenguatge com a mite de la semiologia barthiana, i recolzant-nos en postulats focaultians de poder i en la noció de violència simbòlica de la sociologia de Bourdieu, abordarem la impossibilitat que el llenguatge puga tenir un ús merament referencial. El fet que percebem el llenguatge com a sistema factual quan es tracta d'un sistema semiològic, raó per la qual tota realitat percebuda mitjançant el mateix sembla lògica i natural, ens conduirà a l'existència de certes elits (heteropatriarcals) que controlen, seleccionen i redistribueixen els discursos, factor davant el qual, des d'un punt de vista ontològic i de manera conscient o inconscient, les traductores hauran de posicionar-se. Tot seguit, farem una anàlisi descriptiva de les propostes que les traductores feministes, conscients que com a dones i com a traductores sempre es troben en la perifèria de la realitat (respecte a home i autor), van formular amb dues finalitats concretes: desmantellar el bagatge (hetero)patriarcal del llenguatge i, al mateix temps, crear vincles de solidaritat entre dones. Els postulats de les traductores feministes dels anys vuitanta i noranta ens serviran com a base per a reivindicar una teoria de la traducció que englobe la intersecció entre feminisme i orientació sexual. Per últim, analitzarem el concepte de comunitat $\mathrm{i}$ identitat LGBT+ com a subgrup particular d'un enfocament feminista de la traducció, una praxi, que, sense caure en l'essencialisme, valide una posició identitària i cree al mateix temps un espai d'interacció per a la formulació i recepció de veus homosexuals.

Paraules clau: identitat, traducció, teoria queer, ideologia, feminisme.

\section{Introducció}

Avui dia és un fet incontestable que la llengua, i per extensió la traducció, és una ferramenta de transformació social. Lluny de plantejament asèptics en els quals les traductores, deshumanitzades, exerceixen un paper neutre de transvasament lingüístic, la concepció que tota persona que tradueix intervé de manera conscient o inconscient en el text $\mathrm{i}$ ha de ser responsable de les seues eleccions és ja una idea assentada en els nostres estudis (intervenció textual en tant que absència d'equivalència absoluta en termes de Hermans, Bassnet, Lefevere, etc.). Per tant, en aquest estudi partirem de la base que les traduccions mai no són fidels ni neutrals, sinó un acte deliberat de posicionament ideològic (Tymozcko, 2003). 
A banda, el model d'hibridació cultural fonamentalment homogeneïtzador, occidentalitzant i heteropatriarcal que la globalització i la societat 2.0 han propulsat fa que certes elits de poder puguen modelar l'opinió pública i imposar, de manera subreptícia, determinats corrents ideològics que conformen la percepció de la realitat de forma unidireccional: des de les elits econòmiques cap als sistemes de la perifèria (Vidal, 2010).

Emprant el mateix criteri, és a dir, afirmant que les grans elits econòmiques dominen el procés lingüístic de producció, transmissió i recepció de textos, podem afirmar, des d'una perspectiva queerfeminista, que no hi ha multidireccionalitat en el discurs ni en el llenguatge, sinó que ambdós flueixen des d'una elit social preeminentment heteropatriarcal vers la societat en el seu conjunt, deixant de banda col-lectius com ara dones, emigrants, gais i lesbianes, etc. El discurs d'aquests col-lectius, per tant, serà minoritzat i emmarcat dins unes narratives concretes d'inacceptabilitat i subversió. Com veurem més endavant (Foucault, 1999 [1970]), els discursos estan "controlats, seleccionats i redistribuïts» socialment; i allò considerat vertader, convencional $\mathrm{i}$ acceptable constitueix un dels criteris d'exclusió bàsics quant a la producció textual en una llengua i una cultura determinades, cosa que afavorirà l'estigmatització lingüística.

Sabedores de la seua posició subordinada respecte l'heteropatriarcat, i conscients de l'oportunitat que el llenguatge els podia brindar, durant els anys vuitanta i noranta s'erigeixen els paradigmàtics corrents feministes de la traducció, les propostes dels quals pretenen subvertir el discurs dominant $i$, al mateix temps, crear vincles de solidaritat entre dones (Lotbinière-Harwood, 1991 en Burton, 2010). Aquests corrents, inscrits dins un feminisme de segona onada que va morir per una clara falta d'interseccionalitat respecte a qüestions de classe social, raça, emigració, orientació sexual, etc. representen un valuós llegat lingüístic i traductològic feminista susceptible de ser estudiat i aplicat en els contextos actuals.

La llengua, i per extensió la traducció, pot utilitzar-se per oposar resistència a construccions socials [heteropatriarcals], introduir idees noves i qüestionar l'status quo (Gentzler, 2008: 3 en Vidal, 2010: 26). La traductora, això sí, ha de poder ser capaç de dilucidar els diferents nivells de significat presents en els textos per tal de detectar narratives heteronormatives i tractar de posar-hi solució. Emparada per postulats feministes i, conscients de qüestions com la interseccionalitat, advoquem per una praxi queer de la traducció que done veu i respresente els col-lectius minoritzats que s'allunyen de la norma imposada pel discurs heteropatriarcal dominant.

\section{Objectius}

L'ésser humà aprehén la realitat mitjançant les traduccions amb què interacciona. De la qual cosa pot desprendre's que, com a traductores, hi 
ha una certa responsabilitat i poder de transformar la societat. Conscients d'aquest fet, proposem, mitjançant el present article, els objectius següents:

- Subratllar que la traducció és un acte ideològic i que el llenguatge no és de caràcter únicament referencial.

- Analitzar com el llenguatge pot esdevenir una arma de repressió (i de subversió).

- Partir del postulat feminista "Language is power» (Carter, 1983: 77) per tal de trobar la llavor de l'heteropatriarcat.

- Analitzar les propostes dels estudis feministes de la traducció del segle $x x$.

- Reflexionar sobre la seua viabilitat en el context actual.

- Proposar un marc interseccional inclusiu amb la realitat LGTB+.

\section{Marc teòric}

El fenomen de la traducció, en qualsevol de les seues vessants, mai no és baladí. El ben anomenat espill en el qual la nostra traducció es reflecteix, i ens sembla una còpia exacta, cau per si mateix en el moment en què ens preguntem per la naturalesa de l'espill mateix. Un espill que no ha estat ben polit, un de convex, un espill ben il.luminat o un altre que no ho està gaire, com reflectirà l'objecte en qüestió? Fins a quin punt l'espill, com reflexionà Potter (1996), no crea realitat en compte de reflectir-la? I en la mateixa línia, si el món que percebem està condicionat pel llenguatge que emprem (verbal i no verbal) i les narratives a què estem exposats (Baker, 2006:19) i de les quals en parlarem més endavant, com pot ser el paper del traductor una tasca neutral?

La idea que el llenguatge és predominantment referencial, innocent i asèptic és ja una noció caduca dins la nostra disciplina (Vidal, 2010). Avui dia, però, considerem que la realitat es construeix entorn de discursos parcials, recursos lingüístics diferents. El Ilenguatge, com diu Potter (1996: 98), és el mitjà pel qual construïm aspectes del món i la societat que tenim al nostre voltant.

Igual que Potter, Barthes (1999 [1980]) és conscient dels significats de segon ordre de la llengua i del fet que, encara que percebem una relació directa i referencial entre llengua i realitat, aquesta relació no és mai directa ni clara. El semiòleg francés parla de mite per la creença errònia que hi ha una relació unívoca entre significant i significat: és a dir, que interpretem el mite com a sistema factual quan es tracta d'un sistema semiològic. Per aquesta raó, tota realitat percebuda mitjançant llenguatge sembla lògica i natural, independentment que ho siga. El mite uneix la paraula a un sentit ideològic tant denotat com connotat. Denotat en tant que el signe fa referència a l'objecte; i connotat perquè suggereix un valor secundari i es relaciona amb altre significat (ibid.: 24). Per tant, si establim que el llenguatge crea la realitat i no únicament la designa, no 
podem ni devem, com a traductores, tancar els ulls a la realitat que ens envolta (Vidal, 2010).

Arribades a aquest punt, caldria plantejar-se, seguint postulats foucaultians (Foucault, 1999 [1970]), de quina manera aquestes elits (heteropatriarcals) controlen, seleccionen i redistribueixen els discursos; així com mitjançant quins procediments d'exclusió el discurs esdevé acceptable $\mathrm{i}$, en criteris llecs, ens semble, reprenent Barthes, lògic i natural. En la mateixa línia que Barthes, Baker (2006: 19) empra el terme «narrativa» com a representació compartida per una comunitat amb efecte normalitzador, fins al punt d'esdevenir vertadera, incontestable:

Narratives, as understood here, are dynamic entities; they change in subtle or radical ways as people experience and become exposed to new stories on a daily basis. [...] narrative theory recognizes that people's behaviour is ultimately guided by the stories they come to believe about the events in which they are embedded, rather than by their gender, race, colour of skin, or any other attribute.

Així doncs, caldria preguntar-nos com és possible que no hi haja gaire transgressions i subversions a aquesta norma, aquestes asimetries de poder arbitràries, a priori naturals, establertes per l'heteropatriarcat mitjançant els seus discursos. Per quina raó hi ha relativament poc de qüestionament i molta acceptació inherent interioritzada i externalitzada, fins al punt que hi ha ben poca rebel-lió queer, feminista? Per respondrehi, caldria fer referència al concepte de violència simbòlica de Bourdieu.

Bourdieu (2010) se sorprén que la dona no s'haja rebel·lat contra la dominació masculina i haja acceptat grosso modo les sancions i obligacions imposades per I'heteropatriarcat. La violència simbòlica és, llavors, acceptada i interioritzada socialment, tant pel que fa a la dona, com a un espectre més ample del feminisme que tinga en compte qüestions interseccionals com ara el gènere, la raça o l'orientació sexual. Una determinada sèrie d'esquemes prèviament establerts es perceben com universals per part de la societat i les minories es veuen atrapades en relacions de poder de les quals en són part inferioritzada i apliquen, de manera conscient i inconscient, esquemes mentals que no són sinó el producte de l'assimilació d'aquest poder, de manera que creen la violència simbòlica que sofrim.

Davant tots aquests factors, no és difícil comprovar que, tal com afirma Lambert (1999[1995]:260), les activitats de traducció tenen tendència a adoptar les regles i els valors, fins i tot la seua existència, de l'entorn polític dominant, ja que el que tradicionalment s'espera d'una traductora, o fins i tot s'assumeix, és que no reflexiona sobre la seua pròpia ideologia i la ideologia del text, oberta o subreptícia. Tanmateix, com que la traductora té la sort d'entendre el text original, la seua manera de procedir mai no serà neutra i haurà d'enfrontar-se a complexes negociacions de poder en el procés de reescriptura textual (Vidal, 2010). Per aquests motius, és imprescindible que la traductora sempre siga conscient de les seues eleccions ja que tindran 
conseqüències i deixaran una empremta o altra en el text. Tymozcko (2003) afirma, en la mateixa línia, que la traducció és un acte deliberat de posicionament ideològic i pot utilitzar-se, igual que la llengua, per oposar resistència a construccions socials, en aquest cas heteropatriarcals. Llavors, la traductora hauria de tenir la capacitat de dilucidar els diferents nivells de significació i així detectar certes narratives i asimetries de poder per tal d'intentar posar-hi solució.

En aquest context, no resulta estrany que la interseccionalitat entre gènere (Godanyol, Lotbinière-Harwood, Von Flotow), sexualitat (Harvey, Burton), poder (Schaffner, Tymozco) i llengua siga un tema de debat en els cercles traductològics, no només des d'un punt de vista descriptiu, sinó també en clau prescriptiva, amb la finalitat de proposar formes d'actuació en situacions on hi ha un clar conflicte textual resultat de diverses asimetries de poder.

Des d'aquesta posició prescriptivista, House, Ruano i Baumgarten assenyalen en la introducció de Translation and the Construction of Identity (2005: 4), que hi ha determinades circumstàncies, com ara la traducció, que fan perceptibles els components identitaris de l'individu. Vet aquí la ja mencionada quota de poder i de responsabilitat de la traductora en el procés sempre condicionat de re-producció textual. Les traductores imaginem un concepte de lector en particular, que podrà perpetuar, o no, les narratives subreptícies que, de manera conscient i inconscient, creen els agents globalitzadors fent-nos entendre que els seus discursos són els únics, els vàlids, els normals.

Davant de tots aquests factors, és fàcil entendre per què feminisme $\mathrm{i}$ traducció comencen a caminar de la mà. Va ser en els anys setanta, en plena segona onada feminista, quan es donaren les primeres passes per tal d'arribar fins a allò que avui dia coneixem com els estudis feministes de la traducció. Així doncs, és a partir de l'impuls del moviment feminista, i no a l'inrevés, que disciplines com ara la lingüística o la sociolingüística comencen a interessar-se per les diferències derivades del sexe (Thorne, Kramarae i Henley, 1983: 8).

En els anys setanta i vuitanta, emmarcades dins el paradigma de la dominació, sorgeixen corrents que busquen modificar la llengua existent per evitar un menyspreu o invisibilització cap a les dones. Dins aquest paradigma, Mills (1995) en Feminist Stylistics resumeix propostes per a un ús no sexista del llenguatge (ibid: 96-97):

the use of plural pronouns, passivinzing, the use the female pronoun as a generic, the use the male pronoun as a generic with proviso, the use of alterate propnouns, etc.

Més tard, ja ben entrats els anys vuitanta, sorgeix el paradigma de la diferència, les impulsores del qual advoquen per crear una llengua que puga satisfer les necessitats de les dones. La influència del feminisme francés de la diferència, molt proper a teories postestructuralistes, donarà lloc durant els anys vuitanta i noranta al paradigma discursiu, el 
qual es focalitza en el concepte d'interseccionalitat i que, precisament, per aquest mateix motiu acabarà perdent tota la seua força inicial.

Emparades per aquest darrer paradigma, les feministes hereves de la segona onada dels anys setanta troben en el llenguatge una oportunitat per a subvertir el monòleg que suposa el discurs patriarcal dominant (Godard, 1990: 88). Més concretament, és al Quebec dels vuitanta i noranta, regió francòfona dins d'un estat majoritàriament angloparlant amb un conflicte sociolingüístic més que patent, on un grup d'autores donen el salt de la reflexió nacionalista a la feminista (Brufau, 2010: 50), posant en pràctica una sèrie d'estratègies intervencionistes en la traducció i cimentant les bases del que avui dia coneixem com estudis feministes de la traducció. En aquest context, noms com Barbara Godard, Luise von Flotow, Sherry Simon o Susanne Lotbinière-Harwood engeguen una nova manera de lluitar activament contra l'opressió patriarcal servint-se de la traducció, concebuda sempre com una activitat política. En les pràctiques dutes a terme per les quebequeses subjau una doble finalitat: la primera, construir una forta solidaritat entre dones; i la segona, desmantellar el patriarcat arrelat a la paraula escrita (Castro, 2008).

Aquest propòsit de crear una solidaritat interfemenina es fa patent des del principi, dins del mateix cercle de feministes anteriorment mencionades, on sovint es traduïen entre elles. Aquest grau de proximitat entre autora i traductora, tant pel que fa a la ideologia com a l'àmbit personal, va permetre dur les estratègies experimentals a nivells més alts dels que s'hauria pogut fer en altres contextos. De fet, LotbinièreHarwood reconeix que "solidarity with the 'auther' encourages me to take the same risks she did. This implies aesthetic and ethical choices: 'Always choose in the sense of passion'» (Lotbinière-Harwood, 1995:62). L'acció de les traductores canadenques es titlla ben a sovint de revisionista, ja que en aquesta línia de construcció de solidaritat entre dones, se serveixen de la intertextualitat, recurs ja clau en traducció, que per a Lotbinière-Harwood esdevé bandera del feminisme traductor, ja que rescata $\mathrm{i}$ fa visible el treball d'altres dones, alhora que permet l'extensió de xarxes entre elles.

El segon objectiu que perseguien les traductores quebequeses emana, tal com recull Castro (2008: 289), de la convicció que la reforma lingüística s'erigeix com un pilar fonamental de la reforma social. Basantse en la reivindicació que el feminisme com a moviment polític pot emprar el llenguatge legítimament com a intervenció cultural per a les seues pròpies finalitats, aquestes traductores se serveixen llavors de tècniques de caràcter lingüístic i d'altres estratègies textuals que van més enllà i que, a continuació expliquem, tot parant atenció a la seua possible posada en pràctica des d'un punt de vista queer de la traducció.

Abans, però, cal advertir que per comprendre correctament les propostes feministes hem d'evitar caure en una universalització dels postulats mai buscada ni desitjada, ja que les traductores canadenques traduïen un tipus molt concret de textos, com són els literaris, de 
temàtica molt concreta, la feminista. A més, universalitzar aquestes estratègies només faria caure en el desprestigi el projecte feminista, ja que en determinades circumstàncies pot minvar-lo per la mediació dels estereotips.

Dit això, analitzem les estratègies de què es serviren les traductores feministes. En primer lloc, hi trobem la suplementació o compensació. Von Flotow (1997) es refereix a aquesta mateixa estratègia com a sobretraducció, és a dir, explicitar allò que estava implícit, buscar equivalents que puguen ser innocus per tal de neutralitzar un fragment misogin; o, tot el contrari, buscar intervencions clares, directes i provocadores i subratllar-les. Mitjançant aquesta estratègia, la traducció completa el text original, el desenvolupa i li dóna una vida posterior (Chaume et al., 2010: 82). Es tracta de subvertir l'ordre patriarcal que redueix les dones al silenci. Aquesta estratègia no és més que una intervenció directa en què la traductora busca compensar les diferències entre llengües i sistemes culturals pel que fa a les connotacions i marques de gènere. Dins d'aquesta estratègia s'emmarcarien proposes lingüístiques com les que figuren a continuació:

- L'explicitació del gènere. Aquesta pràctica es duia a terme, fins i tot, en llengües com l'anglesa, on no es determinen tant les diferències de gènere. S'utilitzaven, per exemple, estrangerismes escrits en femení (Québecois-es) o, com en el cas de Lotbinière-Harwood, explicitacions directes amb un "female» o "woman» («female teacher»). LotbinièreHarwood proposa, tal com descriu Castro (2008: 294) una suplementació utilitzant una lletra «e» en negreta per tal d'indicar la marca de gènere del text original en francés. Per exemple, davant l'original "Nulle ne l'ignore, tout est langue», la traductora quebequesa proposa "no one ignores the fact that everything is language». En aquesta solució, podem veure com no només hi afegeix la «e» en negreta per preservar el gènere femení marcat deliberadament en l'original, sinó que a més destria utilitzar una opció tan explícita com podria ser el «No woman ignores...».

- Compensacions dins el text, com va fer Scott traduint Bersianik (1984) on un "le ou la coupable doit être punie» esdevé "the guilty one must be punished, whether she is a man o a woman».

- L'ús de doblets (his/her, he/she).

- L'ús de doblets sexualitzats («les héros» per "the heroes and heroines»).

- L'ús de fórmules neutres («Québecois» per "Québecois people»).

- L'explicitació masculina quan no es tracte d'un neutre ("Québecois men»).

- L'ús de termes que engloben homes i dones («man» per «human being», "la victoire de l'homme» per "our victory»). 
La segona estratègia que mereix ser esmentada és la metatextualitat, la qual busca subratllar el rol actiu de la traductora en el procés de creació i interpretació del significat de l'original. La metatextualitat es posa en pràctica mitjançant la inclusió de prefacis, notes al peu de la traductora i altres paratexts els quals expliquen quines són les intencions polítiques de la traducció, justifiquen les intervencions fetes al text, transmeten totes les estranyeses del text i expliciten els múltiples significats que podrien perdre's en la traducció. Un cas palpable d'aquesta estratègia, tal com recull Castro (2008: 295) és el pròleg que redacta Lotbinière-Harwood, per a la traducció de la novel·la Lettres d'une autre de Lise Gauvin, titulat en la traducció a l'anglés "Letters from An Other» (1989):

«About the her in the other»

Dear Reader:

Just a few words to let you know that this translation is a rewriting in the feminine of what I originally read in French. I don't mean the content. Lise Gauvin is a feinist, and so am I. But I am not her. She wrote in genèric masculine. My translation practice is a political activity aimed at making Language speak for women. So my signature on a translation means this translation has used every possible feminist translation strategy to make the femenine visible in Language.

Veiem, doncs, com aquesta classe de paratextos, lluny de servir de justificació o disculpa, acaben adquirint grau de comentari foucaultià, de resistència en aquest cas, en tant que valoren i contextualitzen l'original i amb això, propulsen un discurs polític particular.

La tercera estratègia va més enllà de la microlingüística, de la transformació de les paraules, i rep el nom de segrest, hijacking en anglés. L'origen d'aquesta denominació, tal com ens explica Brufau (2010: 90) el trobem en una crítica d'Homel cap a les traduccions de LotbinièreHarwood. Segons Homel (en Brufau, ibid)

(...) the translator (...) is so intrusive at times that she all but hijacks the author's work. In the introduction she tells us she intends to make her presence felt (...) to this end she frequently breaks into Gauvin's work explaining what Gauvin really meant and sometimes offering French equivalent for the English on the page.

El segrest, doncs, consisteix en l'apropiació de la traductora d'un text les intencions del qual no són necessàriament feministes, mitjançant la introducció de neologismes (quan el llenguatge patriarcal no ofereix alternatives per a designar la realitat des de la perspectiva feminista); la inclusió de canvis que no té res a veure amb la versió original; la substitució del masculí genèric pel femení genèric o formes inclusives; la inversió d'elements sexistes; la creació de paròdies, etc. El segrest és una feminització deliberada de l'original: una apropiació deliberadament manipuladora del text. Un exemple clàssic d'aquesta tècnica és el que proposa Von Flotow (1991: 69) que parteix de la frase «Ce soir, j'entre dans l'histoire sans relever ma jupe» i en mostra dues traduccions, la d'un home "Tonight I'm entering history without lifting up my skirt» i la de la 
feminista Linda Gaboriau "This evening I am entering history without opening my legs».

A més d'aquestes tres estratègies, també cal destacar aquella pràctica que Lotbinière-Harwood anomena performance, que no és una altra cosa que una mena de coautoria mitjançant la qual es produeix una estreta col-laboració entre l'autora del text original i la traductora, posant en pràctica el concepte de l'escriptura/reescriptura en femení. Llavors, veiem com aquesta darrera estratègia uneix ambdues finalitats perseguides per les traductores canadenques: desmantellar el patriarcat alhora que es consolida una solidaritat entre dones.

Realment, tal com apunta Massardier-Keny (1997:57) moltes d'aquestes pràctiques "feministes» no són més que tècniques de traducció tradicionals posades al servei de l'activisme (les notes, els pròlegs, la compensació i fins i tot el segrest vonflotowià que, en si mateix, implica la violència que se li atribueix a la violació textual masculina).

El cas paradigmàtic de les traductores feministes del Quebec, però, ha caigut sovint en una mala interpretació per falta de contextualització. Les propostes canadenques, en unes circumstàncies espaciotemporals molt específiques, dotaren el moviment feminista d'una nova via d'expressió a l'hora de desmantellar la càrrega patriarcal del llenguatge i de la societat. Tanmateix, han caigut sovint en el desprestigi, fins i tot, dins cercles traductològics no tan conservadors. És el cas de la traductòloga Rosemary Arrojo, per exemple, que acusa aquestes pràctiques d'oportunistes, falses i incongruents (Arrojo apud von Flotow, 1997: 82).

Des del nostre punt de vista, titllar aquests postulats d'una simple Ilista de tècniques de traducció que advoquen per la manipulació seria un error, ja que les traductores feministes demostraren que alliberar el llenguatge de càrrega patriarcal és possible. Les seues reflexions, partint primerament de la praxi i teoritzant després, han esdevingut el punt de partida i de reflexió d'innumerables estudis i debats: i és justament en aquest punt on rau la seua importància, especialment, per al cas concret que ens ocupa. Entre les seues propostes, trobem aspectes que, tot i no ser universalitzables, sí que ens poden servir com a base a l'hora de configurar una teoria queer-feminista de la traducció contemporània, interseccional i que, al mateix temps, abaste un espectre més ampli de tipologies i gèneres textuals. En altres paraules, la tasca de les traductores quebequeses és, com a mínim, instructiva per tal de poder començar a parlar d'una praxi queer de la traducció.

Si bé les propostes de les feministes del Quebec juguen un paper pedagògic, les reflexions de Keith Harvey resulten igualment imprescindibles en aquest terreny. Harvey es posiciona com un dels pioners a l'hora d'abordar la qüestió queer amb la publicació l'any 2000 de Gay Community, Gay Identity and the Translated Text. En línies generals, per a l'autor, i d'acord amb les traductores canadenques, una traducció queer hauria de suggerir models d'alteritat, d'allò alié, que 
pogueren utilitzar-se en els processos de formació d'identitat interna i projecció de l'imaginari queer.

Es pot intuir la influència que rep Harvey de les tècniques canadenques a l'hora de proposar estratègies intervencionistes de traducció, ja que entre les seues propostes s'inclouen moltes de les tècniques que hem analitzat anteriorment, com ara la metatextualitat entesa pràcticament de la mateixa manera en què la posaren en pràctica les feministes quan buscaven subratllar el rol actiu de la traductora en el procés de desmantellament del patriarcat. D'acord amb Harvey, caldria emfatitzar I'homofòbia del text origen i, a continuació, afegir-hi un paratext que la denuncie.

Al mateix temps, també advoca per la sobretraducció (translatedness, en anglés) que tractaria, com hem esmenat abans, de suggerir models d'alteritat que puguen funcionar en l'imaginari del lector meta, de manera que es cree un espai en què allò diferent puga considerar-se un atribut cultural positiu (Harvey, 2000:159). La sobretraducció permetria al lector queer imaginar una comunitat transnacional, fins i tot quan aquesta imaginació no es correspon amb la realitat. Mitjançant aquest recurs no es busca una altra cosa que formar identitat interna entre els membres del collectiu i projectar un imaginari queer.

Tot i això, les propostes de Harvey es veuen tal vegada parcialment limitades pel fet que només tenen en compte textos de temàtica i autoria gai. Així, un projecte queer de traducció hauria de ser antihomòfob en motivació i pràctica, i desestabilitzador i historitzador, pel que fa a normes de gènere, sexe i sexualitat establertes, en tant que les revelaria com anacròniques a ulls de la societat. En aquesta línia, Burton (2010) incideix en la idea, una vegada més, que no hem de perdre mai de vista l'exemple de les traductores del Quebec, les quals ens serveixen de guia a I'hora de desenvolupar certes tècniques des d'una perspectiva queer.

Per la seua banda, Burton proposa una estratègia que ell anomena «inversió», la qual es correspondria amb la subversió feminista, amb l'objectiu de projectar l'imaginari queer de què parla Harvey. La inversió no és més que un gir del text contra si mateix, és a dir, es tracta d'invertir les relacions de poder heteropatriarcals que jauen en el text, per tal de desestabilitzar i desnaturalitzar les normes de gènere $i$ sexualitat des d'una perspectiva antihomofòbica que les mostraria com a anacròniques en el context actual, en altres paraules, es tractaria de queeritzar el text.

Burton suporta els seus arguments posant com a exemple la traducció a l'anglés que fa David Homel -paradoxalment el mateix que encunya el terme de hijacking criticant Lotbinière-Harwood- de l'obra quebequesa dels anys seixanta Le Cassé. Broke City, que així és com es titula la traducció a l'anglés de Homel, és un text que de manera inintencionada crea alguns dels efectes proposats per Burton. De fet, Homel es posiciona en tot moment en contra de l'activisme traductor, justifica els seus canvis al-legant que són producte de les pressions culturals i no dels seus desitjos personals. Tanmateix, el resultat final 
sembla ser un text queeritzat, en què les motivacions marxistes i les denúncies de la història colonial del Canadà desapareixen, mentre que s'accentuen aspectes com la misogínia i una sexualitat queer rehabilitada que acaben per dominar el rerefons de la història (Burton, 2010).

Aquest exemple no és més que una clara mostra de l'efecte determinat que pot provocar la nostra tasca, fins i tot, quan no es fa de manera deliberada. Així, és essencial que, a l'hora de traduir, realitzem certes eleccions de manera conscient, ja que, tal com afirma Rodrigues (2004), tota mínima elecció lèxica i gramatical està impregnada d'ideologia. Per això, actualment una praxi queer de la traducció s'erigeix no només com a necessària, sinó com una pràctica urgent pels motius que més endavant exposem.

\section{Discussió i conclusions}

El col-lectiu queer és l'exemple palpable del poder del llenguatge per a canviar la realitat: "queer» en anglés és, en el seu origen, un terme amb connotacions pejoratives que significa «efeminat», "maricó» i «rar». Tal com recull Fabricio Forastelli (2001), durant els anys vuitanta, el grup antisida ACT-UP s'hi va apropiar del terme i el va resignificar positivament. Tant és així que actualment ha passat a designar una categoria analítica de definició complexa en el terreny de l'activisme i la reflexió gai-lèsbica, que s'ocupa «d'allò oprimit i ridiculitzable i inclou la sexualitat, el gènere, la raça i la classe» (Rapisardi, 1997: 10), i serveix de base per al que coneixem avui dia com a teoria queer.

Aquesta aproximació, hereva de teories feministes i de postulats foucaultians, en línies generals, nega la noció d’identitat sexual única i immutable i pren com a punt de partida els debats de caire potsestructuralista que neguen tota definició i categorització rígida. Aquests postulats es posicionen contra la imposició cultural que estableix I'heterosexualitat com "allò normal», i la inscriuen dins dels límits de l'acceptabilitat i descriuen la resta d'orientacions sexuals com a desviament de la norma. Segons Forastelli (2001: 22), a diferència de les Iluites emancipatòries clàssiques, en què l'element sexual no en tenia cap o molt poca, de rellevància, l'estil queer planteja la importància de la sexualitat en la construcció d'identitats i fronteres polítiques.

Avui dia, després de segles de discriminació i menyspreu, sembla que el col-lectiu queer està obtenint més reconeixement, sobretot als països de cultura occidental. Paradoxalment, les veus d'aquest collectiu apareixen representades de manera problemàtica en les societats postmodernes, tal com recull Sebastiao Rodrigues (2004: 55), per exemple, quan parla d'una romantització i homogeneïtzació del col·lectiu gai. En la mateixa línia, Ávila Saavedra (2009) afirma que les narratives de ficció dels mitjans de comunicació tendeixen a emfatitzar els assumptes interpersonals del col-lectiu homosexual, deixant de banda i, fins i tot, invisibilitzant les seues reivindicacions polítiques. Veiem com, una vegada 
més, ens topem amb el monopoli de les elits heteropatriarcals que controlen i modelen la realitat en funció dels seus interessos, de manera que permeten l'existència de forts prejudicis i estereotips normatius vigents en la societat actual o, com en el cas que ens ocupa, visibilitzen una realitat adherint-la a la ideologia dominant i desposseint-la de part de la seua essència.

De fet, tal com il.lustra Burton en el seu treball de 2010 Inverting the Text: A Proposed Queer Translation Practice, els subjectes queer han eixit de l'armari, encara que continuen havent-hi lluites internes pel que fa a definicions, al mateix temps que han acabant caient en una xarxa de disputes post i neocolonials. Aquesta solidaritat cap al collectiu acaba tornant-se una mica problemàtica i Burton ho il.lustra mitjançant l'exemple del pink washing: un llavat de cara de què es serveixen països com Israel, que duen a terme polítiques xenòfobes contra un sector de la població (en aquest cas el poble palestí), però que ho amaguen mitjançant polítiques que reconeixen els drets del col·lectiu LGTB+, pròpies de "països civilitzats».

La posició privilegiada que tenim com a traductores en tant que treballadores del llenguatge no pot passar desapercebuda, sinó que hem d'aprofitar-la: el discurs emfatitza les relacions de poder alhora que atén les relacions de significats; els processos de producció i intercanvi apareixen, per tant, materialitzats en el text. La traductora ha de saber com reaccionar respecte de l'ordre heteropatriarcal i donar veu a les minories oprimides per qüestions de sexualitat, així com a aquelles que ho són per qüestions de cultura, raça o religió, nocions que no es poden perdre de vista i que complementen la necessària interseccionalitat que proposem. La praxi queer de la traducció, en tant que interseccional, simplement i única assentaria les bases per a guiar-nos en aquest procés.

És important, però, recalcar una vegada més que aquesta pràctica queer ha de quedar emmarcada en tot moment dins la teoria feminista de la traducció, ja no només perquè ens servisca de guia quant a aspectes estratègics a l'hora d'enfrontar-nos als textos; sinó també perquè teoria queer i teoria feminista es nodreixen mútuament. Els postulats queer beuen de teories feministes, i, al mateix temps, la teoria queer ha contribuït a la redefinició dels modes de lluita i visibilitat no només del col-lectiu gai, lèsbic, bisexual, travesti i transgènere sinó a més del feminisme (Forastelli, 2001: 22). Així doncs, ambdues se'ns apareixen com inseparables.

A més, la inscripció dins la teoria feminista de la traducció ens ajudaria evitar caure en problemàtiques de representació d'un colllectiu tan ampli com el queer. És just el que Rodrigues (2004) critica quan parla del que ha quedat encunyat com a «male gay translation», que, lluny de desenvolupar un sentiment de solidaritat, acaba reflectint únicament I'homosexualitat masculina i, a més, sempre dins un context heteronormativament acceptable. En altres paraules: aquestes traduccions s'acaben adscrivint al discurs dominant de manera inconscient. Així, l'anomenat discurs gay-friendly legitima 
I'homosexualitat aplicant els models heteronormatius de relacions socials: tradicionals, monògames, que acaben en matrimoni, aplicant-hi els rols de gèneres tradicionals a les activitats del dia a dia (masculífemení/dalt-baix), etc. En aquest context, els mitjans de comunicació exerceixen un paper crucial ja que tenen el poder de bé perpetuar les asimetries de poder, bé qüestionar-les. La percepció social externa de la comunitat queer, per tant, es veurà també afectada (Harvey, 2000).

La praxi queer per la qual advoquem no pretén dictar sentència, com tampoc ho pretenien les feministes canadenques en el seu moment, sinó simplement marcar unes pautes que permeten les traductores enfrontarse a tot tipus textos, de qualsevol temàtica i autoria, des d'una perspectiva més àmplia que tinga en compte totes les veus que la norma heteropatriarcal silencia diàriament mitjançant els seus discursos dominants. Es tracta de crear consciència, no només entre els lectors i lectores, sinó també, i sobretot, entre les traductores: a les nostres mans es troba el poder de fer evolucionar les mentalitats i de la conseqüent reforma social que això implica; aquest poder és, en definitiva, una gran responsabilitat que no ha de ser eludida.

\section{Bibliografía}

Ávila SaAvedra, G. (2009): «Nothing Queer About Queer Television: televized construction of gay masculinities», Media, Culture \& Society 31:5, p. 5-21.

BAKER, M. (2006): Translation and Conflict: a Narrative Account, Routledge, Londres.

BAKER, P. (2008): Sexed Texts: Language, Gender, Sexuality, Equinox, Londres.

BARTHES, R. (1999 [1980]): Mitologías, Siglo veintiuno de España, Madrid.

BOURDIEU, P (2000): La dominación masculina, Anagrama, Barcelona.

BRUfau Alvira, N. (2010): Las teorías feministas de la traducción a examen: Destilaciones para el siglo XXI, Comares, Granada.

BURTON, W. (2010): "Inverting the text: A proposed queer translation praxis», en EPSTEIN, J.B (ed.) In Other Words, 36.

CARTER, A. (1983): «Notes from the Frontline» en M. WANDOR (ed.) On Gender and Writing, London, Pandora Press

CAStro VÁzquez, O. (2008): "Género y traducción: elementos discursives para una reescritura feminista», Lectora, 14, p. 285-301

Chaume, F. I C. GARCía de TORo (2010) Teories actuals de traductologia. Institut Interuniversitari de Filologia Valenciana, Bromera, Alzira 
FoRASTELLI, F. (2001): "La teoría queer y la construcción de identidades políticas», Dossiers Feministes, 5, Universitat Jaume I, Institut Universitari

d'Investigació Feminista i de gènere, Castelló de la Plana, p. 21-37.

FouCAULt, M. (1999 [1970]): El orden del discurso, Tusquets, Barcelona.

HOUSE, J. i altres (eds.) (2005): Translation and the construction of identity: IATIS Yearbook 2005, International Association for Translation \& Intercultural Studies, Seül.

HARVEY, K. (2000): "Gay Community, Gay Identity and the Translated Text», TTR: Traduction, Terminologie, Redaction, 13:1, p. 137-165.

LAMBERT, J. (1999 [1995]): «Literatura, traducción y (des)colonización» en Iglesias SAntos, M. (ed.) (1999): Teoría de los polisistemas, Arco, Madrid, p. 258-280.

LOTBINIÈRE-HARWOOD, S. (1995): "Geo-graphies of Why», SIMON, S. (ed.): Culture in Transit: Translating the Literature of Quebec, Véhicule Press, Montreal, p. 55-68.

MASSARDIER-KenNEY, F. (1997): "Towards a Redefinition of Feminist Translation Practice», The Translator, 3:1, St. Jerome, Manchester, p. 5569.

MıLLS, S. (1995): Feminist Stylistics, Routledge, Londres i Nova York.

POTTER, J (1996): Representing reality discourse, rhetoric and social construction, London Thousand Oaks, Califòrnia.

RAPISARDI, F. i A. MondAdoRI, (2001): Fiestas, banos y exilios, Sudamericana, Buenos Aires.

RODRIGUES JÚNIOR, A.S. (2004): "'Gender-bend(er)ing' male identity: First Steps in Search of a Critical-Discursive Approach to Gay Literature Translation», Cadernos de Tradução, p. 50-79.

ScotT, H. (1984): «Louky Bersianik's L'Euguélionne: Problems of Translating the Critique of Language in New Québec Feminist Writing», tesi de llicenciatura, Universitat de Concordia, Montreal.

THORNE, B. i altres (eds.) (1983): Language, Gender and Society, Heinle \& Heienle, Massachusetts.

TYMozcko, M. (2003): «Ideology and the Position of the Translator: In what Sense Is Translator 'In-Between'?» en CALZADA, M. (ed.): Apropos of Ideology. Translation Studies on Ideology - Ideologies in Translation Studies. St Jerome, Manchester, p. 181-201.

Vidal Claramonte, A (2010): Traducción y asimetría, Peter Lang, Frankfurt del Main.

Von Flotow, L. (1991): «Feminist Translation: Contexts, Practices and Theories» en TTR, 4:2, p.69-84.

- (1997): Translation and Gender. Translating in the "Era of Feminism», St. Jerome and University of Ottawa, Manchester, Ottawa. 


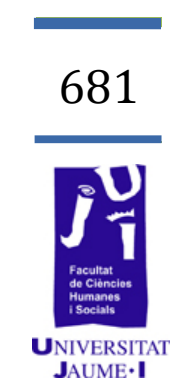

\section{El color rojo en español. Un estudio de su connotación basado en corpus}

Alejandro Teruel Vidal al096312@uji.es 
Las expresiones lingüísticas con sentido figurado se encuentran en el lenguaje cotidiano de todos los hablantes $y$, a menudo, sirven para explicar conceptos abstractos a través de otros más concretos. Nuestro objetivo es demostrar que algo tan usual como un término cromático dentro de una expresión de este tipo puede ser el vehículo perfecto para hacer entender ideas abstractas con sentido metafórico o metonímico. Para ello usaremos una herramienta clave en el análisis lingüístico: el corpus. Mediante los corpus realizaremos un pequeño estudio descriptivo que nos permita ver de qué manera los términos del color favorecen una connotación determinada.

Palabras clave: corpus lingüísticos, corpus electrónicos, estudios de traducción basados en corpus, colores, rojo, metáfora, metonimia, prosodia semántica.

\section{Introducción: investigación en Traducción con corpus textuales}

Si bien la traducción es una actividad que se lleva a cabo desde hace milenios, no fue hasta la segunda mitad del siglo xx cuando se empieza a sentir la necesidad de profundizar en el concepto de Traducción como disciplina. El gran número de avances que se produjeron durante la primera mitad del siglo $\mathrm{xx}$, como el desarrollo de la tecnología y el aumento de las relaciones internacionales, marcaron un punto de inflexión en el campo de la Traducción, que experimentó un boom debido a la aparición de nuevas formas de traducción e interpretación que marcarían un antes y un después en la manera de ver la disciplina.

Este desarrollo de la tecnología facilitó la aparición de herramientas que permitieran profundizar en el estudio de la Traducción y del proceso traductológico, como la herramienta que ocupa nuestro estudio: el corpus lingüístico. Si hablamos de corpus, es imprescindible mencionar el trabajo de Mona Baker (1993), precursora de los estudios de traducción basados en corpus. Las investigaciones de Baker ofrecen un punto de vista empírico que demuestra la gran utilidad de los corpus para poder confirmar hipótesis extraídas mediante este tipo de catálogos textuales. Los corpus se presentan como una de las principales herramientas metodológicas para el estudio de la traducción. Un corpus lingüístico es un conjunto de datos o textos que puede servir de base a una investigación y podemos encontrar todo tipo de corpus lingüísticos, como los monolingües, bilingües, paralelos, comparables, alineados, etc. Las características de nuestro estudio harán que nos centremos en los corpus monolingües, ya que no vamos a realizar por el momento un estudio comparativo y queremos centrarnos en cómo funciona la lengua española en este ámbito de estudio. 
Algunos de los factores que tendremos en cuenta a la hora de seleccionar el corpus que vamos a utilizar para nuestra investigación es la posibilidad de restringir las búsquedas en el corpus, la tipología textual que encontramos en él $y$, sobre todo, el tamaño que tiene el corpus para poder trabajar con una mayor cantidad de datos y que los resultados tengan una mayor envergadura o una mayor validez. Trabajar con un corpus de mayor tamaño puede suponer un problema, ya que el volumen de datos que se obtendrá durante su extracción será también mayor y esto hará que sea algo más difícil comprobar las teorías que tenemos y realizar generalizaciones. Sin embargo, consideramos que si durante el proceso de extracción hemos analizado un mayor número de datos, la validez de los resultados obtenidos será mayor, por lo que es importante ver cómo trabajamos con estos datos para poder llegar a una generalización válida.

El corpus nos permitirá obtener muestras reales de expresiones con sentido figurado, por lo que antes de empezar con el estudio es importante resaltar tres aspectos clave que analizaremos de forma individual: la metáfora, la metonimia y la prosodia semántica. Por lo que respecta a la metonimia, Lakoff y Johnson (1980: 39) la definieron como una manera de «conceptualizar una entidad mediante su relación con otra». Consiste en comprender un concepto abstracto utilizando otro que es más fácil de entender porque nos es más conocido y que guarda algún tipo de relación semántica con el primer término más abstracto. Un ejemplo es la frase "La Casa Blanca no se ha pronunciado al respecto» donde "Casa Blanca» hace referencia a "los portavoces de la Casa Blanca». Los mismos autores estudiaron profundamente la metáfora conceptual, que sirve para explicar un concepto por medio de otra realidad con la que guarda cierta relación de semejanza. Ejemplo de ello sería la metáfora conceptual «El amor es un viaje», algo que se explica mediante frases como «Hemos llegado a una encrucijada en nuestra relación» o "Tenemos que ir un poco más despacio». Lakoff y Johnson revolucionaron la lingüística cognitiva gracias a sus estudios en metáfora y metonimia conceptual, porque se considera que mediante estos dos mecanismos tan simples y que se encuentran tan a la orden del día, es posible entender a menudo cómo se estructuran diversos aspectos del pensamiento humano.

Ya que vamos a analizar expresiones con sentido figurado y a extraer conclusiones sobre cuál es la motivación para utilizar el color rojo en algunas expresiones concretas, es importante considerar un aspecto de la connotación, que es el concepto de prosodia semántica, ya estudiado en el año 1993 por Louw. Por un lado, tenemos la connotación de una palabra, que es fácil de identificar solo con un conocimiento enciclopédico general. Este sería el caso de la palabra «muerte», que ya tiene para el hablante una connotación negativa solo con saberse qué es y en qué contextos aparece. Por otro lado, la prosodia semántica se presenta, en cambio, en una palabra neutra cuando esta se combina con otra palabra que le confiere este valor semántico, ya sea positivo o 
negativo. Esto ocurre cuando usamos palabras como, por ejemplo, "causar» o "suceder», que por sí solas no tienen ningún tipo de connotación, pero que en numerosas ocasiones asociamos a cosas negativas con otras palabras que le confieren este valor («causar daño» o "suceder una tragedia»). Estas coocurrencias o colocaciones pueden ser muy interesantes para estudiar el lenguaje figurado presente en algunas expresiones, por lo que utilizar un corpus textual permite analizar de forma contextualizada aquellas que presentan rasgos de prosodia semántica y sus combinaciones posibles.

\section{Objetivos}

El objetivo de este estudio introductorio es averiguar cuál es el papel de los términos cromáticos cuando se trata de favorecer una connotación determinada en las expresiones en sentido figurado. Sabemos que los términos que hacen referencia a los colores están presentes en un gran número de expresiones figuradas, como "ponerse rojo como un tomate» o "estar rojo de ira», por lo que nuestro fin es saber en qué metáforas o metonimias conceptuales interviene el color rojo y en qué grado este color determina la expresión figurada que hemos analizado.

\section{Metodología}

Teniendo en cuenta los dos planteamientos que presentó la académica Tognini-Bonelli (2001), nuestro estudio ofrecerá un enfoque guiado por corpus. La autora diferenció entre el corpus-based approach (enfoque basado en corpus) y el corpus-driven approach (enfoque guiado por corpus). Mientras que el enfoque basado en corpus es un planteamiento deductivo por el que se utiliza un corpus para comprobar teorías que ya se tenían planteadas mediante ejemplos ilustrativos, el enfoque guiado por corpus ofrece un planteamiento inductivo donde se utiliza un corpus para extraer datos que permitirán hacer generalizaciones sobre aspectos, conceptos o teorías que son nuevos o todavía desconocidos para el investigador. Ya que no tenemos una hipótesis preestablecida sobre qué puede motivar el uso de los términos cromáticos en el lenguaje figurado, utilizaremos el segundo planteamiento durante nuestra investigación y a través del uso del corpus extraeremos las diversas conclusiones. A continuación pasaremos a describir de forma concreta cuál va a ser nuestra metodología y en qué fases dividiremos nuestra investigación.

\subsection{Selección del corpus monolingüe}

Es importante, primero que nada, diferenciar algunos conceptos de terminología básica de corpus. Cada corpus textual se compone de un número determinado de palabras (en inglés, tokens) que son cada unidad 
lingüística que aparece en el corpus y dentro de este conjunto de palabras hay un número determinado de formas (en inglés, types), que son aquellas palabras distintas dentro del corpus. Una vez definidos estos conceptos podemos comentar que, de forma previa a la realización de nuestro estudio, hemos llevado a cabo un análisis de una serie de corpus lingüísticos, entre los que se encuentran, por ejemplo, los diversos del Banco de Datos de la Real Academia Española (Corpus de Referencia del Español Actual, Corpus Diacrónico del Español, Corpus nuclear del Nuevo Diccionario Histórico del Español, Corpus del Español del Siglo XXI) o el Corpus del Español de Mark Davies. Tras valorar cuál se iba a adaptar más a nuestras necesidades decidimos decantarnos por el de Mark Davies, que contiene alrededor de 100 millones de palabras y se compone de textos que abarcan el período que va del siglo XIII al Xx.

El Corpus del Español de Mark Davies ( $\mathrm{CdE}$, de ahora en adelante) es un corpus anotado que da muchas posibilidades, ya que permite restringir la búsqueda de forma cómoda y organizar los resultados de manera que sea muy fácil extraer conclusiones de forma rápida y organizada. Por todas las opciones de trabajo que ofrece y por el carácter de nuestra investigación, consideramos que es el corpus que más se adapta a nuestro estudio y es el que hemos elegido para realizar el análisis de las expresiones con el término cromático «rojo».

\subsection{Proceso de búsqueda en el corpus seleccionado}

Llevaremos a cabo un análisis cuantitativo y cualitativo de los distintos datos del corpus. El análisis cuantitativo servirá para ver, de forma general, cuántas expresiones con el término cromático «rojo» ofrecen carácter fraseológico y el análisis cualitativo consistirá en ver, dentro de las expresiones con sentido figurado, de qué tipo de fraseologismo se trata, cuál es la connotación encontrada y cuáles son las coocurrencias que presenta a menudo. Para terminar, nos gustaría realizar una clasificación no exhaustiva de las diferentes connotaciones encontradas en las expresiones con color rojo.

Hemos valorado cuál va a ser nuestra forma de búsqueda y, en primer lugar, habíamos pensado realizar las búsquedas usando el asterisco $(*)$, roj*, para que además de obtener el término «rojo», obtuviéramos «roja», "rojos», «rojas», sin embargo, una búsqueda así nos ofrece 52 resultados, entre los que se encuentran palabras derivadas como "rojinegro», "rojizo» o "rojillo», por lo que la búsqueda por lemas será la forma que más se adaptará a nuestros objetivos. El CdE utiliza los corchetes en este tipo de búsquedas, y si realizamos una búsqueda tentativo de [rojo] obtendremos los siguientes resultados: 


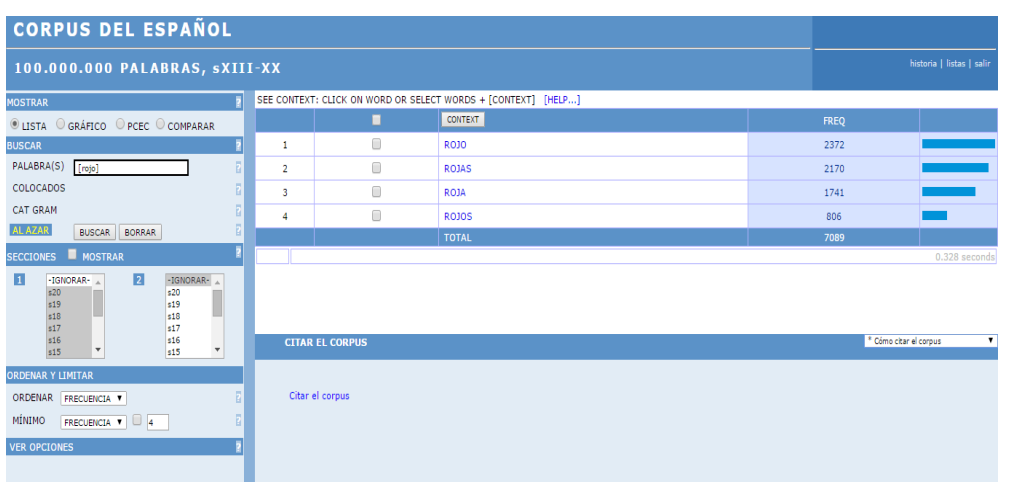

Figura 1

La búsqueda por lemas nos ofrece los términos "rojo», "roja», «rojos» y «rojas» y, como podemos ver en la figura anterior, el CdE ofrece otras posibilidades muy interesantes para ampliar o restringir las búsquedas. Es posible buscar colocaciones con una palabra determinada o también buscar colocaciones con palabras que tengan una categoría gramatical concreta. La búsqueda de colocaciones sería interesante en la fase posterior, cuando procedamos a analizar expresiones metafóricas concretas y los rastros de prosodia semántica de diversas unidades léxicas.

Por último, queremos resaltar dos aspectos de la búsqueda en el CdE. Por un lado, el corpus realiza de forma predefinida la búsqueda de textos solo de los siglos XX y XIX, pero para obtener más resultados y que la variedad de textos sea mayor, hemos decidido realizar una búsqueda del término "rojo» en todos los siglos que están representados en el CdE (del siglo XIII al siglo XX). Por otro lado, el CdE permite realizar la búsqueda en cuatro secciones diferentes: la sección «Oral» presenta textos orales, "Fic» recoge textos de ficción, "Per» contiene textos de periódicos y revistas $\mathrm{y}$, por último, "Acad» ofrece textos académicos. Hemos seleccionado todas las secciones del corpus porque puede ser interesante ver en qué contextos aparecen determinadas expresiones metafóricas y también porque la sección de textos orales puede ayudarnos a demostrar que este tipo de expresiones en sentido figurado están a la orden del día en el habla de los españoles y no son solo una herramienta embellecedora de la lengua escrita.

\subsection{Proceso de clasificación de los resultados obtenidos}

El corpus ordena automáticamente los diferentes resultados por sección, siglo y texto y nuestro objetivo es obtener resultados que representen todas las secciones del corpus y no solo los que primero aparezcan. Es aquí donde hemos dejado de lado la forma de búsqueda por listas que ofrece el $\mathrm{CdE}$ de forma predefinida y hemos pasado a realizar la búsqueda mediante KWIC, que responde a las siglas en inglés de Keyword in Context o lo que es lo mismo en español, palabra clave en su contexto (PCEC). Se trata de la expresión de una palabra clave (en nuestro caso «rojo») y el contexto que aparece delante y detrás de la 
palabra para que podamos comprobar el significado de forma clara. En el Corpus del Español de Mark Davies se presenta de la siguiente forma:
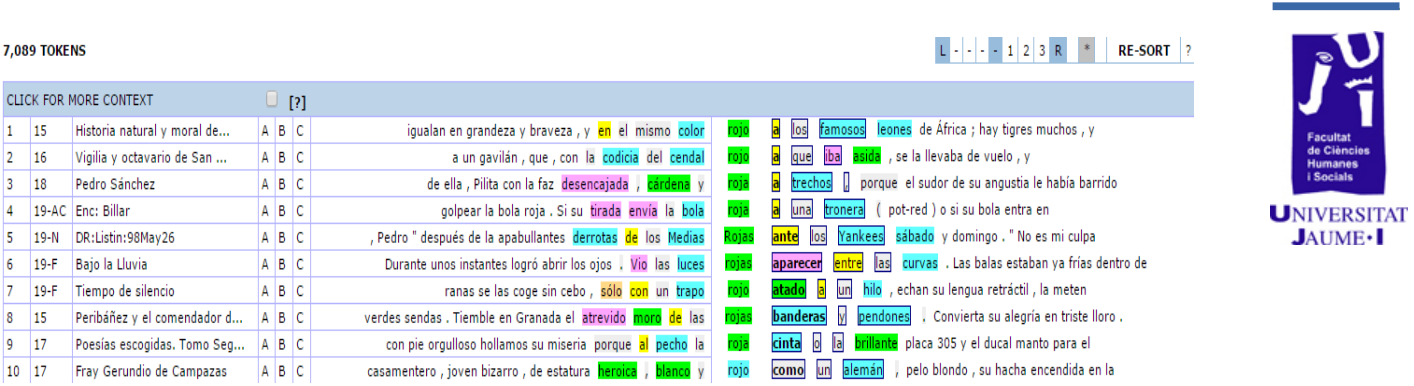

Al ser un estudio introductorio, realizaremos la clasificación de forma casi manual, siguiendo el método Pragglejaz, que se explica en la siguiente fase. Antes que nada, queremos explicar los colores representados en la figura anterior. Cada color hace referencia a una categoría gramatical concreta:

Esto es posible porque el CdE es un corpus anotado, sin embargo, la anotación de un corpus se hace de forma semiautomática y a veces puede fallar, por lo que hay que estar seguro antes de extraer conclusiones. Ejemplo de ello es el KWIC 1 de la Figura 2, donde "famosos» está anotado como un sustantivo, ya que aparece en azul, al igual que "leones», pero en este caso "famosos» cumple la función de adjetivo por lo que debería aparecer subrayado en color verde. Esta opción puede ser muy práctica, pero se deberá usar con sumo cuidado y de forma orientativa para no presentar datos erróneos durante el estudio.

A la hora de determinar qué expresiones tienen sentido figurado hemos decidido seguir el método Pragglejaz, que pretende buscar el significado metafórico de las palabras. Uno de sus precursores en la escuela holandesa, Steen, propuso en su artículo de 2007 los siguientes pasos para dar con la metáfora canónica en el discurso:

- Leer el texto completo para entender de qué se trata.

- Decidir cuáles son los límites de las palabras.

- Establecer el significado contextual de las palabras examinadas.

- Determinar el significado básico de la palabra (más concreta, orientada a las personas y específica).

- Decidir si el significado básico de la palabra es lo suficientemente distinto del significado contextual.

- Decidir si el significado contextual de la palabra se puede relacionar con el significado más básico mediante algún tipo de similitud. 
Hemos decidido dividir el proceso de clasificación de los resultados del $\mathrm{CdE}$ en dos fases. En una primera fase llevaremos a cabo una selección de 700 palabras en su contexto, algo que nos permitirá abordar un estudio más cuantitativo antes de entrar en materia y nos permitirá tener una muestra de expresiones que analizaremos posteriormente. En la segunda fase se procederá a analizar unas 100 coocurrencias para así poder clasificar de forma más sencilla el papel de los términos del color dentro de estas coocurrencias.

\subsubsection{Clasificación de las expresiones metafóricas}

En un primer acercamiento realizamos una búsqueda de 200 expresiones u oraciones en las que aparecía el término "rojo» y en una segunda parte de la primera fase decidimos ampliar la búsqueda a 500 expresiones más ya que comprobamos que con 200 expresiones solamente no teníamos suficiente para extraer la información que necesitábamos para generalizar, por lo que en total analizamos $700 \mathrm{KWIC}$ con el término "rojo». A continuación presentamos las expresiones que hemos considerado que tienen sentido metafórico, según el método Pragglejaz:

\begin{tabular}{|c|c|c|c|c|c|}
\hline 1 & $19-\mathrm{F}$ & $\begin{array}{l}\text { La víspera y } \\
\text { el día }\end{array}$ & $\begin{array}{c}\text { sus citas amorosas en } \\
\text { ese mismo momento. } \\
\text { El coronel, }\end{array}$ & rojo & $\begin{array}{l}\text { de ira pidió a su leal } \\
\text { informante que lo } \\
\text { acompañara como }\end{array}$ \\
\hline 2 & $19-\mathrm{AC}$ & $\begin{array}{l}\text { Enc: China } \\
\text { (república) }\end{array}$ & $\begin{array}{c}\text { sobre las relaciones } \\
\text { exteriores. La actitud } \\
\text { de los } \\
\text { guardias } \\
\end{array}$ & rojos & \begin{tabular}{|l|}
\multicolumn{1}{|c|}{ inspiró } \\
comportamientos \\
similares en Hong \\
Kong que dieron \\
\end{tabular} \\
\hline 3 & $19-N$ & $\begin{array}{l}\text { Cuba: } \\
\text { CubaNet: } \\
\text { 98May5 }\end{array}$ & $\begin{array}{l}\text { hemos decidido hacer } \\
\text { esta ponencia. El } \\
\text { problema de la } \\
\text { carne }\end{array}$ & roja & $\begin{array}{c}\text { tiene solución } \\
\text { solamente dando } \\
\text { autorización a todo el } \\
\text { que }\end{array}$ \\
\hline 4 & $19-A C$ & $\begin{array}{l}\text { Enc: Teoría } \\
\text { cuántica }\end{array}$ & $\begin{array}{l}\text { sin reflejar ninguna). } \\
\text { Un cuerpo a } \\
\text { temperatura alta }- \text { al }\end{array}$ & rojo & $\begin{array}{l}\text { vivo- emite la mayor } \\
\text { parte de su radiación } \\
\text { en las zonas de }\end{array}$ \\
\hline 5 & $19-N$ & $\begin{array}{l}\text { Arg: Prensa: } \\
\text { 260_COY }\end{array}$ & $\begin{array}{c}\text { navegación a las } 8,20 \\
\text { se recibió a bordo un } \\
\text { alerta }\end{array}$ & rojo & $\begin{array}{c}\text { guardacostas por parte } \\
\text { de aviones británicos } \\
\text { fue }\end{array}$ \\
\hline 6 & $19-\mathrm{F}$ & $\begin{array}{l}\text { La catedral } \\
\text { sumergida }\end{array}$ & $\begin{array}{l}\text { de gris, que ladean mis } \\
\text { mejillas. Las sentí } \\
\text { volverse }\end{array}$ & rojas & $\begin{array}{l}\text { a causa de la ira que } \\
\text { se adueñó de mí al } \\
\text { proseguir }\end{array}$ \\
\hline 7 & $19-\mathrm{N}$ & $\begin{array}{l}\text { Méx: } \\
\text { Yucatán: } \\
\text { 97Jun13 }\end{array}$ & $\begin{array}{l}\text {, m. } 46 \text { Stoitchkov, } \\
\text { m. } 72 \text { Ivanov: . m. } 87, \\
\text { Tarjeta }\end{array}$ & roja & $\begin{array}{l}\text { a Nankov por doble } \\
\text { amonestación. } \\
\text { Incidencias: Primer } \\
\text { partido }\end{array}$ \\
\hline 8 & 18 & $\begin{array}{c}\text { Las ilusiones } \\
\text { del doctor } \\
\text { Faustino }\end{array}$ & $\begin{array}{c}\text { qué desenlace van a } \\
\text { tener? D. Faustino se } \\
\text { puso }\end{array}$ & rojo & $\begin{array}{l}\text { como la grana y bajó } \\
\text { los ojos al suelo, } \\
\text { guardando silencio }\end{array}$ \\
\hline 9 & 18 & $\begin{array}{l}\text { El doncel de } \\
\text { Don Enrique }\end{array}$ & $\begin{array}{l}\text { de los feudales señores } \\
\text { de la época. El sol, }\end{array}$ & rojo & $\begin{array}{l}\text { como la lumbre, } \\
\text { despidiendo sus rayos }\end{array}$ \\
\hline
\end{tabular}




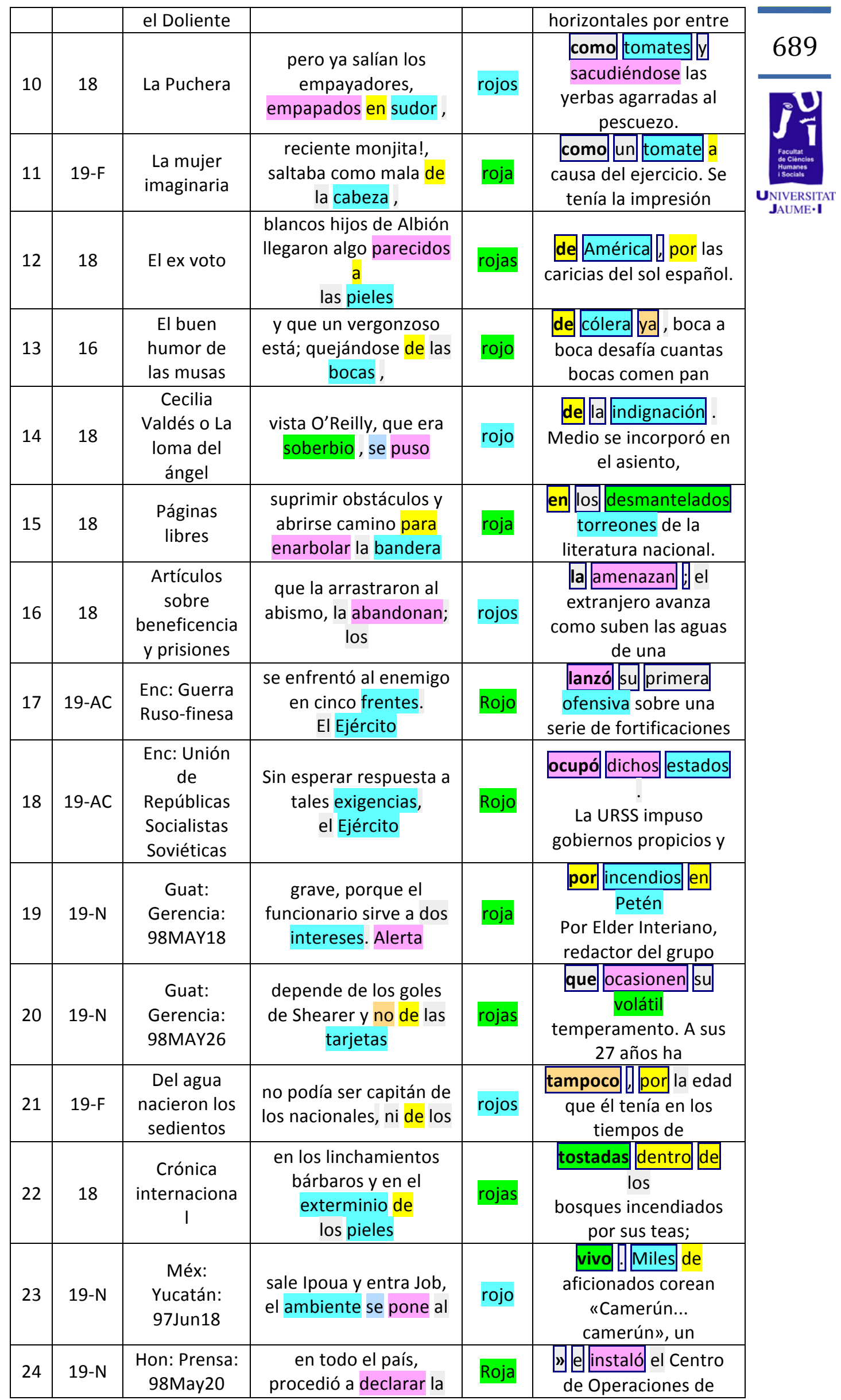




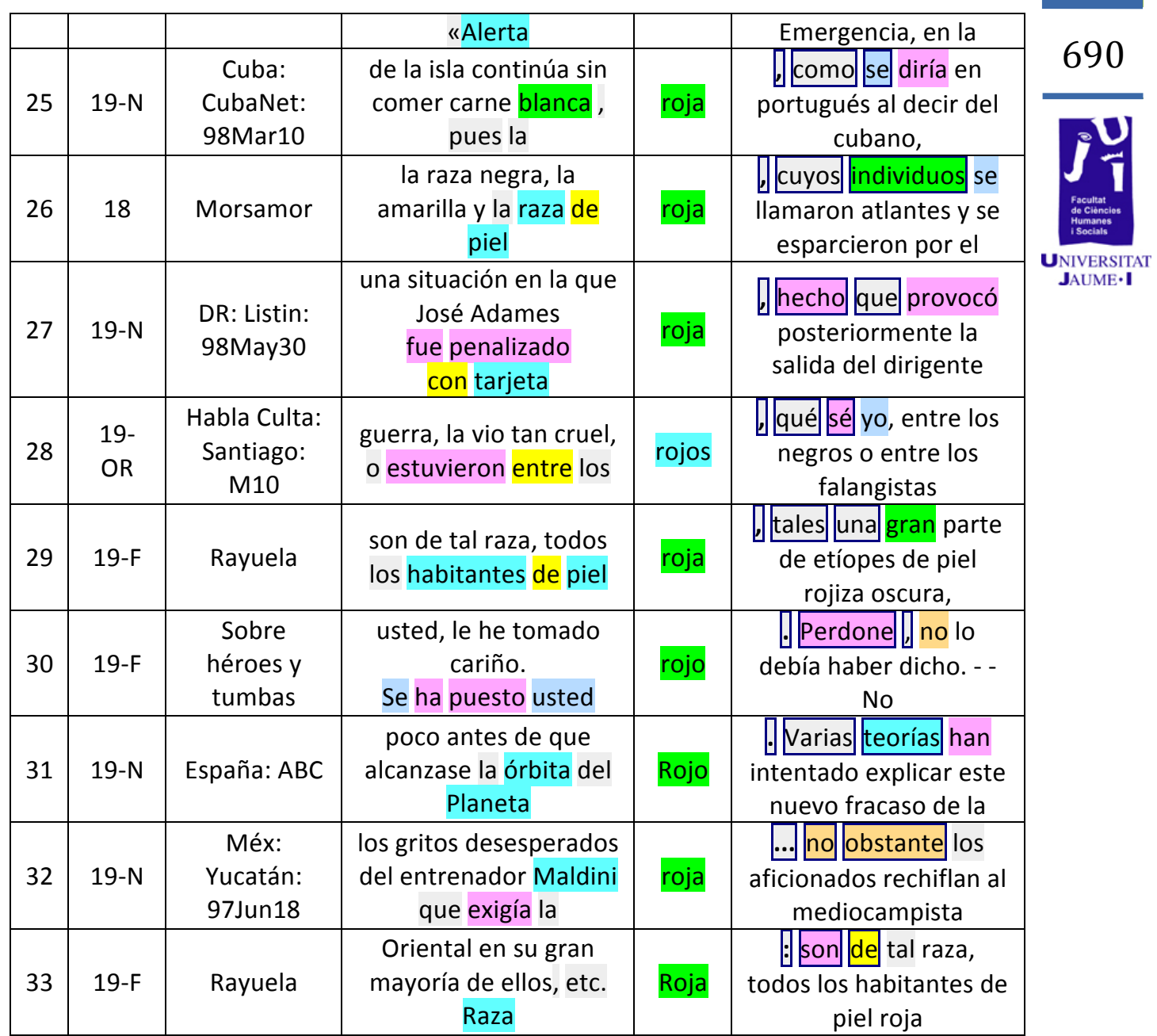

\subsubsection{Análisis de las coocurrencias}

Durante la segunda fase de nuestra investigación intentaremos analizar cuáles son las coocurrencias más comunes del color rojo. Para ello, es importante definir el concepto de colocación y relacionarlo con las unidades fraseológicas. Coseriu (1981:128) define las «colocaciones»o "clichés léxicos» como sintagmas léxicos prefijados de forma tradicional, y para Gloria Corpas (2003:69) las «colocaciones» son a su vez unidades fraseológicas porque son poliléxicas, sus elementos integrantes coaparecen o coocurren con alta frecuencia y tienen otras características compartidas con los fraseologismos, como la institucionalización, la estabilidad, la idiomaticidad y la posibilidad de variación.

Por este motivo, es importante analizar cuáles son las colocaciones más comunes de este término cromático, ya que nos permitirá ver con qué suele coocurrir el color rojo y si la connotación de este conjunto léxico es mayormente positivo o negativo. Esta diferenciación responde al paradigma que Morley y Partington ofrecieron en su estudio de 2009, donde las valoraciones se ofrecen en realidades opuestas: positivo/negativo, bueno/malo, deseado/no deseado, favorable/no 
favorable, recomendable/no recomendable. A continuación mostramos las 100 colocaciones más frecuentes del término «rojo»:

\begin{tabular}{|c|c|c|}
\hline 1 & cruz & 360 \\
\hline 2 & sangre & 192 \\
\hline 3 & color & 175 \\
\hline 4 & mar & 137 \\
\hline 5 & blanco & 126 \\
\hline 6 & azul & 111 \\
\hline 7 & labios & 98 \\
\hline 8 & verde & 97 \\
\hline 9 & luz & 93 \\
\hline 10 & blanca & 75 \\
\hline 11 & negro & 74 \\
\hline 12 & amarillo & 72 \\
\hline 13 & azules & 71 \\
\hline 14 & lope & 66 \\
\hline 15 & blancas & 63 \\
\hline 16 & francisco & 63 \\
\hline 17 & glóbulos & 61 \\
\hline 18 & verdes & 61 \\
\hline 19 & ejército & 61 \\
\hline 20 & villa & 61 \\
\hline 21 & flores & 52 \\
\hline 22 & alvar & 48 \\
\hline 23 & bandera & 47 \\
\hline 24 & soto & 44 \\
\hline 25 & gabriel & 44 \\
\hline 26 & rojo & 43 \\
\hline 27 & blancos & 43 \\
\hline 28 & enrique & 40 \\
\hline 29 & rosa & 38 \\
\hline 30 & roberto & 37 \\
\hline 31 & terciopelo & 36 \\
\hline 32 & medias & 36 \\
\hline 33 & pelo & 36 \\
\hline 34 & rayos & 34 \\
\hline 35 & sánchez & 33 \\
\hline 36 & luces & 33 \\
\hline 37 & rosas & 32 \\
\hline 38 & vestido & 32 \\
\hline 39 & vivo & 32 \\
\hline 40 & corresponsalía & 31 \\
\hline 41 & alerta & 30 \\
\hline 42 & púrpura & 29 \\
\hline 43 & amarillas & 28 \\
\hline 44 & seda & 28 \\
\hline 45 & oriente & 28 \\
\hline 46 & sindical & 27 \\
\hline 47 & colores & 27 \\
\hline 48 & agustín & 26 \\
\hline 49 & piel & 26 \\
\hline 50 & amarillos & 25 \\
\hline
\end{tabular}

\begin{tabular}{|c|c|c|}
\hline 51 & canciller & 25 \\
\hline 52 & brillante & 25 \\
\hline 53 & oscuro & 25 \\
\hline 54 & señoras & 24 \\
\hline 55 & negros & 24 \\
\hline 56 & clavel & 23 \\
\hline 57 & sandoval & 23 \\
\hline 58 & mejillas & 23 \\
\hline 59 & cuello & 23 \\
\hline 60 & manuel & 23 \\
\hline 61 & intenso & 22 \\
\hline 62 & banda & 22 \\
\hline 63 & vergüenza & 22 \\
\hline 64 & cabellos & 22 \\
\hline 65 & gris & 21 \\
\hline 66 & tinta & 21 \\
\hline 67 & mancha & 21 \\
\hline 68 & negra & 21 \\
\hline 69 & trapo & 20 \\
\hline 70 & manchas & 20 \\
\hline 71 & apolo & 20 \\
\hline 72 & punta & 20 \\
\hline 73 & arçobispo & 19 \\
\hline 74 & claveles & 18 \\
\hline 75 & vestida & 18 \\
\hline 76 & barba & 18 \\
\hline 77 & fernández & 18 \\
\hline 78 & capa & 18 \\
\hline 79 & humor & 18 \\
\hline 80 & zorrilla & 17 \\
\hline 81 & independiente & 17 \\
\hline 82 & tarjeta & 16 \\
\hline 83 & alfombra & 16 \\
\hline 84 & amarilla & 16 \\
\hline 85 & cinta & 16 \\
\hline 86 & roja & 16 \\
\hline 87 & jorge & 16 \\
\hline 88 & pinilla & 15 \\
\hline 89 & algas & 15 \\
\hline 90 & lápiz & 15 \\
\hline 91 & violeta & 15 \\
\hline 92 & grana & 15 \\
\hline 93 & pieles & 15 \\
\hline 94 & guardias & 15 \\
\hline 95 & gallo & 15 \\
\hline 96 & simón & 15 \\
\hline 97 & cristóbal & 15 \\
\hline 98 & manto & 15 \\
\hline 99 & enorme & 15 \\
\hline 100 & nubes & 15 \\
\hline
\end{tabular}


En el presente apartado analizaremos cuál ha sido el número exacto de expresiones metafóricas o en sentido figurado encontradas entre las 700 que hemos analizado, clasificaremos estos resultados y a través de estos analizaremos la prosodia semántica que analizamos durante la segunda fase. El proceso de cuantificación de las expresiones no ha sido difícil debido a que el número de frases metafóricas que hemos encontrado en el corpus se ha mantenido siempre en una cifra manejable. Consideramos que de haber analizado otro color, como el blanco o el negro, habríamos obtenido un mayor número de resultados y también un mayor número de expresiones representativas del sentido figurado.

\subsection{Resultados cuantitativos}

A continuación, ofrecemos la lista de expresiones en sentido figurado en las que aparece el color rojo, teniendo en cuenta el número de apariciones obtenidas en el Corpus del Español de Mark Davies:

\begin{tabular}{|c|c|c|c|c|}
\hline Forma & Palabras & Metafóricas & Porcent. & Ejemplos \\
\hline [rojo] & 7089 & 33 & $0,46 \%$ & \\
\hline rojo & 2372 & 12 & $0,17 \%$ & $\begin{array}{l}\text { - rojo de la ira } \\
\text { - al rojo vivo }(x 2) \\
\text { - alerta rojo } \\
\text { - ponerse rojo } \\
\text { - ponerse rojo como la grana } \\
\text { - rojo como la lumbre } \\
\text { - rojo de cólera } \\
\text { - ponerse rojo de la indignación } \\
\text { - Ejército Rojo (x2) } \\
\text { - Planeta Rojo }\end{array}$ \\
\hline roja & 1741 & 12 & $0,17 \%$ & $\begin{array}{l}\text { - } \text { carne roja }(\times 2) \\
\text { - } \text { tarjeta roja }(\mathrm{x} 3) \\
\text { - } \text { roja como un tomate } \\
\text { - } \text { bandera roja } \\
\text { - } \text { alerta roja }(\times 2) \\
\text { - piel roja }(\times 2) \\
\text { - } \text { raza roja } \\
\end{array}$ \\
\hline rojos & 806 & 5 & $0,07 \%$ & $\begin{array}{l}\text { - guardias rojos } \\
\text { - rojos como tomates } \\
\text { - los rojos (x3) }\end{array}$ \\
\hline rojas & 2170 & 4 & $0,06 \%$ & 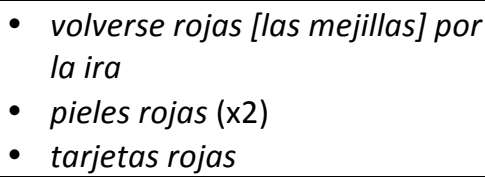 \\
\hline
\end{tabular}


5.2. Resultados cualitativos

Una vez recogidos los resultados de nuestro pequeño análisis del sentido figurado de las expresiones con el término "rojo» hemos definido las expresiones para clarificar su significado uno a uno:

\begin{tabular}{|c|c|}
\hline KWIC 1 & $\begin{array}{l}\text { «Estar rojo de ira» es una expresión metafórica que denota un gran } \\
\text { enfado o irritación por algo. }\end{array}$ \\
\hline KWIC 2 & $\begin{array}{l}\text { Los «Guardias rojos» eran un movimiento de masas comunista } \\
\text { promovido en China por Mao Zedong. }\end{array}$ \\
\hline KWIC 3 & $\begin{array}{l}\text { Con «carne roja» se hace referencia a la carne que tiene un color rosado } \\
\text { cuando está cruda. }\end{array}$ \\
\hline KWIC 4 & $\begin{array}{l}\text { Algo que se encuentra «al rojo vivo» tiene la apariencia de brasas } \\
\text { encendidas, ya sea por su color o por la temperatura que ha alcanzado }\end{array}$ \\
\hline KWIC 5 & $\begin{array}{l}\text { "Alerta rojo» (o roja) hace referencia al nivel más alto de amenaza frente } \\
\text { a algo. }\end{array}$ \\
\hline KWIC 6 & Definición KWIC 1. \\
\hline KWIC 7 & $\begin{array}{l}\text { La «tarjeta roja» es la penalización máxima que se puede obtener en el } \\
\text { ámbito deportivo. En ocasiones se utiliza en otros contextos para denotar } \\
\text { algo que no se puede admitir. }\end{array}$ \\
\hline KWIC 8 & $\begin{array}{c}\text { «Ponerse rojo como la grana» implica que las mejillas de una persona } \\
\text { también se vuelven coloradas debido a la vergüenza, otro de los estados } \\
\text { de ánimo que denota el color rojo. }\end{array}$ \\
\hline KWIC 9 & $\begin{array}{l}\text { «Estar rojo como la lumbre» hace referencia a algo que tiene un tono rojo } \\
\text { muy intenso. }\end{array}$ \\
\hline KWIC 10 & $\begin{array}{l}\text { «Estar rojo como un tomate» es una expresión que se utiliza muy a } \\
\text { menudo en español pero que no denota un estado de ánimo concreto. Se } \\
\text { puede «estar rojo como un tomate» debido a un sofoco por hacer un } \\
\text { esfuerzo, al sol, a un enfado puntual, etc. }\end{array}$ \\
\hline KWIC 11 & Definición KWIC 10. \\
\hline KWIC 12 & $\begin{array}{l}\text { Aunque algunos consideran «pieles rojas» como un término ofensivo, se } \\
\text { trata de la forma de referirse a los pueblos indígenas de América y a la } \\
\text { raza a la que pertenecen. }\end{array}$ \\
\hline KWIC 13 & «Estar rojo de cólera» es sinónimo de «estar rojo de ira». \\
\hline KWIC 14 & $\begin{array}{l}\text { «Ponerse rojo de la indignación» implica ponerse rojo también por este } \\
\text { motivo también. }\end{array}$ \\
\hline KWIC 15 & $\begin{array}{c}\text { «Bandera roja» es la bandera socialista y comunista, por lo que enarbolar } \\
\text { la bandera roja puede significar el luchar por estos ideales. }\end{array}$ \\
\hline KWIC 16 & «Los rojos» son los opositores de la derecha, con ideología comunista. \\
\hline KWIC 17 & $\begin{array}{l}\text { El «Ejército Rojo» es el Ejército de la República Socialista Federativa } \\
\text { Soviética de Rusia. }\end{array}$ \\
\hline KWIC 18 & Definición KWIC 17. \\
\hline KWIC 19 & Definición KWIC 5. \\
\hline KWIC 20 & Definición KWIC 7. \\
\hline KWIC 21 & Definición KWIC 16. \\
\hline KWIC 22 & Definición KWIC 12. \\
\hline KWIC 23 & Definición KWIC 4. \\
\hline KWIC 24 & Definición KWIC 5. \\
\hline KWIC 25 & Definición KWIC 3. \\
\hline KWIC 26 & Definición KWIC 12. \\
\hline KWIC 27 & Definición KWIC 7. \\
\hline KWIC 28 & Definición KWIC 16. \\
\hline
\end{tabular}




\begin{tabular}{|c|c|}
\hline KWIC 29 & Definición KWIC 12. \\
\hline KWIC 30 & Definición KWIC 8. \\
\hline KWIC 31 & «Planeta rojo»: se trata de Marte, expresión que se utiliza debido al color \\
& de su superficie terrestre. \\
\hline KWIC 32 & Definición KWIC 7. \\
\hline KWIC 33 & «Raza roja»: Es la raza que poseían los pieles rojas, indígenas de América. \\
\hline
\end{tabular}

\subsubsection{Clasificación de las expresiones con sentido figurado}

De las definiciones anteriores se podría realizar la siguiente clasificación no exhaustiva de la primera fase:

- Grupo 1: estados de ánimo:

- ira, enfado, cólera (volverse rojo de ira/cólera)

○ vergüenza (ponerse rojo de vergüenza, volverse rojo como la grana)

○ indignación (ponerse rojo de indignación)

- Grupo 2: momentos históricos/políticos:

- bandera roja

- los rojos, Ejército Rojo

- pieles rojas/raza roja

○ zona roja

- Grupo 3: indicación de peligro o falta:

○ tarjeta roja

- alerta roja

○ números rojos

- Grupo 4: Otros:

○ carne roja

- planeta rojo

- marea roja

Como podemos comprobar en la clasificación anterior, la gran mayoría de expresiones que hemos encontrado recogen, además de las diversas connotaciones que el color tiene histórica y políticamente, una connotación negativa (enfado, indignación, vergüenza, etc.), o bien pretenden transmitir una sensación de peligro (alerta, zona roja, etc.). Esto lo confirman, además, expresiones como "línea roja», "luz roja», "teléfono rojo», etc. Tal y como explican Soriano y Valenzuela (2009), la connotación de un conjunto léxico, como los que aparecen en la clasificación anterior, dependen en gran medida de la asociación de los términos cromáticos con situaciones u objetos de la vida real donde este color está presente, como por ejemplo la luz roja que se enciende a menudo en situación de alerta o el color rojo que tiene la sangre. Esto hace que se hayan creado una serie de asociaciones que han llevado a la connotación de algunos términos del color. Si bien esta connotación depende de la experiencia personal de cada uno, puede haber diferencias entre lenguas y colores. 


\subsubsection{Análisis de la connotación}

Durante esta segunda fase, procederemos a analizar los rastros de prosodia semántica obtenidos, teniendo en cuenta aquello que hemos explicado sobre connotación en el marco teórico y valorando la lista de colocaciones que ofrecemos en la fase de análisis de las coocurrencias. Consideramos que es interesante analizar la connotación de las diversas unidades fraseológicas porque este tipo de expresiones dan mucha información sobre la forma de pensar y argumentar en un texto, así que es interesante ver si estas valoraciones son positivas o negativas y esto es un aspecto que se puede estudiar analizando la prosodia semántica presente en estas.

Tomando la lista de coocurrencias más comunes del término cromático "rojo», que hemos incluido en el apartado 4.3.2, hemos realizado la búsqueda de cada unidad léxica $y$, analizando los 100 primeros resultados obtenidos en el $\mathrm{CdE}$, hemos seleccionado aquellas colocaciones que sí que son interesantes para nuestro estudio por presentar sentido metafórico o metonímico. Hemos limitado la búsqueda a cuatro palabras a izquierda y derecha, ya que «rojo» funcionará prácticamente siempre en nuestro caso como adjetivo y no creemos que sea necesario ampliar el rango de búsqueda en este caso.

En un gran número de casos, las coocurrencias no eran colocaciones de ningún tipo, como es el caso del término rojo cuando aparecía con otros términos cromáticos (verde, blanco, azul, etc.), con nombres propios (arçobispo Rojas, Lope Alvar de Rojas, Francisco Rojas, Jesús Villa Rojo, Pedro Soto de Rojas, etc.) o cuando simplemente el término cromático funcionaba como adjetivo calificativo de un sustantivo determinado (labios rojos, flores rojas, rosas rojas, clavel rojo, mejillas rojas, etc.). De la lista, hemos descartado todos estos casos para eliminar el mayor ruido posible a nuestro estudio y también hemos suprimido aquellas expresiones que presentaban significado metonímico, ya que son expresiones en las que simplemente se resalta un aspecto de la realidad (en este caso que la entidad es de color rojo o presenta este color como uno de los que contiene) para hacer referencia al conjunto completo y formar parte de su denominación. Serían los casos de "mar Rojo», "glóbulos rojos», "Medias Rojas», "rayos rojos», "cabellos rojos», "Gran Mancha Roja» y "algas rojas». En la siguiente tabla presentamos aquellas unidades léxicas con sentido figurado que estudiaremos en profundidad. En la segunda columna detallamos cuál es la palabra que coocurre con el término cromático, en la tercera especificamos el número de colocaciones que presenta el CdE para cada caso y en la tercera columna damos la coocurrencia que aparece de forma más común: 


\begin{tabular}{|c|c|c|c|}
\cline { 2 - 4 } \multicolumn{1}{c|}{} & $\begin{array}{c}\text { Palabra } \\
\text { coocurrente }\end{array}$ & $\begin{array}{c}\text { Número de } \\
\text { resultados }\end{array}$ & Colocación más común \\
\hline 9 & luz & 93 & luz roja \\
\hline 19 & ejército & 61 & Ejército Rojo \\
\hline 23 & bandera & 47 & bandera roja \\
\hline 39 & vivo & 32 & alejo vivo \\
\hline 41 & alerta & 30 & piel roja \\
\hline 49 & piel & 26 & rojo de vergüenza \\
\hline 63 & vergüenza & 22 & tarjeta roja \\
\hline 82 & tarjeta & 16 & rojo como la grana \\
\hline 92 & grana & 15 & Guardias Rojos \\
\hline 94 & guardias & 15 & \\
\hline
\end{tabular}

Analizar la prosodia semántica de unidades léxicas con términos cromáticos será una tarea difícil ya que los términos cromáticos suelen aparecer como adjetivos calificativos y la carga semántica de estos no es tan valorativa como podrían serlo adjetivos como "bueno», "agradable» o «denigrante». Aún así procederemos a guiarnos por el contexto que nos da cada KWIC y dividiremos el análisis en tres grupos, siguiendo la clasificación no exhaustiva ofrecida en la fase anterior y dejando de lado el grupo 4, que presentaba mayormente unidades léxicas metonímicas como las descartadas anteriormente.

Grupo 1: estados de ánimo

$$
\text { «rojo de vergüenza» }
$$

Prosodia semántica: negativa, vergüenza, ira

Frecuencia: $12 / 22$

(1). [...] La primera clase fue caótica y la vergüenza tiñó de rojo hasta las paredes. Mi madre dijo que, evidentemente, la profesora no servía [...]

(2). [...] Saltamos de la cama, dichosos, aturdidos, y la tía Julia, roja de vergüenza, se acomodaba la ropa y yo, cerrando los ojos, como [...]

(3). [...] estaba muerta», fue lo primero que contra toda evidencia dijo y se puso rojo de vergüenza porque aquello no era más que una disculpa dirigida a calmar el odio [...]

(4). [...] ilos sexos! (todavía, al recordar ese detalle, se ponía roja de vergüenza), y las figuras alrededor de [...]

(5). [...] al salir de la escuela, con lo cual nos poníamos rojos de vergüenza y de ira. Inmediatamente echaba sobre el mostrador una pieza de [...]

(6). [...] el rostro de la pecadora, rojo de vergüenza por primera vez en su vida, ocultóse en el casto pecho de [...]

(7). [...] sillón en un rincón: cayó en él, y abrumó de nuevo la vergüenza roja de su faz entre los brazos... [...]

(8). [...] le pregunté si ya no la quería. Su contestación fue callarse y ponerse rojo de vergüenza $[\ldots]$

(9). [...] de ser su víctima. Sólo de pensarlo la cara se me pone roja de vergüenza. 
Pero líbreme Dios también de [...]

(10). [...] cavilaciones que le herían y emponzoñaban el alma y sacaban a su rostro el color rojo de la vergüenza. ¿Qué héroe de tan ruin condición era él cuando [...]

(11). [...] Ven acá, quítame esto que me oprime como unas tenazas. Ana estaba roja de vergüenza y de ira. Sentía una indignación tan grande como la cólera de $[\ldots]$

(12). [...] iY allí fue el apuro de la infeliz! Vaciló unos momentos, roja de vergüenza y temblándole la mano; [...]

«rojo como la grana»

Prosodia semántica: negativa, pánico

Frecuencia: 6/15

(1). [...] Ya se ponía pálido como la muerte, ya rojo como la grana. Ora sentía un desvanecimiento parecido al vértigo; [...]

(2). [...] aproximándose luego a ella con inquietud al ver que, después de haberse puesto roja como la grana de su saya, palidecía y vacilaba como si fuera a caerse $[\ldots]$

(3). [...] D. Faustino se puso rojo como la grana y bajó los ojos al suelo, guardando silencio. [...]

(4). [...] Doña Luz se puso roja como la grana. Toda la sangre de su cuerpo se diría que se le subió a la cabeza. [...]

(5). [...] se había propuesto inaugurar la entrevista, y se presentó también trémulo, también rojo como la grana, prolongando tanto sus mudas reverencias que dieron tiempo a la favorita [...]

(6). [...] Stein se puso rojo como la grana, menos de indignación que de vergüenza. - Sobre que ese [...]

Grupo 2: momentos históricos/políticos:

\author{
«Ejército Rojo» \\ Prosodia semántica: negativa, guerra \\ Frecuencia: 19/61
}

(1). [...] Le conocí en la guerra. Él era capitán del ejército rojo; yo estaba al mando de una compañía de nuestro Glorioso Ejército Nacional. [...]

(2). [...] sobrevivió a los progromos de sus años infantiles y a la barbarie del Ejército Rojo y de los nazis y por eso, [...]

(3). [...] esconde todavía uno de los más fabulosos tesoros artísticos, producto del pillaje del Ejército Rojo, vencedor de la Alemania nazi en la II Guerra Mundial. Cientos de obras [...]

(4). [...] donde dio a conocer las primeras noticias sobre los fabulosos tesoros que el Ejército Rojo escondía en la URSS. [...]

(5). [...] que redujo en una cuarta parte las fuerzas del Ejército Rojo (nombre genérico que servía para denominar a las tropas comunistas desde la Larga Marcha) [...]

(6). [...] Así comenzó la II Guerra Mundial. Dieciséis días más tarde el Ejército Rojo cruzaba la frontera polaca, ocupaba la parte oriental de Polonia y comenzaba la 
sovietización $[\ldots]$

(7). [...] soviéticas por sus respectivos territorios. Sin esperar respuesta a tales exigencias, el Ejército Rojo ocupó dichos estados. La URSS impuso gobiernos propicios y reprimió a todos los elementos [...]

(8). [...] donde fueron hostigadas por la milicia campesina y aniquiladas poco a poco por el Ejército Rojo. Sin embargo, [...]

(9). [...] Gracias a la labor del Ejército Rojo, creado y organizado por Liev Trotski, el régimen soviético salió triunfante de este [...]

(10). [...] el Ejército Rojo soviético atacó la frontera. Prácticamente toda Polonia había sido invadida el 20 de septiembre [...]

(11). [...] mediante una reacción violenta y autodestructiva. En Alemania, la llamada Fracción del Ejército Rojo, más conocida como grupo Baader - Meinhof, efectuó numerosos atracos a bancos y [...]

(12). [...] pero fueron repelidos y derrotados en noviembre por el Ejército Rojo. Wrangel y sus tropas abandonaron Rusia [...]

(13). [...] medida incluida en el comunismo de guerra. A mediados de 1921, el Ejército Rojo había sometido a casi todas las bandas [...]

(14). [...] campo. En esta misma época, el Ejército Rojo invadió Transcaucasia, que volvió a quedar bajo control bolchevique. [...]

(15). [...] cuando el líder ruso lósiv Stalin, buscando la seguridad soviética, utilizó al Ejército Rojo para controlar gran parte de [...]

(16). [...] bombardeó Helsinki y otras ciudades, la armada atacó varios puertos fineses y el Ejército Rojo penetró en el país. Los soviéticos desplegaron veinte divisiones completas a lo largo de [...]

(17). [...] El Ejército Rojo lanzó su primera ofensiva sobre una serie de fortificaciones denominada Línea Mannerheim, [...]

(18). [...] de la Línea Mannerheim, que fue ocupada el 11 de marzo por el Ejército Rojo. La lucha cesó el 12 de marzo de 1940. [...]

(19). [...] y el 13 de febrero Budapest cayó en manos del Ejército Rojo soviético. EI gobierno provisional instituyó, [...]

$$
\text { «bandera roja» }
$$

Prosodia semántica: negativa, movimiento revolucionario

Frecuencia: 3/47

(1). [...] También extraño la bandera roja, que era la de los socialistas liberales rusos, y también la de los bolcheviques. [...]

(2). [...] las muy escasas vacaciones que tomaba, mientras paseaba por los muelles descubrió la bandera roja de la URSS en la popa [...]

(3). [...] y del 48, donde todavía se descarga el palo en los manifestantes de bandera roja y se disuelve a tiros las aglomeraciones de huelguistas, nos dice muy bien que $[\ldots]$

$$
\text { «piel roja» }
$$

Prosodia semántica: positiva (¿’), raza

Frecuencia: $6 / 26$

(1). [...] irrefutablemente la estructura humana, sea la de un chino o la de un piel 
roja. Lenguaje quiere decir residencia [...]

(2). [...] Raza Roja: son de tal raza, todos los habitantes de piel roja, tales una gran parte de etíopes de piel rojiza oscura, donde [...]

(3). [...] cuenta en el Libro que «aquel que sentía la necesidad de ser un piel roja, un guerrero de una época anterior a la leyenda [...]

(4). [...] de civilización. Así la raza negra, la amarilla y la raza de piel roja, cuyos individuos se llamaron atlantes y se esparcieron por el mundo cuando la Atlántida

(5). [...] Planeta, nada más natural que la supresión del negro en África, del piel roja en Estados Unidos, del tagalo en Filipinas, del indio en el Perú. [...]

(6). [...] jefes blancos pasaron Missouri arriba, diciendo que eran amigos de los hombres de piel roja. Este país pertenece a los pieles rojas, pero sus hermanos blancos lo atraviesan [...]

$$
\text { «Guardias Rojos» }
$$

Prosodia semántica: negativa, movimiento revolucionario

Frecuencia: $8 / 15$

(1). [...] socialismo completo, Mao contraatacó y movilizó a la juventud a través de los guardias rojos durante la Revolución Cultural proletaria (1966 - 1969), promovidos para atacar [...]

(2). [...] los enfrentamientos entre maoístas y antimaoístas, así como entre diferentes facciones de los guardias rojos, costaron miles de vidas. En algunas zonas la rebelión condujo a la anarquía [...]

(3). [...] había estado a punto de conquistar en 1849 y que fue ocupado por los guardias rojos en 1966; no obstante, [...]

(4). [...] quiso proporcionarles la experiencia de una auténtica lucha revolucionaria. III. Los Guardias Rojos Y El Auge Revolucionario Mao, además, deseó recuperar su liderazgo, $[\ldots]$

(5). [...] La educación en escuelas y colegios fue suspendida cuando los guardias rojos arremetieron contra la autoridad de maestros, educadores y, en ocasiones, de los $[\ldots]$

(6). [...] Millones de guardias rojos comenzaron a ocupar trenes para viajar por todo el país con el fin de difundir [...]

(7). [...] Los opositores a Mao intentaron tomar la iniciativa formando sus propios grupos de guardias rojos, y se produjeron frecuentes enfrentamientos callejeros.

(8). [...] originar ataques sobre sus culturas y sus identidades, normalmente a cargo de los guardias rojos. La mayor parte del patrimonio histórico nacional resultó dañado o destruido y [...]

Grupo 3: indicación de peligro o falta

$$
\text { «luz roja» }
$$

Prosodia semántica: negativa, amenaza

Frecuencia: 8/92

(1). [...] nos prendió la luz roja a varias personas que nos opusimos a su candidatura, entre estas personas estaba [...] 
(2). [...] Ileno, se da el aviso al maquinista con un timbre o con una luz roja, pero antes de la electricidad, tocaban una campana [...]

(3). [...] tiras cómicas, me veo en el bar de la calle sexta. Una luz roja me señala con vergüenza, me siento hurgando en la vida íntima de otros seres [...]

(4). [...] Hubo de parar un momento. La luz roja lo ordenaba. Y al sentir el remolino bramador e interminable, [...]

(5). [...] con sólo una mano izquierda y un rápido reviramiento de cuerpo ágil encendía la luz roja como un aviso de alarma sobre las pobrezas de la verbena llena de humanos semejantes [...]

(6). [...] Un malestar general indicaba que se encendía la luz roja de una caldera apunto de estallar. La playa formaba parte de [...]

(7). [...] la presentó esa noche, hacía ya como seis meses, bajo la tumescente luz roja del Atzimba. «Ésta es Brasil», le dijo [...]

(8). [...] La escena se alumbrará toda con la luz roja de las llamas. Lisardo contempla un momento aterrado tan espantosa visión, [...]

«al rojo vivo»

Prosodia semántica: negativa, amenaza

Frecuencia: $9 / 32$

(1). [...] en una cara redonda y que sufría de una acusada tendencia a ponerse al rojo vivo, a la congestión sanguínea. La miró, Olga, [...]

(2). [...] Antes - recuerdo con cierta sorna - solían mostrarme el rojo vivo de mi propia sangre, pero ese color es ya un hastío. [...]

(3). [...] el diputado ucedeísta Luis Fernando Herrera puso la cuestión al rojo vivo cuando sostuvo que Alsogaray tiene el defecto de creer que el liberalismo [...]

(4). [...] de la crisis El Kremlin admitió ayer que la situación en el país está al rojo vivo, lo cual obligó al presidente de Rusia, [...]

(5). [...] cardenista, eran lucha de rudos, y las pasiones subían a veces al color rojo vivo de sangre. Desfilaban las clientelas [...]

(6). [...] lo aplicó en tres donde los ánimos estaban al rojo vivo. Fue un fracaso. En uno de ellos, Querétaro, se impusieron [...]

(7). [...] cambios de Camerún, sale Ipoua y entra Job, el ambiente se pone al rojo vivo. Miles de aficionados corean «Camerún...camerún», un grito que apaga [...]

(8). [...] Al rojo vivo debate sobre MIDEM y oposición a negocios con Cuba ¿Hasta dónde debe el $[\ldots]$

(9). [...] Escándalo sexual de Clinton al rojo vivo Washington - - El presidente Bill Clinton se vio el viernes más enredado aún [...]

«alerta roja»

Prosodia semántica: negativa, amenaza

Frecuencia: $14 / 30$

(1). [...] mucho más difícil todavía estar encasquetado en un uniforme de bombero y estar en alerta roja todo el tiempo, los hechos transcienden, superan los sucesos de prevención [...]

(2). [...] que aunque no esté en plena actividad beligerante está muchas veces poniéndose en alerta roja, altera la situación del estado y del país, [...] 
(3). [...] se recibió a bordo un alerta rojo. El ataque del guardacostas por parte de aviones británicos fue casi instantáneo. [...]

(4). [...] De inmediato, la Comisión Nacional de Emergencia (CNE) decretó una alerta roja y dispuso varias medidas de seguridad: * Cierre del tránsito por la carretera [...]

(5). [...] doblete de particulares * No es el primero * Prostituyen la función pública

* Alerta roja por incendios en Petén [...]

(6). [...] El Gobierno declaró ayer una alerta roja nacional a causa de la gravedad de los incendios forestales que arrasan gran parte [...]

(7). [...] la Coordinadora Nacional para la Reducción de Desastres declararon alerta roja y evacuaron a unas 250 personas de [...]

(8). [...] quien declaró, en ausencia del mandatario, la emergencia nacional y luego la alerta roja por el fuego. Por ello, [...]

(9). [...] Declaran alerta roja por nueva erupción de volcán Pacaya en Guatemala Guatemala (ACAN-EFE) [...]

(10). [...] Comisión Nacional para la Reducción de Desastres (CONRED) decidió declarar la «alerta roja» en la zona pero todavía no se ha realizado ninguna evacuación, $[\ldots]$

(11). [...] dijo que se ha decretado una "alerta roja» en la zona debido a la nueva actividad volcánica. [...]

(12). [...] domingo unas 1.500 personas, explicó el funcionario. El gobierno decretó el sábado alerta roja para coordinar acciones de los diversos organismos en la lucha contra los siniestros y [...]

(13). [...] El Comité de Emergencia Nacional (COEN) de El Salvador declaró ayer, martes, "Alerta Roja» debido al elevado número de incendios forestales registrados en este país, [...]

(14). [...] Eddy Sánchez, director del Observatorio Nacional. Se decretó una «alerta roja» para las aldeas próximas al cráter, [...]

«tarjeta roja»

Prosodia semántica: negativa, penalización

Frecuencia: 8/16

(1). [...] Bueno Tomás, tarjeta roja, la entrada ha sido a tu juicio merecedora de amarilla [...]

(2). [...] que había salido de la caseta, le preguntó si era tarjeta amarilla o tarjeta roja y sacó tarjeta roja y - y vamos, le expulsó. Entonces juzgando [...]

(3). [...] sancionado ayer el defensor saprissista Rónald González, quien el domingo anterior vio la tarjeta roja en el primer juego [...]

(4). [...] se originó una situación en la que José Adames fue penalizado con tarjeta roja, hecho que provocó posteriormente la salida del dirigente norteño, José Morel. [...]

(5). [...] de lugar. RAMÓN Ramírez dice algo al árbitro y se va con la tarjeta roja a cuestas... iVaya final no apto para cardiacos! [...]

(6). [...] Nankov, m. 43 Benítez, m. 46 Stoitchkov, m. 72 Ivanov:. m. 87, Tarjeta roja a Nankov por doble amonestación. [...]

(7). [...] Al minuto 47 Darryl Powell recibe su segunda amonestación y por lo tanto 
la tarjeta roja, luego que en dos ocasiones seguidas derriba al propio Ortega. [...]

(8). [...] impedir el saque de una falta. Un árbitro puede mostrar la tarjeta roja a un jugador y expulsarle del terreno de juego [...]

\section{Discusión y conclusiones}

Se confirma que en el análisis de la connotación de estos términos cromáticos, no es suficiente con el paradigma bipolar de Morley y Partington (2009), ya que no hay un solo polo positivo o bueno y uno negativo o malo. En las expresiones del primer grupo y en las del tercer grupo, comprobamos que el polo negativo es más claro. En el primer grupo, el término cromático "rojo» se ha utilizado cuando las personas o entidades que intervenían sufrían una situación de vergüenza, de ira o de palidez físicamente visible en el rostro y, en el tercer grupo, el color rojo se ha empleado en situaciones de alerta, de peligro o amenaza.

Sin embargo, vemos que en el segundo grupo, el significado o la connotación de este color no está tan claro, ya que estas unidades refieren a contextos políticos que, vistos desde un determinado prisma o punto, pueden verse como positivos o negativos (socialismo, revolución, etc.). Consideramos que la prosodia semántica debería ir más allá y analizar realidades a otro nivel, diferenciando además aquellas unidades léxicas que se mantienen neutras o que por el motivo que sea (político, cultural, personal) no se puede valorar de forma objetiva.

Con toda la información extraída, consideramos que el papel semántico de los colores dentro de las unidades fraseológicas es muy interesante, ya que estos ofrecen una valoración (ya sea positiva, negativa, neutra o no claramente valorable) sobre aquello de lo que se está hablando. Este análisis se enmarca en un estudio mayor donde se pretende analizar, de forma comparativa entre el idioma español y el alemán, cuál es el papel que tienen los términos del color dentro de las lenguas y si pueden servir para expresar en un idioma aspectos que en el otro se expresan de forma completamente diferente, por lo que, aunque el estudio del "rojo» nos ha dado mucha información sobre el papel de los términos cromáticos, esperamos poder ir más allá y ampliar la paleta de colores.

\section{Bibliografía}

BAKER, M. et al. (1993): Text and Technology. In Honour of John Sinclair, John Benjamins Publishing Company, Ámsterdam y Filadelfia.

CORPAS PASTOR, G. (2003): Diez años de investigación en fraseología: Análisis sintáctico-semánticos, contrastivos y traductológicos, VervuertIberoamericana, Fráncfort del Meno-Madrid.

COSERIU, E. (1981): Lecciones de lingüística general, Gredos, Madrid. 
Instituto de InVEStigación Rafael LapeSA de la ReAl Academia Española (2013): Corpus del Nuevo diccionario histórico (CDH) [en línea]. <http://web.frl.es/CNDHE> [Consulta: 7 de septiembre de 2009]

LAKOFF, G. y M. JOHnSON (1980): Metáforas de la vida cotidiana, University of Chicago Press, Chicago.

Louw, B. (1993): "Irony in the Text or Insincerity in the Writer? The Diagnostic Potential of Semantic Prosodies", BAKER, M. , et al. (ed.): Text 703 and Technology: In Honour of John Sinclair, Benjamins, Ámsterdam y Filadelfia, p. 240-251.

Morley, J. y A. Partington (2009): «A Few Frequently Asked Questions about Semantic -or Evaluative- Prosody». International Journal of Corpus Linguistics, 14(2), p. 139-158.

Real Academia Española. Diccionario de la Real Academia Española [en línea]. Vigesimotercera edición. <http://lema.rae.es/drae/?val=corpus>. [Consulta: 27 de enero de 2015].

- : Banco de datos (CORDE) [en línea]. Corpus diacrónico del español. <http://www.rae.es>. [Consulta: 7 de septiembre de 2015].

- : Banco de datos (CREA) [en línea]. Corpus de referencia del español actual. <http://www.rae.es>. [Consulta: 7 de septiembre de 2015].

Soriano, C. y J. Valenzuela Manzanares (2009): «Emotion and Colour Across Languages: Implicit Associations in Spanish Colour Terms». Social Science Information, Special Issue: The Language of Emotion -Conceptual and Cultural Issues, p. 421-445.

Steen, G. J. (2007): «Finding Metaphor in Discourse: Pragglejaz and Beyond». Culture Language and Representation, V, p. 9-25.

Tognini-BonelLI, E. (2001): Corpus Linguistics at Work, John Benjamins Publishing Company, Ámsterdam y Filadelfia. 
